\title{
Final Program
}

\section{Thirty-Second Annual International Neuropsychological Society Conference}

\author{
February 4-7, 2004 \\ Baltimore, Maryland, USA
}

\section{WEDNESDAY, FEBRUARY 4, 2004}

4:00 PM - 6:30 PM

1. POTTER, G

2. HEBERT, $\mathrm{K}$

3. UNVERZAGT, F

4. WARREN, L

5. WYMER, J

6. PETERS, $\mathrm{K}$

7. KARANTZOULIS, S

8. RABIN, L

9. BROMBERG, $\mathrm{C}$

10. DI FRANCESCO, A

11. FLASHMAN, L

12. LERITZ, E

13. MITSIS, E

14. MEJIA, S

15. JACOBSON, M

16. LARUFFA, G

17. SYMINGTON, S

18. WILDER-WILLIS, K

19. SUHR, J

20. RANDOLPH, J

21. JONES, T

\author{
Poster Session 1 \\ Dementia: Studies Of Dementia Risk and Those With Cortical Dementias \\ Room: Grand Ballroom
}

\section{Dementia Risk}

CONTRIBUTIONS OF OCCUPATIONAL COMPLEXITY TO COGNITIVE STATUS WITHIN ELDERLY TWIN PAIRS.

PRECLINICAL COGNITIVE SIGNS OF ALZHEIMER'S DISEASE IN AGING TWINS.

GENDER AND EDUCATION AND THE RISK OF INCIDENT COGNITIVE IMPAIRMENT: DATA FROM THE INDIANAPOLIS STUDY OF HEALTH AND AGING.

THE TRANSITIONAL COGNITIVE STATE BETWEEN NORMAL AGING AND DEMENTIA: DEFINITIONS MATTER.

CHALLENGES ASSOCIATED WITH THE PRECLINICAL DIAGNOSIS OF ALZHEIMER'S DISEASE IN A 57-YEAROLD WITH MILD COGNITIVE IMPAIRMENT.

FURTHER CHARACTERIZATION OF MEMORY IMPAIRED SUBGROUPS OF COGNITIVELY-IMPAIRED-NOTDEMENTED INDIVIDUALS FROM THE ACCORD STUDY.

FREE RECALL AND RECOGNITION FOLLOWING MEANINGFUL AND BIZARRE SUBJECT-PERFORMED AND VERBAL TASKS IN NORMAL AGING AND MILD COGNITIVE IMPAIRMENT.

TELEPHONE-BASED SCREENING FOR MCI AND COGNITIVE COMPLAINTS: PRELIMINARY VALIDATION BY COMPREHENSIVE ASSESSMENT.

LONGITUDINAL ASSOCIATIONS BETWEEN CLINICAL DEMENTIA RATING, GERIATRIC DEPRESSION SCALE AND MEASURES OF NEUROPSYCHOLOGICAL FUNCTIONING IN THE MILDLY COGNITIVELY IMPAIRED ELDERLY.

COGNITIVE PREDICTORS OF EVERYDAY ACTIVITY LEVEL IN AGING AND MILD COGNITIVE IMPAIRMENT. AWARENESS OF COGNITIVE IMPAIRMENT IN MCI AND CONTROLS WITH COGNITIVE COMPLAINTS: DIMENSION VARIABILITY AND RELATIONSHIP TO NEUROPSYCHOLOGICAL DEFICITS AND BRAIN VOLUME.

EPISODIC AND SEMANTIC PRIMING IN AGING AND MILD COGNITIVE IMPAIRMENT.

EFFECT OF MINI MENTAL STATUS AND MILD COGNITIVE IMPAIRMENT ON EXECUTIVE FUNCTION. HETEROGENEITY OF MILD COGNITIVE IMPAIRMENT: CLINICAL CHARACTERIZATION IN A MEXICAN POPULATION.

ERROR ANALYSIS AND DISCREPANCY SCORES ON A GLOBAL/LOCAL LEARNING AND MEMORY TASK IN AN ELDERLY APOE-E4 GROUP AT RISK FOR AD.

HEALTH QUALITY OF LIFE IN OLDER ADULTS AT RISK FOR DEMENTIA.

PRE-CLINICAL COGNITIVE SIGNS FOR THOSE AT RISK FOR ALZHEIMER'S DISEASE.

PERFORMANCE ON THE DELAYED RESPONSE AND DELAYED MATCHING TO SAMPLE TASKS IN PATIENTS WITH MILD COGNITIVE IMPAIRMENT AND HEALTHY ELDERLY CONTROLS.

THE ROLE OF GENETIC AND NONGENETIC EXPERIENCE WITH ALZHEIMER'S DISEASE (AD) IN PERCEIVED AD THREAT.

EXECUTIVE FUNCTION IN MCI: RELATIONSHIP BETWEEN SUBJECTIVE REPORTS ON THE METEX AND COGNITIVE PERFORMANCE.

APOLIPOPROTEIN E, NON-VERBAL MEMORY AND VISUOCONSTRUCTIONAL ABILITIES IN OLDER ADULTS.

Alzheimer's Disease

EDUCATION AND NEUROPSYCHOLOGICAL TEST PERFORMANCE IN DEMENTIA.

COGNITIVE DECLINE IN ALZHEIMER'S DISEASE: A LONGITUDINAL INVESTIGATION.

HEADMINDER: AN INTERNET BASED SCREENING DEVICE FOR DEMENTIA. 
25. CHANDLER, M

26. WITGERT, M

27. IMBEAULT, H

28. GARRETT, $\mathrm{K}$

29. PRICE, CC

30. OBRAZTSOVA, A

31. LIMOGES, F

32. WEBER, M

33. LINEWEAVER, T

34. SHENAL, B

35. WILD, K

36. KLEINER, J

37. HILL, E

38. SPITZNAGEL, M

39. FERRETTI, L

40. DONINGER, N

41. MAHENDRA, N

42. HAMMOND, C

43. GOULD, F

44. SALVATIERRA, J

45. BUTTROSS, L

46. SHENAL, B

47. JEFFERSON, A

48. NELSON, A

49. SMERZ, JM

50. TRITTSCHUH, E

51. BADENES, D

52. TREMONT, G

53. KIXMILLER, J

54. ADAIR. J

55. FISCHER, $\mathrm{R}$

56. HOPKINS, M

57. DAVIS, J

58. ATCHISON. T

59. HART, R

60. HOLLNAGEL, C

61. BELFOR, $\mathrm{N}$

62. ZIMMERMAN, E

63. FEARING. M

64. GILBERT, P

65. KRAUS, M
A TOTAL SCORE FOR THE CONSORTIUM TO ESTABLISH A REGISTRY FOR ALZHEIMER'S DISEASE (CERAD) NEUROPSYCHOLOGICAL BATTERY.

USE OF THE AMNART AS AN ESTIMATE OF PREMORBID INTELLECTUAL FUNCTIONING IN ALZHEIMERS DISEASE PATIENTS.

REMOTE MEMORY AND RECOLLECTIVE EXPERIENCE IN ALZHEIMER DISEASE.

VERBAL SERIAL LIST LEARNING AMONG DEMENTIA PATIENTS WITH AND WITHOUT WHITE MATTER CHANGES: NEUROPSYCHOLOGICAL CORRELATES.

VERBAL SERIAL LIST LEARNING AMONG DEMENTIA PATIENTS WITH AND WITHOUT WHITE MATTER CHANGES: FACTOR SOLUTIONS.

MORE THAN JUST WORDS: VERBATIM, PROPOSITIONAL AND THEMATIC MEASURES OF STORY RECALL IN PATIENTS WITH ALZHEIMER'S DISEASE.

PROSPECTIVE MEMORY IN ALZHEIMER'S DISEASE : A STUDY USING EVENT-BASED TASKS.

ODOR MEMORY IN OLDER ADULTS WITH AND WITHOUT COGNITIVE IMPAIRMENTS.

WHAT YOU SEE IS NOT ALWAYS WHAT YOU GET: VISUOSPATIAL SKILLS ARE NOT CREATED EQUAL IN PATIENTS WITH ALZHEIMER'S DISEASE.

FINGER AGNOSIA IN ALZHEIMER'S DISEASE.

UNINTENTIONAL MEDICATION NONCOMPLIANCE IN PATIENTS WITH ALZHEIMER'S DISEASE.

UTILITY OF THE TMT B DIVIDED BY A EQUATION IN DIFFERENTIAL DIAGNOSIS OF DEPRESSION AND DEMENTIA.

THE RELATIONSHIP BETWEEN DEPRESSION AND LEVELS OF UNAWARENESS IN DEMENTIA.

DOES COGNITIVE RESERVE PLAY A ROLE IN ANOSOGNOSIA IN DEMENTIA?

FAILURES TO APPRECIATE COGNITIVE IMPAIRMENT IN AD ARE NOT DUE TO AMNESIA.

INHIBITORY PROCESSING AND EMOTIONAL PERCEPTION IN ALZHEIMERS DISEASE.

INHIBITORY FUNCTION AND INTERFERENCE EFFECTS IN AGING AND ALZHEIMERS DISEASE.

CLOCK DRAWING IN ALZHEIMER DISEASE IS MORE RELATED TO MEASURES OF EXECUTIVE FUNCTION THAN TO FIGURE COPYING.

GENDER DIFFERENCES IN PET ACTIVATION ASSOCIATED WITH AD ON A WORKING MEMORY TASK.

VERBAL FLUENCY IN BILINGUAL ALZHEIMER'S DISEASE PATIENTS.

COMPARISON OF THE MMSE AND NCSE IN THE DIAGNOSIS AND ASSESSMENT OF ECOLOGICAL FUNCTIONING IN ALZHEIMER'S DISEASE.

ANALYSIS OF ORIENTATION QUESTIONS IN ALZHEIMER'S DISEASE.

OBJECT RECOGNITION PREDICTS INSTRUMENTAL ACTIVITIES OF DAILY LIVING (IADLS) IN PATIENTS WITH ALZHEIMER'S DISEASE (AD).

COGNITIVE PREDICTORS OF FUNCTIONING

RELATIONSHIP BETWEEN COGNITIVE FACTORS AND FUNCTIONAL ABILITIES IN MODERATE TO SEVERE DEMENTIA.

VISUOSPATIAL FUNCTIONS PREDICT DRIVING STATUS IN AGING AND ALZHEIMERS DISEASE.

DRIVING AND DEMENTIA: SPECIFIC NEUROPSYCHOLOGICAL ASSESSMENT TOOLS.

FAMILY FUNCTIONING AS A PREDICTOR OF BURDEN IN CAREGIVERS OF PATIENTS WITH MILD TO MODERATE DEMENTIA.

EFFICACY OF A SKILLS-TRAINING GROUP FOR CAREGIVERS OF INDIVIDUALS WITH ALZHEIMER'S DISEASE.

IDEOMOTOR APRAXIA IN DEMENTIA: PILOT STUDY OF RESPONSE TO DONEPEZIL.

NEUROPSYCHOLOGICAL FACTORS ASSOCIATED WITH CONTENT-SPECIFIC DELUSIONS IN ALZHEIMERS DISEASE.

NEUROPSYCHOLOGICAL FUNCTIONING IN DEMENTIA PATIENTS WITH AND WITHOUT PSYCHOSIS. UTILITY OF COGNITIVE SCREENING MEASURES FOR DISCRIMINATING DEMENTIA SUBTYPES. PREDICTING ALZHEIMER'S PATIENTS' DECLINE IN BASIC ADLS FROM BASELINE NEUROPSYCHOLOGICAL DATA.

\section{Other Cortical Dementias}

DIVERGENT THINKING IN EARLY ALZHEIMER'S AND FRONTOTEMPORAL DEMENTIA.

VERBAL MEMORY IN FRONTOTEMPORAL DEMENTIA, SEMANTIC DEMENTIA, AND ALZHEIMER'S DISEASE.

PATTERN OF IMPAIRMENT IN CORTICOBASAL DEGENERATION SYNDROME AS COMPARED TO FRONTOTEMPORAL DEMENTIA AND CONTRASTED WITH ALZHEIMER'S DISEASE.

EMOTIONAL PERCEPTUAL DEFICIT IN PERSONS WITH AMYOTROPHIC LATERAL SCLEROSIS. GENERALIZED VS. FOCAL ATROPHY IN DEMENTIA: THEIR RELATIONSHIP TO NEUROPSYCHOLOGICAL FUNCTION.

RECOGNITION MEMORY AND REMOTE MEMORY FOR OLFACTORY AND VISUAL STIMULI IN PATIENTS WITH THE LEWY BODY VARIANT OF ALZHEIMER'S DISEASE, PATIENTS WITH ALZHEIMER'S DISEASE. AND HEALTHY ELDERLY CONTROLS.

COGNITIVE, MOTOR, AND BEHAVIORAL CONTRIBUTIONS TO FUNCTIONAL DECLINE IN ALZHEIMER'S DISEASE AND DEMENTIA WITH LEWY BODIES. 
4:45 PM - 6:30 PM Paper Session 1

Neurologic Injury \& Outcome in Children

Room: Harborside C

1. HANNAY, H

AUDITORY INTERHEMISPHERIC TRANSFER IN SPINA BIFIDA MENINGOMYELOCELE: THE ROLE OF THE LEVEL OF LESION, CORPUS CALLOSUM, OTHER COMMISSURES AND HANDEDNESS.

2. BUTZER, A LONG-TERM NEUROCOGNITIVE SEQUELAE OF POSTERIOR FOSSA TUMORS IN CHILDREN TREATED SURGICALLY.

3. BRANDLING-BENNETT, E SEMANTIC FLUENCY IN CHILDREN WITH FRONTAL STROKE RELATED TO SICKLE CELL DISEASE.

4. LLORENTE, A EARLY NEURODEVELOPMENTAL MARKERS PREDICTIVE OF MORTALITY IN INFANTS AND YOUNG

5. BLACKBURN, L

6. LEE, GP CHILDREN INFECTED WITH HIV-1. DOES VIQ/PIQ DISCREPANCY PREDICT SEIZURE FOCUS LATERALITY IN PEDIATRIC PATIENTS?

4:45 PM - 6:30 PM

Paper Session 2

Brain-Behavior Relationships in HIV

Room: Laurel

1. BRICKMAN, A

2. PAUL, R

3. KISSEL, E

4. MARION, S

5. MARTIN, E

6. GONZALEZ, R

7. RIPPETH, J

\section{4:45 PM - 6:30 PM}

1. MALEC, J

2. DIAZ-ARRASTIA, R

3. GOLDSTEIN, F

4. KEYS, B

\section{4:45 PM - 6:30 PM}

1. KANE, R

2. CERNICH, A

3. PRICE, $\mathrm{L}$

4. SHORT, P

5. REDFIELD, J
CAUDATE MORPHOMETRY AND COGNITION IN HIV.

APATHY IS ASSOCIATED WITH VOLUME OF THE NUCLEUS ACCUMBENS IN PATIENTS INFECTED WITH HIV.

RELATIONSHIP BETWEEN FATIGUE AND NEUROPSYCHOLOGICAL PERFORMANCE IN HIV INFECTION NEUROCOGNITIVE IMPAIRMENT PREDICTS LONGITUDINAL MEDICATION ADHERENCE IN HIV+ INDIVIDUALS.

EXECUTIVE FUNCTION AND MENTAL SLOWING IN DRUG ABUSERS INFECTED WITH HEPATITIS C: PRELIMINARY FINDINGS AND LESSONS LEARNED FROM THE HIV LITERATURE.

SENSATION-SEEKING AND EXECUTIVE FUNCTIONS CORRELATE WITH RISK-BEHAVIORS OF HIV+ AND HIV- POLY-DRUG USERS.

COGNITIVE, PSYCHIATRIC, AND MEDICAL PREDICTORS OF RELAPSE IN HIV+ METHAMPHETAMINE ABUSERS.

\section{Symposium 1}

Genetics in Recovery from Traumatic Brain Injury: Beyond APOE

Chair: James Malec, Discussant: James Malec

Room: Essex

GENETICS IN RECOVERY FROM TRAUMATIC BRAIN INJURY: BEYOND APOE.

USEFULNESS OF ALLELIC ASSOCIATION STUDIES IN IDENTIFYING GENETIC FACTORS INFLUENCING OUTCOME AFTER TRAUMATIC BRAIN INJURY.

APOLIPOPROTEIN E AND COGNITIVE OUTCOMES FOLLOWING MODERATE AND SEVERE TRAUMATIC BRAIN INJURY.

APOLIPOPROTEIN E STATUS, TRAUMATIC BRAIN INJURY, AND FUNCTIONAL OUTCOME.

\section{Symposium 2}

Construct Validity in Neuropsychology: Do We Know What We Measure?

Chair: Robert Kane, Discussant: Glenn Larrabee

Room: Harborside AB

CONSTRUCT VALIDITY IN NEUROPSYCHOLOGY: DO WE KNOW WHAT WE MEASURE?

THE STATE OF CONSTRUCT VALIDATION IN NEUROPSYCHOLOGY: A REVIEW.

THE USE OF CONFIRMATORY FACTORY ANALYSES TO VALIDATE PSYCHOLOGICAL TESTS: LESSONS LEARNED FROM THE WAIS-III AND WMS-III PROJECT.

EVALUATION OF CONVERGENT AND DIVERGENT VALIDITY OF ANAM TASKS.

METHODS OF CONSTRUCT VALIDATION IN NEUROPSYCHOLOGY: MOVING BEYOND TOM SWIFT'S ELECTRIC FACTOR ANALYSIS MACHINE. 
Symposium 3

Dysexecutive States and Frontal Functioning in Aging and Neurodegenerative Disease. Chair: Carol Manning, Discussant: David Geldmacher Room: Harborside DE

1. MANNING, C

2. RAZ, N

3. STOUT, J

4. FUCHS, K

5. MANNING, C

6. SALTHOUSE, T

\section{6:30 PM}

DYSEXECUTIVE STATES AND FRONTAL FUNCTIONING IN AGING AND NEURODEGENERATIVE DISEASE.

DIFFERENTIAL AGE-RELATED CHANGES IN REGIONAL BRAIN VOLUMES AND THEIR MODIFIERS: IMPLICATIONS FOR COGNITIVE AGING.

DIFFERENTIATING UNDERLYING CAUSES OF DYSEXECUTIVE FUNCTION IN PARKINSON'S DISEASE AND HUNTINGTON'S DISEASE USING COGNITIVE SCIENCE METHODS.

NONAMNESTIC MCI IN A MEMORY DISORDERS CLINIC.

COMPONENTS OF EXECUTIVE DYSFUNCTION IN AMNESTIC MCI.

INVESTIGATION OF CONSTRUCT VALIDITY OF EXECUTIVE FUNCTIONING.

INS Welcome Reception

Room: Harborside Foyer 


\section{THURSDAY, FEBRUARY 5, 2004}

8:00 AM - 10:00 AM

1. HARRIS, L

2. ESPY, KA

3. ESPY, $\mathrm{K}$

4. HEFFELFINGER, A

5. CONKLIN, $\mathrm{H}$

6. GERNER, G

7. HODGES, E

8. ISQUITH, P

9. MAHONE, E

10. WOLKENBERG, F

11. GUY, S

12. LANCASTER, V

13. KEY, A

14. WATSON, S

15. KIRK, J

16. CHIU, P

17. HALES, J

18. MCLAUGHLIN-BELTZ, S

19. MOLFESE, D

20. LARSON, E

21. JOHNSON, S

22. SWEET, L

23. RANDOLPH, J

24. JACOBSON, M

25. WELSH, M

26. HALLAM, B

27. MRAZ, R

28. EMICK, J

29. ADAMS, C

30. KINGERY, L

31. WOLK, DA

32. Cosentino, S

33. ESKES, G

34. RICH, JB

35. MANOUSSAKI, K

36. PARK, $\mathrm{N}$

\author{
Poster Session 2 \\ Studies of Normal Cognition Across the Lifespan \\ Room: Grand Ballroom
}

\section{Child Development}

PREDICTION OF PRE-SCHOOL COGNITIVE ABILITY BY PARENT RATING.

USING THE SHAPE SCHOOL TO UNDERSTAND TASK DEMANDS THAT INVOKE EXECUTIVE CONTROL. EXECUTIVE COMPONENTS OF TRAILS-P PERFORMANCE IN YOUNG CHILDREN.

THE MODIFIED LURIA'S TAPPING TEST: AN EFFECTIVE MEASURE TO ASSESS EXECUTIVE FUNGTIONING IN PRESCHOOL CHILDREN?

WORKING MEMORY PERFORMANCE IN TYPICALLY DEVELOPING CHILDREN: A CLOSER LOOK AT BEHAVIORAL INDICES OF FRONTAL LOBE DEVELOPMENT.

WORKING MEMORY AND INTELLIGENCE: A DEVELOPMENTAL PERSPECTIVE.

THE RELATIONSHIP BETWEEN NEUROPSYCHOLOGICAL TEST PERFORMANCE AND EMOTION PERCEPTION AND THEORY OF MIND TASKS IN CHILDREN AND ADOLESCENTS.

ADOLESCENT SELF-REPORTS OF BEHAVIOR AND EXECUTIVE FUNCTION.

THE RELATIONSHIP BETWEEN CPT PERFORMANCE AND BEHAVIOR RATING OF EXECUTIVE FUNGTION IN CHILDREN.

ECOLOGICAL VALIDITY OF NEUROPSYCHOLOGICAL AND SELF-REPORT MEASURES OF DEVELOPMENTAL EXECUTIVE FUNCTION USING LOCUS OF CONTROL AS A CRITERION MEASURE.

SELF, PARENT AND TEACHER RATINGS OF ADOLESCENT EXECUTIVE FUNCTION.

RELATIONSHIP BETWEEN SELF-ESTEEM AND EXECUTIVE FUNCTIONING IN CHILDREN.

LINKS BETWEEN EARLY READING AND MATH SKILLS IN PRESCHOOL CHILDREN: ELECTROPHYSIOLOGICAL EVIDENCE.

PATTERNS OF PHONOLOGIGAL PROCESSING DEFICITS IN SCHOOL-AGED CHILDREN.

LONGITUDINAL PERFORMANCE ON THE CONTINGENCY NAMING TEST (GNT) IN CHILDREN GRADES 1 AND 3.

NEURODEVELOPMENT OF EPISODIC MEMORY ENCODING.

SEX DIFFERENCES IN CHILDREN'S LEARNING AND MEMORY.

COMPARATIVE ANALYSIS OF THE RELATIONSHIP BETWEEN SENSORY INTEGRATION, PRAXIS, AND COG-

NITIVE FUNCTIONING IN CHILDREN.

DELAYED BEDTIME ALTERS BRAIN PROCESSING.

\section{Experimental Studies of Normal Cognition}

FUNCTIONAL MRI ACTIVATION OF THE ANTERIOR TEMPORAL LOBE: A COMPARISON OF THREE PROTOCOLS.

DO HEMOGLOBIN AND HEMATOCRIT LEVELS AFFECT FMRI ACTIVATION?

FMRI CORRELATES OF THE WAIS-III SYMBOL SEARCH SUBTEST.

BRAIN ACTIVATION ASSOCIATED WITH A MODIFIED COUNTING STROOP TASK: AN FMRI STUDY.

DIVIDED VISUAL ATTENTION AND FMRI: SWITCHING BETWEEN HIERARCHICAL STIMULI EVOKES INFERIOR, MEDIAL AND SUPERIOR FRONTAL REGION ACTIVATION.

INTERACTION OF WORKING MEMORY AND INHIBITION IN A LIMITED CAPACITY SYSTEM.

FRONTAL LOBE VOLUMES SPECIFICALLY PREDICT THE CAPACITY FOR SET SHIFTING ON EXECUTIVE TASKS.

COGNITIVE SET-SHIFTING DURING THE TRAIL MAKING TEST: AN FMRI STUDY USING AN FMRI-COMPATIBLE WRITING DEVICE.

THE RELATIONSHIP BETWEEN FORMAL OPERATIONAL THOUGHT AND EXECUTIVE FUNCTIONS.

CONTRIBUTION OF INHIBITION, WORKING MEMORY, AND FLUID REASONING TO TOWER OF HANOIREVISED PERFORMANCE.

HIPPOCAMPAL VOLUME ASYMMETRY CORRELATES WITH WORD VS. DESIGN FLUENCY IN NORMAL ADULTS.

EVENT-RELATED POTENTIAL CORRELATES OF ENHANCED CONCEPTUAL FLUENCY AND FALSE RECOGNITION.

AN INVESTIGATION OF THE NEUROPSYCHOLOGICAL BASIS OF SCRIPTS: DIFFERENTIAL ROLES OF THE PREFRONTAL AND TEMPORAL CORTEX.

DIFFERENTIAL CONTRIBUTION OF THE CEREBELLUM AND FRONTAL LOBES TO MEMORY AND EXECUTIVE FUNCTIONS.

TEMPORAL ORDER AND RECOGNITION MEMORY OF ACTIONS AND OBJECTS IN SUBJECT-PERFORMED AND VERBAL TASKS.

COGNITIVE MECHANISMS UNDERLYING PERSEVERATION ON THE WISCONSIN CARD SORTING TEST. NEUROPSYCHOLOGICAL INVESTIGATION OF THE ENCODING AND PERFORMANCE OF PURPOSEFUL ACTIONS. 
37. PARK, $\mathrm{N}$

38. KIRWAN, C

39. BROWNDYKE, J

40. HISCOCK, M

41. FOSTER, $\mathrm{P}$

42. FOSTER, $P$

43. FOGEL, J

44. PEREIRA, A

45. CUTTING, L

46. ELIAS, L

47. KINGERY, L

48. CIRINO, $\mathrm{P}$

49. BALCONI, M

50. SHENKER, J

51. SHENTON, J

52. LISS, M

53. TECHENTIN, $\mathrm{C}$

54. YOON, S

55. WOO, E

56. VAKIL, E

57. DRISCOLL, I

58. RHODES, RD

59. HOLTZER, $\mathrm{R}$

60. MCAULEY, T

61. POTVIN, M

62. SUHR, J

63. HUH, T

64. HODGES, EK

65. VAN HOOREN, S

66. MUNRO, C

67. GLEASON, C

68. BEGLINGER, L

69. MIELKE, J

70. CARLSON, M

71. SUHR, J

72. DENBURG, $\mathrm{N}$
INVESTIGATION OF THE COGNTIVE PROCESSES UNDERLYING THE ENCODING OF NATURALISTIC ACTIONS. MEDIAL TEMPORAL LOBE ACTIVATION IN ENCODING AND RETRIEVAL OF NOVEL FACE-NAME PAIRS. KNOWING WHAT YOU KNOW AND DON'T KNOW: EVENT-RELATED FMRI EVIDENCE FOR DISSOCIABLE TEMPORAL AND FRONTAL LOBE ACTIVITY ASSOCIATED WITH RECOGNTION MEMORY RESPONSE TYPE. EXPLICIT AND IMPLICIT MEMORY FOLLOWING DICHOTIC LISTENING.

VARYING AGES OF ANGRY MEMORIES: ELECTROENCEPHALOGRAPHIC CORRELATES.

RECOLLECTION OF MIRTHFUL MEMORIES: COVARIATION OF ELECTROPHYSIOLOGICAL AND CARDIOVASCULAR RESPONDING.

SOAP OPERAS AND TALK SHOW TELEVISION USE IN OLDER WOMEN IS SELECTIVELY ASSOCIATED WITH POORER MEMORY.

FMRI BRAIN ACTIVATION AND VISUOSPATIAL MEMORY ABILITY: FUNCTIONAL NEUROANATOMIC CORRELATES OF BVMT-R PERFORMANCE.

FUNCTIONAL MRI OF THE JUDGMENT OF LINE ORIENTATION.

DRIVE ON THE "RIGHT" SIDE OF THE ROAD: PERCEPTUAL ASYMMETRIES FOR JUDGEMENTS OF AUTOMOBILE PROXIMITY.

THE QUALITY OF WORDS PRODUCED ON LETTER FLUENCY TASKS CORRELATES WITH VERBAL ABILITY AND ACHIEVEMENT LEVEL.

PHONOLOGICAL PROCESSING AND CALCULATION SKILL IN SPANISH SPEAKING ENGLISH LANGUAGE LEARNERS.

LINGUISTIC ANOMALIES AND MORPHED FACIAL EXPRESSIONS ELICITED A N400 ERP EFFECT. A CEREBRAL DOMAIN-SPECIFIC SEMANTIC MODULE?

BETTER THE HAND YOU KNOW: DISSOCIATION IN BODY SCHEMA AND METRIC LENGTH JUDGMENTS IN NEUROLOGICALLY INTACT HUMANS.

THE ROLE OF VISION AND PROPRIOCEPTION IN MOTOR PLANNING: EVIDENCE FROM MENTAL MOTOR IMAGERY.

PSYCHOLOGICAL CORRELATES OF SENSORY PROCESSING STYLE.

THE EFFECT OF COLOR ON THE LATERALIZATION OF SPATIAL FREQUENCY.

RELATIONSHIPS BETWEEN COGNITIVE STYLES AND BEHAVIORAL/ COGNITIVE INHIBITION: AN EVENT-RELATED POTENTIAL STUDY.

\section{Normal Aging}

MEMORY PREDICTION ACCURACY IN YOUNGER AND OLDER ADULTS.

THE EFFECT OF AGE ON MOTOR SKILL LEARNING AS DEMONSTRATED BY A MODIFIED VERSION OF THE SERIAL REACTION TIME (SRT) TASK.

TRANSVERSE PATTERNING DISCRIMINATION PROBLEM: CONFIGURAL LEARNING IN THE YOUNG, MIDDLE-AGED, AND ELDERLY HUMANS.

EXTRAPERSONAL ATTENTION BIAS IN THE CORONAL PLANE.

USING INDIVIDUAL DIFFERENCES ON NEUROPSYCHOLOGICAL TESTS TO PREDICT AGE-RELATED DUAL-TASK COSTS.

AGE-RELATED CHANGES IN INHIBITORY CONTROL ACROSS THE LIFE-SPAN.

THE INTERACTION BETWEEN EXECUTIVE DEFICITS AND THE AGE-RELATED COGNITIVE SLOWING. COGNITIVE CORRELATES OF ODOR DISCRMINATION PERFORMANCE IN OLDER ADULTS.

RESPONSE BIAS AND AGING ON A RECOGNITION MEMORY TASK.

THE RELATIONSHIP BETWEEN NEUROPSYCHOLOGICAL FUNCTIONING AND FUNCTIONAL STATUS IN OLDER ADULTS.

INFLUENCE OF COGNITIVE FUNCTIONING ON HEALTH-RELATED QUALITY OF LIFE IN OLD AGE. CORRELATES OF WHITE MATTER HYPERINTENSITY VOLUME IN PHYSICALLY HEALTHY ADULTS. NEUROCOGNITIVE BENEFITS OF SOY ISOFLAVONES.

NEUROPSYCHOLOGICAL TEST PERFORMANCE IN HEALTHY ELDERLY VOLUNTEERS BEFORE AND AFTER DONEPEZIL ADMINISTRATION: A RANDOMIZED CONTROLLED STUDY.

EFFECTS OF DONEPEZIL ON SEMANTIC PROCESSING AND VERBAL MEMORY IN HEALTHY ELDER ADULTS. RATES OF TRANSITION TO IMPAIRMENT ACROSS DOMAINS OF COGNITION.

HYDRATION STATUS AND COGNITIVE PERFORMANCE IN HEALTHY OLDER ADULTS.

PSYCHOPHYSIOLOGICAL CORRELATES OF IMPAIRED DECISION-MAKING IN OLDER ADULTS.

\section{Paper Session 3}

Neuropsychological Functioning in Mid-Life and Late-Life Depression

Room: Essex

OLFACTORY, VERBAL AND FIGURAL RECOGNITION MEMORY IN PATIENTS WITH MAJOR DEPRESSION. EMOTION PROCESSING AND EXECUTIVE FUNCTIONING DEFICITS IN DEPRESSION.

EFFECTS OF DEPRESSION AND ANXIETY ON MOTOR FUNCTION.

NEUROPSYCHOLOGICAL IMPAIRMENT PREDICTS FUNCTIONAL OUTCOMES IN MAJOR DEPRESSION. THE EFFECT OF NEUROPSYCHOLOGICAL IMPAIRMENT ON THE ABILITY TO PROVIDE INFORMED CONSENT IN DEPRESSED INPATIENTS. 
6. POTTER, G

7. ELDERKIN-THOMPSON. V BRAIN METABOLITES AND COGNITIVE FUNCTION AMONG OLDER DEPRESSED INDIVIDUALS EXAMINED

8. FOLDI, N

\section{9:00 AM - 11:00 AM}

1. PEAVY, G

2. FUCHS, K

3. $\mathrm{AU}, \mathrm{R}$

4. NELSON, A

5. ALLY, B

6. WALDSTEIN. S

9:00 AM - 11:00 AM

1. JORDAN, C

2. SHAPIRO, E

3. HUGHES, $\mathrm{S}$

4. ROCHE, B

5. JORDAN, G

9:00 AM - 11:00 AM

1. WOODS, S

2. MARTIN, E

3. CAREY, C

4. WOODS, S

5. GONZALEZ, $\mathrm{R}$

6. MARCOTTE, T

9:00 AM - 11:00 AM

PREFRONTAL NEUROPSYCHOLOGICAL PREDICTORS OF TREATMENT RESPONSE IN GERIATRIC DEPRESSION WITH 2H MR SPECTROSCOPY

SERIAL POSITION PROFILES DISTINGUISH DEPRESSION FROM NORMAL AGING AND ALZHEIMER'S DISEASE.

\section{Paper Session 4}

Dementia Risk: Neuropsychological and Neurofunctional Factors

Room: Harborside AB

CHRONIC STRESS, BEHAVIORAL CHARACTERISTICS, AND MEMORY LOSS IN SUBJECTS WITH MILD COGNITIVE IMPAIRMENT.

DECREASES IN MEMORY AND FLUENCY IN WOMEN AT RISK FOR ALZHEIMER'S DISEASE.

MCI - MORE THAN JUST MEMORY: FINDINGS FROM THE FRAMINGHAM STUDY.

PERFORMANCE ON NON-MEMORY TASKS IN MCI.

P300 AS A DIAGNOSTIC TOOL IN THOSE WITH ALZHEIMER'S DISEASE AND THEIR FIRST GENERATION BIOLOGICAL OFFSPRING.

DIAGNOSED HYPERTENSION, HIGH BLOOD PRESSURE LEVELS, AND COGNITIVE FUNCTION IN OLDER ADULTS.

\section{Symposium 4}

The DREAMS Project: Risks and Developmental Outcomes in

Inner City Preschoolers

Chair: Catherine Jordon, Discussant: Jerilynn Radcliffe

Room: Harborside C

THE DREAMS PROJECT: RISKS AND DEVELOPMENTAL OUTCOMES IN INNER CITY PRESCHOOLERS. THE DREAMS PROJECT: OVERVIEW AND SAMPLE CHARACTERISTICS. DEVELOPMENT OF A TWO FACTOR MODEL OF PARENT ATTRIBUTES. RELATIVE CONTRIBUTIONS OF MATERNAL, SOCIOENVIRONMENTAL, AND BIOMEDICAL VARIABLES TO INFANT AND YOUNG CHILDREN'S DEVELOPMENTAL TRAJECTORIES.

RELATIVE CONTRIBUTIONS OF MATERNAL, SOCIOENVIRONMENTAL, AND BIOMEDICAL VARIABLES TO THE DEVELOPMENT OF VIGILANCE.

\section{Symposium 5}

Advances in the Cognitive Neuropsychology of HIV-1 Infection

Chair: Steven Paul Woods, Discussant: Igor Grant

Room: Harborside DE

ADVANCES IN THE COGNITIVE NEUROPSYCHOLOGY OF HIV-1 INFECTION.

CONTRIBUTIONS OF COGNITIVE NEUROPSYCHOLOGY TO THE STUDY OF HIV-INFECTED DRUG ABUSERS: AN UPDATE.

DIMINISHED VERBAL FLUENCY IS ASSOCIATED WITH INEFFICIENT LEXICAL-SEMANTIC SWITCHING IN HIV-ASSOCIATED NEUROCOGNITIVE DISORDERS.

ACTION (VERB) FLUENCY IN HIV-1 INFECTION.

MEASURING HIV AND METHAMPHETAMINE RELATED COGNITIVE IMPAIRMENTS USING MODIFIED SCORING GUIDELINES FOR THE PASAT.

VISUAL ATTENTION AND DRIVING ACCIDENTS IN HIV INFECTION.

\section{Symposium 6}

Efficacy of Community-Based Interventions For Traumatic Brain Injury:

Evidence From Clinical Trials

Chair: Jennie Ponsford, Discussant: Catherine Mateer

Room: Laurel

1. PONSFORD, J

EFFICACY OF COMMUNITY-BASED INTERVENTIONS FOR TRAUMATIC BRAIN INJURY: EVIDENCE FROM CLINICAL TRIALS.

DVBIC: TREATMENT OUTCOMES BY TBI SEVERITY: THE STUDY OF PATIENT SUBGROUPS. EFFECTIVENESS OF COMMUNITY-BASED REHABILITATION FOLLOWING TRAUMATIC BRAIN INJURY THE EFFECT OF TELEPHONE FOLLOW UP ON OUTCOME AFTER TRAUMATIC BRAIN INJURY: A RANDOMIZED TRIAL.

IMPACT OF EARLY INTERVENTION UPON OUTCOME FOLLOWING MILD HEAD INJURY IN ADULTS. 


\section{0:15 AM-12:15 PM}

1. PRASAD, $\mathrm{M}$

2. SALORIO, $\mathrm{C}$

3. EWING-COBBS, L

4. HANTEN. GR

5. DONDERS, J

6. MCCAULEY, S

7. PIGOTT, $\mathrm{S}$

8. BENJAMIN, M

9. RONCADIN C

10. BEEBE, D

11. HEMME, J

12. KAY, J

13. AYR, L

14. CASS, J

15. GRAY, R

16. MOLFESE, D

17. MORROW, $\mathrm{C}$

18. WOZNIAK, J

19. LEE, K

20. SHUM, D

21. HOWARD, K

22. MOST, M

23. RAZ, S

24. NATALE, $\mathrm{R}$

25. ISQUITH, $\mathrm{P}$

26. MCGAULEY, S

27. MCGAULEY, S

28. BAVA, S

29. WISNOWSKI, J

30. JACOBS, R

31. LANSING, A

32. O'TOOLE, $\mathrm{K}$

33. NICHOLS, S

34. WABER, D

35. O'GRADY. J

36. JAIN, N

\author{
Poster Session 3 \\ Neuropsychological Functioning in Pediatric Disorders \\ Room: Grand Ballroom
}

\section{Traumatic Brain Injury}

GLASGOW COMA SCALE AND OUTCOME IN PRESCHOOLERS WITH TRAUMATIC BRAIN INJURY. THE RELATIONSHIP BETWEEN ACUTE ICU VARIABLES AND OUTCOME AFTER PEDIATRIC TBI. DIFFUSION TENSOR MRI AFTER PEDIATRIC BRAIN INJURY: RELATION TO COGNITIVE OUTCOME. SELECTIVE LEARNING IN VERBAL LEARNING AFTER TRAUMATIC BRAIN INJURY IN CHILDREN. PROACTIVE INTERFERENCE ON THE CVLTC AFTER PEDIATRIC TRAUMATIC BRAIN INJURY. EXTRINSIC MOTIVATION AND PROSPECTIVE MEMORY DEFICITS IN CHILDREN WITH TRAUMATIC BRAIN INJURY.

GENDER DIFFERENCES IN EXECUTIVE FUNCTION FOLLOWING PEDIATRIC BRAIN INJURY.

PILOT DATA ON THE RELATIONSHIP BETWEEN BRIEF SCALES AND TESTS OF EXECUTIVE FUNCTIONING IN CHILDHOOD TBI.

MATH SKILLS FOLLOWING CHILDHOOD CLOSED HEAD INJURY.

SLEEP DISTURBANCES FOLLOWING MODERATE TO SEVERE PEDIATRIC TRAUMATIC BRAIN INJURY (TBI).

COMPARISON OF NEUROPSYCHOLOGICAL AND BEHAVIORAL PROFILES OF CHILDREN WITH TBI AND ADHD.

ATTENTION AS A PREDICTOR OF VERBAL LEARNING IN CHILDREN WITH TRAUMATIC BRAIN INJURY OR ATTENTION-DEFICIT/HYPERACTIVITY DISORDER.

COGNITIVE CORRELATES OF ARITHMETIC SKILLS IN CONGENITAL AND ACQUIRED BRAIN DISORDERS.

IQ AND MEMORY PERFORMANCE IN CHILDREN WITH CONGENITAL AND ACQUIRED BRAIN DISORDER.

\section{Maternal and Perinatal Risks and Outcomes in Young Children}

NEUROPSYCHOLOGICAL CONSEQUENCES OF MALTREATMENT IN AGGRESSIVE CHILDREN.

PRENATAL COCAINE EXPOSURE: CHANGES IN EXECUTIVE FUNCTIONS IN YOUNG CHILDREN AS MEASURED BY EVENT-RELATED POTENTIALS.

ESTIMATED RISK OF DEVELOPING A LEARNING DISABILITY BY AGE 7 AMONG PRENATALLY COCAINEEXPOSED CHILDREN.

NEUROCOGNITIVE DEFICITS IN CHILDREN WITH FETAL ALCOHOL SPECTRUM DISORDER (FASD).

TASK CHARACTERISTICS AFFECT MEMORY PERFORMANCE IN CHILDREN WITH FETAL ALCOHOL SPECTRUM DISORDERS.

ASSESSMENT OF THREE COMPONENTS OF ATTENTION AND THEIR RELATIONSHIP TO LEARNING AND EXECUTIVE FUNCTIONS IN CHILDREN BORN PRETERM.

SIGNIFICANCE OF BRAIN INJURY AND ALTERED BRAIN DEVELOPMENT IN PRETERM CHILDREN.

NEURODEVELOPMENTAL FACTORS AND COGNITIVE ABILITIES OF PRETERM INFANTS.

COGNITIVE AND MOTOR OUTCOME IN PRESCHOOLERS WITH HISTORY OF BACTERIAL INFECTION ORIGINATING IN UTERO.

MEASURES OF RISK AND RESILIENCY IN AN AT-RISK 0-3 POPULATION.

SELF-REGULATION, BEHAVIOR AND EMOTIONAL FUNCTION IN CHILDREN IN FOSTER CARE.

\section{Outcomes in Medical Disorders}

SENSITIVITY OF THE BEHAVIOR RATING INVENTORY OF EXECUTIVE FUNCTION (BRIEF) IN CHILDREN WITH FRONTAL LOBE STROKES RESULTING FROM SICKLE CELL DISEASE: PRELIMINARY DATA. PROSPECTIVE MEMORY DEFICITS IN CHILDREN WITH FRONTAL LOBE STROKES RESULTING FROM SICKLE CELL DISEASE: A PILOT STUDY.

QUANTITATIVE MRI ANALYSIS OF CEREBRAL VOLUME IN CHILDREN FOLLOWING EARLY FOCAL BRAIN DAMAGE: NEUROLOGIC AND COGNITIVE CORRELATES.

FACE AND OBJECT RECOGNITION FOLLOWING EARLY-ONSET FOCAL BRAIN DAMAGE.

FUNCTIONAL LOCALISATION OF EXECUTIVE SKILLS IN CHILDHOOD: ANALYSIS OF CHILDREN WITH FOCAL FRONTAL LOBE LESIONS.

COMPARISON OF CVLT-C SEMANTIC CLUSTERING SCORING METHODS IN A PEDIATRIC STROKE POPULATION.

LONG-TERM PSYCHOSOCIAL, ADAPTIVE AND BEHAVIORAL OUTCOMES IN CHILDREN WITH ARTERIOVENOUS MALFORMATIONS (AVM) AND THEIR FAMILIES.

DOMAINS OF EXECUTIVE FUNCTIONING FOLLOWING EARLY, FOCAL BRAIN DAMAGE.

NEUROPSYCHOLOGICAL BASES OF EVERYDAY COGNITIVE PROBLEMS IN ADOLESCENTS TREATED FOR CRANIOPHARYNGIOMA.

ESTIMATION OF PREMORBID COGNITIVE ABILITY IN CHILDREN TREATED FOR MEDULLOBLASTOMA. COMPARISON OF NEUROCOGNITIVE FUNCTION FOLLOWING INTENSITY-MODULATED RADIATION THERAPY (IMRT) VERSUS CONVENTIONAL RADIATION THERAPY (CRT) FOR MEDULLOBLASTOMA IN CHILDREN. 


37. JANUSZ, J
38. CAREY, $\mathrm{M}$
39. MRAKOTSKY, $\mathrm{C}$
40. HERSHEY, T
41. ISQUTTH, P
42. STEWART, M
43. HINTON, $\mathrm{V}$
44. CYRULNIK, S
45. MCLAUGHLIN-BELTZ,
46. KHEMANI, E
47. PURZNER, J
48. TRAUNER, D
49. GARRELS, S
50. O'LEARY, S
51. BORDEN, K
52. ZAROFF, C

11:15 AM-12:00 PM

Invited Plenary

The Neuroanatomical Substrate of Category-Specific Disorders

Guido Gainotti

Room: Harborside ABC

1:00 PM - 3:00 PM Invited Symposium

How Neuropsychology Drives Neuroimaging Research

Chair: Stephen Rao, Discussant: Stephen Rao

Room: Harborside ABC

$\begin{array}{ll}\text { 1. } & \text { RAO, S } \\ \text { 2. } & \text { FIEZ, J } \\ \text { 3. } & \text { CARTER, C } \\ \text { 4. } & \text { CASEY, B }\end{array}$

\section{1:00 PM - 3:00 PM}

Paper Session 5

Neuropsychological Outcomes of Childhood Injury

Room: Harborside DE

HOW NEUROPSYCHOLOGY DRIVES NEUROIMAGING RESEARCH. CONFLICT, COGNITIVE CONTROL, AND THE FRONTAL LOBES. NEUROPSYCHOLOGICAL AND FUNCTIONAL NEUROIMAGING STUDIES OF WORKING MEMORY.

NEURAL CORRELATES OF COGNITIVE CONTROL: CLINICAL, LESION AND IMAGING STUDIES.

INTRAVENTRICULAR HEMORRHAGE AND COGNITIVE OUTCOME IN EXTREMELY LOW BIRTH WEIGHT PRESCHOOLERS.

LONG-TERM OUTCOMES OF VERY LOW BIRTH WEIGHT.

THE INFLUENCE OF MATERNAL SMOKING DURING PREGNANCY ON COGNITION AND BEHAVIOR DURING THE PRE-SCHOOL PERIOD.

NEUROPSYCHOLOGICAL FINDINGS IN NEGLECTED VERSUS TYPICALLY DEVELOPING CHILDREN. POSTCONCUSSIVE SYMPTOMS IN CHILDREN WITH MILD HEAD INJURY: A PRELIMINARY REPORT. PREDICTORS OF READING AFTER TRAUMATIC BRAIN INJURY IN CHILDREN.

PATHOPHYSIOLOGY AND COGNITIVE FUNCTION FOLLOWING TRAUMATIC BRAIN INJURY IN CHILDREN: A PROTON SPECTROSCOPY STUDY.

\section{1:00 PM - 3:00 PM}

Paper Session 6 Cognitive Response to Metabolic \& Structural Brain Insults Room: Essex

\footnotetext{
1. CLASON, C

2. WHITE, J

3. ALOIA, M

4. ARMSTRONG, C
}

CALLOSAL DAMAGE IN CARBON MONOXIDE POISONING:STRUCTURAL CHANGES AND COGNITIVE CORRELATES.

NEUROCOGNITIVE FUNCTION IN PATIENTS WITH PULMONARY ARTERIAL HYPERTENSION. THE EFFECTS OF CPAP TREATMENT ON WORKING MEMORY AND MR SIGNAL IN SLEEP APNEA. HIPPOCAMPAL RESPONSE TO NEURO-ONCOLOGICAL STRESSORS. 
5. MUELLER-OEHRING, E VISUOSPATIAL PROCESSING IN ALCOHOLISM AND AGING: INHIBITORY DEFICITS IN A GLOBAL/LOCAL LETTER TASK.

6. SCHWEINSBURG, B RECOVERY OF BRAIN FMRI RESPONSE TO A SPATIAL WORKING MEMORY TASK IN ABSTINENT ALCOHOLICS.

FUNCTIONAL IMPLICATIONS OF IPSILESIONAL MOTOR DEFICITS AFTER UNILATERAL STROKE.

7. WETTER, S

8. BREIER, J

1:00 PM - 3:30 PM MAPS OF RECEPTIVE LANGUAGE FUNCTION IN PATIENTS WITH CHRONIC APHASIA AFTER STROKE USING MAGNETOENCEPHALOGRAPHY.

1. ZIZAK, V

Poster Session 4

Neuropsychological Functions in Subcortical Disorders

Room: Grand Ballroom

\section{Subcortical Dementia}

DO ALL PATIENTS WITH SUBCORTICAL PATHOLOGY SHOW A MEMORY RETRIEVAL DEFICIT?

\section{Parkinson's Disease}

2. CRUCIAN, G

3. SIMARD, $\mathrm{M}$

4. YORK, M

5. BROWN, A

6. RHODES, R

7. DAVIDSDOTTIR, S

8. DAVIDSDOTTIR, S

9. AMICK, M

10. KRCH, D

11. LUBOMSKI, M

12. BOWERS, D

13. FARELLA-BUSCH, S

14. ZGALJARDIC, D

15. CHANG, Y

16. SIDERS, C

17. MILLER, $\mathrm{K}$

18. STOLWYK, R

MEMORY IN PARKINSON'S DISEASE: A STEP-WISE ANALYSIS. DIFFERENTIAL IMPAIRMENT OF WORKING MEMORY IN DEMENTIA WITH LEWY BODIES AND PARKINSON'S DISEASE.

INFORMATION PROCESSING SPEED INFLUENCES THE COMPONENT PROCESSES OF VERBAL WORKING MEMORY IN PARKINSONS DISEASE PATIENTS.

VERBAL PERSEVERATIONS IN PATIENTS WITH PARKINSONS DISEASE (PD): RELATION TO DEFICITS IN COGNITIVE PLANNING.

EVIDENCE FOR A PERIPERSONAL SPATIAL BIAS IN PEOPLE WITH PARKINSON'S DISEASE.

DOUBLE DISSOCIATION OF PERFORMANCE ON CLASSIC AND EMOTIONAL STROOP TASKS IN PARKINSON'S DISEASE OF LEFT- VS. RIGHT-SIDE MOTOR ONSET.

ALEXITHYMIA IN PARKINSON'S DISEASE.

BODY SIDE OF PARKINSON'S DISEASE MOTOR SYMPTOM ONSET PREDICTS PERFORMANCE ON HIERARCHICAL PATTERN PERCEPTION.

PERCEPTION OF EMOTION: A PRELIMINARY COMPARISON OF PARKINSON'S DISEASE AND HEALTHY SUBJECTS

NEURAL SUBSTRATES UNDERLYING EMOTIONAL PROCESSING DEFICITS IN PARKINSON'S DISEASE. STARTLING FACTS ABOUT EMOTION IN PARKINSON'S DISEASE.

COGNITIVE AND EMOTIONAL OUTCOME OF SUBTHALAMIC NUCLEUS DEEP BRAIN STIMULATION. A NEUROPSYCHOLOGICAL EVALUATION OF COGNITIVE AND BEHAVIORAL IMPAIRMENTS IN PARKINSON'S DISEASE: RELATIONSHIPS TO FRONTOSTRIATAL CIRCUITRY.

SELF-AWARENESS OF MOTOR AND NEUROCOGNITIVE FUNCTIONS IN NONDEMENTED PATIENTS WITH IDIOPATHIC PARKINSON'S DISEASE.

SELF-REPORT VERSUS CLINICIAN BASED RATINGS OF DEPRESSION ACROSS MILD, MODERATE AND SEVERE STAGES OF PARKINSONS DISEASE.

REDUCED FEAR-POTENTIATED STARTLE IN MEDICATED PARKINSON'S DISEASE PATIENTS. AN INVESTIGATION OF DRIVING PERFORMANCE IN PEOPLE WITH PARKINSON'S DISEASE.

\section{Huntington's Disease}

19. НОТН, К

20. JOHNSON, S

21. NEHL, C

22. CAMPBELL, M

23. SOLOMON, A

SIMPLE AND CHOICE REACTION TIME IS ASSOCIATED WITH ESTIMATED NEARNESS TO SYMPTOM ONSET IN PRESYMPTOMATIC HUNTINGTON'S DISEASE (HD).

RECOGNITION OF STATIC AND DYNAMIC FACIAL EXPRESSIONS IN THE PREDICT-HD COHORT AT BASELINE.

EARLY CHANGES IN PSYCHOMOTOR SPEED IN PRESYMPTOMATIC HUNTINGTON'S DISEASE. ASSOCIATIONS BETWEEN ESTIMATED YEARS TO ONSET AND PERFORMANCE ON COMPUTERIZED 3 AND 4 DISK TOWER TASKS IN THE PREDICT-HD COHORT AT BASELINE. DIFFERENTIAL PATTERNS ON THREE EPISODIC MEMORY TESTS IN ALZHEIMER'S DISEASE AND HUNTINGTON'S DISEASE.

\section{Vascular Dementia}

24. KANG, Y

25. JEFFERSON, A

26. GUNSTAD, J

A COMPARISON OF NEUROPSYCHOLOGICAL FUNCTIONS BETWEEN SUBCORTICAL VAD AND AD. PREDICTORS OF INSTRUMENTAL ACTIVITIES OF DAILY LIVING (IADL) IMPAIRMENT IN VASCULAR DEMENTIA (VAD).

PROGRESSIVE COGNITIVE DECLINE IN VASCULAR DEMENTIA SUBTYPES. 


\author{
27. BENEDICT, R \\ 28. SWEET, L \\ 29. LENGENFELDER, J \\ 30. SHUCARD, J \\ 31. BEATTY, W \\ 32. KALMAR, J \\ 33. ARNETT, P \\ 34. GAINES, J \\ 35. SANCHEZ, A \\ 36. MITCHELL, S \\ 37. LENGENFELDER, J \\ 38. OUELLET, J \\ 39. STROBER, L \\ 40. KING, K \\ 41. HEINZE, L \\ 42. HEINZE. L \\ 43. JULIAN, L \\ 44. BRUCE, J \\ 45. POLEN D \\ 46. WAHLIG, E \\ 47. RANDOLPH, J \\ 48. GOVEROVER, Y \\ 49. MACALLISTER, W \\ 50. ERGH, T \\ 51. SCHURLE, A \\ 52. GENOVA, H \\ 53. SMITH, M
}

54. MOELTER, S

3:15 PM - 4:00 PM

3:45 PM - 6:00 PM

1. LARRABEE, G

2. HALL, S

3. JOHNSON, A

4. BACKHAUS, $\mathrm{S}$

5. HORNER, M

6. DENBOER, J

\section{Multiple Sclerosis}

VALIDATION OF A CONSENSUS PANEL NEUROPSYCHOLOGICAL BATTERY FOR MS PATIENTS. FMRI OF VERBAL WORKING MEMORY TASK DIFFICULTY AMONG MULTIPLE SCLEROSIS PATIENTS. DOES INCREASING INFORMATION PROCESSING TIME IMPROVE WORKING MEMORY ACCURACY IN MS? EVENT-RELATED POTENTIALS AND WORKING MEMORY DEFICITS IN MULTIPLE SCLEROSIS.

MS, PERSEVERATION AND THE WCST.

INFORMATION PROCESSING DEFICITS IN MULTIPLE SCLEROSIS: PROPERTIES OF SCREENING INSTRUMENTS.

RUDIMENTARY MOTOR SPEED CONTRIBUTES SIGNIFICANTLY TO PERFORMANCE ON NEUROPSYCHOLOGICAL TESTS WITH MOTOR DEMANDS IN MS PATIENTS.

INCONSISTENCY DURING VISUAL LEARNING IS CORRELATED WITH DELAYED RECALL AND CEREBRAL ATROPHY IN MS.

THE ROLE OF SEMANTIC MEMORY IN VERBAL FLUENCY TASKS IN MULTIPLE SCLEROSIS PATIENTS. THE NATURE OF VERBAL MEMORY IMPAIRMENT IN MULTIPLE SCLEROSIS: A LIST-LEARNING AND META-ANALYTIC STUDY.

ARE THERE GENDER DIFFERENCES IN VERBAL LEARNING AND MEMORY FOR INDIVIDUALS WITH MULTIPLE SCLEROSIS?

THEORY OF MIND AND FRONTAL LOBE SEMIOLOGY IN ADULTS WITH MULTIPLE SCEROSIS.

THE PREVALENCE AND ETIOLOGY OF FATIGUE IN MULTIPLE SCLEROSIS (MS) IN COMPARISON TO HEALTHY CONTROLS.

ASSOCIATION OF DEPRESSION, FATIGUE, AND COGNITIVE IMPAIRMENT WITH DYADIC ADJUSTMENT IN MULTIPLE SCLEROSIS.

THE RELATIONSHIP BETWEEN PERCEIVED AND OBJECTIVE COGNITIVE FUNCTIONING AND DEPRESSION IN MULTIPLE SCLEROSIS PATIENTS.

ARE DEPRESSION AND ANXIETY OVERESTIMATED IN MULTIPLE SCLEROSIS?

EXECUTIVE FUNCTIONING IS A DIFFERENTIAL PREDICTOR FOR RESPONSE TO TREATMENT FOR DEPRESSION IN MULTIPLE SCLEROSIS.

SELF-REPORTED PAIN AND EMOTIONAL MEMORY BIASES INTERACT TO PREDICT DEPRESSION IN MULTIPLE SCLEROSIS.

CHRONIC PAIN IS ASSOCIATED WITH LEARNED HELPLESSNESS IN MS.

PREDICTING QUALITY OF LIFE IN MULTIPLE SCLEROSIS: ACCOUNTING FOR DISEASE COURSE, PHYSICAL DISABILITY, FATIGUE, COGNITION, DEPRESSION, PERSONALITY, AND BEHAVIOR DISORDER.

SUBJECTIVE REPORTS OF EXECUTIVE FUNCTIONING IN MULTIPLE SCLEROSIS: RELATIONSHIP BETWEEN THE METEX AND COGNITIVE PERFORMANCE.

CONCORDANCE BETWEEN PATIENT AND FAMILY BEHAVIORAL RATINGS AND ITS RELATIONSHIP WITH COGNITIVE PERFORMANCE IN MULTIPLE SCLEROSIS.

COGNITION AND CLINICAL FACTORS IN EARLY-ONSET MULTIPLE SCLEROSIS.

AWARENESS OF DEFICIT IN INDIVIDUALS WITH MULTIPLE SCLEROSIS.

LONGITUDINAL EXAMINATION OF PSYCHOPATHOLOGY IN MS PATIENTS.

THE RELATIONSHIP BETWEEN NEUROPSYCHOLOGICAL MEASURES AND THE TIMED INSTRUMENTAL ACTIVITIES OF DAILY LIVING TASK IN MS AND TBI.

STABILITY OF COPING STRATEGIES IN MULTIPLE SCLEROSIS: DATA FROM A LONGITUDINAL STUDY.

\section{Marchiafava-Bignami Disease}

PROGRESSION OF NEUROPSYCHOLOGICAL DEFICITS IN A CASE OF MARCHIAFAVA-BIGNAMI DISEASE.

\section{Benton Award Winner}

Neuropsychology and Neurodegeneration

Julie Snowden

Room: Harborside ABC

Poster Session 5

Issues in Neuropsychological Assessment and Outcome

Room: Grand Ballroom

\section{Assessment of Effort and Malingering}

IDENTIFICATION OF SUBTYPES OF MALINGERED NEUROCOGNITIVE DYSFUNCTION.

CURRENT USE OF MALINGERING MEASURES: A PRELIMINARY STUDY.

THE ROLE OF SELF-AWARENESS AND EVOLUTION IN DECEPTION.

EXAMINATION OF THE FLOOR EFFECT METHOD IN THE DETECTION OF THE SUB-OPTIMAL PERFORMANCE IN A TRAUMATIC BRAIN INJURY SAMPLE.

AN ABBREVIATED FORM OF THE TEST OF MEMORY MALINGERING.

TOMM VS. WCST: TOMM CLASSIFIES COACHED MALINGERERS AND CONTROLS MORE ACGURATELY. 
7. WEINBORN, M

8. GREVE, $\mathrm{K}$

9. BABIKIAN, T

10. ASHENDORF, L

11. LARRABEE, GJ

12. VAGNINI, VL

13. GROTE, C

14. NELSON, N

15. ARNOLD, G

16. SOLLMAN, M

17. NEUDECKER, J

18. LANGE, $\mathrm{R}$

19. BAUER, L

20. LUIS, CA

21. BAUER, L

22. SHERWOOD, A

23. RAMIREZ, M

24. GOMEZ-PEREZ, E

25. PORTOCARRERO, J

26. SANCHEZ, D

27. ARBOLEDA, A

28. MUNTAL, S

29. OJEDA, N

30. NAGRA, A

31. HO, M

32. KANG, Y
A COMPARISON OF THREE SYMPTOM VALIDITY TESTS IN FORENSIC PSYCHIATRIC INPATIENTS. AGREEMENT BETWEEN THE STANDARD AND ABBREVIATED FROMS OF THE PORTLAND DIGIT RECOGNITION TEST.

SENSITIVITY AND SPECIFICITY OF VARIOUS DIGIT SPAN SCORES IN THE DETECTION OF SUSPECT EFFORT.

DETECTION OF SUBOPTIMAL EFFORT WITH THE WISCONSIN CARD SORTING TEST: THE UNIQUE RESPONSES AND PERFECT MATCHES MISSED INDICES.

SUBTYPES OF MMPI-2 PROFILES IN MALINGERED NEUROCOGNITIVE DYSFUNCTION.

EFFECTIVENESS OF MMPI-2 VALIDITY SCALES FOR DETECTION OF MALINGERED NEUROCOGNITIVE DEFICIT

MMPI-2 OBVIOUS-SUBTLE DIFFERENCE SCORES PREDICT FAILURE ON THE VICTORIA SYMPTOM VALIDITY TEST.

DO MMPI-2 "CONVERSION V" PROFILES IMPACT POOR PERFORMANCES ON THE VICTORIA SYMPTOM VALIDITY TEST?

SENSITIVITY AND SPECIFICITY OF THE FINGER TAPPING TEST FOR DETECTING SUSPECT EFFORT. VALIDITY OF THE LETTER MEMORY TEST IN A COMPENSATION-SEEKING TBI POPULATION. DIRECTED FORGETTING AS A MEASURE OF MALINGERING.

EVALUATING SUPPRESSED ATTENTION ON THE WMS-III AS A MARKER FOR POOR EFFORT.

\section{Cross-Cultural Neuropsychological Assessment}

AN EXAMINATION OF THE SYMBOL DIGIT MODALITIES TEST IN A RACIALLY DIVERSE NON-NEUROLOGICALLY IMPAIRED SAMPLE.

SENSITIVITY AND SPECIFICITY OF THE 7-MINUTE SCREEN IN AFRICAN AMERICAN AND CARIBBEAN BLACKS.

AN EXAMINATION OF PERFORMANCE ON THE BOSTON NAMING TEST IN A NONCLINICAL SOUTHERN SAMPLE.

NEUROPSYCHOLOGICAL TEST PERFORMANCE AMONG NAVAJO NATIVE AMERICANS.

EFFECTS OF AGE AND EDUCATION ON VERBAL FLUENCY. NORMATIVE DATA IN SPANISH SPEAKING POPULATION.

NEUROPSYCHOLOGICAL EVALUATION OF ATTENTION AND MEMORY IN A SPANISH SPEAKING POPULATION: NORMATIVE DATA FROM 6 TO 85 YEARS OF AGE.

RELATIONSHIP BETWEEN TWO EXPRESSIVE LANGUAGE MEASURES IN MONOLINGUAL AND BILINGUAL COLLEGE STUDENTS.

CLINICAL UTILITY OF WAIS-III PERFORMANCE SUBTESTS AMONG URBAN SPANISH-SPEAKING HISPANICS AND WHITE ELDERS.

UTILITY OF A SEMANTIC CUE RECALL MEMORY TEST,SHORTENED VERSION, FOR DEMENTIA DIAGNOSIS IN A COLOMBIAN POPULATION.

RBANS-A: TRANSLATION AND ADAPTATION FOR SPANISH PEOPLE (SPAIN).

CROSS-CULTURAL EQUIVALENCE OF TWO TESTS OF ATTENTION.

THE EFFECTS OF STATE ANXIETY ON NEUROPSYCHOLOGICAL PERFORMANCE IN THE ASIAN-INDIAN POPULATION IN THE UNITED STATES.

THE USE OF A PERFORMANCE-CURVE METHOD FOR DETECTING EXPERIMENTALLY SIMULATED COGNITIVE IMPAIRMENT IN TAIWANESE PARTICIPANTS - A PRELIMINARY STUDY.

AGE- AND EDUCATION-RELATED COGNITIVE AND BEHAVIORAL CHANGES IN THE KOREAN ELDERLY.

\section{Cognitive Rehabilitation}

EXPRESSIVE APROSODIA RESPONDS TO BEHAVIORAL TREATMENT.

COMPARISON OF NOUN RETRIEVAL TREATMENT EFFECTS IN APHASIA.

IMPROVED NAMING AFTER RTMS TREATMENT IN CHRONIC APHASIA PATIENTS.

SUSTAINED IMPROVED NAMING AFTER RTMS TREATMENT IN A SEVERE APHASIA PATIENT. IMPROVEMENT IN MOOD SCALE FOR CHRONIC APHASIA PATIENTS TREATED WITH RTMS.

CUEING TREATMENT FOR NAMING DEFICIT AND GENERALIZATION TO CONNECTED SPEECH. FMRI IN SEVERE APHASIA: SEMANTIC YES/NO DECISIONS ON 'ICON SENTENCES' IN C-VIC. TREATMENT OF APHASIC PERSEVERATION: ERRORFUL VS ERRORLESS COMPARISON. COMPARISON OF ERRORLESS AND ERRORFUL LEARNING IN APHASIA REHABILITATION. ALLOGRAPHIC CONVERSION TRAINING IN A PATIENT WITH PURE AGRAPHIA.

THE EFFECT OF TWO TYPES OF MEMORY TRAINING AND CHARACTERISTICS OF PARTICIPANTS. MULTIFACTORIAL MEMORY TRAINING PROGRAM FOR OLDER ADULTS.

EFFECT OF CIRCADIAN PREFERENCE ON NEUROPSYCHOLOGICAL PERFORMANCE AMONG REHABILITATION INPATIENTS.

DEVELOPMENT OF A JOB COACHING PROGRAM PERFORMED BY THE MEDICAL REHABILITATION TEAM FOR PATIENTS WITH HIGHER BRAIN DYSFUNCTION.

IMPROVED COGNITION WITH METHYLPHENIDATE STATUS POST CEREBELLAR TUMOR RESECTION. DONEPEZIL AND THE POTENTIAL TREATMENT BENEFITS OF CHOLINERGIC STIMULATION IN POLYDRUG USE: A CASE STUDY. 
49. WOODS, A

50. WOODS, A

51. WOODS, A

52. HEUTINK, J

53. BUXBAUM, L

ALTERATIONS IN STIMULUS RESPONSE INFLUENCE CANCELLATION PERFORMANCE. ALTERED MAGNITUDE ESTIMATION IN NEGLECT FOLLOWING LEFT-HEMISPHERE DAMAGE IMPROVES WITH PHARMACOLOGIC TREATMENT FOR AROUSAL.

CALORIC STIMULATION IN NEGLECT: NOT JUST FOR THE VESTIBULAR SYSTEM ANYMORE. TENS IMPROVES SPATIAL DETECTION IN A NEGLECT PATIENT.

INCONSISTENT EFFECTS OF PRISM TREATMENT IN POST-ACUTE NEGLECT.

\section{Prediction of Functional Outcome}

PREDICTING REHABILITATIVE TREATMENT SUCCESS IN CHRONIC NONFLUENT APHASIA: LESION AND PERFORMANCE CHARACTERISTICS.

55. JOHNSON-GREENE, D

56. BOYLE, $\mathrm{P}$

57. TANEJA, C

58. GORSKE, $\mathrm{T}$

59. MEYER, S

60. KREITER, $\mathrm{K}$

61. MOLFESE, D

62. WHITESIDE, D

63. KANG, E

\section{4:15 PM - 6:00 PM}

1. BAIRD, A

2. ESPY, K

3. SANTRA, A

4. HAN, S

5. BOYCE, A

6. SCHWEINSBURG, A

\section{4:15 PM - 6:00 PM}

1. DUFF, M

2. CHAN, A

3. REED, L

4. PARSONS, M

5. DAVIS, R

6. ARMSTRONG, C

\section{4:15 PM - 6:00 PM}

NEUROPSYCHOLOGICAL CORRELATES OF FUNCTIONAL COOKING SKILLS IN PATIENTS WITH STROKE. EXAMINING THE NEUROPSYCHOLOGICAL DETERMINANTS OF FUNCTIONAL IMPAIRMENT IN ALZHEIMER'S DISEASE: WHICH DEFICITS MATTER THE MOST?

UTILITY OF THE GVLT-II SHORT FORM IN PREDICTING FUNCTIONAL OUTCOME POST-STROKE. NEUROPSYCHOLOGICAL FUNCTION AND EMPLOYMENT STATUS IN A WELFARE-TO-WORK SAMPLE. CORRELATES OF RETURN TO WORK FOLLOWING STROKE.

COGNITIVE RECOVERY AFTER SUBARACHNOID HEMORRHAGE IS ASSOGIATED WITH IMPROVEMENTS IN FUNCTIONAL ABILITY, MOOD AND QUALITY OF LIFE.

EVENT-RELATED POTENTIAL INDICES OF BRAIN REORGANIZATION IN SENSORY AND MOTOR AREAS IN A HAND TRANSPLANT PATIENT.

RELATIONSHIP BETWEEN DEPRESSION AND FUNCTIONAL IMPROVEMENT IN CEREBROVASCULAR ACGIDENT INPATIENT UNDERGOING PHYSICAL REHABILITATION.

NEURAL CORRELATES FOR SUCCESSFUL SPEECH PERCEPTION REHABILITATION FOLLOWING COCHLEA IMPLANTATION IN PROFOUND DEAF CHILDREN: FDG-PET STUDIES.

\section{Paper Session 7 \\ Studies of Normal Development in Children \\ Room: Harborside AB}

EXECUTIVE FUNCTION AND FRONTAL LOBE DEVELOPMENT.

MODELS OF EXECUTIVE CONTROL ORGANIZATION IN YOUNG CHILDREN.

THE DEVELOPMENT OF EXECUTIVE FUNCTIONS IN PRESCHOOLERS: A LONGITUDINAL STUDY. RELATIONSHIPS BETWEEN IQ AND PERFORMANCE ON THE DELIS-KAPLAN EXECUTIVE FUNCTION SYSTEM IN CHILDREN.

FMRI EVIDENCE OF DEVELOPMENTAL CHANGES IN MOTOR INHIBITION.

FMRI OF RESPONSE INHIBITION ACROSS ADOLESCENT DEVELOPMENT.

\author{
Paper Session 8 \\ Investigations of Memory Disorders \\ Room: Harborside C
}

THE INTERACTION OF DIFFERENT MEMORY AND COGNITIVE SYSTEMS IN HANDLING REAL-WORLD MEMORY DEMANDS: A CASE STUDY.

AMNESIA IN A PATIENT WITH BILATERAL LATERAL TEMPORAL LOBECTOMY WITH SPARED HIPPOCAMPUS.

RETROSPLENIAL AND MEDIAL TEMPORAL CORTICAL METABOLISM CORRELATE WITH MEMORY PERFORMANCE IN AMNESIA ARISING FROM TEMPORAL HERPES ENCEPHALITIS AND FRONTAL LOBE PATHOLOGY.

ENCODING OF NOVEL WORDS: PREFERENTIAL ACTIVATION OF THE ANTERIOR MESIAL TEMPORAL LOBE WITH FMRI.

IS BASIC MEMORY STRUCTURE INVARIANT ACROSS EPILEPSY PATIENT SUBGROUPS?

EARLY-DELAYED RADIOTHERAPY DAMAGE AFFECTS WIDESPREAD SEMANTIC MEMORY NETWORKS.

\author{
Symposium 8 \\ Neuropsychological Assessment in Less Common Medical Disorders \\ Chair: James Jackson, Discussant: Erin Bigler \\ Room: Essex
}

1. JACKSON, J
2. HOPKINS, R
3. GALE, S
4. JACKSON, J

NEUROPSYCHOLOGICAL ASSESSMENT IN LESS COMMON MEDICAL DISORDERS. NEUROPSYCHOLOGICAL SEQUELAE FOLLOWING ACUTE RESPIRATORY DISTRESS SYNDROME (ARDS). OBSTRUCTIVE SLEEP APNEA AND LONG-TERM COGNITIVE DYSFUNCTION: CURRENT ISSUES AND FUTURE DIRECTIONS.

DELIRIUM AND LONG-TERM COGNITIVE OUTCOMES: A LITTLE RECOGNIZED PROBLEM. 


\section{4:15 PM - 6:00 PM}

1. FERMAN, T

2. BECKER, J

3. FERMAN. T

4. SALMON. D

\section{4:15 PM - 6:00 PM}

1. BILDER, $\mathrm{R}$

2. FERRIS, $\mathrm{S}$

3. BARR, W

4. DELUCA, J

5. BILDER, $\mathrm{R}$
Symposium 9

Distinguishing Dementia With Lewy Bodies (DLB) From Alzheimer's Disease (AD) Chair: Tanis Ferman, Discussant: Clive Ballard

Room: Laurel

DISTINGUISHING DEMENTIA WITH LEWY BODIES (DLB) FROM ALZHEIMER'S DISEASE (AD). LEWY BODIES IN PROBABLE ALZHEIMER'S DISEASE DO NOT ALTER THE PRESENTATION OR COURSE OF THE DEMENTIA.

CLINICAL AND COGNITIVE FEATURES THAT DISTINGUISH DLB FROM AD IN CLINICAL AND NEUROPATHOLOGICALLY-CONFIRMED SAMPLES.

DISTINCT PATTERNS OF COGNITIVE DEFICITS IN NEUROPATHOLOGICALLY-CONFIRMED DEMENTIA WITH LEWY BODIES AND "PURE” ALZHEIMER'S DISEASE.

\section{Symposium 10}

Drug Treatment of Neuropsychological Disorders: Clinical and Regulatory Issues Chair: Robert Bilder, Discussant: Russell G. Katz Room: Harborside DE

DRUG TREATMENT OF NEUROPSYCHOLOGICAL DISORDERS: CLINICAL AND REGULATORY ISSUES. NEW DIRECTIONS IN THE TREATMENT OF DEMENTIA AND RELATED DISORDERS. ASSESSING TREATMENT EFFECTS: CONTRIBUTIONS FROM THE EPILEPSY LITERATURE. DRUG TREATMENT OF NEUROPSYCHOLOGICAL IMPAIRMENTS IN PERSONS WITH TRAUMATIC BRAIN INJURY.

DRUG TREATMENT OF COGNITIVE INDICATIONS IN SCHIZOPHRENIA: NEW TARGETS AND REGULATORY ISSUES. 


\section{FRIDAY, FEBRUARY 6, 2004}

8:00 AM - 10:00 AM
Poster Session 6

Psychometric Studies of Tried and True as Well as New Neuropsychological Instruments

Room: Grand Ballroom
1. SHORT, $\mathrm{P}$

2. BERNS, S

3. DAVIS, A

4. BALL, T

5. BUFFINGTON, A

6. SCHOENBERG, M

7. GONTKOVSKY, S

8. WILDE, M

9. DUFF, K

10. ESPE-PFEIFER, P

11. LANGE, $R$

12. SCHOENBERG, M

13. ROEBUCK-SPENCER, T

14. BARRASH, J

15. BEGLINGER, L

16. GUALTIERI, C

17. JOHNSON, L

18. STERN, R

19. WHITE, T

20. LEDBETTER, M

21. MACAULAY, $\mathrm{C}$

22. LEDBETTER, M

23. STERN, R

24. MARON. L

25. SPENCER, $R$

26. LOUREIRO, C

27. BYRD, D

28. CHERVINSKY, A

29. GONTKOVSKY, S

30. CRUCIAN, G

31. NAKASE-THOMPSON, R

32. SCHUTTE, C

33. NAKAGAWA, S

\section{Measures of Broad Neuropsychological Functions}

CONSTRUCT VALIDIATION THROUGH CONFIRMATORY FACTOR ANALYSIS OF PREVIOUSLY PUBLISHED AND RAW DATA.

POSETS: A NEW APPROACH TO ANALYZING NEUROPSYCHOLOGICAL DATA IN LARGE SAMPLES.

EVALUATING THE RELATIONSHIP BETWEEN THE COGNITIVE ASSESSMENT SYSTEM AND ACHIEVEMENT.

THE UTILITY OF THE BRIEF NEUROPSYCHOLOGICAL COGNITIVE EXAMINATION AS A SCREENING TEST FOR NEUROPSYCHOLOGICAL FUNCTIONING.

A LIMITATION IN USING THE NART-R TO PREDICT NEUROPSYCHOLOGICAL TEST PERFORMANCE.

AN EVALUATION OF THE CLINICAL UTILITY OF THE COMBINED OKLAHOMA PREMORBID INTELLIGENCE ESTIMATE (COPIE) AS AN PREDICTOR OF PREMORBID WAIS-III FSIQ.

DIFFERENTIAL CLASSIFICATION OF GLOBAL IMPAIRMENT BETWEEN THE MMSE AND THE RBANS.

THE INFLUENCE OF EDUCATION AND AGE ON THE REPEATABLE BATTERY FOR NEUROPSYCHOLOGICAL STATUS (RBANS) IN A MIXED CLINICAL SAMPLE.

PREDICTING CHANGE WITH THE RBANS IN AN ELDERLY SAMPLE.

EXPLORATORY FACTOR ANALYSIS OF THE WAIS-III AND WMS-III IN A HETEROGENEOUS NEUROPSYCHOLOGICAL POPULATION.

INTERPRETIVE EFFECTS OF USING CANADIAN VERSUS AMERICAN WAIS-III NORMATIVE SYSTEMS.

CLINICAL VALIDATION OF THE GENERAL ABILITY INDEX-ESTIMATE (GAI-E) AS A PREDICTOR OF WAIS-III GENERAL ABILITY INDEX (GAI) SCORES.

INFLUENCE OF AGE, SEX, AND EDUCATION ON THE AUTOMATED NEUROPSYCHOLOGICAL ASSESSMENT METRICS (ANAM).

APPLICABILITY OF PUBLISHED NORMS VS. NORMS DERIVED FROM SPECIALIZED CONTROL GROUPS: EFFECT ON ASSESSMENT OF NEUROPSYCHOLOGICAL FUNCTIONING AMONG GULF WAR VETERANS

PRACTICE EFFECTS IN SERIAL ASSESSMENT ON THE CANTAB AND STANDARD NEUROPSYCHOLOGICAL TESTS IN HEALTHY ELDERLY VOLUNTEERS.

RELIABILITY AND VALIDITY OF A BRIEF COMPUTERIZED NEUROCOGNITIVE SCREENING BATTERY. DRUG SENSITIVITY OF A COMPUTERIZED NEUROCOGNITIVE TEST BATTERY.

INTRODUCTION TO THE NEUROPSYCHOLOGICAL ASSESSMENT BATTERY (NAB).

STANDARDIZATION AND NORMING OF THE NEUROPSYCHOLOGICAL ASSESSMENT BATTERY (NAB). RELIABILITY OF THE NEUROPSYCHOLOGICAL ASSESSMENT BATTERY (NAB).

VALIDITY EVIDENCE FOR THE NEUROPSYCHOLOGICAL ASSESSMENT BATTERY (NAB): HOW DOES THE NAB COMPARE TO EXISTING TESTS?

VALIDITY EVIDENCE BASED ON THE INTERNAL STRUCTURE OF THE NEUROPSYCHOLOGICAL ASSESSMENT BATTERY (NAB).

VALIDITY EVIDENCE FOR THE NEUROPSYCHOLOGICAL ASSESSMENT BATTERY (NAB): SENSITIVITY, SPECIFICITY, AND CLINICAL PROFILES.

\section{Measures of Specific Neuropsychological Functions}

DETECTING ATTENTIONAL DEFICITS USING THE COGTEST.

INTERNAL CONSISTENCY AND TEMPORAL STABILITY OF THE CONNERS' CONTINUUUS PERFORMANCE TEST: A STATE NOT TRAIT MEASURE.

BEHAVIOURAL INATTENTION TEST: NORMATIVE DATA AND THE NEED FOR A NEW CRITERION. AN EXPLORATION OF THE COMPARABILITY OF DIGIT AND SPATIAL SPAN IN AN ELDERLY AFRICANAMERICAN SAMPLE.

SPEED OF INFORMATION PROCESSING: PERFORMANCE OF CLINICAL GROUPS, INTRAINDIVIDUAL VARIABILITY.

NON-TRADITIONAL CLINICAL ASSESSMENT OF INFORMATION PROCESSING SPEED

THE RELATEDNESS JUDGMENTS TASK: A TEST OF SEMANTIC ASSOCIATION.

BRIEF ASSESSMENT OF SEVERE LANGUAGE IMPAIRMENTS: INITIAL VALIDATION OF THE MISSISSIPPI APHASIA SCREENING TEST.

THE IMPACT OF VISUAL CONTRAST SENSITIVITY ON NEUROPSYCHOLOGICAL PERFORMANCE

EFFECTS OF VISUAL ACUITY, CONTRAST SENSITIVITY \& COLOR VISION ON VISUALLY MEDIATED NEUROPSYCHOLOGICAL TESTS. 
34. DUFF, K

35. BAKER, T

36. JONSDOTTIR, M

37. RASKIN, $\mathrm{S}$

38. KNIGHT, R

39. BUTTARO, M

40. MCGEE, L

41. DANIEL, M

42. SMERZ, J

43. JOHNSON-GREENE, D

44. BROWN, F

45. KILGOUR, A

46. GAINES, J

47. BROOKER, M

48. LEVY, B

49. SHA, S

50. PROVENCAL, S

51. CRAIG, N

52. NELSON, E

53. SUCHY, Y

54. BARRY, D

55. ZINN, S

56. ECKLUND-JOHNSON, E

57. GIOIA, G

58. ISQUITH, $\mathrm{P}$

59. STORTEBOOM, J

60. CANNIZZARO, M

61. MORDHORST, M

62. O'CONNELL, P

63. MILLER, J

64. KAISER, H

\section{9:00 AM - 11:00 AM}

1. DICKINSON, D

2. SHEER, JB

3. MOELTER, $\mathrm{S}$

4. SHEER, J

5. FULLER, $\mathrm{R}$

6. KELLY, K

7. KURTZ, M

\section{9:00 AM - 11:00 AM}

1. HigGINSON, $\mathrm{C}$
COMPARING THE ORIGINAL AND REVISED SCORING CRITERIA FOR THE RBANS FIGURES IN A CLINICAL SAMPLE.

SELF-GENERATED MATERIAL FOR RECALL: EFFECT OF REPEATED TEST ADMINISTRATION.

SELF-EVALUATION OF MEMORY PROBLEMS IN DAILY LIFE: NORMATIVE DATA.

MEMORY FOR INTENTIONS SCREENING TEST.

FORGETTING IN THE VIRTUAL STREET: A COMPUTERISED ASSESSMENT OF REMEMBERING.

AGE- AND SHORT FORM IQ- ADJUSTED MOANS NORMS FOR THE WMS-R.

PROMINENCE OF LOGICAL MEMORY AND VISUAL REPRODUCTION AMONG WESCHLER MEMORY SCALE-REVISED SUBTESTS IN HEALTHY OLDER CONTROLS.

THE EFFECTS OF EDUCATION ON CVLT-II SCORES.

ANALYSIS OF THE FACTOR STRUCTURE AND CONCURRENT VALIDITY OF THE SELECTIVE REMINDING TEST.

PSYCHOMETRIC PROPERTIES OF THE HOPKINS BRIEF TEST OF MEMORY.

A NEW MEASURE OF VISUAL LOCATION LEARNING AND MEMORY: PRELIMINARY PSYCHOMETRIC PROPERTIES AND NORMATIVE DATA FOR THE BROWN LOCATION TEST.

REY VISUAL DESIGN LEARNING TEST: A TRUE LEARNING MEASURE.

ASSESSING ERROR TYPES AND LEARNING CONSISTENCY USING THE BVMT - R.

WMS-III VISUAL REPRODUCTION CUEING: A USEFUL ADJUNCT PROCEDURE.

COMPARING THE ORIGINAL AND A COMPUTERIZED MULTIPLE - CHOICE VERSION OF THE FACES TEST FROM WMS-III IN ALZHEIMER'S PATIENTS.

EXECUTIVE TESTS, ARE THEY ALL THAT THEY SEEM? A COMPARISON OF ACHIEVEMENT SCORES AND ERRORS OF EXECUTIVE TASKS AS AN INDICATION OF FRONTAL VOLUMES.

THE DELIS-KAPLAN EXECUTIVE FUNCTION SYSTEM (D-KEFS)COMPARED TO TRADITIONAL TESTS OF EXECUTIVE DYSFUNCTION IN PATIENTS WITH FRONTAL LESIONS.

AGE- AND SHORT FORM IQ-ADJUSTED MOANS NORMS FOR THE TMT, STROOP, AND COWAT.

CONSIDERATIONS FOR CLINICAL USE OF THE STROOP TEST.

EXAMINATION OF ECOLOGICAL VALIDATY OF SWITCHING TASKS.

COMPARABLE PERFORMANCE ON FAS AND CFL FORMS OF VERBAL FLUENCY IN NORMAL SAMPLES STRATEGY ON THE RUFF FIGURAL FLUENCY TEST: A MEASURE OF EXECUTIVE FUNCTION.

CONFIRMATORY FACTOR ANALYSIS OF THE BEHAVIORAL DYSCONTROL SCALE IN A MIXED CLINICAL SAMPLE.

FACTOR STRUCTURE OF THE BEHAVIOR RATING INVENTORY OF EXECUTIVE FUNCTION SELF-REPORT. DEVELOPMENT OF THE BEHAVIOR RATING INVENTORY OF EXECUTIVE FUNCTION-SELF REPORT VERSION.

ASSESSING BEHAVIORAL CHANGE FOLLOWING STROKE: AN APPLICATION OF THE FRONTAL SYSTEMS BEHAVIOR SCALE.

STORY GRAMMAR PERFORMANCE IN ADULTS: A BALANCED AND ECOLOGICALLY VALID MEASURE OF EXECUTIVE FUNCTION.

SEMANTIC CLUSTERING: CRITERION VALIDITY OF VARIOUS INDICES.

RAN TEST PERFORMANCE: THE CONTRIBUTION OF EXECUTIVE FUNCTION PROCESSES.

VALIDITY OF THE CONDITIONAL GO/NO-GO TASK.

TEST-RETEST RELIABILITY OF EXECUTIVE FUNCTION TASKS FOR USE WITH YOUNG CHILDREN.

\section{Paper Session 9}

The Cognitive Neuropsychology of Schizophrenia Room: Essex

PARSING GENERAL AND SPECIFIC COGNITIVE DEFICITS IN SCHIZOPHRENIA. SPEECH MONITORING DEFICITS IN SCHIZOPHRENIA.

ORGANIZATION OF SEMANTIC CATEGORY EXEMPLARS IN SCHIZOPHRENIA: PRELIMINARY EVIDENCE FROM THE ZOO TEST.

THE RELATIONSHIP BETWEEN DYSFLUENCY IN DELAYED AUDITORY FEEDBACK AND SELF-MONITORING IN SCHIZOPHRENIA.

THE ROLE OF SELECTIVE ATTENTION IN THE WORKING MEMORY IMPAIRMENT OF SCHIZOPHRENIA. RELATIVE PREDICTIVE POWER OF BEHAVIORAL AND FMRI DATA: WORKING MEMORY EFFECTS IN SCHIZOPHRENIA.

THE PENN CONDITIONAL EXCLUSION TEST (PCET): RELATIONSHIP TO THE WISCONSIN CARD SORTING TEST AND WORK FUNCTION IN PATIENTS WITH SCHIZOPHRENIA.

\section{Paper Session 10 \\ Dementia: Parkinson's Disease and Alzheimer's Disease \\ Room: Harborside AB}

RECOGNITION MEMORY IN PARKINSON'S DISEASE WITH AND WITHOUT DEMENTIA: EVIDENCE INCONSISTENT WITH THE RETRIEVAL DEFICIT HYPOTHESIS. 
2. UC, EY

3. ROTHLIND, J

4. GREEN, J

5. GRANT, D

6. KRAMER, J

7. MORTON, $\mathrm{C}$

8. REED, B

\section{9:00 AM - 11:00 AM}

1. NASS, R

2. LEVENTHAL, F

4. PERRY, $\mathrm{R}$

5. NASS, R

6. SHEPHERD, $\mathrm{M}$

7. FORREST, B

\section{9:00 AM - 11:00 AM}

3. SOLODOW, W

EXECUTIVE DYSFUNCTION IN MILD-MODERATE PARKINSON'S DISEASE CORRELATES WITH MOTOR DISABILITY.

NEUROPSYCHOLOGICAL STATUS FOLLOWING UNILATERAL PALLIDAL OR SUBTHALAMIC NUCLEUS DEEP BRAIN STIMULATION FOR PARKINSON'S DISEASE: OUTCOME SIX MONTHS FOLLOWING SURGERY. NEUROPSYCHOLOGICAL SEQUELAE OF POSTERIOR PALLIDOTOMY FOR PARKINSON DISEASE: LONGITUDINAL FINDINGS.

NEUROANATOMY OF PHONEMIC AND SEMANTIC VERBAL FLUENCY. HIPPOCAMPAL AND FRONTAL CONTRIBUTIONS TO MEMORY PERFORMANCE.

PRACTICE EFFECTS AND NEUROPSYCHOLOGICAL CHANGE: A COMPARISON OF ALZHEIMER'S DISEASE AND HEALTHY ELDERLY.

VERBAL LIST LEARNING IN AUTOPSY-DEFINED VASCULAR DEMENTIA AND ALZHEIMER'S DISEASE.

\section{Symposium 11}

Non Verbal Learning Disabilities

Chair: Ruth Nass, Discussant: Ruth Nass

Room: Laurel

NON VERBAL LEARNING DISABILITIES.

SIGNS AND SYMPTOMS OF NVLD.

RATINGS OF NVLD BY DIFFERENT PROFESSIONAL GROUPS USING PUTATIVE INDICATORS OF NONVERBAL LEARNING DISABILITY IN STUDENTS FROM A SPECIAL EDUCATION SETTING.

NVLD AND ASPERGER DISORDER: WHAT IS THE CONNECTION?

THE NEUROANATOMY OF PROCESSING FACIAL EMOTION.

EDUCATIONAL INTERVENTION FOR NVLD.

NVLD: FUTURE RESEARCH DIRECTIONS.

\section{Symposium 12}

PREDICT-HD: Integrating Clinical and Basic Science to Reveal the Neurobiological

Prodrome of Huntington's Disease (HD)

Chair: Julie Stout, Discussant: Jean St. Cyr

Room: Harborside C

\author{
1. STOUT, $\mathrm{J}$ \\ 2. PAULSEN, J \\ 3. LANGBEHN, D \\ 4. ROSS, C \\ 5. JOHNSON, S \\ 6. AYLWARD, E
}

\section{9:00 AM - 11:00 AM}

1. WILSON, B

2. MURRE, J

3. TATE, RL

4. SHIEL, A

5. WILSON, B

6. PRIGATANO, G
PREDICT-HD: INTEGRATING CLINICAL AND BASIC SCIENCE TO REVEAL THE NEUROBIOLOGICAL PRODROME OF HUNTINGTON'S DISEASE (HD).

PREDICT-HD: A WORLDWIDE STUDY OF PRESYMPTOMATIC HUNTINGTON'S DISEASE (HD). ESTIMATED PROGNOSIS AND CROSS-SECTIONAL ANALYSIS OF THE BASELINE PREDICT DATA. PREDICT-HD: ASSOCIATIONS OF ESTIMATED YEARS TO ONSET AND MOTOR FINDINGS FROM THE UHDRS NEUROLOGICAL EXAMINATION IN PRESYMPTOMATIC HUNTINGTON'S DISEASE (HD). PREDICT-HD: A COGNITIVE NEUROSCIENCE APPROACH TO THE STUDY OF COGNITION IN PRESYMPTOMATIC HUNTINGTON'S DISEASE (HD).

PREDICT-HD VOLUMETRIC MRI STUDIES: EVIDENCE FOR PUTAMEN AND CAUDATE VOLUME LOSS IN PRESYMPTOMATIC STUDY PARTICIPANTS.

\section{Symposium 13}

Understanding Recovery From Brain Injury: Group and Single Case Studies. Chair: Barbara A. Wilson, Discussants: Barbara A. Wilson and Robyn Tate Room: Harborside DE

UNDERSTANDING RECOVERY FROM BRAIN INJURY: GROUP AND SINGLE CASE STUDIES. SELF REPAIRING NEURAL NETWORKS: A FRAMEWORK FOR UNDERSTANDING RECOVERY FROM BRAIN DAMAGE.

NEUROPSYCHOLOGICAL RECOVERY AFTER SEVERE TRAUMATIC BRAIN INJURY: A 23-YEAR PERSPECTIVE.

CAN PATTERNS OF RECOVERY AFTER SEVERE HEAD INJURY BE CHANGED BY INTERVENTION? RECOVERY FROM A STATE OF MINIMAL RESPONSIVENESS.

THE STUDY OF CHANGE AND CHOICES SEVERAL YEARS POST SEVERE BRAIN INJURY. 


\section{0:15 AM-12:15 PM}

\author{
Poster Session 7 \\ Brain-Behavior Relationships in Developmental Disorders \\ Room: Grand Ballroom
}

1. PILARSKI. C

2. PINEDA, D

3. WILLIAMSON, T

4. HEATON, S

5. HEATON, S

6. BUBNIK, M

7. WESTHAFER, J

8. LAW, R

9. YEO, $\mathrm{R}$

10. CURKO, E

11. HERVEY, A

12. PALAV, A

13. BAUMGARDNER, $T$

14. WOLFSON, V

15. PINEDA, D

16. DRECHSLER, R

17. LEHTONEN, S

18. RITCH, J

19. RITCH, J

20. KALMAR, J

21. MARKS, D

22. MILLER, C

23. GRAY, R

24. GRAY, R

\section{Attention Deficit Hyperactivity Disorder}

PERFORMANCE OF CHILDREN WITH ADHD ON COMMERCIALLY AVAILABLE CONTINUOUS PERFORMANCE TESTS: A META-ANALYTIC REVIEW.

FACTOR ANALYSIS OF THE NEUROPSYCHOLOGICAL ASSESSMENT OF CHILDREN WITH ATTENTION DEFICIT HYPERACTIVITY DISORDER.

COGNITIVE PREDICTORS OF PARENT AND TEACHER RATING SCALES OF ADHD.

PREDICTING ADHD VS NON-ADHD GROUP MEMBERSHIP: A COMPARISON OF THE CPRS, CPT, AND TEA-CH. CONNERS' CPT VS CPT-II: ADHD CLASSIFICATION ACGURACY.

ADHD SUBTYPE DIFFERENCES ON OBJECTIVE MEASURES IN PRESCHOOLERS.

SUBTYPE DIFFERENCES IN MOTOR DYSFUNCTION AMONG CHILDREN WITH ADHD.

MOTOR CONTROL AND EXECUTIVE FUNCTIONS IN ADHD SUBTYPES.

A MAGNETIC RESONANCE SPECTROSCOPY STUDY ADHD: AN ANALYSIS OF QUANTIFICATION METHOD, SUBTYPE, AND SEX.

ATTENTION AND INHIBITORY CONTROL IN PARENTS OF PRESCHOOLERS WITH AD/HD SYMPTOMS.

REACTION TIME DISTRIBUTION ANALYSIS IN CHILDREN WITH ADHD.

PERFORMANCE OF CHILDREN WITH ADHD ON NEUROPSYCHOLOGICAL EFFORT TESTS,

GENDER AND EXECUTIVE FUNCTION DIFFERENCES IN MENTAL ARITHMETIC AND MATH ERRORS IN CHILDREN WITH ADHD.

EXPRESSIVE LANGUAGE CHARACTERISTICS IN CHILDREN DIAGNOSED WITH AD/HD.

CHILDREN WITH ATTENTION DEFICIT WITHOUT LEARNING DISABILITIES PERFORMED SIMILAR TO CONTROLS ON PHONOLOGICAL AWARENESS TESTS.

METACOGNITION AND EVALUATION OF PERFORMANCE IN CHILDREN WITH ADHD.

EXPLORING DIFFERENCES BETWEEN ADHD AND LD ON MEASURES OF EXECUTIVE FUNCTION. PROSPECTIVE MEMORY ABILITY IN CHILDREN WITH ATTENTION DEFICIT/HYPERACTIVITY DISORDER. COGNITIVE CORRELATES OF PROSPECTIVE MEMORY IN ATTENTION DEFICIT/HYPERACTIVITY DISORDER.

CHILDHOOD NORADRENERGIC FUCTION PREDICTS ADOLESCENT COGNITION IN CHILDREN WITH ADHD.

NEUROPSYCHOLOGICAL OUTCOMES OF ADOLESCENTS WITH CHILDHOOD AD/HD.

FAMILY HISTORY AS A PREDICTOR OF ADOLESCENT ADHD OUTCOME.

\section{Agression}

NEUROPSYCHOLOGICAL CHARACTERISTICS AMONG SUBTYPES OF AGGRESSIVE CHILDREN. NEUROPSYCHOLOGICAL PERFORMANCE OF AGGRESSIVE CHILDREN ON AND OFF STIMULANT MEDICATION.

\section{Autism Spectrum Disorders}

MOTOR AND NEUROLOGIC SIGNS DISTINGUISH HIGH-FUNCTIONING AUTISM FROM CONTROLS. USE OF ELECTRONIC MONITORING TO DEFINE INDIVIDUAL DIFFERENCES AMONG ASPERGER STUDENTS

DISTINGUISHING HIGH FUNCTIONING AUTISM AND ASPERGER'S DISORDER ON THE BASIS OF IMAGINATIVE PLAY.

IS THERE A NEUROPSYCHOLOGICAL DIVERGENCE OF HIGH FUNCTIONING AUTISM AND PDD-NOS? PRESCHOOL PLAY BEHAVIOR AS A PREDICTOR OF SCHOOL AGE OUTCOME IN CHILDREN WITH AUTISM.

AFFECT PROCESSING IN RELATION TO ADAPTIVE FUNCTIONING IN CHILDREN WITH AUTISM SPECTRUM DISORDER.

SELF-REPORTED EXECUTIVE FUNCTION IN ADOLESCENTS WITH AUTISM SPECTRUM DISORDERS: EVIDENCE OF AWARENESS.

THE RELATIONSHIP BETWEEN EXECUTIVE FUNCTIONING AND SYMPTOM PRESENTATION IN AUTISM SPECTRUM DISORDERS.

MODALITY-SPECIFIC DEFICIT IN ABSTRACTION IN AUTISTIC DISORDER AND ASPERGERS DISORDER. ASSESSMENT OF ERROR TYPES ON PRAXIS EXAMINATION IN CHILDREN WITH AUTISM.

CEREBELLUM AND VERMIS DIFFERENCES IN CHILDREN WITH AUTISM SPECTRUM AND BIPOLAR DISORDER.

MORPHOLOGY OF THE CORPUS CALLOSUM IN AUTISM AND MARCOCEPHALY.

VOLUMETRIC ANALYSIS OF THE BASAL GANGLIA IN AUTISM WITH MACROCEPHALY. 


38. NASS, R
39. AKSHOOMOFF, $\mathrm{N}$
40. WOLL, B
41. KLEIN-TASMAN, B
42. GERNER, G
43. LESNIAK-KARPIAK, K
44. KIRK, J
45. VANZUTPHEN, K
46. ROMAIN, J
47. MELIKYAN, Z
48. HOLDNACK, J
49. DIRKS, E
50. FANCHER, J
51. NAILLON, A
52. KIBBY, M
53. PODRAZA, A
54. SPYER, G

55. GIOIA, G

56. ROBBINS, N

57. SCHWEIGER, A

58. BALDWIN, E

59. ELIAS, L

60. KIBBY, M

11:15 AM-12:00 PM
Other Neurodevelopmental Disorders and Learning Disabilities

NON VERBAL LEARNING DISABILITIES: FREQUENCY AND BASIS FOR DIAGNOSIS IN A LEARNING DISABILITY SCHOOL COHORT.

PERCEPTUAL ORGANIZATION AND VISUAL MEMORY IN CHILDREN WITH DEVELOPMENTAL LANGUAGE DISORDER.

THE PROCESSING OF SPOKEN, WRITTEN AND SIGNED LANGUAGE IN LKS: AN FMRI AND LINGUISTIC STUDY.

BEHAVIOR OF YOUNG CHILDREN WITH WILLIAMS SYNDROME: OVERLAP WITH PERVASIVE DEVELOPMENTAL DISORDERS?

MATH PERFORMANCE IN GIRLS WITH FRAGILE X OR TURNER SYNDROME: MODELS OF MATH LD SUBTYPES.

EXAMINATION OF VISUAL SPATIAL SKILLS IN GIRLS WITH TURNER OR FRAGILE X SYNDROME.

EXECUTIVE FUNCTIONING IN GIRLS WITH TURNER OR FRAGILE X SYNDROME.

EXECUTIVE FUNCTIONING IN CHILDREN WITH PHENYLKETONURIA: A PILOT STUDY.

TREATMENT APPROACHES IN THE SYNDROME OF DEVELOPMENTAL AMNESIA.

TWO VISUAL PROCESSING STRATEGIES AMONG LEARNING DISABLED PRESCHOOL AND ELEMENTARY SCHOOL CHILDREN.

CHILDREN WITH READING DISORDER: THE EFFECTS OF IQ AND IQ-ACHIEVEMENT DISCREPANCY. DIFFERENCES BETWEEN CHILDREN WITH SPECIFIC READING AND SPECIFIC ARITHMETIC DISABILITIES ON A NAMING SPEED TASK.

ANGULAR GYRUS MORPHOLOGY IN DEVELOPMENTAL DYSLEXIA.

ROLE OF THE THALAMUS IN THE DOUBLE DEFICIT HYPOTHESIS OF DYSLEXIA

ASSESSMENT OF THE GENICULO-TEMPORAL PATHWAY IN CHILDREN WITH AND WITHOUT DYSLEXIA FACTORIAL COMPLEXITY AND PREDICTIVE VALIDITY OF SEVERAL MEASURES OF PHONOLOGICAL ABILITY UNDERLYING READING SKILL IN CHILDREN.

CHILDREN WITH READING-AND-ARITHMETIC DISABILITY VERSUS CHILDREN WITH SPECIFIC READING OR SPECIFIC ARITHMETIC DISABILITY.

\section{Developmental Disorders in Adults}

ADOLESCENTS WITH ADHD REPORT SIMILAR BEHAVIORAL MANIFESTATIONS OF EXECUTIVE DYSFUNCTION AS PARENTS.

UTILIZING THE REY-OSTERRIETH COMPLEX FIGURE IN THE NEUROBEHAVIORAL SUBTYPING OF ATTENTION DEFICIT HYPERACTIVITY DISORDER.

A NOVEL COMPUTERIZED BATTERY FOR THE ASSESSMENT OF ATTENTIONAL DEFICITS IN ADULT ADHD.

NEUROPSYCHOLOGICAL AND PSYCHOSOCIAL FEATURES OF ADULTS WITH DEFICITS IN ARITHMETIC. A CASE STUDY ON CONGENITAL PROSOPAGNOSIA: BEHAVIOURAL AND STRUCTURAL MRI EVIDENCE. VERBAL SHORT-TERM MEMORY FUNCTIONING IN ADULTS WITH AND WITHOUT DYSLEXIA.

Birch Lecture

Age of Acquisition: Linking Development to Adult Processing of

Neuropsychological Impairment

Andrew Ellis

Room: Harborside ABC

\section{Poster Session 8 \\ Neuropsychology of Psychiatric Disorders and Emotion Processing Room: Grand Ballroom}

\section{General Psychopathology}

VERBAL LEARNING AND MEMORY IN POSTTRAUMATIC STRESS DISORDER. EXECUTIVE DYSFUNCTIONS IN POSTTRAUMATIC STRESS DISORDER.

USING A MODIFIED STROOP PARADIGM IN THE ASSESSMENT OF BULIMIA NERVOSA.

MALES AND FEMALES WITH EATING DISORDERS: A COMPARISON OF NEUROPSYCHOLOGICAL DOMAINS.

ORBITOFRONTAL-BASAL-GANGLIA DYSFUNCTION IN OCD: CONVERGING EVIDENCE FROM SELFREPORT AND NEUROPSYCHOLOGICAL MEASURES.

COGNITIVE FUNCTIONING AND PSYCHOPATHY.

INTERHEMISPHERIC INTEGRATION AMONG PSYCHOPATHIC OFFENDERS.

RESPONSE REVERSAL DEFICITS IN CHILDREN WITH PSYCHOPATHIC TENDENCIES AND ADULT PSYCHOPATHS.

ORBITOFRONTAL FUNCTION IN IMPULSIVE VERSUS PREDATORY VIOLENCE. 
10. MOLLET, $\mathrm{G}$

11. VOELBEL, G

12. MANGUM, N

13. JOVANOVSKI, D

14. ERICKSON, K

15. NUGENT, A

16. SNOW, J

17. GRIGGS, C

18. GETZ, G

19. HARTMAN, M

20. SIMARD, M

21. STEH, K

22. BUTTERS, M

23. BHALLA, R

24. GILDENGERS, A

25. LEBOWITZ, B

26. GUALTIERI, C

27. BERNS, S

28. WILK, C

29. HUA, M

30. NAYAK, G

31. GRIFFITHS, S

32. MATSUI. M

33. MCDERMID VAZ, S

34. MOORE, B

35. JOVANOVSKI, D

36. JOVANOVSKI, D

37. ROALF, D

38. KIM, M

39. KEEDY, S

40. CABALLERO, P

41. GODDARD, $\mathrm{K}$

42. BARNETT, K

43. WALDER, D

44. PAGULAYAN, K

45. DOBEL, D

46. RUBIN. L

47. TWAMLEY, E

48. MEDALIA, A

49. OJEDA, N

50. HUMBER, K

\section{Mood Disorders}

ANXIOUS-DEPRESSION IN CHILDHOOD: AN EVALUATION OF EXECUTIVE FUNCTIONS.

CEREBELLAR CHANGES RELATED TO CHILDREN'S PSYCHIATRIC DISORDER AND FAMILY HISTORY. PREDICTORS OF DEPRESSION IN STROKE PATIENTS. A LONGITUDINAL STUDY THAT ASSESSES STROKE PATIENTS TWO WEEKS AND THREE MONTHS POST-STROKE.

SEMANTIC CLUSTERING AND THE ROLE OF EFFORT IN MEMORY ENCODING PROCESSES IN MAJOR DEPRESSIVE DISORDER.

GENDER-BASED PERFORMANCE DIFFERENCES ON AN AFFECTIVE GO/NO-GO TASK IN UNIPOLAR DEPRESSION.

HIPPOCAMPAL VOLUME CORRELATES WITH MEMORY PERFORMANCE IN DEPRESSED BUT NOT HEALTHY SUBJECTS USING HIGH RESOLUTION MRI.

GVLT-II PERFORMANCE AMONG UNMEDICATED MOOD AND ANXIETY DISORDER PATIENTS.

WORKING MEMORY IN DEPRESSION: IS THERE A MOOD CONGRUENT BIAS?

SOCIAL FUNCTIONING AND FACIAL AFFECT RECOGNITION DEFICITS IN MOOD DISORDERS.

THE RELATIONSHIP OF SELF-REPORTED SLEEP CHARACTERISTICS, NEUROPSYCHOLOGICAL FUNCTIONING, AND DEPRESSION IN OLDER ADULTS.

DIFFERENTIAL COGNITIVE IMPAIRMENT IN SUBJECTS WITH GERIATRIC DEPRESSION WHO WILL DEVELOP ALZHEIMER'S DISEASE, DEMENTIA WITH LEWY BODIES, VASCULAR AND MIXED DEMENTIA INTERACTION OF AGE AND DEPRESSION ON COGNITIVE FUNCTIONING.

NEUROPSYCHOLOGICAL FUNCTIONING IN LATE-LIFE DEPRESSION.

NEUROPSYCHOLOGICAL FUNCTIONING DURING THE DEPRESSED AND EUTHYMIC STATES OF LATELIFE DEPRESSION.

NEUROPSYCHOLOGICAL FUNGTIONING IN LATE-LIFE BIPOLAR DISORDER.

MOTOR INHIBITION IN BIPOLAR DISORDER.

COMPLEX ATTENTION IN BIPOLAR AND UNIPOLAR DEPRESSION.

\section{Schizophrenia}

COMPARISON OF BIPOLAR AND SCHIZOPHRENIA INPATIENTS ON NEUROCOGNITIVE DEFICITS COGNITIVE PROFILE DISPARITIES BETWEEN SCHIZOPHRENIA PATIENTS AND A FSIQ-MATCHED HEALTHY COMPARISON GROUP

NEUROCOGNITIVE FUNCTION IN NONPSYCHOTIC PARENTS OF SCHIZOPHRENIC PATIENTS: A PRELIMINARY STUDY.

SENSITIVITY OF VISUAL AND VERBAL MEMORY TESTS TO COGNITIVE IMPAIRMENT IN SCHIZOPHRENIA.

THE EFFECT OF MONETARY REINFORCEMENT ON VERBAL MEMORY PERFORMANCE IN SCHIZOPHRENIA.

IMPAIRMENT OF MEMORY ORGANIZATION IN PATIENTS WITH SCHIZOPHRENIA SPECTRUM DISORDER. HOW REPRODUCIBLE ARE MEMORY-BASED SUBTYPES OF SCHIZOPHRENIA?

THE EFFECT OF SCHIZOPHRENIA ON THE TEST OF MEMORY MALINGERING

AWARENESS OF ILLNESS AND ITS RELATIONSHIP TO EXECUTIVE FUNCTION IN CHRONIC SCHIZOPHRENIA: THE MISSING EXEGUTIVE?

EVALUATION OF INSIGHT AND ORDER OF ADMINISTRATION EFFECTS: A COMPARISON BETWEEN A RESEARCHER-RATED AND A SELF-REPORT INSIGHT SCALE IN SCHIZOPHRENIA.

UNIRHINAL IMPAIRMENT OF ODOR HEDONICS IN MEN WITH SCHIZOPHRENIA.

ERP STUDY OF VISUAL WORKING MEMORY IN SCHIZOPHRENIA USING A 2-BACK PARADIGM.

SMALLER LEFT AMYGDALA VOLUME PREDICTS GREATER ABNORMALITY FOR RATING FEARFUL AND SURPRISED FACIAL EXPRESSIONS AMONG INDIVIDUALS WITH SCHIZOPHRENIA.

COGNITIVE CORRELATES OF REDUCED STRIATAL VOLUME IN SCHIZOPHRENIA.

LACK OF EVIDENCE FOR DECREASD LATERALIZATION IN SCHIZOPHRENIA FROM A SIMPLE REACTION TIME TASK.

SCHIZOPHRENIA AND COMMUNICATION BETWEEN THE HEMISPHERES.

SEX-SPECIFIC EFFECTS IN DOMAINS OF LANGUAGE IN SCHIZOPHRENIA VERSUS NORMAL COMPARISONS.

VOCAL AFFECT RECOGNITION IN SCHIZOPHRENIA.

AN EXAMINATION OF CROSS-RACIAL DIFFERENCES IN COGNITIVE AND PSYCHOSOCIAL VARIABLES ACROSS TWO PATIENT GROUPS WITH SCHIZOPHRENIA.

SEX DIFFERENCES IN COGNITIVE RESPONSE TO MEDICATION IN FIRST EPISODE SCHIZOPHRENIA. WORK-RELATED ABILITIES IN SCHIZOPHRENIA AND HIV: A DEMOGRAPHICALLY-MATCHED COMPARISON.

THE WORK-READINESS COGNITIVE SCREEN AS AN ASSESSMENT TOOL IN SCHIZOPHRENIA: PSYCHOMETRIC PROPERTIES OF A WEB-BASED SCREENING TEST.

PREMORBID FUNCTIONING RELATES TO TREATMENT RESPONSE AND COGNITIVE PRESEVATION IN CHRONIC SCHIZOPHRENIA.

SOCIAL COGNITION AND FUNCTIONAL OUTCOME IN SCHIZOPHRENIA. 


51. CASTILLO-PARRA, G
52. SCHMIDT, J
53. NAKHUTINA, L
54. CHAYO, R
55. HEUTINK, J
56. EVERHART, D
57. YUHASZ, J
58. HEINLY, M
59. HATTIANGADI, N
60. ESKES, G
61. GRANETZ, J
62. ARIAS, N
63. MITCHELL, D
64. WILLIAMSON, J
65. FRISINA, P
66. SPRINGER, U

\section{1:00 PM - 3:00 PM}

\section{Emotional Processing}

EMOTIONAL PROCESSING IN MAJOR DEPRESSIVE DISEASE AND EVENT-RELATED BRAIN POTENTIALS STUDY

ACOUSTICAL ANALYSIS AND HUMAN RATINGS OF EMOTIONAL PROSODY IN UNILATERAL STROKE. RECOVERY OF POSED PROSODIC EMOTIONAL EXPRESSION IN UNILATERAL STROKE PATIENTS. AFFECTIVE, ACTIVATION, DOMINANCE AND MORAL JUDGMENT OF PICTORIAL STIMULI: NORMATIVE DATA IN SPANISH SPEAKING POPULATION.

SUBCONCIOUS EMOTIONAL PROCESSING MODULATES EARLY VISUAL ERPS DEPENDENT ON TRAITANXIETY.

ADULT SEX-RELATED ERP DIFFERENCES DURING THE PERCEPTION OF AFFECTIVE PROSODY AND FACIAL AFFECT.

FACIAL AFFECT RECOGNITION IN FEMALES: THE ROLES OF LOCUS OF CONTROL AND EXTRAVERSION.

PROCESSING OF EMOTIONAL FACES IN DEVELOPMENTAL PROSOPAGNOSIA.

FACIAL AFFECT PROCESSING ACROSS A PERCEPTUAL TIMELINE: A COMPARISON OF TWO MODELS OF FACIAL AFFECT PROCESSING.

RIGHT HEMISPHERE PERCEPTUAL BIASES IN EMOTION AND FACE PROCESSING

FRONTAL LOBE MECHANISMS IN THE JUDGMENT OF EMOTIONAL FACIAL EXPRESSIONS \& SITUATIONS.

SEX DIFFERENCES IN ELECTROPHYSIOLOGYCAL RESPONSE EVOKED BY MORAL AND NONMORAL PICTURES: AN EVENT RELATED BRAIN POTENTIAL STUDY.

EMOTION AT THE EXPENSE OF COGNITION: INDIVIDUALS WITH PSYCHOPATHY SHOW ENHANCED PERFORMANCE ON A MOTOR RESPONSE TASK.

THE INFLUENCE OF LATERALIZED STRESSORS ON CARDIOVASCULAR REGULATION AND PERCEPTION IN HIGH AND LOW HOSTILE MEN.

WRITTEN EMOTIONAL EXPRESSION AND HEALTH OUTCOMES: A META-ANALYSIS IN CLINICAL POPULATIONS.

LONG-TERM HABITUATION OF STIMULATION-INDUCED SMILE IN A PATIENT WITH DBS.

\section{Featured Symposium}

Mild Traumatic Brain Injury in Sports: An International Neuropsychological Perspective Chair: Mark Lovell, Discussant: Mark Lovell

Room: Harborside C

1. LOVELL, M

MILD TRAUMATIC BRAIN INJURY IN SPORTS:AN INTERNATIONAL NEUROPSYCHOLOGICAL PERSPECTIVE.

NEUROPSYCHOLOGY OF MILD TBI: LESSONS FROM AUSTRALIAN RUGBY LEAGUE. SPORTS CONCUSSION IN THE HIGH SCHOOL ATHLETE: WHAT ARE WE LEARNING? ELECTROPHYSIOLOGICAL ANOMALIES IN CONCUSSED ATHLETES.

NEUROCOGNITIVE FUNCTIONING AND SOCCER: AN ANALYTICAL REVIEW.

GENDER DIFFERENCES DURING BASELINE AND POST-CONCUSSION SYMPTOM REPORTING AND COG-

NITIVE TESTING IN HIGH SCHOOL AND COLLEGE ATHLETES.
ARDS, A NEVER SAY NEVER: TAKING ACCOUNT OF ADDITIVE AND

HINTON-BAYRE, A

LASSONDE, M

ECHEMENDIA, $\mathrm{R}$

6. PODELL, K

7. SHUTTLEWORTH-EDWARDS, A NEVER SAY NEVER: TAKING ACCOUNT OF ADDITIVE AND VARIABILITY EFFECTS IN SPORTS CONCUSSION RESEARCH.

\section{1:00 PM - 3:00 PM}

\section{Symposium 14}

Decision-Making: Role of Prefrontal Cortex and Developmental Issues

Chair: Harvey Levin, Discussant: Jordan Grafman

Room: Harborside DE

\footnotetext{
1. LEVIN, H

2. BECHARA, A

3. CLARK, L

4. ZELAZO, P

5. ERNST, M

6. HANTEN, G
}

DECISION-MAKING:ROLE OF PREFRONTAL CORTEX AND DEVELOPMENTAL ISSUES. GENDER-RELATED ASYMMETRIC UTILIZATION OF THE RIGHT VERSUS LEFT VENTROMEDIAL PREFRONTAL CORTICES IN DECISION-MAKING.

NEURAL AND COGNITIVE MECHANISMS OF DECISION-MAKING IMPAIRMENT FOLLOWING UNILATERAL FRONTAL LOBE DAMAGE.

DEVELOPMENT OF AFFECTIVE DECISION MAKING IN CHILDHOOD: THE CHILDREN'S GAMBLING TASK.

DECISION MAKING: A DEVELOPMENTAL PERSPECTIVE AND APPLICATION TO ADDICTION. DECISION MAKING AFTER TRAUMATIC BRAIN INJURY IN CHILDREN. 


$\begin{array}{ll}\text { 1:00 PM - 3:00 } \\ \\ \\ \text { 1. } \\ \text { 2. } \\ \text { 2AZAR, R } \\ \text { 3. } & \text { LAZAR, R } \\ & \\ \text { 4. } & \text { SPEIZER, A } \\ \text { 5. } & \text { KREITER, K } \\ \text { 6. } & \text { FESTA, J } \\ \text { 7. } & \text { PETRUCCI, R }\end{array}$

1:00 PM - 3:00 PM

1. DIXON, P

2. MATSON, M

3. MATSON, M

4. BOSER, $\mathrm{K}$

5. EVIATAR, Z

6. WAMBACQ, I

7. PAVAWALLA, S

8. MARTENS, M

\section{1:00 PM - 3:00 PM}

1. ROBINS, D

2. KAREKEN, D

3. ROSEN, A

4. WOODARD, J

5. LANGENECKER, $\mathrm{S}$

6. ALEXANDER, G

3:15 PM - 5:15 PM

1. OLSEN, G

2. ROSENBAUM, A

3. MILLER, $\mathrm{S}$

4. MCCREA, M

5. ECHEMENDIA, $\mathrm{R}$

6. CARTER, S

7. MCKEEVER, $\mathrm{C}$

8. ABREU, J

9. GETZ, G

10. PICA, A
Symposium 15

Neurovascular Neuropsychology

Chair: Ronald M. Lazar, Discussant: Gregory G. Brown

Room: Harborside AB

NEUROVASCULAR NEUROPSYCHOLOGY.

BRAIN AVM.

PROVOKING FORMER BEHAVIORAL DEFICITS AFTER STROKE RECOVERY WITH NEUROCHEMICAL CHALLENGE.

NEUROCOGNITIVE ASSESSMENT IN PATIENTS WITH CAROTID ARTERY DISEASE.

COGNITION, EMOTION AND QUALITY OF LIFE AFTER SUBARACHNOID HEMORRHAGE.

NEUROVASCULAR NEUROPSYCHOLOGY: END-STAGE PULMONARY DISEASE.

COGNITIVE DYSFUNCTION IN END-STAGE HEART FAILURE PATIENTS REQUIRING INOTROPE INFUSION OR MECHANICAL CARDIAC ASSIST DEVICES: ANOTHER PARAMETER OF END-ORGAN DAMAGE?

\section{Paper Session 11}

Autism Spectrum and Other Neurodevelopmental Disorders Room: Essex

DIFFERENTIATING BETWEEN AUTISM SPECTRUM DISORDERS AND OTHER DEVELOPMENTAL DISABILITIES USING THE MODIFIED CHECKLIST FOR AUTISM IN TODDLERS (M-CHAT).

DISCRIMINATION AMONG HIGH-FUNCTIONING AUTISM, ASPERGER SYNDROME, AND DEVELOPMENTAL LANGUAGE DISORDER USING A DEVELOPMENTAL NEUROPSYCHOLOGICAL ASSESSMENT. NEPSY SUPPLEMENTAL SCORE ANALYSIS IN HIGH-FUNCTIONING AUTISM AND ASPERGER SYNDROME. PROACTIVE INTERFERENCE IN SUBJECTS WITH AUTISM.

CORTICAL CONNECTIVITY IN AUTISM: AN ANALYSIS OF FUNCTIONAL CONNECTIVITY AND INTEGRATION IN FMRI STUDIES OF COMPREHENSION AND PROBLEM-SOLVING.

ERPS IN CHILDREN WITH AUDITORY PROCESSING DISORDERS.

CEREBRAL HEMISPHERE VOLUME IS RELATED TO SUBTYPES IN READING DISABILITY.

AMYGDALA VOLUME AND SOCIABILITY IN WILLIAMS SYNDROME AND NORMAL CONTROLS.

\section{Paper Session 12}

FMRI Investigations of Normal Cognition Across the Lifespan

Room: Laurel

CROSS-MODAL INTEGRATION OF EMOTIONAL INFORMATION.

CORTICAL MEDIATION OF ODOR DISCRIMINATION.

VERBAL SPAN IS RELATED TO BRAIN REGIONS RECRUITED DURING TASK SWITCHING IN YOUNG AND OLDER ADULTS

FUNCTIONAL NEUROANATOMICAL SUBSTRATES OF THE REMOTE MEMORY TEMPORAL GRADIENT IN HEALTHY OLDER ADULTS.

FUNCTIONAL OR STRUCTURAL MRI: WHICH IS MORE SENSITIVE TO COGNITIVE PERFORMANCE CHANGES WITH AGING?

REGIONAL NETWORK ANALYSIS OF GRAY MATTER ATROPHY IN HEALTHY AGING.

Poster Session 9

Neurocognitive Functioning following Traumatic Brain Injury

Room: Grand Ballroom

\section{Concussion}

RESIDUAL EFFECTS OF CONCUSSION.

FACTOR STRUCTURE OF POST-CONCUSSIVE SYMPTOMS 2 HOURS POST-INJURY.

PRESERVED VISUOSPATIAL MEMORY FUNCTIONING FOLLOWING SPORTS-RELATED CONCUSSION. ACUTE EFFECTS AND RECOVERY TIME FOLLOWING CONCUSSION IN COLLEGIATE FOOTBALL PLAYERS. THE CUMULATIVE IMPACT OF SOCCER-RELATED HEADING ON THE NEUROPSYCHOLOGICAL PERFORMANCE OF MALE COLLEGE ATHLETES.

THE RELATIONSHIP BETWEEN HISTORY OF CONCUSSION. SLEEP DISTURBANCE AND ATTENTION IN COLLEGE ATHLETES.

SPORTS-RELATED CONCUSSIONS IN COLLEGIATE ATHLETES: GENDER DIFFERENCES ACROSS NEUROPSYCHOLOGICAL TEST PERFORMANCES.

COGNITIVE DEFICTS FROM CONCUSSON IN PROFESSIONAL SOCGER PLAYERS IN BRAZIL.

SELF-REPORT SYMPTOMS OF CONCUSSION IN MALE AND FEMALE ATHLETES. PSYCHOLOGICAL FACTORS UNDERLYING POST-CONCUSSIVE SYMPTOM REPORTING. 


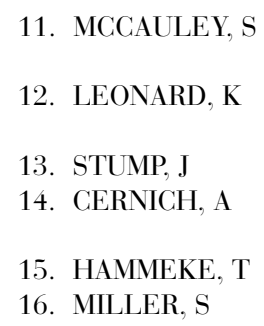

\section{HILLARY, F \\ 18. GALE, S \\ 19. TELLIER, A \\ 20. HILLARY, F \\ 21. WADE, J \\ 22. CARONE, D \\ 23. MCKAY, C \\ 24. KEAVENEY, J \\ 25. WRIGHT, M \\ 26. ROYAN, J \\ 27. TAYLOR-COOKE, $\mathrm{P}$}

28. BURHART, J

29. KENNEDY, M

30. NISSLEY, H

31. YOUSE, $\mathrm{K}$

32. MARK, V

33. COLE, M

34. ZIINO, C

35. DIKMEN, S

36. SUHR, J

37. GONTKOVSKY, S

38. MCDONALD, S

39. HORNER, M

40. TESTA, J

41. SCHRETLEN, D

42. WARSCHAUSKY, S

43. HART, T

44. LILLIE, R

45. CONSTANTINIDOU, F

46. GONTKOVSKY, S

47. RASSOVSKY, Y

48. SCHUTT, L

49. SCHUTT, L

50. BEERS, $\mathrm{S}$

51. CASS, J

52. EVANS, C
FAILURE TO FIND DIFFERENTIAL UTILITY OF THE DSM-IV AND ICD-10 CRITERIA FOR POSTCONCUSSIONAL DISORDER 6 MONTHS POSTINJURY.

GROUP-BASED COGNITIVE-BEHAVIORAL THERAPY FOR PERSISTENT POSTCONCUSSION SYNDROME: A CONTROLLED TREATMENT OUTCOME STUDY.

SENSITIVITY AND SPECIFICITY OF THE IMPACT TEST BATTERY IN ATHLETES' CONCUSSION STATUS. PREDICTION OF CONCUSSION STATUS USING A COMPUTERIZED NEUROPSYCHOLOGICAL MEASURE: A LOGISTIC REGRESSION ANALYSIS.

FUNCTIONAL MAGNETIC RESONANCE IMAGING AFTER ACUTE SPORTS CONCUSSION.

AN FMRI STUDY OF FUNCTIONAL CONNECTIVITY IN THE HIPPOCAMPI OF CONCUSSED ATHLETES: MOTION CONFOUNDS INTERPRETATION.

\section{Traumatic Brain Injury}

ALTERATIONS IN BASELINE BLOOD FLOW AND OXYGEN PERFUSION SECONDARY TO TBI AS MEASURED BY BOLD FMRI.

LONGITUDINAL VOXEL-BASED MORPHOMETRY IN TRAUMATIC BRAIN INJURY: CHANGES IN GRAY MATTER CONCENTRATION.

MILD TRAUMATIC BRAIN INJURY: THE BIAS OF SAMPLING PROCEDURES AND FUNCTIONAL INDICES. APPLICATION OF PROTON MAGNETIC RESONANCE SPECTROSCOPY TO ACUTE TBI.

THE SUPREME COURT OF VIRGINIA PROHIBITS NEUROPSYCHOLGISTS FROM DIAGNOSING MILD TRAUMATIC BRAIN INJURY.

A COMPARISON OF THREE COGNITIVE SCREENING MEASURES IN A TRAUMATIC BRAIN INJURED POPULATION.

COMPARING WAIS-III PROFILES OF TRAUMATIC BRAIN INJURY AND CHRONIC PAIN.

THE WAIS-III MATRIX REASONING TEST (MRT) IN BRAIN INJURY: WHAT DOES IT MEASURE?

CONTENT, SOURCE, AND TEMPORAL ORDER MEMORY FOR PERFORMED AND OBSERVED ACTIVITIES FOLLOWING SEVERE CLOSED-HEAD INJURY.

A CASE FOR DISSOCIATING 'WHAT' FROM 'WHERE' IN PERCEPTION AND MENTAL IMAGERY.

BLINKING MAY COMPENSATE FOR CHANGES IN SUSTAINED VISUAL ATTENTION DUE TO AGE AND BRAIN INJURY.

THE EFFECTS OF TRAUMATIC BRAIN INJURY ON VERBAL AND VISUAL MEMORY IN A VETERAN SAMPLE.

METAMEMORY RECALL PREDICTIONS OF NARRATIVE TEXT AFTER TRAUMATIC BRAIN INJURY

THE EFFECTS OF DIVIDED ATTENTION ON ENCODING AND RETRIEVAL IN SEVERE CLOSED HEAD INJURY PATIENTS.

CONVERSATIONAL ABILITIES AND EXECUTIVE FUNCTIONS FOLLOWING CLOSED HEAD INJURY.

CANCELLATION TARGET MARKING PROCEDURE AFFECTS PERSEVERATION BUT NOT NEGLECT FOLLOWING BRAIN INJURY.

COMMUNALITY ANALYSIS AND CLASSIFICATION OF TBI GROUP MEMBERSHIP AND SEVERITY BASED ON ASSESSMENT OF WORKING MEMORY/EXECUTIVE FUNCTION WITH THE N-BACK AND PASAT TASKS. FATIGUE AND ATTENTION FOLLOWING TRAUMATIC BRAIN INJURY.

NATURAL HISTORY OF DEPRESSION IN TRAUMATIC BRAIN INJURY.

DO ANXIETY. EFFORT. OR DEPRESSION EXPLAIN THE "DIAGNOSIS THREAT" EFFECT?

STATE-TRAIT PERSONALITY CHARACTERISTICS FOLLOWING TRAUMATIC CLOSED HEAD INJURY. PREDICTING DEFICITS IN SOCIAL BEHAVIOUR AFTER TRAUMATIC BRAIN INJURY USING THE AWARENESS OF SOCIAL INFERENCE TEST (TASIT).

PATTERNS OF ALCOHOL USE ONE YEAR AFTER TRAUMATIC BRAIN INJURY: A POPULATION-BASED, EPIDEMIOLOGICAL STUDY.

FAMILY FUNCTIONING IN PATIENTS WITH MILD OR MODERATE/SEVERE TBI IN COMPARISON TO AN ORTHOPEDIC INJURY GROUP.

USE OF META-ANALYSIS TO ESTIMATE COGNITIVE DOMAIN-SPECIFIC RECOVERY FOLLOWING TBI. SOCIAL PROBLEM SOLVING AND SOCIAL INTEGRATION FOLLOWING TRAUMATIC HEAD INJURY IN YOUNG ADULTS.

COMPUTER TECHNOLOGIES IN BRAIN INJURY REHABILITATION: CONSUMER PERSPECTIVES. APPLICATION OF A NEW MEMORY-TRAINING PARADIGM TO INDIVIDUALS WITH TRAUMATIC BRAIN INJURY.

THE EFFECTS OF SYSTEMATIC CATEGORIZATION TRAINING IN POST ACUTE BRAIN INJURY REHABILITATION: PRELIMINARY FINDINGS.

TBI OUTCOMES AS A FUNCTION OF DISTANCE FROM OUTPATIENT TREATMENT SERVICES.

INFORMATION PROCESSING SPEED MEDIATES FUNCTIONAL OUTCOME IN TBI.

CASE MANAGEMENT AND EMPLOYMENT OUTCOMES FOLLOWING POST ACUTE BRAIN INJURY.

IMPACT OF RURALITY OF RESIDENCE ON OUTCOME AFTER TRAUMATIC BRAIN INJURY.

EFFECTS OF AMANTADINE HYDROCHLORIDE ON FUNCTIONAL OUTCOME OF ADULTS AFTER TRAUMATIC BRAIN INJURY.

THRESHOLD THEORY, COGNITIVE RESERVE CAPACITY, AND OUTCOME FOLLOWING ADULT CLOSED HEAD INJURY.

FINANCIAL BENEFITS AND EMPLOYMENT AFTER POST-ACUTE BRAIN INJURY REHABILITATION. 
53. TAYLOR, S

54. WELLS, R

55. SANTAMARIA, B

3:15 PM - 5:15 PM

1. CORKIN, $\mathrm{S}$

2. SQUIRE, L

3. VERFAELLIE, M

4. NADEL, L

\section{3:15 PM - 5:15 PM}

1. ZIMMERMAN, M

2. IANNUZZO, R

3. VASSILEVA, J

4. PESCHARDT, $\mathrm{K}$

5. LOKKEN, K

6. PRENTICE, $\mathrm{K}$

7. BRICKMAN, A

3:15 PM - 5:15 PM

1. ARBOLEDA, A

2. MOSTOFSKY, S

3. MAHONE, E

4. BERWID, $\mathrm{O}$

5. SHEAR, $\mathrm{P}$

5:30 PM - 6:30 PM

6:30 PM - 7:30 PM

7:30 PM
HEAD INJURY ASSOCIATED WITH ORBITOFRONTAL FUNCTION IN ADOLESCENTS. PREDICTORS OF WELL-BEING IN FAMILY MEMBERS OF PERSONS WITH CLOSED HEAD INJURY. EARLY STRUCTURAL ENCODING AND FACE PROCESSING DEFICITS AFTER CLOSED HEAD INJURY.

Invited Symposium

50 Years On: HM and the Quest to Understand the Amnesic Syndrome

Discussant: Michael Kopelman

Room: Harborside ABC

THE AMNESIC PATIENT H.M.: A HALF CENTURY OF LEARNING ABOUT MEMORY. THE HIPPOCAMPUS, THE MEDIAL TEMPORAL LOBE, AND MEMORY IMPAIRMENT. IMPAIRED AND PRESERVED MEMORY PROCESSES IN AMNESIA.

THE AMNESIC SYNDROME: CONSENSUS AND CONTEXT.

Paper Session 13

Brain-Behavior Relationships in Psychopathology

Room: Harborside DE

EXECUTIVE FUNCTIONING CORRELATES OF ANTERIOR CINGULATE SUBREGION VOLUMES IN BIPOLAR DISORDER.

DEFICITS IN NEUROCOGNITIVE FUNCTIONING IN BIPOLAR DISORDER PERSIST IN EUTHYMIA.

PROFILES OF EXECUTIVE DYSFUNCTION DIFFER ACCORDING TO DRUG ABUSE SEVERITY AND ANTISOCIALITY.

DIFFERENTIAL STIMULUS-REWARD AND STIMULUS-PUNISHMENT LEARNING IN INDIVIDUALS WITH PSYCHOPATHY

COGNITIVE DEFICITS IN BULIMIA NERVOSA.

IMPROVING DECISIONAL CAPACITY FOR INFORMED CONSENT IN SCHIZOPHRENIA.

THALAMUS SIZE AND OUTCOME IN SCHIZOPHRENIA.

Paper Session 14

Attention Deficit Hyperactivity Disorder

Room: Laurel

CORRELATION BETWEEN VOLUMES FROM CAUDATE NUCLEUS, AND SEMANTIC LANGUAGE TASK IN COLOMBIAN CHILDREN WITH ATTENTION-DEFICIT HYPERACTIVITY DISORDER.

ABNORMAL MOTOR CORTEX ACTIVATION IN ADHD: EVIDENCE FROM FMRI. EFFECTS OF AGE AND VERBAL IQ ON TIMED MOTOR PERFORMANCE IN CHILDREN. SUSTAINED ATTENTION AND INHIBITORY CONTROL IN PRESCHOOLERS AT-RISK FOR AD/HD. COGNITIVE FUNCTIONING IN MANIC ADOLESCENTS WITH BIPOLAR DISORDER: CONTRIBUTION OF COMORBID ADHD.

Presidential Address

Carving Cognition at its Seams: The Role of Single Case Studies

Elizabeth Warrington

Room: Harborside ABC

INS Business Meeting (Open to AlI) Room: Harborside ABC

INS Reception

Room: Harborside Foyer 


\title{
SATURDAY, FEBRUARY 7, 2004
}

\author{
8:00 AM - 10:00 AM Poster Session 10 \\ Neuropsychological Effects of Neurological Disorders \\ including HIV, Substance Abuse and Other Toxic Exposures, Hormones \\ Room: Grand Ballroom
}

\section{General Medical Disorders}

1. WHITNEY, K

2. WOODS, A

3. GOLDSTEIN, F

4. MOUNT, D

5. GROHMAN, K

6. BROWN, A

7. PARSONS. T

8. MARQUART, M

9. LIN. S

10. PERRY, W

11. BUTTERFIELD, L

12. LLANES, S

13. CERCY, SP

14. FAIRBANKS, J

15. ANDERSON-HANLEY, C

16. WEFEL, J

17. LAGEMAN, S

18. WEFEL, J

19. TATE, D

20. GREEN, E

21. ZIMMERMAN, M

22. ESTERLIS, I

23. HOYT, BD

24. MILLER, K

25. ZIMMERMAN, M

26. HOOK, J

27. LANGENECKER, S

28. SCHMITT, M

29. TRYGGVADOTTIR, H

30. KIXMILLER, J

31. LACY, M

32. RASHIDZADA, W
33. KOZORA, E
34. KOZORA, E
35. JOHNSON, N
36. CLARK, A
37. GAINES, J
38. DONINGER, N
39. DONINGER, N

APPRAISAL OF ILLNESS AND NEUROPSYCHOLOGICAL FUNCTION IN ELDERLY INPATIENTS WITH MULTIPLE MEDICAL PROBLEMS.

COGNITIVE IMPAIRMENT IN “NON-NEUROLOGIC” ELDERLY HOSPITAL INPATIENTS.

HYPERTENSION AND COGNITIVE PERFORMANCE IN AFRICAN AMERICANS WITH ALZHEIMER'S DISEASE.

APOLIPOPROTEIN EE4 DOSE-DEPENDENCE AND COGNITIVE FUNCTIONING IN AFRICAN-AMERICAN PATIENTS WITH ALZHEIMER'S DISEASE.

COGNITIVE "REHABILITATION" WITH NEUROPSYCHOLOGICALLY INTACT SUBSTANCE ABUSERS.

MEMORY RETRIEVAL, CHRONIC PAIN, AND FRONTAL SYSTEM FUNCTION.

IMPROVED VERBAL MEMORY ASSOCIATED WITH HYPOTHYROID TREATMENT.

METAMEMORY IN ELECTRICAL INJURY PATIENTS: IMPACT OF DEPRESSIVE SYMPTOMS AND EXECUTIVE FUNCTION.

NEUROPSYCHOLOGICAL PROFILE OF THREE CASES OF ADRENOLEUKODYSTROPHY.

NEUROPSYCHOLOGICAL CHARACTERIZATION OF PATIENTS AWAITING LIVER TRANSPLANTATION. COGNITIVE COMPLAINTS, COGNITIVE PERFORMANCE, AND PSYCHOLOGICAL DISTRESS AMONG MEN WITH GENITOURINARY CANCERS.

TEMPORAL LOBE RADIATION AND MEMORY IN ADULT BRAIN TUMOR PATIENTS.

A CASE OF INCIDENTAL RADIATION-INDUCED ENCEPHALOPATHY ASSOCIATED WITH THE TREATMENT OF OROPHARYNGEAL SQUAMOUS CELL CARCINOMA.

COGNITIVE FUNCTIONING IN BREAST CANCER PATIENTS AS A FUNCTION OF TREATMENT: A LONGITUDINAL ANALYSIS.

NEUROPSYCHOLOGICAL EFFECTS OF HORMONAL TREATMENTS FOR CANCER: A PILOT STUDY. TAMOXIFEN ASSOCIATED NEUROTOXICITY IN WOMEN WITH BREAST CANCER.

COGNITION IN BREAST CANCER PATIENTS.

"CHEMOBRAIN?" PRE-CHEMOTHERAPY COGNITIVE IMPAIRMENT IN WOMEN WITH BREAST CANCER. WHITE MATTER HYPERINTENSITIES, ATTENTION, AND EXECUTIVE FUNCTIONING IN CHRONIC CARDIOVASCULAR DISEASE.

PREOPERATIVE NEUROPSYCHOLOGICAL TEST MEASURES ARE ASSOCIATED WITH POSTOPERATIVE DELIRIUM IN OLDER PATIENTS UNDERGOING CORONARY ARTERY BYPASS GRAFT (CABG) SURGERY. GENDER DIFFERENCES IN THE RELATIONSHIP BETWEEN CEREBROVASCULAR DISEASE RISK FACTORS AND LEUKOARAIOSIS IN OLDER ADULTS.

PREDICATING REPORTED MEMORY LOSS IN POST TREATMENT LYME DISEASE.

CLUSTERING AND SWITCHING IN VERBAL FLUENCY PERFORMANCE OF EMPHYSEMA PATIENTS. COGNITIVE IMPAIRMENT ASSOCIATED WITH SLEEP APNEA: A DIFFERENTIAL DIAGNOSIS FOR ADULTS PRESENTING WITH MEMORY COMPLAINTS AND/OR INATTENTION.

SLEEP APNEA AND SUBCORTICAL HYPERINTENSITIES IN A COHORT OF OLDER ADULTS.

NEUROPSYCHOLOGICAL IMPAIRMENTS ASSOCIATED WITH CUSHINGS DISEASE: ARE DEFICITS ON VERBAL TASKS MORE LIKELY?

AGE EFFECTS OF HYPERCORTISOLEMIA IN CUSHING'S DISORDER: VULNERABILITY, PLASTICITY, AND RECOVERY OF FUNCTION.

VERBAL LEARNING IN SPINAL CORD INJURY PATIENTS: EFFECTS OF AGE AND TIME SINCE INJURY. COGNITIVE FUNCTIONING IN RESTLESS LEGS SYNDROME.

COGNITIVE-BEHAVIORAL DEFICITS IN AN ADULT WITH DANDY-WALKER SYNDROME.

NEUROCOGNITIVE CORRELATES OF ACUTE CHANGES IN INTERCRANIAL PRESSURE.

\section{Autoimmune Disorders}

AN OBJECTIVE MEASURE OF COGNITIVE FATIGUE. PSYCHOMETRIC PROPERTIES OF THE PROPOSED AMERICAN COLLEGE OF RHEUMATOLGOY BRIEF NEUROPSYCHOLOGICAL BATTERY FOR SLE.

MRI, MRS AND COGNITIVE ANALYSES IN NON-NP-SLE.

NEUROPSYCHOLOGICAL CHANGES FOLLOWING HEMATOPOIETIC STEM CELL TRANSPLANT FOR INTRACTABLE SYSTEMIC LUPUS ERYTHEMATOSUS.

COGNITION AND MEDICATIONS IN SYSTEMIC LUPUS ERYTHEMATOSUS.

C-REACTIVE PROTEIN AND WORKING MEMORY DEFICITS IN SYSTEMIC LUPUS ERYTHEMATOSUS. RACE-RELATED EFFECTS OF SYSTEMIC LUPUS ERYTHEMATOSUS ON NEUROPSYCHOLOGICAL FUNCTION AND HEALTH STATUS.

NEUROPSYCHOLOGICAL AND CLINICAL CORRELATES OF DISABILITY STATUS IN SYSTEMIC LUPUS ERYTHEMATOSUS. 


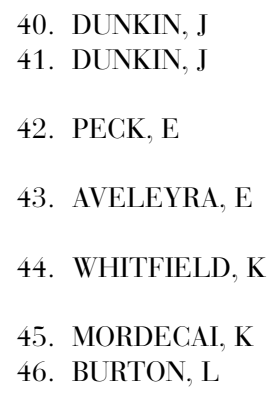

\section{Hormone Effects}

PREDICTORS OF COGNITIVE PERFORMANCE IN HEALTHY POSTMENOPAUSAL WOMEN.

USE OF REGRESSION-BASED CHANGE SCORES TO MEASURE EFFECTS OF ESTROGEN REPLACEMENT ON COGNITION IN HEALTHY, POSTMENOPAUSAL WOMEN.

THE RELATIONSHIP OF NEUROPSYCHOLOGICAL FUNCTION AND HORMONE REPLACEMENT THERAPY IN POST-MENOPAUSAL WOMEN.

NEUROPSYCHOLOGICAL AND ELECTROPHYSIOLOGICAL EVALUATION OF COGNITIVE FUNCTION IN POSTMENOPAUSAL WOMEN FOLLOWING HORMONE REPLACEMENT THERAPY.

INCREASED RESPONSE TIME VARIABILITY IN THE LUTEAL PHASE OF THE MENSTRUAL CYCLE ON A TEST OF PSYCHOMOTOR COORDINATION.

VERBAL AND VISUOSPATIAL ABILITIES IN ORAL CONTRACEPTIVE USERS.

RELATIONSHIPS BETWEEN COGNITIVE MEASURES AND INDIRECT HORMONAL INDICES.

\section{Neurotoxic Exposure Effects}

FACTOR ANALYSIS STUDY TO DEVELOP A SENSITIVE NEUROPSYCHOLOGICAL SCREENING TEST BATTERY FOR THE EVALUATION OF MANGANESE EXPOSURE.

EXPOSURE TO MANGANESE IN WELDERS AND NEUROPSYCHOLOGICAL FUNCTION.

INCREASED BLOOD LEAD LEVEL NEGATIVELY AFFECTS WISC-III PERFORMANCE.

EMOTIONAL FUNCTION FOLLOWING CARBON MONOXIDE POISONING: A LONGITUDINAL STUDY.

ATTENTIONAL FUNCTIONS FOLLOWING DIFFERENT INDUSTRIAL NEUROTOXIC EXPOSURES. LONGITUDINAL COGNITIVE FUNCTIONING IN GULF WAR-ERA VETERANS.

\section{HIV}

UTILITY OF THE HIV DEMENTIA SCALE VERSUS STANDARD NEUROPSYCHOLOGICAL ASSESSMENT TECHNIQUES IN ASSESSING RISK FOR SIGNIFICANT HIV-RELATED COGNITIVE MOTOR DEFICITS. NEUROPSYCHOLOGICAL FUNCTIONING IN DUALLY DIAGNOSED HIV-SEROPOSITIVE INDIVIDUALS AS A FUNCTION OF PTSD DIAGNOSIS.

HIGHLY ACTIVE ANTIRETROVIRAL THERAPY (HAART) MAY IMPROVE NEUROPSYCHOLOGICAL PERFORMANCE IN INDIVIDUALS WITH HIV INFECTION.

LATENT STRUCTURE OF THE PATIENT'S ASSESSMENT OF OWN FUNCTIONING QUESTIONNAIRE: A SUBJECTIVE COGNITIVE EVALUATION TOOL FOR ADULTS LIVING WITH HIV/AIDS. COGNITIVE IMPAIRMENT IS ASSOCIATED WITH MEDICATION ADHERENCE PATTERN IN HIV. ARE THERE ETHNICITY DIFFERENCES IN THE ABILITY OF NEUROPSYCHOLOGICAL TEST PERFORMANCE TO PREDICT FUNCTIONAL IMPAIRMENT IN HIV INFECTION?

THE UTILITY OF NORMS BASED ON EDUCATION VERSUS READING ABILITY IN THE PREDICTION OF FUNCTIONAL IMPAIRMENT IN HIV-INFECTION.

LACK OF AGE-RELATED COGNITIVE DECLINE AMONG AN ADVANCED HIV COHORT.

HEPATITIS C INFECTION IS INDEPENDENTLY ASSOCIATED WITH NEUROCOGNITIVE DYSFUNCTION AMONG INDIVIDUALS WITH HIV CO-INFECTION AND/OR HISTORY OF METHAMPHETAMINE DEPENDENCE.

THE IMPACT OF DEPRESSION ON SELF-REPORTED IMPAIRMENT IN HIV AND METHAMPHETAMINE USE.

RECENT COCAINE USE IS ASSOCIATED WITH NEUROPSYCHOLOGICAL DYSFUNCTION AMONG HIVINFECTED ADULTS.

DISRUPTION OF MOTOR COMPONENT PROCESSES BY ALCOHOLISM, HIV INFECTION, AND THEIR COMORBIDITY.

A COMPONENT PROCESS ANALYSIS OF THE DIGIT SYMBOL TEST IN HIV, ALCOHOLISM AND THEIR COMORBIDITY.

ATAXIA IN HIV INFECTION WHEN COMORBID FOR ALCOHOLISM.

\section{Substance Abuse Effects}

VISUOPERCEPTUAL LEARNING IN DETOXIFIED ALCOHOLIC MEN.

DETECTING IMPAIRMENT IN SUBSTANCE-ABUSING PATIENTS USING THE NEUROPSYCHOLOGICAL ASSESSMENT BATTERY (NAB).

META-ANALYTIC EVIDENCE OF NEUROCOGNITIVE DEFICITS IN COCAINE USERS,

CLASSICAL AND EMOTIONAL (COCAINE) STROOP PERFORMANCE IN COCAINE/OPIATE USERS SUPPORTED BY NIDA P50 DA 12762 AND NIDA K12 DA00167.

DEFICITS IN EXECUTIVE CONTROL OF VERBAL LIST LEARNING AMONG INDIVIDUALS WITH METHAMPHETAMINE DEPENDENCE.

MDMA (ECSTASY) DOSAGE AND VERBAL MEMORY ABILITY.

THE EFFECTS OF 3,4-METHYLENEDIOXYMETHAMPHETAMINE (MDMA OR ECSTASY) USE ON VERBAL ABILITY.

A TWO-YEAR FOLLOW-UP OF MEMORY FUNCTION IN BOTH FORMER AND CURRENT USERS OF +/3,4-METHYLENEDIOXYMETHAMPHETAMINE (MDMA OR ECSTASY). 
75. RAY, S

76. MCCOURT, M

77. PAWLAK, A

\section{9:00 AM - 11:00 AM}

1. BARR, WB

2. HERMANN, B

3. CHEUNG, M

4. DRANE, D

5. GRIFFITH, R

6. FEDIO, $\mathrm{P}$

\section{9:00 AM - 11:00 AM}

1. WALHOVD, $\mathrm{K}$

2. WILSON, T

3. PARK, N

4. LARSON, M

5. HOLDSTOCK, J

6. FJELL, A

9:00 AM - 11:00 AM

1. OSTROSKY-SOLIS, $\mathrm{F}$

2. MALLOY, P

3. OSTROSKY-SOLIS, F

4. KASZNIAK, A

5. DYWAN J

6. MATEER, C

\section{0:15 AM - 12:15 PM}

1. SOETY, E

2. MCDONALD, C

3. GRIFFIN, S

4. ISAACS, K

5. GEARY, E

6. PARRISH, J

7. ABREU, J

8. KELLY, K

9. PHATAK, V
THE ROLES OF ALCOHOL AND WORD FREQUENCY IN EXPLICIT MEMORY TASKS.

THE EFFECT OF ACUTE ALCOHOL INTOXICATION ON PANORAMIC VISUOSPATIAL ATTENTION: EXAGGERATION OF LEFTWARD BIAS IN LINE BISECTION.

INDIRECT EFFECTS OF NEUROPSYCHOLOGICAL ABILITY ON ADDICTION TREATMENT OUTCOME.

\section{Paper Session 15 \\ Neuropsychological Functioning in Temporal Lobe Epilepsy \\ Room: Harborside AB}

DETECTION OF MALINGERING ON ROUTINE TESTING IN PATIENTS WITH TEMPORAL LOBE EPILEPSY. PROGRESSION IN TEMPORAL LOBE EPILEPSY.

A FMRI STUDY ON LANGUAGE PROCESSING IN CHINESE PATIENTS WITH TEMPORAL LOBE EPILEPSY. CATEGORY-SPECIFIC NAMING AND RECOGNITION DEFICITS IN PATIENTS WITH TEMPORAL LOBE EPILEPSY.

MEMORY FOR FAMOUS FACES AND THE TEMPORAL POLE: FUNCTIONAL IMAGING FINDINGS IN TEMPORAL LOBE EPILEPSY.

DIFFERENCES IN RELATING PERSONALLY RELEVANT EMOTIONAL EXPERIENCES BY PATIENTS FOLLOWING A UNILATERAL TEMPORAL LOBECTOMY.

\section{Paper Session 16 \\ Experimental Neuropsychological Studies of Normal Brain-Behavior Relationships Room: Harborside C}

VISUAL RECOGNITION MEMORY INDEXED BY ERP. ORTHOGRAPHIC STIMULI POSSESSING LEXICAL STATUS EVOKE EARLY LEFT PERISYLVIAN ACTIVATION.

EFFECTS OF DUAL TASK ON ENCODING AND PRODUCTION OF NATURALISTIC ACTIONS. DISSOCIATING COMPONENTS OF COGNITIVE CONTROL WITH HIGH-DENSITY ERPS: IMPLEMENTATION OF CONTROL, CONFLICT PROCESSING AND ERROR MONITORING.

THE EFFECT OF PERIRHINAL CORTEX PATHOLOGY ON INTRA-MODAL AND CROSS-MODAL OBJECT MATCHING IN HUMANS.

PREDICTIONS OF INTELLIGENCE FROM SPEED-OF-PROCESSING AND CORTICAL VOLUME.

\author{
Symposium 18 \\ Emotion and Emotional Disorders: Diagnosis and Rehabilitation \\ Chair: Feggy Ostrosky-Solis \\ Room: Harborside DE
}

EMOTION AND EMOTIONAL DISORDERS: DIAGNOSIS AND REHABILITATION. ASSESSING FRONTAL SYSTEMS BEHAVIOR CHANGE: BEYOND COGNITIVE MEASURES. NEW PERSPECTIVES ON MORAL EMOTIONS: AN ELECTROPHYSIOLOGICAL STUDY. A COMPONENTIAL/PSYCHOPHYSIOLOGICAL APPROACH TO THE NEUROPSYCHOLOGY OF EMOTION. HEAD INJURY AND ALTERED IDENTIFICATION AND RESPONSE TO EMOTIONAL EXPRESSION. DISORDERS OF EMOTIONAL REGULATION: REHABILITATION CHALLENGES AND STRATEGIES.

\section{Poster Session 11 \\ Cognition and Epilepsy, Focal Lesions, Memory and Language Disorders, Laterality} Room: Grand Ballroom

\section{Epilepsy}

PREOPERATIVE MEDICAL AND NEUROPSYCHOLOGICAL VARIABLES PREDICT PATHOLOGY IN ANTERIOR TEMPORAL LOBECTOMY PATIENTS

COGNITIVE OUTCOME FOLLOWING GAMMA KNIFE SURGERY IN PATIENTS WITH TEMPORAL LOBE EPILEPSY.

RELATIONSHIPS BETWEEN AGE OF ONSET, FUNCTIONAL REORGANIZATION, AND NEUROPSYCHOLOGICAL OUTCOME IN TEMPORAL LOBECTOMY.

OBSESSIVE-COMPULSIVE SYMPTOMS IN PATIENTS WITH TEMPORAL LOBE EPILEPSY.

NAMING PERFORMANCE AND MR VOLUMETRICS IN TEMPORAL LOBE EPILEPSY.

CEREBELLAR VOLUME AND MOTOR TIMING IN TEMPORAL LOBE EPILEPSY.

RIGHT BUT NOT LEFT TEMPORAL LOBE EPILPESY DISRUPT WORKING SPATIAL AND OBJECT MEMORY.

CONTRALATERAL HEMISPHERE STRUCTURE AND FUNCTION IN RIGHT TEMPORAL LOBE EPILEPSY. THE NATURE OF VERBAL LEARNING DEFICITS IN TEMPORAL LOBECTOMY CANDIDATES. 

10. BELL, B
11. LARSON, E
12. JOHNSON, C
13. DAVIS, R
14. DEER, T
15. KIRLIN, K
16. LORING, D
17. ENG, M
18. MYERS, L

19. INSCORE, A 20. YANUSAS, C

21. SHENKER, J

22. HILL, E

23. VERAMONTI, T

24. MEDINA, J

25. JEWELL, G

26. VAKIL, E

27. BOOTH, J

28. FLORES LAZARO, J

29. RAVIZZA, S

COMPOSITE IMMEDIATE AND DELAYED WMS III INDEXES: APPROPRIATE FOR TEMPORAL LOBE EPILEPSY PATIENTS.

USE OF A NEUROPSYCHOLOGICAL LATERALITY RATING SCALE TO PREDICT SIDE OF SEIZURE FOCUS IN PATIENTS WITH TEMPORAL LOBE EPILEPSY.

SPONTANEOUS STRATEGIES FOR PSYCHOLOGICAL CONTROL/ABORTION OF SEIZURES: AN ANALYSIS.

PREDICTING SIDE OF EPILEPTIC FOCUS USING ACTUARIAL VS. CLINICAL PREDICTION: A PRELIMINARY COMPARISON.

SUBJECTIVE COGNITIVE COMPLAINTS AND OBJECTIVE COGNITIVE PERFORMANCE IN PRE-SURGICAL EPILEPSY PATIENTS.

LONG-TERM FUNCTIONAL OUTCOME OF EPILEPSY PATIENTS POST-SELECTIVE AMYGDALOHIPPOCAMPECTOMY.

CONTRALATERAL THALAMIC ICTAL HYPERPERFUSION IN EPILEPSY IS ASSOCIATED WITH GREATER PERSONALITY ABNORMALITIES.

MEMORY FOR ACTIONS: THE ENACTMENT EFFECT IN EPILEPSY.

PSYCHOEDUCATION IN THE TREATMENT OF PSYCHOLOGICAL NON-EPILEPTIC SEIZURES.

\section{Focal Lesions}

HVLT LEARNING CHARACTERISTICS IN PATIENTS WITH STROKE.

FACIAL AFFECT PERCEPTION: THE ROLE OF POST STROKE EMOTIONAL STATE.

SELECTIVE SUBCORTICAL DAMAGE TO THE "WHAT" VS. "WHERE-HOW TO" VISUAL SYSTEM IN A HUMAN.

NEUROPSYCHOLOGICAL PROFILE OF MELAS SYNDROME.

POSTERIOR VARIANT ALIEN HAND SYNDROME AFTER LEFT THALAMIC INFARCT.

A CASE OF TACTILE SYNCHIRIA: PRESERVED SOMATOTOPY?

MERGING NEUROPSYCHOLOGY AND PSYCHOPHYSICS: RIGHT-HEMISPHERE DOMINANCE FOR RATIO SCALING.

CONTEXT EFFECT IN PATIENTS WITH RIGHT AND LEFT HEMISPHERIC LESIONS.

COGNITIVE DEFICITS ASSOCIATED WITH RIGHT CEREBELLAR INSULT: A CASE STUDY.

METACOGNITION AND FRONTAL LOBE DAMAGE.

DOES THE RIGHT PARIETAL LOBE CONTRIBUTE TO VERBAL WORKING MEMORY PERFORMANCE? A CASE STUDY.

\section{Memory Disorders}

NEURAL CORRELATES OF REMOTE AUTOBIOGRAPHICAL MEMORY. METAMEMORY IN BASAL FOREBRAIN (BF) AMNESTIC SYNDROME.

RECOVERY FROM CONFABULATION AND EFFECTS ON AWARE AND UNAWARE MEMORY IN ANTERIOR COMMUNICATING ARTERY ANEURYSM.

THE ORIGIN AND NATURE OF CONFABULATION: A LONGITUDINAL EXAMINATION OF NEUROPSYCHOLOGICAL FUNCTIONING IN A SPONTANEOUS AND A PROVOKED CONFABULATOR.

AMNESIA AND FUNCTIONAL DISSOCIATIONS WITHIN THE HIPPOCAMPAL SYSTEM: DEFICITS IN MEMORY FOR SCENES VS MEMORY FOR THE RELATIONS AMONG OBJECTS WITHIN SCENES.

THE ROLE OF VARIANCE IN GENERALIZATION: EVIDENCE FROM AN AMNESIC PATIENT.

\section{Language Disorders}

36. MORELLI, C

37. GRINDROD, $\mathrm{C}$

38. STEFANATOS, G

39. WU, D

40. RUBIN, S

41. YEAGER, A

42. MARTIN, P

43. BUCHANAN, L

44. HENRY, M

45. BALASUBRAMANIAN, $\mathrm{V}$

46. DE RIESTHAL, M

EDUCATION AND APHASIA SEVERITY.

THE EFFECT OF UNILATERAL LEFT AND RIGHT HEMISPHERE LESIONS ON SENSITIVITY TO GLOBAL

CONTEXT IN LEXICAL AMBIGUITY RESOLUTION.

A TEMPORAL WINDOW ON PURE WORD DEAFNESS.

CONCEPTUAL AND LINGUISTIC KNOWLEDGE IN BRAIN-DAMAGED PATIENTS.

ENVIRONMENTAL SYMBOL RECOGNITION OF PERSONS WITH AND WITHOUT APHASIA.

LEXICAL AND ENVIRONMENTAL STIMULI PROCESSING IN APHASIA.

OVERT NAMING IN APHASIA: HEMODYNAMIC DELAY DESIGN AND ANALYSIS WITH FMRI BOLD.

PHONOLOGICAL PROCESSING IN DEEP DYSLEXIA.

LESION LOCATION IN ACQUIRED AGRAPHIA.

PURE AGRAPHIA: A CASE REPORT.

INFLUENCE OF THE STIMULUS MODALITY ON PANTOMIME PERFORMANCE IN APHASIA.

\section{Laterality}

47. HISCOCK, M

48. RUSSELL, $N$

49. STRELNIKOV, K

50. GRAFF-RADFORD, J

WHAT STAGE OF AUDITORY PROGESSING PRODUCES THE RIGHT-EAR ADVANTAGE? A SIGNAL-DETECTION STUDY.

TARGET DETECTION IN DICHOTIC LISTENING: A COMPARISON OF WORDS AND SYLLABLES. A COMPARISON OF MOTOSENSOR LATERALITY PROFILE WITH HEMISPHERIC COGNITIVE STYLES. LEFT HEMISPHERE-RIGHT HAND PROXIMAL INTENTIONAL BIAS. 
51. VOYER, D

52. ZHELTUKHIN, A

53. ZHELTUKHIN, A

54. MCKEEVER, W

55. BAILEY, L

56. MCKEEVER, W

57. STRELNIKOV, K

58. SYMINGTON, M

59. SCHILMOELLER, G

60. LAUTZENHISER, A

61. SYMINGTON, S

\section{1:15 AM-1:15 PM}

1. BILDER, $\mathrm{R}$

2. WEFEL, J

3. PARMENTER, B

4. JOHNSON, S

\section{1:15 AM-1:15 PM}

1. CHRISTODOULOU, C

2. CHELUNE, G

3. BASSO, M

4. BEATTY, W

5. BASSO, M

6. GAUDINO, E

\section{1:15 AM - 1:15 PM}

ATTENTION CONTROL AND THE MAGNITUDE OF LATERALITY EFFECTS IN THE FUSED DICHOTIC WORDS TASK.

EFFECTS OF NON-DOMINANT HAND PERFORMANCE ON PROCESSING SPEED.

NON-DOMINANT HAND PERFORMANCE ON THE CLOCK-DRAWING TEST.

GREATER ACTIVATION OF THE RIGHT THAN LEFT ANGULAR GYRUS DURING WRITING IN BOTH INVERTED AND NON-INVERTED SINISTRAL WRITERS.

HANDEDNESS AND THE FIVE FACTOR MODEL OF PERSONALITY.

FAMILIAL SINISTRALITY AND INTERHEMISPHERIC TRANSFER TIME.

HEMISPHERIC INVOLVEMENT IN PROSODIC CLUES PROCESSING.

REASONING AND DECISION MAKING IN INDIVIDUALS WITH AGENESIS OF THE CORPUS CALLOSUM. SOCIAL INTERACTION IN INDIVIDUALS WITH AND WITHOUT A CORPUS CALLOSUM. EMOTIONAL RESPONSIVENESS IN AGENESIS OF THE CORPUS CALLOSUM.

THEORY OF MIND IN INDIVIDUALS WITH AGENESIS OF THE CORPUS CALLOSUM.

\section{Paper Session 17 \\ Genomic Effects on Neuropsychological Functioning Room: Harborside AB}

GENOMIC EFFECTS ON NEUROPSYCHOLOGICAL STABILITY AND PLASTICITY IN SCHIZOPHRENIA. APOE GENOTYPE AND COGNITIVE FUNCTION IN BRAIN TUMOR PATIENTS DIAGNOSED WITH HIGH GRADE GLIOMA.

THE RELATIONSHIP BETWEEN THE APOE E4 ALLELE AND COGNITIVE IMPAIRMENT IN PATIENTS WITH MULTIPLE SCLEROSIS.

APOLIPOPROTEIN E GENOTYPE AFFECTS NEURAL ACTIVATION IN THE MESIAL TEMPORAL LOBE OF A COGNITIVELY NORMAL COHORT WITH FAMILIAL HISTORY OF AD.

\author{
Paper Session 18 \\ Neuropsychological Functioning in Multiple Sclerosis \\ Room: Harborside C
}

LONGITUDINAL ASSOCIATION OF SELF-REPORTED COGNITIVE DYSFUNCTION AND NEUROPSYCHOLOGICAL PERFORMANCE IN PERSONS WITH MULTIPLE SCLEROSIS.

PREVALENCE AND ESTIMATED RISK OF COGNITIVE DEFICITS ON THE WAIS-III AND WMS-III AMONG PATIENTS WITH MULTIPLE SCLEROSIS.

NEUROPSYCHOLOGICAL DEFICIT PREDICTS WORK FUNCTION IN EMPLOYED PATIENTS WITH M.S. CHANGES IN COGNITIVE FATIGUE OVER THE WORKDAY IN MS.

NEUROPSYCHOLOGICAL IMPAIRMENT PREDICTS FUNCTIONAL OUTCOMES IN MULTIPLE SCLEROSIS. AN MS OUTCOME MEASURE PREDICTS OBSERVED PERFORMANCE ON A COGNITIVELY COMPLEX ADL.

\section{Symposium 19}

Executive Functions in Aging: Integration of Behavioral, ERP and fMRI Studies Chair: Yaakov Stern, Discussant: Jordan Grafman

Room: Harborside DE

EXECUTIVE FUNCTIONS IN AGING: INTEGRATION OF BEHAVIORAL, ERP AND FMRI STUDIES. SOURCE MEMORY DEFICITS AND EXECUTIVE DYSFUNCTION IN OLDER ADULTS. EXECUTIVE CONTROL OF WORKING MEMORY IN AGING.

FMRI STUDY OF DELAYED MATCH TO SAMPLE PERFORMANCE IN YOUNG AND ELDERLY ADULTS. AGE-RELATED CHANGES TO DUAL-TASK TIME PRODUCTION. 


\title{
Abstracts Presented at the Thirty-Second Annual International Neuropsychological Society Conference
}

\author{
February 4-7, 2004 \\ Baltimore, Maryland, USA
}

\section{WEDNESDAY AFTERNOON, FEBRUARY 4, 2004}

Poster Session 1: Dementia: Studies Of Dementia Risk and Those With Cortical Dementias/4:00-6:30 p.m.

\section{Dementia Risk}

G.G. POTTER, K.R. HEBERT, M.J. HELMS \& B.L. PLASSMAN. CONTRIBUTIONS OF OCCUPATIONAL COMPLEXITY TO COGNITIVE STATUS WITHIN ELDERLY TWIN PAIRS.

Research suggests that occupational complexity is positively associated with cognitive performance, but other explanatory factors may exist. We examined the effect of occupational complexity on longitudinal cognitive status in members of the NAS-NRC Twins Registry of World War II veterans. As part of an epidemiological study, study participants were administered the modified Telephone Interview for Cognitive Status (TICS-m) at approximately 3-year intervals between 1990-2002, along with demographic and health-related questions. The mean age at baseline was 65.6 years. Occupational data was used to derive a job complexity score based on the Holland Occupational Complexity scale (Cx). Using a multivariate analysis of twin pairs differing on $\mathrm{Cx}$ level by at least 1 standard deviation and who completed 4 consecutive assessment waves, we found that individuals with higher occupational complexity than their co-twin performed significantly better on the TICS$\mathrm{m}$ across all administrations. Subsequent analysis by zygosity found that occupational complexity was not associated with the TICS-m within monozygotic pairs ( $\mathrm{n}=174$ pairs), but higher complexity was associated with higher TICS-m scores within dizygotic pairs ( $\mathrm{n}=138$ pairs) across the four waves. Occupational complexity was not associated with differential cognitive decline over time in these analyses. Based on this investigation of twin pairs who share genetic and environmental similarities for factors related to cognitive function, our preliminary results suggest that the cognitive complexity of an individual's occupation appears to have a positive association with cognitive performance later in life, but may be superceded by the effects of genes on cognitive status. Correspondence: Guy G. Potter, Ph.D., Psychiatry and Behavioral Sciences, Duke University Medical Center, Box 3925, Duke University Medical Center, Durham, NC 27710-3925.E-mail: gop@duke.edu

\section{K.R. HEBERT, B.L. PLASSMAN, M.J. HELMS, S. FOSTER \& D.C. STEFFENS. PRECLINICAL COGNITIVE SIGNS OF ALZHEIMER'S DISEASE IN AGING TWINS.}

Detecting preclinical signs of Alzheimers disease (AD) is key to early intervention and a better understanding of the disease process. However, reports of early cognitive symptoms that progress to $\mathrm{AD}$ have been discrepant. We examined the association between performance on a modified version of the Telephone Interview for Cognitive Status (TICS-m) and development of $\mathrm{AD}$ within three years in members of the NASNRC Twins Registry of World War II veterans. The veterans were administered the TICS-m at approximately 3 -vear intervals between 19902002 as part of an epidemiological study of dementia. We compared the pre-dementia TICS-m scores for 112 incident AD cases with those of 560 controls matched for age $(\mathrm{M}=71.5$, sd $=3.5)$ and education $(\mathrm{M}$ $=13.2, \mathrm{sd}=3.1)$. Individuals who progressed to dementia scored lower on the TICS-m $(\mathrm{M}=29.1$, se $=.40)$ than the control subjects $(\mathrm{M}=$ 33.3 , se $=.18$ ) who did not progress to dementia within three years. Individuals who progressed to dementia scored lower on each of four predetermined cognitive factors of the TICS-m. Lower performance on the factor assessing immediate and delayed word list recall was most predictive of $\mathrm{AD}$, while a lower score on the factor assessing the ability to name the current president and vice-president was second most predictive of conversion to dementia. These preliminary results suggest that a telephone cognitive status measure may be useful in epidemiological studies in identifying individuals with normal cognition or mild impairment who may progress to dementia.

Correspondence: Katina R. Hebert, MS, Memory and Aging Studies, Duke University, 2575-G Mountain Lodge Circle, Birmingham, AL 35216.E-mail: heber002@bamamail.ua.edu

F.W. UNVERZAGT, S. GAO, K. LANE, B. MUSICK, R.M. EVANS, J. DICKENS, V. SMITH-GAMBLE, K.S. HALL \& H.C. HENDRIE. GENDER AND EDUCATION AND THE RISK OF INCIDENT COGNITIVE IMPAIRMENT: DATA FROM THE INDIANAPOLIS STUDY OF HEALTH AND AGING.

Objective: To examine gender and education as risk factors for incident Cognitive Impairment No Dementia (CIND). Design: A two-stage, longitudinal, population-based study of African Americans aged 65 and older. Method: Subjects were seen at baseline and again for 2-year and 5-year follow-up. Residences in a geographically defined area of Indianapolis, IN were randomly sampled for in-home screening with the Community Screening Interview for Dementia. Subjects were selected for diagnostic clinical assessment based on screening performance with sampling for false negatives. The clinical assessment included physician examination, informant interview, and CERAD cognitive testing. Diagnosis was by consensus panel. Criteria for CIND were: Informant-reported or physician-detected abnormal decline in memory/cognition; or one or more CERAD scores at or below the 7th percentile of same age peers; and no impairment in daily living (CDR stage 0 and 0.5 ). Incidence was determined using the person-years method adjusted for the probability of selection for clinical assessment. Results: 2212 persons 
were screened at baseline; 351 were clinically assessed ( 65 prevalent dementia; 105 prevalent CIND). 1668 subjects completed the 2-year rescreening; 290 were clinically assessed (23 incident dementia; 26 incident CIND). 1255 subjects completed the 5-year re-screening; 274 were clinically assessed (68 incident dementia; 62 incident CIND). The overall age-standardized incidence of CIND in this population was $4.77 \%$ (95\% CI 3.15, 6.41). Women had a slightly higher annual incidence rate than men $(4.73 \%$ vs. $4.34 \%)$. There was a trend for subjects with low education (0-6 years completed) to have a slightly higher incidence rate than those with more education $(5.42 \%$ vs $4.50 \%)$. Conclusions: Neither gender nor education are strong risk factors for incident CIND among elderly, community dwelling African Americans.

Correspondence: Frederick W. Unverzagt, PhD, Psychiatry, Indiana University School of Medicine, 1111 W. 10th Street, PB 218A, Indianapolis, IN 46202.E-mail: funverza@iupui.edu

\section{L.H. WARREN, J. TSCHANZ, K.D. GARRETT, M. NORTON, L. SANDERS, T. OSTBYE, C. PIEPER \& K.A. WELSH-BOHMER. THE TRANSITIONAL COGNITIVE STATE BETWEEN NORMAL AGING AND DEMENTIA: DEFINITIONS MATTER.}

Multiple constructs, such as mild cognitive impairment (MCI) or cognitive impairment no dementia (CIND), are used in the literature to describe the transitional state between normal aging and dementia. Frequently, these constructs are used interchangeably and the criteria for each are often inconsistently applied. We assessed the comparability of several of the common constructs (CIND, age-associated memory impairment [AAMI], age-associated cognitive decline [AACD], two different definitions of MCI, and our own construct "mild ambiguous/ prodromal $\mathrm{AD}^{\prime \prime}$ ) in a sample of individuals enrolled in the Cache County Memory Study (CCMS), an epidemiological community study of aging and dementia. We operationalized each construct based on published definitions and then mapped these definitions onto variables collected in the CCMS. Restricting the sample to the individuals without dementia, we retrospectively examined the membership of these study participants in each of the defined groupings. Our results show that the constructs did not completely overlap; the proportion of individuals meeting criteria for the different constructs varied, both in terms of the relative size and varying composition of the groups. More individuals were categorized as CIND (78.6\%) than MCI (7.7\%). AACD and the other constructs emphasizing both functional change and neuropsychological decline yielded intermediate proportions. These results strongly suggest that different constructs for the transitional state between normal aging and dementia are not interchangeable. MCI and CIND likely describe disparate types of transitional states and, depending on how each is defined, may also tap different time periods or aspects of the continuum between normal aging and dementia.

Correspondence: Lauren H. Warren, M. A., Psychology, UNC-Chapel Hill, CB\#3270 Department of Psychology, UNC-Chapel Hill, Chapel Hill, NC 27599-3270.E-mail: lauren_warren@unc.edu

\section{M.T. WAGNER, J.H. WYMER \& A. WALKER. CHALLENGES AS- SOCIATED WITH THE PRECLINICAL DIAGNOSIS OF ALZHEIMER'S DISEASE IN A 57-YEAR-OLD WITH MILD COGNI- TIVE IMPAIRMENT.}

Three topics of intense interest in Alzheimer's disease (AD) research include presenile AD, Mild Cognitive Impairment (MCI), and biological markers of the disease. We present a case study that embodies all three issues. Serial neuropsychological data, APOE, tau and beta-amyloid CFS proteins, MRI, and other clinical parameters are presented to illustrate the challenges of the diagnosis of presenile AD in MCI. Extensive serial assessment data on a 57-year-old white female with complaints of unexplained memory loss and anxiety are presented. The pitfalls of heavy reliance on any single measure are discussed. Correspondence: Joy H. Wymer, M.A., Neurology, MUSC, 428 Wappoo Rd., Charleston, SC 29407.E-mail:wymerjh@musc.edu
K.R. PETERS \& H. FELDMAN. FURTHER CHARACTERIZATION OF MEMORY IMPAIRED SUBGROUPS OF COGNITIVELYIMPAIRED-NOT-DEMENTED INDIVIDUALS FROM THE ACCORD STUDY.

Background: Cognitively-Impaired-Not-Demented (CIND) is a diagnosis given to individuals with cognitive deficits that fall short of meeting formal dementia criteria. Previously, we identified five distinct subgroups of CIND that were characterized by distinct neuropsychological profiles: Verbal Dysfunction, Verbal/Visuospatial Dysfunction, Memory/Verbal Dysfunction, Memory Dysfunction, and Visuospatial Dysfunction. Conversion rate to dementia was highest in the Memory Dysfunction and Memory/Verbal Dysfunction subgroups. Objective: To further characterize the memory deficits in the Memory Dysfunction and Memory/Verbal Dysfunction subgroups. Method: Subjects included 34 CIND individuals from the Memory Dysfunction subgroup $(\mathrm{M}$ age $=$ 66.5; SD $=9.00)$ and 27 from the Memory Verbal Dysfunction ubgroup $(\mathrm{M}$ age $=61.6 ; \mathrm{SD}=11.20)$. Raw scores on the California Verbal Learning Test (CVLT) were converted to normative $\mathrm{z}$-scores using published data. The percentage of individuals impaired on select CVLT variables was calculated for each subgroup. Impairment was defined as $\mathrm{z}$-scores less than or equal to -1 . Chi square analyses were performed to assess subgroup differences. Results: Of the select CVLT variables, the only significant subgroup difference was observed on the Discriminability Index, $\chi(1)=4.56, p=.033$. The percentage of subjects who were impaired on this variable was higher in the Memory Dysfunction subgroup (56.7\%) than in the Memory/Verbal Dysfunction subgroup $(28.0 \%)$. Conclusion: These results suggest that the memory impairment in the Memory Dysfunction subgroup is more likely due to deficient encoding processes. In contrast, difficulties with retrieval might characterize the majority of subjects from the Memory/Verbal Dysfunction subgroup.

Correspondence: Kevin R. Peters, Ph.D., Psychology, Trent University; 1600 West Bank Drive, Peterborough, ON K9J 7B8, Canada. E-mail: kevinpeters@trentu.ca

\section{S. KARANTZOULIS, J.B. RICH \& J.A. MANGELS. FREE RECALL AND RECOGNITION FOLLOWING MEANINGFUL AND BIZARRE SUBJECT-PERFORMED AND VERBAL TASKS IN NORMAL AGING AND MILD COGNITIVE IMPAIRMENT.}

Recall and recognition are superior following subject-performed tasks (SPTs), in which individuals act out a command during encoding, compared to verbal tasks (VTs). We examined the SPT effect in 26 healthy elderly controls ( $\mathrm{M}$ age $=76$ ) and 26 individuals with mild cognitive impairment (MCI; M age $=75$ ). Two lists of 20 action commands were presented in SPT and VT conditions; one list in each condition was semantically meaningful (i.e., Pet the toy $\operatorname{dog}$ ), and one was bizarre (i.e., Pet the compass). As expected, there was a main effect of group for both recall and recognition, in favor of the controls. Consistent with previous findings, both groups showed an SPT effect, but the advantage of SPTs over VTs was greater for the healthy control group than the MCI group. Moreover, SPTs reduced the interference inherent in the semantically bizarre commands, as demonstrated by a smaller recall difference between the meaningful and bizarre lists in the SPT than in the VT condition. Yes/no recognition memory of previously presented objects and forced-choice recognition of previously presented actions was higher for enacted than verbalized commands (i.e., an SPT effect) in both groups. Finally, the MCI group (but not the controls) showed better recognition of the semantically meaningful relative to bizarre commands. These results demonstrate the robustness of the SPT effect in individuals with MCI and may have implications for cognitive rehabilitation in this group, particularly with regard to improving the formation of new associations or reducing interference.

Correspondence: S. Karantzoulis, Psychology, York University, 4700 Keele Street, Toronto, ON M3J1P3, Canada.E-mail: stellak@yorku.ca 
L.A. RABIN, A.J. SAYKIN, H.A. WISHART, B.R. COPENHAVER, L.A. FLASHMAN \& R.B. SANTULLI. TELEPHONE-BASED SCREENING FOR MCI AND COGNITIVE COMPLAINTS: PRELIMINARY VALIDATION BY COMPREHENSIVE ASSESSMENT.

As the prevalence of dementia increases and strategies for its prevention or delay develop, it is imperative that researchers find cost-effective ways to identify the earliest clinical stages of the disease. It is also important to distinguish categories along the continuum from normal aging though varying degrees of cognitive impairment. Brief, efficient screening instruments offer the potential for early detection and discrimination. In this study, we investigated the predictive classification value of a brief, structured telephone interview. Participants included 18 older adults with subjective cognitive complaints (CC) but without deficit on neuropsychological tests, 18 older adults diagnosed with mild cognitive impairment (MCI) using Petersen et al. and CDR criteria, and 18 demographically-matched healthy controls (HC). Using a discriminant analysis that included two variables from the Dartmouth telephone screen (i.e., number of items endorsed on a brief, forcedchoice, yes/no memory self evaluation and total learning across three trials of a 10-item list-learning test), we correctly classified 17 of 18 HCs and 15 of 18 MCIs (sensitivity $=83.3 \%$, specificity $=94.4 \%$ ). The correct discrimination rate was $88.9 \%$, and on cross validation we correctly classified $86.1 \%$ of cases. In a separate discriminant analysis that included the CC group, accuracy dropped markedly (50\% of cases correctly classified). Results indicate that this brief screening measure has strong predictive utility for MCI. However, further identification of items that discriminate CCs from other groups is warranted to facilitate detection of this at-risk group who perform normally on neuropsychological tests but show mild changes in brain structure and activity similar to those seen in patients with MCI and dementia.

Correspondence: Laura A. Rabin, Ph.D., Department of Psychiatry, Dartmouth Medical School, One Medical Center Drive, Lebanon, NH 03756.E-mail: rabin@dartmouth.edu

C.E. BROMBERG, K.L. DAHLMAN, J. SCHMEIDLER, D. MARIN, V. HAROUTUNIAN, M. SANO \& W. HIRST. LONGITUDINAL ASSOCIATIONS BETWEEN CLINICAL DEMENTIA RATING, GERIATRIC DEPRESSION SCALE AND MEASURES OF NEUROPSYCHOLOGICAL FUNCTIONING IN THE MILDLY COGNITIVELY IMPAIRED ELDERLY. .

Background: Depression and dementia are prevalent disorders in the elderly. We explore relationships between Clinical Dementia Rating (CDR), Geriatric Depression Scale (GDS) and measures of neuropsychological functioning in mildly cognitively impaired (MCI) subjects. Methods: 110 nursing home or assisted-living residents were measured two to seven times over 6 to 90 months. Data were analyzed for: longitudinal associations between CDR and GDS; longitudinal associations between CDR, GDS and 7 measures of neuropsychological functioning (Animal Naming Test; Boston Naming Test; Trail Making Test Parts A and B; Symbol Digit Modalities Test; Word List Delayed Recall; and Word List Recognition); for interaction between GDS and CDR on each neuropsychological measure (NP). All within-subjects longitudinal associations were pooled using partial correlation, controlling for dummycoded subject identifiers. Results: CDR and GDS were significantly correlated $(\mathrm{r}=0.213,(96), \mathrm{p}=0.035)$. Our measure of time demonstrated a significant correlation with both GDS $(\mathrm{r}=0.344,(46), \mathrm{p}=.017)$ and CDR $(r=0.624,(46), p=.000)$. Controlling for time, no relationship was found between CDR and GDS. No interaction was found between CDR and GDS for NPs, save for Boston Naming ( $F=4.894,(1,222)$, $\mathrm{p}$ $=0.028)$ and Trail Making Test Part $\mathrm{B}$ (Total Time) $(\mathrm{F}=5.357(1,122)$, $p=0.022)$. Analysis of CDR and NPs revealed main effects for Animal Naming, Boston Naming, Trail Making Test Part A, Symbol Digit Modalities, and Word List Delayed Recall and Recognition. Analysis of GDS and the NPs revealed main effects for Animal Naming, Symbol Digit Modalities, Word List Recognition, and Trail Making Test Part B (Total Errors). Conclusions: Although, in those with mild cognitive impairment, both dementia and depression worsen over time, they are not correlated.

Correspondence: Chaim E. Bromberg, M.A., Psychology, New School University, 93 Highland Avenue, Tarrytown, NY 10591. E-mail: BromC249@newschool.edu

\section{A. DI FRANCESCO, B. HANNA-PLADDY, N. JOHNSON \&. S. WEINTRAUB. COGNITIVE PREDICTORS OF EVERYDAY AC- TIVITY LEVEL IN AGING AND MILD COGNITIVE IMPAIRMENT.}

Everyday activity level is an important marker of physical, emotional, and social well-being in older adults. Participation in such activities can be limited by age-associated cognitive decline. This study investigated the ability of neuropsychological measures to predict participation in different types of leisure activities. The sample consisted of $199 \mathrm{com}-$ munity-dwelling non-demented individuals, aged 50-92, from the Northwestern Alzheimers Disease Center registry. A neuropsychological battery was used to classify subjects as normal controls or as having mild cognitive impairment (MCI). MCI was defined as performance at least two standard deviations below normative values on two or more neuropsychological measures. All subjects were independent in functional activities of daily living. Complex leisure activities were assessed with a modified version of the Adelaide Activities Profile (AAP), measuring participation in five spheres of daily life: domestic chores, household maintenance, service to others, academic/cultural and social activities. Total AAP score was significantly lower for MCI subjects, although there was no main effect for age or age by group interaction. A multiple regression model was utilized to determine the neuropsychological predictors of AAP score, after controlling for age and education. Total activity level was best predicted by Geriatric Depression Scale score and performance on a verbal learning test $(\mathrm{p}<.005)$. Activities involving household maintenance were significantly predicted by retention of visual designs $(p<.005)$, while academic/cultural activities were predicted by verbal retentive memory performance $(p<.01)$. These results suggest that emotional well-being and memory functions are essential to frequent participation in everyday activities in older adults. Correspondence: Audrey Di Francesco, MA, Clinical Psychology, Northwestern University Medical School, 320 East Superior, Searle building, 11th floor, Chicago, IL 60614. E-mail: a-difrancesco@northwestern.edu

K.E. NUTTER-UPHAM, L. FLASHMAN, L.A. RABIN, H.A. WISHART, R.M. ROTH, R.B. SANTULLI \& A.J. SAYKIN. AWARENESS OF COGNITIVE IMPAIRMENT IN MCI AND CONTROLS WITH COGNITIVE COMPLAINTS: DIMENSION VARIABILITY AND RELATIONSHIP TO NEUROPSYCHOLOGICAL DEFICITS AND BRAIN VOLUME.

Patients with Alzheimer's disease (AD) often show unawareness of their cognitive/behavioral deficits. This has been associated with structural brain abnormality and impaired executive functions. In this study, we investigated patterns of awareness deficits in elders with subjective cognitive complaints but no deficits (CC) or Mild Cognitive Impairment (MCI) to determine their association with NP deficits and whole brain volume. Participants included 11 healthy controls (HC), 14 CCs, and 20 patients with MCI, diagnosed using Petersen et al. and CDR criteria. Groups did not differ in terms of age, education, or gender. Participants completed an NP battery and structural MRI. Indices of unawareness were calculated using an Activities of Daily Living Scale, completed by both the participant and a knowledgeable informant (difference score $=$ Self-Report - Informant-report) . Five CDR domains were analyzed including memory, judgment/problem solving, community affairs, home/hobbies, and personal care. HCs ratings were generally consistent with informants. In contrast, CCs ratings suggested that they are "hyperaware" of deficits, while the MCI group was less aware of 
deficits (judgment, home), or similar in rating to their informant (memory, community, personal care). Results indicated significant differences for judgment $(p<.05)$ and community $(p=.05)$ between the CC and MCI groups. The MCI group scored more poorly than other groups on CVLT but not on the WCST. Groups did not differ in terms of whole brain volume. Degree of awareness was not correlated with either NP performance or whole or frontal lobe brain volume. The present findings indicate that patterns of awareness vary between and within groups. Unlike in $\mathrm{AD}$, awareness ratings did not correlate with NP results or with frontal brain volume in MCI. Further investigation of patterns of unawareness and their relationship to disease progression as measured by cognitive and neuroimaging measures are warranted.

Correspondence: Laura Flashman, Ph.D., Psychiatry, Dartmouth Medical School, HB 7750, One Medical Center Dr, Lebanon, NH 03756. Email:flashman@dartmouth.edu

E.C. LERITZ, A.N. KING \& R.M. BAUER. EPISODIC AND SEMANTIC PRIMING IN AGING AND MILD COGNITIVE IMPAIRMENT.

Amnestic mild cognitive impairment (MCI) is characterized by subjective and objective evidence of memory impairment in the absence of other cognitive deficits. It has been suggested that, because MCI represents a prodrome to more serious dementing illnesses, these individuals may have subtle deficits in new learning compared to normal aging. Objectives: The purpose of the present study was to investigate associative priming for unrelated (episodic) and semantically related word pairs in a large cohort of elderly individuals. We predicted that individuals with MCI would demonstrate semantic, but not episodic, priming, in comparison with a control group. Methods: We developed a priming task that investigated both episodic and semantic priming for word pairs presented at different lag lengths. Participants were also administered a stem-completion task to assess explicit (incidental) memory. In addition, each participant completed a brief neuropsychological screening battery that contained several standardized explicit memory measures. Eighteen of the 90 participants met published criteria for MCI. This group was then matched based on demographics and IQ with a group of 18 normal aging participants from the same cohort. Results: Overall, both groups demonstrated significant episodic and semantic priming, indicating acquisition of both unrelated and related word pairs. There were no group differences across lags. In addition, groups did not differ on overall stem completion performance. Conclusions: These results indicate that despite explicit memory impairment on standardized neuropsychological tests, participants with MCI may be able to form novel associations in memory, albeit implicitly. This is in contrast to predictions and suggests that individuals with MCI may have preserved implicit associative learning abilities in the face of impaired explicit memory.

Correspondence: Elizabeth C. Leritz, MS, University of Florida, 185 Quincy Shore Drive,Apt.A22, Quincy, MA 02171.E-mail: bleritz@ufl.edu

\section{E. MITSIS, M. SANO \& J. HALPERIN. EFFECT OF MINI MENTAL STATUS AND MILD COGNITIVE IMPAIRMENT ON EXECUTIVE FUNCTION.}

Although executive function (EF) deficits have been reported in AD, litthe is known regarding the prodromal phase commonly referred to as mild cognitive impairment (MCI). The present study examined the effect of mini mental status on EF. Subjects were 52 elderly normal adults (mean[SD] age=67.9[7.9]), and 27 adults with MCI (mean[SD] age $=73.4[8.6]$ ). MCI subjects, who did not differ in age or education, were subdivided into two groups: those with Folstein mini mental status examination (MMSE) scores $>26(\mathrm{~N}=17)$ and MMSE scores $<26$ $(\mathrm{N}=10)$. An EF battery consisting of the Wisconsin Card Sorting Test, Stroop, Trails A \& B, Category and Verbal Fluency, Continuous Performance Test, Competing Motors Program, Tower of London, and WAISIII Letter-Number Sequencing and Digit Span subtests was administered. Analysis of Variance using paired contrasts was performed for each EF measure and saved factor scores to examine differences among the groups on tests of EF as a function of scores on MMSE. Results indicate significant differences between the two MCI groups on tests of working memory and behavioral inhibition and on saved factors labeled working memory/fluency and behavioral inhibition. No differences were found between the normal elders and the MCI group with MMSE scores greater than 26, except on category fluency, with verbal fluency approaching significance. Longitudinal analyses are needed to determine the predictive value of EF performance, fluency measures, and MMSE scores on outcome, or progression to dementia, over time.

Correspondence: Effie Mitsis, Ph.D., Psychiatry, Yale University, One Church Street, Suite 600,New Haven, CT 06510.E-mail:Effie.Mitsis@ yale.edu

\section{S. MEJIA, F. OSTROSKY \& L. GUTIERREZ. HETEROGENEITY OF MILD COGNITIVE IMPAIRMENT: CLINICAL CHARACTERI- ZATION IN A MEXICAN POPULATION.}

Clinical heterogeneity in subjects with Mild Cognitive Impairment (MCI) represents a major issue in early diagnosis of dementia. Three types of MCI have been described: amnestic form, multiple-domain form and single non-memory-domain (Petersen, 2003). Educational and occupational attainment, medical history, psychiatric illness and leisure activities are some of the sources of variability in aging process that may be related with different types of MCI. The objective was to identify different patterns of cognitive domain impairment in MCI and association with different sources of variability. Subjects were $50 \mathrm{MCI}$ and 50 matched controls from Mexico city, 65 years old or more who participated in a community based study and were seen for a mean follow up of 32.5, sd,5 months. Clinical examination at base line and at follow up included neuropsychological testing and a structured interview carried out by a Geriatric physician concerning medical history, educational, occupational attainment and leisure activities. Cluster analysis of performance at base line showed different cognitive profiles in MCI and control groups associated with educational attainment and medical illness. From the original control subjects $52 \%$ developed MCI at followup and $30.8 \%$ of MCI subjects converted to dementia. Logistic regression analysis showed that individuals who subsequently developed dementia showed evidence of memory, attention and executive function impairment at their initial examination, while control subjects who evolved to MCI had attention deficits. Individual differences are a source of clinical heterogeneity that can predict different patterns of cognitive impairment and evolving forms in MCI subjects.

Correspondence: Silvia Mejia, Magister, Psychology, Universidad Nacional Autonoma de Mexico, Mirador 63 Casa c-40, Mexico DF 14648, Mexico.E-mail: silviama@prodigy.net.mx

\section{M.W. JACOBSON, D.C. DELIS, A. LANSING, W.S. HOUSTON, K. COBELL, M.W. BONDI \& D.P. SALMON. ERROR ANALYSIS AND DISCREPANCY SCORES ON A GLOBAL/LOCAL LEARNING AND MEMORY TASK IN AN ELDERLY APOE-E4 GROUP AT RISK FOR AD .}

Recent studies suggest that elderly with a genetic risk for $\mathrm{AD}$ (ApoE-e4 genotype) have asymmetric cognitive profiles: large discrepancies between verbal and visuospatial skills relative to non-e 4 elderly. We assessed cognitive asymmetry by administering a task sensitive to asymmetric processing, namely, a global/local learning and memory test. Stimuli were Navon-type figures consisting of large global forms and small, detailed local stimuli known to disriminate between right and left hemisphere functioning respectively. METHOD:19 e4+ normal elderly and 19 age/education matched e4- elderly viewed 3 sets of hierarchical stimuli for 10 sec. each and were asked to draw them for 3 learning trials. A 30 min. delayed recognition trial also was administered. RESULTS: Although total learning and recall scores were similar for the groups, the e4+ group showed significantly greater variability in $\mathrm{z}$-scores for the learning trials relative to the e4- group $(F=5.4, p<.05)$. The e4+ group had a significantly larger proportion of participants with a greater than 
$1 \mathrm{SD}$ difference between global and local learning $\mathrm{z}$-scores relative to the e4- group (chi square $=5.7, \mathrm{p}<.02)$. This trend toward greater cognitive discrepancy in the e4+ group also was reflected in an error analysis contrasting global with local perseverations, omissions, and intrusions. DISCUSSION: These findings suggest subgroups within the e4+ group with significant discrepancies between global(R hemisphere bias)and local learning ( $\mathrm{L}$ hemisphere bias). These findings are consistent with previous studies showing cognitive asymmetry in e4+ elderly at risk for $\mathrm{AD}$ who have significant discrepancies between verbal and visuospatial abilities. Although cognitive mechanisms are unclear, asymmetric subgroups may result from preclinical, lateralized decline in hemisphere-specific functions prior to noticeable cognitive deficits and disruption of cortical networks required for efficient processing of complex visual stimuli.

Correspondence: Mark W. Jacobson, PH.D., Research, Veterans Affairs San Diego Healthcare System, 3350 La Jolla Village Dr., mailcode 151B, San Diego, CA 92103. E-mail: mjacobson@vapop.ucsd.edu

\section{G.M. LARUFFA, V. ZEMON, M.J. KATZ \& D. MASUR. HEALTH QUALITY OF LIFE IN OLDER ADULTS AT RISK FOR DEMENTIA.}

Dementia is a growing public health concern. Recently, work in the early detection of dementia has been expanding. Specifically, the neuropsychological indicators of preclinical dementia or those at-risk have been investigated. This cross-sectional study sought to expand this current line of work by examining the relationship between risk for dementia and health quality of life (HQOL) in a sample of 292 communitydwelling older adults (ages 70 to 95). Specifically, it assessed if risk for dementia, as defined by the Blessed Information-Memory-Concentration Test (BIMC), was related to physical (PCS) and mental (MCS) HQOL as measured by the Short Form-36 (SF-36). In addition, memory/learning ability, as defined by the Free Recall score on the Free and Cued Selective Reminding Test (FCSR) was examined in relation to HQOL. Results of univariate analyses suggested no significant mean difference on PCS between those at high-risk for dementia $(\mathrm{n}=129)$ as compared to those at low-risk for dementia $(\mathbf{n}=163)$, although the direction was as predicted, meaning those at high-risk reported a poorer PCS than those at low-risk. A significant mean difference was found between the high-risk and low-risk groups for MCS, indicating those at high-risk for dementia reported a poorer MCS than those at low-risk. Two hierarchical multiple regressions were performed with results indicating that poorer performance on Free Recall did not amplify the HQOL outcomes in those at high-risk for dementia. In addition, the main effects of risk status and Free Recall scores were not significant. Age, pre-morbid intelligence, and number of medications were the only variables to predict PCS while no variables contributed to the prediction of MCS in this sample. The present findings contradict a large portion of previous research and may be due to the cross-sectional design of the study, the inclusion of many demographics in the models, and lack of awareness of HQOL in those at high-risk for dementia.

Correspondence: Gia M. LaRuffa, Ph.D., Cooper Hospital/UMDNJ/Robert Wood Johnson, 239 D Garfield Ave, Collingswood, NJ 08108. E-mail: GML72@hotmail.com

\section{S. SYMINGTON, K.J. MILLER, P. SIDDARTH, L.M. ERCOLI, S.Y. BOOKHEIMER \& G.W. SMALL. PRE-CLINICAL COGNITIVE SIGNS FOR THOSE AT RISK FOR ALZHEIMER'S DISEASE .}

This study examined asymptomatic individuals in terms of pre-clinical signs of Alzheimer's disease (AD), as expressed in memory functioning, in relation to possible risk for AD from either the possession of the ApoE4 genetic marker and/or positive family history for $\mathrm{AD}$. The 53 participants were divided into the following groups: a) 28 positive family history of AD vs. 25 controls; b) 28 ApoE4 vs. 25 non-ApoE4, and c) 16 had no risk factors, 21 had one risk factor (either ApoE 4 or family history), and 16 had both risk factors. There were no significant results between groups $(\mathrm{a}, \mathrm{b}, \mathrm{c})$ on any of the California Verbal Learning Test
(CVLT) measures, including initial encoding, overall encoding, short delay and long delay recall, and recognition. In the current study, those at risk for $\mathrm{AD}$ did not demonstrate a reduced performance on a measure of memory functioning (mean age of group was 65). These results help to further clarify current controversial results: Bondi (1999) found that the presence of either the ApoE4 genetic marker or family history for $\mathrm{AD}$ predicted poorer performance on CVLT and the eventual emergence of AD symptoms, while Chen's (2002) study did not. Chen suggested that his results varied from that of Bondi's, due to a mean age difference of 6 years between the two studies (71 versus 66), suggesting that preclinical signs of AD may not emerge until participants are of the age group represented in Bondi's studies. The results of this current study lend support to Chen's hypothesis.

Correspondence: Scott Symington, M.A. Clinical Psychology, Fuller Graduate School of Psychology, 3217 La Encina Way, Pasadena, CA 91107. E-mail:symington1@earthlink.net

K. WILDER-WILLIS, P.F. MALLOY, S. SALLOWAY, S. CORREIA, H.G. BELANGER, D. KUMARIAH \& K. FLYN-O'BRIEN. PERFORMANCE ON THE DELAYED RESPONSE AND DELAYED MATCHING TO SAMPLE TASKS IN PATIENTS WITH MILD COGNITIVE IMPAIRMENT AND HEALTHY ELDERLY CONTROLS .

Deficits in executive functioning and working memory may be evident in patients with mild cognitive impairment (MCI) and early Alzheimer's disease (AD). The current study investigated performance on two experimental measures of working memory (WM) in 29 MCI patients (Mean age $=76.79, \mathrm{SD}=7.15)$ and 29 healthy aged and education matched controls (Mean age $=76.12, \mathrm{SD}=5.9)$. These paradigms have been used with primates and have been shown to be valid measures of frontal lobe functioning. Participants were administered tasks of spatial WM (Delayed Response Task; DR) and feature WM (Delayed Matching to Sample Task; DM). Participants were shown 8 stimuli on a computer screen and pressed a keypad indicating either the target location (DR task) or shape (DM task) after a delay interval of $0,5,10$, or 20 seconds. It was hypothesized that there would be main effects for group and delay interval on DR and DM accuracy and that the interaction would be significant. Results showed that there were main effects for group $(\mathrm{F}=7.0, \mathrm{p}<.01)$ and delay interval $(\mathrm{F}=4.0, \mathrm{p}<.01)$ for $\mathrm{DR}$ and for group $(\mathrm{F}=10.7, \mathrm{p}<.01)$ and delay interval $(\mathrm{F}=12.9, \mathrm{p}<.01)$ for DM. MCI participants were less accurate than controls and both groups showed greater impairments at the longer delay intervals. The interaction effect for DR was significant $(\mathrm{F}=3.5, \mathrm{P}<.05)$. Findings suggest that the $\mathrm{DR}$ and $\mathrm{DM}$ tasks are valid measures of working memory, sensitive in detecting subtle deficits in patients with MCI, and that patients with MCI are differentially impaired as demands on spatial working memory increase.

Correspondence: kelly wilder-willis, Ph.D., Pyschiatry and Human Behavior, Brown University, 345 Blackstone Blvd, Providence, RI, RI 02906. E-mail: Kelly_Wilder-Willis@Brown.edu

\section{J. SUHR. THE ROLE OF GENETIC AND NONGENETIC EXPERI- ENCE WITH ALZHEIMER'S DISEASE (AD) IN PERCEIVED AD THREAT.}

Prior research suggests personal experience with Alzheimer's disease (AD) can influence perceived AD threat and self-reported memory. However, existing studies have not compared groups with genetic versus nongenetic AD experience. The present study examined the role of both genetic and nongenetic $\mathrm{AD}$ experience on the relation of perceived $\mathrm{AD}$ threat to depression, anxiety, demographic factors, self-reported memory, and belief in aging stereotypes. Participants were community dwelling adults age 50 and older who participated in a free cognitive screening; 28 with no AD experience, 24 with nongenetic AD experience (nongenetic family, close friend, caregiver), and 25 with genetic AD experience (first degree family member). Groups were not different in demographics or any of the self-report variables. The relation of perceived $\mathrm{AD}$ threat to age and self-report variables did vary as a function 
of group membership. For individuals with nongenetic experience, higher age was associated with higher threat, while for those with genetic experience, lower age was associated with higher threat. In the no experience and genetic experience groups, $\mathrm{AD}$ threat was positively related to depression, anxiety, memory complaints, and belief in age stereotypes, while none of these relationships were significant in the group with nongenetic $\mathrm{AD}$ experience. Belief in the inheritance of $\mathrm{AD}$ was strongly associated with AD threat only for the group with nongenetic AD experience. Findings suggest that the nature of one's personal experience with $\mathrm{AD}$ can influence factors that are related to a perception that one is at personal risk for developing AD.

Correspondence: Julie Suhr, Ph.D., Psychology, Ohio University, 200 Porter Hall, Athens, OH 45701.E-mail:suhr@ohio.edu

J.J. RANDOLPH, A. SAYKIN, H. WISHART, L. RABIN, L. FLASHMAN, K. NUTTER-UPHAM \& R. SANTULLI. EXECUTIVE FUNCTION IN MCI: RELATIONSHIP BETWEEN SUBJECTIVE REPORTS ON THE METEX AND COGNITIVE PERFORMANCE.

The diagnosis of mild cognitive impairment (MCI) depends in part on the presence of memory complaints, but little is known about MCI patients' self-reported functioning in other cognitive domains. The present study sought to determine: 1) whether individuals with MCI had executive complaints in addition to memory complaints, and 2) how MCI and other older adults' subjective executive functioning related to neuropsychological performance. Participants were 14 patients with MCI, 16 older adults with cognitive complaints but normal cognition (CC), and 14 matched healthy controls (HC). Participants were administered the METEX, a brief meta-executive scale consisting of four factor-analytically derived executive subscales, and measures of executive functions and verbal memory. Depressed subjects were excluded from analyses. Results indicated that MCI and CC participants reported significantly more overall executive complaints than controls $(p<.05)$, with MCI patients having more complaints than either group $(\mathrm{p}<.01)$. MANOVA indicated that MCI patients had more executive organization and mental flexibility complaints than CC or HC groups, and MCI and CC groups reported more working memory problems than controls $(p$ $<.05)$. No group differences emerged on the self-monitoring subscale. Correlational analyses across the entire sample indicated that total METEX scores and the executive organization subscale were associated with Trails A \& B, CVLT-Semantic Clustering, CVLT-Trials 1-5 total, and CVLT-Long Delay recall, but not with WCST indices. In sum, these findings suggest that: 1) patients with MCI have more executive complaints than CC and HC groups; 2) these complaints arise in the absence of depression; 3) executive complaints in older adults are associated with executive and memory performance.

Correspondence: John J. Randolph, Ph.D., Psychiatry, Dartmouth Medical School, DHMC, One Medical Center Dr, Lebanon, NH 03756-0001. E-mail:john.j.randolph@dartmouth.edu

\section{T. JONES, G.W. SMALL, L.M. ERCOLI \& P. SIDDARTH. APOLIPOPROTEIN E, NON-VERBAL MEMORY AND VISUOCON- STRUCTIONAL ABILITIES IN OLDER ADULTS.}

This study examined whether baseline performance on non-verbal memory, visuoconstructional abilities, and 2-year longitudinal changes were influenced by apolipoprotein E-4. Participants consisted of 31 APOEe4 and 40 non e- 4 adults, 50 to 84 years of age, and without dementia. Non-verbal memory and visuoconstructional abilities were evaluated using the Benton Visual Retention Test and the Rey-Osterrieth Complex Figure Test (copy and delayed recall). The results indicated no significant baseline or longitudinal differences between the two APOE groups on any of the cognitive measures evaluated. The participants' age and education did not exert an impact on the relationship between APOE-e4 and cognitive functioning. Additionally, there was no difference in APOE status among individuals who showed a significant decline on at least two of the three cognitive measures approximately 2 years after initial testing. The results indicated that APOE in and of itself is not necessarily a consistent predictor of cognitive decline. Neuropsychological tests may not be sensitive to the subtle changes in cognition that may be occurring, particularly in fairly highly educated, nondemented adults who may be years away from a diagnosis of dementia.

Correspondence: Tatyana Jones, Ph.D., UCLA, Neuropsychiatric institute, 1311 Canterbury Ln, Fullerton,CA 92831.E-mail: gersht@ aol.com

\section{Alzheimer's Disease}

\section{R.F. KAPLAN, J. CHASMAN \& G. JONES. EDUCATION AND NEUROPSYCHOLOGICAL TEST PERFORMANCE IN DEMENTIA.} Studies have shown that higher levels of education and occupational attainment are associated with reduced risks of dementia. In Alzheimer's disease (AD), more years of education were associated with better cognitive functioning and fewer senile plaques, with neurofibrillary tangles being unaffected. These data suggest that education may increase the threshold for dementia secondary to some neurodegenerative diseases, consistent with the concept of brain reserve capacity. In the present investigation, we examined the influence of education on neuropsychological test performance in 87 patients with probable AD $(n=54)$ and probable vascular dementia (VD) $(\mathrm{n}=33)$. All were administered the Vocabulary and Matrix Reasoning tests from the Wechsler Abbreviated Scale of Intelligence, Orientation and Information from the Wechsler Memory Scale-Revised and the Repeatable Battery for the Assessment of Neuropsychological Status (RBANS). Years of education were dichotomized into low ( $\leq 12$ years) and high ( $>13$ years). AD patients performed more poorly than VD patients on the total RBANS score and there with no education effects for either group. However, higher education was associated with improved performances on the Vocabulary test, Information and Orientation test and the RBANS language section, independent of diagnosis. These data support the concept of brain reserve, but suggest that the proposed protective effects of education in dementia may be domain specific and directly related to education. Correspondence: Richard F. Kaplan, PhD, Psychiatry, UConn Health Center, 263 Farmington Avenue, Farmington, CT 06030. E-mail: kaplan@psychiatry:uchc.edu

\section{J.M. MILLER \& N.H. PLISKIN. COGNITIVE DECLINE IN ALZHEIMER'S DISEASE: A LONGITUDINAL INVESTIGATION. .}

The present study explored the progression of cognitive decline in Alzheimer's disease (AD) by examining patterns of test performance on successive administrations of the Mattis Dementia Rating Scale (DRS). The sample consisted of 25 male and 38 female $(\mathrm{N}=63)$ participants who were 56 to 85 years of age and were diagnosed with Alzheimer's disease. All 63 participants were administered the DRS on two separate occasions (an initial evaluation and a follow-up assessment), while 33 of these individuals were administered the DRS on a third occasion (initial evaluation and two separate follow-up assessments). Assessments were performed at variable intervals ranging from approximately 3 to 38 months apart. Results indicated that the pattern of progression and sequence of neuropsychological decline in $\mathrm{AD}$ is influenced by variables such as gender and age of disease onset. Further, results offered support for the clinical staging of $\mathrm{AD}$ and further substantiated the clinical utility of the Mattis Dementia Rating Scale in staging the degree of dementia.

Correspondence: Julie M. Miller, M.Ed, Psychology, Oak Forest Hospital, 15900 S. Cicero Ave, Oak Forest, IL 60452.E-mail:j4miller@yahoo.com 
A. SCHAFER, P. LICHTENBERG, M. MADDENS, D. ERLANGER, J. BARTH \& F. WEBBE. HEADMINDER: AN INTERNET BASED SCREENING DEVICE FOR DEMENTIA.

The prevalence of dementia is burgeoning and population studies indicate that prevalence will increase three-fold over the next few decades. Primary Care Physicians (PCPs) are being called on to become more adept at identifying and treating late life dementia. Historically, PCPs have paid little attention to dementia. Psychometric testing plays an important role in the detection of cognitive change, and yet traditional paper and pencil tests are fraught with difficulties. The MMSE, for example, is highly related to age and education, and thus a single cut score is not useful clinically. What is needed is an exam that can be administered and interpreted for the physicians, taking into account effects of age and education. The HeadMinder Dementia Screening Instrument (15-20 minutes) is one such an instrument. The HeadMinder system is an Internet-based, HIPAA compliant, computerized assessment and scoring system. Normative data have been collected on older adults and can be used in making judgments. In the current study. 69 Geriatric clinic patients (some with MCI, some with Dementia and some Normal) were utilized. Mean age at time of assessment was 79.7(7.4) years; mean number of years of education was $13.4(2.4)$ years. Physician diagnoses, (evidence of significant cognitive decline) using Primary Care clinical practice guideline were obtained totally independent of the participants HeadMinder performance. HeadMinder diagnoses were based on a composite of age-education-gender based scores of learning and executive functions. These interpretations had a sensitivity of $89.2 \%$, specificity of $90.6 \%$, positive predictive power of $91.7 \%$ and negative predictive power of $87.9 \%$. Correspondence: Amanda Schafer, Wayne State University, 87 E. Ferry St., Detroit, MI 48202.E-mail:ak7070@wayne.edu

\section{M.J. CHANDLER, H.D. BARNARD, L.H. LACRITZ, L.S. HYNAN \& C.M. CULLUM. A TOTAL SCORE FOR THE CONSORTIUM TO ESTABLISH A REGISTRY FOR ALZHEIMER'S DISEASE (CERAD) NEUROPSYCHOLOGICAL BATTERY.}

The Consortium to Establish a Registry for Alzheimer's Disease (CERAD) developed a brief neuropsychological battery that assesses aspects of language, memory, construction, and global cognition in Alzheimer's disease (AD; Morris et al., 1989). This battery has proven sensitive to dementia, and normative data for components of the CERAD battery have been presented (Welsh et al., 1994), but there is no total score to use for dementia staging or differential diagnosis. The purpose of this project was to develop a composite CERAD score that might be useful in various settings. Scores from the individual CERAD subtests (excluding MMSE) were summed into a total composite (maximum score $=100)$. Data from 422 Caucasian, normal aging participants [ $\mathrm{M}$ age $=$ 68.08 (7.98) years; $M$ education $=13.91(3.03)$ years; $65.4 \%$ female $]$ from 23 participating sites in the original CERAD study (1987-1992) were utilized to derive normative scores for the CERAD total. The sample obtained a mean total raw score of 79.8 ( $\mathrm{SD}=8.8$; range $=52-98$ ). Age, gender, and education effects were observed, and normative data by demographic subgroups are presented. CERAD and MMSE total scores were moderately correlated $(\mathrm{r}=.49)$ in the normative group (likely due to the restricted range of MMSE scores) and highly correlated $(\mathrm{r}=$ $.90)$ in a mixed sample of controls $(\mathrm{n}=422)$ and AD subjects $(\mathrm{n}=808)$ from the CERAD study. These results provide support for the validity of a CERAD total score for use in evaluating dementia severity and progression.

Correspondence: Melanie J. Chandler, MS, Clinical Psychology, University of Texas Southwestern Medical Center, 5323 Harry Hines Blvd, Dallas, TX 75390-8846.E-mail:melaniej.chandler@utsouthwestern.edu

\section{M.E. WITGERT \& P. MASSMAN. USE OF THE AMNART AS AN ESTIMATE OF PREMORBID INTELLECTUAL FUNCTIONING IN ALZHEIMERS DISEASE PATIENTS.}

Neuropsychologists are often challenged with the task of estimating premorbid intellectual abilities in patients with Alzheimers Disease (AD).
One of the most commonly used methods for such an estimate is an oral reading test, such as the AMNART. It has been surmised that oral reading abilities remain intact after other cognitive abilities are weakened by dementia. However, it remains unclear whether oral reading abilities are truly unaffected by dementia. The current study precisely matched $105 \mathrm{AD}$ patients on an individual basis with normal controls on age, education, occupation, race, and gender in order to determine whether the groups performed equally on the AMNART. In addition, AD patients who were tested multiple times were used to determine whether AMNART performance remains stable over time. Finally, regression was used to investigate whether language abilities, as measured by Verbal IQ and the Boston Naming Test (BNT), predict AMNART performance above and beyond education and dementia severity, as measured by the Mini Mental State Exam (MMSE). Results indicated that a significant difference does exist between mild $\mathrm{AD}$ patients $(\mathrm{M}=113.17$, $\mathrm{sd}=8.65)$ and normal controls $(\mathrm{M}=118.77, \mathrm{sd}=7.27)$ and between moderate/severe $\mathrm{AD}$ patients $(\mathrm{M}=107.75$, sd=9.33) and normal controls $(\mathrm{M}=116.88$, $\mathrm{sd}=5.39$ ). No significant difference was observed between successive testing in $\mathrm{AD}$ patients who were tested multiple times, despite declines in mean MMSE score over the same time period. Regression analysis indicated that including language abilities in the prediction accounts for more variance in AMNART performance than education and dementia severity alone ( $\mathrm{R} 2$ change $=.093, \mathrm{p}<.001)$.

Correspondence: Marianne E. Witgert, M.A., psychology, University of Houston, 1301 Richmond, Apt E2, Houston, TX 77006. E-mail: mewitgert@hotmail.com

\section{H. IMBEAULT, I. ROULEAU, F. LIMOGES, H. MASSON \& R. LABRECQUE. REMOTE MEMORY AND RECOLLECTIVE EX- PERIENCE IN ALZHEIMER DISEASE.}

To better understand the mechanisms underlying remote memory in Alzheimer's disease $(\mathrm{AD})$, the "know/remember $(\mathrm{K} / \mathrm{R})$ " paradigm was applied to a famous events test with multiple choice recognition covering the period from 1940 to 2000 . For each question, the subject had to indicate whether he /she remembered the event or if he/she had some knowledge of the event without truly remembering it. For every decade, the percentage of correct responses was significantly lower in $\mathrm{AD}$ patients $(\mathrm{N}=16)$ than in NC subjects ( $N=11)$. Contrary to what is often reported, no temporal gradient was observed in AD patients; the slope was flat across all decades. In addition, $\mathrm{AD}$ patients indicate significantly more $\mathrm{K}$ than $\mathrm{R}$ responses suggesting that while they had some familiarity with the events, they did not truly remember having witnessed them, and that, regardless of the decade. In contrast, NC subjects showed a pattern that varied as a function of the decade. For the most remote events (19401950 ), they indicate more $K$ than $R$ responses. For the events from 19601970 , they report as many $K$ as $R$ responses. Finally, for the most recent events (1980-2000), NC subjects indicate significantly more R than K responses. These results suggest that in NC subjects, the older the memories, the less episodic and the more semantic they become. In contrast, in AD patients, even relatively recent events have lost their episodic components and only a familiarity remains. These results will be discussed as a function of Cermak's semantization hypothesis.

Correspondence: Isabelle Rouleau, Ph.D., psychology, UQAM, CP 8888, Succ. centre-ville, Montréal, QC H3C 3PS, Canada. E-mail: rouleau. isabelle@uqam.ca

\section{K.D. GARRETT, C.C. PRICE, D.J. LIBON, R. SWENSON, D. PENNEY, S. COSENTINO \& A.L. JEFFERSON. VERBAL SE- RIAL LIST LEARNING AMONG DEMENTIA PATIENTS WITH AND WITHOUT WHITE MATTER CHANGES: NEUROPSYCHOLOGI- CAL CORRELATES.}

The mechanisms that underlie disturbances in memory and learning associated with subcortical white matter alterations are not well characterized. In our companion poster, Price et al. presented 2 factor solutions derived from the Philadelphia (repeatable) Verbal Learning 
( $\mathrm{P}(\mathrm{r}) \mathrm{VLT})$, a 9-word serial list learning task designed to assess memory and learning in patients with and without MRI subcortical white matter lesions (SWMLs). We investigated the degree to which language and executive control abilities are associated with the factor analysis of general learning characteristics of the P(r)VLT. For factor 1, no significant correlations were found between neuropsychological tests and delayed free and/ cued variables. Regarding factor 2 , better performance on tests of language and executive control were associated with increased output on immediate free recall variables (word-list generation-'FAS', $\mathrm{r}=.37, \mathrm{p}<.01$; Boston Naming Test, $\mathrm{r}=.51, \mathrm{p}<.001$; animal fluency Association Index - 'AI', r=.322, $\mathrm{p}<.004)$. Contrary to expectations, free and cued recall intrusion errors (factor 3 ) were not related to language or executive control variables. For factor 4, delayed recognition trial performance were also associated with language and executive control abilities (FAS, r=.31, p<.012; animal AI, r=.341, p<.002). These data suggest that $\mathrm{P}(\mathrm{r})$ VLT delayed free and/ cued variables (factor 2 ) may provide a relatively pure measure of learning. Capacity for active retrieval (executive control) and lexical/ semantic word knowledge (language) may be related to $\mathrm{P}(\mathrm{r}) \mathrm{VLT}$ variables that assess both immediate free recall and delayed recognition.

Correspondence: Catherine Price, Ph.D., Clinical \& Health Psychology, University of Florida, P.O. Box 100165, Gainesville, FL 32664. Email: cprice@hp.ufl.edu

\section{C.C. PRICE, K.D. GARRETT, D.J. LIBON, R. SWENSON, D. PENNEY, A. JEFFERSON \& S. COSENTINO. VERBAL SERIAL LIST LEARNING AMONG DEMENTIA PATIENTS WITH AND WITHOUT WHITE MATTER CHANGES: FACTOR SOLUTIONS.}

We investigated the constructs that underlie performance on a verbal list learning task among dementia patients with and without MRI subcortical white matter lesions (SWMLs). Severity of SWMLs was measured with the 40 -point Junque scale $(12.5 \pm 6.89)$ among 78 outpatients with mild to moderate dementia (MMSE $=23.03 \pm 3.01$; age $=78.87 \pm 5.36$ ). All patients were administered the Philadelphia (repeatable) Verbal Learning Test $(\mathrm{P}(\mathrm{r}) \mathrm{VLT}$ ); a 9-word serial list learning task (Price et al., 2002) modeled after the 9-word CVLT. Category exemplars were constructed from 100 healthy older adults with similar demographic characteristic as our dementia sample. A factor analysis of general learning characteristics yielded a 4 -factor solution ( $76.4 \%$ variance): Factor 1 $(31.1 \%)$ included delayed recall variables; Factor $2(19.4 \%)$ included immediate free recall variables; Factor $3(13.0 \%)$ included intrusion errors from free and cued recall trials; Factor $4(13.0 \%)$ included variables from the delayed recognition trial. A second 4-factor analysis was conducted on the 5 immediate free recall test trials ( $71.9 \%$ variance): Factor 1 (18.3\% variance) included serial and semantic clustering; Factor $2(18.3 \%)$ included primacy recall and within-trial intrusions errors; Factor $3(18.23 \%)$ included recency recall and recall consistency, and Factor $4(17.0 \%)$ included two types of category-related intrusion errors. These factor solutions indicate that the P(r)VLT elucidates heuristically meaningful cognitive constructs related to memory and learning in dementia patients with and without white matter changes. The neuropsychological correlates of these factor solutions are explored in our companion poster (Garrett et al.).

Correspondence: Catherine Price, Ph.D., Clinical \& Health Psychology, University of Florida, P.O. Box 100165, Gainesville, FL 32664. Email:cprice@hp.ufl.edu

\section{A. OBRAZTSOVA \& N.S. FOLDI. MORE THAN JUST WORDS: VERBATIM, PROPOSITIONAL AND THEMATIC MEASURES OF STORY RECALL IN PATIENTS WITH ALZHEIMER'S DISEASE.}

This study was designed to investigate how severity of Alzheimer's disease (AD) affected different measures of story recall. Transcripts of immediate recall of the modified cowboy story (Talland, 1965) were scored on units of verbatim (exact), propositional (conceptual), and thematic content in patients with mild ( $\mathrm{AD} 1, \mathrm{n}=8$, mean age 72.5), and moder- ate (AD2, n=8, mean age 73.6) $\mathrm{AD}$, and age-matched normal controls $(\mathrm{NC}, \mathrm{n}=9$, mean age 73.6$)$. The aims were to: 1$)$ determine whether verbatim units were more vulnerable than propositional and/or thematic units; 2) determine whether performance on the story task and list recall task (California Verbal Learning Test, CVLT) were similar. Groups performed differently across all measures, $p<.001$, [AD2 2 AD1 $<\mathrm{NC}]$. A Story measures main effect, $p<.001$, [verbatim<propositions $\langle$ themes] indicated that all groups differentiated these recall measures.A Group $\mathrm{x}$ Story measures interaction, $p<.012$, revealed that controls recalled significantly more verbatim units than either $\mathrm{AD}$ group. Propositional units were recalled differentially by all three groups $[\mathrm{AD} 2\langle\mathrm{AD} 1\langle\mathrm{NC}]$. On themes, controls and AD1 significantly outperformed the AD2 group $[(\mathrm{NC}=\mathrm{AD} 1)\rangle \mathrm{AD} 2]$. Each of the story measures captured different strengths and weaknesses at progressive stages of AD. For all patients with $\mathrm{AD}$, the three story measures were not related to recall measures of the CVLT, while for the controls, themes correlated with CVLT immediate recall measures. This suggests that list and story recall may tap related underlying retrieval strategies in $\mathrm{NC}$, but in $\mathrm{AD}$, the relationship between these two memory tasks is not significant. These findings validate differentiating multiple story recall measures.

Correspondence: Anna Obraztsova, Psychology-Neuropsychology, Graduate Center, CUNY, 65-30 Kissena Blvd., New Science Building, E318, Flushing, NY 11367.E-mail: obraztsova@excite.com

\section{F. LIMOGES, I. ROULEAU, H. IMBEAULT, H. MASSON \& R. LABRECQUE. PROSPECTIVE MEMORY IN ALZHEIMER'S DISEASE : A STUDY USING EVENT-BASED TASKS. .}

Although prospective memory (PM) has been extensively studied in normal aging, there have been few studies with dementia patients, which is surprising considering the importance of PM for adequate daily functioning. The purpose of the present study was to evaluate prospective memory across various event-based PM tasks. In those, an external cue indicates to the subject that an action must be performed. Four PM tasks that varied on the salience of the cue and the delay between the instruction and the cue (including one task adapted from McDaniel et al, 1999), were administered to 16 mildly demented (DRS: 106-135) Alzheimer's Disease (AD) patients and to 11 normal control (NC) subjects. Most AD failed all PM tasks. However, when questioned, some could correctly recall the action that they were supposed to perform. In contrast, the performance of the NC subjects was adequate although not perfect in most PM tasks. The three NC subjects who failed the McDaniel task also failed the other PM tasks and obtained the lowest scores on the Dementia Rating Scale. These results suggest that PM tasks are highly sensitive to cognitive impairment and might be affected in early $\mathrm{AD}$. Correspondence: Isabelle Rouleau, Ph.D., psychology, UQAM, CP 8888 , Succ. centre-ville, Montréal, QC H3C 3P8, Canada. E-mail: rouleau. isabelle@uqam.ca

\section{WEBER, H.J. WESTERVELT \& R.J. MCCAFFREY. ODOR MEMORY IN OLDER ADULTS WITH AND WITHOUT COGNITIVE IMPAIRMENTS.}

Olfactory dysfunction is well documented in Alzheimer's disease and there is increasing evidence that deficits in the ability to detect or identify odors are seen early in the disease process, often preceding global cognitive decline. More recently, studies have demonstrated the utility of tests of olfaction in predicting future decline (Bacon et al., 1998; Graves et al., 1999). Most of these studies, however, have examined odor threshold or odor identification. To date, few studies have examined the clinical utility of odor memory tests in the preclinical diagnosis of dementia, despite the fact that memory impairment is a hallmark symptom of dementia. Furthermore, little research has been done to examine the relationship between odor memory and other measures of olfaction and cognition. The present study sought to determine if odor memory performance discriminates between older adults with and without cognitive impairments. Thirty older adults referred for a neuropsy- 
chological evaluation of memory complaints who did not meet criteria for dementia were compared to thirty age-matched community-dwelling controls. Participants were administered a standard neuropsychological battery that assessed attention, executive function, motor function, language, visuospatial skills, memory, and olfaction. The two groups differed significantly on odor memory, but not odor identification. Odor memory test performance significantly correlated with tests of verbal and visual memory, but not tests of motor function. The utility of tests of olfaction, particularly odor memory, in the preclinical diagnosis of dementia is discussed.

Correspondence: Miriam Weber, Ph.D., Department of Neurology, University of Rochester Medical Center, 385 Linden Street, Rochester, NY 14620.E-mail:Miriam_Weber@urmc.rochester.edu

\section{T.T. LINEWEAVER, D.P. SALMON, S. EBERSON-SHUMATE \& M.W. BONDI. WHAT YOU SEE IS NOT ALWAYS WHAT YOU GET: VISUOSPATIAL SKILLS ARE NOT CREATED EQUAL IN PATIENTS WITH ALZHEIMER'S DISEASE.}

Visuospatial skills are known to decline in the context of Alzheimer's disease $(\mathrm{AD})$, particularly in patients with moderate to severe dementia. However, different aspects of visuospatial tasks may render them more or less sensitive to the cognitive changes associated with AD. Twenty older normal control (ONC) participants, eight mildly demented AD (miAD; DRS >120) patients, and ten moderately demented AD (moAD; DRS $<=120$ ) patients were administered a comprehensive battery of seven visuospatial tests that differed in their reliance on visuoperceptual, visuoconstructional, mental rotation, and right/left discrimination skills. The three groups were matched in terms of age, education, and gender. No significant group differences were found on the Right-Left Orientation test. Measures involving a constructional component (Block Design, Stick Construction) differentiated miAD patients from both the ONC group and the moAD group. In contrast, only the moAD patients were impaired on tests primarily assessing visuoperceptual skills (Visual Reproduction Matching, Judgment of Line Orientation) and on measures requiring mental rotation without visuoconstruction (Money Road Map. Luria Mental Rotation). When compared to the results from a verbal measure (Boston Naming Test; $\mathrm{ONC}>$ miAD $=$ moAD), visuoconstructional tests showed the advantage of being sensitive to mild AD, while also differentiating patients with mild versus moderate dementia. Taken together, these results indicate that the neurodegenerative changes that affect patients with AD may result in differential visuospatial deficits as the disease progresses. Tests involving visuoconstruction appear most sensitive to early cognitive decline in $\mathrm{AD}$ and may also help to differentiate mild from moderate $\mathrm{AD}$ patients.

Correspondence: Tara T. Lineweaver, Ph.D., Psychology, Butler University, 4600 Sunset Ave., Indianapolis, IN 46228. E-mail: tlinewea@ butler:edu

\section{JACKSON, B.V. SHENAL, R.D. RHODES, J. MIELKE, G. CRUCIAN, K. WOMACK \& K.M. HEILMAN. FINGER AG- NOSIA IN ALZHEIMER'S DISEASE.}

Finger agnosia is the inability to correctly name individual fingers. Previous research has suggested that the presence of finger agnosia is frequently associated with Alzheimer's Disease (AD) and may help discriminate between patients with $\mathrm{AD}$ and the normal elderly population. The present study sought to determine which digit is the most sensitive marker for identifying finger agnosia and to determine whether or not this naming test effectively discriminates between $\mathrm{AD}$ and age matched normal subjects. Results of finger naming for $\mathrm{AD}$ patients $(\mathrm{n}=38)$ with mild to severe dementia was analyzed and compared to age-matched normal controls $(n=10)$. The digits that all subjects were asked to name were the thumb, index (also 'pointer' or 'dog finger'), and pinky (also 'small' or 'little') fingers. Findings revealed that AD patients had the most difficulty correctly naming the index finger. The finding that no subject who was able to name their index finger was unable to name their thumb or pinky suggests that when examining patients for dementia, the only finger that they should be asked to name is the index finger. The finding that no normal subjects were unable to name their index finger but $63 \%$ of $\mathrm{AD}$ patients were unable to name this finger suggests that having patients name just their index finger is a specific but only moderately sensitive test for AD.

Correspondence: Brian V. Shenal, Ph.D., Neurology, University of Florida, 100 S. Newell Drive, PO Box 100236, Gainesville, FL 32610-0236. Email:shenabv@neurology.ufl.edu

\section{K. WILD \& V. COTRELL. UNINTENTIONAL MEDICATION NONCOMPLIANCE IN PATIENTS WITH ALZHEIMER'S DISEASE.}

Incorrect use of medications is a major health care problem, especially among older adults. Little is known about the medication management behaviors of individuals with dementing illness, although it is known that forgetfulness and confusion are major causes of unintentional nonadherence. This study examined the relationship between the patients' cognitive status, deficit awareness, understanding of their medication regime, and actual medication compliance. The ability of caregivers to accurately assess the patients' understanding and adherence to prescribed medications was also examined. Twenty-seven patients with AD and 20 healthy controls matched for age and medication complexity were interviewed and evaluated with the following measures: Mini Mental State Examination; the Dementia Deficits Scale (Snow et al), a measure of self-perceptions of deficits in dementia; the Drug Regimen Unassisted Grading Scale (DRUGS) a performance measure of understanding of medication regimen. Amount of help received in taking medication was assessed on a four-point scale from "none/minimal" to "complete." A pill count was also performed at baseline and 30 days later as a measure of adherence. MMSE score was not significantly related to our objective measure of compliance, but an ANOVA revealed significant associations between MMSE and amount of help received. We found differences between groups in amount of help received, with $\mathrm{AD}$ patients more likely to receive verbal/visual or complete help, while AD and HC were equally likely to receive none/minimal or physical assistance in taking medications. AD patients receiving no assistance in managing their medications were found to have lowest compliance rates of all group $\mathrm{x}$ level of assistance comparisons.

Correspondence: Katherine Wild, Ph.D., Neurology, Oregon Health and Science University, CR131, Portland,OR 97239.E-mail:wildk@ ohsu.edu

\section{J.S. KLEINER, K.Z. DONNELLY, B.M. HOFFMAN, M.J. MORD- HORST \& J. BURHART. UTILITY OF THE TMT B DIVIDED BY A EQUATION IN DIFFERENTIAL DIAGNOSIS OF DEPRESSION AND DEMENTIA.}

Trail Making Test A and B are widely utilized, easily administered neuropsychological instruments. TMT A is considered a test of visual attention and tracking, while TMT B has an additional focus on executive functioning (Drane, Yusephe, Huthwaite, \& Klinger, 2002). It has been proposed in the literature that, by dividing time to completion for TMT B by TMT A, the demands of graphomotor and visual attention skills are held constant and therefore only reflect a measure of executive functioning (Lamberty et al., 1994). The present study examines the utility of the TMT B/A equation in the differential diagnosis of depression and dementia. The sample consisted of 79 patients with dementia (54 Alzheimer's disease and 25 Vascular dementia) and 59 patients diagnosed with depression. A simple equation of TMT B/ TMT A was completed for all participants. Hierarchical multiple regression analyses yielded a significant difference in Trails $\mathrm{B} / \mathrm{A}$ scores for patients with depression versus Alzheimer's disease $(\mathrm{B}=.389, \mathrm{p}<.001)$ as well as depression versus Vascular dementia $(\mathrm{B}=.338, \mathrm{p}<.003)$, above and beyond age and education. ROC curve analyses demonstrated that $\mathrm{B} / \mathrm{A}$ differentiated those with $\mathrm{AD}$ from those with depression $(\mathrm{AUC}=$ 
$.86,95 \% \mathrm{CI}=.790-.930, \mathrm{p}<.0001)$. Similarly, Trails B/A significantly differentiated patients with depression and $\mathrm{VaD}(\mathrm{AUC}=.778,95 \%$ CI $=.674-.882, \mathrm{p}<.0001)$. Utility of specific cut-off scores for Trails $\mathrm{B} / \mathrm{A}$ are outlined. Implications for future research and clinical practice are discussed.

Correspondence: Jennifer S. Kleiner, University at Buffalo, 2233 St. Charles Ave, \#704, New Orleans, LA 70130.E-mail: jennifer.kleiner2@ med.va.gov

\section{E.K. HILL, J.W. FINK, E. ECKLUND-JOHNSON, J.P. CHOCA, M. HELFORD \& J. MORRIS. THE RELATIONSHIP BETWEEN DEPRESSION AND LEVELS OF UNAWARENESS IN DEMENTIA.}

This study investigates the relationship between depression and levels of unawareness of cognitive deficits in individuals with dementia using a novel, and perhaps more appropriate, statistical approach than previous studies in this area. Traditionally, unawareness has been operationalized as difference scores (e.g., between patient report and caregiver report or patient performance), which have several conceptual and statistical limitations. In the current study, unawareness was defined as the interaction between patient report and patient performance in multiple regression analyses. Ninety-nine outpatients ages 59 to 86 who were referred for a dementia evaluation completed a neuropsychological battery and awareness questionnaire. The first hypothesis, that there would be a negative relationship between self-reported depressive symptoms and levels of unawareness, was not supported. The relationship between depression and unawareness did not vary across different cognitive domains (i.e., memory, attention, language, and executive skills). The analyses revealed that participants self-report of their cognitive abilities significantly predicted their self-reported level of depression, with regard to overall cognitive functioning as well as each cognitive domain. The results of this study suggest that researchers and clinicians should take into account the relationship between depression and report of $\operatorname{cog}_{-}$ nitive deficits in studies of unawareness in individuals with dementia. Correspondence: Erin K. Hill, PsyD, Harvard Medical School, $400 \mathrm{~W}$. Cummings Park,BMG 1725-122, Woburn, MA 01801.E-mail: erinkhill@ comcast.net

\section{M.B. SPITZNAGEL, G. TREMONT, H. WESTERVELT \& R.A. STERN. DOES COGNITIVE RESERVE PLAY A ROLE IN ANOSOGNOSIA IN DEMENTIA?}

Cognitive reserve theory posits that individuals with the same brain insult or disease will vary in clinical symptoms based on premorbid variables. Anosognosia, or lack of insight regarding deficits, is an important component of the clinical presentation in dementia. with implications for safety and caregiver burden. The current study examined the role of cognitive reserve in anosognosia associated with mild cognitive impairment and early dementia. Participants were community-dwelling individuals referred to an outpatient memory clinic and subsequently diagnosed with mild cognitive impairment or dementia using the Clinical Dementia Rating (CDR) scale. Anosognosia was measured by average item discrepancy scores (i.e., family - participant ratings) on the Cognitive Difficulties Scale $(0=$ not a problem to $4=$ significant problem $)$. High and low cognitive reserve groups were created based upon above versus below average single word reading performance. Groups did not differ significantly on CDR ratings. The high cognitive reserve group (n $=40 ; \mathrm{M}=.04, \mathrm{SD}=.91)$ showed a significantly lower discrepancy $(\mathrm{p}<$ $.01)$ between participant and family ratings than the low cognitive reserve group $(\mathrm{n}=36 ; \mathrm{M}=.59, \mathrm{SD}=.92)$. Increased awareness was associated with better reading performance, even after controlling for MMSE $(\mathrm{pr}=.35)$ and $3 \mathrm{MS}(\mathrm{pr}=.31)$ performance. These findings suggest that cognitive reserve is related to anosognosia in mild cognitive impairment and early dementia, and have clinical implications for the assessment of awareness in dementia.
Correspondence: Mary B. Spitznagel, PhD, Neuropsychology, Brown University Medical School, 110 Lockwood Street, Suite 430, Providence, RI 02903. E-mail: Mary_Beth_Spitznagel@Brown.edu

\section{L.E. FERRETTI \& R. BENEDICT. FAILURES TO APPRECIATE COGNITIVE IMPAIRMENT IN AD ARE NOT DUE TO AMNESIA.}

Previous methods of assessing awareness of cognitive impairment in Alzheimer's disease (AD) may have been biased by amnesia. Two methods of assessment devised to place differential demand on memory function were compared to investigate the influence of memory on the assessment of self-awareness. Impaired awareness was defined as a discrepancy between self-rated ability and neuropsychological testing. Patients were asked to rate their cognitive capacity on a visual analogue scale before and after neuropsychological testing. Eighteen mildly to moderately demented patients with probable $\mathrm{AD}$ and eighteen healthy elderly controls were studied in a repeated measures, group comparison design ( $\mathrm{AD} \mathrm{v}$ healthy, before $\mathrm{v}$ after testing appraisal). Only the main effect of Group was significant, as both $\mathrm{AD}$ patients and healthy controls demonstrated comparable levels of impaired awareness across method. AD patients consistently overestimated their abilities compared to healthy controls. The present findings suggest that deficient awareness in AD cannot be explained solely by decline in memory (in other words forgetting they are impaired), because patients continued to deny deficits when confronted with poor task performance.

Correspondence: Louise E. Ferretti, PhD, Pediatrics, University at Buffalo, 936 Delaware Avenue, Buffalo, NY 14209.E-mail:ferretti@buffalo.edu

\section{N.A. DONINGER \& R.J. ERWIN. INHIBITORY PROCESSING AND EMOTIONAL PERCEPTION IN ALZHEIMERS DISEASE.}

Emotional dysregulation and neuroimaging data indicating damage to regions underlying inhibitory control and emotion suggests that individuals with Alzheimers disease (AD) may experience difficulty modulating attention toward processing emotional information. Emotional and traditional Stroop tasks were administered to non-depressed, mild and moderately impaired individuals with $\mathrm{AD}$ and healthy elderly to examine differences in interference processing positive and negative valence emotional words relative to neutral words and the extent to which interference is contingent on semantic content. Groups differed significantly processing color-conflict stimuli on the traditional Stroop test. The amount of interference processing emotional words relative to neutral words increased with greater dementia severity; however, planned comparisons indicated that only healthy elderly experienced significantly less interference than individuals with moderate AD. A habituation effect indicated that participants experienced less interference across time on the emotional Stroop task. Healthy elderly and individuals with moderate $\mathrm{AD}$ experienced significant differences in interference related to semantic content. Healthy elderly experienced more difficulty processing color-conflict stimuli than negative emotional stimuli whereas individuals with moderate $\mathrm{AD}$ experienced more difficulty processing positive emotional stimuli relative to color-conflict stimuli. Deficient inhibitory mechanisms provide a seemingly insufficient account of emotional dysregulation observed early in AD. The applicability of current cognitive models of depression postulating information processing biases to individuals with neurological impairment in regions subserving attention networks requires further study. Inhibitory processing may be more sensitive to variations in the intensity of arousal evoked by emotional information and experience of negative affect (i.e., depression, anxiety).

Correspondence: Nicholas Doninger, Ph.D., Psychiatry, University of Chicago Medical Center, 5841 S. Maryland Ave., MC 3077, Chicago, IL 60637. E-mail: ndoninge@yoda.bsd.uchicago.edu 


\section{N. MAHENDRA. INHIBITORY FUNCTION AND INTERFERENCE EFFECTS IN AGING AND ALZHEIMERS DISEASE.}

Inhibition is a ubiquitous process in human behavior and its role in efficient information processing has received considerable attention. Failure to inhibit activated but irrelevant information can lead to cluttering of working memory and cause performance breakdowns. Inhibitory deficits have been used to explain cognitive declines in healthy aging, minimal cognitive impairment and in Alzheimers disease (AD). The primary purpose of the present study was to investigate and compare inhibitory function in healthy elders and individuals diagnosed with AD A secondary purpose was to determine if inhibitory deficits and increased interference might account for some semantic memory deficits in AD. Thirty age- and education-matched healthy elders and 30 individuals with AD were administered the Stroop color-word test, the proactive interference (PI) word list recall task, the FAS verbal fluency task, and the Recent Memory Screening Test (RMST). Data analysis reveals that individuals with $\mathrm{AD}$ have significantly poorer inhibitory function than healthy elders and are also significantly more prone to interference from related information. Our findings indicate that inhibitory deficits in persons with AD contribute to both semantic and episodic memory deficits. Correspondence: Nidhi Mahendra, PhD, CCC-SLP, University Teaching Center, The University of Arizona, 1017 N. Mountain Avenue, The University of Arizona,Tucson,AZ 85721.E-mail:nidhi@email.arizona.edu

C.J. HAMMOND, J.A. LEVY, L. MCGEE, K. PUTNAM, E. SPOOR, J. BERGESON, R. COHEN \& T. SUNDERLAND. CLOCK DRAWING IN ALZHEIMER DISEASE IS MORE RELATED TO MEASURES OF EXECUTIVE FUNCTION THAN TO FIGURE COPYING.

It is unclear which cognitive processes are represented by the clock drawing task: executive functions, visuospatial ability, or a combination thereof. We examined scores on a clock drawing task relative to executive function measures and visuospatial measures in a population of 40 patients with probable Alzheimer Disease (AD). Clocks were scored using a modified version of the Mendez scale, altered to increase specificity and inter-rater reliability. Twenty patients received the Nelson version of the Wisconsin Card Sort Task (N-WCST). Twenty patients (matched for age, education, gender, and severity-level) received the Delis Kaplan Executive Function System card sort test (DKEFS-sort) and the Trail Making Test (TMT). All patients received the same battery of other measures including the Mattis Dementia Rating Scale (MDRS) and the Rey Complex Figure Test (RCFT). Data from each group was subjected to a factor analysis. In the N-WCST group, four factors emerged: conceptualization and perseveration, initiation, nonperseverative error on the $\mathrm{N}$-WCST, and figure copving. Clock scores correlated highest with the factor representing nonperseverative errors on the N-WCST $(r=.87)$ and lowest with figure copying $(r=.10)$. In the group that received the DKEFS-sort and the TMT, three factors emerged: executive function (including conceptualization and flexibility), figure copying/information processing, and initiation. Clock scores correlated highest with the executive function factor $(r=.65)$ and lowest with the figure copving/processing factor $(\mathrm{r}=.02)$. In conclusion, clock scores were related to executive functioning in two AD populations but were not associated with scores on tasks of simple (MDRS Construction Subscale) and complex (RCFT) figure copving.

Correspondence: Christopher J. Hammond, B.A. Psychology and Marketing, Geriatric Psychiatry Branch, National Institute of Mental Health, Building 10 Rm 3N228, 10 Center Drive, Bethesda, MD 20892. E-mail: hammondc@intra.nimh.nih.gov

\section{F. GOULD, J.L. WOODARD, S.T. GRAFTON, J.R. VOTAW, R.C. GREEN, M. DOBRASKI, K. SHANNON \& J.M. HOFFMAN. GENDER DIFFERENCES IN PET ACTIVATION ASSOCIATED WITH AD ON A WORKING MEMORY TASK.}

This study compared the functional anatomical correlates supporting overt rehearsal versus a reading control task in five female and five male participants with possible or probable AD using PET imaging (mean age $=67.2, \mathrm{SD}=7.3$, range $=56-78$ ). Two rehearsal conditions involving overt rehearsal of five and ten-word lists were contrasted with a reading control condition. Regional cerebral blood flow images were acquired using a modified autoradiographic method and then realigned, normalized, and smoothed using SPM99 before being subjected to pixelby-pixel statistical analysis. Using exclusive masking, activation unique to men and women were revealed. Female AD patients, displayed significant activation in the right occipital lobe and bilateral parietal lobe (BA $7 \&$ 19). They also displayed significant left parietal activation (BA 1, 2, 3, \& 40) and significant left frontal lobe activation (BA 6). In contrast, male $\mathrm{AD}$ patients activated the left frontal lobe in more medial and inferior regions (BA 45 and 46) relative to women. Male AD patients activated the right frontal lobe extensively (BA 8, 9, 10, 13, \& 46). Activation in the cerebellum was also unique to men with AD. In a prior study of healthy controls using the same tasks, women demonstrated greater activation of frontal brain regions, whereas men demonstrated greater activation posteriorally. The reversed pattern of activation in male and female $\mathrm{AD}$ patients may be tied to underlying differences in the neuropathology and neurobehavioral deficits associated with the disease.

Correspondence: Felicia Gould, Psychology, Finch University of Health Sciences/ The Chicago Medical School, 3333 Greenbay Rd., North Chicago, IL 60064.E-mail: feliciagould@finchcms.edu

\section{J.L. SALVATIERRA \&. M. ROSSELLI. VERBAL FLUENCY IN BILINGUAL ALZHEIMER'S DISEASE PATIENTS.}

Numerous studies have demonstrated that in verbal fluency tests monolingual Alzheimer's disease (AD) patients show greater difficulties retrieving words under semantic conditions compared to phonemic conditions. This study tried to determine whether the pattern of greater difficulties retrieving words under the semantic rather than the phonemic condition was reproduced in the two languages of Spanish/English bilingual $\mathrm{AD}$ patients. It also compared the severity of $\mathrm{AD}$ with performance on verbal fluency. A significant difference in performance was found based on language and on cue condition. Patients performed better in their native language (Spanish). They also performed better under the semantic condition rather than the phonemic condition in both languages. An interaction between severity of AD and cue condition was also found. Patients that were categorized as less severe produced more words under the semantic condition compared to the phonemic. Patients that were categorized as more severe did not show a difference between the semantic and phonemic conditions suggesting a faster decline in semantic verbal fluency tests than in the phonemic tests. Correspondence: Judy L. Salvatierra, Psychology, Florida Atlantic University, 699 Tulip Circle,Weston, FL 33327.E-mail:salvajl@aol.com

\section{BUTTROSS, M. BATTISTA, D.I. TEMPLER \& H. GLIDDEN. COMPARISON OF THE MMSE AND NCSE IN THE DIAGNOSIS AND ASSESSMENT OF ECOLOGICAL FUNCTIONING IN ALZHEIMER'S DISEASE.}

Objectives. To (1) compare the Mini-Mental State Examination (MMSE) and the Neurobehavioral Cognitive Status Examination (NCSE) in terms of their accuracy in differentiating patients with Dementia of the Alzheimers Type (DAT) from normal controls and (2) compare the MMSE and NCSE in their relationship to basic and instrumental activities of daily living. Method. Data was collected from 50 individuals located in one of two living situations in central California: nursing home (inpatients) and community-dwelling (outpatients). Eligible cases were males and females, age 65 and older that met criteria for a diagnosis of probable Alzheimers disease according to DSM-IV or NINCDS-ADRDA criteria. Testing data from 25 normal individuals (age 65 or older, with no medical or clinical diagnosis affecting physical, social, or occupational functioning) was used for comparative purposes. Subjects were 
administered the MMSE and NCSE. Significant others were administered the Physical Self-Maintenance Scale (PSMS) and Instrumental Activities of Daily Living Scale (IADL). Results. The MMSE correctly classified $93 \%$ of individuals, and the NCSE correctly classified $92 \%$ of individuals. The MMSE correlated with the PSMS $.53(p<.01)$ for outpatients and $.95(p<.01)$ for inpatients and with the IADL .36 $(p<$ $.05)$ for inpatients. The NCSE correlated with the PSMS $.77(p<.01)$ for outpatients. Conclusion(s). Though the MMSE and NCSE were equally adequate in identifying participants with DAT, the MMSE has a stronger relationship with lower functioning inpatients and basic activities of daily living, whereas the NCSE has a stronger relationship with higher functioning outpatients and basic activities of daily living. Correspondence: Leanne Buttross, Ph.D., Clinical Development 200.3380, INTEGRIS Jim Thorpe Rehabilitation, 4219 South Western Ave., Oklahoma City, OK 73109.E-mail:Leanne.Buttross@integris-health.com

\section{B.V. SHENAL, M. JACKSON, R.D. RHODES, J. MIELKE, G. CRUCIAN, K. WOMACK \& K.M. HEILMAN. ANALYSIS OF ORIENTATION QUESTIONS IN ALZHEIMER'S DISEASE.}

As baby boomers continue to age, there will be an increase in the incidence of Alzheimer's Disease (AD). Thus, there is an urgent need for progress in identifying at-risk individuals as well as preventing and treating this disease. It is important for clinicians to recognize the most sensitive signs of $\mathrm{AD}$. The present study was designed to identify which orientation questions from the Mini Mental Status Exam were most predictive of $\mathrm{AD}$. Data were collected from $55 \mathrm{AD}$ patients (11 men, 44 women, mean age $=74)$ and 17 normal controls ( 6 men, 11 women, mean age $=69)$. Scores on each of these ten questions were then entered into a stepwise hierarchical discriminant analysis, with GROUP (Alzheimer's patients versus controls) as the grouping variable. Variable entry and removal criteria were based on F-values and the level of significance in identifying differences between two groups. The analysis revealed one orientation question that discriminated between controls and those with probable AD. The question "What is the name of this place?" correctly classified $62.5 \%$ of the subjects (Wilks' Lambda $=$ $.803, \mathrm{p}<0.001)$. No other questions contributed significantly in the group discrimination. Knowledge of current location is dependent upon the encoding, storage, and retrieval (recall) of declarative memories as well as the use of contextual (semantic) cues and $\mathrm{AD}$ patients have deficits in both of these cognitive domains.

Correspondence: Brian V. Shenal, Ph.D., Neurology, University of Florida, 100 S. Newell Drive, PO Box 100236, Gainesville, FL 32610-0236. Email:shenabv@neurology:ufl.edu

\section{A.L. JEFFERSON \& G. GLOSSER. OBJECT RECOGNITION PRE- DICTS INSTRUMENTAL ACTIVITIES OF DAILY LIVING (IADLS) IN PATIENTS WITH ALZHEIMER'S DISEASE (AD).}

Background: Cognitive domains such as executive functioning and memory have received much attention regarding their influence on IADL integrity among dementia patients. However, visuoperceptual functions, commonly impaired in dementia, have not been well studied. Objective: The present study aims to assess the relationship between IADLs and one particular aspect of visuoperceptual functions (i.e., object recognition). Method: Forty probable AD patients were administered measures assessing dementia severity (MMSE), verbal recognition memory (RMT), working memory (dual task), and object recognition (BORB). Primary caregivers completed an IADL measure. Results: Simultaneous multiple regression was conducted using the IADL measure as the dependent variable and the four cognitive measures (i.e., MMSE, RMT, dual task, BORB) as predictors. As expected, the regression model was significant, accounting for $26.9 \%$ of the total variance. Not surprisingly, only dementia severity was a significant predictor. The simultaneous multiple regression was repeated to assess the relationship between the IADL measure and the three cognitive measures independent of dementia severity (i.e., RMT, dual task, BORB as predictors). The regression model was significant, accounting for $20 \%$ of the variance. Of the cognitive variables, only object recognition was a significant predictor. Conclusions: These findings suggest that independent of dementia severity, object recognition is a significant predictor of functional abilities among AD patients. These findings compliment previous research in which we found visuoperceptual functions were important for performing visually-based ADLs, as the current findings suggest integrity of instrumental abilities are also dependent on object recognition.

Correspondence: Angela L. Jefferson, Ph.D., CBPM - Neuropsychology Clinic, Brown Medical School, Coro Building 3 West, 1 Hoppin Street, Providence, RI 02903. E-mail: Angela_Jefferson@brown.edu

\section{A. NELSON, R. GEARHART, C. WYSS-CORRAY, J.H. KRAMER \& B.L. MILLER. COGNITIVE PREDICTORS OF FUNCTIONING .}

Few studies have examined how performance on neuropsychological tests relates to daily functioning. The purpose of this study was to investigate which cognitive domains contribute most to functional impairment in a heterogeneous clinical sample. Participants were 89 men and women (mean age 71.5 years), who were seen for evaluation at the UCSF Memory and Aging Center. Diagnoses included Alzheimers Disease, FTD, Lewy Body Dementia, Vascular Dementia, and Mild Cognitive Impairment. Participants were administered a comprehensive neuropsychological screening battery, from which 6 tests were chosen to represent the domains of verbal and visual memory (CVLT-SF, 10 minute delay and modified Complex Figure, 10 minute delay), language (Boston Naming Test-15 item), visuospatial ability (cube copy), and executive functioning (modified Trails and Animal fluency). The Functional Activities Questionnaire (FAQ), served as the index of functional capacity. All 6 cognitive variables were simultaneously entered into a multiple regression analysis, with FAQ total score as the dependent variable. The overall model explained $35.6 \%$ of the variance $(p<.001)$. The 3 domains of delayed verbal memory $(p<.001)$, attention/set switching $(\mathrm{p}<.01)$, and delayed visual memory $(\mathrm{p}<.05)$, significantly contributed to the model, accounting for $33.8 \%$. Age also contributed to the model when added, $(\mathrm{p}<.05)$, increasing the explained variance to $39.0 \%$. In conclusion, while delayed verbal memory is the best predictor, cognitive set switching appears to have a strong and unique relationship with the ability to perform complex daily tasks.

Correspondence: Adam A. Nelson, M.A., University of California, San Francisco, 350 Parnassus Ave., Box 1207, San Francisco, CA 941430984.E-mail: adamnel@yahoo.com

\section{J.M. SMERZ, D.C. OSMON \& C.R. KOVACH. RELATIONSHIP BE- TWEEN COGNITIVE FACTORS AND FUNCTIONAL ABILITIES IN MODERATE TO SEVERE DEMENTIA.}

This study investigated the relationship between cognitive ability and functional skills in moderate to severe dementia. Specific cognitive abilities (Severe Impairment Battery [SIB] subscales of memory, language, praxis, and visuospatial abilities) associated with decreases in specific functional skills were examined. It was expected that all cognitive abilities would decrease as functions were lost, with the greatest drop in the most severe stage when communication abilities were lost. Participants included 51 dementia patients residing across 5 nursing homes. All had a Mini-Mental State Examination score less than 20 (M=8.67; SD=6.39), diagnoses of dementia, lengths of stay greater than 4 weeks, and no chronic psychiatric diagnosis. To measure functional abilities, unit nurses completed the Functional Assessment Staging Tool (FAST). The FAST items were divided into 4 categories in order of progression: required assistance in self-care, inability to perform basic self-care, incontinence, and greatly impaired speech/inability to maintain basic body postures. One-way ANOVAs examined the change in each SIB subscale across the 4 functional categories. A decrease in SIB scores was found across FAST categories for each of the SIB factors. The largest decrease in SIB 
score was consistently found in the progression between incontinence and impaired speech/inability to maintain basic body postures. The SIB decrease may represent a true loss across cognitive abilities at this very late stage of the disease, or may be reflective of the specific loss of communication.

Correspondence: Jessica M. Smerz, M.S., psychology, University of Wisconsin-Milwaukee, 2441 E. Hartford Ave., Milwaukee, WI 53211. Email:jsmerz@uwm.edu

\section{E. TRITTSCHUH, B. HANNA-PLADDY, N. JOHNSON \&. S. WEINTRAUB. VISUOSPATIAL FUNCTIONS PREDICT DRI- VING STATUS IN AGING AND ALZHEIMERS DISEASE.}

Quality of life issues, balanced by safety concerns, complicate the decision of whether to continue driving in advanced age. Driving is a cognitively demanding instrumental activity of daily living that relies heavily on visual processing, attention, and motor coordination, as well as memory for driving routes. While neuropsychological measures are sensitive to age-related cognitive decline and dementia, it is unclear if they are valid predictors of driving ability. The goal of this study was to investigate the cognitive determinants of continued driving in an older population. Participants $(\mathrm{N}=139)$ were subjects aged 60-90 from the Northwestern Alzheimers Disease Center registry who were evaluated and classified into normal cognitive aging $(\mathrm{NC})$ or possible/probable Alzheimers disease (AD) groups. All subjects were assessed with a neuropsychological battery and received functional assessments including an intake report of driving behavior. Driving status differed by age $(p<.001)$ and diagnosis $(p<.001)$, with a higher proportion of AD nondrivers $(46 \%)$ compared to NC non-drivers $(17 \%)$. To determine the best predictors of driving status, we used a multiple regression analysis with severity of impairment on measures of memory, attention, language, executive, and visual perceptual functions as model predictors. The model revealed that age $(p<.001)$ and impairment on the Judgment of Line Orientation test $(\mathrm{p}<.005)$ best predicted driving status (multiple $\mathrm{r}=.53, \mathrm{p}<.0001)$. Dementia diagnosis and decline in other cognitive domains including memory were not significant predictors. This study highlights the importance of advanced age and decline in visuospatial perceptual function as important contributors to regulatory decisions regarding cessation of driving.

Correspondence: E. Trittschuh, Cognitive Neurology and Alzheimer's Disease Center, Department of Psychiatry \& Behavioral Sciences, Northwestern University Feinberg School of Medicine, 320 E. Superior St, Searle 11-447, Chicago, IL 60611.E-mail: e-trittschuh@northwestern.edu

\section{BADENES, M. AGUILAR, N. CERULLA, L. CASAS, Y. PEREZ \&. S. QUINTANA. DRIVING AND DEMENTIA: SPECIFIC NEU- ROPSYCHOLOGICAL ASSESSMENT TOOLS.}

The ASDE DRIVER TEST is the most common assesment used in Spain in order to renew driving licences. However, its use with patients suffering from dementia, has yet to be studied. AIM To show results, validity and suitability of driving tests: UFOV (Useful Field of View), ASDE DRIVER TEST in dementia patients and controls. We examined 62 drivers: 35 dementia patients (age: $X=70.64, \mathrm{SD}=8.52$ ) and 27 healthy controls (age: $65.8 \mathrm{SD}=9.03$ ) matched by ages, educational levels and gender. As well as driving specific tests a series of neuropsychological tests were undertaken by all subjects. RESULTS The UFOV driving test showed greater specificity $(76 \%)$ and sensitivity (85\%) compared to ASDE ( $46 \%$ and $66 \%$ respectively). The ROC area was 0.81 with $95 \%$ IC, $0.69 \sqrt{ } 0.93$. which is significantly higher than the ROC area found for ASDE test. We advised 28 of the 33 patients to stop driving $(84 \%)$. Eighteen month later 21 patients (64\%) stopped driving and the other 12 of them they still drive with important limitations. CONCLUSIONS The UFOV test proud to be an effective assesment of driving ability in dementia patients. Dementia patients who continue to drive may find it useful to carry out a specific assessment of their ability in order to reduce the risks of having an accident.
Correspondence: DOLORS BADENES, neurology-dementia unit, hospital Mútua de Terrassa, Castell 25, Terrassa 08221, Spain. E-mail: dbadenes@copc.es

\section{G. TREMONT, J. DUNCAN DAVIS, C.M. SLAVIN, D. BISHOP \& S. SALLOWAY. FAMILY FUNCTIONING AS A PREDICTOR OF BURDEN IN CAREGIVERS OF PATIENTS WITH MILD TO MOD- ERATE DEMENTIA.}

Caregiver burden in dementia is known to negatively affect physical and emotional health of caregivers, although little is known about the relationship between family functioning and burden. The present study examined caregiver and patient factors associated with caregiver burden. Participants were 43 caregivers of patients with mild $(n=27)$ or moderate dementia $(n=16)$. Caregivers were either spouses $(n=27)$ or adult children $(\mathrm{n}=16)$. Average length of caregiving was 38.86 months (SD $=37.12$ ). Caregivers completed measures of burden, family functioning, depression, and anxiety as part of an ongoing caregiver intervention study. Ratings of memory/behavior problems and patient ADLs were also collected. Results showed no significant differences for outcome variables between mild and moderate dementia groups. However, correlational analysis revealed higher levels of caregiver burden were significantly associated with increased caregiver depression $(\mathrm{r}=.38)$ and anxiety $(r=.30)$, greater frequency of memory and behavior problems in the dementia patient $(r=.49)$, and poorer family functioning $(\mathrm{r}=.49)$. Severity of dementia, patient ADLs, duration of dementia diagnosis, and length of caregiving were unrelated to burden. After controlling for caregiver depression and frequency of memory/behavior problems in dementia patients, poorer family functioning continued to be associated with higher levels of caregiver burden $(r=.29)$. This is the first study to demonstrate a unique contribution of family functioning to caregiver burden. These findings suggest that including a family systems component in caregiver interventions may be beneficial in reducing burden in these very distressed individuals.

Correspondence: Geoffrey Tremont, Ph.D., Brown Medical School, 110 Lockwood Street, Suite 430, Providence, RI 02903.E-mail: gtremont@ lifespan.org

\section{J.S. KIXMILLER, C. BIBEAU \& R. ALLEN. EFFICACY OF A SKILLS-TRAINING GROUP FOR CAREGIVERS OF INDIVIDUALS WITH ALZHEIMER'S DISEASE.}

Common contributing factors to caregiver's sense of burden with individuals with $\mathrm{AD}$ are reduced understanding of the disease and its progression, a sense that behavioral issues are unpredictable and overwhelming, inefficient problem solving, skill deficits in implementing management strategies, and not fully utilizing available community resources. The most common method in which caregiver issues are addressed is through community-based caregiver support groups. Such groups typically provide educational and psychological supportive interventions that seek to provide a greater sense of understanding, cohesion, and shared management approaches. Some caregivers report, however, that these sorts of groups comprise caregivers at qualitatively very discrepant stages of $\mathrm{AD}$ progression which can dilute their sense of shared experience or indicate that such groups are too concentrated on discussing caregiver burdens to the exclusion of management strategies and problem solving. To address the latter concerns, our center developed and piloted a skills-based Alzheimer's caregiver group that targeted acquisition of knowledge of $\mathrm{AD}$, problem solving techniques, symptom management, advocacy, and use of community resources to promote better application of practical skills and information that are necessary for day to day management of issues in AD. Pre/post group evaluations of caregiver knowledge, subjective mood ratings, and post-course evaluations were completed. Results indicated that caregiver mood ratings 
improved overall on the BDI (median 4 points; average 3.5 points), showed good intersession knowledge acquisition (83\% post-session knowledge accuracy), and yielded high satisfaction ratings at a four month follow up (i.e., improved confidence, continued use of course materials, and high course satisfaction).

Correspondence: Jeffrey S. Kixmiller, Ph.D., UC Davis/VA Martinez, VANCHCS, 116, 150 Muir Road, Martinez, CA 94553. E-mail: jeff. kixmiller@med.va.gov

\section{J.C. ADAIR, S.L. RUIZ, R.L. SCHWARTZ \& A.M. RAYMER. IDEOMOTOR APRAXIA IN DEMENTIA: PILOT STUDY OF RE- SPONSE TO DONEPEZIL.}

Background: While cholinesterase inhibitors may modestly improve global clinical and functional outcomes, their impact on specific cognitive domains remains disappointing (e.g. memory) or unexamined (e.g. ideomotor apraxia, IA). Since IA may influence adaptive outcome in other contexts, patients with Alzheimer's disease $(n=14)$ or dementia with Lewy bodies $(n=3)$ underwent comprehensive assessment of IA before and after donepezil treatment ( $5 \mathrm{mg} /$ day) for 12-20 weeks. Design: Primary outcome measures included the Florida Apraxia Battery gesture to command (GTC) and gesture recognition subtests, consisting of 30 transitive and intransitive movements. Raters blinded to treatment status scored videotapes of gesture performance. Secondary outcome indicators included a cognitive battery as well as basic and instrumental activities of daily living (ADL) scales. Results: Treatment reduced GTC error score (pre: $16.0 \pm 14.0$, post: $12.1 \pm 9.8, p=0.04$ ), primarily for transitive gestures $(p=0.08)$. Patients with lower baseline global cognition by Mini Mental State Exam (MMSE) and lower total GTC scores improved the most. No change in gesture recognition was detected. There was no relationship between changes in MMSE and any apraxia measure. While treatment modestly increased mean MMSE scores (pre $20.7 \pm 4$.0, post $22.1 \pm 3.6$ ), no significant effect was observed for the ADL scales or other cognitive tests. However, change in both ADL scores correlated strongly with better production of intransitive gestures, but not with total GTC or transitive movement scores. Conclusion: Treatment improved some aspects of IA, a finding that may be relevant to effects on functional status.

Correspondence: John Adair, Neurology, University of New Mexico, ACC 2nd floor, UNMHSC, 2211 Lomas Blvd NE, Albuquerque, NM 87131. E-mail:John.Adair@med.va.gov

\section{R.S. FISCHER. NEUROPSYCHOLOGICAL FACTORS ASSOCI- ATED WITH CONTENT-SPECIFIC DELUSIONS IN ALZHEIMERS DISEASE.}

There has been considerable uncertainty regarding the nature of neuropsychological deficits that produce non-cognitive neuropsychiatric symptoms in Alzheimers disease. In some cases there have been global cognitive impairments while in others there has been a variety of neuropsychological deficits unrelated to the degree of cognitive impairments. We present 3 patients with Alzheimers disease in the moderate stages of disease progression. Each presented with content specific delusions in the absence of general paranoia or history of psychiatric disturbances involving spousal infidelity, phantom boarders or the belief that dead relatives were making social visits. Neuropsychological findings for each case revealed profound episodic memory and frontal-executive impairments within the context of preserved spatial, attentional and linguistic functions. These patients presented with distinct delusions that could not be attributed to premorbid psychiatric disturbances nor their perceptual, memory of frontal-executive deficits alone. Rather their content specific delusions appear related to severely disturbed memory and a more general defect in the detection, checking and inhibition, of incorrect perceptions and resolving mental conflicts that arise from overwhelming contradictory evidence. When memory dysfunction is superimposed on frontal executive deficits affective and cognitive distortions can occur impairing insight and judgement. On the basis of these cases it appears that content specific delusional misidentification disturbances like Othello or phantom border syndromes are closely related phenomena, although why the particular form of the phenomenon in individuals is different remains unknown. However, analysis of these cases provides confirmation for the necessity of considering interactive neuropsychological and functional deficits in the future study of these underlying neuropsychiatric disorders.

Correspondence: Richard S. Fischer, Ph.D., Neuropsychology, New England Sinai Hospital, 150 York Street, Stoughton, MA 02072. E-mail: RSF1250@AOl.com

\section{M.W. HOPKINS \& D.J. LIBON. NEUROPSYCHOLOGICAL FUNCTIONING IN DEMENTIA PATIENTS WITH AND WITHOUT PSYCHOSIS.}

Delusions and hallucinations are frequent and complicating symptoms of dementia. We compared the neuropsychological functioning of 24 outpatients with psychosis and 24 outpatients without psychosis diagnosed with either probable Alzheimer's disease (AD) or Vascular Dementia (VaD). The severity of psychosis was assessed with a modification of the Neuropsychiatric Inventory(NPI). Groups did not differ with respect to dementia severity (MMSE), age, education, or depression(GDS). Psychotic patients obtained a lower score on tests of executive control (WMS-MC subtest,Boston Revision; F[1,46]=9.92. $\mathrm{p}<.003)$, but produced better scores on the Boston Naming Test (BNT; $\mathrm{F}[1,46]=15.80, \mathrm{p}<.000)$, and the CVLT Recognition Discriminability Index $(\mathrm{F}[1,46]=6.77, \mathrm{p}<.012)$. Within the psychotic group, a median split analysis showed that dementia patients with higher levels of psychosis performed more poorly on executive control tests (WMS-MC subtest $(\mathrm{F}[1,22]=6.46, \mathrm{p}<.019)$;letter fluency ('FAS'); $(\mathrm{F}[1,22]=6.64, \mathrm{p}<.017)$ and made more perceptual errors on the BNT than did patients with lower levels of psychosis $(\mathrm{F}[2,21]=6.11, \mathrm{p}<.008)$. Correlational analyses indicated a relationship between increasing levels of psychosis and decreased executive functioning (WMS-MC subtest, $\mathrm{r}=-.688, \mathrm{p}<.001$; letter fluency, $\mathrm{r}=-.554, \mathrm{p}<.002$; the Clock Drawing Test, $\mathrm{r}=.425, \mathrm{p}<.019)$. These data suggest that psychotic symptoms in dementia are associated with a frontal systems syndrome involving greater impairment on tests of executive functioning combined with a relative preservation on tests of memory and language.

Correspondence: Mary W. Hopkins, Ed.D., Home, 577 Middlesex Road, Darien, CT 06820. E-mail: Hopscotch2000@aol.com

J. DAVIS, G. TREMONT, H. WESTERVELT, C. SLAVIN \& A. JEFFERSON. UTILITY OF COGNITIVE SCREENING MEASURES FOR DISCRIMINATING DEMENTIA SUBTYPES .

Screening measures are often used to identify and monitor cognitive deficits in dementia. The current study was designed to determine if screening measures could detect cognitive patterns of dementia subtypes. Participants were classified as meeting diagnostic criteria for the following: (1) Alzheimer's disease (AD; n=56); (2) Vascular dementia (VaD; n=11); (3) Diffuse Lewy Body disease (DLBD; n=8); (4) both Alzheimer's and Vascular disease $(\mathrm{AD}+\mathrm{VaD} ; \mathrm{n}=12)$; and (5) both Alzheimer's and possible Diffuse Lewy Body disease (AD+DLBD; $n=15$ ). There were no group differences in age, education, gender, dementia severity, or total scores on screening measures. Participants completed the Mini-Mental State Examination (MMSE) and the Modified MiniMental State Examination (3MS). Cognitive domain indices were created for each of these screening measures. Results revealed no significant differences across MMSE domains between AD, VaD, or DLBD or between $\mathrm{AD}, \mathrm{AD}+\mathrm{VaD}$, or $\mathrm{AD}+\mathrm{DLBD}$. In contrast, $\mathrm{AD}$ patients performed significantly worse than $\mathrm{VaD}$ patients on immediate and delayed memory indices on the 3MS. AD patients also performed more poorly than $\mathrm{AD}+\mathrm{VaD}$ patients on the $3 \mathrm{MS}$ on the delayed memory index. Results suggest that the MMSE has very limited utility for differentiating dementia subtypes. The extended memory assessment in the 3MS appears useful for distinguishing some dementia subtypes, though it is lim- 
ited to differentiating individuals with $\mathrm{AD}$ from patients with a vascular component and not other dementia subtypes. Results argue for the development of screening instruments that include extended memory items and measures of other cognitive domains (e.g., executive functioning) to identify and monitor dementia subtypes.

Correspondence: Jennifer Davis, Ph.D., Psychiatry, Rhode Island Hospital/Brown Medical School, 110 Lockwood Street, Suite 430, Providence, RI 02806.E-mail: jdavis3@lifespan.org

\section{T.B. ATCHISON \& P.J. MASSMAN. PREDICTING ALZHEIMER'S PATIENTS' DECLINE IN BASIC ADLS FROM BASELINE NEU- ROPSYCHOLOGICAL DATA.}

Research indicated that neuropsychological measures may have the ability to predict future functional capacity and showed widespread cortical involvement was associated with functional decline (Nussbaum. Goreczny, \& Haddad, 1995). This study analyzed the initial neuropsychological data of $\mathrm{AD}$ patients that went on to decline in functional capacity at different rates to ascertain if an early pattern of cognitive function could predict rapid decline in functional capacity. One hundred and forty-two individuals with a diagnosis of Alzheimer's Disease from the ADRC at Baylor College of Medicine, who had initial and follow-up data available on the Physical Self Maintenance Scale (PSMS)(Lawton \& Brody, 1969) were selected. The follow-up evaluations occurred a mean of 13.45 months after initial evaluations (range 10-28 months). The sample was divided into three groups on the basis of rate of change in PSMS, the mean change per year was +5.25 rapid decline in function, +1.18 median decline in function, improved in function - 0.43 . Higher scores on PSMS indicate a decline in function. Groups were not significantly different on, initial PSMS, AMNART, age, education, or gender. The initial neuropsychological data were subjected to a profile analysis with list-wise deletion leaving 108 subjects. Patients likely to decline rapidly were more likely to have missing data and be deleted. The analysis indicated a lower overall initial neuropsychological function and MMSE scores for the two faster declining groups than the improving group. The analysis also revealed a statistically significant pattern difference between groups with WAIS-R Arithmetic, Digit Symbol, Picture Arrangement, and category fluency (animals) being the most divergent scores and Finger Tapping both hands being the least divergent. Correspondence: Timothy B. Atchison, Ph.D, Behavioral Sciences, West Texas A\&M University, P.O. 60296, Canyon, TX 79016-0001. E-mail: tatchison@mail.wtamu.edu

\section{Other Cortical Dementias}

\section{R.P. HART \& J.B. WADE. DIVERGENT THINKING IN EARLY ALZHEIMER'S AND FRONTOTEMPORAL DEMENTIA.}

Divergent thinking was assessed in patients with early Alzheimer's disease (AD; $\mathrm{N}=19$ ) or Frontotemporal dementia (FTD; $\mathrm{N}=4$ ) and normal elderly ( $\mathrm{N}=12$ ) using Animal Naming, Controlled Oral Word Association, and Ruff Figural Fluency, and two measures of complex fluency. On the latter tests subjects were asked to generate many different uses for common objects (Alternate Uses) or to think of many different jobs that might be indicated by emblems (Possible Jobs). Patients with dementia and control subjects were closely matched on mean age, education, and estimated premorbid ability. Patients were in an early stage of illness as indicated by Mini-Mental State Exam (MMSE) scores (M=25.5. $\mathrm{SD}=2.1)$. MANOVA revealed that the dementia patients and control subjects differed, $F(5,29)=25.2, p<.0001$ and univariate tests showed patients performed worse than controls on all five measures (ps<.003). Larger performance decrements in the patients occured on the two complex fluency tests and on category fluency (8.6 to 9.4 SEs below control group) than on letter and figural fluency (3.0 to 3.2 SEs below control group). Many studies have shown deficits in category, letter, and/or figural fluency in AD or FTD, but this study also assessed complex fluency. Tests of category fluency and complex fluency appear to be more sensitive than other fluency tests to the degradation in, or inaccessibility of, semantic knowledge hypothesized to occur in AD. Additionally, the sensitivity of complex fluency tests to early cognitive decline in AD and FTD may be related to the demands of conceptualization in associating specific attributes to function and perhaps to demands on strategic cognitive processes during self-directed search.

Correspondence: Robert P. Hart, Psychiatry, Virginia Commonwealth University, C/L Psychiatry P.O.Box 980268, Richmond, VA 23298-0268. E-mail: rphart@hsc.vcu.edu

\section{C.R. HOLLNAGEL, J. KRAMER, J. JOHNSON, C. GIBSON, D. DELIS \& B. MILLER. VERBAL MEMORY IN FRONTOTEMPO- RAL DEMENTIA, SEMANTIC DEMENTIA, AND ALZHEIMER'S DISEASE.}

There is increasing attention given to the neuropsychological differences and overlap between various neurodegenerative conditions. The purpose of this study was to better understand the differences in verbal memory performance between individuals with Frontotemporal Dementia (FTD), Semantic Dementia (SD), and Alzheimers Disease (AD). Healthy female and male participants with FTD $(n=29)$, SD $(n=15)$, or $\mathrm{AD}(\mathrm{n}=41)$, and a group of normal controls $(\mathrm{n}=17)$ completed the California Verbal Learning Test- Mental Status (CVLT-MS). Although significantly lower than controls $(\mathrm{p}<.05)$, there were no significant differences between the three patient groups scores on the Mini Mental State Exam. Verbal learning was significantly impaired in all three patient groups relative to controls $(\mathrm{p}<.01)$ and FTD patients demonstrated a trend towards poor semantic clustering compared with controls $(p=.11)$. Furthermore, rate of forgetting was significantly worse for AD patients compared with FTD and SD patients $(p<.01)$, with an interaction between the SD and AD groups at delay. Recognition was significantly worse in all three patient groups compared with than controls $(p<.05)$. Although there were no further differences in recognition discriminability between the patient groups, there was a trend towards a positive response bias in the FTD group $(p=0.55)$. Although patients with SD have poor memory, they do not demonstrate the rapid rate of forgetting that AD patients do. Thus, memory deficits in the SD group appear languagebased. Furthermore, despite major semantic store loss, patients with SD are still able to utilize a normal semantic clustering strategy, whereas patients with FTD are not.

Correspondence: Caroline R. Hollnagel Odell, Ph.D., University of California San Francisco, 2249 Pine Street, San Francisco, CA 94115. Email: crholln@itsa.ucsf.edu

\section{N. BELFOR, J.H. KRAMER, M. GESCHWIND, K.P. RANKIN \& B.L. MILLER. PATTERN OF IMPAIRMENT IN CORTICOBASAL DEGENERATION SYNDROME AS COMPARED TO FRONTOTEM- PORAL DEMENTIA AND CONTRASTED WITH ALZHEIMER'S DISEASE.}

Corticobasal degeneration syndrome (CBD) has traditionally been thought to be a movement disorder. However recent research recognizes cognitive changes associated with CBD, and it has been hypothesized that CBD falls within the spectrum of frontotemporal dementia (FTD). In order to test this hypothesis and to determine if the neuropsychological performance of CBD patients follows the pattern of FTD and contrasts with that of Alzheimer's disease (AD), a group of 15 clinically defined CBD patients were compared to $15 \mathrm{AD}$ patients and 15 FTD patients matched on age and MMSE. Patients were compared on four cognitive domains including memory, calculation, praxis, and executive functioning. Memory was measured by CVLT-SF delayed recall and delayed visual memory. Executive functioning was measured by verbal, category and design fluency. Results showed that AD patients 
performed significantly better than FTD and CBD patients on phonemic and semantic verbal fluency $(\mathrm{p}<.05)$, and better than CBD patients on praxis $(\mathrm{p}<.05)$. However, both FTD and CBD patients performed better than AD patients on verbal memory $(p<.05)$. There were no significant differences between CBD and FTD on any of the cognitive measures. These results suggest that CBD is associated with cognitive impairment and that the pattern of impairment places CBD in the FTD spectrum.

Correspondence: Nataliya Belfor, Ph.D., Psychiatry, University of California San Francisco, 401 Parnassus Ave. CPT, San Francisco, CA 94143.E-mail:nbelfor@memory.ucsf.edu

\section{E.K. ZIMMERMAN, P.J. ESLINGER, K.J. MUNIZ, H. JACK- SON, Z. SIMMONS \& A.M. BARRETT. EMOTIONAL PERCEP- TUAL DEFICIT IN PERSONS WITH AMYOTROPHIC LATERAL SCLEROSIS.}

Recent studies suggest that frontal lobe dysfunction can occur in the progressive motor neuron disease amyotrophic lateral sclerosis (ALS). Individuals with early mouth, tongue and pharyngeal weakness (bulbar ALS) mav be more likely to develop cognitive problems. Some forms of emotional cognition may rely on frontal lobe systems. We examined emotional perception in ALS, to determine whether deficits occur and whether they can be fully accounted for by mood disorders or dementia. Subjects $(\mathrm{n}=13)$ with bulbar ALS completed the Geriatric Depression Scale (GDS) (Yesavage, 1983), Mini-Mental State Examination (MMSE) (Folstein et al., 1975) and tests of facial and prosodic emotional recognition (Adolphs et al., 1996; Adolphs et al., 1999). They were asked to choose the emotion (happy, sad, angry, frightened, disgusted, neutral) that matched 39 facial expressions and 28 taped, semantically neutral, intoned sentences. Twelve of thirteen patients $(92.3 \%)$ performed below criteria in emotional recognition tasks (9/13 abnormal facial emotional recognition, 11/12 abnormal prosodic emotional recognition). Although all patients meeting criteria for depression or dementia on the GDS and MMSE also performed poorly on face or prosodic emotional recognition tasks $(46.2 \%)$, six of thirteen patients $(46.2 \%)$ without dementia or depression also had emotional recognition abnormalities. One patient performed normally on all tasks. Our results suggest that emotional recognition deficits occur in bulbar ALS. Whether these deficits are directly related to other cognitive (e.g., visuospatial) abnormalities, or are a result of frontal-limbic deficits, requires further study. Educating caregivers and others about emotional processing deficit in ALS may be beneficial.

Correspondence: Erin K. Zimmerman, Neurology, Penn State University Milton S Hershey Medical Center, Department of Medicine/Neurology, H094, P.O. Box 850, 500 University Drive, Hershey, PA 17033. E-mail: zimmermane@etown.edu

\section{M.A. FEARING, M.J. LARSON, R.O. HOPKINS \& E.D. BIGLER. GENERALIZED VS. FOCAL ATROPHY IN DEMENTIA: THEIR RE- LATIONSHIP TO NEUROPSYCHOLOGICAL FUNCTION.}

Background and Objectives: Generalized atrophy (e.g. ventricle-to-brain ratio; VBR) and focal cingulate gyrus (CG) atrophy occur in dementia. The purpose of this study was to compare VBR and CG atrophy with neuropsvchological outcome in patients with dementia. Methods: Study groups included Alzheimer disease $(\mathrm{AD} ; \mathrm{n}=85)$, vascular dementia $(\mathrm{VaD}$; $\mathrm{n}=20)$, and normal elderly controls $(\mathrm{n}=20)$. Mean age $=81.0 . \mathrm{SD}=14.2$ for $\mathrm{AD}$, mean $=84.3, \mathrm{SD}=7.2$ for $\mathrm{VaD}$, and mean $=76.9, \mathrm{SD}=6.5$ and the control group. Length of disease mean $=4.7, \mathrm{SD}=2.9$ and mean $=5.2$, $\mathrm{SD}=4.1$ years for $\mathrm{AD}$ and $\mathrm{VaD}$ groups respectively. Results: $\mathrm{VBR}$ was significantly larger in $\mathrm{AD}$ and $\mathrm{VaD}$ groups compared with controls. There were no group differences for anterior, posterior, and overall CG crosssectional surface areas. Combined group analyses; VBR correlated with memory, language, verbal fluency, constructional praxis, and executive function. Within group analyses: VBR correlated with language in the AD group and memory for controls. There were no significant correla- tions for CG and neuropsychological outcome for the combined group. However, significant correlations were found for anterior CG and verbal fluency, and posterior CG and language in the AD group. Anterior CG and language, and total CG and executive function correlated in the controls. Conclusions: AD and VaD result in generalized atrophy which correlated with neuropsychological outcome. There were no differences in CG atrophy when controlling for age and dementia severity. Factors such as age and dementia severity should to be used as covariates when comparing generalized and focal atrophy in dementia. Correspondence: Michael Fearing, Brigham Young University, 1001 SWKT Tower, Provo, UT 84602. E-mail:wisopher@comcast.net

P.E. GILBERT, J.P. BARR \& C. MURPHY. RECOGNITION MEMORY AND REMOTE MEMORY FOR OLFACTORY AND VISUAL STIMULI IN PATIENTS WITH THE LEWY BODY VARIANT OF ALZHEIMER'S DISEASE, PATIENTS WITH ALZHEIMER'S DISEASE, AND HEALTHY ELDERLY CONTROLS.

Recognition and remote memory for odors, faces, and symbols were assessed in patients with pathologically confirmed Lewy body variant of Alzheimer's disease (LBV), patients with pathologically confirmed Alzheimer's disease (AD), and healthy elderly controls. The use of signal detection theory revealed that LBV and AD patients showed significantly lower sensitivity ( $d$ prime) compared to controls, particularly for olfactory stimuli. No significant differences were found on the bias measure (c). An analysis of the number of hits did not reveal any significant differences among the groups for olfactory or visual stimuli. However. LBV and AD patients committed significantly more false positive errors compared to controls, particularly for olfactory stimuli. When participants were asked to rate the familiarity of olfactory stimuli (a proposed measure of remote memory) LBV and AD patients reported significantly lower familiarity ratings compared to controls. Familiarity ratings for olfactory stimuli were significantly lower in patients with LBV compared to patients with AD. However, no significant differences were detected among the groups on familiarity ratings for visual stimuli. Consistent with prior reports, LBV patients showed significantly lower odor thresholds compared to $\mathrm{AD}$ patients. The results suggest that recognition memory for olfactory stimuli is equally impaired in patients with $\mathrm{LBV}$ and $\mathrm{AD}$. However, patients with $\mathrm{LBV}$ are more impaired compared to AD patients on tasks requiring remote memory for olfactory but not visual stimuli. The results suggest that tasks requiring odor memory may be useful in the assessment of LBV and AD. NIH grant \#AG04085 (NIA) and NIH training grant \#DC00032 (NIDCD).

Correspondence: Paul E. Gilbert, PhD, Head and Neck Surgery, University of California San Diego, 6363 Alvarado Court, Suite 101, San Diego, CA 92120.E-mail:poilbert@ucsd.edu

\section{M.W. KRAUS, J.M. HAMILTON, G.M. PEAVY \& D.P. SALMON. COGNITIVE, MOTOR, AND BEHAVIORAL CONTRIBUTIONS TO FUNCTIONAL DECLINE IN ALZHEIMER'S DISEASE AND DE- MENTIA WITH LEWY BODIES.}

Alzheimer's Disease (AD) and Dementia with Lewy Bodies (DLB) are related neurodegenerative diseases that produce similar progressive dementia syndromes. Despite their general similarities, the disorders may differ in the pattern and severity of cognitive, motor, and behavioral disturbances they engender, and these factors could impact functional abilities in unique wavs. To address this possibility, the relative contributions of cognitive, motor, and behavioral dysfunction to decline in Instrumental (IADL) and Physical activities of daily living (PADL) were examined in autopsy-confirmed DLB $(\mathrm{n}=34)$ and AD patients $(\mathrm{n}=$ 34 ) with similar age, education, and MMSE scores. Regression models showed that IADL were significantly related to cognitive dysfunction alone in $\mathrm{AD}\left(\mathrm{p}=.001 ; \mathrm{R}^{2}=44 \%\right)$ and to both cognitive and motor dysfunction in DLB $\left(p=.005 ; \mathrm{R}^{2}=34 \%\right)$. PADL were significantly related to cognitive and behavioral dysfunction in $\mathrm{AD}\left(\mathrm{p}<.001 ; \mathrm{R}^{2}=59 \%\right)$, but to none of the three factors in DLB $\left(p>.10 ; R^{2}=17 \%\right)$. These re- 
sults suggest that the mild motor dysfunction of DLB contributes to decline in IADL over and above the prominent contributions made by $\operatorname{cog}$ nitive dysfunction in both disorders. Additionally, behavioral dysfunction contributes to the cognitive-mediated decline in PADL in AD, but cognitive, behavioral, and motor dysfunction does not appear to strongly impact PADL decline in DLB. The failure of these three factors to predict PADL decline in DLB suggests that other factors such as visuospatial or "executive" dysfunction may be relevant to decline in their ADL. Correspondence: Michael W. Kraus, BA, UC Berkeley, 14066 Riverbend Road,Poway, CA 92064.E-mail:mwkraus@ucsd.edu

Paper Session 1/4:45-6:30 p.m.

\section{Neurologic Injury \& Outcome in Children}

\section{H.J. HANNAY, A. BOUDESQUIE, M. DENNIS, L.A. KRAMER, S. BLASER \& K. COPELAND. AUDITORY INTERHEMISPHERIC TRANSFER IN SPINA BIFIDA MENINGOMYELOCELE: THE ROLE OF THE LEVEL OF LESION, CORPUS CALLOSUM, OTHER COM- MISSURES AND HANDEDNESS.}

Research has implicated the splenium as well as the posterior body of the corpus callosum in interhemispheric transfer of auditory information, left ear extinction being reported for acquired discrete lesions of the corpus callosum in adults. We examined auditory interhemispheric transfer with a $\mathrm{CV}$ dichotic listening task in 93 children with congenital dysmorphologies of the corpus callosum from spina bifida meningomyelocele on whom we also have MRIs. Level of spinal lesion, status of the splenium, and handedness interacted with ear advantage. Children with L1 lesions and below showed a significant right ear advantage while those with T12 lesions and above showed a slight left ear advantage. Children with an intact or hypoplastic splenium showed a significant right ear advantage while children without a splenium showed a very slight left ear advantage. Right handers showed a significant right ear advantage while lefthanders showed a slight left ear advantage. Level of lesion and status of the splenium were related but neither were related to handedness. None of the children showed complete extinction in either ear. The role of the body of the corpus callosum, the anterior, posterior, and hippocampal commissures and subcortical structures is discussed.

Correspondence: HJ. Hannay, PhD, Psychology, University of Houston, 4800 Calhoun, Houston, TX 77204-5022.E-mail:jhannay@uh.edu

\section{A.I. BUIZER, L.M. DE SONNEVILLE \& A.J. VEERMAN. LONG- TERM NEUROCOGNITIVE SEQUELAE OF POSTERIOR FOSSA TUMORS IN CHILDREN TREATED SURGICALLY.}

Around $50 \%$ of brain tumors in children occur in the cerebellum. There is increasing evidence for the importance of the cerebellum for cognitive development. Deficits in the domains of visuo-spatial ability, memory, attention and executive function are among those reported in patients with cerebellar damage. We studied attention and information processing in children who had undergone resection of a tumor of the posterior fossa, that did not require radiotherapy or chemotherapy. Eleven patients between the age of 7 and 18 were included in the study, at least one year after diagnosis. Mean age at diagnosis was 4.3 years and mean time since diagnosis was 4.4 years. 152 Healthy children were recruited as controls, as part of a larger study of sequelae of childhood neoplastic disease. Attention and information processing were assessed using a computerized neuropsychological testbattery. Results: the patient group showed normal simple reaction times. Compared to controls, patients performed worse on tasks assessing working memory $(p=$ $0.017)$, visuo-spatial processing $(p=0.035)$, sustained attention ( $p$
$<0.001)$ and executive function $(p=0.024)$. Z-scores were computed using age-appropriate norm values, and z-scores $\propto 2$ on any of the tasks were considered to reflect a deficient task performance. Of the patients, $45 \%$ showed deficits on one or more tasks, compared to $17 \%$ of the controls (odds ratio: $4.0, p=0.04$ ). In conclusion, in children treated surgically for a posterior fossa tumor, neurocognitive deficits can frequently be detected and are not limited to one domain.

Correspondence: Annemieke I. Buizer, MD, Pediatrics, VU University Medical Center, De Boelelaan 1117, Amsterdam 1081 HV, Netherlands. E-mail:ai.buizer@vumc.nl

\section{E. BRANDLING-BENNETT, D.A. WHITE, M.M. ARMSTRONG \&. M. DEBAUN. SEMANTIC FLUENCY IN CHILDREN WITH FRONTAL STROKE RELATED TO SICKLE CELL DISEASE.}

Cerebral infarcts occur in $25 \%$ of children with sickle cell disease (SCD), primarily affecting the frontal lobes. Semantic fluency has been associated with frontal integrity. Animal fluency was examined in two groups of children with SCD. The CONTROL group comprised 50 children without infarct. The FRONTAL group comprised 9 children with MRIverified infarcts confined to the frontal lobes. Age range was 6 to 17 years. Total number of animals produced was examined. To evaluate possible differences in strategic processing, the contrast between number of semantic and phonemic clusters and the contrast between size of semantic and phonemic clusters were examined. ANCOVA (controlling for age and IQ) revealed no significant between-group difference in the number of animals reported. In examining strategic processing, however, a significant interaction $(p<.05)$ between group (CONTROL FRONTAL) and number of clusters (semantic, phonemic) was observed. The interaction between group (CONTROL, FRONTAL) and size of clusters (semantic, phonemic) was not significant, although there was a trend $(p<.1)$. Further analyses showed that the FRONTAL group produced fewer and smaller semantic clusters but more and larger phonemic clusters than the CONTROL group. Taken together, these results suggest that different strategic approaches were used by the groups to generate a comparable number of animals. The CONTROL group made better use of a frontally-mediated semantic strategy, whereas the FRONTAL group made better use of a posteriorly-mediated phonemic strategy. These findings have implications for understanding the manner in which children with frontal infarcts retrieve information and possibly for the development of remediation strategies.

Correspondence: Erica Brandling-Bennett, M.A., Washington University in St. Louis, One Brookings Drive, Campus Box 1125, Room 225A, St.Louis, MO 63130.E-mail: embrandl@artsci.wustl.edu

\section{A.M. LLORENTE. EARLY NEURODEVELOPMENTAL MARKERS PREDICTIVE OF MORTALITY IN INFANTS AND YOUNG CHIL- DREN INFECTED WITH HIV-1.}

Neurodevelopmental markers are capable of delineating disease progresion in infants and young children with HIV-1 infection, and neurocognitive impairment, less severe than frank dementia, have been shown to be an independent risk factor for moratlity in adults with HIV1 disease. Early neurodevelopmental markers were used from one-hundred, fifty-seven vertically infected HIV-1-positive infants who underwent longitudinal assessment to investigate whether these indices were useful predictors of mortality in those infants who survived to at least four months of age. Survival analysis methods were used to estimate time-to-death for four quartiles of 4-month (baseline) Bayley Scales of Infant Development (BSID) scores. Cox proportional hazards progression was used to estimate relative hazards (RH, 95\%CI) of death for BSID scores and potential cofounders. Thirty infants with BSID scores available at 4 months died during follow-up. Survival analyses revealed greater mortality rates in infants with BSID Mental (MDI)(8349) $(\mathrm{p}=0.004)$ and Motor (PDI)(82-49) Developmental Indexes in the lower quartile. In the unadjusted, univariate analyses, increased mortality was associated with baseline $\mathrm{CD} 4+<29 \%$, gestational age $<37$ 
weeks, smaller head circumference, advanced HIV - 1 disease, and higher plasma viral load. After adjusting for antiretroviral therapy, CDC clinical category, CD4+ percentage, gestational age, and plasma viral load, BSID scores independently predicted mortality. These findings suggest that early neurodevelopmental markers are useful indicators for identifying HIV-1 infected infants who are at risk for rapid progression and death. These findings are consistent with investigations conducted with older children and adults underscoring the usefulness of neurodevelopmental and neurocognitive methods to predict advanced morbidity and mortality.

Correspondence: Antolin M. Llorente, Ph.D., Pediatrics/Neuropsychology, Univ. Maryland School Med. \& Mt. Washington Ped. Hosp., 1708 West Rogers Avenue, Baltimore,MD 21209.E-mail: allorente@mwph.org

L.B. BLACKBURN, G.P. LEE, M. WESTERVELD, A. HEMPEL, Y.D. PARK \& D.W. LORING. DOES VIQ/PIQ DISCREPANCY PREDICT SEIZURE FOCUS LATERALITY IN PEDIATRIC PATIENTS? .

A discrepancy between Verbal IQ (VIQ) and Performance IQ (PIQ) on the Wechsler Scales has been interpreted as a sign of lateralized brain dysfunction. This study investigated the validity of VIQ/PIQ discrepancy in predicting lateralization of seizure focus for children with intractable epilepsy. A difference score (VIQ-PIQ) was calculated from pre-surgical Wechsler testing for 101 children (Mean age $=13.35)$ who underwent neurosurgical resection of a seizure focus. All children had Wada confirmation of left hemisphere language mediation. The direction of discrepancy accurately predicted hemisphere of seizure focus for $69 \%$ of left and $67 \%$ of right hemisphere foci. When a significant discrepancy (> 15 points) was present, regardless of direction, children were significantly more likely to become seizure free following surgery. Presence of a significant discrepancy was unrelated to age of seizure onset, gender or location of focus (lobe). A trend was found for age at testing with younger children more likely to demonstrate a significant discrepancy, but the direction of discrepancy more likely to correctly lateralize seizures in adolescents. Results of the current study suggest that the presence of a significant VIQ/PIQ discrepancy in pediatric epilepsy patients is not, by itself, a valid indicator of lateralization of seizure focus. Even when controlling for language mediation, other factors that may contribute to differential skill development (environment, parental skill pattern, etiology of seizure disorder) or skill demonstration (age at testing) may need to be considered in a multi-factorial model as the basis for prediction.

Correspondence: Lynn B. Blackburn, Ph.D., Psychologist Department, St. Louis Children, Suite 3 S 32, One Children, St. Louis, MO 631101077. E-mail:lynnab@bjc.org

\section{G.P. LEE, M. WESTERVELD, A. HEMPEL, L.B. BLACKBURN, Y.D. PARK \& D.W. LORING. LOW PRESURGICAL IQ PREDICTS POOR SEIZURE OUTCOME AFTER EPILEPSY SURGERY IN CHILDREN.}

OBJECTIVE. There is considerable controversy over whether or not presurgical intellectual functioning influences seizure relief outcome after epilepsy surgery, especially in children. To address this question, four comprehensive epilepsy surgery centers pooled their data to determine if lower IQs were associated with poorer seizure outcome in children. METHOD. One hundred and fifty-six children ( 75 boys, 81 girls) between the ages of 5 and 16 years underwent IQ testing as part of their preoperative evaluation for epilepsy surgery using the age-appropriate Wechsler scale. All 156 underwent some form of resective epilepsy surgery: 88 temporal lobectomies, 68 extratemporal lobe resections. 93 children had left hemisphere excisions, and 63 had surgery in the right hemisphere. Seizure outcome was determined at a minimum of 12 months after surgery. $104(67 \%)$ were seizure-free and $52(33 \%)$ were non-seizure-free. RESULTS. Children who were non-seizure-free had significantly lower VIQ $(p=.0009)$, PIQ $(p=.003)$, and FSIQ $(p=$ .003 ) scores than children who were seizure-free (Non-seizure-free mean
FSIQ = 80.6; Seizure-free mean FSIQ = 89.6) . There were no significant differences between seizure outcome groups in demographic or seizure history variables including age of onset of habitual seizures or duration of seizure disorder. CONCLUSION. Results suggest children with lower IQ scores tend to have poorer seizure outcomes after epilepsy surgery. Lower IQs probably reflect more severe or diffuse brain damage, and thus, increase the likelihood of having multiple seizure foci. Multifocal seizure onset, in turn, increases the probability of poor seizure surgery outcomes.

Correspondence: Gregory P. Lee, Ph.D., Medical College of Georgia, EF102, 1120 15th Street, Augusta, GA 30912-0700.E-mail: glee@mail. mcg.edu

\section{Paper Session 2/4:45-6:30 p.m.}

\section{Brain-Behavior Relationships in HIV}

\section{A.M. BRICKMAN, R.H. PAUL, R.A. COHEN, D.F. TATE, A.L. JEF- FERSON, C. RITCHIE, J. GUNSTAD \& B. NAVIA. CAUDATE MORPHOMETRY AND COGNITION IN HIV.}

Background: Several studies have reported neuropsychological and structural neuroanatomical abnormalities in individuals infected with HIV. Among the most commonly observed areas of neuropsychological deficit are information processing speed and simple motor skills. While reported neuroanatomical abnormalities include various brain regions, the caudate nucleus has consistently been shown to be related to both infection severity and to these neuropsychological measures. However, the exact relationship between neuropsychological functioning and caudate size in individuals infected with HIV $(\mathrm{HIV}+)$ as compared to individuals without HIV (HIV-) has not been clearly elucidated. Objective: The purpose of this study was to examine the relationship between neuropsychological functioning and caudate size as a function of seropositive status. Method: HIV+ and high-risk HIV- individuals were scanned with high resolution magnetic resonance imaging. The caudate nucleus was manually traced on two axial slices corresponding to Matsui-Hirano Atlas levels 8 and 9. Size of the caudate was calculated by summing across slice level and hemisphere. Participants were also assessed with a comprehensive neuropsychological battery that targeted cognitive areas of weakness associated with HIV (e.g., information processing and psychomotor speed). A normalized summary score was derived from neuropsychological battery and correlated to caudate size separately in $\mathrm{HIV}+$ and HIV- individuals. Results: Preliminary analyses on a group of mild-stage HIV+ individuals $(n=15)$ and HIV- individuals $(n=6) r e-$ vealed a moderate correlation between caudate size and the neuropsychological summary score $(r=0.45)$, whereas essentially no relationship was observed in the HIV- group ( $r=-0.07)$. Conclusions: This study provided further evidence of caudate-associated cognitive dysfunction in HIV and suggests that the relationship between cognition and caudate size is unique to seropositive status.

Correspondence: Adam M. Brickman, M.A., Department of Psychiatry, Mount Sinai School of Medicine, Neuroscience PET Laboratory Box 1505, One Gustave L. Levy Place, New York, NY 10029. E-mail: adam. brickman@mssm.edu

\section{R. PAUL, R. COHEN, D. TATE, A. JEFFERSON, J. GUNSTAD \& A.M. BRICKMAN. APATHY IS ASSOCIATED WITH VOLUME OF THE NUCLEUS ACCUMBENS IN PATIENTS INFECTED WITH HIV.} Apathy refers to a reduction in self-initiated behavior, and it is commonly reported by patients infected with human immunodeficiency virus (HIV). It remains unclear whether apathy among HIV patients reflects a direct effect of the virus on subcortical brain circuits or a secondary 
neuropsychiatric symptom. In the present study we examined the relationship between ratings of apathy and quantitative analysis of the nucleus accumbens (NA), a subcortical brain structure that regulates initiation of behavioral activation. $12 \mathrm{HIV}$-positive individuals without dementia were administered the Marin Apathy Scale and underwent neuroimaging. Voxel-based quantification of the nucleus accumbens was completed using a segmentation protocol. Results of our study revealed that increased ratings of apathy were significantly correlated with lower volume of the nucleus accumbens. By contrast, ratings of depression were unrelated to either apathy or nucleus accumbens volume. The results are consistent with the functional properties of the anterior cingulate frontal subcortical circuit and provide convincing evidence that apathy reflects direct involvement of the central nervous system in patients with HIV.

Correspondence: Robert Paul, Ph.D., Psychiatry, Brown Medical School, 1 Hoppin St., Providence, Providence,RI 02828.E-mail:Rpaul@lifespan.org.

\section{R.A. BORNSTEIN \& E. KISSEL. RELATIONSHIP BETWEEN FA- TIGUE AND NEUROPSYCHOLOGICAL PERFORMANCE IN HIV INFECTION.}

Fatigue is a common complaint in HIV infection, as well as many other neurological and psychiatric disorders. The relationship between fatigue and cognitive function is often suggested, but there have been relatively few studies to directly address the question. Furthermore, fatigue is often associated with depression, anxiety, aging, and other conditions which can also affect cognitive performance. We examined the relationship between measures of fatigue and cognitive function in a sample of $247 \mathrm{HIV}+$ and HIV- men. Fatigue measures were based on subjective severity and chronicity, and the $\operatorname{cog}$ nitive battery included measures of reasoning, memory, attention, processing speed, and motor speed. Data were analyzed using partial correlation analyses controlling for depression, age, education, anxiety and alcohol use. After controlling for all these potential confounding variables there were numerous significant relationships with the measure of chronicity of fatigue, but relatively few relationships on measures of perceived fatigue severity. These data suggest that fatigue may be a factor in neuropsychological performance independent of the effects of various confounding variables, but that subjective perception of fatigue does not predict test performance. Correspondence: Robert A. Bornstein, Ph.D., Ohio State University, 130N, 1670 Upham Dr., Columbus, OH 43210. E-mail: bornstein.1@osu.edu

\section{S.D. MARION, A. LEVINE, S.A. CASTELLON, S. CHOVAN, R.S. DURVASULA, D.J. HARDY, M.N. LAM, K.I. MASON, H. MY- ERS, A. PERKINS, M. STEFANIAK \& C.H. HINKIN. NEUROCOGNITIVE IMPAIRMENT PREDICTS LONGITUDINAL MEDICATION ADHERENCE IN HIV+ INDIVIDUALS.}

A critical factor in successful prevention of viral proliferation and development of treatment-resistant strains of the HIV virus is strict adherence to highly active antiretroviral mediation therapy (HAART). Recent cross-sectional investigations suggest that neurocognitive functioning in $\mathrm{HIV}+$ individuals may be an important predictor of adherence. In the current investigation, adherence to HAART was assessed longitudinally in 57 participants with and without neurocognitive deficits at study entry as determined by comprehensive neuropsychological testing. Medication adherence was objectively tracked using electronic monitoring technology (MEMS caps) over the course of six monthly intervals. Repeated measures Group (NP normal vs. NP impaired) x Time (monthly HAART adherence levels) MANOVA revealed that neuropsychological impairment at entry was associated with significantly poorer adherence $(\mathrm{F}=11.15, \mathrm{p}<.01)$. There was a significant main effect for time with adherence levels declining over 6 months $(\mathrm{F}=5.36, \mathrm{p}<.001)$. Of particular relevance, a significant Group $X$ Time interaction effect was obtained, $(\mathrm{F}=2.67, \mathrm{p}<.05)$. While the NP normal group demonstrated relative stable adherence over time, the NP impaired group adherence dramatically declined over time from $66 \%$ at entry to $47 \%$ at month 6 . Measures of executive functioning were particularly sensitive to declines in adherence in NP impaired individuals $(\mathrm{F}=2.38, \mathrm{p}<.05)$. These data indicate that poor neurocognitive performance is significantly associated with declines in adherence to HAART over time. It further underscores the importance of considering neurocognitive status when designing interventions to improve medication adherence among HIV-infected adults.

Correspondence: Sarah D. Marion, Ph.D., Psychiatry, UCLA, 1511 Beloit Ave.\#9, Los Angeles, CA 90025.E-mail:smarion@mednet.ucla.edu

\section{E. MARTIN, R. NOVAK, D. PITRAK, G. NUNNALLY, N. RAINS \& A. BECHARA. EXECUTIVE FUNCTION AND MENTAL SLOW- ING IN DRUG ABUSERS INFECTED WITH HEPATITIS C: PRE- LIMINARY FINDINGS AND LESSONS LEARNED FROM THE HIV LITERATURE.}

Neurocognition in drug users infected with hepatitis $\mathrm{C}$ virus $(\mathrm{HCV})$ is not well characterized despite high prevalence of positive HCV serostatus among this population. HCV infection appears to have neuroinvasive properties and shares neuropathological and neurocognitive features with HIV disease, including prominent involvement of frontostriatal circuitry, evidence of early psychomotor slowing and working memory deficits. There is a growing literature on cognitive neuropsychological aspects of HIV infection among drug users and we hypothesized that similar methods could be successfully used to investigate the neurocognitive deficits associated with HCV. We present results from a preliminary study of mental speed and executive function among 200 drug users classified according to HIV and HCV serostatus, controlling for age, education and severity of substance abuse. We employed cognitive neuropsychological measures that are sensitive to HIV-associated cognitive impairment, which included a voice-activated reaction time Stroop task, and a delayed-response working memory task. Both groups of seropositive subjects showed evidence of executive deficits compared with controls, but the pattern of findings differed according to virus type. HIV+ subjects showed impairment primarily in the executive/inhibition component of the Stroop, while HCV + subjects evidenced overall slower reaction times. Only HIV+ subjects showed evidence of impaired delayed response performance, suggesting more selective defects of working memory among HCV+ subjects. These preliminary findings indicate that lessons learned from the literature on the neurocognition of HIV in drug abusers can inform development of similar studies involving HCV disease, with potential implications for treatment adherence and continued risk behavior. Supported by HHS R01DA12828. Correspondence: Eileen Martin, PhD, Psychiatry, University of Illinois, 1601 W. Taylor St., M/C 912, Chicago, IL 60612.E-mail: emartin@ psych.uic.edu

\section{R. GONZALEZ, J. VASSILEVA, D. PITRAK, R.M. NOVAK, G. NUN- NALLY, N.A. RAINS, A. BECHARA \& E.M. MARTIN. SENSATION- SEEKING AND EXECUTIVE FUNCTIONS CORRELATE WITH RISK- BEHAVIORS OF HIV+ AND HIV- POLY-DRUG USERS.}

Evidence suggests that some medical disorders and personality traits that are often associated with drug abusers may contribute to the cognitive deficits they exhibit. These conditions may share common neurobiological substrates involving prefrontal-subcortical circuitry and are sometimes associated with compromise of executive functions, which are hypothesized to modulate engagement in high risk behaviors. The current investigation examined the unique variance in risk behaviors that is accounted for by sensation-seeking and measures of executive functions. A sample of 265 poly-drug users primarily dependent on cocaine and/or heroin, with and without HIV (HIV-, $\mathrm{n}=155 ; \mathrm{HIV}+, \mathrm{n}=$ $110)$, were administered three cognitive neuropsychological measures that emphasized specific aspects of executive functioning (i.e., working memory, response inhibition, and decision making). Risk behaviors were indexed using the Risk Assessment Battery (RAB). We found that sensation seeking was positively correlated with level of engagement in risk behaviors, $p<.01$. Additional unique variance in $R A B$ scores was accounted for by two of the three measures of executive function (i.e., RT Stroop and a delayed response working memory task). Our results 
demonstrate that risk-behaviors are associated with the executive functions of response inhibition and working memory, as well as with the personality trait of sensation-seeking, regardless of HIV serostatus. By using tasks that examine specific subcomponents of complex cognitive abilities, the current investigation provides a better understanding of the neurocognitive mechanisms and personality factors that may underlie engagement in risky behaviors, and thus presents several areas that may be targeted for intervention in poly-drug users. Supported by HHS R01 DA12828.

Correspondence: Raul Gonzalez, M.S., Psychiatry, University of Illinois, Chicago, Department of Psychiatry (MC 747), 840 South Wood Street, Suite 130 CSB, Chicago, IL 60612.E-mail: rgonzalez@psych.uic.edu

\section{J. RIPPETH, C.L. CAREY, S.P. WOODS, R.K. HEATON, I. GRANT \& T. HNRC GROUP. COGNITIVE, PSYCHIATRIC, AND MEDICAL PREDICTORS OF RELAPSE IN HIV+ METHAMPHETA- MINE ABUSERS .}

Methamphetamine (METH) abuse and HIV-1 infection are independently associated with neuropsychological (NP) deficits, with recent research indicating these risk factors confer additive deleterious NP effects. This study examined predictors of relapse for HIV+ METH abusers. The sample consisted of $34 \mathrm{HIV}+$ participants who met lifetime DSM-IV criteria for METH dependence and abuse/dependence criteria within 18 months of the baseline evaluation. Participants reported abstinence from METH a minimum of 21 days prior to evaluation. A comprehensive NP battery with demographically corrected T-scores was administered; $65 \%$ of the sample exhibited global NP impairment, with learning, delayed recall, and motor domains exhibiting the highest impairment rates. Relapse was defined as meeting METH abuse/dependence criteria any time during a 2-year follow-up period. The overall relapse rate was $41 \%$. At baseline, relapsers did not differ from nonrelapsers for demographics, lifetime METH use, HIV disease characteristics, prevalence of global NP impairment, or rates of affective or substance use disorders. Relapsers did exhibit higher rates of baseline motor impairment and Antisocial Personality Disorder (ASPD). In fact, $71 \%$ of relapsers displayed baseline motor impairment (versus $30 \%$ in nonrelapsers), and $100 \%$ were diagnosed with ASPD. Rates of NP impairment in this METH dependent sample were substantial; however, among NP domains, only motor impairment was significantly associated with relapse. These results also suggest psychiatric disorders (i.e., ASPD) are salient predictors of relapse. Clinicians should be cognizant that ASPD and motor impairment, which is particularly sensitive to the neurotoxicity associated with HIV and METH, are risk factors for relapse, and preventive interventions should be targeted appropriately.

Correspondence: Julie Rippeth, PhD, UCSD HNRC, 150 West Washington, 2nd Floor, San Diego, CA 92122. E-mail:jrippeth@ucsd.edu

\section{Symposium 1/4:45-6:30 p.m.}

\section{Genetics in Recovery from Traumatic Brain Injury: Beyond APOE}

\author{
Chair: James Malec \\ Discussant: James Malec
}

\section{R. DIAZ-ARRASTIA, F.C. GOLDSTEIN, B.A. KEYS \& J.F. MALEC. GENETICS IN RECOVERY FROM TRAUMATIC BRAIN INJURY: BEYOND APOE.}

Scientific attention has turned increasingly to possible genetic factors in outcome after traumatic brain injury (TBI) because (1) other identified outcome predictors (injury severity, age, gender, race, education, pre-injury adjustment) account for less than half the variance in outcome; $(2)$ the predictable neurophysiological response to TBI likely has genetic underpinnings; (3) this research could lead to innovative treatments addressing genetic vulnerabilities to brain trauma. Initial studies have focused on Apolipoprotein $\varepsilon$ (APOE) alleles with mixed results. Other patient characteristics contributing to these variable findings require further study. More significantly for future research, the complex neurophysiological response to TBI is most likely regulated by a combination of alleles. In this symposium, R. Diaz-Arrastia will review basic science and statistical considerations in gene research and his studies of APOE and trauma at The University of Texas Southwestern. He will explain minimal requirements for credible identification of genetic associations to TBI outcome. F. C. Goldstein will review collaborative work from Emory/Shepherd Center and the Mayo Clinic on effects of APOE on cognitive outcomes after moderate-severe TBI. She will discuss results in the context of other research, methodological issues, and potential modifying variables. B. A. Keys will present additional Mayo/Emory-Shepherd Center collaborative work examining the impact of APOE on community integration after moderate-severe TBI and explore other potential candidate genes based on TBI neurophysiology. J. F. Malec, as moderator and discussant, will lead a panel discussion/Q\&A session with goals of defining the current state-of-the-art and identifying promising future directions in the genetics of TBI.

Correspondence: James F. Malec, PhD, Psychiatry \& Psychology, Mayo Clinic, PM\&R-1D-St. Marys, Rochester, MN 55905. E-mail: malec. james@mayo.edu

\section{R. DIAZ-ARRASTIA. USEFULNESS OF ALLELIC ASSOCIATION STUDIES IN IDENTIFYING GENETIC FACTORS INFLUENCING OUTCOME AFTER TRAUMATIC BRAIN INJURY.}

Recognized factors such as severity of the initial injury and age are imperfect predictors of outcome. Recently, the possibility that genetic factors may influence functional outcome after TBI has been supported by the finding from several independent groups that inheritance of the APOE-e4 allele increases the risk of poor neurologic recovery. It is likely that polymorphisms in other genes also influence the response of neural tissue to injury or the extent of recovery and repair. Recent progress in the Human Genome Project has made it possible to perform allelic association studies with a very large number polymorphisms in candidate genes that have been postulated, on the basis of animal models of pathologic observations, to play a role in the pathophysiology of TBI. Understanding which genes may predispose to poor outcome may be useful in developing tailored therapy to limit damage and improve recovery after traumatic brain injury. Despite their potential power, allelic association studies have in many cases yielded associations of clinical outcomes with candidate genes that have not held up to scrutiny. Such spurious associations primarily result from insufficient sample size or inadvertent population stratification artifacts. It is also likely that for multifactorial pathologies such as TBI, genetic influences will be complex. This presentation will review recent discoveries on the structure of the human genome, discuss the statistical requirements for rigorous allelic association studies, and use examples from TBI and other human diseases to illustrate the value of this approach to the development of novel therapies. Correspondence: Ramon Diaz-Arrastia, MD, PhD, Neurology, Univ. of Texas Southwestern Medical Center, 5323 Harry Hines Blvd., Dallas, TX 75390-9036. E-mail:Ramon.Diaz-Arrastia@UTSouthwestern.edu

\section{F.C. GOLDSTEIN, A.Y. STRINGER, J.F. MALEC, S. MACCIOC- CHI, A.M. MOESSNER, M. GEARING \& A. GREENSPAN. APOLIPOPROTEIN E AND COGNITIVE OUTCOMES FOLLOWING MODERATE AND SEVERE TRAUMATIC BRAIN INJURY.}

A delineation of risk factors that influence individual differences in outcome following traumatic brain injury (TBI) is crucial to planning acute and long-term service needs as well as to designing and testing pharmacological and behavioral interventions. One such risk factor, the $\varepsilon 4$ allele of Apolipoprotein E (APOE), has been identified as potentially important to outcome from TBI. The majority of studies, however, have focused on functional outcome, with little known about whether APOE is associated with cognitive func- 
tioning after TBI. In the current study, patients who sustained moderate-severe TBI were prospectively recruited from postacute inpatient rehabilitation programs. Twenty five $\varepsilon 4$ positive and $49 \varepsilon 4$ negative patients received a comprehensive neuropsychological battery an average of one month post-injury. A subset of these patients were retested at one year. The $\varepsilon 4$ positive and negative groups were comparable in injury severity, length of rehabilitation, and demographic features at both follow-up periods. Analyses revealed no significant differences between the $\varepsilon 4$ positive and negative patients for any of the cognitive domains involving memory, attention, visual analytic skills, language, and executive functioning. These findings do not support an association between APOE status and cognitive functioning after TBI. The results will be discussed in terms of a possible selection bias of patients with a good rehabilitation outcome as well as a consideration of other nongenetic vulnerability factors that may interact with APOE status to influence outcome.

Correspondence: Felicia C. Goldstein, Ph.D., Neurology, Emory University School of Medicine, 1841 Clifton Rd., N.E., Atlanta, GA 30329. E-mail: fgoldst@emory.edu

\section{B. KEYS, J.F. MALEC, A.M. MOESSNER, F.C. GOLDSTEIN, A.Y. STRINGER, M. GEARING, A. GREENSPAN \& S.N. MAC- CIOCCHI. APOLIPOPROTEIN E STATUS, TRAUMATIC BRAIN IN- JURY, AND FUNCTIONAL OUTCOME.}

The role of Apolipoprotein $\varepsilon$ (APOE) and its isoforms in traumatic brain injury (TBI) remains controversial. Isoform-specific hypotheses have not been thoroughly examined in a TBI population. To determine if APOE status ( $\varepsilon 2, \varepsilon 4$ alleles) predicts functional outcome following moderate and severe TBI, 75 consecutively admitted individuals with moderate-severe TBI provided genetic assays. Rehabilitation staff rated participants on the Disability Rating Scale, Vocational Independence Scale, and the Independent Living Scale at hospital discharge and one year following injury. Isoformspecific hypotheses regarding functional outcome were not confirmed. APOE status was not associated with injury-related, demographic, or personal history variables. In linear regression models, only length of stay and posttraumatic amnesia consistently and significantly predicted functional outcome at either discharge or one year follow-up. Limiting the current study to moderate-severe cases may have limited the power to detect an association between APOE status and outcome. Prior studies demonstrating an association may have failed to account for a priori differences in age, multiple TBI, or other physiological factors. Given the controversial role of APOE status and outcome in TBI, and the multitude of points for variability in the neurophysiological cascade that follows acute trauma, other genetic factors should be considered in understanding outcome variability following TBI. Candidate genes, particularly dopamine regulating genes, that contribute to the neurophysiological response to TBI will be discussed. Correspondence: Beth Keys, Ph.D., Psychiatry \&. Psychology, Mayo Clinic, 200 First St. SW, Rochester, MN 55905.E-mail: keys.beth@mayo.edu

Symposium 2/4:45-6:30 p.m.

\section{Construct Validity in Neuropsychology: Do We Know What We Measure?}

\author{
Chair: Robert Kane \\ Discussant: Glenn Larrabee
}

\section{R. KANE, A. CERNICH, D. TULSKY, L. PRICE, P. SHORT, J. REDFIELD \& G. LARRABEE. CONSTRUCT VALIDITY IN NEU- ROPSYCHOLOGY: DO WE KNOW WHAT WE MEASURE?}

Neuropsychologists make assumptions about what their tests measure. These assumptions are the foundation of neuropsychological reports and drive dependent variable selection in clinical research. The presumed domains measured by a particular test are frequently based on a mixture of common sense and theory. Research designed to explore and validate tests as measures of specific neurocognitive domains is lacking or hampered by methodological or theoretical shortcomings. It is rare to find a series of well-designed programmatic studies that evaluate the underlying constructs of neurocognitive instruments or batteries. Methodological issues such as sample size, selection of marker variables, inadequate attention to method variance, failure to adequately develop hypotheses from research and theory, and failure to validate theory with confirmatory analysis limit interpretation of many studies. In this symposium we review the literature pertaining to the construct validity of common neuropsychological tests. Dr. Cernich reviews the concept of construct validity and the literature on communally used neruocognitive measures. Drs. Tulsky and Price present findings from construct validation studies of the Wechsler tests of intelligence and memory and use these studies to illustrate construct model development. Dr. Short presents construct validation data for the Automated Neuropsychological Assessment Metrics (ANAM) test system developed by the DoD. Dr. Redfield reviews approaches to construct validation and discuss methodological and procedural issues and pitfalls encountered in this research. Dr. Larrabee serves as discussant and will offer observations regarding our current knowledge of constructs assessed by neuropsychological tests, address methodological issues, and suggest future directions.

Correspondence: Robert Kane, Ph.D., Neuropsychology, VA Medical Center, 10 N. Greene Street, Baltimore, MD 21044.E-mail: rlkane@ comcast.net

\section{A.N. CERNICH. THE STATE OF CONSTRUCT VALIDATION IN NEUROPSYCHOLOGY: A REVIEW.}

Since the time of Halstead and Luria, neuropsychologists have characterized individual behavior on assessment measures as component cognitive processes or domains. But more often than not, these measures have not been subject to individual construct validation nor have they been validated as part of a neuropsychological battery. Construct validation becomes essential as clinicians and researchers define and use these measures to form operational definitions of domains, with no consistent evidence of their contribution to the domain's structure. Though criterion validation has been explored in various disease populations and has been demonstrated for many measures, the understanding of the fundamental constructs and their variation across these groups is fundamental to our understanding of measurement. The construct validation studies that do exist follow three major trends: 1) exploratory factor analysis for validation of single measures; 2 ) exploratory factor analysis of multiple measures to explore domains of cognitive function or to establish overlapping variance; and more recently, 3 ) confirmatory factor analyses which have as their a priori function the confirmation of exploratory analysis or theory. Studies that have utilized common neuropsychological measures (i.e., Trail Making Tests, Wisconsin Card Sorting Test) will be reviewed to elucidate the current state of known constructs or domains of neuropsychological function, to explore difficulties with method variance, and to provide a context for the discussion of methodological issues relating to construct validity. As it stands, construct validation in the field of neuropsychology remains limited, though use of face valid operational definitions of domains of $\mathrm{cog}$ nitive function is widespread.

Correspondence: Alison N. Cernich, Ph.D., Neuroscience Research, National Rehabilitation Hospital, 724 1/2 11th Street SE, Washington, DC 20003.E-mail: alison.cernich@medstar.net

\section{PRICE \& D. TULSKY. THE USE OF CONFIRMATORY FAC- TORY ANALYSES TO VALIDATE PSYCHOLOGICAL TESTS: LESSONS LEARNED FROM THE WAIS-III AND WMS-III PROJECT. Confirmatory Factor Analyses that include cross-validation strategies provide a comprehensive framework for testing existing or proposed}


models. Recent studies conducted with the WAIS-III and WMS-III (Tulsky \& Price, 2003) and within the WMS-III (Price, Tulsky, Millis, \& Weiss, 2002) have been used to develop new models of cognitive functioning and develop a structure from which test data can be interpreted (Tulsky, Ivnik, Price, \& Wilkins, 2003). This session will review these factor analytic studies to illustrate the flexibility and power of Structural Equation Modeling (SEM) with a cross-validation approach. The importance of proper model specification as related to the test and the construct will also be discussed. For instance, when using factor analytic techniques to validate memory tests with immediate and delayed measures, multicollinearity due to the relationship between these measures often occurs. As an example, the impact of the high correlation between the WMS-III immediate and delayed components will be discussed and also, how the observed methodological variance of the test has impacted interpretation of the results.

Correspondence: Larry Price, PhD, Texas State University-San Marcos, Doctoral Pgm in Education, 601 University Dr., San Marcos, TX 78666. E-mail:lprice@txstate.edu

\section{P. SHORT. EVALUATION OF CONVERGENT AND DIVERGENT VA- LIDITY OF ANAM TASKS.}

A systematic evaluation of tests from the Automated Neuropsychological Assessment Metrics (ANAM) battery will demonstrate the construct validation process and allow presentation of previously unreported findings. In order to establish convergent validity of the ANAM tasks with other measures tapping attention, working memory and recall each will be modeled in a confirmatory factor analysis (CFA). Finally, in order to assess the divergent validity of these ANAM tasks, the constructs will be combined to form a single structural model. A series of nested changes will be evaluated to determine how distinctly these ANAM tests (and traditional counterparts) measure their putative latent constructs.

Correspondence: Paul Short, Ph.D., Baltimore VAMC, Baltimore Research and Education Foundation, 10 North Greene, Baltimore, MD 21201.E-mail:psycwala@comcast.net

\section{J. REDFIELD. METHODS OF CONSTRUCT VALIDATION IN NEUROPSYCHOLOGY: MOVING BEYOND TOM SWIFT'S ELEC- TRIC FACTOR ANALYSIS MACHINE.}

Construct validation is multifaceted, concerning issues that include process models for task performance, the internal structure of tests, generalizability of score inferences, and convergent and discriminant relations with external variables. Two broad classes of research design typify most approaches for investigating construct validity in neuropsychological assessment. The first emphasizes contrasts between scores and score profiles, whether between groups of individuals, between distinct variables, or before and after physical intervention or environmental manipulation. Though important, research designs based on score contrasts usually evaluate narrow hypotheses, tending to advance knowledge of a test score's meaning in small increments. More commonly, construct validation of neuropsychological assessment procedures is accomplished using correlational designs investigating patterns of covariation among multiple variables, with factor analysis frequently being the preferred statistical technique. Judicious use of factor analysis, either exploratory or confirmatory, requires investigators to make a series of important choices about variable selection, subject sampling, model specification, and model fitting technique. A survey of current applications of factor analysis to construct validity in neuropsychology suggests that many researchers' decisions about such matters are less than optimal, resulting in data analytic approaches that are not well suited to the structure of data to be analyzed. These considerations are illustrated by examining the methods used in construct validation of memory tests. Problems unique to validating procedures to assess behavioral correlates of brain dysfunction are identified, and promising solutions to those problems are proposed.
Correspondence: Joel Redfield, PhD, Independent Practice, 145 Duane Street, New York, NY 10013. E-mail: redfield@inch.com

$$
\text { Symposium 3/4:45-6:30 p.m. }
$$

\section{Dysexecutive States and Frontal \\ Functioning in Aging and Neurodegenerative Disease.}

\author{
Chair: Carol Manning \\ Discussant: David Geldmacher
}

\section{C.A. MANNING \& D.S. GELDMACHER. DYSEXECUTIVE STATES AND FRONTAL FUNCTIONING IN AGING AND NEURODEGEN- ERATIVE DISEASE.}

There is increasing awareness of the importance of executive functioning and neurocognitive behavioral changes associated with fronto-striatal circuits. However, this awareness is accompanied by limited understanding of the construct of executive function and raises numerous questions about how this relates to other cognitive abilities in healthy states and neurodegenerative disease. This symposium addresses the complex issues regarding interpretation of dysexecutive states in normal aging and neurodegenerative disease. We bring together individuals with different perspectives and backgrounds including experimental neuropsychology, cognitive psychology and neuroscience. We will present findings representative of different lines of research and different levels of analysis. Topics directly addressed include the construct validity of executive function as a distinct entity. To this end, data examining executive functioning as distinct from other abilities in normal aging will be presented. Cognitive science paradigms will be used to understand individual differences in performance on measures of executive functioning in Parkinson's and Huntington's diseases. The relationship between aging and frontal subcortical structures as revealed by neuroimaging and performance on executive tasks will be presented. Clinical data examining dysexecutive states in the setting of normal memory functioning in older adults will be discussed along with implications for functional independence. In addition, the relationship between executive processes and changes in semantic memory in neurodegenerative disease will be examined. This symposium will encourage critical thought regarding the interpretation of the construct of executive functions.

Correspondence: Carol A. Manning, Ph.D., Neurology, University of Virginia, Box 800394, Charlottesville,VA 22908.E-mail:cm4r@ virginia.edu

\section{N. RAZ. DIFFERENTIAL AGE-RELATED CHANGES IN REGIONAL BRAIN VOLUMES AND THEIR MODIFIERS: IMPLICATIONS FOR COGNITIVE AGING.}

The extant literature reveals consistent age-related differences in the executive functions, and cross-sectional studies of brain aging indicate that their substrate (the prefrontal cortex, PFC) may be more vulnerable to aging than other brain regions. However, longitudinal studies reveal a more complex pattern of differential aging trends. Whereas significant linear declines are observed in the prefrontal cortex, inferior parietal cortex also shows significant decline. The prefrontal white matter exhibits a significant nonlinear trend, characterized by growth in the younger subjects, plateau at the middle age, and decline in the older participants. By contrast, the volumes of the primary visual and the entorhinal cortex show minimal (if any) change, as suggested by cross-sectional findings. Limited research 
evidence indicates that cross-sectional age differences in the PFC and increased prefrontal burden of white matter lesions are associated with increased perseveration, poorer acquisition on cognitive skill and reduced speed/efficiency of visual information processing. To some extent the magnitude of differential age-related brain changes and differences, as well as their association with cognition depends on powerful modifiers of aging such as hypertension and aerobic fitness. Separating various sources of age-related variance in brain and cognition remains a challenge. Support Contributed By: NIH Grant R01-AG-11230

Correspondence: Naftali Raz, PhD, Institute of Gerontology, Wayne State University, 87 E. Ferry St., Detroit, MI 48202. E-mail: nraz@ wayne.edu

\section{J.C. STOUT. DIFFERENTIATING UNDERLYING CAUSES OF DY- SEXECUTIVE FUNCTION IN PARKINSON'S DISEASE AND HUNT- INGTON'S DISEASE USING COGNITIVE SCIENCE METHODS.}

Complex behaviors, such as those encompassed by the notion of executive function, are built on multiple, interacting attentional, sensory, perceptual, memorial, and response processes. Therefore, observations of executive task performance alone (or in conjunction with additional neuropsychological tests) allow us to make only weak inferences regarding what psychological mechanisms are responsible for dysexecutive states. This paper will describe the application of cognitive science methods, both in experimental task design and in formal cognitive modeling of empirical data, to several studies of Huntington's and Parkinson's disease. In particular, we will describe studies of shifting/flexibility of attention, and decision making. Using these studies, we will show how methods informed by cognitive theories, research on healthy subjects, and the application of formal modeling approaches, can provide quantitative findings that differentiate among various explanations for dysexecutive states. This talk will stress the notion of individual differences, showing how similar observations of performance on executive function measures can be a result of different underlying psychological processes in different patient groups and in different individuals. These findings from cognitive science methods will then be linked back to observations from clinical neuropsychology.

Correspondence: Julie C. Stout, Ph.D., Psychology, Indiana University, 1101 East 10th St., Bloomington, IN47401-7007.E-mail: jcstout@ indiana.edu

\section{K. FUCHS. NONAMNESTIC MCI IN A MEMORY DISORDERS CLINIC.}

Nearly $50 \%$ of patients referred to the Memory Disorders Clinic at the University of Virginia perform above the level clearly indicative of dementia on initial screening (MMSE $>25$ ). Within this group, a substantial number demonstrate some decline in cognitive functioning greater than expected for normal aging, but insufficient to meet criteria for a dementia diagnosis. Additionally, only a minority fully meet the criteria for Mild Cognitive Impairment (MCI) as proposed by Peterson and collegaues. The majority show reductions in cognitive efficiency suggestive of mild decline in executive functioning or nonamnestic MCI. While memory functioning on formal assessment remains within normal limits, information obtained during interview suggests that incidental learning, prospective memory, and retrieval speed are reduced. These changes are noticeable and worrisome and are often the impetus for referral to the clinic. This pattern of mild decline in efficiency relative to prior abilities is also apparent on formal neuropsychological evaluation, and the contrast between preserved and reduced abilities is greater than would be expected in the setting of normal aging. Data from serial cognitive assessments will be presented to suggest that individuals with higher levels of education tend to show a mild dysexecutive state prior to frank impairment in memory functioning. Without careful assessment, these individuals might be classified as the "worried well" and opportunities for early intervention and/or long term planning would be missed. Further, the impact of depression, anxiety, and stress on subjective assessment of cognitive functioning will be discussed. Correspondence: Kathleen Fuchs, PhD, Neurology, University of Virginia, PO Box 800394, Charlottesville, VA 22908-0394.E-mail:klf2n@ virginia.edu

\section{C.A. MANNING, S.A. WYLIE \& K.L. FUCHS. COMPONENTS OF EXECUTIVE DYSFUNCTION IN AMNESTIC MCI. .}

Mild Cognitive Impairment (MCI) is a diagnosis applied to elderly adults with memory deficits that are below expectation for normal aging but not severe enough to warrant a diagnosis of dementia. The utility of the MCI diagnosis is evidenced by estimates that individuals with MCI are at greater risk for conversion to Alzheimers disease (AD). Because memory impairment is a hallmark symptom of $\mathrm{AD}$, studies of MCI have focused primarily on identifying early cognitive changes associated with memory systems. However, recent reviews in AD suggest an early and significant influence of frontal lobe pathology in determining the quality and progression of AD. MCI typically focuses on amnestic symptoms with less focus on the presence of frontally mediated tasks. This paper presents longitudinal data comparing cognitive performance in individuals diagnosed with amnestic MCI relative to age and education matched healthy controls. As expected according to diagnostic criteria, memory performance differed between the groups ( $p$ 's $<0.005)$. Although not all tasks associated with executive functioning were worse in the MCI group, aspects of executive functioning including interference from distraction and working memory capacity were significantly worse $(p ' s<0.01)$ in the MCI group. This difference between groups was observed across assessments. These data suggest that change in executive functioning is not unitary and may represent several domains. Furthermore, declines in performance on specific aspects of executive functioning in MCI may be missed due to definitional reliance on semantic memory. Careful examination of executive functions may provide additional predictive value into conversion from MCI to frank dementia.

Correspondence: Carol A. Manning, Ph.D., Neurology, University of Virginia, Box 800394, Charlottesville,VA 22908.E-mail:cm4r@ virginia.edu

\section{T.A. SALTHOUSE. INVESTIGATION OF CONSTRUCT VALIDITY OF EXECUTIVE FUNCTIONING.}

Although the concept of executive functioning is frequently invoked in the neuropsychological literature, there is relatively little evidence regarding its construct validity. In a recent project, both convergent and discriminant validity of an executive functioning construct were examined in a sample of 261 adults ranging from 18 to 89 years of age. Although variables from the Wisconsin Card Sorting Test, Tower of Hanoi, Verbal Fluency, Figural Fluency, and a version of the Trail Making Test had significant correlations with one another, the variance these variables had in common overlapped almost completely with the common variance among variables assessing the psychometric construct of fluid intelligence. The possibility that there might be different types of executive functioning was examined by including several tests hypothesized to represent updating, inhibition, and time-sharing, but these constructs also shared nearly all of their common variance with fluid intelligence. It is suggested that caution needs to be exercised when referring to executive functioning because it may not be a coherent construct distinct from constructs representing other cognitive abilities.

Correspondence: Timothy A. Salthouse, PhD, Dept. of Psychology, University of Virginia, PO Box 400400, Charlottesville, VA 22904-4400. E-mail:ts4v@virginia.edu 


\section{THURSDAY MORNING, FEBRUARY 5, 2004}

\section{Poster Session 2: Studies of Normal Cognition Across the Lifespan/8:00-10:00 a.m.}

\section{Child Development}

\section{HARRIS, P. BROUWERS \& R. CATES. PREDICTION OF PRE- SCHOOL COGNITIVE ABILITY BY PARENT RATING.}

Valid assessment of neurocognitive functioning in young children with acute medical illness is often confounded by external factors, and it would be helpful to have an instrument that would be less open to such factors and possibly could be used retrospectively to estimate premorbid functioning. The Child Development Inventory (CDI), a parent rating scale assessing a child's functioning across a range of ability domains, may be such an instrument. CDI General Development Index scores of 50 children (age range $0.75-6.0$ yrs) were related to the composite scores of either the Mullen Scales of Early Learning (MSEL) or the Differential Ability Scales preschool version (DAS) using archival data to assess the predictive relationship. Overall, the predictive relation between these scores was highly significant $(\mathrm{R}$ Square $=.91, \mathrm{~F}=163.25, \mathrm{p}<.001)$ and accounted for almost all the variance. The prediction was similar for both MSEL and DAS as well as when the estimates for children with IQs lower than $80(\mathrm{R}$ Square $=.93, \mathrm{~F}=95.19, \mathrm{p}<.001)$ and those children with IQs above 80 ( $\mathrm{R}$ Square $=.89, \mathrm{~F}=54.90, \mathrm{p}<.001)$ were calculated separately. In sum, the CDI can be used to estimate cognitive functioning of pre-school children. It conceivably could be used to estimate premorbid functioning in children who have suffered neurological insult by way of retrospective parent report. Within a non-clinical population, it potentially could be utilized to determine simply whether or not a given child needs a more in-depth evaluation of developmental progress. Correspondence: Lynnette Harris, Texas Children's Hospital / Baylor College of Medicine, 6621 Fannin, 1630.00, Houston, TX 77030. Email:llharri1@texaschildrenshospital.org

\section{K.A. ESPY, R. BULL \& T.E. SENN. USING THE SHAPE SCHOOL TO UNDERSTAND TASK DEMANDS THAT INVOKE EXECUTIVE CONTROL.}

Prefrontal systems undergo remarkable changes during the preschool period, yet the emergence and development of executive control have not been well specified. The Shape School (Espy, 1997), developed to assess executive control under different task demands that are known to engage prefrontal systems, was administered to 219 typically-developing preschool (3- to 6-year-olds; 119 females) children. Performance among different Shape School conditions was compared using a multivariate mixed model design, revealing that efficiency differed as a function of the child's age group and whether the task demands 1) were "executive" or not, 2 ) required inhibition of a prepotent response or shifting among relevant response sets, and 3) included unitary or concurrent processing, and the child's age. Findings are discussed in light of current unitary and fractionated models of executive control. The Shape School may be an effective tool by which to measure executive control in young children with neurological, developmental, psychiatric, and other medical disorders.

Correspondence: Kimberly Andrews Espy, Ph.D., Family \& Community Medicine, Southern Illinois University School of Medicine, SIUSOM, MC 6503,600 Agriculture Dr., Carbondale, IL 62901-6503.E-mail: kespy@ siumed.edu

\section{K.A. ESPY \& M.F. CWIK. EXECUTIVE COMPONENTS OF TRAILS-P PERFORMANCE IN YOUNG CHILDREN.}

The Trail Making Test is a widely-used neuropsychological test that often is administered clinically to assess executive control. There remains comparatively few tools to assess executive control in young children. Therefore, a preschool version with colorful illustrations in a story format (Trails-P) was developed. The Trails-P was administered to 103 typically-developing, preschool children ( 45 males, $75 \%$ White). Latency to stamp all relevant condition stimuli differed as a function of Trails-P condition type (Control, Shift, Reversal, Distraction) and child age group. Younger children made more errors; but the number of errors did not differ among Trails-P conditions. The Trails-P is developmentally sensitive and yields performance patterns that are consistent with modern theories of executive control. The Trails-P may be useful in the assessment of executive abilities in children with neurological, developmental, psychiatric, and other medical disorders.

Correspondence: Kimberly Andrews Espy, Ph.D., Family \& Community Medicine, Southern Illinois University School of Medicine, SIUSOM, MC 6503,600 Agriculture Dr., Carbondale, IL 62901-6503.E-mail: kespy@ siumed.edu

\section{A.K. HEFFELFINGER, C. MRAKOTSKY \& J. LUBY. THE MODI- FIED LURIA'S TAPPING TEST: AN EFFECTIVE MEASURE TO AS- SESS EXECUTIVE FUNCTIONING IN PRESCHOOL CHILDREN?}

Assessment tools for executive function (EF) in preschool children are sparse despite frequent referrals for neuropsychological evaluation. Luria's Tapping Test requires rule learning/application and response set inhibition. Children 4-6 years of age acquire the skills to complete this task (Diamond and Taylor, 1996). One hundred and one children ages 4:00:00 and 5:11:30, recruited from pediatrician's offices, completed a comprehensive mental health evaluation and were included in these analyses. Attention Deficit Hyperactivity Disorder with other psychopathology (ADHD-any) group $(\mathrm{n}=32)$ was hypothesized to perform more poorly on Luria's Tapping Test than Major Depressive/Anxiety Disorders (INT) group $(n=27)$ and normal control $(\mathrm{NC})$ group $(\mathrm{n}=32)$. Tapping Test performance was related to age $[\mathrm{r}=.425, \mathrm{p}<.001]$ and gen$\operatorname{der}[\mathrm{t}=1.98, \mathrm{p}<.10]$ and were controlled for in further analyses. Analysis of Covariance revealed significant group differences $[\mathrm{F}(2.98)=3.46$. $\mathrm{p}<.05]$ with the ADHD group performing worse than the NC group $[\mathrm{F}(1,71)=7.24, \mathrm{p}<.01]$ and the INT group $[\mathrm{F}(1,56)=4.19, \mathrm{P}<.05]$. When investigating the performance of 4 year olds, there was a trend for the ADHD group to perform worse than the $\mathrm{NC}$ group $[\mathrm{F}(1$, $32)=4.068, \mathrm{P}<.06]$. In the 5 year olds, the ADHD group did not perform more poorly than the $\mathrm{NC}$ group when gender was controlled for. Especially during the 4th year of life, Luria's Tapping Test may be a useful clinical measure of $\mathrm{EF}$, as it was able to detect poorer EF in children with ADHD, a population with known executive dysfunction. Careful consideration of age and gender must be made in interpretation. Correspondence: Amy K. Heffelfinger, Ph.D., Neurology, Medical College of Wisconsin, MCW Clinics at Froedtert, 9200 W. Wisconsin Ave, Milwaukee,WI 53226.E-mail: aheffelf@mcw.edu

\section{H.M. CONKLIN, M. LUCIANA, C. HOOPER \& R. YARGER. WORKING MEMORY PERFORMANCE IN TYPICALLY DEVELOP- ING CHILDREN: A CLOSER LOOK AT BEHAVIORAL INDICES OF FRONTAL LOBE DEVELOPMENT.}

Post-mortem histological and in vivo neuroimaging studies indicate that frontal lobe development persists well bevond the adolescent vears. Despite increasing interest in frontal lobe development, few studies have investigated whether this protracted neurodevelopment coincides with behavioral performance of adolescents on putative frontal lobe tasks. A primary function supported by the frontal lobes is working memory. integral in the facilitation of future-directed behavior. Consequently. this study examined the performance of typically developing children ( $\mathrm{N}=117$; ages 9-19; 53 males, 64 females) on a comprehensive battery of working memory tasks (Wechsler Digit and Spatial Span tasks; a letter span task; computerized spatial, verbal and object self-ordered point- 
ing tasks; a computerized spatial delayed response task; and a computerized spatial n-back task). Findings indicate that on-going frontal lobe development can be captured in behavioral performance, with the emergence of adult levels of performance evident sometime between 11 and 16 years of age on the majority of selected tasks. In contrast, adult levels of performance were found for even the youngest age group ( 9 and 10 year olds) on tasks believed to be more posteriorly mediated (i.e. verbal and facial recognition memory tasks). While significant associations among tasks supported tapping of a common underlying function, working memory, neither domain- nor process-specific working memory models were better substantiated. Findings from the current study have important implications for mapping normal developmental trajectories in frontally-mediated behavior. Further, by investigating performance of relevant clinical populations on similar tasks, researchers can increase understanding of when and how development gets off track in disorders with suspected frontal lobe involvement (e.g., ADHD, substance abuse and schizophrenia).

Correspondence: Heather M. Conklin, Ph.D., Neuropsychology, Kennedy Krieger Institute, 1750 East Fairmount Avenue, Baltimore, MD 21231. E-mail:conklin@kennedykrieger:org

\section{G. GERNER \& M. MAZZOCCO. WORKING MEMORY AND IN- TELLIGENCE: A DEVELOPMENTAL PERSPECTIVE.}

Current studies in adult populations suggest a relationship between intelligence and working memory (e.g. Colom et al., 2003). However, few studies have examined the IQ and working memory relationship in normally developing children, within the context of the development of verbal and nonverbal skills. Working memory may be an important factor in the interaction between language and visual spatial systems during problem solving tasks on current measures of intelligence. To examine this hypothesis, we examined different performance profiles on the Wechsler Abbreviated Scale of Intelligence (WASI) subtests and the Contingency Naming Test (CNT) (Taylor, 1996), a measure of working memory, among 204 children (104 boys and 108 girls) ranging in age from 7.95 years to 9.49 years. Results suggest that children with average or better WASI verbal and Matrix Reasoning (MR) subtests perform best on the CNT (Group I), regardless of performance on Block Design. Children with below average performance on the verbal and MR subtests and above average performance on Block Design, had the lowest scores on the CNT (Group III). Children with average or better performance across all WASI subtests had intermediate CNT scores (Groups II). Furthermore, the CNT scores for children in Groups I and II were significantly better than CNT scores for children in Group III. These results demonstrate the complexity in the IQ and working memory associations, and support the hypothesis that working memory is an important factor in the interaction between language and the visual spatial system on tasks traditionally conceptualized as nonverbal reasoning tasks. Correspondence: Gwyn Gerner, M.A., Loyola College, 1029 Campbell Meadows Rd, Owings Mills, MD 21117.E-mail: gwyngirard@aol.com

\section{E.K. HODGES, S. LANGENECKER, C. PERSAD, B. GIORDANI, M. GHAZIUDDIN, K. HART \& C. CALKIN. THE RELATIONSHIP BETWEEN NEUROPSYCHOLOGICAL TEST PERFORMANCE AND EMOTION PERCEPTION AND THEORY OF MIND TASKS IN CHILDREN AND ADOLESCENTS.}

Research has shown that children with autistic spectrum disorders (including Autism, Asperger Syndrome and Nonverbal Learning Disabilities) share a core deficit in social functioning. These deficits have often been observed on tasks of emotion perception and Theory of Mind. To date there has been limited research examining the relationship of performance on these tests to performance on neuropsychological measures. The purpose of the present study was to examine the relationship of neuropsychological functioning and performance on the Eyes Test and Happe stories in a group of 21 children who were referred for outpatient neuropsychological testing. The results of correlational analy- ses revealed a moderate relationship between childrens' performances on the Eyes test and WISC-III Verbal IQ scores. In addition, results showed a modest relationship between childrens' performance on a measure of Theory of Mind (Happe Stories). There were no other significant relationships among the variables, suggesting that emotion perception and theory of mind may be more complicated than assessed on these measures.

Correspondence: Elise K. Hodges, Ph.D, Psychiatry, University of Michigan, 2101 Commonwealth Blvd., Suite C, Ann Arbor, MI 48105. E-mail: ekhodges@umich.edu

\section{P.K. ISQUITH, G.A. GIOIA \& S.C. GUY. ADOLESCENT SELF-RE- PORTS OF BEHAVIOR AND EXECUTIVE FUNCTION.}

Evidence for the validity of a new instrument can be gleaned from convergent and discriminant relationships with existing measures of similar traits. In the absence of extant adolescent self-report measures of executive function, we examined correlations between the newly developed Behavior Rating Inventory of Executive Function-Self Report Version (BRIEF-SR) and an established measure of behavioral and emotional functioning. Ratings on the BRIEF-SR and the BASC-Self Report of Personality (BASC-SRP) completed by 104 clinically referred adolescents formed a coherent and logical pattern of correlations. Problems with inhibitory control, flexibility and emotional modulation captured by the BRIEF-SR Behavioral Regulation Index were associated ( $\mathrm{p}$ $<.01)$ with social stress $(r=.51)$, anxiety $(r=.49)$, atypicality $(r=.46)$, an external locus of control $(\mathrm{r}=.41)$, sensation seeking $(\mathrm{r}=.35)$, low self-esteem $(r=-.32)$, and depression $(r=.27)$. Problems with metacognitive aspects of executive function were associated with feelings of inadequacy $(r=.42)$, depression $(r=.36)$, anxiety $(r=.29)$, and lower self-esteem $(r=-.29)$. This pattern of findings indicates that adolescents reporting poor inhibitory control, limited flexibility and fragile emotional modulation viewed themselves as experiencing greater emotional distress, as seeking excitement, as different from their peers, and as externally controlled. They experienced greater levels of social stress and lower self-esteem than their better modulated peers. While adolescents with greater metacognitive difficulties sustaining working memory, remaining planful and organized and completing their work also experienced greater levels of anxiety and depression than their more regulated peers, they also felt less competent.

Correspondence: Peter K. Isquith, Ph.D., Department of Psychiatry, Dartmouth Medical School, One Medical Center Drive, Lebanon, NH 03756-0001.E-mail: isquith@dartmouth.edu

\section{E.M. MAHONE, C. PRAHME, M. ROEDER, A. LEVINE, S. SLATER \& A. ZABEL. THE RELATIONSHIP BETWEEN CPT PERFORMANCE AND BEHAVIOR RATING OF EXECUTIVE FUNCTION IN CHILDREN.}

Recent literature has emphasized the need to examine executive function (EF) in children using multiple sources, including parent rating and performance-based measures (Mahone et al., 2002). Computerized continuous performance tests (CPTs) represent one of the most commonly used methods of assessing inhibitory control and sustained attention, variables central to the $\mathrm{EF}$ construct. We examined the relationship between CPT performance and parent ratings of EF in a mixed clinical sample of 109 children, ages 6-18. Using paired t-tests, parent ratings on scales of the BRIEF (Gioia et al., 2000) were compared with related scores from Conners CPT II (Conners, 2000). The BRIEF Inhibit Scale (mean T-score $=62.3)$ was significantly higher than the CPT-II commissions score $($ mean T-score $=50.7 ; p<.0001)$, with low correlation $(\mathrm{r}=-.12)$. Similarly, the BRIEF Working Memory Scale (mean T-score $=69.2$ ) was significantly higher than the CPT-II omission errors (mean $\mathrm{T}$-score $=61.7 ; \mathrm{p}<.01)$, with low correlation $(\mathrm{r}=.08)$. Principal components analysis was used to explore how three primary CPT II variables (omissions, commissions, D Prime) were related to the eight BRIEF scales. A three-factor solution was obtained with all eight BRIEF scales 
comprising the first factor, CPT commissions and D Prime loading on a second factor, and CPT omissions comprising the third factor. In a mixed outpatient clinical sample, the BRIEF appears to measure different aspects of inhibitory control and attention than those assessed by the CPT-II, with behavior ratings consistently identifying greater impairment.

Correspondence: Ernest M. Mahone, Ph.D., Neuropsychology, Kennedy Krieger Institute, 1750 East Fairmount Ave., Baltimore, MD 21231. Email:mahone@kennedykrieger.org.

\section{F. WOLKENBERG, J. SCHROEDER, S. STENGER, R.J. SPENCER, L. SPURGEON, L.M. EVANS, E.T. MOOLCHAN, M. ERNST \& A.S. KIMES. ECOLOGICAL VALIDITY OF NEU- ROPSYCHOLOGICAL AND SELF-REPORT MEASURES OF DE- VELOPMENTAL EXECUTIVE FUNCTION USING LOCUS OF CONTROL AS A CRITERION MEASURE.}

To assess the relationship between neuropsychological tests and everyday behaviors and beliefs associated with executive function, we used the Nowicki-Strickland Locus of Control scale (LOC), a measure of selfefficacy beliefs, as a marker for ecological validity. We examined correlations between neuropsychological measures (CPT, Tower of London, Rey complex figure, Trails A \& B) and the self and parent report versions of the Behavioral Rating Scales of Executive Function (BRIEF) and the LOC, in an adolescent sample. The sample, part of a larger study, comprised males between the ages of 12 and 18 years (mean 14.8 SD 1.7), 25 of whom met DSM-IV criteria for a diagnosis of ADHD and 12 controls. LOC correlated significantly with both the parent and self-report versions of the BRIEF, but with none of the neuropsychological measures. BRIEF scores were moderately, but significantly, correlated with CPT errors of commission and with Verbal IQ, but otherwise uncorrelated with neuropsychological measures. Taken together, these findings suggest that these neuropsychological tests may have limited ability to predict patterns of everyday behavior ascribed to executive function in adolescents. However, the results do suggest that descriptive measures such as the BRIEF capture elements of behavior that have significant impact on the day-to-day sense of self of adolescent boys.

Correspondence: Frank Wolkenberg, Ph.D., NIDA/IRP, 713 E. Lake Avenue, Baltimore,MD 21212.E-mail:f.a.wolkenberg@att.net

\section{S.C. GUY, P. ISQUITH \& G.A. GIOIA. SELF, PARENT AND TEACHER RATINGS OF ADOLESCENT EXECUTIVE FUNCTION.}

Interrater agreement between adolescents and caregivers on standardized emotional and behavioral rating scales is typically low. We examined correlations between adolescents' self-reports of executive function and their parents' and teachers' reports. Adolescent ratings on the BRIEFSelf Report Version (BRIEF-SR), a new 80-item, 8-scale, inventory for ages 11-18 years, were correlated with the BRIEF Parent $(\mathrm{N}=243)$ and Teacher $(\mathrm{N}=148)$ forms. Correlations between self- and parent ratings on like-scales were moderate, ranging from .36 to .57 . The lowest correlations were seen for the Emotional Control $(r=.39)$ and Organization of Materials scales $(r=.36)$. Strong correlations were seen for the Plan/Organize scale $(\mathrm{r}=.56)$, Behavioral Regulation $(\mathrm{r}=.52)$ and Metacognitive $(r=.57)$ Indexes, and the Global Executive Composite $(\mathrm{r}=.56)$. Correlations between self- and teacher ratings were significant but smaller in magnitude, with an overall mean of .25. The highest correlation was seen for the Monitor scale $(r=.41)$. Modest correlations were seen for the Inhibit $(\mathrm{r}=.32)$, Plan/Organize $(\mathrm{r}=.29)$ and Organization of Materials $(r=.32)$ scales with smaller correlations for the Shift $(r=.22)$ and Emotional Control $(r=.20)$ scales. Overall, the correlations between adolescents' self-reports of executive functioning and their parents and teachers were modest but higher than those found for many standardized behavioral rating scales. This pattern of findings can assist in interpreting the BRIEF-SR in the context of parent and teacher reports on the BRIEF.
Correspondence: Steven C. Guy, Ph.D., Private Practice, 170 North Woods Boulevard, Suite 220, Columbus, OH 43235.E-mail:stevenguy@ columbus.rr.com

\section{V.M. LANCASTER, A.J. NAILLON \& M.Y. KIBBY. RELATIONSHIP BETWEEN SELF-ESTEEM AND EXECUTIVE FUNCTIONING IN CHILDREN.}

The purpose of this study was to examine the relationship between selfesteem, mood, and executive functioning, as few studies have been published focused upon the role self-esteem may play in cognition and vice versa. Participants included 21 children ages 8 to 12.9 participants had dyslexia, 4 had ADHD and 8 were controls. In order to maximize power and variance with this small sample size, analyses included all children rather than conducting the analyses by group. All participants underwent a neuropsychological battery, including measures of mood and selfesteem. Self-Esteem was measured through the Self-Esteem Index (SEI), anxiety was measured through the Revised Children's Manifest Anxiety Scale (RCMAS), and depression was measured through the Children's Depression Inventory (CDI). Questionnaires were read to all participants, as some had reduced reading ability. Executive functioning was measured with the Wisconsin Card Sorting Task (WCST) and the NEPSY Tower. Results included a negative correlation between the WCST Perseverations standard score and SEI peer popularity, suggesting those with more perseverations had inflated perceptions of peer popularity. This relationship was not mediated by depression or anxiety, indicating a possible frontal origin to faulty perceptions of peer popularity. In contrast, Tower performance was positively correlated with SEI familial acceptance, and this relationship was mediated by feelings of depression and anxiety. This suggests that depression, anxiety and self-esteem may play a role in planning ability. Based upon this study, it appears evaluation of self-esteem and mood is critical in neuropsychological assessment as they are related to executive functioning performance.

Correspondence: Michelle Y. Kibby, PhD, Psychology, Washington State University, Department of Psychology, Pullman, WA 99164-4820. Email:mkibby@wsu.edu

\section{A. KEY, D.L. MOLFESE, V. MOLFESE, M. FERGUSON, S. STRAUB, K. PEACH, J. WALKER \& J. NEAMON. LINKS BE- TWEEN EARLY READING AND MATH SKILLS IN PRESCHOOL CHILDREN: ELECTROPHYSIOLOGICAL EVIDENCE.}

Visual event-related potentials (ERPs) were recorded using a 128-channel high-density array in 13 healthy children (age 4-5 years) in a geometrical shape match/mismatch task. The children viewed pairs of color figures (e.g.., a square and a circle) and indicated their decision by a button press. The results indicated that brain activity of children with lower reading readiness scores did not readily discriminate between the matching and mismatching geometrical shapes, while in high performing children distinct patterns and sources of brain activity characterized the two condition. Children with better rhyming and letter identification skills displayed earlier and larger frontal and posterior voltages and evidenced more bilateral hemisphere symmetry as compared to the lower performing group where brain activity was more asymmetrical and showed no or greatly reduced frontal activity. The results suggest that reading and math abilities mav rely on related brain mechanisms

Correspondence: Alexandra Key, Ph.D., Psychological \& Brain Sciences, University of Louisville, 317 Life Sciences Bld, Louisville, KY 40292. Email:a0fona01@athena.louisville.edu

\section{S. WATSON, E. ABRAHAMSEN, L. HARPER, A. PAGELS \& A.M. RAYMER. PATTERNS OF PHONOLOGICAL PROCESSING DEFICITS IN SCHOOL-AGED CHILDREN.}

Phonological awareness (PA), phonological memory (PM), and rapid naming $(\mathrm{RN})$ are all component skills for adequate phonological reading abilities. These skills are not always assessed in school-aged chil- 
dren undergoing testing for potential reading disability. This study examined patterns of phonological processing difficulties among students identified with disabilities and others considered at risk of reading failure. It was hypothesized that disability would be associated with phonological awareness deficits. Two groups of students served as participants: at risk students $(n=22)$ and students with identified disabilities $(n=21)$. All students were given the Comprehensive Test of Phonological Processing (CTOPP) (Wagner, Torgesen, \& Rashotte, 1999), which measures all three component skills for phonological processing, PA, PM, and RN. Deficits were observed for two or three component skills in 12/21 students with disabilities and 4/22 at risk students. Only one component was impaired in 7/21 students with disabilities and 15/22 at risk students. That is, the two groups had significantly different patterns of phonologic impairment $(\mathrm{X} 2=6.91, \mathrm{p}<.01)$. An isolated phonologic awareness deficit was evident in 1/7 disability students and 7/15 at risk students, contrary to our hypothesis. These differences suggest that educators must include all components of phonologic processing skills in instruction to address the full range of difficulties that may be evident in classes of students experiencing learning difficulties.

Correspondence: Anastasia M. Raymer, Ph.D., Dept of ESSE, Old Dominion University, 110 Child Study Center, 45th \& Hampton, Norfolk, VA 23529-0136.E-mail: sraymer@odu.edu

\section{J.W. KIRK, M.M. MAZZOCCO \& S.T. KOVER. LONGITUDINAL PERFORMANCE ON THE CONTINGENCY NAMING TEST (CNT) IN CHILDREN GRADES 1 AND 3.}

The CNT, developed by Taylor (1987) is an executive function (EF) measure of cognitive set-shifting and working memory. We used the CNT to assess EF development in 6-9-year-old, typically developing boys $[\mathrm{n}=92$; mean FSIQ=109 (14.0)] and girls $[\mathrm{n}=96$; mean FSIQ $=110$ (12.6)]. CNT variables (per task) include trials to learn a task (TLT); speed, self-corrections, and errors; and an efficiency index (speed/error-rate ratio). We examined effects of grade (1 vs. 3 ) and sex, comparing performance on simple naming (PartA), a one-attribute contingency rule (PartB3), and a two-attribute contingency rule (PartB4). As expected, boys and girls became more efficient (more rapid, more accurate) on each task, for all performance variables, over time. More children completed B4 at grade $3(n=185)$ vs. grade $1(n=52)$. There were unexpected Sex X Grade interactions: On grade 1 tasks showing sex differences, girls did significantly more poorly; on grade 3 tasks showing sex differences, boys did significantly more poorly. Correlations within and across years varied for boys vs. girls, with a higher number of significant correlations for boys. For boys, Grade 1 efficiency on PartB3 most strongly predicted PartB4 at grade 3; TLT also predicted Grade 3 efficiency on PartB4 for girls, and self-correction rate at grade 1 also predicted later efficiency for boys. Successful completion of PartB4 in grade 1 predicted 3rd grade performance, for boys only. Our findings suggest important sex differences in EF development from ages 6-9years, and that both TLT and Self-Corrections contribute to determining efficiency of EF performance.

Correspondence: John W. Kirk, Psy:D., Department of Neuropsychology, Kennedy Krieger Institute, 1750 East Fairmount Ave., 3rd Floor, Baltimore, MD 21231. E-mail: kirkj@kennedykrieger.org

\section{P. CHIU, R. BROWN, V. SCHMITHORST \& S. HOLLAND. NEURODEVELOPMENT OF EPISODIC MEMORY ENCODING.}

Many studies have demonstrated that multiple brain areas in human adults (e.g., the prefrontal cortex, the medial temporal lobe, and the posterior parietal lobe) may be involved to support the efficient encoding of memories connected to a specific time and place. In this study, we explored the neural substrate of such episodic encoding in children using functional magnetic resonance imaging (fMRI). Two groups of children (age 7 to 8 vs. age 17 to 18) were scanned while generating verbs to nouns heard alternated with a finger-tapping task in a block design. Post-scanning, all participants were given a recognition mem- ory test for the nouns they heard earlier. Across participants, brain activation elicited by verb generation relative to finger tapping was correlated with noun recognition performance; analyses were performed for the younger and older children respectively. Activation in right cerebellum, right orbitofrontal cortex, left prefrontal cortex, and right superior parietal cortex was correlated with memory performance for the younger children. In contrast, activation predominantly in bilateral cuneus / precuneus, left lingual gyrus, and left prefrontal cortex was correlated with memory performance for the older children. These results suggest that there may be dynamic changes during development in how brain areas interact to support episodic memory encoding. Correspondence: Peter Chiu, Ph.D., Psychology, University of Cincinnati, 401A Dyer Hall, ML 0356, Cincinnati, OH 45221-0376. E-mail: peter.chiu@uc.edu

\section{J.G. HALES, M.J. COHEN \& G.W. HYND. SEX DIFFERENCES IN CHILDREN'S LEARNING AND MEMORY.}

Studies of adults have found sex differences in learning and memory of varying direction and effect, often dependent upon the type of memory task examined. However, the relatively few studies of children on various memory tasks revealed many inconsistent findings with regard to sex differences during the developmental period. As a result, this investigation aimed to characterize sex-related variations in memory ability, particularly from a developmental perspective, so that the timing of the emergence of adult-like differences could be determined. These goals were achieved using the standardization sample of the Children's Memory Scale (CMS, Cohen, 1997), a comprehensive, standardized measure of children's memory skills. In order to determine if the memory structures of boys and girls were similar, exploratory factor analyses were conducted on 20 subtest scores from the CMS. These analyses revealed similar structure between the sexes consisting of six factors: word memory, spatial location memory, prose memory, scene memory, facial memory, and working memory/span. Comparison of memory factor scores revealed significant sex effects in some memory areas, but no significant sex by age group interactions. Specifically, boys outscored girls at memory for location of a visual spatial pattern; girls were significantly higher than boys on memory for scenes, which required memory for concrete objects and their locations. In addition, girls tended to score higher than boys on memory for faces, although this finding was not statistically significant. The neuropsychological implications of these findings will be discussed.

Correspondence: Jessica G. Hales, M. Ed., Educational Psychology, University of Georgia, 2423 Cherokee Road, Augusta, GA 30904. E-mail: jessicagranthales@yahoo.com

\section{S. MCLAUGHLIN-BELTZ, D. ARMSTRONG, L. LAPOINTE- D'AMORE, G. MONTENEGRO, D. MICHAUD \& J. MOROPITO- HUOT. COMPARATIVE ANALYSIS OF THE RELATIONSHIP BE- TWEEN SENSORY INTEGRATION, PRAXIS, AND COGNITIVE FUNCTIONING IN CHILDREN.}

Sensory Integration is a form of information processing that organizes sensation from the body and the environment (Ayres, 1989). It has long been argued that deficits in sensory integration result in difficulty with planning, producing, and organizing behavior, thus impacting conceptual and motor learning (Fisher, Murray, and Bundy, 1991). The current study examines the relationship between sensory integration, praxis, and cognitive functioning in children. Thirty-two children (19 males and 13 females) participated in the study. The mean age was 85.97 months (range $=39$ to 164 months). All caregivers completed a Sensory Profile and, all subjects were administered either, the WPPSI-R or the WISC-III. Additionally, 11 of the 32 children were administered the Sensory Integration and Praxis Tests. Partial Correlation Coefficients, controlling for age, revealed a positive correlation between Vestibular Processing and Auditory Processing $(.6501, \mathrm{p}=.001)$, a positive trend between Auditory Processing and Oral Praxis (.6291, $p=.070)$, and a 
positive correlation between Oral Praxis and Performance IQ (.6762, $\mathrm{p}=.046)$. Additionally, positive correlations were found between Localization of Tactile Stimuli and Bilateral Motor Coordination (.6688, $p=.049)$, Bilateral Motor Coordination and Praxis on Verbal Command $(.7486, p=.020)$, and, finally, Praxis on Verbal Command and Verbal IQ $(.7061, p=.034)$, as well as, Full Scale IQ $(.8105, p=.008)$. Interestingly, no correlation was found between Auditory Processing and Verbal IQ, suggesting that one may be able to process information but be unable to execute a verbal response.

Correspondence: Susan McLaughlin-Beltz, PhD, Neurodevelopmental Institute of NH, 1461 Hooksett Rd., Hooksett, NH 03106.E-mail: sbeltz@ niatmba.com

\section{D.L. MOLFESE, A. KEY, K. PEACH, D. GOZAL, L. O'BRIEN \& A. IVANENKO. DELAYED BEDTIME ALTERS BRAIN PROCESSING.}

The effects of mild sleep restriction, a highly prevalent occurrence in modern society, on child neurocognitive performance are unknown. Auditory and visual event-related potentials (ERPs) were recorded using a 128-channel high-density array in 6 normal male children (age 7-8 years) with confirmed absence of any sleep disturbances. ERPs were recorded after a week of normal sleep and a week of one hour per night sleep restriction (delayed bedtime). A series of tasks were designed to elicit brain activity in different regions and included an auditory P300 paradigm (1000 vs $1500 \mathrm{~Hz}$ tones) to assess attention, a speech sounds discrimination task (computer-generated consonant-vowel syllables), and an executive function task (Directional Stroop). ERPs after sleep reduction were more diffuse and less organized although there were no significant differences in behavioral performance on all tasks. Sleep-related effects were present over all electrode regions for both hemispheres, beginning immediately after stimulus onset, and continuing through the entire $700 \mathrm{~ms}$ post-stimulus epoch. The altered brain activity suggests that neurocognitive functioning and development in young children is highly susceptible to sleep disruption. High-density brain mapping using specific tasks may lead to the identification of children who are more cognitively vulnerable because of chronic sleep disturbances.

Correspondence: Alexandra Key, Ph.D., Psychological \&. Brain Sciences, University of Louisville, 317 Life Sciences Bld, Louisville, KY 40292. Email:a0fona01@athena.louisville.edu

\section{Experimental Studies of Normal Cognition}

\section{E.R. LARSON, T.A. HAMMEKE, S.J. SWANSON, E. POSSING, S. KORTENKAMP \& J.R. BINDER. FUNCTIONAL MRI ACTIVA- TION OF THE ANTERIOR TEMPORAL LOBE: A COMPARISON OF THREE PROTOCOLS.}

Many language activation tasks have successfully been used with functional magnetic resonance imaging to measure cerebral dominance. Still, these protocols do not reliably activate the anterior temporal lobe, the most common site of epilepsy surgery. Based on evidence that the left anterior temporal lobe is involved in name retrieval and sentence-level processing, we examined patterns of activation in 20 healthy participants during a Definition Naming task, in which subjects retrieved names in response to brief auditory-verbal descriptions. This task was contrasted with two nonverbal control conditions: a Target Detection task emphasizing low-level audition and working memory, and a Tone Matching task emphasizing analysis of melodic and amplitude contours (prosody). A clustered image acquisition sequence was used to avoid movement artifacts associated with the oral responses and to allow monitoring of accuracy and vocal reaction time. Subjects were also scanned during a single-word Semantic Decision protocol previously shown to elicit widespread, left-lateralized activation correlated with Wada language results. Language lateralization by the Definition Naming task was strongly correlated with lateralization derived from the Semantic
Decision task, regardless of which control task was used with Definition Naming. Definition Naming produced stronger and more extensive activation of the dominant anterior temporal lobe than the Semantic Decision task. The greatest degree of anterior temporal activation was observed using the Target Detection control task with Definition Naming, but anterior temporal activation was more left-lateralized using the Tone Matching control task with Definition Naming. The latter combination seems optimal for anterior temporal lobe language mapping. Correspondence: Eric R. Larson, PhD, Neurology, Medical College of Wisconsin, 9200 West Wisconsin Avenue, Milwaukee, WI 53226-3596. E-mail: elarson@mcw.edu

T.N. KAWAHARA-BACCUS, T.W. SCHMITZ, C.M. CARLSSON \& S.C. JOHNSON. DO HEMOGLOBIN AND HEMATOCRIT LEVELS AFFECT FMRI ACTIVATION?.

Blood oxygenation level dependent (BOLD) contrast is the source of activation signal in functional magnetic resonance imaging (fMRI). However, BOLD is dependent upon the ability of oxygen molecules to bind with hemoglobin $(\mathrm{Hgb})$, and thus may affect interpretation of fMRI results. Few small studies have been done to look at this, however there are contradictions between whether or not Hgb (and or hematocrit (Hct) levels) have an effect on fMRI activation. For that reason, this study was performed to evaluate the effect of Hgb and Hct levels on activation in a sample of persons with risk factors for Alzheimer's disease. Thirty-six middle age subjects ( 22 females/14 males), ages 40-65 years old were asked to participate in this study which included the following procedures: blood pressure, blood draw, brief cognitive testing and fMRI scanning. The blood pressure and blood draw occurred between 5-10 minutes prior to entering the MRI scanner. While in the MRI scanner, fMRI task of higher cognitive functions involving self-knowledge retrieval and memory acquisition were administered. The regions of peak activation was extracted and correlated with the blood measures. Mean Hgb concentration was $14.1+/$ - SD 0.9 (range 15.9 to 12.1 ) and mean Hct was 41.0+/- SD 2.7 (range 46 to 36 ). These measures were intercorrelated $r=.93$. Correlations between activation and hemoglobin were $r=.09$ in the temporal lobe and $r=.35$ in the medial frontal lobe. These results suggest that in this healthy middle-aged population, Hgb levels may effect activation in a task dependent manner. This knowledge is important and may suggest that hgb levels may need to be considered when interpretating fMRI results.

Correspondence: Tisha N. Kawahara-Baccus, MS, Geriatrics, UW-Madison, 2870 University Ave. Suite 106, Madison,WI53705.E-mail:tnk@ medicine.wisc.edu

\section{L.H. SWEET, J.F. PASKAVITZ, M.J. O'CONNOR, J.N. BROWNDYKE, J.J. WELLEN, K.G. HELMER \& R.A. CO- HEN. FMRI CORRELATES OF THE WAIS-III SYMBOL SEARCH SUBTEST.}

Clinical applications of functional magnetic resonance imaging (FMRI) are emerging that will likely improve diagnostics and treatment. For instance, FMRI may be used to test assumptions about the localization of brain function associated with performance on neuropsychological measures. Previous studies have used substantial adaptations of standard neuropsychological measures for feasibility in the FMRI environment. As a consequence, generalizability of imaging and behavioral findings to the original tests is questionable. The purpose of this study was to identify FMRI correlates of a well-standardized clinical measure, with only minor adaptations to standard administration. Fifteen healthy righthanded adults completed the Wechsler Adult Intelligence Scales - Third Edition Symbol Search subtest during whole-brain FMRI. Regions of interest (ROI) were empirically derived using a cross-correlation method with a false discovery rate thresholding procedure. Local baseline subtractions were performed individually on a voxel-wise basis within these ROIs. Compared to a simple visuospatial control task, significantly greater activity was detected in bilateral primary visual cortex, occipi- 
toparietal regions, and dorsolateral prefrontal cortex. Within the association cortices, volumes of activity were larger and more intense in the left compared to the right hemisphere. All participants performed within the average range according to age and education corrected norms. Our findings suggest that Symbol Search performance is associated with executive, visuospatial, and primary visual processing. Lateralization supports literature suggesting that detailed symbolic matching requires greater left hemisphere brain function, specifically the left dorsal visuospatial processing stream. In the neuropsychology clinic, poor Symbol Search performance may reflect dysfunction in any of these regions. Correspondence: Lawrence Sweet, Brown University, Miriam Hospital, Coro-West, One Hoppin Street, Providence, RI 02903. E-mail: sweet@ brown.edu

\section{J.J. RANDOLPH, R. ROTH, H. WISHART, J. RANDOLPH, K. SCHUSCHU, B. MCDONALD, H. PIXLEY, J. MACDONALD \& A. SAYKIN. BRAIN ACTIVATION ASSOCIATED WITH A MODI- FIED COUNTING STROOP TASK: AN FMRI STUDY.}

Previous studies have successfully adapted the classic Stroop task to the functional MRI environment (fMRI). However, the congruent condition of the Counting Stroop fMRI task is somewhat difficult to interpret, and modifications are possible to maintain consistency with the original Stroop paradigm and to examine additional executive processes. The present study sought to determine: 1) whether BOLD fMRI activation associated with our modified Counting Stroop task was similar to previous studies when using a congruent condition with number words, and 2) whether brain regions engaged during task preparation differed from those engaged during task performance. Eight healthy adult controls ( 6 females) completed an fMRI Counting Stroop task that allows for analysis of activation associated with task preparation as well as congruent and incongruent task conditions. Brain activation associated with response inhibition (incongruent $>$ congruent contrast) included right inferior and middle prefrontal gyri, bilateral dorsolateral prefrontal cortex, left hippocampus, and, to a lesser extent, right medial frontal cortex, bilateral parieto-occipital, and right cerebellar regions $(p<.01$, $\mathrm{k}=3$ ). Task preparation (preparation $>$ incongruent contrast) was associated with activation in orbitofrontal, anterior and posterior cingulate, and bilateral parieto-occipital regions $(\mathrm{p}<.01, \mathrm{k}=3)$. These findings indicate that: 1) the modified fMRI Counting Stroop task is associated with brain activation patterns consistent with previous studies; 2) medial fronto-parietal regions are particularly active during task preparation; 3) multiple executive cognitive processes can be dissociated and examined during a single Counting Stroop scan run.

Correspondence: John J. Randolph, Ph.D., Psychiatry, Dartmouth Medical School, DHMC, One Medical Center Dr, Lebanon, NH 03756-0001. E-mail:john.j.randolph@dartmouth.edu

\section{M.W. JACOBSON, S.L. ARCHIBALD, C. FENNEMA-NOTESTINE \& T.L. JERNIGAN. DIVIDEDVISUAL ATTENTION AND FMRI: SWITCHING BETWEEN HIERARCHICAL STIMULI EVOKES INFE- RIOR, MEDIAL AND SUPERIOR FRONTAL REGION ACTIVATION.}

BACKGROUND: Cognitive neuroscience paradigms in conjunction with fMRI have yielded new information about frontal, parietal and cingulate regions involved in visual attention. The current study used a divided attention task with hierarchical stimuli to examine changes in regional brain activation resulting from switching attention from the large. global level to detailed local levels at unpredictable intervals. METHOD: Six young adults (21-30) viewed Navon type stimuli constructed from numbers at 2 sec. intervals, identifying them with a corresponding response key while images were obtained. In the divided attention condition, Ss were asked to identify target numbers $(1-4)$, which could appear at either global or local level at unpredictable intervals. Stimuli were presented in pseudorandom order, with 2 to 4 stimuli presented at a given level before switching. In the sustained attention blocks, Ss identified numbers only at the specified global or local level. Images were acquired using a 1.5T scanner with EPI sequence weighted for blood oxygenation level dependent (BOLD) response. RESULTS: Response accuracy was above $90 \%$ for all Ss. In whole-brain voxel-by-voxel analyses, BOLD signal was correlated with a reference function contrasting divided attention (switching)blocks with sustained attention blocks. The attention switching condition evoked larger BOLD response $(t=2.70, p$ $<.05)$ in bilateral middle and superior frontal regions, and bilateral cerebellum relative to blocks of sustained attention to a single hierarchical level. There also was a trend toward greater right than left hemisphere activation in inferior and medial frontal regions. DISCUSSION: These findings replicate previous neuroimaging studies identifying frontal and parietal regional activation using a divided attention task. Greater right hemisphere activation may result from the inhibition of the global precedence effect that typically occurs when attending to hierarchical stimuli.

Correspondence: Mark W. Jacobson, PH.D., Research, Veterans Affairs San Diego Healthcare System, 3350 La Jolla Village Dr., mailcode 151B, San Diego, CA 92103.E-mail:mjacobson@vapop.ucsd.edu

\section{WELSH, C. MARTEJA, S. PRICE, A. OBLANDER \&. T. SIEBERT. INTERACTION OF WORKING MEMORY AND INHI- BITION IN A LIMITED CAPACITY SYSTEM.}

Behavioral and neurophysiological evidence supports the conceptualization that working memory is composed of verbal and visual-spatial slave systems, the functions of which are mediated by a central executive (Baddeley \& Hitch, 1974). Moreover, newer theoretical models propose that the central executive not only processes relevant information in a dynamic fashion, but also inhibits the processing of irrelevant stimuli. That is, if both working memory and inhibition processes draw from the same limited capacity pool of resources, one should observe increasing errors as the demands for each increase in a dual-task paradigm. Sixtyone college-student participants (mean age $=18.57$, sd=.78) were administered the Modified Mental Counters task, in which the demands for verbal working memory storage and updating were systematically increased. Participants were randomly assigned to three groups: No Interference, Verbal Interference, and Non-verbal Interference (the latter two conditions represented dual-task situations). An interaction between working memory load and interference type was predicted, with increasing number of errors expected as working memory load increased, but only in the Verbal Interference condition. The results were consistent with this predicted interaction, such that errors significantly increased from the 2 - to the 3-load conditions only in the Verbal Interference group. Surprisingly, errors stabilized from the 3 - to the 4-load conditions in this group, perhaps reflecting learning and increased cognitive effort exerted in this relatively challenging task. These preliminary results support the view that both working memory and inhibition processes draw from the same limited capacity system, and that these pools or resources may be domain specific.

Correspondence: Marilyn Welsh, Ph.D., Psychology, University of Northern Colorado, McKee Hall 14, Campus Box 94, Greeley, CO 806390121.E-mail:marilyn.welsh@unco.edu

\section{B.J. HALLAM, J.H. KRAMER, H.J. ROSEN, G. SCHAUER, C. PACE-SAVITSKY, D.C. DELIS, M. WEINER \& B.L. MILLER. FRONTAL LOBE VOLUMES SPECIFICALLY PREDICT THE CA- PACITY FOR SET SHIFTING ON EXECUTIVE TASKS.}

Introduction: The contribution of frontal regions to executive task performance is frequently obfuscated by component tasks that rely on lower order cognitive abilities. We were interested in correlating regions of interest from MRI with the isolated set switching demands of 2 executive tasks to elucidate structure-function relationships. Method: 23 older adults (9 normal controls, 8 semantic dementia patients and 6 frontotemporal dementia patients) representing a continuum of neuronal and cognitive integrity completed the D-KEFS Trail Making and Design Fluency tasks. Data were analyzed with multiple regression. In the first 
step of the model, component skills were entered to isolate the set switching demands of the tasks. Regions of interest from MRI, specifically, frontal lobe, anterior temporal lobe, orbitofrontal region, and posterior cortex, were entered into the model in the second step. Results: After partialling out component skills, frontal lobes accounted for $18 \%$ of the variance for set switching demands on Trail Making $(\beta=-.506, p=.01)$ and $49 \%$ of the variance on the set shifting condition of Design Fluency $(\beta=.721, p<.001)$. No other region of interest remained significant in the regression over and above frontal lobe volume. Discussion: Frontal lobe volume was the only MRI predictor of performance on the isolated set shifting demands of two executive tasks. These data support the specific role of the frontal lobes for cognitive set shifting. This study further emphasizes the need to control for component skills when studying complex neuropsychological processes like executive functioning. Correspondence: Bradley.J. Hallam, Ph.D., Psychiatry, Vancouver General Hospital, 715 West 12th Avenue, Health Centre, Fourth Floor East, Vancouver, BCV5Z 1M9, Canada. E-mail: bradleyjh@hotmail.com

\section{R. MRAZ, K.K. ZAKZANIS \& S.J. GRAHAM. COGNITIVE SET- SHIFTING DURING THE TRAIL MAKING TEST: AN FMRI STUDY USING AN FMRI-COMPATIBLE WRITING DEVICE .}

The purpose of this study is to investigate the neural substrates involved during the trail making test (TMT), a commonly used measure of $\operatorname{cog}$ nitive set-shifting ability. Functional magnetic resonance imaging (fMRI) was used to assess brain activation while subjects performed the TMT using a custom-built, fiber-optic fMRI-compatible writing device. Unlike previous studies which have used verbal adaptations of the test, we implemented a very close approximation of the conventional TMT during fMRI for a more realistic depiction of the brain regions engaged by the actual pencil-and-paper task. The fMRI task consisted of two parts: in Part A, subjects were required to link in ascending order numbers that were randomly distributed on a computer screen (1-2-3..); in Part $\mathrm{B}$, subjects were required to link alternately between numbers and letters (1-A-2-B..). Each part was presented in $40 \mathrm{~s}$ blocks and alternated with blocks of dark-screen visual fixation. FMRI-compatible goggles presented the visual stimuli, including drawing movements captured by the writing device. Preliminary results from four healthy, righthanded, subjects (mean age 27) are reported. A distributed network of activations was observed for both Part A and B that included sensorimotor and bilateral occipital and precuneus activity. Differences were evident in the left inferior and left middle frontal gyri, which both exhibited increased activation during cognitive switching (Part B). Our findings are consistent with the notion that set-shifting tasks are sensitive to frontal regions in the left hemisphere, but also indicate varying levels of right frontal and left precuneus involvement.

Correspondence: Richard Mraz, B.A.Sc., Imaging Research, Sunnybrook and Women, 2075 Bayview Avenue - SG28, Toronto, ON M4N3M5, Canada.E-mail:rmraz@sten.sunnybrook.utoronto.ca

\section{J. EMICK, M. WELSH, S. CHANDRAN \& Z. HOWELL. THE RE- LATIONSHIP BETWEEN FORMAL OPERATIONAL THOUGHT AND EXECUTIVE FUNCTIONS.}

The purpose of this study was to examine the association between formal operational thought and executive function, the cognitive processes attributed to the prefrontal cortex. Formal operations, the final stage in Piaget's theory of cognitive development, involve such skills as hypothetical reasoning and understanding of interpropositional relationships. Executive functions are goal-oriented cognitive processes such as working memory, inhibition and planning that are typically required for novel problem solving. The current study used the Logical Reasoning Test (Burney, 1974) as a measure of formal operational reasoning and the Tower of Hanoi-Revised (TOH-R) disk transfer task as a measure of executive functions. Past research has found that cognitive processes such as working memory, inductive reasoning, and procedural learning contribute to performance on the TOH-R, and it was interest whether for- mal operational thought also predicted performance on this task. Fortyseven participants (mean age $=19.1 \mathrm{yrs}$ ) were administered five tasks including: the Tower of Hanoi-Revised, Mirror Tracing, Spatial Span, Matrix Reasoning, and Logical Reasoning Test. The findings indicated a moderate association between formal operational reasoning and performance on the TOH-R. Additionally, inductive reasoning, as measured by the Matrix Reasoning Task, predicted performance on the Logical Reasoning Test. Regression analyses revealed that the Logical Reasoning Test explained a greater proportion of variance on TOH-R scores than did the Matrix Reasoning Task. These findings contribute to our emerging understanding of executive function by linking it to formal operational thought, as well as to fluid intelligence.

Correspondence: Jessica Emick, M.A., University of Maryland, 7501 Mandan Rd., Apt.201, Greenbelt, MD 20770.E-mail:jemick@umd.edu

\section{C.L. ADAMS, M. WELSH, A. JOHNSON, L. CHRISTINA, M. FREDRICKS \& H. WAKINEN. CONTRIBUTION OF INHIBI- TION, WORKING MEMORY, AND FLUID REASONING TO TOWER OF HANOI-REVISED PERFORMANCE .}

The Tower of Hanoi is purported to measure executive functioning (EF), which encompasses a broad range of cognitive constructs. The underlying cognitive processes contributing to performance on one EF task, the Tower of Hanoi-Revised (TOH-R), was examined by including tasks tapping working memory, fluid reasoning, and inhibition as possible predictor variables in a regression analysis. To date, the contribution of inhibition to Tower of Hanoi performance has not been well established in the literature. One possible explanation for the lack of consistent findings is that measures of inhibition do not tap a single construct, but instead tap independent types of inhibition. The inhibition literature was examined to identify measures that heretofore have not been correlated with the Tower of Hanoi, but that nevertheless might contribute to performance. Delay of Gratification, a behavioral inhibition paradigm, was chosen. It was theorized that upon presentation of the Tower of Hanoi, delay of gratification allows participants to engage working memory, and once engaged, participants can begin planning move sequences and utilizing fluid reasoning. The results indicated a significant association between Delay of Gratification and the TOH-R. A multiple regression analysis yielded a significant model including visuospatial working memory, fluid reasoning, and delay of gratification that explained approximately $30 \%$ of the variance in TOH-R performance. These results provide new evidence that behavioral inhibition, as measured by the Delay of Gratification task, contributes to Tower of Hanoi performance in addition to working memory and fluid reasoning skills.

Correspondence: Christy L. Adams, M.A., Psychology, University of Kansas, 3920 Stetson Dr., Lawrence, KS 66049.E-mail: chyadams@ku.edu

\section{KINGERY, L.K. LANGLEY, N. MARANO \& D.J. SCHRETLEN. HIPPOCAMPAL VOLUME ASYMMETRY CORRELATES WITH WORD VS. DESIGN FLUENCY IN NORMAL ADULTS.}

Word and design fluency tasks are thought to measure left and right frontal lobe functioning, respectively, and lesion studies generally support this (Jones-Gotman \& Milner, 1977; Ruff et al, 1994). Using 130 right-handed healthy adults between the ages of 20 and 92 years $(M=58$; $\mathrm{SD}=19$ ), in whom structural brain MRI and fluency test data were available, we tested the hypothesis that better word than design fluency would correlate with larger left- than right-sided volumes of the frontal lobes and hippocampus, and vice versa. We first computed neuroanatomic asymmetry scores (left minus right) for standardized measures of these brain regions, and then derived cognitive asymmetry scores by subtracting standardized estimates of design fluency from (letter and semantic) word fluency test performance. As hypothesized, better word than design fluency correlated with relatively larger left than right hip- 
pocampal volumes (Pearson $\mathrm{r}=.26, \mathrm{p}<.005)$. Contrary to expectation, left vs. right frontal lobe volume asymmetry did not correlate with word vs. design fluency differences. Results are discussed in the context of the role of the hippocampus in verbal and spatial fluency and the meaning of fluency asymmetry.

Correspondence: Lisle Kingery, Ph.D., Medical Psychology, Johns Hopkins University School of Medicine, 6704 Bonnie Ridge Dr., Apt 202, Baltimore, MD 21209. E-mail: lisle.kingery@umit.maine.edu

\section{D.A. WOLK, A.R. BERMAN, K.R. DAFFNER, D.L. SCHACTER \& A.E. BUDSON. EVENT-RELATED POTENTIAL CORRELATES OF ENHANCED CONCEPTUAL FLUENCY AND FALSE RECOGNITION.} Previous research has argued that the ease with which an item is processed - that is, its 'fluency' - provides a basis for familiarity and can be responsible for false memories. Event-related potentials (ERP) research has demonstrated an electrophysiologic correlate of familiarity: an attenuated, frontally distributed $\mathrm{N} 400$ wave. In the present study, young adults studied words in a letter counting task. On a recognition test, studied and nonstudied words were preceded by either a 'consistent' or 'predictive' sentence stem. 'Predictive' stems were hypothesized to enhance conceptual fluency of the final word. Participants showed higher levels of false recognition to nonstudied words preceded by predictive stems versus those preceded by consistent ones. The negative peak amplitude in the $300-500$ msec interval was decreased for all words (studied or nonstudied) preceded by a 'predictive' stem relative to a 'consistent' one. This effect of stem type was also larger for nonstudied than studied words. In the 1000-1600 msec interval, there was an increased, frontally distributed, positive peak amplitude that was greater for 'yes' responses (hits and false recognition) compared to 'no' responses (misses and correct rejections). The finding that false recognition increased in the setting of enhanced conceptual fluency and is related to an attenuated negative peak amplitude in the time interval of the N400 wave suggests that fluency may play a critical role in the generation of familiarity. Additionally, late frontal processes may be related to the attribution of fluency to prior experience.

Correspondence: David A. Wolk, MD, Neurology, Brigham and Women, Brigham Circle, 1620 Tremont Street, Boston, MA 02120. E-mail: dwolk@partners.org.

\section{S. COSENTINO, D.L. CHUTE, D.J. LIBON \& M. GROSSMAN. AN INVESTIGATION OF THE NEUROPSYCHOLOGICAL BASIS OF SCRIPTS: DIFFERENTIAL ROLES OF THE PREFRONTAL AND TEMPORAL CORTEX.}

Scripts are multi-step, goal-oriented plans with a general action sequence (i.e., organization), and a set of actors and objects (i.e., content). While some work associates prefrontal disease with degraded script knowledge, we hypothesize that this distribution of neuropathology is related to poor organization of script actions, and that script content is represented in temporal cortex. We evaluated these proposals using a novel test administered to 40 dementia patients. 25 patients were diagnosed with frontotemporal dementia, including 13 semantic dementia (SD) patients thought to have temporal lobe disease and 12 dysexecutive (EXEC) patients thought to have prefrontal disease. 15 patients were diagnosed with Alzheimers disease (AD). Patients judged the correctness of 66, four-step, typical event sequences presented in written format; foils included errors of sequence or content. We found a significant main effect for group, $\mathrm{F}(1,55)=13.56, \mathrm{p}=.001$, and a group $\mathrm{X}$ error interaction effect, $\mathrm{F}(3,55)=5.36, \mathrm{p}=.003$. EXEC patients failed to identify significantly more sequencing errors $(\mathrm{M}=12.08, \mathrm{SD}=7.38)$ than content errors $(\dot{\mathrm{M}}=7.08, \mathrm{SD}=5.63), \mathrm{t}(12)=3.79, \mathrm{p}=0.003$, consistent with the claim that prefrontal disease interferes selectively with script organization. Patients with SD and $\mathrm{AD}$ were equally insen- sitive to content and sequencing errors, suggesting that temporal cortex may be critical to representation of script content, and sequencing errors in these groups may be secondary to semantic impairment. Findings indicate that a large-scale network involving temporal and frontal structures supports scripts.

Correspondence: Stephanie Cosentino, M.S., University of California at San Diego, 2151 Glasgow Ave, Apt. A, Cardiff, CA 92007. E-mail: scosentino76@yahoo.com

\section{R. LAFORCE, G. ESKES \& S. EISNOR. DIFFERENTIAL CONTRI- BUTION OF THE CEREBELLUM AND FRONTAL LOBES TO MEM- ORY AND EXECUTIVE FUNCTIONS.}

Several elegant clinical and brain imaging demonstrations have provided evidence for a cerebellar contribution to spatial working memory and executive skills. These results were supported by anatomical studies which have shown connections between the cerebellum and the dorsolateral prefrontal cortex, an area well-known to be involved in similar functions. The distinct nature of their relative contribution to memory and executive abilities has yet to be determined, however. In an attempt to explore how cerebellar contribution differs from that of the frontal lobes on these abilities, the performance of 14 patients with damage to the cerebellum $(\mathrm{CE})$ and 5 patients with damage to the prefrontal cortex (FR) was compared to 5 matched normal controls (NC) on a comprehensive battery of neuropsychological tests. In addition, an adapted version of the Brooks Matrices was used to assess visuospatial working memory. Results supported our prediction that FR patients would experience greater difficulty than $\mathrm{CE}$ and $\mathrm{NC}$ groups in performing the visuospatial working memory paradigm but this failed to reach significance $(p<0.07)$. CE patients performed significantly worse than FR and NC groups on verbal memory (immediate and delayed) and lexical verbal fluency. As expected, FR patients made significantly more perseverations (i.e., 46) than CE patients (29.6) and NC participants (12.3). Both FR and CE groups showed significant fine motor coordination deficits. None of these differences could be explained by age, education, gender, general IQ, or anxiety and depression levels. Given the connections between the cerebellum and the dorsolateral prefrontal, posterior parietal and paralimbic cortices, future attempts at exploring the distinct nature of cerebellar deficits from those traditionally found with injuries to these neocortical areas would help better delineating cerebellar involvement to cognition.

Correspondence: Robert Laforce, Ph.D., Psychology, University of New Brunswick, PO Box 5050, Saint John, NB E2L 4L5, Canada. E-mail: rlaforce99@hotmail.com

\section{J.B. RICH, S. KARANTZOULIS \& J.A. MANGELS. TEMPORAL ORDER AND RECOGNITION MEMORY OF ACTIONS AND OB- JECTS IN SUBJECT-PERFORMED AND VERBAL TASKS.}

Recall and recognition are superior in subject-performed tasks (SPTs) compared to verbal tasks (VTs), termed the SPT effect. We examined temporal order memory (measured by deviation scores and bidirectional serial associations) in 78 undergraduates. Two lists of 20 action commands were presented in SPT and VT conditions; one list in each condition was meaningful ("Put money in the wallet."), and one was bizarre ("String a thread through the wallet."). Contrary to findings from free recall studies, there was no SPT effect on temporal order memory for objects $(\mathrm{n}=30)$, actions $(\mathrm{n}=24)$, or object-action pairs $(\mathrm{n}=24)$. In general, temporal order memory was better for semantically meaningful relative to bizarre lists. Yes/no recognition memory of previously presented objects was much higher for enacted than verbalized commands (i.e., an SPT effect), but there was no effect of meaningfulness. When participants identified an object as old, they were given a four-alternative, forced-choice recognition test to identify the action that had been paired with that object at study. Recognition of the actions was significantly better for enacted than verbalized action commands (i.e., an SPT effect) and for meaningful relative to bizarre commands. SPTs increase 
item-specific information during encoding, which benefits free recall and recognition memory performance. In contrast, there is no benefit of SPT encoding on the formation of interitem associations necessary for successful temporal order memory. This would account for findings of an SPT effect on free recall and recognition but no such effect on temporal order tasks.

Correspondence: Jill B. Rich, PhD, Psychology, York University, 4700 Keele Street,Toronto,ON M3J1P3, Canada.E-mail: jbr@yorku.ca

\section{K. MANOUSSAKI. COGNITIVE MECHANISMS UNDERLYING PERSEVERATION ON THE WISCONSIN CARD SORTING TEST.}

Two studies were undertaken on order to investigate the idea that perseveration is a result of an inability to disengage from a behaviour that is "overlearned" or that has become habitual. Following this premise, it was hypothesised that perseveration on a particular response would increase as reinforcement of this particular response increases. In the first study, the standard WCST as well as two variations differing in number of correct consecutive trials per category (CCT) (WCST5 and WCST15) were administered to twenty individuals with brain injury and an equal number of healthy participants. The purpose of the study was to examine a possible difference in perseveration when individuals were offered more (15) or less CCTs (5) for each sorting category on the WCST. All groups showed significantly fewer perseverative errors and total errors on WCST15 when compared both to WCST10 and to WCST5. The findings indicated that perseveration is not likely to be a result of an inability to inhibit well-learned responses. In the second study, participants included sixteen individuals with Traumatic Brain Injury and four individuals with Korsakoff's disease, who were tested on either WCST5 or WCST15, to eliminate practice effect. Also ambiguous cards were removed and participants were allowed to determine the sequence of sorting categories. The earlier findings were confirmed. Overall the findings contradicted the prevalent idea that forming a strong "response set" would increase perseveration. In fact, they indicated that performance on the WCST is facilitated by a stronger response set, and perseveration decreases.

Correspondence: kallia manoussaki, bell college, 20 hayburn crescent, glasgowg11 5ay; United Kingdom. E-mail:kalliaman@netscape.net

\section{N.W. PARK, L. TARITA-NISTOR, A.P. ARVANITIDIS \& M.R. BERGER. NEUROPSYCHOLOGICAL INVESTIGATION OFTHE ENCODING AND PERFORMANCE OF PURPOSEFUL ACTIONS.}

The current study investigated the organization of novel naturalistic actions, which are goal-directed tasks requiring a sequence of steps to complete. We studied twelve undergraduate controls and four individuals with a unilateral stroke. Participants verbally described a series of novel actions as the tasks were performed by the experimenter. Then they performed the just observed task. Performance was analyzed using the hierarchical Action Coding System. At the bottom level are A1 actions, the smallest observable action achieving a specific result. A1 actions representing a higher-level subgoal are grouped into A2s. It is assumed that some A1 steps, called crux actions, are more central to achieving a particular subgoal than are other A1 steps (non-crux). Controls were significantly more likely to verbally describe the tasks in terms of crux (M $=75.85 . \mathrm{SD}=8.92)$ compared to non-crux actions $(\mathrm{M}=22.15, \mathrm{SD}=$ 10.84). However, the difference between performed crux $(M=89.39$, $\mathrm{SD}=9.88)$ and non-crux actions $(\mathrm{M}=87.37, \mathrm{SD}=3.72)$ was not significant. High and low functioning patients showed this pattern of results, but low functioning patients scored significantly lower in all categories, and made more A2 errors than the control group. The achievement of the final goal was not affected significantly by the A2 errors for the control group, as measured on an eight-point scale $(\mathrm{M}=$ 7.33, $\mathrm{SD}=0.96$ ), but it was significantly impaired for the low functioning patients $(\mathrm{M}=3.75, \mathrm{SD}=3.01)$. These results suggest that low functioning stroke patients mastered the basic units of action, but were impaired in organizing basic units into higher-level goals.
Correspondence: Norman W. Park, Ph.D., Psychology, York University, Atkinson Faculty, 4700 Keele Street, Toronto, ON M3J 1P3, Canada. E-mail:npark@yorku.ca

\section{N.W. PARK, J. CHUNG \& E. BARBUTO. INVESTIGATION OF THE COGNITIVE PROCESSES UNDERLYING THE ENCODING OF} NATURALISTIC ACTIONS.

Stroke patients are more vulnerable to making errors when performing routine naturalistic actions (e.g., preparing a cup of tea). They also take more trials and make more errors when learning and performing novel naturalistic actions (NNAs; e.g., transferring from a wheelchair) than age-matched controls. The purpose of the present study was to investigate the role of controlled processing in the encoding of NNAs using a dual-task paradigm. Furthermore, we studied the components of working memory involved in the encoding of NNAs to determine whether there is a differential effect of a verbal or a spatial distracter task. College undergraduates learned novel NNAs (e.g.., ear guitar) under full attention or dual-task conditions. Attention was divided using a verbal or a spatial matrix secondary task (Brooks, L.R., 1967, JEP, v.19, pp. 289-299), which was performed concurrently with the novel naturalistic action at encoding. These two secondary tasks have been shown to require verbal and spatial cognitive processes respectively. The novel naturalistic action was then retrieved under full attention conditions. Participants made significantly fewer errors while performing NNAs when encoded under full attention $(\mathrm{M}=87.81, \mathrm{SD}=9.82)$ compared to dual-task conditions $(\mathrm{M}=70.56, \mathrm{SD}=14.65)$. Analysis of the secondary task yielded the same pattern of results. Further analyses suggest that participants made more errors when performing NNAs concurrently with a spatial task $(\mathrm{M}=68.00, \mathrm{SD}=9.94)$ as compared to a verbal task $(\mathrm{M}=73.12, \mathrm{SD}=18.59)$. These findings show that the encoding of NNAs requires significant cognitive resources, and that spatial components of working memory may be particularly involved in learning NNAs.

Correspondence: Norman W. Park, Ph.D., Psychology, York University, Atkinson Faculty, 4700 Keele Street, Toronto, ON M3J 1P3, Canada. E-mail:npark@yorku.ca

\section{C.B. KIRWAN \& C.E. STARK. MEDIAL TEMPORAL LOBE ACTI- VATION IN ENCODING AND RETRIEVAL OF NOVEL FACE- NAME PAIRS.}

A central aspect of many theories of human medial temporal lobe (MTL) functioning is that the hippocampal formation supports associative, conjunctive or recollective forms of memory, while the surrounding cortical structures support single-item or familiarity-based memory. We used fMRI to assess brain activity during learning and later recognition testing of novel face-name pairs to investigate evidence for this functional distinction. When examining activity for associative versus single-item encoding. we found greater activity for encoding of associative information than for single-item information in the right hippocampal region. the left amvgdala and in right parahippocampal cortex. Additionally, typical subsequent-memory effects were observed in the right temporal polar region of the perirhinal cortex and in the right parahippocampal cortex. During recognition, activity for the retrieval of associative information was greater than for non-associative information not only in the right hippocampus, but also in the left temporal polar portion of perirhinal cortex, right entorhinal cortex, and right parahippocampal cortex. In addition, a subsequent-memory effect associated with incidental encoding of novel foils was observed during recognition in the left parahippocampal cortex and an inverted effect was observed in the right temporal polar region of perirhinal cortex. These results do not support a functional isolation of the hippocampal region relative to adjacent cortical structures for associative versus non-associative memory. Rather, they indicate that associative encoding and retrieval is carried out in numerous regions throughout the MTL. NSF BCS-02036431 
Correspondence: C. B. Kirwan, BS, Psychological and Brain Sciences, Johns Hopkins University, $3400 \mathrm{~N}$ Charles St, Ames Hall, Baltimore, MD 21218. E-mail: kirwan@jhu.edu

\section{J. BROWNDYKE, L. SWEET, J. WELLEN, M. O'CONNOR, K. TUCKER, J. GUNSTAD, R. COHEN \& J. PASKAVITZ. KNOWING WHAT YOU KNOW AND DON'T KNOW: EVENT-RE- LATED FMRI EVIDENCE FOR DISSOCIABLE TEMPORAL AND FRONTAL LOBE ACTIVITY ASSOCIATED WITH RECOGNITION MEMORY RESPONSE TYPE.}

In this study, we employed event-related functional magnetic resonance imaging (fMRI) to study whether episodic memory retrieval under recognition response demands involves medial temporal lobe (MTL) activity and to determine if recognition response type affects this activity. Eight normal subjects were asked to remember 50 black-and-white line drawings of common objects, immediately after which the subjects were asked to distinguish between 25 foils and 25 target object stimuli. fMRI was undertaken during recognition recall of the object stimuli, and performance data were collected concurrent with the scanning procedure. Task results revealed perfect recognition retrieval accuracy for all subjects. Task output was divided into true positive (TP; affirmative target recognition) and true negative ( $\mathrm{TN}$; foil negation) responses. To visualize hemodynamic activity related to each response type, BOLD signal associated with TP and TN events were extracted from the MR time-series using deconvolution analyses. Difference contrasts between response type conditions yielded significant brain activation $(\mathrm{p}<.001)$ unique to TN responding within the right perirhinal cortex (BA 35), right inferior temporal gyrus (BA 20), right fusiform gyrus (BA 36), and right inferior parietal subgyral white matter. Conversely, significant activity $(p<.001)$ unique to TP responding was noted within the left superior occipital gyrus (BA 19), left superior frontal gyrus (BA 10), left precuneus (BA 7), and right middle frontal cortex (BA 46). Our results demonstrate MTL activity during episodic memory retrieval; clearly dissociable fMRI activity as a function of recognition response type; and point toward greater MTL involvement during TN responding. Correspondence: Jeffrey Browndyke, Ph.D., Department of Psychiatry \&. Human Behavior, Brown Medical School, Bryan Alzheimer's Disease Research Center, 2200 West Main St., Suite A-230, Durham, NC 27705. E-mail:j.browndyke@worldnet.att.net

\section{K.G. PRUITT \& M. HISCOCK. EXPLICIT AND IMPLICIT MEM- ORY FOLLOWING DICHOTIC LISTENING.}

Although striking dissociations between implicit and explicit memory have been observed in cases of amnesia, similar dissociations in neurologically intact participants have been difficult to demonstrate consistently. In an experiment involving 90 university undergraduates ( $45 \mathrm{fe}$ males, 45 males), we show that different attention instructions for dichotic listening differentially influence subsequent performance on implicit and explicit memory tasks. Participants were assigned randomly to left-ear, right-ear, and divided-attention conditions before being presented 66 dichotic pairs of words. Following the dichotic listening task, each participant undertook implicit and explicit fragment-completion tasks as well as an explicit recognition task. Test stimuli were related to the words that had been presented dichotically. Analysis of data from the fragment-completion tasks yielded a significant Attention Condition $x$ Task interaction $(p<.0001)$. Participants in the two focused-attention conditions produced more words on the implicit task and fewer words on the explicit task than did participants in the divided-attention condition. No difference was found between left- and right-ear attention conditions. Comparable results were obtained when performance on the implicit fragment-completion task was compared with performance on the explicit recognition task. Adjusting scores for differences in performance on the dichotic listening task did not alter the findings. The results indicate that dividing attention during encoding had a differential effect on implicit and explicit memory for words.
This may reflect the greater number of words that were attended to during encoding in the divided-attention condition and thus were processed explicitly rather than implicitly. The findings support the existence of a fundamental difference between implicit and explicit memory, but do not allow us to specify the nature of that difference.

Correspondence: Merrill Hiscock, Ph.D., Psychology, University of Houston, Heyne Bldg, Room 126, Houston, TX 77204-5022. E-mail: mhiscock@uh.edu

\section{P.S. FOSTER, K. THOMPSON \& D.W. HARRISON. VARYING AGES OF ANGRY MEMORIES: ELECTROENCEPHALOGRAPHIC CORRELATES.}

Recollection of emotional memories has often been used as an emotion induction method in studies seeking to investigate the cerebral correlates of emotional arousal. However, a paucity of research has been conducted to examine the specific effects of the ages of the memories recalled on resulting changes in cerebral activity. Hence, the purpose of the present study was to investigate the cerebral correlates of varying ages of emotional memories. Based on an integration of the spreading activation and parallel distributed processing models, it was hypothesized that significant positive correlations would be found between ages of angry memories and changes in high beta $(21$ to $32 \mathrm{~Hz})$ magnitude at the right frontal and temporal regions. A total of 28 male undergraduates were asked to recollect an angry memory while quantitative electroencephalography was recorded. Following recollection, they were asked to indicate the age of the memory recalled and the intensity of the memory on a scale of 1 (low intensity) to $?$ (high intensity). The results indicated that significant positive correlations existed between ages of angry memories and changes in the magnitude of high beta (21 to $32 \mathrm{~Hz})$ at the left prefrontal ( FP1; $\mathrm{r}=.377)$, left frontal $(\mathrm{F} 3 ; \mathrm{r}=.352)$, right frontal $(\mathrm{F} 4 ; \mathrm{r}=.408)$, and left parietal $(\mathrm{C} 3 ; \mathrm{r}=.326)$ regions. Given the present findings, it may be important for investigators to determine the ages of the memories recalled so as to control or otherwise account for the effects of this potentially confounding variable.

Correspondence: Paul S. Foster, MS, Psychology, Virginia Tech, 1320-1 Ephesus Church Road, Chapel Hill, OH 27517.E-mail:pfoster@vt.edu

\section{P.S. FOSTER, K. THOMPSON \& D.W. HARRISON. RECOLLECTION OF MIRTHFUL MEMORIES: COVARIATION OF ELECTROPHYSIO- LOGICAL AND CARDIOVASCULAR RESPONDING.}

Using angry memories, research has indicated that a relationship exists between changes in cerebral activity and cardiovascular functioning (Foster \& Harrison, 2002; Waldstein et al., 2000). However, no research has been conducted using positive emotions to investigate this relationship. Hence, the purpose of the present investigation was to determine whether the same relationship exists for positive emotions. Specifically, it was hypothesized that significant positive correlations would be found between changes in heart rate and blood pressure and low and high beta magnitude at the right frontal and left posterior regions and that significant negative correlations would be found at the left frontal and right posterior regions of the brain. To test this hypothesis, 11 male participants were asked to recollect mirthful memories while quantitative electroencephalography (QEEG) as well as heart rate and blood pressure were recorded. The results indicated that, as hypothesized, significant positive correlations were found between changes in high beta magnitude and changes in heart rate at the right frontal $(\mathrm{FP} 2, \mathrm{r}=.679)$ and left posterior regions ( $\mathrm{T} 3, \mathrm{r}=.814 ; \mathrm{C} 3, \mathrm{r}=.550)$. Further, a significant negative correlation was found for systolic blood pressure at the left frontal lobe $(\mathrm{F} 1, \mathrm{r}=-.733)$. Changes in low beta magnitude were also positively correlated with changes in heart rate at the left posterior region $(\mathrm{T} 3, \mathrm{r}=.673)$. Hence, the results provide further support for the existence of a relationship between changes in cerebral activity and cardiovascular functioning, even among positively valenced emotions. Correspondence: Paul S. Foster, MS, Psychology, Virginia Tech, 1320-1 Ephesus Church Road, Chapel Hill,OH 27517.E-mail: pfoster@vt.edu 


\section{J. FOGEL \& M.C. CARLSON. SOAP OPERAS AND TALK SHOW TELEVISION USE IN OLDER WOMEN IS SELECTIVELY ASSOCI- ATED WITH POORER MEMORY.}

Objective: We studied whether television use is associated with memory as measured by the Hopkins Verbal Learning Test (HVLT). Methods: Older women (n=285) were asked, "What is your favorite type of TV program?" The 14 categories included: 1) detective/adventure, 2) talk shows, 3) soaps, 4) game shows, 5) news/documentaries, 6) variety, 7) nature, 8) mysteries, 9) comedies, 10) Westerns, 11) sports, 12) shopping, 13) movies, 14) other. Using cross-sectional linear regression analyses, we separately regressed both the HVLT-immediate and -delayed memory scores onto the television categories, with "news" as the reference category. Analyses were repeated with demographic and medical covariates. Logistic regressions were conducted to predict clinical memory impairment. Results: Soaps $(p<.001)$ or talk shows $(p<.01)$ were associated with poorer HVLT-immediate memory. Addition of the covariates showed soaps as significant $(\mathrm{p}<.05)$ while talk shows had a trend $(p=.07)$. Soaps $(p=.001)$ or talk shows $(p<.01)$ were associated with poorer HVLT-delayed memory. Addition of the covariates showed a trend for talk shows $(p=.07)$ while soaps fell from significance. None of the other 12 defined television categories were significantly related to memory. Odds ratios for impaired HVLT-immediate memory were: soaps (unadjusted $=3.75$, adjusted $=2.39$ ) and talk shows (unadjusted $=3.86$, adjusted $=2.76$ ). Odds ratios for impaired HVLT-delayed memory were: soaps (unadjusted $=5.12$, adjusted $=2.83$ ) and talk shows (unadjusted=7.25, adjusted=5.12). Conclusion: Soap operas and talk shows were selectively associated with poorer immediate and delayed memory. As these are typically davtime shows, it may be that the older women watching these shows are losing the opportunity to engage in stimulating davtime activities to maintain and/or improve their memory.

Correspondence: Joshua Fogel, PhD, Mental Health, Johns Hopkins University, 624 North Broadway, Suite 861, Baltimore, MD 21205. E-mail: ifogel@jhsph.edu

\section{A.A. PEREIRA, T.W. SCHMITZ, T.N. KAWAHARA-BACCUS \& S.C. JOHNSON. FMRI BRAIN ACTIVATION AND VISUOSPATIAL MEMORY ABILITY: FUNCTIONAL NEUROANATOMIC CORRE- LATES OF BVMT-R PERFORMANCE.}

The present study describes the relationship between the results in a visuospatial memory test, the Brief Visualspatial Memory Test-Revised (BVMT-R), and functional MRI (fMRI) activation to novel line figures. It was hypothesized that better performance on the encoding phase of the BVMT-R would correlate to brain activation level during the presentation of novel figures. Seventeen healthy adults (mean age $=22.88$, $\mathrm{SD}=4.02$; mean education $=15.88, \mathrm{SD}=1.46$ ) were studied. The $\mathrm{t}$ score for the total figures recalled (TRS) during the learning phase of the BVMT-R was adopted as one variable. The second variable was the activation difference between novel and familiar line figures. Five line figures (Snodgrass and Vanderwart, 1980) were presented in two training session prior to the scan. During the scanning session, the participants had to differentiate between novel and the previously learned figures. Imaging parameters were as follows: sagittal plane: $T R=2$; repetitions 141: $\mathrm{TE}=30 \mathrm{~ms}$; Matrix $64 \times 64$; number of slices $=30$; slice thickness $4 \mathrm{~mm}$ with $1 \mathrm{~mm}$ skip. Images were realigned, normalized, and smoothed to 8mm using SPM99. The relationship of TRS t-scores and fMRI activation was tested at each voxel in the brain. The region of peak positive correlation $(\mathrm{r}=.83)$ was the right anterior hippocampus, a major brain structure involved in learning and memory. Replicating a prior result (Johnson et al 2001, JINS), the findings suggest that increasing activation of the right hippocampus is associated with better visuospatial learning ability.

Correspondence: Ana A. Pereira, psychology, Rehabilitation Psychology and Special education, University of Wisconsin-Madison, $432 \mathrm{~N}$. Murray Street, Madison, WI 53705. E-mail: pereira@wisc.edu
L. CUTTING, A. CLEMENTS, J. SCHAFER, S.H. MOSTOFSKY, J. PEKAR \& M.B. DENCKLA. FUNCTIONAL MRI OF THE JUDGMENT OF LINE ORIENTATION.

The Judgment of Line Orientation (JLO) is a visual spatial test that has traditionally been considered a test of parietal lobe functioning; this supposition has primarily been derived from research on individuals with focal or diffuse brain damage. To date, research utilizing functional neuroimaging to examine the neural circuitry associated with the JLO is limited. In the current study, functional MRI was used to investigate the neural circuitry associated with the JLO. Eleven adult controls performed an analogue of the JLO while in the scanner. The task consisted of a fan of eleven lines displayed at the bottom of the screen with two lines highlighted in yellow to be compared to two lines above the fan. The subject was asked whether the yellow lines in the bottom fan were in the same or different position as the two lines in the above fan. This task was contrasted to a visual discrimination task in which the subjects were asked whether the lines above the fan were the same or different in color compared to the lower fan that was displayed in blue. Results of random effects analyses showed that significant activation was found in areas traditionally implicated in visual spatial functioning, including bilateral inferior parietal lobe, right superior parietal lobe, and left occipital lobe; in addition, bilateral cerebellar activation was found. Significant activation was also observed in right dorsolateral prefrontal cortex, indicating that performance on the JLO may also involve executive function.

Correspondence: Laurie Cutting, Kennedy Krieger Institute, 707 North Broadway, Baltimore, MD 21205. E-mail: cutting@kennedykrieger:org

\section{L.J. ELIAS \& B. ROBINSON. DRIVE ON THE “RIGHT" SIDE OF THE ROAD: PERCEPTUAL ASYMMETRIES FOR JUDGEMENTS OF AUTOMOBILE PROXIMITY.}

Most roadways are right-side drive. After correcting for differences in population, approximately $66 \%$ of the world drives on the right and $72 \%$ of the length of the world's highways are right-side drive. A general leftward perceptual bias for judgments of distance could make rightside driving safer than left-side driving. We had 20 neurologically normal students perform 64 trials of an automobile distance judgement task wherein a centrally presented vehicle was presented for 90 msecs followed by a lateralized image of the same vehicle. Participants tended to overestimate the proximity of automobiles appearing on the left side. Therefore, countries that require right-side driving could be less prone to accidents between opposing vehicles.

Correspondence: Lorin J. Elias, Ph.D., Psychology, University of Saskatchewan, 9 Campus Dr., Saskatoon, SK S7N 5A5, Canada. Email:Lorin.Elias@usask.ca

\section{KINGERY, J.C. WERTHEIMER \& K.M. ADAMS. THE QUAL- ITY OF WORDS PRODUCED ON LETTER FLUENCY TASKS COR- RELATES WITH VERBAL ABILITY AND ACHIEVEMENT LEVEL.}

Clinical experience suggests that the quality of words (i.e., grade level) produced on letter fluency tasks correlates with verbal skills. In order to test this hypothesis, words produced on a letter fluency task (C, F, \& L) were coded using the grade level ratings provided by The Living Word Vocabulary (Dale, \& ORourke, 1981). The Living Word Vocabulary is a comprehensive listing of the grade level of over 44,000 words. In a sample of 134 adults (mean age $=39 . \mathrm{SD}=12$ ) evaluated in a forensic neuropsychology private practice, correlation and regression analyses were conducted to evaluate the relationship between word quality and verbal abilities. Results revealed that word quality correlated significantly with education $(\mathrm{r}=.35, \mathrm{p}<.001)$, but not age or gender. Word quality also correlated significantly with measures of achievement (reading, spelling, arithmetic) and general verbal skills (vocabulary, NART), even after controlling for education level. Multiple regression analyses revealed that word quality accounted for unique variance in vocabulary subtest scores over and above education level (7\% using WAIS-III, 
$4 \%$ using WAIS-R). Findings were more robust in predicting achievement scores using education and grade level. These findings indicate that the quality of words produced on letter fluency tasks is a meaningful variable in and of itself. Implications for clinical practice and further research exploring the qualitative features of letter fluency are offered.

Correspondence: Lisle Kingery, Ph.D., Medical Psychology, Johns Hopkins University School of Medicine, 6704 Bonnie Ridge Dr., Apt 202, Baltimore, MD 21209. E-mail: lisle.kingery@umit.maine.edu

\section{P.T. CIRINO, C.D. CARLSON, D.J. FRANCIS \& J.M. FLETCHER. PHONOLOGICAL PROCESSING AND CALCULATION SKILL IN SPANISH SPEAKING ENGLISH LANGUAGE LEARNERS.}

Phonological working memory (PM), rate of phonological access (ROA), and particularly phonological awareness (PA), have been found to be predictive of growth in math calculation skills in fluent English speaking children (Hecht et al., 2001). The relationship between phonology and calculation has not been addressed in Spanish speaking English Language Learners (ELLs); the current study did so in a cross-sectional sample $(n=1645)$ of children in grades K through 3 , assessing phonology in both English and Spanish. PA, ROA, and PM were assessed with several common subtests of these constructs (e.g., Elision, Rapid Automatized Naming, Nonword Repetition), and math and reading skills were assessed with the Woodcock Language Proficiency Battery. English measures of phonology accounted for $32 \%$ of the variance in calculations, with unique contributions of PM and ROA (but not PA). Spanish measures of phonology accounted for $38 \%$ of the variance in calculations, and each factor contributed significant unique variance. Phonology was also predictive of single word reading measured in the same language (59\% English, and 66\% Spanish), and each factor contributed unique variance. In general, stronger relations between phonology and math (and reading) skills were evidenced in grades $\mathrm{K}$ and 1 relative to grades 2 and 3 . Results indicate that phonology is predictive of calculation skill in Spanish ELL children, although the pattern of unique phonological sub-skill contributions was different from that found by Hecht et al. (2001) for growth in computation. Future directions include examination of the three factor model of phonology in Spanish ELL children.

Correspondence: Paul Cirino, Ph.D., University of Houston, Dept. of Psychology, Ste. 126, Heyne Bldg., Houston, TX 77204. E-mail: pcirino@uh.edu

\section{BALCONI. LINGUISTIC ANOMALIES AND MORPHED FACIAL EXPRESSIONS ELICITED A N400 ERP EFFECT. A CEREBRAL DO- MAIN-SPECIFIC SEMANTIC MODULE?.}

Previous studies have revealed that decoding of facial expressions is a specific component of face comprehension and that semantic information might be processed separately from the basic stage of face perception. Basic question of this research is if it is likely to suppose the comparability of semantic information processing for linguistic stimuli with semantic elaboration for non-linguistic facial stimuli. In order to explore brain potentials (ERPs) related to decoding of facial expressions and the effect of semantic valence of the stimulus, we analyzed twenty normal subjects. Faces with three basic emotional expressions (fear, happiness, sadness) and with three morphed expressions were presented in random order. The neutral stimuli were the control condition. Whereas ERP profiles were similar with respect to an early negativity (N170), considered as a structural marker of face perception, differences in peak amplitude were observed later for incongruous (morphed) expressions compared with congruous (prototypical). In fact, the results demonstrated that the emotional morphed faces elicited a negative peak at about 360 ms, distributed mainly over the posterior site. The electrophysiological activity observed may represent specific cognitive processing underlying the decoding of facial expressions in case of semantic anomaly detection. The evidence is in favour of comparability of this negative deflection with the N400 elicited for linguistic task. A domain-specific semantic module is proposed to explain these results.

Correspondence: Michela Balconi, Ph.D., Psychology, Catholic University of Milan, L.go Gemelli, 1, Milan 20123, Italy. E-mail: michela. balconi@unicatt.it

\section{J.I. SHENKER, G.A. GHACIBEH, J. MALMAD, G.P. CRUCIAN, J.B. MIELKE, R.D. RHODES, B.V. SHENAL \& K.M. HEILMAN. BETTER THE HAND YOU KNOW: DISSOCIATION IN BODY SCHEMA AND METRIC LENGTH JUDGMENTS IN NEUROLOGI- CALLY INTACT HUMANS.}

A modular representation for body schema is suggested by brain damage that affects judging body size, shape, or location but not other visuoperceptual functions. If the brain has specialized body schema representations, then we hypothesized that non-brain damaged people might be differently accurate at estimating the distance of body parts versus estimating spatial distances. We studied 22 right-handed student volunteers (11 female; ages 20-23). We stood them so that their midsagittal plane was parallel to a blank wall, with arms at their sides. A collar prevented participants from seeing their body or the floor. We told them to move laterally to "end up so that:" "..the outside of your shoulder is 3 feet from the wall," "..2 feet..," "..1 foot..," or "..if you extended the arm nearest the wall, the fingers would barely touch." Randomly ordered trials (48) began by standing participants with either their left or right arm adjacent to the wall, or 5 feet away. After the participant finished moving, we measured the distance between the wall and his/her midsaggital plane. Participants mis-estimated all metric distance judgments, but accurately estimated arm length. They overestimated one foot, but underestimated two and three foot distances, even though both the one and two foot distances were actually closer than the actual distance for arm length estimates. These data show that in normal people there is a dissociation between estimating distances based on body schema and judgments of metric dimensions, arguing for a specialized (modular) body schema representation.

Correspondence: Joel I. Shenker, M.D., Ph.D., Neurology, University of Virginia, PO Box 800394, UVA Health System, Charlottesville, VA 22908-0394.E-mail:jis2p@virginia.edu

\section{J.T. SHENTON, J. SCHWOEBEL \& H. COSLETT. THE ROLE OF VISION AND PROPRIOCEPTION IN MOTOR PLANNING: EVI- DENCE FROM MENTAL MOTOR IMAGERY.}

Previous studies have demonstrated that visual and proprioceptive feedback substantially influences motor control. The relative contributions of these sensory modalities remain unclear. Studies have either claimed a bias toward the dominance of visually-perceived location information relative to proprioceptive location information, or an integrative weighting of the two modalities. This study was designed to explore the roles of vision and proprioception in motor processing. The task required subjects to judge if a pictured stimulus was a right or left hand; stimuli included pictures of a right or left hand in a palm up or palm down position and in 6 different angular rotations $\left(0^{\circ}, 60^{\circ}, 120^{\circ}, 180^{\circ}, 240^{\circ}\right.$, $300^{\circ}$ ). Each subject was tested with his/her right hand palm down and palm up. There were three conditions: a "control" condition (real hand in view), a "fake hand" condition (fake hand in view, real hand out of view), and a "proprioception" condition (no fake hand, real hand out of view). Across the conditions, results showed that proprioceptive input (that is, subject's hand position) had a significant influence on mental rotation, while the visually-perceived posture of the hand (the "seen 
position") did not. This result suggests that the bias favoring vision reported in previous studies may not be due to visual dominance, but may instead rely on crossmodal integration of sensory signals (for example, seeing and feeling a stimulus simultaneously but incongruently). In addition, this study suggests a larger role for sensory input in mental motor imagery and, by extension, in motor planning.

Correspondence: Jeffrey T. Shenton, Neurology, University of Pennsylvania, 3 West Gates, HUP, 3400 Spruce St., Philadelphia, PA 19104. E-mail: jshenton@mail.med.upenn.edu

\section{LISS, K. BAXLEY, P. KILLINGSWORTH, L. TIMMEL \& E. JEROME. PSYCHOLOGICAL CORRELATES OF SENSORY PRO- CESSING STYLE.}

The processing of sensory information is perhaps the most basic psychological element underlying how individuals perceive and react to their environment, yet research exploring the impact of sensation on other psychological variables is sparse. The goal of this investigation was to gain a better understanding of how individuals process sensory information and how sensory processing sensitivity relates to other psychological variables. Although many claims have been made about people who have low thresholds for sensory information (are highly sensitive), few have been validated. For example, it has been suggested that highly sensitive people are more creative than other individuals (Aron, 1997). It has also been suggested (Aron \& Aron, 1997) that sensory processing interacts with parental care such that highly sensitive people with low levels of parental care are more likely to suffer from psychological distress. In this investigation 213 undergraduate psychology students were given the Highly Sensitive Person Scale (Aron \& Aron, 1997), State Anxiety Inventory (Spielberger, 1983), Alternate Uses Test (Guilford, Christensen, Merrifield, and Wilson, 1978) to measure creativity, the Beck Depression Inventory (Beck, Ward, Mock, and Erbaugh, 1961), and the Parental Bonding Scale (Palmer, Oppenheimer, and Marshall, 1988). Sensory processing sensitivity was significantly related to depression, trait anxiety, relationship anxiety, introversion, and having a judging personality style. It was unrelated to creativity. Furthermore, a significant interaction was found between sensory processing sensitivity and parental care for depression indicating that highly sensitive people with low parental care were more likely to be depressed $\mathrm{F}(1,209)=4.94, \mathrm{p}<.05$.

Correspondence: Miriam Liss, Ph.D, Mary Washington College, Department of Psychology, 1301 College Avenue, Fredericksburg, VA 22401. E-mail:mliss@mwc.edu

\section{TECHENTIN \& D. VOYER. THE EFFECT OF COLOR ON THE LATERALIZATION OF SPATIAL FREQUENCY.}

The current study investigated the effect of color and spatial frequency on visual field advantage in a discrimination task. Thirty-eight undergraduate students completed a lateralized task involving 4 different color combinations (red/green, blue/red, yellow/white, and black/white) in two different frequencies (high and low). Participants were presented with a central square wave bar grating followed by a second grating in either the right or left visual field. They were then required to indicate whether the gratings were the same or different by pressing one of two designated computer keys. Accuracy data showed an interaction between sex, color and visual field, reflecting a significant right visual field advantage in males for the blue/red and the yellow/white conditions whereas females showed a significant left visual field advantage in the yellow/white condition. A significant interaction between sex, color and type of response (same, different) emphasized the complex interplay between these factors. Results are discussed within the context of the Total Information theory.

Correspondence: Cheryl Techentin, B. Sc., Psychology, University of New Brunswick, Bag Service \#45444, Fredericton, NB E3B 6E4, Canada. E-mail:Cheryl.Techentin@unb.ca

\section{S. YOON. RELATIONSHIPS BETWEEN COGNITIVE STYLES AND BEHAVIORAL/ COGNITIVE INHIBITION: AN EVENT-RELATED POTENTIAL STUDY.}

The aim of this study was to investigate the relationships between $\operatorname{cog}$ nitive styles and the behavioral/cognitive inhibitions, and to determine whether cognitive style differences are revealed in ERP activities. Nine healthy subjects ( 3 males, 6 females) with a mean age of 25.25 years ( $\mathrm{SD}=2.34)$ participated. The Korean version of Thinking Style Inventory was used to measure cognitive styles. Behavioral inhibition was measured using a Go/Nogo paradigm, and the Stroop paradigm was adopted to assess cognitive inhibition. EEG was recorded at 64 sites. The time windows for N200 (250-350ms) and P300 (350-450ms) for Go/Nogo task, and N400 (400-520ms) for Stroop incongruent task were determined. The associations between amplitude/latency of N200, P300, N400 and Thinking style dimension were analyzed. The results showed that Nogo N200 latency was negatively correlated with legislative/monarchy style, and positively correlated with hierarchy/global style, and Nogo P300 amplitude was negatively correlated with oligarchic style. The Stroop incongruent N400 amplitude was negatively correlated with legislative style, and positively correlated with global style. All of these results indicate the strong relationships between cognitive styles and behavioral/cognitive inhibitions, and these relationships could be reflected in ERP. For example, the relationship between N200 latency and legislative/monarchy style suggests that having creative strategies or focusing on one thing elicits fast behavioral inhibition. In contrast, the positive correlation between N200 latency and hierarchical /global styles (mean slow response) seems to reflect the distribution of attention to several tasks. And the association between N300 amplitude and oligarchic style may indicate the tendency to work on multiple tasks in the service of multiple objectives.

Correspondence: Seon-Ah Yoon, Dr., Neuroscience Research Institute, Seoul National University, Medical Research Center, 3303, Neuroscience Research Institute, Seoul National University, Medical Research Center, Yeon-gun Dong Chong-ro Ku, seoul 110-744, South Korea. E-mail: k880913@neuroimage.snu.ac.kr

\section{Normal Aging}

\section{E. WOO \& M. SCHMITTER-EDGECOMBE. MEMORY PREDIC- TION ACCURACY IN YOUNGER AND OLDER ADULTS.}

Across three experiments, the effects of age and normative information on memory prediction accuracy were examined using a performanceprediction paradigm. In Experiment 1, younger adults $(\mathrm{N}=65)$ and older adults $(\mathrm{N}=65)$ were given an arbitrary midpoint anchor and made global predictions about how they expected to perform on subsequent verbal, visual, and name-face memory tasks. In Experiment 2, the normative information was varied by providing a new group of older adults $(\mathrm{N}=81)$ and younger adults $(\mathrm{N}=81)$ with either a midpoint anchor, an accurate anchor, or no anchor. Participants also made predictions about their performance on a vocabulary task, a task in which older adults typically outperform younger adults. Across both experiments, the older adults were just as accurate as the younger adults in assessing their memory performance abilities. In addition, the anchors generally affected the prediction accuracy of both age groups similarly, and the older adults were able to successfully adjust their predictions in accordance with task demands. In Experiment 3, a subset of the older adults ( $N=31)$ returned for a five-year follow-up to measure longitudinal changes in prediction accuracy. Prediction accuracy in the older adults was found to be just as accurate as it had been five years previously. Overall, the results indicate that older adults do not appear to operate on a negative stereotype of global cognitive decline with age.

Correspondence: Ellen Woo, Washington State University, $225 \mathrm{NW}$ Terre View \#7, Pullman,WA 99163.E-mail: ewoo@wsu.edu 


\section{E. VAKIL, A. STADLER \& L. KOLMAN . THE EFFECT OF AGE ON MOTOR SKILL LEARNING AS DEMONSTRATED BY A MODI- FIED VERSION OF THE SERIAL REACTION TIME (SRT) TASK.}

Little research has been carried out on the effect of age on motor skill learning and the research that has been carried out on this subject has produced inconsistent results. The Serial Reaction Time (SRT) task is frequently used as a skill-learning task. Performance on this task has been found to be spared in patients with amnesia but impaired in patients with Parkinson's disease. In the present study we used a modified version of the task that enables a clear dissociation between two skills learned simultaneously during performance of the task: "reaction-timetask learning" (i.e., mapping the specific response to the specific stimulus position) and "sequence-specific learning" (i.e., implicit learning of the specific sequence in which stimuli were presented). The task was administered to young $(n=22)$ and older $(n=18)$ individuals. Results indicate that although the older group's reaction time was consistently slower than that of the younger group, the groups' learning rate, for both skills, was not reliably different. These results can be interpreted in light of the dissociation between two components of skill learning, baseline performance and learning rate. The finding that the former but not the latter is sensitive to age is consistent with previous research.

Correspondence: Eli Vakil, PhD, Psychology, Bar Ilan University, Ramat Gan, Ramat Gan 52900, Israel.E-mail:vakile@mail.biu.ac.il

\section{DRISCOLL, J. EPP, D.A. HAMILTON \& R.J. SUTHERLAND. TRANSVERSE PATTERNING DISCRIMINATION PROBLEM: CON- FIGURAL LEARNING IN THE YOUNG, MIDDLE-AGED, AND ELD- ERLY HUMANS.}

In 1952, Spence presented a learning problem that cannot be solved by responding to or avoiding a single cue. The transverse patterning discrimination (TPD) problem involves a simultaneous two-choice task using three cues (A, B, \& C). The relations among the cues are: A+vs. B; B+ vs. C-; and C+ vs. A-. Each cue in the set is equally ambiguous. The only way to solve the problem is to learn the relationship between the cues; linear solutions will not be successful. Animal research informs us that TPD success largely depends upon the hippocampal integrity, a finding that has been confirmed in humans with amnesia (Rickard \& Graffman, 1998; Reed \& Squire, 1999). Normal adults, however, have little trouble solving this problem (Astur \& Sutherland, 1998). Given the vulnerability of the hippocampal formation to old age, we set out to evaluate whether TPD success will vary as a function of aging. We tested voung (20-39), middle-aged (40-59), and elderly (60-85) adults. Our findings suggest that young and middle-aged adults have little trouble solving TPD, while the elderly group was significantly impaired. The current results are especially interesting in light of our previous findings suggesting that performance on a spatial hippocampus-dependent task seems to decline linearly across different age-groups: a pattern that is different from our current findings with a nonspatial task (TPD). Correspondence: Ira Driscoll, Psychology and Neuroscience, Canadian Centre for Behavioural Neuroscience, 4401 University Drive, University of Lethbridge, Lethbridge, AB T1K3M4,Canada.E-mail: ira.driscoll@ uleth.ca

\section{R.D. RHODES, D.W. BURKS, G.P. CRUCIAN, B.V. SHENAL, J.B. MIELKE, K.B. WOMACK, A.R. RIESTRA \& K.M. HEILMAN. EXTRAPERSONAL ATTENTION BIAS IN THE CORONAL PLANE.}

Previous research has revealed that normal participants demonstrate a bias toward extrapersonal space when they attempt to bisect radial or vertical lines. Both radial and vertical line bisections, however, take place in the midsagittal plane. The purpose of this study was to learn if there is also a bias toward extrapersonal space in the coronal plane (horizontal lines). Normal participants ( 6 women, 5 men, mean age $=68$ ) bisected horizontal lines (intersection of the coronal and transverse planes) that were positioned in different trials either to the right (RS) or left (LS) of midline and participants used either their left (LH) or right hands (RH). There were 12 trials for each of these 4 conditions (RHLS, RH-RS, LH-LS, LH-RS). Overall, we found that participants had a bias toward extrapersonal space, such that independent of hand, when the line was in left space participants deviated to the left and when the line was in right space participants deviated to the right. Vision, unlike touch, is a tele-receptor and these results suggest that in the visual modality, independent of the viewer-centered plane, normal participants have an attention bias toward extrapersonal space.

Correspondence: Robert D. Rhodes, Neurology, University of Florida, McKnight Brain Institute, 100 S. Newell Drive, Gainesville, FL 326100236.E-mail: rhodes@neurology.ufl.edu

\section{R. HOLTZER, B.C. RAKITIN \& Y. STERN. USING INDIVIDUAL DIFFERENCES ON NEUROPSYCHOLOGICAL TESTS TO PRE- DICT AGE-RELATED DUAL-TASK COSTS .}

The negative effect of old age on dual-task performance has been reported in previous research but reasons for this finding remain controversial. The current study took a different approach to addressing this issue. We examined whether individual differences on empirically derived neuropsychological factors can shed light on why dual-task performance decreases as a function of old age. Methods: Participants were 16 young (mean age $=21.2$ ) and 16 old (mean age $=74.3$ ) healthy individuals. The two groups were comparable in education, estimated IQ, current cognitive status, and gender distribution. Measures: A computerized delayed visual recognition task (DVRT) was run in single and dual-task conditions. Neuropsychological tests battery covered a range of cognitive functions. Results: Neuropsvchological tests scores from the young and old participants were simultaneously submitted to a factor analysis that vielded two factors (attention/executive, memory) that differed by age and two that did not (motor speed, cognitive status). Significant age differences were noted on chronometric and discrimination indices of the DVRT in the single and dual-task conditions. Moreover age-related dual-task costs were disproportionate to group differences in the single task. Regression analyses revealed that the neuropsychological factors were significant predictors of age-related performance differences on the DVRT (predicting 52 to 71 percent of the variance) but the relation varied with task condition. The memory and motor speed factors were the strongest predictors of single task performance but the attention/executive factor was the most important predictor of dual-task performance. Conclusion: compromised central executive may underlie the effect of aging on dual-task performance.

Correspondence: Roee Holtzer, Ph.D., Columbia University, 630 West 168th Street, P\&S Box 16, New York, NY 10032.E-mail: rh2034@ columbia.edu

\section{T. MCAULEY, M. YAP, S.E. CHRIST \& D.A. WHITE. AGE-RE- LATED CHANGES IN INHIBITORY CONTROL ACROSS THE LIFE-SPAN.}

Age-related changes in inhibitory control occur during both childhood and older adulthood and have been associated with alterations in prefrontal function. Traditionally, inhibitory control has been measured using reaction time (RT) tasks. The statistical approach conventionally used to analyze such data has relied on means and standard deviations. Although this conventional approach has provided valuable insights, RT data may be examined at a finer level of detail. Using an ex-Gaussian approach. the shape of an entire RT distribution may be characterized using three parameters: $\mathrm{Mu}$, the mean of the normal component; Sigma the standard deviation of the normal component: and Tau, the mean and standard deviation of the exponential component. In this study, exGaussian analysis was used to reexamine RT data (Christ et al., 2001) from an inhibitory control task. Participants (age 6 to 84 years) comprised three groups: children $(n=37)$, young adults $(n=43)$, and older adults $(n=33)$. Older adults differed from young adults in terms of mu, sigma, and tau. For children, mu and tau were comparable to those of young adults; sigma, however, was different. Thus, changes in inhibitory 
control in older adults were due to slower, more variable, and more extreme responding. Conversely, changes in inhibitory control in children were due only to more variable responding. These findings suggest that different mechanisms underlie age-related changes in inhibitory control during different epochs of the life-span.

Correspondence: Tara McAuley, B. Sc, Psychology, Washington University, Campus Box 1125, St. Louis, MO 63130.E-mail: tmcauley@ artsci.wustl.edu

\section{POTVIN \& I. ROULEAU. THE INTERACTION BETWEEN EX- ECUTIVE DEFICITS AND THE AGE-RELATED COGNITIVE SLOWING.}

It is well established that there is a slowing of processing speed with aging. Salthouse's initial observation of this slowing reported in 1988 has since been extended and it is now generally accepted that task-specific factors such as task difficulty, similarity and novelty influence the general slowing observed (see McDowd \& Shaw for a review, 1999). Considering the executive deficits related to the structural modifications in the frontal lobes during normal aging (West, 1996), we hypothesized that the general cognitive slowing would be exacerbated in executive tasks. We administered several executive and visual-perceptual tasks to 22 young participants (mean age $=26$ ) and 48 healthy elderly participants (mean age $=72$ ). Statistical analysis revealed a main effect of age for all tasks as well as significant interactions between age and the level of executive skills required for the tasks. Slowing was more pronounced on tests involving a higher level of executive skills such as Trail B and Complex Mazes. The effect was even more pronounced when the complexity level was systematically increased. Elderly participants also committed more errors on executive tasks in comparison to visual-perceptual tasks which mobilize less executive skills (Trail A, Cancellation Task, Visual Discrimination). The number of errors was similar in both groups on visuo-perceptual tests. Therefore, our study appears to support the hypothesis that the age-related cognitive slowing is both generalized and task-specific. The general slowing is indeed accentuated on high level executive tasks.

Correspondence: Isabelle Rouleau, Ph.D., psychology, UQAM, CP 8888, Succ. centre-ville, Montréal, QC HЗC 3P8, Canada. E-mail: rouleau. isabelle@uqam.ca

\section{J. SUHR. COGNITIVE CORRELATES OF ODOR DISCRMINATION PERFORMANCE IN OLDER ADULTS .}

Odor discrimination deficits are associated with disorders causing frontal lobe dysfunction, including head injury, schizophrenia, attention deficit hyperactivity disorder, obsessive compulsive disorder, and Alzheimer's disease $(\mathrm{AD})$, and odor discrimination tests have been suggested as an early screening device for AD. Studies in schizophrenia and attention deficit disorder suggest that odor discrimination skill correlates with performance on measures of executive functioning, such as the WCST, SCWT, and working memory tasks. There is little data available, however, on the relation between odor discrimination and various cognitive skills in older adults, particularly in the context of screening for dementia. In the present study, the relation of odor identification skill to cognitive performance on the Dementia Rating Scale (DRS) was examined in a sample of 28 older adults (50-81 years old, mean college educated, 8 male) seen for a cognitive screen at baseline and again at 1year follow-up. Individuals with smoking history, chronic sinus problems, or other peripheral nasal impairments were excluded from analyses $(\mathrm{n}=3)$. Performance on the Alberta Smell Test at follow-up was significantly associated with Time 1 performance on the DRS conceptualization subtest $(r=.41, p<.05)$, Time 2 DRS conceptualization subtest $(r=.62$. $\mathrm{p}<.001)$, DRS total score at time $2(\mathrm{r}=.52, \mathrm{p}<.01)$, and change in conceptualization performance over time $(\mathrm{r}=-.40, \mathrm{p}<.05)$, but not other DRS subtests. Results support the idea that odor discrimination is associated with frontal lobe functioning, and lend support to the use of odor discrimination tests in cognitive screening of older adults.
Correspondence: Julie Suhr, Ph.D., Psychology, Ohio University, 200 Porter Hall, Athens, OH 45701.E-mail:suhr@ohio.edu

\section{T. HUH, J. KRAMER, A. GAZZALEY \& D. DELIS. RESPONSE BIAS AND AGING ON A RECOGNITION MEMORY TASK.}

Response bias is a measure that reflects the decision rule an individual might make when faced with uncertainty on recognition memory tasks and is thought to be distinct from recognition discrimination. Recent studies indicate that frontal regions may mediate response bias. Exploring response bias as a function of aging may provide important clues toward understanding the neurocognitive effects of aging on memory performance. Methods: 356 participants from the California Verbal Learning Test, second edition, normative sample participated in this study. We examined their performance on the CVLT-2 delayed yes-no recognition task. We used parametric measures of discriminability and response bias provided by the CVLT- 2 scoring program. There were 244 younger participants (age 20-59) and 112 older participants (75+). Groups were similar in IQ (mean $=102.8$ ) and ses. Multi-level regression models were created to examine the effects of moderating variables. Results: Discriminability was a significant predictor for response bias in the older group $(p=.017)$ and explained $5.5 \%$ of the variance to response bias. Age was also a significant predictor $(p=.027)$, which contributed $3.7 \%$ but not IQ or gender in the older group. In the younger group discriminability provided the only significant variance $(\mathrm{p}<.001)$. There were no other predictors in the younger group. Conclusions: Older individuals seem to become more liberal with their responses as they get older in making their decision on a recognition task. The frontal regions are considered to be affected early in the aging process and may be contributing to changes in response bias performance in older populations.

Correspondence: Terri Huh, MA, Psychiatry, University of CaliforniaSan Francisco, 401 Parnassus Ave., CPT, San Francisco, CA 94143. Email:thuh@itsa.ucsf.edu

\section{E.K. HODGES \& R.D. WHITMAN. THE RELATIONSHIP BE- TWEEN NEUROPSYCHOLOGICAL FUNCTIONING AND FUNC- TIONAL STATUS IN OLDER ADULTS.}

The frontal lobe theory of aging proposes that aging selectively disrupts structural and functional integrity of the frontal lobes in older adults. Neuropsychological investigations have shown that on tasks sensitive to frontal lobe functioning, older adults perform less well than younger adults. What is less clear is how the relationship between aging and frontal lobe functioning affects older adults' ADL and IADL abilities. The present investigation examined the predictive ability of baseline neuropsychological performance in a group of community-dwelling older adults' prospective ADL and IADL abilities. Results showed that baseline neuropsychological factor scores did not predict patients' subjective ratings of their current ADL and IADL skills, but did predict informant ratings of patients' current ADL and IADL abilities. Patients' baseline executive functioning and visuospatial functioning predicted informant ratings of patients' current ADL skills, and patients' baseline memory, executive functioning and visuospatial functioning predicted informant ratings of patients' IADL skills. The results also showed that patients' current perceptions of their ADL and IADL skills were somewhat predictive of their perceptions of social support and global life satisfaction. Patients' baseline neuropsychological performance and informants' perceptions regarding patients' ADL and IADL skills were predictive of informants' perceptions of social support and life satisfaction. The findings from this study provided mixed support for the frontal aging hypothesis in this group of community dwelling older adults and also showed that patients' neuropsychological performance was predictive of informant ratings of ADL and IADL skills. 
Correspondence: Elise K. Hodges, Ph.D, Psychiatry, University of Michigan,815 North Melborn, Dearborn, MI 48128.E-mail: ekhodges@ umich.edu
S. VAN HOOREN, M. VAN BOXTEL, S. VALENTIJN, H. BOSMA, TIONING ON HEALTH-RELATED QUALITY OF LIFE IN OLD AGE.

In neuropsychological assessments, it is often assumed that cognitive functioning is more or less directly related to the functional status and the quality of life. Neuropsychologists are often asked to evaluate the extent to which the cognitive capacity of a patient precludes independent living and adversely affects the quality of life. Few studies have investigated this association. The present study explored whether several cognitive domains, such as memory, executive functioning, and speed of information processing are related to health-related quality of life in a large population sample of healthy adults aged 60 years and older $(n=485)$ derived from the Maastricht Aging study. Data from the baseline (1993-1995), the 3-year follow-up phase and the 6-year follow-up phase were examined. Five neuropsychological tests were used to evaluate cognitive function. Health-related quality of life was measured using the SF-36, a self-administered 36-item questionnaire. After adjustment for age, sex, and educational level, results indicated that high cognitive functioning was associated with better scores on all eight scales of the SF-36. Longitudinal analysis revealed that cognitive functioning was not related to health-related quality of life. These findings support the notion that cognitive performance can influence health-related quality of life at the moment of testing. However, cognitive functioning is not a predictor of quality of life 3 or 6 years later. The strong cross-sectional association provides evidence that in clinical settings specific cognitive tests may be used for making judgements about people's quality of life.

Correspondence: Susan Van Hooren, Psychiatry and Neuropsychology, Maastricht University, P.O. box 616, Maastricht 6200MD, Netherlands. E-mail:s.vanhooren@np.unimaas.nl

\section{C.A. MUNRO, D.J. SCHRETLEN, P. RIVKIN, L. LU \& G. PEARL- SON. CORRELATES OF WHITE MATTER HYPERINTENSITY VOL- UME IN PHYSICALLY HEALTHY ADULTS.}

A number of studies have explored the correlates of white-matter hyperintensities (WMH) among elderly subjects. Such investigations of healthy individuals across the adult-age spectrum however, have not been reported. We examined a community sample of 139 physically healthy adults (age range $20-92$ ), using quantitative measures of WMH volume. Analyses revealed no relation between WMH volume and education, APOE genotype, Geriatric Depression Scale score, or Mini Mental State Examination score. Furthermore, men and women did not differ in volume of WMH. After controlling for age, significant correlations were revealed between WMH volume and number correct on the Brief Test of Attention (BTA), seconds to complete the Grooved Pegboard Test, ratings of functional ability, and Quantified Neurological Exam (QNE) score. However, cognitive measures assessing naming, fluency, memory, visuo-constructional abilities, and set-shifting were not related to WMH volume. Because previous researchers have suggested that these relations might be strongest among those with low education, we divided our sample into those with $\leq 12$ years vs. $>12$ years of education. Results did not change in the less educated group, whereas among those with more education, only the BTA and the QNE remained significantly related to $\mathrm{WMH}$ volume. These findings indicate that although the majority of tests did not reveal significant consequences of WMH in physically healthy adults, aggregate volume is nevertheless related to poorer auditory divided attention and motor functioning. Furthermore, these correlates of WMH are perhaps more pronounced among those with less education.
Correspondence: Cynthia A. Munro, Ph.D., Psychiatry and Behavioral Sciences, Johns Hopkins University, 600 N. Wolfe St., Meyer 218, Baltimore, MD 21287-7218. E-mail: cmunro@jhmi.edu
C.E. GLEASON, K.D. SETCHELL, A. SLATTERY, T. OHRT, S. MEADE, C. CARLSSON \& S. ASTHANA. NEUROCOGNITIVE BENEFITS OF SOY ISOFLAVONES.

This on-going investigation examines the cognitive effects of soy isoflavones in healthy older adults. There is abundant evidence suggesting estrogen's neuroprotective and neuromodulatory effects; however, findings from the Women's Health Initiative have raised concerns over the feasibility of traditional hormone replacement therapy (HRT). Investigations of the neurocognitive effects soy isoflavones, a potential alternative to HRT, offer intriguing but preliminary support for isoflavones' beneficial actions on cognition (memory and executive functions in particular.) This on-going investigation evaluates the effects of isoflavones on cognition in older adults. It is hypothesized that isoflavone supplements will ameliorate age-associated cognitive declines for healthy older adults (i.e., decrease rate of decline, stabilize or enhance cognitive abilities), when compared to subjects on placebo. Methods: Eight of a planned thirty cognitively healthy older adults have been enrolled in this randomized, placebo-controlled, double-blind, parallel-group design clinical pilot study. Subjects received $100 \mathrm{mg} /$ day of soy isoflavones or a placebo for 6 months. Cognitive evaluations, assessing memory and executive functioning in particular are conducted at Baseline and at months 1, 3 and 6 post-initiation of study medications. Results: In this small group subjects, those receiving $100 \mathrm{mg}$ of soy isoflavones demonstrated significant improvement on a spatial memory test compared to subjects receiving placebo $(t[3]=-5.5, p=.01)$. Nonsignificant improvements were noted on tests of verbal memory, selective and divided attention, and planning for individuals receiving active medication. The placebo group remained stable or declined on these measures. These pilot data suggest a potential cognitive benefit associated with soy isoflavones treatment for cognitively healthy older adults.

Correspondence: Carey E. Gleason, PhD, Department of Medicine, University of Wisconsin, 2500 Overlook Terrace, Madison VA GRECC (11G), Madison,WI 53705.E-mail:ceg@medicine.wisc.edu

\section{L.J. BEGLINGER, O. TANGPHAO-DANIELS, L. ZHANG, E.R. SIEMERS, R. MOHS \& D.A. KAREKEN. NEUROPSYCHOLOGICAL TEST PERFORMANCE IN HEALTHY ELDERLY VOLUNTEERS BEFORE AND AFTER DONEPEZIL AD- MINISTRATION: A RANDOMIZED CONTROLLED STUDY.}

Healthy volunteers are often utilized in Phase I studies to explore safety and dosing, but this early investigational stage in new drug development also permits exploration of additional domains, such as cognition, in healthy adults prior to use in patients. Neuropsychological performance was examined in elderly healthy volunteers administered the cholinesterase inhibitor, donepezil. Of principal interest was the sensitivity of neuropsychological measures to detect cognitive changes after drug administration using typical Phase I research parameters (small sample over a short treatment period). In this double-blind, parallel study over a period of 6 weeks, 26 healthy elderly adults aged 55-75 years $(\mathrm{M}=65.4, \mathrm{SD}=5.7)$ were randomized into two arms: (14 donepezil, 12 placebo) and completed 14 days of donepezil $(5 \mathrm{mg}$, bid) or placebo. Means on cognitive screening instruments were within the average range (WRAT-3 Reading=94.5, SD=4; MMSE=27.9, SD=2.1). A battery of neuropsychological tests and the CANTAB were administered on Days 0, 14 (pre-randomization), 28 (end of treatment), and 42 (wash-out). After 2 weeks of donepezil, subjects performed significantly worse on Trails B ( $p=0.02)$ and Delayed Match to Sample $(p=0.03)$ compared to 
placebo. No improvement in performance was present on any test after donepezil. These results replicate a previous study in healthy young adults in which a transient mild worsening on similar tests was observed after donepezil. The negative findings may reflect perturbation of an already optimized cholinergic system in healthy adults.

Correspondence: Leigh J. Beglinger, Ph.D., Neurology, Indiana University School of Medicine,, AL. E-mail: lbegling@iupui.edu

\section{J.B. MIELKE, G.P. CRUCIAN, B. SHENAL, R. RHODES, D. BURKS, K. WOMACK, M. KODSI, G. GHACIBEH, J. SHENKER, E. VALENSTEIN \& K.M. HEILMAN. EFFECTS OF DONEPEZIL ON SEMANTIC PROCESSING AND VERBAL MEM- ORY IN HEALTHY ELDER ADULTS. .}

The purpose of this preliminary study was to evaluate the effects of donepezil (Aricept), a cholinesterase inhibitor on verbal memory performance in healthy elder adults. Participants included three females and three males with a mean age of 68.5 years. The study was conducted as a double-blind placebo controlled design. The repeated measures memory task involved computer administration of a levels of processing task with shallow (consonant counting) versus deep (pleasantness rating) levels of processing. The task was administered initially for baseline performance and again after six weeks on medication/placebo. It was hypothesized that participants given donepezil would perform better on a verbal memory task than participants given a placebo. There was no statistically significant difference in memory performance between the two groups on baseline administration of the levels of processing test, but participants given donepezil $(n=4)$ perform better overall on verbal memory tasks than those given a placebo $(\mathrm{n}=2)$. Specifically, the benefits of donepezil on memory function were statistically significant for delayed recall of words presented at a deep level of processing $(p=.03)$, suggesting activation of semantic networks. There was, however, no evidence of cholinergic augmentation of words processed at a shallow level. These preliminary findings suggest that in healthy elder adults donepezil may enhance the performance of semantic networks, improving memory.

Correspondence: Jeannine B. Mielke, PhD, Neurology, University of Florida, 100 S. Newell Dr., Rm L3-100, Gainesville, FL 32610. E-mail: mielke@neurology.ufl.edu

\section{M.C. CARLSON, J. ZHOU, Q. XUE \& L.P. FRIED. RATES OFTRAN- SITIONTO IMPAIRMENT ACROSS DOMAINS OF COGNITION.}

Cognitive declines are progressive and incipient, and often represent a transitional stage between normal brain aging and dementia. Defining the onset and nature of such impairment will help to identify high-risk individuals and provide insight into developing targeted preventive interventions. However, little is known about patterns of onset of impairment across domains of cognition prior to the onset of dementia. Because normal aging is often accompanied by selective deterioration of frontal lobe functions, we hypothesized that clinical declines in executive function would precede declines in memory, which in turn, would precede declines in mental speed. In a cohort of 340 initially high-functioning older women, we sought to identify rates of transition to clinical impairment (i.e., 5 th percentile of performance) across cognitive domains (executive function, mental speed, and memory) over a 6-year interval using two discrete-time modeling approaches to model time to event. The observed survival curve, depicted in the figure, suggested that the risk of onset of impairment was highest for executive function, as represented by impairment on the Trail Making Test, Part B. The risk of impairment was lowest for mental speed, as measured by the Trail Making Test, Part A. The risk of onset of memory impairment, represented by the Hopkins Verbal Learning Test Immediate and Delayed Recall, was intermediate. The order of transitions to cognitive impairment across domains is consistent with our hypothesis that impairment in executive functions precede onset of impairments in memory.
Correspondence: Michelle C. Carlson, PhD, Center on Aging and Health, Johns Hopkins University, 2024 E. Monument St., Suite 2-700, Baltimore, MD 21205.E-mail: mcarlson@jhsph.edu

\section{J. SUHR, J. HALL, S. PATTERSON \& R. TONG-NIINISTRO. HYDRATION STATUS AND COGNITIVE PERFORMANCE IN HEALTHY OLDER ADULTS.}

Although much is known about the effects of significant dehydration on cognition, little is known about the effects of mild dehydration, especially in older adults, who may be more vulnerable to both dehydration and cognitive impairment. We examined whether hydration status $(\% \mathrm{TBW} / \mathrm{kg})$ was related to cognitive functioning in 31 relatively healthy older adults living independently in the community (age 50-82 years, mean 62.9, average college educated, range $11-20$ years). We hypothesized that psychomotor speed and memory would be related to hydration status. TBW was measured by bioimpedance. Cognition was assessed using the Repeatable Battery for the Assessment of Neuropsychological Status, the Grooved Pegboard Test, and the Trailmaking Test. Hydration status ranged from 34 to $58 \%$ TBW/wt. Hydration status was not related to age or education. Males $(n=8)$ were more hydrated than females. In the whole sample, hydration status was related to psychomotor speed $(\mathrm{r}$ values $=-.27$ to $-.31, \mathrm{p}$ values $<.10$ to $<.05)$ and to aspects of attention and memory processing ( $\mathrm{r}$ values $=.23$ to .29 , $\mathrm{p}$ values $<.01$ to $<.05)$ and visuospatial skills $(\mathrm{r}=.33, \mathrm{p}<.05)$. In just the females, there were strong and significant relationships between hydration status and psychomotor speed ( $\mathrm{r}$ values $=-.35$ to -.50 , all $\mathrm{p}<.05)$, attention $(\mathrm{r}=.51, \mathrm{p}<.05)$, and immediate memory $(\mathrm{r}=$ $.35, \mathrm{p}<.05)$, with less strong relationship to visuospatial skills $(\mathrm{r}=.23)$. Results suggest even mild dehydration can be related to psychomotor efficiency and immediate memory in older adults.

Correspondence: Julie Suhr, Ph.D., Psychology, Ohio University, 200 Porter Hall, Athens, OH 45701.E-mail:suhr@ohio.edu

\section{N.L. DENBURG, E.C. RECKNOR, D. TRANEL \& A. BECHARA. PSYCHOPHYSIOLOGICAL CORRELATES OF IMPAIRED DECI- SION-MAKING IN OLDER ADULTS. .}

Previous studies have demonstrated that aging has an adverse effect on laboratory decision-making (Iowa Gambling Task) in some older adults, and such findings have important implications for real-world reasoning and judgment. Emotion, and its accompanying somatic responses, are thought to contribute significantly to decision-making. Electrodermal activity, specifically skin conductance response (SCR), has been used with the Gambling Task as a dependent measure of somatic state activation. The focus of this study was on "anticipatory SCRs" that participants produce in the short time period immediately prior to their behavioral response, i.e., the time period during which they are pondering their choice and decision. We hypothesized that participants with Gambling Task impairments would show a lack of discriminatory anticipatory SCRs during playing of the Gambling Task. We compared anticipatory SCRs for advantageous vs. disadvantageous choices in a group of healthy older adults with Gambling Task impairments (Older-Impaired) and in a group of well-matched non-impaired older adults (OlderUnimpaired). Using paired-samples t-tests, we found that the OlderUnimpaired participants demonstrated the predicted difference in anticipatory SCRs for advantageous vs. disadvantageous choices while the Older-Impaired participants did not show such discrimination. Our data suggest that poor decision-making performance in the Older-Impaired group may arise from a weak somatic response generated in anticipation of a future event; that is, findings reminiscent of those observed in patients with ventromedial prefrontal lobe dysfunction. The findings could have important clinical implications for potential screening or identification of older adults who may be at risk for making poor real-world decisions. 
Correspondence: Natalie L. Denburg, Ph.D., Department of Neurology, University of Iowa, \#2155 RCP, UIHC, 200 Hawkins Drive, Iowa City, IA 52242-1053.E-mail: natalie-denburg@uiowa.edu

\section{Paper Session 3/9:00-11:00 a.m.}

\section{Neuropsychological Functioning in Mid- Life and Late-Life Depression}

\section{C.C. BALDERSTON, G.D. PEARLSON, G. DEUTSCH \& P. . MOBERG. OLFACTORY, VERBAL AND FIGURAL RECOGNITION MEMORY IN PATIENTS WITH MAJOR DEPRESSION.}

Limbic regions of the brain that are responsible for the processing of olfactory information are also thought to be important for the regulation of emotion. While the literature examining odor identification in patients with depression has been mixed, there has been no investigation of odor memory in this patient group and how it relates to other domains of recognition memory. Olfactory, verbal and figural recognition memory were measured in 29 patients with major depressive disorder (MDD) with melancholia (11 men, 18 women) and 29 healthy controls (10 men, 19 women) using a test of odor recognition memory and measures of verbal and figural recognition memory matched for response characteristics. Two measures of memory performance were computed for each subject on the three recognition tasks: 1) Discrimination Index $(\mathrm{Pr})$ and, 2) Bias Index (Br). Raw $\mathrm{Pr}$ and $\mathrm{Br}$ scores were rescaled to Zscores. Patients demonstrated an overall deficit in recognition memory performance across all modalities relative to controls $(\mathrm{F}[1,54]=46.1$, $\mathrm{p}<.001)$. No differential impairment in accuracy $(\mathrm{Pr})$ was observed among the different recognition memory measures. While verbal and figural Pr scores were significantly correlated with each other in patients. odor recognition memory appeared to be unrelated to these other modalities. In patients, only odor memory scores were significantly related to mood ratings $(r=.47, p=.009)$. Response bias of the MDD group did not differ from that of controls with both groups responding slightly liberally on olfactory recognition and conservatively on the verbal and figural recognition tests. Taken together, these data demonstrate that significant impairment in all types of recognition memory exists in MDD patients, but that odor memory measures may be more sensitive to alterations in mood in this patient group. The underlying anatomic and physiologic mechanisms for these deficits warrant further attention. Correspondence: Catherine C. Balderston, M.S., Psychiatry, University of Pennsylvania, 3400 Spruce St., 10 Gates/HUP, Philadelphia, PA 19104.E-mail: cbalders@bbl.med.upenn.edu

\section{S.A. LANGENECKER, L.A. BIELIAUSKAS, L.J. RAPPORT, J. ZU- BIETA, E.A. WILDE \& S. BERENT. EMOTION PROCESSING AND EXECUTIVE FUNCTIONING DEFICITS IN DEPRESSION.}

Frontal, limbic and temporal regions of the brain are known to be important in emotion perception and executive functioning. These same brain regions have been implicated in the etiology and maintenance of depression. Yet the relationship between functioning of these regions, these cognitive functions, and depressive illness is poorly understood. The present study evaluated emotion perception using the Facial Emotion Perception Test (FEPT) and executive functioning using the conditional Go/No-go test (cGNG) between 21 depressed women and 19 nondepressed women controls. The groups did not differ in age, education, verbal and visual learning and memory, motor dexterity, or accuracy on a multiple target continuous performance task. The depressed women, however, performed significantly worse than control subjects in emotion perception accuracy and in inhibitory control, an aspect of executive functioning. Analysis of errors on the FEPT suggest that de- pressed individuals are less likely than control subjects to misclassify a facial expression as happy $(\mathrm{Z}=-2.21, \mathrm{p}<.03)$ and more likely to make no response at all $(\mathrm{Z}=-2.78, \mathrm{p}<.01)$. Performance on the emotion perception task was negatively correlated with core depressive symptoms $(\mathrm{r}(18)=-.38, \mathrm{p}<.12)$. Notably, the correlation between inhibitory performance FEPT accuracy was not significant $(r=.08, p>.7)$ The present findings suggest that emotion perception and executive functioning are disproportionately negatively affected relative to other cognitive functions, even in a high-functioning group of moderately depressed women. The implications of these cognitive findings in relation to functional neuroanatomical foci of interest are discussed.

Correspondence: Scott A. Langenecker, Ph.D., Psychiatry, University of Michigan Health Systems, C480 Med Inn Building, 1500 E. Medical Center Drive, Ann Arbor, MI 48109. E-mail: slangen@umich.edu

\section{MORA, E.R. TORRES, R.R. FIROOZABADI, E. DIAMOND \& R.M. BOWLER. EFFECTS OF DEPRESSION AND ANXIETY ON MOTOR FUNCTION.}

This study examines the relationship between depression, anxiety and motor function among skilled blue-collar workers from the Southern U.S. exposed to different organic solvents and other chemicals at chemical plant for an average of 22.63 years. It was hypothesized that higher levels of depression and anxiety would be associated with decreased motor performance. This is re-analysis of data from a previously published study of workers (Bowler et al., 2001). Mean age of the 667 participants was 55.7 years, with a Mean 12.15 years of education. There were $38.7 \%$ African Americans, $61.3 \%$ White; and of those tested $89.7 \%$ were male. Scores on the mood tests indicate that $36.96 \%$ have clinical levels of depression and $70.81 \%$ had anxiety. Measures of depression and anxiety included: BDI, BAI, BSI and POMS. Psychomotor functioning was assessed with Grooved Pegboard, Finger Tapping, Cancellation H, Trails A and Dynamometer tests. Higher levels of anxiety and depression was associated with lower motor speed, grip strength and tactile function. Partial correlations adjusted for age, education and ethnicity when appropriate, revealing significant $(\mathrm{p}<.05)$ correlations for POMS tension with Dynamometer and Grooved Pegboard; POMS depression with Dynamometer and Grooved Pegboard; BSI anxiety with Grooved Pegboard; BDI and BSI with Dynamometer and Grooved Pegboard. Although correlations between the mood tests with Cancellation H, Trails A and Finger Tapping are of lower magnitude these results were statistically significant, ranging from -0.189 to +0.147 . This study supports past research indicating increased levels of depression and anxiety are associated with decreased motor performance.

Correspondence: Rosemarie M. Bowler, Ph.D., Psychology, S.F.State Univ, 8371 Kent Drive, El Cerrito, CA 94530.E-mail: rbowl@sfsu.edu

\section{BASSO, C. GHORMLEY, N. LOWERY, R. PURDIE, J. NEEL \& D. COMBS. NEUROPSYCHOLOGICAL IMPAIRMENT PREDICTS FUNCTIONAL OUTCOMES IN MAJOR DEPRESSION.}

Previous research indicates that major depression (MDD) is associated with impaired self-care and vocational status. However, factors that contribute to functional impairment are poorly understood. In this regard, accumulating evidence indicates MDD corresponds with significant neuropsychological impairment. Possibly, neurocognitive deficits may contribute to diminished functional outcomes. Towards this end, 36 depressed inpatients, and 24 control individuals were administered Vocabulary and Block Design from the WAIS-III, Trailmaking Tests A and B, Ruff figural fluency, COWAT, CVLT, logical memory, faces, digit span, spatial span, and letter number sequencing from the WMS-III, JLO, Grooved Pegboard, MMPI-2, Endicott Work Performance Scale, and the SF-36. Number of performances falling 1.5 SD below the normative mean on the cognitive measures comprised an impairment index, and sum of the MMPI-2 clinical scales provided an emotional distress index. Together with age and education, these index scores served 
as independent variables in multiple regression analyses. Financial dependence, employment and disability status served as categorical dependent variables, as did SF-36 ratings. Neuropsychological impairment predicted poor employment performance and functional impairment ratings across most SF-36 scale scores. Additionally, neuropsychological impairment predicted financial dependence on others, unemployment, and whether the patient received a mental illness disability, with semi-partial correlations ranging from .4-.7. Emotional distress, indexed via MMPI-2 scores, failed to account for meaningful variance in work or functional outcomes. These findings indicate that neuropsychological deficits predict functional impairment and work status in MDD, and this occurs independently of emotional distress. Theoretical and clinical implications of these findings are discussed.

Correspondence: Michael Basso, Ph.D., Psychology, University of Tulsa, 600 South College Avenue,Tulsa, OK 74104.E-mail: michael-basso@ utulsa.edu

\section{C.O. GHORMLEY \& M.R. BASSO. THE EFFECT OF NEUROPSY- CHOLOGICAL IMPAIRMENT ON THE ABILITY TO PROVIDE IN- FORMED CONSENT IN DEPRESSED INPATIENTS.}

Research has demonstrated that mentally ill individuals often experience alterations in cognitive functioning, which can affect decision-making capacity (Appelbaum \& Grisso, 1995). As such, cognitively impaired patients may be unable to provide competent consent to research or treatment participation (Appelbaum \& Grisso, 1998). Specifically. deficits in executive function, attention, and memory seem to contribute to such incapacity (e.g., Marson et al., 1999). Because these functions are commonly impaired in major depressive disorder (MDD), MDD patients may be incapable of providing informed consent. Several studies have examined the capacity of depressed individuals to provide informed consent, however, most have included individuals being treated on an outpatient basis and found no difference between depressed outpatients and controls in their ability to provide consent. The present study expands on this research and examines the decisional capacity of depressed inpatients given that this group is more likely to experience cognitive impairment. In the present study, 31 MDD inpatients and 27 control subjects were given the digit span subtest, CVLT-II, and WCST. Participants' ability to understand information presented during informed consent was measured using the Understanding Treatment Disclosures Scale (UTD, Appelbaum \& Grisso, 1995). Compared to controls and unimpaired patients, cognitively impaired MDD inpatients were less able to understand the fictional informed consent vignette $(p<.05)$. Nonetheless, understanding of the fictional vignettes was significantly enhanced with cueing $(p<.05)$. These data indicate that neurobehavioral deficits can diminish the ability of MDD inpatients to provide valid informed consent, but their ability to do so may be remediated with cueing. Furthermore, the CVLT-2 was determined to be the best predictor of the ability to provide valid informed consent.

Correspondence: Courtney O. Ghormley, M.A., Psychology, University of Tulsa,6 Athena Ct., Little Rock,AR 72227.E-mail: courtney-ghormley@ utulsa.edu

\section{G.G. POTTER, J.D. KITTINGER, H.R. WAGNER \& D.C. STEF- FENS. PREFRONTAL NEUROPSYCHOLOGICAL PREDICTORS OF TREATMENT RESPONSE IN GERIATRIC DEPRESSION.}

Recent studies suggest that neurocognitive functions of the prefrontal cortex, particularly the dorsolateral region, are associated with treatment response in geriatric depression. To further explore this issue, we studied the neurocognitive performance of 153 depressed individuals aged 60 and over who are participating in an ongoing treatment study. Participants were clinically depressed at entry to the study as rated by the Montgomery-Asberg Depression Rating Scale (MADRS > 15), at which time they also completed a comprehensive neuropsychological battery that included measures of memory, language, visuospatial processing, and executive/prefrontal functions. A geriatric psychiatrist treat- ing the patient using a standardized protocol evaluated the patient at baseline and three-month follow-up, completing a MADRS at both visits. Using logistic discriminative procedures to predict depression remission at 3 months while controlling for age, gender, education, ethnicity, and baseline MADRS severity, we found Digit Span forward and the number of perseverative responses during verbal initiation tasks to significantly predict remission status (MADRS $<7$ ). The current findings are consistent with previous studies suggesting a relationship between prefrontal neurocognitive function and treatment response in depression, but appear to include simple attention in addition to "higher order" executive functions. Neuroanatomically, the current results appear to implicate ventrolateral as well as dorsolateral prefrontal cortex and subcortical pathways.

Correspondence: Guy G. Potter, Ph.D., Psychiatry and Behavioral Sciences, Duke University Medical Center, Box 3925, Duke University Medical Center, Durham, NC 27710-3925.E-mail: gop@duke.edu

\section{ELDERKIN-THOMPSON, N. BINESH, J. MINTZ, E. HAROON, J.J. DUNKIN \& A. KUMAR. BRAIN METABOLITES AND COGNI- TIVE FUNCTION AMONG OLDER DEPRESSED INDIVIDUALS EXAMINED WITH 2H MR SPECTROSCOPY.}

Brain metabolites of Choline (Ch) and myo-Inisotol (MI) are elevated among geriatric depressed patients. Previous studies have reported inconsistent associations between $\mathrm{Ch}$ and cognitive function, but the one dimensional MR spectroscopy estimates of Ch included choline-containing compounds of phosphoethanolamine (Pe) and phosphocholine (PCh) as well as Ch. Two dimensional MRS (2H MRS) can estimate the individual resonances of $\mathrm{PE}, \mathrm{PCh}$, and Ch together with those of MI and creatine (Cr). In this cross-sectional study, 14 geriatric depressed patients and 14 healthy controls, comparable in age, gender, education, comorbid medical burden and MMSE scores, completed 2H MRS and a neurocognitive battery. A voxel in the left dorsolateral cortex, which was approximately $60 \%$ white matter, was used to estimate ratios of $\mathrm{Ch} / \mathrm{Cr}, \mathrm{Pe} / \mathrm{Cr}, \mathrm{PCh} / \mathrm{Cr}$ and MI/Cr. Composite scores for cognitive function were developed for verbal learning, recall, recognition, executive function, working memory, hypothesis generation and processing speed. Controls showed strong positive correlations between $\mathrm{Ch} / \mathrm{Cr}$ and five of the seven cognitive domains and between MI/Cr and four domains. $\mathrm{PCh} / \mathrm{Cr}$ had inverse associations with another three domains. $\mathrm{Pe} / \mathrm{Cr}$ had a positive association with one domain, processing speed. In contrast, depressed patients showed no relationships between either $\mathrm{Ch} / \mathrm{Cr}$ or $\mathrm{Pe} / \mathrm{Cr}$ and cognition. MI/Cr was inversely related to processing speed; $\mathrm{PCh} / \mathrm{Cr}$ was inversely related to the verbal executive domain. In summary, higher levels of $\mathrm{Ch} / \mathrm{Cr}$ and MI/Cr and lower levels of $\mathrm{PCh} / \mathrm{Cr}$ were associated with higher overall cognitive function among healthy elders. Among depressed patients, the metabolites showed no clear pattern of associations with cognitive function.

Correspondence: Virginia Elderkin-Thompson, Ph.D., Geriatric Psychiatry, UCLA, 760 Westwood Plaza, Rm. C8-688, UCLA Neuropsychiatric Research Institute, Los Angeles, CA 90024-1759. E-mail: velderkin@mednet.ucla.edu

\section{N.S. FOLDI, A.M. BRICKMAN, M.E. KNUTELSKA \& L.A. SCHAE- FER. SERIAL POSITION PROFILES DISTINGUISH DEPRESSION FROM NORMAL AGING AND ALZHEIMER'S DISEASE.}

Geriatric depression is associated with cognitive deficits that share similar features with Alzheimer's disease (AD) and normal aging. This study examined serial position profiles on the California Verbal Learning Test (CVLT) in patients with geriatric depression (DEP, $\mathrm{N}=20), \mathrm{AD}(\mathrm{N}=32)$ and age-matched controls ( $\mathrm{NC}, \mathrm{N}=18)$ using conventional standard scores and newly devised regional scores. Regional scores were the percentage of items recalled from the possible number of items presented in each of the three list regions. Differences between DEP and NC groups were shown with regional scores during learning trials: while both groups showed U-shaped serial position functions, regional scores from the mid- 
dle region were significantly lower in DEP than NC $(p<.01)$; primacy and recency regional scores did not differ between groups. Moreover, unlike NC, regional scores from the middle region in DEP were significantly lower than either primacy or recency regions. The recall pattern in DEP (primacy>recency) was inverse to that of the characteristic pattern seen in AD (recency>primacy). On both short- and long-term delay, overall recall was lower in DEP than $\mathrm{NC}(\mathrm{p}=.01)$; both groups showed similar patterns with greatest vulnerability in the recency region. As expected, AD showed the greatest decay over time. The study showed that these measures can be used to differentiate geriatric depression from normal aging. Deficits in recall from the middle region may reflect the impaired attentional resources or working memory in geriatric depression. Results are also discussed in terms of the role of consolidation of items from these regions over time.

Correspondence: Nancy S. Foldi, Ph.D., Department of Psychology, Queens College - CUNY, 65-30 Kissena Blvd., NSB E318, Flushing, NY 11367.E-mail:nsfoldi@qc.edu

\section{Paper Session 4/9:00-11:00 a.m.}

\section{Dementia Risk: Neuropsychological and Neurofunctional Factors}

\section{G.M. PEAVY, D.P. SALMON, A.N. SEPP, P.J. MILLS, T.L. PAT- TERSON \& D. GALASKO. CHRONIC STRESS, BEHAVIORAL CHARACTERISTICS, AND MEMORY LOSS IN SUBJECTS WITH MILD COGNITIVE IMPAIRMENT.}

Neuropathologic changes associated with Alzheimer's Disease (AD) begin in brain regions known to be crucial for memory (i.e., hippocampus and surrounding areas) and can lead to a pre-clinical condition of relatively circumscribed amnesia known as Mild Cognitive Impairment (MCI). Chronic psychological stress promotes the release of glucocorticoids that cause neuron and synapse loss in the hippocampus, and could accelerate memory loss in individuals with MCI. In order to understand relationships among measures of psychological stress (Life Events and Difficulties Schedule / Psychiatric Epidemiology Research Interview (LEDS/PERI)), physiological stress (salivary cortisol), anxiety (StateTrait Anxiety Scale), depression (Geriatric Depression Inventory), and memory (California Verbal Learning Test; CVLT), we tested 10 MCI subjects (mean age $=77.7$ years). The High stress group (LEDS rating) did not differ from the Low stress group on level of depression $(p=.75)$ but acknowledged significantly more anxiety $(p=.04)$. There was a trend $(p<.09)$ for the High stress group to produce higher levels of cortisol. Cortisol levels were significantly correlated with the number of stressful negative events (PERI) (Spearman rho $=.80 ; p=.03$ ), but not with scores on measures of depression or anxiety. Finally, there was a trend for the total number of chronic stressful events to correlate with rate of decline over one year on the CVLT delayed recognition score $($ rho $=.76 ; p=.08)$. These preliminary results suggest that in MCI subjects, chronic psychological stress is positively related to anxiety, physiological stress, and memory decline, but not to depression. These findings could aid in the investigation of the effects of chronic stress on conversion to $\mathrm{AD}$ in older adults who may be in a pre-clinical phase of the disease.

Correspondence: Guerry M. Peavy, PhD, Neurosciences, U. of Calif., San Diego, 8950 Villa La Jolla Dr., Suite C-129, La Jolla, CA 92037. E-mail: gpeavy@ucsd.edu

\section{K. FUCHS \& C. MANNING. DECREASES IN MEMORY AND FLU- ENCY IN WOMEN AT RISK FOR ALZHEIMER'S DISEASE.}

A family history of Alzheimer's disease (AD) is a risk factor for developing the disease. In our Memory Disorders Clinic, daughters of AD pa- tients often present with subjective memory complaints and express concern about their own potential to develop $\mathrm{AD}$. To test the hypothesis that these memory complaints are related to emotional factors rather than objective deficits, we compared middle aged women with a parent with AD to women without a family history of AD on a battery of neuropsychological tests. Results: The groups (at risk $=42$, control $=33$ ) did not differ in age (mean $=51.7$ years), education $($ mean $=15.9$ years $)$, or on indices of general intellectual functioning. The at-risk group performed within normal limits but significantly worse than controls on CVLT-II learning $(\mathrm{p}=.04)$, short delay recall $(\mathrm{p}=.05)$, and long delay recall $(\mathrm{p}$ $=.04)$. Further investigation into learning characteristics indicated that the at-risk group did not utilize an effective learning strategy (semantic clustering, $p=.008$ ). The groups were comparable on a letter fluency task (FAS; $p=.19$ ) but the at risk group performed worse than controls on category fluency $(p=.03)$. Measures of emotional functioning indicated that both groups were relatively free from symptoms of depression, but the at-risk group scored higher on indices of anxiety $(p=.03)$. Further analysis with anxiety as a covariate showed a continuing significant difference between the groups in memory. Conclusions: Our findings of reductions in episodic memory and verbal fluency are similar to other studies assessing at risk individuals prior to the onset of clinical symptoms. The presence of anxiety may account for a difference in fluency but not learning.

Correspondence: Kathleen Fuchs, PhD, Neurology, University of Virginia, PO Box 800394, Charlottesville,VA 22908-0394.E-mail:klf2n@ virginia.edu

\section{R. AU, A. BEISER, S. AUERBACH \& P. WOLF. MCI - MORE THAN JUST MEMORY: FINDINGS FROM THE FRAMINGHAM STUDY.}

Recent research on Mild Cognitive Impairment (MCI) suggests that there are two types, one related to memory and another to executive function, each reflecting different etiologies. The Framingham Study has collected cardiovascular risk factor data on an original cohort of community-based individuals for over 54 years. In 1974-76, we administered neuropsychological tests to 1625 of these subjects and followed them prospectively for 20 years, documenting incident cases of dementia. For this study, we identified from the 1974-76 testing, those subjects who scored 1.5 standard deviations below age and education based norms on one or more cognitive tests and divided these subjects into three groups, those whose cognitive deficits were only in (1) memory (MCIM), (2) executive function (MCI-E) or (3) both (MCI-B). We found that presence of ApoE4 genotype was a significant risk factor for dementia in the MCI-M and MCI-B groups (HR 3.3, $\mathrm{p}=0.026$; HR 2.5, $\mathrm{p}=0.003$, respectively) but not for MCI-E. ApoE had a similar effect on incident AD in both MCI-M and MCI-B (HR 4.1, p=0.005; HR 3.9, p= 0.024 , respectively). Interestingly, lower systolic blood pressure was a significant risk factor for dementia for MCI-E and MCI-B (HR 0.2, $\mathrm{p}=0.025 ;$ HR $0.6 ; \mathrm{p}=0.24$.), but too few cases of $\mathrm{AD}$ in the MCI-E group precluded further analysis. Our results support current models purporting an MCI presumed to be a prodromal stage of $\mathrm{AD}$, and an MCI which is reflective of vascular brain injury, and potential for risk of vascular dementia or mixed dementia.

Correspondence: Rhoda Au, Ph.D., Neurology, Boston University School of Medicine, B608, 716 Albany Street, Boston, MA 02118. E-mail: rhodaau@bu.edu

A. NELSON, R. GEARHART, C. WYSS-CORRAY, J.H. KRAMER \&. B.L. MILLER. PERFORMANCE ON NON-MEMORYTASKS IN MCI. Current diagnostic criteria for Mild Cognitive Impairment (MCI) emphasize the memory components of cognitive functioning, while suggesting that other domains are relatively intact. Significant proportions 
of individuals with MCI, however, progress to multiple-domain impairment. This study examined non-memory cognitive domains in 70 participants with MCI (mean age 76.6 years) and 31 healthy controls (mean age 67.8 years) seen for evaluation at the UCSF Memory and Aging Center. Cognitive variables included language (Boston Naming Test-15 item), visuo-construction (complex figure copy \& cube copy), and executive functioning (letter, category, \& design fluency, modified Trails, backward digit span). MANCOVA was used with age as a covariate, due to the significant difference in age between groups. Significant differences were observed between groups in letter fluency $(p<.05)$, category fluency $(p<.001)$, confrontational naming $(p<.05)$, and a set switching task $(\mathrm{p}<.001)$, with the MCI group mean scores being consistently lower than the control group mean scores. No group differences were observed on visuo-constructional tasks. In conclusion, individuals with MCI appear to show sub-clinical markers of decline in non-memory domains. While the observed group differences in confrontation naming and verbal fluency may relate to an overall semantic memory decline in MCI, the highly significant difference in set switching abilities suggests that these individuals may have unique weaknesses in higher order cognitive tasks.

Correspondence: Adam A. Nelson, M.A., University of California, San Francisco, 8065 N. Poplar \#203, Fresno, CA 93711. E-mail: adamnel@ yahoo.com

\section{B. ALLY, G.E. JONES \& J. COLE. P300 AS A DIAGNOSTIC TOOL IN THOSE WITH ALZHEIMER'S DISEASE AND THEIR FIRST GENERATION BIOLOGICAL OFFSPRING.}

OBJECTIVE: The current study examined whether the amplitudes and latencies of the exogenous P300 event-related potential (ERP) component could correctly identify individuals with Alzheimer's disease (AD), and perhaps be used as a predictive measure in individuals with a significant family history of $\mathrm{AD}$ with no clinical markers, when compared with age and gender-matched controls. P300 has been identified as reflecting cognitive processing-related activities. METHODS: P300 was examined at three locations $(\mathrm{Fz}, \mathrm{Cz}, \& \mathrm{Pz})$ in each of four groups (AD, AD-Control (ADC), Children of AD (CAD), and Children of AD-Control (CADC)). The 20 subjects in each group had ERPs elicited by standard procedure using the auditory oddball paradigm for P300. RESULTS: Alzheimer's disease patients demonstrated significantly smaller P300 amplitudes $(p=.003)$ than did controls. P300 latency was marginally significant $(p=.084)$ from their controls, with the $\mathrm{AD}$ group displaying longer latency times. In addition, the Children of AD group showed significantly smaller P300 amplitudes ( $p=$ $.005)$ and significantly longer peak latency times $(p=.003)$ compared to their controls. CONCLUSIONS: The findings suggest that $80 \%$ of patients with $\mathrm{AD}$ were identifiable through P300. Even more important, the current study demonstrated $55 \%$ of first generation, biological children of those with AD displayed abnormal P300 amplitude and latencies compared to their controls. The current findings are consistent with the hypothesis that P300 represents the activity of multiple neural generators that are differentially disrupted by the Alzheimer's disease process.

Correspondence: Brandon Ally, M.A., Geriatric Research Education and Clinical Center (GRECC), Harvard Medical School / VA Boston Healthcare System, 121 Chestnut St., Brookline, MA 02445. E-mail: brandonally@yahoo.com

\section{S.R. WALDSTEIN, J.R. PELLETIER BROWN, K.J. MAIER \& L.I. KATZEL. DIAGNOSED HYPERTENSION, HIGH BLOOD PRESSURE LEVELS, AND COGNITIVE FUNCTION IN OLDER ADULTS.}

Here we examined potential synergistic effects of diagnosed hypertension and high blood pressure (systolic BP >/= $140 \mathrm{~mm} \mathrm{Hg}$ and/or diastolic BP >/= $90 \mathrm{~mm} \mathrm{Hg}$ ) on cognitive function in 101 healthy, older adults (ages 54-83; 62\% male; 90\% White; $29 \%$ diagnosed hypertension); excluded were dementia, stroke, major medical and psychiatric comorbidities. Participants engaged in tests of attention, memory, mental flexibility, motor speed, and manual dexterity, and clinical assessment of BP. ANCOVAs (age and education as covariates) revealed that persons with high BP performed significantly more poorly than those with normal BP on Visual Reproductions - Immediate and Delayed Recall, Grooved Pegboard tests, and Trail Making B ( $p$ 's $<.05)$. Diagnosed hypertension was related to poorer performance on Grooved Pegboard $(p$ 's $<.05)$. Synergistic and negative effects of diagnosed hypertension and high BP level were noted on Grooved Pegboard and Trail Making A ( $\mathrm{p}$ 's $<.05)$. These results indicate that, in older adults, high BP, diagnosed hypertension, and their interaction negatively impact select tests of nonverbal memory, mental flexibility, motor speed, and manual dexterity. The findings suggest the need for increased attention to preventative efforts with respect to BP assessment and control in older adults.

Correspondence: Shari R. Waldstein, Ph.D., Department of Psychology, University of Maryland, Baltimore County, Department of Psychology, UMBC, 1000 Hilltop Circle, Baltimore, MD 21250.E-mail: waldstei@ umbc.edu

\section{Symposium 4/9:00-11:00 a.m.}

\author{
The DREAMS Project: Risks and \\ Developmental Outcomes in Inner City \\ Preschoolers
}

\author{
Chair: Catherine Jordon \\ Discussant: Jerilynn Radcliffe
}

\section{E.G. SHAPIRO, S.J. HUGHES, B.K. ROCHE, C.M. JORDAN \& J. RADCLIFFE. THE DREAMS PROJECT: RISKS AND DEVELOP- MENTAL OUTCOMES IN INNER CITY PRESCHOOLERS.}

This symposium will present longitudinal data on 281 inner city multi-ethnic children participating in the DREAMS Project (Developmental Research on Early Attention and Memory Skills). This data was collected in the context of a prospective study of the effects of low level lead burden. However, the careful collection of data on a variety of social, environmental, parental, and biomedical variables allowed examination of the relative contributions of these factors to the development of early attention, memory, behavior, and cognition. In this symposium, we will describe the derivation of a novel two-factor model of maternal assets and risk factors. This model, in combination with composite scores of social risk (low SES, single parent, maternal age under 19) and biomedical risk (birth weight, lead levels, zinc protoporphyrin, months of breast feeding), was used to model the developmental trajectories of a subset of child outcomes, including vigilance (early attention) and mental development. Using Hierarchical Linear Modeling (HLM), a model was developed demonstrating the relative contribution of these risk variables to developmental status and rate. Emphasis will be placed on the implications of our findings for prevention and educational and social policy. 
Correspondence: Catherine M. Jordan, PhD, Pediatrics, University of Minnesota, MMC486, 420 Delaware St. Se, Minneapolis, MN 55455. E-mail: jorda003@umn.edu

\section{E.G. SHAPIRO. THE DREAMS PROJECT: OVERVIEW AND SAM- PLE CHARACTERISTICS.}

Living in poverty has negative effects on development. Many variables contribute to this effect but their relative contribution is unknown. The DREAMS Project studied children's development using a community based research (CBR) model that resulted in success in prospectively studying 281 children (155 male, 126 female) recruited from local clinics and through grassroots methods. Children with birth weights under $5 \mathrm{lbs}$, born at $<37$ weeks (except twins) and those with pregnancy/birth/medical complications were excluded. Children had 14 visits from 8 to 48 months during which cognitive, attention, memory and behavioral measures were obtained. Blood lead levels (BL), zinc protoporphyrin $(\mathrm{ZP})$, and hemoglobin $(\mathrm{Hg})$ were checked every 4 months. Two home visits included measurement of home environment, demographics, medical history, psychopathology and parenting style. Maternal IQ was also assessed. Tests were administered by trained community residents matched to mother's ethnicity. Sample description: $29 \%$ were single mothers living alone and $26 \%$ were single living with family of origin; $65 \%$ were of lowest SES and $85 \%$ were on welfare. Of the children, 33\% were African American, 20\% Native American, 27\% Caucasian, $3 \%$ Latino, and $18 \%$ multi-racial. Of the mothers, $25 \%$ were not high school graduates, $8.5 \%$ were $<19$ years at the child's birth, $26 \%$ had more than five persons living in the household. Home Observation for Measurement of the Environment scores were quite good $(z$ $=+.67)$ probably due to same ethnicity raters. Mean distress index on the Brief Symptom Inventory was T score of 57 and mother's mean Raven IQ was 85 . At 24 months mean BL was 5 micrograms/dl, $14 \%$ had a $\mathrm{ZP}$ over 40, and the mean $\mathrm{Hg}$ was 11.3. Overall, this sample represents a low SES, diverse community, with increased social and biomedical risks, though healthy at birth. In the presentations that follow we ask the question of how these risk factors affect mental and attentional development.

Correspondence: Elsa G. Shapiro, PhD, Pediatrics, University Of Minnesota, MMC 486, 420 Delaware St., Minneapolis, MN 55455. E-mail: shapi004@umn.edu

\section{S.J. HUGHES. DEVELOPMENT OF A TWO FACTOR MODEL OF PARENT ATTRIBUTES.}

Research examining the developmental effects of single variables typically requires the measurement and statistical control of confounding parental dispositional or behavioral attributes believed to contribute to developmental outcome. The DREAMS Project design included an unusually large number of parent attribute variables, and analysis of our dataset necessitated a reduction in the number of these variables. Through factor analysis, we reduced the number of maternal variables to two orthogonal factors, which we named Assets and Distress. Variables loading on the Assets factor included maternal Raven Progressive Matrices score, total score from the Home Observation for Measurement of the Environment, the Child Abuse Potential Inventory (CAPI) Rigidity Scale (reversed) and demographic variables of maternal age and maternal education. The Distress factor consisted of the Brief Symptom Inventory (BSI) Global Severity Index and the CAPI Distress scale score. An experimental scale from the CAPI, Ego Strength (reversed), also loaded on the Distress scale. Classification of participants based on factor configurations has been shown to predict cognitive development in children, and even lead exposure risk status. These results suggest that the model may be useful in capturing at least some important variance associated with parental risk status. Additional information will be presented on an expansion to the model currently under development, which we have tentatively named Warmth and Acceptance. It is believed that this model will be useful in research assessing a variety of developmental outcomes.

Correspondence: Steven J. Hughes, PhD, Pediatrics, University of Minnesota, MMC 486, 420 Delaware St. SE, Minneapolis, MN 55455. Email:hughe029@umn.edu

\section{B.K. ROCHE. RELATIVE CONTRIBUTIONS OF MATERNAL, SO- CIOENVIRONMENTAL, AND BIOMEDICAL VARIABLES TO INFANT AND YOUNG CHILDREN'S DEVELOPMENTAL TRAJECTORIES.}

Maternal, socioenvironmental, and biomedical predictors of cognitive abilities were studied using the Bayley Scales of Infant Development-II (BSID-II) administered to 116 DREAMS Project participants at 8, 12, 24 , and 36 months to obtain regular measures on the infants' mental development. Most children performed in the average range on the Mental Development Index (MDI). Using MDI raw scores over time, Hierarchical Linear Modeling demonstrated that level of cognitive ability was highest in children who were female, had fewer socioenvironmental risks, and whose mothers had flexible parenting styles and provided quality home environments. The literature suggests strong correlation between home environment and parent intelligence, which raises the issue of how much of children's success is due to home environment and how much is a function of maternal intelligence. The present study demonstrated that both are predictors of positive outcome for children; however, positive parenting style (emotional and verbal responsiveness, acceptance of the child's behavior, flexible expectations), and quality home environment (organization of the physical environment, appropriate play materials, daily opportunities for varied stimulation) facilitated mental development more than did maternal intelligence. These findings have implications for intervention. Although changes in some socioenvironmental risk factors can be accomplished through adult education, job training, raising minimum wage, and state or federal programs for the disadvantaged; interventions focusing on the home environment, flexible parenting styles and training parents in effective ways to stimulate children's cognitive development may have a direct effect on developmental outcome.

Correspondence: Brenda K. Roche, PhD, Montana Family and Juvenile Treatment Courts, MMC 486, 420 Delaware St. SE, Minneapolis, $M N$ 55455.E-mail:bkroche@earthlink.net

\section{C.M. JORDAN. RELATIVE CONTRIBUTIONS OF MATERNAL, SO- CIOENVIRONMENTAL, AND BIOMEDICAL VARIABLES TO THE DEVELOPMENT OF VIGILANCE.}

Maternal, socioenvironmental, and biomedical predictors of attention were studied using the Early Childhood Vigilance Task (ECVT) administered to 213 DREAMS Project participants every six months between 14 and 38 months. The ECVT, a measure of vigilance (anticipatory attention) records gaze during administration of a computerized cartoon in which characters appear and disappear from the screen. Total time spent looking at the screen is the resulting score and has been previously shown to increase with age. Using Hierarchical Linear Modeling, we found that level of vigilance was highest in children who were male, had low biological risk, high Mental Development Index, and whose mothers had higher cognitive abilities, had flexible parenting styles and provided quality home environments. Children of distressed mothers tended to develop vigilance more slowly. Further analyses demonstrated that parenting style and home environment were more predictive of vigilance than maternal intelligence. These findings have implications for early intervention and prevention strategies and social policy change. Early prevention and intervention efforts should focus on parenting style and quality of the home environment, encourage quality prenatal care 
and breastfeeding, and prevent toxin exposure. Distressed parents should receive additional supports in order to facilitate development of vigilance in their children. Plans for community dissemination and application of this data and additional planned analyses of the DREAMS Project data will be discussed.

Correspondence: Catherine M. Jordan, PhD, Pediatrics, University of Minnesota, MMC486, 420 Delaware St. Se, Minneapolis, MN 55455. E-mail:jorda003@umn.edu

Symposium 5/9:00-11:00 a.m.

\section{Advances in the Cognitive Neuropsychology of HIV-1 Infection}

\section{Chair: Steven Paul Woods Discussant: Igor Grant}

\section{S. WOODS. ADVANCES IN THE COGNITIVE NEUROPSYCHOL- OGY OF HIV-1 INFECTION.}

A 1990 National Institute of Mental Health (NIMH) workgroup on neuropsychological research in HIV-1 infection strongly encouraged clinical investigators to use methodologies informed by advances in cognitive psychology. Indeed, hypothesis-driven analyses of component cognitive processes can enhance our understanding of the neuropsychological effects of HIV-1 infection, facilitate clinical diagnosis of HIVassociated neurocognitive disorders, and inform treatment planning. This symposium discusses recent developments in the application of several cognitive neuropsychological principles to the study of HIV-1 disease. In the first paper, Dr. Eileen Martin presents a series of studies that employed cognitive neuropsychological methods to delineate the cognitive effects of HIV-1 infection and substance abuse. Next, Carey et al. demonstrate that inefficient cognitive switching, rather than a degradation of lexical-semantic memory networks, underlies the verbal fluency deficits in HIV-associated neurocognitive disorders. In the third paper, Woods et al. present data on the sensitivity of a novel, action (i.e., verb) fluency task adapted from the neurolinguistics literature to HIV1 disease. In the fourth presentation, Gonzalez et al. discuss the construct validity of several component cognitive process measures (e.g., dyads) derived from the Paced Auditory Serial Addition Test in an HIV1-infected group. Finally, Marcotte et al. present data regarding the application of cognitive neuropsychological principles to the assessment of automobile driving in persons with $\mathrm{HIV}-1$ infection. The discussant (Dr. Igor Grant) critically assesses these studies and comments on the evolving role of cognitive neuropsychology in the research and clinical science of HIV disease.

Correspondence: Steven Paul Woods, Psy.D., HNRC/Psychiatry, UCSD, 150 W. Washington St., 2nd Floor, San Diego, CA 92103. E-mail: spwoods@ucsd.edu

\section{E. MARTIN. CONTRIBUTIONS OF COGNITIVE NEUROPSY- CHOLOGY TO THE STUDY OF HIV-INFECTED DRUG ABUSERS: AN UPDATE.}

Studies of the neuropsychological performance of HIV-infected drug abusers are complicated by nonspecific effects of drug abuse and by multiple comorbid conditions known to affect cognitive functions. These include psychiatric disorders; personality traits such as sensation seeking and impulsivity; and medical complications such as head injury. Consequently the challenge for investigators of neurocognitive aspects of HIV disease in drug abusers has been to develop theory based measures that reliably capture and isolate cognitive effects of a positive HIV serostatus compared with HIV-seronegative drug users. The use of $\operatorname{cog}_{-}$ nitive neuropsychological measures as well as recent developments in addiction neuroscience have enabled these investigations to move forward. We have employed cognitive neuropsychological measures successfully in a series of programmatic studies of neurocognitive function in HIV+ compared with HIV- crack cocaine and heroin addicts. These studies have addressed components of attention, working memory, and additional cognitive functions associated with prefrontal-subcortical networks, which are common substrates for neurocognitive dysfunction in addiction and in HIV disease. This presentation will provide an overview of the rationale for this approach for the study of neurocognition in HIVinfected drug users, present highlights of current research, and describe implications for study of hepatitis C-infected drug abusers and for preliminary fMRI work.

Correspondence: Eileen Martin, PhD, Psychiatry, University of Illinois, 1601 W. Taylor St., M/C 912, Chicago,IL 60612.E-mail: emartin@ psych.uic.edu

C.L. CAREY, S.P. WOODS, J.D. RIPPETH, E. CONOVER, R.K. HEATON, I. GRANT \& T. HNRC GROUP. DIMINISHED VERBAL FLUENCY IS ASSOCIATED WITH INEFFICIENT LEXICAL-SEMANTIC SWITCHING IN HIV-ASSOCIATED NEUROCOGNITIVE DISORDERS.

Verbal fluency tasks are generally regarded as being sensitive to frontalbasal ganglia circuit dysfunction such as that associated with HIV infection. Whereas deficits in verbal fluency are consistently reported in HIVassociated neurocognitive disorders (HAND), the component cognitive processes driving these deficits are not known. Accordingly, the present study investigated several qualitative features of two fluency measures (i.e., letter and category fluency) in 25 nondemented individuals with HAND (i.e., persons with subsyndromic neuropsychological impairment or minor cognitive/motor disorder) and 37 demographically comparable healthy controls (HC). For each task, we calculated the total number of correct words, average lexical-semantic cluster size, total number of switches between clusters, and the proportion of error responses (i.e., intrusions and perseverations). The HAND group generated fewer correct words than HC and made significantly fewer switches on both letter $(\mathrm{p}=$ $.03)$ and category fluency $(p=.02)$, but no between-group differences were evident for average cluster size or errors. Receiver-operating characteristic curves revealed that switching accurately classified participants in the HAND and HC groups. These results support the hypothesis that verbal fluency deficits in HAND are associated with inefficient switching between lexical-semantic clusters, rather than a depletion of the lexicalsemantic memory stores themselves. These findings also demonstrate the importance of investigating the qualitative features of neuropsychological test performance, which can elucidate the cognitive mechanisms of impairment and enhance clinical detection of HAND.

Correspondence: Catherine L. Carey, M.S., SDSU/UCSD, 5544 Renaissance Ave - 3, San Diego, CA 92122. E-mail: ccarey@ucsd.edu

\section{S. WOODS, C.L. CAREY, A.I. TROSTER, I. GRANT \& T. HNRC GROUP. ACTION (VERB) FLUENCY IN HIV-1 INFECTION.}

Although HIV-1 infection is associated with cognitive impairment in domains mediated by frontal-basal ganglia circuits, conventional measures of verbal fluency (e.g., category fluency) have shown surprisingly unreliable sensitivity to HIV disease. However, action (verb) fluency a verbal fluency task requiring the spontaneous generation of verbs has not previously been examined in an HIV-infected sample. The action fluency task evolved from literature indicating that object naming is principally mediated by left temporal-parietal networks, whereas verb naming is primarily associated with left frontal-basal ganglia circuits. Consistent with this premise, studies in Parkinson's disease indicate that action fluency is more sensitive to frontal-basal ganglia pathophysiology than lexical and semantic fluency. The present study examined action, letter (f), and category (animals) verbal fluency in 20 healthy 
controls (HC) and 100 persons with HIV-1 infection who were comparable in demographics, handedness, and estimated verbal IQ. The HIV+ group performed significantly worse on action fluency $(p<=.01, d=-$ $.57)$; however, there was no significant difference for animal fluency ( $p$ $>.10$ ) and only a trend for the HIV + group to perform worse on letter fluency $(p=.08)$. Findings indicate that persons infected with HIV-1 experience greatest difficulty in rapidly retrieving verbs from semantic memory, which is consistent with research indicating that HIV-1 disease is associated with deficits in processing speed and retrieval strategies mediated by frontal-basal ganglia circuits. Data also provide further support for the construct validity of action fluency as a putative measure of frontal-basal ganglia circuit functions.

Correspondence: Steven Paul Woods, Psy.D., HNRC/Psychiatry, UCSD, 150 W. Washington St., 2nd Floor, San Diego, CA 92103. E-mail: spwoods@ucsd.edu

R. GONZALEZ, R.K. HEATON, W. MILLER, M.J. TAYLOR, T. JERNIGAN, S.L. ARCHIBALD, M.A. NORMAN, C.L. CAREY, B.C. SCHWEINSBURG, J.D. RIPPETH, S.P. WOODS, D. LAZZARETTO \& I. GRANT. MEASURING HIV AND METHAMPHETAMINE RELATED COGNITIVE IMPAIRMENTS USING MODIFIED SCORING GUIDELINES FOR THE PASAT.

Snyder et al. (1993) presented modified scoring guidelines for the Paced Auditory Serial Addition Test (PASAT) that credit only correct responses immediately preceded by a correct response (i.e., Dyads). Dyads putatively reflect cognitive operations that tax working memory systems, and has been shown superior to Total Correct scores at detecting cognitive impairments in patients with multiple sclerosis. Using data from 500 healthy men and women, we developed demographically corrected normative data for several indexes of PASAT performance based on Dyads. The major measures were intended to differentially assess working memory (Total Dyads) and information processing speed (average percent change in Dyads with increasing stimulus presentation speed; APCID). PASAT performance of a normal control group $(\mathrm{n}=55)$ was compared with results of three demographically similar clinical groups at risk for working memory and processing speed deficits: individuals with HIV infection $(\mathrm{n}=62)$, methamphetamine dependence $(\mathrm{n}=71)$, or both $(\mathrm{n}=$ 59). The group with only HIV infection performed significantly worse than controls on Total Dyads and Total Correct. Both PASAT scores were more sensitive to overall neuropsychological impairment than were two WAIS-III measures of working memory and processing speed. Some participants from the clinical groups underwent structural magnetic resonance brain imaging $(n=63)$ and evidenced modest correlations between frontal gray matter volume and Total Dyads, Total Correct, and APCID scores; the latter of which only correlated with basal ganglia volume. Our findings suggest that Total Dyads and Total Correct are comparable measures that primarily reflect working memory.

Correspondence: Raul Gonzalez, M.S., Psychiatry, University of Illinois, Chicago, Department of Psychiatry (MC 747), 840 South Wood Street, Suite 130 CSB, Chicago, IL 60612.E-mail: rgonzalez@psych. uic.edu

T.D. MARCOTTE, E. ROBERTS, R.K. HEATON, H. BENTLEY, D. LAZZARETTO, S.P. WOODS, I. GRANT \& T. HNRC GROUP. VISUAL ATTENTION AND DRIVING ACCIDENTS IN HIV INFECTION.

The impact of visual attention deficits on "real world" functioning in HIV-infected (HIV+) individuals is not well understood. The Useful Field of View (UFOV), a computerized measure assessing processing speed (PS), divided attention (DA), and selective attention (SA), requires subjects to attend to central objects while remaining vigilant to objects in the periphery. Reduced UFOV has been associated with poor driving performance in the elderly and neurologic populations. The aim of the current study was to determine the relationship between attentional impairments and on-road driving performance within an HIV-infected cohort. Sixty-four subjects ( $43 \mathrm{HIV}+$ and $21 \mathrm{HIV}-$ ), all of whom had driven an automobile in the last year, completed a neuropsychological (NP) battery, the UFOV and a driving history questionnaire. Twenty of the HIV+ participants were NP impaired, as was one HIV- participant. 10 subjects had a total of 19 accidents. Drivers identified as "high risk" by UFOV $(\mathrm{n}=6$, all HIV+) had a significantly higher number of accidents in the prior year, even after adjusting for miles driven $(p=.02)$. Among $\mathrm{HIV}+$ participants, UFOV, NP performance, and the interaction were significant predictors of accidents in the prior year $\left(R^{2}=.45\right)$. NP impaired/UFOV "high risk" subjects had the highest number of accidents. Poor performance on PS and DA were independently associated with recent accident history. These findings suggest that HIV+ individuals with significant impairments in processing speed and divided attention, particularly in the context of other NP dysfunction, may be at increased risk for automobile accidents.

Correspondence: Thomas D. Marcotte, PhD, Psychiatry, Univ. of California, San Diego, HNRC, 150 West Washington, 2nd Floor, San Diego, CA 92103.E-mail:tmarcotte@ucsd.edu

\section{Symposium 6/9:00-11:00 a.m.}

\section{Efficacy of Community-Based Interventions For Traumatic Brain Injury: Evidence From Clinical Trials}

\author{
Chair: Jennie Ponsford \\ Discussant: Catherine Mateer
}

\section{J.L. PONSFORD, K.A. SCHWAB, J.L. PONSFORD, S. DIKMEN, J. PONSFORD \& C.A. MATEER. EFFICACY OF COMMUNITY- BASED INTERVENTIONS FOR TRAUMATIC BRAIN INJURY: EVI- DENCE FROM CLINICAL TRIALS.}

Although the need for post-acute rehabilitation services for traumatically brain-injured (TBI) individuals has been established, debate regarding the optimal model of service delivery continues. These services were traditionally delivered via attendance at a rehabilitation centre. However, it has been argued that many TBI individuals have difficulty generalizing from one setting to another due to executive difficulties, and therapy might be more effective if delivered in settings where tasks are normally performed. This has led to the establishment of community-based models of intervention. There have, however, been few controlled studies evaluating the relative impact of these approaches, their practicality and cost-effectiveness. There has been increasing pressure to decrease costs of rehabilitation, which has reduced length of stay in hospital-based programs and opportunities for follow-up. The potential impact of telephone-based support and/or provision of written information is thus also of interest. In this symposium, results of four controlled studies evaluating different models of post-acute rehabilitation following TBI will be presented. Schwab will compare the impact of inapatient versus limited home-based rehabilitation, with findings suggesting differential benefit as a function of injury severity. Ponsford will examine outcomes following community-based post-acute rehabilitation versus the traditional outpatient model, suggesting that practical constraints may limit client contact time and benefits from community-based care. Dikmen will present findings showing clear benefits of telephone follow-up support after discharge from rehabilitation. Ponsford will present data indicating that provision of an information booklet to patients with mild head injury is effective in reducing reported symptoms and stress three months post-injury. 
Correspondence: Jennie L. Ponsford, PhD, Department of Psychology, Monash University, Wellington Road, Clayton (Melbourne), VIC 3800, Australia.E-mail: jennie.ponsford@med.monash.edu.au
Correspondence: Jennie L. Ponsford, PhD, Department of Psychology, Monash University, 1026 Malvern Road, Armadale, VIC 3143, Australia. E-mail: jennie.ponsford@med.monash.edu.au
K.A. SCHWAB \& D.L. WARDEN. DVBIC:TREATMENT OUT-
COMES BY TBI SEVERITY:THE STUDY OF PATIENT SUBGROUPS. To determine the efficacy of inpatient versus at home rehabilitation for patients with TBI, the Defense and Veterans Brain Injury Center at Walter Reed Army Medical Center conducted a randomized controlled trial of patients with moderate to severe TBI (Salazar et al, 2000, JAMA). One hundred twenty active duty military personnel with TBI were randomized to receive treatment in an inpatient rehabilitation program for two months $(n=67)$ or a limited home rehabilitation program with weekly telephone support from a psychiatric nurse $(n=53)$. There were no overall effects of treatment. The study team carefully considered subset analyses possibilities and decided to conduct an analysis by dichotomized loss of consciousness (LOC $>1$ hour vs. $<1$ hour). Subset analysis revealed two different treatment outcomes depending upon TBI severity. Patients with longer LOC had improved outcomes on the studys primary outcome measure (fit for duty status at one year follow-up) if treated in the inpatient rehabilitation program $(\mathrm{p}=0.05$, Chi-Square), compared to patients treated in the limited home rehabilitation program. Conversely, patients with less severe injuries tended towards better outcomes if treated in the home program (trend, $p=0.13$, Chi-Square). The success of the home treatment program has implications for cost-efficient treatment of patients with less severe TBI. However, the importance of the finding of improved outcome from inpatient rehabilitation for more severely injured patients needs to be emphasized. This study underscores the need to fit correct treatment to the patient to maximally enhance future productivity and quality of life after TBI.

Correspondence: Karen A. Schwab, PhD, Defense and Veterans Brain Injury Center, Walter Reed Army Medical Center, P.O. Box 59181, Washington, DC 20012. E-mail: Karen.Schwab@na.amedd.army.mil

\section{J.L. PONSFORD, H. HARRINGTON \& J.H. OLVER. EFFECTIVENESS OF COMMUNITY-BASED REHABILITATION FOLLOWING TRAUMATIC BRAIN INJURY.}

In recent years there has been a growing trend towards communitybased post-acute rehabilitation for individuals with traumatic brain injury (TBI), as opposed to the traditional centre-based model, based on the premise that they will learn more effectively in settings where they usually have to perform. In the present study, outcomes at two years post-injury in 77 individuals with mod-severe TBI ( $73 \%$ males), treated within the community-team model were compared on measures of ADL, vocational status, and emotional adjustment with those of 77 TBI patients individually matched for gender, age, education, occupation, PTA duration, GCS score and time in inpatient rehabilitation, who had previously attended the hospital for outpatient therapy. There were no significant differences between groups in terms of employment outcomes, independence in personal or domestic ADL or return to leisure interests at two years. However those treated in the community were less likely to be independent in shopping, banking and financial management, showed lower levels of social integration, reported more changes in communicaton, cognition and behaviour and were somewhat more likely to report being depressed. Due to constraints of time and resources imposed by provision of community-based therapy, these patients had received fewer one-on-one sessions of occupational and speech therapy and social work consultation. They had attended the centre for physiotherapy, and physical outcomes remained good. Attendant care costs were lower in the community treatment group. There were no other significant cost differences. Strengths and weaknesses of the community-based model of post-acute rehabilitation will be discussed in light of these findings.

\section{K. BELL, N. TEMKIN, C. BOMBARDIER, P. ESSELMAN, J. DOCTOR, R. FRASER, J. HOFFMAN, J. POWELL, K. JOHN- SON \& S. DIKMEN. THE EFFECT OF TELEPHONE FOLLOW UP ON OUTCOME AFTER TRAUMATIC BRAIN INJURY: A RANDOM- IZED TRIAL.}

Traumatic brain injury can be associated with numerous impairments and disabilities. After inpatient rehabilitation, coverage for psychological and psychosocial problems is limited and the services needed are often fragmented or difficult to find. A series of provider-initiated telephone calls could provide a low-cost means of addressing TBI-related problems as they become relevant. OBJECTIVE: To determine whether a scheduled telephone intervention for survivors of traumatic brain injury (TBI) and their families following inpatient rehabilitation will improve functional outcomes at one year post injury. DESIGN: Two-group randomized, clinical trial. SETTING: Level I Trauma Center PARTICIPANTS: 144 subjects with acute moderate to severe TBI randomly assigned to the telephone intervention $(n=74)$ or treatment-as-usual $(n=70)$ groups at discharge from inpatient rehabilitation. INTERVENTIONS: We contacted the experimental group at scheduled intervals to one year post-injury. Phone contact was made with the survivor and/or caregiver to assist with problem solving, and to provide information, advice, and appropriate referrals. The control group received care as usual. MAIN OUTCOME MEASURES: A composite based on a number of functional, emotional and quality of life measures was used as the primary endpoint. RESULTS: The composite measure shows significantly better outcome in those assigned to the scheduled telephone intervention $(p<.01)$; similar effects are seen on a number of individual measures. CONCLUSIONS: The scheduled telephone intervention for persons with TBI led to better functioning at one-year post injury as compared to those receiving usual care. Telephone follow-up may be an effective, cost-efficient method of delivering care and information to persons with TBI. Correspondence: Sureyya Dikmen, PhD, Rehabilitation Medicine, University of Washington, Box 356490,Seattle,WA 98195.E-mail: dikmen@ u.washington.edu

\section{J.L. PONSFORD, C. WILLMOTT, A. ROTHWELL, P. CAMERON, A. KELLY \& R. NELMS. IMPACT OF EARLY INTERVENTION UPON OUTCOME FOLLOWING MILD HEAD INJURY IN ADULTS .} The impact of mild head injury (MHI) is variable and determinants of outcome remain poorly understood. Results of previous intervention studies have been mixed. This study aimed to evaluate the impact of provision of an information booklet upon outcome measured in terms of reported symptoms, cognitive performance and psychological adjustment three months after mild head injury. Eighty-four adults with MHI (mean age $=26.4$ years, mean education $=11.4$ years $)$ alternately assigned to the Intervention Group, were assessed one week and three months post-injury, and 126 mild TBI adults assigned to the Non-Intervention Control group (mean age $=29.1$ years, mean education $=$ 11.3 years) were seen at three months post-injury only. Participants completed measures of pre-injury psychological adjustment (SCL 90R), concurrent life stresses (Holmes Rahe Survey of Life Events), postconcussion symptoms (PCSC) and tests of IQ, attention, speed of information processing and memory (NART, four-choice reaction time, WAIS-R Digit Span and Digit Symbol subtests, PASAT, SCOLP Speed of Comprehension subtest and the Rey Auditory-Verbal Learning Test). MHI subjects seen at one week were also given an information booklet outlining symptoms associated with mild head injury and suggested coping strategies. Those seen at three months post-injury only did not re- 
ceive this booklet. Results indicated that the MHI Intervention group seen at one week and given the information booklet reported fewer symptoms overall and was significantly less stressed at three months post injury. It would appear that provision of an information booklet reduces anxiety and reporting of ongoing problems following MHI.

Correspondence: Jennie L. Ponsford, PhD, Department of Psychology, Monash University, Wellington Road, Clayton (Melbourne), VIC 3800, Australia.E-mail: jennie.ponsford@med.monash.edu.au

\section{Poster Session 3: Neuropsychological Functioning in Pediatric Disorders/10:15 a.m.-12:15 p.m.}

\section{Traumatic Brain Injury}

\section{M.R. PRASAD, L. EWING-COBBS \& L. KRAMER. GLASGOW COMA SCALE AND OUTCOME IN PRESCHOOLERS WITH TRAU- MATIC BRAIN INJURY.}

The Glasgow Coma Scale is the most commonly used measure of traumatic brain injury severity (Teasdale and Jennett, 1974). Developed initially for adults, we modified the motor and verbal subscales to reflect the developmental abilities of very young children. Serial GCS scores were recorded in a sample of 78 children with moderate to severe accidental or inflicted brain injuries under the age of 72 months. In children treated with sedatives or paralytics, hourly GCS scores were recorded and the best level of response was coded for each 24 hour period. For the purposes of this study, two GCS scores were analyzed: admission and lowest post-resuscitation scores. Children who had a significant decrease in GCS following admission were found on average to decrease 4 points. Those with decreasing GCS scores were found to be significantly younger ( $\mathrm{M}=13$ months of age) than those with no change, have a significantly greater probability of surgery, and to have a significantly greater incidence of infarcts, infratentorial subdural hematomas, and cerebral hemorrhages. Children who had decreasing GCS scores performed significantly lower on measures of cognitive functioning and had worse Glasgow Outcome Scale scores at baseline than those with no change in GCS. These findings indicate the lowest GCS score following hospital admission is a better indicator of injury severity than admission or initial GCS scores. In this sample, a decrease in GCS scores was more often seen in infants, suggesting that initial or admission GCS scores are not appropriate indicators of brain injury severity in infants.

Correspondence: Mary R. Prasad, Ph.D., Pediatrics, University of Texas Medical School-Houston, 7000 Fannin, Suite 2401, Houston, TX 77025. E-mail:mary.r.prasad@uth.tmc.edu

\section{SALORIO, B. SLOMINE, J. CHRISTENSEN \& J. GERRING. THE RELATIONSHIP BETWEEN ACUTE ICU VARIABLES AND OUTCOME AFTER PEDIATRIC TBI.}

Traumatic brain injury (TBI) is a leading cause of death and disability in children. Many studies have documented the neurobehavioral consequences of pediatric TBI. Fewer studies have examined how variables in the acute post-traumatic period predict outcome in children. Hypotension has been linked to poor survival and functional outcome in children after TBI, but the effects of acute hypertension are less certain. Fever during the acute period has also been associated with poorer survival rate and overall global disability outcome. This study examined the relationship of acute variables (blood pressure, temperature) in the first 24 hours after admission to the PICU following moderate-severe TBI to functional and cognitive outcome at one-year post-injury. Subjects included 130 children (ages 4-19) who were consecutively admitted to Kennedy Krieger for rehabilitation after sustaining a TBI. Retrospective chart reviews were performed to obtain blood pressure and temperature variables during the acute period. Children underwent neuropsychological testing at one-year post-injury, and global functional skills were assessed through parent interview. Overall, both high and low blood pressure in the PICU was associated with worse outcome. Higher maximum blood pressure and hypertension, particularly at in the first 6 hours after admission to the PICU, was associated with worse functional outcome and worse memory functioning at time 2 (one year after injury). Hypotension, particularly during the period $12-24$ hours after admission to the PICU, was associated with worse intellectual functioning, and worse memory ability at time 2 . Implications for treatment and further research will be discussed.

Correspondence: Cynthia F. Salorio, Ph.D., Rehabilitation, Kennedy Krieger Institute, 707 North Broadway, Baltimore, MD 21205. E-mail: salorio@kennedykrieger.org.

\section{EWING-COBBS, K. HASAN, L. KRAMER, M. PRASAD, P. SWANK \& P. NARAYANA. DIFFUSIONTENSOR MRI AFTER PE- DIATRIC BRAIN INJURY: RELATION TO COGNITIVE OUTCOME.}

Diffusion tensor magnetic resonance imaging (DT-MRI), which assesses self-diffusion of water molecules within tissues, allows quantification of microstructural changes in the integrity of white matter that are undetectable by conventional imaging. DT-MRI measures include fractional anisotropy (FA), which indicates the degree of restriction of diffusion of water molecules within a voxel. Studies examining DT-MRI after TBI in adults reported reduced FA in the internal capsule and corpus callosum. We obtained DT-MRI and measures of executive processing from 4 children with severe TBI and 4 comparison children matched for age, gender, and socioeconomic status. The TBI cases had a mean age at injury of 8.1 years. The mean age at DT-MRI was 12.2 years. FA values of the corpus callosum were obtained from a $3 \times 3$ voxel area of the genu and splenium from the same section in the axial plane. For the 4 TBI cases, there were sizeable correlations between regional callosal FA and the total GCS score. The TBI group had lower FA values than the comparison group in the splenium $(p<.04)$; group differences approached significance for the genu. For the total sample, FA values from the genu and splenium were significantly correlated with measures of speeded performance and working memory but not with an index of inhibitory control. For the TBI group, correlations were strong between FA values and speeded performance. The strong correlation between DT-MRI and cognitive measures is quite promising and suggests that DT-MRI has excellent potential for characterizing brain-behavior relations after TBI.

Correspondence: Linda Ewing-Cobbs, PhD, Pediatrics, University of Texas Health Science Center, 7000 Fannin, Suite 2401, Houston, TX 77030.E-mail: linda.ewing-cobbs@uth.tmc.edu

\section{G.R. HANTEN, S.B. CHAPMAN, J.F. GAMINO, L. ZHANG, S. BENTON, G. ROBERSON \& H. LEVIN . SELECTIVE LEARN- ING IN VERBAL LEARNING AFTER TRAUMATIC BRAIN INJURY IN CHILDREN .}

Selective learning (SL), the ability to preferentially learn items of higher value from among other items of lower value, engages cognitive control which is purportedly mediated by the frontal cortex and its circuitry. Recent evidence suggests that selective learning of verbal information is among the complex cognitive abilities vulnerable to TBI (Hanten et al., 2002) which have important implications for classroom learning and adaptive behavior of children. To extend these findings using methods with ecological validity we used incentive-based auditory word recall and expository discourse tasks to study the efficiency of selective learning in 11 children (ages 6-16 vears) who had sustained severe traumatic brain injury (TBI) at least one year earlier, and 11 age-matched typically developing children. We hypothesized that selective learning but not memory span would be compromised by severe TBI. The results revealed that children with severe TBI performed significantly worse 
than age-matched typically developing children on selective learning efficiency with auditory word lists $\mathrm{F}(1,20)=5.19, \mathrm{p}=0.03$; effect size, $\mathrm{d}=0.97$, with discourse level materials $\mathrm{F}(1,18)=4.53, \mathrm{p}=0.04$, effect size, $d=0.952$. In contrast there were no significant group differences in number of items recalled from auditory word lists or declarative facts. We conclude that severe TBI disrupts incentive-based cognitive control processes. This provides some of the first evidence of a functional disparity between the measures of recall and selective learning. possibly due to involvement of frontal neural networks.

Correspondence: Gerri R. Hanten, Ph.D., Physical Medicine and Rehabilitation, Baylor College of Medicine, 6560 Fannin St., Suite 1144, Houston,TX 77030.E-mail: ghanten@bcm.tmc.edu

\section{J. DONDERS \& M. MINNEMA. PROACTIVE INTERFERENCE ON THE CVLTC AFTER PEDIATRIC TRAUMATIC BRAIN INJURY.}

The performance of 167 children with traumatic brain injury (TBI) on the Child version of the California Verbal Learning Test (CVLTC) was evaluated within one year of injury. The children were selected from an eight-year series of consecutive referrals to a Midwestern rehabilitation hospital. Potential participants with premorbid complicating factors (e.g., learning disability, child abuse) were excluded. A large proactive interference (PI) effect, defined as performance on the second list that was at least 1.5 standard deviations below that on the first list, was statistically significantly more common in this clinical sample $(21 \%)$ than in the CVLTC standardization sample (11\%). Other performance discrepancies, including retroactive interference, rapid forgetting, and retrieval problems, occurred at approximately the same rate in the clinical and standardization samples. Children with anterior cerebral lesions were about three times less likely to have a large PI than children without such lesions, but the former group performed generally worse on all CVLTC variables. It is concluded that failure to release from PI is common, although not universal, in children with TBI. Unlike with adults, anterior cerebral lesions are not selectively associated with an increased risk for PI after pediatric TBI but rather with a generalized reduced efficiency of allocation of learning and memory resources.

Correspondence: Jacobus Donders, PhD, Psychology, Mary Free Bed Hospital, 235 Wealthy, S.E., Grand Rapids, MI 49503.E-mail:jdonders@ mfbrc.com

\section{S.R. MCCAULEY \& H.S. LEVIN. EXTRINSIC MOTIVATION AND PROSPECTIVE MEMORY DEFICITS IN CHILDREN WITH TRAU- MATIC BRAIN INJURY.}

The nature and extent of prospective memory (PM) deficits in children with traumatic brain injury (TBI) is poorly understood. Even less evidence is available concerning effective remediation strategies for PM deficits. This pilot study investigated levels of extrinsic motivation to determine if PM performance could be improved in children with severe TBI. Twenty-four uninjured normal children (age at testing $=11.8$, range 6-17 years) were compared to 21 children with severe TBI (age at testing $=12.1, \mathrm{p}=\mathrm{ns}$, range 6-17 years) who were at least 1 year post-injury. Children were instructed to request a specific number of points following the examiner's verbal cue occurring every 15 minutes during an ongoing test battery. In this crossover design, children were told they would be paid dollars for points earned in the motivated condition and pennies for points in the unmotivated condition. The order of conditions was counterbalanced across subjects. There was no main effect for age. Within-subject analyses indicated that the Control group performed equally well in both conditions $(\mathrm{p}<.34)$, but the TBI group performance improved significantly in the motivated condition $(\mathrm{p}<$ .001). Between-subject analyses suggested that the TBI group performed more poorly than Controls in the unmotivated condition $(p<.008)$, but performed similarly to Controls in the motivated condition $(\mathrm{p}<.34)$. This manipulation appears to significantly improve PM performance in the TBI group suggesting that this group can perform near the level of the Control group with a sufficient extrinsic motivator.
Correspondence: Stephen R. McCauley, Ph.D., Physical Medicine and Rehabilitation, Baylor College of Medicine, 6560 Fannin St., Ste. 1144, Houston, TX 77030.E-mail: mccauley@bcm.tmc.edu

\section{E.R. VRIEZEN \& S. PIGOTT. GENDER DIFFERENCES IN EXEC- UTIVE FUNCTION FOLLOWING PEDIATRIC BRAIN INJURY.}

Recent studies have shown that in children with traumatic brain injury (TBI), girls score significantly better than boys on tests of memory (Donders et al, 2002, 2003) and adaptive function (Papero et al, 1993). To explore whether gender differences exist in executive functioning following pediatric brain injury, 25 boys and 23 girls who had sustained a moderate to severe TBI were compared on tests of executive function. The groups did not differ with respect to initial Glasgow Coma Scale score, age at injury, time since injury, or Full Scale IQ. Several performance-based tests of executive function were administered to the children (Trail Making, Wisconsin Card Sorting Test, Phonemic and Semantic Verbal Fluency); no significant gender differences were observed any on these measures. Parents also completed a questionnaire assessing their observations of their child's executive functioning in the home environment, the Behaviour Rating Inventory of Executive Function (BRIEF). There were no gender differences on the Behavioural Regulation Index of the BRIEF, but girls were rated as having significantly greater difficulties than boys on the Metacognitive Index $(\mathrm{t}=-2.3, \mathrm{p}<$ $.03)$. On each of the individual scales comprising the BRIEF, girls were rated as having greater difficulty than boys, though the difference was statistically significant only on the Working Memory Scale $(t=-2.3, p$ $<.02)$. Thus, in contrast to previous findings of greater difficulties for boys in memory and adaptive function, the current results suggest that girls are perceived as experiencing greater difficulties in some aspects of executive functioning following TBI.

Correspondence: Susan Pigott, LHSC, 339 Windermere Rd, London, ON N6C4C6, Canada. E-mail: pigotts@lhsc.on.ca

\section{M.L. BENJAMIN, S.C. HEATON, E.B. FENNELL \& A. BOWER. PILOT DATA ON THE RELATIONSHIP BETWEEN BRIEF SCALES AND TESTS OF EXECUTIVE FUNCTIONING IN CHILDHOOD TBI. .} Executive dysfunction has been reported in a number of studies of pediatric traumatic brain injury (TBI). The Behavior Rating Inventory of Executive Function (BRIEF) is a relatively new parental questionnaire purported to measure everyday executive function. Initial studies of the BRIEF in pediatric TBI have focused on severe TBI evaluated several years post-injury, and little is known about the relationship between the BRIEF and traditional tests of executive function. Furthermore, previous studies did not explore individual BRIEF scales, but used global composite scores. The current study presents pilot data examining the relationship between ratings on selected individual scales of the BRIEF and performance on traditional tests of executive functioning in an mild and severe pediatric TBI sample within the first year of recovery. Participants consisted of 8 Mild TBI and 11 Moderate/Severe TBI children ages 6-16 who were evaluated within one year of injury as part of a larger research test battery. Correlations were computed between ratings on selected scales from the BRIEF (Inhibit, Shift, Emotional Control) and scores from neuropsychological tests of executive functioning (Stroop, Trails B, WCST, CPT-II Commissions, TEA-Ch Creature Counting and Opposite Worlds). Results failed to find a significant relationship between the BRIEF scales examined and the objective measures of executive function. While group descriptives suggest the severe TBI group scored worse across both BRIEF and traditional tests of executive dysfunction, $t$-tests failed to reveal significant differences between the injury severity groups. Findings are discussed in terms of sample size limitations and possible future directions.

Correspondence: Michelle Benjamin, B.S., University of Florida, 2115 SW39th Way, Gainesville, FL 32607.E-mail:mbenjami@hp.ufl.edu 


\section{RONCADIN, H. TILEY, L. EWING-COBBS, H.S. LEVIN \& M.A. BARNES. MATH SKILLS FOLLOWING CHILDHOOD CLOSED HEAD INJURY.}

Competence in reading and arithmetic is necessary for educational and vocational success. Closed head injury (CHI) in childhood affects the development of literacy, however less is known about whether CHI also affects the development of numeracy. We investigated math performance in children with $\mathrm{CHI}$ (at least 18 months post-injury) in relation to injury severity and age at injury. Performance on two math tests (WJ-R Calculation and Applied Problems) was compared among four injury severity groups matched for age (28 mild; 30 moderate; 29 severe; 28 controls). On the calculation test each error was classified as due to difficulties in math fact retrieval, knowledge of algorithms, or switching and monitoring. There were no group differences in overall performance or types of calculation errors made. By contrast, the severe CHI group performed more poorly than controls on the test of applied math problem solving. The CHI sample was then divided into two age at injury groups (less than age 6 ; age 6 or older) matched for age and injury severity. An older age at injury was associated with poorer calculation ability, but the groups did not differ in applied math problem solving ability. The findings are compatible with the notion that math problem solving involves not only calculation abilities, but also skills such as working memory and executive processes that may be particularly vulnerable after CHI. Results are discussed in terms of the neural underpinnings of math skills and theories of functional recovery and the acquisition of new skills after brain injury.

Correspondence: Caroline Roncadin, Ph.D., Psychology, Hospital for Sick Children, 555 University Ave., Toronto, ON M5G 1X8, Canada. Email: caroline.roncadin@sickkids.ca

D.W. BEEBE, L. ASKINAZI, C. WELLS, S. WADE, H. TAYLOR \& K.O. YEATES. SLEEP DISTURBANCES FOLLOWING MODERATE TO SEVERE PEDIATRIC TRAUMATIC BRAIN INJURY (TBI).

INTRODUCTION: Adult TBI can cause sleep disturbance, but little is known about sleep after pediatric TBI. Outside of TBI, pediatric sleep has been linked to behavior problems and parenting burden. This study examines parent-reported sleep disturbances following pediatric TBI. and whether sleep problems six months post-injury predict later behavior and family burden. METHODS: As part of a larger study. 109 children with moderate to severe TBI were compared to 80 with only orthopedic injuries (OI). Data were collected at baseline (reported preinjury functioning) and at six-month and one-year follow-ups. Seven sleep-related items were abstracted from the Achenbach CBCL. Behavior problems were measured by the CBCL externalizing, attention, anxiety/depression, and school performance subscales. Family burden was measured with the Family Burden of Injury Inventory. RESULTS: MANOVA indicated no differences on the sleep items at baseline, but a trend at six months and a significant difference at one year. Compared to OI, the TBI group was overtired and had trouble sleeping at both postinjury time points, and had nightmares and more sleep than normal at one year. On non-parametric tests, at one year post-injury, the TBI group differed from OI on 4 of 7 items and from norms on 6 of 7 items. TBI was associated with behavior problems and family burden one year postinjury; covarying reported "overtired" and "problems sleeping" at six months shrunk this effect by $43-74 \%$. CONCLUSIONS: Pediatric TBI is associated with post-injury parent-reported sleep problems. Sleep problems at six months predicted later TBI-related behavior problems and family burden.

Correspondence: Dean W. Beebe, Ph.D., Psychology, Cincinnati Children's Hospital Medical Center, 3333 Burnet Avenue, MLC 3015, Cincinnati,OH 45229.E-mail:dean.beebe@cchmc.org

\section{J.M. HEMME, S.A. WARSCHAUSKY, R. SKEEL, L. NIEC \& S. HEATON. COMPARISON OF NEUROPSYCHOLOGICAL AND BEHAVIORAL PROFILES OF CHILDREN WITH TBI AND ADHD.}

This retrospective archival study investigated the similarities and differences in attentional and behavioral profiles of children with history of TBI or ADHD. The neuropsychological correlates of ADHD symptomatology also were examined. The sample consisted of 56 children, ages 6-16 ( $\mathrm{M}=11, \mathrm{SD}=2.9)$, including 24 children who sustained a moderate or severe TBI and 32 diagnosed with ADHD. TBI was sustained at a mean age of 8.7 (4.7) years with evaluations 3.8 (3.7) years postinjury. Groups were similar in terms of age, gender, IQ, race, and SES In addition to the WISC-III, data from the Test of Everyday Attention for Children. Test of Variables of Attention, and Conners Parent Rating Scale- Revised (CPRS-R) were collected as part of a larger clinical test battery. Children with ADHD were rated significantly higher on the Inattentive and Hyperactivity scales of the CPRS-R than children with TBI. Using strict cut off scores from the CPRS-R Symptom Subscales, based on DSM-IV ADHD criteria, $17 \%$ of children with TBI scored in the range suggestive of ADHD. Contrary to predictions, children with TBI and ADHD performed similarly on all cognitive-based measures of attention. Neurobehavioral correlates of attention did not differ between groups. These findings were replicated in an independent study examining group differences in separate ADHD and TBI populations. Results are compared with previous findings that suggest risk for an acquired ADHD following TBI.

Correspondence: Jannel M. Hemme, Masters of Arts, University of Florida, 108 NW 35th Terrace, Gainesville, FL 32607.E-mail: jhemme@ hp.ufl.edu

\section{J.B. KAY, M. VAN TUBBERGEN, J.E. EVANS, J. HEMME \& S. WARSCHAUSKY. ATTENTION AS A PREDICTOR OF VERBAL LEARNING IN CHILDREN WITH TRAUMATIC BRAIN INJURY OR ATTENTION-DEFICIT/HYPERACTIVITY DISORDER.}

Clinical lore posits that children with attentional impairments exhibit a discrepancy between recall of contextual familiar versus discrete verbal information, with poorer performance on the latter due to lower degree of structure. Children diagnosed with Traumatic Brain Injury (TBI) or Attention-Deficit/Hyperactivity Disorder (ADHD) are known to be vulnerable to problems in aspects of attention (Anderson et al, 1998; Seidman et al, 1995). This study examines the predictive power of attentional indices for performance on a verbal list-learning task, while controlling for performance on an auditory verbal narrative memory task. A sample of 56 children, ages $6-16,57 \%$ male with a diagnosis of either moderate/severe TBI or ADHD completed a neuropsychological evaluation including the WISC-III. CMS Stories, CVLT-C, and TEA-Ch. The mean age of the sample was 132.1 months (35.7), with $43 \%$ diagnosed with TBI and $57 \%$ with ADHD. For the TBI group, $71 \%$ were severe. There were no statistically significant sex differences on measures of attention or verbal learning. There were also no significant differences between the TBI group and the ADHD group on measures of verbal learning or attention. Multiple regression with the pooled sample indicated that visual attention explained unique variance in verbal list-learning after controlling for nonverbal intellectual ability and memory for auditory verbal narratives, which were empirically and theoretically derived control variables. Findings support the notion that discrepancies in the recall of contextual versus discrete verbal information may reflect the adverse effects of attention on aspects of learning. Correspondence: Joshua B. Kay, PhD, Physical Medicine \& Rehabilitation, University of Michigan, D4100 MPB, Box 0718, 1500 E. Medical Center Drive, Ann Arbor, MI 48109-0718. E-mail: jbkay@umich.edu

\section{L.K. AYR, K. YEATES \& B.G. ENRILE. COGNITIVE CORRE- LATES OF ARITHMETIC SKILLS IN CONGENITAL AND AC- QUIRED BRAIN DISORDERS.}

Mathematical disabilities occur commonly, but little is known about the cognitive correlates of arithmetic skills, particularly in children with congenital and acquired brain disorders. The literature suggests that 
working memory, explicit memory, processing speed, executive functions, and visuospatial abilities are all involved in arithmetic performance. We examined the cognitive correlates of arithmetic skills in 25 children with myelomeningocele and shunted hydrocephalus (MM), 28 children with severe traumatic brain injury (TBI), and 28 children with orthopedic injury (OI), ranging in age from 8 to 15 years. The groups did not differ in age, gender, or ethnicity, and all children had a WISCIII Verbal Comprehension or Perceptual Organization index score of at least 80. Children in the TBI and OI groups were at least 1 year postinjury. We conducted a regression analysis with the WRAT-3 Arithmetic standard score as the dependent variable. Independent variables were the WISC-III Perceptual-Organization, Processing Speed, and Working Memory Indexes, the Tower of London total score, and an explicit memory score (i.e., mean of the CMS Verbal Immediate and Verbal Delayed composites). After controlling for group membership and age, the five cognitive abilities explained $48 \%$ of the variance in arithmetic skills. Processing speed, working memory, and explicit memory accounted for unique variance. Exploratory analyses showed that executive functions and working memory were stronger predictors in the MM group than in the OI group and that visuospatial skill was a stronger predictor in the TBI group. Multiple cognitive abilities contribute to arithmetic skills, and their importance varies across clinical populations. Correspondence: Keith Yeates, PhD, Psychology, The Ohio State University, Children's Hospital, 700 Children's Dr., Columbus, OH 43205. E-mail:yeatesk@chi.osu.edu

\section{J.E. CASS, K.O. YEATES \& B.G. ENRILE. IQ AND MEMORY PERFORMANCE IN CHILDREN WITH CONGENITAL AND AC- QUIRED BRAIN DISORDER.}

IQ and memory performance was examined in children with myelomeningocele and shunted hydrocephalus (MM), children with severe traumatic brain injuries (TBI), and a comparison group of children with orthopedic injuries (OI). The groups included 22 to 29 children. all from 8 to 15 years of age. The groups did not differ in age, gender, race/ethnicity, or socioeconomic status. All children had Full Scale IQs of at least 70. Children in the TBI group were injured a mean of 2.16 years before the study $(\mathrm{SD}=0.71)$. Participants were administered a short form of the WISC-III and core memory subtests from the Children's Memory Scale (CMS). The groups differed on prorated Full Scale IQ (FSIQ), Perceptual Organization (PO), and Processing Speed (PS) index scores, and on CMS Visual Immediate, Verbal Immediate, and Verbal Delayed composites. The MM group performed more poorly than the OI group on many IQ and memory measures, while the TBI and OI groups differed only on FSIQ and PO scores. We also calculated simple discrepancies between FSIQ and CMS composite scores, as well as discrepancies between predicted and actual CMS composite scores. The MM group exhibited a larger discrepancy between VC and the Verbal Delayed composite than the TBI and OI groups. Contrary to expectations, the groups did not differ in discrepancies between WISC-III index scores (VC-PO, VC-FD, VC-PS), but differed in discrepancies between CMS Delayed composites (Visual Delayed-Verbal Delayed). Descriptive data will be presented comparing FSIQ-CMS discrepancy scores to base rates in the CMS standardization sample.

Correspondence: Jennifer E. Cass, Ph.D., Department of Psychology, Children's Hospital, 700 Children's Dr., Columbus, OH 43205. E-mail: cassj@chi.osu.edu

\section{Maternal and Perinatal Risks and Outcomes in Young Children}

\footnotetext{
R. GRAY, J.A. HAJJ, M.R. DEHOFF, J.M. PITCHFORD \& H. SCHONBACHLER. NEUROPSYCHOLOGICAL CONSEQUENCES OF MALTREATMENT IN AGGRESSIVE CHILDREN .

Child maltreatment has consistently been associated with negative longterm effects, which may include aggression, anxiety/depression, disso-
}

ciation, delinquent behaviors, academic and social problems, and neuropsychological deficits. Many, but not all maltreated children will meet diagnostic criteria for Conduct Disorder (CD) and Oppositional Defiant Disorder (ODD). There is limited research investigating behavioral and neuropsychological characteristics of aggressive children with and without a history of maltreatment. The current study examined neuropsychological variables (IQ, attention, academic achievement) and parent behavioral ratings among children diagnosed with CD and ODD with and without histories of maltreatment. Children with histories of maltreatment demonstrated significantly worse performance on several neuropsychological variables including measures of verbal reasoning, attention and concentration, and executive functioning. These children also demonstrated worse developmental histories, more severe proactive aggression, more severe callous/unemotional behaviors, and greater sexual misconduct. Further analyses of children classified according to severity of maltreatment indicated significant but more subtle neuropsychological and behavioral findings suggesting worse outcomes for those children experiencing high versus low levels of maltreatment. Results support a cumulative risk factors model suggesting that children with disruptive behavior disorders who also experience a history of maltreatment may be at higher risk for worse neuropsychological and behavioral outcomes.

Correspondence: Robert Gray, PhD, Neuropsychology, Kennedy Krieger Institute,1750 E. Fairmount Ave, Baltimore,MD 21231.E-mail:grayr@ kennedykrieger.org

\section{D.L. MOLFESE, A. KEY, L.C. MAYES, E. RATAJCZAK \& N. CUN- NINGHAM. PRENATAL COCAINE EXPOSURE: CHANGES IN EX- ECUTIVE FUNCTIONS IN YOUNG CHILDREN AS MEASURED BY EVENT-RELATED POTENTIALS.}

Due to cocaine's effect on the developing monoaminergic system, prenatal cocaine-exposure may interfere with the ontogeny of prefrontal cortical executive functions. This study presents findings regarding cortical functioning in prenatally cocaine exposed and non-exposed 7 to 9 year old children. Visual event-related potentials (ERPs) were recorded using a 128-channel high-density array while children performed a standard Stroop task. In the Stroop paradigm, prenatally cocaine exposed children generated prolonged ERP responses to the words while the nonexposed children produced briefer responses. Effects are noted in the region of the initial positive peak (P1), the following large negative peak (N1) and the later positive peak (P2). The results suggest that early cocaine exposure may inhibit the specialization and streamlining of brain region involvement during cognitive processing such that task processing is slower to begin, requires more diverse cortical involvement, and requires more time to complete. ERP methodology has considerable potential for studying frontal maturation and may provide additional information to clarify the specific effects of prenatal cocaine exposure on cortical functioning and the developmental course of cognitive functions.

Correspondence: Alexandra Key, Ph.D., Psychological \& Brain Sciences, University of Louisville, 317 Life Sciences Bld, Louisville, KY 40292. Email:a0fona01@athena.louisville.edu

\section{C.E. MORROW, J.L. CULBERTSON, V.H. ACCORNERO, L. XUE, J.C. ANTHONY \& E.S. BANDSTRA. ESTIMATED RISK OF DE- VELOPING A LEARNING DISABILITY BY AGE 7 AMONG PRENA- TALLY COCAINE-EXPOSED CHILDREN.}

OBJECTIVE: To estimate the risk of developing a learning disability (LD) by age seven in prenatally cocaine-exposed children when compared to non-cocaine-exposed children and to evaluate underlying neuropsychological processes related to increased risk. DESIGN/METHODS: Participants included 403 African-American children (207 cocaine-exposed, 196 non-cocaine-exposed) enrolled prospectively at birth in the Miami Prenatal Cocaine Study. Prenatal drug exposure was documented by maternal interview, urine and meconium screens. The 
WISC-III and WIAT were administered at age seven. Ability-Achievement discrepancy scores were calculated using regression-based predicted-achievement methods described in the WIAT manual. Children were categorized as learning disabled in accord with discrepancy score cutoffs $(p<05)$. The generalized linear model (GLM) estimated the cumulative incidence proportion (risk) for development of LD by age seven. RESULTS: Cocaine-exposed children had 2.8 times greater risk of developing a learning disability by age seven than non-cocaine-exposed children $(95 \% \mathrm{CI}=1.05,7.67 ; \mathrm{p}=0.039)$. Estimated risk was $7.3 \%$ for cocaine-exposed children and $2.6 \%$ for non-cocaine-exposed children $($ risk difference $=4.7 \% ; 95 \% \mathrm{CI}=0.01,0.09 ; \mathrm{p}=0.038)$. Estimates were not attenuated with covariate adjustment for age, sex, prenatal exposures to alcohol, marijuana, and tobacco, and child lead levels $($ risk ratio $=3.5 ; 95 \% \mathrm{CI}=1.23,10.24 ; \mathrm{p}=0.019)$. Specific LD categorizations could not be analyzed due to sparse cell counts, although math processing appeared most affected. Additional results on possible underlying neuropsychological processes will be presented. CONCLUSIONS: By age seven, cocaine-exposed children are more likely to qualify as learning disabled than non-cocaine-exposed children. ACKNOWLEDGEMENTS: NIDA R01DA06556; T32 DA 07292; State of Florida Healthy Start Program; Health Foundation of South Florida; Kenneth A. Lattman Foundation.

Correspondence: Connie E. Morrow, PhD, Pediatrics, University of Miami, PO Box 016960 (M808), Miami, FL 33101.E-mail: cmorrow@ med.miami.edu

\section{J. WOZNIAK, P. CHANG \& G.P. MAUREN. NEUROCOGNITIVE DEFICITS IN CHILDREN WITH FETAL ALCOHOL SPECTRUM DISORDER (FASD).}

We report on an ethnically and geographically diverse sample of 323 children, ages 3 to 17, seen in an FASD clinic for comprehensive physical, neurocognitive, and behavioral evaluations. Overall, the sample scored 1.0 to 1.5 SD below normative range on measures of IQ, achievement, visual-perception, executive function, and language. Attention deficits for the sample were in the range of $2.0 \mathrm{SD}$ below normal. $\mathrm{U}_{\mathrm{s}}$ ing Astley \& Clarren's four-point diagnostic system, the sample breakdown was as follows: $10 \%$ Fetal Alcohol Syndrome (FAS), $69 \%$ Fetal Alcohol Effects (FAE), \& 21\% undiagnosed. Analysis of the neurocognitive variables demonstrated that children with FAS performed significantly below the other groups on global cognition, adaptive functioning, and memory. No significant group differences were seen in other domains. Behavioral measures showed that the FAS group had more social and attentional problems than the other two groups. The FAE group was virtually indistinguishable from the "undiagnosed" group on the majority of cognitive and behavioral measures. These results suggest that the distinction between FAS and FAE is useful because it is relevant to neurocognitive and behavioral outcome. The results also indicate that children for whom there is suspicion of exposure but no documentation have the same level of impairment as children with FAE. Thus, the results suggest that a substantial number of these "undiagnosed" children may actually have been exposed to alcohol and suffered from the negative effects. Relevant developmental data and findings related to social variables (abuse, etc.) are also reported and discussed. Correspondence: Jeffrey Wozniak, Ph.D., Psychiatry, University of Minnesota, F256/2B West, 2450 Riverside Ave., Minneapolis, MN 55454. Email:jwozniak@umn.edu

\section{K.T. LEE \& S.N. MATTSON. TASK CHARACTERISTICS AFFECT MEMORY PERFORMANCE IN CHILDREN WITH FETAL ALCO- HOL SPECTRUM DISORDERS.}

Children with fetal alcohol spectrum disorders (FASD) exhibit memory impairments, although recent evidence suggests that these deficits are not global in nature and may reflect underlying deficits in encoding. It has also been proposed that an implicit strategy (e.g., semantic clustering) helps memory performance. In the current study, the effects of task characteristics on memory performance were investigated. Children (9-16 yrs) with FASD ( $\mathrm{N}=38)$ and matched non-exposed controls $(\mathrm{N}=38)$ were administered the Wide Range Assessment of Memory and Learning. Immediate recall performances on single (Story Memory, Finger Windows) vs. multiple-trial tasks (Verbal Learning, Visual Learning) were analyzed by 2 (group) x 2 (domain) x 2 (trial type) repeated measures ANOVA. Children with FASD demonstrated stronger performance on multiple-trial tasks, relative to single-trial tasks, whereas controls demonstrated similar performance on the two types of tasks. When retention for verbal material was examined, a different pattern emerged. Delayed recall performances on two tasks (Story Memory and Verbal Learning) were analyzed, taking into account the amount of information initially recalled. In comparison to controls, children with FASD demonstrated impaired retention on the multiple-trial word list task (Verbal Learning) but spared retention on the single-trial story task (Story Memory). These results support reports of memory deficits and those suggesting the benefits of specific task characteristics in children with FASD. Specifically, repeated exposure to material was related to better encoding and the presence of an implicit strategy (e.g., story context) was related to better retention. Research supported by NIAAA grant AA10820.

Correspondence: Sarah N. Mattson, Ph.D., Psychology, San Diego State University, 6363 Alvarado Court, Suite 209, San Diego, CA 92120. Email:smattson@sunstroke.sdsu.edu

\section{SHUM, M. O'CALLAGHAN, K. NEULINGER \& H. MOHAY. ASSESSMENT OF THREE COMPONENTS OF ATTENTION AND THEIR RELATIONSHIP TO LEARNING AND EXECUTIVE FUNC- TIONS IN CHILDREN BORN PRETERM.}

With advances in medical technology, more babies born preterm survive. However, there is evidence to suggest that many of these preterm babies develop cognitive problems such as attention deficits. We employed neuropsychological tests to assess three components of attention (specifically, attention span, selective/focused attention and divided attention), executive functions and learning ability. Forty-five preterm children (born less than $1000 \mathrm{~g}$ or less than 27 weeks) aged 7-9 were compared with a control group of 49 full-term children matched for gender and age. Results indicated that the preterm group performed significantly lower on tests measuring the three components of attention. as well as executive functions including working memory and cognitive verbal fluency. No differences were found between the groups on measures of inhibition and planning. Further, preterm children were found to be significantly lower on academic achievement measures of reading, spelling and numerical operations. Associations between measures of attention and academic performance were examined, with components of both attention span and selective/focused attention associated with reading, while only attention span was associated with maths and spelling. Overall, results suggest that children born very preterm are at greater risk at exhibiting attentional problems and that these problems may be related to their academic performance, including other higher order functions such as planning and working memory.

Correspondence: David Shum, PhD, Applied Psychology, Griffith University, Mt Gravatt Campus, Brisbane, QLD 4111, Australia. E-mail: D.Shum@griffith.edu.au

\section{K. HOWARD, P. ANDERSON, H. WANG, V. ANDERSON, M. KEANE, M. BEAR \& I. TERRIE. SIGNIFICANCE OF BRAIN INJURY AND ALTERED BRAIN DEVELOPMENT IN PRETERM CHILDREN.}

Very preterm children are known to have higher rates of cognitive, educational and behavioral impairments. To date, several potential predictors of outcome have been identified, including gestation age, birth weight, medical complications, as well as socio-demographic and environmental factors. The impairments exhibited by children born very 
preterm are also likely to be partly related to brain injury (intra-ventricular haemorrhage (IVH), periventricular leukomalacia (PVL)) and alterations in brain development during the neonatal period, however this relationship has not been adequately investigated. The objective of this study was to evaluate the relationship between brain injury, altered brain development and early cognitive development in a sample of 200 very preterm children ( $<32$ weeks of gestation). This paper presents preliminary results from the first series of 40 participants at 24 months of age. Participants were recruited at birth, and at term ( 40 weeks of gestation) underwent neuroimaging utilizing advanced quantitative volumetric 3D-MRI techniques. At 24 months of age participants were administered the Bayley Scales of Infant Development (BSID-II), as well as measures of executive control (Delayed Alternation, Spatial Reversal). The relationships between white matter injury, brain volumes at term (total grey matter (GM), cortical GM, basal ganglia, total white matter (WM), myelinated WM, unmyelinated WM) and cognitive measures at 24 months will be presented. These findings provide an understanding of early brain maturation in children born very preterm, and the functional significance of IVH, PVL, and altered brain development. Correspondence: Kelly Howard, BSc(Hons), Psychology, University of Melbourne, Royal Children, Flemington Rd, Parkville, VIC 3052, Australia.E-mail: howardk@cryptic.rch.unimelb.edu.au

\section{M.L. MOST, W.J. BURNS \& J. VALDES. NEURODEVELOPMENTAL FACTORS AND COGNITIVE ABILI- TIES OF PRETERM INFANTS.}

The purpose of this study was to investigate which neurodevelopmental factors contribute to the wide range of abilities observed in the $\operatorname{cog}$ nitive functioning of premature infants. A sample of 174 premature infants with a mean chronological age of 19.6 months were administered the Mullen Scales of Early Learning. Infant performance that fell at least one standard deviation below the mean was categorized as "deficient." Performance that fell at least one standard deviation above the mean was categorized as "above-average." Lastly, infant performance that fell between these extremes was categorized as "average." The Early Learning Composite (ELC) index provides an overall measure of performance in the areas of visual reception, fine motor, receptive language, and expressive language. Results revealed that two factors significantly influenced performance: one-minute apgar scores and length of hospitalization at the Neonatal Intensive Care Unit. Infants who performed within the deficient range on the ELC had significantly longer lengths of hospitalization than those in the above-average range $\mathrm{F}(2,154=3.37$, $\mathrm{p}<.04)$; as well as lower apgar scores than those in the above-average range, $\mathrm{F}(2,124)=5.70, \mathrm{p}=.004$. With specific regards to Receptive Language, infants who performed within the deficient range had significantly longer lengths of hospitalization than those in the average and above-average range $\mathrm{F}(2,157), 5.37$, $\mathrm{p}=.006$. Infants categorized as deficient also had significantly lower apgar scores than those in average range and above-average range, $F(2,127)=4.87, p=.009$. Findings indicate that perinatal complications can have long term effects on neurodevelopment. Particularly vulnerable is the brain's capacity to develop language appropriately.

Correspondence: Miriam L. Most, M.S., Psychology, Nova Southeastern University, 3301 College Avenue, Fort Lauderdale, FL 33314. Email:miriamlisa@netzero.net

\section{M.D. LAUTERBACH, S. RAZ \& C.J. SANDER. COGNITIVE AND MOTOR OUTCOME IN PRESCHOOLERS WITH HISTORY OF BACTERIAL INFECTION ORIGINATING IN UTERO .}

We examined the association between bacterial infection diagnosed at birth and cognitive or motor outcome in preschoolers. Fifty nine children who had received neonatal intensive care services at birth were recruited. Children in the target group $(n=20)$ had been diagnosed with septicemia within the first week of life based on blood culture $(n=16)$, or clinical course $(n=4)$. Children in the comparison group $(n=19)$ had been diagnosed with suspected sepsis within the first week of life life $(n=13)$, or had history of maternal factors associated with intrauterine infection $(n=6)$. A control group $(n=10)$ with history of minimal perinatal complications was also recruited. Analyses using Mancova (with birthweight, number of complications, and socioeconomic status as covariates) revealed that group affiliation had no effect on motor or cognitive outcome (Wilks' Lambda $=1, \mathrm{~F}[4,78]<1$ for cognitive, and Wilks' Lambda $=.88, \mathrm{~F}[4,66]<1$ for motor skills). However, substituting the ratio of immature to total neutrophils (an index of degree of immune response and exposure to infection) for group affiliation revealed significant associations with fine motor outcome $(\mathrm{F}[1$, $22]=7.74, p<01)$. In sum, our findings suggest that elevated exposure to infection at birth is selectively associated with compromised fine motor control.

Correspondence: Sarah Raz, Ph.D., Merrill Palmer Institute, Wayne State University, Merrill Palmer Institute, 71 E. Ferry St., Detroit, MI 48202.E-mail: sarahraz@wayne.edu

\section{R. NATALE \& N. SHEINBERG. MEASURES OF RISK AND RE- SILIENCY IN AN AT-RISK 0-3 POPULATION.}

The purpose of this study was to assess the cognitive, social, and behavioral development of at-risk infants and toddlers and determine what factors are related to risk and resiliency. Sixty children enrolled in a YWCA childcare center participated in the evaluation. Children were ? months to 36 months of age, African American and received subsidized childcare. The assessment battery consisted of the Mullen Scales of Early Learning (MSEL), Devereux Childhood Assessment (DECA), Parenting Stress Index (PSI), and Maternal Behavior Rating Scales (MBRS) used to assess the quality of maternal interactive behaviors. Demographic data will be presented on the parents and children. Simple correlations revealed statistically significant associations between maternal reports of parenting stress and resiliency and protective factors in their children. Children whose mothers reported high levels of parenting stress on the PSI obtained lower scores on measures of resiliency as measured by the DECA $(r=-.670, p<.01)$. Parents who were more accepting and effective at engaging their children had children who had higher levels of initiative $(r=.593, p<.05)$ and higher overall levels of resiliency $(r=.548$, $\mathrm{p}<.05)$. Higher levels of resiliency were also correlated with higher IQs as measured by the Mullen Scales of Early Learning $(\mathrm{r}=.623, \mathrm{p}<.01)$. Regresssion analyses revealed that stress in the parent-child interaction and visual receptive abilities of the child are the most important variables predicting for overall levels of resilience, accounting for $56.8 \%$ of the variation in resiliency scores as measures by the DECA $(\mathrm{R} 2=.568)$. Based on the above research findings, inferences can be made regarding enhancing resiliency in early intervention settings.

Correspondence: Ruby Natale, Ph.D., Psy.D., Psychology, University of Miami School of Medicine, 861 Cypress Point Drive East, Pembroke Pines, FL 33027.E-mail: rnatale@med.miami.edu

\section{A.C. MAERLENDER, P.K. ISQUITH, R. RACUSIN, A. SENGUPTA \& M. STRAUS. SELF-REGULATION, BEHAVIOR AND EMO- TIONAL FUNCTION IN CHILDREN IN FOSTER CARE.}

Children in foster care are at extremely high risk for psychiatric disorders and poor long-term outcomes (dosReis et al., 2001). While most research focuses on clinical diagnoses and behavior problems, another perspective can be gained by describing their ability to modulate their affective state and the behavioral manifestations of self-regulatory difficulties. Parents of 25 children (16 boys, 9 girls) in long-term foster care now aged 9-18 years $(\mathrm{M}=13.31, \mathrm{SD}=2.84)$ completed the Behavior Rating Inventory of Executive Function (BRIEF), Behavior Assessment System for Children (BASC) and the Childrens Global Assessment Scale (CGAS). Foster children were rated as having significantly $(p<.01)$ greater difficulties on the BRIEF Behavioral Regulation Index including inhibitory control, emotional modulation and flexibility and on the Metacognitive Index including working memory, planning, or- 
ganization, and self-monitoring relative to normative expectation. Clinically significant problems ( $\mathrm{T}$ scores $>65,90$ th percentile) with behavioral regulation were reported for $62 \%$ of foster children, and $73 \%$ were rated as having clinically significant difficulty with metacognitive aspects of self-regulation. Ratings on the BRIEF Behavior Regulation Index were significantly correlated with both internalizing $(\mathrm{r}=.61)$ and externalizing $(\mathrm{r}=.86)$ problems on the BASC and to overall functioning on the CGAS $(r=-.71)$. Metacognitive aspects of executive function were not significantly related to internalizing or externalizing problems or to global functioning. Executive deficits, particularly the more fundamental components of behavioral and emotional regulation, are strongly related to emotional and behavioral difficulties and to global functioning in the everyday environment.

Correspondence: Peter K. Isquith, Ph.D., Department of Psychiatry, Dartmouth Medical School, One Medical Center Drive, Lebanon, NH 03756-0001.E-mail: isquith@dartmouth.edu

\section{Outcomes in Medical Disorders}

\section{S.R. MCCAULEY, K.R. KRULL, P. BROUWERS, K. ADKINS \& B. MUELLER. SENSITIVITY OF THE BEHAVIOR RATING INVEN- TORY OF EXECUTIVE FUNCTION (BRIEF) IN CHILDREN WITH FRONTAL LOBE STROKES RESULTING FROM SICKLE CELL DIS- EASE: PRELIMINARY DATA.}

Children with sickle cell disease (SCD) are at increased risk for ischemic stroke, particularly affecting the distribution of the anterior and middle cerebral arteries. The BRIEF has become popular recently for detecting executive dysfunction in children, particularly those with presumed frontal lobe damage. Its sensitivity in sickle cell disease (SCD) has not yet been investigated. As a preliminary study 9 children with SCD (mean age $=10.0$ ), and MRI confirmed strokes primarily affecting the frontal lobes, were compared to a non-SCD sibling control group $(\mathrm{N}=9$; mean age $=10.2, \mathrm{p}=\mathrm{ns})$. ANOVA of the Global Executive Composite indicated that the SCD children had poorer overall executive functioning $(p<.02)$. MANOVA of the T-scores revealed that SCD children demonstrated poorer functioning on the Behavioral Regulation $(\mathrm{p}<.003)$ and Metacognition $(p<.04)$ indices. MANOVA of the 8 subscale scores indicated impaired functioning of the SCD children on Shift $(p<.001)$, Emotional Control $(p<.0001)$, Initiate $(p<.003)$, Working Memory $(\mathrm{p}<.02)$, Organization of Materials $(\mathrm{p}<.002)$, and Monitor $(\mathrm{p}<.0001)$. A trend was noted for the Plan/Organize and Inhibit subscales (both $\mathrm{p}$ $<.06)$. These preliminary findings suggest that the BRIEF is sensitive to certain types of executive dysfunction in SCD children with frontal lobe strokes.

Correspondence: Stephen R. McCauley, Ph.D., Physical Medicine and Rehabilitation, Baylor College of Medicine, 6560 Fannin St., Ste. 1144, Houston, TX 77030.E-mail:mccauley@bcm.tmc.edu

\section{S.R. MCCAULEY, K.R. KRULL, P. BROUWERS, K. ADKINS \& B. MUELLER. PROSPECTIVE MEMORY DEFICITS IN CHILDREN WITH FRONTAL LOBE STROKES RESULTING FROM SICKLE CELL DISEASE: A PILOT STUDY.}

Prospective memory tasks (remembering to do something in the future) are part of everyday executive activities. Children with sickle cell disease (SCD) are at increased risk for ischemic stroke, particularly affecting the distribution of the anterior and middle cerebral arteries. No studies have yet investigated prospective memory deficits in children with strokes resulting from SCD. Nine children with SCD (mean age = 10.0) and MRI-confirmed strokes predominantly affecting the frontal cortex were compared to a non-SCD sibling control group ( $\mathrm{N}=9$; mean age $=10.2, \mathrm{p}=\mathrm{ns})$. Naturalistic tests of prospective memory $(\mathrm{PM})$ were administered. The child and parent also separately completed a PM questionnaire (PMQ) measuring everyday memory failures (with PM and general forgetting subscales). MANOVA indicated that the children with SCD performed more poorly on tests of time-based PM (performing an action at a specific time; $\mathrm{p}<.005$ ) and event-based PM (performing an action in response to an environmental cue; $p<.01$ ), but there was not a significant difference on a test of activity-based PM (child determines when action is performed; $p<.47$ ). MANOVA of the parent report on the PMQ indicated poorer everyday memory performance for SCD children (PMQ-PM, $p<.01$; PMQ-Forgetting, $\mathrm{p}<.05$ ). The child report on the PMQ also indicated poorer PM performance for SCD children, but not for general forgetting (PMQ-PM, $\mathrm{p}<.04$; PMQ-Forgetting, $\mathrm{p}<.39$ ). These results suggest that poor PM performance can be demonstrated in children with SCD using clinical and everyday measures of PM. Correspondence: Stephen R. McCauley, Ph.D., Physical Medicine and Rehabilitation, Baylor College of Medicine, 6560 Fannin St., Ste. 1144, Houston,TX77030.E-mail:mccauley@bcm.tmc.edu

\section{S. BAVA, A.L. SARAH, T.L. JERNIGAN \& D.A. TRAUNER. QUANTITATIVE MRI ANALYSIS OF CEREBRAL VOLUME IN CHILDREN FOLLOWING EARLY FOCAL BRAIN DAMAGE: NEU- ROLOGIC AND COGNITIVE CORRELATES.}

Studies detailing the cognitive profiles of children with early unilateral brain damage report relatively spared intellectual function regardless of the size or location of the lesion. Volumetric measurement of brain structures in these children may provide more exact information as to whether differences in regional brain volumes are associated with level of cognitive function. We studied seven children ages 2-12 years who had unilateral focal lesions with onset prior to 6 months of age. Whole-brain magnetic resonance images (MRI) were analyzed based on regional volumes of cortical gray matter, total white matter, cortical and ventricular cerebrospinal fluid (CSF), lesion, and lesion fluid. We explored the relationship of these variables with cognitive function and clinical variables. MRI readings revealed two distinct patterns of abnormality. Children's lesioned hemispheres were either atrophic or consisted of cystic encephalomalacia. Data indicated that atrophy in the lesioned hemisphere was associated with the presence of seizures during the neonatal period as well as visual field deficits. Lesion size, as indicated by the proportion of supratentorial cranial volume consisting of lesioned matter, was inversely related to cognitive function. Those children with cystic encephalomalacia combined with large lesion size deviated from the other children in the group, demonstrating cognitive ability in the low average to mildly impaired range. Findings suggest that the size of the lesion in addition to the type of lesion (atrophic or encephalomalacic) may be better predictors of cognitive outcome than either index alone.

Correspondence: Sunita Bava, Neurosciences, UCSD, Division of Pediatric Neurology, 9500 Gilman Dr. 0935, La Jolla, CA 92093-0935. Email:sbava@crl.ucsd.edu

\section{J.L. WISNOWSKI, S.W. ANDERSON, M. RIZZO, H. DAMASIO, N.H. NAQVI \& D. TRANEL. FACE AND OBJECT RECOGNITION FOLLOWING EARLY-ONSET FOCAL BRAIN DAMAGE}

Little is known regarding the consequences of focal damage to human visual cortex when the damage occurs early in life. We studied a 13vear-old girl who had bilateral lesions in temporal and parietal cortices resulting from herpes simplex encephalitis at age 10. Following onset of her lesions, she has demonstrated persistent impairments in her ability to recognize faces and objects. In contrast, other aspects of cognition, including verbal intellect, verbal memory, basic language and academic abilities were normal. Her ability to discriminate between unfamiliar faces was also normal. Visual function assessment showed normal visual acuity and spatial contrast sensitivity. Visual fields were full to confrontation. Color discrimination was only mildly impaired (despite initial severe achromatopsia), but she could not correctly name colors. Perception of 3-D shape from motion cues was abnormal. The subject's performance in a facial recognition paradigm was markedly 
impaired: she overtly recognized $40 \%$ of familiar faces and misrecognized $20 \%$ of unfamiliar faces. Additionally, unlike some patients with adult-onset prosopagnosia, she failed to demonstrate covert recognition via differential skin conductance responses. Her recognition of emotion from faces was severely impaired, characterized by a near complete inability to identify even basic emotions. The subject's object recognition was also impaired, with greater impairments in recognition of living ( $12 \%$ correct) versus non-living objects ( $57 \%$ correct). This case, in conjunction with a few others reported in the literature, suggests that plasticity in regions which support face and object recognition is limited beyond age 10 .

Correspondence: Jessica L. Wisnowski, BA, Neurology \& Psychology, University of Iowa, 11 Seashore Hall East, University of Iowa, Iowa City, IA 52242.E-mail: jessica-wisnowski@uiowa.edu

\section{R.K. JACOBS, V. ANDERSON, R. LEVENTER \& A. HARVEY. FUNCTIONAL LOCALISATION OF EXECUTIVE SKILLS IN CHILDHOOD: ANALYSIS OF CHILDREN WITH FOCAL FRONTAL LOBE LESIONS.}

Adult lesion studies have shown that executive processes can be localised to specific prefrontal brain regions (e.g. Stuss et al., 2002). A major distinction has been demonstrated between dorsolateral and medial prefrontal cortex, with the dorsolateral regions playing an important role in mediating cognitive aspects of executive function while medial regions primarily mediate social and emotional processes (Damasio et al., 1994; Mesulam, 1981; Rolls, 1996; Stuss et al., 2002). In children, this distinction may be less clear, due to the protracted development of both executive skills and the corresponding prefrontal regions that underpin them, as well as the immaturity of these processes at the time of insult (e.g. Anderson, 2002; Bell \&. Fox, 1992; Levin et al., 1991). This study examined this hypothesis by investigating the performance of 38 children with focal frontal lobe lesions confined to the frontal lobes and involving the prefrontal cortex and 40 age matched controls, by comparing performance according to lesion laterality (left, right, bilateral) and then by lesion location (dorsolateral, medial, orbitofrontal). Results suggest less clear functional specificity of executive processes in children compared with adults.

Correspondence: Rani K. Jacobs, Phd, Psychology, Royal Children, Flemington Road, Parkville, Melbourne, VIC 3052, Australia. E-mail: rani. jacobs@mcri.edu.au

\section{A.E. LANSING, J.E. MAX, D.C. DELIS \& J.L. STRICKER. COMPARISON OF CVLT-C SEMANTIC CLUSTERING SCORING METHODS IN A PEDIATRIC STROKE POPULATION.}

The CVLT-C is a process-oriented memory task that provides information about encoding strategies that may facilitate recall. Semantic clustering has been identified as an efficient method of maximally recalling words. Consistent with past cognitive-science methods, the CVLT-C originally used a recall-based clustering $(R B C)$ formula. RBC formulas use words recalled during a trial as the baseline for calculating expected values of chance clustering; however this method implies organizational processes do not occur until after word recall. Recent research suggests that a list-based clustering ( $L B C$ ) formula, where the word list is the baseline for calculating semantic clustering expectancy, is more consistent with current neuropsychological theories postulating organization as an antecedent to recall that facilitates better memory performance (Stricker, et al., 2002). Method: RBC and LBC formulas of semantic clustering strategies were compared in a sample of 26 single stroke (16 prenatal, 10 postnatal) and 26 orthopedic control subjects between the ages of 5 and 16 years old. Results: Scatterplot analyses revealed that the LBC formula provides a better fit for the semantic clustering data. While no significant differences were observed using the RBC formula, significantly greater use of LBC semantic recall strategies were observed among control relative to stroke subjects (1.37(1.13) and .43(1.05), respectively; $\mathrm{df}=50, \mathrm{t}=3.10, \mathrm{p}<.01)$ and post-natal relative to prenatal stroke subjects $(1.01(1.37)$ and $.06(.57)$, respectively; $\mathrm{df}=24, \mathrm{t}=2.479$, $\mathrm{p}=.02)$. Conclusion: A list-based semantic clustering formula, like that used in the CVLT- 2 adult version, provides the most sensitive assessment of a semantically based learning strategy in pediatric stroke populations.

Correspondence: Amy E. Lansing, Ph.D., University of California, San Diego, 3350 La Jolla Village Drive, 116B, San Diego, CA 92161. E-mail: alansing@casrc.org

\section{K. O'TOOLE, C. MILLER \& K. BORDEN. LONG-TERM PSY- CHOSOCIAL, ADAPTIVE AND BEHAVIORAL OUTCOMES IN CHILDREN WITH ARTERIOVENOUS MALFORMATIONS (AVM) AND THEIR FAMILIES.}

Little information exists on long-term, adaptive and emotional functioning in children with arteriovenous malformations (AVM). The cause of AVM is unknown although clotting of a blood vessel during prenatal development has been proposed. Our previous studies of five children with AVM (INS, Chicago, 2001) and (INS, Toronto, 2002) found that acute cognitive deficits were localized. We are now conducting followup evaluations that suggest neuropsychological deficits may be localized with only slight improvement over time, but without cascading effects on adjacent or distant areas often found in other acquired brain injury (INS, Honolulu, 2003). An important question to answer is how these children fare emotionally and adaptively over time. Additionally, it is crucial to examine family functioning to determine if the level of parental stress increases due to the trauma, treatment and outcomes of AVM. The results of our current long-term (1-4 year) follow-up of 5 children with AVM suggest that these children are not reporting significant internalizing problems on structured checklists and that their selfreports are corroborated by parent and teacher checklists. Parents and teachers are not reporting significant problems with attention, hyperactivity, or emotional control. Except in one case, parents are not reporting increased family stress. These findings are in positive contrast to the literature on children who sustain a traumatic brain injury or stroke and their families. Adaptively, the children with AVM are reported to have difficulties in socialization, similar to other groups of children with acquired brain injury. While parents are reporting more withdrawn behaviors and less ability to socialize, the children are either unaware or less sensitized to social responsibilities. Further studies are needed to examine the psychosocial profile of children with AVM.

Correspondence: Kathleen O'Toole, Children, 1001 Johnson Ferry Road, Atlanta,GA30342.E-mail:ins@osu.edu

\section{S.L. NICHOLS \& D.A. TRAUNER. DOMAINS OF EXECUTIVE FUNCTIONING FOLLOWING EARLY, FOCAL BRAIN DAMAGE.}

The impact of focal brain damage on complex executive functions such as problem solving and behavioral inhibition in children is poorly understood. This is in part due to the rarity of children with relatively discrete lesions such as those seen in adults following strokes. Existing studies of language and spatial functioning in children with early focal lesions have demonstrated that the degree of functional plasticity and similarity to adult lesion/deficit relationships vary across cognitive domains. We have shown previously that schoolage children with early, focal brain damage exhibit problems on some measures of executive functioning. The purpose of this study was to look for dissociations between domains of executive functioning in these children. A group of 18 children with perinatally acquired, unilateral, focal brain damage (FL) and 36 matched controls, age 8-13, completed a battery of executive function tasks. Tasks were grouped into three domains: working memory, problem solving, and inhibition. Each domain was comprised of variables from two or three tasks, plus parent ratings. Measures of adaptive functioning and response speed were also included. A multivariate analysis of variance was performed for each domain. A dissociation was seen, with FL children differing significantly from controls on problem solving and 
working memory domains, as well as on adaptive functioning and response speed, but not on tasks measuring inhibition. It is hypothesized that the previously reported long-term impact of early, focal damage on adaptive and social functioning may be related to basic deficits in cognitive speed and working memory efficiency, but not to inhibitory deficits.

Correspondence: Sharon L. Nichols, Ph.D., Neurosciences, University of California, San Diego, 9500 Gilman Dr., \#0935, La Jolla, CA 92093.

E-mail:slnichols@ucsd.edu

\section{WABER, A. CHIVERTON, M. KIERAN, S.L. POMEROY \& M.J. RIVKIN. NEUROPSYCHOLOGICAL BASES OF EVERYDAY COGNITIVE PROBLEMS IN ADOLESCENTS TREATED FOR CRANIOPHARYNGIOMA. .}

We evaluated self-reported everyday cognitive problems in relation to laboratory measures of declarative memory (California Verbal Learning Test, CVLT), working memory (CANTAB Spatial Working Memory Test, SWM) and speed of processing (Wechsler Coding/Digit Symbol, C/DS) in 10 patients with a history of treated craniopharyngioma (6F/4M; median age 17, range 13-34; median IQ 97, range 84-130). All were treated surgically; 7/10 also had stereotactic radiotherapy. The Cognitive Failures Questionnaire (CFQ, Broadbent, Cooper, Fitzgerald, \& Parkes, 1982) was used to assess everyday cognitive difficulties. The mean (S.D.) CFQ score of 49 (11.7) for these patients is well above the reported mean (19) for American college students (Pollina, Greene, Tunick \& Puckett, 1992), indicating significantly increased prevalence of cognitive difficulties. Mean scores on the 8-item SWM and C/DS were somewhat below expectation (both -0.9 S.D.), and the CVLT (+0.8 S.D.) was somewhat above. Age $(\mathrm{r} 2=.31, \mathrm{p}<$ $0.1)$ and the Beck Depression Inventory (BDI) $(\mathrm{r} 2=.32, \mathrm{p}<0.1)$ predicted CFQ, but IQ was unrelated $(\mathrm{r} 2=.02, \mathrm{p}<0.7)$. After adjusting for the effects of age and BDI, we found CANTAB Spatial Working Memory best predicted the CFQ score $(\mathrm{r} 2=.45, \mathrm{p}<0.04)$; the CVLT $(\mathrm{r} 2=.24, \mathrm{p}<0.2)$ and C/DS $(\mathrm{r} 2=.05, \mathrm{p}<0.6)$ were not good predictors. Item analysis of the CFQ indicated that distractibility and memory for names were the most frequent cognitive complaints. Everyday cognitive difficulties in patients with craniopharyngioma are related to working memory. Working memory in these patients therefore merits more detailed analysis.

Correspondence: Deborah Waber, Ph.D., Psychiatry, Children's Hospital,300Longwood Avenue, Boston, MA 02115.E-mail: deborah.waber@ tch.harvard.edu

\section{J. O'GRADY, S.L. PALMER, A. GAJJAR, C.J. LONG, L. KUN \& R.K. MULHERN. ESTIMATION OF PREMORBID COGNITIVE ABILITY IN CHILDREN TREATED FOR MEDULLOBLASTOMA. .}

Cognitive deficits in children following treatment for medulloblastoma (MB) have been well documented. As baseline measures of $c 0 g$ nitive function are generally conducted post-diagnosis, it is assumed that these scores do not represent the patient's true premorbid abilities due to the effects of disease. Therefore, this study was designed to determine how well premorbid cognitive ability can be estimated using available regression formulas, and to determine whether a MBspecific estimation equation could be developed that would more accurately estimate premorbid IQ by the inclusion of clinical variables related to treatment and current reading ability. Forty-seven patients $(\mathrm{M}=9.7$ years of age $)$ treated for $\mathrm{MB}$ and four hundred and twenty-three matched case controls $(\mathrm{M}=9.44$ years of age $)$ were included in the analysis. A comparison of the scores obtained in the first post-diagnosis assessment in the MB sample with wellmatched proxy subjects revealed a mean decrement of 8.2 IQ points in the MB sample. The main implication of this finding is that past studies of cognitive late effects in children treated for MB likely underestimate the toxic effects of disease and treatment on cognitive ability. Existing formulas which include only demographic infor- mation were shown to be a valid method to estimate premorbid IQ in the MB sample. The addition of the patient's current ability information (WISC-III subtest scores) was shown to consistently underestimate premorbid IQ. Results of a weighted blockwise regression analysis revealed the inclusion of clinical treatment variables and current reading ability did not improve formulas to estimate premorbid IQ.

Correspondence: Joy O'Grady, Ph.D., St. Jude Children's Research Hospital, 2693-9 Barracks Road, Charlottesville, VA 22901. E-mail: jogrady9177@yahoo.com

\section{N. JAIN, P. BROUWERS, K. KRULL, M. CHINTAGUMPALA \& S. WOO. COMPARISON OF NEUROCOGNITIVE FUNCTION FOL- LOWING INTENSITY-MODULATED RADIATION THERAPY (IMRT) VERSUS CONVENTIONAL RADIATION THERAPY (CRT) FOR MEDULLOBLASTOMA IN CHILDREN.}

We have previously shown that IMRT compared to CRT significantly reduced the prevalence of ototoxicity in children treated for medulloblastoma, despite a higher dosage of cisplatin, while maintaining a high rate of event free survival (Int J Rad Onc Biol Phys, 2002,52:599). IMRT, allows a more specific distribution of the radiation, in this case sparing the cochlea and 8th cranial nerve. However, compared to CRT, the redistribution leads to other brain areas receiving low dose exposure. The issue that we wanted to retrospectively investigate was whether the benefit in hearing had been associated with a decline in neurocognitive function due to this exposure. To avoid bias from the effects of the ototoxicity, we focused on the non-verbal tests from our battery. Neurocognitive functioning from the most recent evaluation of $96 \%$ of the children from the original ototoxicity study (mean age 10.5; range 4-19 years; median time since diagnosis 37.2 months) was compared following the completion of treatment with IMRT ( $\mathrm{N}=15)$ or CRT $(\mathrm{N}=10)$. The results indicated that on an overall measure of nonverbal intelligence children treated with IMRT (mean=93.3; 95\% CI 81.1-105.5) did not perform worse than children treated with CRT (mean=80.6; 95\% CI 64.4-96.9). In fact, on a test of visual motor integration children treated with IMRT had significantly higher scores (mean= 89.5) than those treated with CRT (mean= 76.7; $<<.05$ ). In summary, our data do not support the notion that the benefit of decreased ototoxicity associated with IMRT comes at the cost of increased neurocognitive deficit.

Correspondence: Neelam Jain, BA, Learning Support Center, Texas Children, Clinical Care Center, Suite 1630, 6621 Fannin St., CC 1630.00, Houston, TX 77030-2399.E-mail:neurojain@yahoo.com

\section{J. JANUSZ, T. ROSSER, C. COBLE \& G. GIOIA. PROFILES OF EXECUTIVE FUNCTIONING IN CHILDREN WITH NEUROFIBRO- MATOSIS TYPE 1: PRELIMINARY FINDINGS.}

Neurofibromatosis Type 1 (NF1) is the most common autosomal dominant genetic disorder. Children with NF1 are at increased risk for neurocognitive, learning, and behavioral difficulties. While most research has focused on the verbal and nonverbal abilities of children with NF1, few studies have examined executive functions. This study provides pilot data regarding parent-report of executive functioning in school-age children with NF1. Ten parents of children, age 6-12, attending an NF1 clinic completed the Behavior Rating Inventory of Executive Function (BRIEF). Screening of general intellectual functioning in a subsample revealed average abilities. To examine departure from normality, a one-sample Kolmogorov-Smirnov non-parametric test was conducted. The Metacognition Index deviated significantly from the normal range $(p=.003)$. Each of the component scales of the Metacognition Index, with the exception of the Organization of Materials scale, significantly differed from the expected norm. Mean scores in the clinical range $(T>65)$ were observed for the Working Memory, Plan/Organize, and Monitor scales while the Initiate scale showed a mild elevation. No scales from the Behavioral Regulation Index (Inhibit, Shift, Emotional Control) departed significantly from 
the normal range $(p>05)$. Findings of this preliminary study indicate that children with NF1 are at significant risk for deficits in aspects of executive functioning as manifested in their everyday behavior. Continued investigation of executive functioning in children with NF1 is underway, including the role of such factors as age and sex. This domain should be explored more fully to determine impact on everyday functioning.

Correspondence: Jennifer Janusz, Psy.D., Pediatric Neuropsychology, Children's National Medical Center, 4900 Massachusetts Ave., NW, Suite 320, Washington, DC 20016.E-mail:.jjanusz@cnmc.org

\section{CAREY, I. MOORE, A. PASVOGEL, J. HUTTER \& K. KAEM- INGK. DECLINES IN MATH ACHIEVEMENT ONE YEAR AFTER ALL DIAGNOSIS.}

We have previously reported difficulties in math skills in long-term survivors of acute lymphoblastic leukemia (ALL) when compared to healthy children. Currently, we are evaluating children newly diagnosed with ALL treated with standard systemic and intrathecal chemotherapy and following them longitudinally. A neuropsychological evaluation is conducted within 8 weeks of diagnosis and then annually. A healthy sibling group is also being followed for comparison. Preliminary findings, examining changes in performance between Baseline and Year 1 for 13 children with ALL and 11 healthy siblings, are reported here. Mean age at Baseline was 7.10 years $(S D=1.91)$ for the ALL group. The siblings were older $(p=.002)$ with a mean age of 9.90 years $(\mathrm{SD}=2.04)$ at Baseline. Using age-corrected scores, paired-samples t-tests revealed a significant $(p=.024)$ decline in written math achievement (WJ-R Calculation) in the ALL group, but not in the sibling group. No significant changes in IQ, reading, receptive vocabulary, attention/memory, or visual-motor skills were found for either group. No significant group differences were found in this small sample at Baseline or Year 1. These findings are consistent with previous reports of greater academic difficulties in math compared to reading following treatment for ALL. Frequent school absences during the first year of treatment are common and may be contributory. Continued follow-up of these children should help to clarify this question. Our findings and previous literature suggest that early intervention for academic math skills is important. This work was supported by the NIH (HD37816).

Correspondence: Marissa Carey, Ph.D., Pediatrics, University of Arizona, 1501 N. Campbell Ave., P.O. Box 245073, Tucson, AZ 85716. Email:mcarey@peds.arizona.edu

\section{MRAKOTSKY, L. SILVERMAN, D. LEVY, T. MILLER \& D. WABER. NEUROBEHAVIORAL SIDE EFFECTS OF STEROID TREATMENT IN CHILDREN WITH LEUKEMIA.}

Corticosteroids are highly effective anti-leukemic agents, yet their toxic effects on the developing nervous system are poorly understood. Clinically, steroids are observed to cause a range of problems with executive functions (dysregulated behaviors, mood swings, attention problems), with some steroids appearing more toxic than others. There are few controlled studies, however. We investigated acute neurobehavioral side effects in children randomized to prednisone (PRED) or dexamethasone (DEX) as components of therapy for Acute Lymphoblastic Leukemia (ALL). Parents of 18 children (NPRED=9, NDEX=9) age 2-17 years completed subscales of the preschool and school-age versions of the Behavior Inventory of Executive Functions (BRIEF) and the Child Behavior Checklist (CBCL) at 4 time points during one steroid cycle in maintenance therapy to evaluate the fluctuations in the child's behavior and executive functions relative to steroid therapy. Findings document a general increase in behavior problems during the steroid-week of treatment and a decrease after steroids are tapered, regardless of steroid type. Our ability to detect steroid differences (PRED/DEX) was limited by a high degree of variability in responses within each group. We did, however, detect significant age effects. Younger children ( $<6$ years) showed a more pronounced increase in regulation problems during the steroid week than older children ( $>=6$ years) (Inhibit(BRIEF), Emotional Control(BRIEF) Aggression(CBCL), Anxiety/Depression(CBCL): $\mathrm{p}<.05$ to $<.1$ ), and a greater decrease of attention/working memory problems ( $\mathrm{p}<$ $.05)$ after steroid taper. Younger children appear to be more vulnerable to acute behavioral effects of steroid therapy, possibly due to less well developed frontal brain systems.

Correspondence: Christine Mrakotsky, Ph.D., Department of Psychiatry, Childrens Hospital Boston, HMS, 300 Longwood Avenue, Boston, MA02115.E-mail: christine.mrakotsky@tch.harvard.edu

\section{T. HERSHEY, D.C. PERANTIE, S.L. WARREN, B.E. GOLDBERG, J.L. HARTLEIN, K.J. BLACK, A.Z. SNYDER, Y.I. SHELINE, M. SADLER \& N.H. WHITE. NEUROIMAGING OF CHILDHOOD DIABETES: HYPOGLYCEMIA, MEMORY AND HIPPOCAMPAL VOLUMES.}

Severe hypoglycemia may affect memory and the hippocampus in patients with type 1 diabetes mellitus (T1DM), particularly during childhood. We tested this hypothesis in children with T1DM $(n=29)$ and nondiabetic sibling controls $(n=13)$ ages 7-16. Children performed a memory task previously shown to be sensitive to effects of hypoglycemia (spatial delayed response or SDR task). In addition, at least 3 T1-weighted magnetic resonance images (MRIs) of the brain and a detailed history of T1DM complications were obtained on each child. The volumes of left and right hippocampi were measured on averaged MRIs in atlas space using stereology and well-defined criteria (ICCs >.91). Data were analyzed to determine the relationship between disease, hypoglycemic history, cognitive performance and hippocampal volumes. We found that absolute hippocampal volume was stable across this age range $(\mathrm{r}=-.03$, $\mathrm{p}=.84)$, but hippocampal volume relative to whole brain volume tended to decrease $(\mathrm{r}=-.32, \mathrm{p}=.04)$. Hypoglycemic history did not significantly affect hippocampal volume (semi-partial $r=.01, p=.94$ ) but did negatively affect SDR long delay performance after controlling for age (semipartial $\mathrm{r}=.35, \mathrm{p}=.009$ ). Within the T1DM group, hippocampal volumes were related to SDR long delay performance after controlling for age (semi-partial $r=-.39, p=.04$ ), with larger volumes associated with better SDR performance. In conclusion, hypoglycemia affected long delay spatial memory but not hippocampal volumes. A larger and more varied sample is necessary to improve power. Alternatively, the hippocampus could be dysfunctional in ways not reflected in MRI-based volume measurements.

Correspondence: Tamara Hershey, Ph.D., Psychiatry, Washington University, 4525 Scott Avenue, Campus Box 8225, St. Louis, MO 63110. E-mail: tammy@npg.wustl.edu

\section{P.K. ISQUITH, M.J. DETZER \& K.R. WHITAKER. SELF REPORTS OF EXECUTIVE FUNCTION IN ADOLESCENTS WITH IDDM.}

Insulin-Dependent Diabetes (IDDM) can be associated with effects on executive function (Rovet \& Ehrlich, 1999). We examined self-reports of executive function on the Behavior Rating Inventory of Executive Function-Self Report Version (BRIEF-SR) in 67 adolescents with IDDM and 48 controls aged 11 - 20 years along with their parents ratings on the BRIEF. Nineteen of the adolescents with IDDM were also diagnosed with learning, attentional, anxiety or mood disorders (IDDM+). There were significant $(p<.05)$ group effects for the Inhibit $(\eta=.07)$, Shift $(\eta=.10)$, Emotional Control $(\eta=.08)$ and Task Completion $(\eta=.09)$ scales. Bonferroni-corrected post-hoc tests $(\mathrm{p}<.05)$ demonstrated that all differences were explained by the IDDM+ group. Examination of parent BRIEF ratings revealed similar significant effects for the BRIEF scales, again explained primarily by the IDDM+ group. There was only one difference between the IDDM and control group: Parents of adolescents with IDDM rated their children as significantly better organized $(p<.01)$ than both controls and the IDDM+ group. Correlations between adolescent and parent ratings were moderate (overall $\mathrm{r}=.51$ ). While adolescents with insulin dependent diabetes are at risk for greater 
difficulties with executive function, this was true primarily for adolescents with diabetes who were also diagnosed with an additional learning, attentional or emotional disorder. Screening for these difficulties may be a helpful procedure in endocrine clinics to detect adolescents at risk for self-regulatory problems.

Correspondence: Peter K. Isquith, Ph.D., Department of Psychiatry, Dartmouth Medical School, One Medical Center Drive, Lebanon, NH 03756-0001.E-mail: isquith@dartmouth.edu

\section{STEWART \& K. O'TOOLE. EARLY ONSET PEDIATRIC MUL- TIPLE SCLEROSIS: A CASE STUDY.}

Multiple sclerosis (MS) is a disease of the central nervous system which typically affects adults in the third or fourth decade of life. Prevalence of early onset MS (before age 16) is low (Miakealoff, Thibault, Debouverie et al., 2001) accounting for 3 to $5 \%$ of cases (Duquette et al., 1987). Current research is investigating the diagnosis and treatment of children and teenagers with MS. Preliminary findings suggest MS affects sensiomotor, visual-perceptual, and semantic verbal memory functioning (Kalb et al., 1999) since MS plaques are generally distributed throughout the white matter of the optic nerve, chiasm and tracts, the brain stem, cerebellum and the spinal cord (Swanson et al., 1989). Demyelination and thinning of the corpus callosum are implicated in memory difficulties (Rao et al., 1989). This case study explores the cumulative effects that MS has on cognitive development in a very young child. The participant was a 7-year old girl, with a 3 year history of MS, diagnosed by serial MRI's that showed progressive worsening and an increased volume of white matter lesions. The girl was referred for a neuropsychological evaluation prior to discharge from a day rehabilitation program at a major medical center. Neuropsychological results were consistent with recent literature findings (Kalb et al., 1999). This study highlights the need for early recognition of unusual neurological disease processes in young children to facilitate appropriate therapeutic and educational interventions. Serial MRI's will be presented. Correspondence: Marilyn Stewart, Children, 1001 Johnson Ferry Road, NE, Atlanta, GA 30342.E-mail: marilyn.stewart@choa.org

\section{V.J. HINTON. POOR ACADEMIC ACHIEVEMENT DUE TO LIM- ITED VERBAL SPAN IN DUCHENNE MUSCULAR DYSTROPHY.}

Duchenne muscular dystrophy (DMD) is a genetic disorder that has selective effects on the development of the central nervous system and cognitive skills. DMD is known mainly as a disease of muscle and it presents with progressive muscular weakness. Yet DMD has long been known to be associated with mean IQ scores that are about one standard deviation lower than the population mean, and affected individuals generally have lower Verbal than Performance IQ scores. Prior work has demonstrated selective deficits on tests of verbal span and immediate memory, and across all areas of academic achievement. DMD is caused by a mutation in a single gene and results in the absence of specific protein products that normally localize to circumscribed areas of the CNS. For the current study, 26 boys with DMD (and normal intellectual function) and their unaffected sibling controls were evaluated. Paired comparisons demonstrated the children with DMD had significantly poorer academic achievement scores in reading, math and writing than their siblings $(\mathrm{ts}=4.86,4.44,5.32 \mathrm{p}<.005)$, even though their vocabulary levels, and home and educational environments were comparable. Linear regression indicated that behavioral concerns, physical severity, abstraction ability and age did not contribute substantially to academic performance, whereas performance on Digit Span did. Thus, DMD presents with a selective developmental aberration in verbal span that has wide-ranging consequences on learning skills.

Correspondence: Veronica J. Hinton, Ph.D., Sergievsky Center \& Dept Neurology, Columbia University, $P \& S$ Box 16, 630 West 168th Street, New York, NY 10032.E-mail: vjh9@columbia.edu

\section{S. CYRULNIK, R. FEE \& V.J. HINTON. DELAYED LANGUAGE ACQUISITION IN CHILDREN WITH DUCHENNE MUSCULAR DYSTROPHY (DMD).}

Duchenne muscular dystrophy (DMD) is a fatal, X-linked neuromuscular disorder that is associated with cognitive deficits. In individuals with DMD, mean verbal IQ scores are approximately one standard deviation lower than the general population. According to retrospective parental report, children with DMD were delayed in acquiring language as well as motor milestones. The goal of the current study was to examine language acquisition in preschool children with DMD. Twelve preschool children with DMD (mean age $=66$ months, $\mathrm{SD}=13.5$ ) and six unaffected siblings (mean age $=65$ months, $\mathrm{SD}=26.5$ ) were evaluated. According to parental report, preschool children with DMD are, on average, approximately a year and a half behind their peers on communicative abilities (mean age equivalent score $=47$ months, range 13-75 months). Parental report of unaffected siblings indicate that they are, on average, approximately two and a half years ahead of their peers on communicative abilities (mean age equivalent score=95 months, SD=64.4). Comparison to unaffected siblings using paired t-tests indicate that preschool children with DMD exhibit significant delays on a test of expressive vocabulary. They perform similarly to their unaffected siblings on a test of single word comprehension. These preliminary data indicate that preschool children do indeed exhibit a language delay relative to their unaffected siblings and to their peers. This early language delay in preschool children with DMD may have wide-ranging effects across all skills in these young children, and may affect the acquisition of other skills as they develop.

Correspondence: Shana Cyrulnik, Sergievsky Center, Columbia University, 630 West 168th Street, P\& S Box 16, New York, NY 10032. Email: ssteiner@pobox.com

\section{S. MCLAUGHLIN-BELTZ. NEURODEVELOPMENTAL ASPECTS IN CHILDREN WITH HIV/AIDS: A NEURORADIOLOGICAL AND NEUROPSYCHOLOGICAL ANALYSIS.}

Most research concerning the neuropsychological development in children with AIDS indicates increased frequency of developmental delays in all areas including motor, language, and memory skills. Although an increased incidence of cerebral atrophy, ventricular enlargement, widening of sulci, attenuation of deep cerebral white matter, symmetrical calcification of the basal ganglia, calcification of the frontal white matter, and microcephaly in children infected with HIV have been reported, the pattern of early brain development in children with HIV is poorly understood. The present study investigated the relationship between neuropsychological status and neuroradiological findings in 19 symptomatic children. Neuropsychological status was based on age-standardized mental and motor scores; either the Bayley Scales of Infant Development or the McCarthy Scales of Children's Abilities was administered. Neuroradiological results included T1-weighted MRI sequences in sagittal and coronal planes and computer assisted planimetry and volumization. No significant correlations were found between neuropsychological measures and cerebellum to whole brain ratios. Brain volume, cerebellar volume, and cerebellar Lobuli I- $\mathrm{V}$ were significantly smaller in this sample than those reported in previous studies with children with autism and acute lymphoblastic leukemia (ALL), as well as control subjects described in the literature. Previous studies suggest that both enlarged and decreased cerebellar volumes may be associated with motor and cognitive dysfunction. The findings from this study suggest that abnormal development of the cerebellum may be important to understanding the abnormality of brain growth and neurological deficits associated with HIV in young children.

Correspondence: Susan McLaughlin-Beltz, PhD, Neurodevelopmental Institute of NH, 1461 Hooksett Rd.,Hooksett,NH 03106.E-mail: sbeltz@ niatmba.com 


\section{E.K. KHEMANI, B. SMITH-CHANT \& M.A. BARNES. BASIC COMPUTATIONAL MATH SKILLS AND MATH FLUENCY IN CHILDREN WITH SPINA BIFIDA.}

Children with Spina Bifida (SB) have intact reading, but high rates of math disability. It has been suggested that math disability in SB is related to their characteristic problems in visual spatial cognition, rather than to problems in math fact retrieval processes. Sixty-two children with SB were compared to 62 same age controls on a multi-digit written subtraction task in which errors due to problems in visual spatial processing, math fact retrieval accuracv, and procedural knowledge were investigated. We hypothesized that the SB group would make more visual spatial errors, but not more math fact errors than controls. The SB group made similar numbers of visual spatial and math fact errors as controls. but more procedural errors. The visual-spatial hypothesis was not supported. Although the SB group was accurate at math fact retrieval on the written subtraction task, it is unknown whether their math fact retrieval is also fluent. In math, as in other domains, skilled performance is both accurate and fluent. A cognitive addition task was used (e.g. $7+3=$ ?) to measure math fact retrieval accuracy, fluency, and strategy use. The SB group was as accurate as controls in solving these problems, but they were slower and they used less mature problem solving strategies. Children with SB are inefficient in math fact retrieval suggesting that their math disabilities may arise from deficits in the basic building blocks of mathematical cognition. Results are discussed with reference to developmental delay and cognitive deficit models of skill acquisition. Correspondence: Marcia A. Barnes, Ph.D., Brain and Behavior Research, Hospital for Sick Children, 555 University Avenue, Toronto, ON M5G 1X8,Canada.E-mail:marcia.barnes@sickkids.ca

J.G. PURZNER, M. WILKINSON, A. BOUDOUSQUIE, B. SMITHCHANT, M. DENNIS, J.M. FLETCHER \& M.A. BARNES. VERBAL AND VISUAL WORKING MEMORY IN CHILDREN WITH SPINA BIFIDA.

Children with spina bifida (SB) have difficulties in math and reading comprehension. areas of academic achievement that have been related to working memory function. Studies of memory in children with SB have demonstrated intact verbal memory span, but deficient verbal learning and long-term verbal memory. The status of verbal and visual working memory (VerWM \& VisWM) in SB is unknown. VerWM and Vis WM were compared in 102 children with SB and 38 age-matched controls using N-Back tasks. VerWM span was higher than VisWM span for both groups. The SB group had lower VerWM and Vis WM spans than the controls; they were less accurate than controls at each working memory span level, and they were also less accurate on the 0-Back trials, a measure of sustained attention with minimal memory load. In order to determine whether working memory performance of the SB group reflected a working memory deficit or primary difficulties in sustained attention, 38 children with SB were matched to 38 controls for age and accuracy on the Verbal 0-Back trials. The SB group was still less accurate on the 1-back and 2-back trials for both verbal and visual versions of the task. Working memory span was related to performance on standardized measures of reading comprehension and math computations. The results demonstrate that children with SB have deficits in both verbal and visual working memory. Findings are discussed with reference to models of working memory and the relation of working memory to academic skills such as mathematics and reading comprehension. Correspondence: Marcia A. Barnes, Ph.D., Brain and Behavior Research, Hospital for Sick Children, 555 University Avenue, Toronto, ON M5G 1X8,Canada.E-mail:marcia.barnes@sickkids.ca

\section{D.A. TRAUNER, H. DANG \& A. SCHATZ. PERFORMANCE OF CHILDREN WITH CYSTINOSIS ON THE MODIFIED REY-O FIGURE.}

Cystinosis is a genetic disorder in which the amino acid cystine is trapped within lysosomes of all organs, including the brain, because of absence of the carrier protein for cystine. We have documented a specific visual spatial deficit in children with cystinosis, on a background of normal intellectual function and normal language skills. In order to further characterize the visual spatial problem, we administered a modified form of the Rey-Osterreith Complex Figure to 17 children with cystinosis and 32 age-matched controls, age range 5 to 17 years. Both copy and recall tasks were administered. Children with cystinosis performed significantly more poorly on the copy task than did controls. However, there was no additional deficit associated with reproducing the figure from memory. Most of the errors made on the copy task were related to misplacements or rotations of parts of the figure, suggesting a visual spatial problem. These findings suggest that children with cystinosis have deficits in visual spatial and constructional abilities, but that visual memory appears to be spared.

Correspondence: Doris A. Trauner, M.D., Neurosciences, University of California, San Diego, 9500 Gilman Drive, MC 0935, La Jolla, CA 92093-0935.E-mail:dtrauner@ucsd.edu

\section{S. GARRELS, L.K. PAUL, M. SYMINGTON \& W.S. BROWN. DIVERGENT THINKING AND PROBLEM SOLVING IN CHILDREN WITH AGENESIS OF THE CORPUS CALLOSUM.}

It has been suggested that interhemispheric interactions via the corpus callosum (CC) are important in creativity (Bogen and Bogen, 1988). This study examined the role of the $\mathrm{CC}$ in divergent thinking (a factor contributing to creativity) and in problem solving through the assessment of children with agenesis of the corpus callosum (ACC). The Torrance Tests of Creative Thinking (TTCT) and the Children's Category Test (CCT) were administered to 5 children (age 7-10) with complete ACC and normal intelligence (FSIQ 86-122), and to 7 age- and IQmatched controls (age 8-12: FSIQ 87-120). Children with ACC performed significantly worse than controls on the CCT $(\mathrm{p}<.05)$, while no differences were found between groups on either Verbal or Figural subsets or any subscales of the TTCT. Results from the CCT are consistent with previous research indicating deficits in abstract problem solving in adults with ACC - presumably due to reduced availability of bihemispheric cognitive resources. The lack of significant differences on the TTCT suggests that children with ACC have the ability to think divergently in a manner equivalent to their age peers. This finding may be explained in terms of intrahemispheric compensation, where processing within one hemisphere is sufficient for divergent thought as demanded by the TTCT. Alternatively, because interhemispheric interactions are limited in normal children due to an immature CG, divergent thinking may be enhanced by interhemispheric interactions only later in child development. Therefore, deficits in divergent thinking may become more apparent with an increase in age and task complexity. Correspondence: Warren S. Brown, Ph.D., Fuller Graduate School of Psychology, Travis Research Institute, 180 N. Oakland Ave, Pasadena, CA 91101. E-mail:wsbrown@fuller.edu

\section{S.D. O'LEARY, T.G. BURNS, K.A. BORDEN \& R. FLAMINI. PERFORMANCE OF CHILDREN WITH EPILEPSY AND NORMAL CONTROLS ON THE WISC-III.}

The effects of childhood epilepsy on general intelligence are not well known. Relevant research has produced contradictory findings, with some reports of epileptic children producing average IQ scores, and others finding significant deficits compared to normal controls. The current study included children with pure epilepsy (graphical summary of neuroimaging-EEG findings will be presented), who were assessed with the WISC-III and achieved either Full Scale. Verbal, or Performance IQ score $\geq 80$. Thirty-two children (aged $6-16$ years, average age of seizure onset $=7.3$ years) were age-gender matched with subjects from the normative standardization sample for the WISC-III. A one-way ANOVA revealed that epileptic children performed significantly below normative controls on all index standard scores $(p \leq 0.01)$, and the following subtest scaled scores: Vocabulary, Comprehension, Coding, Picture 
Arrangement, Symbol Search ( $\mathrm{p} \leq .01)$; Similarities, Block Design, Object Assembly ( $\mathrm{p} \leq .05)$. Based on contradictory data provided through previous research, these findings suggest that pure epileptic children perform consistently lower than the normal population on the WISC-III. A meta-analysis of previous research findings, taking into account the factors discussed, would provide a clearer understanding of the cognitive functioning of children with epilepsy. In efforts to explain this vast discrepancy, preliminary analysis considering monotherapy $(n=15)$ versus polytherapy $(n=11)$, and age of seizure onset $(\langle 6$ years, $n=12 ;\rangle 6$ years, $n=15$ ) was conducted. Observed trends suggested that polytherapy and early onset groups performed qualitatively below monotherapy and late onset groups. Future research should explore effects of drug therapy and age of onset as mitigating factors of cognitive functioning in epileptic children.

Correspondence: Stephanie D. O'Leary, M.A., Clinical Psychology, Georgia School of Professional Psychology, 3062 Leafwood Drive, Decatur, GA 30033.E-mail:sdo527@hotmail.com

\section{K. BORDEN, T.G. BURNS, S.D. O'LEARY \& R.J. HUGINS. A COMPARISON OF CHILDREN WITH EPILEPSY TO AN AGE-AND IQ-MATCHED CONTROL GROUP ON THE CHILDREN'S MEM- ORY SCALE.}

Past research has found that children with epilepsy exhibit decreased memory skills. A preliminary analysis comparing the performance of children with temporal lobe epilepsy (TLE) and controls on the Childrens Memory Scale (CMS), using an IQ cutoff criteria of $\rangle 80$, found that children with TLE performed significantly lower on all CMS indexes (Cohen, 1997). While some studies have found that children with epilepsy obtain significantly lower IQ scores than controls and others have found no such differences, the present study compared the performance of children with epilepsy $(\mathrm{n}=32)$ to an age- and IQ-matched control group $(\mathrm{n}=32)$ on the CMS to investigate whether differences in memory skills persist when IQ is controlled. Children ranged in age from 6 to 16 years and were diagnosed with pure epilepsy (average age of seizure onset 7.3 years) A one-way ANOVA comparing index and scaled scores was performed. The results indicated that when IQ is controlled for, children with epilepsy do not differ significantly on most indexes and subtests on the CMS. Children with epilepsy did perform significantly lower on the Learning Index ( $p<.01)$. This difference was due to a significantly lower scaled score on the Word Pairs Learning subtest
( $p\langle .01)$. In addition, children with epilepsy performed significantly lower on the Word Pairs Total Scaled Score ( $p<.01)$. Therefore, the results suggest that children with epilepsy, who exhibit memory deficits, may have more global cognitive impairments. Future research should explore the impact of lateralization and localization while controlling for intellect. Correspondence: Kristine Borden, MA, Neuropsychology, Children's Healthcare of Atlanta at Scottish Rite, 5385 Peachtree-Dunwoody Road, Apartment 1125, Atlanta, GA 30342.E-mail: kristineborden@ hotmail.com

\section{ZAROFF, H.A. BENDER, W.B. BARR, D.K. MILES \& O. DEVINSKY. USE OF THE CVLTC IN PEDIATRIC EPILEPSY: THE EFFECTS OF LATERALITY AND AGE AT SEIZURE ONSET.}

Verbal memory in a sample of pediatric patients with complex partial epilepsy, as determined by video EEG monitoring, was examined. Thirty subjects between the ages of 7 and 16 years with either left $(n=21)$ or right $(n=9)$ hemisphere onset complex partial seizures (CPS) comprised the sample. Verbal memory was assessed using the California Verbal Learning Test Children's Version (CVLTC). An ANOVA was used to examine the difference between the two groups. The total number of words recalled over 5 trials, verbal learning index, semantic cluster index, long delay free recall score, and recognition hits were examined. The correlation between age at seizure onset and performance on each of the variables was examined using a Pearson correlation coefficient. The two groups did not differ in age or IQ score. A significant difference between the two groups was found only on the verbal learning score $(\mathrm{F}=6.29, \mathrm{p}=0.01)$. Examination of data post-hoc revealed a significantly lower verbal learning score in the left CPS group (Left $\mathrm{M}=2.92$. $\mathrm{SD}=2.63$; Right $\mathrm{M}=5.33, \mathrm{SD}=1.58$ ). There was a significant correlation between age at seizure onset and semantic cluster index score ( $\mathrm{r}$ $=0.81, p=0.04)$. The results suggest comparable recall in children having either left or right hemisphere onset CPS. However, considerably greater difficulty in learning over trials was evidenced in the left CPS group. Both groups demonstrated poorer learning strategies with a younger age at seizure onset.

Correspondence: Charles M. Zaroff, Comprehensive Epilepsy Center, NYU Medical Center, 403 East 34th Street 4th Floor, NY, NY 10016. Email: charles.zaroff@med.nyu.edu

\section{THURSDAY AFTERNOON, FEBRUARY 5, 2004}

Invited Symposium/1:00-3:00 p.m.

\author{
How Neuropsychology Drives \\ Neuroimaging Research
}

\section{Chair: Stephen Rao Discussant: Stephen Rao}

\section{S.M. RAO. HOW NEUROPSYCHOLOGY DRIVES NEUROIMAGING RESEARCH .}

Neuroimaging and neuropsychology can provide complementary approaches to understanding the organization of the human brain. Without lesion studies, it is unclear that we would fully appreciate the critical role of the medial temporal lobes in memory consolidation. By contrast, without functional imaging studies, we would have an incomplete appreciation of the role of the cerebellum in language and executive processes. Each approach has its limitations: neuroimaging studies performed on healthy subjects can reveal a widely distributed system of activated regions, yet it is unclear to what extent a particular region is critical for a given function. Conversely, lesion studies are typically performed on chronic patients who have had the benefit of extensive brain reorganization, clouding the interpretation of the affected brain region's function. An increasing number of studies have begun to meld the two approaches by performing neuroimaging studies in clinical populations. Neuropsychological studies are now guiding hypotheses that can be confirmed/disconfirmed by functional activation studies, and vice versa. In this symposium, three leading investigators will provide an insightful account of the benefits and pitfalls associated with interfacing neuroimaging and neuropsychological research strategies in the study of attention, working memory, behavioral inhibition, and selfmonitoring.

Correspondence: Stephen M. Rao, Neurology, Medical College of Wisconsin, 9200 W. Wisconsin Ave., Milwaukee,WT 53226.E-mail: srao@ mcw.edu

\section{J.A. FIEZ. NEUROPSYCHOLOGICAL AND FUNCTIONAL NEU- ROIMAGING STUDIES OF WORKING MEMORY.}

This talk will review neuropsychological and neuroimaging research in the area of working memory. Apparently discrepant results between the 
two methods will be reviewed. For instance, findings from neuropsychology indicate that a region near the temporoparietal junction plays a critical role in the selective maintenance of verbal information, but sustained activity in this region is not typically observed in neuroimaging studies of verbal working memory. Similarly, findings from neuropsychology indicate that brain systems involved in motoric aspects of speech production do not contribute to the rehearsal of information via inner speech, while neuroimaging studies reveal significant activation in the cerebellum during verbal working memory tasks. Such discrepancies may arise because methodological assumptions made by one or both methods are violated (for instance, it is often assumed that only regions that play a critical role in task performance will exhibit robust changes in fMRI signal). The discrepancies may also arise because the underlying models of the cognitive functions and neural substrates are flawed. For instance, if temporoparietal cortex contributes to a transitory phonological process that is crucial for verbal working memory, damage to this area may lead to selective impairments in verbal working memory even though sustained activity in the region is not observed in neuroimaging studies of verbal working memory. Thus, a central goal of the talk will be to highlight how failures to find converging results across methods can drive advances in both the theories and the methods of cognitive neuroscience.

Correspondence: Julie A. Fiez, Ph.D., Psychology, University of Pittsburgh, Dept. of Psychology, Pittsburgh, PA 15213. E-mail: fiez+@pitt.edu

\section{CARTER. CONFLICT, COGNITIVE CONTROL, AND THE FRONTAL LOBES.}

Executive functions refer to a broad set of cognitive operations required for controlled information processing and coordinated actions. A distributed network of brain regions, which includes dorsolateral prefrontal cortex (DLPFC), anterior cingulate cortex and their subcortical connections, is engaged when task performance requires executive control. Evidence from event-related fMRI and ERP studies supports a model of modular functions within this frontally based neural network. These data suggest that lateral areas of the prefrontal cortex, particularly DLPFC, are directly involved in the top down control of attention and working memory by representing and maintaining the context for responding required to regulate processing in the service of task performance. Activity in this region appears strongly correlated with individual differences in executive functions. In contrast, the ACC on the medial frontal surface does not appear to be directly involved in top down control. Rather, activity in this region appears to support evaluative functions related to monitoring performance. New data supporting the hypothesized interactions of the ACC and DLPFC in trial to trial adjustments in cognitive control will be presented. The utility of this model of complementary functions of medial and lateral prefrontal cortex during executive control for investigating dysexecutive syndromes in brain injury and disease will be discussed.

Correspondence: Cameron Carter, MD, Psychiatry, UC Davis, Stockton Blvd, Sacramento, CA 95817.E-mail: cscarter@pitt.edu

\section{B. CASEY. NEURAL CORRELATES OF COGNITIVE CONTROL: CLINICAL, LESION AND IMAGING STUDIES.}

One key feature of cognitive development is the gradual ability to more efficiently override one action in favor of another or to suppress attention to irrelevant information in favor of more relevant information (i.e., cognitive control). This presentation will provide a summary of work examining the normal development of cognitive control, its neural basis and is disruption in developmental disorders. Behavioral and imaging results will be presented that emphasize the structural and functional connectivity of brain systems including the prefrontal cortex and basal ganglia, assumed to play a role in cognitive control. Specifically findings from structural magnetic resonance imaging (MRI), diffusion tensor imaging, and functional MRI that help constrain current theories on the cognitive and neural basis of cognitive control and its development will be presented. Finally, studies examining ge- netic variation in performance on tasks of cognitive control will be related to measures of structural and functional brain development. This work has significant implications at the behavioral, biological, and genetic level for developmental disorders that have as a core deficit, a problem overriding or suppressing inappropriate thoughts and behaviors like Attention Deficit-Hyperactivity Disorder, Obsessive Compulsive Disorder and Tourette Syndrome. Correspondence: BJ Casey, Ph.D., Sackler Institute, Weill Medical College of Cornell, 1300 York Ave, Box 140, New York, NY 10021. E-mail: bjc2002@med.cornell.edu

\section{Paper Session 5/1:00-3:00 p.m.}

\section{Neuropsychological Outcomes of Childhood Injury}

\section{K.L. WANKE, K.A. ESPY, J.M. NESS \& F.J. BIASINI. INTRAVENTRICULAR HEMORRHAGE AND COGNITIVE OUT- COME IN EXTREMELY LOW BIRTH WEIGHT PRESCHOOLERS.}

General cognitive outcome of preschool children born at extremely low birth weight was compared in those with intraventricular hemorrhage (IVH) and those without (noIVH), using the Differential Ability Scales (DAS). The effect of IVH laterality on verbal and nonverbal abilities also was examined. Preschool participants $($ IVH $n=65 ;$ noIVH n $=65$ ), sampled from a neonatal follow-up clinic serving primarily low-income and African-American children, were matched on sex, race, birth gestational age, birth weight, maternal education, multiple gestation, and DAS-level administered. Contrary to expectation, general cognitive abilities were comparable in the IVH and noIVH groups, with no withintask differences between verbal and non-verbal abilities. Furthermore within the IVH group, general cognitive abilities did not differ as a function of IVH laterality, nor were there specific within-task differences between the verbal and nonverbal DAS composite scores related to IVH laterality. These findings are consistent with the pervasive effects on cognitive outcome in young children of both the biological risks associated with prematurity and extremely low birth weight generally, and the substantial social risks of socioeconomic disadvantage. The findings are considered in light of the limitations of clinical neonatal neuroimaging methods and the general biological risk associated with extremely low birth weight.

Correspondence: Kay L. Wanke, PhD, MPH, Tobacco Control Research Branch, National Cancer Institute, 6116 Executive Blvd. Suite 109, MSC 8318, Bethesda, MD 20892-8318.E-mail:wankek@mail.nih.gov

\section{H.G. TAYLOR, N. KLEIN \& M. HACK. LONG-TERM OUTCOMES OF VERY LOW BIRTH WEIGHT.}

As part of a longitudinal study of children with very low birth weight (VLBW, $<1500 \mathrm{~g}$ ), we followed a sample of 48 children with $<750 \mathrm{~g}$ birth weight, 47 with 750-1499 g birth weight, and 52 term-born controls to mean age 17 years. Consistent with findings from previous follow-ups, we found pervasive impairments in cognitive skills, achievement, and behavior in the $<750 \mathrm{~g}$ group. Mean IQs for the $<750 \mathrm{~g}$, $750-1499 \mathrm{~g}$, and term groups were 83,91 , and 98 , respectively. When analysis was restricted to the 126 children without neurosensory deficits or MR ( $86 \%$ of the sample), the $<750 \mathrm{~g}$ group had more selective deficits in perceptual-motor skills, executive function, and math. Risks for poor outcomes within the VLBW groups included multiple neonatal complications and social disadvantage. The findings suggest persistent sequelae of VLBW that are related to the degree of low birth weight, neonatal complications, and social status. The presence of both global and 
selective deficits is consistent with data showing diffuse effects on brain development with more severe insult to the periventricular region. We are currently examining brain volumes to explore the neuropathological basis of group differences and increase our ability to predict individual outcomes.

Correspondence: H G. Taylor, Ph.D., Pediatrics, Case Western Reserve Univ, Rainbow Babies \& Children's Hospital, 11100 Euclid Ave., Cleveland, OH 44106-6038.E-mail: hot2@po.cwru.edu

\section{S. HUIJBREGTS, J.R. SEGUIN, M. ZOCCOLILLO, P.D. ZELAZO \& R.E. TREMBLAY. THE INFLUENCE OF MATERNAL SMOKING DURING PREGNANCY ON COGNITION AND BEHAVIOR DUR- ING THE PRE-SCHOOL PERIOD.}

The associations between maternal smoking during pregnancy (MSP) and cognition and behavior of offspring have typically been studied in school-age children, adolescents and young adults. The aim of this study was to assess these relationships in early childhood (1.5-3.5 years). Behavioral data of 2223 children born in 1997 were collected at ages 17 . 30. and 42 months. Cognition was assessed at 42 months. MSP showed a dose-dependent association with performance IQ (WPPSI-blocks). verbal IQ (PPVT), and short-term memory (VCR), and with physical aggression, hyperactivity, opposition, inattention, and separation anxiety at all assessments. The effect of MSP on cognitive functioning was entirely mediated by parental education. Multiple stepwise regression did however show a significant contribution of MSP to hyperactivity and physical aggression at all assessments over and above variance explained by socio-demographic, socio-economic, family background and parenting factors. Further, we found increased physical aggression when MSP (from 10 cigarettes a day or more) interacted (in MANOVA) with low maternal education. low family income, family history of antisocial behavior, maternal depression and poor parenting. The fact that these effects can be detected in preschoolers has implications for early developmental models of behavior regulation. The results strongly suggest that, among individual and family characteristics that predispose to chronic behavior problems, prevention of MSP should be a primary target. Despite the fact that the aspects of cognition examined here were not as sensitive to MSP as some behavior problems, the relation between MSP and self-regulatory aspects of cognition requires further study.

Correspondence: Stephan Huijbregts, Ph.D., Biopsychosocial Research Unit, University of Montreal, Hopital Ste-Justine, Bloc 5 - Etage A, 3175 chemin Cote Ste-Catherine, Montreal, OC H3T 1C5, Canada. E-mail: Stephan.Huijbregts@UMontreal.CA

\section{S.R. HOOPER, M. CROWSON, S. BEERS, C. BUIST, L. TUPLER \& M. DE BELLIS. NEUROPSYCHOLOGICAL FINDINGS IN NE- GLECTED VERSUS TYPICALLY DEVELOPING CHILDREN.}

Neglect in childhood is one of the most prevalent forms of child maltreatment. Evidence documenting the negative impact of neglect on the developing brain has begun to surface, with available findings indicating lower IQ, emotional dysregulation, speech/language deficits, and academic delays. Preliminary neuroimaging data indicate the presence of brain structure malformations (e.g.., corpus callosum), but few neuropsychological findings exist. This study examined neuropsychological functioning in two groups of children: (1) healthy children who had a documented history of neglect with no history of severe physical abuse. no sexual abuse or prenatal substance exposure, and no perinatal insults $(\mathrm{n}=12)$; and $(2)$ a typically developing group of healthy children with no history of abuse, neglect, brain injury, or psychiatric disorders $(\mathrm{n}=25)$. All participants and their parents were administered the KSADS-PE to determine their diagnostic presentation. All participants were given the core battery of the NEPSY and a brief IQ measure. Initial group comparisons revealed differences in terms of age and maternal education, but no differences in race, gender, or handedness. The groups did differ in IQ, with the Typical Group being significantly higher than the Neglected Group, $\mathrm{t}(35)=2.01, \mathrm{p}<.001$. A repeated measures MANCOVA controlling for age, maternal education, and IQ revealed significant group differences across all NEPSY domains, but one domain was not more impaired than another. These finding were generally consistent with the available literature, with the Neglect Group showing global dysfunction in IQ and all neurocognitive functions.

Correspondence: Stephen R. Hooper, Ph.D., Psychiatry, University of North Carolina School of Medicine, Center for Development and Learning, CB\# 7255, UNC, Chapel Hill, NC 27599-7255. E-mail: stephen. hooper@cdl.unc.edu

\section{K. YEATES, G. TAYLOR, B. BANGERT, A. DIETRICH, K. NUSS, J. RUSIN \& M. WRIGHT. POSTCONCUSSIVE SYMPTOMS IN CHILDREN WITH MILD HEAD INJURY: A PRELIMINARY REPORT.}

We are conducting a prospective, longitudinal study of postconcussive symptoms (PCS) in children with mild head injuries (MHI) and those with mild orthopedic injuries (OI). The children are 8 to 15 years of age when recruited. They and their families are assessed at 1 week, 1 month, 3 months, and 12 months post-injury. Both children and parents provide ratings of PCS, with pre-injury PCS assessed retrospectively shortly after the injury. Predictors of PCS include injury characteristics and cognitive abilities, as well as non-injury related child and family variables. Recruitment is ongoing, and the current preliminary findings are based on 80 children in the MHI group and 54 in the OI group, most of whom have been followed through 3 months post-injury. The groups are comparable in age, gender, socioeconomic status, and ratings of pre-injury PCS. In the MHI group, $42 \%$ report a loss of consciousness (LOC) and 16\% demonstrate abnormalities on MRI. Parents report more PCS in the MHI group than in the OI group at the baseline, 1 month. and 3 month assessments, controlling for pre-injury PCS. Differences are more pronounced for cognitive and somatic symptoms than for emotional or behavioral symptoms. Children in the MHI group also report more PCS, but only at baseline and only for cognitive and somatic symptoms. No group differences are apparent on tests of $\operatorname{cog}$ nitive abilities, although PCS are correlated with cognitive abilities in both groups. Within the MHI group, LOC is associated with greater parent report of cognitive symptoms, but not with other types of parentreported PCS or any child-reported PCS. The preliminary findings suggest that MHI result in specific PCS that may be related to injury severity. despite an absence of significant cognitive deficits.

Correspondence: Keith Yeates, PhD, Psychology, The Ohio State University, Children's Hospital, 700 Children's Dr., Columbus, OH 43205. E-mail:yeatesk@chi.osu.edu

\section{EWING-COBBS, M. BARNES, P. SWANK, H. LEVIN, M. DEN- NIS, S. CHAPMAN \& J. ARCHIBALD. PREDICTORS OF READ- ING AFTER TRAUMATIC BRAIN INJURY IN CHILDREN.}

Reading is vulnerable to disruption following pediatric traumatic brain injury (TBI). To examine variables influencing reading rate, accuracy and comprehension after TBI, we analyzed the contribution of demographic, injurv, and cognitive predictors of reading in children who sustained TBI and in 46 comparison children. The mean age at injury was 7.6 years. The mean age at testing for both groups was 12.5 years. Performance of the mild TBI $(n=43)$ and comparison groups $(n=40)$ was comparable on the dependent measures; therefore, their scores were combined and contrasted against scores from children with moderate and severe TBI $(n=46)$. Hierarchical regression models examined the following predictor variable groupings:1-TBI severity and age; 2 -word identification and rapid naming, and 3 -working memory. Predictors of comprehension also included indices of expressive language and syntactic comprehension. The Sobel test examined the significance of mediation paths. Across all reading outcomes, children with moderate to severe TBI performed more poorly than the comparison groups. Neither age at injury nor age at testing predicted the level of reading variables. The relationship between severity of TBI and both reading rate 
and accuracy was partially mediated through the impact of TBI on word decoding, rapid naming, and working memory (model R2=.60 and .63 , respectively). The effect of TBI on comprehension was partially mediated by word decoding and expressive language scores; however, rapid naming, working memory, and syntactic comprehension scores did not contribute to prediction (model R2=.50). Results are discussed in terms of multicomponent models of reading and studies of academic skills after TBI.

Correspondence: Linda Ewing-Cobbs, PhD, Pediatrics, University of Texas Health Science Center, 7000 Fannin, Suite 2401, Houston, TX 77030.E-mail: linda.ewing-cobbs@uth.tmc.edu

D.C. WEERS, R.A. YEO, J.P. PHILLIPS, W.M. BROOKS, H. PETROPOULOS, S. KERNEN, D.L. STIBICK, I. DRISCOLL \& B. HART. PATHOPHYSIOLOGY AND COGNITIVE FUNCTION FOLLOWING TRAUMATIC BRAIN INJURY IN CHILDREN: A PROTON SPECTROSCOPY STUDY.

Cognitive impairment following TBI in children has been well documented, although conventional clinical and neuroradiological diagnostic methods generally are poor predictors of functional outcome. Proton magnetic resonance spectroscopy (1H-MRS) is a non-invasive technique for measuring brain metabolites thought to indicate neuronal damage, metabolic depression, mitochondrial dysfunction, and inflammation following TBI. The present study utilized 1H-MRS and neuropsychological assessment to determine the contribution of regional neuronal injury and metabolic changes to cognitive deficits in pediatric TBI patients. Method: Eleven patients with TBI (mean age $=13.9)$ and ten normal controls (mean age $=14.9$ ) completed a general neuropsychological assessment of cognitive function. In addition, 1H-MRS measures of N-acetylaspartate (NAA) and choline (Cho) were acquired for all subjects in a slice of parenchyma superior to the lateral ventricles, using a multi-voxel spectroscopic imaging technique. Results: Children with TBI had lower mean NAA and higher mean Cho than controls. NAA and Cho were negatively correlated in the TBI group, although not in controls, reflecting neuropathological processes following TBI in children. TBI patients performed more poorly than controls on neuropsychological tests. NAA and Cho were strongly related to neuropsychological test performance in TBI patients, but not in controls. Conclusions: 1H-MRS findings parallel results of other clinical and experimental studies in demonstrating reduced metabolism and/or cellular injury following TBI in children. 1H-MRS can detect pathophysiological processes invisible to MRI and thereby provide accurate early measures of injury severity in children, leading to improved outcome prediction in pediatric TBI.

Correspondence: David C. Weers, Ph.D., Neurosurgery, Univ. of Texas Health Science Center at Houston, 1333 Moursund St., Suite H114, Houston, TX, TX 77030.E-mail: david.weers@uth.tmc.edu

Paper Session 6/1:00-3:00 p.m.

\section{Cognitive Response to Metabolic \& Structural Brain Insults}

\section{CLASON, R.O. HOPKINS, L.K. WEAVER, A.R. KEUNING \& W.S. BROWN. CALLOSAL DAMAGE IN CARBON MONOXIDE POISONING:STRUCTURAL CHANGES AND COGNITIVE CORRE- LATES. .}

Carbon monoxide $(\mathrm{CO})$ poisoning results in white matter lesions and demyelination. Corpus callosum (CC) damage occurs following $\mathrm{CO}$ poisoning yet the etiology of and its consequences are unknown. This study explored the structural effects of $\mathrm{CO}$ poisoning on the $\mathrm{CC}$ and the im- pact of regional CC atrophy and its relationship to neuropsychological performance. MRIs were obtained within 24 hours of $\mathrm{CO}$ exposure and 6 months post-CO poisoning from 54 patients with mild to moderate $\mathrm{CO}$ exposure. MRIs were also obtained from 59 control participants matched for age and gender. Callosal outlines were traced from midsaggital views, and then divided into 99 equidistant widths. Factor analysis of these 99 widths revealed 8 contiguous callosal subregions. Total $\mathrm{CC}$ area was significantly smaller in CO patients than controls $(\mathrm{p}=.04)$. Callosal subregions were consistently smaller in $\mathrm{CO}$ patients than controls, particularly in anterior $(\mathrm{p}=.01)$ and posterior $(\mathrm{p}=.04)$ subregions. Within the CO patients, comparing the 24 hour scans with the 6 month scans, the callosal midbody was significantly smaller across time $(p=.03)$. Neuropsychological performance improved in $\mathrm{CO}$ patients across time. Correlations between callosal subregions and neurocognitive performance in $\mathrm{CO}$ patients 6 months post-CO exposure revealed a significant correlation between a smaller anterior midbody and worse block design performance $(\mathrm{r}=-.27)$. We found subtle atrophic effects of $\mathrm{CO}$ poisoning on callosal morphology. Since most CC fibers are homotopic, our findings suggest that anterior callosal fibers may participate in the executive aspects of block design performance.

Correspondence: Warren S. Brown, Ph.D., Fuller Graduate School of Psychology, Travis Research Institute, 180 N. Oakland Ave, Pasadena, CA 91101. E-mail: wsbrown@fuller.edu

\section{J. WHITE, R.O. HOPKINS, N. KITTERMAN, E.W. GLISSMEYER \&. C. ELLIOT. NEUROCOGNITIVE FUNCTION IN PATIENTS WITH PULMONARY ARTERIAL HYPERTENSION.}

Background: Pulmonary arterial hypertension (PAH) is a rare and often fatal disease in which pulmonary artery pressure increases above normal levels (e.g. mean pulmonary artery pressure is $>25 \mathrm{mmHg}$ at rest). Little information is known regarding cognitive and emotional function in PAH patients. The purpose of this study was to assess neurocognitive function in PAH patients. Methods: 21 PAH patients, 16 females and 5 males with a mean age of 49.8 SD 11.0 years and mean education of 13.2 SD 2.9 years were enrolled. Demographic and medical data were obtained. Neuropsychological tests, questionnaires, and pre- and post $\mathrm{SpO} 2$ and heart rate were assessed. Cognitive impairments were defined as a score more than 1.5 SD below the mean on 2 tests per domain. Results: NY Heart classification: 19\% were class II, $71.4 \%$ class III, and $9.5 \%$ class IV. Mean time from PAH diagnosis to testing was 2.9 years. At diagnosis the mean $\mathrm{PaO} 2$ was 65.2 SD 10.9\%, mean pulmonary artery pressure of $48.0 \mathrm{SD} 15.2 \mathrm{mmHg}$. There was significant decline in FSIQ (mean=102.2 SD 18) compared with premorbid estimated IQ (mean=112.4 SD $8.9 ; \mathrm{p}<0.001)$. There were no significant differences in pre vs. post $\mathrm{SpO} 2$ or heart rate. $19 \%$ had impaired memory, $5 \%$ impaired executive function, $5 \%$ impaired motor speed, and $5 \%$ cognitive impairments. The mean BDI was 10.9 (range 0-26) and BAI was 13.4 (range $0-47$ ), significant symptoms of depression (19\%) and anxiety $(24 \%)$ were reported. Conclusions: PAH patients have significant cognitive impairments. The etiology of the cognitive impairments is unclear but may be due to hypoxia/ischemia, medications, severity and duration of disease.

Correspondence: Joanne White, Clinical Psychology, Brigham Young. University, 14731 S.Brewster Drive, Draper, UT 84020.E-mail: jodave@ comcast.net

\section{M.S. ALOIA, L. SWEET, R.L. RIGGS, J. ARNEDT \& L. SMITH. THE EFFECTS OF CPAP TREATMENT ON WORKING MEMORY AND MR SIGNAL IN SLEEP APNEA.}

OBJECTIVE: Sleep Apnea Syndrome (SAS) has been associated with both medical and psychological consequences. Cognitive correlates have been reported in most cognitive domains, but a clear picture of cogni- 
tive dysfunction has not yet been determined. Continuous Positive Airway Pressure (CPAP) treatment for SAS, has been shown to result in improvements in cognitive functioning. Our objective was to determine the degree to which treatment affected MR signal in SAS. METHODS: We recruited 5 individuals with moderate to severe sleep apnea, who were known users of treatment for our study. Participants underwent a functional MRI protocol using a working memory task, the 2-back, as an activation tool. Participants were studied after effective treatment and after withholding treatment for 2 consecutive nights. Conditions were delivered in a counterbalanced manner and participants were practiced on the activation task before each testing session. RESULTS: The on-treatment condition increased activation in the dorsolateral prefrontal cortex, supplementary motor region, and posterior parietal cortex during the 2-Back. Statistically, activation increased in the posterior parietal, supplementary motor, and dorsolateral prefrontal cortices when applying conservative comparison thresholds. Behaviorally, participants reacted to stimuli more slowly in the off-treatment condition than in the on-treatment condition. Accuracies were similar across conditions. CONCLUSIONS: CPAP treatment for sleep apnea may enhance brain activation in expected areas during a complex working memory task. Enhanced activation is accompanied by behavioral changes in reaction time. This study has implications for better understanding the neurofunctional underpinnings of SAS and the effects of treatment on brain function.

Correspondence: Mark S. Aloia, PhD, Psychiatry and Human Behavior, Brown University, Duncan Building, Butler Hospital, 700 Butler Drive, Providence, RI 02906.E-mail: aloia@brown.edu

\section{C.L. ARMSTRONG, B.M. HAMPSTEAD \& L. GUGLIELMI. HIPPOCAMPAL RESPONSE TO NEURO-ONCOLOGICAL STRESSORS.}

Problem: Cognitive studies of patients with brain tumors prior to radiotherapy (RT) show a robust impairment in visual configural memory followed by improvement over one year, unrelated to RT. This suggests that the hippocampus may be highly sensitive to neuro-oncological stressors, including emotional and endocrine responses to tumor diagnosis, neurosurgery, immune-mediated effects of the tumors, and RT. This study examined hippocampal response over time in patients with brain tumors. Methods: Magnetization transfer (MT) imaging of 21 patients with low-grade supratentorial brain tumors who received RT, and who had no other co-morbid risk for white matter or neural injury, was done prior to RT, 1.5 mos post full dose RT, and 4.5 mos post RT. MT ratios (MTR) were measured for the right and left hippocampi for each patient time point, and examined with a mixed model that accounted for individual random effects, tumor and surgery effects, and cognitive function. Results: The MTR for hippocampus ipsilateral to tumor and surgery was unchanged over time, indicating that the biological determinants of the MTR were indiscriminable, resulting in noise. The MTR for hippocampus contralateral to tumor/surgery showed improvement after diagnosis: it was lowest and impaired at baseline, and recovered significantly to 1.5 mos after RT, and correlated with the improvement in visual configural memory. However, the MTR of the hippocampus declined by 4.5 mos post-RT, suggesting the possibility that RT caused damage. Conclusions: It is unknown which brain structures are most sensitive to RT-induced damage. Recent animal studies have shown that irradiation induces dysfunction of neurogenesis with the hippocampus (decrease in hippocampal neurogenesis, loss of microglia, and disruption of microvascular angiogenesis within the neurogenic microenvironment). This is the first study to measure hippocampal response to neuro-oncological stressors including RT in humans.

Correspondence: Carol L. Armstrong, Neurology, The Children's Hospital of Philadelphia and University of Pennsylvania, 3535 Market Street,Rm.1410, Philadelphia, PA 19104.E-mail: armstrongc@email. chop.edu
E.M. MUELLER-OEHRING, T. SCHULTE, C. RAASSI, A. PFEFFERBAUM \& E.V. SULLIVAN. VISUOSPATIAL PROCESSING IN ALCOHOLISM AND AGING: INHIBITORY DEFICITS IN A GLOBAL/LOCAL LETTER TASK.

Higher-order visuoperception entails extraction of global features, dependent on right hemispheric functioning, and local details, dependent on left hemispheric functioning. Here, we studied inhibitory and facilitative effects of attention to local and global stimulus features on response speed in aging and alcoholism. We developed a computerized block-design, two choice (yes/no) reaction time (RT) task to examine the effects of attention to global, local, or combined stimulus features of letters. The same stimuli were presented in each block; only the instruction differed. Subject groups comprised 11 alcoholics, 11 agematched controls, and 12 older controls (>60 years). Overall, older subjects had longer RTs than alcoholics who had longer RTs than younger controls. All subjects had longer RTs when attending to global than local targets and even longer RTs when dividing attention between both processing levels. However, all groups profited when target letters were presented on both levels, even when attending only to one feature (global or local); this gain indicated processing and facilitative effect of the unattended feature. Additionally, alcoholics and older controls had significantly longer RTs than younger controls when attending to local features embedded in a global target and also when rejecting local targets when attending to the global level. This RT slowing suggests inhibitory compromise in the global/local interaction process. Age and alcoholismrelated alterations in inhibitory and facilitative mechanisms of visuoperception may be related to compromised information exchange between the cerebral hemispheres caused by disruption of callosal fiber integrity known to occur in both aging and alcoholism. [Support: AA10723, AA05965, AG17919]

Correspondence: Eva M. Mueller-Oehring, Ph.D., Dept. of Psychiatry and Behavioral Sciences, Stanford University School of Medicine, 401 QuarryRoad, Stanford, CA 94305-5723.E-mail: evamoe@stanford.edu

\section{B.C. SCHWEINSBURG, A.D. SCHWEINSBURG, M.J. TAYLOR, S.F. TAPERT \& I. GRANT. RECOVERY OF BRAIN FMRI RE- SPONSE TO A SPATIAL WORKING MEMORY TASK IN ABSTI- NENT ALCOHOLICS.}

Previous functional magnetic resonance imaging (FMRI) studies in adult and young-adult alcoholics have revealed aberrant brain response to a spatial working memory (SWM) task during sobriety. While quantitative magnetic resonance imaging and neuropsychological studies show improvements with abstinence, the potential for recovery with long-term sobriety has not been evaluated with FMRI. We studied two groups of male alcoholics at different stages of abstinence, and healthy male controls. We predicted that long-term sober individuals would be comparable to controls, while recently detoxified alcoholics would have an abnormal FMRI response to SWM. Twenty-three recently detoxified alcoholics sober 2 -8 weeks (RDA: age=46.3, education=12.4), 11 long-term abstinent alcoholics sober $>18$ months (LTA: age $=46.3$, education=13.4), and 7 healthy controls (age $=46.6$, education=13.8) were scanned. Blood oxygen level dependent (BOLD) imaging was collected while subjects performed the task, which contrasted "2-back" SWM for locations with an active vigilance baseline. The groups had comparable accuracy rates on the SWM task. In addition, the groups had similar patterns of response during the active vigilance baseline condition. RDA showed significant increases in brain response to the SWM task in superior frontal and posterior parietal regions compared to CON and LTA $(p=.0167$, cluster volume $=1072 \mu \mathrm{L})$. However, LTA and CON displayed similar patterns of activation, including no significant superior frontal or parietal differences. The results are consistent with previous studies demonstrating aberrant BOLD response in detoxified alcoholics. The increased activation patterns found in RDA may be a compensatory response due to underlying changes in neuronal integrity. Furthermore, despite being cross-sectional in nature, these findings support the notion that protracted sobriety from alcohol is associated with improvement in brain functioning. VA Merit Review SA325 to I. Grant 
Correspondence: Brian C. Schweinsburg, B.A., Psychiatry, SDSU/UCSD, 3350 La Jolla Village Drive, 116A, San Diego, CA 92161. E-mail: bschweinsburg@ucsd.edu
Correspondence: Joshua I. Breier, PhD, Neurosurgery, University of Texas Health Science Center at Houston, 1333 Moursund St., Suite H114, Houston, TX 77098. E-mail: joshua.i.breier@uth.tmc.edu

\section{Poster Session 4: Neuropsychological Functions in Subcortical Disorders/1:00-3:30 p.m.}

\section{Subcortical Dementia} but more subtle ipsilesional deficits have also been reported. Limb apraxia is the most common clinical example of these deficits and is more common after left hemisphere damage (LHD). However, few studies have examined the impact of ipsilesional deficits on rehabilitation outcome. The Jebsen-Taylor Hand Function Test (JHFT), which simulates activities of daily living, is widely used for stroke rehabilitation purposes, but ipsilesional deficits after stroke have not been methodically investigated. The present study assessed 34 stroke patients with LHD, 24 with right-hemisphere damage (RHD), 41 control subjects using their left hand (LNC), and 25 using their right hand (RNC). All participants were right-handed. Ipsilesional JHFT performance was impaired to the same extent in the LHD and RHD groups. LHD apraxics had worse scores on the JHFT than the LHD non-apraxics and the LNC group. Regression analyses demonstrated that severity of apraxia was the best predictor of the JHFT for the LHD group and right (ipsilesional) motor performance (grip strength and finger tapping) was the best predictor of JHFT for the RHD group. These findings indicate 1) ipsilesional deficits are present on simulated activities of daily living, suggesting that rehabilitation after stroke must include the unparalyzed arm, and 2) limb apraxia is a better predictor of functional skills than aphasia or simple motor skills (grip strength and finger tapping) suggesting that limb apraxia should be assessed more routinely by neuropsychologists.

Correspondence: Spencer R. Wetter, Ph.D., Psychiatry, UC San Diego, 4465 Vision Dr. \#8, San Diego, CA 92121.E-mail:spwetter@yahoo.com

\section{J.I. BREIER, E. CASTILLO, C. BOAKE, R. BILLINGSLEY, L.M. MAHER, E. NOSER, G. FRANCISCO \& A.C. PAPANICO- LAOU. MAPS OF RECEPTIVE LANGUAGE FUNCTION IN PA- TIENTS WITH CHRONIC APHASIA AFTER STROKE USING MAGNETOENCEPHALOGRAPHY.}

In order to examine neural correlates of language function following stroke, six individuals with moderate chronic aphasia secondary to ischemic left MCA stroke and six age-matched controls were given a running recognition memory task for spoken words while evoked magnetic fields were recorded using magnetoencephalography. Relative to controls, patients exhibited an elevation in language-specific activation (after the resolution of the $\mathrm{N} 1 \mathrm{~m}$ ) of right temporoparietal (TMP) areas homologous to receptive language areas of the left hemisphere during the time window between 200 and $600 \mathrm{~ms}$ post-stimulus onset. While left hemisphere activation in controls was generally confined to perisylvian language areas, patients exhibited a greater probability of activation in extra-perisylvian areas surrounding the lesion, including angular, inferior temporal, and fusiform gyri $\left(\chi^{2}=15.4, p \leq .0001\right)$. The timing of peak activity in left TMP was delayed by $220 \mathrm{~ms}$ inpatients compared to controls, $\mathrm{F}(1,11)=5.53, \mathrm{p} \leq .04$, and the timing of the onset of language-specific activation was delayed by over $250 \mathrm{~ms}, \mathrm{~F}(1,10)$ $=3.86, \mathrm{p} \leq .08$, despite normal timing of the $\mathrm{N} 1 \mathrm{~m}$. In patients, the ability to respond to multistep spoken instructions (Token Test) was an inverted $U$ shaped function of the relative degree of activation of the left as compared to right hemisphere, with greater activation in either hemisphere associated with better performance, $F(1,4)=11.97, \mathrm{p} \leq .025$. Results are consistent with suggestions that re-organization of language function within peri-lesional areas, as well as areas within right TMP, can support recovery of language function after stroke.

\section{V.S. ZIZAK, V. FILOTEO, J.A. LUCAS, L.M. RILLING, D.P. SALMON, K.L. POSSIN \& A. WONG. DO ALL PATIENTS WITH SUBCORTICAL PATHOLOGY SHOW A MEMORY RE- TRIEVAL DEFICIT?}

Previous studies have shown that patients with subcortical pathology perform better on recognition tasks than free recall, suggesting an impairment in retrieval processes. However, this "retrieval deficit" profile has not been seen in all subcortical patients (Filoteo et al., 1997 and Massman et al. 1990). To explore this issue further, we examined free recall and recognition memory in 150 Parkinson's disease (PD) patients and 66 Huntington's disease (HD) patients using three indices from the California Verbal Learning Test (standard scores for Trial 5 recall, Recognition Discriminability, and Long Delay Free Recall). Participants were classified as either showing a retrieval deficit profile (Recognition Disciminability-Trial $>=2$ ) or not showing a retrieval deficit profile (Recognition Disciminability -Trial $5<2$ ), and as having normal-to-mildly impaired memory (Long Delay Free Recall $>-2$ ) or moderately-to-severely impaired memory (Long Delay Free Recall $<=-2$ ). Results indicated that (1) a retrieval deficit was not highly prevalent in patients with PD, (2) a retrieval deficit was observed with greater frequency in the HD patients, and (3) HD patients with moderate-to-severe recall were more likely to demonstrate a retrieval deficit than HD patients with normalto-mildly impaired recall. These findings suggest that not all patient groups with subcortical pathology display a retrieval deficit profile, but in groups that do, it is more frequent in patients with significant memory impairment.

Correspondence: Vincent Filoteo, Ph.D., Psychiatry, UCSD, Psychology 116-B, VASDHS, 3350 La Jolla Village Dr., San Diego, CA 92161. Email: vfiloteo@ucsd.edu

\section{Parkinson's Disease}

\section{G.P. CRUCIAN, D. BURKS, J. MIELKE, B. SHENAL, R. RHODES, L. GRANDE, K. WOMACK, A. RIESTRA, M.S. OKUN, D. BOW- ERS \& K.M. HEILMAN. MEMORY IN PARKINSON'S DISEASE: A STEP-WISE ANALYSIS.} common in Parkinsons Disease (PD). On clinical measures of memory, PD patients consistently exhibit deficits on word-list learning tests, such as the California Verbal Learning Test (CVLT). Several possible explanations for these deficits include deficient encoding, consolidation and/or retrieval. Difficulties with distractibility, rapid forgetting, and semantic organization/processing have also been suggested. A direct relationship between these cognitive processes and PD patients' word-list learning performance, however, has not been demonstrated. We report data from a study using the CVLT in a group of medicated, non-demented PD subjects (28 men, 20 women) and a group of matched controls (9 men, 17 women). Preliminary analysis revealed deficits on first-trial learning, 5trial total learning, short-delay free recall, long-delay free recall, and recognition recall in PD subjects. A forward step-wise regression analysis was conducted using long-delay free recall as criterion, and the re-
Difficulties with memory and generating problem-solving strategies are 
maining CVLT scores, along with age, education, sex, and group, as predictors. This analysis revealed three variables that significantly predicted long-delay free recall. Short-delay free recall accounted for the largest proportion of variance $\left(B=0.47, \mathrm{R}^{2}\right.$ change $\left.=0.696\right)$, followed by 5 trial total learning $\left(B=0.44, \mathrm{R}^{2}\right.$ change $\left.=0.095\right)$, and serial-order clustering $\left(B=-0.12, \mathrm{R}^{2}\right.$ change $\left.=0.012\right)$. That group membership did not contribute to the equation, yet was associated with significant differences in recall, suggests that PD might affect memory function indirectly. Thus, long-term free recall was primarily influenced by a failure to encode or consolidate this new information, likely induced by distractibility. This encoding impairment might be related to use of an inefficient stimulus-driven learning strategy such as rote repetition, rather than a self-generated semantic clustering strategy.

Correspondence: Gregory P. Crucian, PhD, Neurology, University of Florida, 100 S. Newell Drive, Rm. L3-100, Gainesville, FL 32610. Email: crucigp@neurology.ufl.edu

\section{SIMARD, R. VAN REEKUM, M. PANISSET, M. FREEDMAN \& S. GAUTHIER. DIFFERENTIAL IMPAIRMENT OF WORKING MEMORY IN DEMENTIA WITH LEWY BODIES AND PARKIN- SON'S DISEASE.}

Introduction: Dementia with Lewy bodies (DLB) and Parkinson's disease (PD) are two clinical syndromes sharing parkinsonism and attentional deficits. However, a comparative study of the functioning of the Central Executive System (CES) and slave sub-systems of Working Memory (WM) has never been performed in patients with DLB and PD. The goal of the present study was therefore to investigate the functioning of WM components in DLB and PD+dementia and PD. Method: Four subjects with possible DLB and parkinsonism, 8 subjects with PD + dementia (D), 6 subjects with PD, and 11 controls were tested using the dual task paradigm (measure of the CES), tracking and digit span tasks (respectively, measures of the visuospatial and verbal slave sub-systems). Results: A oneway ANOVA showed a significant difference between the 4 groups on the tracking task $(\mathrm{F}=6.732, \mathrm{df}=3,25, \mathrm{P}=0.002)$, the dualtask $(\mathrm{F}=3.050, \mathrm{df}=3.25, \mathrm{P}=0.047)$, and the digit span task $(\mathrm{F}=7.123$. $\mathrm{df}=3,25, \mathrm{P}=0.001)$. Post hoc SNK analyses $(\mathrm{alpha}=0.05)$ showed that only subjects with DLB were significantly impaired when compared to controls on the dual task. The patients with $\mathrm{PD}+\mathrm{D}$ were more impaired than the other subject groups on the tracking task, and more impaired than subjects with PD and controls on the verbal span task, but their performance did not significantly differ from that of subjects with DLB. Conclusion: The results suggest a differential alteration of WM in DLB and $\mathrm{PD}+\mathrm{D}$, with a more impaired CES in DLB than in PD+D, and more impaired slave sub-systems in PD+D than in DLB.

Correspondence: Martine Simard, Ph.D., Universite Laval, Pavillon Felix-Antoine Savard, Quebec City, QC G1K 7P4, Canada. E-mail: Martine.Simard@psy.ulaval.ca

\section{M.K. YORK, H.S. LEVIN, E.M. SOETY, E.C. LAI, J. JANKOVIC \& R.G. GROSSMAN. INFORMATION PROCESSING SPEED INFLU- ENCES THE COMPONENT PROCESSES OF VERBAL WORKING MEMORY IN PARKINSONS DISEASE PATIENTS.}

Parkinsons disease (PD) is purported to disrupt the frontostriatal neural circuitry responsible for successful performance of working memory. A three-component model of working memory has been proposed, including two slave systems and a Central Executive, which is responsible for monitoring and manipulation of material. Researchers have also suggested that declines in working memory may be the result of general slowing of processing speed, which is a cardinal symptom of PD. We investigated 1). the dissociation between the component processes of verbal working memory in PD patients and 2). the role information processing speed plays on verbal working memory in PD patients. We examined 18 mild PD patients, 24 moderate PD patients, and 20 control subjects, using the N-Back task (maintenance), the Dual-Processing task (monitoring/manipulation), and Digit Symbol Oral task (pro- cessing speed). Mild PD patients demonstrated a deficit in the monitoring/manipulation component of working memory, while moderate PD patients demonstrated deficits in both the maintenance and monitoring/manipulation components of working memory as compared to the controls. However, when information processing speed was entered as a covariate, stage of disease progression did not account for any additional variance in the component processes of working memory. These findings suggest that the component processes of working memory can be dissociated in Parkinsons disease. However, slowed information processing speed, rather than a change in the specific cognitive domain, accounts for the decline in these component processes of working memory.

Correspondence: Michele K. York, Ph.D., Baylor College of Medicine, 6560 Fannin, Ste 944, Houston, TX 77008.E-mail:myork@bcm.tmc.edu

\section{P.J. MCNAMARA, A. BROWN, G. CHAPMAN \& R.R. DURSO. VERBAL PERSEVERATIONS IN PATIENTS WITH PARKINSONS DIS- EASE (PD): RELATION TO DEFICITS IN COGNITIVE PLANNING..}

Background. Difficulties in shifting of attentional set and perseverative motor behavior are common in patients with PD. We hypothesized that PD patients would evidence elevated levels of verbal perseverations relative to age-matched controls and that these errors would be related to a deficit in cognitive planning. Methods. Twenty-four patients with PD (mean H-Y stage= $2.7(.65)$; mean $\mathrm{MMSE}=25.5(3.1)$; mean age $=70.7$ (10.4)); and 17 age-matched elderly controls (mean age $=66.6$ (8.2), vs. PD mean $\mathrm{p}=.16$ ) were administered 2 versions of the letter and category fluency tasks as well as a task of cognitive planning (Tower of LondonTOL, Shallice, 1978). Outcome Measures. Total number of perseverations across all tasks, total recurrent perseverations, and average lag between perseverations. Analyses. Protected t-tests for independent groups and with-in group Pearson product moment correlations. Results. PD patients evidenced a significantly greater number of total perseverations (PD mean=3.1(1.8), (C)ontrol mean=1.8(1.3), p=.01), and a greater number of perseverations adjusted for total number of responses (PD mean $=.05(.02), \mathrm{C}$ mean $=.02(.01), p=.0001)$. No differences between PD patients and controls were obtained for average lag (distance in \#words) between two perseverations. PD performances on measures of planning were significantly impaired relative to controls (Mean1stmove $\mathrm{PD}=4.9(6.2), \mathrm{C}=10.4(4.3), \mathrm{p}=.0001)$; total rule violations: (PD mean $=4.09(2.5)$, $\mathrm{C}$ mean=1.3(1.8), $\mathrm{p}=.01)$. Total recurrent perseverations in PD patients were significantly correlated with mean first move $(\mathrm{r}=.72, \mathrm{p}=.001)$ and move accuracy $(\mathrm{r}=-.89, \mathrm{p}=.0001)$ on the TOL. Conclusions. Recurrent verbal perseverations are elevated in word generation tasks in PD patients and are strongly related to impairment in cognitive planning.

Correspondence: Ariel Brown, BA, Research Service, Boston VA Medical Center, Department of Neurology (127), 150 South Huntington Ave., Boston, MA 02459.E-mail: Ariel.Brown@med.va.gov

\section{R.D. RHODES, D.W. BURKS, G.P. CRUCIAN, B.V. SHENAL, J.B. MIELKE, K.B. WOMACK, A.R. RIESTRA \& K.M. HEILMAN. EVIDENCE FOR A PERIPERSONAL SPATIAL BIAS IN PEOPLE WITH PARKINSON'S DISEASE.}

Previous research has revealed that when normal participants attempt to bisect radial or vertical lines they demonstrate a bias toward extrapersonal space. Additionally, recent research from our laboratory indicates that this extrapersonal bias also exists for the bisection of horizontal lines (coronal plane). Thus, when horizontal lines are placed on the right side of normal participants' midsagittal plane (viewer-centered right hemispace) and participants attempt to find the middle of these lines, they are biased to the right. Similarly, when these lines are placed in left hemispace, participants' attempted bisections are biased to the left. The purpose of the current study was to determine if participants with Parkinson's Disease (PD) also show an altered spatial bias in the coronal plane using horizontal lines. Participants with PD ( 4 women, 8 
men, mean age $=62$ ) were asked to bisect 48 horizontal lines (intersection of the transverse and coronal planes) that were positioned either to the right or left of midline, alternately using their right or left hand. Analyses indicate that the participants with PD had a significant peripersonal, or medial, bias in their midline estimations. The peripersonal or medial bias found in these PD participants is in the opposite direction from that found in the control participants. Therefore, these results suggest that normal individuals have an extrapersonal bias while individuals with PD have a peripersonal bias.

Correspondence: Robert D. Rhodes, Neurology, University of Florida, McKnight Brain Institute, 100 S. Newell Drive, Gainesville, FL 326100236.E-mail:rhodes@neurology.ufl.edu

\section{S. DAVIDSDOTTIR \& A. CRONIN-GOLOMB. DOUBLE DISSOCI- ATION OF PERFORMANCE ON CLASSIC AND EMOTIONAL STROOP TASKS IN PARKINSON'S DISEASE OF LEFT- VS. RIGHT- SIDE MOTOR ONSET.}

Parkinson's disease (PD) is a progressive neurodegenerative disorder that is associated with motor, cognitive and affective symptoms. This study investigated attention and mood in PD with respect to relevant cognitive and anatomical substrates. METHOD: Twenty-two nondemented PD patients, including 13 with right-hemisphere onset (LPD) and 9 with left-hemisphere onset (RPD), and 15 healthy control participants (HC) participated in the study. LPD and RPD had similar motor severity and duration of disease and all groups were matched for age and education. Participants completed self-report mood questionnaires and two Stroop attention experiments that have been related to frontal functioning; the classic Stroop and the emotional Stroop test with words of different emotional valences. RESULTS: Mood questionnaires indicated a higher severity of anxiety and depression in LPD than HC, who were similar to RPD on these measures. Results indicated a double dissociation between classic and emotional Stroop performance. Whereas RPD showed greater interference than HC on a combined analysis for words of sad and PD-related content on the emotional Stroop but did not perform differently from HC on the classic Stroop. LPD showed the elevated interference effect for the classic Stroop but not the emotional Stroop. CONCLUSIONS: These results indicate that in PD, the right frontal lobe has a predominant role in the successful inhibition of automatic verbal responses to affect-neutral stimuli, whereas the left frontal lobe is more involved for affect-laden stimuli. These findings underline the importance of including left and right hemiparkinsonian patients in research on emotion and attention in PD.

Correspondence: Sigurros Davidsdottir, MA, Boston University, 648 Beacon Street, 2nd floor, Boston, MA 02215. E-mail: rdavids@bu.edu

\section{S. DAVIDSDOTTIR \& A. CRONIN-GOLOMB. ALEXITHYMIA IN PARKINSON'S DISEASE.}

Affective problems in Parkinson's disease (PD) are increasingly recognized, including a high prevalence of mood disorders and abnormal emotional processing. Alexithymia is characterized by an external focus of thinking, inability to identify one's own emotions and difficulty communicating one's emotional state to others. Whereas alexithymia is associated with disturbances in emotional processing, this construct has not been examined in PD. The aim of this study was to investigate alexithymic features in PD. METHOD: The study included twenty-two nondemented patients with PD and fifteen age- and education-matched healthy control participants (HC). Participants completed self-report measures of alexithymia, depression and anxiety. RESULTS: PD patients reported a significantly greater difficulty identifying feelings than HC, whereas no differences was found between the two groups in regard to the extent of external focus of thinking or the ability to communicate emotions to others. Difficulty identifying feelings in PD was significantly associated with a lower score on a general measure of overal mental status (Mini Mental State Examination) and endorsement of greater numbers of symptoms of anxiety and depression. There was a trend for education level to be associated with ease of identifying feelings in PD. CONCLUSIONS: These results from self-report questionnaires are consistent with findings of affective problems and abnormal emotional processing in PD. PD patients' difficulty in identifying their emotional state is relevant for the planning of psychotherapy treatment with this population and should be specifically targeted in therapy.

Correspondence: Sigurros Davidsdottir, MA, Boston University, 648 Beacon Street, 2nd floor, Boston, MA 02215.E-mail: rdavids@bu.edu

\section{M.M. AMICK, H.E. SCHENDAN \& A. CRONIN-GOLOMB. BODY SIDE OF PARKINSON'S DISEASE MOTOR SYMPTOM ONSET PREDICTS PERFORMANCE ON HIERARCHICAL PATTERN PERCEPTION.}

The relation between body side of Parkinson's disease (PD) motor symptom onset and visuospatial processing was examined with hierarchical images. In hierarchical images, local forms are spatially arranged to create a global form. Convergent evidence indicates that the right occipito-temporal-parietal junction (OTP) preferentially processes information at the global level, whereas the left OTP preferentially processes information at the local level. Damage to the left but not right rostral inferior parietal lobule (L-IPL) disrupts controlled attention to different hierarchical levels. Because hierarchical pattern processing is independent of dorsolateral prefrontal cortex function, impaired performance on this task reflects posterior association cortex dysfunction. We hypothesized that patients with right-side onset (RPD, left hemisphere dysfunction) would demonstrate global primacy, whereas left-side onset patients (LPD, right hemisphere dysfunction) should show local primacy. It was also predicted that the RPD patients (L-IPL dysfunction) would demonstrate impaired controlled attention relative to the LPD and control groups. PD patients (10 LPD, 10 RPD) and 12 age- and education-matched control participants viewed hierarchically arranged alphanumeric stimuli and identified targets occurring at the local or global level. Manipulating the probability of targets occurring at either level assessed controlled attention. The groups did not differ on tasks requiring controlled attention. By contrast, LPD participants exhibited deficient global processing, whereas RPD participants exhibited deficient local processing. These findings emphasize that side of PD motor symptom onset predicts different types of visuospatial impairments and suggest that the neuropathology of PD results in asymmetrical dysfunction of the parietal lobes and related posterior regions.

Correspondence: Melissa M. Amick, Ph.D., Neurology/ Medical Rehabilitation, Memorial Hospital, 111 Brewster Street, Pawtucket, RI 02860. E-mail:Melissa_Amick@Brown.edu

\section{KRCH \& J.C. BOROD. PERCEPTION OF EMOTION: A PRE- LIMINARY COMPARISON OF PARKINSON'S DISEASE AND HEALTHY SUBJECTS.}

The existing literature on the expression of emotion delineates clear-cut deficits in patients with Parkinson's disease (PD) as compared to healthy controls, across communication channels (Borod \& Brickman, 2001). However, there is contradictory evidence as to whether patients with PD have deficits in perceiving emotion. In addition, few studies have examined emotional perception using a range of modalities (e.g., facial, prosodic, gestural, postural, and/or lexical). In the present study, the performance of individuals with $\mathrm{PD}(\mathrm{n}=9)$ and demographically matched healthy controls $(n=9)$ was compared on identification and discrimination tasks from the New York Emotion Battery (Borod, Welkowitz, \& Obler, 1992) using stimuli from facial, prosodic, and lexical (both single words and sentences) channels. Overall, there were no significant subject group differences in the ability to process emotional stimuli or significant interactions between Group and Task or Channel. Results are consistent with a number of studies in the PD literature (for review, see Zgaljardic, Borod, Foldi, \& Mattis, in press). Importantly, we also included measures to control for nonemotional aspects of the experimental perception tasks, general cognitive ability, attention, and depression. 
None of these factors affected the pattern of results on the emotion tasks. When relationships among channels were examined, for identification, facial and prosodic channels were more strongly related to each other than to the lexical channel. As expected, the two lexical tasks were significantly correlated. For discrimination, a different pattern among channels emerged, as the only significant correlation was between prosodic and lexical tasks.

Correspondence: Denise Krch, M.A., Psychology, Queens College and The Graduate Ctr of CUNY, NSB-E318, 65-30 Kissena Blvd., Flushing, NY 11367.E-mail: dkrch@netzero.net

\section{M.M. LUBOMSKI, J.C. BOROD, M.L. ZAVALA, J.L. SPIELMAN, T.D. HALBIG, T. NICHOLLS, D.J. ZGALJARDIC, N. GATES, L. RAMIG \& W. KOLLER. NEURAL SUBSTRATES UNDERLYING EMOTIONAL PROCESSING DEFICITS IN PARKINSON'S DIS- \\ EASE. .}

Individuals with Parkinson's disease (PD) have been characterized as displaying masked facies and reduced voice amplitude. More recently, another communication disorder has been examined in PD - emotional processing deficits (EPDs) - which refer to emotional expression, perception, and experience across multiple channels (e.g., facial, prosodic, or gestural). In Borod and Brickman (2001), 23 studies were reviewed in terms of behavioral findings, revealing that PD patients demonstrated consistent expression deficits, equivocal findings for perception, and no experiential deficits. The current paper focuses on ascertaining the neurobiological bases for EPDs observed in PD. We conducted a re-examination of the studies mentioned above, as well as an update of that literature, and a review of neuroimaging literature pertaining to PD and emotion. Our review revealed a number of brain regions that appear to underlie the association between PD and emotion, including frontostriatal circuitry and connections between the basal ganglia and the limbic system (e.g., anterior cingulate cortex), as well as the role of dopamine in emotional processing. Furthermore, the review suggested (e.g., Breitenstein et al., 2001) that cognitive deficits found in PD (e.g., working memory) may contribute to difficulties in emotional perception. In light of findings that PD patients often convey negative impressions through facial and vocal channels, further consideration is directed towards ascertaining whether PD patients have difficulty with discrete emotions and examining possible neuroanatomical structures. Finally, literature on the effects of deep brain stimulation on mood is reviewed and considered as another approach to understanding the neural substrates for EPDs in PD.

Correspondence: Michelle M. Lubomski, B.S., Psychology, Queens College and The Graduate Center of the City University of New York, NSBE318, Queens College and the Graduate Center of CUNY, 65-30 Kissena Blvd., Flushing, NY11367.E-mail:TLubomski@aol.com

\section{BOWERS, W. BOSCH, T. GOBER, H. MONTIJO, K. . MILLER, U. SPRINGER, F. KELLY \& M. OKUN. STARTLING FACTS ABOUT EMOTION IN PARKINSON'S DISEASE.}

Recent studies have suggested abnormalities of the amygdala in patients with Parkinsons disease. Not only does the amygdala play a key role in danger detection and fear potentiated startle, it is closely linked to basal ganglia limbic circuitry including the ventral striatum. In the present study, we examined whether patients with Parkinsons disease (PD) had normal emotional modulation of startle to unpleasant and pleasant pictures and hypothesized that PD patients would show diminished emotional reactivity relative to controls. To test this hypothesis, 24 medicated Parkinson patients and age- and education matched Controls viewed standard sets of pleasant (erotica), unpleasant (mutilations) and neutral pictures for six seconds each. During this time, white noise bursts (95db, 50ms) were binaurally presented to elicit startle eyeblinks, measured from the orbicularis oculi. Subjective ratings of valence and arousal were also obtained. The PD and Control groups were not demented or depressed based on neurocognitive and psychiatric screening. We found that both the PD patients and Controls showed significantly larger startles during unpleasant versus pleasant pictures (i.e., the normal pattern of emotion modulation). However, this effect was significantly weaker and less robust in the PD patients than the Controls (i.e., Group X Affect interaction). Specifically, startle to negative pictures was significantly smaller in PD than Controls, with no group differences to pleasant pictures. In summary, our findings suggest that medicated PD patients are less emotionally reactive to aversive pictures that Controls. The basis for diminished reactivity to aversive stimuli is unknown, but may reflect altered modulation of the startle circuitry by the amygdala of PD patients, even in medication-on states. The relationship between our findings and the common occurrence of emotional blunting and apathy in Parkinsons disease will be discussed.

Correspondence: Dawn Bowers, Ph.D., Clinical \& Health Psychology, University of Florida, PO Box 100165, Gainesville, FL 32608. E-mail: dbowers@hp.ufl.edu

\section{S. FARELLA-BUSCH, M.J. HAMBERGER, R.S. FORSTER \&. A.C. WILLIAMS. COGNITIVE AND EMOTIONAL OUTCOME OF SUBTHALAMIC NUCLEUS DEEP BRAIN STIMULATION.}

Several investigators have examined various aspects of cognitive and motor functioning before and after subthalamic nucleus deep brain stimulation (STN DBS) in patients with Parkinson's disease. Virtually all studies have reported improvements in motor functioning and mood. However, the cognitive effects of STN DBS have been more equivocal. The most common outcome reported has been reduced verbal fluency and many studies reported memory decline. Thirteen Parkinson's disease patients underwent pre- and post-operative DBS implantation neuropsychological testing. Domains assessed included: global cognitive functioning, visual perceptual and spatial functioning, language, executive functioning, and verbal and visual memory. Psychological functioning was assessed utilizing a detailed self-administered inventory. Preand post-operative test scores were compared via paired sample t-tests. Results showed declines in categorical fluency $(\mathrm{p}<.05)$ and subjective anxiety $(p<.05)$. Pearson's correlations using pre to postoperative change scores showed that reduced categorical fluency was associated with longer time to postoperative assessment, suggesting that declines continue postoperatively. Correlations also showed that declines in list learning were associated with increasing age $(\mathrm{r}=.68, \mathrm{p}<.05)$, suggesting that older individuals are more likely to have greater memory decline postoperatively. These findings, if reliable, might assist in predicting postoperative cognitive and emotional functioning, which would assist patients in surgical decisions, and in preparing for postoperative care. Correspondence: Susan Farella-Busch, Ph.D., The Neurological Institute, Columbia University, 710 West 168th Street, New York, NY 10032. E-mail:samfare@aol.com

\section{D.J. ZGALJARDIC, J.C. BOROD, N.S. FOLDI, P. MATTIS, M.F. GORDON, A.S. FEIGIN \& D. EIDELBERG. A NEUROPSY- CHOLOGICAL EVALUATION OF COGNITIVE AND BEHAVIORAL IMPAIRMENTS IN PARKINSON'S DISEASE: RELATIONSHIPS TO FRONTOSTRIATAL CIRCUITRY.}

Parkinson's disease (PD) is a neurodegenerative hypokinetic movement disorder presenting with subcortical pathology and characterized by motor deficits. However, as is frequently reported in the literature, individuals with PD can exhibit cognitive and behavioral impairments. executive dysfunction and depression being the most prominent. Attention has been given to the involvement of the frontostriatal circuits connecting the frontal cortical regions and the basal ganglia (i.e., dorsolateral prefrontal [DLPFC], anterior cingulate [ACC], and orbitofrontal cortex $[\mathrm{OFC}])$ and to how these circuits might mediate behavioral and executive dysfunction in PD. Our objective in the current study was to ascertain how frontostriatal circuitry might explain the substrate of neuropsychological impairments exhibited in this patient population. Standardized executive neuropsychological tests and self-report behavioral 
scales, categorized by circuit function, were administered to 32 nondemented dopamine-alleviated PD patients and to 29 demographically matched, healthy control subjects. Our findings revealed significant group differences between task circuit conditions, with the PD group performing worse relative to the control group. Calculated effect sizes revealed that the DLPFC best differentiated subject groups. In the PD group, indices of impairment were greater for tasks mediated by the DLPFC circuit than by the ACC and OFC circuits. Furthermore, an index of DLPFC circuit performance was discovered to be the only significant predictor in discriminating between individuals with and without PD. In conclusion, our findings suggest that executive impairments in our PD sample appear to predominantly reflect dysfunction of the DLPFC circuit.

Correspondence: Dennis J. Zgaljardic, M. Phil., Neuropsychology, North Shore University Hospital, 400 Community Drive, Manhasset, NY 11030. E-mail:dzgaljar@nshs.edu

\section{Y. CHANG, M. HUA, R. WU, Y. WU \& P. YIP. SELF-AWARENESS OF MOTOR AND NEUROCOGNITIVE FUNCTIONS IN NONDE- MENTED PATIENTS WITH IDIOPATHIC PARKINSON'S DISEASE.}

The literature showed that impaired self- awareness is frequently associated with frontal lobe lesion. Researchers have suggested that frontalsubcortical circuit dysfunction may compromise the functional integrity of frontal lobes, thereby may undermine normal cognitive functioning awareness in patients with subcortical lesions. Using a sample of nondemeted patients with idiopathic Parkinson's disease (PD), the present study, thus, made an attempt to examine the issue of whether frontalsubcortical circuit dysfunction can affect self-awareness functioning. Three groups of idiopathic PD patients with varying degree of motor disabilities and one group of normal control subjects, matched for age, education, and IQ, received a battery of neuropsychological tests, and a self-report inventory of self-awareness of cognitive and motor functions. The important third informants of each subject also received a copy of the self-awareness inventory to rate the subject's cognitive and motor functions. Results revealed that our patients had normal awareness of their motor deficits, while they were impaired in awareness of their cognitive deficits. Based on these findings, we suggest that dysfunction of the frontal-subcortical circus can impair self-awareness functioning. However, the deficit is domain-specific rather than general in nature.

Correspondence: Yu-Ling Chang, Clinical and Health Psychology, University of Florida, Department of Clinical and Health Psychology, College of Health Professions, University of Florida, P.O. Box 100165, Gainesville, FL 32610-0165. E-mail:ychang@hp.ufl.edu

\section{C.R. CIMINO \& C.A. SIDERS. SELF-REPORT VERSUS CLINI- CIAN BASED RATINGS OF DEPRESSION ACROSS MILD, MOD- ERATE AND SEVERE STAGES OF PARKINSONS DISEASE .}

Studies in Parkinsons Disease patients reveal discrepancies in both prevalence of depression and relationship between depression level and disease severity. Many authors suggest variation in source of information (clinician vs. patient ratings) across studies partially explain these discrepancies and question accuracy of self-report in this population. Studies comparing patient and clinician depression ratings report strong agreement but do not compare correlations across stages of disease. This issue may be relevant because positive correlations between disease severity and discrepancies between self-report and clinician based estimates of cognitive ability have been reported. The current study explores the relationship between self-report and clinician ratings among PD patients with mild or moderate/severe symptoms. Forty-nine patients with idiopathic PD were classified according to Hoehn and Yahr stage into a group $(\mathbf{N}=29)$ with mild symptoms (H\&Y stage I and II) or a group $(\mathbf{N}=20)$ with moderate to severe symptoms (H\&Y stage III-V). Each patient completed two clinician rating based scales (HAM-D and MADRAS) and two self report scales (BDI-2 and GDS). As predicted, correlations be- tween self-report and clinician based ratings among mild PD patients were significant (all p<.05) except for the GDS and MADRAS which demonstrated a strong trend toward significance $(p<.056)$. In addition, the correlations between self-report measures and clinician based ratings of depression for moderate-severe PD patients were also significant (all $\mathrm{p}<.05)$. These results suggest that patients with Parkinson's Disease are capable of accurately assessing their own depression level, even during late stages of the disease.

Correspondence: Craig A. Siders, M.A., Psychology, University of South Florida, 15210 Amberly Drive, Tampa, FL 33647. E-mail: siders@helios. acomp.usf.edu

\section{K.M. MILLER, D. BOWERS, W. BOSCH, T. GOBER, H. MON- TIJO, U. SPRINGER, K. FOOTE \& M. OKUN. REDUCED FEAR- POTENTIATED STARTLE IN MEDICATED PARKINSON'S DIS- EASE PATIENTS.}

Rationale: In a companion abstract, we reported diminished modulation of startle to negative pictures in Parkinson's Disease, as compared to healthy controls. The purpose of the current study was to investigate whether certain discrete categories of negative stimuli affect startle modulation of PD patients more than others. Specifically, we examined startle reactivity to disgust-eliciting pictures versus fear-eliciting pictures. Methods: Twelve medicated PD patients and 12 age- and educationmatched controls were tested. The two groups were screened for dementia and depression. Startle eyeblinks were elicited by delivery of binaural white noise bursts via headphone while subjects viewed standard sets of pleasant, unpleasant and neutral pictures for six seconds each. Eyeblinks were recorded from sensors placed over the orbicularis oculi. Results: The negative pictures were sub-divided into pictures designed to elicit disgust (i.e., an anorexic, mutilated bodies) and pictures designed to elicit fear (i.e., a snake, a dog with fangs showing). In controls, the fear pictures elicited a significantly greater blink amplitude than disgust pictures. In the PD patients, the difference between fear and disgust pictures was not significant. Conclusions: These findings suggest that fear-eliciting pictures did not prime the startle responses of PD patients to the degree observed in controls. Previous studies have found that the amygdala is a key structure involved in modulation of the startle response to fearful stimuli. Patients with bilateral amygdalotomy have been shown to have a diminished fear response, and rats with lesions to the amygdala do not display normal fear towards threatening stimuli. There is evidence that dopamine can modulate the startle response of the amygdala. We will discuss several hypotheses regarding the basis of reduced fear potentiated startle among PD patients including a possible loss of dopaminergic terminals in the amygdala. Correspondence: Kimberly M. Miller, B.A. Psychology, Clinical \&. Health Psychology, University of Florida, P.O. Box 100165, Gainesville, FL 32610-0165.E-mail:kmmiller@hp.ufl.edu

\section{R.J. STOLWYK, T.J. TRIGGS, J.L. CHARLTON \& J.L. BRAD- SHAW. AN INVESTIGATION OF DRIVING PERFORMANCE IN PEOPLE WITH PARKINSON'S DISEASE.}

Introduction: People with Parkinson's disease (PD) carry an increased risk of on-road collisions. General measures of cognitive impairment regularly correlate with poor driving simulator performance in this population, however, the effects of specific cognitive difficulties on discrete aspects of driving behaviour have not been thoroughly investigated. Previous studies have demonstrated that people with PD exhibit difficulties internally cueing cognitive processes. The current study examined the impact of impaired internal cueing on specific driving behaviours. Method: A simulator was used to measure the driving behaviour of 18 current drivers in the mild to moderate stages of PD and 18 matched controls. Participants were required to navigate through a number of driving conditions where the opportunity to use internal and external cues was manipulated. Results: Results indicated that people with PD exhibited difficulties using internal cues to regulate approach speed and 
initiate deceleration, which compromised their ability to stop at traffic signals consistently. Instead of using internal cues, participants with PD were more reliant on external environmental cues to regulate their driving behaviour. Conclusions: Findings from the current study suggest that impaired internal cueing exhibited by people with PD compromised specific aspects of their driving performance. Interestingly, all participants were current drivers, in the mild to moderate stages of the disease. These findings challenge the assumption that cognitive difficulties only impact on driving performance in the moderate to severe stages of PD.

Correspondence: Rene J. Stolwyk, BSocSci.(Hons), Psychology, Monash University, P.O. Box 17, Clayton Campus, Monash University, VIC 3800 , Australia.E-mail: rene.stolwyk@med.monash.edu.au

\section{Huntington's Disease}

\section{K.F. HOTH, J.C. STOUT, S.A. JOHNSON, D.R. LANGBEHN, A. MIKOS, J.S. PAULSEN \& H. PREDICT-HD. SIMPLE AND CHOICE REACTION TIME IS ASSOCIATED WITH ESTIMATED NEARNESS TO SYMPTOM ONSET IN PRESYMPTOMATIC HUNT- INGTON'S DISEASE (HD).}

PREDICT-HD is a multi-site, longitudinal study of persons at risk, as verified by genetic testing, for HD. Previous research indicates that simple and choice reaction time correlates with $\mathrm{CAG}$ repeat size. For the PREDICT assessment of response times, we varied difficulty level $(1,2$. and 6 choices) and the response device (touchscreen and button box). Reaction times were measured as two segments, initiation time (from stimulus onset to lift from start key) and movement time (from lift to target). Multiple regression analyses in the initial 107 participants, controlling for age and education, showed that estimated years to onset (derived from an equation based on previous samples) was related more to initiation times than movement times. Estimated years to onset was significantly and independently associated with initiation times for the simple ( 1 choice) button box condition, the 2 choice condition for both the button box and touchscreen, and the 6-choice (touchscreen) condition (beta $=-.23, \mathrm{p}=.02 ;$ beta $=-.21, \mathrm{p}=.04 ;$ beta $=-.24, \mathrm{p}=.02$, beta $=-.20, p=.05$, respectively). For movement times, only the 6 choice task was independently associated with estimated years to onset (beta $=-.22, \mathrm{p}=.04)$. Results indicate that initiation time is a sensitive measure of early changes in presymptomatic HD. These results will be discussed in relation to CAG expansion and other individual differences in the participants.

Correspondence: Karin F. Hoth, M.A., University of Iowa, 2-103 Medical Education Building, University of Iowa, Iowa City, IA 52242. Email: karin-ferneyhough@uiowa.edu

\section{S.A. JOHNSON, J.C. STOUT, D. LANGBEHN, R. CONEYBEARE, J.S. PAULSEN \& H. PREDICT-HD. RECOGNITION OF STATIC AND DYNAMIC FACIAL EXPRESSIONS IN THE PREDICT-HD CO- HORT AT BASELINE.}

Studies of emotion recognition in Huntington's Disease (Sprengelmeyer et al., 1996, 1997) and a gene-positive pre-symptomatic sample (Gray et al., 1997) have reported a selective impairment in the recognition of disgust, which has been hypothesized to be linked to the insula and basal ganglia. In recent years, facial expression research has expanded beyond the use of the traditional Ekman faces to include dynamic displays which show facial movement and depict a change in facial expression. Initial results from the first 118 participants of the Predict-HD study, all genepositive and pre-symptomatic, indicate no evidence for a relative impairment in disgust when the traditional Ekman faces were presented. There was, however, an association between estimated years to onset and poorer performance on the recognition of fear. This association did not hold for disgust. On a dynamic emotion recognition task, recogni- tion of emotion in dynamic facial stimuli was compared with the same expressive faces presented without movement (static). Results indicate that for all emotions, except fear, there was significant improvement ( $p$ $<.001$ for all) with the addition of movement. Disgust recognition was impaired relative to fear and anger for the static displays $(p<.001$ for both), but disgust recognition was superior to fear $(p=.01)$ and did not differ from anger for the dynamic displays. These preliminary data suggests that further study of emotion recognition using alternative methodology in HD and pre-symptomatic HD is required.

Correspondence: Shannon A. Johnson, Ph.D., Psychology, Indiana University, 1101 E.10th Street, Bloomington, IN 47401.E-mail:sjohnso4@ indiana.edu

\section{NEHL, J.S. PAULSEN, S.A. JOHNSON, D.R. LANGBEHN, R. REESE, J.C. STOUT \& H. PREDICT-HD. EARLY CHANGES IN PSYCHOMOTOR SPEED IN PRESYMPTOMATIC HUNTINGTON'S} DISEASE.

Predict-HD is a longitudinal, multi-site study aimed at identifying neurobehavioral and neurobiological markers of HD prior to disease onset. The Predict-HD cognitive battery includes several measures designed to detect early psychomotor changes. Previous studies of pre-symptomatic HD samples have indicated that psychomotor changes may be among the earliest neuropsychological findings in presymptomatic HD. For the PREDICT-HD cognitive battery, we developed a computerized tapping task that uses a button box for response input. The task includes two conditions. For free tapping, participants tap as quickly as possible within a specified time interval. For tone tapping, participants tap in time with a tone, which occurs at a fixed interval, and then the tone stops and they must continue tapping at the same rate for several seconds. In the first 104 participants studied at baseline, all carrying the CAG expansion for HD, multiple regression analyses showed that estimated years to onset was independently associated with free tapping variability for both dominant and non-dominant hands (beta $=-.22, \mathrm{p}$ $=05$, beta $=-.22, p=.045$, respectively). For the tone tapping task with the dominant hand, estimated years to onset was at trend level for tone tapping (beta $=-.21, p=.06$ ), and was significantly associated with self-paced tapping variability (dominant hand). Estimated years to onset was also associated with alternating thumb tapping (beta = $.24, \mathrm{p}=.03)$. Relative sensitivity of the tapping measures to individual differences in the presymptomatic sample, such as CAG number, and other neurobiological findings will be described.

Correspondence: Carissa Nehl, Psychology/Psychiatry, The University of Iowa, Psychiatry Research, 2-103, Iowa City, IA 52242. E-mail: carissa-nehl@uiowa.edu

\section{CAMPBELL, J.C. STOUT, S.A. JOHNSON, J.S. PAULSEN \&. T. PREDICT-HD HSG INVESTIGATORS. ASSOCIATIONS BE- TWEEN ESTIMATED YEARS TO ONSET AND PERFORMANCE ON COMPUTERIZED 3 AND 4 DISK TOWER TASKS IN THE PRE- DICT-HD COHORT AT BASELINE.}

The PREDICT-HD study is a longitudinal, multi-site study of presymptomatic Huntington's Disease (HD). Early cognitive changes in HD are linked to basal ganglia-frontal function, which is known to play a role in planning and strategy. Therefore, we studied the PREDICT-HD cohort using a computerized tower task similar to one already shown to be sensitive to the pathology of diagnosed HD. Participants were instructed to move all of the disks from the starting position on one peg to a target position on another peg using as few moves as possible. We measured the timing of each move, total number of moves, and errors (i.e., rule breaks) on 4 trials each of 3 -disk and a 4 -disk versions of the tower task. In the first 106 participants (all gene-positive for HD) studied at baseline, we found that estimated years to onset was not significantly associated with 3-disk tower performance. For the more difficult 4-disk level, however, multiple regression analyses showed that estimated years to onset added a significant increment to the equation (as 
did age and education) for average trial completion time $(\beta=-.20, p=05)$ and average time per move $(\beta=-23, p=.03)$. Results suggest that proximity to onset may relate to timing of decisions on the tower task. Additional results from the presymptomatic cohort under study will be discussed.

Correspondence: Meghan Campbell, Department of Psychology, Indiana University, 1101 E. 10th St., Bloomington, IN 47405-7007. E-mail: meghcamp@indiana.edu

\section{A. SOLOMON, J.C. STOUT, S.A. JOHNSON, M.C. CAMPBELL \& F. UNVERZAGT. DIFFERENTIAL PATTERNS ON THREE EPISODIC MEMORY TESTS IN ALZHEIMER'S DISEASE AND HUNTINGTON'S DISEASE.}

Neuroanatomical and cognitive data suggest that episodic memory involves several sub-processes: encoding, storage, and retrieval. Alzheimer's disease $(\mathrm{AD})$, characterized by dramatic and relatively circumscribed cell death in the medial temporal lobe, is associated with impaired encoding, storage, and retrieval processes. In contrast, Huntington's disease (HD), involving selective pathology of striatal projection neurons, is linked to impaired encoding and retrieval with relatively spared storage processes. We reasoned that if specific sub-processes of episodic memory are supported by distinct neuroanatomical substrates, then relatively specific neurological damage in AD and HD should be consistently reflected in memory performance. Three tests of episodic memory, the California Verbal Learning Test (CVLT), the Rey Auditory Verbal Learning Test (RAVLT), and the CERAD Word List Learning task, were administered to document patterns of memory impairment associated with $\mathrm{AD}$ and $\mathrm{HD}$. As predicted, the $\mathrm{AD}$ and $\mathrm{HD}$ groups demonstrated encoding and retrieval impairments on all three memory tests $(\mathrm{p}<.001$ for all). The AD group also demonstrated impaired storage processes on all three tests $(p<.001$ for all $)$, as measured by recognition indices. The HD group demonstrated relatively better storage according to recognition measures from the CERAD and CVLT ( $p>.05$ for both), but performed worse than comparison subjects on the RAVLT recognition index $(p<.001)$. Generally, these results show good reliability between memory tests. These data are consistent with distinct memory patterns and neurobiological substrates for memory processes in AD and HD. Correspondence: Andrea Solomon, Psychology, Indiana UniversityBloomington, 1101 E. 10th Street, Bloomington, IN 47405. E-mail: ansolomo@indiana.edu

\section{Vascular Dementia}

\section{S. HAN, K. OH, J. LEE \& Y. KANG. A COMPARISON OF NEU- ROPSYCHOLOGICAL FUNCTIONS BETWEEN SUBCORTICAL VAD AND AD.}

In patients with subcortical $\mathrm{VaD}$ (SVD) as a subtype of $\mathrm{VaD}$, the onset of cognitive symptoms is relatively insidious and the course is more slowly progressive like AD. Their focal neurological signs especially early in the course are often subtle only. Little is known about the pattern of cognitive decline in SVD. Accordingly, the differentiation between SVD and $\mathrm{AD}$ in the early stage is not easy. The present study was conducted to find the neuropsychological measures to differentiate SVD from AD in their early stages. A comprehensive neuropsychological test battery (Seoul Neuropsychological Screening Battery) was administered to 24 SVD, $24 \mathrm{AD}$, and 24 normal elderly (NC). The groups did not differ in age and education level. There was no difference between SVD and AD in the severity of dementia $(\mathrm{CDR}=.75 \pm .26, \mathrm{~K}-\mathrm{MMSE}=21.94 \pm 4.25)$. Discriminant analysis showed that delayed recalls of the Seoul Verbal Learning Test (SVLT) and the Rey-Osterrieth Complex Figure Test (RCFT), the Korean-Boston Naming Test (K-BNT), the Digit Span Test, and the Phonemic Word Fluency Test were the best measures for differentiating SVD from AD. SVD showed significantly poor performance on the
Digit Span Test (forward) and the Phonemic Word Fluency Test than $\mathrm{AD}$, whereas $\mathrm{AD}$ showed significantly poor performance on delayed recalls of the verbal (SVLT) and visual (RCFT) memory tests and the KBNT than SVD. Discriminant analysis also suggested that the delayed recalls of verbal/visual memory tests and some measures of frontal lobe functions (stroop task and phonemic/semantic word fluency tests) were good indicators for distinguishing the dementia patients from the normal elderly.

Correspondence: Yeonwook Kang, Hallym University, 1 Okchon-dong Chunchon, Kangwondo 200-702, South Korea.E-mail:ykang@ hallym.ac. $\mathrm{rr}$

\section{A.L. JEFFERSON, R.H. PAUL, D.A. CAHN-WEINER, R.A. CO- HEN, J. GUNSTAD, D.F. TATE \& A.M. BRICKMAN. PREDICTORS OF INSTRUMENTAL ACTIVITIES OF DAILY LIVING (IADL) IM- PAIRMENT IN VASCULAR DEMENTIA (VAD).}

Background: While the cognitive correlates of functional decline in $\mathrm{VaD}$ have been well documented, less is known regarding clinical predictors of functional decline in this patient population. Objective: The aim of this study was to identify the relative importance of clinical and cognitive measures for predicting IADL impairment among VaD patients. Method: Thirty-eight patients diagnosed with VaD (NINDS-AIREN \& DSM-IV) underwent neuropsychological and neurological examinations. Primary caregivers completed an IADL measure. Results: Simultaneous multiple regression was conducted to determine the relative contribution of several cognitive variables (i.e., MMSE, DRS I/P, Trail Making Test-A, COWA) to IADL performance. The regression model was significant, accounting for $33.8 \%$ of the variance, with only the I/P subscale of the DRS emerging as a significant predictor. Next, a hierarchical regression was conducted with the Hachinski score entered in the first block and the I/P subscale entered in the second block. Results revealed a significant model accounting for $41.1 \%$ of the variance with both measures emerging as significant predictors of functional impairment. Conclusions: These findings suggest that in addition to cognitive measures, some clinical measures may also be important predictors of functional decline. Information obtained from neurological and neuropsychological examinations may be pooled to more accurately identify those patients with $\mathrm{VaD}$ who are at risk for functional impairments or decline over time.

Correspondence: Angela L. Jefferson, Ph.D., CBPM - Neuropsychology Clinic, Brown Medical School, Coro Building 3 West, 1 Hoppin Street, Providence, RI 02903. E-mail: Angela_Jefferson@brown.edu

\section{J. GUNSTAD, A.M. BRICKMAN, R.H. PAUL, R.A. COHEN, D.J. MOSER, B.R. OTT, N. GORDON, A.L. JEFFERSON, D.F. TATE \& L.H. SWEET. PROGRESSIVE COGNITIVE DECLINE IN VASCULAR DEMENTIA SUBTYPES. \\ Persons with vascular dementia $(\mathrm{VaD})$ are typically believed to exhibit} a progressive deterioration in cognition, with decline associated with exacerbation of cerebrovascular pathology. However, support for progressive cognitive decline in $\mathrm{VaD}$ patients is far from universal, with many studies showing little or no decline over time. One explanation for these inconsistent findings is the heterogeneity of pathology encompassed by the $\mathrm{VaD}$ diagnosis. It is possible that subtypes of $\mathrm{VaD}$ (i.e. those resulting from different etiological factors) show different patterns of cognitive decline. In the present study, a heterogeneous VaD group demonstrated cognitive decline from baseline to 12-month follow-up. Although this decline was coincident to morphometric changes (i.e. increased SH, decreased WBV), no relationship emerged between cognitive decline and morphometric changes. However, results also indicated an interaction between $\mathrm{VaD}$ subtype and cognitive decline, as $\mathrm{VaD}$ pa- 
tients with SH-only exhibited greater decline on language and memory-based tasks than those with cortical or subcortical stroke. Such findings are consistent with the hypotheses of other researchers, and raise the question as to whether some subset of $\mathrm{VaD}$ patients convert to mixed dementia (MD).

Correspondence: John Gunstad, Brown University, Coro West-Third Floor, 1 Hoppin St, Providence, RI 02903.E-mail: John_Gunstad@ brown.edu

\section{Multiple Sclerosis}

\section{R.H. BENEDICT, I. FISHMAN, R. BAKSHI, B. WEINSTOCK- GUTTMAN, J. KUWATA \& F. MUNSCHAUER. VALIDATION OF A CONSENSUS PANEL NEUROPSYCHOLOGICAL BATTERY FOR MS PATIENTS.}

The Minimal Assessment of Cognitive Function in MS (MACFIMS) is a neuropsychological battery recently proposed by a consensus conference that included experts from the United States, Canada, United Kingdom, and Australia (Benedict et al, 2002). The MACFIMS is composed of the following neuropsychological tests: Paced Auditory Serial Addition Test, Symbol Digit Modalities Test, California Verbal Learning Test - II (CVLTII), Brief Visuospatial Memory Test - Revised, Judgement of Line Orientation Test, Controlled Oral Word Association Test (COWAT), D-KEFS Sorting Test. We tested the validity of the MACFIMS prospectively in 161 patients with definite MS and 44 normal controls, group-matched on age, education, gender and race. Patients were screened for prior neurological and psychiatric disorder and had not undergone relapse within 4 weeks of testing. The MACFIMS was reduced to 12 measures - Wisconsin Card Sorting Test (WCST) was exchanged for the D-KEFS Sorting Test. ANOVAs showed that all tests except CVLT-II Recognition and WCST Categories discriminated the groups $(p<.05)$. After controlling for Beck Depression Inventory, COWAT and WCST Perseverative Responses also failed to distinguish MS from controls. Global Impairment was defined as a defect $(\mathrm{z}$ of normal $<-1.5)$ on two or more tests. Using this standard, the frequency of cognitive impairment was $62.7 \%$. The most sensitive test in the MACFIMS battery was the Symbol Digit Modalities Test (55\% impaired). These findings support the validity of the MACFIMS in a prospective sample.

Correspondence: Ralph H. Benedict, Ph.D., Neurology, SUNY Buffalo School of Medicine, Buffalo General Hospital, Suite D-6, 100 High Street, Buffalo, NY 14203.E-mail: benedict@buffalo.edu

\section{L.H. SWEET, S.M. RAO, M. PRIMEAU, S. DURGERIAN \& R.A. COHEN. FMRI OF VERBAL WORKING MEMORY TASK DIF- FICULTY AMONG MULTIPLE SCLEROSIS PATIENTS.}

Multiple Sclerosis (MS) patients frequently exhibit verbal working memory (VWM) deficits. Functional magnetic resonance imaging (FMRI) may help identify neural mechanisms underlying these deficits. FMRI studies of healthy adults have characterized neural responses associated with increased VWM demands during the n-Back task, suggesting that this experimental paradigm could help understand VWM deficits among MS patients. Fifteen MS patients and 15 age, IQ, and education matched control participants completed the n-Back during whole-brain FMRI. Mean blood-oxygen-level-dependent (BOLD) signal during 0-Back local baselines were subtracted, on a voxel-wise basis, from BOLD signal observed during 1-, 2-, and 3-Back blocks. Resulting difference scores were compared across groups and difficulty levels. BOLD intensity was positively related to difficulty level in anterior regions reported by $n$ Back studies of healthy adults, including premotor, supplementary motor, and dorsolateral prefrontal cortices. Group by difficulty level interactions were observed in these regions. MS patients exhibited greater intensity than the control group at each difficulty level in these areas, while the left superior frontal gyrus, Broca's area, and other inferior tem- poral and cerebellar areas were less intense at more difficult levels. MS group responses were slower during the 1- and 3-Back; however, accuracy did not significantly differ at any level. Findings suggest that previous reports of compensatory increases in brain activity among impaired patients may be extended to include high-functioning MS patients performing at several levels of VWM difficulty. These findings may help to explain why MS patient performance decreases as a function of effortful task demand on neuropsychological tests.

Correspondence: Lawrence Sweet, Brown University, Miriam Hospital, Coro-West, One Hoppin Street, Providence,RI 02903.E-mail: sweet@ brown.edu

\section{J. LENGENFELDER, N.B. MOORE, D. BRYANT \& J. DELUCA. DOES INCREASING INFORMATION PROCESSING TIME IM- PROVE WORKING MEMORY ACCURACY IN MS?}

Previous research has demonstrated that impaired working memory performance among MS subjects is due to diminished speed of information processing. This suggests that individuals with MS may require more time to perform complex working memory (WM) tasks as well as healthy adults. This study examined whether allowing increased time would improve MS subjects performance on a complex working memory task, irrespective of task difficulty. The Keeping Track Task (KTT) was used to compare performance accuracy under increasing demands on the slave systems of WM and the central executive. The KTT allows manipulation of both structural ( 1 or 3 elements of information) and operational (1 or 3 arithmetic operations) loads within WM. Performance on a less difficult WM condition was compared with a more difficult condition, across three times (i.e., 1, 3, 5 seconds) in $48 \mathrm{MS}$ and $27 \mathrm{HC}$ subjects. As expected, performance decreased as the task got harder $(\mathrm{p}<.01)$ which was true for both groups. However, increasing the amount of time to process information significantly improved performance $(p<.05)$ but only for the most difficult condition $(p<.01)$. This effect of increased performance with more time on the most difficult condition was the same in both the MS and healthy groups. Therefore, when additional time was presented to MS subjects to perform a challenging information processing task within WM, performance significantly improved. The results have implications for the cognitive rehabilitation of persons with MS. Correspondence: Jean Lengenfelder, Kessler Medical Rehabilitation Research \& Education Corporation, 1199 Pleasant Valley Way, West Orange, NJ 07052. E-mail: jlengenfelder@kmrrec.org

\section{J.L. SHUCARD, D.C. MCCABE, D.W. SHUCARD, R.H. BENE- DICT, B. WEINSTOCK-GUTTMAN \& J.A. BRAUN. EVENT-RE- LATED POTENTIALS AND WORKING MEMORY DEFICITS IN MULTIPLE SCLEROSIS.}

Event-related potentials (ERPs) were used to explore deficits in working memory (WM) and information processing speed in Multiple Sclerosis (MS). We hypothesized that the P3 component of the ERP, recorded during a spatial WM task, would reflect slowed processing speed and reduced neuronal output during certain stages of WM in MS. We further hypothesized that P3 measures would be related to performance on the paced auditory serial addition task (PASAT), which places high demand on processing speed and WM. Participants were 14 MS patients and 14 controls. ERPs were recorded to encoding, maintenance, and match (target detection) or no match (response inhibition) stimuli of the WM task. Findings revealed that the topography of P3 amplitude from the anterior to posterior scalp sites differed between MS and controls and was dependent on the stage of WM. P3 amplitude was greater at the frontal site in MS compared to controls during encoding of stimuli, while amplitude at the posterior site was reduced in MS compared to controls during both encoding and response inhibition. P3 amplitude was also related to PASAT scores in the MS group. Poorer PASAT 
performance was associated with greater P3 amplitude at the frontal site during encoding; however, during response matching, poorer performance was associated with reduced amplitude at the posterior site. These findings suggest a disruption in anterior and posterior neural networks associated with the encoding and response stages of WM in MS. Correspondence: Janet L. Shucard, Ph.D., Neurology, State University of New York at Buffalo, 100 High Street (D-6), Buffalo, NY NY. E-mail: shucard@buffalo.edu

\section{W. BEATTY. MS, PERSEVERATION AND THE WCST.}

On the Wisconsin Card Sorting Test (WCST) some patients with multiple sclerosis (MS) produce increases in the numbers of perseverative responses and errors, possibly indicating that their defects in conceptual behavior may arise from cognitive inflexibility or deficits in using feedback. Other findings, however, demonstrate that patients with MS are impaired on conceptual tasks on which perseveration does not occur. Those results support an alternative interpretation, namely that the increase in perseverative responding observed on the WCST is secondary to a more basic deficit in concept formation. To examine these hypotheses, 63 patients with clinically definite MS completed the WCST, the Shipley Abstraction Test and three measures of general cognitive functioning: the Mini-Mental State Exam, the Repeatable Battery for the Assessment of Neuropsychological Status (RBANS), the Paced Auditory Serial Addition Test (PASAT), and the Shipley Vocabulary Test. Correlational analyses showed that the Total Score on the RBANS, the Abstraction test and the PASAT were positively related to the number of Categories attained on the WCST and negatively correlated with the number of Perseverative Errors. Multiple regression analyses showed that the Abstraction score was the best predictor of performance on both WCST measures. The PASAT score increased the accuracy of prediction on the Perseverative Response measure, but no other variables increased the accuracy of prediction of either WCST variables. These results indicate that deficient concept formation is the main reason patients with MS perseverate on the WCST.

Correspondence: William Beatty, University of Oklahoma Health Sciences Center, P.O. Box 26901 - ROB410, Oklahoma City, OK 73190. E-mail:william-beatty@ouhsc.edu

\section{J.H. KALMAR, N.D. CHIARAVALLOTI, D. BRYANT, D. TULSKY \& J. DELUCA. INFORMATION PROCESSING DEFICITS IN MULTI- PLE SCLEROSIS: PROPERTIES OF SCREENING INSTRUMENTS.}

Objective: A substantial body of literature exists indicating that working memory dysfunction is common in Multiple Sclerosis (MS). Additionally, recent research has shown that deficits in information processing speed may account for a large portion of this working memory dysfunction in MS. The purpose of the present study was to examine the relative contribution of working memory and information processing speed to everyday life activities. Method: Participants were 52 adults with clinically definite MS who underwent neuropsychological testing and completed the Executive Functions Performance Test (EFPT), an objective measure of everyday life activities, at an outpatient rehabilitation research institution. Working memory was assessed using the Letter Number Sequencing (LNS) subtest of the WAIS-III, which minimizes processing speed. Processing speed was measured using the Symbol Digit Modalities Test (SDMT), which minimizes working memory. Results: Pearson product moment correlations indicate that performance on both the LNS and SDMT was related to measures of memory, executive functions, processing speed and verbal and visual new learning. Specifically, better performance on LNS, indicating better working memory functions, and better performance on the SDMT, indicating faster processing speed was related to better performance on tasks assessing new learning and long term memory. Conclusions: Findings suggest that the SDMT and LNS have differential clinical utility, inasmuch as the SDMT assesses not only working memory ability but processing speed as well. However, performance of individuals with MS on either test is related to indices of cognition and everyday life functioning. Funded by the $\mathrm{Na}-$ tional Multiple Sclerosis Society (RG 2596B2/2) and the National Institutes of Health (T32-HD7522).

Correspondence: Nancy D. Chiaravalloti, PhD, Neuroscience and Neuropsychology, Kessler Medical Rehabilitation Research and Education Corporation, 1199 Pleasant Valley Way, West Orange, NJ 07052. Email:nchiaravalloti@kmrrec.org

\section{P. ARNETT, M. BASSO, C. GHORMLEY, N. LOWERY \& D. POLEN. RUDIMENTARY MOTOR SPEED CONTRIBUTES SIG- NIFICANTLY TO PERFORMANCE ON NEUROPSYCHOLOGICAL TESTS WITH MOTOR DEMANDS IN MS PATIENTS.}

Many neuropsychological tests used with MS patients require some type of written or oral motor response. Because MS patients commonly experience significant motor difficulties, their performance on some neuropsychological tests may be compromised by such output problems. The goal of the present study was to examine the contribution of rudimentary motor skill to performance on selected neuropsychological tests with manual or oral-motor demands in MS patients and non-MS controls. Method. Eighty-eight clinically definite MS patients and 25 nonMS controls were administered the Trailmaking Tests (TMT) A \& B, Symbol Digit Modalities Test (SDMT)Written \& Oral forms, and the COWA. Grooved Pegboard was used as a measure of rudimentary manual motor speed, and a task requiring only that examinees verbally repeat numbers in sequence on a page as quickly as possible was used as a measure of rudimentary oral-motor speed. Results. ANCOVA's with the MS and control groups as between-groups factors showed that when Grooved Pegboard was used as a covariate, the TMT-A F-value declined from $10.03(\mathrm{p}<.005)$ to $1.68(\mathrm{~ns})$ and the TMT-B F-value dropped from $11.48(\mathrm{p}<.002)$ to $2.16(\mathrm{~ns})$. Additionally, SDMT-Written group effect F-value declined from $22.26(p<.001)$ to $8.03(p<.01)$. When the rudimentary oral motor task was used as a covariate, the group effect for the COWA went from $6.95(\mathrm{p}<.02)$ to $1.96(\mathrm{~ns})$, and the group effect for the SDMT-Oral dropped from $17.74(\mathrm{p}<.001)$ to 7.55 ( $\mathrm{p}<$ .01 ). Discussion. Our study shows that lower level rudimentary motor skills often compromised in MS are more responsible than higher level cognitive difficulties for patients' poor performance relative to controls on several commonly used clinical neuropsychological tasks requiring either rapid spoken or written responses.

Correspondence: Peter Arnett, Ph.D., Psychology, Penn State University, 522 Moore Building, University Park, PA 16803.E-mail: paa6@ psu.edu

\section{J.J. GAINES, J. LYNCH, R. BAKSHI, L. HERZIG, J. KUWATA, J. SHARMA, C. TJOA, B. WEINSTOCK-GUTTMAN \& R.H. BENEDICT. INCONSISTENCY DURING VISUAL LEARNING IS CORRELATED WITH DELAYED RECALL AND CEREBRAL AT- ROPHY IN MS.}

Several studies have documented visual memory impairment in multiple sclerosis (MS) although little is known about the quality of visual learning in patients with this disease. This study examined error types and recall consistency during learning of visual material in MS patients $(\mathrm{n}=38)$ and controls $(\mathrm{n}=24)$. Participants underwent brain MRI and a neuropsychological exam that included the Brief Visuospatial Memory Test - Revised (BVMT-R: Benedict et al., 1997). MRI atrophy variables were third ventricle width and brain parenchymal fraction. In addition to traditional BVMT-R indices (total recall, 25-min delayed recall, delayed recognition index), we assessed configuration errors, misplaced figures, rotated figures, perseverated elements/figures, intruded elements/figures, and across-trial recall consistency. Compared to controls. MS patients had defective recall and recognition tests. Patients also made more intrusion errors than controls, and showed lower across-trial re- 
call consistency. Patient across-trial recall consistency was predictive of delayed recall performance. Across-trial recall consistency was also correlated with third ventricle width. Findings suggest that inconsistent recall for visual material across successive learning trials may partly explain delayed recall deficits in MS.

Correspondence: jeffrey J. gaines, Ph.D., Developmental and Behavioral Neurosciences, University of Buffalo Medical School, 66 Summer St., Apt.7K, Buffalo, NY 14209. E-mail: gainesjeffreyj@hotmail.com

\section{A. SANCHEZ, T. ROIG, R. SANCHEZ-CARRION, S. ALFONSO, J. PORCEL, R. LLUENT \& J. PENA. THE ROLE OF SEMANTIC MEMORY IN VERBAL FLUENCY TASKS IN MULTIPLE SCLERO- SIS PATIENTS.}

Introduction: Low verbal fluency performance in multiple sclerosis patients (MS) is frequently related to executive dysfunction. Very little is known, however, about the role of semantic memory in this. Objective: To study the role of semantic memory in verbal fluency tasks. Method: Thirty-one patients (25 RRMS / 6 SPMS) and 31 healthy volunteers were assessed in verbal fluency tasks: Beginning letter, Excluded letter and Semantic association; access to semantic memory: Pyramids and Palm Trees Test (P\&P); non verbal fluency: Five Point Test (FPT); information processing speed: Symbol Digit Modalities Test (SDMT) and oral and verbal agility: Boston Diagnostic Aphasia Examination (BDAE). Results: It was found that patients performed significantly worse than controls on verbal fluency, non-verbal fluency, information processing speed and verbal and non-verbal agility. There were no significant differences in the access to semantic memory. The regression analysis showed that predictable variables of the performance in verbal fluency tasks were the outcomes in the FPT, the SDMT and the BDAE. Conclusion: Low verbal fluency performance could be related to impairment in planning strategies, information processing speed and oral agility, although it seems that access to semantic memory has no influence. Further research using a specific linguistic battery to assess cognitive-linguistic tasks is needed to better understand the relation of executive functions and language abilities in MS patients.

Correspondence: Angela Sanchez, Institut Guttmann, C/ Camí de Can Ruti,s/n, Badalona 08916, Spain.E-mail:angelasanc@yahoo.com

\section{S.M. MITCHELL, J.M. LAFOSSE \& C.M. FILLEY. THE NATURE OF VERBAL MEMORY IMPAIRMENT IN MULTIPLE SCLEROSIS: A LIST-LEARNING AND META-ANALYTIC STUDY.}

Memory impairment is one of the most extensively studied cognitive effects of multiple sclerosis (MS), yet the specific nature of the deficit remains unclear. Memory impairment in MS has been characterized as a retrieval deficit. Recent work, however, has suggested that memory dysfunction may be better attributed to deficits in acquisition. Fifty-three patients with relapsing-remitting MS and 31 matched controls were evaluated using normative data from the California Verbal Learning TestII. The MS group performed significantly worse than the HC group on measures of acquisition, $(\mathrm{p}<0.05), \mathrm{d}=0.55$, and long-delay free recall, $(p<0.01), d=0.83$, with no significant differences on recognition, $\mathrm{d}=0.36$. A meta-analysis of studies that utilized verbal list-learning measures in MS patients provided additional support for these findings. Whereas previous meta-analyses have combined a broad range of verbal and non-verbal memory measures, our meta-analysis was restricted to studies employing verbal list-learning tasks. Unlike other meta-analyses, we evaluated subtype groups and mixed groups separately on measures of acquisition, recall and recognition. Our metaanalysis revealed moderate effects on acquisition, $\mathrm{d}=0.72$, and delayed free recall, $d=0.55$, and smaller effects on recognition, $d=0.37$ among relapsing-remitting patients. A similar pattern of effects, though of greater magnitude, was found among progressive patients. While there has been some stimulating recent debate about what theory best describes the nature of memory deficits in MS, our findings demonstrate that difficulties in both acquisition and retrieval contribute to memory impairment in MS.

Correspondence: Jose M. Lafosse, Ph.D., Psychology, Regis University, 3333 Regis Boulevard, D-12, Denver, CO 80221-1099. E-mail:jlafosse@regis.edu

\section{J. LENGENFELDER, J.H. KALMAR \& J. DELUCA. ARE THERE GENDER DIFFERENCES IN VERBAL LEARNING AND MEMORY FOR INDIVIDUALS WITH MULTIPLE SCLEROSIS?}

Gender differences in verbal learning and memory have been reported in numerous studies of healthy males and females. Specifically, it has been demonstrated that females outperform males on measures of verbal learning and memory. This study explored whether gender differences in memory are present in individuals with multiple sclerosis (MS), a disease which includes cognitive impairments. It is well established that there is a difference in the prevalence of MS across gender with females twice as likely to be affected, however, there is little research to ascertain whether males and females with MS would present a differential effect across gender on cognitive processes such as memory. In this study, 42 males and 43 females received a modified version of the Selective Reminding Test. Gender differences were found for both learning and memory. Males took a significantly greater number of trials to reach a learning criterion compared to females $(\mathrm{p}<.01)$. After learning was equated (e.g. individuals learned all 10 words), recall was examined at 30 and 90 minutes. Females were able to recall a significantly greater number of words than males at both 30 minutes $(p<.05)$ and 90 minutes $(p<.05)$. Males and females did not differ on demographic variables or duration of MS. The results indicate that the pattern across gender on learning and memory observed in MS is the same as reported in the literature for healthy adults.

Correspondence: Jean Lengenfelder, Kessler Medical Rehabilitation Research \& Education Corporation, 1199 Pleasant Valley Way, West Orange, NJ 07052. E-mail: jlengenfelder@kmrrec.org

\section{J. OUELLET, C. BERTRAND-GAUVIN, A. POIRIER, P.B. SCHERZER, I. ROULEAU \& P. DUQUETTE. THEORY OF MIND AND FRONTAL LOBE SEMIOLOGY IN ADULTS WITH MULTIPLE SCEROSIS.}

The aim of the present study was to assess the ability of adults with multiple sclerosis (MS) and suffering from a frontal lobe semiology to infer mental states on a series of theory of mind (TOM) tasks. Ten MS participants with a frontal lobe semiology were compared to ten MS participants with an intact cognitive profile. The test materials comprised a newer and 'advanced' test of TOM (Conversations and Inferences) consisting of five computerized two-minute clips extracted from different television series. Appearing in each extract are two or three adults using irony, lies, faux pas, sarcasm, jokes and indirect messages. Two other tasks presenting written stories completed the TOM battery. Participants were also tested on various standardized executive tests. Results show that the participants with a frontal lobe semiology had more difficulties attributing mental states in a more realistic context (Conversations and Inferences), but not on the written tasks. Significant relationships between this advanced measure of TOM and executive functions were also found. These results indicate that TOM, as measured by performance on a more 'naturalistic' task, tends to be affected by a frontal lobe semiology. This study supports and extends findings with an earlier version of Conversations and Inferences that intact TOM reasoning relies on the integrity of some frontal cognitive functions. This is also the first study to demonstrate that MS can affect one's ability to make correct inferences in social situations.

Correspondence: Julie Ouellet, psychology, UQAM, 2064 Melrose, Montreal, QCH4A 2R5, Canada.E-mail: ouellet.julie.2@courrier.uqam.ca 


\section{L.B. STROBER \& P.A. ARNETT. THE PREVALENCE AND ETIOL- OGY OF FATIGUE IN MULTIPLE SCLEROSIS (MS) IN COMPARI- SON TO HEALTHY CONTROLS .}

Although fatigue is widely recognized as a common, debilitating problem in multiple sclerosis (MS) patients, its etiology is poorly understood. In the present study, we examined attributions MS patients make for their fatigue and evaluated comparisons to a healthy control sample. 82 definite MS patients and 20 healthy controls were administered the Fatigue Impact Scale (FIS), and a measure that asked individuals to assign precedence to contributors of endorsed neurovegetative symptoms of depression (i.e., fatigue, sleep disturbance, problems with appetite) that may be easily construed as MS symptomatology. Consistent with previous findings, a high percentage of our MS sample (91\%) reported a feeling of tiredness/fatigue in comparison to only $45 \%$ of our control sample $\left(\chi^{2}=28.29, \mathrm{df}=1, \mathrm{p}<.001\right)$. MS patients also reported a significantly higher level of fatigue on the FIS $(t(100)=7.91, p<.001)$. When patients were asked what they attributed their fatigue to, four different domains were reported. In our sample, $65 \%$ of our MS sample compared to $14 \%$ of controls reported that their fatigue was due to physical problems (daily physical exertion, chronic pain, difficulties with tremors and gait), $11 \%$ of MS versus $14 \%$ of controls attributed it to cognitive problems, $15 \%$ of MS and $71 \%$ of controls due to sleep disturbance, and $9 \%$ of MS stated it was due to psychological factors (e.g. worry and inability to get going) compared with none of controls. Our data show that MS patients report a significantly higher amount of fatigue than healthy controls. Furthermore, a majority of MS patients attributed their fatigue to physical problems; however, sleep disturbance, cognitive problems, and psychological difficulties were also identified as contributors by some patients. To the extent that particular physical problems, cognitive difficulties, sleep problems, and psychological complaints are treatable in MS, fatigue in these patients may be mitigated. Correspondence: Lauren B. Strober, MS, Psychology, Penn State University, 429 Moore Building, University Park, PA 16802.E-mail: lbs131@ psu.edu

\section{K. KING \& P. ARNETT. ASSOCIATION OF DEPRESSION, FA- TIGUE, AND COGNITIVE IMPAIRMENT WITH DYADIC ADJUST- MENT IN MULTIPLE SCLEROSIS.}

Multiple Sclerosis (MS) is a disease that typically has its onset between the ages of 20 and 40. Because people usually begin serious marital or marital-like relationships during this stage of life, dyadic adjustment for MS patients may be negatively affected. In the present study, we predicted that MS patients showing evidence of three common sequelae of MS-depression, fatigue, and cognitive dysfunction-would be most likely to display problems with dyadic adjustment. Sixty-four definite MS patients' depression levels, fatigue, cognitive functioning, and dyadic adjustment were assessed; a subset of 49 significant others of the patients were also assessed on dyadic adjustment. Patient reported dyadic adjustment was significantly associated with depression $(r=-.48, p<.001)$ and fatigue $(r=-.31, p<0.01)$, but not cognitive functioning. Significant other reported dyadic adjustment was significantly associated with patients' depression $(r=-.38, p<0.005)$, fatigue $(r=-.30, p<0.02)$, and executive functioning $(r=-.37, \mathrm{p}<.05)$. Stepwise regression analyses revealed that depression was the only significant independent predictor of dyadic adjustment, regardless of whether significant other $(F$ $=6.76, \mathrm{p}<.02, \mathrm{r} 2=.16)$ or patient reported $(\mathrm{F}=5.67, \mathrm{p}<.05, \mathrm{r} 2=$ .10) dyadic adjustment was used as the criterion variable. Our finding of a significant association between significant other reports of dyadic adjustment and patient depression suggests that the patient depression-dyadic adjustment association was most likely not simply a function of patients' negative response bias. If depression leads to dyadic problems in MS patients, treatment of depression may result in improved dyadic adjustment. Conversely, if dyadic problems contribute to depression in MS, then treatment of dyadic problems may lead to relief from depression in these patients.
Correspondence: Peter Arnett, Ph.D., Psychology, Penn State University, 522 Moore Building, University Park, PA 16803.E-mail: paa6@ psu.edu

\section{HEINZE, D. DENNEY, B. PARMENTER \& S. LYNCH. THE RE- LATIONSHIP BETWEEN PERCEIVED AND OBJECTIVE COGNI- TIVE FUNCTIONING AND DEPRESSION IN MULTIPLE SCLERO- SIS PATIENTS.}

The relationship between perceived and objective cognitive functioning and depression was evaluated in 247 patients with multiple sclerosis (MS). Patients were administered a cognitive battery (Neuropsychological Screening Battery for Multiple Sclerosis, Tower of London, and California Verbal Learning Test) and questionnaires (Cognitive Failures Questionnaire and the Center for Epidemiologic Studies-Depression Scale). They were also presented questions in which they were asked to estimate their performance on the cognitive tests. Linear regression analyses were conducted in order to evaluate the prediction of perceived ability from cognitive ability, as measured by objective cognitive tests. The first pair examined the relationship between objective cognitive functioning and perceived general cognitive functioning. As expected, cognitive ability did not predict perceptions of general cognitive functioning, $\mathrm{F}(1,221)=2.87, \mathrm{p}=.091$. However, when depression was controlled, objective functioning did predict perceived general functioning, $\mathrm{F}(2,217)=40.23, \mathrm{p}<.001$. These findings suggest that feelings of depression may distort patients' views regarding daily cognitive abilities. The second pair examined the relationship between cognitive ability and perceived performance on the cognitive tests. Actual performance predicted perceptions of performance, $F(1,213)=99.34$, $p<.001$. When depression was controlled, actual performance continued to predict perceptions of performance, $F(2,209)=46.86, p<.001$. These findings indicate that the MS patients, despite any depression they were experiencing, were able to accurately assess their performance on the cognitive tests. These results have implications for the treatment of cognitive dysfunction in MS. Rather than relying solely on patient reports of overall cognitive decline, it may be necessary for health care workers to objectively assess both cognitive decline and distress to guide treatment of cognitive dysfunction.

Correspondence: Laura Heinze, MA, Psychology, University of Kansas, 4020 El Camino Real, Apt. 1102, Palo Alto, CA 94306. E-mail: lauraheinze@comcast.net

\section{HEINZE \& D. DENNEY. ARE DEPRESSION AND ANXIETY OVERESTIMATED IN MULTIPLE SCLEROSIS?}

Depression and anxiety are common symptoms of Multiple Sclerosis (MS). However, it has been argued that rates of depression and anxiety may be inflated due to the content of questionnaires used to measure these constructs. Widely used scales for depression and anxiety inquire about physical symptoms which are common in MS. In the present study, a content analysis was conducted on the Center for Epidemiologic Studies-Depression Scale (CES-D) and the Zung Anxiety Scale (Zung) to determine if items which inquire about physiological symptoms inflate overall scores in an MS population. A total of 256 MS patients completed these questionnaires. Items on the CES-D and the Zung that inquire about common MS symptoms were identified and pulled from the scale. Revised CES-D and Zung scores were compared with original scores to determine whether the scores changed significantly when those items were eliminated. Percentages of patient scores from total possible scores were calculated for each of the versions of the questionnaires, and the means of these percentages were compared using paired samples ttests. Results from the first t-test indicate that the mean percentage for the original CES-D $(M=.428, \mathrm{SD}=.136)$ was significantly greater than the mean percentage on the revised CES-D $(M=.399, \mathrm{SD}=.140)$, $\mathrm{t}(255)=15.276, \mathrm{p}<.001$. Results from the second $\mathrm{t}$-test indicate that the mean percentage for the original $\mathrm{Zung}(\mathrm{M}=.464, \mathrm{SD}=.098)$ was not significantly greater than the mean percentage on the revised Zung 
$(\mathrm{M}=.465, \mathrm{SD}=.010), \mathrm{t}(255)=-.853, \mathrm{p}=.394$. These results have implications for research on emotional factors within MS. According to these findings, reported rates of anxiety in MS may be accurate while rates of depression may be artificially inflated given the content of the respective scales.

Correspondence: Laura Heinze, MA, Psychology, University of Kansas, 3801 Miranda Ave, Palo Alto, CA 94304.E-mail: lauraheinze@ comcast.net

\section{L.J. JULIAN \& D.C. MOHR. EXECUTIVE FUNCTIONING IS A DIFFERENTIAL PREDICTOR FOR RESPONSE TO TREATMENT FOR DEPRESSION IN MULTIPLE SCLEROSIS.}

Specific domains of cognitive dysfunction, specifically, executive dysfunction (ED), have been demonstrated to predict poorer treatment response to anti-depressant medications. The purpose of this investigation was to evaluate measures of cognitive functioning as treatment predictors across three treatments for depression in patients with multiple sclerosis (MS). Instruments that assessed executive functioning (i.e. Stroop Color Word Test, Verbal Fluency) and memory (Rey Auditory Verbal Learning Test, 7/24 Spatial Learning Test) were administered to 59 MS patients with depression, randomly assigned to one of three 16week treatments for depression. Depression severity was evaluated by the Hamilton Rating Scale for Depression (HRSD). Repeated measures analyses of covariance (rANCOVAs) were performed using pre-post HRSD as the dependent variables, treatment as the fixed factor, and cognitive variables as covariates. Executive functioning was a significant covariate detecting differences across treatment groups $[\mathrm{F}(2,53)$ $=4.85, \mathrm{p}<.05), \eta 2=.16]$. Subsequent regression analyses found that ED predicted poorer treatment response to anti-depressant pharmacological interventions accounting for $28.7 \%$ of the variance in post-treatment HRSD scores as compared to less than $1 \%$ post- treatment scores in the two psychotherapy treatment conditions. These findings suggest that both depression and the ED may be precipitated by an underlying brain dysfunction contributing to poor antidepressant response in patients with MS. Conventional anti-depressant treatments, such as sertraline, may be less beneficial for MS patients with depression and ED. Findings are discussed in the context of similar findings in geriatric depression.

Correspondence: Laura J. Julian, Ph.D., Medicine, University of California San Francisco, 6234 California Street, San Francisco, CA 94121. E-mail: ljulian@itsa.ucsf.edu

\section{J. BRUCE, D. POLEN, P. ARNETT, L. STROBER \& M. SMITH. SELF-REPORTED PAIN AND EMOTIONAL MEMORY BIASES IN- TERACT TO PREDICT DEPRESSION IN MULTIPLE SCLEROSIS.}

Patients with multiple sclerosis (MS) frequently experience both pain and depression. Despite an extensive literature supporting a direct relationship between pain and depression in other patient populations, no relationship between pain and depression has been found in MS. It is hypothesized that MS patients in pain will only experience depression if they also exhibit a concomitant cognitive vulnerability towards depression. In the present investigation, 90 clinically definite MS patients completed self-report questionnaires that assessed various aspects of depression and pain. Furthermore, a mood congruent memory (MCM) task was administered to assess patients' vulnerabilities toward depression. Consistent with other studies that examined pain and depression in MS, pain intensity and pain-mediated interference in life activities were not correlated with patients' scores on the Depression Proneness Rating Scale (DPRS) or the Chicago Multi-Scale Depression Inventory (CMDI). Multiple regression was used to test the hypothesis that cognitive vulnerability and pain interact to predict depression in MS. An additive interaction of pain intensity and MCM predicted patients' scores on the CMDI $\left(\mathrm{R}^{2} \Delta=.06, \mathrm{p}<.05\right)$. Synchronously, an additive interaction of pain-mediated interference in life activities and MCM predicted patients' scores on the DPRS $\left(\mathrm{R}^{2} \Delta=.08, \mathrm{p}<.01\right)$ and CMDI $\left(\mathrm{R}^{2} \Delta=\right.$
$.08, \mathrm{p}<.01)$. Patients who demonstrated high levels of pain intensity/interference and concomitant negative MCM biases were more likely to experience depression than when either pain or negative MCM biases occurred alone. Implications for the identification and treatment of depression in MS are discussed.

Correspondence: Jared Bruce, M.S., Psychology, Penn State University,314 Moore Building, University Park,PA 16802.E-mail:jmb518@ psu.edu

\section{D.M. POLEN \& P.A. ARNETT. CHRONIC PAIN IS ASSOCIATED WITH LEARNED HELPLESSNESS IN MS.}

Individuals with Multiple Sclerosis (MS) consistently show high rates of depression. Shnek et al. (1995) found that a measure of learned helplessness predicted depression better than other attributional measures in these patients, and learned helplessness has been theorized to be a final pathway to depression generally. The present study explored whether one symptom of MS, chronic pain, contributes to learned helplessness. Chronic pain was assessed with a modified version of the Brief Pain Inventory (BPI), and learned helplessness was assessed with the MS Attitudes Index (MSAI), in 80 definite MS patients. Two separate indices of chronic pain were assessed, including a total pain score (a composite score calculated from all BPI responses) and a pain interference score (a composite score calculated from only the responses to the BPI questions inquiring about the degree to which pain interferes with ones life). Correlational analyses revealed that the MSAI correlated significantly with the BPI total pain score $(\mathrm{r}=.24, \mathrm{p}<.05)$ and the BPI interference score $(r=.28, p<.05)$. Stepwise linear regression indicated that, when both pain measures were used as predictors of learned helplessness, only the BPI interference score predicted significant variance in the MSAI ( 12 $=.08)$. Our results suggest that chronic pain is related to learned helplessness in MS patients. Although our data are correlational and causal conclusions are precluded, if chronic pain leads to learned helplessness in MS, it may put these patients at risk for depression. Furthermore, a measure of pain interference may be a more useful measure of chronic pain for this population than a total pain score, though both measures were significantly associated with learned helplessness. It may be that chronic pain management, along with psychotherapeutic treatment that targets learned helplessness, may reduce the risk of depression and chronic pain in individuals with MS.

Correspondence: Dawn M. Polen, Pennsylvania State University, 131 Moore Building, University Park, PA 16802.E-mail:dmp262@psu.edu

\section{E.L. WAHLIG, I. FISHMAN, B. WEINSTOCK-GUTTMAN, R. BAKSHI, J. KUWATA \& R.H. BENEDICT. PREDICTING QUAL- ITY OF LIFE IN MULTIPLE SCLEROSIS: ACCOUNTING FOR DIS- EASE COURSE, PHYSICAL DISABILITY, FATIGUE, COGNITION, DEPRESSION, PERSONALITY, AND BEHAVIOR DISORDER.}

Chronic diseases are associated with deterioration in health-related quality of life (HQOL). Recent work identifies a number of predictors of HQOL in MS patients, but few studies have considered multiple variables simultaneously. To understand which clinical factors are most important for HQOL and vocational status, we measured 36 variables covering seven clinical domains (disease characteristics, physical disability, fatigue, depression, cognitive function, personality traits, behavioral disorder). Dependent variables were MSQOL-54 (Physical Health, Mental Health, and Overall Composites) and vocational status (employed vs. disabled). MS patients ( $\mathrm{N}=120)$ and controls ( $\mathrm{N}=44)$ were equivalent on demographic variables by ANOVA and chi-square tests. Regression models first predicted outcome variables within domains, and then accounted for retained predictors from the first analysis. The final model predicting Physical Health QOL included Fatigue Severity Scale (FSS; R square=.57), Center for Epidemiologic Studies Depression Scale-10 (CESD-10; R square change=.08), Beck Depression Inventory (BDI; $\mathrm{R}$ square change $=.04)$, and Extended Disability Status Scale (R square change=.02) The Mental Health QOL model included 
CESD-10 ( $\mathrm{R}$ square=.56) and FSS ( $\mathrm{R}$ square change=.03). The Overall QOL model included CESD-10 (R square=.59)and NEOPI Self-Report Conscientiousness ( $\mathrm{R}$ square change=.04). Vocational status logistic analysis retained five variables: Symbol Digit Modalities Test (Wald=12.8), Wisconsin Card Sorting Test Perseverations (Wald=7.8), Informant-Report NEOPI Conscientiousness (Wald=6.7), disease duration (Wald=5.3), and Judgment of Line Orientation (Wald=3.8), correctly classifying $79 \%$ of cases. Findings indicate that depression and fatigue predict self-reported HQOL and cognitive function is most important in predicting vocational function.

Correspondence: Elizabeth L. Wahlig, M.S., GSE Counseling Psychology, University at Buffalo/SUNY, 409 Baldy Hall, Buffalo, NY 14260. E-mail: elwahlig@buffalo.edu

\section{J.J. RANDOLPH, H. WISHART, B. MCDONALD, K. SCHUSCHU \& A. SAYKIN. SUBJECTIVE REPORTS OF EXECUTIVE FUNC- TIONING IN MULTIPLE SCLEROSIS: RELATIONSHIP BETWEEN THE METEX AND COGNITIVE PERFORMANCE.}

Although previous work has examined memory complaints in patients with multiple sclerosis (MS), little is known about MS patients' self-reported functioning in other cognitive domains. The present study sought to determine: 1) what types of executive complaints characterize MS patients; 2) whether MS patients have more executive complaints than matched controls; and 3) how MS patients' subjective executive functioning relates to cognitive performance. Eighteen MS patients and 17 matched controls were administered the METEX, a 21-item meta-executive scale consisting of four factor-analytically derived subscales corresponding to executive organization, mental flexibility, working memory, and self-monitoring, as well as neuropsychological measures of executive functions and verbal memory. Results indicated that MS patients reported significantly more overall and domain-specific executive complaints than controls $(p<.05)$. Correlational analyses indicated that MS patients' total executive and mental flexibility complaints were associated with CVLT Trials 1-5 total, CVLT-Delayed Recall, and PASAT performance $(p<.05)$ but not with other indices. A stepwise regression analysis using these measures indicated that only verbal learning remained associated with total executive complaints $(p<.05)$. Executive complaints were also associated with mood and duration of MS symptoms but not with fatigue. In sum, these findings suggest that: 1) patients with MS have more executive complaints than healthy controls, 2) executive complaints in MS are associated with executive and memory performance, and 3) subjective executive reports in MS correlate with emotional functioning but not with fatigue.

Correspondence: John J. Randolph, Ph.D., Psychiatry, Dartmouth Medical School, DHMC, One Medical Center Dr, Lebanon, NH 03756-0001. E-mail:john.j.randolph@dartmouth.edu

\section{Y. GOVEROVER, N. CHIARAVALLOTI \& J. DELUCA. CONCORDANCE BETWEEN PATIENT AND FAMILY BEHAVIORAL RATINGS AND ITS RELATIONSHIP WITH COGNITIVE PER- FORMANCE IN MULTIPLE SCLEROSIS.}

Many individuals with Multiple Sclerosis (MS) appear to be unaware of the impairments they have developed as a result of their illness. However, few studies have examined self-awareness of impairments in individuals with MS. The current study was designed to examine self-awareness in MS by measuring the concordance between reports of neurobehavioral symptoms made by participants with MS and by a significant other, and then determining the relationship of this concordance with cognitive ability. Twenty-six individuals with MS and 15 healthy controls completed neuropsychological testing and measures of emotional functioning for the current study. In addition, all participants, plus a significant other of each participant with MS, rated neurobehavioral symptoms using the Frontal Systems Behavior Scale (FreSBe). Results indicated a significant correlation between concordance on the FReSBe and cognitive ability. Specifically, the integrity of frontal lobe function, as measured by neuropsychological testing, was predictive of concordance on the FreSBe executive dysfunction subscale. No significant predictive relationships were found for the FreSBe disinhibition or apathy subscales. Results of the current study indicate that concordance in the rating of neurobehavioral symptoms between individuals with MS and their significant others is related to impairment in some cognitive abilities (i.e. deficits in executive control), but not others (i.e. disinhibition or apathy). This result is significant in suggesting that for many persons with MS, particularly those with cognitive impairment, ratings of significant others may be necessary to derive a full picture of the range, severity, and the clinical importance of the affected individual's neurobehavioral symptoms.

Correspondence: Yael Goverover, PhD, Outcome, Kessler Medical Rehabilitation Research and Eduction Corporation, 1199 Pleasant Valley Way, West Orange, NJ 07052. E-mail: ygoverover@kmrrec.org

W.S. MACALLISTER, C. CIANCIULLI, L.B. KRUPP, M. MILAZZO, C. CHRISTODOULOU, A. BELMAN, W. SCHERL, T. PRESTON, B. MELVILLE \& T. MORGAN. COGNITION AND CLINICAL FACTORS IN EARLY-ONSET MULTIPLE SCLEROSIS.

It has been suggested that, as episodes of inflammation and demyelination co-occur with central nervous system development in children and adolescents with multiple sclerosis (MS), they may be especially vulnerable to cognitive impairment. Unfortunately, there is currently little available information regarding the cognitive functioning in these patients, despite recent recognition of MS occurring in this group. In the present investigation, twenty-three early-onset MS patients received a brief neuropsychological battery and an overall composite score was calculated. Twenty-six percent of the sample demonstrated significant cognitive impairment. Clear and consistent relations between clinical factors and cognition emerged. Pearson correlations between the neuropsychological composite score and current Expanded Disability Status Scale (EDSS) was -.502 ( $\mathrm{p}=.015)$, highest historical EDSS was -.612 ( $p=.002)$, number of relapses was -.625 ( $p=.001)$ and total length of the disease was $-.683(p<.001)$. Subjective report of fatigue was not significantly related to cognition $(\mathrm{r}=-.367 ; \mathrm{p}=.085)$, although a trend was evident. Multiple regression analysis assessing the combination of clinical factors was more highly associated with overall cognition than any of the clinical factors alone $(\mathrm{R}=.776 ; \mathrm{p}<.001)$, accounting for over half of the variance in cognition $(\mathrm{R}$ squared $=.602)$. However, disease length accounted for the majority of variance and other variables did not add significantly more predictive power. These results suggest that cognitive impairment is a significant aspect of the disease for many earlyonset MS patients and may be predicted by neurological factors with disease duration being the strongest.

Correspondence: William S. MacAllister, Ph.D., SUNY Stony Brook, HSC T-12-020, Stony Brook, NY 11794-8121.E-mail:wmacallister@notes. cc.sunysb.edu

\section{T. ERGH, L. RAPPORT, K. RYAN, P. KEENAN, R. HANKS, R. LISAK \& O. KHAN. AWARENESS OF DEFICIT IN INDIVIDU- ALS WITH MULTIPLE SCLEROSIS .}

The present study examined awareness of cognitive and functional deficits among individuals with MS. Most studies examining unawareness of deficit in MS have been complicated by including both symptoms of unawareness and euphoria together in their measurement. Seventy four pairs of MS patients and their significant others $(n=148)$ participated. Duration of illness ranged from .4 to 31.4 years $(M=10.1$, $\mathrm{SD}=7.5)$. Overall, $55.4 \%$ of patient participants had Relapsing Remitting (RR) MS and $44.6 \%$ had Secondary Progressive (SP) MS. Awareness of cognitive deficit was measured by discrepancy scores between patient reports of their abilities and objective neurological and neuropsychological test results. Awareness of functional deficit was measured by the discrepancy between the patient and significant other reports of the patient functional abilities. Cognitive functioning was 
assessed using neuropsychological tests. Results suggest that about onethird of MS patients have diminished awareness of their cognitive and/or functional deficits. Notably, diminished awareness of deficit was more common among patients with SP MS as compared to those with RR MS. Greater patient physical disability was significantly associated with more unawareness of deficit. After controlling for patient physical disability, duration of illness was not related to unawareness of deficit. In contrast, neuropsychological dysfunction was associated with greater unawareness of cognitive deficits, beyond that afforded by differences in physical disability and duration of illness. In sum, the current study provides evidence that a sizable portion of MS patients do have diminished awareness of their deficits.

Correspondence: Tanya Ergh, M.A., Psychology, Wayne State University, 382 Blunk St., Plymouth, MI 48170.E-mail: tergh@sun.science. wayne.edu

\section{A.C. SCHURLE \& P.A. ARNETT. LONGITUDINAL EXAMINA- TION OF PSYCHOPATHOLOGY IN MS PATIENTS.}

Introduction: Although depression has been studied extensively in multiple sclerosis (MS) patients, little attention has been devoted to other forms of psychopathology. Even less work has been done using longitudinal data. In the current study, we examined the longitudinal course of varying forms of psychopathology as reported by MS patients and then evaluated the extent to which patients' scores were clinically elevated. Method: The SCL-90-R, a 90-item self-report symptom inventory designed to reflect the psychological symptom patterns of psychiatric and medical patients, was included, using all nine symptom scales and all three global indices. Participants/Procedure: The SCL-90-R was administered to 47 definite MS patients and then again three years later. Results: Across scales, only between $9 \%$ and $21 \%$ of patients' scores on the SCL-90-R changed. Intercorrelations among SCL-90-R indices at Time 1 and Time 2 were all significant $(p<.01)$ with values ranging from $\mathrm{r}=.44$ to $\mathrm{r}=.83$. After converting patients' raw scores (Time 1 ) to t-scores, using non-patient normative data as the reference point and using t-scores of 63 and above as clinically significant (according to the SCL-90-R manual), clinical elevations on the scales ranged from $26 \%$ (anxiety, paranoid ideation) to $52 \%$ (somatization) across the two time points. Conclusions: Consistent with other longitudinal studies of specific forms of psychopathology (e.g. depression), this study demonstrated that other types of psychopathology are very stable over time. Because a relatively high percentage of patients displayed clinical elevations across the scales over time, our data suggest that the stability of psychopathology seen in MS patients is of clinical concern. It appears vital, therefore, to target all types of psychopathology in psychological assessments of individuals with MS so that interventions appropriate to the type of psychopathology they manifest may be employed. Correspondence: Amanda C. Schurle, M.S., Psychology, The Pennsylvania State University, $710 \mathrm{~S}$. Atherton, Apt. \#305, State College, PA 16801.E-mail:acs220@psu.edu

\section{H.M. GENOVA, Y. GOVEROVER, F.G. HILLARY \& J. DELUCA. THE RELATIONSHIP BETWEEN NEUROPSYCHOLOGICAL MEA- SURES AND THE TIMED INSTRUMENTAL ACTIVITIES OF DAILY LIVING TASK IN MS AND TBI .}

Both Traumatic Brain Injury (TBI) and Multiple Sclerosis (MS) can result in cognitive deficit, emotional instability, and loss of functional independence. Very little research to date has linked the observed cognitive and behavioral deficits in MS and TBI to performance on tasks of everyday competency. The present study examined the relationship between performance on measures of neuropsychological functioning and a task of everyday competency, the Timed Instrumental Activity of Daily Living (TIADL). The TIADL is a functional measure that assesses both accuracy and speed of performance of everyday activities. Analyses examined the relationship between the performance on neuropsychological tests and the TIADL in individuals with MS and TBI and healthy adults. Results revealed significant differences between TIADL scores in HCs and individuals with TBI and MS. Additionally, TIADL scores of individuals with MS and TBI were significantly correlated with neuropsychological measures of speed of information processing but not with neuropsychological measures of memory or general intellectual functioning. These results indicate that the TIADL is sensitive to speed of information processing and working memory deficits typically observed in individuals with MS and TBI. Furthermore, these specific cognitive impairments may contribute to impairments in every day living activities. The TIADL can provide important information about the cognitive functional abilities of individuals with TBI or MS.

Correspondence: Helen M. Genova, BA, Neuroscience, University of Medicine and Dentistry of New Jersey, 244 Delaware Ave., Union, NJ 07083. E-mail: helen_genova@alum.shu.edu

\section{M.M. SMITH \& P.A. ARNETT. STABILITY OF COPING STRATE- GIES IN MULTIPLE SCLEROSIS: DATA FROM A LONGITUDI- NAL STUDY.}

Individuals with MS must cope with a variety of disease-related stressors and the unpredictability of their illness. Carver et al.'s (1989) COPE scale is a self-rated measure designed to assess individual differences in coping strategies. Though coping has been found to moderate the relationship between cognitive dysfunction and depression in MS populations (Arnett, et al., 2002), very little is known about the stability of coping strategies over time. 49 definite or probable MS patients were administered the COPE at two time points three years apart. The use of emotion-focused coping strategies at Time 1 was correlated at .78 $(p<.001)$ with their use at Time 2 , while the use of problem-focused coping strategies at Time 1 was correlated at $.68(p<.001)$ with Time 2 . When a subset of coping strategies involving avoidance or active coping was considered, the correlations were found to be $.58(\mathrm{p}<.001)$ for active coping and .48 ( $\mathrm{p}<.001)$ for avoidance coping. Denial was found to be the least stable individual coping scale, with a correlation of .15 (ns). Use of religion as a coping strategy was found to be the most stable, with Time 1 and Time 2 ratings correlating at .78. Correlations for all other scales fell between .31 and .69 ( $p<.03$ level or less). Although broad categories of coping appear stable longitudinally in MS, there is some variability across particular types of coping. Intervention may be warranted for patients who differentially employ maladaptive coping strategies (e.g., emotion-focused, avoidance), because many of these strategies appear unlikely to change spontaneously over time. Correspondence: Megan M. Smith, BA, Psychology, Pennsylvania State University, 131 Moore Bldg, University Park, PA 16802. E-mail: mms295@psu.edu

\section{Marchiafava-Bignami Disease}

\section{S. MOELTER, J. RAGLAND, R.C. GUR \& C.G. KOHLER. PROGRESSION OF NEUROPSYCHOLOGICAL DEFICITS IN A CASE OF MARCHIAFAVA-BIGNAMI DISEASE.}

Marchiafava-Bignami Disease (MBD) is a rare disorder of chronic alcoholism that results in necrosis and subsequent demyelination of the corpus callosum. Neuropsychological investigations have demonstrated left hand agraphia and apraxia, reductions of executive functions and memory, and reduced verbal output culminating in mutism. Due to high mortality, longitudinal assessment of MBD is uncommon and, to our knowledge, no serial neuropsychological reports have been published. We describe serial neuropsychological and neuroimaging findings in a 58-year-old, right-handed man with MBD first diagnosed and assessed in 1996. The patient has a history of alcoholism that has been in remission for 10 years, and he has lived in a supervised setting since the initial diagnosis. Brain MRI in 1996 revealed generalized cerebral atrophy, bilateral white matter abnormalities, and marked atrophy of the 
corpus callosum. More recent MRI in 2002 demonstrated progression of general volume loss, now characterized as left > right, and substantial thinning of the posterior corpus callosum. Periventricular white matter hyperintensities, extending into frontal and subcortical regions, were also noted. Neuropsychological assessment revealed cognitive deterioration over six years. Consistent with neuroimaging, left hemispheric functions, such as word list generation, sentence repetition, and verbalauditory command comprehension, were especially affected. Sensoryperceptual examination also showed right-sided extinctions during somatosensory, auditory, and visual stimulation. Limb praxis evaluation was more impaired on the left, consistent with hemispheric dysconnection. In the setting of abstinence from alcohol, neuropsychological and neuroimaging findings indicate progression of brain dysfunction over the past six years.

Correspondence: Stephen Moelter, PhD, Social Sciences, University of the Sciences in Philadelphia, Kline Hall, 600 South 43rd Street, Philadelphia,PA 19104.E-mail: s.moelte@usip.edu

\section{Poster Session 5: Issues in Neuropsychological Assessment and Outcome/3:45-6:00 p.m.}

\section{Assessment of Effort and Malingering}

\section{G.J. LARRABEE. IDENTIFICATION OF SUBTYPES OF MALIN- GERED NEUROCOGNITIVE DYSFUNCTION.}

Recently, Larrabee (2003) correctly discriminated $87.8 \%$ of litigants with either probable or definite malingered neurocognitive dysfunction (MND) and $94.4 \%$ of clinical patients with brain trauma, and other neurological and psychiatric disorders, using atypical performance patterns on Benton Visual Form Discrimination (VFD), Finger Tapping (FT), Reliable Digit Span (RDS), Wisconsin Card Sorting Test Failure-toMaintain-Set (FMS), and the Lees-Haley Fake Bad Scale of the MMPI2 (FBS). The present investigation performed hierarchical agglomerative followed by K-means iterative divisive cluster analyses of the VFD, FT, RDS, FMS and FBS scores of 33 male and 35 female litigants meeting Slick et al. (1999) criteria for either definite or probable MND. Five clusters were identified: 1) a cluster with particularly poor memory and low RDS ( $\mathrm{n}=11) ; 2$ ) a cluster with particularly poor motor function and FT (n=21);3) a cluster with globally poor perceptual (VFD), memory (RDS), and cognitive (FMS) function $(n=7)$; and clusters 4) and 5) performing relatively better than clusters 1,2 , and 3 , and showing an admixture of different patterns of motivational impairment. The finding that only $7 \mathrm{Ss}$ presented with global failure suggests that most malingerers do not fail every test measure but rather, selectively fail on tasks. Since most current Symptom Validity Tests (SVTs) simulate memory tasks, development of new SVTs related to motor, perceptual and problem solving skills is recommended.

Correspondence: Glenn J. Larrabee, Ph.D., Independent Practice, 630 South Orange Ave., Suite 202, Sarasota,FL34236.E-mail: GLarrabee@ aol.com

\section{A.L. SHANDERA, S. HALL, J.W. DENBOER \& E.M. CROUSE. CURRENT USE OF MALINGERING MEASURES: A PRELIMI- NARY STUDY.}

Tan, Slick, Strauss \& Hultsch (2003) surveyed the practices of expert neuropsychologists in detecting malingering. Expert status was defined by publications in the area of malingering detection and having examined individuals seeking financial compensation. The goal of the present study was to survey a broader spectrum of neuropsychologists to characterize practices common throughout the discipline. Frequency of test use as well as confidence in test accuracy was surveyed. Sixty-two practicing clinical neuropsychologists responded to the survey via email. The majority of respondents reported using tests to detect malingering in their assessments $(88.7 \%)$. For those who used tests of malingering, they were used in $55.78 \%$ of adult cases and $10.83 \%$ of child cases. The Test of Memory Malingering (TOMM) was the most commonly used test of malingering $(66.13 \%)$. Other measures that were used frequently were the Rey 15-Item Memory Test (Rey-15; 35.48\%), Word Memory Test (WMT; 29.03\%), Validity Index Profile (VIP; 25.81\%), Computerized Assessment of Response Bias (CARB; 19.35\%), Victoria Symptom Validity Test (VSVT; 16.13\%), and the Portland Digit Recognition Test (PDRT; 12.90\%). Confidence ratings varied widely, with the WMT, TOMM, and the VIP rated higher than other tests. Interestingly, although the Rey-15 was the second most commonly used test, it received the lowest confidence rating. Administration time and research support were identified as important factors in selecting a malingering test. Additional factors that characterize malingering detection practices are reported.

Correspondence: Stuart Hall, PH.D., Psychology, University of Montana, Skaggs Building, Missoula, MT59802-1584.E-mail:stuart.hall@ umontana.edu

\section{A.K. JOHNSON, A.L. BARNACZ \& J.P. KEENAN. THE ROLE OF SELF-AWARENESS AND EVOLUTION IN DECEPTION.}

The ability to decieve is key to effective mating strategies. It has been theorized that without self-awareness one would not be able to employ these vital deceptive tactics (Keenan et al., 2003). In the current study, 42 undergraduates were presented with a video paradigm consisting of twelve actors. The actors' information was adjusted according to gender differences in deception, consistent with evolutionary theory. It was found that females with higher self-awareness scores were more effective deceivers. Further, females with higher self-awareness were also more effective truth tellers. Males with lower self-awareness, under certain conditions of deception, were more effective. Results of this study indicate that while evolution of self-awareness may be beneficial for a female's ability to deceive, it may not be advantageous for males. Correspondence: Amanda K. Johnson, B.A., Psychology, Montclair State University, 1 Normal Ave., Dickson Hall Room 225, Upper Montclair, NJ07043.E-mail:johnsona6@mail.montclair.edu

\section{S.L. BACKHAUS, N. FICHTENBERG \& R. HANKS. EXAMINATION OF THE FLOOR EFFECT METHOD IN THE DE- TECTION OF THE SUB-OPTIMAL PERFORMANCE IN A TRAU- MATIC BRAIN INJURY SAMPLE.}

Utility of the normative floor effect method to detect suboptimal performance on neuropsychological assessment was examined with a selection of clinical measures based on medical histories and established criteria. Participants included 131 individuals, divided into moderatesevere TBI, mild TBI, and a poor effort group. Several levels of stringency for the floor effect $(50 \mathrm{th}, 25 \mathrm{th}$, and 10th percentiles of moderate-severe brain injury) and baserates of deficient motivation ( $40 \%$ and $20 \%$ ) were examined due to the paucity of research comparing these parameters. The results revealed that a floor level set at the 50th percentile consistently provided the best overall classification of individuals with mild brain injury-versus-poor effort. Positive predictive power was impressive due to high specificity, suggesting that the floor effect appears to be better at ruling in than ruling out poor effort. Due to the rarity of positive scores among mild TBI patients, floors set at the 25 th and 10 th percentiles served as a pathognomonic sign of poor effort. When the floor was set at 50th percentile and the baserate for poor motivation set at $40 \%$, probability of poor motivation was adequate for positive scores on all of the measures. Examination of the percentage of positive scores 
within individual profiles revealed that a floor level at the 50th percentile yielded impressive results with overall correct classification above $90 \%$ when more than $30 \%$ of the scores were positive. Within the mild head injury population, the 50th percentile of moderate-to-severe TBI may serve as an effective floor for the detection of insufficient effort. Correspondence: Samantha L. Backhaus, Ph.D., Rehabilitation Institute of Michigan / Wayne State University Medical School, 9935 LancasterDrive, Belleville, MI 48111.E-mail:davebackhaus@hotmail.com

\section{M.D. HORNER, J.S. BEDWELL \& A. DUONG. AN ABBREVIATED FORM OF THE TEST OF MEMORY MALINGERING.}

While the importance of effort testing has become increasingly apparent, many clinicians face pressures to streamline clinical batteries. The Test of Memory Malingering (TOMM) is an effort test in which scores below 45 on Trial 2 or the optional Retention Trial indicate insufficient effort, but score on Trial 1 is not used. This study attempted to develop an abbreviated form of the TOMM by identifying cut points on Trial 1 above and below which further trials need not be administered. Data were analyzed from 114 consecutive referrals to a VA Medical Center Neuropsychology Clinic to whom the TOMM was administered. A cut score of 35 or lower on Trial 1 yielded $96 \%$ sensitivity and $92 \%$ specificity to identify failure on Trial 2 (positive predictive value $[\mathrm{PPV}]=$ $77 \%$, negative predictive value $[\mathrm{NPV}]=99 \%)$, and $100 \%$ sensitivity and $87 \%$ specificity on the Retention Trial $(\mathrm{PPV}=65 \%, \mathrm{NPV}=100 \%)$. Conversely, a cut score of 27 or lower on Trial 1 yielded $48 \%$ sensitivity and $100 \%$ specificity for Trial $2(\mathrm{PPV}=100 \%, \mathrm{NPV}=87 \%)$, and $67 \%$ sensitivity and $100 \%$ specificity for the Retention Trial (PPV $=$ $100 \%, \mathrm{NPV}=87 \%)$. Thus, in this sample, Trial 1 scores of 36 or higher indicated $99 \%$ likelihood that the TOMM would be passed, while Trial 1 scores of 27 or below indicated $100 \%$ likelihood that it would be failed. Sensitivity and specificity of Trial 1 cutoff scores can also be computed using more stringent interpretive criteria than the cutoff score of 45 suggested in the TOMM manual.

Correspondence: Michael D. Horner, Ph.D., Psychiatry, Ralph H. Johnson VA Medical Center / Medical University of South Carolina, Mental Health Service (116), VAMC, 109 Bee St., Charleston, SC 29401. Email:hornermd@musc.edu

\section{J. DENBOER \& S.R. HALL. TOMMVS. WCST: TOMM CLASSIFIES COACHED MALINGERERS AND CONTROLS MORE ACCURATELY.}

There has been little research directly comparing the efficacy of traditional cognitive measures to instruments specifically designed to detect neuropsychological malingering. As a malingering measure, the Wisconsin Card Sorting Task (WCST) has received mixed support. Bernard, McGrath, and Houston (1996), using a self-developed malingering equation, found that the test demonstrated good accuracy, sensitivity, and specificity, while work by Greve and Bianchini (2002) found that equations developed by Bernard et al. (1996) [and Suhr and Boyer (1999)], produced high positive error rates in most samples. In contrast, the Test of Memory Malingering (TOMM) has received strong empirical support (Tombaugh, 2002). The purpose of the present study is to compare the ability of the WCST Bernard(B) and TOMM to detect coached malingerers. The coached malingerer group $(n=$ 28) received instructions to fake bad while minimizing the risk of detection by the examiner. The controls $(\mathrm{n}=23)$ were instructed to perform to the best of their ability. All participants were administered complete, standardized versions of both tests. Analysis revealed that the TOMM accurately identified significantly more coached malingerers than the WCST-B $(66 \%$ vs. $22 \%$, respectively; $\mathrm{z}=2.44, \mathrm{p}=.007)$. The $\mathrm{WCST}(\mathrm{B})$ also demonstrated a high false positive error rate (i.e., identifying actual controls as suspected malingerers) significantly more than the TOMM $(12 \%$ vs. $0 \%$, respectively; $\mathrm{z}=1.73, \mathrm{p}=.042)$. The results of this study suggest that well-validated tests designed to detect malingering may be superior in identifying malingerers when compared with traditional instruments of brain functioning.
Correspondence: John DenBoer, M.A., Psychology, The University of Montana, Skaags Building, Missoula,MT59801.E-mail:jwdenboer@ yahoo.com

M. WEINBORN \& S. WOODS. A COMPARISON OF THREE SYMPTOM VALIDITY TESTS IN FORENSIC PSYCHIATRIC INPATIENTS.

Symptom validity tests (SVT) are designed to be sensitive to feigning or exaggeration of neurocognitive impairment, but insensitive to true impairment. Much of the SVT literature, however, has focused on mild brain injury litigants and other higher functioning populations, with fewer studies examining the performance of populations with characteristics that may adversely impact SVT performance; e.g., severe psychiatric illness. The present study examined performance of 66 consecutively referred involuntary state psychiatric inpatients on The Test of Memory Malingering, Word Memory Test, and Reliable Digits. The first group $(\mathrm{n}=25)$, was comprised of individuals being evaluated for Competency to Stand Trial (CST/MSO), and were hypothesized to be more likely to feign impairment to avoid prosecution or incarceration. The second group $(n=41)$ included civilly committed inpatients, and those previously adjudicated Not Guilty by Reason of Insanity (CIVIL/NGRI), who had no known motivation to feign neurocognitive impairment. Groups were comparable in age, education, estimated premorbid intelligence, and severity of psychiatric symptoms. Of the three SVT procedures, only the TOMM successfully differentiated the groups, with a significantly greater proportion of CST/MSO patients (32\%) scoring below a recommended cutoff (Colby, 2001) indicative of suboptimal effort relative to the CIVIL/NGRI group (5\%). The WMT and reliable digits procedure did not differentiate groups $(p>.10)$ and produced an unacceptable number of false positive errors. On the basis of these findings. the TOMM appears most useful in identifying dissimulation in a forensic psychiatric population.

Correspondence: Michael Weinborn, Ph.D., Martinburg VAMC, Rte. 9 East, Martinsburg,WV 25401.E-mail:mweinbo@hotmail.com

\section{B.M. DOANE, K.W. GREVE \& K.J. BIANCHINI. AGREEMENT BE- TWEEN THE STANDARD AND ABBREVIATED FROMS OF THE PORTLAND DIGIT RECOGNITION TEST.}

The Portland Digit Recognition Test (PDRT) is a well-established 72item (36 "easy" and 36 "hard") symptom validity test (SVT). The average time of administration is 40 minutes or more. Binder (1993) suggests the use of an abbreviated form to avoid a lengthy task in well-motivated patients. If at least 19 of the 36 "easy" items are correct, then the test is discontinued with at least 7 of the first 9 "hard" items correct, or, failing that, 12 of the first 18 "hard" items. Otherwise the entire test is administered. Sensitivity and specificity of the standard PDRT are well established. The purpose of this study was to determine the agreement between the standard and abbreviated forms. PDRT's were obtained from 200 (100 traumatic brain injury [TBI], 100 pain) randomly selected medico-legal psychological assessments. Thirty-five patients (22 TBI, 13 pain) failed the standard PDRT. Sixteen of the failing patients (10 TBI, 6 pain) were not eligible for the abbreviated PDRT because they failed the "easy" section. Of the 165 (78 TBI, 87 pain) eligible patients, only one (a pain patient) passed the abbreviated form but failed the standard PDRT. This patient failed none of the other SVT's administered, showed no exaggeration on the MMPI-2, and did not meet any other Slick (1999) criteria for Malingered Neurocognitive Dysfunction. Overall, agreement between the standard and abbreviated forms of the PDRT was $99.5 \%(100 \%$ TBI, $99 \%$ pain). This study demonstrates that there is little or no risk of False Negative Errors when using the abbreviated PDRT and suggests it can be used with confidence in medico-legal evaluations.

Correspondence: Kevin W. Greve, Ph.D., Psychology, University of New Orleans, UNO-Lakefront, New Orleans, LA 70148.E-mail: kgreve@ uno.edu 


\section{T. BABIKIAN, K. BOONE, P. LU \& G. ARNOLD. SENSITIVITY AND SPECIFICITY OF VARIOUS DIGIT SPAN SCORES IN THE DETECTION OF SUSPECT EFFORT.}

When predicting suspect effort, preference is given to measures that are part of a standard battery to minimize administration time. Digit Span (DS) Scaled Score and Reliable Digits (RD) (sum of longest string forward and backward with both items correct) cutoffs have been suggested as effective means of assessing credibility. However, these studies have generally relied on simulated faking volunteers rather than real world patients. The purpose of this study was to confirm the efficacy of suggested cutoffs for DS and RD and to determine whether adding time scores to DS variables increases its sensitivity/specificity when identifying suspect effort. Seventy suspect effort patients (confirmed by suspect performance on at least two effort tests and one behavioral criteria), 36 clinical patients (not in litigation or seeking disability), and 32 controls, were administered a full neuropsychological battery at Harbor-UCLA Medical Center. All cut-off scores were selected based on a $>90 \%$ specificity. Sensitivity of the DS Scaled Score increased from 34\% to $44 \%$ when a $<6$ cutoff was used instead of the recommended $\leq 4$. The RD recommended cutoff of $<7$ resulted in a sensitivity of $46 \%$. Among all DS variables measured, a cutoff of $>1.5$ seconds average time to complete a 3 -digit string yielded a higher sensitivity $(54 \%)$ than DS or RD. A combination score composed of RD minus average time for the 2-digit string significantly increased the sensitivity to $80 \%$. Results suggest that adding a time component to DS scores can significantly improve its ability to detect suspect effort.

Correspondence: Talin Babikian, M.A., Psychology, Loma Linda University, 11130 Anderson St. Suite 201, Loma Linda, CA 92354. E-mail: tbabikian06g@univ.llu.edu

\section{ASHENDORF, B. GAVETT \& R.J. MCCAFFREY. DETECTION OF SUBOPTIMAL EFFORT WITH THE WISCONSIN CARD SORT- ING TEST: THE UNIQUE RESPONSES AND PERFECT MATCHES MISSED INDICES.}

The detection of suboptimal effort has become a key concern in clinical neuropsychological assessment in recent years. In addition to the development of symptom validity tests, which are specifically designed to detect insufficient effort, indices of response bias have also been developed within commonly-used neuropsychological assessment instruments, such as the Wisconsin Card Sorting Test (WCST). Two such indices for the WCST are the Unique Responses index, which measures the number of responses given that match no categorv. and the Perfect Matches Missed index, which measures the number of errors made in placing the eight cards that perfectly match one of the four key cards (Greve, Bianchini, Mathias, Houston, \& Crouch, 2002). For the present study, WCST protocols of 185 community-dwelling, older adults, of ages 55 to 75 , were examined to determine the specificity of the Unique Responses and Perfect Matches Missed indices in this population. Results suggest that these indices may be promising for the identification of suboptimal effort using the WCST.

Correspondence: Lee Ashendorf, M.A., Psychology, University at Albany, SUNY, SS 369, 1400 Washington Ave., Albany, NY, NY 12222. E-mail: la2297@albany.edu

\section{G.J. LARRABEE. SUBTYPES OF MMPI-2 PROFILES IN MALIN- GERED NEUROCOGNITIVE DYSFUNCTION.}

Recent research suggests that there are at least two patterns of response exaggeration characteristic of malingering on the MMPI-2: 1) malingered severe psychopathology or "psychosis" (Graham et al., 1991), and 2 ): malingered cognitive, physical and affective complaints or malingered "injury/illness" (Larrabee, 2003). The present investigation performed hierarchical agglomerative followed by K-means iterative divisive cluster analyses on MMPI-2 L. F. K. and the ten standard clinical scale scores of 33 male and 35 female litigants who met the Slick et al. (1999) criteria for either definite or probable malingered neurocogni- tive dysfunction (MND). Four clusters were identified: 1$)$ a cluster $(n=26)$ that showed a "conversion V" with elevations on Scales Hs and Hy, and a lower secondary elevation on D; 2$)$ a cluster $(n=19)$ with very high elevations on the Lees-Haley FBS (raw score $=31$ ), and on Hs, D and Hy (Hy=T92.7), with secondary elevations on $\mathrm{Pa}, \mathrm{Pt}$ and $\mathrm{Sc} ; 3)$ a cluster $(\mathrm{n}=11)$ with high elevations on Hy, D, and Hy (though lower than cluster 2; e.g. $\mathrm{Hy}=\mathrm{T} 83.3$ ), with modest secondary elevations on Pt and Sc; $4)$ a cluster $(n=12)$ with very high elevations on $F(T=94.8)$, and $\mathrm{Sc}$ $(\mathrm{T}=100)$, with secondary elevations on $\mathrm{Hs}, \mathrm{D}, \mathrm{Hy}, \mathrm{Pa}$ and Pt. These data show that only $12 / 68(17.6 \%)$ of probable malingerers show the "traditional" MMPI-2 malingering profile characterized by extreme elevations on $\mathrm{F}$ and Sc. By contrast, the majority of personal injury malingerers $(82.4 \%)$ show primary elevations on $\mathrm{Hs}, \mathrm{D}$ and $\mathrm{Hy}$, as well as elevated FBS scores

Correspondence: Glenn J. Larrabee, Ph.D., Independent Practice, 630 South Orange Ave., Suite 202, Sarasota,FL 34236.E-mail: GLarrabee@ aol.com

\section{V.L. VAGNINI, M. SOLLMAN, D.T. BERRY, R.P. GRANACHER \&. J.N. HOPKINS. EFFECTIVENESS OF MMPI-2 VALIDITY SCALES FOR DETECTION OF MALINGERED NEUROCOGNITIVE DEFICIT.}

Recent publications have suggested the existence of several distinct types of feigning that may occur during forensic neuropsychological examinations. Although validity scales from the MMPI-2 appear to have some utility for identification of feigned psychiatric disorder, it is not clear that these scales are effective for the detection of Malingered Neurocognitive Deficit (MNCD) which involves deliberate exageration or fabrication of cognitive deficits. Additionally, traditional MMPI-2 validity scales have been reported to be insensitive to somatic feigning. involving exaggeration or fabrication of physical complaints. In the present study, 180 consecutive patients receiving neuropsychological evaluations in compensation-seeking circumstances were classified as feigning psychiatric symptoms only (PSY: $n=9$ ), feigning neurocognive deficits only (MNCD: $\mathrm{n}=40$ ), combined feigners (PSY+MNCD: $n=17$ ), honest (HON: $\mathrm{n}=54$ ), or indeterminate (IND) on the basis of results from the SIRS and three motivational tests (VSVT. TOMM. LMT). IND results were removed from analysis. MMPI-2 validity scale results across the remaining 4 groups indicated significant group differences for all validity scales. However, at the level of individual classification, the traditional MMPI-2 validity scales F, Fp, F-K were not effective at detecting MNCD. The $\mathrm{Fb}$ scale had the best operating characteristics (Sen.=.72 Spec.=1.00). The FBS scale had the best sensitivity to MNCD (.94), but modest specificity $(.50)$. Potential implications for clinical practice will be discussed.

Correspondence: Victoria L. Vagnini, MS, Psychology, University of Kentucky, 115 Kastle Hall, University of Kentucky, Lexington, KY 40506. E-mail:vvagn0@uky:edu

\section{C.L. GROTE, T.D. PARSONS, N.W. NELSON, C.A. SMITH \& E. GEARY. MMPI-2 OBVIOUS-SUBTLE DIFFERENCE SCORES PREDICT FAILURE ON THEVICTORIA SYMPTOMVALIDITYTEST.}

Previous research has challenged the utility and conceptual basis of the MMPI-2 Obvious-Subtle scales. However, we hypothesized that the Total T score, which purportedly reflects the difference between endorsement of subtle and obvious symptoms of psychopathology, would be a better predictor of failure on the Victoria Symptom Validity Test (VSVT) than the other MMPI-2 validity scales. Retrospective analyses of the MMPI-2 and VSVT scores of 53 compensation seeking patients were conducted. MMPI- 2 validity scores were examined among the 29 who clearly "passed" the VSVT (difficult score at or above 21) and the 14 who clearly "failed" (score at or less than 15). The "fail" group scored significantly higher on the Total $\mathrm{T}$ score and lower on the $\mathrm{K}$ scale than did the "pass" group. Subsequent linear regression, using stepwise criteria, showed that Total T, L, F and K scores collectively and signifi- 
cantly predicted the VSVT difficult item score, but only the Total T score made a unique contribution $(\mathrm{p}=.003)$ to this prediction. In conclusion, the Total T score (reflecting a higher rate of endorsement of "obvious" than "subtle" symptoms of psychopathology) is a significant predictor of failure of a test of effort. This suggests that compensation seeking patients who seem to over-endorse symptoms of psychopathology are likely to make poor effort on cognitive tests as well. Patients who achieve elevated Total T scores should be given a test of effort.

Correspondence: Christopher L. Grote, Ph.D., Psychology, Rush University Medical Center, 1650 W. Congress Parkway, Chicago, IL 60612. E-mail: cgrote@rush.edu

\section{N.W. NELSON, C.L. GROTE, T.D. PARSONS, C.A. SMITH \& E. GEARY. DO MMPI-2 “CONVERSION V” PROFILES IMPACT POOR PERFORMANCES ON THE VICTORIA SYMPTOM VALID- ITYTEST?}

Although numerous studies have examined compensation-seeking patients' attempts to feign cognitive symptoms, few studies have examined how psychogenic conditions such as somatoform disorder affect performances on cognitive effort tasks. Boone and Lu (1999) found that 13 of $19(68.4 \%)$ litigating patients who showed a "conversion- $V$ " (i.e., 1-3/3-1 profile) on the MMPI-2 also demonstrated poor performances on one or more cognitive effort task or symptom validity indicator. The present study attempted to confirm these results on a cognitive effort measure not employed by Boone and Lu, the Victoria Symptom Validity Test (VSVT). Data were obtained from 36 compensation-seeking patients, 18 of which demonstrated "conversion-V" profiles on the MMPI2 and 18 of which demonstrated other elevated two-point profiles. All patients were referred for neuropsychological evaluation in relation to cognitive complaints. Consistent with the findings of Boone and Lu, twothirds $(12$ of $18,66.7 \%)$ of the patients showing 1-3/3-1 code types performed below suggested cognitive effort cutoffs on the VSVT. However, 9 of $18(50 \%)$ participants from the comparison group also demonstrated poor performances on the VSVT and did not show statistically different scores from the somatoform group. These results suggest that many patients with somatoform/conversion disorders perform poorly on cognitive effort tasks, but not to an extent that differs significantly from that of other diagnostic groups. It is likely that litigation status is the greater predictor of poor effort performance rather than MMPI-2 profile per se.

Correspondence: Nathaniel W. Nelson, M.A., Psychology, Rush-Presbyterian-St. Luke's Medical Center, 1653 W Congress Parkway, Chicago, IL 60612-3833.E-mail:nathaniel_nelson@rush.edu

\section{G.L. ARNOLD, K.B. BOONE, P.H. LU, A.C. DEAN \& S. MCPHER- SON. SENSITIVITY AND SPECIFICITY OF THE FINGER TAPPING TEST FOR DETECTING SUSPECT EFFORT.}

Past studies indicate that patients with incentive to fake neuropsychological symptoms often have lower Finger Tapping Test (FTT) scores than credible patients. This study builds on past studies by comparing FT scores for patients with confirmed suspect effort (CSE; N = 82) with those of credible patients with (1) traumatic brain injury (TBI; N $=22),(2)$ dementia $(\mathrm{N}=24),(3)$ depression $(\mathrm{N}=31)$, and $(4)$ healthy older controls $(\mathrm{N}=18)$. Each patient completed 310 -second trials for each hand. Men tapped faster than women with their dominant (DH; $\mathrm{p}$ $<.001$ ) and non-dominant hands (NDH; $\mathrm{p}=.003$ ). Group comparisons, divided by gender, revealed that credible patients tapped faster than CSE patients with both hands ( $p<.001$ for men, $p \leq .001$. for women). Sensitivity was highest for the DH for both genders, with specificity being maintained at $\geq 90 \%$ for all groups. A cutoff of 42 for male DH performance yielded $64 \%$ sensitivity for the TBI sample. A cutoff of 39 had $57 \%$ sensitivity for depressed men, and a cutoff of 32 achieved $40 \%$ sensitivity in the male dementia group. For women, a DH cutoff of 34 yielded $69 \%$ sensitivity in the TBI group, a cutoff of 35 yielded $74 \%$ sensitivity in the depressed sample, but a cutoff of 15 resulted in only $17 \%$ sensitivity for AD patients. Cutoffs, sensitivity, specificity, and positive and negative predictive validity for DH and NDH for both genders will be included. These results suggest the FTT shows considerable promise for detecting suspect effort.

Correspondence: Ginger L. Arnold, Ph.D., Psychiatry, Harbor UCLA, $1000 \mathrm{~W}$ Carson Street, Bldg F-9, Box 495, Torrance, CA 90509. E-mail: gingerue@fuller.edu

\section{M.J. SOLLMAN, D.R. BERRY, R.P. GRANACHER, V.L. VAGNINI, A. FRAZIER, J. HOPKINS, A. WETTER \& M.W. WETTER. VALIDITY OF THE LETTER MEMORY TEST IN A COMPENSA- TION-SEEKING TBI POPULATION.}

Because base rates for malingering of cognitive deficits in forensic neuropsychological populations may be as high as 40\% (Larrabee, 2003; Mittenberg et al., 2002), and information about evading detection may be available to clients, there is a constant need for new and valid malingering detection tools. The present study evaluated the validity of the Letter Memory Test (LMT: Inman et al., 1998), a forced-choice measure for detecting cognitive malingering, using a known-groups design. Previous research supported the LMT's sensitivity and specificity through simulation and known-groups designs (Inman et al., 1998). However, the present study used a larger sample and more stringent classification criteria. Participants were 131 litigating TBI claimants (mean age=42.2. $75 \%$ male), referred for neuropsychological evaluation. Individauls were classified as Malingering $(\mathrm{N}=21)$ (or Honest, $\mathrm{N}=64$ ) if the failed (or passed) both of two well-validated measures: the Victoria Symptom Validity Test (VSVT; Slick et al., 1994) and the Test of Memory Malingering (TOMM; Tombaugh, 1997). The lower apparent base rate of malingering in this sample $(16 \%)$ is likely due to the relatively conservative classification criteria. Using a cutting score of $<93 \%$ on the LMT to predict malingering, sensitivity was $91 \%$ and specificity was $98 \%$. This suggests that the LMT may be a useful "back-up" test of effort when concerns exist about the possible coaching of evaluees on the better known VSVT \& TOMM. Continued development and validation of new motivational tests may be necessary in the apparent "arms race" between forensic neuropsychologists and unscrupulous individuals involved in the legal system.

Correspondence: Myriam J. Sollman, BS, Psychology, University of Kentucky, Kastle Hall, Lexington, KY 40504.E-mail: myriamsollman@ yahoo.com

\section{J. NEUDECKER, C. SCHUTTE \& R. SKEEL. DIRECTED FOR- GETTING AS A MEASURE OF MALINGERING.}

Inadequate effort threatens neuropsychological evaluation validity. A number of techniques have been developed to detect malingering. A common rationale in testing of effort is that malingerers overestimate the impact of traumatic brain injuries (TBIs), and thus perform more poorly than someone with a genuine injury would be expected to perform. For the current study researchers created a measure based on a directed forgetting paradigm, in which each word is paired with directions to either remember or forget the word. Eight 14-word lists consisting of "forget" and "remember" words were presented via computer to each group. Task difficulty was variable, with the number of "to be remembered" words ranging from 4 to 8 . Three groups of test takers were evaluated for the study: individuals educated on the effects of brain injury and instructed to malinger $(n=28)$, individuals instructed to give adequate effort $(\mathrm{n}=27)$, and individuals who had sustained a documented TBI $(n=8)$. Correct recall, intrusions, and confabulations were recorded for each individual after administration of each list. Results showed that total recall $(\mathrm{p}<.001)$ and intrusions $(\mathrm{p}<.001)$ discriminated 
malingerers, while confabulations $(p<.055$.) did not. In addition, learning slopes of control participants were steeper than both the TBI and malingering groups. Using this information, researchers set cut score criteria for correct answers (twenty-eight or less) and intrusions (five or more), resulting in a combined sensitivity of .86, a specificity of .97 , and positive predictive power of .96. Clinical implications are discussed. Correspondence: Reid Skeel, Ph.D., Central Michigan University, 136 Sloan Hall, Mt.Pleasant, MI 48859.E-mail: reid.skeel@cmich.edu

\section{R. LANGE, G. IVERSON, D. ANDERSON \& K. SULLIVAN. EVALUATING SUPPRESSED ATTENTION ON THE WMS-III AS A MARKER FOR POOR EFFORT.}

Suppressed attention and concentration, relative to memory, has received some support in the literature as a means for identifying cognitive exaggeration. To date, the majority of research has focused on WMS-R performance patterns. The purpose of this investigation was to examine the clinical utility of unusually suppressed attentional ability on the WAIS-III as a means of detecting poor effort in a sample of 145 personal injury litigants. Participants were divided into two effort groups based on TOMM and/or Warrington RMT performance; Suspected poor effort $(n=19)$ and Presumed adequate effort $(n=126)$. The poor effort group performed significantly lower on all WMS-III memory indices (i.e., IMI, ADI, WMI, GMI, AII) and demonstrated larger Memory-WMI discrepancy scores compared to the presumed adequate effort group (i.e. GMI-WMI, AII-WMI, ADI-WMI, and IMI-WMI). Discriminant function analyses using Memory-WMI discrepancy scores as independent variables revealed poor overall classification rates $(60.0 \%$ to $63.4 \%)$. Based on the prevalence of unusually suppressed attentional ability relative to memory functioning using unidirectional Memory-WMI discrepancy base rate tables developed by Iverson and Tulsky, high specificity (range $=.95$ to .98$)$ and negative predictive power (range $=.86$ to .88) values were demonstrated for these scores. However, unacceptably low sensitivity (range $=0 \%$ to $11 \%$ ) and positive predictive power (range $=0 \%$ to $40 \%$ ) values were found. These results indicate that Memory-WMI discrepancy scores did not provide useful information for identifying poor effort in this sample.

Correspondence: Rael Lange, Ph.D., Neuropsychology and Psychology, Riverview Hospital, Riverview Hospital - North Lawn, 500 Lougheed Highway, Port Coquitlam, BC V3C 4J2, Canada. E-mail: rlange@bcmhs.bc.ca

\section{Cross-Cultural Neuropsychological Assessment}

\section{BAUER, S.E. O'BRYANT, R.C. HILSABECK \& R.J. MCCAF- FREY. AN EXAMINATION OF THE SYMBOL DIGIT MODALITIES TEST IN A RACIALLY DIVERSE NON-NEUROLOGICALLY IM- PAIRED SAMPLE.}

Neuropsychologists routinely assess patients from racially, ethnically, and culturally diverse backgrounds. Therefore, if a measure is to be shown valid for use in diverse patient populations, it is imperative that we investigate what influence, if any, these demographic variables have on neuropsychological test performance. The present study sought to examine the validity of the Symbol Digit Modalities Test (SDMT) across a racially diverse (African American, Asian, Caucasian, and Hispanic) sample of 181 non-impaired individuals aged 18-24 with 13 or more years of education. Results indicated that performance on the SDMT in all racial groups fell within normal limits in comparison to the normative sample. Further, in all racial groups, specificity did not fall below $83 \%$. These preliminary findings suggest that although previously published normative data did not include demographic information about race or ethnicity, the SDMT is a valid instrument for use in diverse racial populations.
Correspondence: Lyndsey Bauer, BA, Psychology, University at Albany, SUNY, 1400 Washington Ave, Albany, NY 12222. E-mail: lt3346@ albany.edu

\section{C.A. LUIS, T.A. CRUM, H.J. GINART, D.A. LOEWENSTEIN, W. BARKER \& R. DUARA. SENSITIVITY AND SPECIFICITY OF THE 7-MINUTE SCREEN IN AFRICAN AMERICAN AND CARIBBEAN BLACKS.}

The 7-Minute Screen (7MS) is a brief screening instrument that has been shown to have good ability to detect mild AD in clinic and community samples of varying Euro-American origin. This study examined the instrument's ability to discriminate mild dementia from normal cognition in community dwelling African-American (AA) and Caribbean Black (CB) elderly. Fifty-seven subjects (37 AA and $20 \mathrm{CB}$ ) were administered 7MS, the MMSE, and a brief neuropsychological examination. Based on neuropsychological findings, 37 subjects were classified as cognitively normal $(\mathrm{AA}=26, \mathrm{CB}=11)$ while 20 met neuropsychological criteria for a dementia $(A A=11, C B=9)$. No differences were found between ethnic groups on age, education, MMSE score, and on any neuropsychological test ( $p$-values $>.01$ ). The results using the 7MS calculated scores of "high" versus "low" probability for dementia indicate that the 7MS has acceptable specificity ( $100 \%$ for AA, $82 \%$ for CB) but poor sensitivity ( $36 \%$ for AA, $56 \%$ for $\mathrm{CB}$ ). Logistic regression using individual 7MS component scores (i.e., free recall total, cued recall total, fluency total, clock drawing total, and orientation total) found that the best discriminator for cognitive classification was the clock drawing component score alone in $\mathrm{AA}(\mathrm{sen} / \mathrm{spec}=72.7 \% / 88.5 \%)$ and the free recall and fluency components scores combined in $\mathrm{CB}$ (sen/spec $=$ $77.8 \% / 81.8 \%$ ). These results suggest that separate screening instruments for dementia may be needed between these two ethnic groups. Correspondence: Cheryl A. Luis, PhD, Wien Center for Alzheimer's Disease, Mount Sinai Medical Center, 4300 Alton Rd. - MRI Bldg., Miami Beach, FL33141.E-mail: cluis@msmc.com

\section{BAUER, S.E. O'BRYANT, R.C. HILSABECK \& R.J. MCCAF- FREY. AN EXAMINATION OF PERFORMANCE ON THE BOSTON NAMING TEST IN A NONCLINICAL SOUTHERN SAMPLE.}

The effects of demographic variables on neuropsychological test performance have been examined in myriad studies. Findings have demonstrated that age, education, gender, and ethnicity affect neuropsychological measures to varying degrees. One potentially important variable that has been examined less rigorously is regionalism. The present study sought to add to the literature by investigating possible regional performance differences on the Boston Naming Test (BNT). The present sample was comprised of 19 residents from a large southern city and was compared to normative data collected from Canada. Results showed that the mean performance of the southern sample (M=53.47) fell within the 10th percentile of the normative data from Canada. Further, $42 \%$ of the present sample performed one standard deviation below the mean, creating an unacceptably high false positive rate. These preliminary findings warrant further investigation of possible regional performance differences on the Boston Naming Test. Implications and suggestions for future research are discussed.

Correspondence: Lyndsey Bauer, BA, Psychology, University at Albany, SUNY, 1400 Washington Ave, Albany, NY 12222. E-mail: lt3346@ albany.edu

\section{A.R. SHERWOOD, J.H. HALPERN \& H.G. POPE. NEUROPSYCHOLOGICAL TEST PERFORMANCE AMONG NAVAJO NATIVE AMERICANS.}

This study examined the pattern of neuropsychological test scores among 140 Navajo adult volunteers. Additionally, we tested a method to minimize the impact of cultural differences by making the content more familiar and relevant for Navajos. Demographic information potentially 
related to the acculturation process and preservation of tradition was also collected. It was found that the pattern of Navajo test scores differed from an Anglo normative pattern, in that Navajo verbal scores were frequently lower than Anglo normative scores, whereas tests of visual memory and visual-spatial abilities were similar or higher. This pattern was significantly affected by sex, such that significant strengths existed among Navajo men on visual-spatial construction, memory, and reasoning tests in comparison to Navajo women, who in turn performed significantly better than the men on speeded, visual-attention tests. Childhood home language (i.e. Diné/Navajo or English) was found to significantly affect scores on two of the tests. In particular, participants who grew up in a home where English was the predominant language did better on an expressive vocabulary test and a visual-spatial abstract reasoning test. The relationship between home language and abstract reasoning on a visual-spatial test was unexpected, as this latter test has traditionally been considered to be a non-verbal, culture-fair assessment tool. Partial support was found for modifying test content to include more culturally relevant ideas. Improvement in performance was seen in recall of a modified short story, but not recall of a modified word list.

Correspondence: Andrea R. Sherwood, M.S., Department of Psychology, University of New Mexico, Logan Hall Rm\#180, Albuquerque, NM 87131.E-mail: asherwood@salud.unm.edu

\section{M.J. RAMIREZ, A. LOZANO, E. GOMEZ, G. CASTILLO-PARRA \& F. OSTROSKY-SOLIS. EFFECTS OF AGE AND EDUCATION ON VERBAL FLUENCY. NORMATIVE DATA IN SPANISH SPEAKING POPULATION.}

Test of verbal fluency is a commonly used neuropsychological test, which assesses language functions (vocabulary size, naming), speed of response, mental organization, search strategies, short-term memory and longterm memory. This test is sensitive to cognitive impairment from a variety of etiologies and is used in both clinical and experimental examinations (Kempler et al, 1998). Subjects are required to generate as many words as possible within a limited time from a particular semantic category. While existing norms have been reported for English Speaking population, norms in Spanish are scarce, in small samples and within limited age ranges. The purpose of this study was to obtain normative data for verbal fluency of animals in a Spanish speaking population. A sample 2564 healthy participants from 6 to 85 years of age performed a verbal fluency task. Adults were grouped into four educational levels: illiterates, 1-4, 5-9, >10 years of formal education. Results showed significant effects of age and of level of education. Age showed a quadratic relationship, from 6 to 30 years scores increased, between 31 and 65 years scores remained constant and from 66 to 85 scores decreased. Level of education was highly significant. Normal illiterate subjects obtain the lower scores. Normative data should take into account a finer stratification by years of education in order to avoid false positives on test for cognitive functioning. Implications for cross-cultural studies will be discussed.

Correspondence: maura J. ramirez, Lab. of Neuorpyschology and Psychophysiology, National University of Mexico, Av. Universidad 3004 Col. Coplico-Universidad, Mexico City 04510, Mexico. E-mail: maurilandya@yahoo.com

\section{E. GOMEZ-PEREZ \& F. OSTROSKY-SOLIS. NEUROPSYCHOLOGICAL EVALUATION OF ATTENTION AND MEMORY IN A SPANISH SPEAKING POPULATION: NORMATIVE DATA FROM 6 TO 85 YEARS OF AGE. .}

The assessment of cognitive dysfunctions requires the development of reliable and objective instruments. Neuropsychological studies have demonstrated that social and cultural factors are important variables when applying neuropsychological tests. In Latin America and among Spanish speaking countries, it is necessary to have neuropsychological tests that include the normative data of Spanish speaking populations.
The purpose of this research was to develop and standardize an instrument that assesses attention and memory in Spanish speaking populations. The instrument includes the assessment of orientation (time, space and person), attention and concentration, frontal functions and verbal and visual memory during coding and recall of information. Normative data in a 950 monolingual Spanish speaking sample from 6 to 85 years of age, divided according to 9 groups of age, is presented. The adult sample was stratified according to three schooling levels: low (0-3 years of school), middle (4-9 years of school) and high (10-24 years of school). The scoring system provides quantitative and qualitative data. Normative data and areas of application are presented.

Correspondence: Esther Gómez, Laboratory of neuropsychology and Psychophysiology, National University of Mexico, Av. Universidad \#3004, Col. Copilco-Universidad, Del. Coyoacan, Mexico, D. F. 04510, Mexico.E-mail:estgom1@yahoo.com

\section{J.S. PORTOCARRERO, S.P. ARNOLD, R.G. BURRIGHT \& P.J. DONOVICK. RELATIONSHIP BETWEEN TWO EXPRESSIVE LANGUAGE MEASURES IN MONOLINGUAL AND BILINGUAL COLLEGE STUDENTS.}

The Controlled Oral Word Association test (COWA) assesses verbal fluency and spontaneous word production. Although COWA is sensitive to brain injury and disorders such as multiple sclerosis, little is known about the processes involved (e.g. word knowledge, attention) in this measure. Despite that COWA can be easily adapted into other languages, little has been done to assess if the processes involved differ between monolingual and bilingual speakers. We assessed the relationship between performance on COWA and the Expressive Vocabulary Test (EVT) in bilingual and monolingual college students. The monolingual sample consisted primarily of Euro-Americans (19 males, 20 females, mean age $=19$ ). The born abroad bilingual group moved to the U.S. from various Asian, European, and Latin American countries (17 males, $22 \mathrm{fe}-$ males, mean age $=19$ ). The native languages of the bilingual group included Russian, Mandarin, and Spanish. Significant correlations were found between COWA and EVT performance in the bilingual sample. Correlation between phonetic fluency (i.e., FAS) and EVT was $r=.41$ $(p<.05)$. Correlation between semantic fluency and EVT was $r=.35$ $(p<.05)$. No significant correlations were found in the monolingual sample. The correlations between phonetic and semantic fluency with EVT were $r=-.041$ and $r=.136$, respectively. Results for our monolingual sample are inconsistent with previous findings that COWA and measures of vocabulary are significantly correlated. Our findings indicate that for our bilingual sample, vocabulary is significantly correlated with COWA, suggesting that word knowledge is a significant factor in COWA performance of bilinguals.

Correspondence: Jose S. Portocarrero, BA, Psychology, SUNY Binghamton, 89 Park St. \# 2, Binghamton, NY 13905. E-mail: abbeyroad_1969@yahoo.com

\section{SANCHEZ, D. BYRD \& J.J. MANLY. CLINICAL UTILITY OF WAIS-III PERFORMANCE SUBTESTS AMONG URBAN SPANISH- SPEAKING HISPANICS AND WHITE ELDERS.}

A valid measure of visuospatial abilities is essential in establishing a baseline of cognitive functioning and to differentiate between dementia syndromes. This preliminary analysis examined the sensitivity of the WAIS-III performance subtests in detecting cognitive impairment among urban clinical populations of Spanish- speaking Hispanic elders (SSH) and non-Hispanic Whites (NHW). A sample of 144 participants (72 SSH and 72 NHW) selected from the Alzheimer Disease Research Center of Columbia University were administered a comprehensive neuropsychological battery including Picture Completion, Picture Arrangement, Block Design, Digit Symbol-Coding, and Object Assembly subtests from the WAIS-III. Dementia diagnosis was made by a neurologist independent of neuropsychological test results. SSH and NHW were matched on Selective Reminding Test delayed recall memory score and 
on dementia diagnosis $(\mathrm{AD}=30$, non- $\mathrm{AD}=42$, thus equating ethnic groups on severity of memory deficit and dementia status. Ethnicityspecific logistic regression analyses were performed to determine the predictive value of WAIS-III performance subtests for predicting dementia group membership (AD vs. non-AD). Results reveal that in the NHW group, Block Design, Digit Symbol, and Object Assembly were significant predictors of dementia status $(\mathrm{p}<.05$ for all). However, in the SSH group, none of the subtests were significant predictors of dementia diagnosis. These preliminary results suggest that WAIS-III performance subtests should not be used in the diagnosis of dementia among Spanish-speaking elders.

Correspondence: Danurys Sanchez, B.A., Columbia University, 2332 Tiebout Avenue, Apt.7G, Bronx, NY NY.E-mail: sanchez@sergievsky. cpmc.columbia.edu

\section{A. ARBOLEDA, D.A. PINEDA, E. LARA, F. LOPERA, E. HENAO, D.C. AGUIRRE, C. FRANCO \& A. ARANA. UTILITY OF A SEMAN- TIC CUE RECALL MEMORY TEST,SHORTENED VERSION, FOR DEMENTIA DIAGNOSIS IN A COLOMBIAN POPULATION.}

Existing treatments for dementia can slow down the problems and can be more effective when they are administered in the first stages. Then, the early detection of dementia has become an important issue (Grober, et al. 1988). The objective of this reported is to present the utility of a Semantic Cue Recall Memory Test (SCRMT) -shortened version- for dementia and Mild Cognitive Deficit (MCD) diagnoses in a sample of Colombian adults, over 50 years-old. The sample was conformed by 60 cases [30 with probable Alzheimer Disease (AD) and 30 with MCD] and 60 controls. Sex, age and socio economic status were statistically controlled. Comparisons were developed using non parametric Kruskal Wallis analyses for three groups, and Mann Whitney $U$ for pared comparisons. There were significant differences in all SCRMT variables groups $(\mathrm{p}<0.05)$ between AD, MCD and controls. As it was expected, AD and MCD groups performed lower than controls. Significant differences between $\mathrm{AD}$ and MCD groups were observed. Our results showed that SCRMT - shortened version- can be used for detecting AD and MCD patients. The presence of a lower score on free recall and recognition plus one intrusion would like to support MCD diagnosis. Performing with low scores on free and cue recall and on recognition, plus false recognitions and / or intrusions would be compatible with AD. Correspondence: Alejandra Arboleda, Group of Neuroscience, University of Antioquia, Calle 62\# 52-72, Medellin 00, Colombia. E-mail: alear@epm.net.co

\section{S. MUNTAL, B. DOLORS, S. ZARAGOZA, M. DE GRACIA, I. NAVAS, L. CASAS, N. CERULLA \& M. AGUILAR. RBANS-A: TRANSLATION AND ADAPTATION FOR SPANISH PEOPLE (SPAIN) .}

AIM To obtain a translated and adapted version of the RBANS version A (RBANS-A) in Spanish, following the standard method of translationbacktranslation as a neuropsychological assessment test for screening of neuropsychological disturbances PATIENTS AND METHODS The standard procedure for test adaptation was followed, involving translation and back-translation to the original English version and adminitration to a sample of healthy volunteers. RBANS final Spanish version was administered to 73 subjetcs (35.6\% male and $64.4 \%$ female) with an average age of 53 years and an average of 9 years full time education. None of the subjects had cognitive (MMSE >24) or functional impediments RESULTS Results for reliability were 0.84 for learning list and 0.82 for story recall. Subtest correlations are similar to the results obtined by the author: significant correlation were found for verbal memory, attention, visuospatial skills and delayed memory. External correlation was found with the MMSE for delayed memory and visuospatial skills subtests. CONCLUSION The Spanish version of the RBANS-A (for Spain) showed similar features to the original English version, following the administration to healthy subjects.
Correspondence: SILVIA MUNTAL, NEUROLOGT, HOSPITAL MUTUA DE TERRASSA, CASTELL 25, TERRASSA O8221, Spain. E-mail: DOLORS.BADENES@terra.es

\section{N. OJEDA, D.J. SCHRETLEN, E. APALATEGUI \& G. PEARL- SON. CROSS-CULTURAL EQUIVALENCE OF TWO TESTS OF ATTENTION.}

As the sociocultural diversity of the United States population increases, there is a growing need to develop or adjust neuropsychological instruments accordingly. The aim of this study was to assess the cross-cultural equivalence of two widely-used measures of attention and psychomotor speed, the Brief Test of Attention (BTA) and the Trail Making Test (TMT). The test stimuli for both consist of letters and numbers. As part of the Deusto Neuropsychological Study, the directions and stimuli for both tests were translated into Spanish and administered to 170 adults from Bilbao, Spain. In addition, standard English versions of both tests also were administered to American participants in the Johns Hopkins ABC study of normal aging. Participants at the two sites were individually matched in terms of age, sex, and years of education. Persons with serious medical conditions, MMSE scores below 24/30, IQ scores below 75, or severe sensory impairments were excluded from both samples. Data analyses revealed that performance on both the BTA and TMT correlated significantly (ps <.001) with age, years of education, and economic status in each sample. However, after controlling for socioeconomic status, there were no significant between-group differences on the Brief Test of Attention ( $\mathrm{p}>$.151) or Trail Making Test (Part A, p >.122; Part B, $\mathrm{p}$ >.216). Altogether, our findings suggest that these two versions of the BTA and TMT have similar psychometric properties and yield equivalent performance among Spaniards and Americans matched for age, sex, and education.

Correspondence: NATALIA OJEDA, PhD, of Psychology, Universidad de Deusto, Apartado 1,, Bilbao 48080, Spain.E-mail:nojeda@fice. deusto.es

\section{A. NAGRA, T. PENIX SBRAGA \& R. SKEEL. THE EFFECTS OF STATE ANXIETY ON NEUROPSYCHOLOGICAL PERFORMANCE IN THE ASIAN-INDIAN POPULATION IN THE UNITED STATES.}

The present study evaluated the effects of anxiety on neuropsychological test performance in a sample of Asian-Indian males in the United States. While ample support exists for an adverse effect of anxiety states on cognitive performance, there is relatively little data on its effects on neuropsychological performance. Additionally, research has shown the race of the examiner may have effects on the minority subjects' performance. This study examined the effects that race of the examiner and anxiety had on the neuropsychological performance of Asian-Indian males. Participants were 60 male Asian-Indian college students (M age $=25.32, \mathrm{SD}=3.80)$ randomly assigned to one of four conditions in a 2 $x 2$ factorial design. The first factor was level of anxiety induction, with high and neutral conditions. The second factor was Caucasian versus Asian-Indian examiner. Results indicated that performance on more cognitively demanding tasks such as the PASAT and Spatial Span were impacted by anxiety $(F=47.42, p<.01 ; F=60.72, p<.01)$ and race of examiner $(\mathrm{F}=238.35, \mathrm{p}<.01 ; \mathrm{F}=42.63, \mathrm{p}<.01)$ respectively. PASAT $(\mathrm{F}=13.41, \mathrm{p}<.01)$ and Spatial Span $(\mathrm{F}=9.26, \mathrm{p}<.01)$ displayed an interaction between anxiety and race of examiner. Digit Span displayed a main effect for anxiety $(F=19.14, p<.01)$. Results suggested both anxiety inducing instructions and examiner race impacted highly demanding tasks, while moderately difficult tasks were less sensitive to race of the examiner. Clinical implications are discussed. Correspondence: Reid Skeel, Ph.D., Central Michigan University, 136 Sloan Hall, Mt. Pleasant, MI 48859. E-mail: reid.skeel@cmich.edu 


\section{J. HSIEH, M. HONG, C. LIANG, L. LEE, M. HO, Y. YANG \&. C.M. BRADSHAW. THE USE OF A PERFORMANCE-CURVE METHOD FOR DETECTING EXPERIMENTALLY SIMULATED COGNITIVE IMPAIRMENT IN TAIWANESE PARTICIPANTS - A PRELIMINARY STUDY.}

A "performance-curve" method has been shown to be useful in detecting simulated cognitive impairment in English-speaking participants. However, it is not known whether the same approach can be applied to people from different cultural backgrounds. The present study aims to evaluate this performance-curve method for detecting simulated cognitive impairment in Taiwanese subjects. The method was based on quantitative analysis of choice reaction times in a series of eight matchingto-sample tasks of graded difficulty. The stimuli used for the test consisted of arrays of English letters, ranging from 1 to 10 letters. An alternative version was also developed using geometric designs as stimuli. The participants were required to identify which of two comparison stimuli was identical to a simultaneously presented sample stimulus. 26 healthy young Taiwanese adults were presented with letter stimuli, and the other 28 participants with the geometric stimuli. Their mean reaction times were used to construct standardized regression equations to describe the behaviour of four testing groups. These groups were non-simulator with letter stimuli ( $n=37)$, non-simulator with geometric stimuli $(n=36)$, simulator with letter stimuli $(\mathrm{n}=27)$ and simulator with geometric stimuli $(n=26)$. There was a linear relationship between individual participant's reaction times and the mean reaction times of the standardization sample. The simulators with letter stimuli and with graph stimuli both showed flatter slopes and higher intercepts than the two non-simulator groups. A univariate measure of performance, based on the proportionate increase in reaction time was able to identify $17 / 27$ simulators with letter stimuli and 18/26 simulators with geometric stimuli. Although this suggests that the performance-curve method used in the present study may be quite robust across different cultural backgrounds, further experiments involving clinical populations are needed to attest its applicability.

Correspondence: $M-Y H O, P h D$, Institute of Clinical Behavioral Sciences, Chang Gung University, 259, Wen Hwa 1st Road, Kwei Shan, Tao Yuan County 333, Taiwan.E-mail: myho@mail.cgu.edu.tw

\section{Y. KANG, J. PARK, K. YU \& B. LEE. AGE- AND EDUCATION-RE- LATED COGNITIVE AND BEHAVIORAL CHANGES IN THE KO- REAN ELDERLY.}

Diagnosing the dementia in its initial stage is often confounded by the gradual cognitive decline associated with normal aging. The present study was conducted to investigate the age-related cognitive and behavioral changes in the Korean normal elderly. The Korean Dementia Questionnaire (KDQ) consists of 33 items that assess cognitive, emotional, and physical problems often reported in the elderly. We administered the KDQ to 1,582 (616 men, 966 women) neurologically healthy adults between 45 and 90 years old selected from urban and rural areas. The subjects were stratified into 9 age groups and 6 educational levels. The KDQ total score was significantly associated with age $(\mathrm{F}(8$, $1486)=3.75, \mathrm{p}<.001)$ and educational level $(\mathrm{F}(5,1486)=7.71, \mathrm{p}<.001)$, but not with sex. Comparing the means of each two consecutive age groups showed that there were significant differences in KDQ score between the age groups "60-64" and "65-69" and between the age groups "70-74" and "75-79." For the elderly with less than 7 years of schooling, the more they were educated, the less cognitive and behavioral problems they had. However, such effect of education was not observed in the elderly with more than 6 years of schooling. The factor analysis of the KDQ scores yielded 9 factors. Among them, only 3 factors (memory problem, language problem, \& visuospatial problem) were influenced by age and educational level. These results suggest that significant declines in memory, language, and visuospatial function occurs around 65 and around 75 years old in the healthy elderly.
Correspondence: Yeonwook Kang, Hallym University, 1 Okchon-dong Chunchon, Kangwondo 200-702, South Korea.E-mail: ykang@ hallym.ac.kr

\section{Cognitive Rehabilitation}

\section{S.A. LEON, J.C. ROSENBEK, G.P. CRUCIAN, A.D. RODRIGUEZ, B. HEIBER, B. HOLIWAY, T.U. KETTERSON, M.Z. CIAMPITTI, K.M. HEILMAN \& L.J. GONZALEZ ROTHI. EXPRESSIVE APROSODIA RESPONDS TO BEHAVIORAL TREATMENT.}

This study investigates the effects of two conceptually based treatments for expressive aprosodia. One, an imitative paradigm, requires the participant to imitate emotional tones of voice modeled by the clinician. The other, a cognitive linguistic paradigm, provides the participant with a written description of a tone of voice together with a representative facial picture and the participant produces to command. The six participants, three men and three women, ranged in age from 49 to 83 . All had suffered a right hemisphere cerebral infarction resulting in affective aprosodia. Trained raters determined presence of aprosodia by judging each participants performance on receptive and expressive batteries of emotional communication. A single subject ABAC design, with replication across six participants, was employed. All participants received both treatments in randomly assigned order with an intervening one month no treatment phase. Probes of sentence production using treated and non-treated emotional tones of voice were completed during baseline and treatment phases. Probe sentences were scored for accuracy by a trained rater blind to time of testing. Effect sizes were calculated on the resulting data for each participant and treatment. Examination of effect sizes confirmed modest to substantial treatment effects for both treatments in all six participants. Due to a relative paucity of treatment studies investigating expressive aprosodia, these data are among the first to suggest that aprosodia may be amenable to behavioral treatments. Correspondence: Susan A. Leon, MA, Department of neurology, University of Florida, $1601 \mathrm{SW}$ Archer Rd 151A, Gainesville, FL 32608. Email:susan.leon@med.va.gov

\section{J. RIPPEL, F. KOHEN, A. TOWNLEY \& A.M. RAYMER. COMPARISON OF NOUN RETRIEVAL TREATMENT EFFECTS IN APHASIA.}

Several treatment strategies have been identified to address word retrieval impairments in aphasia. Some strategies work through restoration of normal semantic-phonologic processes engaged in word retrieval, while others invoke compensatory cognitive mechanisms (e.g., gesture) to promote word retrieval. Reactivation strategies may be less effective in late recovery than compensatory strategies. In this study, we contrasted effects of restorative and compensatory strategies in three individuals with aphasia following unilateral strokes affecting left frontal or subcortical regions. Two of three individuals were greater than one year post stroke onset. Noun retrieval impairments ranged from mild to severe across participants. The experiment incorporated time series designs in which word and gesture retrieval were probed for trained and untrained pictured nouns across baseline and training phases. We contrasted semantic-phonologic treatment and pantomime treatment in counterbalanced order across participants. Results indicated that the two patients with mild to moderate impairments demonstrated significant gains $(\mathrm{p}<.01)$ for retrieval of trained words in both treatment phases. Only 1 of these 2 demonstrated significantly increased gesture use $(p<.01)$ following pantomime training, however. The third participant with severe impairment showed significant gains $(p<.01)$ only following pantomime training for both word and gesture retrieval. No significant improvements were evident for retrieval of untrained words and gestures across participants. Training effects related more to severity than to time post stroke as the two mild/moderate patients showed the greatest gains in word retrieval, whereas the two moderate/severe patients showed greatest increases in gesture use. 
Correspondence: Anastasia M. Raymer, Ph.D., Dept of ESSE, Old Dominion University, 110 Child Study Center, 45th \& Hampton, Norfolk, VA23529-0136.E-mail:sraymer@odu.edu

M.A. NAESER, P.I. MARTIN, M.L. NICHOLAS, E.H. BAKER, H.E. SEEKINS, K.W. DORON, M. KOBAYASHI, H. THEORET, F. FREGNI \& A. PASCUAL-LEONE. IMPROVED NAMING AFTER RTMS TREATMENT IN CHRONIC APHASIA PATIENTS.

In fMRI studies with chronic nonfluent aphasia patients, we have observed "over-activation" in right $(\mathbf{R})$ cortical regions during overt picture naming. This "over-activation" may represent a dead-end or maladaptive strategy (Rosen et al., 2000, Belin et al., 1996) and limit, rather than account for, aphasia recovery. If so, suppression of this "over-activation" may result in behavioral improvement. Slow, $1 \mathrm{~Hz}$ repetitive transcranial magnetic stimulation (rTMS) reduces cortical excitability, and applied to the appropriate $\mathrm{R}$ cortical region may provide a novel treatment approach for aphasia (Naeser et al., 2002). We used rTMS to treat four R-handed, chronic aphasia patients who were recovered Broca/anomic; mild nonfluent; moderate nonfluent; or severe nonfluent. Their ages ranged 52-58 Yr., and they were treated with rTMS beginning at 5-11 Yr. poststroke. Treatment was $1 \mathrm{~Hz}$ rTMS applied to posterior R BA 45 (part of R "Broca's area") for 20 minutes a day, 10 days, over a two-week period at $90 \%$ of motor threshold intensity. On language testing performed at +2 Mo. post-rTMS, each patient improved on naming of the first 20 items of the Boston Naming Test, $\mathrm{p}=.003$ (mean $=+42 \%, \mathrm{SD}=26.4$ ); on the 12 tools/implements, BDAE, $\mathrm{p}=.035$ (mean $=+108 \%, \mathrm{SD}=63) ;$ and on the 12 animals, BDAE, $\mathrm{p}=.015$ (mean $=$ $+49 \%, \mathrm{SD}=36$ ). Future research may suggest a combination approach for aphasia treatment - i.e., rTMS treatments followed by a period of intensive speech therapy for at least two months.

Correspondence: Margaret A. Naeser, Ph D, Harold Goodglass BU Aphasia Research Center, V.A. Boston Healthcare System, Psychology Research (116-B), 150 So. Huntington Ave., Boston, MA 02130. E-mail: mnaeser@bu.edu

M.A. NAESER, P.I. MARTIN, M.L. NICHOLAS, E.H. BAKER, H.E. SEEKINS, K.W. DORON, M. KOBAYASHI, H. THEORET, F. FREGNI \& A. PASCUAL-LEONE. SUSTAINED IMPROVED NAMING AFTER RTMS TREATMENT IN A SEVERE APHASIA PATIENT.

We have observed on fMRI, chronic nonfluent aphasia patients show "over-activation" in right $(\mathrm{R})$ cortical regions during overt picture naming. This "over-activation" may represent a maladaptive strategy and limit, rather than account for, aphasia recovery. If so, suppression of this "over-activation" may result in behavioral improvement. Slow, $1 \mathrm{~Hz}$ rTMS reduces cortical excitability, and applied to the appropriate $\mathrm{R}$ cortical region may provide a novel treatment approach for aphasia (Naeser et al., 2002). When $1 \mathrm{~Hz}$ rTMS was applied to posterior R BA 45 (R Broca's area) for 20 minutes a day, 10 days, over a two-week period at $90 \%$ of motor threshold intensity, we observed dramatic improvement in picture naming at +2 Mo. and +8 Mo. in a 56 Yr. old woman, with severe nonfluent speech who was 6 Yr. post $\mathrm{L}$ intracerebral hemorrhage (subcortical lesion only). At Baseline (pre-rTMS) her score on the first 20 items, Boston Naming Test was only $4 ;+2$ Mo. post-rTMS, 7; +8 Mo., 12 (+200\%); on BDAE, naming tools/implements, 2, 3, 5/12 $(+150 \%)$; and on BDAE, naming animals, 0, 1, 6/12 (+600\%). It is posited, 1-Hz rTMS decreased excitation in R BA 45 which in turn modulated activity in the distributed, bi-hemispheric language network leading to improved naming. This patient received no speech therapy postrTMS. If the brain is undergoing re-organization during +2 to +8 Mo. post-rTMS, this may be an ideal time to provide speech therapy. A combination approach to treatment (rTMS followed by a period of speech therapy) may promote best recovery
Correspondence: Margaret A. Naeser, Ph D, Harold Goodglass BU Aphasia Research Center, V.A. Boston Healthcare System, Psychology Research (116-B), 150 So. Huntington Ave., Boston, MA 02130. E-mail: mnaeser@bu.edu

\section{H.E. SEEKINS, M.A. NAESER, P.I. MARTIN, E. BAKER, K. DORON, M. KOBAYASHI, H. THEORET, F. FREGNI \& A. PAS- CUAL-LEONE. IMPROVEMENT IN MOOD SCALE FOR CHRONIC APHASIA PATIENTS TREATED WITH RTMS.}

Slow $(1 \mathrm{~Hz})$ repetitive transcranial magnetic stimulation (rTMS) to the right (R) BA 45 (part of $R$ "Broca's" area) appears to result in a significant improvement in naming in patients with chronic, nonfluent aphasia following a left hemisphere stroke (Naeser et al., 2002). In patients with treatment resistant major depression, Klein et al (1999) reported a significant antidepressant effect of $1 \mathrm{~Hz}$ rTMS applied to $\mathrm{R}$ prefrontal cortex. Therefore, in addition to speech effects, we examined possible mood effects of $\mathrm{R}$ frontal rTMS in our aphasia patients. We examined three right-handed, male aphasia patients, ages 52,53 , and $58(5,11$, and $10 \mathrm{Yr}$. poststroke), and with recovered Broca's/anomic aphasia, moderate or mild Broca's aphasias. We used a VAS for rating mood (Krengel et al., 1994) at Baseline, and +2 weeks and +2 months postrTMS. Treatment consisted of ten, 20-minute sessions of $1 \mathrm{~Hz}$ rTMS to the posterior portion of R BA 45 at $90 \%$ of motor threshold. Data were evaluated using a one-way Repeated Measures Analysis of Variance. In all three patients studied to date 'happiness' showed a significant increase post-rTMS $(p=.02)$ and the 'sadness' score decreased in two of them (the third patient was already almost at floor on Baseline, and had little room for change; and with only three subjects, this prevented it from being significant). These mood effects may be secondary to the improvement in naming ability, but there may be rTMS-induced mood effects from $R$ frontal stimulation independent of language effects that warrant further investigation.

Correspondence: Heidi E. Seekins, B.A., VA Boston Healthcare Center, Harold Goodglass Boston Univesity Aphasia Research Center, 150 South Huntington Avenue, (116-B), Jamaica Plain, MA 02130. E-mail: heidis@bu.edu

\section{J. PATTERSON, C. DELTON, C. MCINTIRE, C. LLOYD \& J. CRANEY. CUEING TREATMENT FOR NAMING DEFICIT AND GENERALIZATION TO CONNECTED SPEECH.}

Cueing treatments are often used to improve naming in persons with anomia. While many studies have reported their effectiveness on naming trained and untrained single-word targets, few studies have reported generalization to connected speech. We report findings from three individuals with moderate anomia in whom we studied the effectiveness of cueing treatment to improve naming and subsequent generalization to connected speech. Method: Participants were three persons with chronic naming deficit following left CVA who demonstrated a locus of deficit in the phonological output lexicon following a model of lexical processing (Raymer \& Rothi, 2002). In the context of a multiple baseline design, a two-part cueing treatment was initiated to improve retrieval of high and low frequency nouns. The semantic-phonologic part was a modified cueing hierarchy providing information about the meanings and sounds of target words and requiring oral responses. The written part was a letter-by-letter cueing procedure requiring written responses. After achieving baseline stability, treatment was applied twice weekly, with regular probe trials on treatment targets and semantically and phonologically related generalization items. Connected speech was examined in pre- and post-testing. Results: Positive treatment effects, but with varying word-frequency effects, were noted for all participants. Stimulus item generalization patterns varied across participants. Per- 
formance change on connected speech tasks did not reach clinical or statistical significance for any participant. Conclusion: The clinical value of cueing treatment was reaffirmed, however the functional value for improving connected speech remains in question, perhaps due to differing production constraints in single-word and connected speech tasks. Correspondence: Janet Patterson, Ph.D., Communicative Sciences and Disorders, California State University Hayward, 25800 Carlos Bee Boulevard, Hayward, CA 94542.E-mail:jpatters@csuhayward.edu

\section{J. KURLAND, E.H. BAKER, M.A. NAESER, P.I. MARTIN, K. DORON, A. BOGDAN, H. SEEKINS, P. RENSHAW \& D. YURGELUN-TODD. FMRI IN SEVERE APHASIA: SEMANTIC YES/NO DECISIONS ON 'ICON SENTENCES' IN C-VIC .}

We present fMRI for 2 severe aphasics after 1 Yr. of training to communicate with the nonverbal, computer-assisted visual communication (C-ViC) program (Steele et al., 1989). Both were R-handed M, with LMCA stroke. Patient \#1 (62 Yr., 11 Yr. poststroke) had "best response", and could use the icons to initiate communication on the computer (Naeser et al., 1998). Patient \#2 (65 Yr., 7 Yr. poststroke) had "moderate response" and was unable to initiate communication with $\mathrm{C}-\mathrm{ViC}$. Both had extensive white matter lesion adjacent to ventricle, compatible with no meaningful speech (Naeser et al., 1989). During block design fMRI, each was shown C-ViC "icon sentences" (S-V-O); half contained a correct direct object ('man cook soup') and half, an incorrect (semantically unrelated) one ('man cook car'). They used a Yes/No button box for correct/incorrect. Control epochs consisted of viewing checkerboard patterns. The fMRI BOLD scans (1.5 T, GE scanner) were analyzed with SPM 99. Patient \#1 was 100\% correct, patient \#2, $62.5 \%$. Both significantly activated ( $\mathrm{p}<.01$ or beyond) major $\mathrm{R}$ frontal and temporal language homologues (R BA 44, 45, 21, 20) and L perilesional areas (L BA 21), and other ROIs. Two factors separated them: Patient \#1 had larger areas of cortical activation in L and R SMA, than Patient \#2. Patient \#2 had considerably larger areas of cortical activation in $R$ frontal and temporal areas than patient \#1. This may represent "overactivation" and poor modulation of $\mathrm{R}$ language homologues in patient \#2, explaining his limited response to this aphasia treatment.

Correspondence: Jacquie Kurland, MS, Harold Goodglass BU Aphasia Research Center, V.A. Boston Healthcare System, Psychology Research 116-B, 150 S. Huntington Ave., Boston, MA 02130.E-mail: kurlandj@ colorado.edu

\section{T. ALLEN, L. BABASHANIAN, C. HANEY \& A.M. RAYMER. TREATMENT OF APHASIC PERSEVERATION: ERRORFUL VS ER- RORLESS COMPARISON.}

A common error evident in the verbal productions of individuals with aphasia is perseveration, the repeated occurrence of an unintended verbal response. The source of perseveration can differ across individuals, representing disruption of multiple aspects of word retrieval. Helm-Estabrooks et al. (1987) developed Treatment of Aphasic Perseveration (TAP) to reduce perseverations within a verbal cueing hierarchy. TAP involves errorful training, as intervention is administered only after the perseveration occurs. Recent rehabilitation studies have emphasized errorless training methods, avoiding error production to reduce the recurrence of the same errors. We proposed that an errorless adaptation may increase the effectiveness of TAP. We assessed effects of TAP in three individuals (2 right-handed/left CVA, 1 left-handed/right CVA) with severe aphasia and perseveration observed in all verbal tasks. In single participant research designs, we probed verbal performance in baseline and daily training probes on several verbal behaviors: oral reading of trained and untrained phrases, color naming, and number naming. When TAP was administered in an errorful format, two of three participants reduced the number of perseverations, while one increased the number of correct verbal responses. After one month, TAP was applied for 2 participants in an errorless format. Results of errorless TAP were positive for the third participant who now reduced the number of perseverations and improved the accuracy of verbal responses. TAP appears effective for reducing perseverations and improving verbal responses. Some individuals may benefit from an errorless adaptation to gain maximal effects for improving verbal productions.

Correspondence: Anastasia M. Raymer, Ph.D., Dept of ESSE, Old Dominion University, 110 Child Study Center, 45th \& Hampton, Norfolk, VA 23529-0136.E-mail:sraymer@odu.edu

\section{L.M. MAHER, F. SINGLETARY, M. CIAMPITTI \& L.J. GONZA- LEZ ROTHI. COMPARISON OF ERRORLESS AND ERRORFUL LEARNING IN APHASIA REHABILITATION.}

Evidence that under certain conditions errorless learning procedures can facilitate the acquisition of new information prompted the application of errorless learning to the rehabilitation of sentence processing deficits associated with aphasia. In order to explore the impact of avoiding errors during therapy (i.e., errorless learning, we compared mapping therapy for sentence production in a group of 7 individuals with agrammatism under two conditions: an errorless learning condition using constant time delay, and errorful condition (i.e. the traditional trial and error approach) in a multiple baseline, crossover design. Participants were considered to have a positive treatment response if they demonstrated post TX gains of $15 \%$ or more on the baseline averages, a significant $\mathrm{C}$ statistic and a large effect size (.80 or higher). Using these criteria, four of the seven participants demonstrated a positive outcome following errorless mapping, and three of the seven responded positively to errorful mapping treatment. Paired t-test comparisons suggested both methods of treatment delivery yielded significant improvement. Group average pre/post TX gain and effect size comparisons revealed gains of greater than $25 \%$ and large group effect sizes for both methods of delivery, however errorless mapping therapy yielded a larger effect $(d=1.10)$ than errorful mapping $(\mathrm{d}=.88)$. These results suggest that for some patients with aphasia, the errorless version of mapping therapy may be more potent; however both methods of treatment delivery can yield a positive impact.

Correspondence: Lynn M. Maher, PhD, Physical Medicine and Rehabilitation, Baylor College of Medicine, SMTH 1421, 6550 Fannin, Houston, TX 77381.E-mail:Imaher@bcm.tmc.edu

\section{E.C. TOKAJER \& A.M. RAYMER. ALLOGRAPHIC CONVERSION TRAINING IN A PATIENT WITH PURE AGRAPHIA.}

Agraphia is a common and enduring manifestation of left hemisphere brain damage. Yet studies of treatments for agraphia have been limited. We evaluated a gentleman who five years earlier suffered a left hemisphere occipito-parieto-frontal stroke that preserved perisylvian language cortex. Although acute aphasia and dyslexia quickly resolved, severe agraphia persisted. Preliminary testing indicated that his agraphia related to disruption of several aspects of the spelling process, including allographic conversation, the process by which we select and form letters for the intended script and case when writing. With his consent, we applied a systematic writing treatment to address his allographic conversion impairment in a single participant research design. For two weeks he completed daily exercises requiring him to copy and spontaneously generate letters and nonwords. At baseline and post-training. we measured accuracy and speed in direct and delayed copying for words and nonwords, and accuracy in written and oral spelling to dictation tasks. Following training this man significantly increased his writing speed and reduced the numbers of spelling errors in direct and delayed copying. No improvements were evident in dictation tasks, however. We thought that improvements in writing might translate to improved written, but not oral, spelling, as increased writing speed may allow a word to be spelled before the memory for the spelling faded. Instead, our study suggests that different treatments need to be applied to address the distinct aspects of spelling that are disrupted in individuals with dysgraphia. 
Correspondence: Anastasia M. Raymer, Ph.D., Dept of ESSE, Old Dominion University, 110 Child Study Center, 45th \& Hampton, Norfolk, VA23529-0136.E-mail:sraymer@odu.edu

\section{S.A. VALENTIJN, S. VAN HOOREN, H. BOSMA, J. JOLLES, M. VAN BOXTEL \& R. PONDS. THE EFFECT OF TWO TYPES OF MEMORY TRAINING AND CHARACTERISTICS OF PARTICIPANTS.}

We designed a training program that combines cognitive restructuring techniques with memory skills training in order to improve memory performance and memory self-efficacy. The training was offered as a collective and as an individual training. The effectiveness of the intervention, and whether personality (neuroticism) and mood (anxiety, depression) can predict which individuals benefit most from this training, was examined. Participants were 139 community-dwelling older individuals recruited through media advertisements asking for people with subjective memory complaints to participate in a study. Data were collected at baseline and 1 week and 4 months after the intervention. Results indicated that participants in the collective training group reported significantly more stability in memory functioning and had fewer feelings of anxiety and stress about memory functioning. In addition, collective training group participants had an improved recall of a previously learned word list. However, compliance was selective, in that most drop-outs were assigned to the collective training. Analyses revealed that non-compliant participants were more neurotic and experienced more mental distress symptoms. No evidence was found that personality or mood was associated with treatment outcome. Moreover, in order to learn more about the characteristics of this group of individuals, participants in the intervention study were compared with normal healthy individuals enrolled in the Maastricht Ageing Study (MAAS), a longitudinal study of cognitive ageing. Results indicated that individuals who sign up for a memory intervention have more depressive symptoms and higher levels of neuroticism, but better memory performance than MAAS participants.

Correspondence: Susanne A. Valentijn, psychiatry and neuropsychology, Maastricht University, PO Box 616, Maastricht 6200 MD, Netherlands.E-mail:s.valentijn@np.unimaas.nl

\section{LACY, M. RIES, J. WISE \& K. LONSER. MULTIFACTORIAL MEMORY TRAINING PROGRAM FOR OLDER ADULTS.}

Over the last 20 years considerable research has been directed at investigating different approaches to improve the objective and subjective memory performance in older adults. Several training programs have shown effectiveness in enhancing and maintaining memory skills. These approaches include 1) education and support for pre-existing strategies; 2) teaching elaborative verbal strategies which require a depth of processing; 3 relaxation skill training to decrease anxiety and increase attention and 4) promoting cognitive modification of participant's self efficacy and beliefs about aging related memory abilities. METHODS: Participants met for 1 hour per week for 8 weeks with training focused on incorporating the above approaches. SUBJECTS: Fourteen community dwelling adults completed the training program, with six subjects acting as a control group. Participants had a mean age of 69.56 (10.11), mean years of education of 16.96 (2.8), and a GDS-15 total score of 2.8 (3.1). MEASURES: Participants completed the following measures: The Hopkins Verbal Memory Test, Logical Memory from the Weschler Memory Scale-3, Name-Face Test, The Memory Functioning Questionnaire, and the Geriatric Depression Scale. RESULTS: Post training, participants demonstrated improved memory functioning compared to controls. Discussion of current training program and impact on future research will be provided.

Correspondence: Maureen Lacy, Ph.D, Psychiatry Dept, University of Chicago Medical Center, 5837 S. Maryland, Chicago, IL 60637. E-mail: mlacy@yoda.bsd.uchicago.edu

\section{PARADEE, L.J. RAPPORT, R.A. HANKS \& J.A. LEVY. EFFECT OF CIRCADIAN PREFERENCE ON NEUROPSYCHOLOGICAL PERFORMANCE AMONG REHABILITATION INPATIENTS.}

Circadian preference is the most powerful difference between individuals in the realm of circadian rhythms. The present study examined the influence of testing time on performance among 56 morning-oriented rehabilitation inpatients with cognitive $(n=28)$ and noncognitive $(n=28)$ impairments. Each patient was tested twice: Once in the morning (preferred time) and once in the evening (nonpreferred time); sessions and test batteries were counterbalanced to control for practice effects. Patients were assessed with standard neuropsychological measures of attention, language, memory, visuospatial ability, and executive function. An index of brain function in response to cognitive challenge was obtained via tympanic temperature changes during a continuous performance task (CPT). Results demonstrated a differential effect of circadian preference: Patients with cognitive impairment showed disproportionate vulnerability to the effects of circadian preference and time of testing, performing more poorly at nonpreferred than preferred times. Substanital effects ( eta $^{2} .12$ to .48 ) were found on tests of executive function, including working memory, flexibility and set-shifting, impulsivity, and tasks incorporating similar complex, higher-order demands (e.g., copying a complex figure). Patients without cognitive impairment were better able to compensate for the challenges of performing at nonoptimal times. Moreover, this phenomenon was demonstrated on physiological (brain temperature) as well as behavioral (neuropsychological test) indices. Tympanic temperature changes during the CPT indicated that patients with cognitive impairment showed less cognitive engagement at nonpreferred versus preferred times, whereas patients without cognitive impairment showed similar patterns at both testing times. Cognitive reserve theory is suggested as a possible explanation for differential effects. These findings may have implications for rehabilitation interventions and discharge planning.

Correspondence: Christine Paradee, M.A., Psychology, Wayne State University, 2422 Nita, Warren, MI 48091. E-mail: cparadee@comcast.net

\section{T. HONDA, K. SAKATSUME \& K. TAKAHASHI. DEVELOPMENT OF A JOB COACHING PROGRAM PERFORMED BY THE MED- ICAL REHABILITATION TEAM FOR PATIENTS WITH HIGHER BRAIN DYSFUNCTION. .}

[Introduction] It is difficult for individuals with higher brain dysfunction (HBD) to be integrated into the workforce. In the Tokyo metropolis, only $4 \%$ of HBD individuals returned to their former employment position, suggesting that the rehabilitation programs at institutions are not effectively preparing HBD patients to return to work. Our medical rehabilitation team developed a Job Coaching program for HBD patients. [Subjects and Methods] Patients with acquired HBD, aged 18 to 64 years, in a stable medical condition after more than 3 months since the onset of the disease or trauma, were eligible. Patients were nearly independent in performing ADL skills and were on a leave of absence from their employment. In the Job coaching, two staff members of our rehabilitation hospital go with the HBD patient from home to his/her office, and sit beside his/her desk while he/she is working. The staff members point out behavioral problems and obstacles in the surroundings in the office, and help to ameliorate them. They instruct his/her co-workers and family members on how to communicate with the HBD individual. For each patient, Job coaching was performed for 3 hours weekly for 3 months. [Results] Nineteen of 54 HBD patients fulfilled the study criteria, and eight consented to participate. Three individuals dropped out of the study. After Job coaching, two individuals returned to their former employment position, 2 changed positions, and 1 is apprenticing to work. [Conclusion] Job coaching performed by medical rehabilitation staff members may help HBD patients return to the workforce.

Correspondence: Tetsumi Honda, MD,Ph.D, Rehabilitation Medicine, Tokyo Metropolitan Rehabilitaion Hospital, 2-14-1 Tsutsumi-Dori, Sumida-ku, Tokyo 131-0034, Japan. E-mail: h-tetsu@mth.biglobe.ne.jp 


\section{S.T. GONTKOVSKY \& M.H. WINKELMANN. IMPROVED COG- NITION WITH METHYLPHENIDATE STATUS POST CEREBELLAR TUMOR RESECTION.}

Pharmacological intervention with Methylphenidate to address the neurobehavioral deficits associated with various neurological disorders (e.g.. stroke and traumatic brain injury) has increased substantially during the past decade. More recently, reports have surfaced in the literature demonstrating beneficial effects of the medication in patients with brain tumor. The present case study examines the impact of Methylphenidate on the cognitive functioning of a 38-year-old female who had been admitted for inpatient rehabilitation to address functional limitations status post resection of a cerebellar tumor. Approximately 38 hours following pre-treatment neuropsychological screening utilizing Form A of the Repeatable Battery for the Assessment of Neuropsychological Status (RBANS), Finger Tapping Test, and Grooved Pegboard Test, pharmacological intervention with Methylphenidate $10 \mathrm{mg}$, bid was initiated. Physical and occupational therapies were continued without alteration, and no other modification was implemented in the patient's medication regimen. One week subsequent to initiation of Methylphenidate, neuropsychological screening was repeated using Form B of the RBANS, Finger Tapping Test, and Grooved Pegboard Test. A significant change in cognitive status from pre-treatment to post-treatment evaluation was defined as an increase/decrease in performance equal to or greater than one standard deviation. Based on this criterion, a significant improvement was observed in both learning/immediate memory and language functioning as measured by the RBANS. Further analysis revealed these increases to reflect enhanced performance across the List Learning, Story Memory, and Semantic Fluency subtests of the measure. Results demonstrate improved cognitive functioning in selected domains with use of Methylphenidate in a patient status post cerebellar tumor resection. Correspondence: Samuel T. Gontkovsky, Psy.D., Neuropsychology, Methodist Rehabilitation Center, 1350 East Woodrow Wilson, Jackson, MS 39216.E-mail:sto@mmrcrehab.org

\section{JOVANOVSKI \& K. ZAKZANIS. DONEPEZIL AND THE PO- TENTIAL TREATMENT BENEFITS OF CHOLINERGIC STIMULA- TION IN POLYDRUG USE: A CASE STUDY.}

Despite the abundance of research on the cognitive impairments associated with polydrug use, the possibility of a potential treatment for these impairments has received relatively little attention. Cholinergic stimulation has produced beneficial cognitive effects in normal healthy controls and in various clinical populations. Accordingly, the objective of the current study was to explore the potential cognitive benefits of an anticholinesterase inhibitor, donepezil, in a former polydrug user. An ABA design was used. A neuropsychological test battery composed of the Vocabulary and Matrix Reasoning subtests of the Wechsler Adult Intelligence Scale-III, measures of everyday executive functioning (Behavioural Assessment of the Dysexecutive Syndrome [BADS]), and verbal learning and memory tasks (California Verbal Learning Test-II; Rivermead Behavioural Memory Test) was completed at baseline, at 3 months after introducing donepezil, and at 11 weeks after donepezil was discontinued. After donepezil treatment, substantial improvements were found on tasks of nonverbal fluid reasoning (i.e.., Matrix Reasoning) and other executive functioning tests (i.e., BADS). Dramatic increases in academic performance (i.e., grades) and subjective improvements in concentration and episodic memory were also noted. The finding of improvements in tests of executive functioning and in academic performance in this case study, together with the minimal adverse effects of donepezil, warrants the investigation of controlled studies of cholinergic enhancement in polydrug users.

Correspondence: Diana Jovanovski, Honours B.Sc., Division of Life Sciences, University of Toronto (at Scarborough), 1265 Military Trail, Scarborough, ON M1C 4B6, Canada.E-mail: diana.jovanovski@ utoronto.ca

\section{A.J. WOODS, V.W. MARK \&. M. MENNEMEIER. ALTERATIONS IN STIMULUS RESPONSE INFLUENCE CAN- CELLATION PERFORMANCE.}

Control subjects typically exhibit well-organized search patterns on cancellation tests, while rarely demonstrating target omissions or perseverations. Because standard pen and paper cancellation leaves a visible trace and thus obviates reliance on visuospatial memory for task completion, the characteristics of control subject performance may be determined in part by the visibility of markings. We wished to evaluate whether cancellation without visible markings would lead control subjects to resemble brain-injured patients during cancellation (i.e., increased omissions, perseverations and disorganized search), due to stressing spatial working memory. Such a finding might be useful for modeling performance changes following brain injury. Therefore, we gave healthy subjects $(\mathrm{n}=23)$ a standard star cancellation test on a touch-sensitive display using two different versions of target response: "strike" (marking visible) and "static" (marking invisible). Results indicated that the static cancellation test version was associated with a significantly higher number of target omissions $(\mathrm{t}=-3.36, \mathrm{p}<.01)$ and perseverations $(\mathrm{t}=-3.18, \mathrm{p}<$ $.01)$. In contrast, several measures of search organization did not change with test condition. However, the total number of pen contacts also did not change with test condition $(t=-.18, p=.86)$, indicating that increased omissions were matched by increased perseverations. These findings suggest that $(1)$ the static cancellation test may model some aspects of performance changes with brain injury, and (2) consistent with previous research in brain injury, response perseveration is partly determined by the extent of spatial "neglect."

Correspondence: Adam J. Woods, B.S., Physical Medicine and Rehabilitation, University of Alabama at Birmingham, 2848 Regal Circle Apt. G, Birmingham, AL 35216.E-mail: awoods@uab.edu

\section{A.J. WOODS, E. GARCIA-RILL, J. MEYTHALER, V.W. MARK, G.R. JEWELL \& M. MENNEMEIER. ALTERED MAGNITUDE ES- TIMATION IN NEGLECT FOLLOWING LEFT-HEMISPHERE DAM- AGE IMPROVES WITH PHARMACOLOGIC TREATMENT FOR AROUSAL.}

Right neglect following left-hemisphere injury is less frequent than left neglect following right-hemisphere injury and is typically complicated by aphasia. The relative infrequency of testable patients with right neglect following left-hemisphere injury makes it hard to determine if deficits observed in patients with left neglect are neglect-specific or a result of right-hemisphere damage. For instance, we know that patients with neglect are impaired at estimating stimulus intensity but do not know if neglect plays a specific role or is merely a marker of extensive righthemisphere injury. We recently observed a 39 year-old, right-handed, male patient with right neglect (Behavioral Inattention Test. BIT. $=124 / 145$ ) following a left putaminal hemorrhage who was not aphasic (Western Aphasia Battery=95.8). Like many patients with neglect following right-hemisphere injury, he had acute deficits in arousal and often fell asleep during tasks and exercises in rehabilitation. His ability to estimate stimulus intensity was impaired across eleven tasks, spanning five perceptual continua (gustatory, visual, thermal, proprioceptive, and tactile). He was also unable to perform Trails-B. He was prescribed Provigil (modafinil), a narcolepsy medication, to improve arousal during therapy. We had an opportunity to retest him two days later. His BIT score normalized from 124 to 143 . His performance also normalized on 10 of 11 magnitude estimation tasks, $p<.05$, binomial test. He remained unable to complete Trails-B. This is the first report of impaired magnitude estimation in neglect following left-hemisphere injury. Improvement after pharmacological treatment appeared specific to neglect and magnitude estimation, exceeding expectations for both retesting and the normal course of recovery following right-hemisphere injury. 
Correspondence: Adam J. Woods, B.S., Physical Medicine and Rehabilitation, University of Alabama at Birmingham, 2848 Regal Circle Apt. G, Birmingham, AL 35216.E-mail:awoods@uab.edu

\section{A.J. WOODS, G.R. JEWELL, G. FISK, S. TIPTON, R. DOWLER \& M. MENNEMEIER. CALORIC STIMULATION IN NEGLECT: NOT JUST FOR THE VESTIBULAR SYSTEM ANYMORE.}

Reubens (1985) attributed the temporary but dramatic improvement of left neglect following cold caloric stimulation (CCS) of the left ear to a vestibular-mediated, leftward shift of attention. Cappa et al. (1987) attributed the same effect to vestibular-mediated activation of the intact left-hemisphere. We hypothesized instead that CCS improves neglect secondary to changes in arousal rather than vestibular stimulation per se. In a series of 14 patients with unilateral brain lesions $(\mathrm{RHL}=9$, $\mathrm{LHL}=5)$, seven of whom $(\mathrm{RHL}=4, \mathrm{LHL}=3)$ had neglect on the BIT, we compared baseline performances on line-bisection, cancellation, and midline pointing to four stimulation conditions. Stimulation included CCS of the left and right ears and cold pressor stimulation (CPS: immersing the right or left foot in iced-water). All patients without neglect demonstrated a consistent shift of attention to the right following all types of stimulation ( 15 of 16 experimental conditions, $\mathrm{p}<.001$, binomial test). Patients with neglect were variable demonstrating both improvement and decline following CCS and CPS stimulation of both sides of the body. In conclusion, vestibular stimulation is not a necessary component of the CCS effect on neglect because immersing the foot in icedwater can produce the same effect. Stimulation appears to activate the left-hemisphere in patients without neglect, shifting attention to the right. Stimulation-induced changes in arousal probably interact with the patient's baseline level of arousal in neglect, yielding relative changes in hemispheric activation and variable response patterns. While the explanations of Reubens and Cappa et al. seem contradictory, they are equally viable if predicated on relative changes in arousal rather than vestibular stimulation.

Correspondence: Adam J. Woods, B.S., Physical Medicine and Rehabilitation, University of Alabama at Birmingham, 2848 Regal Circle Apt. G, Birmingham,AL 35216.E-mail:awoods@uab.edu

\section{J. HEUTINK, W.H. BROUWER, E. SCHERDER, S. BOUMAN, N. WEISSCHER \& A. BOUMA. TENS IMPROVES SPATIAL DE- TECTION IN A NEGLECT PATIENT.}

There is considerable evidence to suggest that the persistence of unilateral neglect is strongly determined by deficits in a non-spatial, partly right-hemisphere-based system for maintaining arousal in the brain. In this study we investigated whether long term treatment with Transcutaneous Electrical Nerve Stimulation (TENS) aiming to increase arousal, would enhance spatial detection in a female patient (MB, age 46) suffering from chronic neglect after a right hemisphere stroke. After five weeks of baseline measurement, the patient received five weeks of treatment, followed by two weeks of reversal, during her stay in a rehabilitation centre. Treatment consisted of daily 30 -minute sessions of BURSTTENS (asymmetric biphasic square impulses, applied in bursts of trains, nine pulses per train, with an internal frequency of $160 \mathrm{~Hz}$, a repetition rate of $2 \mathrm{~Hz}$, and a pulse width of $40 \mu \mathrm{s}$ ), applied to the left dorsal neck muscles and the left forearm (nervus radialis), while performing a simple copying task. Given on its own, the copying task would not be expected to improve neglect. The number of left omissions on the Bells Cancellation Task reduced during the treatment period (week 6-10) and increased after treatment ended. However, not only contralateral detection improved, ipsilateral detection also benefited from TENS treatment. This illustrates that both spatial and non-spatial attentional performance can be improved by arousal manipulation. Further investigation is needed to determine the immediate and long term effects of TENS treatment in neglect patients.
Correspondence: Joost Heutink, MSc, Neurology, Academic Hospital Groningen, Hanzeplein 1, Poortweg 4 - 2e Verdieping, Groningen 9700RB, Netherlands.E-mail: j.h.c.heutink@ppsw.rug.nl

\section{BUXBAUM, T. MCFALLS, K. KYLE, J. WHYTE \& H. COSLETT. INCONSISTENT EFFECTS OF PRISM TREATMENT IN POST-ACUTE NEGLECT.}

Previous investigations using base-left wedge prisms to treat hemispatial neglect have reported striking and consistent improvements across tasks in right hemisphere stroke (RCVA) patients with post-acute neglect (e.g., Frassinetti et al., 2002). We sought to replicate these findings using methods highly similar to those previously reported. Five postacute RCVA patients ( $\mathrm{mn}$. months post $\mathrm{CVA}=21.8$, range 4-58) performed reaching to visual targets while wearing 10 diopter prisms twice a day for 10 days. Performance was assessed with a battery of paper and pencil (e.g., line cancellation) and computerized (e.g., attentive search) tasks in three baseline sessions, half-way through treatment, at the conclusion of treatment (post-tx), and 1 week post-treatment. For each patient, data from each task were ranked across sessions to assess whether mean ranks of the post-tx session was superior to pre-treatment sessions. Visual inspection of the data indicated that the post-tx session had the highest mean rank of all 6 sessions in all 5 patients for either RT or percent correct data or both. Raw data from each patient's baseline and post-tx sessions were subjected to Wilcoxon Signed Ranks Test. Although statistical power was not high, consistent directionality of scores would nevertheless result in significant effects. However, there were significant treatment effects in only 1 patient $(p<.05)$ due to intertask variability, with trends $(p<.1)$ present in 2 other patients. Previous claims of the efficacy of prism treatment should be tempered to reflect the inconsistency of the treatment effect in some patients.

Correspondence: Laurel Buxbaum, Psy.D., Moss Rehabilitation Research Institute, Thomas Jefferson University, Korman 213, 1200 W. Tabor Rd, Philadelphia, PA 19141. E-mail: lbuxbaum@einstein.edu

\section{Prediction of Functional Outcome}

\section{M.A. CATO, R.B. PARKINSON, C.E. WIERENGA \& B.A. CROSSON. PREDICTING REHABILITATIVE TREATMENT SUCCESS IN CHRONIC NONFLUENT APHASIA: LESION AND PERFORMANCE CHARACTERISTICS.}

The factors that predict recovery potential in chronic nonfluent aphasia are not well understood (Basso \& Farabola, 1997). Recently, Crosson and colleagues (Richards et al., 2002) developed an innovative rehabilitative treatment targeting intentional mechanisms of language production in aphasia. We present preliminary findings on lesion volumetric data and adjunctive language evaluation performances that reveal predictors of treatment success and generalization. Nine left-hemisphere MCA stroke nonfluent aphasic patients with a wide variation in lesion sizes were included in this analysis. We hypothesized that lesion size, regardless of location, would be negatively correlated with level of treatment success. Further, we hypothesized that pre-treatment adjunctive language measures of comprehension, repetition, naming, and spontaneous speech would be positively correlated with level of treatment success. Lesion volumes were measured on 3-D T1-weighted MRI scans using ANALYZE (Robb, 2001) software and were expressed as percentage of whole brain volume. Surprisingly, lesion size was not correlated with level of treatment success, as defined by improvement on naming of treatment words or improvement on adjunctive measures of language. Rather, lesion size was negatively correlated with several pretreatment performances, including WAB word repetition $(r=-.90)$ and WAB naming $(r=-.85)$. On the other hand, as predicted, some pre-treat- 
ment language variables were positively correlated with level of treatment success, including $\mathrm{WAB}$ comprehension $(\mathrm{r}=.66)$. Findings suggest that nonfluent aphasic patients can benefit from rehabilitative treatments even in chronic stages and that factors other than lesion size contribute to the level of treatment success.

Correspondence: Margaret A. Cato, Ph.D., LOCI, VA San Diego Healthcare System, Bldg 13, Floor 3, 151B, 3350 La Jolla Village Drive, San Diego,CA 92161.E-mail: acato@ucsd.edu

\section{D.E. JOHNSON-GREENE, A. INSCORE, L. COLLINS \& L. MCGINNIS. NEUROPSYCHOLOGICAL CORRELATES OF FUNCTIONAL COOKING SKILLS IN PATIENTS WITH STROKE.}

In recent years there has been increased interest in the ecological validity of neuropsychological tests. With an improved understanding of the relationship between cognitive dysfunction and decline in activities of daily living there can be development of interventions aimed at remediation of cognitive substrates of ADL dysfunction. In this study nineteen patients (mean age 68; mean education 13 years; 11 males and 8 females) with acute stroke (5 left hemisphere without significant aphasia, 13 right hemisphere and 1 unspecified) were admitted to an inpatient rehabilitation program and were administered a comprehensive battery of neuropsychological tests. Patients also were administered a standardized performance-based test of cooking skills, the Rabideau Kitchen Evaluation. Among measures of memory, attention, language, spatial, motor, and executive skills, cooking performance was most highly correlated with a measure of executive functioning, the Cognitive Estimation Test $(\mathrm{r}=.46 ; \mathrm{p}<.05)$. Consistent with previous studies showing the importance of intact executive skills in performance of activities of daily living, these results suggest that executive skills involving estimation and deductive reasoning are significantly correlated with intact cooking performance. Results imply that executive skills play a significant role in performance of ADLs, such as meal preparation, and should be a focus of rehabilitation efforts aimed at improving ADL function. Correspondence: Anjeli Inscore, Physical Medicine and Rehabilitation, Johns Hopkins University School of Medicine, Good Samaritan Hospital POB, Suite 406, 5601 Lock Raven Blvd., Baltimore, MD 21239. Email: anjeli_inscore@yahoo.com

\section{P. BOYLE, W.L. MCKERNON, P.F. MALLOY \& R.C. GREEN. EXAMINING THE NEUROPSYCHOLOGICAL DETERMINANTS OF FUNCTIONAL IMPAIRMENT IN ALZHEIMER'S DISEASE: WHICH DEFICITS MATTER THE MOST?}

The purpose of this study was to examine the contributions made by executive versus memory dysfunction to functional impairment in patients with Alzheimer's disease (AD). Seventy mild-moderate probable AD patients completed a neuropsychological assessment battery including multiple executive and memory measures, and caregivers provided ratings of patients' functional status using the Lawton and Brody Activities of Daily Living (ADL) Scale. Significant associations were found between all executive measures and ADL performance $(\mathrm{p}<.05)$, but only one memory measure was significantly associated with ADLs. Moreover, regression analyses indicated that executive dysfunction accounted for a significant proportion of the variance in ADLs $(p<.05)$, even after accounting for dementia severity and memory impairment. These findings suggest that executive dysfunction is a significant and powerful contributor to functional impairment, even among patients with a primary memory disorder. Evaluations of executive functions therefore may aid in the identification of $\mathrm{AD}$ patients in need of ADL assistance.

Correspondence: Patricia Boyle, PhD, Department of Neurology, Boston University, Alzheimer's Disease Center, 715 Albany St., B7, Boston, MA 02118.E-mail: boyle@bu.edu

\section{TANEJA, B.P. ROURKE \& R. HANKS. UTILITY OF THE CVLT- II SHORT FORM IN PREDICTING FUNCTIONAL OUTCOME POST-STROKE.}

The California Verbal Learning Test - Second Edition (CVLT-II; Delis, Kramer, Kaplan, \& Ober, 2000) is a commonly used measure of verbal learning and memory. For populations with severely impaired cognition or greater susceptibility to fatigue this test can be overwhelming, and therefore it may be more appropriate to administer the Short Form (CVLT-II SF). Due to its brevity the CVLT-II SF is also more time efficient. Unfortunately, there is limited research on this measure. The objective of the current study is to examine the predictive validity of the CVLT-II SF, by exploring its contribution to functional outcome measures post-stroke. In this retrospective study, subjects included 70 individuals admitted for inpatient rehabilitation following a recent stroke. Participants were administered the CVLT-II SF as part of a comprehensive neuropsychological evaluation. Functional outcome was based on three variables: scores from the Functional Independence Measure (FIM) at discharge, length of hospital stay, and discharge disposition. Results indicated that after admission FIM scores were controlled for, the CVLT-II SF (total score from trials 1-4) was found to be predictive of FIM scores at discharge, accounting for $34 \%$ of the variance of the FIM cognitive score and $6 \%$ of the variance of the FIM total score. The CVLT-II SF was not predictive of length of hospital stay or discharge setting. It was concluded that the CVLT-II SF is a useful addition to a neuropsychological battery, in part because of its ability to predict functional outcome based on FIM scores in an inpatient stroke rehabilitation population.

Correspondence: Chand Taneja, MA, Dept. of Psychology, University of Windsor, 401 Sunset Ave., Windsor, ON N9B 3P4, Canada. E-mail: taneja@uwindsor.ca

\section{T.T. GORSKE, D.C. DALEY, E. . YENERALL \& L.A. MORROW. NEUROPSYCHOLOGICAL FUNCTION AND EMPLOYMENT STA- TUS IN A WELFARE-TO-WORK SAMPLE.}

Since 1996, individuals who participate in welfare programs are mandated to find employment. Welfare recipients may have difficulty transitioning to the work force due to impairments in psychosocial functioning. Examples include mental health and substance use disorders, medical problems, academic and learning difficulties, and lack of resources such as childcare and transportation. An area unexplored as a potential barrier is cognitive functioning as influencing recipients ability to transition into the work force. This is important because many Welfare to Work $(\mathrm{WtW})$ recipients have personal risk factors related to impaired cognitive ability. We evaluated the relationship between demographics, cognitive functioning and substance abuse severity in a group of $93 \mathrm{WtW}$ recipients in order to assess predictors of employment impairment. No relationship was found between employment functioning and alcohol use, drug use, or psychiatric impairment. However, neuropsychological test results demonstrate that $\mathrm{WtW}$ study subjects with poorer educational attainment, and lower scores on tests of learning, memory, and general intelligence, are more impaired in their employment functioning. Tests of general intelligence emerged as the best predictor of employment functioning. The results have implications for identifying patients at risk for unsuccessful transition into the work force and for the development of effective vocational rehabilitation strategies. Correspondence: Tad T. Gorske, PhD, Clinical Neuropsychology, Western Psychiatric Institute, 3811 O, 1101 Lillian Kauffman Building, Pittsburgh,PA 15213.E-mail: gorskett@msx.upmc.edu

\section{S. MEYER, J. BAERWALD, D. JOHNSON-GREENE \& D.J. SCHRETLEN. CORRELATES OF RETURN TO WORK FOL- LOWING STROKE.}

Nearly one-third of stroke victims are afflicted before age 65 , often during their prime working years. However, the specific cognitive and functional predictors of return to work following stroke remain poorly understood. We examined correlates of return to work (RTW) in 24 stroke survivors and 40 age-, sex-, race-, and education-matched healthy. employed adults (NCs). Eight of the patients (33\%) returned to work 
during the first year after their strokes. All participants completed a brief cognitive screening test and self-report measures of depression and activities of daily living (ADLs). Analyses revealed significant differences between patients who returned vs. did not return to work only on self-report measures of instrumental ADLs and depression, with a nonsignificant trend on cognitive screening. A three-group (NC, RTW, no RTW) multivariate analysis of variance revealed significant group differences on every measure. Post-hoc analyses showed that both stroke groups performed more poorly than NCs (but did not differ from each other) on the cognitive screening test at follow-up. In contrast, only the stroke patients who were unemployed at follow-up reported significantly more ADL limitations and symptoms of depression than NCs. The stroke patients who returned to work reported few ADL limitations or depressive symptoms and did not differ from the NCs. These findings suggest that some stroke survivors return to work despite mild cognitive deficits, but that those with more severe cognitive deficits, especially in concert with functional limitations and depression, are unlikely to return to work following stroke.

Correspondence: David J. Schretlen, Ph.D., Department of Psychiatry, Johns Hopkins University, 600 N. Wolfe Street, Meyer 218, Baltimore, MD21287-7218.E-mail:dschret@jhmi.edu

\section{K.T. KREITER, R.M. LAZAR, R. MARSHALL, S. PEERY, J. FESTA \&. S.A. MAYER. COGNITIVE RECOVERY AFTER SUBARACHNOID HEMORRHAGE IS ASSOCIATED WITH IMPROVEMENTS IN FUNCTIONAL ABILITY, MOOD AND QUALITY OF LIFE.}

The ecological validity of neuropsychological instruments is often questioned. We sought to evaluate the relationship between cognitive recovery and functional ability, mood and quality of life (QOL) in patients with subarachnoid hemorrhage (SAH). We prospectively studied 339 consecutively admitted patients with SAH between July 1996 and April 2000 and recorded their acute clinical course during hospitalization. At 3- and 12-months post-SAH, survivors completed a comprehensive assessment of cognition, functional disability, mood and QOL. Individual cognitive test scores were standardized to sample means at the 3 -month visit, then summed and averaged across 5 domains to create a summary score for each visit. Three-month summary scores were subtracted from 12-month summary scores to create a cognitive change score, which was then dichotomized (cut-point $<0.4$ SD) for data analysis. For noncognitive outcome instruments, 3 -month raw scores were subtracted from 12-month raw scores to produce a change score for functional disability, mood and QOL assessments. Analysis of Covariance models were used to evaluate the association between cognitive change groups and degree of improvement on functional status, mood and QOL change scores after controlling for the effects of age, education and initial SAH severity. Of 82 patients who satisfied inclusion criteria and completed both assessments, $17(21 \%)$ exhibited significant cognitive improvement (cognitive change summary score $>0.4 \mathrm{SD})$. Cognitive improvement was associated with significant improvement in functional status $(p=.023), \operatorname{mood}(p=.033)$, physical QOL $(p=.000)$, psychosocial QOL $(p=.017)$ and total QOL $(p=.004)$. Cognitive improvement during the first year following $\mathrm{SAH}$ is associated with statistically and clinically significant levels of improvement in functional ability, mood and QOL. These results validate the use of cognitive tests as relevant endpoints in clinical trials and rehabilitation programs.

Correspondence: Kurt T. Kreiter, PhD, Neurology, Columbia University, 177 Ft. Washington Ave, Milstein 8GS-313, New York, NY 10032. Email:kkreiter@neuro.columbia.edu

\section{D.L. MOLFESE, A. KEY, M. VOSSEN, J. BARKER, C. FRAN- COIS, C. MALDONADO, F. GROSSI \& W. BREIDENBACH. EVENT-RELATED POTENTIAL INDICES OF BRAIN REORGANI- ZATION IN SENSORY AND MOTOR AREAS IN A HAND TRANS- PLANT PATIENT.}

Previous research demonstrated that the loss of a limb results in major brain reorganization where the part of the brain responsible for a lost limb is often "taken over" by neighboring areas of the brain. Recent advances in hand transplantation procedures and brain imaging techniques enabled us to systematically track brain changes during such reorganization when a patient received a new limb. Event-related potentials (ERPs) were recorded using a 128-channel high-density sensor array in a male hand transplant recipient for four months after the surgery. The patient had originally lost his left hand through an accident four years prior to the transplant. The "probe" tasks for the transplanted and the unaffected hands were designed to repeatedly elicit activity in the motor and sensory areas of the brain. The results indicated that the acquisition of a new limb produced significant brain reorganization over time. The patterns and sources of brain activity associated with the transplanted hand gradually became comparable to those of the unaffected hand. Further, the changes involved not only the motor and sensory areas of cortex usually assigned to the hand but also the auditory cortex as well, suggesting a more global pattern of brain reorganization. Correspondence: Alexandra Key, Ph.D., Psychological \& Brain Sciences, University of Louisville, 317 Life Sciences Bld, Louisville, KY 40292. Email:a0fona01@athena.louisville.edu

\section{WHIPPLE \& D. WHITESIDE. RELATIONSHIP BETWEEN DE- PRESSION AND FUNCTIONAL IMPROVEMENT IN CERE- BROVASCULAR ACCIDENT INPATIENT UNDERGOING PHYSI- CAL REHABILITATION.}

Previous research has provided support for the hypothesis that depressive symptoms adversely impact cognitive and functional improvement in cerebrovascular accident (CVA) patients participating in physical rehabilitation (Clark and Smith, 1998). The current study was undertaken as a replication of this previous research. Eighty-five consecutive rehabilitation inpatients with CVAs (mean age $=73$, 12 years of education), and who met research protocol criteria, were administered the FIM by treatment team members. Team members evaluated the functional memory, social interaction, comprehension, grooming, ambulation and bed transfers of patients using the Functional Independence Measure (FIM) at both admission and discharge (average length of stay $=18$ days). In addition, at admission, the patients were also administered a neuropsychological battery that included assessment of depressive symptoms (Geriatric Depression Scale, GDS). It was hypothesized that the level of depression severity, as measured by the GDS, would predict functional progress, measured by the FIM, from admission to discharge. Data was analyzed utilizing a multiple hierarchical regression analysis, with length of stay and the admission FIM scores entered as control variables. A Bonferoni correction was utilized to minimize the possibility of Type I error. The results indicated the severity of depressive symptoms did not significantly predict functional improvement as measured by the FIM scores $(\mathrm{R} 2=.017, \mathrm{p}>.05)$. Data was analyzed using aggregate FIM scores as well as specific functional FIM scores. Explanations for this lack of significant finding were examined, including concerns with the psychometric properties of the FIM scores.

Correspondence: Douglas Whiteside, Ph.D., Clinical Psychology, Argosy University-Seatle, 3525 Colby Avenue, Suite 200, Everett, WA 98201. E-mail:dougnp@msn.com

\section{E. KANG, S. OH, J. LEE, C. KIM \& D. LEE. NEURAL CORRE- LATES FOR SUCCESSFUL SPEECH PERCEPTION REHABILITA- TION FOLLOWING COCHLEA IMPLANTATION IN PROFOUND DEAF CHILDREN: FDG-PET STUDIES.}

Following successful cochlea implantation (CI), auditory speech perception capacity can be acquired in some but not all profound pre/perilingual deaf children. In this study, we investigated if activity level of particular brain regions was associated with the degree of later auditory speech perception following the CI which those children could achieve. Eight pre/perilingual profound deaf children, who had undergone CI surgery, were participated in this study. They were evaluated with CID (Central Institute of Deaf) test for auditory speech perception 
and the FDG $<$ sup $>18</$ sup $>$-PET for cerebral glucose metabolism measure, both before and after the CI surgery. The profound deaf children showed greater individual variability in auditory speech perception after average two years following CI surgery (post-CI CID score group average $=42$, ranged from 0 to 96 ; pre-CI CID group average $=0$ ). Brain regions whose activity level was positively correlated with the post-CI CID scores were examined both from the pre-CI PET and the post-CI PET images respectively, using voxel-wise covariate analysis (SPM99). Brain activity was greater in the right parieto-frontal and the medial visual regions already during the pre-CI period in the patients who later achieved greater auditory language, i.e., higher post-CI CID scores. This positive correlation was shown only in a limited region of right dorsolateral prefrontal cortex in the post-CI brain. These findings suggested that brain imaging method can be used to predict the individual differences of the brain, which in turn might determine the degree of success in auditory language development following the CI. The pre-existing differences of brain activity before the CI surgery in association with the recovery of auditory language function could be due to pre-existing individual differences in the information-processing strategy.

Correspondence: Eunjoo Kang, Ph.D, Nuclear Medicine, Seoul National University College of Medicine, 28 Yongun-dong, Jongno-gu, Seoul 110744, South Korea. E-mail: eunjookang@yahoo.com

\section{Paper Session 7/4:15-6:00 p.m.}

\section{Studies of Normal Development in Children}

\section{A.A. BAIRD, P.K. ISQUITH, B.R. WALLING \& S.A. GOLUB. EXECUTIVE FUNCTION AND FRONTAL LOBE DEVELOPMENT.}

Adolescence is a time of transformation, requiring an individual to assimilate their often-changing internal states with the ongoing flux of external pressures and expectations. During this time individualism emerges, and there is a substantial increase in attention allocated to, and memory for, affectively salient stimuli. An individuals ability to successfully integrate cognitive, emotional and social processes is thought to rely, at least in part, on executive functioning. Germane to the investigation of the neurophysiological mechanisms that may support the maturation of executive functioning is the structural and functional development of the frontal lobe system. The present study examined this brain/behavior relation in a group of 30 adolescent subjects. Brain structure was examined using high resolution MR and Diffusion Tensor Imaging (DTI), while fMRI (BOLD) was used to index resting neural activity, as well as activity during an affect recognition task. The Behavioral Rating Inventory of Executive Function (BRIEF) was used to assess individual differences in the ability to initiate behavior, inhibit competing actions or stimuli, select relevant goals, plan and organize a means to solve complex problems, shift problem solving strategies flexibly when necessary, and monitor and evaluate behavior, as well as overall executive functioning. Preliminary results demonstrate that individual differences in executive function are closely related to both structural and functional components of frontal lobe development. The results presented will also detail the relation of specific domains of executive function and regionally specific differences in frontal structure, function and connectivity.

Correspondence: Abigail A. Baird, Ph.D., Psychological and Brain Sciences, Dartmouth College, HB6207, Department of PBS, Hanover, NH 03755.E-mail:aab@dartmouth.edu

\section{K.A. ESPY, T.E. SENN, P.M. KAUFMANN \& D.A. CHARAK. MODELS OF EXECUTIVE CONTROL ORGANIZATION IN YOUNG CHILDREN.}

There remains considerable debate concerning the nature of executive control. One method to better understand cognitive organization is to examine ability structure early in ontogeny, that is in young, typicallydeveloping children. A battery of 10 tasks, adapted from developmental, cognitive and neuroscience paradigms and designed to assess executive control, was administered to 178 preschool children (3- to 6 -year-olds). Confirmatory factor analysis was used to investigate the structural organization of executive abilities, where a unitary, as well as several fractionated models, were fit. Results indicated that the fractionated model best fit the obtained data, although the latent factors were highly correlated (>.80). Consistent with developmental theory, executive control abilities are highly interdependent in this age range, yet meaningful cognitive dimensions can be distinguished that are similar in nature to those identified in adults and older children.

Correspondence: Kimberly Andrews Espy, Ph.D., Family \&. Community Medicine, Southern Illinois University School of Medicine, SIUSOM, MC 6503,600 Agriculture Dr., Carbondale,IL 62901-6503.E-mail:kespy@ siumed.edu

\section{A. SANTRA, D.J. MARKS, O.G. BERWID, E.A. CURKO \& J.M. HALPERIN. THE DEVELOPMENT OF EXECUTIVE FUNC- TIONS IN PRESCHOOLERS: A LONGITUDINAL STUDY.}

Objective: Executive Functions (EFs) are believed to begin developing early in childhood. Nevertheless, developmental studies primarily focus on latency aged children. Thus, little is known about the development of EFs during the preschool years. Further, virtually all developmental studies of EFs have used cross-sectional, rather than longitudinal designs, and have relied on non-experimental measures that lack control conditions which are necessary for the isolation of specific constructs. This study evaluated the development of EFs in a non-referred sample of preschool children using a longitudinal design and novel experimental measures with manipulations designed to assess four cognitive functions: perceptual inhibition/interference control, motor inhibition, nonverbal working memory, and memory for relative time. Method: Twenty eight preschool children (mean age $=4.41 ; \mathrm{SD}=.78$ ) were administered a 2-hour test battery containing four experimental tests; Stimulus Conflict Task, Recency Memory Test, Response Conflict Task, Delayed NonMatching to Sample Test. The battery was re-administered one year later $($ mean age $=5.47 ; \mathrm{SD}=.79)$. Data were analyzed using 2 (Condition) X 2 (Time) repeated measures analyses of variance (ANOVA). Result: All four ANOVAs yielded significant main effects for Condition, supporting the validity of the manipulations, and significant main effects for Time, indicating improved overall performance at follow-up. However, there were no significant Condition $x$ Time interactions. Conclusion: The lack of significant Condition $\mathrm{x}$ Time interactions suggests that, contrary to popular belief, the specific constructs of interest targeted by the manipulations did not differentially develop during the intervening period.

Correspondence: Amita Santra, BA, Neuropsychology/Psychology, Graduate Center/Queens College, CUNY, 65-30 Kissena Blvd, Flushing, NI 11367.E-mail:amita1130@yahoo.com

\section{S. HAN, D.C. DELIS, J.A. HOLDNACK, J.H. KRAMER \& W.S. HOUSTON. RELATIONSHIPS BETWEEN IQ AND PERFOR- MANCE ON THE DELIS-KAPLAN EXECUTIVE FUNCTION SYS- TEM IN CHILDREN.}

The focus of cognitive assessments in school settings tends to be on rote verbal intellectual skills such as vocabulary, reading, and arithmetic, with minimal evaluations of higher-level executive functions. The question arises as to whether or not verbal intellectual measures adequately account for the variance on tests of executive function in school-age children. In this study, we examined relationships between VIQ and executive-function measures from the D-KEFS in a normative sample of 470 children, ages 8 to 19. Results revealed generally low correlations between VIQ and D-KEFS measures (ranging from 0.16 to 0.49 ), with a median correlation of 0.28 and the highest correlations accounting for 
only about 16 to 24 percent of the variance. Further analysis of the DKEFS Sorting Test, a test of concept formation and problem solving, and Verbal IQ revealed three distinct subgroups of children: (a) children with disproportionately low executive functions relative to VIQ (18.7\% to $20.6 \%$ ); (b) children with disproportionately high executive functions relative to VIQ $(11.9 \%$ to $16.4 \%)$; and (c) children with equivalent levels (i.e., within 1 standard deviation) of executive functions and VIQ $(63.0 \%$ to $69.6 \%)$. The findings suggest that the current assessment practices in school settings may fail to identify two relatively large subgroups of children: (a) children with specific weaknesses in executive functions; and (b) children with special talents in higher-level creative thinking in the face of lower rote verbal skills. In older students, the emphasis in using group verbal achievement tests (e.g., SAT) for making important college admission decisions may discriminate against some children with high levels of creative-thinking skills.

Correspondence: S. Duke Han, MA, UCSD/VASDHS, Psychology (116B), 3350 La Jolla Village Drive, San Diego, CA 92161. E-mail: dhan1@ partners.org

\section{A.C. BOYCE, J.G. SCHAFER, A. VENKATADRI, M.C. GOLDBERG, M.B. DENCKLA, J.J. PEKAR \& S.H. MOSTOFSKY. FMRI EVI- DENCE OF DEVELOPMENTAL CHANGES IN MOTOR INHIBITION.}

There are observable changes in the refinement of the motor system throughout childhood and adolescence. This study used functional magnetic resonance imaging (fMRI) to assess developmental changes associated with motor inhibition during the performance of a Go/No-go task. Participants included twenty-two typically developing children, ages 8-13 years, and twenty-two adults who reported no mental health problems, ages 18-35 years. Both groups completed a rapid presentation Go/No-go task with green (go) and red (no-go) spaceship stimuli. SPM99 was used to perform event-related analysis for each subject as well as group random effects (RFX) analyses and comparisons. Further analysis was performed using both functional and anatomical regions of interest (ROIs). Functional ROIs within the supplementary motor area (SMA) and bilateral cerebellum were derived from a separate sample of adults $(n=29)$ performing the same task, while anatomical ROIs in the basal ganglia and frontal lobe were chosen based on inhibitory circuits determined from the literature. Separate whole brain analyses revealed No-go associated activation for both adults and children in the SMA and bilateral cerebellum. ROI-based group comparisons in both adults and children revealed that adults showed greater activation than children in the SMA, as well as ventral premotor areas and in interconnected subcortical regions, including the putamen and anterior cerebellum. Children showed greater activation in bilateral prefrontal regions and in the caudate. These findings suggest a developmental shift in activation from prefrontal regions to premotor regions, suggesting less demand for cognitive control when adult inhibitory function is attained. Correspondence: Avery C. Boyce, B.A., DCN, Kennedy Krieger Inst., 707 NBroadway, Baltimore, MD 21224.E-mail:boyce@kennedykrieger.org.

\section{A. SCHWEINSBURG, B. NAGEL, V.C. BARLETT, L.A. KILLEEN, L.C. CALDWELL, C. PULIDO, S.A. BROWN, M.P. PAULUS \& S.F. TAPERT. FMRI OF RESPONSE INHIBITION ACROSS ADO- LESCENT DEVELOPMENT.}

Recent studies have examined neuromaturation during youth. Frontal lobe development continues throughout adolescence, and may underlie maturation of executive functions, such as response inhibition. We used functional magnetic resonance imaging (fMRI) to investigate brain response to an inhibition task among adolescents. Participants were 14 girls and 10 boys ages 12-17 who were demographically similar. Exclusion criteria were left handedness, history of head injury, psychiatric disorders, and neurological problems. During fMRI acquisition, participants performed a go/nogo task that assesses response inhibition. Regression analyses predicted go/nogo response from age, gender, and their interaction. Go/nogo task performance was not related to age or gen- der. Increasing age predicted more brain activation in anterior cingulate, bilateral insula, and right precuneus, but decreased response in left superior/middle frontal and parahippocampal gyri. Girls showed more activation than boys in anterior cingulate, bilateral insula, and right precuneus, but less response in left superior/middle frontal cortex. Gender by age interactions were observed in the anterior cingulate and right insula, where boys showed a positive relationship between age and response that was not evidenced in girls. Consistent with previous studies, these findings indicate that fMRI response to a go/nogo task increases during adolescence in most brain regions. Further, boys and girls demonstrated different activation patterns. Specifically, girls showed more response than boys and no relationship between age and activation, while boys exhibited increasing response with age. This suggests that girls evidenced a more mature response pattern than boys, indicating that girls may develop inhibition-related brain response earlier than boys. Supported by NIAAA R21 AA12519 and R01 AA13419 to S.F. Tapert. Correspondence: Alecia D. Schweinsburg, Psychology, University of California San Diego, VA San Diego Healthcare System 151B, 3350 La Jolla Village Drive, San Diego, CA 92161.E-mail: aschweinsburg@ucsd.edu

\section{Paper Session 8/4:15-6:00 p.m.}

\section{Investigations of Memory Disorders}

\section{DUFF, D. TRANEL \& N.J. COHEN. THE INTERACTION OF DIFFERENT MEMORY AND COGNITIVE SYSTEMS IN HAN- DLING REAL-WORLD MEMORY DEMANDS: A CASE STUDY.}

We report here the case of A, a 48 year-old woman with profound amnesia (WMS-III GMI = 49) following a closed head injury in 1985. Structural MRI revealed white-matter lesions in the pathways surrounding the hippocampus, but the structure and volume of the hippocampal region itself appeared intact. In contrast to other reported cases in the literature with amnesias as severe as hers, A has achieved an extraordinary level of academic success and independence in everyday life and employment, has a remarkable degree of self awareness and insight into her memory deficits, and compensates so fully that few people are aware of her impairment. Formal testing indicates superior IQ (WAISIII Full Scale = 126), executive function ability within the normal range $(\mathrm{BADS}=108 ; \mathrm{TOL}=104)$, and preserved semantic memory and knowledge (WAIS-III Information subtest $\mathrm{SS}=13$; Verfaellie Word Test $=$ $100 \%)$.However, the aspect of her performance abilities that we believe to be most associated with her unique success in navigating through the world in the face of her severe amnesia is her ability to develop and implement self-generated strategies that she uses to exercise control over her environment. Although she has received no formal rehabilitation, she manages to find and exploit various procedures that reduce the complexity of the task and that, once mastered, can be performed with ease although with little flexibility in their execution. This case provides insights into the interaction of different memory systems and cognitive systems in handling real-world memory demands.

Correspondence: Melissa Duff, University of Illinois, 1035 Baytowne Dr. 13, Champaign, IL 61822.E-mail: macollns@uiuc.edu

\section{A.S. CHAN \& M. CHEUNG. AMNESIA IN A PATIENT WITH BI- LATERAL LATERAL TEMPORAL LOBECTOMY WITH SPARED HIPPOCAMPUS.}

It is well understood that the medial temporal lobe is vital for memory processing. However, the involvement of other areas within the temporal lobe beyond the medial region in memory processing remains unclear. To better understand this issue, the present study examined the memory functioning of a patient with bilateral damage to the temporal 
lobe with relatively spared hippocampus. M. H. was a 52 -year-old male with 7 years of education. He underwent the right temporal lobectomy in 1993 and the left one in 1994 to remove the radionecrosis due to radiotherapy for his carcinoma of nasopharynx. The results of the MRI performed in 1998 demonstrated that the lesions on both hemispheres were bilaterally symmetrical, starting from the temporal poles and extending caudally to cover the inferior, middle and superior temporal gyri, amygdaloid nucleus and lateral amydala. However, the medial portion of the temporal lobe, including the hippocampus and parahippocampal gyrus, was relatively spared. The volume of the hippocampal formation $(2.2 \mathrm{~cm} 3)$ was within normal limited as compared to the normative data (range from $2.0 \mathrm{~cm} 3$ to $3.0 \mathrm{~cm} 3$ ) reported by Jack et al. (1989). The memory profile of M. H. assembled that of individuals with amnesia after damage to the medial temporal lobe. He demonstrated impairment on both free recall and recognition trials and manifested rapid rate of forgetting. Specifically, M. H. was only able to retain only $38 \%$ of the newly learned information after 30 minutes while normal subjects could retain about $74 \%$. His memory deficit was not modality-specific in which his verbal and visual memory was both impaired. The results suggested that apart from medial temporal lobe, the temporal area beyond the medial portion is also important for memory processing.

Correspondence: Agnes S. Chan, Ph.D., Psychology, Chinese University of Hong Kong, Sino Building, CUHK, Shatin, N.T. 00000, Hong Kong. E-mail:aschan@psy.cuhk.edu.hk

\section{L.J. REED, D. LASSERSON, P. MARSDEN, P. BRIGHT, N. STAN- HOPE \& M.D. KOPELMAN. RETROSPLENIAL AND MEDIAL TEMPORAL CORTICAL METABOLISM CORRELATE WITH MEM- ORY PERFORMANCE IN AMNESIA ARISING FROM TEMPORAL HERPES ENCEPHALITIS AND FRONTAL LOBE PATHOLOGY.}

The application of 18FDG-PET imaging to the investigation of amnesia arising from cerebral damage aims to identify common patterns of impairment of functional neuronal networks across aetiologically distinct groups. Key functional and structural components in mnemonic processing include the medial temporal cortex, retrosplenial cortex and the frontal lobes. Cerebral FDG-PET data from patients suffering amnesia following herpes encephalitis $(n=7)$ and frontal lobe pathology $(\mathrm{n}=13)$ were compared with age-matched non-amnesic subjects $(\mathrm{n}=10)$. All subjects received structural MRI, resting 18FDG-PET scans and neuropsychological evaluation. PET data were analysed using complementary statistical parametric mapping and region of interest methods. Differential patterns of hypometabolism were found relative to healthy controls, consistent with the underlying neuropathologies, as well as involvement of the retrosplenial cortex. Factor analysis of the neuropsychological data revealed that memory performance was associated with retrosplenial and medial temporal metabolism and executive function with dorsolateral frontal metabolism. The significance of the retrosplenium as a major relay station between the thalamus and the medial temporal and frontal lobes, sensitive to changes in either, is discussed in the light of our findings.

Correspondence: laurence J. reed, institute of psychiatry, de crespigny park, londonse5 8af, United Kingdom.E-mail: l.reed@ btinternet.com

\section{M.W. PARSONS, S.K. LEMIEUX, M.T. MORAN, S.G. LEACH \& M.W. HAUT. ENCODING OF NOVEL WORDS: PREFERENTIAL ACTIVATION OF THE ANTERIOR MESIAL TEMPORAL LOBE WITH FMRI.}

Functional Magnetic Resonance Imaging (FMRI) studies of memory have supported the role of the mesial temporal lobes (MTL) in encoding, but foci of activation seen with FMRI have differed from those suggested by other methods. Using a paradigm in which frequently presented stimuli are contrasted with repeatedly presented stimuli (the novelty paradigm), FMRI studies have shown more activation in the posterior than anterior MTL, whereas the reverse pattern has been shown in Positron
Emission Tomography (PET) studies and lesion studies. Review articles have suggested that this discrepancy is due to differences in imaging methods and task parameters. This study tested the hypothesis that anterior MTL activation during memory encoding is present, but is not typically detected by FMRI due to methodological limitations. Seventeen participants made semantic judgments of words presented in a standard novelty paradigm while undergoing FMRI. Words were presented auditorily and visually. Analysis was performed by constructing individually drawn regions of interest that divided the mesial temporal lobes into 8 subregions. To control for susceptibility artifact in the anterior MTL, FMRI image acquisition parameters were optimized and ROI values were corrected to account for signal dropout. Greater activation was observed in the anterior than posterior MTL for both modalities of stimulus presentation $(\mathrm{F}[1,16]=4.99, \mathrm{p}<0.05)$. The results of this study indicate that anterior MTL activation during encoding of novel words occurs independent of modality of stimulus presentation. Image acquisition parameters and analysis techniques required to measure FMRI activation in this region are discussed.

Correspondence: Michael W. Parsons, Ph.D., Behavioral Medicine, West Virginia University, 930 Chestnut Ridge Rd, Morgantown, WV 26505. E-mail:mparsons@hsc.wvu.edu

\section{R. DAVIS, M. WITGERT \& J. BREIER. IS BASIC MEMORY STRUC-} TURE INVARIANT ACROSS EPILEPSY PATIENT SUBGROUPS?

It is well known that epilepsy patients often exhibit material-specific deficits in memory for verbal vs. nonverbal material. However, it is also apparent that such deficits are not always discernible, and that numerous factors may potentially moderate the degree to which fractionation between verbal and nonverbal material is evident. Using confirmatory factor analysis, we compared the relative fit of one-factor (general) and two-factor (material-specific) models of memory in data from 330 patients with intractable seizure disorder. Data from verbal and nonverbal selective reminding tests, as well as Logical Memory and Visual Reproduction (immediate and delayed recall indices), were used in analyses. The one-factor model fit the data poorly in the full sample, whereas the two-factor model fit the data significantly better. We then assessed the invariance of these two models using multiple-group modeling across subsamples of patients with left vs. right sided seizure focus, earlier vs. later age of seizure onset, lower vs. higher Full Scale IQ, fewer vs. more years of education, younger vs. older patients, and male vs. female patients. In all cases, the two-factor model comprised of verbal and nonverbal memory factors fit the data better than a one-factor (general) model. However, the absolute fit of this model was somewhat weak among patients varying in Full Scale IQ. These findings indicate robust consistency of verbal and nonverbal memory constructs in the epilepsy population, which remain viable in this patient group despite considerable heterogeneity.

Correspondence: Rob Davis, Psychology, The College of New Jersey, P.O. Box7718, Ewing, NJ 08628-0718.E-mail: rdavis@tcnj.edu

\section{C.L. ARMSTRONG, L. GUGLIELMI \& C. SEILER. EARLY-DE- LAYED RADIOTHERAPY DAMAGE AFFECTS WIDESPREAD SE- MANTIC MEMORY NETWORKS.}

Problem: Cranial RT is a standard treatment for brain tumors and is used prophylactically for non-CNS cancers. However, RT has been associated with many damaging side-effects, including changes in brain physiology, cognition, and quality of life. The multiple phases of the effects of radiotherapy have not been well defined. This is the culmination of a series of studies to define the cognitive processes of the early-delayed phase of RT that occurs 1.5-3 months after completing full dose RT, is apparently reversible, and is thought to be due to demyelination. We hypothesized that this phase would be most associated with long-term association memory based in the neocortex. Methods: After excluding patients for any comorbidity, high-grade of tumors, age $<18>69$, and subtentorial tumor location, 82 patients were 
available for study of the early-delayed effects of RT on cognition, (48 patients with RT, 34 without RT). Changes in cognition were examined preRT, 1.5 mos post-RT, and 4.5 mos post RT using a mixed model that controlled for medications, practice, and individual random effects. Results: Our hypothesis of a temporary depression and then rebound in retrieval from verbal semantic long-term memory was confirmed, as well as a double dissociation from configural visual memory. Additional experimental tests revealed the early-delayed decline/rebound only for reaction time and hit rate for recognition of familiar, nameable pictures, indicating that only memory most reliant on broad semantic networks showed the early-delayed pattern. Conclusions: Discernment of the specific cognitive changes following RT, even though temporary, is important for patient care, for differentiation of cognitive systems and brain structures that are vulnerable to RT, and for identifying the physiological mechanisms of RT effects on the brain. Correspondence: Carol L. Armstrong, Neurology, The Children's Hospital of Philadelphia and University of Pennsylvania, 3535 Market Street, Rm. 1410,Philadelphia,PA 19104.E-mail:armstrongc@email.chop.edu

Symposium 8/4:15-6:00 p.m.

\section{Neuropsychological Assessment in Less Common Medical Disorders}

\author{
Chair: James Jackson \\ Discussant: Erin Bigler
}

\section{J. JACKSON, R. HOPKINS, S. GALE \& E. BIGLER. NEUROPSYCHOLOGICAL ASSESSMENT IN LESS COMMON MEDICAL DISORDERS.}

The contributions of neuropsychological assessment to the study of medical disorders are well known. Investigations have frequently addressed cognitive outcomes related to syndromes such as HIV, Multiple Sclerosis, and Hypertension. Numerous other disorders receive little attention from clinicians and researchers, despite their associations with adverse neuropsychological sequelae. In this symposium, we will identify 3 medical conditions infrequently studied by neuropsychologists (delirium, acute respiratory distress syndrome, obstructive sleep apnea), discuss the neuropsychological consequences of these, and highlight their importance and relevance to neuropsychologists: 1. Delirium: Delirium is a neuropsychiatric syndrome frequently experienced by general medical, ICU, and nursing home patients. Once believed to be a benign condition, it is associated with negative cognitive outcomes such as an increased risk for dementia and may be an early marker of cognitive decline. 2. Acute Respiratory Distress Syndrome (ARDS): ARDS is a severe respiratory disorder frequently effecting critically ill patients, occurring in response to sepsis, trauma, pneumonia, and other medical/surgical conditions. Although few studies have been done to date, existing evidence suggests that ARDS is associated with the development of significant cognitive impairment. 3. Obstructive Sleep Apnea: Obstructive Sleep Apnea (OSA) is characterized by absence (apnea) or reduction (hypopnea) of airflow lasting despite normal respiratory exertion and is associated with sleep disruption and hypoxemia. The cognitive and behavioral manifestations associated with OSA are related to both intermittent hypoxia and sleep fragmentation including deficits in alertness, attention, memory (immediate and remote), motor speed, visual spatial ability, and executive dysfunction.

Correspondence: James Jackson, Psy:D, Center for Health Services Research, Vanderbilt University, 6th Fl Med Center East, Suite 6100, Nashville,TN,TN 37232.E-mail: james.c.jackson@vanderbilt.edu

\section{R. HOPKINS. NEUROPSYCHOLOGICAL SEQUELAE FOLLOW- ING ACUTE RESPIRATORY DISTRESS SYNDROME (ARDS).}

Acute Respiratory Distress Syndrome (ARDS) is a severe form of lung injury that effects more than 150,000 people per year in the United States with a mortality rate of $11 \%$ to $43 \%$, depending upon the etiology of the lung injury. The inflammatory and coagulopathic disturbances associated with ARDS have recently been the subject of intense clinical outcomes research, and result in multiple organ dysfunction, including central nervous system (CNS) dysfunction. Despite the significant cognitive effects of ARDS, few neuropsychologists are knowledgeable about this syndrome. While only a few investigations have been done to date, ARDS appears to be associated with significant cognitive impairments. At hospital discharge, ARDS survivors have deficits in multiple cognitive domains including memory, attention, concentration, and processing speed, and also experience global intellectual decline. At long-term follow up, impairments persist in approximately 3 out of 4 patients, who continue to demonstrate difficulties with memory, attention/concentration, processing speed, and executive function. In addition to neurocognitive impairments, ARDS survivors experience significant depression, anxiety, and PTSD, as well as decreased quality of life. The medical establishment recognizes ARDS as a very serious disorder yet neuropsychologists, who are well positioned for this task, have done little investigation of neuropsychological outcome in ARDS survivors. Given the significant cognitive and emotional sequelae associated with ARDS, it is important for neuropsychologists to be aware of the sequelae associated with this syndrome, and contribute to the understanding of the mechanisms associated with the neuropsychological sequelae and work toward possible interventions to improve outcome.

Correspondence: Ramona Hopkins, PhD, Psychology, Brigham Young University, 1122 SWKT, Provo,UT 84602.E-mail: ramona.hopkins@byu.edu

\section{S. GALE. OBSTRUCTIVE SLEEP APNEA AND LONG-TERM COGNITIVE DYSFUNCTION: CURRENT ISSUES AND FUTURE DIRECTIONS.}

Obstructive Sleep Apnea (OSA) is a sleep disorder resulting in the absence (apnea) or reduction (hypopnea) of airflow lasting at least 10 seconds despite normal respiratory exertion. These episodes result in decreased oxygen saturation levels in the blood (hypoxemia) and disruption or fragmentation of the sleep cycle. OSA affects an estimated $2 \%$ to $4 \%$ of the middle-aged population with increasing prevalence with ageing. Common symptoms include excessive daytime sleepiness (EDS), snoring, gasping or choking during sleep, observed apneas, headaches (especially upon waking), irritability and mood disturbance, personality change, motor restlessness, and cognitive impairments. Although OSA has been investigated extensively, limited research has assessed the resultant cognitive and affective sequelae. Cognitive deficits are common in OSA patients, due to the effects of intermittent hypoxia, and occur in multiple domains. Patients with OSA frequently show impaired vigilance, attention, short-term memory, general intellectual functioning, executive dysfunction, visuo-spatial function, and psychomotor speed. The neuropsychological impairments in OSA patients with intermittent hypoxia are similar to those observed following $\mathrm{CO}$ poisoning and its associated hypoxia. The medical establishment and lay public recognize OSA to be a serious and disruptive disorder. Until recently, however. neuropsychologists have conducted limited investigations of the neuropsychological effects of OSA associated with other medical conditions such as stroke. Given the impact of OSA on cognitive function, work performance and quality of life, it is important for neuropsychologists to be aware of the sequelae associated with this syndrome, and contribute to the understanding of the mechanisms of brain injury and implications of treatments of OSA.

Correspondence: Shawn Gale, PhD, Barrow Neuropsychological Institute, 222 West Thomas Rd, Suite 315, Phoenix, AZ 85013. E-mail: s2gale@chw.edu 


\section{J. JACKSON. DELIRIUM AND LONG-TERM COGNITIVE OUT- COMES: A LITTLE RECOGNIZED PROBLEM.}

Delirium is a neurobehavioral syndrome characterized by acute confusion, inattention, disorganized thinking and a fluctuating course. It may be the most common psychiatric condition experienced by hospitalized elderly, affecting between $15 \%$ to $20 \%$ of general hospital patients, $25 \%$ to $65 \%$ of surgical patients and as many as $80 \%$ of patients in intensive care unit (ICU) settings. Although once considered benign, recent evidence has linked delirium with a wide-range of adverse outcomes, including prolonged hospitalization, poor recovery from surgery, and increased morbidity and mortality. Of the many investigations conducted to date, very few have explored post-discharge cognitive outcomes following an episode of delirium. Recent evidence suggests an association between delirium and adverse cognitive outcomes, however, including an increased risk of the development of dementia in patients after a delirium episode. Although the mechanisms responsible for such adverse outcomes remain unknown, it may be that delirium is a harbinger of emerging cognitive abnormalities. For example, some researchers speculate that delirium may be a marker of early or a subclinical dementing illness and similar pathophysiologic and/or genetic mechanisms might underlie both syndromes. Neuropsychologists are well positioned to make contributions to the ongoing scientific research regarding the effects of delirium on long-term cognitive outcome. To date, the formal involvement of clinical neuropsychologists in investigations and clinical interventions related to delirium has been limited. Research on delirium and the development of appropriate clinical interventions for patients with delirium is an important and burgeoning area in which neuropsychologists should become involved.

Correspondence: James Jackson, PsyD, Vanderbilt Medical Center, 6th Floor Med. Center East, Nashville, TN37232. E-mail:james.c.jackson@ vanderbilt.edu

Symposium 9/4:15-6:00 p.m.

\section{Distinguishing Dementia With Lewy Bodies (DLB) From Alzheimer's Disease (AD)}

\author{
Chair: Tanis Ferman \\ Discussant: Clive Ballard
}

\section{T.J. FERMAN. DISTINGUISHING DEMENTIA WITH LEWY BOD- IES (DLB) FROM ALZHEIMER'S DISEASE (AD).}

Neocortical Lewy bodies are found in about $20-35 \%$ of demented elderly at autopsy, $\{531,1144,1155,335,337,1201\}$ and do not commonly occur in normal brains. $\{1172\}$ As such, dementia with Lewy bodies (DLB) is considered the second most common cause of neurodegenerative dementia following Alzheimer's disease (AD). In 1996, consensus criteria for the clinical diagnosis of DLB were put forth that requires dementia plus one or two of the following core features: Recurrent fully formed visual hallucinations (VH), parkinsonism and fluctuating $\operatorname{cog}$ nition. Diagnostic accuracy, in terms of valid differentiation of DLB from other dementias, varies considerably across studies from very poor to excellent. Distinguishing DLB from AD early in the disease course has implications for symptom management such as avoiding iatrogenic treatment complications secondary to neuroleptic or anticholinergic sensitivity in DLB. The symposium provides a forum for discussion of the DLB criteria and its capacity to distinguish DLB from AD. Dr. Becker will discuss the problems and limitations of the current diagnostic criteria with an emphasis on the controversial role of AD pathology. Dr. Salmon will provide data that supports a neurocognitive distinction between neuropathologically confirmed DLB and AD in relation to the de- gree of AD pathology. Dr. Ferman will discuss clinical and cognitive data that supports refining the current criteria in order to facilitate the clinical differentiation of DLB from AD. The symposium will provide three different approaches to the issue of using DLB criteria to differentiate DLB from AD. The discussant, Dr. Ballard, is an expert on DLB and he will discuss the main findings in the context of the most recent advances in the field.

Correspondence: Tanis J. Ferman, PhD, Dept of Psychiatry, Mayo Clinic, 4500 San Pablo Road, Jacksonville, FL 32224.E-mail:ferman.tanis@ mayo.edu

\section{J.T. BECKER \& O.L. LOPEZ. LEWY BODIES IN PROBABLE ALZHEIMER'S DISEASE DO NOT ALTER THE PRESENTATION OR COURSE OF THE DEMENTIA.}

There is a distinct clinical syndrome associated with Lewy Bodies in the cerebral cortex. However, when these neuropathological abnormalities occur in Probable Alzheimer's Disease the situation is less clear. We will describe a series of studies that suggest that LBs exert little clinical effect when they occur in the context of $\mathrm{AD}$. In a retrospective cohort of 185 cases of Definite AD and 60 cases of Definite AD with LBs the accuracy of the $\mathrm{AD}+\mathrm{LB}$ diagnosis varied according the dementia severity. The low sensitivity and specificity suggested that mild AD+LB patients do not present with unique clinical characteristics. High sensitivity and low specificity in moderate/ severe dementia stages suggested that $\mathrm{AD}$ patients can also have characteristic symptoms of DLB. A prospective analysis using the Consensus Guidelines classification, included 11 patients with probable DLB, and 35 with possible DLB. Autopsies were performed and cortical Lewy bodies were identified in 13, but only 4 of these had an antemortem diagnosis of DLB (sensitivity $30.7 \%$, specificity $100 \%$ ). Patients with AD+LB had shorter time to develop incident EPS and diurnal hypersomnia, but not psychosis or depression. The rate of cognitive and functional decline was not different between $\mathrm{AD}+\mathrm{LB}$ and AD. Finally, we analyzed the neuropsychological characteristics of 180 Probable AD patients, 41 with Definite AD and 24 with AD+LB. There were no significant differences between AD patients and those with LBs on any neuropsychological domain score, and the natural history of the dementia did not differ significantly between groups. Current criteria for DLB are useful when LBs occurs in isolation, but not when they coexist with AD. When LBs occur in the context of Probable $\mathrm{AD}$, it is the AD syndrome that predicts clinical outcomes.

Correspondence: James T. Becker, Ph.D., Psychiatry, University of Pittsburgh, Suite 830, 3501 Forbes Avenue, Pittsburgh, PA 15213. E-mail: beckerjt@upmc.edu

\section{T.J. FERMAN, G. SMITH, B. BOEVE \& D. DICKSON. CLINICAL AND COGNITIVE FEATURES THAT DISTINGUISH DLB FROM AD IN CLINICAL AND NEUROPATHOLOGICALLY-CONFIRMED SAMPLES.}

Diagnostic accuracy for DLB compared to AD is variable across studies. We present results suggesting considerations for refining the DLB criteria including clarifying the nature of fluctuations, identifying when visual hallucinations (VH) should occur in relation to dementia onset, specifying neurocognitive differences between DLB and AD and the inclusion of REM sleep behavior disorder (RBD) in the DLB criteria. In a sample of DLB $(n=70), A D(n=70)$ and normal elderly $(\mathrm{n}=200)$, an informant questionnaire revealed that drowsiness, somnolence, staring into space and disorganized speech differentiated groups $(63 \%$ DLB, $12 \%$ AD, $0.5 \%$ normal elderly; $p<0.01)$ with acceptable test-retest reliability and cross validation. In a sample of autopsy-confirmed patients with DLB $(n=41)$ and AD $(n=70)$, the onset of VH relative to dementia onset was earlier for DLB $($ mean = 3 yrs) than AD (mean $=7$ yrs $)(p<0.01)$. Neurocognitive performance in 97 clinically diagnosed DLB and 141 AD demonstrated significantly worse performance on visuoperceptual, visuoconstruction, attention and speeded word finding and significantly better on 
tasks of confrontation naming and verbal memory in the DLB group $(p<0.01)$. REM Sleep behavior disorder (RBD) has been shown to frequently occur in DLB, but is rare in $\mathrm{AD}$. The cognitive profile of patients with RBD plus dementia (without parkinsonism or hallucinations) is indistinguishable from DLB, and both groups differ from AD. As such, a clinical history of RBD with dementia is likely to represent the earliest stages of DLB. These data suggest that refinement of the DLB criteria improves the diagnostic distinction between $\mathrm{DLB}$ and $\mathrm{AD}$.

Correspondence: Tanis J. Ferman, PhD, Dept of Psychiatry, Mayo Clinic, 4500 San Pablo Road, Jacksonville, FL 32224.E-mail:ferman.tanis@ mayo.edu

\section{D.P. SALMON. DISTINCT PATTERNS OF COGNITIVE DEFICITS IN NEUROPATHOLOGICALLY-CONFIRMED DEMENTIA WITH LEWY BODIES AND “PURE” ALZHEIMER'S DISEASE.}

Approximately $20 \%$ of patients who clinically manifest a dementia syndrome similar to Alzheimer's disease (AD) are found at autopsy to have subcortical and diffusely distributed neocortical Lewy body pathology solely or in conjunction with AD pathology. Attempts to clinically differentiate between dementia with Lewy bodies (DLB) and AD on the basis of motor dysfunction, hallucinations, and fluctuating attention have met with limited success. However, the ability to distinguish between the two disorders might be improved by considering the pattern of cognitive deficits they engender. Toward this end, the neuropsychological deficits of patients with autopsy-proven DLB $(n=69$; all but four with concomitant AD pathology) or "pure" AD (n=138) were compared. Despite similar age, education, and mental status scores, DLB patients performed significantly worse than AD patients on measures of visuoconstructive ability (e.g.., Block Design, Figure Copying) and attention/executive functions (e.g., Phonemic Fluency, Trail Making), but better on specific measures of episodic memory. Several derived measures contrasting memory and visuoconstructive performance were significantly different in DLB and AD patients, and were at least moderately successful in distinguishing between patient groups $(77 \%$ correct classification). The distinct pattern of cognitive deficits was maintained across stages of dementia and was inversely related to degree of concomitant AD pathology in the DLB patients. Consideration of these distinct patterns may lead to improved diagnostic accuracy for DLB and AD during life.

Correspondence: David P. Salmon, Ph.D., Neurosciences, UCSD, 9500 Gilman Drive, La Jolla, CA 92093-0948.E-mail: dsalmon@ucsd.edu

Symposium 10/4:15-6:00 p.m.

\author{
Drug Treatment of Neuropsychological \\ Disorders: Clinical and Regulatory Issues
}

Chair: Robert Bilder Discussant: Russell G. Katz

\section{R.M. BILDER, S. FERRIS, W.B. BARR, J. DELUCA, R.M. BILDER \& R.G. KATZ. DRUG TREATMENT OF NEU- ROPSYCHOLOGICAL DISORDERS: CLINICAL AND REGULA- TORY ISSUES.}

Despite advances in understanding of brain-behavior relationships and clinical psychopharmacology, few drugs are approved for the treatment of cognitive disorders. Alzheimer's disease remains the sole "cognitive disorder" for which drug treatment has received FDA approval, but there are promising candidates in other arenas, including epilepsy, schizo- phrenia and traumatic brain injury. This symposium highlights current efforts and future directions in the development of drug treatments for diverse neurocognitive syndromes. Extensive background comes from treatment of dementia. New agents are being examined, and new design strategies and measurement methods are being deployed to expand existing indications to patients with mild impairment, and to target novel indications such as prevention of disease progression (Ferris). Further important experience comes from epilepsy treatment, where attention has been paid to cognitive effects of anticonvulsants, and novel methods have been applied to the determine what changes on cognitive tests are clinically significant (Barr). Traumatic brain injury has been a focus of trials of putative pro-cognitive agents, raising challenges of demonstrating meaningful changes in the context of significant spontaneous recovery (DeLuca). Cognitive deficits are now being targeted in schizophrenia, and a variety of new agents are being examined, triggering questions about the most appropriate design and measurement methods to demonstrate such effects (Bilder). A central question spanning all areas is the need to demonstrate that changes on neuropsychological measures have a meaningful clinical impact. Discussion will focus on the common methodologic issues and regulatory hurdles that must be addressed by the next generation of clinical trials of drugs for neuropsychological indications (Katz).

Correspondence: Robert M. Bilder, Ph.D., Psychiatry \& Biobehavioral Sciences, UCLA, 760 Westwood Plaza, NPI Room C8-849, Los Angeles, CA 90024.E-mail: rbilder@mednet.ucla.edu

\section{S.H. FERRIS. NEW DIRECTIONS IN THE TREATMENT OF DE- MENTIA AND RELATED DISORDERS.}

As the first disorder to receive FDA approval for a cognitive indication. Alzheimer's disease (AD) has provided an important road-map for other efforts to target cognitive indications. This experience highlights a range of methodological issues, including optimal neuropsychological procedures and other outcome measurements designed specifically for clinical trial applications. Recent efforts have focused on a range of new compounds in the development pipeline for treatment of $\mathrm{AD}$ and related disorders, highlighting possibly novel mechanisms of action at cognitively relevant targets. Another critical new direction is the extension of treatment trials earlier in the putative disease process, with a focus on slowing progression and prevention rather than intervention, and raising questions about the boundaries of treatable syndromes encompassing mild cognitive impairment (MCI) and age-associated memory impairment (AAMI), which represents the cognitive consequence of "normal" brain aging. Further challenges are now being addressed, and new guidelines are evolving to target the novel indication of attenuation or prevention of disease progression. Many but not all of these efforts may generalize well to clinical trials involving other cognitive disorders.

Correspondence: Steven H. Ferris, PhD, Psychiatry, NYU School of Medicine, 550 First Avenue, New York, NY 10016.E-mail: steven.ferris@med. nyu.edu

\section{W.B. BARR. ASSESSING TREATMENT EFFECTS: CONTRIBU- TIONS FROM THE EPILEPSY LITERATURE.}

Neuropsychologists studying epilepsy have provided significant advances to the methodology for assessing treatment effects. However, most of the studies using these methods have focused on the effects of surgical intervention. Less emphasis has been placed on using these techniques for assessing the changes in attention and memory associated with treatment using antiepileptic drugs (AEDs). Even less attention has been devoted to the direct treatment of cognitive deficits in epilepsy through pharmacological management. In most AED drug trials, changes in neuropsychological test performance have been defined in statistical terms, based on differences in group means. There is little information to determine whether these differences are meaningful in any other sense. Methods for assessing changes in test scores need to account for test- 
retest reliability, practice-effects, regression to the mean, and the impact of initial performance. All of these factors may vary according the individual characteristics of the subject. This presentation will review two methods from the epilepsy literature that have attempted to account for these sources of test-retest bias. The Reliable Change Index (RCI) provides a confidence interval for predicted change in individual subjects, by taking into account the test-retest reliability of the measure. Standardized regression based (SRB) measures utilize a more sophisticated statistical approach that enables them to better account for other potential sources of confound. These methods also have the potential for enhancing the interpretation of neuropsychological test data in AED protocols and other drug treatment settings by providing an empirically based definition of clinically meaningful change.

Correspondence: William B. Barr, Ph.D., Neurology and Psychiatry, NYU School of Medicine, NYU Comprehensive Epilepsy Center, 403 East 34th Street, EPC - 4th Floor, New York, NY 10016. E-mail: william. barr@med.nyu.edu

\section{J. DELUCA \& E.P. ELOVIC. DRUG TREATMENT OF NEUROPSY- CHOLOGICAL IMPAIRMENTS IN PERSONS WITH TRAUMATIC BRAIN INJURY.}

The incidence of Traumatic Brain Injury (TBI) in the United States is estimated at 1,500,000 persons per year. A significant proportion of these individuals sustain brain damage sufficient to produce significant cognitive and behavioral impairments, primarily in episodic memory, information processing speed/efficiency and executive functions. Further, the nature of this brain damage and resultant cognitive deficits vary significantly across individual, leading to significant heterogeneity in presentation. Despite an improved understanding of these cognitive difficulties following TBI and recent advances in medication regiments designed to improve cognitive deficits, there is little systematic study of medications which can effectively treat these problems after TBI. This presentation will provide an overview of the various medications used for the treat- ment of cognitive impairment following TBI. These include the stimulants, SSRI's, and cholinesterase inhibitors, as well as more recent medications which may improve cognitive performance. Critical analysis of effectiveness studies as well as directions for future research will be discussed.

Correspondence: John DeLuca, PhD, KMRREC, 1199 Pleasant Valley Way, West Orange, NJ 07052. E-mail: jdeluca@kmrrec.org

\section{R.M. BILDER. DRUG TREATMENT OF COGNITIVE INDICA- TIONS IN SCHIZOPHRENIA: NEW TARGETS AND REGULATORY ISSUES.}

Schizophrenia is increasingly acknowledged as a cognitive disorder and it has become clear that the first generation of antipsychotic agents provided at best limited normalization of cognitive function. Recent clinical trials of newer antipsychotic agents have shown some promise in ameliorating cognitive deficits in schizophrenia, albeit the effect sizes are generally modest and some questions remain about the superiority of the newer treatments over optimal treatment with low doses of conventional agents. Multiple efforts are underway to identify new agents that may have direct effects on unique pharmacologic targets in catecholaminergic, cholinergic, GABAergic, and glycinergic receptor systems. As these new strategies are undergoing early trials, regulatory questions have been raised regarding the optimal methods for determining whether significant changes on neuropsychological tests translate to meaningful clinical improvements. Another complex set of questions attends questions about whether neuropsychological changes are simply "pseudospecific" reflections of other symptomatic changes (such as changes in "negative" symptoms). A federally funded effort to help delineate the path to approval for cognitive indications in schizophrenia has already generated some consensual validation of certain measurement and design issues. The impact of these efforts on clinical research and future clinical trial designs will be discussed.

Correspondence: Robert M. Bilder, Ph.D., Psychiatry \& Biobehavioral Sciences, UCLA, 760 Westwood Plaza, NPI Room C8-849, Los Angeles, CA 90024.E-mail: rbilder@mednet.ucla.edu

\section{FRIDAY MORNING, FEBRUARY 6, 2004}

\section{Poster Session 6: Psychometric Studies of Tried and True as Well as New Neuropsychological Instruments/8:00-10:00 a.m.}

\section{Measures of Broad Neuropsychological Functions}

\section{P. SHORT \& R.L. KANE. CONSTRUCT VALIDIATION THROUGH CONFIRMATORY FACTOR ANALYSIS OF PREVIOUSLY PUB- LISHED AND RAW DATA.}

The process of construct validation as theory-testing is outlined through analysis of published data and raw data from a separate source. This poster highlights the importance of inclusion of correlation matrices in published studies as a means for developing and testing theory through secondary analysis. The correlation matrix from a factor analytic study performed by ODonnell and colleagues (1994; Journal of Clinical Psychology, 50, 596-600) was analyzed with structural equation modeling. Whereas the factor structures were consistent with the reported findings, a strong correlation between latent variables for attentional shift and focused attention was observed. This finding was then modeled with new data from patients with relapsing-remitting multiple sclerosis $(\mathbf{n}=$ $50)$ and normal controls $(\mathrm{n}=33)$ to determine how well it explained observed covariance. In addition to logical reasoning and code substitution, two tests from the Automated Neuropsychological Assessment Met- ric (ANAM) battery, the following traditional neurocognitive measures served as manifest variables: Trails B, COWA-CFL, animal naming., Wisconsin Card Sort perseverative responses, WAIS-III digit symbol, and CVLT first trial. Both the factor structure and the strong correlation between latent constructs were replicated with this different set of indicators. In addition to supporting the construct validity of two ANAM tests, this study uncovered a relationship between constucts that could not have been modeled with typical exploratory techniques. The findings suggest that two components of Mirskys attention model, focus/execute and switch, share considerable common variance and thus may not be completely distinct forms of attention.

Correspondence: Paul Short, Ph.D., Baltimore VAMC, Baltimore Research and Education Foundation, 10 North Greene, Baltimore, MD 21045.E-mail:psycwala@comcast.net

\section{J. JAEGER, C. TATSUOKA, S.M. BERNS \& S. UZELAC. POSETS: A NEW APPROACH TO ANALYZING NEUROPSYCHOLOGICAL DATA IN LARGE SAMPLES.}

Most neuropsychological tests are polyfactorial. Though a test may be designed to selectively sample a discrete cognitive domain or attribute, performance is almost always subject to influence by more than one such attribute. Consequently, current methods for analyzing neuropsychological test data in large samples are insufficient for revealing valid cognitive impairment profiles. In a single clinical case, the neuropsychologist considers the attributes required for each test in a battery. and forms judgments about the integrity of each cognitive operation. 
However, when group data are analyzed, test scores are assigned a single attribute (e.g. attention) for which subscale scores are calculated. This approach can yield misleading information about underlying $\operatorname{cog}$ nitive impairments. We report preliminary findings using finite partially ordered sets (posets) for examining neuropsychological test data. Poset models attempt to mimic the clinical/cognitive diagnoses of a neuropsychologist: Based upon their individual performance pattern on an array of tests (each tapping a different set of cognitive attributes), patients are individually classified with respect to proficiency on each underlying attribute. A preliminary analysis was conducted using conventional tests of attention, working memory, and executive functioning within a comprehensive NP test battery given to 222 schizophrenia or schizoaffective outpatients. The validity of poset modeling of NP response data is demonstrated. Resulting classification models provided detailed "diagnoses" into "attribute-based" profiles of cognitive strength/weakness, mimicking a clinician's diagnoses. The potential scientific benefits of using posets for extracting more precise cognitive information from NP data are substantial, revealing more valid relationships between cognition and clinical/functional outcome.

Correspondence: Sarah Uzelac, Ph.D. Candidate, Hillside Hospital, 7559 263rd St., Glen Oaks, NY 11004.E-mail:suzelac@lij.edu

\section{A. DAVIS, K. WOODWARD, N. POLITIKOS \& A.N. BARDOS. EVALUATING THE RELATIONSHIP BETWEEN THE COGNITIVE ASSESSMENT SYSTEM AND ACHIEVEMENT.}

The Cognitive Assessment System (CAS) is a relatively new test of cognitive processing that is based on the Planning, Attention, Simultaneous and Successive (PASS) neuropsychological processing theory. Early research suggests that one of the advantages that the CAS offers when compared to traditional tests of intelligence is that it can guide academic interventions. This study compared 42 childrens performance on the CAS, the Wechsler Individual Achievement Test-Second Edition (WIATII) and the Peabody Picture Vocabulary Test-Third Edition (PPVTIII). Significant correlations were found at the .01 level between the Planning, Attention, and Simultaneous processing composites and the WIAT-II composites of Reading, Written Language, and Mathematics. Successive processing was correlated at the .05 level of significance with the Written Language composite. Low correlations were found between the PPVT-III and the Planning, Attention, and Successive composites. The PPVT-III was significantly correlated at the .01 level with Simultaneous processing. The high correlations between the CAS and WIATII indicate the link between the PASS theory of neuropsychological processing and academic tasks. The mixed correlations between the CAS and PPVT-III were expected, as the Planning, Attention, and Successive composites were designed to be free of language requirements, while Simultaneous processing is needed to successfully complete the PPVTIII. This presentation will present and discuss these results as they relate to neuropsychological processing, as well as implications for practitioners.

Correspondence: Andrew S. Davis, Ph.D., Ball State University, Teachers College Room 515, Ball State University, Muncie, IN 47306. Email:davis@bsu.edu

\section{T.D. BALL, M. SOLLMAN, R.G. BURRIGHT \& P.J. DONOVICK. THE UTILITY OF THE BRIEF NEUROPSYCHOLOGICAL COGNI- TIVE EXAMINATION AS A SCREENING TEST FOR NEUROPSY- CHOLOGICAL FUNCTIONING.}

The Brief Neuropsychological Cognitive Examination (BNCE) is a screening device designed to detect neuropsychological deficits in an individual's "major cognitive functioning." Data were collected from an archival database consisting of 84 males who had received neuropsychological services while residing in a prison or jail. Tests included in these neuropsychological evaluations other than the BNCE were the WAIS-III or Kaufman Brief Intelligence Test (KBIT), the CVLT, and the RCFT. These additional tests measure intelligence, verbal memory, and visuospatial constructional ability and memory, respectively. Based on task demands, we selected specific BNCE subtest scores that most closely assessed performance within these four neuropsychological domains and examined their relationship to scores from selected measures of the WAIS-III, KBIT, CVLT, and RCFT. We investigated the ability of the BNCE to predict performance on these selected measures. Although significant linear relationships emerged, we found that BNCE Total Score was only a moderate predictor of IQ (adjusted R2=.5), and that BNCE Constructive Praxis was a moderate predictor of visuospatial constructional ability (adjusted R2=.32). Weaker predictability was found for BNCE Shifting Set (Recurring Figures; Copy) as a measure of visuospatial constructional ability (adjusted R2=.14) and BNCE Shifting Set (Recurring Figures; Draw) as a measure of visuospatial constructional memory (adjusted R2=.12). BNCE Working Memory was not significantly linearly related to verbal memory in either short-delay or long-delay conditions. Overall, results suggest that if the BNCE is used as a screening device in neuropsychological evaluations, results should be interpreted with extreme caution.

Correspondence: Tabitha D. Ball, B.S., Psychology, Binghamton University, P.O.Box6000, Binghamton, NY 13902.E-mail:wowby@yahoo.com

\section{A. BUFFINGTON, S. MEYER, P. GRAHAM \& D.J. SCHRETLEN. A LIMITATION IN USING THE NART-R TO PREDICT NEUROPSY- CHOLOGICAL TEST PERFORMANCE.}

The National Adult Reading Test-Revised (NART-R; Blair \& Spreen, 1989) was designed to estimate only premorbid IQ, but clinicians also use it to anchor their expectations about a patient's performance in other cognitive domains. The NART-R has been shown to correlate highly with measures of IQ, but its correlation with other neuropsychological tests is less clear. In this study, we correlated NART-R scores with performance on a 7-subtest form of the WAIS-R and 14 other neuropsychological tests administered to over 200 healthy adult participants in the Johns Hopkins Aging, Brain Imaging, and Cognition study. As expected, NART$\mathrm{R}$ scores correlated highly $(r=.71 ; p<.0001)$ with prorated WAIS-R Full Scale IQ. In contrast, Pearson correlations between the NART-R and other cognitive test scores ranged from (-.259 to .481), with a mean (absolute value) $r=.164$. A series of t-tests revealed that every one of these correlations was significantly $(p<.001)$ weaker than the correlation between the NART-R and WAIS-R Full Scale IQ scores. These findings demonstrate that the NART-R predicts concurrent IQ far better than it predicts concurrent performance on other neuropsychological measures among healthy adults. They further suggest the need for caution when using the NART-R to anchor expectations of post-morbid functioning on other neuropsychological measures in clinical assessment. Correspondence: David J. Schretlen, Ph.D., Department of Psychiatry, Johns Hopkins University, 600 N. Wolfe Street, Meyer 218, Baltimore, MD 21287-7218.E-mail:dschret@jhmi.edu

\section{M.R. SCHOENBERG, K. DUFF, J. SCOTT \& R.L. ADAMS. AN EVALUATION OF THE CLINICAL UTILITY OF THE COMBINED OKLAHOMA PREMORBID INTELLIGENCE ESTIMATE (COPIE) AS AN PREDICTOR OF PREMORBID WAIS-III FSIQ.}

The clinical utility of the Combined Oklahoma Premorbid Intelligence Estimate (COPIE; Schoenberg, Duff, Scott, \& Adams, 2003) as a method to estimate premorbid FSIQ in patients with suspected or known brain injury was investigated using the Wecshler Test of Adult Reading standardization sample (WTAR; The Psychological Corporation, 2001). The COPIE algorithms combine Vocabulary and/or Matrix Reasoning subtest raw scores with WTAR scaled scores and demographic variables to predict WAIS-III FSIQ. WTAR raw scores were forced into the algorithm first followed by the remaining predictor variables. Estimated WAIS-III FSIQ scores are presented for patients diagnosed with dementia $(n=47)$, traumatic brain injury $(n=20)$, Huntington's disease $(n=15)$, Korsakoff's disease $(n=12)$, temporal lobectomy $(n=15)$, and schizophrenia $(n=44)$. A group of patients diagnosed with depression $(n=32)$ was used as a 
clinical reference group. The COPIE algorithms performed well, with all three algorithms yielding FSIQ estimates that approximated the mean FSIQ of healthy adults (mean FSIQ ranged from 98.8 to 100.4 for the combined patient sample). Additionally, IQ estimates significantly differed from the patients obtained WAIS-III FSIQ. The COPIE-Best, which is a procedure that employs either the COPIE-V, COPIE-MR, or COPIE2ST algorithms in a best performance method, was presented. Recommendations in the application of the COPIE are made and future research is proposed.

Correspondence: Mike R. Schoenberg, Ph.D., Neurology, University Hospitals of Clevelad/Case Western Reserve University School of Medicine, 11100 E. Euclid Ave., Cleveland, OH 44106-5000. E-mail: Michael. Schoenberg@uhhs.com

\section{S.T. GONTKOVSKY. DIFFERENTIAL CLASSIFICATION OF GLOBAL IMPAIRMENT BETWEEN THE MMSE AND THE RBANS.}

Within the context of inpatient rehabilitation, psychologists often are consulted to evaluate the cognitive status of persons secondary to documented or suspected brain dysfunction. Pragmatic issues, including time constraints and patient fatigue, however, many times necessitate administration of a brief screening measure rather than a more lengthy/complex neuropsychological battery. This investigation examined classification with respect to severity of global cognitive impairment between two commonly employed screening measures, the Mini-Mental State Examination (MMSE) and Repeatable Battery for the Assessment of Neuropsychological Status (RBANS), in a sample of 39 patients with medically documented neurological impairment referred for neuropsychological evaluation during the course of acute inpatient rehabilitation. Classification of patients into one of four groups according to degree of global cognitive impairment was based on MMSE total raw score utilizing criteria provided by Folstein, Folstein, McHugh, and Fanjiang (2001), with serial 7s employed in the calculation of attention, and RBANS Total Scale Index using criteria of one, two, and three standard deviation cutoffs. Analyses revealed a significant positive association between ordinal global impairment classifications for the tests $(\rho=.55, p<.0005)$. Agreement between measures with respect to classification of impairment, however, was only $48 \%$. Based on classification according the MMSE, RBANS concurrence was $40 \%, 60 \%, 33 \%$, and $0 \%$ within the unimpaired, mildly impaired, moderately impaired, and severely impaired ranges of performance, respectively. Only $5 \%$ of cases were classified as less impaired by the RBANS. Results suggest increased sensitivity of the RBANS relative to that of the MMSE to global neuropsychological functioning.

Correspondence: Samuel T. Gontkovsky, Psy.D., Neuropsychology, Methodist Rehabilitation Center, 1350 East Woodrow Wilson, Jackson, MS 39216.E-mail:stg@mmrcrehab.org

\section{M.C. WILDE. THE INFLUENCE OF EDUCATION AND AGE ON THE REPEATABLE BATTERY FOR NEUROPSYCHOLOGICAL STA- TUS (RBANS) IN A MIXED CLINICAL SAMPLE.}

The Repeatable Battery for the Assessment of Neuropsychological Status (RBANS) was developed as a brief neurocognitive evaluation instrument for use in situations where rapid screening is preferable to lengthier batteries (Randolph, 1998). The published norms for the RBANS are stratified by age. However, the norms do not stratify by education, which is widely known to exert a significant influence on neuropsychological measures. Recent studies suggest that education has a significant influence on the RBANS indices in normal elderly samples (Gontkovsky et al., 2002; Lineweaver et al., 2001). The present study examines the influence of age and education on RBANS total and index scores in a mixed clinical sample of 517 neurologic patients. The mean age and educational levels of the sample are $60.2(\mathrm{SD}=14.7)$ and 12.4 $(\mathrm{SD}=3.17)$. There were 261 women and 256 men. The majority of the patients carried a diagnosis of stroke $(\mathrm{n}=372)$, followed by mod- erate brain injury $(n=40)$, brain tumor $(n=36)$, and cerebral aneurysm $(\mathrm{n}=26)$. There were smaller numbers of patients with other diagnoses (e.g. epilepsy, anoxia, and hydrocephalus). The results of a stepwise multiple regression analysis disclosed that education accounted for a significant proportion of the variance across all six RBANS indices $(r 2=$ $.03-.10)$. Age entered as a secondary predictor for the RBANS Attention Index $(r 2=.009)$. These results extend previous findings which suggest that education is a significant contributor to performance on the RBANS in a clinical sample. Implications for clinical assessment are discussed. Correspondence: Mark C. Wilde, Psy.D., Physical Medicine and Rehabilitation, UT Medical School Houston, 6411 Fannin 4 East Jones Pavillion, Houston, TX 77030.E-mail:mark.c.wilde@uth.tmc.edu

\section{K. DUFF, M.R. SCHOENBERG, D.E. PATTON, J. MOLD, J.G. SCOTT \& R.L. ADAMS. PREDICTING CHANGE WITH THE RBANS IN AN ELDERLY SAMPLE.}

Repeated neuropsychological assessments are common with older adults, and the determination of clinically significant change across time is an important issue. Regression-based prediction formulas have been utilized with other patient and healthy control samples to predict followup test performance based on initial performance and demographic variables. Comparisons between predicted and observed follow-up performances can assist clinicians in determining the significance of change in the individual patient. In the current study, multiple regression-based prediction equations for the five Indexes and Total Score of the RBANS were developed for a sample of 223 community dwelling older adults. These algorithms were then validated on a separate elderly sample $(\mathrm{n}=222)$. Minimal differences were present between $\mathrm{Ob}$ served and Predicted follow-up scores in the validation sample, suggesting that the prediction formulas are clinically useful for practitioners who assess older adults.

Correspondence: Kevin Duff, Ph.D., Psychiatry, University of Iowa, 200 Hawkins Dr., 2880.JPP, Iowa City, IA 52240.E-mail:kduff22624@ aol.com

\section{P.B. ESPE-PFEIFER, C.J. GOLDEN, E. SIMCO \& S. VALLEY- GRAY. EXPLORATORY FACTOR ANALYSIS OF THE WAIS-III AND WMS-III IN A HETEROGENEOUS NEUROPSYCHOLOGICAL POPULATION.}

The Wechsler Adult Intelligence and Memory Scales are among the most widely used measures of intellectual functioning and memory within the field of neuropsychology. Historically, revisions to these instruments have been met with increasing attempts to statistically explore and clinically understand the underlying structure of each test. The purpose of the study was to examine the combined factor structure of the Wechsler Adult Intelligence Scale-Third Edition and Wechsler Memory Scale-Third Edition in a heterogeneous neuropsychological population. Participants were 113 adults referred for neuropsychological evaluation (average age $=35.98$ years; average education=13.39 years). Exploratory factor analyses with principal axis factoring and varimax rotation were conducted on the WAIS-III and WMS-III subtest scaled scores. In the first analysis, 22 subtests were subjected to an exploratory factor analysis. The analysis revealed a five-factor model that includes (I) Visual-Processing Speed/VisualSpatial, (II) Verbal, (III) Complex Memory, (IV) Sequential Memory, and $(\mathrm{V})$ Memory for Faces. Three of the five factors represented memory abilities that were separate from the Verbal and Performance subtests of the WAIS-III. In the second and third analyses, immediate and delayed subtest scaled scores of the WMS-III were analyzed separately, and three-factor solutions emerged. The results of this study indicate that the WAIS-III and WMS-III provide distinct measures of 
intelligence and memory and do not reflect the same underlying cognitive skills. However, the distinct measures of auditory memory, visual memory, and working memory that were represented in the test manuals did not emerge. Clinical implications and directions for future research are discussed.

Correspondence: Patricia B. Espe-Pfeifer, Ph.D., Psychiatric Medicine/Neuropsychology, University of Virginia Health System, P.O. Box 800203, Charlottesville,VA 22901.E-mail:pe3c@virginia.edu

\section{R. LANGE, G. IVERSON, H. VILJOEN, T. BRICKELL \& J. BRINK. INTERPRETIVE EFFECTS OF USING CANADIAN VER- SUS AMERICAN WAIS-III NORMATIVE SYSTEMS.}

The recently published WAIS-III Canadian Technical Manual includes normative data for 1,105 Canadians between the ages of 16 and 69. The purpose of this study was to compare the interpretive effects of employing American versus Canadian normative data in 66 inpatients from a Canadian Provincial Forensic Psychiatric Hospital. The correlations between the two normative systems ranged from $r=.98$ to $r=.99$ for all IQ and Index scores. Similarly high correlations were demonstrated for all individual subtests with the exception of Vocabulary $(r=.88)$ and Picture Arrangement $(r=.93)$. Paired samples t-tests revealed statistically significantly lower scores on all IQs, Indexes, and subtest scores for the Canadian norms versus the American norms. Comparison of the clinical interpretation of American versus Canadian norms revealed that only $57 \%$ to $64 \%$ of the sample had IQ scores that fell within +5 points and only $54 \%$ to $71 \%$ of the sample with IQ scores that fell within the same ability classification range (e.g., High Average). Higher proportions of the sample had Index scores that fell within +5 points (i.e., $71 \%$ to $91 \%$ ) and within the same ability classification range (i.e., $62 \%$ to $82 \%$ ). The Processing Speed Index demonstrated the highest rate of agreement between the two normative systems. These results suggest that the interpretation of WAIS-III performance will often vary when applying Canadian norms. The clinical implications of applying American norms in a Canadian population are discussed.

Correspondence: Rael Lange, Ph.D., Neuropsychology and Psychology, Riverview Hospital, Riverview Hospital - North Lawn, 500 Lougheed Highway, Port Coquitlam, BC V3C 4J2, Canada. E-mail: rlange@bcmhs.bc.ca

\section{M.R. SCHOENBERG, R.T. LANGE, G.J. CHELUNE, G.L. IVER- SON, J.G. SCOTT \& R.L. ADAMS. CLINICAL VALIDATION OF THE GENERAL ABILITY INDEX-ESTIMATE (GAI-E) AS A PRE- DICTOR OF WAIS-III GENERAL ABILITY INDEX (GAI) SCORES.} The WAIS-III General Ability Index (GAI; Tulsky, Saklofske, Wilkins, \& Weiss, 2001) is a recently developed 6-subtest measure designed to assess global intellectual ability. In an effort to enhance the clinical utility of this index, Lange et al. (2003) developed regression algorithms that estimate GAI scores using the clinical sample of the WAIS-III standardization sample. The General Ability Index-Estimate (GAI-E) algorithms combine Vocabulary, Information, Matrix Reasoning, and Picture Completion subtest raw scores with demographic variables to predict premorbid GAI scores. The purpose of this study was to examine the clinical utility of the GAI-E in estimating intellectual ability in a mixed clinical sample. WAIS-III GAI-E scores are presented for patients' diagnosed with dementia $(n=50)$, traumatic brain injury $(n=20)$, Huntington's disease $(n=15)$, Korsakoff's disease $(n=12)$, temporal lobectomy $(n=17)$, and schizophrenia $(n=44)$. A small sample of patients diagnosed with depression $(n=38)$ was included as a clinical reference group. The GAI-E algorithms provided estimates of GAI that, on average, closely approximated scores expected for a healthy adult population (mean GAI-E ranged from 97.8 to 92.8 for the combined patient sample). The greatest differences between average predicted and obtained GAI for the combined clinical sample was observed for the GAI-
E using Matrix Reasoning with demographic variables (mean difference $=10.9$ points) and the GAI-E using Vocabulary with demographic variables (mean difference $=10.9$ ). The utility of predicting GAI scores are evaluated and preliminary recommendations in the use of the GAI-E algorithms as an estimate of premorbid functioning is discussed. Correspondence: Mike R. Schoenberg, Ph.D., Neurology, University Hospitals of Clevelad/Case Western Reserve University School of Medicine, 11100 E. Euclid Ave., Cleveland, OH 44106-5000. E-mail: Michael. Schoenberg@uhhs.com

T.M. ROEBUCK-SPENCER, J. BLEIBERG, C.N. ALISON, B. IVINS, K. SCHWAB, W. SUN, D.L. REEVES, F. BROWN \& D. WARDEN. INFLUENCE OF AGE, SEX, AND EDUCATION ON THE AUTOMATED NEUROPSYCHOLOGICAL ASSESSMENT METRICS (ANAM).

Computerized testing instruments such as the Automated Neuropsychological Assessment Metrics (ANAM) have been used successfully to measure changes in cognitive processing speed as a result of concussion, disease state, and medication effectiveness. Few norms for such computerized measures have been corrected for age and sex, and none to our knowledge has been corrected for education. The current study examined the effects of age, sex, and education on ANAM performance in a military personnel sample. Demographic information was available for over 2000 individuals. The ANAM battery included the following subtests: Simple Reaction Time, Mathematical Processing, Running Memory CPT, Sternberg Memory, Matching to Sample, and Simultaneous and Delayed Code Substitution. Age, sex, and education all proved to have significant effects across ANAM subtests. Sex effects were found on 4 of the 7 ANAM subtests. Differences tended to favor males with respect to reaction time and females with respect to accuracy. Age effects (age range 17-46) were found on 6 of 7 ANAM subtests with decreases in reaction time associated with increased age. Education effects were seen on all subtests, with the exception of Simple Reaction Time. Increases in accuracy generally were associated with higher education levels. The current study illustrates that, as with traditional neuropsychological measures, demographic variables should be taken in account when interpreting performance on computerized reaction-time-based measures of cognitive processing speed and efficiency.

Correspondence: Tresa M. Roebuck-Spencer, Ph.D., Neuroscience Research Center, National Rehabilitation Hospital, 2275 Wheel Cog Place, Woodbridge,VA 22192. E-mail: tresa.roebuck@medstar:net

\section{J. BARRASH, A. SCHUMACHER, T. SAMPSON, V. FORMAN- HOFFMAN, C. FRANCISCUS, R. WOOLSON \& B. DOEBBELING. APPLICABILITY OF PUBLISHED NORMS VS. NORMS DERIVED FROM SPECIALIZED CONTROL GROUPS: EFFECT ON ASSESS- MENT OF NEUROPSYCHOLOGICAL FUNCTIONING AMONG GULF WAR VETERANS.}

The applicability of published norms to certain populations may be limited, depending on the extent to which the normative sample differs from the population of interest in ways related to test performance. In a population-based study of Gulf War veterans, we investigated whether use of normative data based on a control group highly similar to the population of interest affects characterizations of level of performance. Study groups were Gulf War veterans complaining of or denying cognitive dysfunction ( $\mathbf{n}=159$ and 142, respectively), and Gulf Era veterans deployed elsewhere complaining of or denying cognitive dysfunction $(\mathrm{n}=$ 35 and 63). "Veterans norms" corrected for age, gender and estimated premorbid IQ were derived from 146 veterans denying cognitive dysfunction at both 5 and 10 years after the war. Mean performances of study groups, as characterized by the two sets of norms, were highly similar on Digit Span, Digit Symbol, Similarities, COWA, AVLT-learning, Trailmaking (A\&B), Stroop-Interference and Grooved Pegboard. However, when referenced to veterans norms, performances were weaker than suggested by external norms across all study groups on Block De- 
sign, AVLT-Delayed Recall, and RMT-Words; and were substantially stronger (e.g., "average" rather than "impaired") on Stroop-Words, RMT-Faces and Starry Night Test (sustained visual attention, reaction time). These findings appear attributable to preexisting differences between military personnel and some external normative groups in demographics and neuropsychological strengths and weaknesses. Use of norms derived from highly comparable control groups may yield more accurate inferences regarding the integrity of neuropsychological abilities in special populations of interest.

Correspondence: Joe Barrash, Ph.D., Psychology (116B), Iowa City VAMC, 601 Hwy 6 West, Iowa City, IA 52246. E-mail:Joseph.Barrash@ med.va.gov

\section{L.J. BEGLINGER, L. ZHANG, E.R. SIEMERS, O. TANGPHAO- DANIELS \& D.A. KAREKEN. PRACTICE EFFECTS IN SERIAL AS- SESSMENT ON THE CANTAB AND STANDARD NEUROPSYCHO- LOGICAL TESTS IN HEALTHY ELDERLY VOLUNTEERS .}

In serial assessment (e.g., acute stroke recovery, drug trials), knowing the point at which performance typically plateaus is beneficial. We examined 26 healthy, elderly adults $(M=65.4, S D=5.7)$ who participated in a 6-week, double-blind, parallel study and who were randomized into donepezil $(n=14)$ or placebo $(n=12)$. There were no significant demographic differences between the two groups. Participants had average cognitive screening scores prior to enrollment (WRAT-3 Reading=94.5. $\mathrm{SD}=4 ; \mathrm{MMSE}=27.9, \mathrm{SD}=2.1$ ). The Cambridge Neuropsychological Test Automated Battery (CANTAB) and standard neuropsychological tests were administered bi-weekly on Days 0, 14 (pre-randomization), 28 (end of treatment), and 42 (wash-out). Thus, practice effects data are available for the entire sample for the first 2 sessions (before donepezil) and in the placebo group across all 4 sessions. Repeated measures ANCOVAs, and subsequent paired t-tests were used to test session changes. For all participants, there was an improvement on Digit Symbol $(\mathrm{p}=0.001)$ and PASAT 2 -second interval $(\mathrm{P}=0.001)$ from sessions 1 to 2 , despite the use of alternate test forms. A similar session 1 to $2 \mathrm{im}$ provement was evident on the CANTAB Match to Sample response latency $(p=0.02)$ and Intra-/Extra-dimensional Shift $(p=0.03)$ without alternate forms. Examination of the placebo group revealed that only the Stroop Interference condition (no alternate form) showed a trend of continued improvement beyond the second session (session 4 vs. 3; $p=0.006)$. Therefore, alternate forms appear to have reduced practice effects for many tests. Tests of working memory, attention, and speeded processing were most susceptible to retest effects, but largely disappeared after the second assessment.

Correspondence: Leigh J. Beglinger, Ph.D., Neurology, Indiana University School of Medicine,, AL.E-mail: lbegling@iupui.edu

\section{C.T. GUALTIERI, L.G. JOHNSON \& K.B. BENEDICT. RELIABILITY AND VALIDITY OF A BRIEF COMPUTERIZED NEU- ROCOGNITIVE SCREENING BATTERY.}

The authors describe a new, internet-based neurocognitive screening battery, "CNS Vital Signs." The battery is comprised of seven familiar tests: Verbal and Visual Memory, Finger Tapping, Symbol Digit Coding, the Stroop test, Shifting Attention and the Continuous Performance Test. The test battery is self-administered on an ordinary PC, and takes about 30 minutes. Normative data are presented from a sample of 600 normal subjects, age 10-90. The tests in the "Vital Signs" battery are as reliable as the conventional tests upon which they are based (test-retest, $r=0.45-0.85, \mathrm{~N}=81$, interval 12 days). Normative data indicate performance differences by age and gender, precisely as observed in the parent tests. The battery generates distinct profiles for patients with ADHD, traumatic brain injury and dementia. Clinical data is presented for more than 1,000 patients with neurocognitive and psychiatric disorders. Concurrent validity is demonstrated in two studies, comparing the Vital Signs battery to established computerized tests (the NES and the TOVA), and to conventional neuropsychological tests. This new computerized battery may prove to be suitable as a screening instrument for mild cognitive dysfunction of various origins. It is also appropriate to use as a brief follow-up instrument for patients who are in treatment programs, or who have been administered centrally-acting medications. Correspondence: C T. Gualtieri, MD, Neuropsychiatry, North Carolina Neuropsychiatry PA, 1829 E Franklin St, Suite 400, Chapel Hill, NC 27514.E-mail:tg@ncneuropsych.com

\section{C.T. GUALTIERI, L.G. JOHNSON \& K.B. BENEDICT. DRUG SENSITIVITY OF A COMPUTERIZED NEUROCOGNITIVE TEST BATTERY.}

One potential role for the clinical neuropsychologist is to evaluate the effects of centrally-acting drugs; drugs like the stimulants and cholinesterase inhibitors, that may enhance cognitive performance; or anticonvulsants, analgesics and antispasticity drugs (to list a few) that sometimes impair cognition. The "CNS Vital Signs" battery includes seven tests: Verbal and Visual Memory, Finger Tapping, Symbol Digit Coding, the Stroop test, Shifting Attention and the Continuous Performance Test. The test is about 30 minutes long, is self-administered by patients on an ordinary $\mathrm{PC}$, and is suitable for repeated administration in a medical clinic. Five of the seven tests generate reaction time data, with millisecond accuracy. Data are presented to support the relative sensitivity of the Vital Signs battery to psychostimulant drugs in a study of 60 patients with ADHD. Significant differences are detected in measures of psychomotor speed, reaction time, complex and sustained attention and executive function, when ADHD patients are treated with psychostimulant drugs. Comparative data from no fewer than 500 patients on antiepileptic drugs, opioid analgetics and antidepressants are also presented. The data were developed in a naturalistic setting using serial assessment techniques. This evaluation model is suitable for adoption by clinicians, as they follow patients on various medications, and by neuropsychologists who consult to medical practitioners.

Correspondence: C T. Gualtieri, MD, Neuropsychiatry, North Carolina Neuropsychiatry PA, 1829 E Franklin St, Suite 400, Chapel Hill, NC 27514.E-mail:tg@ncneuropsych.com

\section{R.A. STERN \& T. WHITE. INTRODUCTION TO THE NEUROPSY- CHOLOGICAL ASSESSMENT BATTERY (NAB).}

The Neuropsychological Assessment Battery (NAB) is a new battery of 33 neuropsychological instruments, each with two equivalent forms, developed to provide a common set of core tests (in the areas of attention, language, memory, spatial, and executive functions) that serve as a comprehensive standard reference base suitable for most routine clinical and research applications with adults, age 18 and older. Individual tests are grouped into six modules: Screening, Attention, Language, Memory, Spatial, and Executive Functions. Administration of the entire battery takes less than 4 hours, with most examinations requiring less time. The $\mathrm{NAB}$ was designed to combine the strengths of both the flexible and fixed battery approaches to assessment. In addition, each module includes measures related to everyday functioning. Decisions pertaining to the content and format of the $\mathrm{NAB}$ were guided by the results of a national survey of neuropsychological assessment practices and needs, and by feedback from members of the NAB Advisory Council and other consultants. This presentation will provide an overview of the history of the NABs development, including the rationale and goals for its creation and the underlying constructs of the NAB. The processes and methods used in task creation will be presented and each of the individual tests will be briefly described.

Correspondence: Robert A. Stern, PhD, Psychiatry and Neurology, Brown Medical School, Neuropsychology Program, 110 Lockwood St., Suite 430, Providence, RI 02903. E-mail: bob_stern@comcast.net 


\section{T. WHITE, M.A. DAVIS \& R.A. STERN. STANDARDIZATION AND NORMING OF THE NEUROPSYCHOLOGICAL ASSESS- MENT BATTERY (NAB).}

The Neuropsychological Assessment Battery (NAB) is a new adult battery of 33 neuropsychological tests, each with two equivalent forms. The NAB standardization data were collected at five sites located in each of the four geographic regions of the U.S. The sampling matrix was constructed to obtain a large overall standardization sample and sufficient participants in each age, education, and sex group to provide stable estimates of performance. Demographically corrected norms $(\mathrm{N}=1,448)$ are provided to interpret brain-behavior relationships from NAB performance. Alternatively, the NAB age-based, U.S. Census-matched sample $(\mathrm{N}=950)$, which is a subsample of the overall NAB standardization sample, is also provided to interpret an individuals performance relative to a group that closely matches the U.S. population with regard to educational attainment ethnic-minority representation, and geographic region. The two $\mathrm{NAB}$ forms were equated using equipercentile equating methods. Regression techniques were used to evaluate the potential effects of age, education, and sex on raw scores. The method of continuous norming was used to derive both the NAB demographically corrected and age-based, U.S. Census T score norms. The accuracy of the demographic correction process was confirmed by the fact that the derived $\mathrm{T}$ scores in the standardization sample were approximately normally distributed and had an approximate mean of 50.0 and a standard deviation of 10.0. The demographic variables of age, education, and sex accounted for very little, if any, residual variance in the derived $\mathrm{T}$ scores. Correspondence: Travis White, PhD, Research \& Development, PAR, Inc., 16204 N. Florida Ave., Lutz, FL 33549.E-mail: twhite@parinc.com

\section{M.F. LEDBETTER, M.A. DAVIS, T. WHITE \& R.A. STERN. RELIABILITY OF THE NEUROPSYCHOLOGICAL ASSESSMENT BATTERY (NAB).}

The Neuropsychological Assessment Battery (NAB) is a new battery of 33 neuropsychological instruments, developed to provide a common set of core tests (in the areas of attention, language, memory, spatial, and executive functions) that serve as a standard reference base suitable for most routine clinical and research applications with adults, age 18 and older. As part of its initial development, the NAB underwent several reliability studies. Internal consistency (using alpha coefficients) was examined for different age groups using data from the standardization sample ( $\mathrm{N}=1448)$. Good-to-excellent internal consistency was found for most test scores, though, as expected, those scores with limited variability in a healthy sample (e.g., some Language Module scores) had lower alphas than other scores. Test-retest reliability was examined in a study of 95 healthy subjects, with a test-retest interval that exceeded 6 months. Resulting stability coefficients were generally good, especially given the length of the retest interval (e.g., Total NAB Index, $r=.86$ ). Equivalent-form reliability was evaluated according to generalizability theory in a study of 100 healthy adults (members of the standardization sample) who were administered forms 1 and 2 of the NAB in a counterbalanced design, with an average test-retest interval of 25 days. Resulting generalizability coefficients demonstrated good to excellent reliability. The interrater reliability for those NAB tests that require more subjective scoring was examined using intraclass correlation coefficients or \% agreement in a study of $60 \mathrm{NAB}$ protocols. Results indicated excellent interrater reliability.

Correspondence: Mark F. Ledbetter, PsyD, Research and Development, Psychologist Assessment Resources, 16204 N. Florida Ave, Lutz, FL 33549.E-mail:mledbetter@parinc.com

\section{MACAULAY, S.A. ROBERT \& W. TRAVIS. VALIDITY EVIDENCE FOR THE NEUROPSYCHOLOGICAL ASSESSMENT BATTERY (NAB): HOW DOES THE NAB COMPARE TO EXISTING TESTS?}

The Neuropsychological Assessment Battery (NAB) is a new battery of 33 neuropsychological tests, developed to provide a common set of core measures (in the areas of attention, language, memory, spatial, and executive functions) that serve as a standard reference base suitable for most clinical and research applications with adults, age 18 and older. As part of its initial development, the NAB underwent several convergent and divergent validity studies. The first investigation involved 50 healthy adults (i.e., non-neurologically impaired), age 18-80, who also participated in the standardization study. Participants were administered the $\mathrm{NAB}$ on one day and then returned three weeks later for an additional evaluation using well-accepted criterion measures, including: BNT, BQSS for ROCF, CVLT-II, COWA, DRS-2, JOLO, MMSE, Porteus Mazes, RBANS, $2 \& 7$ Test, Token Test, Trailmaking A\&B, WAIS-III (Comprehension, Block Design), WMS-III (Digit Span, Letter-Number Sequencing, Logical Memory, Mental Control, Orientation, Visual Reproduction), and WCST. Correlations between NAB scores/indexes and the criterion measures indicated mostly good to excellent validity. The exceptions included those $\mathrm{NAB}$ scores with expected limited variability in a healthy sample (i.e., some Language Module scores). Additional validity evidence was obtained through a series of studies with clinical samples of patients with dementia, aphasia, or TBI, who were administered all or some of the NAB modules in addition to several of the criterion measures listed above. Again, results indicated good to excellent validity, including those tests in the NAB Language Module which had inadequate validity in the healthy sample.

Correspondence: Caitlin Macaulay, PhD, Neuropsychology, Elliot Hospital, 17 Magnolia Lane,Derry, NH 03038.E-mail: cmacaulay@ elliot-hs.org

\section{M.F. LEDBETTER, T. WHITE \& R.A. STERN. VALIDITY EVI- DENCE BASED ON THE INTERNAL STRUCTURE OF THE NEU- ROPSYCHOLOGICAL ASSESSMENT BATTERY (NAB). .}

The Neuropsychological Assessment Battery (NAB) is a new battery of 33 neuropsychological tests, developed to provide a common set of core measures that serve as a standard reference base suitable for most clinical and research applications with adults. In order to examine the internal structure of the NAB, a series of exploratory factor analyses (EFA) and confirmatory factor analyses (CFA) were conducted. Separate analyses were conducted for the Screening Module test scores and for test scores of the remaining five main modules (Attention, Language, Memory, Spatial, and Executive Functions). Results from the main module analyses will be presented. EFA factors were extracted by principal axis factoring followed by Promax rotation of retained factors. Using both traditional methods (e.g., scree plot, eigenvalues) and the theoretical underpinnings of the NAB, five and six factor solutions were examined which accounted for $48.3 \%$ and $52.8 \%$ of the variance, respectively. Whereas the five factor solution was consistent with the underlying constructs and modular format of the NAB, there were several scores dependent on psychomotor speed that also loaded highly on the Executive factor. These speed-dependent scores loaded together on the six factor solution, resulting in the following distinct factors: Spatial Skills, Memory, Attention, Psychomotor Speed, Language, and Executive Functions. The factor structure was evaluated with the AMOS structural equation modeling software program $(\mathrm{n}=1417)$. Of three competing models examined, one model demonstrated excellent goodness-of-fit and was seen as strongly supporting the underlying constructs and modular structure of the NAB.

Correspondence: Mark F. Ledbetter, PsyD, Research and Development, Psychologist Assessment Resources, 16204 N. Florida Ave, Lutz, FL 33549. E-mail: mledbetter@parinc.com

\section{R.A. STERN, T. WHITE \& M.F. LEDBETTER. VALIDITY EVIDENCE FOR THE NEUROPSYCHOLOGICAL ASSESSMENT BATTERY (NAB): SENSITIVITY, SPECIFICITY, AND CLINICAL PROFILES.}

The Neuropsychological Assessment Battery (NAB) is a new modular battery of 33 neuropsychological tests, developed to provide a common set of core measures that serve as a standard reference base suitable for 
most clinical and research applications with adults, age 18 and older. The tests are grouped in a modular format with a Screening Module and five main modules, including Attention, Language, Memory, Spatial, and Executive Functions Modules. During its initial development, several clinical groups were administered the NAB, including samples of patients with dementia, traumatic brain injury, aphasia, multiple sclerosis, HIV/AIDS, and attention deficit hyperactivity disorder (ADHD). For each clinical group, an age-, education-, and gender-matched control group was selected from the NAB standardization sample. Discriminant function analyses were conducted using the five NAB Screening Domain scores and the five main Module Index Scores, as well as the Total Screening Index and the Total NAB Index. Resulting sensitivities and specificities were good to excellent for all clinical groups. In addition, the profiles of clinically relevant standardized score ranges for each group were consistent with those expected for the specific clinical disorders. These results provide evidence for the clinical validity and utility of the NAB for a variety of patient groups commonly examined by neuropsychologists in both clinical and research settings.

Correspondence: Robert A. Stern, PhD, Psychiatry and Neurology, Brown Medical School, Neuropsychology Program, 110 Lockwood St., Suite 430,Providence, RI 02903.E-mail:bob_stern@comcast.net

\section{Measures of Specific Neuropsychological Functions}

\section{MARON, W. PERRY, R. BILDER \& T. SHARMA. DETECTING ATTENTIONAL DEFICITS USING THE COGTEST. .}

Cogtest (Cogtest plc, London, 2002) is a newly developed computerized neurocognitive test battery designed for use with a variety of clinical populations. The computerized platform allows for accurate recording of reaction time data, enhanced standardization and is easily adapted for implementation in functional neuroimaging environments. Additionally, it is amenable to repeated testing sessions across time making it an excellent tool for clinical trials. The Cogtest consists of 16 subtests that assess a number of neuropsychological domains, including working memory, executive functioning and attention. The Continuous Performance Test - AX Version (CPT-AX), for example, is an experiment of conditional target-nontarget discimination ability, sustained attention and the ability to sustain effort in a cognitively demanding situation. The Continuous Performance Test - Flanker (CPT-Flanker) version is a test of selective attention, particularly sensitive to executive dysfunction. We administered the CPT-AX and the CPT-Flanker to 2 patient groups with known attentional difficulties, adults with attention deficit hyperactivity disorder (ADHD) and acutely ill inpatients with schizophrenia (Scz), in addition to a healthy comparison group. Preliminary data reveals that Scz patients have a decreased probability of making a correct discrimination on the CPT-AX task $[\mathrm{F}(2,14)=6.75$; $\mathrm{p}=.009]$ relative to both the comparison and the ADHD group. Scz patients also demonstrated fewer correct responses to all trials types of the CPT-Flanker task. No differences were observed between the ADHD and control groups. Taken together, results suggest that the Cogtest may be sensitive to parsing attentional deficits in different patient populations

Correspondence: Leeza Maron, Ph.D., Department of Psychiatry, UCSD, UCSD Medical Center, 200 West Arbor Drive, San Diego, CA 921038620.E-mail:Imaron@ucsd.edu

R.J. SPENCER, F.A. WOLKENBERG, L. SPURGEON, S. STENGER, L.M. EVANS, E.T. MOOLCHAN, E. MONIQUE \& A.S. KIMES. INTERNAL CONSISTENCY AND TEMPORAL STABILITY OF THE CONNERS' CONTINUOUS PERFORMANCE TEST: A STATE NOT TRAIT MEASURE.

Continuous performance tasks (CPTs), in general, and the Conners' CPT (Conners, 1995, 2000) in particular, are widely used in research and in clinical assessments of attention, including measurement of medication effects (Riccio, Waldrop, Reynolds, \& Lowe, 2001). Despite this widespread use, remarkably limited data exist concerning the reliability of these instruments. Here, we report on the reliability after a one year interval of four measures of the Conners' CPT (omission, commission, response time and standard error of response time) in a sample of 53 adolescents between the ages of 12 and 14 (mean age 12.8 SD .9), (24 control participants without diagnosis, 20 participants with a diagnosis of ADHD and 9 participants with a diagnosis of ADHD and at least one other disorder). Performance consistency within session (internal consistency) was high for three of the four measures. However, while statistically significant, for all four measures, correlations of performance across sessions (temporal stability) were too low to offer much reassurance concerning their discriminative utility in clinical practice. There were few practice effects among the control participants, but the ADHD-diagnosed adolescents improved significantly between CPT administrations one and two. We conclude that the Conners' CPT demonstrates acceptable internal consistency, but unacceptable temporal stability, suggesting that this neuropsychological test is a better state than trait measure. It also suggests that on the individual level, practice effects may lead to a misunderstanding of medication effects.

Correspondence: Robert J. Spencer, M.A., Psychology, University of Maryland/Baltimore County, 1 Shawnee Ct., Apt 104, Parkville, MD 21234. E-mail: rspencer@umbc.edu

\section{LOUREIRO, T. FERNANDES, I. PAVAO MARTINS \& J. FERRO. BEHAVIOURAL INATTENTION TEST: NORMATIVE DATA AND THE NEED FOR A NEW CRITERION .}

Background: Behavioural Inattention Test (BIT) is a neuropsychological instrument for the evaluation of brain damage patients with possible neglect. In the original version (Wilson et al., 1987) the diagnostical criteria for neglect is defined as a score bellow the cut-off point in at least one of the subtests. In this study we propose an additional criterion: a lateralized pattern of errors/omissions. This aspect is special important because it is one of the major characteristics of neglect. Aims: To obtain normative data for the Portuguese population considering the two criteria; and to analyse the performance pattern of patients with neglect according to the new criterion. Method: Two groups performed the BIT. The healthy group were 72 Portuguese adults with ages 20-82 yrs old $(48,46 ; 17,48)$ and educational level 0 - 17 years $(8,43 ; 6,30)$. The clinical group were 47 patients with ages 21 - 83 yrs old $(57,62$; $13,86)$ and educational level $0-17$ years $(6,32 ; 4,96)$. Results: On the healthy group it was found a main effect of the level of education, with significant differences between the illiterate group and the others. We did not find any gender or age effects on the global score. In the clinical group, the use of the new criterion permitted a reduction of false positive clinical diagnostics. Discussion: The use of the new criterion is of major importance for a reliable neglect diagnosis. The definition of cutpoints according to educational level is essential for a correct evaluation of the Portuguese population.

Correspondence: Isabel Pavão Martins, phD, Language Reseach Laboratory - Centro de Estudos Egas Moniz, Faculdade de Medicina de Lisboa, Avenida Prof Egas Moniz, Lisbon 1649-028, Portugal. E-mail: labling@mail.telepac.pt

\section{BYRD, D. SANCHEZ \& J. MANLY. AN EXPLORATION OF THE COMPARABILITY OF DIGIT AND SPATIAL SPAN IN AN ELDERLY AFRICAN-AMERICAN SAMPLE.}

Working memory is theorized to be a major contributor to higher level cognition and the main deficit in some psychiatric symptomatology. Yet empirical investigations of commonly used clinical tests of this domain are lacking. We explored the relationship between clinical measures of verbal (WAIS-III Digit Span (DS)) and nonverbal (WMS-III Spatial Span 
(SS)) working memory in a sample of 70 non-demented African-American elders. Average raw scores for DS (mean $=13.6(4.5))$ were significantly higher than SS (mean $=9.6(3.0), p<.01))$. As expected, participants' raw scores on the forward portions of both tasks were significantly higher than backward portions $(\mathrm{p}<.01)$. Examination of the correlations between forward and backward performances of the tasks revealed that the backward portions of DS and SS were more strongly associated with each other $(\mathrm{r}=.51, \mathrm{p}<.01)$ than the forward portions $(\mathrm{r}=.26, \mathrm{p}<.05)$, suggesting that the backward tasks are more analogous to each other than the forward tasks. Stepwise multiple regression analyses were performed on the backward portions of each task with demographic (age, education, literacy, and acculturation) and cognitive (verbal and nonverbal memory, fluency, naming, abstraction, and visuoconstruction) predictors. SS backward was predicted $(\mathrm{R} 2=.55)$ by age, literacy level, visuoconstruction and nonverbal memory ability. The only significant contributors to DS backward were age and literacy, $(\mathrm{R} 2=.35)$. Results suggest that while both tasks are sensitive to aging, they are not directly analogous and may reflect unique aspects of working memory.

Correspondence: Desiree Byrd, PhD, G.H. Sergievsky Cntr, Columbia University, 630W 168th Street, PH19, NY, NY 10029.E-mail: dab2006@ columbia.edu

\section{A.B. CHERVINSKY. SPEED OF INFORMATION PROCESSING: PERFORMANCE OF CLINICAL GROUPS, INTRAINDIVIDUAL VARIABILITY.}

This study addressed performance on several tests of speed of information processing including the Symbol Digit Modalities Test, Trail Making Test, WAIS-III Digit Symbol, and Symbol Search. The sample consisted of 40 adult individuals with various neurological conditions and/or psychopathology. Speed of processing measures showed strong correlations with each other and with the WAIS-III Processing Speed Index. Correlations with the WAIS-III Working Memory Index were considerable, yet weaker, suggesting that speed of processing is distinguishable from attention. Tests of speed of information processing showed significant differences between groups of patients with and without history of central nervous system pathology. There were essentially no significant differences in speed of processing among patients with or without psychiatric history, with or without active psychopathology, and with or without psychotropic medication. Substantial variability was observed among the speed of processing test standard scores. Average discrepancies among the scores were more than 1.5 SD regardless of neurological history, psychopathology, or medication status.

Correspondence: Alexander B. Chervinsky, Ph.D., ABPP, Independent Practice, 142 Joralemon S., Suite 5F, Brooklyn, NY 11201. E-mail: achervin@webspan.net

\section{S.T. GONTKOVSKY \& W.W. BEATTY. NON-TRADITIONAL CLIN- ICAL ASSESSMENT OF INFORMATION PROCESSING SPEED.}

The rate at which individuals are capable of processing information is considered to be a sensitive indicator of brain dysfunction, particularly among clinical populations such as patients diagnosed with multiple sclerosis (MS) whose impairments generally are less severe than those seen in many other neurological disorders. Assessment of information processing speed often is confounded, however, by comorbid impairments in other constructs of neurocognition, including attentional capacity, visual-spatial perception, language, and motor speed/coordination. The requisite component among tests designed specifically to evaluate mental processing speed obviously is that of time. Measures targeted towards the evaluation other domains frequently involve an element of time for performance and therefore may be considered as potential indictors of mental processing speed. This investigation examined the relationship among instruments purported to measure processing speed and other tests traditionally viewed as indicators of functioning in other domains but which involve a timing component.
Participants were 64 patients diagnosed with clinically definite MS. Analyses indicated a significant positive relationship among the Semantic Fluency and Coding subtests of the RBANS, Symbol Digit Modalities Test, PASAT, and COWA. Furthermore, associations were found to remain significant on reanalyses controlling for independent effects of motor functioning and fatigue as well as untimed indicators of attentional (digit span), visual-spatial perceptual (figure copy), and language (naming and vocabulary) functioning. Results suggest clinical assessment of information processing speed may be accomplished utilizing scores obtained from measures involving a timing element for performance but which are not designed specifically for evaluation of this construct. Correspondence: Samuel T. Gontkovsky, Psy:D., Neuropsychology, Methodist Rehabilitation Center, 1350 East Woodrow Wilson, Jackson, MS 39216.E-mail:stg@mmrcrehab.org

\section{G.P. CRUCIAN, J. TULMAN, S. SELL, L.J. GRANDE, D.W. BURKS, B.V. SHENAL, R. RHODES, J.B. MIELKE, A. RIESTRA, K. WOMACK, M.S. OKUN, D.L. REEVES, B. CROSSON \& K.M. HEILMAN. THE RELATEDNESS JUDG- MENTS TASK: A TEST OF SEMANTIC ASSOCIATION.}

Lexical priming and word association tasks provide a measure of semantic organization/processing. In lexical priming, a semantic relationship with the cue facilitates recognition of the target word, suggesting cues increase activation within that semantic network. In word association tasks, subjects say the first word that comes to mind in response to a cue, suggesting a conceptual/associative relationship between words. Whereas both tasks presume existence of a semantic relationship between words, neither takes into account degree of conceptual/associative relationship in semantic processing. Thus, these semantic processing tasks may not reflect the full extent of semantic associations being generated. In this study, we report findings of a semantic processing measure currently under development. In this task, subjects are presented with word pairs and asked to rate degree of "relatedness" using a Likert scale. Strength of relationship between words was manipulated, deriving 3 groups (strong, moderate, weak) based on word association normative data. Two groups of mediated word pairs (the relationship between words is "mediated" by one or two words) were also included to broaden the range of semantic processing being assessed. Results from a group of young (14 men, 16 women; mean age $=20.8$ years) and older adults ( 7 men, 9 women; mean age $=68.5$ years $)$ reveal the categories of word pairs are reliably differentiated as expected. That is, strongly-associated word pairs are rated as more related than weakly-associated or mediated word pairs. Findings confirm the premise that semantic processing involves assessment of degree of similarity between two concepts. Results suggest that assessment of degree of conceptual relationship may be an important consideration in evaluating semantic processing. This measure may have utility in assessing neurological conditions such as Alzheimer's and Parkinson's Disease where there might be alterations in semantic representations.

Correspondence: Gregory P. Crucian, PhD, Neurology, University of Florida, 100 S. Newell Drive, Rm. L3-100, Gainesville, FL 32610. Email: crucigp@neurology.ufl.edu

\section{R. NAKASE-THOMPSON, E. MANNING, M. SHERER, S.T. GONTKOVSKY, S.A. YABLON \& C. VICKERY. BRIEF AS- SESSMENT OF SEVERE LANGUAGE IMPAIRMENTS: INITIAL} VALIDATION OF THE MISSISSIPPI APHASIA SCREENING TEST.

Severe communication impairments can be common among individuals with significant brain injury. For patients with severe language impairments, lengthy aphasia batteries are inefficient for serial evaluations during brief inpatient hospitalization and may be excessive for patients with severe aphasia or poor endurance. A brief instrument that surveys a broad array of language abilities is better suited to tracking patients' progress through their early clinical course. The purpose of this study was to develop a brief screen of an array of language abilities to quan- 
tify communication abilities in patients with severe language impairment. The screening test (Mississippi Aphasia Screening Test [MAST]) includes subscales to measure naming, automatic speech, repetition, yes/no responding, object recognition, auditory comprehension, reading comprehension, spelling/writing, and verbal fluency. Total (TS), Receptive (RI) and Expressive (EI) Index Scores can be derived. Inpatients admitted to Neurology, Neurosurgery, or Rehabilitation Units at 2 local hospitals and who were within 60 days of onset of a unilateral ischemic or hemorrhagic stroke were potential participants (Left Hemisphere [LH; N=38]; Right Hemisphere [RH; $\mathrm{N}=20]$ ). Additional participants were recruited from the community to comprise a control sample (CS; $\mathrm{N}=36$ ). The LH group performed significantly poorer than the RH and CS on the TS, EI, and RI ( $p<.0005$ for all). The LH group performed worse than the CS on all subscales. The object recognition and verbal fluency subscales did not discriminate the LH from the RH groups. Analyses suggest good criterion validity for the MAST in differentiating communication impairments among clinical and control samples. Correspondence: Risa Thompson, Ph.D., Methodist Rehabilitation Center, 1350 East Woodrow Wilson Drive, Jackson, MS 39232. E-mail: nakase@aol.com

\section{SCHUTTE, W. VANVOORST \& R. SKEEL. THE IMPACT OF VI- SUAL CONTRAST SENSITIVITY ON NEUROPSYCHOLOGICAL PERFORMANCE.}

Tests used in a neuropsychological setting to estimate cognitive functioning are used in the diagnosis and recommendations for individuals. It is assumed that results from tests such as the Repeatable Battery for the Assessment of Neuropsychological Status (RBANS) reflect cognitive functioning, after basic motor and sensory contributors are screened out. However, if unmeasured abilities, such as visual acuity or visual contrast sensitivity, predict performance on cognitive tests, then it may be that error variance associated with sensory ability affects conclusions. It is relevant to examine cognitive tests to evaluate their relationship to visual functioning in an effort to measure the impact of less than optimal sensory functioning. The current study included 48 healthy elderly individuals ranging from 70 to 92 years of age $(\mathrm{M}=79.9 \mathrm{SD}=5.9)$. Cognition was measured with the RBANS, while vision was measured with a Snellen-type near visual acuity chart and a contrast sensitivity chart. Contrast sensitivity was significantly related to Total Score on the RBANS $(r=.324, p<.05)$. Upon further examination it was found that contrast sensitivity was significantly related to visual subtests Figure Copy, Figure Recall, Coding and the Visual Construction Index. Visual acuity was unrelated to performance. Examination of quartiles based on contrast sensitivity revealed a significant difference between the top and bottom $25 \%$ of individuals that was approximately 1 standard deviation, $\mathrm{F}(1,25)=7.26, \mathrm{p}=.013$. Clinical implications are discussed. Correspondence: Reid Skeel, Ph.D., Central Michigan University, 136 Sloan Hall, Mt. Pleasant, MI 48859. E-mail: reid.skeel@cmich.edu

\section{S. NAKAGAWA, J. FUSAGER, E. DIAMOND, T. NOVAKOVIC- AGOPIAN \& R.M. BOWLER. EFFECTS OF VISUAL ACUITY, CON- TRAST SENSITIVITY \& COLOR VISION ON VISUALLY MEDIATED NEUROPSYCHOLOGICAL TESTS.}

The purpose of this study was an investigation of previously published data in order to examine the effect of visual function on visually mediated neuropsychological tests. Participants were 221 hazardous cleanup workers. Tests administered were: near visual acuity (Snellen), contrast sensitivity (Vistech 2000), color vision (Lanthony d-15), visual reaction time test, Trails A \& B, Stroop, Cancel H, and WAIS-III performance tests. After appropriate exclusions 197 remained for analysis: $94.9 \%$ were males and $5.1 \%$ females, $44.2 \%$ were African Americans and $55.8 \%$ Whites, mean age was 40.02 years and mean education was 12.03 years. Participants scored within 1 SD of the mean for all but the Digit Symbol, Digit Span and Processing Speed Index from the WAISIII. Hierarchical regression analyses controlling for age, education, and ethnicity predicted a highly significant association of poorer near visual acuity and contrast sensitivity with impaired performance on: WAIS-III Block Design ( $p<.001)$, Matrix Reasoning, Picture Completion $(\mathrm{p}<.01)$, Picture Arrangement; Symbol Search, LNS, Spatial Span, and Digit Span; Trail Making B, Stroop and visual reaction time tests $(\mathrm{p}<.05)$. There was no relationship between visual acuity and Boston Naming and Controlled Oral Word Association Test. Examination of the relationship of color vision indicates highly significant associations with tests including visual stimuli and lower scores on the WAISIII performance tests, Trails B, and Stroop but not for the achromatic computer administered reaction time test. This suggests that results of neuropsychological test results are significantly impacted by the patient's visual system and should be routinely included.

Correspondence: Rosemarie M. Bowler, Ph.D., Psychology, S.F.State Univ, 8371 Kent Drive, El Cerrito, CA 94530.E-mail: rbowl@sfsu.edu

\section{K. DUFF, W.R. LEBER \& D.E. PATTON. COMPARING THE ORIGINAL AND REVISED SCORING CRITERIA FOR THE RBANS FIGURES IN A CLINICAL SAMPLE.}

Despite attempts by test developers to specify scoring procedures, unclear or subjective criteria can jeopardize the utility of a test. Recent evidence suggests that the scoring criteria for the RBANS Figure Copy and Figure Recall (Randolph, 1998) may suffer from a similar problem, and Duff et al. (in press) revised the standard scoring criteria for those figures to accommodate the available normative data. The present study compared the standard and revised scoring criteria in a clinical sample of 95 patients. Two experienced clinicians independently rated both the Figure Copy and Recall drawings, one (who was blind to the revised criteria) using the standard criteria, and the other using the revised criteria. Although scores based on the two sets of criteria correlated highly $($ Copy $r=.94 ;$ Recall $r=.96)$, the revised scoring criteria consistently yielded higher scores for both Figure Copy (1.4 points) and Figure Recall ( 0.9 points). Given the available normative data on these subtests, even these small differences can have dramatic clinical implications. Although revised scoring criteria for visuospatial construction and visual memory tasks are not new, they can cause us to re-evaluate these domains and how we measure them.

Correspondence: Kevin Duff, Ph.D., Psychiatry, University of Iowa, 200 Hawkins Dr., 2880.JPP, Iowa City, IA 52240.E-mail: kduff22624@ aol.com

\section{T.J. BAKER, L. GRAYBEAL \& A.M. BARRETT. SELF-GENER- ATED MATERIAL FOR RECALL: EFFECT OF REPEATED TEST ADMINISTRATION.}

Background. Self-generated (Internal) material is remembered preferentially over externally-originating (External) material by young (Slamecka \& Graf, 1978), aged, and demented subjects (Barrett et al., 2000). Repeatedly administering memory tests may be a sensitive means of detecting memory dysfunction (Collie et al., 2003), but performance changes may occur due to learning or other factors. Objective. To learn how repeatedly administrating a memory test assessing Internal versus External recall would affect an Internal memory bias. Method. Thirty control (mean 74.4 years; 16 female) and nine pAD participants (mean 73.6 years; 5 female) took a verbal list-learning test (Barrett, et al., 2000) assessing incidental recall and recognition of Internal and External words, and Internal recall with conscious intent to remember (INR), twice, in sessions two days apart. Results. Participants demonstrated Internal recall bias (Internal word $74.28 \%$ correct, s.d. 11.62; External word $67.71 \%$, s.d. $13.72, \mathrm{p}<0.005)$. Controls remembered more External words (72.86\% correct, s.d. 9.58) than pAD subjects $(50.52 \%$, s.d. $11.35, p<0.001)$. External bias significantly increased over testing sessions (word type * session interaction $\mathrm{p}<0.05$ ). Controls had better recall $(67.13 \%$ correct, s.d. 10.85$)$ than pAD subjects 
(43.52\%, s.d. 10.60 p< 0.001). Replicating previous findings, pAD subjects demonstrated less benefit of a conscious intent to remember on Internal recall (word type * group interaction, $\mathrm{p}<0.005$ ). Conclusions. These data for repeated administration of a memory test including Internal and External material suggest additional control/pAD performance differences may emerge with repeated administration. Further studies in larger patient groups are needed.

Correspondence: Thomas J. Baker, MA, Neurology, The Pennsylvania State University College of Medicine, 500 University Drive., Long Lane Building HS83, Hershey, PA 17033. E-mail: tjb229@psu.edu

\section{M.K. JONSDOTTIR. SELF-EVALUATION OF MEMORY PROB- LEMS IN DAILY LIFE: NORMATIVE DATA.}

While the correlation between subjective memory complaints and performance on objective memory tests may not be high, memory questionnaires are nevertheless useful clinical instruments. They can, for example, help clinicians evaluate the accuracy of their clients' complaints and whether they are likely to reflect ordinary forgetfulness or not. Memory questionnaires may reveal negative or positive biases in self-perception and thus show impaired insight or undue worry about normal lapses in memory. However, in order to effectively use memory questionnaires adequate norms are necessary. A short memory questionnaire, which was originally designed for chronic pain patients (Shnurr \& MacDonald, 1995) and includes 13 questions rated on a 5 point scale was administered to healthy volunteers. Participants were 401 females (mean age $=39.7$; range 18-90) and 210 males (mean age $=39.2$; range 16 82). Males and females did not, on average, rate their everyday memory differently ( 22.5 vs. 22.2 ) but there was a significant negative correlation between age and total score on the questionnaire reflecting greater complaints in the younger age groups. Thus the $50 \%$ ile for those younger than 40 was 23, 20 for those between 41 and 60 years of age. and 18 for participants 60 years and older. A subset of 92 participants (mean age $=24)$ had a repeat administration 4 weeks later to assess testretest reliability. This group was representetive of the larger group of the same age (mean on questionnaire $=24.2(\mathrm{SF}=5.2)$ ). Reliability proved to be good (Pearson $=0.83)$. The advantage of the memory questionnaire discussed here is that it is short and easy to respond to. Moreover, as it was designed for chronic pain patients it may be ideally suited for patients who complain of memory impairments following head injury or whiplash as they frequently have pain-related problems.

Correspondence: Maria K. Jonsdottir, Ph.D., Landspitali-University Hospital, Grensasvegur 62, Reykjavik 108, Iceland. E-mail: marijon@ landspitali.is

\section{S. RASKIN. MEMORY FOR INTENTIONS SCREENING TEST.}

Failures of prospective memory, or memory for intentions, are one of the most frequent sequelae of brain injury. Although interest in prospective memory has increased substantially in the last several years, there is still no adequate assessment tool available. We have developed a screening measure, the Memory for Intentions Screening Test (MIST). The test takes approximately thirty minutes to administer. It contains items that require a 2 minute or 10 minute delay. There are two different tasks to perform during the intervening delay, one that is more difficult than the other. The tasks are cued either by time (e.g., in two minutes please stop working) or by cue (e.g.. when the tape stops, please turn it over and listen to the other side.) Responses are either verbal or an action. Scoring is available for a variety of error types, so that a differentiation can be made between true prospective memory errors and retrospective memory errors for the content of the task. Normative data is available for ages 18-70 on a sample of 500 subjects and data is available on 50 brain-injured sub- jects. There are four versions of the task to ease in retesting. The validity is high (compared to prospective items on the Rivermead Behavioral Memory Test) (.80) and measures of prospective memory in daily life (.92). Internal reliability mean Cronbach alpha of .87. Alternate form reliability between Form 1 and the other three forms is $.85, .89$, and .90 respectively.

Correspondence: Sarah Raskin, Ph.D., Psychology, Trinity College, 300 Summit Street, Hartford, CT 06119. E-mail:sarah.raskin@ trincoll.edu

\section{R.G. KNIGHT \& N. TITOV. FORGETTING IN THE VIRTUAL STREET: A COMPUTERISED ASSESSMENT OF REMEMBERING.}

The virtual street is a simple web-based computer procedure that aims to simulate the experience of walking through a shopping precinct. Participants are able to enter shops and complete a range of tasks as a clinical measure of prospective remembering and multitasking. Participants see one photograph and sound (or "Page") at a time, from a network of over 2000 pages and are able to "walk along" the street or around the interior of a shop using a touch screen connected to a laptop. There is a navigation bar beneath each picture which allows movement in different directions and the illusion of "walking" is created by fading the pages into each other. Once the test is completed, a detailed record of the participant's movements and time taken to complete each segment of the walk is available from the web server. We report evidence for the reliability and sensitivity of the procedure from a series of studies comparing older and younger adults. Preliminary data from inividuals with cognitive deficits consequent on severe traumatic brain injury are also detailed, providing further evidence for the clinical utility of the procedure. Our results suggest that computer simulations can be developed into useful clinical measures to supplement current neuropsychological tests in order to enhance the ecological validity of assessment and rehailitation.

Correspondence: Robert G. Knight, PhD, Psychology, University of otago, Box 56, Dunedin 9001, New Zealand.E-mail: rknight@psy.otago.ac.nz

\section{M.A. BUTTARO, J.R. CROMER, B. STEINBERG, L.A. BIELI- AUSKAS, G.E. SMITH \& R.J. IVNIK. AGE- AND SHORT FORM IQ- ADJUSTED MOANS NORMS FOR THE WMS-R.}

In a past investigations of healthy older individuals in the Mayo Clinic's MOANS database, we found that performances on the Wechsler Memory Scale-Revised were more closely related to Mayo age-adjusted WAISR FSIQ scores and AMNART scores than with years of formal education. In the present study, we explored associations between scores on a two-subtest WAIS-R short form (sum of Mayo age-adjusted scaled scores for Block Design and Vocabulary) and performances on this commonly used battery of memory tests. (This short form reduces administration time and provides a reasonably accurate estimate of premorbid intelligence; cf Silverstein, 1982.) Consistent with our expectations, short form IQ (SFIQ) scores were more strongly associated with Mayo age-adjusted WMS-R primary index scores $(r=.318$ to .565$)$ than was education $(r$ $=.179$ to .310$)$. The former correlations compared favorably to correlations that involved FSIQ $(r=.366$ to .631$)$. Moreover, SFIQ scores were associated with larger unique increases in index score variances in multiple regression models ( $6.7 \%$ to $22.2 \%)$ than was education $(0.0 \%$ to $0.4 \%$ ), and the former results compared favorably to results from similar analyses that used FSIQ scores $(9.7 \%$ to $32.1 \%)$. Based on these findings, we developed tables of age- and SFIQ-adjusted norms for the WMS-R.

Correspondence: Brett Steinberg, Ph.D., Psychology, University of Connecticut, 406 Babbidge Rd, Unit 1020, Storrs, CT 06269. E-mail: brett. steinberg@uconn.edu 
L.L. MCGEE, J.A. LEVY, K. PUTNAM, J. BERGESON, C.J. HAMMOND, N. MIRZA, E.D. HUEY, R. COHEN \& T. SUNDERLAND. PROMINENCE OF LOGICAL MEMORY AND VISUAL REPRODUCTION AMONG WESCHLER MEMORY SCALE-REVISED SUBTESTS IN HEALTHY OLDER CONTROLS.

Although the Wechsler Memory-Scale-Revised (WMS-R) has been shown to be a valid and reliable clinical assessment of memory functioning in a population of older participants, the factor structure of the WMS-R has been debated. Previous factor analytical studies on a diversity of populations have failed to support a visual-verbal dichotomy for the WMS-R. In the present study, a factor analysis was conducted on the nine subtests of learning on the WMS-R that were administered to a population of 129 older controls volunteering for a longitudinal study examining long term risks for developing Alzheimer disease. Participants were administered the WMS-R at baseline and again at second annual follow-up as a part of a neuropsychological evaluation. The present factor analysis suggested a three-factor model at baseline: visual reproduction and immediate recall of visual material, logical memory, and delayed paired associate learning. At two-year follow-up, however, a two-factor structure of logical memory and visual learning emerged. Visual reproduction II accounted for the largest amount of the variance on the visual learning factor both at baseline and at follow-up. Moreover, performance on the paired associates subtests, due to the brevity of the items administered, were at ceiling at baseline, whereas visual reproduction and logical memory exhibited a range of performance at baseline and at follow-up. Our results do not support either immediate versus delayed factors for the WMS-R or aggregate visual and verbal factors. Consequently, the greatest utility of the WMS-R rests primarily with logical memory and visual reproduction subtests, which is largely consistent with current clinical and research practice.

Correspondence: Lori L. McGee, B. S., Geriatric Psychiatry, National Institutes of Mental Health, 10 Center Drive, Bethesda, MD 20814. Email:mcgeel@intra.nimh.nih.gov

\section{DANIEL \& B. SCOTT. THE EFFECTS OF EDUCATION ON CVLT-II SCORES.}

Education has been shown to affect neurocognitive test scores generally and memory test performance in particular, indicating it is an important consideration in neuropsychological assessment. The California Verbal Learning Test-II (CVLT-II) is commonly used in clinical memory evaluation. On the first version of this test, education effects were demonstrated for several indices. The second version has not yet been normed for education. This study examined CVLT-II scores for normal subjects, 30 with a high school education or less and 30 with a bachelor's degree or more. While those with higher education consistently outperformed those with less education, there was considerable within group variability for many CVLT-II variables and the differences between groups were not statistically significant in this sample. The clinical utility of using education-corrected norms for the CVLT-II is discussed. Correspondence: Michael Daniel, Ph.D., School of Professional Psychology, Pacific University, 511 SW 10th Ave., 4th floor, Portland, OR 97205.E-mail: danielm@pacificu.edu

\section{D.C. OSMON \& J.M. SMERZ. ANALYSIS OF THE FACTOR STRUCTURE AND CONCURRENT VALIDITY OF THE SELECTIVE REMINDING TEST.}

The Selective Reminding Test (SRT) is commonly used to assess memory and includes several scores (e.g.., total recall, long-term storage, longterm retrieval, and consistent long-term retrieval) that differ conceptually but measure the same construct according to factor analysis. The purpose of the current study was to replicate this finding in a learning problem sample and examine what construct is measured by the SRT. College students $(n=124)$ referred for a learning disability assessment were administered the SRT, the California Verbal Learning Test (CVLT). and Woodcock Johnson-Revised short-term and long-term memory
(STM, LTM) factor subtests as part of a larger battery. Factor analysis of the SRT revealed a single factor, yielding a factor-weighted composite score. In a factor analysis with the CVLT, the SRT composite had a small primary loading on an encoding factor (.313) and secondary loadings on learning and interference factors (.223 and .220 , respectively). Regression analysis found that CVLT Short Delay $(F[1,122]=14.28$, $\mathrm{p}<.001, \mathrm{R} 2=.098)$ and $\operatorname{LTM}(\mathrm{F}[1,122]=9.44, \mathrm{p}<.001$, adjR2=.023) predicted the SRT composite. The current SRT scores measure a single construct that relates most to measures of encoding and learning and overlaps only slightly with the other memory measures.

Correspondence: Jessica M. Smerz, M.S., psychology, University of Wisconsin-Milwaukee, 2441 E. Hartford Ave., Milwaukee, WI 53211. Email:jsmerz@uwm.edu

\section{JOHNSON-GREENE, A. INSCORE \& L. COLLINS. PSYCHOMETRIC PROPERTIES OF THE HOPKINS BRIEF TEST OF MEMORY.}

Cognitive screening tests often fail to adequately assess important facets of memory function. While more comprehensive tests of memory are available, they can be both time consuming and intimidating to elderly patients. Using a memory assessment paradigm first proposed by Binder (1992), we sought to validate the Hopkins Brief Test of Memory (HBTM), which utilizes the names of well-known cities as the stimuli. The HBTM was administered to 65 elderly patients who had undergone orthopedic surgery and 25 patients with acute stroke. Using a selective reminding paradigm we recorded total trials to the correct repetitions, 20 minute delayed recall, and a recognition discrimination index. The instrument was significantly correlated with general measures of cognition (MMSE) and learning and memory (HVLT). Performance on the HBTM differed for patients with stroke in terms of number of trials to criterion $(\mathrm{p}<$ $.007)$ and delayed recall $(\mathrm{p}<.05)$, but not recognition discrimination $(\mathrm{p}<.08)$, compared to orthopedic controls. In summary, the HBTM uses familiar cities as stimuli and was designed to be potentially less intimidating to hospitalized elderly patients. Preliminary results suggest this instrument possesses good construct and discriminative validity. Correspondence: Anjeli Inscore, Physical Medicine and Rehabilitation, Johns Hopkins University School of Medicine, Good Samaritan Hospital POB, Suite 406, 5601 Lock Raven Blvd., Baltimore, MD 21239. Email: anjeli_inscore@yahoo.com

\section{F. BROWN, G. GIBSON-BEVERLY, R.M. ROTH, W.C. BUBOLTZ \& A.J. SAYKIN. A NEW MEASURE OF VISUAL LOCATION LEARN- ING AND MEMORY: PRELIMINARY PSYCHOMETRIC PROPER- TIES AND NORMATIVE DATA FOR THE BROWN LOCATION TEST.} Clinical, experimental, and fMRI studies suggest that inconsistent laterality findings on visual memory measures may be related to verbal encodability, administration difficulties, and insufficient differentiation of object and location memory. Nondistinct object location measures (e.g. dots or squares) are strongly associated with right medial temporal lobe activation and volume. Further, they are least influenced by verbal interference. For the Brown Location Test (BLT), examinees are shown a series of individually presented dot locations in a non-grid format over five learning trials. Then examinees are asked to recall these locations after an interference trial and a 20-minute delay, with and without egocentric cues. In this study, healthy participants were administered the BLT, CVLT-II, WASI Short Form, and Nonverbal Cancellation tests. Alternate forms of the BLT and CVLT-II were administered after 24 davs in a counterbalanced order. Preliminary analysis of 27 participants found split-half reliabilities of .92 for both forms of the BLT. Alternate form test-retest reliabilities were also significant $(r=.80$ for encoding trials, $r=.73$ for short delay, $r=.53$ for long delay, and $r=.51$ on recognition format). These correlations were generally comparable or higher than reliabilities for the CVLT-II in this sample. The BLT had a steady 
learning curve without evidence of ceiling or floor effects. Factor analysis revealed distinct memory, intellectual functioning, and visual-scanning speed factors. These findings provide evidence for adequate psychometric properties of the BLT and support continued data collection, validation studies among patients, and adaptation for computer-based administration during fMRI tasks.

Correspondence: Franklin Brown, Ph.D., Psychiatry, Dartmouth Medical School, 1 Medical Center Drive, Lebanon, NH 03766. E-mail: franklin.c.brown@dartmouth.edu

\section{A.R. KILGOUR, F.F. SARAZIN \& L. WALKER. REY VISUAL DE- SIGN LEARNING TEST: A TRUE LEARNING MEASURE.}

The Rey Visual Design Learning Test (RVDLT; Rey, 1964) is clinically used to assess visual learning and memory. Although this test was designed as a nonverbal analogue to verbal learning tests, its use has been quite limited and there has been no published research to support this hypothesis. We carried out a factor analysis using retrospective data from 187 outpatients assessed in a tertiary care hospital setting to determine whether the RVDLT is more commensurate with rote verbal learning and memory than other visual memory tests, visuoconstruction measures, or indices of executive functioning. The maximum-likelihood factor analysis with varimax rotation yielded four factors with the RVDLT loading with the California Verbal Learning Test (CVLT; Delis, Kramer, Kaplan, \& Ober, 1987), a learning and memory assessment tool. The three other factors each comprised the immediate and delayed scores of three other visual memory tests: Rey Complex Figure Test (Meyers \& Meyers, 1995), Visual Reproduction from the Wechsler Memory Scale Revised (Wechsler, 1987), and Family Pictures from the Wechsler Memory Scale III (Wechsler, 1997). We conclude that the RVDLT is, in fact, a measure of nonverbal learning, homologous to verbal learning measures such as the CVLT, and the three other visual memory tests each provide unique information. Furthermore, none of these measures loads with executive functioning measures. Further research is required to update the normative data, and statistically validate the RVDLT to warrant its more common usage by clinicians for neuropsychological evaluations.

Correspondence: Francine F. Sarazin, Ph.D, Psychology, The Ottawa Hospital, 501 Smyth Rd., Suite 7300, Ottawa, ON K1H 8L6, Canada. E-mail:fsarazin@ottawahospital.on.ca

\section{J.J. GAINES, J. LYNCH, K. SARGEANT, R. BAKSHI, B. WEIN- STOCK-GUTTMAN \& R.H. BENEDICT. ASSESSING ERROR TYPES AND LEARNING CONSISTENCY USING THE BVMT - R.}

Verbal memory tests have traditionally incorporated a variety of learning and error indices (e.g., perseverations, intrusions, and recall consistency). Such indices shed light on the qualitative aspects of learning but they are yet to be developed for visual memory tests. This study describes the development of such variables for the Brief Visuospatial Memory Test-Revised (BVMT - R: Benedict et al., 1997) and evaluates their reliability. A scoring system was developed and standardized for the following error types: configuration errors, misplaced figures, rotation errors, perseverations, intrusions. Learning consistency (i.e., the frequency with which one recalls the same items from one trial to the next) was calculated using a formula adapted from the California Verbal Learning Test. As it was calculated mathematically, its reliability was not examined. Distribution of the consistency measure was negatively skewed. Of the error measures, only the rotation error scores approximated a normal distribution. There were no configuration errors. Inter-rater reliability was examined in a sample of healthy adults aged $21-57(\mathrm{n}=$ 24). Kappa interrater reliability statistics ranged from good (.65 for both misplaced figures and intrusions) to excellent $(1.0,1.0$, and .82 for configuration errors, perseverations, and rotations, respectively). Rotation errors correlated negatively with BVMT-R total learning and delayed recall. Total error index also correlated negatively with BVMT-R total learning. Results suggest that these new learning indices are reliable, are associated with good recall performance, and are potentially useful for developing a better understanding of the visual learning/memory process. Correspondence: jeffrey J. gaines, Ph.D., Developmental and Behavioral Neurosciences, University of Buffalo Medical School, 66 Summer St., Apt.7K, Buffalo, NY 14209. E-mail: gainesjeffreyj@hotmail.com

\section{M.G. BROOKER, J. SHAW, L.H. LACRITZ \&. C.M. CULLUM. WMS-III VISUAL REPRODUCTION CUEING: A USEFUL AD- JUNCT PROCEDURE.}

Retention rates from the Wechsler Memory Scale-III (WMS-III) are lower for Visual Reproduction (VR) than any other WMS-III subtest, and a significant percentage of individuals forget one or more designs on delayed recall (Lacritz et al, in press). It is not known whether these findings relate to true memory loss or more isolated retrieval deficits in some individuals. This study developed visual prompts to assess the effect of cueing on VR recall. Separate prompts were made for each card that provided aspects of design gestalts without giving details. A diagnostically mixed sample of 20 outpatients [M age $=46.8$ (18.7); M education $=12.95(3.6)]$, were shown each of the cueing cards (in between VR Delayed Recall and Recognition) for ten seconds, instructed to add the details, and scored using WMS-III VR criteria. Ten (50\%) subjects showed improvement ( $>10$ points) on cued recall, with an average increase of 21.6 points, whereas $50 \%$ showed little or no improvement. Improvers demonstrated significantly better recognition than delayed recall performance using a paired samples t-test $(p=.002)$, while nonimprovers scored similarly across those subtests. To assess the effect on recognition performance, scores from the cued group were compared to a non-cued sample matched for VRI scaled score, age and education, showing no significant difference in recognition total score between the cued $(\mathrm{M}=41.1)$ and non-cued $(\mathrm{M}=40.9)$ samples. These results support the validity of a VR cued recall trial that may enhance understanding of visual memory performance without detracting from recognition testing.

Correspondence: Matthew G. Brooker, B.S., Psychiatry, UT Southwestern Medical Center at Dallas, 5323 Harry Hines Blvd, Dallas, TX 753908846.E-mail:matthew.brooker@utsouthwestern.edu

\section{B. LEVY, G. REGER \& A. PETRE. COMPARING THE ORIGINAL AND A COMPUTERIZED MULTIPLE - CHOICE VERSION OF THE FACES TEST FROM WMS-III IN ALZHEIMER'S PATIENTS .}

In recent work, Levy (in press) provided a statistical explication of the inadequacy of the Faces test from WMS-III for detecting impairment in visual memory among the elderly. The quantitative analysis pointed to the considerable overlap between the distribution of test scores in the norms for older adults and the distribution of scores that is expected under chance performance. By implication, older adults may rarely obtain a score within the severely impaired range and often score within normal limits, even when they simply guess on all items of the test. From a clinical viewpoint, it is possible that the test, as currently administered, exceeds the limits of many healthy older adults, thereby producing a floor effect. The presentation of 24 pictures at 2 sec. intervals may overwhelm the attention and concentration of older people in a manner that interferes with a proper encoding process. This format of administration introduces age-related confounds to the test. The current study compared the original and a computerized version of the Faces test in 16 Alzheimer's patients and 16 controls. Using the same stimuli, the computerized version limited the presentation to only 3 pictures in one sequence, which was followed by a multiple-choice test of immediate recall. This procedure was repeated 6 times, presenting an overall of 18 target items and 54 distracters, all taken from the original test. Results indicated that the computerized version offered significantly better differentiation between $\mathrm{AD}$ patients and controls. The proposed for- 
mat may therefore improve the validity and clinical utility of the test. References Levy, B. (in press). About the Power for Detecting Severe Impairment in Older Adults with the Faces Test from Wechsler Memory Scale III: Simply Guess and Save Face. Journal of Clinical and Experimental Neuropsychology.

Correspondence: Boaz Levy, Ph.D, Harvard Medical School/McLean Hospital, 115 Mill St. South Belknap 336, Belmont, MA 02478-9106. E-mail:boaz_levy@hms.harvard.edu

\section{S.J. SHA, H. ROSEN, G. SCHAUER, M. WEINER, B.L. MILLER \& J.H. KRAMER. EXECUTIVE TESTS, ARE THEY ALL THAT THEY SEEM? A COMPARISON OF ACHIEVEMENT SCORES AND ER- RORS OF EXECUTIVE TASKS AS AN INDICATION OF FRONTAL VOLUMES..}

Frontal lobe function has traditionally been assessed using neuropsychological tests of executive function. However, studies have shown that people with frontal lobe lesions can perform normally on these measures ${ }^{1}$. In addition, the multi-factorial nature of some tasks makes accurate assessment difficult. One study suggests that analysis of test errors is a more sensitive measure of frontal lobe function rather than achievement score ${ }^{2}$. In order to investigate this hypothesis, 62 subjects (13 normal controls, 17 Frontotemporal Dementia patients, 14 Semantic Dementia patients, 18 Alzheimer's disease patients) were administered a neuropsychological assessment battery. The achievement scores of the modified Stroop and modified Trails test were compared to error scores. Set-shifting and sequencing errors from the Trails test and disinhibition errors from the Stroop test were inversely correlated with frontal volumes, but not with anterior temporal lobe or orbitofrontal cortex. Conversely, achievement scores from these measures were not significantly correlated with frontal volumes. These findings indicate that specific analysis of error on executive measures can better determine frontal lobe deficits. This assessment of executive failures may also be more sensitive than achievement scores as a diagnostic clinical tool. ${ }^{1}$ Anderson CV et al, J Clin Exp Neuropsychol 1995; Anderson SW et al, J Clin Exp Neuropsychol 1991; Hermann BP et al, J Clin Exp Neuropsychol 1988; Reitan RM et al, Neuropsychol Rev $1994{ }^{2}$ Stuss DT et al, Psychol. Assess 2001; Stuss DT et al., Principles of Frontal Lobe Function 2002

Correspondence: Sharon J. Sha, M.S., UCSF, 2500 Wisconsin Ave NW \#914,Washington, DC 2007. E-mail: sharonsha_us@yahoo.com

\section{S. PROVENCAL \& E.D. BIGLER. THE DELIS-KAPLAN EXECU- TIVE FUNCTION SYSTEM (D-KEFS)COMPARED TO TRADI- TIONAL TESTS OF EXECUTIVE DYSFUNCTION IN PATIENTS WITH FRONTAL LESIONS.}

Four patients, 22 to 49 -years-old, underwent repeated neuropsychological evaluations to monitor sequelae of acquired traumatic brain injuries. All patients had well documented frontal lobe injuries as a result of head trauma. Patients ranged from 15 to 26 years of age at the time of injury. Neuroimaging studies revealed focal lesions to the right frontal region for two patients and bilateral lesions to the frontal lobe for the other two patients. Initial neuropsychological testing and interviews with family members suggested cognitive, personality, and behavioral changes consistent with frontal lobe syndrome. Premorbid intellectual functioning was estimated to be in the high average range to superior range for all patients. At the time of follow-up evaluation, patients were gainfully employed and/or attending full-time college. General cognitive abilities from the Wechsler Abbreviated Scale of Intelligence (WASI) averaged 117 (range $=109-132)$. Neuropsychological findings on follow-up testing were generally within normal limits consistent with measured IQ, although two patients demonstrated lower than expected working memory skills as measured by the Wechsler Memory Scale-Third Edition (WMS-III). Scores on standard tests of executive functions (Category Test and Wisconsin Card Sorting Test) were within normal limits. Subtests scores from the Delis-Kaplan Executive Function System (D-KEFS), however, suggested variable performance in executive functions that were consistent with reported real-life problems in areas of abstract thinking, planning, and cognitive flexibility. Findings suggest the DKEFS is a useful neuropsychological tool for evaluating subtle neurocognitive deficits in high-functioning patients with frontal lobe injuries where other traditional measures of executive dysfunction are negative.

Correspondence: Sherri Provencal, Psychiatry, University of Utah, 421 Wakara Way, Suite 143, Salt Lake City, UT 84108-3528. E-mail: sherri_provencal@msn.com

\section{N.P. CRAIG, I. ESTERLIS, B. STEINBERG, L.A. BIELIAUSKAS, G.E. SMITH \& R.J. IVNIK. AGE- AND SHORT FORM IQ-AD- JUSTED MOANS NORMS FOR THE TMT, STROOP, AND COWAT.}

In previous studies, we showed that older individuals' performances on the Trail-Making Test, the Stroop Color-Word Test, and the MAE Controlled Oral Word Association Test had stronger associations with intelligence (Mayo age-adjusted WAIS-R FSIQ scores) and sight-reading (Mayo age-adjusted AMNART scores) than with level of education. Because short forms of the WAIS-R are often used to ob-tain brief but reasonably accurate estimates of FSIQ under time con-straints, we combined scaled scores from Vocabulary and Block De-sign (the two subtests that have shown the strongest correlations with FSIQ; e.g. Silverstein, 1982) and examined the adequacy of this ab-breviated version as an alternative to FSIQ. As predicted, short-form IQ (SFIQ) scores were more closely associated with Mayo age-adjusted TMT, Stroop, and COWAT scaled scores $(r=.339$ to .419$)$ than was years of formal education $(r$ $=.161$ to .367$)$. In addition, SFIQ correlations compared favorably with correlations that involved FSIQ $(r=.368$ to .495). SFIQ scores were associated with larger unique increases in TMT, Stroop, and COWAT scaled score variances in multiple regression models $(6.6 \%$ to $11.0 \%)$ than was education $(0 \%$ to $3.5 \%)$, and the former similarly compared favorably with re-sults from analyses that included FSIQ scores $(9.6 \%$ to $18.6 \%$ ). Based on these data, we developed tables of age- and SFIQadjusted norms for the TMT, the Stroop, and the COWAT.

Correspondence: Brett Steinberg, Ph.D., Psychology, University of Connecticut, 406 Babbidge Rd, Unit 1020, Storrs, CT 06269. E-mail: brett. steinberg@uconn.edu

\section{E.A. NELSON, K.B. BOONE, L.K. PAUL \& N.W. NELSON. CONSIDERATIONS FOR CLINICAL USE OF THE STROOP TEST.}

The Stroop test has a lengthy history as an experimental measure in psychological studies and more recently has been adopted for neuropsychological use. Although there are different versions, the most common formats involve a word reading trial, a color naming trial, and a response inhibition trial in which subjects are presented with color names printed in incongruent ink color, and instructed to name the ink color rather than read the word. Stroop C is a variable of interest reflecting executive function. However, despite the Stroop's widespread use, there is no current literature providing a technique for the clinician to control for the effect of processing speed in Stroop A and B from response inhibition in Stroop C. This is important because Stroop C is only reflective of executive functioning when deficits in processing speed are partialled out. This study introduces a subtraction technique, the Stroop Interference Algorithm, applied to the Comalli version of the Stroop ( $\mathrm{cf}$ Mitrushina, Boone, \& D'Elia, 1999), that accurately represents response inhibition by controlling for the effects of Stroop A and B on Stroop C. Comparisons between various diagnostic groups (depression, psychosis, psychotic depression, bipolar disorder, left and right frontotemporal dementia, dementia NOS, myotonic muscular dystrophy, Klinefelter's disease, non-penetrating head injury, seizure disorder, brain tumor, obsessive-compulsive disorder, substance abuse, HIV, memory problems NOS, attention problems NOS, and cognitive disorder NOS) and controls on the Interference Algorithm are reported. 
Correspondence: Elizabeth A. Nelson, M.A., Clinical, Fuller Graduate School of Psychology, 828 Washington Street, Apt \#3N, Evanston, IL 60202.E-mail:adams@fuller:edu

\section{Y. SUCHY, A. GOLD \& A. GOLD. EXAMINATION OF ECOLOGI- CAL VALIDATY OF SWITCHING TASKS .}

Recently there has been an increase in the use of switching tasks (Jersild, 1927) in the study of executive abilities. Although switch costs (SCs) are often greater among several populations characterized by executive weaknesses (e.g., ADHD; Cepeda et al., 2000), the relationship of SCs to behavioral markers of executive dysfunction has not been demonstrated. The present study examined whether SCs would be related to reports of impulsive and inattentive symptoms, and to several types of errors across two tasks. Participants were 76 college students. Instruments included CAARS Self-Report Inventory to assess ADHD symptoms, and verbal and nonverbal switching tasks. SCs were computed by subtracting the median response latency on the nonswitch trials from that on the switch trials. Largely consistent with Cepeda and colleagues (2000), verbal SCs correlated with Impulsive/Hyperactive subscale of the CAARS ( $\mathrm{r}=.343, \mathrm{p}=.008)$. Additionally, verbal SCs correlated with perseverative $(\mathrm{r}=.278, \mathrm{p}=.015)$ and nonperseverative errors $(\mathrm{r}=.274$, $\mathrm{p}=.017$ ), but not with commissions or omissions. No relationship with nonverbal SCis was found. The results provide support for ecological validity of verbal, but not nonverbal, SCs. Given that a variety of switching tasks have been employed in past research, the present study serves as a reminder that SCs need to be interpreted with caution in the absence of validation data. By the same token, it is encouraging that the verbal CSs, which correlated with ADHD symptoms, also correlated with behavioral data.

Correspondence: Yana Suchy, Ph.D., Psychology, University of Utah, 380 S. 1530 E.Rm.502, Salt Lake City, UT 84112.E-mail:yana.suchy@ psych.utah.edu

D. BARRY, M. BATES, E. LABOUVIE, J. MORGAN, R. PANDINA \& S. MILLIS. COMPARABLE PERFORMANCE ON FAS AND CFL FORMS OF VERBAL FLUENCY IN NORMAL SAMPLES.

The Verbal Fluency or Controlled Oral Word Association (COWA) Test is a popular method of assessing verbal and executive abilities. The original COWA included three letters, CFL or PRW, and most norms currently in use are based on these sets of letters. Currently, however, a third form (FAS) appears to be more popular than the original COWA. Analysis of the difficulty of generating words in response to a letter indicates that CFL and PRW each contain one easy and two difficult letters, while FAS contains two easy letters and one difficult letter, suggesting that interpretations of FAS scores using norms based on the COWA should be made cautiously. Previous research on a clinical sample, however, found comparable results using CFL and FAS forms of verbal fluency. The current study uses a meta-analytic technique to examine the comparability of the two forms and the influence of demographic factors and sample characteristics on mean performance across 159 studies of normal participants. Multiple regression analysis indicates that test form does not significantly affect performance but that age and education account for $32 \%$ of variance in mean verbal fluency performance. Younger age and higher education are associated with better performance on verbal fluency tests. Gender, use of college student samples, age of study, and strictness of exclusion criteria did not affect performance. This study suggests that norms based on one form of verbal fluency provide an accurate normal comparison group for alternate forms, and that norms should be stratified by age and education.

Correspondence: Danielle Barry, M.S., Center of Alcohol Studies, Rutgers University, 408 South Graham Street, \#3, Pittsburgh, PA 15232. E-mail: danbarry@rci.rutgers.edu

\section{S. ZINN, A.C. CARTER \& S. SWARTZWELDER. STRATEGY ON THE RUFF FIGURAL FLUENCY TEST: A MEASURE OF EXECU- TIVE FUNCTION.}

The ability to strategically respond to a real-world challenge requires intact executive functioning. Instruments that constrain individuals to employ a particular strategy may not measure this adaptive use of strategy. As strategy may be more freely employed (or not) on the Ruff Figural Fluency Test (RFFT), a strategy scoring system was codified to examine whether this would be useful for assessing strategy performance in a clinical population likely to have executive function deficits. This system measures both number of strategies attempted and number of unique designs generated by sustained strategy use. These two new scoring indices were used to contrast the strategy employment of patients who were initiating treatment for alcohol dependence $(\mathrm{N}=27)$ with a group of age-matched controls ( $\mathrm{N}=18$ ). The RFFT was administered as part of a neuropsychological battery in a longitudinal study evaluating the executive functions of individuals recovering from alcoholism. Inter-rater reliability was excellent (.93-.99). Significant group differences were found for both number of strategies ( $\mathrm{T}$ [one-sided $\mathrm{t}$ approximation] $=0.005)$ and number of strategic designs ( $\mathrm{T}$ [one-sided $\mathrm{t}$ approximation $]=0.001)$. Correlations of the RFFT strategy scores and other executive function measures for the combined sample suggested that the number of differing strategies related to psychomotor speed, and possibly cognitive flexibility. The number of designs generated by strategy use is associated with higher order reasoning. It is possible that reasoning depends on the ability to repeatedly apply the same logical operation over time. Thus, the scoring of strategy employment on the RFFT is reliable, valid, and has clinical utility.

Correspondence: Sandra Zinn, PhD, 151, Durham VA Medical Center, 508 Fulton St., Durham, NC 27705. E-mail: sandra.zinn@duke.edu

\section{E. ECKLUND-JOHNSON, J.J. SWEET \& S.A. MILLER. CONFIRMATORY FACTOR ANALYSIS OF THE BEHAVIORAL DYSCONTROL SCALE IN A MIXED CLINICAL SAMPLE.}

The Behavioral Dyscontrol Scale (BDS) is a brief measure of executive functioning originally designed for use primarily with older adults. Previous research suggests that factors derived from exploratory factor analysis of the BDS have clinical utility not only with older adults, but also with younger adult patient samples (e.g., TBI). However, the factor structure has not been previously submitted to confirmatory analysis, and there are several potential methodological problems with the previous exploratory factor analysis. In this study, we conducted a confirmatory factor analysis of the BDS. Findings were largely consistent with the original exploratory analysis (Grigsby, Kaye, \& Robbins, 1992) in suggesting a three-factor model, although modifying the model to allow the error terms corresponding to the initial two items to correlate with one another resulted in a better fitting model than any of the a priori specified models. Furthermore, the three factor model was a better fit if factors were allowed to correlate with one another; correlations between factors were high. The findings of this study lend support to the current practice of using factor scores in clinical and research applications. Additional issues related to interpretation of the factors are discussed, particularly in light of evidence that factor analytic methods in mixed clinical samples can sometimes lead to problematic conclusions (Delis, Jacobson, Bondi, Hamilton, \& Salmon, 2003).

Correspondence: Eric Ecklund-Johnson, Ph.D., Psychiatry \& Behavioral Sciences, Evanston Northwestern Healthcare, 909 Davis St., Evanston, IL 60201. E-mail: eecklund@enh.org

\section{G.A. GIOIA, P.K. ISQUITH \& S. GUY. FACTOR STRUCTURE OF THE BEHAVIOR RATING INVENTORY OF EXECUTIVE FUNC- TION SELF-REPORT.}

We examined evidence of the validity of a self-report version of the Behavior Rating Inventory of Executive Function (BRIEF-SR) via exploratory factor analyses of normative and clinical samples. Prin- 
cipal factor analysis (PFA) with oblique rotation was performed on a normative sample $(\mathrm{N}=1000)$ of adolescents aged $11-18$ years. Variables that loaded greater than .30 were retained on a factor. A two-factor model, accounting for $70 \%$ of the variance, was retained as the best fitting model in all of the analyses. Three-factor solutions were not viable and a single factor model was rejected based on clinical and experimental grounds. Four scales- Working Memory, Plan/Organize, Organization of Materials, and Task Completion defined a Metacognition factor. The Inhibit, Shift, Emotional Control and Self-Monitor scales defined a Behavioral Regulation factor. The two factors were strongly correlated, $\mathrm{r}=.77, \mathrm{p}<.05$. A second PFA conducted with a mixed clinical sample $(\mathrm{N}=364)$ yielded a simlar two-factor solution that accounted for $75 \%$ of the variance. Again, the two factors were highly correlated, $\mathrm{r}=.75, \mathrm{p}<.05$. Agespecific factor analyses were conducted separately for the two normative age groups (11-14, 15-18 years), yielding two-factor structures similar to the full normative and clinical samples. Separate PFAs for boys and girls in the normative sample also revealed similar two-factor structures. In summary, a robust two-factor structure was demonstrated across multiple samples with the BRIEF-SR, supporting the Metacognition and Behavioral Regulation domains of executive function similar to that found for the BRIEF Parent and Teacher forms.

Correspondence: Gerard A. Gioia, Ph.D., Pediatric Neuropsychology, Children's National Medical Center, 4900 Massachusetts Avenue NW, Suite 320, Washington, DC 20016.E-mail: ggioia@cnmc.org

\section{P.K. ISQUITH, S.C. GUY \& G.A. GIOIA. DEVELOPMENT OF THE BEHAVIOR RATING INVENTORY OF EXECUTIVE FUNCTION- SELF REPORT VERSION.}

Parent and teacher rating scales of executive function can enhance ecological validity of assessment (Silver, 2000). Explicitly assessing and providing feedback about adolescents perspectives on their own selfregulation can also inform assessment and facilitate a collaborative working relationship that serves as a starting point for intervention. Indeed, adolescents level of self-awareness helps gauge the amount of support they require. We developed a standardized self-report measure of executive function for adolescents aged 11- 18 years as a tool for external validation of clinical assessment and as an easily administered, psychometrically sound means of evaluating executive difficulties in this age group. The measure is based on its predecessor, the BRIEF (Gioia, et al. 2000), and includes 80 items within 8 non-overlapping scales (Inhibit, Shift, Emotional Control, Self-Monitor, Working Memory, Plan/Organize, Organization of Materials, Task Completion), each with 5 to 13 behaviorally anchored items. Item-total correlations for combined clinical $(\mathrm{N}=464)$ and normative groups $(\mathrm{N}=1000)$ were in the appropriate range. Internal consistency ranged from $\alpha=.75$ to .87 for scales and $\alpha=.96$ overall. Test-retest stability was high $(r=.89)$ over a 5 week period. There were small $(\eta=.01$ to .05$)$ but significant $(\mathrm{p}<$ $.01)$ age and sex differences, with older adolescents and girls reporting fewer difficulties, with the exception of the Emotional Control scale, on which girls reported more problems. The BRIEF-SR is a reliable behaviorally-anchored rating scale that can assist with assessment and focused intervention planning for adolescents with self-regulatory difficulties.

Correspondence: Peter K. Isquith, Ph.D., Department of Psychiatry, Dartmouth Medical School, One Medical Center Drive, Lebanon, NH 03756-0001.E-mail: isquith@dartmouth.edu

\section{J. STORTEBOOM, D.L. NYENHUIS \& P.B. GORELICK. ASSESSING BEHAVIORAL CHANGE FOLLOWING STROKE: AN APPLICATION OF THE FRONTAL SYSTEMS BEHAVIOR SCALE.}

Behavior and mood changes are often present in persons following stroke. The Frontal Systems Behavior Scale (FrSBe) (Grace \& Malloy, 2001) is designed to measure behavior change in patients with damage involv- ing frontal systems. The present study investigated the validity and internal consistency of the FrSBe in a population of ischemic stroke patients. It also examined relationships between the FrSBe and neuropsychological measures. 109 ischemic stroke patients, 3 - 6 months post stroke, and ranging in age from 49 to 85 participated in the study. The family form of the FrSBe was completed by a family member or friend of the patient. A battery of neuropsychological tests was administered to each patient as well. Exploratory factor analysis supported the threesubscale structure of the test, but also revealed several items that crossloaded or did not load on any of the factors. High coefficient alpha scores were found for each subscale as well as the total score. The patients scored significantly higher on the POST scale than on the PRE scale, revealing a significant level of change in their behaviors $(\mathrm{t}=-7.03, \mathrm{p}=$ $<.001)$. Significant correlations were also found with several neuropsychological measures. These data support use of the FrSBe with stroke populations to assess behavior change and relationships with other neuropsychological measures.

Correspondence: Julie Storteboom, Psychology, Calvin College, 6770 Paris SE, Grand Rapids, MI 49548.E-mail: jstort38@calvin.edu

\section{M.S. CANNIZZARO \& C.A. COELHO. STORY GRAMMAR PER- FORMANCE IN ADULTS: A BALANCED AND ECOLOGICALLY VALID MEASURE OF EXECUTIVE FUNCTION.}

Investigations of cognitive aging have provided preliminary evidence that language and executive functions (EF) change as a consequence of advanced age. The use of narrative discourse measures has increased our understanding of the subtle cognitive-linguistic changes associated with aging. It has been hypothesized that discourse organization, specifically story grammar (SG), and EF are both dimensions of goal-directed behaviors described as managerial knowledge. The present study investigated age-related changes of story grammar performance and executive functions in neurologically intact adults. Two questions were addressed: (a) Are measures of story grammar related to standardized linguistic and non-linguistic measures of executive functions? and (b) Do measures of executive function and story grammar represent a unified construct of managerial knowledge? Participants were 46 independent, community dwelling adults, between the ages of 18-98, without prior history of neurological, psychiatric, language or learning disabilities. Two story narratives were elicited from each participant, and analyzed with regard to SG performance. Results indicated that three of the SG measures were related to both linguistic and non-linguistic measures of executive function. Factor analysis of the related SG and EF variables yielded two distinct factors termed: output-fluidity, and organizational-efficiency. It is concluded that the measures of SG and EF represent different aspects of managerial knowledge that are not bound by a traditional linguistic vs. non-linguistic division. Thus, SG presents as an ecologically valid measure of both linguistic and nonlinguistic executive functioning that is sensitive to subtle age-related changes.

Correspondence: Michael S. Cannizzaro, PhD, Clinical Technologies, Neurosolutions Inc., 80 Liberty Street, Pawcatuck, CT 06379. E-mail: mscannizzaro@comcast.net

\section{M.J. MORDHORST, K.Z. DONNELLY, B.M. HOFFMAN, J.S. KLEINER \& J.A. BURHART. SEMANTIC CLUSTERING: CRI- TERION VALIDITY OF VARIOUS INDICES.}

The Hopkins Verbal Learning Test-Revised is a brief list-learning and memory test consisting of words from three semantic categories. The extent to which respondents consecutively recall words from the same category is thought to reflect use of an organizational strategy and executive function. This study examined the criterion validity of different semantic clustering indices. Participants consisted of VA medical center patients diagnosed with dementia of the Alzheimers type, vascular 
dementia, depressive disorder, and no cognitive deficit. Semantic clustering indices varied according to the basis of correction for chance clustering: the original list (list-based), words recalled from each category (category recall-based), or total number of words recalled (total recallbased). Both dementia groups scored significantly lower than patients with depressive illness and no cognitive deficit according to most clustering indices. The method of calculating the clustering score was associated with observed differences between groups. Category recall-based indices were significantly different for more groups on the delayed trial than learning trials. Conversely, total recall-based and list-based scores differentiated more groups on the learning and combined trials. The results suggest that semantic clustering indices are valid indicators of executive function and can discriminate between diagnostic groups. The method of calculating semantic clustering scores also influences the clinical utility of scores. Considering both the ability to differentiate diagnostic groups and ease of calculation, a total recall-based method of calculating semantic clustering scores is recommended for use in clinical practice.

Correspondence: Matthew J. Mordhorst, University of Iowa, 3028 Randolph Court Drive, Ann Arbor, MD 48108.E-mail:matthew-mordhorst@ uiowa.edu

\section{P.A. O'CONNELL. RAN TEST PERFORMANCE: THE CONTRIBU- TION OF EXECUTIVE FUNCTION PROCESSES.}

Researchers have long used the Rapid Automatized Naming tests to examine the development of reading skills. RAN performance consistently has proven to be a predictor of reading success. The multi-part test requires rapid naming of letters, numbers, colors, and objects. Recently, RAN performance has been examined in children with attentional problems, with results indicating these subjects have difficulty efficiently performing the task. Some researchers have hypothesized that RAN task demands include both linguistic and executive function processes. This study examined RAN object naming performance in a nonclinical group of adults. Two hundred undergraduate students $(M$ age $=21.47$, range 17-50) were administered a 2 -hr battery of tests as part of a study of executive functions. Subjects were divided into three groups based on RAN object naming performance: average (within +/- $1 S D$ from the sample mean); slow (-1 SD from the sample mean); and fast $(+1 S D$ from the sample mean). Comparisons were made between the slow naming group ( $\mathrm{SN}$ ) and fast naming group $(\mathrm{FN})$ across several executive function tasks. The SN group exhibited significantly weaker performance across measures including computerized vigilance tasks, Verbal Fluency, Repetitive Graphomotor Sequencing, and the Wisconsin Card Sorting Test. There were no differences between the SN and FN group on tasks of flexible thinking, generativity, and IQ. Results of this study suggest that RAN object naming may not tap "automatized skills" as the measure's name implies. It appears that efficient RAN object naming performance requires a complex set of skills, including executive aspects of cognition.

Correspondence: Patricia A. O'Connell, Ph.D., Psychology, Georgia State University, Department of Psychology, University Plaza, Atlanta, GA 30303.E-mail:psypao@langate.gsu.edu

\section{J.B. MILLER, S.A. LANGENECKER, A.K. FREYMUTH, C.A. PERSAD \& K.A. NIELSON. VALIDITY OF THE CONDI- TIONAL GO/NO-GO TASK.}

The Go/No-Go (GNG) task is a newer measure of inhibitory control, specifically executive function. However, very little data currently exist regarding convergent and divergent validity for this task. It is believed based on previous findings that this task does effectively measure the capabilities of an individual to suppress irrelevant or interfering stimuli. The purpose of this study is to determine if the GNG is a valid measure of inhibitory control. Two hundred and six participants (M-Age=38; M-Education=16) were recruited and included individuals with depression $(n=130)$, normal control subjects $(n=52)$, and individuals with obstructive sleep apnea $(n=24)$. The task utilizes a computer interface where the participants are instructed to respond to select targets and to inhibit their response to these same targets when they are presented in succession without presentation of an alternate target. Four versions of the task were used, each of which had distinct target groups consisting of two, three, or four targets. The correlation between the percentage of correctly inhibited (PCI) responses with another measure of executive function (Trails B-Trails A) was significant and negative $(r=-.695, p<.01)$ demonstrating the convergent validity of the GNG. The depressed performed significantly worse than the control groups in PCI $(F=3.604$, $\mathrm{p}<.015)$, verifying discriminant validity. Divergent validity was demonstrated by computing the correlation between PCI and two separate measures of verbal IQ (Shipley r=.181, p>.10; AMNART r=.113, p>.10) Although further studies are needed, these initial results demonstrate that the GNG is a promising measure of executive function.

Correspondence: Scott A. Langenecker, Ph.D., Psychiatry, University of Michigan Health Systems, C480 Med Inn Building, 1500 E. Medical Center Drive, Ann Arbor, MI 48109.E-mail: slangen@umich.edu

\section{H.A. KAISER, J.E. MARTIN, M.S. BANET \& K.A. ESPY. TEST- RETEST RELIABILITY OF EXECUTIVE FUNCTION TASKS FOR USE WITH YOUNG CHILDREN.}

Executive dysfunction, such as deficits in working memory or inhibitory control, have been implicated in a number of neurological, developmental, and psychiatric disorders. Although several executive function tasks are available for use with adults and school-aged children, there remains a paucity of tasks appropriate for preschool-aged children (2.56 years). Concomitantly, of the available experimental tasks, psychometric test properties largely are unknown. Therefore, a battery of executive function tasks was administered to preschool-aged children twice, 1-week apart. Evidence for reliability was examined using correlations between the test-retest administrations. Calculated test-retest correlations of some, but not all, executive function tasks were consistent with acceptable standards, even in these very young children. Executive functions can be reliably assessed in this age range by tasks that utilize carefully selected, developmentally appropriate materials and procedures.

Correspondence: Kimberly Andrews Espy, Ph.D., Family \& Community Medicine, Southern Illinois University School of Medicine, SIUSOM, MC 6503,600 Agriculture Dr., Carbondale,IL 62901-6503.E-mail: kespy@ siumed.edu

\section{Paper Session 9/9:00-11:00 a.m.}

\section{The Cognitive Neuropsychology of Schizophrenia}

\section{DICKINSON, V. IANNONE, C. WILK \& J. GOLD. PARSING GEN- ERAL AND SPECIFIC COGNITIVE DEFICITS IN SCHIZOPHRENIA.}

Background: There is a long-standing debate among schizophrenia researchers regarding how much of the cognitive impairment in the illness is due to a generalized deficit and how much to independent deficits in specific cognitive domains. This parallels a similar debate concerning non-clinical populations. Resolution of this debate not only has important clinical implications but also relates to the search for the genetic underpinnings of schizophrenia. Methods: The WAIS-III and WMS-III were administered to 192 participants: 97 clinically stable outpatients with a diagnosis of schizophrenia or schizoaffective disorder and 95 healthy controls. We used a structural equation modeling technique, single common factor analysis, to analyze index scores from the two instruments (VCI, POI, WMI, PSI from the WAIS-III; AII, VII from the 
WMS-III). We hypothesized that the analysis would reveal a strong common factor distinguishing the two groups, and that there would be few and/or weak independent effects. Results: As predicted, the schizophrenia participants were distinguished from healthy controls primarily by a single, generalized cognitive deficit. Each Wechsler index score showed a strong relationship with this generalized deficit dimension, with significant loadings ranging from .64 to .83 . The independent associations of group status with the index scores were fewer and considerably smaller in magnitude. Conclusions: These findings are consistent with prior studies that show evidence of a generalized cognitive deficit in patients with schizophrenia. The results have implications regarding the design of genetic studies of the illness, as well as clinical implications related to neuropsychological assessment and intervention.

Correspondence: Dwight Dickinson, Ph.D., Psychiatry, University of Maryland Medical School, VA Medical Center, 10 North Greene St. (BT/MIRECC), Baltimore, MD 21201.E-mail:Dwight.Dickinson@ med.va.gov

\section{J.B. SHEER, .A. MATEER \& R.E. GRAVES. SPEECH MONITOR- ING DEFICITS IN SCHIZOPHRENIA.}

Recent literature (Frith, 1992) has implicated deficits of self-monitoring as a possible cause of positive symptomotology in schizophrenia. The current project compared the performance of 31 schizophrenics (16 hallucinators \& 15 nonhallucinators) to 15 non-schizophrenic psychiatric participants on measures of speech monitoring of internal and overt speech. The combined group of schizophrenics was found to be impaired relative to controls on two measures of internal speech monitoring including: silent reading [one-tailed $U(1,45)=102.50 ; p<.001 ; d=1.44$ ], and identification of speech errors during white noise [one-tailed $U(1,45)=140 ; p=.021 ; d=.70]$; however, the group was also impaired on a task of speech-monitoring when provided with external feedback. contrary to expectation [one-tailed $U(1,45)=120 ; p=.009 ; d=.51$ ]. Analysis of the subgroup data (hallucinators vs. nonhallucinators) revealed significant differences only on the silent reading test in which the hallucinators performed significantly worse. Further, nonparametric correlations revealed relationships between performances on both the silent reading and external speech-monitoring tasks and neuropsychological measures including IQ, divided attention, and selective attention. Speech monitoring during exposure to white noise was correlated only with divided attention. These results suggest that 1 ) speech-monitoring deficits in schizophrenia are not limited to the internal speech plan, but can also involve monitoring of overt speech; 2) speech-monitoring deficits are not limited to schizophrenics who experience hallucinations; and 3) speech-monitoring deficits may be related to deficits of neuropsychological functioning such as attention which are well documented in the schizophrenia literature.

Correspondence: Jeffrey B. Sheer, Ph.D., Spaulding Rehabilitation Hospital, 125 Nashua Street,Boston, MA 02114.E-mail:jsheer@partners.org

\section{S. MOELTER, S. HILL, P. HUGHETT, R.C. GUR, R.E. GUR \&. J. RAGLAND. ORGANIZATION OF SEMANTIC CATEGORY EXEM- PLARS IN SCHIZOPHRENIA: PRELIMINARY EVIDENCE FROM THE ZOO TEST.}

Semantic memory in schizophrenia was investigated using an animal exemplar organization task that did not require lexical retrieval. $\mathrm{Pa}$ tients $(\mathrm{n}=27)$ and controls $(\mathrm{n}=30)$ worked on a computer display to arrange 12 common animal names according to their similarity. Distances between names were recorded in a 12 X 12 matrix that was submitted to multidimensional scaling and cluster analysis. Participants were also asked to describe their organizational strategies at the conclusion of the test. Validation of the matrix was tested by comparing distances between animal pairs to the number of shared semantic attributes. Results indicated that both groups arranged highly related animal pairs in close proximity. The schizophrenia group, however, was less able to incorporate semantically diverse animals into larger clusters, sug- gesting less efficient use of broad organizational strategies. Comparison of self-reported strategies supported this finding as patients relied heavily on a categorization of cats/feline, while controls recognized domesticity as a framework that better defined the animals. Strong negative correlations revealed that as shared semantic attributes increased, spatial distances decreased. This finding validated the premise that visual organization and distance measures are related to semantic features. Our results suggest that impaired performances on semantic tasks in schizophrenia are related more to organizational strategy limitations than to semantic degradation. Of greatest importance, however, is the promise of the Zoo Test for future investigations of semantic functioning. Alternate versions of this test, with varying degrees of organizational demand based on semantic features and category proto-typicality, are in development.

Correspondence: Stephen Moelter, PhD, Social Sciences, University of the Sciences in Philadelphia, Kline Hall, 600 South 43rd Street, Philadelphia, PA 19104.E-mail: s.moelte@usip.edu

\section{J.B. SHEER, C.A. MATEER \& R.E. GRAVES. THE RELATION- SHIP BETWEEN DYSFLUENCY IN DELAYED AUDITORY FEED- BACK AND SELF-MONITORING IN SCHIZOPHRENIA.}

Goldberg et al. (1997) reported that schizophrenics were more dysfluent than controls in delayed auditory feedback (DAF). These data were interpreted as evidence against the self-monitoring theory of positive symptoms in schizophrenia (Frith \& Done, 1987) based on the logic that a "disconnection" between "willed intention" and a "monitoring center" should improve fluency in DAF. The current study examined the fluency of 30 schizophrenics (15 hallucinators \& 15 nonhallucinators) and 15 controls in DAF. The results indicated that the combined group of schizophrenics was significantly more dysfluent in DAF than the controls (one-tailed $U(1,44)=146, p=.028, d=.68$ ). No differences were found between the hallucinators and nonhallucinators. Dysfluency in DAF was also found to be correlated (Spearman nonparametric correlation) with measures of self-monitoring for speech including: identification of speech errors, $(\rho=.508, p<.001)$; identification of speech errors in white noise, $(\rho=.365, p=.015)$; and identification of speech sounds while silent reading $(\rho=-.365, p=.016)$. These data represent a replication of previous work, but are reinterpreted as support for the selfmonitoring theory. Specifically, it is argued that the self-monitoring deficit is not a true "disconnection" syndrome, but rather an inefficiency of monitoring internal action plans in comparison to monitoring of external feedback (as is indicated by the bulk of the literature). If schizophrenics are less efficient with "internal monitoring", than it is possible that they would be even more reliant on external feedback and hence more affected by DAF, as the data indicate.

Correspondence: Jeffrey B. Sheer, Ph.D., Spaulding Rehabilitation Hospital, 125 Nashua Street, Boston, MA 02114.E-mail:jsheer@partners.org

\section{R. FULLER, B.M. ROBINSON, S.J. LUCK \& J.M. GOLD. THE ROLE OF SELECTIVE ATTENTION IN THE WORKING MEMORY IMPAIRMENT OF SCHIZOPHRENIA.}

Given that working memory capacity is very limited, attention is needed to facilitate working memory performance when the number of items presented exceeds storage capacity and only a subset of the stimuli can be successfully encoded. One potential explanation for the working memory impairment in schizophrenia is that ineffective selective attention leads to poor utilization of limited working memory capacity. This hypothesis was tested with two visual change-detection experiments where we manipulated the validity of cues to guide working memory encoding as in Posner's visual orienting paradigm. Stimuli were red and green rectangles (experiment 1: 4-10 rectangles) or circles and rectangles (experiment 2: 4-8 shapes) displayed on a computer screen, half of which were cued to be remembered. Subjects, 18 patients with schizophrenia 
and 16 controls, were tested on the cued stimuli $75 \%$ and on the uncued stimuli $25 \%$ of the trials. In both experiments, controls successfully increased the benefit of attention on performance as set-size increased, i.e., cued minus uncued difference scores increased with increasing set size. Patients were able to selectively attend at smaller set sizes but were unable to benefit from the use of selective attention at larger set-sizes, as seen in significant group by set-size interactions, when the number of items presented exceeded capacity and attention was maximally required. These results support the hypothesis that patients with schizophrenia do not use selective attention successfully to assist working memory.

Correspondence: Rebecca L. Fuller, PhD, Maryland Psychiatric Research Center, University of Maryland SOM, PO Box 21247, Baltimore, MD 21228.E-mail:bfuller@mprc.umaryland.edu

\section{K.A. KELLY, M.A. COLE, N.K. DIXIT \& W.M. PERLSTEIN. RELATIVE PREDICTIVE POWER OF BEHAVIORAL AND FMRI DATA: WORKING MEMORY EFFECTS IN SCHIZOPHRENIA.}

Functional neuroimaging has been used extensively to examine the neural bases and mechanisms underlying cognition in healthy and disordered subjects. However, no studies have examined the predictive power of functional neuroimaging data to distinguish between patient and control groups. While both cognitive task performance and functional neuroimaging data have reliably identified abnormalities in patients with schizophrenia (SZ), the relative accuracy with which these data classify SZ and control subjects is unknown. We recently reported that, compared to healthy controls $(n=16)$, medicated SZ patients $(n=17)$ showed selective impairments in behavioral performance on the highest load level (2-back) of the N-Back working memory task with concomitant focal deficits in right dorsolateral prefrontal cortex activity measured by fMRI (Perlstein et al., 2001, Am J Psychiatry, 158, 1105-13). We returned to these data to examine the relative predictive power of the behavioral and fMRI data in differentiating among the groups. We examined the specificity (Spec), sensitivity (Sens), and positive (PPP), negative (NPP) and overall predictive power (OPP), and odds-ratio (OR) of both behavioral and fMRI data at the level of the 2-back load (cutoff criterion $>1.0$ SD below the control's mean). fMRI data provided greater predictive power than did behavioral performance (Sens=.65 vs. .47 ; Spec $=.94$ vs. $.81 ; \mathrm{PPP}=.91$ vs. $.73 ; \mathrm{NPP}=.71$ vs. $.59 ; \mathrm{OPP}=.79$ vs. .64 ; $\mathrm{OR}=10.35$ vs. 2.51 ; classification $\chi^{2}=13.71, p<.001$ vs. $\left.2.06, p>.08\right)$. We will discuss a potential role for fMRI as part of an overall assessment regimen that may extend beyond the research domain.

Correspondence: William M. Perlstein, Ph.D., Clinical \& Health Psychology, University of Florida, HSC Box 100165, Gainesville, FL 32610. E-mail:wmp@grove.ufl.edu

\section{KURTZ, B.E. WEXLER \& M.D. BELL. THE PENN CONDI- TIONAL EXCLUSION TEST (PCET): RELATIONSHIP TO THE WIS- CONSIN CARD SORTING TEST AND WORK FUNCTION IN PA- TIENTS WITH SCHIZOPHRENIA.}

Performance on the Penn Conditional Exclusion Test (PCET), a new computerized measure of executive-function with alternate forms (Kurtz et al., in press), was compared with performance on the Wisconsin Card Sorting Test (WCST) in a sample of thirty-two patients with schizophrenia. In Analysis 1 the PCET and WCST were administered with several other standard neuropsychological measures to assess convergent and divergent validity. Results revealed that categories achieved and total errors on the PCET were closely related to analogous measures from the WCST. Divergent validity was supported through nonsignificant correlations between the PCET and measures of speeded visual sequencing, verbal learning and psychomotor speed. In Analysis 2 the relationship between the PCET, WCST and a detailed measure of vocational function, the Work Behavior Inventory (WBI), was compared. Results revealed that both executive-function measures were related to specific dimensions of work function as measured in a vocational set- ting. More specifically, categories achieved and total errors on both the WCST and PCET were related to measures of cooperativeness on the job. Errors on the PCET were also related to measurements of work quality and general impressions of work. These results provide the first evidence of criterion-related validity for the PCET and are part of a growing literature suggesting a relationship between performance on measures of executive-function and work skills.

Correspondence: Matthew Kurtz, PhD, Schizophrenia Rehabilitation Program, Institute of Living, 200 Retreat Avenue, Fuller 1, Hartford, CT 06106.E-mail:mkurtz@harthosp.org.

Paper Session 10/9:00-11:00 a.m.

\section{Dementia: Parkinson's Disease and Alzheimer's Disease}

\section{C.I. HIGGINSON, V.L. WHEELOCK, K.E. CARROLL \& K.A. SIG- VARDT. RECOGNITION MEMORY IN PARKINSON'S DISEASE WITH AND WITHOUT DEMENTIA: EVIDENCE INCONSISTENT WITH THE RETRIEVAL DEFICIT HYPOTHESIS.}

Conventional wisdom holds that Parkinson's disease (PD) patients exhibit impaired free recall but near-normal recognition and cued recall. This pattern of performance is thought to reflect problems with memory retrieval, a characteristic of the subcortical dementia syndrome. Recently the notion that recognition memory is intact in PD has been challenged, however. The current study set out to provide evidence that neither recognition nor cued recall are intact in PD. Ninety-nine (32 female; 17 with DSM-IV dementia) medicated, idiopathic PD patients were administered the California Verbal Learning Test. Mean(SD) age, education and disease duration were $67(7), 15(3)$ and $12(5)$ years, respectively. A well-matched normative sample was used to transform raw scores to $\mathrm{z}$-scores then one-sample t-tests were used to determine: 1) whether patients' free recall, cued recall, and recognition were below expectations, and 2) if difference scores comparing z-transformed cued recall and recognition to free recall indicated substantial improvement in performance with the provision of retrieval cues. Results indicate clear impairment on multiple measures of cued recall and recognition in patients with dementia. Although much less severe, deficits were also detected in non-demented patients. Difference scores generally indicated that cued recall and recognition deficits were similar in magnitude to that of free recall. Hit rate and false positive error rate indicate that recognition problems were due to a positive response bias. These results are inconsistent with the retrieval deficit hypothesis of memory impairment but are consistent with the notion that PD memory problems are secondary to prefrontal dysfunction.

Correspondence: Christopher I. Higginson, Ph.D., Center for Neuroscience, UC Davis, 1544 Newton Ct., Davis, CA 95616. E-mail: cihigginson@ucdavis.edu

\section{E.Y. UC, M. RIZZO, S.W. ANDERSON, Q. SHI \& J.D. DAWSON. EXECUTIVE DYSFUNCTION IN MILD-MODERATE PARKIN- SON'S DISEASE CORRELATES WITH MOTOR DISABILITY.}

Objective: Assess the association between executive dysfunction and motor disability in mild-moderate Parkinson's disease (PD). Background: Besides the hallmark motor dysfunction due to striatal dopaminergic depletion, patients with PD suffer from cognitive impairments in multiple domains, including executive dysfunction (EDF). The relationship between EDF and motor disability in mild-moderate PD is not well established. Design/Methods: We assessed performance on TrailMaking Test subtests A and B (TMT-A and TMT-B), and the Controlled Oral Word Association (COWA) performance in 22 subjects with mild- 
moderate PD (Hoehn-Yahr Score I-III) and 117 age and gender matched healthy control subjects. All subjects were legally licensed drivers who continued to operate a motor vehicle and functioned independently. Results: Patients with PD performed worse than controls on all tests: TMT$\mathrm{A}=54.2 \pm 23.9 \mathrm{sec}$ vs. $34.2 \pm 10.1$, TMT-B $=160.5 \pm 130.1$ vs. $77.9 \pm 39.3$, COWA $=31.7 \pm 9.0$ vs. $39.4 \pm 10.1$ (for all: $\mathrm{p}<0.001$, Wilcoxon Rank Sum test). Subtracting TMT-A from TMT-B, i.e., TMT(B-A), provided an index of EDF independent of motor function and showed greater cognitive set-shifting time in the PD group: $106.3 \pm 104.2$ vs. $43.7 \pm 34.0$ $(\mathrm{p}<0.001$, Wilcoxon Rank Sum test). The TMT(B-A) index correlated with Hoehn-Yahr stage (Rs=0.49, p=0.024), total Unified Parkinson's Disease Rating Scale (UPDRS) score ( $\mathrm{Rs}=0.45, \mathrm{p}=0.039)$, and motor UPDRS score $(R s=0.46, p=0.034)$. COWA did not correlate with these variables. Conclusions: Patients with mild-moderate PD performed worse than neurologically normal controls on measures of EDF. Impaired set shifting, but not fluency, correlated with measures of motor disability. Specific aspects of EDF in PD appear to be related to striatal dopaminergic depletion.

Correspondence: Ergun Y. Uc, MD, Neurology, Univ of Iowa, 200 Hawkins Drive-2RCP, Dept. of Neurology-UIHC, Iowa City, IA 52242. E-mail:ergun-uc@uiowa.edu

\section{J.C. ROTHLIND, R.W. COCKSHOTT, J. WALKER, P.A. STARR \& W.J. MARKS. NEUROPSYCHOLOGICAL STATUS FOLLOWING UNILATERAL PALLIDAL OR SUBTHALAMIC NUCLEUS DEEP BRAIN STIMULATION FOR PARKINSON'S DISEASE: OUTCOME SIX MONTHS FOLLOWING SURGERY.}

Studies of neuropsychological outcomes after deep brain stimulation (DBS) surgery for Parkinson's disease (PD) have indicated the potential for mild decline in executive functioning, specifically in generative naming. The influence of brain target treated (globus pallidus internus [GPi] or subthalamic nucleus [STN]) and extent of stimulation (unilateral vs. bilateral) on postoperative cognitive state remains unclear. We prospectively evaluated 42 non-demented patients with disabling PD in a randomized, staged evaluation of DBS of the GPi and STN, comparing performance on an extensive battery of neuropsychological tests at baseline and 6 months after the first, unilateral DBS surgery. DBS leads were implanted into the GPi in 23 patients (14 left, 9 right) and into the STN in 19 (13 left, 6 right). The groups did not differ in age, education, or in baseline Hoen-Yahr disease stage, UPDRS motor scores, or Dementia Rating Scale score. In a mixed ANOVA analysis, we observed small but statistically significant decrements in phonemic and category fluency $(p<0.01)$ and Stroop Word reading speed $(p<0.05)$ following unilateral DBS. STN DBS patients showed decrements on the WAIS-R Digit Symbol subtest following DBS $(p<0.05)$, contrasted with a trend toward improved performance in those undergoing GPi DBS $(p<0.10)$. More generally, the effect of DBS on cognitive functioning did not differ in those receiving GPi versus STN DBS. Furthermore, there were no other significant post-operative neuropsychological effects overall. The present findings suggest a small decrement in verbal fluency 6 months following unilateral DBS surgery regardless of brain target, without evidence of generalized neuropsychological decline.

Correspondence: Johannes C. Rothlind, Ph.D., Mental Health Service, San Francisco VA Medical Center, Psychology (116B), 4150 Clement Street, San Francisco, CA 94121. E-mail: Johannes.Rothlind@Med.VA.GOV

\section{J. GREEN, M. HABER, J.L. VITEK, W. MCDONALD, R.A. BAKAY \& M.R. DELONG. NEUROPSYCHOLOGICAL SEQUELAE OF POS- TERIOR PALLIDOTOMY FOR PARKINSON DISEASE: LONGITU- DINAL FINDINGS.}

This study examined longitudinal neuropsychological changes in Parkinson disease $(\mathrm{PD})$ patients treated with posterior pallidotomy. Fifty-five patients (mean age $=59$ ) with advanced $\mathrm{PD}$ participating in a clinical trial were assessed at baseline before surgery and longitudinally to 2 years. Analysis was performed on 20 measures derived from 10 tests
(Mattis Dementia Rating Scale (DRS), WMS-R Digit Span, Stroop Test, Letter fluency, Category Fluency, Wisconsin Card Sorting Test (WCST), Boston Naming Test, Judgment of Line Orientation (JOLO), California Verbal Learning Test (CVLT), Warrington Visual Recognition Memory Test (VRMT)). Repeated measures regression was used to examine effects of assessment time (baseline, 6, 12, 24 months) and lesion location (left $(\mathrm{n}=37)$ or right $(\mathrm{n}=18)$ posterior internal pallidum), controlling for age, time since disease diagnosis, education, and changes in motor and psychiatric function since surgery. Patients with left lesions showed significant longitudinal improvement in visual memory (VRMT immediate, $\mathrm{p}<.05)$ but near significant decline in overall intellectual function (total DRS, $p=.05$ ) and semantic fluency $(\mathrm{p}=.08$ ). Patients with right lesions showed significant improvement in visuoperceptual judgment (JOLO, p<.05) and verbal learning (CVLT cumulative learning, $\mathrm{p}<.05$ ) and near-significant improvement in problem solving (WCST trials to first sort, $\mathrm{p}<.10)$. These findings are consistent with shorterterm studies indicating that different patterns of neuropsychological change are associated with left as compared to right pallidotomy, and extend these findings to indicate that the differences may persist over time. Neural changes and individual differences underlying the findings will be discussed.

Correspondence: Joanne Green, Ph.D., Neurology, Emory University School of Medicine, Wesley Woods Geriatric Center, 1841 Clifton Road, Atlanta, GA 30329.E-mail: jgreen@emory.edu

\section{D.E. GRANT, J.H. KRAMER, H. ROSEN, G. SCHAUER, C. PACE- SAVITSKY, K. RANKIN, J. JOHNSON, M. WEINER \&. B.L. MILLER. NEUROANATOMY OF PHONEMIC AND SEMAN- TIC VERBAL FLUENCY.}

Verbal fluency tasks are widely believed to measure executive functioning, although clinical studies suggest that phonemic and category fluency may be subserved by different neural systems. The purpose of this study was to use quantitative MRI to better understand the neuroanatomy of these two types of verbal fluency. We examined 90 subjects reflecting a range of diagnoses and cognitive competencies, including normal controls and patients with Mild Cognitive Impairment (MCI), Alzheimer's disease (AD), and Fronto-temporal Lobar Degeneration spectrum disorders (FTLD.) Participants had completed an average of 16 years of formal education and had a mean of 23 on the MMSE. Phonemic fluency (number of d-words in 1-min) and category fluency (number of animals in 1-min) were assessed. Left and right frontal volumes, left and right anterior temporal volumes, left and right orbitofrontal volumes, and bilateral posterior cortex were simultaneously entered into a regression analysis. Results from the present study show that a regression model explains approximately $25 \%$ of the variance in " $\mathrm{d}$ " word generation and almost $50 \%$ of the variance in animal fluency. Left frontal volume was the only significant predictor of " $\mathrm{d}$ " word generation ( $\beta .672)$ whereas left anterior temproal lobe and posterior cortex predicted animal fluency ( $\beta .357$ and .233 respectively.) These results show that different brain regions mediate different fluency tasks. These results are consistent with the literature that shows lower phonemic fluency in subcortical-frontal system disorders, and lower category fluency in $\mathrm{AD}$, a disorder with more posterior atrophy. Correspondence: Douglas E. Grant, MA, Neurology, UCSF, 350 Parnassus St, Suite 706, San Francisco, CA 94143.E-mail: dgrant@alliant.edu

\section{J. KRAMER, C. ODELL, H. ROSEN, D.C. DELIS, N. SCHUFF, M. WEINER \& B.L. MILLER. HIPPOCAMPAL AND FRONTAL CONTRIBUTIONS TO MEMORY PERFORMANCE.}

Although episodic memory is typically associated with the hippocampus, the frontal lobes also play a primary role in memory. The purpose of this study was to use quantitative MRI to better understand the role of these and other brain structures in different aspects of episodic memory performance. We studied 42 elderly subjects, including 8 normal controls, $13 \mathrm{AD}$ patients, 11 frontotemporal dementia patients, and 10 
semantic dementia patients. The sample had a mean age of 64.8 years and mean MMSE of 23.7. Subjects were administered the CVLT-Short Form, which consists of 4 learning trials of a 9-item list, and delayed recall and recognition trials. We hypothesized that memory indices like delayed recall and recognition discriminability would be hippocampal dependent, whereas metamemory variables like semantic clustering during recall and response bias during recognition would be more related to frontal volume. Data were analyzed with multiple regression, with the 4 CVLT-SF measures serving as dependent variables, and volumes of hippocampus, frontal lobes, anterior temporal lobes, and posterior cortex as predictor variables. Consistent with the hypotheses, hippocampus was the only MRI variable predicting delayed free recall $(\beta=.34$; $33.4 \%$ of the variance) and recognition discriminability $(\beta=.40 ; 34.9 \%$ of the variance). In contrast, frontal volume was the only significant predictor of semantic clustering $(\beta=.45 ; 19.8 \%$ of the variance) and response bias ( $\beta=-.47 ; 16.5 \%$ of the variance). These results highlight the specific contributions of hippocampus and frontal lobes to human memory performance, and offer strong support for parsing memory into components that are subserved by different neural systems.

Correspondence: Joel Kramer, UCSF, 401 Parnassus, San Francisco, CA 94143.E-mail:kramer@itsa.ucsf.edu

\section{C.H. MORTON, J.L. WOODARD, K.D. SHANNON \& F. GOULD. PRACTICE EFFECTS AND NEUROPSYCHOLOGICAL CHANGE: A COMPARISON OF ALZHEIMER'S DISEASE AND HEALTHY ELDERLY.}

Serial assessment in neuropsychology is common, especially with the elderly and those with dementia. However, the potential for practice effects, particularly on measures without alternate forms, is a significant problem. We examined practice effects across three assessment points, each separated by one year (Baseline, Time 1, and Time 2). Participants were 14 healthy older adults (control group) and 15 patients with probable Alzheimer's disease (AD group). The neuropsychological battery consisted of the Ward 7-subtest WAIS-R short form, Wechsler Memory Scale-Revised, letter and category fluency, Boston Naming Test, Wisconsin Card Sorting Test, Stroop Test (Dodrill Version), California Verbal Learning Test, and Judgment of Line Orientation. The results indicated that there was a significant Group $\mathrm{x}$ Time interaction for performance on WAIS-R PIQ and CVLT List A Immediate Recall. Despite concerns regarding practice effects, the only measure showing improvement across time was PIQ in the control group. The AD group, on the other hand, demonstrated a decline in PIQ. Group differences on the CVLT were solely the result of performance deterioration in the AD group. There were no practice effects on other measures for either group. In sum, while one measure did show improvement, practice effects were not an issue across two year-long test-retest intervals for the majority of tests. Means and standard deviations as well as test-retest reliabilities and reliable change indices are also reported.

Correspondence: Carla H. Morton, MS, MT-BC, Finch U of Health Sciences/CMS, 7034 N. Sheridan Rd., Apt. 3-I, Chicago, IL 60626. E-mail: carla.morton@finchcms.edu

\section{B.R. REED, D. MUNGAS, J.H. KRAMER, W.G. ELLIS, H.V. VIN- TERS, C. ZAROW, W.J. JAGUST \& H.C. CHUI. VERBAL LIST LEARNING IN AUTOPSY-DEFINED VASCULAR DEMENTIA AND ALZHEIMER'S DISEASE.}

Impaired verbal learning with rapid forgetting is an established early feature of Alzheimer's disease (AD). Clinical studies suggest that relatively well preserved memory may be a useful diagnostic feature in ischemic vascular dementia (IVD). Methods: Subjects were 60 autopsied cases; 47 from a prospective study of vascular dementia and 13 from a university dementia center. Here we examine performance on a 12 word list learning task with free and cued delayed recall and delayed yes-no recognition, obtained at their last evaluation. Cases were classified based on cognitive status when last tested, the likelihood of AD using to NIA-
Reagan Institute criteria, and the level of cerebrovascular ischemic pathology. There were 31 cases with AD alone, 8 with IVD alone, 8 with mixed AD/IVD (MIX), and 13 cognitively normal cases (NL). Groups were similar in education (mean 14.2), and (excepting NL) global impairment as measured by the MMSE (means for AD, MIX, and IVD = 20.1, 19.6, 19.9, respectively). Time between last testing and death was similar in all groups (mean 2.1 years). Results: AD, IVD, and MIX were impaired and nearly identical on initial learning (list acquisition) with means of $24.8,24.3$, and 24.7 words, respectively. Rate of forgetting, measured by a savings score based on free recall was also very similar in each patient group $(p=0.93)$. Differences emerged in recognition performance: IVD had a lower hit rate $(p<.02)$, a non-significantly lower false alarm rate, and a more negative response bias ( $p$ $<.02)$. Accuracy, adjusted for false alarms, did not differ between groups $(p=.45)$. Conclusions: Contrary to our hypotheses, learning and rate of forgetting did not differentiate autopsy confirmed AD and IVD cases. There is considerable variability in the performance of $\mathrm{AD}$ and IVD cases alike, suggesting that it may prove difficult to use characteristics of verbal learning to differentiate these groups.

Correspondence: Bruce R. Reed, PhD, Neurology, UC Davis, 150 Muir Rd (127a), Martinez, CA 94553.E-mail: BRReed@ucdavis.edu

\section{Symposium 11/9:00-11:00 a.m.}

\author{
Non Verbal Learning Disabilities
}

\author{
Chair: Ruth Nass \\ Discussant: Ruth Nass
}

\section{R. NASS. NON VERBAL LEARNING DISABILITIES.}

Nonverbal learning disabilities (NVLD), while recognized by a wide range of professionals, remain inexactly defined. This symposium will provide both historical and suggested current criteria for the diagnosis of NVLD, addressing the social-emotional, paralinguistic, executive, spatial, sensorimotor, and academic difficulties. An assessment battery that taps the range of skills in these domains will be presented in the context of exemplary cases. Measures of social emotional functioning will also be discussed as a lead in to a discussion of the overlap or identity between Asperger disorder and NVLD. The neuroanatomical basis of NVLD will be presented in the context of the localization of social cognition and processing of facial emotions. Dorsolateral and medial frontal areas, the amygdala and the somatosensory cortex will be the focus. A discussion of educational interventions for deficits seen in NVLD like problem solving difficulties and pragmatics problems will be presented. Finally, we will address future research directions.

Correspondence: Ruth Nass, MD, NYU Medical Center, 400 east 34th street, New York, NY 10016. E-mail: ruth.nass@nyu.edu

\section{F. LEVENTHAL \& R. NASS. SIGNS AND SYMPTOMS OF NVLD.}

Although the exact diagnostic criteria for NVLD remain up for debate, it is clear that NVLD is a disorder with symptoms that may not only present differently in different individuals, but also change over time as a child matures and develops. Right hemisphere deficits most certainly dominate the clinical picture, but the way in which they and other manifestations of NVLD materialize in specific individuals is quite variable. For example, a preschooler may be referred for evaluation because of a low tolerance for frustration, poor graphomotor skills, and significant peer problems, while an adolescent with NVLD may exhibit more difficulties with depression, disorganization, and reading comprehension or math. Academic failure may be an issue in some students; whereas, 
the cognitive profile of other students may permit them to be academically successful, but silently overwhelmed and anxious. The focus of this section of the symposium will be on the signs and symptoms of NVLD as they surface in neuropsychological assessment, parent/teacher observation, psychosocial interactions, and academic performance. After outlining the major characteristics of the disorder,a discussion about which neuropsychological measures, checklists, and questionnaires best tap deficits, as well as highlight strengths, in the NVLD child or adolescent will follow. Clinical examples will be used throughout the presentation to better illustrate the diagnostic picture.

Correspondence: Fern Leventhal, NYU Medical Center, 400 East 34th Street, New York, NY 10016. E-mail: ruth.nass@nyu.edu

\section{W. SOLODOW, R. NASS, F. LEVENTHAL, R. PERRY, S. GOLD- MAN, J. COHEN, M. SHEPHERD \& S. BEZSYLKO. RATINGS OF NVLD BY DIFFERENT PROFESSIONAL GROUPS USING PUTA- TIVE INDICATORS OF NON-VERBAL LEARNING DISABILITY IN STUDENTS FROM A SPECIAL EDUCATION SETTING.}

Three groups of professionals - educators, psychotherapists and neurodevelopmentalists - evaluated the school records of 100 special education students at a private high school in NYC that specialized in dealing with learning related problems. Each student was rated as to whether they met the criteria for having a Non-Verbal Learning Disability or not. After making this rating,professionals were also asked to choose which items from a list of 45 putative indicators of the disorder were considered to be the most salient. Although there was within and between group discussions of NVLD in general, ratings of each particular child were not discussed. There were no formal efforts to insure within group reliability. The different groups did not make efforts to reach agreement about what they considered to be salient attributes of the disorder. Although each student record differed widely in terms of materials contained within it, main sources of data that were generally present included scores on standardized tests, written reports from teachers, individualized education plans and psychoeducational batteries given as part of admission requirements. In comparing the 3 groups with each other, there was very mixed levels of agreement about which students were classified as NVLD - all 3 groups actually agreed on rather few cases. Various hypotheses as to what may have caused these different ways of classifying can be generated. In the overall sample, 8 key variables were identified statistically as being salient to making the classification. In a smaller subsample of students where all 3 groups agreed, 7 of these same 8 variables plus 4 more emerged as salient indicators of the disorder.

Correspondence: William Solodow, Columbia University, ., New York, NY.E-mail:ruth.nass@nyu.edu

\section{R. PERRY, F. LEVENTHAL \& R. NASS. NVLD AND ASPERGER DISORDER: WHAT IS THE CONNECTION?}

The extent of the overlap between Asperger Disorder (AD) and NVLD is debated. The issue can be addressed from two vantage points. One can ask the question of how often children diagnosed with AD based on DSM criteria have non verbal learning issues involving dysgraphia, math, science, written expression and/ or reading comprehension. Or one can examine the frequency with which $\mathrm{AD}$ and NVLD children share specific cognitive characteristics germane to the concept of non verbal disabilities. Virtually all children diagnosed with AD and many diagnosed with NVLD have paralinguistic difficulties involving prosody, pragmatics, humor, irony etc. Many children with AD and some with NVLD have executive dysfunction reflected as inflexibility, slow processing. poor problem solving skills and /or difficulty dealing with novelty. Some children with $\mathrm{AD}$ and most children with NVLD have problems in the spatial domain that may or may not hamper learning. Many children with $\mathrm{AD}$ and most, perhaps all, children with NVLD have problems in the sensorimotor domain that may or may not hamper learning and/ or processing of emotional stimuli. Some children with AD and most chil- dren with NVLD have specific learning disabilities involving dysgraphia, math, science, written expression and/or reading comprehension. All children with AD and some/ many children with NVLD have difficulties with social emotional functioning. Whether the social emotional difficulties of the two groups are qualitatively similar remain to be determined. It is apparent that DSM criteria for NVLD would be useful and help resolve issues about the overlap between NVLD and AD.

Correspondence: Richard Perry, NYU Medical Center, .550 First Avenue, NewYork, NY.E-mail: ruth.nass@nyu.edu

\section{R. NASS. THE NEUROANATOMY OF PROCESSING FACIAL EMOTION.}

The face is at the epicentre of human social emotional interactions. Newborns pay attention to faces. The development of social cognition (the ability to construct representations of the relations between ones self and others and to use those representations flexibly to guide social behavior) is closely tied to the development of emotion and the communication between mother and the infant. Perception of faces and facial emotion is abnormal in the autistic spectrum disorders and possibly in NVLD. Faces are recognized as such in the fusiform face area. Characterizing facial movements, eye gaze, gesture, as well as reading emotions from the eyes begins in the superior temporal gyrus. The amygdala is particularly important for the recognition of negative emotions and determining trustworthiness. Orbitofrontal cortex also plays a role in recognizing facial emotions and is central to gut feelings - social judgments that are complex, but do not allow for prolonged analysis. The right somatosensory cortex plays a role in recognizing facial expressions, possibly because we recognize anothers emotional state by internally generating somatosensory representations that simulate how the other individual feels when displaying a certain facial expression. In view of the somatosensory difficulties common in the NVLDs, this may be a crucial locus to the breakdown of recognition of facial expressions in NVLD. Correspondence: Ruth Nass, MD, NYU Medical Center, 400 east 34th street, New York, NY 10016.E-mail: ruth.nass@nyu.edu

\section{SHEPHERD \& S. BEZSYLKO. EDUCATIONAL INTERVEN- TION FOR NVLD.}

Students with an NVLD diagnosis experience increasing difficulty in school as the curriculum changes from a focus on acquisition of foundation skills in reading and math, where rote verbal learning strengths serve them well, to use of foundation knowledge in the service of more complex learning and reasoning. Special education for these students is operationalized as a combination of remedial and compensatory interventions. Compensatory interventions accommodate to or bypass learning problems (e.g. calculators to compensate for difficulty with arithmetic operations). Remedial interventions work directly with the learning problem (e.g. instruction that enables understanding cause-effect relationships). We focus, today, on remedial interventions, particularly those designed to enhance learning word meanings, reading comprehension and problem solving with academic and social tasks, arguing that these interventions should begin early in the student's school career before the need is evident. First, we illustrate interventions in each of these domains. Then, we present, for discussion, case material from the life of an adolescent who has experienced these interventions. Finally, we will present some, less obvious, examples of compensatory interventions and comment on the need for remedial language intervention for students with an NVLD diagnosis.

Correspondence: Margaret Shepherd, Columbia University, 120th and Broadway, New York, NY 10025. E-mail: ruth.nass@nyu.edu

\section{B. FORREST. NVLD: FUTURE RESEARCH DIRECTIONS.}

Nonverbal Learning Disabilities (NVLD) were first described broadly in the late sixties in children with nonverbal deficits. Since then, NVLD 
has been defined both narrowly, to represent a profile of neuropsychological assets and deficits that leads to social difficulties, and more broadly across numerous neurological disorders. The research to date, however. leaves many questions for future research, including 1) the relationships among the neuropsychological assets and deficits, and between that neuropsychological profile and social disability, and 2) the applicability of definitions of NVLD across cultures and developmental levels. First, when NVLD was defined on the basis of a distinction between verbal and non-verbal processing, it included a number of nonverbal disorders, only one of which involved social disability. Today, NVLD is most commonly defined as a profile of neuropsychological assets and deficits that always results in social difficulties. Yet most neuropsychologists would agree that they have seen many children who display the neuropsychological characteristics of NVLD (i.e., visual spatial difficulties) but for whom social relationships are not problematic. The relation among the neuropsychological assets and deficits, and social cognition, needs investigation. Second, the majority of studies of NVLD involve young Caucasian children. This emphasis leaves two significant gaps in the literature. These studies involved participants raised in a culture heavily dependent on verbal communication, and most studied young children. Future investigations should explore both how the profile applies to children who are raised in environments more heavily dependent on nonverbal communication and how the disorder is expressed across development.

Correspondence: Bonnie Forrest, NYU Medical, 400 East 34, NY, NY 10016.E-mail:ruth.nass@nyu.edu

Symposium 12/9:00-11:00 a.m.

\author{
PREDICT-HD: Integrating Clinical and \\ Basic Science to Reveal the \\ Neurobiological Prodrome of Huntington's \\ Disease (HD)
}

Chair: Julie Stout

Discussant: Jean St. Cyr

\begin{abstract}
J.C. STOUT, J. PAULSEN, D. LANGBEHN, C. ROSS, S. JOHNSON, E. AYLWARD \& J.A. SAINT-CYR. PREDICT-HD: INTEGRATING CLINICAL AND BASIC SCIENCE TO REVEAL THE NEUROBIOLOGICAL PRODROME OF HUNTINGTON'S DISEASE (HD).
\end{abstract}

This symposium highlights PREDICT-HD, a large, multi-continental, interdisciplinary, federally-funded longitudinal study of 525 persons genetically at risk for Huntington's Disease (HD). The aim of PREDICTHD is to chart the neurobiological course that leads to onset of clinical signs of HD. Results will provide the essential methods for measuring onset and progression of neurobiological changes, which is essential for effective trials of candidate treatments to delay onset or slow progression of disease. This symposium will highlight findings from a cross-sectional analysis of the first annual visit data, focusing on the associations of estimated years to onset and cognitive, neurological, and neuroimaging measures. Symposiasts will include: Jane Paulsen, neuropsychologist and principal investigator of the study, who will describe the specialized genetically-informative design, the cohort under study, and ethical considerations; Douglas Langbehn, biostatistician and psychiatrist, will describe findings related to estimated years to onset from the sample, Christopher Ross, neurobiologist and psychiatrist, will describe the neurological and motor findings; Shannon A. Johnson, a neuropsychologist, will describe associations between cognitive function and estimated years to onset in the baseline data; and, Dr. Eliziabeth Aylward, a neuropsychologist and imaging scientist, will report on associ- ations of estimated years to onset and specialized volumetric MRI analysis methods that target the basal ganglia. The symposium highlights the role of neuropsychology in an integrative clinical science study. Jean Saint-Cyr will discuss the presentations and moderate discussion with the attendees.

Correspondence: Julie C. Stout, Ph.D., Psychology, Indiana University, 1101 East 10th St., Bloomington, IN 47401-7007.E-mail: jcstout@ indiana.edu

\section{J.S. PAULSEN, J.C. STOUT, M. GUTTMAN, E. AYLWARD, M. HAYDEN, C. ROSS, M. NANCE, D. LANGBEHN, E. KAYSON, K. KIEBURTZ, I. SHOULSEN \& H. PREDICT-HD. PREDICT-HD: A WORLDWIDE STUDY OF PRESYMPTOMATIC HUNTINGTON'S DISEASE (HD).}

Clinical and experimental neuropsychological measures are at the core of this interdisciplinary NINDS-funded research study being conducted at 25 sites throughout the world. PREDICT-HD is the first study to recruit and evaluate persons at $100 \%$ genetic risk for an adult-onset fatal illness. The recruitment and evaluation of 280 participants has been completed and data from the first 125 has been analyzed. Our sample has an average age of $41.7(\mathrm{SD}=9.9)$ and 14.5 mean years of education (2.4 SD). Fifty-eight percent of the sample is female, nearly $70 \%$ are currently married, and nearly all are currently employed (99.5\%). As expected, the demographic data suggests that the recruited sample is currently functioning similar to the general population in terms of employment and marital status. Despite the fact that all of the enrolled participants are considered "presymptomatic" for HD, over $12 \%$ report that they have symptoms of disease. Findings suggest that depression was over twice as common in the Predict-HD sample and suicide attempt was four to six times greater that what is reported in the general population. Several measures of neuropsychological function suggested that cognitive performances are compromised in this presymptomatic sample. Although the underlying mechanisms of cognitive decline and depression in early HD are poorly understood, it is critical for health care providers to include cognitive and psychiatric assessment as part of the traditional evaluation for HD.

Correspondence: Jane S. Paulsen, Ph.D., Psychiatry, Neurology, University of Iowa, 200 Hawkin's Drive \#2880JPP, Iowa City, IA 52241. Email: jane-paulsen@uiowa.edu

\section{D.R. LANGBEHN, R.R. BRINKMAN, D. FALUSH, J.S. PAULSEN, M.R. HAYDEN \& C. INTERNATIONAL HUNTINGTON DISEASE. ESTIMATED PROGNOSIS AND CROSS-SECTIONAL ANALYSIS OF THE BASELINE PREDICT DATA.}

Ultimately, our goal is to relate variability in neuropsychological and other clinical and neuroimaging measurements to the development of Huntington's Disease (HD) as verified by repeated observation of the same subjects. However, before such data become available, there is potential for tentative inference regarding these relationships by analysis of cross-sectional data collected at the PREDICT baseline visits. By design, our subjects do not have HD at baseline. Therefore, one of the primary challenges for such cross-sectional inference is incorporation of a suitable proxy measure for estimated prognosis. One class of such measures can be derived from lifetime onset-distribution models based on the varying CAG repeat lengths in the underlying $\mathrm{HD}$ gene mutation. We have previously developed such a model using a separate international data set $(\mathrm{N}=2,900)$. I will briefly describe this model, including it's limitations, and demonstrate that it appears, so far, to be consistent with the age-cag-length distributions of presymptomatic subjects we are obtaining in the PREDICT sample. I will then compare and contrast the utility of various quantitative prognostic variables that can be derived from this model and each subject's known CAG length and current age. My goal is to establish a groundwork of understanding re- 
garding the concept of estimated prognosis that will be used in common by the subsequent speakers in this symposium. Finally, time permitting; I will briefly discuss some novel modeling issues relevant to neuropsychological measures as disease progression markers in the eventual longitudinal analysis of the PREDICT study.

Correspondence: Douglas R. Langbehn, MD, PhD, Psychiatry, Univ. of Iowa, 5107 Westlawn Building, Univ. of Iowa, Iowa City, IA 52242. Email:douglas-langbehn@uiowa.edu

\section{ROSS, J. STOUT, K. BIGLAN, J. PAULSEN \& H. PREDICT- HD. PREDICT-HD: ASSOCIATIONS OF ESTIMATED YEARS TO ONSET AND MOTOR FINDINGS FROM THE UHDRS NEURO- LOGICAL EXAMINATION IN PRESYMPTOMATIC HUNTING- TON'S DISEASE (HD).}

The presence of unequivocal otherwise unexplained extrapyramidal movement disorder (e.g., chorea, dystonia, rigidity, uncoordination, ataxia) in the clinical neurological examination is used as the "gold standard" for the diagnosis of Huntington's Disease (HD). The PREDICTHD study is designed to determine the neurobiological course that leads to the onset of clinical diagnosis. For this paper, we will describe findings from the Unified Huntington's Disease Rating Scale (UHDRS) motor exam at baseline, and relate these findings to our estimate of years to onset, neuropsychological, and neuroimaging findings. Results from the first 171 PREDICT-HD participants who have CAG expansions show that estimated years to onset (based on an equation derived from previous large datasets, described in Langbehn paper, this symposium) is associated with several clinically rated motor signs; for those subjects $(\mathrm{n}=129)$ judged to have no abnormalities (0), or only non-specific motor abnormalities (1) on a diagnostic confidence scale (range $0-4$ ), we found significant associations between estimated years to onset and chorea (buccal-oro-lingual, $\mathrm{r}=-.16, \mathrm{p}=.05$ ), finger to thumb tapping $(\mathrm{r}=-.17, \mathrm{p}=.04$ for right, and $\mathrm{r}=-.20, \mathrm{p}=.03$ for left hand $)$, and tandem walking $(t=-.17, p=.04)$. Our data suggest that subtle motor signs (specifically chorea, fine motor skills, and tandem gait) predate the development of definitive HD. Clinical trials for identifying drugs to forestall clinical disease onset or slow progression should take this into account.

Correspondence: Christopher Ross, M.D., Ph.D., Johns Hopkins University, Neurobiology Ross Bldg Rm 618, 720 Rutland Avenue, Baltimore,MD 21205-2196.E-mail: caross@jhu.edu

\section{S.A. JOHNSON, J.C. STOUT, J.S. PAULSEN \& H. PREDICT-HD. PREDICT-HD: A COGNITIVE NEUROSCIENCE APPROACH TO THE STUDY OF COGNITION IN PRESYMPTOMATIC HUNTING- TON'S DISEASE (HD).}

Some studies have reported decline in psychomotor or other cognitive functions prior to the clinical onset of HD, although the significance and course of development of cognitive decline in the presymptomatic period is not well understood. For PREDICT-HD, a longitudinal study of people genetically at risk for HD, we developed a set of computerized and paper-pencil cognitive tasks designed specifically for their sensitivity to basal ganglia function. We implemented this test battery at 25 sites, and trained cognitive examiners to ensure interrater reliability. Data from 123 subjects, who were studied at their baseline visit, show evidence of associations between estimated years to onset and poorer performances on several cognitive tasks assessing diverse domains. Some examples include significant associations between estimated years to onset and choice reaction time, finger tapping, facial recognition of selected emotions, a smell identification test, and a tower task. Estimated years to onset were computed as in the Langbehn abstract, this symposium. This talk describe the results of baseline cognitive testing of the PREDICT-HD cohort, and our analysis of the relative sensitivity to estimated years of onset of particular cognitive tests in this baseline sample. Associations of cognitive measures with motor and volumetric MRI findings will also be discussed.
Correspondence: Shannon A. Johnson, Ph.D., Psychology, Indiana University, 1101 E.10th Street, Bloomington, IN 47401.E-mail:sjohnso4@ indiana.edu

\section{E. AYLWARD, V. YALLAPRAGADA, K. FIELD, J.S. PAULSEN \& H. PREDICT-HD. PREDICT-HD VOLUMETRIC MRI STUDIES: EVIDENCE FOR PUTAMEN AND CAUDATE VOLUME LOSS IN PRESYMPTOMATIC STUDY PARTICIPANTS.}

All PREDICT-HD participants undergo MRI at their study sites, using a standardized protocol. Image data are then transferred to the University of Washington where MRI measurements of caudate and putamen are performed by raters with established reliability. We will present preliminary MRI findings from 112 PREDICT-HD subjects (53 M, $75 \mathrm{~F})$, scanned at study entry, who are positive for the gene expansion and who have both MRI measurements and a calculated estimation of onset age. Mean age for this sample was 41.9 (s.d.=10.0) and mean estimated years to onset was $13.2($ s.d. $=6.0)$. Measurement of caudate and putamen was completed blind to gene status and to other clinical variables. Results indicate a strong correlation for the entire sample between estimated years to onset and volumes of caudate $(r=.50, p<$ $.001)$, putamen $(\mathrm{r}=.55, \mathrm{p},<.001)$, and total striatum $(\mathrm{r}=.55, \mathrm{p}<$ $.001)$. Linear equations appeared to best fit the data for the entire sample. A regression analysis using CAG repeat length, age, putamen and caudate to predict estimated years to onset indicated that putamen was the single best predictor $(\mathrm{p}<.001)$, but that age and CAG repeat length also added significantly to the predictive equation.

Correspondence: Elizabeth Aylward, Ph.D, Radiology, Univ. of Washington, Box357115, University of Washington, Seattle, WA 98040. Email:eaylward@u.washington.edu

Symposium 13/9:00-11:00 a.m. Understanding Recovery From Brain
Injury: Group and Single Case Studies.

\author{
Chair: Barbara A. Wilson \\ Discussants: Barbara A. Wilson and Robyn Tate
}

\section{B.A. WILSON, J. MURRE, R. TATE, A.M. SHIEL \& G. PRIGATANO. UNDERSTANDING RECOVERY FROM BRAIN INJURY: GROUP AND SINGLE CASE STUDIES..}

How people recover from Brain Injury is poorly understood despite the fact that good understanding would help us plan and monitor our rehabilitation services, enable us to give better advice to families and allow us to improve the focus of rehabilitaion. This symposium considers some of the issues involved in recovery from brain injury to help improve our understanding of the recovery process. The first paper introduces the concept of self repairing neural networks as a model for recovery from brain damage; it suggests that lesion size informs us of which rehabilitation strategy to implement. The second paper looks at patterns of recovery following traumatic brain injury and considers whether altering posture in TBI patients changes recovery patterns. The third paper is a twenty three year follow-up of 100 patients documenting the natural history of recovery from TBI and looks at the contribution of specific variables to psychosocial outcome. The last two papers present 
case studies to see how individual patients can contribute to our understanding of recovery. One considers the cognitive and emotional recovery of a young woman reported to be in the vegetative state for almost 6 months. So recovery can occur even in cases some would consider hopeless. The final paper presents four patients who have been followed for 10 to 25 years. The main point made here is that individual choices can influence the course of recovery. We conclude with a summary of the main lessons that can be drawn from these papers.

Correspondence: Barbara A. Wilson, Ph.D, Cognition and Brain Sciences Unit, Medical Research Council, MRC-CBU, Box 58, Addenbrooke, Cambridge CB2 2QQ, United Kingdom. E-mail: barbara. wilson@mrc-cbu.cam.ac.uk

\section{J. MURRE. SELF REPAIRING NEURAL NETWORKS: A FRAME- WORK FOR UNDERSTANDING RECOVERY FROM BRAIN DAMAGE.}

There is now abundant evidence that the brain remains plastic throughout the entire lifespan. With Ian Robertson, I have developed a framework for investigating the implications of this for rehabilitation theory. We have introduced selfrepairing neural networks as a model for recovery from brain damage. Small lesions are repaired through reinstatement of the redundancy in the network's connections, in particular through Hebbian learning. With mild lesions, this process can model autonomous recovery, where the success rate depends on the quality of the remaining representations. Moderate lesions require patterned input. Only severe lesions should be treated with compensation strategies. In this talk, I will discuss implementations in attractor networks and in more biologically plausible networks. I will discuss some implications for rehabilitation theory, in particular the importance of classification of lesion size, which requires new diagnostic tools.

Correspondence: Jaap Murre, Ph.D., Department of Psychology, University of Amsterdam, Roetersstraat 15, Amsterdam 1018 WB, Netherlands.E-mail:jaap@murre.com

\section{R.L. TATE, C.A. SOO, T. BROE, A. HODGKINSON \& I.D. CAMERON. NEUROPSYCHOLOGICAL RECOVERY AFTER SEVERE TRAUMATIC BRAIN INJURY: A 23-YEAR PERSPECTIVE.}

Although a large number of studies have examined outcomes after severe traumatic brain injury (TBI), very few have examined long-term outcomes or included objective assessment of neuropsychological impairments. The principal aim of the present study was to comprehensively document the natural history of recovery from TBI, and determine the contribution of specific variables to long-term psychosocial outcome. A consecutive series of 100 people admitted to a TBI rehabilitation unit was followed-up on two occasions in the medium-term (39 years post-trauma) and long-term (20-26 years post-trauma): 67 individuals were located and examined on both occasions (17 deceased, 10 lost to follow-up, 6 incomplete data). At rehabilitation discharge, physical disability was present in $21 \%$ and neuropsychological disability in $36 \%$. Seven test variables representing characteristic domains of neuropsychological impairment after TBI were examined at each follow-up, sampling memory, concept formation, speed of information processing, and behavioural regulation. A series of logistic regression analyses, using variables collected in the post-acute stages (length of unresponsiveness and presence of physical and neuropsychological disability at rehabilitation discharge) along with time post-trauma, predicted successful psychosocial reintegration (in each of occupational activity, interpersonal relationships and living skills) for both the medium and long-term. In all domains, the presence of neuropsychological disability at rehabilitation discharge was a significant individual predictor of both medium and long-term psychosocial outcomes. Comparison of specific neuropsychological functions at the medium and long-term suggested some areas of deterioration, with the importance of memory and behavioural regulation in determining successful long-term psychosocial reintegration highlighted.
Correspondence: Robyn L. Tate, PhD, Rehabilitation Studies Unit, University of Sydney, Royal Rehabilitation Centre Sydney, PO Box 6, RYDE, NSW1680,Australia.E-mail: rtate@med.usyd.edu.au

\section{A. SHIEL. CAN PATTERNS OF RECOVERY AFTER SEVERE HEAD INJURY BE CHANGED BY INTERVENTION?}

Acute recovery after head injury (ie that taking place in the weeks immediately after the injury) may be predominantly as a result of biological recovery. Thus it can be hypothesised that the sequences and patterns of recovery observed are relatively predetermined in relation to the type of injury sustained. In a previous study (Shiel et al, 2000) patterns and sequences of recovery after head injury were identified and developed into a behavioural assessment ie the Wessex Head Injury Matrix (WHIM). In a new cohort of patients, the WHIM was used to evaluate recovery after severe head injury. However, in addition to standard assessment, patients were assessed in different postures and positions eg lying, sitting and standing on a tilt table or in an electric standing frame. Results, which were analysed on a single case basis, suggest that both the sequence and patter of behavioural recovery can be influenced by changes in posture with patients showing higher levels of responsiveness when standing. The mechanism underlying this is unclear but increased arousal may contribute to changes. These results show that assessment of patients with severe brain injury should include assessment in different positions and postures. In addition, although intervention during the early stages of recovery after severe head injury may affect the patterns and sequences of behaviour the effect of such intervention on long term outcome has yet to be determined.

Correspondence: Agnes Shiel, PhD, NUI Galway, NUI Galway, Galway, Galway N/A, Ireland. E-mail: agnes.shiel@nuigalway:ie

\section{B.A. WILSON, F. GRACEY, J. MACNIVEN \& K. BAINBRIDGE. RECOVERY FROM A STATE OF MINIMAL RESPONSIVENESS.} We describe a young woman who contracted encephalitis in 1997. She was reported to be in a vegetative state for almost 6 months. At best she was minimally responsive for 5 months. Even though less than $10 \%$ of such patients regain consciousness (and extremely few show significant recovery) we demonstrate here that it is possible to achieve a considerable degree of recovery and emotional adjustment in someone who was unresponsive for several months. During this period of unresponsiveness this woman received a PET scan. This showed that she was able to differentially respond to photographs of her family demonstrating she could perceive and process visual stimuli. Two years later she was referred for an assessment of her cognitive functioning. Despite being severely physically handicapped, tube fed, with a tracheostomy tube and communicating with a letter board, her test scores were almost all within the normal range. She was very angry and distressed at her earlier treatment and the loss of so many things in her life. Using a new model of cognitive rehabilitation as a framework we addressed the emotional factors central to her rehabilitation. She changed from being angry and suicidal to recognising her strengths and becoming more involved in life. In conclusion, cognitive assessment showed that this woman was functioning at a much higher level than most of her carers believed. Her anger and distress was treated using a new model of rehabilitation as a framework. So even for people who are in a vegetative/minimally responsive state for several months, a significant degree of cognitive recovery and emotional adjustment is possible.

Correspondence: Barbara A. Wilson, Ph.D, Cognition and Brain Sciences Unit, Medical Research Council, MRC-CBU, Box 58, Addenbrooke, Cambridge CB2 2QQ, United Kingdom. E-mail: barbara. wilson@mrc-cbu.cam.ac.uk

\section{G. PRIGATANO. THE STUDY OF CHANGE AND CHOICES SEV- ERAL YEARS POST SEVERE BRAIN INJURY.}

Long term follow up data after various brain lesions are needed to assess: 1) The impact of rehabilitation interventions 2) The stability ver- 
sus changing nature of various neurocognitive and neuroaffective disturbances 3) The vulnerability of the damaged brain to develop "new brain disorders" 4) The choices patients make which aid or interfere with the adaptation process Detailed individual case studies can provide insights that are important in the design of group studies to address these important questions. Four case examples will be presented (two with severe traumatic brain injury, one with cerebral anoxia, and one post surgical resection of a third ventricle tumor) that have been followed between 10 to 25 years. These case studies highlight the point that the patient's subjective experience of their "strengths" and "weaknesses" influences choices which seem to correlate with adaptive versus maladaptive functioning. While neuropsychological impairments are important for the overall level of recovery, they may not predict the degree to which the individual adapts to permanent neuropsychologic impairments. These four case examples will be discussed in light of the empirical and theoretical work of Teuber (1975), Corkin et al. (1989), Goldstein (1942), Thompson (1984, 1987), and Prigatano et al., (1984, 1994). The goal of the presentation will be to highlight key variables which should be considered in the design of meaningful studies in this area.

Correspondence: George Prigatano, Ph.D., Clinical Neuropsychology, Barrow Neurological Institute, 222 W. Thomas Road, Suite 315, Phoenix, AZ 85013. E-mail: gprigat@chw.edu

\section{Poster Session 7: Brain-Behavior Relationships in Developmental Disorders/10:15 a.m.-12:15 p.m.}

\section{Attention Deficit Hyperactivity Disorder}

\section{PILARSKI, J. HEMME, L. NIEC \& R. SKEEL. PERFORMANCE OF CHILDREN WITH ADHD ON COMMER- CIALLY AVAILABLE CONTINUOUS PERFORMANCE TESTS: A META-ANALYTIC REVIEW .}

Although there is a large body of research pertaining to the performance of children with Attention Deficit Hyperactivity Disorder (ADHD) on continuous performance tests (CPT), no systematic reviews of commercially available CPTs have been conducted using meta-analytic procedures. In order to examine both the comparability of individual commercially available measures as well as to compare these to groups of experimental measures, a meta-analytic review of the literature on commercially available CPTs was conducted. The current study focused on the omission and commission errors of the Gordon Diagnostic System (Gordon, 1983), the Conners' Continuous Performance Test (Conners, 1995), and the Test of Variables of Attention (Leark et al., 1996). Following the screening of 330 articles, 17 studies were analyzed. The analysis revealed that individuals diagnosed with ADHD committed more errors of omission and commission on each of the CPTs. A mean effect size (ES) of $0.58(95 \% \mathrm{CI}=0.42$ to 0.74$)$ was found for omission errors. An ES of $0.48(95 \% \mathrm{CI}=0.33$ to 0.63$)$ was found for commission errors. An analysis of the studies using Conners' Continuous Performance Test revealed an ES of $0.63(95 \% \mathrm{CI}=0.37$ to 0.89$)$ for omissions and an ES of 0.39 (95\% CI = 0.14 to 0.65$)$ for commission errors. An analysis of the studies using the Gordon Diagnostic System revealed an $\mathrm{ES}$ of $0.53(95 \% \mathrm{CI}=0.31$ to 0.74$)$ for omission errors and an ES of $0.53(95 \% \mathrm{CI}=0.34$ to 0.72$)$ for commission errors. Clinical implications are discussed.

Correspondence: Reid Skeel, Ph.D., Central Michigan University, 136 Sloan Hall, Mt. Pleasant, MI 48859. E-mail: reid.skeel@cmich.edu

\section{D.A. PINEDA, I.C. PUERTA \& L.A. GOMEZ. FACTOR ANALYSIS OF THE NEUROPSYCHOLOGICAL ASSESSMENT OF CHILDREN WITH ATTENTION DEFICIT HYPERACTIVITY DISORDER.}

A factor analysis of executive function in a sample of DSM III-R ADHD children found a different structure when was compared with control children (Pineda et al., 1998). The objective of this reporter is to analyze the factor structure of a wide range neuropsychological assessment battery, and to observe if this structure significantly differentiated between ADHD and control children. A sample of 200 ADHD DSM-IV ADHD and 286 control children, aged 6 to 11 year old and the both sexes, was selected, using randomized approaches. All children had Wechsler full scale IQ over 85. The neuropsychological assessment comprised auditory continuous performance, WMS mental control, visual/ verbal learning curve, Rey-Osterrieth complex figure, token test, verbal fluency and Wisconsin card sorting test (WCST). An exploratory factor analysis, using a VARIMAX rotated solution was developed. The analysis disclosed a structured of five factor, which explained $63.7 \%$ of the variance. The first factor was integrated by verbal fluency, WMS mental control, Rey-Osterrieth complex figure, WCST category, token test and organization index of the visual/ verbal learning curve. This factor explained $27.35 \%$ of the variance. ANOVA and ANCOVA (using age and sex as covariables) show that this factor significantly differentiated between ADHD and control children $(p=0.002)$.

Correspondence: David A. Pineda, MD, Neuropsychology, University of San Buenaventura And University of Antioquia, Carrera 46 \# 2 sur 45 of 254, Medellín 000, Colombia. E-mail:dpineda@epm.net.co

T. WILLIAMSON, J.L. RITCH \& D.M. TUCKER. COGNITIVE PREDICTORS OF PARENT AND TEACHER RATING SCALES OF ADHD.

There are many different approaches used in the diagnosis of Attention Deficit Hyperactivity Disorder (ADHD); most include the use of parent and teacher rating scales. However, factors that may influence or perhaps bias these ratings have not been fully investigated. This study examines how specific cognitive (dis)abilities affect ratings of ADHD behavior by both parents and teachers. Subjects included 83 children with a clinical diagnosis of ADHD (combined $=20$; inattentive $=37$; NOS $=$ 26) and 25 non-ADHD controls. Participants were administered an extensive battery of tests measuring common cognitive elements of ADHD such as working memory, processing speed, cognitive impulsivity, and vigilance as well as more general cognitive abilities including intelligence, verbal memory, and reading ability. Parent and teacher ratings of DSM-IV behavioral symptoms of Inattention and Hyperactivity/Impulsivity were entered into separate stepwise regression analyses with the following predictor variables: Verbal IQ, Performance IQ, working memory, verbal short term memory, vigilance, impulsivity, speed of processing and reading ability. The only predictor of both parent $(\mathrm{R} 2=.194)$ and teacher $(\mathrm{R} 2=.166)$ ratings of inattention was reading ability. Ratings of Hyperactivity/Impulsivity by parents were predicted by verbal short-term memory $(\mathrm{R} 2=.070)$ and cognitive impulsivity $(\mathrm{R} 2=.110)$; while the only predictor of teacher ratings was verbal short-term memory $(\mathrm{R} 2=.096)$. These results suggest that cognitive abilities other than attention influence parent and teacher ratings of ADHD.

Correspondence: Thomas Williamson, Pitzer College, 1050 N. Mills AVE, box \# 457, Claremont, CA 91711. E-mail: twilliamsur@yahoo.com

\section{L.E. MCALISTER, S.C. HEATON, D. GRIBBINS \& M. ROBIN- SON. PREDICTING ADHD VS NON-ADHD GROUP MEMBER- SHIP: A COMPARISON OF THE CPRS, CPT, AND TEA-CH.}

Accurate assessment of ADHD is critical for identifying impairment and providing appropriate treatment. Although no single neuropsychological assessment should be used in isolation, it is useful to know the comparative predictive abilities of some of the most popular measures on the market. Previous studies have shown that the Conners Parent Rating Scale (CPRS) and the Conners Continuous Performance Test (CPT) are capable of identifying children who have ADHD. The Test of Everyday Attention for Children (TEA-Ch) is a relatively new measure that shows promising potential as a tool for differentiating between ADHD and non-ADHD groups based on attention-related constructs. This study 
explores the abilities of these three measures to determine group membership to an ADHD (N=27) or Clinical Control ( $N=27)$ subset of children. Participants included children ages 6-16 diagnosed with ADHD or a non-ADHD clinical condition (e.g., disorders of conduct, mood, or learning). Discriminant Analysis procedures revealed that composite scores from the CPRS, the TEA-Ch and the CPT each predicted group membership better than chance. Of the three measures, the TEA-Ch exhibited the best predictive ability, correctly classifying $68.5 \%$ of the children with sensitivity and specificity rates of $66.7 \%$ and $70.4 \%$, respectively. While addition of the CPRS and CPT measures to the equation improved classification rates, the combined model only improved the classification rate to $74.1 \%$, with identical sensitivity and specificity rates of $74.1 \%$. Results suggest that the TEA-Ch may be a very useful new tool in the assessment of ADHD, with predictive properties rivaling those of well-established measures.

Correspondence: Lindsay E. McAlister, B.A., University of Florida, 310 NW 50th Blvd, Gainesville, FL 32607.E-mail: Imcalist@hp.ufl.edu

\section{D.M. GRIBBINS, S.C. HEATON, J.K. GUSTAFSON \& L.E. MCALISTER. CONNERS' CPT VS CPT-II: ADHD CLASSIFI- CATION ACCURACY.}

Continuous Performance Tests (CPT's) are frequently used to assess childhood attentional impairments and aid in the diagnosis of Attention Deficit Hyperactivity Disorder (ADHD). The CPT developed by Dr. Conners is one of the more popular versions on the market. A revised edition of the Conners' CPT (CPT-II) was recently published with significantly improved and expanded normative data. No studies have been published, however, comparing the utility of the original and revised versions of the Conners' CPT. The current study sought to evaluate the effectiveness of the two versions in correctly classifying children as ADHD or non-ADHD using the composite scores and recommended cutoff values provided with each version. Of critical importance is the fact that the CPT-II generates both the old composite score ("Overall Index") as well as the revised composite score ("Confidence Index"), allowing the two versions to be evaluated directly within a single administration. Participants, ages 6-16, included an ADHD group and a non-ADHD Clinical Control group who completed the CPT-II as part of a larger research test battery. Comparison of classification rates using the old and new composite scores revealed significant differences in terms of sensitivity, specificity, and overall hit rate. While specificity was higher for the old CPT and sensitivity was higher for the CPT-II, the overall hit rate was found to be significantly higher using the CPT-II. Results suggest that the CPT-II composite score has more balanced and accurate classification properties than the old CPT. Factors influencing classification accuracy are explored and implications are discussed.

Correspondence: David M. Gribbins, BS, University of Florida, $2777 \mathrm{SW}$ ArcherRd, AH304, Gainesville,FL 32608.E-mail:dgribbin@hp.ufl.edu

\section{M.G. BUBNIK, O. BERWID, A. SANTRA, E.A. CURKO, D.J. MARKS \& J.M. HALPERIN. ADHD SUBTYPE DIFFERENCES ON OBJECTIVE MEASURES IN PRESCHOOLERS.}

This study examined whether ADHD subtypes in preschool-aged children can be differentiated using laboratory assessments of inattention, impulsivity and activity level. A large non-referred sample of preschool children was rated by parents and teachers using DSM-IV ADHD symptom lists. Based on the ratings, children were divided into those meeting symptom criteria for ADHD-Inattentive (ADHD-I), Hyperactive/Impulsive (ADHD-H/I) and Combined (ADHD-C) subtypes, in addition to a non-ADHD control group. Sustained attention and inhibitory control were measures using continuous performance (CPT) and go-no/go tasks. In addition, each child wore a solid-state actigraph throughout the evaluation. On the CPT, children with ADHD-I appeared most inattentive, as indicated by significantly slower reaction times and high num- bers of missed targets as compared to controls. Only the ADHD-C group, as measured by the actigraph, was significantly more active than the control group. Object measures were able to significantly differentiate preschoolers by subtype. However, their utility as a diagnostic tool is questionable due to their inconsistent results.

Correspondence: Michelle G. Bubnik, Psychology, Queens College, 65-30 Kissena Blvd., Flushing, NY11376.E-mail: eminemgur114369@aol.com

\section{J.G. WESTHAFER, C.L. CARLSON \& D.M. TUCKER. SUBTYPE DIFFERENCES IN MOTOR DYSFUNCTION AMONG CHILDREN WITH ADHD.}

Children with DSM-IV ADHD combined (ADHD/C) and inattentive (ADHD/IA) subtypes, and an experimental construct (ADHD/IA with sluggish cognitive tempo (SCT), and non-disordered control children completed a motor skills battery that assessed both fine and gross motor function. Approximately $40 \%$ of each diagnostic group performed in the lowest $5 \%$ of normative samples, while none of the control children performed at this level. Children with $\mathrm{ADHD} / \mathrm{C}$ and $\mathrm{ADHD} / \mathrm{IA}$ performed more poorly than controls on a composite score of fine and gross motor functioning. At the individual subtest level, children with both $\mathrm{ADHD} / \mathrm{C}$ and ADHD/IA performed more poorly on a measure of fine motor control and one that assessed static balance, while only children with $\mathrm{ADHD} / \mathrm{C}$ performed more poorly on a task requiring throwing and catching a ball. Parents rated all diagnostic groups as having poor handwriting compared to controls, but only ADHD/IA and ADHD/C as having less athletic ability. While there were no differences between groups on self-report ratings of handwriting and athletic ability, children with $\mathrm{ADHD} / \mathrm{C}$ significantly overestimated their handwriting ability. Children with ADHD/IAoverestimated their athletic ability, while there was a trend for children with ADHD/C to do so as well ( $\mathrm{p}=.053)$. Correspondence: J G. Westhafer, BBA, BS, Clinical Psychology, University of Texas-Austin, 1 University Station A-8000, Austin, TX 78712. E-mail:westhafer@mail.utexas.edu

\section{R.T. LAW \& K.R. KRULL. MOTOR CONTROL AND EXECUTIVE FUNCTIONS IN ADHD SUBTYPES.}

Children with Attention-Deficit/Hyperactivity Disorder (ADHD) often demonstrate a wide range of behavioral, psychiatric, and cognitive difficulties, particularly in the domain of executive functioning. ADHD is also frequently associated with increased difficulties in motor control, dexterity, and sequencing. Although there have been past reports of motor differences between subtypes of ADHD, only one known study has examined such differences using current diagnostic standards for identifying ADHD-Combined Type (ADHD-C) and ADHD-Predominantly Inattentive Type (ADHDI). The current study examined the differential pattern of motor deficits between subtypes of ADHD and investigated the relationship between motor deficits and problems in attention, hyperactivity, behavioral inhibition, and executive functioning. Seventy-nine children were studied who were between 5 and 12 years of age and were diagnosed with either ADHD-C (n $=49)$ or ADHD-I $(\mathrm{n}=30)$. Results showed a significant subtype effect on fine motor measures and parent ratings of gross motor skills, with the ADHD$\mathrm{C}$ group performing more poorly than the ADHD-I group. However, these effects were only observed when the effects of age and subtype by age interaction were factored out. The interaction effect on several measures suggested that the younger ADHD-C group tended to perform worse than the ADHD-I group, but that the trend diminished or reversed as age increased. In addition, reduced motor performance in this study was correlated with problems in attention, vigilance, impulsivity, and working memory, but not with behavioral ratings of hyperactivity or disinhibition. These findings provide partial support for Russell Barkley's model of ADHD (1997), which proposes that the behavioral, executive, and motor symptoms of ADHD are primarily produced by a central disorder of inhibition.

Correspondence: Robert T. Law, Ph.D., Learning Support Center, Texas Children's Hospital, 6621 Fannin St., CC 1630.00, Houston, TX 770302399.E-mail: rtlaw@texaschildrenshospital.org. 


\section{R.A. YEO, D.E. HILL, L. MCDANIEL, R.C. CAMPBELL, H. PETROPOULOS, A.J. BROWN, D.C. WEERS \& W.M. BROOKS. A MAGNETIC RESONANCE SPECTROSCOPY STUDY ADHD: AN ANALYSIS OF QUANTIFICATION METHOD, SUBTYPE, AND SEX. .}

Many studies have now shown that neurodevelopmental disorders are characterized by distinct patterns of regional variation in the concentrations of specific metabolites. We have recently conducted an evaluation of children with ADHD and controls (Yeo et al., 2003) and found evidence of an interaction of diagnosis with sex: right frontal white matter N-acetyl-aspartate (NAA) levels were lower in girls with ADHD and higher in control girls. In this present study we compared two different quantification methods (MRUI and LCModel) in a sample of 23 controls, 14 ADHD children with the Hyperactive/combined subtype, and 11 with the Inattentive subtype. Concentrations of NAA, Creatine (Cre), and Choline (Cho) were significantly greater using MRUI than LCModel. Correlations between concentrations derived with the two methods varied considerably across specific metabolites, with estimates of Cho being most similar, followed by NAA, Cre and then metabolite ratios with Cre as denominator. Glutamate concentration estimates derived from LCM analyses did not differ in comparisons of ADHD children vs. controls or as a function of ADHD subtypes, in contrast to recent reports with smaller samples. However, patterns of correlations between myoinositol and Glu with attention skill differed as a function of subtype. For NAA, Cre, Cho, and Glu, significant sex by group interactions were noted such that girls with ADHD had especially low values and control girls had high concentrations.

Correspondence: Ronald A. Yeo, Ph.D., Psychology, University of New Mexico, Logan Hall, Albuquerque, NM 87131.E-mail: ryeo@unm.edu

\section{E.A. CURKO, D.J. MARKS, O.G. BERWID, A. SANTRA \& J.M. HALPERIN. ATTENTION AND INHIBITORY CONTROL IN PARENTS OF PRESCHOOLERS WITH AD/HD SYMPTOMS.}

Data indicate a considerable genetic component to the etiology of AD/HD, but the nature of the neuropsychological profile that runs in families has not been systematically explored. This study objectively assessed attention and inhibitory control in the parents of preschool children with and without AD/HD symptoms. Based on parent and teacher ratings of DSM-IV AD/HD symptoms, preschool children were divided into those with high $(\mathrm{N}=22)$ and low $(\mathrm{N}=31) \mathrm{AD} / \mathrm{HD}$ symptomatology. One parent of each child was administered an identical pairs Continuous Performance Test (CPT-IP) and a Go/No-Go task, as well as the Brown Adult ADD Scales. There were no significant group differences reported on the Brown Scale. However, significant differences emerged on both objective laboratory measures. Parents of preschoolers with AD/HD symptoms displayed a pattern of slower reaction times and higher rates of false alarms as compared to control parents on the two computer tasks. Further, the lack of a significant inverse correlation between reaction times and false alarms suggests that the pattern of responding is more likely due to inattention than impulsivity. These data suggest that neuropsychological tests may be more sensitive than clinical self-reports in identifying genetically transmitted cognitive deficits associated with $\mathrm{AD} / \mathrm{HD}$.

Correspondence: Elizabeth A. Curko, MA, Neuropsychology, CUNY Graduate Center, Dept. of Psychology/Queens College, 65-30 Kissena Blvd., Flushing, NY, NY 11367.E-mail: eac212@yahoo.com

\section{A.S. HERVEY, J.N. EPSTEIN, J.F. CURRY, S. TONEV, H. ABIKOFF, E. ARNOLD, L. GREENHILL, L. HECHTMAN, S. HINSHAW, P. JENSEN, W. PELHAM \& J. SWANSON. REACTION TIME DISTRIBUTION ANALYSIS IN CHILDREN WITH ADHD.}

Children with ADHD are more variable in their reaction times (RT) compared to normal controls on neuropsychological tests. The mechanism for this difference is unclear. Using a discrimination task, Leth-Steensen,
Elbaz, and Douglas (2000) more accurately characterized typical neuropsychological RT data and allowed examination of various components of the RT curve using an Ex-Gaussian RT distribution, rather than a normal distribution. Consistent with Leth-Steenson et al. (2000), the present study evaluates RT distribution on the Conners Continuous Performance Test in the Multimodal Treatment Study of ADHD (MTA) sample. The Conners CPT is a Go/No-Go test that emphasizes behavioral inhibition and attention. Differences on RT variability between children with and without ADHD have been documented using this task with normal distribution estimators. The present study compared a matched sample of children with ADHD and normal controls $(n=286)$ on RT and RT variability using the Ex-Gaussian curve to describe the data. Results indicate that children with ADHD demonstrated a greater proportion of quick responses associated with the normal portion of the curve $(F(1,284)=6.58, p=.0108)$, and a greater portion of abnormally slow responses associated with the exponential portion of the curve $(\mathrm{F}(1,284)=17.65, \mathrm{p}<.0001)$. These results suggest that increases in RT variability demonstrated by children with ADHD is primarily explained by a greater proportion of abnormally long RT intervals during the task compared to normal controls. These results replicate previous research findings of differences associated with specific aspects of the ExGaussian curve with a much larger sample. Further, this replication of findings demonstrates that these results are consistent across very different tasks.

Correspondence: Aaron S. Hervey, M. A., Psychology: Social Health Sciences, Duke University, 442 S. Convent Ave., Tucson, AZ, AZ 85701. Email:ash5@duke.edu

\section{A. PALAV, R.J. MCCAFFREY \& T. HARRISON-GOLDMAN. PERFORMANCE OF CHILDREN WITH ADHD ON NEUROPSY- CHOLOGICAL EFFORT TESTS.}

In comparison to the extensive literature on the detection of dissimulation in adults, there has been a paucity of literature on the objective assessment of effort in children and adolescents. The current study examined the performance of children and adolescents between the ages of 5 and 14 on the Test of Memory Malingering (TOMM) and the oral version of the Word Memory Test (WMT), two effort measures commonly used in adult neuropsychological evaluations. It was hypothesized that a mixed group of children (Attention Deficit/Hyperactivity Disorder (ADHD) both with and without comorbid Reading Disability (RD) and healthy controls) would perform above previously established adult cutoff scores on both measures. The results indicated that children as young as age five were capable of surpassing the cutoff on the TOMM. Children were also able to surpass the cutoff on the WMT, but children younger than eight years of age had more difficulty than older children on this measure. The results support the use of the TOMM with children as young as age five and the use of the oral WMT with children as young as age eight. Preliminary analyses found no differences between the ADHD and control subgroups on Trial 2 of the TOMM and the effort variables of the WMT, suggesting that these measures are insensitive to the effects of ADHD.

Correspondence: Anjali Palav, M.A., Neurodevelopmental Center of MHRI, Brown Medical School, 555 Prospect St., Pawtucket, RI 02860. E-mail:Anjali_Palav@Brown.edu

\section{T. BAUMGARDNER, M. CARSWELL \& V. CULOTTA. GENDER AND EXECUTIVE FUNCTION DIFFERENCES IN MENTAL ARITH- METIC AND MATH ERRORS IN CHILDREN WITH ADHD.}

A clinic based sample of 18 females and 18 males (6-16 y.o.) with ADHD were compared with a cognitive test battery assessing executive functions. Participants with a history of head injury, seizure disorder, Learning Disabilities, or multiple psychiatric co-morbidities were excluded. All participants in the study were medication free at the time of assessment. Both groups were impaired on a Continuous Performance Test 
and the Rey Complex Figure Test; however, only performance on WISCIII Arithmetic significantly differentiated these groups, with males outperforming females. Analysis of correlation matrices among all variables revealed that, in males, the ability to perform mental arithmetic computations was positively correlated with computerized continuous performance test measures of impulsivity and inattention, the California Verbal learning Test trials1-5 total score and Long Delay free recall score, and WISC-III Digit Span backward. Among females, the ability to perform mental arithmetic computations was solely correlated with CVLTC trials 1-5 total score. Subsequent analysis of performance on standardized tests of written mathematical computation, revealed a distinct pattern of error types. Males made more total number of errors and more procedural errors than females, while females made errors that were restricted primarily to errors associated with inattention to mathematical operation/sign and computational mistakes. These findings suggest that males and females with ADHD may differ in the underlying neurocognitive processes that contribute to mental arithmetic ability and the type of mathematical computation errors. In males, performance of mental arithmetic reflected broader executive control processes, including attention, response control, verbal working memory, and processing speed. In females, the ability to perform mental arithmetic was narrowly associated with a measure of verbal learning and working memory.

Correspondence: Thomas Baumgardner, MedPsych Associates, $2324 \mathrm{~W}$. Joppa Road, Suite 220, Lutherville, MD 21093. E-mail: phdbaumgardner@aol.com

\section{V.M. WOLFSON, E. SAMUELS, J. REYNOSO, J. UENG-MCHALE, V.C. TARTTER \& H. GOMES. EXPRESSIVE LANGUAGE CHAR- ACTERISTICS IN CHILDREN DIAGNOSED WITH AD/HD.}

A subset of children with $\mathrm{AD} / \mathrm{HD}$ often meets criteria for a codiagnosis of specific language impairment (SLI). As part of a NIDCD funded project at City College examining the relationship between attention and language we found during neuropsychological testing that many children with $\mathrm{AD} / \mathrm{HD}$, who did not meet criteria for SLI, nonetheless evidenced qualitative expressive language difficulties. This clinical observation was supported by significantly $(p=<.001)$ elevated teacher ratings on the expressive language subscale of the Clinical Evaluation of Language Fundamentals, Third Edition (CELF-3): Teacher Observation obtained by AD/HD children who did not otherwise meet criteria for SLI. To further investigate the communicative abilities of these children, this pilot study analyzed both quantitative and qualitative features of each child's language output on Formulated Sentences (FS), a CELF3 subtest. Both groups received similar standardized scores on FS. Parent and teacher ratings of $\mathrm{AD} / \mathrm{HD}$ from 32 children $(\mathrm{M}=8 \mathrm{y}, 1 \mathrm{~m}$; $\mathrm{SD}=10 \mathrm{~m})$ were positively correlated with utterance length $(\mathrm{p}=.088 ; \mathrm{p}$ $=.099$, respectively) after controlling for the effects of IQ, age, and language skills. Although the ability to adequately describe a picture was found to be comparable in both groups, a rater blind to diagnostic category of the sentence producer rated the children with $\mathrm{AD} / \mathrm{HD}(\mathrm{N}=13)$ as significantly $(\mathrm{t}(28)=2.95, \mathrm{p}=.006)$ more frequently embedding themselves into the sentence content than children without $\mathrm{AD} / \mathrm{HD}(\mathrm{N}=17)$. Encouraged by these early findings we are continuing our analysis of error types of expressive language generated by $\mathrm{AD} / \mathrm{HD}$ children. Correspondence: Virginia M. Wolfson, B.A., Psychology, The City College of New York, 138th Street and Convent Avenue, New York, NY 10031. E-mail:Ginwolf50@aol.com

\section{D.A. PINEDA \& L.A. GOMEZ. CHILDREN WITH ATTENTION DEFICIT WITHOUT LEARNING DISABILITIES PERFORMED SIM- ILAR TO CONTROLS ON PHONOLOGICAL AWARENESS TESTS.}

Children with reading disabilities (RD), with or without attention deficit (ADHD), have deficit in phoneme perception that correlates with phonological processing ability (Breier, et al., 2002). Significant differences were found between the ADHD and control children on three phonological processing tasks (Miranda-Casas, et al., 2002). The objective of this reporter is to analyze the performance on seven phonological awareness tasks by two ADHD and one control groups. A sample of 96 (48 boys and 48 girls), 7 to- 10 - year- old, native Spanish speaker children, with normal Wechsler Full Scale IQ, was selected. The sample was divided in three equal groups, according to DSM IV criteria for ADHD diagnosis: ADHD inattentive and combined types, and control group. A teacher rating scale for detecting learning disabilities (LD) (in spanish: cuestionario de problemas del aprendizaje: CEPA) was administered. ADHD and control groups obtained normal scores on the CEPA. Seven phonological awareness tasks, given orally and visually, which included auditory discrimination, visual recognition, sequential repetition, oral segmentation, syllable inversion, similar words reading and writing, and pseudo-words reading and writing, were administered to the participants. Non-parametric Kruskal Wallis comparison tests for three equal groups were developed. The seven phonological awareness tasks did not show any significant differences between both ADHD and control groups. Our results suggest that phonological awareness deficit would not be presented by ADHD children without LD.

Correspondence: David A. Pineda, MD, Neuropsychology, University of San Buenaventura And University of Antioquia, Carrera 56C \# 51 - 90 of 101, Medellín, Colombia. E-mail: dpineda@epm.net.co

\section{R. DRECHSLER, P. RIZZO, K. BREM \& H. STEINHAUSEN. METACOGNITION AND EVALUATION OF PERFORMANCE IN CHILDREN WITH ADHD.}

Objective: ADHD has been interpreted as a deficit in resource allocation, as a motivational deficit, or as incapacity to provide an appropriate effort, in connection with a deficit in executive functioning. Although a positive bias in the self-perception of social and academic performance has been described in the ADHD literature, metacognitive abilities regarding attention and executive functions have rarely been studied so far. The goal of the present pilote study was to investigate the self-evaluation of performance in attention and executive function tasks in children with ADHD. Method: Twenty children with ADHD and twenty normal control children (mean age $=9.8$ years) performed six executive function and attention tasks (four subtests of a computerized test battery, Tower of London, Wisconsin Card Sorting Test). The children rated their performance, the effort provided, how much they liked the task, and task difficulty retrospectively on a five point scale. Results: Children with ADHD evaluated their own performance significantly better than normal control children in three out of six tests, among them two tests rated as the most easy and least effort demanding. No significant differences between the groups were found regarding the evaluation of difficulty, effort or pleasure. Conclusion: Children with ADHD seem to show a positive bias in the self-evaluation of performance in some executive function and attention tasks compared to normal controls, as long as the tasks are not especially effort demanding. Further research will have to confirm these preliminary results.

Correspondence: Renate Drechsler, Ph.D., University of Zurich, Department of Child and Adolescent Psychiatry, Klosbachstr. 107, Zurich CH - 8032, Switzerland. E-mail: rdrechs@kjpd.unizh.ch

\section{S.E. LEHTONEN, M.K. MORRIS \& A. BLALOCK. EXPLORING DIFFERENCES BETWEEN ADHD AND LD ON MEASURES OF EX- ECUTIVE FUNCTION.}

Existing literature is inconsistent in reporting significant group differences on measures of attention and executive functions when Attention-Deficit Hyperactivity Disorder (ADHD) groups are compared to clinical contrast groups. However, it has been hypothesized that ADHD may differ from other groups, not in level of performance, but in performance variability. 376 college students, diagnosed with either ADHD or Learning Disability (LD) at a university assessment center, were included in the study. Groups were matched on demographic variables but the ADHD group had a higher Full Scale IQ (FSIQ). Standardized scores based on published norms for six attention and executive function tasks 
were examined. Standardized score range across these measures was calculated for each participant as the measure of performance variability. We hypothesized that: 1) the ADHD and LD groups would not differ in level of performance, 2) the ADHD group would have greater variability in performance across tasks, and 3) scores on ADHD symptom checklists would be positively correlated with performance variability. ANCOVA, controlling for FSIQ, revealed differences on Digit Span and the Stroop Test, with poorer performance in the LD group. Groups did not differ in performance variability. Furthermore, there were no correlations between symptom checklist scores and the variability score. These findings highlight the limitations of using attention and executive tasks to discriminate individuals with ADHD from other diagnostic groups. Poor or variable performance on these tasks may also characterize individuals with LD, reflecting associated attention and executive impairments and/or processing problems in cognitive domains tapped by task content.

Correspondence: Sanna E. Lehtonen, M.A., Psychology, Georgia State University, 33 Gilmer Street SE, Atlanta, GA 30303-3082. E-mail: slehtonen1@student.gsu.edu

\section{J.L. RITCH, D. TUCKER \& R. VAURIO. PROSPECTIVE MEMORY ABILITY IN CHILDREN WITH ATTENTION DEFICIT/HYPERAC- TIVITY DISORDER.}

Children with ADHD are frequently reported to have failures in prospective memory (PM). The aim of this investigation was to examine if there is a difference in PM ability between children diagnosed with ADHD and control children. Seventeen children referred to the Austin Neurological Clinic who received a clinical diagnosis of ADHD and 10 control children completed a battery of tests assessing a variety of cognitive abilities. Among the tests were measures of time production ability, timebased PM, and event-based PM. Using analysis of variance we examined differences between the groups on all PM measures. Results revealed that parents of children with ADHD rated their children as having significantly more failures in PM than parents of control children $(p=.000$, $\mathrm{F}=34.19$ ). On performance based measures of $\mathrm{PM}$, children with ADHD performed significantly poorer than controls in total task performance $(p=.01, F=7.847)$. Specific differences were observed on an event-based measure of PM with an embedded cue $(\mathrm{p}=.018, \mathrm{~F}=6.456)$. Other PM tasks displayed trends in the hypothesized direction, but were not significant at the .05 level. On measures of time production ability, children with ADHD did not differ from controls in their ability to estimate 5 -minutes. However, the ADHD group was significantly less reliable in their estimation than controls over a repeated trial $(\mathrm{p}=.024, \mathrm{~F}=5.68)$. Results indicate that there does appear to be greater failures in PM ability in children diagnosed with ADHD than non-referred controls. Identifying the specific deficits and their cognitive correlates may provide important information for how to best work with these children. Correspondence: Janice L. Ritch, MA, Psychology, University of Texas at Austin, 227 San Saba, New Braunfels, TX 78130.E-mail: jlritch@ mail.utexas.edu

\section{J.L. RITCH \& D. TUCKER. COGNITIVE CORRELATES OF PROSPECTIVE MEMORY IN ATTENTION DEFICIT/HYPERAC- TIVITY DISORDER.}

Though the effects of prospective memory failures are disabling for adults and children alike, prospective memory (PM) has received limited attention in the children's literature. The aim of this investigation was to examine the cognitive correlates of PM in children referred for attentional difficulties and non-referred controls. Seventeen children referred to the Austin Neurological Clinic who received a clinical diagnosis of ADHD and 10 control children completed a battery of tests assessing a variety of cognitive abilities including performance based measures of time- and event-based PM. Using stepwise multiple regression analysis we examined which cognitive tests predicted scores on PM. Results revealed that vigilance (continuous performance test), working memory
(Digit Span Backwards), and verbal memory (list learning) were significant predictors of PM ability, together accounting for more than $69 \%$ of the variance in total PM scores. Time-based PM was predicted by time production ability and verbal memory (adjusted $\mathrm{R}$ square $=.51$ ), while an event-based PM task with a salient cue was predicted by vigilance and executive functioning (card sorting) (adjusted R square =.46). An event-based PM task with an embedded cue was best predicted by parent report of their child's PM difficulties, and not by any cognitive measure obtained in this investigation (adjusted $\mathrm{R}$ square $=.18$ ). PM as a cognitive ability is multiply determined and different PM tasks appear to rely on different underlying cognitive abilities.

Correspondence: Janice L. Ritch, MA, Psychology, University of Texas at Austin, 227 San Saba, New Braunfels, TX 78130.E-mail: jlritch@ mail.utexas.edu

\section{J.H. KALMAR, K.P. SCHULZ, D.J. MARKS, V. SHARMA, J.H. NEWCORN \& J.M. HALPERIN. CHILDHOOD NORADREN- ERGIC FUCTION PREDICTS ADOLESCENT COGNITION IN CHILDREN WITH ADHD.}

Objective: Considerable data suggest a role for central noradrenergic (NA) mechanisms in the pathophysiology of ADHD. Specifically, previous research found that plasma levels of the NA metabolite 3-methoxy4-hydroxy-phenylglycol (MHPG) were inversely related to verbal and academic measures in ADHD children. This study was designed to assess prospectively the extent to which early NA function is predictive of adolescent cognitive and behavioral functioning. Method: Participants were 32 14-18 year old boys who were diagnosed with ADHD when they were 7-11 years old. Plasma levels of MHPG were obtained as an index of NA function at the time of childhood diagnosis. Adolescents were clinically re-evaluated on average $6.73(1.09)$ years following the initial assessments. Follow-up assessments included the WISC-III/WAIS-R, the WIAT, and parent, teacher, and adolescent ratings of behavior. Evaluators were blind to baseline biological data. Results: After controlling for baseline Full Scale IQ, early NA function was significantly negatively correlated with follow-up Verbal IQ $(r=-.50)$ and academic achievement in decoding $(\mathrm{r}=-.41)$ and arithmetic $(\mathrm{r}=-$. 43), and positively associated with follow-up Performance IQ $(r=.40)$. When controlling for baseline levels of aggression, childhood NA function was not related to adolescent behavioral outcome in the areas of aggression, substance use or antisocial behavior. Conclusion: These data suggest that NA function in ADHD children may have prognostic utility with regard to cognitive function, but not behavior, in adolescence, above and beyond that predicted by early cognitive functioning.

Correspondence: Jessica H. Kalmar, Ph.D., Neuropsychology, Kessler Medical Rehabilitation Research and Education Corporation, 1199 Pleasant ValleyWay, West Orange, NJ 07307. E-mail: jhkalmar@kmrrec.org

\section{D.J. MARKS, A. SANTRA, N. THORN, S. HARTY, J.H. NEWCORN \& J.M. HALPERIN. NEUROPSYCHOLOGICAL OUTCOMES OF ADOLESCENTS WITH CHILDHOOD AD/HD.}

Executive function deficits have frequently been implicated in the pathogenesis of attention-deficit/hyperactivity disorder (AD/HD). However, few studies have examined such deficits in adolescents using experimental paradigms designed to isolate circumscribed constructs. The current cross-sequential study examined the neuropsychological status of 43 adolescents with childhood onset $\mathrm{AD} / \mathrm{HD}$ and current residual features of the disorder in relation to the performance of 46 adolescent controls matched for age, gender, and Full Scale IQ. Participants were administered a test battery comprised of measures of sustained attention (Identical Pairs CPT, CPT-IP), perceptual inhibition/interference control (Stroop Color-Word Test; Stimulus Conflict Test, SCT), and motor inhibition (Response Conflict Test, RCT). The Stroop, SCT, and RCT all included paired control conditions designed to isolate the constructs of interest. Relative to controls, adolescents with a childhood history of $\mathrm{AD} / \mathrm{HD}$ performed significantly worse on both measures of perceptual 
inhibition and displayed significantly greater reaction time variability on the CPT-IP; no groupwise differences were evident with respect to performance on the RCT. These data indicate that deficits in interference control represent a central neurocognitive outcome of adolescents with documented childhood AD/HD. Adolescents previously diagnosed with $\mathrm{AD} / \mathrm{HD}$ do not display precipitous declines in attention over time, but rather show "spotty" or inconsistent levels of concentration over time which may be due to interference from competing stimuli. Correspondence: David J. Marks, Ph.D., Psychiatry, Mount Sinai Medical Center, 1 Gustave L. Levy Place, Box 1230, New York, NY 10029. E-mail:djmarks@bigfoot.com

\section{MILLER, S. HARTY, J.M. HALPERIN \& R. SUH. FAMILY HIS- TORY AS A PREDICTOR OF ADOLESCENT ADHD OUTCOME.} Attention-deficit/hyperactivity disorder (ADHD) is a childhood disorder for which symptoms persist into adolescence and early adulthood in many affected individuals. However, the factors predicting course and adolescent ADHD outcome have remained elusive. Recent data provide compelling evidence for a considerable genetic component to the emergence of ADHD. This study examined the degree to which heredity predicts course and outcome in children with ADHD. Adolescents, originally diagnosed with ADHD when they were 7-11 years old, were re-evaluated between the ages of 16-21 years. During the childhood evaluations, parents and teachers completed a series of rating scales, and parents participated in a series of structured and semi-structured interviews about the child's status as well as family history of symptoms associated with ADHD. At follow-up, parents and adolescents completed several rating scales and participated in a semi-structured psychiatric interview focusing on the adolescent's current psychiatric and behavioral status. As expected, a significant number of ADHD symptoms continued to manifest during adolescence, although for many individuals, the number of symptoms was not sufficient for clinical diagnosis. As predicted, after controlling for severity of childhood symptoms as rated by parents and teachers, regression analyses indicated that family history of ADHD behaviors in first and second degree relatives was a significant predictor of adolescent outcome such that those with a positive family history of ADHD had increased persistence of ADHD symptoms into adolescence. Thus, it appears that for individuals with ADHD, genetic heritage is a better predictor of long-term outcomes than childhood symptom presentation.

Correspondence: Carlin Miller, Ph.D., Psychology, Queens College, CUNY, 65-30 Kissena Blvd., Flushing, NY 11376. E-mail: Carlin_Miller@qc.edu

\section{Agression}

\section{R. GRAY, M.R. DEHOFF, J.M. PITCHFORD, H. SCHONBACHLER \& J.A. HAJJ. NEUROPSYCHOLOGICAL CHARACTERISTICS AMONG SUBTYPES OF AGGRESSIVE CHILDREN.}

Children with a history of aggressive and antisocial behaviors should not be considered a homogenous population, as they demonstrate differing pathways in the quality, development and course of their aggressive and antisocial behaviors. Increasingly, empirical evidence supports the use of subtypes to classify children based on qualitative differences in aggressive behavior. Reactive aggression is viewed as a defensive reaction to a perceived threat, and is more strongly associated with overall dysregulated behavior. Proactive aggression is viewed as instrumental in nature and less motivated by emotional dysregulation and social deficits. Additional proposed subtypes include a combined reactive-proactive subtype and a subtype based on adult conceptualizations of psychopathology, in which aggressive children demonstrate callous and unemotional traits. Limited research has been completed investigating neuropsychological functioning among these subtypes. The current study examines neuropsychological differences among a clinicreferred sample of children diagnosed with conduct disorder and oppositional defiant disorder classified according to reactive (RA), proactive (PA), mixed reactive-proactive (RPA), or callous/unemotional (CU) subtype characteristics. Significant differences were noted on measures of receptive and expressive language, with CU children demonstrating better language functioning in comparison to below average performance among all other subtypes. Children in the CU group also demonstrated more evidence of low-arousal/sensation-seeking behaviors and were viewed as exhibiting more severe conduct related problems and atypi$\mathrm{cal} /$ unusual behaviors according to parent behavioral ratings. Additional comparisons among subtypes are discussed as well as implications for the clinician working with aggressive or antisocial children.

Correspondence: Robert Gray, PhD, Neuropsychology, Kennedy Krieger Institute, 1750 E.Fairmount Ave, Baltimore,MD 21231.E-mail: grayr@ kennedykrieger:org

\section{R. GRAY, J.M. PITCHFORD, M.R. DEHOFF, H. SCHONBACHLER \& J.A. HAJJ. NEUROPSYCHOLOGICAL PERFORMANCE OF AG- GRESSIVE CHILDREN ON AND OFF STIMULANT MEDICATION.}

Positive effects of stimulant medication have consistently been noted in children diagnosed with Conduct Disorder (CD), Oppositional Defiant Disorder (ODD), and comorbid attentional deficits (ADHD). Although many studies have investigated the role of stimulants on the reduction of behavior problems and aggression, few studies have examined the effect of stimulants on neuropsychological performance in this population. The current study examines behavioral, neuropsychological and historical data among 83 children diagnosed with CD and ODD. The majority of the children $(76 \%)$ were also diagnosed with comorbid ADHD. Approximately $26 \%$ of the children were on a stimulant medication at the time of their evaluation, while $73 \%$ were not prescribed any medication at the time of their evaluation. In general, no significant neuropsychological differences were noted between the groups, although children who were on medication performed more poorly on a measure of visual scanning and executive functioning (trails test). Significant differences were noted in the behavioral presentation among the groups, as children who were on medication demonstrated more severe reactive and proactive aggressive behaviors and greater sensation seeking behaviors compared to those children who were not on medication. Results suggest that CD and ODD children who are prescribed medication may represent a population that is demonstrating more severe aggressive behaviors than their CD/ODD peers who are not referred for medication therapy. It is also possible that use of medication may result in improvements in test performance resulting in equivalent neuropsychological profiles between those children who are on versus off medication

Correspondence: Robert Gray, PhD, Neuropsychology, Kennedy Krieger Institute, 1750 E. Fairmount Ave, Baltimore,MD 21231.E-mail: grayr@ kennedykrieger.org

\section{Autism Spectrum Disorders}

\section{E.M. JANSIEWICZ, M.C. GOLDBERG, C.J. NEWSCHAFFER, M.B. DENCKLA, R. LANDA \& S.H. MOSTOFSKY. MOTOR AND NEUROLOGIC SIGNS DISTINGUISH HIGH-FUNCTIONING AUTISM FROM CONTROLS.}

While many studies of motor control in autism have focused on specific motor signs (e.g. examination of gait, balance, and performance of skilled movements/gestures), there has been a lack of research examining the complete range of subtle neurologic signs such as overflow and dysrhythmia, as well as motor inhibition. This study compared performance on a neurologic examination standardized for children (Physical and Neurological Exam of Subtle Signs; PANESS; Denckla, 1974) in a 
group of 40 boys ages 6-17 with High Functioning Autism/Asperger Syndrome (HFA/AS) to a group of 55 typically-developing boys. There were no significant differences between HFA and AS groups on any of the motor measures. The combined HFA/AS group was shown to have significant impairment on several measures of motor control compared to the control group. Regression analyses revealed that a model including the PANESS variables measuring overflow, gaits, balance, and speed of patterned timed movements best distinguished HFA/AS from control subjects. ROC curve analyses showed that the PANESS offers a high level of discrimination in distinguishing autism from controls.

Correspondence: Eva M. Jansiewicz, M.A., Dept. of Clinical Psychology, Georgia State University, 321 10th St. NE, Apt. 1, Atlanta, GA 30309.E-mail:ejwhat@juno.com

\section{O'CALLAGHAN, R. CALVANIO, M. LEVINE, H. FISHBEIN \& C. GRANT. USE OF ELECTRONIC MONITORING TO DEFINE IN- DIVIDUAL DIFFERENCES AMONG ASPERGER STUDENTS.}

Children with Asperger's Syndrome often have considerable deficits in self-awareness and poor perception of others' feelings. In an effort to assess the possible benefit of hand held computers to promote self-awareness and to better understand some of the differences among Asperger children, twenty students and their teachers rated the students' behavior and affective expression three times/day over the course of 4 weeks in two different settings (classroom and lunchroom). A preliminary analysis of the data revealed three subtypes. Group 1 showed less negative emotion and a high level of teacher-student agreement on positive emotions and behavior. Group 2 was characterized by a high level of negative emotion on teacher reports. Group 3 was defined by a higher level of negative emotion in student reports than in teacher reports. The differences in predominant affects and behavior were analyzed across settings. The impact of self-monitoring with the hand held computer was assessed. The subtypes were compared with ratings on the Conners' and Gilliam Autism and Asperger Rating Scales. Differences in pre- and poststudy questionnaires were also analyzed. The data suggested a positive impact of electronic monitoring on certain affects and behaviors in more than half of the students. The intensive electronic monitoring and the detailed analysis defined which students would benefit from using a PDA as a regular part of their treatment and educational programs. Similar electronic monitoring programs could be adapted to work with children with various diagnoses.

Correspondence: Clare O'Callaghan, R.N., C.S., Ed.D., Mental Health, South End Community Health Center, 1601 Washington St., Boston, MA 02118.E-mail: clareoc68@aol.com

\section{BLACK, G. WALLACE, G. WALLACE, P. LEE, L. GILOTTY, T. AHLUVALIA, A. WAGNER \& L. KENWORTHY. DISTINGUISHING HIGH FUNCTIONING AUTISM AND AS- PERGER'S DISORDER ON THE BASIS OF IMAGINATIVE PLAY.}

A key distinction in the DSM-IV between high functioning autism (HFA) and Asperger's disorder $(\mathrm{AD})$ is the normal development of imaginative play in AD. While there has been much speculation on the relationship of imaginative play and the development of verbal ability among children with an autism spectrum disorder, relatively little research has examined this empirically. Verbal ability has been identified as an important prognostic factor in this sample and a key distinction between HFA and AD. Given this, the present study examines the relationship of imaginative play with neuropsychological measures of verbal, visual and executive functioning. We hypothesize that imaginative play is more related to verbal ability than it is to either visual ability or executive functioning. We identified 8 (M age=10.3, M FSIQ=95) children diagnosed with HFA solely on the basis of a lack of spontaneous imaginative play by age 5 (i.e., intact language development; HFA-IP) and compared them to 36 children with HFA (M age $=10.9$, M FSIQ=101) and 29 children with AD (M age=10.4, M FSIQ=112). We hypothesize that imaginative play is more related to verbal ability than it is to either vi- sual ability or executive functioning. While there were no consistent differences between the three groups on visual or executive measures, a consistent pattern emerged on verbal tasks. On all three verbal measures, the AD sample achieved the highest score, followed by the HFAIP sample, and the HFA sample's scores were the lowest. These findings suggest that imaginative play is an important diagnostic and prognostic factor in autism spectrum disorder.

Correspondence: Greg Wallace, MA, Child Psychiatry, NIMH, Building 10, Room 4C110, 10 Center Drive, MSC 1367, Bethesda, MD 208921367. E-mail: gregwallace@mail.nih.gov

\section{G. WALLACE, D. BLACK, L. GILOTTY, P. LEE, T. AHLUVALIA, A. WAGNER \& L. KENWORTHY. IS THERE A NEUROPSYCHO- LOGICAL DIVERGENCE OF HIGH FUNCTIONING AUTISM AND PDD-NOS?}

Pervasive Developmental Disorder-Not Otherwise Specified (PDD-NOS) is a diagnostic category used to designate a group of individuals whose symptom presentation is reminiscent of autism but does not meet the full criteria for the disorder. Despite its inclusion in the DSM-IV and in contrast to other autism spectrum disorders, very few neuropsychological studies have been completed on PDD-NOS. The present exploratory study provides a neuropsychological characterization of school-age children with PDD-NOS and seeks to determine if there is a divergence from the neuropsychological profile of individually-matched (on FSIQ) children with high functioning autism (HFA). The subjects included 15 children with PDD-NOS (M age=10.2, M FSIQ=96.5) and 15 children with HFA (M age=10.6, M FSIQ=97.5) evaluated in a pediatric neuropsychological service. A neuropsychological test battery assessing attention (TOVA), executive functioning (Phonemic Fluency, Rey-Osterrieth Complex Figure Organization, BRIEF), memory (WRAML Sentence and Story Memory, CMS Dot Locations and Family Picture Memory), and behavior problems (BASC Internalizing and Externalizing behavior scores) was utilized. This study found the neuropsychological profiles were very similar between groups, with one notable exception. Children with HFA demonstrated more impaired ability to use organizational strategies in both verbal and visual domains than did PDD-NOS children (r2\&\#8710;=0.15). Given that PDD-NOS represents a sub-threshold version of autism, these organizational difficulties may be tied to severity of autistic traits and therefore impact prognosis.

Correspondence: Greg Wallace, MA, Child Psychiatry, NIMH, Building 10, Room 4C110, 10 Center Drive, MSC 1367, Bethesda, MD $20892-$ 1367.E-mail:gregwallace@mail.nih.gov

\section{J.B. REED, M. BARTON, D. FEIN, M. STEVENS, M. DUNN, L. WAINWRIGHT \& L. WATERHOUSE. PRESCHOOL PLAY BE- HAVIOR AS A PREDICTOR OF SCHOOL AGE OUTCOME IN CHILDREN WITH AUTISM. .}

Children with autism show absent, infrequent, or simplified symbolic play and their play is qualitatively different from the play of mentally retarded, typical, or physically handicapped children. Many studies have found that play behavior in children with autism spectrum disorder (ASD) is positively correlated with language development and cognitive functioning. These studies have been limited by small sample sizes and few have examined play as a longitudinal predictor of outcome for children with ASD. A longitudinal analysis was conducted using a sample of 78 children with ASD to investigate whether play behavior in preschool age children predicted school age functioning when nonverbal IQ and language were covaried. Nonverbal IQ, receptive and expressive language, and play variables, including mouthing toys, waving/banging toys, construction play, symbolic animate play, and symbolic inanimate play, were examined at preschool age. School age functioning was indexed by autistic symptoms, communication skills, socialization skills, receptive language, and nonverbal IQ. Results indicate that symbolic animate play predicted total autistic symptoms at school age. Symbolic inanimate, symbolic animate, and construction play predicted 
communication skills at school age. Play variables did not predict socialization, nonverbal IQ, or receptive language at school age, once IQ and language were controlled. Overall, the data suggest that some types of play in preschool age children with autism can predict the outcome when both IQ and language are controlled. This demonstrates the importance of looking at play behavior in assessing preschool aged children with autism and also has implications for intervention with these children.

Correspondence: Jillian B. Reed, B.A. Psychology, University of Connecticut, 26 Hickory Hill Dr., Andover, CT 06232. E-mail: jillruconn@ yahoo.com

\section{J. LORD, K. DALBEC-MRAZ, H. BOORSTEIN, L. WILSON, E. ESSER \& D. FEIN. AFFECT PROCESSING IN RELATION TO ADAPTIVE FUNCTIONING IN CHILDREN WITH AUTISM SPEC- TRUM DISORDER.}

Autism Spectrum Disorder (ASD) is a neurodevelopmental disorder characterized by impairments in communication and socialization and atypical and stereotypical patterns of interest and activity. Research has suggested that individuals with ASD are impaired in the identification and expression of affect. The present study investigated the relationship between affect processing and adaptive functioning in children with ASD $(n=12)$ and typically developing children $(n=22)$ between the ages of 6 and 12. Participants were matched by age and Stanford-Binet Vocabulary raw score. Two batteries of affect processing were administered to all participants to examine their ability to verbally identify emotion from video- and audio-taped visual and auditory stimuli and to match affect based on photographs of facial expressions and situations. In addition, the Vineland Adaptive Behavior Scales were administered to all participants to explore the relationships between affect processing and adaptive functioning. Results indicated no differences between the two groups in their performance on the matching battery. However, the children with ASD were significantly impaired in their ability to verbally identify emotion when presented with dynamic visual $(p=.045)$ and auditory/visual stimuli $(p=.028)$ but not auditory only stimuli $(p=.064)$. Performance on both affect batteries was significantly correlated with scores on the Daily Living Skills and Socialization domains of the Vineland Adaptive Behavior Scales for both groups. These results suggest that sensory modality and static vs. dynamic mode of presentation have a significant impact on the ability to process affect in individuals with ASD and that these impairments are significantly related to the deficits in socialization and daily living skills observed in this population. Correspondence: Jessica Lord, BA, Psychology, University of Connecticut, 406 Babbidge Road, U-1020, Storrs, CT 06492-1020. E-mail: jessicalord@sbcglobal.net

\section{S.C. GUY, E. AMIGO, P. ISQUITH \& G.A. GIOIA. SELF-RE- PORTED EXECUTIVE FUNCTION IN ADOLESCENTS WITH} AUTISM SPECTRUM DISORDERS: EVIDENCE OF AWARENESS .

Executive dysfunction plays an important role in the cognitive and social impairments of children with autism spectrum disorders (ASD). We present a study examining the self-identified executive functioning of adolescents with ASD using the BRIEF-Self Report (BRIEF-SR), an 80-item inventory for ages 11-18 years. Ratings of 46 adolescents (34 boys, 12 girls) clinically diagnosed with ASD were compared with matched controls. A MANOVA revealed significant elevations on all BRIEF-SR scale and index scores for the clinical group with the exception of the Inhibit scale. Effect sizes ranged from small for Organization of Materials $(\eta 2=.04)$ to large for Task Completion $(\eta 2=.26)$, Working Memory $(\eta 2=.21)$ and Shift $(\eta 2=.19)$. The highest mean T scores were reported by adolescents with ASD on the Shift scale $(\mathrm{M}=$ 61.72, SD = 11.87) with elevations on both the Behavioral Shift and Cognitive Shift subscales. Parent ratings on the BRIEF were available for a subset of the ASD sample $(n=21)$. Correlations were strong between like scales including the Inhibit $(r=.55, \mathrm{p}<.01)$, Shift $(\mathrm{r}=.68$, $\mathrm{p}<.001)$, Monitor $(\mathrm{r}=.56, \mathrm{p}<.01)$, Working Memory $(\mathrm{r}=.52, \mathrm{p}<$ $.05)$, Plan/Organize $(\mathrm{r}=.72, \mathrm{p}<.001)$ and Organization of Materials $(\mathrm{r}=.47, \mathrm{p}<.05)$ scales. While self-reports on the BRIEF-SR were lower than parent BRIEF ratings, the pattern of elevations was similar. Adolescents with ASD were able to identify their own executive strengths and weaknesses.

Correspondence: Steven C. Guy, Ph.D., Private Practice, 170 North Woods Boulevard, Suite 220, Columbus, OH 43235.E-mail:stevenguy@ columbus.rr.com

\section{GILOTTY, P. LEE, G. WALLACE, D. BLACK, T. AHLUVALIA, A. WAGNER \& L. KENWORTHY. THE RELATIONSHIP BE- TWEEN EXECUTIVE FUNCTIONING AND SYMPTOM PRESEN- TATION IN AUTISM SPECTRUM DISORDERS.}

This study examines the relationship between executive functioning and autistic symptomatology. We hypothesized that severity of executive dysfunction would be related to severity of autistic symptomatology on parent report measures. Specifically, we predicted that executive dysfunction, as measured by the Behavior Rating Scale of Executive Function (BRIEF) would be related to the level of autistic symptomatology, as measured by the Autism Diagnostic Interview-Revised (ADI-R). Subjects were 27 children with autism spectrum disorders (ASD), between 6-17 years of age $(\mathrm{M}=9.49, \mathrm{SD}=3.04)$, who were consecutively evaluated in a neuropsychological service. Results found a significant correlation between the Repetitive Behaviors and Stereotyped Patterns scale of the ADI-R and the Shift $(r=.69, p<.001)$, Emotional Control $(r=.59$, $\mathrm{p}=.001)$, and Monitor subscales $(\mathrm{r}=.38, \mathrm{p}=.048)$, as well as the Behavior Regulation Index (r=.61, p=.001) and the Global Executive Composite $(\mathrm{r}=.48, \mathrm{p}=.019)$ of the BRIEF. No other significant relationships were noted. The Repetitive Behaviors and Stereotyped Patterns scale of the ADI-R assesses, in part, the extent of verbal and behavioral rituals and rigidity in interests. On the BRIEF, the subscales that were significantly correlated with the ADI-R evaluate the ability to flexibly move from one task or idea to another, modulate emotional responses, and track the effect of one's own behavior on others. Thus, several different relationships were demonstrated between level of autistic symptomatology and severity of executive dysfunction. Regression analysis found that within the domains of executive functioning, Shift was most predictive of autistic symptomatology (Standard Beta=.548, p=.01), indicating that flexibility is an important determinant within ASD.

Correspondence: Philip Lee, Children's National Medical Center, 4900 Massachusetts Ave., NW, Suite 320, Washington, DC 20016. E-mail: pslee@cnmc.org

\section{N. KLEINHANS, N. AKSHOOMOFF \& E. COURCHESNE. MODALITY-SPECIFIC DEFICIT IN ABSTRACTION IN AUTISTIC DISORDER AND ASPERGERS DISORDER.}

The ability to think and reason abstractly is recognized to be deficient in individuals with autism spectrum disorders (ASD). However, a recent study proposed that abstraction ability may not be globally impaired in autism. Rather, this deficit may reflect a specific difficulty in concept formation, with concept identification remaining intact. The present study used the Sorting Test from the Delis-Kaplan Executive Function System to evaluate verbal and perceptual concept formation and problem solving abilities in individuals with ASD. Twelve males with Autistic Disorder or Aspergers Disorder, aged 14 to 42 years, with low average to high average intellectual abilities participated. Participants sorted cards into two groups and described the sorting principles used to create the groups during Free Sorting (concept formation) and described card sorts that were generated by the examiner during Sort Recognition (concept identification). The ASD participants were not significantly below average in their ability to generate target sorts in the Free Sorting condition. Further, contrary to previous claims, our participants performed significantly worse on Sort Recognition relative to Free Sorting. indicating that concept identification ability may not be spared in ASD. 
Despite generating comparable levels of perceptually and verbally based sorts, the ASD group displayed a significant impairment in the ability to describe the verbal but not the perceptual sorting principles. These findings indicate that high functioning individuals with ASD do not have a deficit in forming concepts; however, difficulty describing abstract concepts may reflect a modality-specific impairment limited to the verbal domain.

Correspondence: Natalia Kleinhans, SDSU/UCSD, Children, $8110 \mathrm{La}$ Jolla Shores Dr., La Jolla, CA 92037.E-mail:nkleinhans@ucsd.edu

\section{V.K. JERATH, P. DUBEY, E. JANSIEWICZ, A.M. BARRETT, M.C. GOLDBERG \& S.H. MOSTOFSKY. ASSESSMENT OF ER- ROR TYPES ON PRAXIS EXAMINATION IN CHILDREN WITH AUTISM.}

Children with autism have been reported to show impaired performance on praxis examination; however, much less is known about the types of errors made while performing skilled motor gestures. A videotaped version of the Florida Apraxia Screening Test-Revised was used to determine whether children with autism show impaired performance on gesture to command (GTC), imitation, and gesture with tool use (TU) and to assess the types of errors made by children with autism compared with those made by controls. Seventeen children with high functioning autism (HFA) or Asperger syndrome, ages 8-12 years and 30 agematched controls participated in the study. Preliminary analyses revealed no significant differences in performance between children with HFA and those with Asperger syndrome; these two groups were collapsed into a single autism group in subsequent comparisons with controls. Children with autism made significantly more errors than controls during GTC, Imitation, and TU (all at $\mathrm{p}<0.0001$ ). Multivariate linear regression analyses controlling for age and IQ demonstrated higher errors in children with autism across all error types, except temporal. Spatial errors were the most common errors made in both groups, and comprised a similar percentage of total errors made by each group $(76 \%$ of total errors made by children with autism; $80.9 \%$ of total errors made by controls). The findings suggest that children with autism have impaired performance on praxis examination. The profile of errors is consistent with that made by typically developing children and suggests abnormalities in neural mechanisms important for acquisition of spatial representations of movement.

Correspondence: Vandna K. Jerath, Undergraduate Student, Johns Hopkins University, Department of Developmental Cognitive Neurology, Kennedy Krieger Institute, 707 N. Broadway, Baltimore, MD 21205. E-mail:VJ2100@aol.com

\section{G. VOELBEL, G. LOCASCIO, M.E. BATES, C. DESAI, G. PAND- INA \& R. HENDREN. CEREBELLUM AND VERMIS DIFFER- ENCES IN CHILDREN WITH AUTISM SPECTRUM AND BIPOLAR DISORDER.}

In comparing adults diagnosed with bipolar disorder (BD) to control samples, neuroimaging studies have reported no difference in cerebellum volume, while mixed results have been reported for the vermis. Prior studies of children diagnosed with autism have more consistently found larger cerebellum volumes and smaller area measurements of vermis lobules VI-VII. This study examined the volumes of the cerebellum and vermis in children diagnosed with $B D(N=20,16$ males, mean age $=10.50$ $\mathrm{SD}=1.27$ ), autism spectrum disorder (Aspergers Syndrome and High Functioning Autism, ASD; $\mathrm{N}=44,42$ males, mean age=10.25 SD=1.96) and children without psychiatric diagnoses ( $N C ; \mathrm{N}=22,16$ males, mean age $=10.55 \mathrm{SD}=1.87$ ). After controlling for total brain volume, age, and gender, a significant group difference was found for total cerebellum volume $(F(5,79)=10.08, p<.0001)$. Post-hoc analyses demonstrated that the ASD group had significantly larger volumes than the BP and NC groups; no other group differences were found. For the vermis volume analyses, cerebellum volume, age, and gender were controlled $(\mathrm{F}(5,72)=5.04, \mathrm{p}<.001)$. The BP group had a significantly smaller mean volume than the ASD and NC groups, while the ASD and NC groups did not differ. These results support the hypothesis of unusual brain growth in the cerebellar hemispheres of children diagnosed with ASD, but not BP. The results further suggest that children with BP may have abnormal growth of the vermis compared to same age children without any psychiatric disorders and children diagnosed with ASD. Potential differences in the neurodevelopment of the cerebellum and vermis between the diagnostic groups will be discussed.

Correspondence: Gerald Voelbel, MS, Rutgers University, 607 Allison Road, Piscataway, NJ 08902. E-mail: gvoelbel@rci.rutgers.edu

\section{S. KILIAN, W.S. BROWN, P.J. POLITO, E. BIGLER, W. MCMA- HON \& J. LAINHART. MORPHOLOGY OF THE CORPUS CALLO- SUM IN AUTISM AND MARCOCEPHALY.}

Although most previous investigations report decreased size of the corpus callosum $(\mathrm{CC})$ in autism, results are inconsistent and there is little agreement regarding what parts of the $\mathrm{CC}$ are smaller. Macrocephaly, occurring in $14-27 \%$ of individuals with autism, was not controlled for in previous studies. This study investigated differences in regional callosal size in 4 groups: males with high functioning autism who were either normocephalic ( $\mathrm{N}=28$ ) or macrocephalic ( $\mathrm{N}=13)$, non-autistic normocephalic controls $(\mathrm{N}=20)$, and non-autistic participants with benign macrocephaly $(\mathrm{N}=8)$. Factor analysis of 99 equidistant $\mathrm{CC}$ widths obtained from midsaggital MRI tracings resulted in a best fit with 10 contiguous CC subregions. A series of 2 X 2 (diagnosis of autism X head size) MANCOVAs of total CC area and regional CC areas (controlling for age and total intracranial volume) revealed that participants with macrocephaly (autism with macrocephaly and benign macrocephaly) had larger total callosal area $(\mathrm{p}<.01)$ and a larger CC midbody $(\mathrm{p}<.05)$. There was no main effect of autism, or an interaction between autism and macrocephaly. However, in a post-hoc MANCOVA including only normocephalic participants, the genu $(\mathrm{p}<.05)$ and midbody $(\mathrm{p}<.05)$ were found to be smaller in individuals with autism. These results underscore the importance of considering head size in brain studies of autism. The divergent findings of larger CC and subregions in individuals with autism and macrocephaly and smaller CC subregions in normocephalic individuals with autism suggest different neurobiological mechanism involved in autism with vs. without macrocephaly.

Correspondence: Warren S. Brown, Ph.D., Fuller Graduate School of Psychology, Travis Research Institute, 180 N. Oakland Ave, Pasadena, CA 91101. E-mail: wsbrown@fuller.edu

\section{J.L. SAYER, M.A. FEARING, E.D. BIGLER, W.M. MCMAHON \&. J.E. LAINHART. VOLUMETRIC ANALYSIS OF THE BASAL GAN- GLIA IN AUTISM WITH MACROCEPHALY.}

Background and Objectives: Some speculation has been made implicating an association of basal ganglia abnormalities with autism; however, not all neuroimaging studies have demonstrated the presence of volumetric differences. One reason for the lack of consistent findings may be failure to control for the increased prevalence of macrocephaly found in autism. Methods: In the current study, using 1.5 Tesla magnetic resonance (MR) imaging and controlling for head size, we obtained basal ganglia volumes including the caudate nucleus, putamen, and globus pallidus in 65 subjects (age range 7-25). Four groups were examined: a normocephalic normal control group $(\mathrm{N}=22)$, an autistic normocephalic group $(\mathrm{N}=20)$, an autistic macrocephalic group $(\mathrm{N}=$ 14), and a comparison benign macrocephalic group ( $\mathrm{N}=9)$. All autism subjects met ADI, ADOS, and DSM-IV criteria for autism and most of them were high-functioning. The areas of measurement included left, right, and total caudate, putamen and globus pallidus. Intra- and interrater reliabilities were assessed $(\mathrm{r}=.90)$ and quantitative analyses performed by two independent raters following an established protocol. Results: Significant differences in the caudate, putamen and total basal ganglia measures were found using a between subjects comparison for all groups, influenced solely by the presence of the autism and 
control groups with macrocephaly. However, after controlling for head size, no significant differences were found. Conclusions: No unique or gross volumetric differences in basal ganglia structures were associated with autism. These findings suggest the importance of functional imaging studies to examine the potential role of the basal ganglia in autism. Correspondence: Erin D. Bigler, Ph.D., Psychology, Birgham Young University, 1001 SWKT, Provo, UT 84606.E-mail: erin_bigler@byu.edu

\section{Other Neurodevelopmental Disorders and Learning Disabilities}

\section{R. NASS, F. LEVENTHAL, R. PERRY, J. COHEN, S. BEZSYLKO, M. SHEPHERD, S. GOLDMAN \& W. SOLODOW. NON VERBAL LEARNING DISABILITIES: FREQUENCY AND BASIS FOR DIAG- NOSIS IN A LEARNING DISABILITY SCHOOL COHORT.}

To investigate frequency and diagnostic criteria for NVLD, 3 professional groups reviewed the files of the 98 junior-senior high school students at a NYC LD school. Files included admission psychometrics, parent applications, report cards with comments, and biannual standardized tests of reading, arithmetic and writing. Indicating whether the diagnosis was NVLD or not, raters spontaneously listed the main reasons for their decision and completed a 44 item 1-5 Leikart scale rating the degree to which each item influenced diagnosis in each student. Educators classified 22 students as NVLD; psychotherapists classified 40; neurodevelopmentalists classified 49.11 students were classified as NVLD by all groups, 33 students as not NVLD. The 2 clinical groups were each more likely than the educators to classify a student as NVLD. All groups used a large VIQ PIQ difference, math and visuospatial difficulties as the most common reasons for diagnosis. 12 Leikart items correlated with an NVLD diagnosis: VIQ PIQ discrepancy; gross motor difficulties; peer relationship problems; math concepts difficulties; weak visual organization; poor visual memory; arithmetic difficulty; slow visual processing; poor perceptual skills; inability to find salient features; difficulty perceiving gestalt; nonverbal reasoning problems. $23 \%$ to $56 \%$ of the students at this LD school were judged to have NVLD, a higher frequency than is usually reported. Ratings by the professional groups varied considerably with the educators least likely to diagnose NVLD. The educators required an early strength in reading and spelling and a clear discrepancy between ability and achievement. The educators did not consider social emotional problems as a criterion for NVLD and excluded children with ADHD. All professional groups vacillated about the diagnosis of NVLD in children with both language based dyslexia and NVLD.

Correspondence: Ruth Nass, MD, NYU Medical Center, 400 east 34th street, New York, NY 10016.E-mail:ruth.nass@nyu.edu

\section{N. AKSHOOMOFF, J. STILES \& B. WULFECK. PERCEPTUAL ORGANIZATION AND VISUAL MEMORY IN CHILDREN WITH DEVELOPMENTAL LANGUAGE DISORDER.}

Recent studies indicate that children with developmental language disorder (DLD) may also have developmental difficulties with certain aspects of nonverbal processing. The present study sought to test the hypothesis that despite the diversity of this disorder, subtle deficits in visuospatial skills would be found across subjects. Participants included 15 children with DLD (ages 11 to 12 years; mean PIQ = 102 and VIQ = 87). A group of 40 typically developing same-age children also participated. All participants were given the Rey-Osterrieth Complex Figure task. Using a standardized approach to scoring copy and immediate memory performance (BQSS; Stern et al., 1994), the scores for the children with DLD generally fell within the range of their peers. However, similar to the results of our study of children with early unilateral stroke (Akshoomoff et al., 2002), visuospatial deficits were observed upon analysis of the method used to copy the figure. Despite generally good production performance, the children with DLD tended to use a fairly piecemeal approach when copying the figure, which compromised their ability to recall the figure. The neuropsychological implications of these findings, as well as how these may intersect with aspects of language and academic functioning in children with DLD will be discussed. Correspondence: Natacha Akshoomoff, Ph.D., Psychiatry, University of California San Diego, 8110 La Jolla Shores Drive, Suite 200, La Jolla, CA 92037.E-mail: natacha@ucsd.edu

\section{J.S. SIERATZKI, S. SURGULADZE, G. CALVERT, A.S. DAVID \& B. WOLL. THE PROCESSING OF SPOKEN, WRITTEN AND SIGNED LANGUAGE IN LKS: AN FMRI AND LINGUISTIC STUDY.}

Landau Kleffner Syndrome (LKS) is an enigmatic acquired auditory agnosia of childhood, associated with and most likely caused by severe bilateral epileptic activity in temporo-parietal regions. The exact association between epilepsy and the loss of already functioning language is unclear; as is the reason for the persistence of global aphasia after the remission of epileptic activity. Clinical signs of epilepsy invariably cease at puberty, and often show significant fluctuations during earlier childhood. Previous functional imaging studies in adult patients with LKS have reported metabolic hypoactivity in affected cortical areas, supporting the concept of functional ablation originally suggested by Landau and Kleffner. However, in these studies, patients were at rest and not challenged by any language processing task. We have now completed two fMRI case studies of patients with LKS - a 25 year old man, and an 11 year old girl - in which cortical activity was measured during various language tasks: listening to speech, reading text, lipreading of silently mouthed words, and viewing British Sign Language signs. The most prominent finding is very strong temporo-parietal activation in response to speech input, suggesting an underlying state of hyper-connectivity or hyper-reactivity rather than of post-epileptic neural ablation. The pattern of fMRI findings in all four tasks in combination with comprehensive language performance tests, has provided new insights into the pathophysiology of LKS and further supports our previous recommendation regarding the use of a sign language in patients affected by this condition.

Correspondence: Bencie Woll, PhD, City University London, Northampton Square, London EC1V OHB, United Kingdom. E-mail: b.woll@city:ac.uk

\section{B. KLEIN-TASMAN, K.T. LI \& F. GALLO. BEHAVIOR OFYOUNG CHILDREN WITH WILLIAMS SYNDROME: OVERLAP WITH PER- VASIVE DEVELOPMENTAL DISORDERS?}

Williams syndrome (WS) is a genetically-based neurodevelopmental disorder with a characteristic pattern of cognitive and personality characteristics. Although children with WS are sociable and may show a relative strength in their linguistic abilities, language acquisition and gestural development (especially pointing) are typically delayed. Abnormality in the modulation of eye contact (e.g.., overly intense gaze) has also been demonstrated. Given these observations of socio-communicative deficits, there is evidence that the behavior shown by very young children with WS may overlap with the autism spectrum. In the current study, we examined the correspondence between Autism Spectrum Disorder (ASD) classification on Module 1 of the Autism Diagnostic Observation Schedule (ADOS) and elevated scaled score on the Child Behavior Checklist Pervasive Developmental Problems scale (CBCLPDP) for children with Williams syndrome and children with developmental disabilities of other etiologies (DD; e.g., Down, XXX, Kabuki syndromes). Participants ranged in age from 26 to 62 months. Divergent patterns of correspondence between the CBCLPDP and the ADOS were found for the two participant groups. For the children with other DD, elevation on the CBCLPDP scale was more likely than elevation on the ADOS. The opposite was found for the children with WS; very few showed elevated CB- 
CLPDP, whereas more than half showed behavior consistent with ADOS ASD classification. The specific pattern of abnormalities observed on the two measures, and the implications of these findings for the understanding of the socio-communicative behavior of children with WS will be discussed.

Correspondence: Bonnie Klein-Tasman, Ph.D., Psychology, University of Wisconsin - Milwaukee, PO Box 413, Garland 210, Milwaukee, WI 53211.E-mail:bklein@uwm.edu

\section{G.F. MYERS, G. GERNER \& M. MAZZOCCO. MATH PERFOR- MANCE IN GIRLS WITH FRAGILE X OR TURNER SYNDROME: MODELS OF MATH LD SUBTYPES.}

Relative to research on reading disability (RD), far less is known about math disability (MD). We present results of an ongoing longitudinal study of MD in girls at risk for poor math achievement due to having fragile $X(n=11)$ or Turner syndrome $(n=20)$. Results are compared to those from children who present with persistent MD (MD for $>2$ years) in primary school $(\mathrm{n}=22)$, drawn from a prospective longitudinal study with a relatively random sample of participants $(n=209)$. Comparisons were based on (a) Gearys (1993) model of MD subtypes, and (b) data on early predictors of poor math achievement (Mazzocco \& Myers, 2003). Results indicate that (1) girls with either disorder are at significantly greater risk for poor math achievement than children in the general population. (2) In both groups, early MD is likely to reflect persistent MD. Among kindergartners scoring <10th percentile on the Test of Early Math Ability (TEMA), $85 \%$ of those with Turner, and $100 \%$ with fragile $\mathrm{X}$, continued to perform at that level between grades 1-3, relative to the rate of $63 \%$ reported in the general population (Mazzocco \& Myers. 2003). (3) Neither group showed evidence of a Semantic Memory MD subtype that typically co-occurs with RD, although (4) both groups showed different associations between math and either visuospatial or working memory performance. Neither group showed clear evidence of a Procedural or Visuospatial MD subtype, but different aspects of each. We argue that comparisons of these groups may facilitate differentiation of these two MD subtypes.

Correspondence: Michele Mazzocco, PhD, MSDP, Kennedy Krieger Institute, 3825 Greenspring Avenue, Painter Bldg, Top Floor, Baltimore, MD 21211.E-mail:mazzocco@kennedykrieger.org

\section{K. LESNIAK-KARPIAK \& M.M. MAZZOCCO. EXAMINATION OF VISUAL SPATIAL SKILLS IN GIRLS WITH TURNER OR FRAGILE X SYNDROME.}

Neuropsychological profiles of females with Turner or fragile $X$ syndromes suggest that both groups have impairments in visuospatial skills. However, most visuospatial measures that have been used in studies thus far do not examine component processes (e.g., spatial location or visual object perception) that might contribute to the poor performance. We compared girls with Turner syndrome $(n=19)$ or fragile $X(n=9)$ to girls with neither disorder $(n=107)$ on a modified version of the Developmental Test of Visual Perception - Second Edition (DTVP-2), used to assess various aspects of visual perception. The four subtests administered included spatial orientation (Position in Space), figure/ground distinction in embedded designs (Figure/Ground), form detection from degraded designs (Visual Closure), and shape constancy (Form Constancy). An experimental measure of incidental visual short-term memory followed standardized administration of Figure/Ground; it involved recalling the overall array of ten stimuli appearing one each page of the Figure/Ground subtest, and recalling precise location of each shape. All three groups of girls performed within the average range on the standardized Figure/Ground subtest but important findings emerged on the experimental memory measure. Girls with fragile $\mathrm{X}$ were more likely to miss the overall pattern of the layout while girls with Turner syn- drome placed significantly fewer shapes in the correct locations. The problems demonstrated by girls with Turner syndrome seem indicative of visual memory problems versus visual perception skills. In contrast difficulties displayed by girls with fragile $\mathrm{X}$ may be explained in terms of global vis-a-vis local processing.

Correspondence: Katarzyna Lesniak-Karpiak, Ph.D., Private Practice, 104 Indian Run Dr., Douglassville, PA 19518. E-mail: kasiaL@ ceinetworks.com

\section{J.W. KIRK, S.T. KOVER \& M.M. MAZZOCCO. EXECUTIVE FUNCTIONING IN GIRLS WITH TURNER OR FRAGILE X SYN- DROME .}

The construct of executive functioning (EF) subsumes a broad range of skills important in development; disruption of its development can significantly influence behavioral, academic, and emotional functioning. Various studies have documented poor EF performance by individuals with fragile $\mathrm{X}$ (FXS) or Turner syndrome, without identifying type(s) of executive dysfunction. The aim of this study was to describe subcomponents of EF, using the Contingency Naming Test (CNT), in groups of high-functioning girls with FXS ( $\mathrm{n}=11$, mean age=9.05yrs) or Turner syndrome $(n=20$, mean age $=8.98$ yrs $)$ relative to FSIQ-matched comparison groups $(n=12$, mean age $=8.70 \mathrm{yrs} / \mathrm{n}=90$, mean age $=8.63 \mathrm{yrs}$, respectively). We hypothesized that both groups would be slower than their comparison group on warm-up naming tasks (PartA) and have more difficulty with executive tasks (PartB); that girls with Turner syndrome would make self-corrections, showing more impulsivity; and girls with FXS would make more errors, reflecting a lower threshold for working memory demands. Using nonparametric tests, both groups were slower on the basic naming task (PartA,p<.03), despite group-matching for IQ (FXS-FSIQ=87.18; Control-FSIQ=91.42; TurnerFSIQ=103.95; Control-FSIQ=107.07). Also, both groups were inefficient on executive tasks $(p<.03)$; but for different reasons. The FXS group needed more trials to learn the first executive task $(\mathrm{p}<.02)$; whereas the Turner group made more errors on the second, more difficult executive task (ErrorsB4,p<.05). No significant group difference emerged for self-corrections. Thus results support previous research suggesting EF deficits in both groups relative to controls: the FXS group had a lower working memory threshold and the Turner group had greater difficulty than their peers on the more complex executive task.

Correspondence: John W. Kirk, Psy.D., Department of Neuropsychology, Kennedy Krieger Institute, 1750 East Fairmount Ave., 3rd Floor, Baltimore, MD 21231. E-mail: kirkj@kennedykrieger.org

\section{K.H. VANZUTPHEN \& W. PACKMAN. EXECUTIVE FUNCTION- ING IN CHILDREN WITH PHENYLKETONURIA: A PILOT STUDY.} There is evidence suggesting cognitive and neuropsychological deficits in early-treated and optimally managed patients with PKU. Specifically, metabolic disturbances in children with PKU may affect development of the prefrontal cortex and executive functioning (Welsh \& Pennington, 2000). Further, it has been suggested that higher-order executive functions are disrupted in children with PKU, with relatively spared lower-order functions and normal intelligence. We examined executive functioning in a clinical sample of 15 children and adolescents with PKU. Using independent t-tests, performance on several subtests from the Delis-Kaplan Executive Function System (D-KEFS) were compared to D-KEFS normative data. The mean Free Sorting Description and Sort Recognition Description scores from the PKU group were significantly lower than normative data $(\mathrm{p}<.05)$. Large effect sizes were calculated between groups for other D-KEFS subtests utilized (Tower, Color-Word Interference, Verbal Fluency, Design Fluency and specific error analyses), while no differences were found between the PKU group and normative data on a measure of intelligence (Wechsler Abbreviated Scale of Intelligence). In this clinical sample of children and adolescents with PKU, higher-order executive functioning such as verbal concept formation and reasoning skills were significantly lower than normative 
data. This finding is concurrent with recent literature suggesting deficits in higher-order skills in children with PKU, with relatively intact overall intelligence. Clinically, deficits in higher-order skills can affect daily functioning and maintenance of life or job skills. More research is needed in this area.

Correspondence: Kelly H. vanZutphen, M.S., kennedykrieger/johns hopkins university school of medicince, 333 Paddington Rd., Baltimore, MD 21212. E-mail: vanzutphen@kennedykrieger.org

\section{J. ROMAIN, A. HEFFELFINGER \& L. CONANT. TREATMENT AP-} PROACHES IN THE SYNDROME OF DEVELOPMENTAL AMNESIA.

There has been extensive research into our understanding of the amnesic syndrome within the adult population; however, modest gains have been made in the treatment of developmental amnesia (DA) secondary to prenatal/perinatal insult. The hallmark of this disorder appears to be an absence of memory declines over time and preserved semantic memory, which challenges the current perception of amnesic disorders. At present, minimal focus has been placed on interventions. We present a case of a young girl with a history of prematurity, fetal distress, and perinatal seizures associated with neonatal abstinence syndrome, who was initially evaluated for attentional and behavioral problems. Although intelligence and general knowledge was average, immediate and delaved recall of verbal and nonverbal information was well below average, despite adequate attention and effort. At one-year follow-up, continued gains in acquired knowledge were evident, with persistent memory impairments (2-3 SD below the mean). Attention and working memory were relative strengths and high average. Clinical conclusions were that her symptoms were consistent with DA, which largely accounted for her perceived attentional difficulties. Recommendations included home and classroom modifications for memory, and attention and behavior. These neurobehavioral strategies and the recent inclusion of psychostimulant medication have been ineffective in ameliorating the core memory deficits. Recent studies have reported antidepressant treatments to increase cell proliferation in the hippocampus and dentate gyrus in adult humans and in animal models (McEwan et al., 2002). Consideration might be given to the potential combination of antidepressants and neurobehavioral strategies in the treatment of developmental amnesia. Correspondence: Jonathan Romain, Ph.D., Neurology, Medical College of Wisconsin, 9200 West Wisconsin Avenue, Wauwatosa, WI 53226. Email:jromain@mcw.edu

\section{Z.A. MELIKYAN. TWO VISUAL PROCESSING STRATEGIES AMONG LEARNING DISABLED PRESCHOOL AND ELEMENTARY SCHOOL CHILDREN.}

In an individualized approach to cognitive rehabilitation in learning disabled (LD) children, it is important to reveal the types of information processing strategies among these children. Present investigation demonstrates two types of visual information processing associated with primary functional deficit of the left vs. right hemisphere among LD children. 51 LD children, age 5 - 9 y.o. (mean 7.9) were compared to 50 controls, age 5 - 8 y.o. (mean 6.11). LD children attended special kindergarten or school, and their diagnoses were verified by a neurologist who revealed a minimal brain damage in all the children, and by a psychologist who demonstrated the delay in cognitive development. Children from the control group attended regular kindergarten or school and demonstrated no neurological, cognitive, or behavioral disorders. Modified Luria's neuropsychological assessment battery for children (Akhutina et al., 1996, 2001) was applied to both groups, followed by the test of memory reproduction of hierarchical letter stimuli (THL). Neuropsychological assessment results allowed to separate two subgroups in each group - children with functional deficit of the right vs. left hemisphere. Differences in functional brain organization were confirmed by the results of EEG registration during visual-spatial task processing. These subgroups demonstrated different strategies of visual information processing in THL. Children with functional left hemisphere deficit significantly more often $(p<0.05)$ reproduced the global level of visual pattern, whereas children with functional right hemisphere deficit tended to reproduce local level. While differences in the strategies of visual information processing in children with local brain injury were reported in literature earlier (Stiles \& Thal, 1993), present findings demonstrate similar results in children with mild cognitive disorders.

Correspondence: Zara A. Melikyan, Psychology, LMSU, Mokhovaya str.8-5, Moscow103009, Russian Federation.E-mail: zmelikyan@ yahoo.com

\section{J.A. HOLDNACK, L. WEISS \& J. HALE. CHILDREN WITH READ- ING DISORDER: THE EFFECTS OF IQ AND IQ-ACHIEVEMENT DISCREPANCY.}

The re-authorization of IDEA sparked intense debates regarding the utility of the IQ-Achievement discrepancy model and questioned the value of any cognitive assessment in the identification of children with learning disabilities (Pasternak, 2002). This study analyzed a large, nationally representative, community sample of 713 children, ages 6.0 to 13.5 years. This data was collected as part of the WISC-IV-WIAT-II linking study. In this sample, 128 children were determined eligible for special education services due to a reading disorder. Of the diagnosed group, 34\% had FSIQ > Reading Decoding by 15 or more points. The main effects and interactions of reading diagnosis (DX), IQ-Reading Decoding Discrepancy (IQD), and Ability (AB) on reading, writing, language, and math performance were analyzed. Main effects for each independent variable were significant for most academic skills and multiple interactions also occurred. A significant interaction between DX and IQD occurred for reading and pseudoword decoding. The (DX no IQD) and the (IQD no DX) groups exhibited significantly worse decoding than the (no DX no IQD) group, while the (IQD + DX) group displayed the worst decoding skills. A significant trend for a 3-way interaction (DX $\mathrm{X}_{\mathrm{X}}$ IQD $x \mathrm{AB}$ ) was observed for reading comprehension. The results indicated that a complex relationship exists between diagnosis, IQ-Reading discrepancy and ability. Evaluation of unique contributions of the independent variables indicated that discrepancy and ability level contribute to the observed effects of diagnosis. These results are discussed in relationship to recent research findings and clinical practice.

Correspondence: James A. Holdnack, Ph.D., PMG, The Psychological Corporation, 5 Rose Hill Drive, Bear, DE 19701. E-mail: holdwork@ yahoo.com

\section{E. DIRKS, G. SPYER, E. VAN LIESHOUT \& L. DE SON- NEVILLE. DIFFERENCES BETWEEN CHILDREN WITH SPE- CIFIC READING AND SPECIFIC ARITHMETIC DISABILITIES ON A NAMING SPEED TASK.}

The purpose of this study was to further our understanding of a possible link between reading and arithmetic skills. Children with reading disabilities are generally slower than their average-reading peers on naming speed tasks, in which they are required to rapidly name visually presented material. Additional findings show that children with arithmetic disabilities retrieve phonological information, such as letters and simple arithmetic answers, more slowly than their normally achieving peers. Some researchers therefore suggest that there might be a link between naming speed and arithmetic retrieval, because of a possible deficit in the retrieval of visual-verbal representations. In our study we compared the performance of three groups of children (9-10 year olds) on three naming speed tasks (letters, digits and pictures). A reading disability group (RD) with reading achievement scores below the 25 th percentile; an arithmetic disability group (AD) with arithmetic achievement scores below the 25th percentile; and, a normal achievement group (NA). The main findings were as follows: the RD group was significantly slower in naming letters and numbers than the $\mathrm{AD}$ and NA groups; the performance of the reading group on naming pictures was only significantly 
slower than that of the control group; the AD group tended to be slower than the NA group on naming pictures. These findings might suggest that rapid naming of letters and numbers are processes that are specifically related to phonological processes, while rapid naming of pictures is a process more related to visual-spatial skills.

Correspondence: Evelien Dirks, Special Education, Vrïe Universiteit Amsterdam, Van der Boechorststraat 1, Amsterdam 1081 BT, Netherlands. E-mail:e.dirks@psy:vu.nl

\section{J.B. FANCHER, M.Y. KIBBY \& G.W. HYND. ANGULAR GYRUS MORPHOLOGY IN DEVELOPMENTAL DYSLEXIA.}

Early neurobiological studies of dyslexia focused on lesions of the angular gyrus (AG). As functional neuroimaging studies proliferate, a consensus is growing that the AG demonstrates reduced activation during reading tasks in developmental dyslexia (DD). Nonetheless, this region remains understudied in the current anatomical literature. One reason for this is that the AG often eludes area or volumetric analysis due to the region's high cortical variability. This cortical variability is analyzed in the current study using the typologies proposed by Naidich et al. (1995). Using anatomical MRI scans and linguistic measures from 51 children ages 8 to 12, the relationships among angular morphology, presence of DD, and linguistic performance is evaluated. Results demonstrate that children with DD are more likely to have atypical angular morphology in the right hemisphere than children without DD. Analysis of the relationship between linguistic measures and angular morphology indicates that atypical morphology of the $\mathrm{AG}$ is related to poorer performance on a measure of complex phonological processing in the left hemisphere of children with DD. In the right hemisphere atypical AG morphology is related to reduced single word reading and semantic understanding in DD. Thus, children with DD are more likely to present with atypical AG morphology in the right hemisphere; moreover. when children with DD have atypical AG morphology it is related to poorer performance on linguistic measures.

Correspondence: Jill B. Fancher, Psychology, Washington State University, PO Box 644820, Pullman,WA 99164-4820.E-mail:jbfancher@ wsu.edu

\section{A.J. NAILLON, S.P. PAVAWALLA, J.B. FANCHER, M.Y. KIBBY \& G.W. HYND. ROLE OF THE THALAMUS IN THE DOUBLE DEFICIT HYPOTHESIS OF DYSLEXIA.}

Research by Galaburda and colleagues using histological techniques has suggested that the thalamus may be atypical in dyslexia. In addition, research has suggested that the thalamus may play a role in naming. Given that phonological processing and rapid naming skills are often deficient in dyslexia, and that the thalamus may play a role in these skills, the contribution of the thalamus to dyslexia was assessed. Participants included 27 children between the ages of 8-12; 15 with dyslexia and 12 controls. All children underwent a MRI scan and a neuropsychological battery. Area of the thalamus was measured by following published boundaries from other research. Those with and without dyslexia were comparable in thalamic area. As groups differed in the cognitive variables of interest, phonological processing and rapid naming, correlations between thalamus area and cognitive functioning were analyzed separately for each group. Findings revealed a significant relationship between left thalamic size and complex phonological processing skills in controls. In contrast, none of the correlations between thalamic size and phonological processing and rapid naming skills were significant in dyslexia. Thus, while the thalamus may be involved with phonological processing in typically developing children, it does not appear to play a significant role in dyslexia, consistent with other research suggesting children with dyslexia may be using alternate brain regions in their processing of linguistic material. Replication of these findings with a larger sample size and/or $f$ MRI is warranted.

Correspondence: Angela J. Naillon, Psychology, Washington State University, 1630 NE Valley Rd, Apt N104, Pullman, WA 99163. E-mail: naillon@mail.wsu.edu
M.Y. KIBBY, A.J. NAILLON, S.P. PAVAWALLA, J.B. FANCHER, A.E. MORGAN, M.J. COHEN \& G.W. HYND. ASSESSMENT OF THE GENICULO-TEMPORAL PATHWAY IN CHILDREN WITH AND WITHOUT DYSLEXIA.

Some researchers suggest children with dyslexia present with reduced auditory processing. In addition, prior research has demonstrated children with dyslexia have anomalous morphology in the planum temporale and atypical histology in the thalamus. Nonetheless, no study to date has assessed the relationship between auditory processing and structure of the geniculo-temporal regions in dyslexia. Participants included 24 children with dyslexia and 32 controls, ages 8-12. The two groups were comparable in age, intellect, gender, race, and handedness. Participants underwent a MRI scan and a neuropsychological battery including measures of dichotic listening, filtered speech (identifying a word when specific frequencies are filtered out), and auditory figure ground (identifying a word in the presence of background noise). The two groups were comparable on measures of auditory processing and on the brain regions assessed: planum temporale, temporal and parietal banks bilaterally; both Heschl's gyri and both thalami. As a result, the two groups were combined for further analyses. Analysis of significant correlations revealed levels of processing within the geniculo-temporal pathway, with bilateral auditory figure ground being correlated with bilateral thalamus area, left Heschl's gyrus length and left parietal bank length, and bilateral filtered speech being correlated with left temporal bank length. Hence, while children with dyslexia are not significantly different from controls on the auditory processing measures and brain regions assessed, there does appear to be a relationship overall between auditory processing and the geniculo-temporal pathway as demonstrated by neuropsychological measures and neuroimaging.

Correspondence: Michelle Y. Kibby, PhD, Psychology, Washington State University, Department of Psychology, Pullman, WA 99164-4820. Email:mkibby@wsu.edu

\section{A.M. PODRAZA, J.D. THOMAS \& T. PIERCE. FACTORIAL COM- PLEXITY AND PREDICTIVE VALIDITY OF SEVERAL MEASURES OF PHONOLOGICAL ABILITY UNDERLYING READING SKILL IN CHILDREN.}

Recent research (Morris, Stuebing, Fletcher, et. al., 1998) has shown phonological processing to have a major role in specific reading disability. There are several published measures of phonological ability, but few comparisons of diagnostic efficacy exist in the literature. Aims: We assessed the factorial complexity and predictive validity of the NEPSY Phonological Processing subscale, the two phonological and the Rapid Naming subscales of the CTOPP, and the WIAT-II Pseudoword Decoding subtest, to determine if they tapped different aspects of reading skill. The WIAT-I Basic Reading and Reading Comprehension subtests were the criterion variables. Subjects: Forty-four children between the ages of 7 and 12 years with Full Scale IQ above 85 were selected for the present study. The sample included children with traumatic brain injury, ADHD, and/or reading disability. Results: Factor analysis produced two factors: a phonological factor and an attentional factor. All the phonological measures loaded on the first factor. Multiple regression found Pseudoword Decoding was the single best predictor of Basic Reading and Reading Comprehension. Excluding Pseudoword Decoding from the analyses, NEPSY Phonological Processing and CTOPP Rapid Naming predicted basic reading, while NEPSY Phonological Processing alone predicted Reading Comprehension. Conclusions: The different measures of phonological processing do not appear to tap different underlying language abilities. In theory, any would be acceptable for a particular assessment, but overall Pseudoword Decoding was the best predictor of reading skills. NEPSY Phonological Processing and CTOPP Rapid Naming were the next best predictors. This research supports the idea of a phonological core underlying reading skills.

Correspondence: James D. Thomas, Ph.D. Psychology, Maine Rehabilitation Neuropsychology Service, Eastern Maine Medical Center, 905 Union Street Suite 9, Bangor, ME 04401. E-mail: jthomas@emh.org 


\section{G. SPYER, E. DIRKS, J. GEELHOED, E. VAN LIESHOUT \& P. REITSMA. CHILDREN WITH READING-AND-ARITHMETIC DISABILITY VERSUS CHILDREN WITH SPECIFIC READING OR SPECIFIC ARITHMETIC DISABILITY.}

In general, studies on learning disabilities focus on one subject domain, e.g., reading disabilities or arithmetic disabilities. Although co-occurrence of reading and arithmetic disabilities is widely recognised, little is known about the magnitude of the coexistence and the characteristics of children with both reading and arithmetic disabilities versus those with only one of these. In a preliminary study we selected elementary school children, from third through sixth grade, whose achievement was below the 25th percentile in single-word decoding ability and/or in computational ability. Of the 65 children (mean age:127.1, s.d:14.4 months mean IQ:96.3, s.d:9.8) selected, 33.8 percent proved to have disabilities only in reading (RD), 21.5 percent only in arithmetic (AD), and 44.6 percent in both reading and arithmetic (RAD). The three groups were subsequently compared, along with a normal achievement group (NA), on 7 subtests of the WISC-R. The main findings were as follows: the AD group performed more poorly, when compared to the NA and/or the RD groups, primarily on measures of visual-spatial ability (Block Design, Object Assembly, Picture Completion, Spatial Ability Factor); the RAD group, when compared to the NA group, showed more general problems (verbal: Information, Digit-Span: and nonverbal: Coding. Block Design); the RD group only differed from the NA group on Digit-Span. Both the high incidence of children with coexisting reading and arithmetic disabilities (RAD) in this preliminary sample and the observed differences in performance between the groups underscores the need for differentiation among mixed learning disabilities and those in one subject.

Correspondence: Ginny Spyer, PhD, Special Education, Vrïe Universiteit, v.d. Boechorststraat 1, Amsterdam 1081BT, Netherlands. E-mail: g.spyer@psy.vu.nl

\section{Developmental Disorders in Adults}

\section{G.A. GIOIA, P. ISQUITH \& S. GUY. ADOLESCENTS WITH ADHD REPORT SIMILAR BEHAVIORAL MANIFESTATIONS OF EXECU- TIVE DYSFUNCTION AS PARENTS.}

ADHD has gained attention as a signature developmental disorder of executive function. We present profiles of self-identified executive functioning in adolescents with inattentive and combined subtypes of ADHD. 127 adolescents ( 87 boys, 40 girls) clinically diagnosed with ADHD (42 ADHD-I, 85 ADHD-C) and matched controls completed the BRIEF-Self Report Version (BRIEF-SR), an 80-item inventory for ages 11-18 years tapping 8 executive domains. A MANOVA with group (Control, ADHDI, ADHD-C) as the between subjects factor and BRIEF-SR Scales and Indexes as dependent variables revealed significant group differences on all Clinical Scales, both Indexes and the GEC. Effect sizes ranged from $\eta 2=.02$ for the Organization of Materials scale to $\eta 2=.10$ for the Inhibit scale and $\eta 2=.11$ for the Task Completion scale. Both ADHD subtypes reported significantly more problems than controls on the Shift scale and the scales comprising the Metacognition Index. The ADHD-C group reported significantly greater difficulties than both ADHD-I and normative groups on the Inhibit, Emotional Control and Self-Monitor scales. Both subtypes had higher T scores on the Metacognition Index than the normative group, while only the ADHD-C group was significantly elevated on the Behavioral Regulation Index. Parent BRIEF ratings in a subsample of the ADHD-I $(\mathrm{n}=33)$ and ADHD-C $(\mathrm{n}=40)$ groups demonstrated similar profiles of elevation although adolescent T scores were lower. In summary, subtype-specific profiles of executive dysfunction, similar to those of parent ratings on the BRIEF, were reported by adolescents with ADHD on the BRIEF-SR.

Correspondence: Gerard A. Gioia, Ph.D., Pediatric Neuropsychology, Children's National Medical Center, 4900 Massachusetts Avenue NW, Suite 320, Washington, DC 20016.E-mail:ggioia@cnmc.org
N.C. ROBBINS, D.A. GANSLER, W.M. DINN, C.L. HARRIS \& A. MILLER. UTILIZING THE REY-OSTERRIETH COMPLEX FIGURE IN THE NEUROBEHAVIORAL SUBTYPING OF ATTENTION DEFICIT HYPERACTIVITY DISORDER.

There is a relative dearth of research into the differences between the inattentive and the hyperactive subtype of adults with attention-defici hyperactivity disorder (ADHD). The performance of adults with ADHD on the Rev-Osterrieth Complex Figure (ROCF) was compared with that of matched control participants. The ROCF was evaluated using the Boston Qualitative Scoring System (BQSS), which extended the preliminary research on the BQSS in adults with ADHD, conducted by Schreiber, Javorsky, Robinson, and Stern (1999). We hypothesized that the adults with ADHD would have dysfunction on subscales related to attention/executive function, immediate recall, and visuospatial lateralization. Adults with ADHD demonstrated dysfunction on the copy and recall neatness, copy presence and accuracy, and detail placement subscales, which partially confirmed our hypotheses. Although sufficient subjects were lacking for a formal sub-type versus sub-type analysis. examination of the data suggests trends toward a dissociation of executive dysfunction (worse in combined subtype) and immediate recal (worse in inattentive subtype). Further research into the neurobehavioral subtyping of ADHD, especially utilizing the BQSS, is warranted in the near future.

Correspondence: Nicole C. Robbins, M.A., psychology, Suffolk University, 28 Fisher St.,North Attleboro, MA 02760.E-mail:nicole_robbins@ msn.com

A. SCHWEIGER, A. ABRAMOVITCH, G.M. DONIGER \& E. SIMON. A NOVEL COMPUTERIZED BATTERY FOR THE ASSESSMENT OF ATTENTIONAL DEFICITS IN ADULT ADHD.

Computerized testing has distinct advantages (and some disadvantages) over traditional testing. Mindstreams is a brief. Internet-based, computerized neuropsychological battery, originally constructed for the purpose of identifying mild cognitive impairment in the geriatric population. It also provides a valid and reliable screening tool for repeated testing (with three alternate forms) in research. We present new data which demonstrate the clinical utility of this battery in young adults, for the purpose of assisting in the diagnosis of pathological condition with emphasis on attentional deficits (e.g.. ADHD and head injuries.) In the present study, a group of young adults fulfilling ADHD diagnosis according to DSM-IV criteria was compared with normal, age-matched controls on Mindstreams and on the CPT-II. Results confirm similarities in identifying attentional deficits by the two batteries. In addition, Mindstreams results demonstrated other deficits in skills not covered by CPT-II (or by other, similar attentional batteries such as the TOVA and IVA), and also provided information on strengths in skills such as language, visuospatial analysis, verbal and non-verbal memorv, problemsolving, planning, inhibition and arithmetic abilities. The present study demonstrates that Mindstreams provides information not only regarding attentional deficits in adult ADHD, but also on a wide range of $\operatorname{cog}_{-}$ nitive skills with important clinical implications for related disorders, such as learning disabilities. Recent research demonstrated that the adult ADHD population presents with complex clinical picture. Therefore a brief, computerized but relatively comprehensive assessment, such as Mindstream, providing objective data on different neuropsychological parameters can be highly useful in the clinic and in research. Correspondence: Avraham Schweiger, Ph.D., Behavioral Sciences, Academic College of Tel Aviv, 952 5th Ave., 1-C, New York, NY 10021. Email:schweige@mta.ac.il

\section{E. BALDWIN, M. MORRIS \& B. ROBINSON. NEUROPSYCHOLOGICAL AND PSYCHOSOCIAL FEATURES OF ADULTS WITH DEFICITS IN ARITHMETIC.}

Rourke et al. (1986b) suggested that the pattern of neuropsychological and socio-emotional strengths and deficits found in children with aca- 
demic achievement in math lower than reading can also be identified in adults. This investigation examined the utility of the Nonverbal Learning Disability Model for characterizing the neurocognitive features of a clinical sample of adults in an academic setting. Participants were 352 college students referred for psychoeducational evaluation. Three groups were identified using classification criteria based on academic achievement patterns in reading and math. The groups were compared on measures of socio-emotional functioning, intellectual functioning, phonological awareness, expressive language, visual perception, visual-motor integration, visual-nonverbal memory, fine motor skills, and complex psychomotor skills. Groups did not significantly differ on demographic or socio-emotional factors; however, participants with a deficit in math relative to reading demonstrated less impairment on phonological tasks and more impairment on a constructional task requiring planning and organizational skills and on a measure of nonverbal memory than adults with a deficit in reading relative to math. The findings of impaired constructional ability and nonverbal memory coupled with intact verbal abilities in adults with relative deficits in math are consistent with the previous research. However, the lack of significant group differences in visual-perceptual skills, bilateral psychomotor skills, and increased socio-emotional difficulties in adults with a relative deficit in math was not consistent with previous research. Overall, the findings suggest that there is a need for further investigation into the developmental course of the NVLD Syndrome. Potential confounding factors are discussed. Correspondence: Erin Baldwin, MA, Psychology, Georgia State University, PO Box 33312, Decatur, GA 30033. E-mail: ebaldwin1@student. gsu.edu

\section{M.D. PRESNIAK, L.J. ELIAS, M. CROSSLEY \& G.E. SARTY. A CASE STUDY ON CONGENITAL PROSOPAGNOSIA: BEHAV- IOURAL AND STRUCTURAL MRI EVIDENCE.}

Prosopagnosia is an impairment in facial recognition which is not characterized by a primary sensory visual deficit. Congenital prosopagnosia is the lifelong inability to recognize faces that is not caused by acquired brain injury. Few cases of congenital prosopagnosia have been described in the literature, only five of which appear to exhibit prosopagnosia in the absence of other object recognition deficits. The current study investigated another apparent case of congenital prosopagnosia in SM, a middle-aged college-educated North American Aboriginal female. Both a standardized facial recognition test (the Benton Facial Recognition Test) and a locally generated famous faces test were administered to SM. as well as tests of basic visual perception and object recognition. SM was clearly impaired on both tasks of facial recognition, but exhibited performance within normal range on other perceptual tests. The results of an anatomical MRI demonstrated no obvious brain injury or disease. Collectively these results support the conclusion that SM has "pure" congenital prosopagnosia.

Correspondence: Lorin J. Elias, Ph.D., Psychology, University of Saskatchewan, 9 Campus Dr., Saskatoon, SK S7N 5A5, Canada. Email:Lorin.Elias@usask.ca

\section{M.Y. KIBBY, J. SANCHEZ, C.J. MILLER \& G.W. HYND. VERBAL SHORT-TERM MEMORY FUNCTIONING IN ADULTS WITH AND WITHOUT DYSLEXIA.}

Previous research has demonstrated reduced verbal short-term memory (VSTM) in children with dyslexia, and VSTM has been shown to contribute to decoding of nonwords in children. Nonetheless, limited research has focused upon VSTM in adults with dyslexia. Participants included 15 adults with dyslexia and 28 controls, ages 29-54. Groups were matched for age and nonverbal intellect. Participants underwent a thorough neuropsychological battery including clinical and experimental measures of VSTM. When using a task assessing VSTM according Baddeley's model of the phonological loop, adults with dyslexia were found to display reduced VSTM compared to controls. The deficit appeared specific to the store, with intact functioning of the subvocal rehearsal mechanism. Furthermore, the deficit was pronounced when required to remember items phonologically as opposed to semantically. Follow-up analyses using traditional measures of VSTM supported these findings. Adults with dyslexia performed most comparably to controls on WJ-R Memory for Words (which can be coded semantically) but had greater difficulty compared to controls on WJ-R Memory for Sentences (which requires phonological coding as items must be remembered verbatim), CTOPP Memory for Digits, and CTOPP Nonword Repetition. Also of interest, VSTM was found to predict reading ability in all areas assessed: word identification, word attack/decoding, and reading comprehension. These findings are in spite of VSTM being entered into regression equations along with measures of VIQ, phonological awareness and rapid naming. Hence, our results suggest VSTM makes a unique contribution to the reading process in adults in addition to phonological processing and verbal intellect.

Correspondence: Michelle Y. Kibby, PhD, Psychology, Washington State University, Department of Psychology, Pullman, WA 99164-4820. E-mail:mkibby@wsu.edu

\section{FRIDAY AFTERNOON, FEBRUARY 6, 2004}

\begin{abstract}
Poster Session 8: Neuropsychology of Psychiatric Disorders and Emotion Processing/1:00-3:00 p.m.
\end{abstract}

\section{General Psychopathology}

\section{G.E. JOHNSEN, P. KANAGARATNAM \& A.E. ASBJORNSEN. VERBAL LEARNING AND MEMORY IN POSTTRAUMATIC STRESS DISORDER.}

Attention and memory impairment are reported in patients with posttraumatic stress disorder (PTSD), but these findings are not conclusive. Performance of PTSD patients on a variety of neuropsychological measures suggests that learning and memory should be closer examined. The present study was designed to explore at what stage of processing the cognitive deficits in patients with PTSD occur. By using a different memory tests, several aspects of learning and memory can be evaluated separately. Method: The sample consisted of 22 individuals exposed to war and political violence that fulfilled the DSM-IV criteria for PTSD, and a control sample (N-23) with similar exposure but without PTSD. The samples were matched for ethnicity, age and gender. To assess learning and memory impairment California Verbal Learning Test (CVLT) were administrated in addition to Digit Span and Paced Auditory Serial Addition Test (PASAT). Assessment instruments for PTSD included Impact of Event Scale (IES) and Clinical-Administered PTSD Scale (CAPS). Results: As expected, an ANOVA on the CVLT-performance yielded a main effect for learning trials. In addition, a main effect for groups occurred, showing less efficient learning in the PTSD sample. The PTSD patients also showed impaired performance on the immediate free recall, delayed free recall and delayed cued recall as compared to the control sample, but not specific working memory impairments as revealed by PASAT. Conclusion: The results showed impaired learning and memory in the PTSD patients. The findings are discussed in the context of impaired cognitive capacity and ineffective coding associated with PTSD.

Correspondence: Arve E. Asbjornsen, Ph. D., Department of Psychosocial Sciences, University of Bergen, Christiesgt 12, Bergen N-5015, Norway. E-mail: arve.asbjornsen@psysp.uib.no 


\section{P. KANAGARATNAM, G.E. JOHNSEN \& A.E. ASBJORNSEN. EXECUTIVE DYSFUNCTIONS IN POSTTRAUMATIC STRESS DISORDER.}

Posttraumatic Stress Disorder (PTSD) is described as a disorder characterized by intrusions, arousal and avoidance. Intrusion of memories from the traumatic event may represent more generally impaired impulse inhibition and control with information processing. It is therefore important to understand how symptoms of PTSD are related to general executive functions as measured with standardized tests. We measured executive functions (EF) assumed to have clinical significance among individuals diagnosed with PTSD. Method: Twenty individuals that fulfilled the DSM-IV criteria for PTSD after exposure to political violence (PV) were compared to a control sample $(\mathrm{N}=20)$ with similar exposure to PV and matched for ethnicity, age and gender. Based on the model of EF proposed by Burgess et al, (1998), the three cognitive components of EF intentionality, inhibition and executive memory were measured using the Tower of London (TL), a Stroop color-word test (SCWT) and Wisconsin Card Sorting Test (WCST). Results: The PTSD group showed impaired inhibition and executive memory as reflected in SCWT and WCST compared to the control group. Impairments were seen as automatic processing bias, temporal sequencing problems and increased perseveration. Intentionality as seen on TL did not differ between the groups. While SCWT and WCST performances were predicted from arousal, intrusive symptoms and avoidance, only avoidance could predict intentionality. Conclusion: Posttraumatic symptoms are related to executive impairment, and the impairments are mainly related to mental flexibility. The finding has implications the understanding of cognitive processes following exposure to potentially traumatizing events, and assessment of executive functions may be of importance for treatment planning in PTSD.

Correspondence: Arve E. Asbjornsen, Ph. D., Department of Psychosocial Sciences, University of Bergen, Christiesgt 12, Bergen N-5015, Norway. E-mail: arve.asbjornsen@psysp.uib.no

\section{H. MARX, A. BOEKA, R. CARROLL, A. MORRIS \& K. LOKKEN. USING A MODIFIED STROOP PARADIGM IN THE ASSESSMENT OF BULIMIA NERVOSA.}

It has been frequently noted that individuals with bulimic symptoms are impulsive and show deficits in attention, focusing, and inhibition of irrelevant information on neuropsychological tasks. Such neurobehavioral performances provide a reasonable rationale for using neuropsychological measures to assess the presence and severity of bulimic symptoms. Currently, there is no universally accepted assessment protocol for measuring the psychopathology of bulimia nervosa (BN), and contemporary measures tend to be based on self-report questionnaires. Given the limitations of such measures, reliable quantitative measures that minimize self-report biases are needed. The present study examined whether a modified Stroop paradigm using eating, weight, and shape words could provide an objective cognitive measure of psychopathology in a group of bulimic women. Performances of three groups: (1) women diagnosed with $\mathrm{BN}(\mathrm{N}=27)$; (2) women at risk for $\mathrm{BN}(\mathrm{N}=30)$; and (3) a control group $(\mathrm{N}=30)$ were compared on the modified verbal Stroop paradigm. Groups were matched on variables such as age, education, body mass index, and vocabulary level as measured by the WAISIII. Results demonstrated that interference scores on modified verbal Stroop strongly correlated with self-report indices of BN symptoms. In addition, bulimic participants showed greater interference in the colornaming of eating $(p<.01)$, weight $(p<.05)$, and shape-related $(p<.01)$ words in comparison to the at-risk and control groups. The results provide further evidence of disinhibition in the disorder of $\mathrm{BN}$ and give credence for the use of neuropsychological measures in the assessment of the disorder.

Correspondence: Abbe Boeka, University of Alabama, 120 East 15th \#8305,Tuscaloosa, AL 35401.E-mail: boeka001@bama.ua.edu

\section{J. HOPPS, J.D. BAYLESS, D.L. CLAY \& A.E. ANDERSEN. MALES AND FEMALES WITH EATING DISORDERS: A COMPARISON OF NEUROPSYCHOLOGICAL DOMAINS.}

The neuropsychological impact of eating disorders in men has received little attention, separately or comparatively in relation to women. Deficits in a variety of neuropsychological domains have been found to accompany eating disorders in women, such as executive functioning and attentional skills, verbal and nonverbal memory, processing speed, and visuospatial ability (e.g., Moser at al, 2003). All males admitted to a large Midwestern hospital for inpatient eating disorder care from 1999$4 / 2003$ were administered a neuropsychological battery. Those who met inclusion criteria $(n=11)$ were matched (by age, education, and diagnosis) with females from the same time period. Several domains were selected for analysis: attention, verbal memory, visuospatial ability; verbal, performance, and full scale IQs (VIQ, PIQ, \& FSIQ). Differences within subjects (i.e., individual profile variability) and between the male and female groups were measured. Findings suggest subtle differences in performance that manifest as statistically and clinically significant differences in neuropsychological profiles between males and females, although statistically significant group differences in domains were not found. That is, males' and females' abilities in the domains examined did not differ, but males showed significantly different variability in their neuropsychological profiles. For example, males had a significantly larger split between VIQ and PIQ (M=18.18) than did females ( $\mathrm{p}=.017)$, and verbal memory was lower than expected for males given FSIQ scores, while the converse was true for females $(p=.019)$. Therefore for males, certain abilities may not be as robust to the effects of eating disorders as for females. These differences can represent a loss of function from a previously high level of ability and may prove to be a source of dysfunction even if they are not deficits in the normative sense. Hypotheses for these differences and future research are discussed.

Correspondence: Josh Hopps, M.Ed., University of Iowa, 1641 Ranier Dr., Iowa City, IA 52246.E-mail: joshua-hopps@hotmail.com

\section{N. LOWERY \& M.R. BASSO. ORBITOFRONTAL-BASAL-GAN- GLIA DYSFUNCTION IN OCD: CONVERGING EVIDENCE FROM SELF-REPORT AND NEUROPSYCHOLOGICAL MEASURES.}

Neurobehavioral abnormalities in obsessive-compulsive disorder (OCD) have been more frequently associated with orbitofrontal than dorsolateral deficits (e.g.., Abbruzzese et al.,1995; Basso et al., 2001). The Frontal Lobe Personality Scale (FLOPS, now the FrSBe), purportedly measures three frontal systems: apathy, disinhibition, executive dysfunction. The FLOPS has not been examined in OCD. Since the orbitofrontal nature of OCD has been well established, we anticipated that the FLOPS Apathy and Disinhibition indices but not the Executive Dysfunction index would predict OCD. Also, we expected that OCD would be associated with reduced inhibition and sensory-motor function, consistent with orbitofrontal-basal-ganglia deficits. Method: Individuals with OCD ( $n=43)$ and non-psychiatric, healthy participants $(n=40)$, similar in estimated intelligence and handedness, completed the FLOPS. Participants also completed measures of inhibition (Stroop Color-Word) and sensory-motor function (Grooved Peg Board, Tactile Form Recognition). Results: MANOVA revealed that OCD participants yielded higher scores across FLOPS indices and poorer scores across age and education corrected neuropsychological measures $(\mathrm{ps}<.05)$ relative to the comparison group. suggesting relative deficits across measures. Regression analysis of the FLOPS revealed that Apathy $(\mathrm{t}=-8.12, \mathrm{p}<=.001)$ and Disinhibition $(\mathrm{t}=-2.82, \mathrm{p}<=.05)$ but not Executive Dysfunction $(\mathrm{t}=.54, \mathrm{p}>.05)$ indices predicted group membership. Discussion: Taken together, these findings are consistent with past literature suggesting orbitofrontal-basal ganglia involvement in OCD. Depression, as measured by the Positive and Negative Affect Scale (PANAS) does not appear to account for these findings. The FLOPS appears to differentiate between frontal systems, as purported, in OCD. 
Correspondence: Natasha Lowery, Ph.D., Psychiatry, Neuropsychiatry, University of Pennsylvania, 10 Gates Building, 3400 Spruce Street, Philadelphia,PA 19143.E-mail: nlowery@bbl.med.upenn.edu

\section{T.R. WODUSHEK, C.S. NEUMANN \& E. HARRELL. COGNITIVE FUNCTIONING AND PSYCHOPATHY.}

It has long been proposed that psychopathy is associated with dysfunction in interpersonal and affective functioning, but relatively intact cognitive functioning. However, more recent research has suggested that the dimensions of psychopathy may be differentially associated with cognition. We predicted that the arrogant and deceitful interpersonal dimension would be positively associated with intelligence (IQ); while the poor behavior inhibition dimension would be inversely associated with IQ. One hundred offenders within a county jail were assessed with the Psychopathy checklist: Screening Version (PCL:SV) as well as a battery of cognitive tasks. Using confirmatory factor analysis (CFA), good model fit was found for a recent four-factor model of psychopathy, which posited problems in interpersonal and affective functioning, behavioral inhibition, and antisocial behavior. Next, structural equation modeling (SEM) was used to determine if these four psychopathy factors could predict an intelligence factor (IQ), which reflected both verbal and performance IQ. As hypothesized, interpersonal deceitfulness predicted increased IQ, while behavioral dis-inhibition predicted decreased IQ. Interestingly, disturbances in affective functioning also predicted decreased IQ. Finally, the current study will also present post-hoc models that were developed to further explicate the relationship between left- and righthemisphere based measures of cognitive functioning and the dimensions of psychopathy.

Correspondence: Thomas R. Wodushek, Ph.D., Neurology, University of Virginia Health Sciences Center, Box 800394, Charlottesville, VA 22908.E-mail:trw3a@hscmail.mcc.virginia.edu

\section{K. HIATT \& J.P. NEWMAN. INTERHEMISPHERIC INTEGRA- TION AMONG PSYCHOPATHIC OFFENDERS.}

Recent evidence suggests that psychopathy may involve poor accommodation of right-hemisphere $(\mathrm{RH})$ processing when the left hemisphere (LH) is predominantly engaged. Such a deficit would limit psychopaths' access to RH functions (e.g., emotion processing, behavioral inhibition, and contextual processing) when the LH is engaged (e.g., approach behavior, reward-seeking, language processing, and right-sided motor responses), and may provide a proximal mechanism for the disorder. The present study examined interhemispheric integration among incarcerated PCL-R (Hare, 1991) psychopaths and controls using a version of Banich \& Belger's (1990) name-identity task. This task produces a reliable interhemispheric advantage (IHA; i.e., better performance on bilateral versus unilateral trials). Poor interhemispheric integration should result in a reduced IHA. To examine whether psychopaths show a particularly weak IHA when the LH is predominantly engaged, we compared performance on trials in which the majority of the stimuli were presented to the LH to performance on trials in which the majority of the stimuli were presented to the RH. Consistent with predictions, preliminary analyses reveal that (a) psychopathy is negatively correlated with IHA, and (b) this correlation is driven by the LH-dominant trials. These findings are consistent with previous findings among undergraduates assessed with Levenson et al.'s (1995) self-report psychopathy scale (Hiatt \& Newman, 2002), and suggest that psychopathy is associated with difficulty utilizing right-hemisphere information when the left hemisphere is predominantly engaged.

Correspondence: Kristina Hiatt, M.S., Psychology, University of Wisconsin-Madison, 1202 W. Johnson St., Madison, WI 53705. E-mail: kdhiatt@wisc.edu

\section{S. BUDHANI, R.A. RICHELL \& J. BLAIR. RESPONSE REVERSAL DEFICITS IN CHILDREN WITH PSYCHOPATHIC TENDENCIES AND ADULT PSYCHOPATHS.}

Response reversal involves the alteration of a learned behavioural response to a previously rewarded stimulus based on changing reinforcement contingencies. This form of cognitive flexibility has been shown to rely on orbitofrontal cortex. Individuals with psychopathy present with impairments in response reversal. However, whilst adult psychopaths have been found to perform consistently poorly on measures of response reversal, the findings with children with psychopathic tendencies are less consistent. The purpose of this study was to explore one possible reason for this inconsistency: that children with psychopathic tendencies may only display impairment in response reversal when the contingency change to be detected is subtle rather than highly salient. We used a probabilistic response reversal task to examine this issue, examining response reversal under conditions of 100:0 (i.e., choice of S1 is always rewarded and S2 never rewarded until reversal when S1 is never rewarded and $\mathrm{S} 2$ always rewarded) and 80:20 (i.e., S1 is rewarded on $80 \%$ of choices and punished on $20 \%$ of choices while $\mathrm{S} 2$ is rewarded on $20 \%$ of choices and punished on $80 \%$ of choices until response reversal when the contingencies reverse). This task was used with children with psychopathic tendencies and adults with psychopathy and appropriate comparison groups. Acquisition of the discrimination was performed comparably across both groups and age ranges. However, while the adults with psychopathy presented with impairment in response reversal even for the salient 100:0 contingency change, the children with psychopathic tendencies only presented with impairment for the $80: 20$ contingency change.

Correspondence: salima budhani, nimh, 5413 west cedar lane, building 106-c room 18, bethesda, MD 20814-9692. E-mail: salima. budhani@nih.gov

\section{R. LIKEWISE. ORBITOFRONTAL FUNCTION IN IMPULSIVE VERSUS PREDATORY VIOLENCE.}

Converging data from multiple disciplines implicates the orbitofrontal cortex as a neural structure involved significantly with the mediation of human aggressive behavior. Evidence of site-specific, brain-based impairment in behavioral regulation has important implications for the adjudication of guilt within many western criminal justice systems and for the assumptions about free will and moral agency upon which guilt is premised. This study examines neuropsychological correlates of orbitofrontal dysfunction specifically in relation to impulsive vs. predatory aggressive behavior. Forty-one inmates confined in a maximumsecurity correctional facility participated. Scores of 21 impulsively violent inmates were compared with those of 20 inmates whose violent crimes were premeditated, on a battery of measures assessing functions thought to be at least partially subserved by the orbitofrontal cortex. Significant between-group differences were obtained on measures of inhibition (Delis-Kaplan Executive Function Color-Word Interference Test; Delis, Kaplan, and Kramer, 2001), emotional experience while viewing emotionally-evocative images (International Affective Picture System; Lang, Bradley, and Cuthbert, 1999), recognition of facial emotional expression (Pictures of Facial Affect; Ekman and Friesen, 1975), and decisionmaking in uncertain circumstances (Bechara Gambling Task; Bechara, Damasio, Damasio, \& Anderson, 1994). Impulsively violent inmates demonstrated inferior abilities to inhibit overlearned behavioral responses and to accurately identify emotional expression on the faces of others, poorer decisionmaking strategies in unstructured situations, and higher levels of emotional arousal, valence, and feelings of dominance compared to inmates whose violent crimes were premeditated. Implications for social interaction and capacity to conform behavior to societal standards is discussed.

Correspondence: Roger Likewise, M.A., J.D., V.A. Connecticut Healthcare System, West Haven Campus, 950 Campbell Avenue, West Haven, CT06516-2700.E-mail:krlikewise@msn.com 


\section{Mood Disorders}

\section{G.A. MOLLET, C.S. EMERSON, A.L. BECK \& D.W. HARRISON . ANXIOUS-DEPRESSION IN CHILDHOOD: AN EVALUATION OF EXECUTIVE FUNCTIONS.}

The neurocognitive effects of anxiety and depression were tested in two groups of 9-11 year old boys. Participants were classified as anxiousdepressed or non-anxious, non-depressed based on scores from the Trait scale of the State-Trait Anxiety Inventory for Children and the Child Depression Inventory. Previous research in our laboratory has indicated that boys high in anxious-depression are impaired in affect identification in incongruent conditions, grip strength and have decreased posterior right hemisphere functioning relative to boys low in anxiety and depression (Emerson, Harrison \& Everhart, 1999; Emerson, Harrison, Everhart, \& Williamson, 2001). In order to assess the effects of anxious-depression on frontal executive functions, performance on the Trail Making Test, Forms A and B, and the on concept formation/problem solving subtest of the Woodcock Johnson was compared groups. As predicted, anxious-depressed boys demonstrated patterns similar to those found in previous research using depressed adult participants. Specifically performance time for boys in the anxious-depressed group (mean $=38.13$, S.D. $=19.34)$ was significantly increased on Trail Making Form $\mathrm{B}$ (sequential alternation) when compared to boys in the non-anxious, non-depressed group $($ mean $=29.90$, S.D. $=9.63)$. Performance time on Trail Making Form A (simple alternation) was similar across groups. Additionally, anxious-depressed participants made significantly more errors on Trails A and B when compared to non-anxious, non-depressed participants $(\mathrm{F}(1,36)=8.93, \mathrm{p}<.003)$. On the subtest of the Woodcock Johnson, boys in the non-anxious, non-depressed group (mean $=26.61$, S.D. $=4.35$ ) were significantly more accurate on concept formation/problem solving relative to the anxious-depressed boys (mean $=22.94$, S.D $=4.09$ ). These results provide supportive evidence for dysfunction of the frontal lobes with anxiety and depression.

Correspondence: Gina A. Mollet, BA, Psychology, Virginia Tech, Psychology Department,Blacksburg,VA 24061.E-mail:gmollet@vt.edu

\section{M.E. BATES, G. VOELBEL \& G. LOCASCIO. CEREBELLAR CHANGES RELATED TO CHILDREN'S PSYCHIATRIC DISORDER AND FAMILY HISTORY.}

This study examined the influence of familial alcohol use disorders and other familial psychiatric disorders on brain structure in children (mean age $=10.31, \mathrm{SD}=1.92$ ) diagnosed with a pervasive developmental disorder of high functioning autism or Asperger's Disorder (PDD N=42), bipolar disorder (BPD N=11), or no psychiatric disorder (NPD N=11). The aim was to examine the contribution of familial histories to potential changes in the cerebellum that have been previously associated with PDD and BPD. Magnetic resonance imaging (MRI) was used to quantify whole brain and cerebellar volumes. Controlling for total brain volume, full scale IQ, socioeconomic status, and gender, the PDD group exhibited a significantly larger cerebellar volume than the NPD group $(4 \%$ variance explained) as has been found in some other studies, but not the BPD group. Familial alcoholism was uniquely related to significantly smaller cerebellar volumes when quantified by number of 1 st degree relatives ( $9 \%$ variance explained) or density in the extended family $(6 \%$ variance explained). A combined family density measure of alcohol and five other psychiatric disorders was unrelated to brain volumes. The data were reanalyzed after deleting 5 cases that had a mother's lifetime alcohol use disorder diagnosis. Familial alcoholism was no longer a significant predictor of cerebellar volume suggesting that associations to familial alcoholism history may have been related to maternal heavy drinking during pregnancy. Maternal alcohol use disorders, although not typically assessed in the childhood psychopathology MRI literature, may be important contributors to individual differences in offsprings brain volume.
Correspondence: Gerald Voelbel, MS, Rutgers University, 607 Allison Road, Piscataway, NJ 08902. E-mail: gvoelbel@rci.rutgers.edu

\section{N.M. MANGUM, M.S., B. SCHROCK, PH.D. \& A. PHILLIPS, B. A. . PREDICTORS OF DEPRESSION IN STROKE PATIENTS. A LON- GITUDINAL STUDY THAT ASSESSES STROKE PATIENTS TWO WEEKS AND THREE MONTHS POST-STROKE. .}

The cause of post-stroke depression has been researched and debated for many years. Factors such as localization (Gainotti, Azxoni, et al., 1997), biochemical changes (Stanley, Malison, and Innis 1998), and personality variables (Aben, Denollet et al., 2002) have been suggested as causal factors in post-stroke depression. Continued research is needed to determine what causes post-stroke depression, or whether the depression suffered by patients after stroke is specific to stroke at all. This study examined the predictors of depression 2 weeks (Time One) and 3 months post-stroke (Time Two). Sixty-four patients at Time One and twenty five patients at Time Two with first- ever cerebrovascular accidents were asked to complete the Mini Mental Status Exam (MMSE), Ways of Coping Scale, and Center for Epidemiological Studies-Depression (CES-D). Physical functioning was measured with the Functional Independent Measure (FIM). A linear regression analysis showed that patients who demonstrated a $10 \%$ increase in escape-avoidance coping mechanism at Time One demonstrated a 4.5 unit increase on CES-D at Time Two, controlling for FIM and CES-D scores at Time One. Thus, escape-avoidance coping mechanism at Time One explains $23 \%$ of the variance on the CES-D at three months post-stroke. Depression history, localization, level of cognitive functioning, physical functioning were not significantly correlated with depressed mood at Time One or Time Two. In summary, escape-avoidance coping mechanism is an important predictor of depression three months after stroke. These findings suggest that a portion of the depression suffered by patients three months post-stroke may not be specific to stroke.

Correspondence: Nicole M. Mangum, M.S., M.S., Clinical Psychology, Ph.D., california school of professional psychology, 332 Palomar Ave., La Jolla, CA 92037.E-mail: nicolemangum@yahoo.com

\section{K. ZAKZANIS, D. YOUNG \& D. JOVANOVSKI. SEMANTIC CLUSTERING AND THE ROLE OF EFFORT IN MEMORY ENCOD- ING PROCESSES IN MAJOR DEPRESSIVE DISORDER.}

Memory dysfunction in depression results from weak or incomplete encoding strategies, reflecting poor effort. A previous meta-analysis revealed that patients with depression showed large differences in the magnitude of effect when comparing performances on the Rey Auditory Verbal Learning Test (RAVLT) to the California Verbal Learning Test (CVLT), whereby patients performed substantially worse on the RAVLT. The CVLT and RAVLT are identical in form except that, in the CVLT, words belong to semantic categories that support encoding strategies. The authors concluded that patients with major depressive disorder seem to have particular difficulty when tasks require effortful processing that is specific to memory-encoding processes and that only the RAVLT provided measures that were most sensitive to discriminating these patients from healthy normal controls. The objective of the present study was to replicate these findings in a clinical population. The sample included 10 inpatients with major depressive disorder recruited from three different hospitals who were all receiving pharmacological medication for depression; there were 21 normal controls also included in the study. All participants were administered a battery of neuropsychological tests that included the RAVLT and CVLT. Across all verbal learning measures, impairments were found in patients with depression (when compared to normal controls) except on semantically-cued recall trials of the CVLT. The expected dissociation between semantically related and 
semantically unrelated words was found on these verbal learning measures. The results suggest that clinicians would be in a better position to differentiate memory deficits caused by depression from an underlying neurologic dysfunction, for example dementia, on the basis of CVLT scores instead of RAVLT scores.

Correspondence: Diana Jovanovski, Honours B.Sc., Division of Life Sciences, University of Toronto (at Scarborough), 1265 Military Trail, Scarborough, ON M1C 4B6, Canada.E-mail: diana.jovanovski@ utoronto.ca

\section{K. ERICKSON, W.C. DREVETS, L. CLARK, D. CANNON, E.E. BAIN, C.A. ZARATE, D.S. CHARNEY \& B.J. SAHAKIAN. GENDER-BASED PERFORMANCE DIFFERENCES ON AN AFFEC- TIVE GO/NO-GO TASK IN UNIPOLAR DEPRESSION.}

Most prior neuropsychological studies of attention to and memory for affectively-laden stimuli in unipolar depression included subjects on psychotropic medications. The current study investigated performance of unmedicated depressives on an Affective Go/No-go task. Nineteen unmedicated ( $>3$ weeks), currently depressed MDD subjects and 19 healthy subjects (10 male and 9 female in each group), matched for age and full scale IQ, performed an Affective Go/No-go task in which subjects were required to press a response bar to positively-valanced words during "happy" conditions or to negatively-valanced words during "sad" conditions. To assess the specificity of performance on this affective task, attention and memory tests from the CANTAB were administered. Unipolar depressed and healthy subjects performed equivalently on the memory tests, but depressed subjects made more omission errors than the healthy subjects on the attention test. On the Affective Go/No-go task, male depressives made more omission and commission errors to affective words than controls and female depressives, while female depressives required more time to respond to affectively-valanced words than other subjects. Conclusions: The pattern of deficits may be distinct for male and female depressives. The increased commission errors by male depressives on the affective task suggest difficulty with inhibiting responses to affectively-valanced stimuli, or difficulty interpreting valence of affective stimuli. Conversely, the female depressives did not display the attention deficit on the affective task that they showed on the attention task, suggesting that the affective nature of the stimuli may have enhanced processing of the information.

Correspondence: Kristine Erickson, PhD, Psychology, American University, 5413 W. Cedar Lane, Suite 106-C, MSC 2606, Bethesda, MD 20814-9692.E-mail: ericksok@intra.nimh.nih.gov

\section{A.C. NUGENT, K. ERICKSON, S.E. WOOD, E.E. BAIN, D. CAN- NON, B.J. SAHAKIAN, D.S. CHARNEY \& W.C. DREVETS. HIPPOCAMPAL VOLUME CORRELATES WITH MEMORY PER- FORMANCE IN DEPRESSED BUT NOT HEALTHY SUBJECTS US- ING HIGH RESOLUTION MRI.}

The hippocampus is important for certain memory processes. In MDD, neuropharmacological changes (e.g. reduced 5HT1A receptor expression) and subtle volumetric changes have been identified. This has implications for the load placed on the hippocampus during recognition memory tasks in MDD. This study investigated the relationship between hippocampal volume and memory in healthy $(\mathrm{N}=17)$ and umedicated (>3 weeks), currently depressed MDD ( $\mathrm{N}=9$ ) subjects. Subjects underwent high resolution $(0.6 \mathrm{~mm}$ isotropic) T1-weighted MP RAGE MRI scans and completed memory and attention subtests from the CANTAB. Hippocampal volumes were measured by manual segmentation of the MRI images by a single rater, blind to diagnosis. Intrarater reliability was assessed by retracing 15 images on a separate day. Interclass correlation coefficients for the two tracings were 0.99 and 0.95 for left and right hippocampus, respectively. On the CANTAB tests, MDD subjects made more omission errors than controls on the attention test, but the groups did not perform differently on the memory tests. In controls, hippocampal volume did not correlate significantly with CANTAB vari- ables. However, in MDD, performance on pattern and spatial recognition memory was correlated positively with left hippocampal volumes; delayed-match-to-sample performance was positively correlated with right hippocampal volumes in MDD. In contrast, spatial span and attentional variables were not significantly correlated with volumes in either group. These preliminary findings suggest that hippocampal volume is potentially important for memory operations in depressed subjects, perhaps because in a subset of MDD subjects subtle changes in the the hippocampus interferes with memory processes.

Correspondence: Allison C. Nugent, PhD, Mood and Anxiety Disorders Program, National Institue of Mental Health, 1 Center Drive, MSC 0135, Bethesda, MD 20892. E-mail: wymorea@intra.nimh.nih.gov

\section{J. SNOW, D. JACOBSON, D.G. MITCHELL, K. ERICKSON, O. BONNE, A. NEUMEISTER, D. LUCKENBAUGH, D. CANNON, E. BAIN, D.S. CHARNEY \& W.C. DREVETS. CVLT-II PERFOR- MANCE AMONG UNMEDICATED MOOD AND ANXIETY DISOR- DER PATIENTS.}

Episodic memory problems have been reported in a variety of psychiatric disorders, including Major Depression, Bipolar Disorder, and PTSD. One theory, supported by reduced hippocampal volume in such disorders, suggests that such memory difficulties are the result of excessive glucocorticoid secretion, resulting in dendritic atrophy, inhibition of adult neurogenesis, and/or neurotoxic effects (Sapolsky, 2000) in the hippocampus. An alternative theory regards poor memory performance as a nonspecific finding, related to motivational effects. The WASI and CVLT-II were administered to a sample of unmedicated individuals with DSM-IV diagnosed mood and anxiety disorders (21 PTSD, 21 Major Depression, 44 remitted Major Depression, 13 Panic Disorder, 15 Bipolar) as well as 71 healthy controls. There were no significant differences between groups on demographic variables (IQ, age, education). An ANCOVA with age as covariate, diagnosis as independent variable, and 13 CVLT-II indices as dependent variables, revealed an overall effect only for Trial 1 and Total 1-5. Post-hoc comparisons revealed that for each major effect, only the Major Depression group performed significantly worse than the healthy control and remitted Major Depression groups (and in one comparison, also worse than PTSD). Supplemental analyses suggest that poor implementation of strategies, possibly of frontal origin, may account for performance decrements among those with Major Depression. Taken together, the pattern of results does not support a strong version of the theory that mood and anxiety disorder patients, in general, manifest hippocampus-mediated memory dysfunction, but does suggest possible frontal involvement or reduced motivation/effort in the Major Depression group.

Correspondence: Joseph Snow, PhD, MAP, NIH/NIMH, 15 K North Drive, Room 115c, Bethesda, MD 20892. E-mail: joseph.snow@nih.gov

\section{C.B. GRIGGS, G.E. BRUDER, J.C. BOROD, M. SHIKHMAN \& J. KAYSER. WORKING MEMORY IN DEPRESSION: IS THERE A MOOD CONGRUENT BIAS?}

Mood congruent biases have been demonstrated to affect long-term memory in depressed and healthy individuals. Healthy individuals are more likely to recall information having positive emotional valence, whereas depressed individuals are more likely to recall negatively valenced information. Disturbances in frontal lobe activity in depression suggest that executive function and working memory may also be involved in the mood congruent bias. To examine this possibility, we used a modified Word Serial Position Task, adapted from Wexler et al., 1998. Depressed individuals $(n=8)$ and healthy controls $(n=10)$ were required to learn word lists, each comprised of 6 words of positive, negative, or neutral valence. Following each list and a 5 -second delay, participants were shown one of the list words and required to indicate its serial position. Preliminary results of this ongoing study support the hypothesis that working memory is influenced by mood congruent material. Depressed 
individuals showed a tendency to make more errors when recalling positive than neutral words, whereas controls showed a tendency to make more errors when recalling negative than neutral words. The third wordtype condition for each group (negative-depressed; positive-control) did not differ from the other two. While larger sample sizes are necessary, these preliminary results suggest that working memory is disrupted by emotional content that is incongruent in valence with the current mood state. As a result, in depression, there may not only be preferential recall of information which maintains the negative mood state, but also an active interference of positive emotional information within working memory.

Correspondence: Carlye B. Griggs, Psychology, Queens College and Graduate Center of CUNY, NSB-E318, 65-30 Kissena Blvd, Flushing, NY 11367.E-mail: griggsc@pi.cpmc.columbia.edu

\section{G. GETZ, P. SHEAR, D. FLECK, M. ZIMMERMAN, R. KOWATCH \& S. STRAKOWSKI. SOCIAL FUNCTIONING AND FACIAL AF- FECT RECOGNITION DEFICITS IN MOOD DISORDERS.}

Many patients diagnosed with bipolar disorder (BPD) exhibit impairments in social functioning and in facial affect recognition skills even during periods of clinical stability. However, it remains unclear as to whether facial affect recognition deficits are related to social skills problems in this population. The present study examined this question in 18 clinically stable BPD patients as well as comparison groups of 18 clinically sable unipolar depressed (UPD) patients and 18 healthy participants. The groups did not differ significantly in terms of age, race, sex or estimated IQ. Both patient groups demonstrated normal levels of performance on facial recognition tasks that did not require them to decode facial emotion. In contrast, the BPD group performed significantly more poorly than the other two groups on a novel facial affect matching task. Social functioning, as measured by the global assessment of functioning scale, was also impaired in both patient groups. Furthermore, poorer facial affect recognition performance was significantly correlated with increased feelings of discomfort in social situations, but not with several other social skills, in both patient groups. This study indicates that the facial affect recognition deficits evident in clinically stable patients with BPD may not be shared by other patients with mood disorders. Facial affect processing skills appear to be related to social comfort levels in people diagnosed with mood disorders.

Correspondence: Glen E. Getz, Dept. of Psychiatry, Allegheny General Hospital, Four Allegheny Center, Eight Floor, Pittsburgh, PA 152125234.E-mail:getzg@email.uc.edu

\section{HARTMAN, B.W. CARLSON, J. CARLSON, C. NIELSEN \& V.J. NEELON. THE RELATIONSHIP OF SELF-REPORTED SLEEP CHARACTERISTICS, NEUROPSYCHOLOGICAL FUNCTIONING, AND DEPRESSION IN OLDER ADULTS. .}

Age-related changes in sleep are common and may represent an important factor in neuropsychological functioning in older adults. Cognitive processes such as attention and memory may be particularly sensitive to sleep integrity. Furthermore, depression may affect sleep as well as neuropsychological function. To examine the inter-relationships of sleep, depression, and cognitive functioning, we administered the Pittsburgh Sleep Quality Index (PSQI), Geriatric Depression Scale to $55 \mathrm{com}$ munity-dwelling older adults (aged 70 - 91) without clinical sleep disorders, depression, or dementia. Participants also completed tests of attention (Trail-Making Part B, Color Trails Part 2, the Letter-Number Sequencing Test, and the Color-Word Interference Subtest of the Stroop Test) and long-term memory (Delayed Recall portions of the Wechsler Memory Scale Logical Memory, Visual Reproduction, and Word List tests.) Results showed significant or near-significant correlations between the global PSQI and three of the four tests of attention. Of the PSQI subscales, the strongest relationships involved self-reported sleep latency, quality, and daytime dysfunction. None of the long-term memory tests were correlated with PSQI global scores, but they all showed significant or near significant correlations with the sleep quality subtest. In addition, the global score and four of the PSQI subscales were significantly correlated with depression. After controlling for depression, most but not all of the previously significant correlations between neuropsychological and sleep measures remained significant. The pattern of findings indicates stronger associations of sleep characteristics with attention than memory. Furthermore, only part of these relationships can be explained by the effects of subclinical depression.

Correspondence: Marilyn Hartman, Ph.D., Psychology, University of North Carolina, Davie Hall CB \# 3270, Chapel Hill, NC 27599. E-mail: hartman@email.unc.edu

\section{SIMARD, L. JEAN, R. VAN REEKUM \& D. CLARKE. DIFFERENTIAL COGNITIVE IMPAIRMENT IN SUBJECTS WITH GERIATRIC DEPRESSION WHO WILL DEVELOP ALZHEIMER'S DISEASE, DEMENTIA WITH LEWY BODIES, VASCULAR AND MIXED DEMENTIA.}

Introduction: The link between geriatric depression (GD) and dementia has been studied in the past. However, few data are available regarding the differential cognitive profile at the onset of cognitive impairment in GD subjects who will indeed develop dementia. This study examined the cognitive profile at the first admission to a day hospital for depression of GD subjects with a diagnosis of dementia at follow-up in order to specify the differential markers of future dementia. Method: Baseline data were taken from the day hospital for depression database from which participants were recruited. Diagnoses of dementia at follow-up were determined by committees comprised of Neurologists, Psychiatrists and Neuropsychologists under double-blind conditions. The baseline Mini-Mental-State Examination (MMSE) and Mattis Dementia Rating Scale (MDRS) scores of the subjects found demented at follow-up were compared using independent t-tests with Levene's tests for equality of variances. Results: Fourteen of the forty-four subjects with GD followed-up over a mean of 7.5 years developed either Alzheimer's disease (AD), dementia with Lewy bodies (DLB), vascular $(\mathrm{VaD})$ or mixed dementia. At baseline, the DLB subjects were inferior to the AD subjects on MMSE-Calculation ( $\mathrm{t}=2.934, \mathrm{P}=0.031)$, MMSELanguage $(\mathrm{t}=2.521, \mathrm{P}=0.045)$, and MDRS-Conceptualization $(\mathrm{t}=3.545$, $\mathrm{P}=0.036)$. The $\mathrm{AD}$ subjects were inferior to the VaD subjects on MDRSAttention ( $\mathrm{t}=-3.382, \mathrm{P}=0.015)$ and inferior to the mixed dementia subjects on MDRS-Initiation/Perseveration $(\mathrm{t}=-2.563, \mathrm{P}=0.034)$. Conclusions: The DLB subjects had more impairment of executive function and language than $\mathrm{AD}$ subjects, whereas $\mathrm{AD}$ subjects had more impairment of attention and prefrontal function than subjects with vascular and mixed dementia.

Correspondence: Martine Simard, Ph.D., Universite Laval, Pavillon Felix-Antoine Savard, Quebec City, QC G1K 7P4, Canada. E-mail: Martine.Simard@psy.ulaval.ca

\section{K.W. STEH, J.J. DUNKIN, A. LEUCHTER, I. COOK, S. DAVID, J. KASL-GODLEY \& M. ABRAMS. INTERACTION OF AGE AND DEPRESSION ON COGNITIVE FUNCTIONING.}

There has been limited research investigating the effect of depression on cognition across age groups, with some studies finding that depression exerts a greater impact on cognition in elderly individuals, and other studies demonstrating no differences. This is an important area in which to conduct further research as greater cognitive morbidity in older populations may lead to greater functional disability. The aim of this study was to examine the effect of depression on cognition across a broad age range. A battery of neuropsychological tests was administered to sixtyone individuals in three age cohorts (21-37, $\mathrm{N}=24 ; 38-57, \mathrm{~N}=23 ; 62$ $76, \mathrm{~N}=14$ ) diagnosed with a Major Depressive Episode (mild to moderate) as defined by the DSM-IV and SCID. The neuropsychological tests were grouped into four domains: learning and memory, attention and concentration, executive functioning, and language functioning. The data were transformed into standard scores for comparison between age 
groups based on available normative data. Data were then analyzed using the MANCOVA procedure, controlling for baseline group differences in years of education, depression severity, and WAIS-R Vocabulary score. No significant differences were found between age groups in any cognitive domains. The results of this study suggest that the older individuals in this sample were not more vulnerable to the effects of depression on cognition as compared to their younger counterparts. Additional thought regarding the morbidity of late-life depression is warranted, as it may be more favorable than previously believed. For example, future research may investigate functional impairment using variables relevant to each age group.

Correspondence: Kristi W. Steh, Ph.D., Psychiatry and Behavioral Sciences, UCLA, 760 Westwood Plaza, Room 37-372A, Los Angeles, CA 90024.E-mail:ksteh@mednet.ucla.edu

\section{M.A. BUTTERS, R. BHALLA, A.E. BEGLEY, B. SCHODERBEK, M. ZMUDA, R. NEBES \& J. BECKER. NEUROPSYCHOLOGICAL FUNCTIONING IN LATE-LIFE DEPRESSION.}

Background: While there is a substantial risk of developing progressive dementia after a depressive episode, cognitive impairment in late-life depression (LLD) is poorly understood. The purpose of this study was to characterize neuropsychological functioning in LLD and examine its association with putative risk factors for cognitive impairment. Methods: We compared neuropsychological functioning in 100 non-demented subjects age 60+, meeting DSM-IV criteria for current episode of unipolar major depression (non-psychotic) and 40 non-depressed, age- and education-equated elderly controls. We also examined the relationship between clinical and biologic factors and performance across cognitive domains. Results: Relative to controls, LLD subjects performed more poorly in all cognitive domains. More than half of the LLD subjects exhibited performance below the 10th percentile of the controls. Information processing speed, visuospatial and executive abilities were the most broadly and frequently impaired. The neuropsychological deficits in LLD were mediated almost entirely by slowed information processing speed. Education and ventricular atrophy made additional modest contributions to language ability. Medical and vascular disease burden, APOE allele type and serum anticholinergic burden did not contribute to variance in cognitive functioning. Conclusions: Cognitive dysfunction in LLD is characterized by impairment in information processing speed, which affects all realms of performance. This model of cognitive dysfunction lends support to the concept that subcortical/frontal lobe dysfunction plays a key role in LLD. Further neuropsychological studies in remitted LLD patients, in order to parse episode-related and persistent cognitive deficits, are indicated. Such data will shed additional light on the role of underlying neural dysfunction.

Correspondence: Meryl A. Butters, Ph.D., Psychiatry, University of Pittsburgh, WPIC, 3811 O, Pittsburgh, PA 15213.E-mail: buttersma@ upmc.edu

\section{R.K. BHALLA, M.A. BUTTERS, B.H. MULSANT, A. GILDENGERS, A.E. BEGLEY, M.D. ZMUDA, B.A. SCHODER- BEK, R.D. NEBES, M. DEW, B.G. POLLOCK, C.F. REYNOLDS \& J.T. BECKER. NEUROPSYCHOLOGICAL FUNCTIONING DUR- ING THE DEPRESSED AND EUTHYMIC STATES OF LATE-LIFE DEPRESSION.}

Background: While there is a substantial risk of developing progressive dementia after a depressive episode, cognitive impairment in late-life depression (LLD) is poorly understood. The purpose of this study was to characterize neuropsychological functioning in LLD patients first when they are depressed and later while euthymic. Methods: We compared performance on a comprehensive neuropsychological battery in 60 non-demented subjects age 60+, meeting DSM-IV criteria for current episode of unipolar major depression (non-psychotic) and 40 nondemented, non-depressed, age-and education-equated controls at baseline when patients were depressed, and one year later when euthymic.
Results: A repeated measures MANOVA revealed a group effect, indicating that relative to controls, LLD subjects performed more poorly across all cognitive domains. There was a significant time effect across all cognitive domains indicating for both groups, worse performance at baseline and better performance one year later during the euthymic state. Interestingly, there was no significant group by time interaction, indicating that both groups changed across time at the same rate. Conclusions: As a group, depressed subjects exhibited significant cognitive impairments while depressed and once they achieved a euthymic state. These data are strikingly inconsistent with the general belief that LLD patients' cognitive impairments are related to being in a depressed state. Rather, they suggest that the impairments may be less dependent on mood state and more likely reflect permanent trait deficits. Further analyses examining the role of age of onset, depression severity and baseline severity of cognitive impairment on cognitive functioning in the euthymic state will be discussed.

Correspondence: Rishi K. Bhalla, MS, Geriatric Psychiatry, Western Psychiatric Institute and Clinic, 5840 Alderson St. \# 3, Pittsburgh, PA 15217.E-mail:bhallark@upmc.edu

\section{A.G. GILDENGERS, M.A. BUTTERS, K. SELIGMAN, R. BHALLA, M. MILLER, B. MULSANT, D. KUPFER \&. C.F. REYNOLDS. NEUROPSYCHOLOGICAL FUNCTIONING IN LATE-LIFE BIPOLAR DISORDER.}

Objective: To characterize neuropsychological functioning in elderly patients with bipolar disorder. Methods: Neuropsychological functioning of 18 euthymic patients with history of bipolar I or II disorder, aged 60 years and older, was tested with the Mini-Mental State Examination (MMSE), Mattis Dementia Rating Scale (DRS), and Executive Interview (EXIT). Neuropsychological functioning in these 18 bipolar subjects was compared with that of an age- and education- equated group of control subjects without mood disorders $(n=45)$. Results: Approximately half of the bipolar subjects scored one or more standard deviations below the control mean on the MMSE $(n=8,44 \%)$ and DRS total $(n=10$, $55 \%)$. On the EXIT, $3(16 \%)$ subjects scored between one and two standard deviations worse than the control mean. Conclusion: A significant proportion of older bipolar subjects exhibit cognitive deficits when clinically euthymic.

Correspondence: Ariel G. Gildengers, MD, Psychiatry, University of Pittsburgh, WPIC, 3811 Ohara Street, Pittsburgh, PA 15213. E-mail: gildengersag@upmc.edu

\section{B.K. LEBOWITZ, P.K. SHEAR, M.A. STEED, F.E. KLEIN \& S.M. STRAKOWSKI. MOTOR INHIBITION IN BIPOLAR DISORDER.} The ability to inhibit a prepotent motor response has been shown to be impaired in a number of disorders that are characterized in part by impulsive behavior. While impulsivity is a ubiquitous feature of bipolar disorder (BPD), little research has explored motor inhibition in this population. Further, because a successfully inhibited response is a non-observable event, the assessment of motor inhibition ability requires specialized tools. The stop signal test, a computer administered task requiring the participant to inhibit a prepotent motor response, allows for the parsing of response behavior into measures of facilitation (Go reaction time) and inhibition (Stop latency). In the current study we administered the stop signal test to 26 non-syndromal individuals with BPD and 24 demographically matched healthy controls. It was hypothesized that individuals with BPD would demonstrate slower Stop latencies as compared to healthy controls. A 2 (Patients, Controls) X 2 (Go reaction time, Stop latency) repeated measures ANOVA was performed, revealing only a trend towards significant group differences $\mathrm{F}(1$, $48)=3.431, p=.07$. However, univariate follow-up analyses revealed that group differences were due to significantly slower Go reaction times $(p<.05)$ in the patient group, with no differences in Stop latency $(p>$ .7). Further, the patient group made significantly more omission errors 
than the healthy volunteer group $(p<.01)$. Taken together, the results of this study suggest that simple motor inhibition is intact in non-syndromal individuals with BPD. However, the slow response times and increased omission errors are suggestive of a generalized impairment of attention.

Correspondence: Brian K. Lebowitz, M.S., Psychology, University of Cincinnati, University of Cincinnati, PO BOX 210376, Cincinnati, OH 45221-0376.E-mail: lebowibk@email.uc.edu

\section{C.T. GUALTIERI, L.G. JOHNSON \& K.B. BENEDICT. COMPLEX ATTENTION IN BIPOLAR AND UNIPOLAR DEPRESSION.}

The depression that occurs in patients with bipolar affective disorder is usually associated with complaints of cognitive dysfunction: poor memory, inattention, problems with planning, initiation and perseverance. While it is true that all forms of depression can be associated with cognitive complaints, they are thought to occur more commonly, and with greater severity, in patients with bipolar depression, compared to unipolar depressives. The authors have tested this widely-held clinical belief in a study of patients with bipolar depression $(\mathrm{N}=20)$, compared to an age/gender/race matched comparison group of unipolar depressives $(\mathrm{N}=20)$ and to normal controls. The three groups are comparable in tests of verbal and visual memory. Both patient groups performed less favorably on tests of reaction time, motor control and psychomotor speed, compared to normal controls, but the differences between bipolar and unipolar depressives was not significant. Both patient groups performed less well on tests of complex and sustained attention, and executive function, compared to controls, but patients with bipolar depression were significantly more impaired than patients with unipolar depression. Theses differences cannot be explained on the basis of patient characteristics, disease severity or medication status. If these observations are replicated, the clinical implications for diagnosis and treatment will not be unimportant. They may support the routine application of neurocognitive testing in the psychiatric setting.

Correspondence: C T. Gualtieri, MD, Neuropsychiatry, North Carolina Neuropsychiatry PA, 1829 E Franklin St, Suite 400, Chapel Hill, NC 27514.E-mail:tg@ncneuropsych.com

\section{Schizophrenia}

\section{S.M. BERNS, J. JAEGER, C. GONZALEZ, S. UZELAC, G. MUSSO, S. LOFTUS \& S. ABDELMESSIH. COMPARISON OF BIPOLAR AND SCHIZOPHRENIA INPATIENTS ON NEUROCOGNITIVE DEFICITS.}

Many researchers report similar neurocognitive deficits in bipolar disorder (BPD) and schizophrenia (SZ). Some have used these observations to support the existence of a SZ-BPD continuum. We compared the neurocognitive performance of BPD $(\mathrm{N}=65,40 \%$ male, mean age $=34.1(\mathrm{SD}=10.3))$ and $\mathrm{SZ}(\mathrm{N}=42,33 \%$ female, mean age $=36.2$ (SD=9.4)) inpatients. BPDs performed significantly better on the WCST (fewer perseverative errors $(\mathrm{p}=.05)$ and more categories $(\mathrm{p}=.012)$ ), WMS-R Logical Memory immediate recall $(p=.005)$, WAIS-R Performance IQ $(p=.012)$ and phonemic fluency (fewer perseverations, $\mathrm{p}=.048$ ). No differences were observed on list learning (CVLT Lists 15), WMS-R Logical Memory delayed, Ruff Figural Fluency (unique designs or perseverative errors), VIQ, Animal Naming, WMS-R Visual Reproduction, Letter Number Span or Trails A. When BPDs (excluding mixed cases) were divided into groups based on current mood, manic $(\mathrm{N}=19)$ versus depressed ( $\mathrm{N}=31)$, an interesting pattern emerged. The diagnostic differences observed above were seen in depressed but not in manic patients who, in these instances, did not differ from the schizophrenia sample. The only exception was COWAT perseverations and total correct, where manics performed better, while depressed subjects did not differ from SZs. Since the currently depressed BPD patients had been (by definition) manic at a previous time, these findings suggest that neurocognitive deficits in BPD may fluctuate in tandem with mood state, with only mania producing deficits that are comparable to SZ. The BPD-SZ continuum is therefore not supported by these data, "state fluctuation" may be a hallmark feature of BPD that distinguishes bipolar and schizophrenia patients.

Correspondence: Sarah Uzelac, Ph.D. Candidate, Hillside Hospital, 7559 263rd St., Glen Oaks, NY 11004.E-mail: suzelac@lij.edu

\section{C.M. WILK, K. HUMBER, V.N. IANNONE, R.W. BUCHANAN \& J.M. GOLD. COGNITIVE PROFILE DISPARITIES BETWEEN SCHIZOPHRENIA PATIENTS AND A FSIQ-MATCHED HEALTHY COMPARISON GROUP.}

Objective: To determine if patients with schizophrenia (SC) and healthy comparison $(\mathrm{HC})$ participants show similar cognitive profiles (i.e. are SC patients "neuropsychologically normal"?) when individually matched on the basis of FSIQ. Method: Sixty-four patients meeting the DSM-IV criteria for schizophrenia and 64 healthy comparison participants were tested with the WAIS-III and WMS-III. SC patients were matched with healthy comparison participants to within 3 FSIQ points (SC M=99.33, $\mathrm{SD}=12.45$; $\mathrm{HC} \mathrm{M}=99.37, \mathrm{SD}=12.24 ; 75.0 \%, 20.3 \%$, and $4.7 \%$ were matched exactly, within 1 point, and within 3 points respectively). sults: The cognitive profile of the SC group was similar to that typically observed in the illness, yet distinctly different from the HC group. Relative to HC, SC patients showed marked impairment on the WAIS-III Processing Speed Index (PSI) and the Working Memory Index (WMI) $(p<0.05)$, and all WMS-III Index scores $(p<0.05)$, with the exception of the Auditory Recognition Delayed Index (ARDI; $p=0.07$ ). Patients tended to score higher than controls on the WAIS-III Verbal Comprehension In$\operatorname{dex}(\mathrm{VCI})$ and the Perceptual Organization Index (POI), though the differences were not statistically significant $(\mathrm{p}=0.079, \mathrm{p}=.095$, respectively). Conclusion: Scoring in the "normal" range on FSIQ does not preclude impairment; our data suggest that SC patients demonstrate clear evidence of illness related cognitive dysfunction even when scoring in the "normal" range of overall intellectual ability. Impairments of processing speed, working and episodic memory appear to be core features of the illness irrespective of FSIQ.

Correspondence: Christopher M. Wilk, Maryland Psychiatric Research Center, P.O. Box 21247, Baltimore,MD 21228. E-mail: cwilk@mprc. umaryland.edu

\section{HUA \& H. HWU. NEUROCOGNITIVE FUNCTION IN NONPSYCHOTIC PARENTS OF SCHIZOPHRENIC PATIENTS: A PRELIMINARY STUDY.}

Neurocognitive deficits of attention, memory, and executive function have often been reported in literature studying schizophrenic patients, and some attention/executive measures have been suggested to be phenotypic markers of predisposition to schizophrenia. The underpinning of neuropathological correlates of these deficits has often been associated with frontal, temporal, and related subcortical structures. The issue of whether the first-degree adult relatives of schizophrenic probands share similar neurocognitive problems with these probands, however, remains controversial. In the present study, we examined verbal intellectual function, attention and executive function in a sample of nonpsychotic parents of schizophrenic probands and of normal control adults to make an attempt to explore this issue. The results revealed that parents of schizophrenic patients evidenced deficits of selective attention and semantic association of verbal fluency compared with their normal counterparts, while there were no remarkable differences between the two subject groups in verbal intellectual function. Based on the preliminary data, we suggest parents of schizophrenic probands did share schiz- 
ophrenic patients with certain deficits of attention/executive functions implicating frontal and temporal dysfunction, and the results seem to be in line with the proposal that neurocognitive deficits in the first-degree relatives of schizophrenic patients reflect their gradation of genetic predisposition to schizophrenia.

Correspondence: Mau-Sun Hua, Ph.D., Psychology, National Taiwan University, Dept. of Psychology, National Taiwan University, \#1, Sec. 4, Roosevelt Rd., Taipei 106,Taiwan.E-mail: huams@ntu.edu.tw

\section{G.V. NAYAK, B.W. PALMER, D.V. JESTE \& R.K. HEATON. SENSITIVITY OF VISUAL AND VERBAL MEMORY TESTS TO COG- NITIVE IMPAIRMENT IN SCHIZOPHRENIA.}

Neurocognitive theories of schizophrenia often focus on verbal episodic learning as a core deficit. This perspective has, in part, inspired lateralization theories of schizophrenia positing that the neuropathology may be more prominent in the left versus right brain. One question is whether the emphasis on verbal learning reflects a differential deficit, or rather merely reflects the relative preponderance of studies incorporating verbal versus visual learning/memory tests. In this study we compared the sensitivity of the Story Memory and Figure Memory Tests (Heaton et al, 1991) to cognitive impairment in schizophrenia. Subjects were 174 schizophrenia/schizoaffective disorder patients ranging in age from 18 to 84 years (mean=44.5); participants included 118 men and 56 women. All subjects completed the memory tests as part of a larger neuropsychological evaluation. The "learning" score from each of these tests was converted to a demographically corrected T-score based on published norms; "impaired scores" were defined as those wherein the Tscore was less than 40 ( $1 \mathrm{SD}$ worse than the normative mean). Using these criteria 106 patients $(60.9 \%)$ were impaired in verbal learning (Story Memory Test), and $105(60.30 \%)$ were impaired in visual learning (Figure Memory Test); although 73 (42.0\%) were impaired on both tests, a non-trivial number (33 on Story Learning and 32 on Visual Learning) were impaired on one but not the other. These results suggest visual memory tests may provide unique information about cognitive deficits in schizophrenia, and should be considered for inclusion as part of comprehensive evaluations of memory dysfunction in this disorder.

Correspondence: Gauri V. Nayak, M.A., Psychiatry, University of California, San Diego, VA San Diego Healthcare System 116A-1, 3350 La Jolla Village Drive, San Diego, CA 92161. E-mail: gnayak@vapop.ucsd.edu

\section{S. GRIFFITHS, T. FAWKES, V. BOUDREAU, T. WOODWARD \& A.E. THORNTON. THE EFFECT OF MONETARY REINFORCEMENT ONVERBAL MEMORY PERFORMANCE IN SCHIZOPHRENIA.}

Schizophrenia is characterized by heterogeneous cognitive and psychiatric symptoms. In contrast to the positive or florid symptoms such as hallucinations, the negative symptom cluster in schizophrenia reflects a deficit state, including poverty of movement and speech, flattened affect, and an apparent loss of drive. Interestingly, verbal memory impairment in schizophrenia has been correlated with the negative symptomatology this disorder entails. The relationship between degraded motivation and verbal memory dysfunction has not, however, been systematically investigated. To evaluate this association, 32 patients with schizophrenia were administered experimental modifications of the Standard and Alternate Forms of the California Verbal Learning Test, 2nd Edition (CVLT-II, Kramer, Delis, Kaplan \& Ober, 2000) under unrewarded and rewarded conditions. During the rewarded condition, patients were told that they would be paid for successful recall, even though all patients ultimately received equivalent compensation. The overall effect of this manipulation was marginally significant across trials $(\mathrm{F}=$ $2.0, \mathrm{p}<.09)$, with the largest performance difference observed during the final, long-delay recall trial $(\mathrm{t}=2.0, \mathrm{p}<.05)$. These results suggest that motivational level is related to verbal memory performance in schizophrenia. Nonetheless, the observed performance improvement is relatively small and only partially accounts for the severe verbal memory disorder associated with schizophrenia.

Correspondence: Allen E. Thornton, Ph.D., Department of Psychology, Simon Fraser University, Burnaby, B.C., Canada, 8888 University Drive, Burnaby, BCV5A 1S6, Canada.E-mail: aethornt@sfu.ca

\section{MATSUI, H. YUUKI, K. KATO \& M. KURACHI. IMPAIRMENT OF MEMORY ORGANIZATION IN PATIENTS WITH SCHIZO- PHRENIA SPECTRUM DISORDER.}

Previous research have suggested that patients with schizophrenia have greater impairments in memory than in other cognitive functions. The purpose of this study was to investigate organizational strategies in patients with schizophrenia or schizotypal personality disorder (SPD) or normal controls divided by age. Participants were 31 patients with schizophrenia and 20 patients with SPD, and 115 healthy volunteers. All participants were administered the Japanese Verbal Learning Test (JVLT). The verbal learning task was composed of three 16-word lists: a random list, a blocked list, and a unblocked list. These three lists differed in degree of semantic organization. Clustering according to serial order of word presentation (Serial Clustering) and semantic content (Semantic Clustering) was calculated with an observed / expected ratio. An analyses of covariance (ANCOVA) was carried out to evaluate differences in each index across the groups. Group was used as between-group factor, and Organization Index was used as a within-group factor. Score of Vocabulary (WAIS-R) was used a covariate. There were significant main effects for group and organization index. Patients with schizophrenia showed less semantic clustering than normal people irrespective of the number of recall, but not serial clustering. Early adolescents healthy subjects showed significantly better semantic clustering than other groups and the latter teen-age subjects showed worse than early adolescence subjects. Patients with SPD also used less semantic clustering than the normal group. These results provide further support for the view that impairment of memory organization is a marker of the schizophrenia spectrum disorder.

Correspondence: Mie Matsui, Ph.D., Psychology, Toyama Medical \& Pharmaceutical University, 2630 Sugitani, Toyama 930-0194, Japan. E-mail:mmatsui@ms.toyama-mpu.ac.jp

\section{S.A. MCDERMID VAZ \& R. HEINRICHS. HOW REPRODUCIBLE ARE MEMORY-BASED SUBTYPES OF SCHIZOPHRENIA? .}

The clinical and neurobiological variability of the schizophrenia patient population is a major impediment to understanding the syndrome. The present investigation examined a typology based on memory performance as a way of organizing the heterogeneity of schizophrenia. We attempted independent replication of a cluster analytic model recently described by Turetsky et al. (2002). This was done in the context of an archival sample of 102 atypical neuroleptic naive patients receiving conventional antipsychotic medications. Atypical drugs may have a mildly beneficial effect on memory functioning. The typology was defined by three scores from the California Verbal Learning Test: Total Recall (Trials I-V), Cued Recall Intrusions (Short and Long Delay Cued Trials) and Recognition: Recall (Discriminability - Trial V Recall). Performance patterns on these scores described cortical, subcortical, and normal memory profiles in previous reports (Massman et al., 1990; Squire, 1992). Raw CVLT scores were transformed into $\mathrm{z}$-scores and entered into a kmeans cluster analysis following procedures outlined in the original report. Our results represent a partial replication of the clusters reported by Turetsky et al. One cluster comprised relatively unimpaired patients like those in the original report, while two impaired clusters showed some (impaired Total Recall, intrusion rates), but not all (recognition) 
score patterns found in the cortical-subcortical distinction. These findings provide evidence that memory performance is a valuable heuristic tool in the search for neurocognitive subtypes of schizophrenia. However, not all subtypes are equally reproducible or independent of treatment influences.

Correspondence: Stephanie A. McDermid Vaz, M.A., Psychology, York University, 4700 Keele Street, Toronto, ON M3J 1P3, Canada. E-mail: stephani@yorku.ca

\section{B.A. MOORE. THE EFFECT OF SCHIZOPHRENIA ON THE TEST OF MEMORY MALINGERING.}

The Test of Memory Malingering (TOMM) has been shown to be unaffected by various neurological conditions including dementia, traumatic brain injury (TBI), and aphasic disorders. In addition, research has shown that unipolar depression and anxiety do not negatively impact performance on this instrument. However, one clinical group that has not been a focus of study with the TOMM is individuals diagnosed with schizophrenia. The present study investigated the performance of 56 individuals diagnosed with schizophrenia on the TOMM that were receiving outpatient psychiatric and psychological services. Particpants that were currently involved in financial compensation seeking cases (disability) were excluded from the study. The results indicate that no subjects fell below a raw score of 45 on Trial 2 of the TOMM (score indicative of malingering). Furthermore, chronicity of the disorder was not shown to be a factor on performance. These findings suggest that schizophrenia, as with other neurological and psychiatric disorders, does not impact peformance on the TOMM.

Correspondence: Bret Moore, M. A., Psychological Services of Michigan, 4431 Dover Hills Dr. \#102, Kalamazoo, MI 49009. E-mail: bretandrewmoore@yahoo.com

\section{JOVANOVSKI, K. ZAKZANIS \& D. YOUNG. AWARENESS OF ILLNESS AND ITS RELATIONSHIP TO EXECUTIVE FUNCTION IN CHRONIC SCHIZOPHRENIA: THE MISSING EXECUTIVE?}

Past research has documented a relationship between lack of insight or awareness of illness and executive deficits in chronic schizophrenia. However, previous research on insight has not emphasized the use of ecologically valid tests of executive function in patients with schizophrenia. The Behavioural Assessment of the Dysexecutive Syndrome (BADS) is a test battery aimed at predicting everyday problems arising from the Dysexecutive Syndrome. Accordingly, the objective of the current study was to explore whether an association exists between performance on the BADS and level of insight in patients with chronic schizophrenia. The study included 21 patients (17 males) with a DSM-IIIR or DSMIV diagnosis of chronic schizophrenia or schizoaffective disorder. The sample was comprised of outpatients who were administered the BADS and the Scale to Assess Unawareness of Mental Disorder (SUMD). The majority $(57 \%)$ of the sample group was classified as being impaired on the BADS total profile score. Three of the four significant correlations found were between the Rule Shift Cards subtest and SUMD measures, indicating that poorer performance on this BADS subtest, a measure of reactive flexibility, was associated with poorer insight. These findings demonstrate that a specific executive ability (i.e., reactive flexibility), rather than generalized executive functioning, is associated with insight in chronic schizophrenia. The results are in line with prior studies, which have found correlations between another measure of reactive flexibility (i.e., Wisconsin Card Sorting Test) and insight. Past research has shown that both patients with basal ganglia lesions and patients with frontal lobe lesions show impairments in reactive flexibility. The current results therefore suggest that both frontal and subcortical structures are likely related to insight in chronic schizophrenia.

Correspondence: Diana Jovanovski, Honours B.Sc., Division of Life Sciences, University of Toronto (at Scarborough), 1265 Military Trail, Scarborough, ON M1C 4B6, Canada.E-mail: diana.jovanovski@ utoronto.ca
D. YOUNG, D. JOVANOVSKI \& K. ZAKZANIS. EVALUATION OF INSIGHT AND ORDER OF ADMINISTRATION EFFECTS: A COMPARISON BETWEEN A RESEARCHER-RATED AND A SELF-REPORT INSIGHT SCALE IN SCHIZOPHRENIA.

Previous research has shown that a moderate correlation exists between several researcher-rated and self-report insight scales in patients with schizophrenia. An earlier study demonstrated that the order of administration using these two types of scales can affect the results. The objective of the current study was to investigate the association between the two types of insight measures and to explore order of administration effects using a different combination of insight scales from those used in past research. The study included 21 outpatients with chronic schizophrenia or schizoaffective disorder. Participants were administered the researcher-rated Scale to Assess Unawareness of Mental Disorder (SUMD) and the self-report Self-Appraisal of Illness Questionnaire (SAIQ) using counterbalancing techniques to vary order of administration. The only SAIQ subscale that was found to be (positively) correlated with the SUMD was Need for Treatment. In the self-report first group, only scores on the SAIQ Need for Treatment measure were found to be significantly correlated with SUMD measures whereas, in the researcher-rated first group, none of the scores on the two scales were found to be correlated. The present study replicated the findings of the earlier study on order of administration effects in that only when the self-report measure was administered first did the two insight scales correlate. The current results further stress the importance of order of administration effects and hence the questionable reliability of many previous studies on the correlation between researcher-rated and self-report insight measures, which neglected to utilize counterbalancing to vary administration order.

Correspondence: Diana Jovanovski, Honours B.Sc., Division of Life Sciences, University of Toronto (at Scarborough), 1265 Military Trail, Scarborough, ON M1C 4B6, Canada.E-mail: diana.jovanovski@ utoronto.ca

\section{D.R. ROALF, B.I. TURETSKY, R.L. DOTY, R.E. GUR \& P.J. MOBERG. UNIRHINAL IMPAIRMENT OF ODOR HEDONICS IN MEN WITH SCHIZOPHRENIA.}

Objective: Deficits in affect recognition have been reliably established in schizophrenia with anhedonia being a core feature of the illness. Patients with schizophrenia also show deficits in olfactory functioning, with impairment on tests of odor identification, detection threshold sensitivity, discrimination, memory, and hedonic valence being reported. The olfactory system structure is relatively simple and relies upon ipsilateral connections to the brain. Despite structural and functional evidence suggesting olfaction and emotion are regulated via overlapping limbic structures, little has been done to parse out specific connections between the two systems. This study examined unirhinal intensity and hedonic judgments in patients with schizophrenia to determine whether these functions were differentially impaired or lateralized. Method: Suprathreshold scaling of odor intensity and pleasantness was acquired in 34 male patients with a DSM-IV diagnosis of schizophrenia and 22 age- and sex-matched healthy comparison subjects, using the Suprathreshold Amyl Acetate (AA) Odor Intensity and Odor Pleasantness Rating Test. Results: Patients showed impairment in right nostril intensity ratings and bilateral deficits in pleasantness scaling relative to controls. Posthoc analysis revealed that these deficits were driven by impaired ratings to the highest concentration of AA. The impact of smoking status and general cognitive impairment on this deficit was insignificant. Conclusions: Male patients with schizophrenia show a disruption in the ability to attribute appropriate intensity and hedonic valence to strong pleasant odors. Such difficulties are consistent with clinical observations of anhedonia and points to a neural substrate that might contribute to the emotional disturbances seen in patients with schizophrenia. 
Correspondence: David R. Roalf, B.S., Neuropsychiatry, Univ. of Pennsylvania, 3400 Spruce Street, Gates 10, Philadelphia, PA 19130. Email: roalf@bbl.med.upenn.edu

\section{KIM \& J. KWON. ERP STUDY OF VISUAL WORKING MEM- ORY IN SCHIZOPHRENIA USING A 2-BACK PARADIGM.}

Visual working memory of the schizophrenics was investigated. 10 schizophrenics and 15 controls participated, and geometric figures were used as stimuli. The target stimulus was a circle, while triangle and square were non-targets. Target stimulus was further divided into the match and nonmatch target. If the current stimulus was a circle, and the circle was presented 2 trials earlier (match target), the subject was required to respond. If the current stimulus was a circle, but the circle was either not presented 2 trials earlier(nonmatch target), or the current stimulus was either a triangle or a square(non-target), the subject was asked not to respond. The grand-averaged ERP showed N100, P300 and slow potential(SP) in both groups. Match and nonmatch target elicited larger N100 amplitude than non-target in both groups, indicating that more attention was directed to the target than non-target. In terms of P300, match target elicited a greater amplitude and earlier latency in both groups. P300 was at a maximum at the parietal sites in the match target, while it was at its highest at the frontal sites in the nonmatch target or nontarget. However, the two groups showed differences with regard to SP amplitude. In the control group, all types of stimuli produced a positive slow potential with similar amplitudes and latencies, while in patient group, match target elicited a larger amlplitude than nonmatch target $(\mathrm{p}<.05)$ or nontarget $(\mathrm{p}<.05)$. These results indicate that schizophrenics have deficits in the storage and manipulation of the information, since in order to perform the 2 -back task successfully, it is required to hold sequences of all types of stimuli whether the stimulus is target or non-target. These results indicate that such temporal stages of $\operatorname{cog}$ nitive functions underlying working memory as attention allocation, updating the working memory contents and the retention of sequential information can be reflected by ERP components.

Correspondence: Myung-Sun Kim, ph.D, Psychology, Sungshin Women's Univ., 249-1, 3ka, Dongsun-dong, Sungbuk-gu, Seoul 136-742, South Korea.E-mail:kimms@sungshin.ac.kr

\section{S. KEEDY, M. MARLOW-O'CONNOR, I. TORRES \& M. GOLD- MAN. SMALLER LEFT AMYGDALA VOLUME PREDICTS GREATER ABNORMALITY FOR RATING FEARFUL AND SUR- PRISED FACIAL EXPRESSIONS AMONG INDIVIDUALS WITH SCHIZOPHRENIA.}

Research suggests that the pathophysiology of schizophrenia involves medial temporal lobe structures. To investigate the possible role of amygdala dysfunction, we obtained amygdala volumes from manual traces (intra-class correlation Cronbach $\alpha=.90$ ) on T1-weighted MR images acquired from a 3T GE scanner. Amygdala function was indexed with a task developed by Adolphs et al. (1999), who demonstrated that individuals with amygdala lesions displayed specific deficits for rating fearful facial expressions. We hypothesized that in patients with schizophrenia, smaller amygdala volumes would also result in these deficits. Participants rated 36 photos of actors exemplifying one of six a prioridefined emotions and three photos of neutral expressions. Participants rated each photo on a five-point scale for intensity of fear, happiness, sadness, surprise, disgust, and anger. 16 individuals with schizophrenia performed the task and had MRIs adequate for analysis. Their ratings of the six emotions for each photo were correlated with the group mean of 11 normal controls, group-matched for age and gender. Linear regression analyses on z-transformed correlation coefficients, group averaged by a priori-defined emotional expression, were performed, controlling for facial perception (Benton Facial Recognition test). We entered right and left amygdala volumes in a stepwise fashion. Left amyg- dala volumes significantly predicted correlations for photos a priori-categorized as fearful $(p=.02)$ and surprised $(p=.03)$. These results support our hypothesis that diminished amygdala volumes disrupt accurate assessment of fearful faces, and may also disrupt surprised faces, which share expressive features of fear.

Correspondence: Sarah Keedy, M.S., Psychology, Finch University of Health Sciences, 3333 Green Bay Road, North Chicago, IL 60064. Email:sk101@ureach.com

\section{P. CABALLERO, N. CASCELLA, V. RAO, G. PEARLSON \& D.J. SCHRETLEN. COGNITIVE CORRELATES OF REDUCED STRIATAL VOLUME IN SCHIZOPHRENIA.}

Structural abnormalities of the striatum have been found in many studies of schizophrenia, but their functional significance remains unclear. Stratta et al. (1997) reported correlations between reduced striatal volumes and executive functioning, but these have not been replicated. Therefore, we sought to determine whether striatal volumes would correlate with neuropsychological test performance in 12 patients with schizophrenia (all treated with atypical neuroleptics) and 14 age-, sex, race-, eduction-, and NART-R estimated IQ-matched healthy adult participants in the Johns Hopkins Aging, Brain Imaging and Cognition study. All subjects completed a brief battery of cognitive tests, and underwent a brain MRI scan in which T1-weighted, SPGR images were obtained on a 1.5 Tesla GE Signa scanner. Volumetric measures of the caudate nucleus and putamen were obtained using locally developed image analysis software. Independent samples t-tests revealed significant group differences for the left, right, and total volumes of both the caudate and putamen (all $p \mathrm{~s}<.05$ ). Patients with schizophrenia had smaller volumes than matched controls in both structures. The patients also performed more poorly than matched controls on several cognitive measures, including Conners' Continuous Performance Test (CPT). Correlation analyses based on the pooled data revealed significant relationships between CPT hit reaction time and total caudate $(r=-.517)$ and putamen $(r=-.660)$ volumes. These findings support the hypothesis that schizophrenia is characterized by reductions in the volume of striatal nuclei, and that these reductions are associated with the slowed choice reaction time from which these patients suffer.

Correspondence: David J. Schretlen, Ph.D., Department of Psychiatry, Johns Hopkins University, 600 N. Wolfe Street, Meyer 218, Baltimore, MD 21287-7218.E-mail:dschret@jhmi.edu

\section{K. GODDARD, P.J. WASS \& E.B. SLAWINSKI. LACK OF EVI- DENCE FOR DECREASD LATERALIZATION IN SCHIZOPHRENIA FROM A SIMPLE REACTION TIME TASK.}

Anomalous lateralization has long been of interest in schizophrenia research, but conflicting results exist as to the presence, degree, and direction of these anomalies. In this study, we examined whether individuals with schizophrenia would demonstrate less pronounced lateralization using a dominant and non-dominant hand version of the continuous performance task. Specifically, we hypothesized that schizophrenia patients would evidence a reduction in the normatively-observed non-dominant hand advantage for visual stimuli in a simple reaction time task. Methods: 31 DSM-IV diagnosed chronic schizophrenia patients were recruited from an in-patient psychiatric hospital and were age-, handedness-, and gender-matched with 31 healthy controls. Participants ranged in age from 20 to 50 years. Simple reaction time for visual stimuli with dominant and non-dominant hands was assessed with the California Computerized Assessment Package (CalCAP) as described in the manual (Miller, 1986-1995). Results: Schizophrenia patients demonstrated significantly slower mean reaction times compared to healthy controls with both dominant ( $424.1 \mathrm{vs} 351.0 \mathrm{~ms}$ ) and non-dominant (358.8 vs $308.4 \mathrm{~ms}$ ) hands ( $\mathrm{p}$ 's $<.05$ ), and dominant-hand performance was disproportionately slower relative to non-dominant-hand performance (73.1 vs $50.4 \mathrm{~ms}$ ). Conclusions: These results do not support the contention that schizophrenia patients show less lateralized performance at least 
on unimanual simple reaction time tasks. Rather, it appears that not only are schizophrenia patients generally slower to process information, but are differentially impaired when information must be processed by or integrated with the non-dominant hemisphere. Findings are discussed with respect to emerging methodological and theoretical issues in the assessment of laterality in schizophrenia.

Correspondence: Kim Goddard, Department of Psychology, University of Calgary, 2500 University Dr. N.W., Calgary, AB T2N 1N4, Canada. E-mail: kgoddard@ucalgary.ca

\section{K. BARNETT. SCHIZOPHRENIA AND COMMUNICATION BE- TWEEN THE HEMISPHERES.}

It has been demonstrated that stimuli presented simultaneously to both hemispheres of the brain are processed more rapidly than stimuli presented to only one hemisphere. It has been suggested that there may be a deficit in this "bilateral field advantage" in people with schizophrenia due to a lack of cooperation between the hemispheres. The paper presented will report and discuss behavioural and EEG data obtained from a task designed to assess communication between the hemispheres of the brain in 10 participants diagnosed with schizophrenia and controls with no psychiatric diagnosis. Participants underwent 320 trials in which they were required to make "word or non-word" judgements to stimuli presented to either a single visual field or bilaterally to both visual fields. Individuals with schizophrenia had normal lateralization of language to the left hemisphere. Controls exhibited the expected bilateral advantage (i.e. an increase in reaction time) when identical stimuli were presented simultaneously to both sides of the brain. This effect was not apparent in individuals with schizophrenia. The results will be discussed with reference to language symptoms observed in schizophrenia and the role of the corpus callosum.

Correspondence: Kylie Barnett, Ph.D. enrolled, Psychology, The University of Auckland, Private Bag 92019, Auckland, Auckland n/a, New Zealand.E-mail:k.barnett@auckland.ac.nz

\section{WALDER, L.J. SEIDMAN, N. CULLEN, M. TSUANG, J. SU \& J.M. GOLDSTEIN. SEX-SPECIFIC EFFECTS IN DOMAINS OF LAN- GUAGE IN SCHIZOPHRENIA VERSUS NORMAL COMPARISONS.}

The research literature, including our own, suggests sex differences in language processing among adult patients with schizophrenia, with males tending to perform worse than females. However, it is still unclear whether there is a differential effect among men and women for different domains of language. The current study was aimed at clarifying this question for the domains of phonology, semantics and grammar. Patients were systematically ascertained from an extensive outpatient treatment system covering a Boston city catchment area, and included 31 (17 male/14 female) individuals with DSM-III-R schizophrenia. Normal controls ( $\mathrm{n}=27 ; 13$ male/14 female) were ascertained from the same catchment area and made proportionately comparable, within-sex, on age, handedness, parental socioeconomic status, and ethnicity. The mean age of the patients was 39.1 years $(\mathrm{SD}=7.0)$, which was not significantly different from the normal controls nor between men and women. An extensive language battery including tests of semantics, grammar, and phonological processing was administered in the context of a comprehensive neuropsychological battery. A multivariate general linear model was used to test for sex-specific effects in the 3 language domains, controlling for potential confounders such as attention. Women with schizophrenia compared to their normal counterparts had relative preservation of function in semantics and grammar, but not phonology. Men with schizophrenia compared to normal men showed diffuse dysfunction across the language domains. These sex-specific effects in language dysfunction will be related to our recent findings on sex differences in volumetric brain abnormalities in regions associated with these domains.
Correspondence: Deborah J. Walder, Ph.D., Psychiatry, Massachusetts General Hospital/Harvard Medical School, MGH Center for Biomedical Imaging, 149 13th Street, MGH-East, CNY-9, Rm. 9127, Charlestown, MA 02129.E-mail:dwalder@hms.harvard.edu

\section{K.F. PAGULAYAN, P.K. SHEAR \& P. FARRELL. VOCAL AFFECT RECOGNITION IN SCHIZOPHRENIA.}

Emotional functioning deficits are prominent in schizophrenia, but research has focused more on facial affect recognition than vocal affect recognition. This study investigated performance of 44 individuals with schizophrenia $(M$ age $=42 ; S D=7.78)$ on the Emotional Perception Test (EPT). This administration of the vocal affect measure included a Sense task that presented neutral statements in one of five emotional valences (happy, angry, frightened, neutral, sad) and a Nonsense task that presented non-word strings in the same emotional valences. Participants completed both tasks in a counterbalanced order. In comparison to published normative data, patients made an elevated number of errors on both the Sense $(Z=2.5)$ and Nonsense $(Z=3.1)$ conditions. An ANCOVA revealed a significant task by order effect that persisted after covarying for the IQ differences between the groups $[F(1,41)=5.654$. $p<0.05]$. Specifically, participants who completed the Sense condition first made similar numbers of errors on both conditions, whereas those who completed Nonsense first were significantly more impaired on this component of the task. Thus, these findings suggest that individuals with schizophrenia are impaired in their overall ability to recognize vocal affect, and even more so when initially presented with a task that involves a novel, non-word context. Further investigation of the nature of the vocal affect recognition impairment in schizophrenia is critical because this skill is a key component of social communication.

Correspondence: Kathleen F. Pagulayan, M.A., Harborview Medical Center, 325 9th Ave., Box 359740, Seattle,WA 98104.E-mail:farrelkn@ email.uc.edu

\section{D.M. DOBEL, M. FISHER, J. POOLE \& S. VINOGRADOV. AN EX- AMINATION OF CROSS-RACIAL DIFFERENCES IN COGNITIVE AND PSYCHOSOCIAL VARIABLES ACROSS TWO PATIENT GROUPS WITH SCHIZOPHRENIA.}

The purpose of our study is to investigate whether cognitive differences exist between African-American and Euro-American subjects with schizophrenia, and if these differences are linked with symptom profile and/or quality of life. We evaluated 106 clinically stable patients with schizophrenia and schizoaffective disorders (79 Euro-Americans and 27 African-Americans). Groups were matched by age, gender, education, and symptom severity. Performance on a comprehensive neuropsychological battery, the PANSS (Positive and Negative Symptom Scale), and the QLS (Quality of Life Scale) was compared across groups. Results confirmed that African-American patients perform significantly worse on some, though not all, measures of executive functioning, working memory, and visuo-spatial processing compared to Euro-American patients. African-American patients also reported significantly higher rates of passive and apathetic social withdrawal in comparison to EuroAmerican patients. However, there were no significant overall differences in positive or negative symptom grouping of our samples, indicating that cognitive variables may not be correlated with negative symptoms in African-American patients with schizophrenia. In contrast, the literature indicates that cognitive deficits are correlated with negative symptoms in Euro-American patients with schizophrenia. Notable results of our study include that Euro-American patients reported significantly greater quality of life compared to African-American patients. In summary, cognitive variables may not be associated with negative symptoms in African-American patient populations, but may be linked with worse subjective assessment of quality of life in African-American patient populations. Mediating variables of culture and socio-economic status in ethnic minority populations may result in a different cognitive and psychosocial presentation unrelated to symptomatology. 
Correspondence: Danielle M. Dobel, Psy.D., Neuropsychology, McLean Hospital, 115 Mill Street, South Belknap, Belmont, MA 02478. E-mail: ddobel@yahoo.com

\section{L.H. RUBIN, P.M. MAKI, G.L. HAAS, M.S. KESHAVAN \&. J.A. SWEENEY. SEX DIFFERENCES IN COGNITIVE RESPONSE TO MEDICATION IN FIRST EPISODE SCHIZOPHRENIA.}

Sex differences in the presentation of diseases and in cognition may reflect the activational and/or organizational effects of gonadal hormones on brain function. Here we report the first study to examine sex differences in cognitive responses to medication in antipsychotic naive schizophrenic patients as a way of exploring possible hormone effects on cognitive deficits. The primary outcomes were scores on neuropsychological tasks that typically favor either men (Finger Tapping, Judgment of Lines Orientation) or women (Grooved Pegboard, Digit Symbols, California Verbal Learning Test). Participants included 101 men and women participating in the University of Pittsburgh First Episode Project. Pretreatment and post-treatment (5 weeks) testing was performed with never medicated first-episode men $(n=35)$ and women $(n=23)$ with schizophrenia, and in matched healthy men $(n=26)$ and women $(n=$ 16) at a similar time interval. Multivariate analyses of variance of the effects of sex, group, and time on "female" tasks showed advantages for females, controls, and the second session. Notably, female patients showed significant differential improvement on "female tests" following treatment ( $\operatorname{ex} \mathrm{x}$ group $\mathrm{x}$ time interaction). A similar analysis of "male tasks" showed an advantage for male patients and controls, but male patients did not show differential improvement on these tasks after treatment. Results show specific sex differences in treatment response in favor of females on female tests. Findings suggest that early organizational effects of estrogen on brain structure or activational effects of gonadal hormones on brain function might influence response to antipsychotic treatment.

Correspondence: Leah H. Rubin, M.A., Psychiatry and Psychology, University of Illinois at Chicago, 912 S. Wood St., M/C 913, Chicago, IL 60605.E-mail: lrubin@psych.uic.edu

\section{E.W. TWAMLEY, J.R. SADEK, J.M. NARVAEZ, R.K. HEATON,} D.V. JESTE, H. BENTLEY, M. RIVERA MINDT, I. GRANT \& T. HNRC GROUP. WORK-RELATED ABILITIES IN SCHIZOPHRENIA AND HIV: A DEMOGRAPHICALLY-MATCHED COMPARISON. Using a standardized vocational assessment (COMPASS), we examined vocational abilities in previously employed, but currently unemployed subjects with either schizophrenia $(n=23)$ or HIV infection $(n=23)$. We compared the two groups on COMPASS estimates of current levels of vocational abilities (performance on standardized work samples) and highest previous level of vocational abilities (based on Department of Labor classifications of their previous jobs). Groups were comparable in age (mean $=49$ years), education (mean $=12$ years), gender $(72 \%$ men), and ethnic minority status (28\% minorities). Both groups demonstrated lower vocational abilities than would be expected based on their prior work histories; these discrepancies were equivalent for the two groups $(p=.822)$. However, the schizophrenia sample had lower estimates of previous job functioning $(\mathrm{p}=.010)$ and somewhat lower current vocational abilities $(p=.125)$. An estimation algorithm suggested that, given their current performance, the HIV+ group could perform an average of $6.3 \%$ of the jobs in the national economy, whereas the subjects with schizophrenia group could perform only $1.7 \%$ of these jobs. These results are consistent with the neurodevelopmental nature of schizophrenia as well as acquired cognitive and vocational dysfunction in both schizophrenia and HIV.

Correspondence: Elizabeth W. Twamley, Ph.D., Psychiatry, University of California San Diego, 140 Arbor Drive, San Diego, CA 92103. E-mail: etwamley@ucsd.edu

\section{A. MEDALIA, R. LIM, T. KAUSHIK \& D. ERLANGER. THE WORK-READINESS COGNITIVE SCREEN AS AN ASSESSMENT TOOL IN SCHIZOPHRENIA: PSYCHOMETRIC PROPERTIES OF A WEB-BASED SCREENING TEST.}

Objective: This study examines the psychometric properties of the WorkReadiness Cognitive Screen (WCS), a web-based neuropsychological measure, as a screening tool for cognitive deficits in schizophrenia. The diagnostic group differences in cognitive functioning between those with schizophrenia and affective disorders were also examined using the WCS. Method: 185 outpatients with schizophrenia and 29 outpatients with affective disorders were administered the WCS to measure cognitive ability. The WCS consists of subtests that measure attention, working memory, nonverbal and verbal memory along with one educational index and various self and clinican report measures of vocational, social and learning preferences. Differences between the 93 low-functioning and 92 higher-functioning schizophrenia clients were examined. Reliability for alternate forms of the WCS was obtained from 38 schizophrenia clients. WCS performance of 29 clients with schizophrenia was compared to 29 clients with affective disorders for diagnostic group differences. Results: Participants with schizophrenia demonstrated marked cognitive impairment on the WCS measures of attention, working memory, immediate and delayed visual memory, and verbal recognition memory, scoring 1.3-2 S.D. below the mean for age matched normals. The higher-functioning schizophrenia group tended to perform better on the WCS cognitive domains than the low-functioning group. Retest reliability ranged from moderate to high. Cognition was more impaired in the schizophrenia than the affective disorder group, with working memory the most significant factor explaining group differences between schizophrenia and affective disorders. Conclusions: The WCS is a useful cognitive screening measure for schizophrenia. It is easily administered and time- and cost-effective.

Correspondence: Alice Medalia, Ph.D., Psychiatry and Behavioral Sciences, Albert einstein College of Medicine, Montefiore Medical Center, Montefiore Medical Center, K-2, 111 East 210 Street, Bronx, NY 10467. E-mail:amedalia@aol.com

\section{N. OJEDA, P. SANCHEZ, E. ELIZAGARATE, J. EZCURRA, A. YOLLER \& E. IBARROLA. PREMORBID FUNCTIONING RE- LATES TO TREATMENT RESPONSE AND COGNITIVE PRESEVA- TION IN CHRONIC SCHIZOPHRENIA. .}

The role of premorbid functioning $(\mathrm{PF})$ is usually considered in normal functioning as the baseline to compare to when the CNS is altered, or illness appears. In dementia, a relationship between higher PF and slower decline has been described in the literature. In this study we analyzed the relation between PF and cognitive deficiency in a sample of 85 hospitalized patients with chronic schizophrenia. 42 of the patients met Kane criteria of treatment refractant schizophrenia. Patients were classified into two subgroups: treatment responders $(R)$ and non- responders (NR). All subjects underwent a complete neuropsychological battery including measures of attention, learning and memory, executive functioning, visuospatial abilities, and psychomotor speed. The R group had significantly higher levels of PF $(p<.001)$ compared to NR. Also, the $R$ group performed significantly better in measures of attention, executive functioning and psychomotor speed, regardless of age, sex, and time since onset. When the variable time between first diagnosis and start of treatment was controlled for, the differences in the cognitive areas described above were still significant. However, no significant differences between the groups were found in measures of verbal and visual memory. None of these results were significantly related to negative or positive symptoms, although there was a tendency for poorer performance in memory by patients with negative symptoms. These results suggest a positive relationship among higher PF and better cognitive performance regardless of time since onset of schizophrenia and treatment response. Does higher PF prevent greater cognitive decline in chronic patients with schizophrenia? 
Correspondence: NATALIA OJEDA, PhD, of Psychology, Universidad de Deusto, Apartado 1,, Bilbao 48080, Spain. E-mail: nojeda@fice. deusto.es

\section{K. HUMBER, C.M. WILK, M. LEDUC \& J.M. GOLD. SOCIAL COG- NITION AND FUNCTIONAL OUTCOME IN SCHIZOPHRENIA.}

While previous research has documented that neurocognitive deficits in schizophrenia (SC) are associated with functional outcome, models that exclusively emphasize the role of neurocognition account for only a modest amount of outcome variance. It is likely that the cognitive impairments found in SC diminish the ability to effectively process socially relevant information and generate socially appropriate behavioral responses. It is also widely believed that the ability to understand the mental state of others (theory of mind) is impaired in SC populations and this deficit may be particularly salient to functional outcome. The present work examines the relationship between social cognition, general intellectual capacity and two types of functional outcome: social functioning and instrumental functioning (work and living status). Fifty outpatient SC and thirty healthy control subjects were given measures of neurocognitive functioning (processing speed, episodic and working memory, executive functioning, general ability) and social cognition as determined by Facial Emotion Recognition measures (BLERT, PEAT, PERT, EDT) and Theory of Mind measures (TOM stories and cartoons). Results show that SC subjects perform significantly worse than controls on all measures of neurocognition and social cognition, particularly on TOM measures. TOM was found to be associated with both social functioning (Stories: $\mathrm{r}=.379, \mathrm{p}<.01$; Cartoons: $\mathrm{r}=.313, \mathrm{p}<.05)$ and instrumental functioning (Stories: $\mathrm{r}=.477, \mathrm{p}<.01$; Cartoons: $\mathrm{r}=.294, \mathrm{p}<.05$ ). TOM deficits persist even when generalized cognitive deficits are controlled, suggesting that social cognition impairment is at least partially domain specific. Our findings suggest that deficits in TOM may be important targets for treatment development.

Correspondence: Katherine Humber, M.A., Maryland Psychiatric Research Center, P.O. Box 21247, Baltimore, MD 21228. E-mail: khumber@mprc.umaryland.edu

\section{Emotional Processing}

\section{G. CASTILLO-PARRA, M. PEREZ \& F. OSTROSKY-SOLIS. EMOTIONAL PROCESSING IN MAJOR DEPRESSIVE DISEASE AND EVENT-RELATED BRAIN POTENTIALS STUDY.}

Depression is a severe disorder of the representation and regulation of mood and emotion (Elliott et al., 2002). Event-related brain potentials (ERPs) in conjunction with cognitive paradigms have been used successfully to study changes in brain electrical activity produced by judgments of emotional stimuli in normal subjects (Shupp et al., 2000). However, very few studies have characterized psychophysiologically emotional processing in patients with major depression. Therefore the purpose of this study was to investigated emotional processing through of ERPs in major depressive patients. 210 color pictures selected from the International Affective Picture System (Lang et al., 1999) were presented, 70 unpleasant, 70 neutral and 70 pleasant pictures appear whit equal probability in a random sequence. Seven major depressive patients and seven normal subjects with a range of 25 to 45 years were registered. In all subjects emotional pictures (pleasant and unpleasant) evoked a larger Late Positive Potential (LPP) than neutral materials mainly in parietal areas of both hemispheres. However, the depressive patients show a delayed in latency for pleasant stimuli in comparison of normal subjects and equal amplitude for the unpleasant and pleasant stimuli. These data suggest that patients with severe depression respond to the pleasant stimuli as if they were unpleasant stimuli probably due to a dysfunction in the cerebral function related to emotional processing. Implications for diagnosis and recovery of these patients are discussed.
Correspondence: Gabriela Castillo-Parra, Master, Laboratory of Neuropsychology and Psychophysiology, National University of Mexico, Av. Universidad 3004, Ed. D-11, Mexico City 04510, Mexico. E-mail: gcastillo_parra@yahoo.com.mx

\section{J. SCHMIDT, J.C. BOROD, N.S. FOLDI \&. S.J. SHETH. ACOUSTICAL ANALYSIS AND HUMAN RATINGS OF EMO- TIONAL PROSODY IN UNILATERAL STROKE.}

This study investigated two areas of emotion: acoustical parameters used to communicate discrete emotions and brain structures involved in the expression of prosodic emotion. Speech samples $(\mathrm{n}=796)$ produced by 20 right brain-damaged, 17 left brain-damaged, and 18 demographically matched normal control adult men and women were selected from happy, sad, angry, and neutral monologues, low-pass filtered to eliminate language cues, and presented to 14 naive judges who rated the speech samples for emotional intensity and emotion-type identification. Additionally, these samples underwent computerized acoustical analysis to measure pitch, duration, and volume. Analyses revealed that pitch mean and standard deviation, volume standard deviation, and speech rate were greatest for the expression of happiness and smallest for sadness. Anger was also associated with high pitch mean and standard deviation level, as well as smaller volume standard deviation and slower speech rate. Raters judged the left-frontal patients to be the most impaired group followed by the right-frontal and right-subcortical patients. Acoustical analysis revealed that left-frontal patients had significant difficulty with duration cues including slower speech rates and more silence in their samples than normal controls, providing some support for the cue-lateralization hypothesis. Right-frontal and right-subcortical patients used less pitch variation in their speech, consistent with findings in the literature regarding the ability to modulate pitch range. Left subcortical patients did not demonstrate prosodic impairment. These findings support the notion that fronto-striatal circuitry, not just subcortical structures, is important for prosodic emotional production. Correspondence: J. Michael Schmidt, Psychology, Queens College, 6530 Kissena Blvd, Flushing, NY 11367.E-mail: michael.schmidt2@ verizon.net

\section{NAKHUTINA, J.C. BOROD \& D.J. ZGALJARDIC. RECOVERY OF POSED PROSODIC EMOTIONAL EXPRESSION IN UNILAT- ERAL STROKE PATIENTS.}

Recovery of emotional functioning following stroke has received little attention in the literature. The current study focused on the course that prosodic emotional expression takes in stroke patients. On two separate occasions, posed prosodic expression tasks from the New York Emotion Battery (NYEB; Borod, Welkowitz, \& Obler, 1992) were administered to 9 right brain-damaged $(\mathrm{RBD}$; mean age $=66.3$ years), 8 left braindamaged (LBD; $\underline{\mathrm{M}}=64.3$ ), and 7 demographically matched normal control (NC; $\underline{\mathrm{M}}=58.7)$ adults. Participants were requested to produce neutral-content sentences in four different emotional tones. Raters evaluated prosodic output via accuracy, intensity, and confidence judgments. For accuracy ratings, RBDs and LBDs were impaired relative to NCs at Time 1 and recovery took place for LBDs but not for RBDs. The latter finding is consistent with previous studies, suggesting that deficits in arousal and attention, frequently observed in RBDs, may be involved. Visual inspection of group means indicated that frontal lobe lesions had a negative impact on prosodic expression in RBDs and that lesion extent did not systematically influence performance. Of note, the group, as a whole, maintained its relative standing on the NYEB expression tasks over time (Accuracy $-r=.71, p<.001$; Intensity $-r=.62, p$ $<.001$; and Confidence $-r=.45, p=.027$ ). Finally, nonsignificant correlations between subject performance on prosodic emotional perception and expression tasks at both testing times indicated that the two processing modes are relatively separate, consistent with previous findings in the literature. 
Correspondence: Luba Nakhutina, MA, Psychology, CUNY Graduate Center, 1380 Riverside Dr., Apt. 8G, New York, NY 10033. E-mail: luba_ny@hotmail.com

\section{R. CHAYO, A. VELEZ, N. ARIAS, G. CASTILLO \& F. OSTROSKY. AFFECTIVE, ACTIVATION, DOMINANCE AND MORAL JUDG- MENT OF PICTORIAL STIMULI: NORMATIVE DATA IN SPANISH SPEAKING POPULATION .}

The experimental study of emotions requires stimuli that reliable evoked psychological and physiological reactions that vary systematically over the range of emotions and according to the dimension of valence (pleasant to unpleasant), arousal (calm-excited) and dominance ( high and low) ( Lang et al, 2001). Different types of stimuli have been used to provoked emotion including visual (photograph, faces, words and movies), auditory (sounds, words and music), tactile (electric shock), smell (aromas) and gustatory (eaten and flavor). Although the brain correlates of basic emotions have been explored, the neural organization of "moral emotions" in the human brain is poorly understood. The objective of the present study was to obtain a group of differentiated stimuli (806 photograph) and characterized them in terms of its affective valence, arousal, dominance and moral content in a Mexican population. Photographs that represent a wide range emotionally charge, unpleasant social scenes, representing moral violations (i.e. war scenes, physical assault), unpleasant pictures of aversive scenes not conveying moral connotations (i.e. tumors, mutilated bodies), pleasant pictures(i.e. scenes of people and landscapes) and neutral pictures (i.e. household objects) were selected. Subjects rated each picture according to its valence, level of arousal, dominance and moral content ( absent to extreme). The Self- Assessment Manikin Affective Rating System devised by Lang (1980) was used. The normative data obtain in Mexican population are presented. Stimuli can be use in basic as well as in applied studies of moral emotions.

Correspondence: Raquel Chayo, National University of Mexico, Sierra Fria 540, Mexico City 11000, Mexico.E-mail: rdichy@hotmail.com

\section{J. HEUTINK, W.H. BROUWER, B. WIJERS, N. BORGER \& A. BOUMA. SUBCONCIOUS EMOTIONAL PROCESSING MODU- LATES EARLY VISUAL ERPS DEPENDENT ON TRAIT-ANXIETY.}

Although it is widely accepted that limbic brain structures such as the thalamus and the amygdala allow emotional processing without awareness, there is debate about the specificity and function of this type of emotional processing. It has been suggested that limbic structures only allow quick and dirty analysis of relevant emotional stimuli. While employing ERP measurements on 32 subjects, we subliminally presented Conditioned Angry faces (CS+) which were paired with a $90 \mathrm{~dB}$ burst of white noise prior to the experiment, Unconditioned Angry faces (CS-) and Neutral faces (N). We found different P100 amplitudes at the right occipital electrode position (O2) for each of these three stimulus conditions. Compared to the Neutral condition, the CS- elicited a higher P100 amplitude, whereas the CS+ evoked the lowest P100 amplitude. This result indicates that subcortical emotional decoding allows discrimination based on both facial expression and facial identity. Moreover, this tuning of the visual system not only increases cortical sensitivity for potentially threatening stimuli (CS-) as has been previously suggested, but also decreases cortical sensitivity for threatening stimuli which are recognised from past unpleasant experiences (CS+). Analysing individual differences in our subject group, we found that people experiencing relatively high anxiety in everyday situations had higher cortical sensitivity to all three types of stimuli, but showed no decrease in cortical sensitivity to CS+ stimuli as compared to people experiencing relatively low anxiety. This suggests an explanation of high trait-anxiety as the inability to subconsciously down-regulate cortical processing of known aversive stimuli.
Correspondence: Joost Heutink, MSc, Psychology, University of Groningen, Hanzeplein 1, Poortweg 4 - 2e Verdieping, Groningen 9700RB, Netherlands.E-mail: j.h.c.heutink@ppsw.rug.nl

\section{D.E. EVERHART, M.D. CARPENTER, A. JORDAN, J.E. CAR- MONA \& H.A. DEMAREE. ADULT SEX-RELATED ERP DIFFER- ENCES DURING THE PERCEPTION OF AFFECTIVE PROSODY AND FACIAL AFFECT.}

Sex-related neurophysiological differences were examined in 10 men and women during two "oddball" emotion perception tasks that were designed to elicit the P300. During the first task participants were required to keep a running count of emotional utterances that depicted happy (block 1) or fear (block 2), while the second task required participants to keep a running count of faces that depicted happy (block 1) or fear (block 2). ERPs were recorded from 10 scalp sites(F3, F4, T3, T4, T5, T6, C3, C4, P3, P4). Analyses of P300 amplitude data recorded during the affective prosody task yielded higher amplitude over right versus left hemisphere scalp sites regardless of valence (happy versus fear). Sex differences were noted on this task for P300 latency data in that significantly longer P300 latency was observed for men than women regardless of valence or site. For the facial affect task a significant hemisphere $\mathrm{x}$ site interaction was evidenced for P300 amplitude; post hoc analyses revealed that the differences were isolated to T5 and T6 scalp sites, with higher P300 amplitude over the right hemisphere regardless of valence. No sex-related differences were noted for P300 data on the facial affect task. These findings are generally consistent with the right-hemisphere model for emotion perception. However, the sex differences noted during the affective prosody task are possibly indicative of differences in cortical organization during processing of emotional prosodic stimuli.

Correspondence: D. E. Everhart, PhD, Psychology, East Carolina University, Dept of Psychology, Rawl Building, Greenville, NC 27858. Email: everhartd@mail.ecu.edu

\section{J. YUHASZ \& B.J. CANNON. FACIAL AFFECT RECOGNITION IN FEMALES: THE ROLES OF LOCUS OF CONTROL AND EXTRA- VERSION.}

The purpose of this investigation was to examine whether locus of control or extraversion would better predict scores on a facial affect recognition task. Previous research has shown support for a relationship between locus of control and facial affect recognition ability (Nowicki \& Duke, 1992), as well as extraversion and an individual's ability to recognize facial affect (McCown et al., 1989). Forty-six undergraduate females completed the Adult Nowicki-Strickland Internal-External Scale, the NEO-Five Factor Inventory, and the adult facial subtest of the Diagnostic Analysis of Nonverbal Accuracy-II. Following a multiple regression analysis, only locus of control was found to be a significant predictor of facial affect recognition; the more internal the locus of control, the better the performance on the facial recognition task. Exploratory analyses found that, of the "big 5" personality dimensions, only Agreeableness was found to be predictive of facial affect recognition - the more agreeable, the better the performance on the facial affect recognition task. Implications of these results are discussed and recommendations for future research are given.

Correspondence: Brooke J. Cannon, Ph.D., Psychology, Marywood University, 2300 Adams Avenue, Scranton, PA 18509.E-mail: cannonb@ marywood.edu

\section{HEINLY \& K. GREVE. PROCESSING OF EMOTIONAL FACES IN DEVELOPMENTAL PROSOPAGNOSIA.}

Developmental prosopagnosia is characterized by the inability to recognize familiar faces since birth or early in development. However, little is known about their ability to process other aspects of the face stimulus. In cases of acquired prosopagnosia the ability to recognize facial 
emotions is intact. Since developmental prosopagnosics present with similar spared and impaired abilities compared to the acquired prosopagnosics, the question of their facial emotion processing abilities arises. Studying developmental prosopagnosics affords the opportunity to investigate individuals who have never had normal face processing. Does facial emotion processing develop in persons with this limited experience? Two different models of face processing have different predictions. Cognitive models predicted that developmental prosopagnosics would have intact facial expression analysis whereas computational models predicted that the developmental prosopagnosics would be impaired on the emotional face tasks. The Florida Affect Battery was administered to four patients with developmental prosopagnosia and age-matched control subjects. In three of the four developmental prosopagnosics, performance on the facial emotion tasks was considered normal compared to age-matched control groups. These patients all had normal visual perceptual ability. The patient who was impaired on these tasks had globally impaired perception. All four patients were normal on the emotional prosody tasks. Developmental prosopagnosics with intact visual perceptual abilities (associative prosopagnosics) have preserved ability to process emotional faces. These results are consistent with the predictions of the cognitive model. The implications for models of face perception are discussed.

Correspondence: Matthew Heinly, M.S., Psychology Dept, University of New Orleans, 3410 Severn Ave, Apt 514, Metairie, LA 70002. E-mail: mattheinly@hotmail.com

\section{N. HATTIANGADI \& D.M. TUCKER. FACIAL AFFECT PROCESS ING ACROSS A PERCEPTUAL TIMELINE: A COMPARISON OF TWO MODELS OF FACIAL AFFECT PROCESSING .}

Two models of affective information processing were compared in normal subjects. The LeDoux Model suggests that an initial thalamo-amygdala circuit rapidly appraises the positive or negative nature of the stimulus (affective valence), while slower cognitive processing more accurately classifies and interprets the stimulus. Phenomena such as affective priming support such a model. In contrast, the Pandya Model posits that areas within the cortex of older evolutionary origin are unspecialized and responsible for crude appraisal of stimulus features, while more specialized cortex provides detailed analysis. This suggests that the visual salience of an emotional expression is more important to initial processing than its affective valence. In the first study, emotional expressions of same or opposite affective valence were presented at both optimal and suboptimal levels. Results supported the Pandya Model in that subjects demonstrated no ability to make affective discriminations of any kind at suboptimal levels. A second experiment was then conducted to determine if distinct thresholds existed that would reflect the engagement of separate subcortical and cortical circuits. Results again supported the Pandya model in that findings could be explained solely by the visual similarity or dissimilarity of the expressions. Performance across time was linear, rather than consistent with a threshold model. The current experiments indicate that affective priming effects previously described in the literature may be an artifact of the high visual salience of the "happy" emotion, and may not be present for other positive or negative emotions.

Correspondence: Nina Hattiangadi, Ph.D., Neuropsychology, Kennedy Krieger Institute, 20 Hartley Circle \#433, Owings Mills, MD 21117. Email: ninahattian@comcast.net

\section{J. COOLICAN, G. ESKES \& P. MCMULLEN. RIGHT HEMISPHERE PERCEPTUAL BIASES IN EMOTION AND FACE PROCESSING.}

A left-sided perceptual bias in processing emotion is found in normal subjects. We examined whether this phenomenon is related to the right hemisphere role of configural face processing. Twenty-one university students were asked to judge which of two chimeric faces (smile on left vs. smile on right side) was happier. The left-sided perceptual bias was replicated. In a second condition, the chimeric faces were inverted to eliminate configural facial processing. Inversion had no effect on the left perceptual bias. The left-sided bias was also examined in a neutral facial matching task. Composite faces made of the left or right side of a neutral face were created and subjects chose which composite most nearly matched the original face. A left-sided bias was found, which again was unaffected by inversion. In addition, faces placed on the top of the page were more likely to be judged similar to the original than those on the bottom of the page. Unlike the lateral bias, this top-sided vertical bias disappeared with inversion. Fourteen patients with right hemisphere (RH) stroke were also tested to examine RH involvement in these tasks. RH damage eliminated the left-sided perceptual bias in both tasks. Like controls, patients also showed a top-of-the-page bias in the upright condition, which disappeared when faces were inverted. The right hemisphere role for emotion processing may not always involve configural processes. In addition, the effect of inversion on the top-of-the-page bias for facial matching suggests involvement of the left hemisphere ventral stream in configural processes.

Correspondence: Gail Eskes, Ph.D., Psychiatry, Dalhousie University, 5909 Veterans Memorial Lane, AJL Bldg, room 9216, Halifax, NS B3H 4B8,Canada.E-mail: Gail.Eskes@Dal.Ca

\section{J. GRANETZ, P. FEDIO, B. FANTIE \& J. GRAFMAN. FRONTAL LOBE MECHANISMS IN THE JUDGMENT OF EMOTIONAL FA- CIAL EXPRESSIONS \& SITUATIONS.}

The frontal lobes have been implicated in the regulation of emotional behavior. This study was designed to explore the differential roles of the frontal lobes in mediating the perception of facial expressions of emotion and the judgment of emotional situations. The performance of individuals with focal frontal lobe lesions was compared with the performance of respective matched normal controls on a battery of facial perception tasks. Frontal patients performed worse than normal controls on tasks measuring face perception and judgment of emotional situations. The data revealed significant correlations between test performance and damage to specific brodmann areas. There was no effect of lesion laterality. Differences in the ability to judge emotional situations as a function of emotion category were evident, such that the left and right frontal patients had comparable difficulty interpreting angry social situations, but the left patients also had difficulty interpreting sad situations. These findings support the hypothesis that both left and right frontal lobes are involved in the judgment of facial expressions and emotional situations and that these impairments have distinct frontal correlates.

Correspondence: Joy Granetz, M.A., George Mason University, 25990 Rose Lane, South Riding, VA 20152. E-mail: jgranetz@hotmail.com

\section{N. ARIAS, A. VELEZ, R. CHAYO-DICHY, M. PEREZ \& F. OS- TROSKY-SOLIS. SEX DIFFERENCES IN ELECTROPHYSIOLOGY- CAL RESPONSE EVOKED BY MORAL AND NONMORAL PIC- TURES: AN EVENT RELATED BRAIN POTENTIAL STUDY.}

Moral emotions have been the focus of several recent experimental psychology studies (Damasio, 1994; de Waal, 1996; Rozin et al., 1999; Haidt, 2002). Significant sex differences have been reported in psychophysiologycal responses (skin conductance and electromyography) during affective judgment, female generate greater corrugator and $\mathrm{zy}-$ gomatic activity, and tend to judge negative stimuli more extremely (Shwartz et al., 1980; Greenwald et al., 1989). Cognitive processing occurs in a time frame of milliseconds and up to now only electrophysiological recordings can offer the possibility of studying cognitive phenomena within this time frame. In the present study we recorded Event Related Potentials (ERP) on 20 normal subjects, 10 male and 10 female with an average age of 25.7 years. Subjects were registered while viewing pictures of emotionally charged scenes with and without moral content, as well as emotionally neutral pictures. All the stimuli were previously standardized in our laboratory according to the dimension of unpleasant with moral content (i.e. physical assaults, war scenes) neu- 
tral (i. e. household objects) and unpleasant pictures without moral content (i.e. body mutilation, dangerous animals). Unpleasant pictures with and without moral content prompt a marked negative-going slow wave around $500 \mathrm{~ms}$, with higher amplitude at frontal, parietal and temporal sites of the left hemisphere. The latency of this component was earlier for the unpleasant pictures without moral content. The female group showed an additional positive component around 700 to $900 \mathrm{~ms}$ during the processing or the unpleasant pictures with moral content. Implications for the study of sex differences in moral judgment and empathy are discussed.

Correspondence: Nallely Arias, bachellor, National University of Mexico, Av. Universidad 3004, Copilco Universidad., México, D.F. 04510, Mexico.E-mail:naxiillii21@hotmail.com

\section{MITCHELL, R.A. RICHELL, A. LEONARD \& J. BLAIR. EMOTION AT THE EXPENSE OF COGNITION: INDIVIDUALS WITH PSYCHOPATHY SHOW ENHANCED PERFORMANCE ON A MOTOR RESPONSE TASK.}

Psychopathy is a disorder characterized by high levels of antisocial behavior, but perhaps more central to the disorder is a profound emotional disturbance resulting in a callous affective style. We wished to test the hypothesis that the emotional impairment evident in psychopathic individuals would result in superior performance under conditions where emotional material may reduce proficiency in healthy individuals. The introduction of an emotional component not relevant to ongoing behavior can have a detrimental impact on operant behavior through at least two processes: 1) by producing an incompatible response (i.e. freezing/ conditioned suppression) or 2 ) affective properties of an irrelevant stimulus can result in increased saliency of this stimulus, which is subsequently processed at the expense of other neutral, but goal-relevant stimuli. We investigated the impact of emotional processing on a simple stimulus motor response task in psychopathic $(n=16)$ and non-psychopathic individuals $(n=19)$. Participants were asked to make left and right button presses to circle/ square stimuli that were temporally bracketed by positive, negative or neutral images from the International Affective Picture System. The stimuli were presented serially: a distracter stimulus $(200 \mathrm{~ms})$ followed by a response signal $(150 \mathrm{~ms})$ followed by the same distracter $(400 \mathrm{~ms})$. In contrast to the comparison group, the reaction time for psychopathic individuals was not adversely affected by the presentation of emotionally laden stimuli. The results are interpreted with reference to an emotional dysfunction in psychopathic individuals and the disruption of simple ongoing activity in the presence of emotional material.

Correspondence: Derek Mitchell, National Institute of Mental Health, National Institute of Mental Health, 15 K North Drive, Bethesda, MD 20892-2670.E-mail:mitcheld@intra.nimh.nih.gov

\section{J.B. WILLIAMSON \& D. HARRISON. THE INFLUENCE OF LAT- ERALIZED STRESSORS ON CARDIOVASCULAR REGULATION AND PERCEPTION IN HIGH AND LOW HOSTILE MEN .}

Earlier experiments show promise for making increasingly accurate predictions based on functional cerebral systems associated with emotion and arousal. In this experiment, current knowledge on the functional cerebral systems of hostility and cardiovascular regulation were applied to make predictions of cardiovascular regulation, fluency performance (verbal and nonverbal), and dichotic listening performance. Twenty-four subjects divided into two groups, high- and low-hostile men, in a repeated measures design were administered verbal and nonverbal fluency tasks (counterbalanced administration). Prior and subsequent to each fluency task SBP, DBP, and HR were taken to assess cardiovascular response to the lateralized stressors. Subsequent to the administration of each fluency task, dichotic listening performance was evaluated across unfocused, focus left, and focus right trials. It was expected that high-hostile men would produce results indicative of differential right hemisphere activation when compared with low-hostile men. As predicted, high-hostile men produced more perseverative errors than did low hostile men on nonverbal fluency. Further, subsequent to administration of the nonverbal fluency task, high-hostile men produced a reliable increase in blood pressure when compared to baseline and to low-hostile males. Differences in dichotic listening performance were also expected as a function of the fluency tasks. It was predicted that high-hostile men would evidence a priming effect in that a left-ear bias would be detected after the nonverbal fluency task but not the verbal fluency task. This was indeed the case. Results are discussed within the context of the functional cerebral systems of emotion and arousal. Implications for further research are explored.

Correspondence: John B. Williamson, M.S., Psychiatry, University of Chicago, 2238 North Lawndale Ave, Apartment 2, Chicago, IL 60647. E-mail: jwilliam@yoda.bsd.uchicago.edu

\section{P.G. FRISINA, J.C. BOROD \& S.J. LEPORE. WRITTEN EMO- TIONAL EXPRESSION AND HEALTH OUTCOMES: A META- ANALYSIS IN CLINICAL POPULATIONS.}

A meta-analysis was conducted to examine the effects of the written emotional disclosure treatment on health outcomes in individuals with medical (e.g., arthritis and cancer) or psychiatric disorders (e.g., posttraumatic stress disorder and severe depression). After conducting a literature search using various keyword permutations (e.g., emotion, writing, and clinical disorders), 13 published and 2 unpublished studies were found within the research databases (e.g.., Psychinfo, Medline, and Dissertation Abstracts Online). Altogether, nine published studies qualified for inclusion in this meta-analysis as they met the following criteria: (a) had at least one quantitative measure of health assessing psychological, behavioral, physical, and/or general functioning; (b) possessed data from which an effect size could be computed; (c) used a trueexperimental design; and (d) did not instruct subjects to write about imaginary or perceived benefits of trauma. Overall, findings revealed that written emotional disclosure significantly improved health measures $(\mathrm{d}=.19, \mathrm{r}=.10, \mathrm{p}<.05)$. However, a non-significant test of homogeneity $\left(Q_{w}=5.27, p=.73\right)$ revealed that moderating variables were not operative. Nonetheless, a planned contrast of outcome type was conducted and illustrated that writing improved physical $(\mathrm{d}=.21, \mathrm{p}=.01)$ but not psychological functioning $(\mathrm{d}=.07, \mathrm{p}=.17)$ significantly from zero. Further, the effect size for physical outcomes was significantly greater than the one for psychological outcomes $(\mathrm{Qb}>10.83$, $\mathrm{p}<.001)$. In light of these results, it can be concluded that the written emotional disclosure paradigm has a therapeutic effect in clinical populations. Future research will be directed at extending this treatment from psychiatric and medical disorders to neurological disease.

Correspondence: Pasquale G. Frisina, MA, Psychology; 5315 James Hall, Brooklyn College and The Graduate Center of CUNY, 2900 Bedford Avenue, Brooklyn, NY 11210. E-mail: pfrisina@aol.com

\section{U.S. SPRINGER, D. BOWERS, N. SHAPIRA, W. GOODMAN, B. GREENBERG, K.M. HEILMAN, K. FOOTE \& M.S. OKUN. LONG-TERM HABITUATION OF STIMULATION-INDUCED SMILE IN A PATIENT WITH DBS.}

Introduction. Deep brain stimulation (DBS) for affective disorders involving basal ganglia circuitry has recently emerged as a promising therapy. Recently, we (DBS for OCD collaborative group) observed a reproducible asymmetric stimulation-induced smile in a patient with OCD that was induced by DBS in the internal capsule and region of the nucleus accumbens. Chronic DBS, however, resulted in habituation of this response. We present data documenting the stimulation induced-smile with chronic DBS. Methods. Computer-imaging techniques were used to quantify stimulation-induced dynamic facial movement in a patient implanted with DBS for OCD. Quantification of facial movement was performed intra-operatively and at 2 post-operative sessions (at 39 days and 71 days). Each lead contact was tested (in monopolar), and results 
were compared from proximal and distal locations of stimulation. Expressions were videotaped, digitized, and analyzed for movement changes using custom software developed by Gokcay (2000). This software automatically computed overall movement change (entropy) during the temporal course of each expression. Results. Smiles were easily induced contralateral to the stimulated side during the initial intra-operative procedure. Testing at 39 days post-surgery revealed a significantly reduced intensity in the response, particularly with right-DBS. Seventy-one days after the procedure, testing revealed a complete loss of the stimulationinduced smiles (with identical stimulation parameters). Conclusion. Our findings indicate that chronic DBS may result in habituation of the stimulation-induced smile. The mechanisms of habituation are unknown, but likely involve a physiological adaptation of fibers in this region or their target synapses, lead location, or both. The mechanisms behind the habituation of the stimulation-induced smile will be important to elucidate as we work toward a better understanding of the fronto-limbic circuitry involved in this response.

Correspondence: Utaka S. Springer, B.S., Clinical and Health Psychology, University of Florida, PO Box 100165, Gainesville, FL 32610. Email: uspringe@hp.ufl.edu

\section{Featured Symposium/1:00-3:00 p.m.}

\section{Mild Traumatic Brain Injury in Sports: An International Neuropsychological Perspective}

\section{Chair: Mark Lovell Discussant: Mark Lovell}

\section{LOVELL. MILD TRAUMATIC BRAIN INJURY IN SPORTS:AN INTERNATIONAL NEUROPSYCHOLOGICAL PERSPECTIVE.}

The involvement of neuropsychologists in the evaluation and management of sports-related brain injury has become increasingly common over the past decade. Recently, the application of neuropsychlogical assessment technology within the field of sports medicine has been hailed as the "cornerstone" of the mTBI evaluation process by the International Olympic Committee, the international governing body for soccer (FIFA) and a number of other sports organizations. The increasing involvement of the neuropsychologist within the sports arena has been prompted by concerns about the acute and chronic consequences of brain injury in athletes. This symposium will review new developments in the assessment of sports-related mTBI from an international perspective and symposia presentors will focus specifically on the generalization of their current research to the issue of mTBI in non-athletes.

Correspondence: Mark Lovell, Ph.D., Orthopaedic Surgery, University of Pittsburgh, 3200 South Water Street, Pittsburgh, PA 15203. E-mail: lovellmr@msx.upmc.edu

\section{A.D. HINTON-BAYRE, G. GEFFEN, L. GEFFEN, K. MCFARLAND \& P. FRIIS. NEUROPSYCHOLOGY OF MILD TBI: LESSONS FROM AUSTRALIAN RUGBY LEAGUE.}

Contact ball sports are highly popular in Australia, with Rugby League having the highest incidence of mild traumatic brain injury (mTBI). We prospectively examined a professional team over three consecutive seasons with a view to standardising the assessment and management of $\mathrm{mTBI}$. The findings are relevant to the management of $\mathrm{mTBI}$ in general. First, with pre- and post-injury data we found measures of speed of information processing were the most reliably impaired following trauma, suggesting that assessment of mTBI cases includes such meas- ures. Moreover, we were led to question the veracity of subjective symptom reporting as concussed players tended to under-report compared to controls. Second, traditional group-based analyses revealed return to practice adjusted preseason levels within two-weeks, yet individual recovery curves varied considerably. In the usual circumstance with general mTBI no pre-injury performance is available, making access to retest normative data even more important. Third, our preliminary findings suggest that attempts to classify sub-groups of mTBI (using Concussion grades) requires further investigation and has limited empirical support at present. Finally, contact sports provide a unique environment to investigate the effects of repeated trauma. Our early results have indicated no evidence of greater impairment or prolonged recovery, however there is limited prospective data on this topic. The sports model of $\mathrm{mTBI}$ is fundamental to the assessment and management of mTBI in general.

Correspondence: Anton D. Hinton-Bayre, PhD, Cognitive Psychophysiology Laboratory, University of Queensland, Edith Cavell Building, Royal Brisbane Hospital, Brisbane, QLD 4006, Australia. E-mail: s309339@student.uq.edu.au

\section{COLLINS \& M. LOVELL. SPORTS CONCUSSION IN THE HIGH SCHOOL ATHLETE: WHAT ARE WE LEARNING?}

The management of sports concussion, regardless of participation level. is currently one of the most hotly debated topics in sports medicine. At the high school level, less access to on-field medical care and a general naivete regarding signs/symptoms of concussion may increase the risk of mismanaging the injury. Returning an athlete to participation prior to complete recovery from concussion may greatly increase the risk of lingering, long-term, or catastrophic neurological sequelae. As such, determination of existing neurological difficulties proves critical to the safe management of the concussed athlete. In short, no athlete should return to participation until all signs and symptoms or concussive injury have abated. To help uncover subtle lingering deficits of concussion, neuropsychological testing is now considered the "cornerstone" of proper, post-injury concussion management. The focus of this presentation will be the management of concussion in the high school athlete. The goals of the presentation are to: 1.) present data regarding neurocogntive/symptom recovery curves in the high school athlete, 2.) present data examining potential age-related differences in vulnerability to and recovery from concussion in the high school aged athlete, 3 .) present data examining the potential cumulative effects of concussion in the high school athlete, 4.) examine the relevance of acute (on-field) markers of concussive injury, and 5.) discuss the relevance of our large sports concussion database to a more general, MTBI high school population.

Correspondence: Michael Collins, Ph.D., Orthopaedic Surgery, University of Pittsburgh, 3200 South Water Street, Pittsburgh, PA PA. E-mail: Collinsmw@msx.upmc.edu

\section{LASSONDE, M. LAVOIE, S. LECLERC, K. JOHNSTON \& M. THERIAULT. ELECTROPHYSIOLOGICAL ANOMALIES IN CONCUSSED ATHLETES.}

In order to assess whether cerebral anomalies may be observed in the absence of clinical symptoms, we carried out two studies examining the effects of concussions using Event Related Potentials (ERP). The first study compared the electrophysiological responses in concussed athletes with $(n=10)$ or without $(n=10)$ symptoms as well as in athletes who never had a concussion $(n=10)$. The athletes had sustained their concussion less than two years prior to testing. The P300 response was recorded from 28 electrodes during a modified visual oddball paradigm. The P300 amplitude to the rare target stimuli was significantly attenuated in the symptomatic athletes with respect to the other two groups. Moreover, the P300 amplitude varied inversely with the severity of post-concussion symptoms. In a second study, we examined the P300 response to auditory stimulation using a modified auditory paradigm in 10 asymp- 
tomatic athletes who had had a concussion more than two years prior to testing, 10 athletes whose last concussion occurred less than two years before testing and 10 non-concussed athletes. The P300 amplitude was reduced in the athletes who had sustained their concussion within the last two years. The results suggest that symptom severity may be a crucial indicator of functional impairments following mild traumatic brain injury. The absence of symptoms, however, may not necessarily indicate full recovery as a normal electrophysiological pattern could only be observed in the asymptomatic athletes who sustained their concussions more than than two years prior to testing.

Correspondence: Maryse Lassonde, Ph.D., Psychology, University of Montreal, C.P. 6128 Succursale Centre-ville, Montreal, QC H3C3J7, Canada.E-mail: Maryse.lassonde@umontreal.ca

\section{R. ECHEMENDIA. NEUROCOGNITIVE FUNCTIONING AND SOCCER: AN ANALYTICAL REVIEW.}

Soccer is the most popular sport in the world, played by millions of children, adolescents and adults. There has been increased interest in the neurocognitive consequences of playing soccer because of the unique use of the head to propel the ball (heading) offensively and defensively. Some studies have suggetsted that there are long term neuropsychological consequences to heading while others have not. Safety in soccer has also been called into question because soccer players experience concussions at a relatively high rate. This paper examines the data that have been published with a particular focus on the strengths and limitations of those studies. The relationship between heading and concussion will be discussed and prospective data that examine heading in young soccer players and college athletes will be presented.

Correspondence: Ruben Echemendia, Ph.D., Pennsylvania State University, Psychological Clinic, State College, PA 16802.E-mail: rje2@ psu.edu

\section{K. PODELL, M. LOVELL, M. COLLINS \& G. IVERSON. GENDER DIFFERENCES DURING BASELINE AND POST-CON- CUSSION SYMPTOM REPORTING AND COGNITIVE TESTING IN HIGH SCHOOL AND COLLEGE ATHLETES.}

The recent surge in sports concussion research has lead to advances targeting basic neuroscience, phenomenology, and clinical application. These findings are changing the way we conceptualize, measure, and treat sports concussions. For example, the trend towards individualized assessment and treatment rather than depending upon standard, one size fits all, guidelines is one example of how recent research has changed how we approach sports concussion. One important clinical area that has not been explored is gender differences. While we know that male and female cognitive abilities can differ in some aspects of formal neuropsychological abilities, we are unsure how this translates in the area of sports concussion. It is unknown if a gender difference exists for baseline cognitive skills, base-rate symptom reporting, post-concussive symptom reporting and cognitive deficits, or even recovery rate. We present data on gender differences in both high school and college athletes from over 1,800 athletes who underwent baseline computerized assessment using ImPACT during the 2000-2002 seasons. Of these, 400 athletes sustained an in-season concussion and were followed with post-concussion testing. Data addressing gender differences in both high school and college athletes will be presented for both baseline and post-concussion symptom reporting and cognitive performance. Possible mechanisms and implications for clinical application will also be discussed. Correspondence: Ken Podell, Ph.D., Neuropsychology, Henry Ford Hospital, One Ford Place, Detroit, MI 48202. E-mail: Kpodell1@hfhs.org

\section{A. SHUTTLEWORTH-EDWARDS. NEVER SAY NEVER: TAKING ACCOUNT OF ADDITIVE AND VARIABILITY EFFECTS IN SPORTS CONCUSSION RESEARCH.}

The aim of this paper is to provide a review on the residual (chronic) effects of cumulative mild traumatic brain injury in the contact sports, with a focus on research conducted on South African Rugby Union at the professional and school levels. Theoretical parameters for the neuropsychological investigation of sports concussion will be discussed, including the utility of Brain Reserve Capacity (BRC) theory. Within the context of BRC theory, a synthesis of research findings on boxing, soccer, American football, Australian Rules football, and South African Rugby Union will be presented. The tenets of BRC theory imply (i) increasing clinical signs in association with additive neuronal attrition, and (ii) significant inter-individual variability in outcome following mild traumatic brain injury. These factors have crucial methodological implications when designing research studies in the sports concussion area, and for the interpretation of results. Outcome from selected studies on South African Rugby Union provides support for these indications in that: (i) there was a higher percentage of cognitive deficit and postconcussive symptoms for rugby players versus controls, rugby forwards versus rugby backs, and older versus younger players; (ii) there was a higher percentage of cognitive deficit for rugby players with a prior learning disability compared with those without a prior learning disability; (iii) the examination of inter-individual variability revealed effects that were obscured in group mean comparisons. Finally, new directions in research on South African Rugby Union, including computer-based assessment and its validation, will be discussed.

Correspondence: Ann B. Edwards, PhD, Psychology, Rhodes University, Psychology Clinic, Rhodes University, Grahamstown 6140, South Africa. E-mail: a.edwards@ru.ac.za

\section{Symposium 14/1:00-3:00 p.m.}

\section{Decision-Making: Role of Prefrontal Cortex and Developmental Issues}

\author{
Chair: Harvey Levin \\ Discussant: Jordan Grafman
}

\section{H.S. LEVIN, M. ERNST, A. BECHARA, P. ZALAZO, L. CLARK \& J. GRAFMAN. DECISION-MAKING:ROLE OF PREFRONTAL COR- TEX AND DEVELOPMENTAL ISSUES.}

Since the initial report by Bechara and co-workers of a relatively specific decision-making deficit in adults with ventromedial prefrontal lesions, researchers have addressed the contributions of prefrontal subregions to performance on tasks which evaluate response to differential rewards and punishments and anticipation of the consequences of actions. Based on infrahuman primate and human research, there is mounting evidence that a network involving orbitofrontal/ventromedial prefrontal cortex (PFC) mediates response to reward, possibly by linking the somatic response to events with their representations and thus biasing future decisions. Dopaminergic modulation of decision making via prefrontal projections from the ventral tegmentum and striatum, which is supported by neurophysiological studies of infrahuman primates and investigation of patients with drug addiction, has implications for treatment. Innovative aspects of this research include the rekindled interest in motivation, improved methodology for studying decision-making using procedures such as the Iowa Gambling Task, applications of functional brain imaging, the elucidation of distributed, frontally-guided networks including integration of prefrontal subregions, the effects of dopaminergic modulation, the relationship of decision-making to measures of executive functioning, and developmental issues. With evidence for the relevance of decision-making and response to reward to adaptive behavior and psychosocial adjustment, it is timely to integrate findings from various domains of decision-making research and relate them 
to cognitive neuroscience. The speakers will address (1)decision-making in patients with prefrontal lesions, including lateralization and gender effects; (2)development of decision making in children;(3) altered decision-making in persons with drug addiction and its relationship to executive functioning.

Correspondence: Harvey S. Levin, Ph.D., Cognitive Neuroscienc e Lab, Baylor College of Medicine, 6560 Fannin Ste 1144, Houston, TX 77030. E-mail:hlevin@bcm.tmc.edu

\section{A. BECHARA, D. TRANEL \& N.L. DENBURG. GENDER-RELATED ASYMMETRIC UTILIZATION OF THE RIGHT VERSUS LEFT VEN- TROMEDIAL PREFRONTAL CORTICES IN DECISION-MAKING.}

In a previous study, we attempted to parse the relative contributions of the right and left ventromedial prefrontal cortices (VMPF) in regard to social conduct, decision-making, and emotional processing. We found that for these functions, the right-sided component of the VMPC system appeared to be critical, whereas the left-sided component appeared to be less important. However, in that study, almost all the participants happened to be males. The aim of the current study is to examine whether these findings also apply to females. Twelve participants with focal, stable unilateral lesions to the right ( 3 males and 3 females) or left ( 3 males and 3 females) VMPC were studied using the Iowa Gambling Task (IGT) to measure decision-making. The right-sided participants, on the whole, had poorer scores on the IGT relative to the left-sided participants. Most intriguing, we found that the right- versus left-sided impairment interacted with gender: left-sided damage impaired performance in females, whereas right sided-damage impaired performance in males. The results suggest that there is an asymmetric utilization of right versus left VMPC in males and females. An important question to be addressed with future work is whether these findings generalize to the real-life social behavior of these participants, and does left versus right VMPC damage differentially impact the social conduct, decision-making, and emotional processing of affected males and females. Supported by NIH Program Project Grant PO1 NS19632. Correspondence: Antoine Bechara, Neurology, University of Iowa, 200 Hawkins Dr., Iowa City, IA 52242. E-mail: antoine-bechara@uiowa.edu

\section{CLARK, F. MANES, T. ROBBINS \& B. SAHAKIAN. NEURAL AND COGNITIVE MECHANISMS OF DECISION-MAKING IMPAIR- MENT FOLLOWING UNILATERAL FRONTAL LOBE DAMAGE.}

The effects of prefrontal cortex (PFC) lesions in human case studies indicate a critical role for this region in decision-making. The neural and cognitive mechanisms of decision-making deficits have begun to be elucidated. We tested patients with unilateral PFC lesions on three measures: 1) the Iowa Gambling Task (Bechara et al 1994) 2) the Cambridge Decision-Gamble Task (Rogers et al 1999a) and 3) the Cambridge Risk Task (Rogers et al 1999b). In an initial analysis of 19 patients, discrete, mostly left-sided, orbitofrontal lesions $(n=5)$ were not associated with risky decision-making, whereas large, mostly right-sided, frontal lesions $(n=5)$ were associated with severe impairments (Manes et al 2002). The patient group was subsequently expanded to 46 patients to dissociate contributions of lesion laterality, lesion size, and lesion location. MRI scans were acquired and regions of interest used to compute volumes of damage in discrete prefrontal subregions. Patients with right frontal lesions were impaired on the Iowa Gambling Task, and differed significantly from left frontals and healthy controls. In the right frontal group, risk-taking correlated with total lesion volume $(\mathrm{r}=.51, \mathrm{p}=.026)$ and volume of damage outside the ventromedial region $(r=.54, p=.016)$. The two Cambridge tasks were less sensitive to the effects of unilateral PFC lesions and may be more selectively associated with ventral PFC damage. Successful performance on these tasks requires inhibitory control and response adaptation. Recent research has explored the contributions of these processes to decision-making impairments in the same patient group, using Stop Signal and reversal learning tasks.
Correspondence: Luke Clark, D.Phil, University of Cambridge, Department of Experimental Psychology, Downing Street, Cambridge CB2 3EB, United Kingdom.E-mail: lc260@cam.ac.uk

\section{P.D. ZELAZO. DEVELOPMENT OF AFFECTIVE DECISION MAK- ING IN CHILDHOOD: THE CHILDREN'S GAMBLING TASK.}

Although executive function (EF) can be understood in fairly domaingeneral terms, a distinction can be made between the relatively "hot" affective aspects of $\mathrm{EF}$ associated more with ventral and medial regions of prefrontal cortex and the more purely cognitive, "cool" aspects associated more with dorsolateral regions (Zelazo \& Mueller, 2002). Whereas cool EF is more likely to be engaged by relatively abstract, decontextualized problems, hot EF is more likely to be involved in problems with high motivational significance (cf. Rolls, 1999). Most research on EF and its development has focussed on cool EF. To examine the development of hot EF during the preschool years, we created a simplified gambling task (based on Bechara et al., 1994) that consists of 2 decks of cards that, when turned, display a number of happy and sad faces. Happy faces indicate the number of candies won whereas sad faces indicate candies lost. One deck is advantageous (net gain over trials); the other is disadvantageous (more rewards per trial but net loss over trials). Results from a first experiment revealed that 3 -year-olds made more disadvantageous choices than 4-year-olds, and 3-year-olds made more such choices than would be expected by chance, whereas 4-year-olds made fewer. These findings, which were especially pronounced for girls, indicate that hot EF develops over the preschool period: 3-year-olds, but not 4-year-olds, perform like VMPFC patients. Results from subsequent studies will be discussed, and we will attempt to explain what changes between 3 and 4 years of age that allows children to choose advantageously despite the allure of the disadvantageous deck.

Correspondence: Philip D. Zelazo, PhD, Psychology, University of Toronto, 100 St. George St., Toronto, ON M5S 3G3, Canada. E-mail: zelazo@psych.utoronto.ca

\section{ERNST, S. GRANT, E.D. LONDON, D. PINE \& E. NELSON. DECISION MAKING: A DEVELOPMENTAL PERSPECTIVE AND APPLICATION TO ADDICTION.}

Decision-making is often impaired in psychiatric disorders, especially with substance abuse (SA). Identification of vulnerabilities and prevention are at the forefront of efforts aimed at treating maladaptive behaviors. We are investigating developmental changes in decision-making in healthy participants, and abnormalities of decision-making in populations at risk for disorders,i.e., SA. We present performance and functional neuroimaging data in healthy adolescents and adults, and adolescents at risk for SA disorder. Decision-making was probed using two different tasks, the Iowa Gambling Task (Bechara et al., 1994) and the Wheel of Fortune task (Ernst et al., in press). Healthy adolescents and healthy adults showed similar performance on the Iowa Gambling Task. Adolescents at risk for SA performed worse than healthy adolescents after the Gambling task was learned. Adults with SA performed worse than healthy adults during an early stage of the Gambling task, when participants presumably begin to understand the rewards and penalties involved in the task, but are unsure of the actual risk of incurring penalties. The wheel of fortune permits assessment of the three stages of motivated action, i.e., decision-making, anticipation and feedback. Decision-making per se did not differ between adolescents and adults. Adolescents tended to be more responsive to both positive and negative feedbacks. Functional magnetic resonance imaging showed distinct patterns of activation of the selection, anticipation and feedback processes. Findings differed between healthy adolescents and healthy adults in some processes but not others. In conclusion, performance on decision-making tasks is, for the most part, similar in healthy adolescents and healthy adults. The neural substrates of decision-making show some developmental differences. Implications for psychopathology will be discussed. 
Correspondence: Monique Ernst, M.D., Ph.D., Section of Developmental and Affective Neuroscience, National Institute of Mental Health, $15 \mathrm{~K}$ North Drive, Room 118, Bethesda, MD 20892-2670.E-mail: ErnstM@ intra.nimh.nih.gov

\section{G.R. HANTEN, H. LEVIN \& P.R. SWANK. DECISION MAKING AFTER TRAUMATIC BRAIN INJURY IN CHILDREN. .}

Matched groups of 16 children with moderate to severe TBI, (M=12.9 years, $\mathrm{SD}=2.5$, range 9.0-16.8); and typically developing children $(\mathrm{M}=12.8$ years, $\mathrm{SD}=2.4$, range 9.0-16.4) completed a modified version of the Iowa Gambling Task. Procedure. Children played a computer game in which four "card decks" appeared on the computer screen. Each deck was a different color (red, yellow, blue, green). Consistently choosing two of the decks (e.g., red or yellow) resulted in net loss; choosing the other two decks resulted in net gain. On 100 trials, children were told to choose a deck to win monev, and that some decks were better than others. After each trial, the computer displayed a graphic representation (green or red bar) of amount won or lost, and displayed the numeric amount, read aloud by the experimenter. Children were given $\$ 2.00$ to start, and kept the money they won. Following the task, children were given a post-test of memory. Results. A significant group difference over trials, $\mathrm{F}(8,21)=2.54, \mathrm{p}=.04$ indicated children with TBI were more likely to choose advantageous decks than the control children on the 1st block of 10 trials, $F(1,29)=4.52, p=.04$, but the trend reversed in following blocks with control children choosing advantageous decks more often than children with TBI on the 5th block, $\mathrm{F}(1,29)=4.96$. $\mathrm{p}=.034$, and 6th block, $\mathrm{F}(1,29)=4.5, \mathrm{p}=.04$. Although children with TBI were less likely to avoid the disadvantageous deck over trials than control children, differences did not reach significance. There were no between-group differences on the post-test memory measure.

Correspondence: Gerri R. Hanten, Ph.D., Physical Medicine and Rehabilitation, Baylor College of Medicine, 6560 Fannin St., Suite 1144, Houston, TX 77030.E-mail: ghanten@bcm.tmc.edu

\section{Symposium 15/1:00-3:00 p.m.}

\section{Neurovascular Neuropsychology}

\author{
Chair: Ronald M. Lazar \\ Discussant: Gregory G. Brown
}

\section{R.M. LAZAR, K.R. PERRINE, A.E. SPEIZER, K.T. KREITER, J. FESTA, R.J. PETRUCCI \& G.G. BROWN. NEUROVASCULAR NEUROPSYCHOLOGY.}

The cerebral circulation is a unique network of vessels providing blood flow within the hemispheres. The nature and extent of cognitive and neurological dysfunction resulting from abnormalities of the vasculature can be demonstrated via the study of vascular brain diseases: Ischemic stroke and brain arteriovenous malformations can cause focal defects; carotid artery disease may produce whole hemispheral dysfunction; and subarachnoid hemorrhage, congestive heart failure and end-stage pulmonary disease can cause global abnormalities. Recent studies of neurovascular disease have now shown that higher cerebral function may be a more sensitive measure of brain integrity than motor or sensory function, or coordination. The purpose of this symposium is to present methodology and data that support the use of cognition and behavior as a means of shedding light on cerebral localization, plasticity and vascular pathophysiology. We will demonstrate that systematic investigation of hemodynamics, neurotransmitter systems, blood oxy- genation levels and cardiac failure with neuropsychological outcomes provides unique insight into brain mechanisms. The implications of these findings will be shown to bear directly on our understanding of the nature and extent of disease, treatment efficacy, disease progression, and prognosis for recovery or disease recurrence.

Correspondence: Ronald M. Lazar, PhD, Neurology, Columbia University, Neurological Institute, 710 West 168th Street, New York, NY 10032. E-mail:ral22@columbia.edu

\section{K. PERRINE. BRAIN AVM.}

An arteriovenous malformation (AVM) is a congenital tangle of blood vessels with irregular capillary beds and anomalous anastomotic shunts between the arterial feeders and draining veins. Brain AVMs may be dormant for many years, but cerebral dysfunction can occur from hemorrhage, seizures, insufficient blood flow to subjacent cortex, venous thrombosis, or from iatrogenic interventions. Although many AVMs are simply followed without intervention, many are treated with neurosurgical resection or with endovascular embolization (closing off of the feeding arteries with glue through transfemoral catheterization). This presentation will review the anatomy and pathology of AVMs and their treatment, with special emphasis on endovascular embolization. Neuropsychological applications to the evaluation and treatment of AVMs will be presented, such as Amytal challenges prior to embolization and pre-operative functional MRI of cognitive functions. The benefits and limitations of these techniques will be reviewed, including the dilemma of false-negative data arising from the unique vascular and anatomical anomalies of AVMs and from the need to tailor tests to the localization of the AVMs and their associated arterial supply and venous drainage. Data from both fMRI studies and Amytal challenges will be presented, with a focus on multiple case studies of patients with AVMs in locations on or adjacent to eloquent cortex.

Correspondence: Kenneth Perrine, Ph.D., Queens College, Dept. of Psychology, 65-30 Kissena Blvd., Flushing, NY11367.E-mail:krp1@nyu.edu

\section{R.M. LAZAR, M.F. BERMAN \& J. LIFF. PROVOKING FORMER BEHAVIORAL DEFICITS AFTER STROKE RECOVERY WITH NEU- ROCHEMICAL CHALLENGE.}

BACKGROUND: After stroke, most patients recover some degree of function. Despite descriptions from functional imaging of new brain areas that may come to govern function after stroke, the mechanisms by which such regions come to assume these new roles after cerebral injury in these patients are largely unknown. DESIGN/METHODS: Following informed consent, 20 patients stroke or TIA whose syndromes had subsided/recovered were studied. In a baseline-sedation-postsedation design, we used a brief challenge with 2 short-acting, commonlyused agents to unmask former deficits: Midazolam, a $\mathrm{GABA}_{\mathrm{A}}$ agonist, and scopolamine, an anticholinergic agent. Ischemic events had occurred from 3 days to 6 years earlier. Each patient underwent baseline testing for motor function in each upper extremity, aphasia (left hemisphere function), and hemi-spatial neglect (right hemisphere function). Then, IV scopolamine or IV midazolam was delivered, respectively. Each patient was then administered a comparable version of the motor/aphasia/neglect battery. RESULTS: Following drug administration, all patients transiently demonstrated features of their original strokes syndromes but never abnormalities associated with function of the presumably-unaffected cerebral hemisphere. Moreover, the $\mathrm{GABA}_{\mathrm{A}}$ agonist exerted more effect on prior motor dysfunction and the anticholingergic agent had greater impact on re-eliciting former aphasia and hemineglect. At 2 hours after drug infusion, all patients returned to baseline. CONCLUSIONS: Our drug-challenge proved capable of unmasking former deficits in patients who had suffered focal ischemic brain events, with evidence of neurochemical specificity in the nature of these effects. This model holds promise for shedding new insight into brain plasticity and recovery mechanisms. 
Correspondence: Ronald M. Lazar, PhD, Neurology, Columbia University, Neurological Institute, 710 West 168th Street, New York, NY 10032. E-mail:ral22@columbia.edu

\section{A.E. SPEIZER \& R.S. MARSHALL. NEUROCOGNITIVE ASSESS- MENT IN PATIENTS WITH CAROTID ARTERY DISEASE.}

BACKGROUND: Internal carotid artery (ICA) stenosis or occlusion can produce a state of hypoperfusion in the ipsilateral cerebral hemisphere. In addition to strokes that can result from the carotid artery disease, the low cerebral blood flow (CBF) may further affect cognitive function. Restoration of good blood flow to that hemisphere may improve brain function, but studies investigating the effects of such treatment to date have been inconsistent, in part because the methods to measure the $\operatorname{cog}$ nitive change have not reflected the specific brain functions most likely to change with alterations of hemispheral CBF. METHODS: We devised a tailored neurocognitive battery and composite scoring system that reflects the pathophysiology of the expected cognitive dysfunction in carotid artery disease. In a group of 22 patients with carotid artery stenosis, those with left ICA disease were assessed for elements of language and global cognitive dysfunction; patients with right ICA disease were assessed for visual-spatial and global dysfunction. RESULTS: We were able to demonstrate a 0.49 SD cognitive improvement as a result of revascularization surgery, with changes corresponding to the expected hemisphere. We further showed that the cognitive improvement we could identify had a large impact on quality of life. CONCLUSION: The use of a cognitive assessment specific to the pathophysiology of hemispheral hypoperfusion can reveal cognitive change less likely to be detected with a traditional neuropsychometric approach. Matching assessment method with pathophysiology is crucial to evaluate cognitive change in cerebrovascular disease.

Correspondence: Allison E. Speizer, Columbia University, $710 \mathrm{~W} 168$

Street, New York, NY 10032. E-mail: aspeizer@neuro.columbia.edu

\section{K.T. KREITER, S.A. MAYER \& Y. STERN. COGNITION, EMOTION AND QUALITY OF LIFE AFTER SUBARACHNOID HEMORRHAGE.}

Subarachnoid hemorrhage presents a unique challenge to neuropsychologists both in clinical as well as in research settings due to the complexity of the initial insult and variety of CNS-related complications. Acute hemorrhagic stroke can present with a number of features capable of impacting brain-behavior relationships, including: anoxia from intracranial circulatory arrest, intracerebral hematomas, intraventricular blood, global cerebral edema and hydrocephalus. Adding to this initial insult are a number of potential complications that have been shown to affect cognition and usually occur during the first two weeks post-hemorrhage and include focal ischemia from cerebral vasospasm. fever, cardiac dysfunction, anemia and hyperglycemia. Cognitive dysfunction is a commonly reported sequela of subarachnoid hemorrhage $(\mathrm{SAH})$, and can been attributed to specific disease factors that reflect both focal (e.g., ischemic infarction) and diffuse (e.g., global hypoxia) injuries, however, the exact relationship between these disease factors and cognition continues to evolve due to advances in acute management. Further, because of the diverse demographic characteristics of the patients, the impact of non-neurological factors on recovery can also contribute to poor outcomes. Citing data from an ongoing prospective study of 3 - and 12-month outcomes after SAH $(n>700)$, the impact of demographics, SAH-related disease factors, and physical disability on outcome will be discussed as well as the associations between long-term recovery in the areas of cognition, functional ability, mood and quality of life.

Correspondence: Kurt T. Kreiter, PhD, Neurology, Columbia University, 177 Ft. Washington Ave, Milstein 8GS-313, New York, NY 10032. Email:kkreiter@neuro.columbia.edu

\section{J.R. FESTA, S.M. KAWUT, M.N. BARTELS \& S.M. ARCASOY. NEUROVASCULAR NEUROPSYCHOLOGY: END-STAGE PUL- MONARY DISEASE.}

Background: End-stage pulmonary disease, including COPD, interstitial lung disease, pulmonary fibrosis, emphysema, and cystic fibrosis, is associated with a demonstrated pattern of variable and diffuse cognitive deficits. Severe pulmonary patients have been shown to have global processing deficits in attention, memory, abstract reasoning, and perceptual motor speed. Research has demonstrated that cognitive deficits increase with more severe hypoxia indicating that cognitive dysfunction may progress with the disease. In addition to hypoxemia, the hypothesized pathophysiology of these includes hypercapnia, hypocapnia, and acidosis. Patients are also subject to cognitive deficits secondary to mood disorders and immunosuppression. We sought to examine the effects of these different disease processes on neurocognition and to use transplantation as a model for the cognitive effects of physiological restoration in pulmonary function. Methods: We are prospectively recruiting all referred transplant candidates into a longitudinal study of neurocognition, mood, and quality of life. Listed and non-listed patients undergo longitudinal cognitive evaluation: baseline, 6 months and 1 year. A subset of those patients undergo single photon emission computed tomography (SPECT) to examine cerebral perfusion patterns and transplant patients undergo a second SPECT post-transplant to examine the effects of transplant. Results/Discussion: The study of pulmonary disease provides a unique model of global cerebral dysfunction arising from a deoxygenated blood supply. Cognitive profiles specific to each disease process, the potential window of cognitive recovery, treatment implications, the impact of cognitive outcomes on candidate selection and transplant outcomes will be discussed.

Correspondence: Joanne R. Festa, PhD, Neurology, Neurological Institute, Columbia University College of Physicians and Surgeons, 710 West 168th Street, 604, New York, NY 10032. E-mail: jf2128@columbia.edu

\section{R.J. PETRUCCI. COGNITIVE DYSFUNCTION IN END-STAGE HEART FAILURE PATIENTS REQUIRING INOTROPE INFUSION OR MECHANICAL CARDIAC ASSIST DEVICES: ANOTHER PARA- METER OF END-ORGAN DAMAGE?}

Abstract Background- The clinical use of intravenous inotropic therapy and mechanical cardiac assist devices (MCAD) for the management of end stage heart failure (ESHF) is consistently rising. Extended periods of hypoperfusion in an ESHF population may place these patients at high risk for neurobehavioral compromise and appropriate post surgical adaptation. Methods- The present prospective cognitive study evaluated 252 heart transplant aspirants selected from a group of 604 inand outpatients; and 56 of 106 potential MCAD patients meeting inclusion criteria. The ESHF patients were divided into three groups based broadly on the severity of disease; Gr 1 included 113, Gr 2 in-patients $(\mathrm{n}=83)$, and Gr 3 in-patients required MCAD support $(\mathrm{n}=56)$. Cognitive testing was performed to evaluate memory, motor, and processing speed functions. Analysis included aggregate z scores for memory, motor, and processing speed and independent samples t-tests to assess inter-group differences on thirteen cognitive measures. Results- Progressive cognitive impairment was observed with increasing severity of ESHF. Mental processing speed, as well as verbal and visual memory, was slower among Gr 3, compared to Grs 1 and 2. A decline in motor functions was observed early as Grs 2 and 3 showed significant deterioration compared with Gr 1. Conclusions- Neuropsychological measures allow a view of the cognitive changes associated with perfusion and hemodynamic changes in heart failure. These cognitive deficits may reflect yet another parameter of end organ dysfunction in ESHF patients. If demonstrated that MCAD implantation could arrest cognitive dysfunction, earlier intervention may become appropriate.

Correspondence: Ralph J. Petrucci, Ed.D., Heart Failiure/ Transplant Center, Drexel University College of Medicine, MS 115, Broad and Vine St,Phila.PA, PA 19102.E-mail: ralph.petrucci@drexel.edu 
Paper Session 11/1:00-3:00 p.m.

\section{Autism Spectrum and Other Neurodevelopmental Disorders}

\section{P.E. DIXON, J. KLEINMAN, J. PANDEY, S. LANZ, M. BARTON, S. ALLEN, J. GREEN, G. MARSHIA, D. ROBINS \& D. FEIN. DIFFERENTIATING BETWEEN AUTISM SPECTRUM DISORDERS AND OTHER DEVELOPMENTAL DISABILITIES USING THE MODIFIED CHECKLIST FOR AUTISM IN TODDLERS (M-CHAT).}

The early detection of autism is crucial for early intervention. The Modified Checklist for Autism in Toddlers (M-CHAT; Robins, Fein, Barton, \& Green, 2001) is a parent-report checklist designed to detect Autism Spectrum Disorders (ASD) in 16-30 month old children. To date, 2,442 children have been screened. Those who failed the screening and a telephone follow-up $(n=136$, mean age at evaluation $=26$ months $)$ were evaluated; 97 were diagnosed with ASD and 30 with language or global developmental delay. The other 9 children were eliminated from the following analyses because of a unique diagnosis (e.g., 1 ODD, 1 ADHD). Previously published results analyzed screening items that differentiated the ASD children from the total screened non-autistic population, most of whom were typically developing. The sample of non-autistic evaluated children is now large enough to compare to the ASD children. Percent failure rates will be presented for each diagnostic group for each of the 23 M-CHAT items. Using chi-square test, significantly more of the children diagnosed with ASD failed items: pointing to request, $\mathrm{p}<.05$, pointing to show interest, $\mathrm{p}<.001$, taking an interest in other children, $\mathrm{p}<.05$, responding to name, $\mathrm{p}<.02$, understanding what people say, $p<.05$, appearing deaf, $p<.003$, and unusual finger movements, $p<.05$. These items largely overlap with the items identified as most critical in distinguishing ASD from normal development. Therefore, these items can differentiate ASD children, not only from normally developing children, but also from children with other early manifesting developmental disabilities.

Correspondence: Pamela E. Dixon, BA, psychology, University of Connecticut, 406 Babbidge Road, Unit 1020, Storrs, CT 06269. E-mail: pamdixon2001@yahoo.com

\section{M.A. MATSON, S. KEMP, M. BASSO, M. MAHONE, E. DALEI- DEN \& J. BERRY. DISCRIMINATION AMONG HIGH-FUNC- TIONING AUTISM, ASPERGER SYNDROME, AND DEVELOP- MENTAL LANGUAGE DISORDER USING A DEVELOPMENTAL NEUROPSYCHOLOGICAL ASSESSMENT.}

Research in pervasive developmental disorders (PDDs) suggests that while Asperger Syndrome (AS) and high-functioning autism (HFA) may be on a continuum with respect to symptoms and etiological mechanisms, there may be enough variation in trajectory or outcome to make clinically useful distinctions. In order to characterize the neuropsychological profiles of children with PDD, we administered the NEPSY to children aged 6-11with HFA ( $n=15)$, AS ( $n=16)$, or Language Disorders (LD; $\mathrm{n}=17$ ), along with age-, sex-, and parental SES-matched controls. Discriminant function analysis was conducted in order to examine the utility of the NEPSY in group prediction and classification. The strongest discriminators between HFA and AS included verbal measures involving auditory attention (favoring HFA) and executive components (favoring AS), which produced the highest pairwise comparison classification rate. The best discriminators between AS and LD included visuospatial (favoring LD) and language measures (favoring AS). The strongest discriminators between HFA and LD included measures of language (favoring HFA) and sensorimotor (favoring LD) functioning. Matched control comparisons for HFA yielded group differences on sensorimotor, memorv/learning and attention/executive cores (all favoring controls). AS and matched control comparisons revealed group differ- ences on all 5 NEPSY cores (favoring controls), including visuospatial, attention/executive, language, sensorimotor, and memory/learning. For LD and matched control comparisons, group differences were observed on all NEPSY cores (favoring controls) except visuospatial functioning. The NEPSY appears to be useful in characterizing differences among neuropsychological profiles of children with high functioning PDD and LD, with profile differences contributing to our ability to discriminate among these groups clinically.

Correspondence: Melissa A. Matson, M.A., Department of Neuropsychology, Kennedy Krieger Institute, 1750 E. Fairmount Ave, Baltimore, MD 21231.E-mail:matson@kennedykrieger.org

\section{M.A. MATSON, M. MAHONE, S. KEMP \& M. BASSO. NEPSY SUPPLEMENTAL SCORE ANALYSIS IN HIGH-FUNCTIONING AUTISM AND ASPERGER SYNDROME.}

The NEPSY provides the clinician the opportunity to explore subtle aspects neurobehavioral functioning in children using supplemental scores and quantified observations. We examined NEPSY supplemental score performance for 15 children with high-functioning autism (HFA), 16 children with Asperger Syndrome (AS), and 31 age-, sex-, and SESmatched controls, to identify more discrete cognitive skill patterns that contribute to observed differences in core scores. Compared to matched controls, the AS group had poorer motor and executive function performance, with supplemental score analysis revealing more auditory attention commission errors, more novel intrusions on list-learning, more difficulty with oromotor and manual motor sequencing, and bilateral differences in finger discrimination. While the AS group performed comparably to controls in speed on a timed graphomotor measure, they made significantly more errors of imprecision. Compared to matched controls, the HFA group had poorer executive function, memory, motor, and language performance, with differences noted on verbal fluency (categories), design fluency (structured and random arrays), and omission (but not commission) errors on auditory and visual attention. On verbal memory, the HFA group performed more poorly than controls on narrative free recall, and worse than both controls and the AS group on delay recall from list-learning trials. While the HFA group performed more poorly than matched controls on finger discrimination in their nonpreferred hand, they performed better than the AS group on the preferred hand. These findings highlight the utility of NEPSY supplemental scores in examination of the processes by which clinical groups perform atypically.

Correspondence: Melissa A. Matson, M.A., Department of Neuropsychology, Kennedy Krieger Institute, 1750 E. Fairmount Ave, Baltimore, MD 21231.E-mail:matson@kennedykrieger.org

\section{K.I. BOSER. PROACTIVE INTERFERENCE IN SUBJECTS WITH AUTISM .}

Proactive interference (PI) is argued to arise from difficulty inhibiting responses to previously shown items. With development, normal subjects show increasing executive abilities and reduced PI. The reduced ability of subjects with autism to use semantic information to aid word recall has been argued to result from an executive deficit in activation and/or inhibition of contextual features. Though important to understanding executive functioning. PI and its possible mechanisms have not been extensively studied in individuals with autism. To do so, 6 and 8 word lists were presented to autistic and age-matched subjects in sets of 3 same-category trials in a target detection paradigm based on Halford (1988). All positions were equally probed. The first and third trials were considered low and high interference, respectively. Within the first half of 48 trials, 16 unique categories were tested. The second half consisted of 8 more unique categories plus repetition of 8 of the initial 16. Across the task, every other probe word was repeated (i.e., also an item in a previous list). Subjects with autism showed significantly less release from PI at low interference trials. They were significantly worse with 6 word lists and demonstrated less interference from repeated probes 
relative to controls. Both groups showed less accuracy for high interference trials during the second half compared to the first. These results support a theory of impairment in the appropriate timing of activation of semantic memory in autism, rather than inhibition only. Implications for related language and memory functions will be discussed.

Correspondence: Katharina I. Boser, Ph.D., Neurology, Johns Hopkins University School of Medicine, Cognitive Neurology/Neuropsychology, 1629 Thames Str., Suite 350, Baltimore, MD 21231-3449. E-mail: kboser@jhmi.edu

\section{Z. EVIATAR, V. CHERKASSKY, T.A. KELLER, P.A. CARPEN- TER, N.J. MINSHEW \& M.A. JUST. CORTICAL CONNECTIVITY IN AUTISM: AN ANALYSIS OF FUNCTIONAL CONNECTIVITY AND INTEGRATION IN FMRI STUDIES OF COMPREHENSION AND PROBLEM-SOLVING.}

This study examined the characteristics of cortical networks for a sentence comprehension task and a planning task (Tower of London) in a group of high functioning autistic and control adults using fMRI. Raw asymmetry of activation levels in the two tasks revealed similar patterns in the two groups: higher activation patterns in the LH for the language task, and high bilateral activations for the planning task. Correlations of activation levels between pairs of brain regions were computed and interpreted as indications of connectivity. These measures revealed striking differences between the groups. The control participants revealed very different patterns in the two tasks: higher co-activation patterns between pairs of brain regions within the left hemisphere for the language task, and higher co-activation patterns within the right hemisphere, and across hemispheres in the planning task. The participants with autism showed much more similar patterns for the two tasks: higher connectivity amongst regions within the LH than within the right hemisphere, or bilaterally. Both groups revealed higher levels of connectivity in the more bilateral task, suggesting that the more extensive the cortical network involved in the execution of a task, the higher the correlations of activation time courses between these areas. The autistic participants revealed lower levels of functional connectivity than controls in general. We interpret this as reflecting under-connectivity in the brains of autistic participants. We suggest that the critical difference between the groups may be flexibility of brain responses, which allow the activation of very different networks to perform different tasks.

Correspondence: Zohar Eviatar, Ph.D., Psychology, University of Haifa, Mount Carmel, Haifa 31905, Israel.E-mail: zohare@research.haifa.ac.il

\section{I.J. WAMBACQ, K.J. SHEA-MILLER, A. ECKERT \& V. TOTH.} ERPS IN CHILDREN WITH AUDITORY PROCESSING DISORDERS. The goal of this study was to use event-related potentials (ERPs) to examine the underlying processing deficit of children with auditory processing disorders (APD). ERPs offer a way to identify processing deficits that are specific to one sensory modality, and therefore, are likely to be useful in the diagnosis of APD. Twenty children were grouped based on their performance on a complete behavioral test battery for APD. Ten children were classified as having APD and ten children were classified as not having an auditory processing deficit. Electrophysiologic measures were obtained at 30 electrode sites for auditory and visual gap detection. No group differences were observed in the ERP components in response to the visual task. Children without APD had a large increase in the P3 amplitude between the gap and no-gap conditions of the auditory task. In contrast, for children with APD, the difference in P3 amplitude between auditory gap and no-gap conditions was minimal. It is of note that the activation patterns for the auditory no-gap condition were similar between subject groups, as would be expected when no processing of target information (i.e., gap) is required. The results of this work demonstrate that children diagnosed with APD have reduced brain activation for an auditory gap detection task while ERPs to visual gap detection appear normal. The existence of a deficit specific to the auditory system has research and clinical implications. Correspondence: Ilse J. Wambacq, Ph.D., New Jersey Neuroscience Institute, JFK Medical Center, 65 James Street, Edison, NJ 08818. Email:iwambacq@solarishs.org.

\section{S.P. PAVAWALLA, A.J. NAILLON, J.B. FANCHER, M.Y. KIBBY \& G.W. HYND. CEREBRAL HEMISPHERE VOLUME IS RELATED TO SUBTYPES IN READING DISABILITY.}

Previous research has found a relationship between specific neuroanatomical regions and reading and language disorders. In a study by Leonard et al. (2001), multiple brain regions were examined in conjunction with adult dyslexia. The findings suggested low cerebral volume predicted oral and written comprehension skills, while other brain measures predicted phonological working memory. When assessing the same brain regions in children, Leonard et al. (2002) discovered that cerebral hemisphere volume was able to accurately classify children with dyslexia into subtypes: those with and without comprehension and/or phonetic difficulties. The purpose of this study was to replicate these findings in a sample of 47 children, ages of $8-12$, who were divided into Reading Disability (RD) or No Reading Disability (NRD) groups. The RD group was further divided into two groups: RD with receptive language problems (RL) and $\mathrm{RD}$ without receptive language problems (NRL). All children underwent MRI and a neuropsychological battery. Results indicated a lack of significant group differences for right and left cerebral hemisphere volumes when comparing RD versus NRD. However, when the RD group was further divided into RL versus NRL, significant differences in bilateral cerebral hemisphere volumes between the two groups were observed. Consistent with Leonard and colleagues' previous findings (2002), our results suggest that there are not only cognitive differences between subtypes of reading disabilities, but also biological differences. This lends further support to the argument that research on dyslexia should focus on subtypes rather than considering it a homogeneous, phonologically-based, disorder.

Correspondence: Shital P. Pavawalla, Psychology, Washington State University, 1890 NE Merman Dr., Apt. B203, Pullman, WA 99163. Email:spavawalla@wsu.edu

\section{M.A. MARTENS, S.J. WILSON \& D.C. REUTENS. AMYGDALA VOLUME AND SOCIABILITY IN WILLIAMS SYNDROME AND NORMAL CONTROLS.}

The amygdala has been implicated in recognition of emotions in facial expression. Individuals with Williams syndrome (WS) have been found to view unfamiliar faces as more approachable than normal controls. The current research investigated the relationship between amygdala volume and approachability in both normal controls and WS individuals. Twenty-two WS individuals (mean age 17.1, SD 7.3 years; range 8-41 years) and 22 healthy controls matched for age, gender and handedness (mean age 17.1, SD 7.3 years; range $8-41$ years) underwent T1-weighted high-resolution MRI brain scans and rated the approachability of unfamiliar faces (Adolphs, 1998). The results showed that WS individuals rated the unfamiliar faces as significantly more friendly than controls $[\mathrm{t}(40)=2.29, \mathrm{p}=.02]$, supporting the trait of hypersociability in WS. Despite an 18\% reduction in overall brain volume for WS individuals, the volumes of left and right amygdala were similar in WS individuals and controls. The proportionally larger amygdala in WS individuals may account for their increased positive ratings. Furthermore, in comparison to controls, WS individuals based their friendliness ratings significantly more on peripheral features $[\mathrm{t}(30)=-2.45, \mathrm{p}=.02]$ than on references to eyes or mouth $[\mathrm{t}(17)=3.17, \mathrm{p}=.005]$, suggesting that WS individuals use atypical facial processing when determining how friendly a person appears. 
Correspondence: Marilee A. Martens, Ed.S., M.A., Behavioural Science, University of Melbourne, 12 Murray St., Mentone, VIC 3194, Australia. E-mail:m.martens@pgrad.unimelb.edu.au

\section{Paper Session 12/1:00-3:00 p.m.}

\section{FMRI Investigations of Normal Cognition Across the Lifespan}

\section{D.L. ROBINS \& R.T. SCHULTZ. CROSS-MODAL INTEGRATION OF EMOTIONAL INFORMATION.}

Emotional processing rarely occurs in one isolated sensory modality, yet most research on face perception utilizes static images. Integration of emotional information (visual and auditory) is more ecologically valid, and may draw upon different neural systems. We studied the effects of processing conflicting emotional information using novel stimuli, in order to better understand emotional processing. Movie clips were digitally altered to mismatch emotional information contained in the audio and video tracks. Critically, lip synchrony was maintained, and semantic content of the auditory-visual information was preserved and natural. These clips, however, contained conflicting emotional content, that could be detected only through emotional processing. Movie stimuli used emotionally ambiguous sentences (e.g.., "Look in the box," "The door is open") spoken by two professional actors (one male, one female) in four emotional tones: angry, fearful, happy, or neutral. Clips were presented in the original matched format and each possible mismatched format, totaling 320 clips. Fourteen participants ( 9 male, 4 female; mean age 19) viewed the clips and labeled the emotion. Participants indicated when assigning an emotional label was difficult. Two $(2.5 \%)$ matching and $179(74.6 \%)$ mismatching clips were perceived as difficult by more than 2 participants. Dominance was strongly visual for $67 \%$ of mismatched stimuli; strongly auditory for $22 \%$, and $11 \%$ showed possible evidence of blending (i.e., fearful face, happy voice blends to surprise). Blending will be further investigated with a larger sample. We will present pilot functional MRI data assessing the role of the amygdala in the cross-modal integration of emotional stimuli.

Correspondence: Diana L. Robins, PhD, Child Study Center, Yale University, 230 South Frontage Road, New Haven, CT 06520. E-mail: diana. robins@yale.edu

\section{D.A. KAREKEN, J. PLAILLY, A. RADNOVICH \& M. SABRI. CORTICAL MEDIATION OF ODOR DISCRIMINATION.}

The ability to differentiate between odors is critical to olfactory perception, but the cortical network underlying conscious odorant discrimination remains unclear. We studied 16 healthy right-handed subjects (8 males, age $=25.06, \mathrm{SD}=3.23)$ using $\mathrm{H}_{2}{ }^{15} \mathrm{O}$ positron emission tomography (PET) during counterbalanced conditions of odorless sniffing, repeated single odorant detection, multiple odorant detection, and conscious discrimination between odorants. Eight odorant solutions were calibrated with air-dilution to approximate equal perceived intensities and pleasantness using a computer-controlled olfactometer, and delivered through a bi-rhinal nasal cannula. PET data were analyzed with SPM99 (random effects, $p<.005$, analyses limited to olfactory regions). Multiple odorant detection proved simple (94.9\% accuracy \pm 7.8 ), while detection accuracy for a single repeated odor was more difficult because of habituation $(87.1 \% \pm 14.0)$; odor discrimination was equally difficult $(87.7 \% \pm 9.2)$. Activation from a single repeated odor occurred principally in the bilateral middle orbital and middle/inferior frontal gyri, while activation from multiple odors elicited additional activity in the bilateral piriform/amygdala area. However, orbital areas thought to be olfactory association cortex were activated equally by both single and multiple odors. Compared to multiple odorant detection, conscious odorant discrimination evoked a large cluster of significantly greater activity in the left anterior insula. Discrimination task accuracy also correlated significantly with activity in the right posterior insula. Conscious analysis of differences in odorant quality above and beyond simply reporting odorant presence appears to engage insular regions. By contrast orbital associative regions seem equally active regardless of odor quality variation, and may be engaged automatically to code for odor characteristics.

Correspondence: David A. Kareken, Ph.D., Neurology, Indiana University School of Medicine, RI-1773, 702 Barnhill Drive, Indianapolis, IN 46202.E-mail:dkareken@iupui.edu

\section{A. ROSEN, D.J. ACHESON \& J.D. GABRIELI. VERBAL SPAN IS RELATED TO BRAIN REGIONS RECRUITED DURING TASK SWITCHING IN YOUNG AND OLDER ADULTS.}

Reaction time slows when task rules change, yet different cues can change the size of this switch cost. This fMRI study compared individual differences in switch costs as affected by external (redundant visual) and internal (expectancy) cues. Participants pressed a keypad with their right hand to indicate responses to two decision-rules concerning the direction of center target arrows. There were four conditions which were indicated by color cues: 1) Indicate the direction of a central arrow (SAME TASK). 2) Indicate the opposite direction (OPPOSITE TASK). 3) Alternate on every trial between rules 1 and 2 while color cues were present (EXTERNAL SWITCH) 4) Alternate on every trial between rules 1 and 2 while color cues were absent (INTERNAL SWITCH). Right-handed older adults $(11 \mathrm{M} / 7 \mathrm{Fmean}$ age $=69$, range $=61-81)$ and young adults $(10 \mathrm{M} / 8 \mathrm{~F}$, mean age $=24$, range $=18-28)$ underwent $2 \mathrm{im}-$ aging series in a blocked design. Older adults recruited the left frontal lobe under both EXTERNAL and INTERNAL SWITCH conditions while young adults recruited this region more during the EXTERNAL than INTERNAL SWITCH CONDITIONS. Older adults with lower verbal (digit) span recruited this region to a greater degree than those with higher spans. This finding extends work by Smith et al., (2000) demonstrating that older adults and low performing young adults recruit frontal lobe regions more during task switching than high performing young adults. (Supported by: NIA Grants AG12995 and AG0586501).

Correspondence: Allyson C. Rosen, Ph.D., Stanford University, Psychology Department, Bldg.420, Jordon Hall, Stanford, CA 94305. Email:rosena@stanford.edu

J.L. WOODARD, K.L. DOUVILLE, M. SEIDENBERG, K.A. NIELSON, S.K. MILLER, C. LEVERONI \& S.M. RAO. FUNCTIONAL NEUROANATOMICAL SUBSTRATES OF THE REMOTE MEMORY TEMPORAL GRADIENT IN HEALTHY OLDER ADULTS.

A variety of neurobehavioral disorders demonstrate remote memory dysfunction characterized by a temporal gradient. However, the neuroanatomical substrate of the temporal gradient is uncertain, and whether or to what extent specific brain regions demonstrate differential response patterns to stimuli from different time epochs is unclear, particularly in healthy, unimpaired individuals. We used fMRI to identify candidate brain regions that demonstrate evidence of a temporal gradient in 15 healthy older participants (mean age $=70.4$ years, $\mathrm{SD}=6.4$ ). Using an event-related design, participants viewed names of famous individuals from 2 different time epochs (1950s-1960s vs. 1990s) or unfamiliar names (foils) of persons selected from a metropolitan telephone book. They were asked to indicate whether or not each presented name was famous via button press. Impulse response functions were generated for the three stimulus categories $(1990 \mathrm{~s}, 1950 \mathrm{~s}$, foils) for right and left hippocampus and for posterior cingulate gyrus. Famous names for both time epochs demonstrated significantly greater activity relative to foils in right and left hippocampus $6 \mathrm{~s}$ after stimulus onset, although no differentiation was observed between epochs. In contrast, a robust signal difference in the posterior cingulate gyrus was observed between each 
of the three conditions $(1990 \mathrm{~s}>1950 \mathrm{~s}>$ foils $)$ at $4 \mathrm{~s}, 6 \mathrm{~s}$, and $8 \mathrm{~s}$ poststimulus onset. Consistent with previous literature, posterior cingulate gyrus appears to play a critical role in memory retrieval. Our results suggest that the posterior cingulate gyrus may be involved in temporally dating items in remote memory as part of a distributed network of regions subserving long-term memory.

Correspondence: John L. Woodard, Ph.D., Psychology, Finch University of Health Sciences/The Chicago Medical School, 3333 Green Bay Rd., North Chicago, IL 60064.E-mail: john.woodard@finchcms.edu

\section{S.A. LANGENECKER, N.M. HAMID \& K.A. NIELSON. FUNCTIONAL OR STRUCTURAL MRI: WHICH IS MORE SENSI- TIVE TO COGNITIVE PERFORMANCE CHANGES WITH AGING?}

Recent neuroimaging articles have suggested that functional MRI is superior to structural MRI in detecting age differences, yet no studies to date have undergone detailed analysis of which is actually more sensitive to age and performance. To test the assumption that structural and functional measurements of basal ganglia structures may in fact be unique in their contributions to our understanding of age-related changes in the CNS, we compared 11 younger to 11 older subjects while they completed a Go/No-go cognitive task. The putamen and globus pallidus (PGP) were measured together as one structure and the caudate head. body, and tail $(\mathrm{C})$ were measured as a second structure, with both measurements conducted blinded to group and identity ( $r>93$ for all structures). Structural measurements were used to extract average activation values in each of the four regions of interest. In two multiple regression equations computed using both functional and structural measurements, greater activation in the left PGP was predictive of poorer accuracy $(27 \%)$ and slower reaction time $(34 \%)$, while greater activation in the right $\mathrm{C}$ was predictive of better accuracy $(12 \%)$. On the contrary, structural measurements were better predictors of group membership (older. younger), with the left $\mathrm{C}$ accounting for much of the variance in group membership. These findings suggest that functional MRI is indeed more sensitive to cognitive performance than structural MRI measurements. Furthermore, it can be seen that activation within the left putamen and globus pallidus, although evidence of recruitment, is predictive of poorer PCRT performance and slower reaction time.

Correspondence: Scott A. Langenecker, Ph.D., Psychiatry, University of Michigan Health Systems, C480 Med Inn Building, 1500 E. Medical Center Drive, Ann Arbor, MI 48109. E-mail: slangen@umich.edu

\section{G.E. ALEXANDER, K. CHEN, E.M. REIMAN, R.J. CASELLI, D.J. LEWIS, T.J. WALTON, K. MOORE, P. PIETRINI, S.J. TEIPEL, H. HAMPEL, S.I. RAPOPORT \& J.R. MOELLER. REGIONAL NETWORK ANALYSIS OF GRAY MATTER ATROPHY IN HEALTHY AGING .}

Healthy aging has been associated with reductions in brain volume, most consistently affecting the prefrontal cortex. We used a statistical model of regional covariance together with voxel-based morphometry (VBM) to identify networks of MRI gray matter concentration associated with age in 29 healthy adults (Group 1) with a wide age range and crossvalidated our findings with an independent sample of 26 healthy individuals (Group 2). Fifty-five healthy adults with ages from 22 to 84 years $[$ Group 1: mean age $=47 \pm 18$ yr, $11 \mathrm{M} / 18 \mathrm{~F}$, Mini-Mental State Exam $($ MMSE $)=29.7 \pm 0.5$; Group 2: mean age $=51 \pm 16$ yr, $15 \mathrm{M} / 11 \mathrm{~F}$, MMSE $=29.6 \pm 0.7]$ were included. T1-weighted MRI scans were analyzed using statistical parametric mapping (SPM99) with VBM to segment them into gray matter images and a modified principal component analysis, the Scaled Subprofile Model (SSM), to identify patterns of regional interactions in MRI concentrations of gray matter associated with aging. Separate $S S M$ analyses for Group $1\left(\mathbf{R}^{2}=0.85, p \leq 0.0001\right)$ and Group $2\left(\mathbf{R}^{2}=0.74, p \leq 0.0001\right)$ each identified a linear combination of component patterns whose subject scores were correlated with age. In both groups, greater age was associated with lower gray matter concentrations in medial frontal and anterior cingulate, bilateral parietal, and bilateral anterior temporal/perisylvian regions with relative preservation in the midbrain. Healthy aging is associated with a regionally distributed pattern of brain atrophy that includes frontal, anterior temporal, and parietal regions. If these gray matter patterns are found to progress over time, network analyses may be helpful in tracking brain changes associated with aging.

Correspondence: Gene E. Alexander, Ph.D., Dept. of Psychology, Arizona State University, 950 S. McAllister, Tempe, AZ 85287-1104. Email: gene.alexander@asu.edu

\section{Poster Session 9: Neurocognitive Functioning following Traumatic Brain Injury/3:15-5:15 p.m.}

\section{Concussion}

\section{G.S. OLSEN, M. MCCREA, T. A. HAMMEKE, K. GUSKIEWICZ, P. LEO \& J. WOODARD. RESIDUAL EFFECTS OF CONCUSSION.}

The chronic effects of concussion or multiple mild head injuries remains unclear. This study investigated the influence of previous concussion on subjective symptoms reported by athletes and their performance on tests of cognition and postural stability. A total of 1,725 collegiate football players and 1,755 high school football players were enrolled in parallel studies. All players completed a health history questionnaire surveying history of concussion, learning disability, attention deficit disorder, and other neurologic disorders. Players also underwent preseason baseline testing on several concussion assessment measures, including: the Graded Symptom Checklist (GSC), Standardized Assessment of Concussion (SAC), Automated Neuropsychological Assessment Matrix (ANAM), Neuropsychological Test Battery, and Balance Error Scoring System (BESS). Statistical analysis on these measures compared: 1) subjects with and without a history of concussion, and 2) subjects with no history vs. subjects with 3 or more previous concussions. Players with a prior history of concussion reported a higher frequency and intensity of post-concussive symptoms, with modest effect sizes, but there were no significant group differences on the SAC, ANAM, neuropsychological test battery, or BESS. These findings suggest that a history of previous concussion does not result in significant residual effects related to cognition or balance, and provide limited evidence of chronic symptomatology. This study does not speak to the effects of sustaining multiple concussions in a short period of time, however, and does not address the potential long-term effects of sustaining several head injuries over a lengthier athletic career.

Correspondence: Gary S. Olsen, MS, Department of Clinical and Health Psychology, University of Florida/Shands Hospital, Psychology Clinic, PO Box 100165, Gainesville, FL 32610-0165.E-mail: golsen@hp.ufl.edu

\section{A. ROSENBAUM \& R.J. ECHEMENDIA. FACTOR STRUCTURE OF POST-CONCUSSIVE SYMPTOMS 2 HOURS POST-INJURY.}

Previous research has identified the factor structure of post-concussive symptoms and has identified 3-4 factors: affective, cognitive, and physical/sensory. However, these factors were found using data obtained weeks and months post-injury. The current study used data reported by athletes at 2 hours post-concussion Method: Data used in the study were obtained from 70 athletes participating in the Penn State concussion program, and these athletes reported symptoms at 2 hours postinjury. The athletes completed the Post Concussion Symptoms Scale (PCSS) which consists of 18 commonly-reported symptoms. An exploratory factor analysis (EFA) with promax rotation was conducted. Results: The EFA identified the following factors (eigenvalue): cognitive and cerebellar (5.13), predominantly physical (4.37), and affective (3.12). According to a reliability analysis, scales generated from 
these factors have adequate to good reliability (cognitive/cerebellar, $\alpha$ $=0.88$; physical, $\alpha=0.80$; and affective, $\alpha=0.79)$. Discussion: These results indicate that, in an athlete sample at 2 hours post-injury, factors do not contain exclusive physical or cognitive symptoms, but rather, there appears to be overlap in the type of symptoms that are reported. Symptoms soon after injury may be more variable than symptoms reported at several weeks or months post-concussion. If so, this variability underscores the perspective that cerebral concussions are dynamic and change over time. It is consistent with animal models that suggest early diffuse neurological disruption with gradual and non-linear symptom resolution. This finding needs to be replicated in other studies with larger sample sizes.

Correspondence: Aaron Rosenbaum, B.S., Clinical Psychology, Penn State University, 710 University Dr., State College, PA 16801. E-mail: amr262@psu.edu

\section{S.K. MILLER, J.L. WOODARD, M. MCCREA, T.A. HAMMEKE, G. OLSEN \& P. LEO. PRESERVED VISUOSPATIAL MEMORY} FUNCTIONING FOLLOWING SPORTS-RELATED CONCUSSION.

Verbal memory deficits following sports-related concussion have been demonstrated in a number of studies (e.g. Collins et al., 1999; Grindel et al., 2001; McCrea, 2001, Olsen et al., 2002). However, little has been published regarding visuospatial memory in concussed athletes. Thus, it is not clear whether concussion results in global or system-specific memory deficits. The present study examined visuospatial memory functioning in a group of concussed and control high school football players. Sixty injured players and 62 controls completed a neuropsychological test battery, including the incidental recall of the Symbol Digit Modalities Test (SDMT) at 24-hours, six days, and 50 days post-injury. In addition, 20 of these injured players and 19 of the controls completed the Brief Visuospatial Memory Test-Revised (BVMT-R) at the same time intervals. Previously reported data with a subset of this sample (Olsen et al., 2002) demonstrated verbal memory deficits in concussed athletes at 24 hours post-injury that resolved by six days post-injury. In contrast to these previous findings, BVMT-R immediate and delayed recall showed no between groups differences at any time point, $t s(33,32,34)$ $<1, p s=$ n.s. Likewise, there were no group differences on SDMT incidental recall, $t s(113,110,111)<1, p s=$ n.s. Based on these results, it appears that the visuospatial memory system is either resilient to injury following sports-related concussion, or the concussed brain is able to compensate for insult to this system. Alternative methodological explanations for this pattern of findings are also discussed.

Correspondence: Sarah K. Miller, M.S., Finch University of Health Sciences/The Chicago Medical School, 2301 NW 122nd, Apt. 2102, Oklahoma City, OK 73120.E-mail: sarahkmiller@juno.com

\section{M.A. MCCREA, K.M. GUSKIEWICZ, W. BARR, S.W. MARSHALL, C. RANDOLPH, R. CANTU, J.A. ONATE \& J.P. KELLY. ACUTE EFFECTS AND RECOVERY TIME FOLLOWING CONCUSSION IN COLLEGIATE FOOTBALL PLAYERS.}

Lack of information on the expected recovery time following sports-related concussion hampers clinical decision-making about return to play after injury. The current study was designed to prospectively measure the immediate effects and plot the natural recovery course in subjective symptoms, cognitive functioning and postural stability following sportsrelated concussion. A 3-year prospective study of collegiate football players was conducted from 1999-2001. All players $(n=1,725)$ underwent preseason baseline testing on several concussion assessment measures. Concussed players ( $n=94)$ and non-injured controls $(n=56)$ underwent repeated assessments of symptoms, cognitive functioning, and postural stability immediately, three hours after injury, and on days 1, 2, 3, 5, 7 and 90 post-injury. Main outcome measures included a concussion symptom checklist, the Balance Error Scoring System (BESS), Standardized Assessment of Concussion (SAC), and neuropsychological test battery. Injured subjects exhibited most severe symptoms, cognitive impair- ment and postural stability deficits immediately after concussion, followed by a gradual recovery within 7 days in most cases. Mild deficits on select neuropsychological testing were evident one week after concussion, and a significant percentage of players who reported being asymptomatic continued to exhibit impairments on standardized testing. These are the most extensive human data to illustrate the natural recovery course after cerebral concussion, and have important implications for clinical management of sports-related concussion. A comprehensive assessment model is critical for sensitive injury detection and tracking recovery over time. Relying solely on reported symptoms may result in prematurely returning an athlete to competition and increasing potential risks of cumulative impairment or catastrophic outcome after concussion.

Correspondence: Michael A. McCrea, PhD, Neuroscience Center, Waukesha Memorial Hospital, 721 American Avenue, Suite 501, Waukesha, WI 53188. E-mail: michael.mccrea@phci.org

\section{R.J. ECHEMENDIA, C.M. BAILEY \& J.M. BRUCE. THE CUMU- LATIVE IMPACT OF SOCCER-RELATED HEADING ON THE NEUROPSYCHOLOGICAL PERFORMANCE OF MALE COLLEGE ATHLETES.}

The neuropsychological repercussions of heading in soccer have never been sufficiently demonstrated. However, it has been suggested that the cumulative affect of heading may negatively impact cognitive performance. One way to examine the impact of heading is to compare the cognitive performance of individuals with and without a history of repeated heading. The current project compared the performance of male, college varsity soccer players ( $\mathrm{N}=94)$ and male, non-contact varsity athletes (Baseball, Male Tennis, and Male Swimming; N=76) on a standard battery of neuropsychological tests (the Symbol Digit Modalities Test, Trail Making Tests A and B, Controlled Oral Word Association Test, Digit Span Backward, and the Stroop Color-Word Test). The data were collected as part of the Penn State Concussion Program. No significant differences were observed on a MANOVA comparing the performance of male soccer players and non-contact athletes $(\mathrm{F}(7,162)=1.32, \mathrm{p}=.246)$. Upon further inspection, a significant difference was observed between the SAT scores of the two groups $(t(162.97)=-2.16, p=.032)$. However, no significant difference was observed between the reported previous head injury experience of the two groups (X2(1)=.037,p=.848). When analyzed with SAT scores as a covariate, the MANOVA still found no significant difference between the neuropsychological performance of the soccer athletes versus that of the non-contact athletes $(\mathrm{F}(7,161)=0.89, \mathrm{p}=.520)$. Based on these results, it was concluded that a history of repeated soccer-related heading does not appear to affect the cognitive performance of male college athletes.

Correspondence: Christopher M. Bailey, Psychology, Penn State University, 339 Moore Building, State College, PA 16803.E-mail:cmb373@ psu.edu

\section{S.E. CARTER, R. ADAMS, E. MOES, P. FINN \& I. SCHULOVA. THE RELATIONSHIP BETWEEN HISTORY OF CONCUSSION,} SLEEP DISTURBANCE AND ATTENTION IN COLLEGE ATHLETES.

Common symptoms following a traumatic brain injury (including mild TBI) are a decline in attention and sleep disruption. While researchers have investigated these adverse effects as separate variables, few studies have carefully examined the relationship between sleep disruption and attention difficulties. In the current study 41 college athletes, 19 with and 22 without a history of head injury, matched on age, sex, handedness, alcohol use and years of education, completed the Matrix Reasoning subtest of the WAIS-III, a questionnaire investigating sleep complaints (nightmares, sleep walking, sleep talking, teeth grinding. myoclonic jerks, trouble breathing), subjective sleepiness scales (Epworth Sleepiness Scale and Stanford Sleepiness Scale), the Brown ADD scale (a self-report measure of attention difficulties) and the Vigil continuous performance test. No significant differences between TBI and 
non- TBI participants on both subjective and objective attention measures, frequency of sleep complaints and sleepiness measures were found. Furthermore, sleepiness and TBI accounted for a non-significant $8 \%$ to $9 \%$ of variance on attention measures. The absence of differences is discussed in relation to the length of time between injury and testing (median $=4$ years $)$ and the mildness of concussions sustained. Correspondence: Shannon E. Carter, BA, Psychology, Suffolk University, 8 Ashburton Place, Boston, MA 02108.E-mail: shannon_carter@ hotmail.com

\section{C.K. MCKEEVER, P. SCHATZ, T. COVASSIN, M. SACHS, J. SCHNEIDER, J. HEYDT \& E.A. ZILLMER. SPORTS-RELATED CONCUSSIONS IN COLLEGIATE ATHLETES: GENDER DIFFER-} ENCES ACROSS NEUROPSYCHOLOGICAL TEST PERFORMANCES. Although professional American football and boxing are likely associated with concussions, data indicate relatively high rates of sports-related concussions transcending all sports, athletic age groups and genders. It is highly common for young athletes to have sustained at least one concussion in their athletic careers and $10 \%$ of all college sports injuries and $20 \%$ of all high school sports injuries result in concussions. Additionally, there is growing concern regarding potential gender differences that may exist in the prevalence and severity of and recovery from concussion. Female athletes participating in high school sports are consistently at higher risk for sustaining a concussion than their male counterparts. Further, female soccer players are at almost twice the risk for concussion than male soccer players. The current study examined the potential for gender differences on neuropsychological tests among approximately 1,400 varsity and club collegiate athletes at five universities. Each athlete underwent preseason baseline neuropsychological testing and received post-concussion testing as well. MANOVA revealed that there were no significant differences on baseline neuropsychological test performances between male and female athletes; $\mathrm{F}$ $(5,1280)=1.39, p=.224$. MANOVA further indicated significant differences between genders on post-concussive neuropsychological testing; $\mathrm{F}(5,186)=3.269, \mathrm{p}=.007$. Univariate $\mathrm{F}$ tests indicated that male and female athletes differed on impulse control performances; $\mathrm{F}$ $(1,190)=5.07, \mathrm{p}=.025$ as well as visual memory performances; $\mathrm{F}$ $(1,190)=8.35, p=.004$. Implications of these results will be discussed. Correspondence: Catherine K. McKeever, M.S., Psychology/Neuropsychology, Drexel University, 2614 Brown Street, Philadelphia, PA 19130. E-mail: cim22@drexel.edu

\section{J.N. ABREU, A. PITIA, C.P. ANDRADE \& G. SPIELMANN. COGNITIVE DEFICTS FROM CONCUSSON IN PROFESSIONAL SOCCER PLAYERS IN BRAZIL.}

This study was designed to assess cognitive deficits from possible concussions between professional soccer playes (PSP) in a soccer team in Salvador (Brazil). Eighteen (18) professional players (PSP, N=18; Age= 21,33 and Years of School=9,55) and 18 controls were assessed (Age= 21,38 and years of school=13,61). Three tests were used: ToulousePieron test for visual attention; Rey Auditory Verbal Learning Test and Rey Complex Figure (ROCFR). Our results show with an ANOVA a defict for quality of visual attention on Toulouse-Pieron test; on RAVLT professional soccer player showed significant differences on all the tentatives, except for second and fourth ones(PSP: Trial 2: 8,75, Trial 4: 10,0 and Control Trial 2: 9,16 Trial 4: 11,8). On Complex Figure they showed deficts for short (PSP: 18,83 and Control: 22,13) and long-time visual memory (PSP: 18,32 and Control: 22,93) when compared to control group. These results extend the hipothesis of shows that sucessive exposition to concussion can reduce professional soccer players cognitve performance.
Correspondence: Jose N. Abreu, Ph.D student, Psicologia, Faculdade Ruy Barbosa, Av. Luis Viana Filho, 2774 Ap. 604 Ed. Adriano - Imbuí, Salvador41770-000, Brazil. E-mail: neander@frb.br

\section{G.E. GETZ, M.R. LOVELL, M.W. COLLINS, K. PODELL \& G.L. IVERSON. SELF-REPORT SYMPTOMS OF CONCUSSION IN MALE AND FEMALE ATHLETES.}

Many studies during the past decade have emphasized the importance of utilizing clinically objective measures when diagnosing and managing concussion in athletes. Specifically, the Postconcussion Scale (PCS) has become a widely used self-report instrument to measure the severity of symptoms in the acute phase of recovery from concussion. However, it remains unclear as to whether differences occur in reporting concussive symptoms on the PCS between male and female athletes as well as between high school and university athletes. The current study examined 398 (351 males, 87 females) high school and university athletes at pre-season baseline as well as within 7 days of experiencing a concussion on the PCS. Results indicate that females reported a higher level of symptoms at both baseline $(\mathrm{F}=3.65, \mathrm{p}<.06)$ and following concussion $(F=3.88, p<.04$. $)$. A comparison of differences between high school and college athletes did not yield significant differences in overall symptom reporting either at baseline $(\mathrm{F}=.87, \mathrm{p}<.35)$ or after concussion $(\mathrm{F}=1.67, \mathrm{p}<.20)$. Further, there was no significant interaction between level of competition and gender, either at baseline $(F=.16, p$ $<.70)$ or following concussion $(\mathrm{F}=2.12, \mathrm{p}<.15)$. The results from this study suggest that regardless of level of competition, female athletes may be more likely to report a higher degree of concussive symptoms, both at baseline and post-concussion periods as compared to males. These sex differences should be taken into consideration when clinically managing athletes with concussion.

Correspondence: Glen E. Getz, Dept. of Psychiatry, Allegheny General Hospital, Four Allegheny Center, Eight Floor, Pittsburgh, PA 152125234.E-mail:getzg@email.uc.edu

\section{A.A. PICA, J.L. WOODARD \& J.E. CALAMARI. PSYCHOLOGICAL FACTORS UNDERLYING POST-CONCUSSIVE SYMPTOM REPORTING.}

The factors that influence the experience and reporting of post-concussive symptoms are unclear. Potential explanations include the influential role of pre-existing expectations coupled with a misattribution of pre-existing benign symptoms to concussion. This study examined these factors in the context of sports related concussion in a sample of 59 high school football players. The constructs of anxiety sensitivity (AS) and negative affect (NA; measured with the PANAS) were also evaluated as potential influences to the patterns of post-concussive symptom reporting. Results showed that athletes with a history of concussion in the past five years reported a greater number of symptoms than athletes without a history of concussion. NA was significantly correlated with the frequency and severity of post-concussing symptom reporting. In comparison to never concussed athletes, previously concussed athletes reported a smaller expected increase in symptom severity following a concussion, and reported experiencing fewer symptoms prior to their injury. AS was a significant predictor of the expected change in the number of symptoms experienced following concussion, and the degree of change in the number of symptoms reported retrospectively as compared to presently reported symptoms. Taken together, these results suggest that the symptom report of high school athletes may be influenced by expectations regarding the effects of a concussion and underestimations of previously occurring symptoms. In addition, psychological factors such as AS and general negative affectivity may contribute to the patterns of symptom reporting both prior to and following a concussion.

Correspondence: Ashley A. Pica, B.A., Psychology, Finch University of Health Sciences/Chicago Medical School, 802 W. Buckingham Pl. Apt. 3, Chicago, IL 60657.E-mail: ashleypica@excite.com 


\section{S.R. MCCAULEY, C. BOAKE, S.A. BROWN, H.S. LEVIN \& C.F. CONTANT. FAILURE TO FIND DIFFERENTIAL UTILITY OF THE DSM-IV AND ICD-10 CRITERIA FOR POSTCONCUSSIONAL DISORDER 6 MONTHS POSTINJURY.}

Little research has been conducted comparing the differential utility of the DSM-IV and ICD-10 diagnostic criteria for Postconcussional Disorder (PCD). This study prospectively recruited a consecutive series of patients with mild to moderate TBI from the ER or hospital wards of a Level-1 trauma center. Outcome was measured at 6 months post-injury. The diagnosis of PCD was made using a semi-structured interview based on the DSM-IV and ICD-10 clinical criteria for PCD. Outcome was measured using the SF-36, Community Integration Questionnaire (CIQ), Centers for Epidemiologic Studies Depression Scale (CESD), and the Visual Analog Scale for Depression (VASFD). Of the 165 TBI patients (126 mild / 39 moderate), 19 (11.5\%) met DSM-IV criteria for PCD, and 73 $(44.2 \%)$ met ICD-10 criteria. Separate analyses were performed comparing participants meeting DSM-IV PCD vs. no-PCD and participants meeting ICD-10 PCD vs. no-PCD. Significant differences were found between participants with PCD vs. no-PCD using either diagnostic criteria for all composite and subscales of the SF-36 (all $p<.0001$ ), CESD (both $\mathrm{p}<.0001$ ), and VASFD (both $\mathrm{p}<.0001$ ). The CIQ Total, Social, and Home scores were poorer for participants with DSM-IV PCD, whereas the CIQ Productivity score was poorer for participants with PCD under both systems. These results suggest little if any differential utility of one set of diagnostic criteria over the other. In spite of the significant differences in criteria and timeframes for symptom duration, there appears to be no substantial difference in outcome between the two diagnostic systems.

Correspondence: Stephen R. McCauley, Ph.D., Physical Medicine and Rehabilitation, Baylor College of Medicine, 6560 Fannin St., Ste. 1144, Houston,TX 77030.E-mail:mccauley@bcm.tmc.edu

\section{K.N. LEONARD \& D.M. TUCKER. GROUP-BASED COGNITIVE- BEHAVIORAL THERAPY FOR PERSISTENT POSTCONCUSSION SYNDROME: A CONTROLLED TREATMENT OUTCOME STUDY.}

Of the estimated one million people who experience a mild brain injury each year, up to $40 \%$ report persistent postconcussion symptoms months after injury. However, surprisingly little research has been devoted to developing beneficial treatments for this disorder. The current study sought to examine the relative efficacy of two different psychosocial treatment interventions for persistent postconcussion syndrome. Forty participants were randomly assigned to either group-based cognitivebehavioral therapy (GCBT, $\mathrm{N}=15$ ), group-based education and support (GEST, $\mathbf{N}=16$ ), or a wait-list control group (WL, $N=9$ ). GCBT offered traditional cognitive-behavioral components including education, automatic thought identification and cognitive restructuring, in vivo exposure, relaxation training, and structured homework assignments. GEST included the full education component plus non-directive psychosocial support. Treatment outcome was evaluated in four domains (postconcussion svmptomatology, quality of life, cognitive functioning. and emotional distress) at three time points (pre-treatment, post-treatment, three-month follow-up). Results revealed significant improvement for treated individuals in postconcussion symptoms, neurocognitive functioning, and emotional distress. Active treatment demonstrated significant superiority over delayed treatment in reducing postconcussion symptoms, but was not superior to delayed treatment in other outcome domains. GCBT was marginally superior to GEST in improving quality of life; no other differences between GCBT and GEST were detected. Criteria for clinically significant improvement were met for $27 \%$ of GCBT participants and $31 \%$ of GEST participants. Exploratory analyses showed that several clinical and baseline variables significantly moderated group effects on outcome, including medication use at the time of study entry and baseline level of depression. Implications of these findings are discussed.
Correspondence: Kari N. Leonard, PhD, CNS Therapeutics, INC Research, 1910 Ann Arbor Ave, Austin, TX 78704.E-mail:kleonard@ incresearch.com

\section{J. STUMP, P. SHATZ, M. LOVELL \& M. COLLINS. SENSITIVITY AND SPECIFICITY OF THE IMPACT TEST BATTERY IN ATH- LETES' CONCUSSION STATUS.}

Current standards of the magament of athletes following cerebral concussion are often based on sujective experiences and do not utilize neurocognitive measures for decisions regarding return-to-play. Although most concussed athletes recover, a significant number may experience chronic cognitive and behavioral symptoms that impair congitive functions or affect personality. ImPACT is a battery of neuropsychological tests that can be administered on a computer, and can detect cognitive abnormalities associated with concussion. The purpose of the current study was to determine the sensitivity and specificity of the test battery in discriminating concussed and nonconcussed athletes. Data from 76 concussed high school athletes were compared to a control group, matched by age ( $N=71)$. All athletes were evaluated using the ImPACT computerized neuropsychological battery. This program vields composite scores derived from tests of reaction time, memory, and processing speed. For this study, total score on a post-concussion symptom index and performance on the five ImPACT composite scores were evaluated. A stepwise discriminant function analysis was conducted with symptom score and the five ImPACT composite scores. One discrminant function identified that the significant factors of symptom, processing speed, verbal memory, and impulse control scores correctly classified $85 \%$ of cases ( $79 \%$ of concussed, $92 \%$ of nonconcussed). The eigenvalue (.776) suggests high discrimination power, with a canonical correlation of .661. CONCLUSIONS: Results of the current study suggest that ImPACT scores, together with postconcussion symptoms, provide an accurate way to discriminate the performance of concussed from nonconcussed athletes. The findings add support for using ImPACT as a tool in the diagnosis and treatment of concussion, as well as in the decision process regarding return-to-play following concussion.

Correspondence: Jamie Stump, UPMC Sports Med, 3200 Water St., Pittsburgh,PA 15217.E-mail: jstump@verizon.net

\section{A.N. CERNICH, J. BLEIBERG, T.M. ROEBUCK-SPENCER, B. IVINS, K. SCHWAB, D.L. REEVES, F. BROWN \& D. WAR- DEN. PREDICTION OF CONCUSSION STATUS USING A COM- PUTERIZED NEUROPSYCHOLOGICAL MEASURE: A LOGISTIC REGRESSION ANALYSIS.}

Although standard practice in concussion research and practice often includes baseline measurement of normal cognitive function for withinsubject comparison, due to practical constraints, some concussed subjects do not receive baseline testing prior to injury. This study examined the sensitivity of a computerized neuropsychological battery, the Automated Neuropsychological Assessment Metrics (ANAM), to concussion in a sample of military personnel that did not receive baseline testing. Subjects with $(n=52)$ and without concussive injury $(n=62)$ received ANAM as part of a larger assessment battery. The ability of each ANAM subtest to predict group membership was examined using logistic regression. A backward stepwise logistic regression was used to determine the most parsimonious group of ANAM subtests needed to predict group status. Four of the seven ANAM subtests were significant predictors of group status and demonstrated good classification accuracy (ranging from $63-70 \%$ ). The model utilizing the full battery revealed good model fit $\left(\chi^{2}=36.3, p=.0001\right)$ and good classification accuracy $(76.3 \%)$. The most statistically parsimonious model retained three of seven predictors and revealed good model fit $\left(\chi^{2}=32.7, p=.001\right)$ and good classification accuracy $(71.9 \%)$. This study suggests that ANAM subtests are effective in classifying individuals as concussed and are reliably sensitive to concussive injury. Future studies should cross validate these results in separate samples. 
Correspondence: Alison N. Cernich, Ph.D., Neuroscience Research, National Rehabilitation Hospital, 724 1/2 11th Street SE, Washington, DC 20003.E-mail: alison.cernich@medstar:net

\section{T.A. HAMMEKE, M. MCCREA, M. VERBER, S. DURGERIAN, G.S. OLSEN, P. LEO, T.A. GENNARELLI \& S.M. RAO. FUNCTIONAL MAGNETIC RESONANCE IMAGING AFTER ACUTE SPORTS CONCUSSION.}

The speed and extent of recovery after sports concussion remain controversial. Functional magnetic resonance imaging (fMRI) was used to study 15 players with AAN Grade $2(n=10)$ or $3(n=5)$ concussion within 12-18 hours of injury and again 6 weeks after injury. Measures of postconcussive symptoms, neuropsychological function and postural steadiness were completed at the same intervals. Teammates matched to the injured players on a preseason neurocognitive measure underwent the same studies. Whole brain echoplanar imaging was done while subjects performed the Sternberg memory scanning task with set sizes of 2,4 and 6 digits. An event-related design and deconvolution analysis was used to investigate fMRI signal changes under each memory load condition. Injured players had significantly more complaints and impaired postural steadiness on the day following injury, but did not perform differently than controls on neuropsychological measures. Sternberg behavioral data found the concussed players to show slower reaction times than control subjects for each memory load condition in the initial postinjury session that resolved by the 6 -week session. Imaging results showed similar task-related activation profiles for each group with a trend for injured players to show less activation than control subjects on the day following injury. These subtle differences were not apparent at the 6week session. Overall, fMRI results indicate subtle changes in activation profiles can be seen on the day following concussion that were not present 6 weeks later, findings that paralleled symptom report and measures of postural steadiness. Alternative explanations of the findings will be reviewed.

Correspondence: Thomas A. Hammeke, PhD, Neurology (Neuropsychology), Medical College of Wisconsin, 9200 West Wisconsin Avenue, Milwaukee, WI 53226. E-mail: thammeke@mcw.edu

\section{S.K. MILLER, T.A. HAMMEKE, J.L. WOODARD, M. MCCREA, G. OLSEN, M. VERBER \& P. LEO. AN FMRI STUDY OF FUNC- TIONAL CONNECTIVITY IN THE HIPPOCAMPI OF CONCUSSED ATHLETES: MOTION CONFOUNDS INTERPRETATION .}

Researchers have recently attempted to use functional magnetic resonance imaging (fMRI) to understand the sequelae of sports-related concussion (Hammeke et al., 2002). However, variability in subject compliance with task activation protocols in fMRI often complicates interpretation of cerebral activation profiles. An alternative to cognitive activation protocols involves the study of spontaneous low frequency BOLD signal fluctuations during the resting state that are thought to correlate between functionally connected brain regions, thereby enabling an index of regional connectivity or conversely brain dysfunction. This method, referred as the COSLOF index, has been widely used in the animal literature, and has recently been applied in humans with the study of hippocampal functioning in Alzheimer's disease (Li et al., 2002). Because concussion involves a decrease in functional neural connectivity, and many of the metabolic sequelae of this injury presumably affect the hippocampi, the hippocampal COSLOF index was expected to be disrupted following concussion. Seventeen injured players with grade 2 or 3 concussions and 16 controls were scanned with fMRI within 24 hours and 50 days post-injury. Hippocampi were traced, and COSLOF indices were calculated for each resting functional scan. The COSLOF index failed to discriminate between concussed and control groups at either time point. Moreover, the COSLOF index was significantly negatively correlated with movement (correlation range $=-.13$ to -.48 ). This unexpected correlation raises a serious methodological issue that must be addressed in future studies using the COSLOF index to understand functional connectivity in the human brain.

Correspondence: Sarah K. Miller, M.S., Finch University of Health Sciences/The Chicago Medical School, $2301 \mathrm{NW} 122 n d$, Apt. 2102, Oklahoma City, OK 73120.E-mail:sarahkmiller@juno.com

\section{Traumatic Brain Injury}

\section{F.G. HILLARY, B.B. BISWAL, B. RYPMA, H.M. GENOVA \& J. DELUCA. ALTERATIONS IN BASELINE BLOOD FLOW AND OXYGEN PERFUSION SECONDARY TO TBI AS MEASURED BY BOLD FMRI.}

Functional magnetic resonance imaging (fMRI) allows for the examination of brain function by measuring a combination of several hemodynamic factors including cerebral blood flow, cerebral blood volume, and cerebral oxygen perfusion. Given the individual differences in the cerebrovascular architecture, the fMRI signal intensity is influenced by inherent physiological differences that vary within groups as well as across groups. Separately, research with animals has shown that brain trauma may alter baseline cerebral blood flow both acutely and months after the injury. Recently, fMRI has been employed in studies of cognition in individuals with traumatic brain injury (TBI) and results from these neuroimaging studies have suggested important differences in the activation patterns of healthy adults compared to individuals with TBI These differences in brain activation have been presumed to reflect fundamental differences in the neural networks responsible for cognition in healthy adults and individuals with TBI. However, there remains significant variability in the activation patterns observed within the TBI samples and one source of variability may be linked to baseline changes in the cerebral blood blow and perfusion in the injured brain. The current study examined the baseline differences in blood flow and oxygen perfusion using arterial spin labeling (ASL) during Breath Hold and Finger Tapping challenges in healthy adults and individuals with TBI. Findings reveal significant voxel-wise differences in the baseline hemodynamic response when comparing individuals with TBI to healthy adults. Continued observations of trauma induced alteration of the hemodynamic response will be important to characterize in order to best interpret fMRI data in individuals with TBI.

Correspondence: Frank G. Hillary, Ph.D., KMRREC, 1199 Pleasant ValleyWay, West Orange, NJ 07052. E-mail: fhillary@kmrrec.org

\section{S.D. GALE, L. BAXTER, N. ROUNDY, L. WILDER \& S. JOHNSON. LONGITUDINAL VOXEL-BASED MORPHOMETRY IN TRAUMATIC BRAIN INJURY: CHANGES IN GRAY MATTER CONCENTRATION.}

Previous neuroimaging research has suggested that traumatic brain injury (TBI) can result in diffuse changes in cerebral integrity. In the past, quantitative measures of atrophy have been carried out on regions of interest through manual or semi-automated techniques that were often limited to identifiable structures. A more recent method. voxel-based morphometry (VBM), is a completely automated procedure that examines every voxel to provide whole brain analyses. In this pilot study VBM was utilized to examine changes in gray matter concentration (GMC) over time in 6 male patients with a history of TBI. Average age was 28.2 years $(\mathrm{SD}=9.1$ : range $19-41)$ and admission Glasgow coma score (GCS) was $9.7(\mathrm{SD}=3.2$; range $7-15)$. Time1 MRI was performed at 3 months post-injury ( $\mathrm{SD}=.6$; range $2-4$ ) and Time 2 was at approximately 1 year post-injury (mean $=11.8$ months; $\mathrm{SD}=1.3$; range 10-14). T1-weighted 3D MRI images were obtained on the same $1.5 \mathrm{~T}$ MRI and processed with SPM2 as described by Good et al. (2001). Paired $\mathrm{t}$-tests were carried out to determine if there were reductions in GMC at 
Time 2 compared to Time1. Significant decreases $(p<0.005)$ in GMC over time were found in cerebellar and subcortical regions including the right cerebellum, right thalamus, and putamen bilaterally. Furthermore, subcortical regions with reduced GMC on Time 2 imaging correlated with GCS. Taken together, these findings suggested that subcortical gray matter changes are apparent 1 year post-injury compared to an earlier postacute stage ( 3 months), and that these changes are associated with the injury severity.

Correspondence: Shawn D. Gale, Ph.D., Barrow Neurological Institute, 222 West Thomas Rd. Ste. 315, Phoenix, AZ 85013. E-mail: s2gale@ chw.edu

\section{A. TELLIER, S.C. MARSHALL, K.G. WILSON, A.M. SMITH, B. GARBER, I.G. STIELL, D.A. COYLE \& K. O'ROURKE. MILD TRAUMATIC BRAIN INJURY: THE BIAS OF SAMPLING PROCE- DURES AND FUNCTIONAL INDICES.}

Controversy surrounds the concept of mild traumatic brain injury (TBI). That different sampling procedures and different functional indices (neuroimaging versus neuropsychological measures) have been used likely contribute to the conflicting evidence regarding the morbidity associated with this condition. The present investigation, which took place in the context of a larger prospective study, consists of a one-month follow-up of $141 \mathrm{mTBI}$ patients who visited the Emergency Department of a lead trauma hospital over a 15-month period. Although the majority of participants $(89.4 \%)$ had an initial GCS score of $15,83.9 \%$ sustained some loss of consciousness. Sixty-five percent of the sample $(n=92)$ was sent for CT scanning as per the usual practice of Emergency medicine. Of those, $83.7 \%$ had a negative CT scan, $5.4 \%$ had evidence of non-TBI related findings, and $10.9 \%$ had evidence of trauma-related intracranial abnormalities such as cerebral contusions, cerebral edema, subarachnoid hemorrhage, and subdural and epidural hematomas. This abnormality rate represents a significantly lower figure than those previously reported by our group in the context of a retrospective chart review (31\% of cases; Tellier et al., 1999) or by others in hospitalized samples (21.6\% of cases; Shackford, Wald, Ross et al., 1992). These different figures highlight the disparity of data stemming from various sampling procedures. Furthermore, the finding of cognitive impairment in $37.3 \%$ of participants, as gauged by their performance on a battery of attentional measures, suggests a level of functional impairment that would not be suspected on the basis of the neuroimaging data. That the positive CT and negative CT groups did not differ with respect to their neuropsychological performance reflects the imperfect relationship between neuroimaging and neuropsychological data and the relative insensitivity of CT scanning in the study of mTBI. Correspondence: Andree Tellier, Ph.D., Neuropsychology (Psychology), Ottawa Hospital, Civic Campus, 1063 Carling Avenue CPC 3rd Floor, Ottawa, ON K1Y4E9, Canada.E-mail:Atellier@ottawahospital.on.ca

\section{F.G. HILLARY, B.G. GREENWALD, W.C. LIU, H.M. GENOVA, K. KEPLER \& J. DELUCA. APPLICATION OF PROTON MAG- NETIC RESONANCE SPECTROSCOPY TO ACUTE TBI.}

Individuals with traumatic brain injury (TBI) form a heterogeneous population with distinct, but frequently overlapping, injury types (e.g., diffuse axonal injury, cortical contusions) and varied clinical presentations. Determining acute recovery potential is critical for treating specialists, yet because of the variation in patient recovery course following TBI, proper clinical intervention and is often difficult to determine. Proton magnetic resonance spectroscopy (pMRS) allows for measurement of important neurometabolites such as N-acetylaspartate (NAA), Choline (Cho) and Lactate (Lac) during the acute phases of recovery following TBI. By examining the acute changes in neurometabolism in individuals with TBI, MRS may provide new methods to better characterize the recovery course. Patients with severe TBI (Glasgow Coma Scale score < 8) were assessed using MRS at less than one week post injury and at 3 weeks post injury. The results of these MRS assessments were com- pared to healthy adults of similar age and education. Consistent with prior literature, the ratio of NAA/Cho was reduced in all individuals with TBI compared to healthy adults. In addition, individuals with TBI who experienced elevated intracranial pressure showed significant increases in Lac, which may be indicative of ischemia and hypergylosis in the most severe cases of TBI. Further characterization of the neurometabolic environment in acute TBI using MRS holds the promise of providing clinical researchers with a noninvasive and sensitive instrument to validate the efficacy of acute treatments (e.g., hypothermia, novel pharmacologic interventions) and new strategies in the acute management of TBI.

Correspondence: Frank G. Hillary, Ph.D., KMRREC, 1199 Pleasant ValleyWay,West Orange, NJ 07052. E-mail: fhillary@kmrrec.org

\section{J. WADE, D. DEMATTEO \& R.P. HART. THE SUPREME COURT OF VIRGINIA PROHIBITS NEUROPSYCHOLGISTS FROM DIAG- NOSING MILD TRAUMATIC BRAIN INJURY.}

The case of John v. Im (2002) stands for the proposition that clincial neuropsychologists are not qualified to diagnose traumatic brain injury. This controversial decision, which is in direct conflict with prior Virginia case law, case law from several other states, and Virginia statutory law governing psychologists, will likely have serious implications for the practice of neuropsychology in Virginia. Furthermore, several other states have reached similar conclusions, so that presentation of expert testimony by neuropsychologists is far from uniform. In this paper the authors provide an anaylsis of the neuropsychological testimony at issue in John v. Im using the admissibility standards for expert testimony that were established and refined by a trilogy of cases from the Supreme Court of the United States - Daubert v. Merrell Dow Pharmaceuticals, Inc. (1993), General Electric Co., v. Joiner (1997), and Kuhmo Tire Co., v. Carmichael (1999). The paper provides support for the notion that the neuropsychological method has an established scientific base of knowledge, standards for clincial competence, and evidence of peer-reviewed acceptance by related medical disciplines. No other scientific discipline has developed a more rigorous methodology for assessing cognitive function and disentangling the relative contributions of brain dysfunction and psychological factors to presenting symptomology. By limiting the testimony of neuropsychologists as to cause of an individual's cognitive impairment, courts will exclude opinions based on scientific research and specialized knowledge that would assist the trier of fact. The paper argues that neuropsychology as a scientific discipline meets the admissibility standards put forth in the triology of cases from the Supreme Court of the United States. The paper can be relied upon by neuropsychologists when they are confronted in court by attorneys attempting to restrict their testimony.

Correspondence: Jim Wade, Ph.D., Medical College of Virginia, Box 980402, Richmond,VA 23298-0402.E-mail: jbwade@hsc.vcu.edu

\section{D.A. CARONE, W. BURNS, S. GOLD, W. MITTENBERG \& D. CONDIT. A COMPARISON OF THREE COGNITIVE SCREENING MEASURES IN A TRAUMATIC BRAIN INJURED POPULATION.}

Due to increasing amounts of patients and time limitations facing many neuropsychologists in inpatient medical settings, brief cognitive screening tests have been invaluable tools for quick and efficient assessments. Three commonly used cognitive screening tests used by neuropsychologists are the Mini-Mental State Examination (MMSE; Folstein, Folstein, \& McCugh, 1975), the Cognistat (Northern California Behavioral Group, 1995), and the Repeatable Battery for the Assessment of Neuropsychological Status (RBANS; Randolph, 1998). The present study is the first to examine performance on the MMSE, Cognistat, and the RBANS with three groups of patients $(\mathrm{N}=51)$ that neuropsychologists commonly assess - those with mild, moderate, and severe traumatic brain injury (TBI). Results showed that when the three TBI groups were combined, the Cognistat and RBANS had approximately the same degree of 
high sensitivity ( $90 \%$ and $94 \%$ respectively), which both differed significantly from the low sensitivity of the MMSE (8\%). Similarly, the RBANS and Cognistat were both significantly more sensitive than the MMSE within the three TBI groups, but no significant differences were found between the Cognistat and RBANS. No differences in the sensitivity of the MMSE, Cognistat, or RBANS were found across the three TBI groups. These overall findings generally remained the same when less stringent cutoff criteria were used on the Cognistat and RBANS. Explanations of differential sensitivity and practical applications of the present findings are discussed.

Correspondence: Dominic A. Carone, Ph.D., Neurology, SUNY Buffalo Scool of Medicine, 140 East Amherst Lane, Apt H, East Amherst, NI 14051.E-mail:dcaronejr@aol.com

\section{MCKAY \& J. CASEY. COMPARING WAIS-III PROFILES OF TRAUMATIC BRAIN INJURY AND CHRONIC PAIN.}

Traumatic brain injury (TBI) is a common neuropsychological phenomenon characterized by both behavioural and cognitive sequelae, the most common of which include information processing deficits. To improve its usefulness as a neuropsychological measure, the newest revision of the Wechsler Adult Intelligence Scale, the WAIS-III, developed specific tasks tapping these deficits (e.g., Symbol Search). Despite considerable research examining WAIS performance in TBI sufferers, previous research failed to compare TBI sufferers to other clinical groups with observed processing speed deficits, such as chronic pain sufferers. Previous research has also failed to examine the composition of SS scores (i.e, fast/inaccurate response pattern versus slow/accurate pattern). This study compared the WAIS-III profiles and SS raw scores of both mild and moderate-severe TBI to chronic lower back pain (LBP). Results showed no significant differences between the three groups on WAIS-III IQ or Index scores. Several subtest score differences were observed, but were eliminated when education level was matched. Within-group analyses revealed that both TBI groups displayed significant processing speed deficits in comparison to other Index scores. The LBP group also showed this pattern, but results failed to reach significance. Examination of Symbol Search raw scores revealed no significant group differences. The results of this study provide further support of the PSI's sensitivity to TBI and primary evidence for its sensitivity to LBP.

Correspondence: Cherisse McKay, BSc, Psychology, University of Windsor, 542 Randolph Ave., Windsor, ON N9B 2T6, Canada. E-mail: cherissemckay@hotmail.com

\section{J.E. KEAVENEY, L.M. RYAN, L.M. FRENCH, M.P. KELLY \& D.L. WARDEN. THE WAIS-III MATRIX REASONING TEST (MRT) IN BRAIN INJURY: WHAT DOES IT MEASURE?}

The MRT was added to the WAIS-III as a measure of abstract, fluid reasoning and as such it should be sensitive to brain injury. However, the limited literature available to date suggests that the MRT is not sensitive to brain dysfunction and that it may tap visuospatial abilities, working memory, and abstraction. Given the test's lack of sensitivity to brain injury, its potential as a nonverbal hold test is considered. This study sought to identify what cognitive domains the MRT measures in a head injured population. A sample of 118 mild to moderate traumatic brain injured patients were administered a comprehensive neuropsychological battery including the Tower of London (TOLDX), Wisconsin Card Sorting Test (WCST), Hooper Visual Organization Test (HVOT), Auditory Consonant Trigrams (ACT), North American Adult Reading Test (NAART), and WAIS-III: Similarities, MRT, Letter-Number Sequencing, and Block Design subtests. Factor analysis yielded four factors accounting for $70 \%$ of the variance. MRT loaded on the first factor (33\% variance) with Similarities, HVOT, Block Design, and the NAART. The WCST and TOL were unrelated to MRT, as were measures of working memory. A stepwise multiple regression analysis re- vealed Block Design, NAART, and HVOT scores predicted $51 \%$ of the variance in MRT scores with Block Design alone accounting for $41 \%$ of the variance. The implications of these findings are that the MRT may represent a nonverbal hold test to use in estimations of premorbid nonverbal abilities in a brain injured population.

Correspondence: Julie E. Keaveney, Psy.D., Psychology, Walter Reed Army Medical Center, 6900 Georgia Avenue, Washington, DC 20307. E-mail:docjuls@comcast.net

\section{WRIGHT \& M. SCHMITTER-EDGECOMBE. CONTENT, SOURCE, AND TEMPORAL ORDER MEMORY FOR PERFORMED AND OBSERVED ACTIVITIES FOLLOWING SEVERE CLOSED- HEAD INJURY.}

Multimodal inputs for performed activities have been suggested to improve memory performances in a variety of neurologically impaired populations. In this study, we evaluated the importance of motoric aspects of activity performance on memory for content, source, and temporal order information. Fifteen severe CHI participants (more than one year post injury) and 15 matched controls completed eight activities (e.g., crossword puzzle, letter editing) and observed the experimenter complete another set of eight activities. Each activity was performed for one minute. The order in which the activities were performed by the experimenter and the participants was randomly assigned. To increase incidental encoding of the activities, participants rated how much they would like to perform each activity (performed or observed) in the future. Following completion of the 16 activities, participants completed a free recall test, a recognition test where they also indicated the source of each activity (the participant or the experimenter), and a temporal order reconstruction test. CHI participants recalled and recognized fewer activities than the controls. Also, the controls demonstrated better temporal ordering abilities than the CHI participants. The groups did not differ, however, in source memory. Neither group showed better recall, recognition discriminabilty, or source memory for performed over observed activities. These findings indicate a dissociation between content memory and source memory in a CHI population. Furthermore, motoric aspects of activity performance did not improve memory. Correspondence: Matthew Wright, Psychology, Washington State University, $225 \mathrm{NW}$ Terre View \#7, Pullman, WA 99163. E-mail: matthewjustinwright@hotmail.com

\section{J. ROYAN, R.E. GRAVES \& E. STROOP. A CASE FOR DISSOCI- ATING 'WHAT' FROM 'WHERE' IN PERCEPTION AND MENTAL IMAGERY.}

Experimental lesion studies with primates have shown that visual pattern discrimination and visual spatial locating abilities rely on two separate 'what' and 'where' neural pathways. Several lines of human research have also provided evidence for the dissociation of visual and spatial processing. Group studies in cognitive psychology and neuroimaging provide evidence of a double dissociation of visual from spatial processing in working memory. A few neuropsychological case studies have also shown a dissociation of visual from spatial perception and/or imagery. This report describes a 42 year old, female patient who had experienced two early incidences of head injury and had reported a lifelong history of way-finding and other spatial imagery difficulties. Neuropsychological assessment results revealed that the patient had impaired spatial processing abilities but spared visual processing abilities. This case, when paired with another well-known case from the literature with the converse spared and impaired abilities, demonstrates a double dissociation of visual from spatial perception and imagery. In addition to the theoretical implications, these findings emphasize the importance of careful measurement of visual vs. spatial perception and mental manipulation in individual patients for assessment purposes. Correspondence: Jodie Royan, University of Victoria, 5-1615 Belmont ave, Victoria, BCV8R3Y9, Canada.E-mail:royanj@uvic.ca 


\section{P.A. TAYLOR-COOKE, G.D. FISK \& M.S. MENNEMEIER. BLINKING MAY COMPENSATE FOR CHANGES IN SUSTAINED VISUAL ATTENTION DUE TO AGE AND BRAIN INJURY.}

Troxler fading is a form of sustained visual attention. Stationary objects in peripheral vision fade from awareness during sustained fixation, while moving objects do not. Fading time is negatively correlated with distance from fixation; however, young normal subjects (20-30 years) also show fading asymmetries. Object fading is faster on vertical than horizontal meridia. Brain injury alters Troxler fading. Early studies showed that focal parietal lobe damage accelerates fading in the contralateral visual half-field and that frontal lobe damage inhibits fading; however, age may confound these findings because patients were much older than normal subjects. In this study, older control subjects $(n=11$, range $=43$ to $81, M=61)$ were compared to patients with focal brain injury $(\mathrm{n}=26$, range $=30$ to $81, \mathrm{M}=54)$. Indeed, half $(45 \%)$ of the older normal subjects failed to demonstrate Troxler fading and fade times increased with age in those who did, F $(3,2)=159.4, p<.01$. In contrast to young normal subjects, fade times were slower on the vertical $(M=16.32$, S.D. $=7.73)$ than horizontal $(\mathrm{M}=12.25$, S.D. $=5.93)$ meridia, $\mathrm{F}(1,5)=6.96, \mathrm{p}<.05$. Brain injury was associated with accelerated fading in $61 \%$ of individuals regardless of frontal versus parietal lobe involvement with $33 \%$ demonstrating fading of moving objects. Blinking was positively correlated with fade time $(\mathrm{r}=0.426, \mathrm{p}<.001)$ suggesting that patients may blink to help sustain attention. In fact, older subjects who failed to demonstrate Troxler fading blinked four times as much as those who demonstrated fading, suggesting that they too may blink to sustain visual attention.

Correspondence: Patricia A. Taylor-Cooke, B.S., Department of Psychology, University of Alabama at Birmingham, 2008 3rd Ave. N., Apt. 7C, Birmingham, AL 35203.E-mail: pataylor@uab.edu

\section{J. BURHART, K. DONNELLY, J. DONNELLY, J. KLEINER, B. HOFFMAN \& M. MORDHORST. THE EFFECTS OF TRAU- MATIC BRAIN INJURY ON VERBAL AND VISUAL MEMORY IN A VETERAN SAMPLE.}

Cognitive deficits following traumatic brain injury (TBI) may be most prominent in the memory domain (Makatura, Lam, Leahy, Castillo, \& Kalpakjian, 1999). However, clarification of specific aspects and degree of memory impacted by brain injury is needed at both scientific and clinical levels. The present study compared three tests of verbal and visual memory performance in a sample of veterans $(\mathrm{N}=130)$ with $(\mathrm{n}=88)$ and without $(\mathrm{n}=42)$ a history of cerebral trauma. The sample was primarily male $(93.1 \%)$, Caucasian $(85.8 \%)$ and right-handed $(90.3 \%)$. The assessment battery included the Hopkins Verbal Learning Test- Revised (HVLT), a modified version of Logical Memory I and II from the WMS-III, and three visual memory indices based on a moderately complex, ambiguous figure (incidental recall, learning with additional exposure, and delayed recall). The groups differed significantly on the HVLT delayed recall trial, with the brain injured group recalling an average of 3.08 fewer words $(t=3.58, p=.001)$. The TBI group performed significantly worse than the comparison group on the learning $(t=7.20$, $\mathrm{p}=.001)$ and delayed recall $(\mathrm{t}=8.33, \mathrm{p}<.001)$ trials of the logical memory test. The TBI group also demonstrated significantly worse performance than the comparison group in incidental recall $(t=3.59$. $\mathrm{p}<.001$ ), learning trials (trial 1: $\mathrm{U}=952.00, \mathrm{p}<.001$; trial 2: $\mathrm{U}=443.00$, $\mathrm{p}<.001)$, and delayed recall $(\mathrm{U}=761.00, \mathrm{p}<.001)$ on the visual reproduction test. These findings highlight the broad nature of memory impairment following traumatic brain injury and suggest potential difficulties for rehabilitation. Implications for treatment and future research are highlighted.

Correspondence: Kerry Donnelly, Ph.D., VA WNY Healthcare System, 3495 Bailey Ave., 116B, Buffalo, NY 14215. E-mail: kerry.donnelly@ med.va.gov

\section{M.R. KENNEDY. METAMEMORY RECALL PREDICTIONS OF NARRATIVE TEXT AFTER TRAUMATIC BRAIN INJURY.}

Rationale and Methodology Predicting what you will or will not recall during learning is critical to self-regulation and sometimes impaired after traumatic brain injury (TBI). Reduced predictive accuracy could result in decisions based on erroneous self-feedback. Adults with TBI (and matched controls) are more accurate when predictions are delayed rather than immediately after studying word-pairs, even though adults with frontal injuries are less accurate than adults without frontal injuries. There is little evidence that predictive accuracy generalizes from word-pairs to text. Kennedy \& Nawrocki (2003) compared the predictive accuracy of adults with mild, moderate and severe TBI to controls using narrative text. Participants made delayed question-by-question recall predictions that varied in salience (main ideas, details) and explicitness (stated, implied). Although recall differed by groups, no differences were found in predictive accuracy. Additionally, both groups were more accurate predicting recall of stated than implied information. In the current study all TBI adults had severe injuries and immediate and delayed recall predictions were made. The research question was: Will adults with severe TBI and controls predict recall of narrative information that varies by salience and explicitness similarly when predictions are immediate and delayed? Twenty adults with severe TBI and controls listened to narratives, making immediate and delayed predictions. Results " TBI adults recalled less and were less accurate at predicting recall than controls. "No 'delayed prediction effect' was found. "Predictive accuracy was higher for stated information than for implied. These findings expand upon earlier ones. Clinical implications will be highlighted.

Correspondence: Mary R. Kennedy, Ph.D., Communication Disorders, University of Minnesota, 115 Shevlin Hall, 165 Pillsbury Dr. SE, Minneapolis, MN 55455.E-mail:kenne047@umn.edu

\section{H.M. NISSLEY \& M. SCHMITTER-EDGECOMBE. THE EFFECTS OF DIVIDED ATTENTION ON ENCODING AND RETRIEVAL IN SEVERE CLOSED HEAD INJURY PATIENTS.}

This study examined the effects of attentional control on encoding and retrieval processes in a severe closed head injured (CHI) population. Using a divided attention (DA) paradigm, 16 severe CHI participants (> 1 year post-injury) and 16 matched controls performed a verbal pairedassociates memory task under a full attention condition and while simultaneously completing a continuous reaction time task at encoding in one condition and retrieval in another. CHI patients correctly recalled fewer word pairs and had slower reaction times than controls across all three conditions. Despite the overall poorer performance of the CHI participants, both groups exhibited a similar pattern of performance. DA during encoding resulted in a disruption of memory performance, whereas DA during retrieval had little effect on recall. Secondary task performance, however, was significantly impaired under DA conditions, with DA during retrieval producing larger secondary reaction time task cost than DA during encoding. Response costs were further disproportionately reduced in the $\mathrm{CHI}$ participants relative to controls. These results are consistent with the hypothesis that there are different attentional demands at encoding and retrieval. Whereas encoding is a controlled and attention demanding process, retrieval appears more elementary and relatively protected. However, the significant secondary reaction time costs, indicate that substantial attentional resources are necessary in order to preserve retrieval processes. For CHI survivors, this protection may come at an even greater cost or effort than for controls, as RT performances for the CHI participants were disproportionately affected at retrieval, but not encoding, when attention was divided. Correspondence: Heather M. Nissley, M.S., Psychology, Washington State University, 1506 Summerchase Dr., Hoover, AL 35244. E-mail: hmnissley@prodigy:net 


\section{C.A. COELHO \& K.M. YOUSE. CONVERSATIONAL ABILITIES AND EXECUTIVE FUNCTIONS FOLLOWING CLOSED HEAD INJURY}

Effective participation in a conversation is dependent on a variety of factors such as: topic maintenance, turn taking, appropriate referencing, sensitivity to the conversational partner, and general cognitive abilities such as attention and memory. Social cognition (i.e., social: perception, knowledge, and decision making) will also have important influences on conversational skill. Social competence requires the ability to apply social skills flexibly in accordance with the rules of an interaction. The present study investigated the relationship between conversational proficiency and a measure of executive functioning in adults with closed head injuries (CHI). Conversational samples were elicited from 32 adults (mean age $=31.7$ years) with $\mathrm{CHI}$ and analyzed in terms of response appropriateness and topic management. These measures were then correlated with their scores from the Wisconsin Card Sort Test (WCST). Results revealed a number of significant correlations with large relational effect sizes $(\mathrm{r}>.50)$. Findings support the notion that the inability to flexibly apply behavior according to rules, which entails executive functioning, may account for conversational difficulty following CHI (Godfrey \& Shum, 2000).

Correspondence: Kathleen M. Youse, M.A., Department of Communication Sciences, University of Connecticut, 850 Bolton Road, Unit 1085, Storrs, CT 06269.E-mail: kyouse@prodigy.net

\section{V.W. MARK, A.J. WOODS \& M. MENNEMEIER. CANCELLATION TARGET MARKING PROCEDURE AFFECTS PERSEVERATION BUT NOT NEGLECT FOLLOWING BRAIN INJURY.}

Although the cancellation test has long been used to assess spatial neglect following brain injury, it is unknown whether the specific method of target marking (i.e., crossing out vs. circling) affects results. Furthermore, case reports have generally shown perseveration more often when crossing out targets than when circling them, but studies have not compared the two approaches within subjects. We prospectively evaluated 29 adults with various acute brain injuries on two cancellation formats (line, star) when they either crossed out or circled targets, using black ink. Test formats and marking procedures were counterbalanced within subjects, who marked up to 8 cancellation pages each. Two raters subsequently scored cancellation pages independently with high inter-rater reliability. Raters were blind to subject identities and averaged scores were used for analysis. Results indicated that although the patients showed neglect on both test formats (mean lines omitted $>5$, mean stars omitted $>9$ ), the particular marking procedure did not alter neglect $(p$ 's $>0.3)$. In contrast, perseverations were significantly greater when crossing out stars than when circling them (mean perseverations crossing out $=4.4$, circling $=1.0 ; p=.009)$, and tended to increase when crossing out lines than when circling them (mean perseverations crossing out $=4.8$, circling $=0.2 ; p=.08)$. These findings suggest that crossing out targets is more likely to elicit perseveration than when circling them. The reasons for this difference are unclear but may relate to discriminability of markings and that circling limits the space available for repetitious marking.

Correspondence: Victor W. Mark, M.D., Physical Medicine and Rehabilitation, University of Alabama at Birmingham, 619 19th Street South, SRC 190, Birmingham, AL 35249-7330.E-mail:vwmark@uab.edu

\section{M.A. COLE, J.A. DEMERY, M.J. LARSON, P.J. SEIGNOUREL \& W.M. PERLSTEIN. COMMUNALITY ANALYSIS AND CLASSIFI- CATION OF TBI GROUP MEMBERSHIP AND SEVERITY BASED ON ASSESSMENT OF WORKING MEMORY/EXECUTIVE FUNC- TION WITH THE N-BACK AND PASAT TASKS.}

Few studies have explicitly examined working memory (WM) function in TBI patients, and none to date have parametrically manipulated WM load across a range of difficulties and a range of TBI severity. The present study uses a task borrowed from the cognitive neuroscience tradition called the "n-back", which parametrically manipulates WM load, to evaluate WM deficits in predominantly chronic patients with mild $(n=16)$, moderate $(n=8)$ and severe $(n=18)$ TBI and healthy controls $(n=26)$. Additionally, we compared the ability of the n-back to predict presence/severity of TBI to the Paced Auditory Serial Addition Task (PASAT). Results from the n-back revealed significantly more errors at higher load levels in TBI patients compared to controls $(p<.001)$. Results from the PASAT yielded significant main effects of severity $(p<.0002)$ and trial $(p<.0001)$, but no significant interaction. A communality analysis was performed in latent space to determine the predictive variance in TBI presence/severity that was unique to, and shared among, the PASAT and n-back. Variance shared by the n-back and PASAT when predicting TBI was $16 \%$ (total variance $=31 \%$ ). The PASAT uniquely explained $3 \%$ of the variance, whereas the n-back uniquely explained $12 \%$ of the variance. While both tasks revealed significant WM/executive function deficits in TBI patients, the n-back demonstrated greater predictive power for these deficits and revealed increasing levels of WM impairment with incremental increases in WM load.

Correspondence: Michael A. Cole, Masters, Clinical and Health Psychology, University of Florida, Health Science Center, PO Box 100165, Gainesville, FL 32610-0165. E-mail: mcole@hp.ufl.edu

\section{ZIINO \& J. PONSFORD. FATIGUE AND ATTENTION FOLLOW- ING TRAUMATIC BRAIN INJURY.}

Introduction: Despite the fact that more than sixty percent of patients with traumatic brain injury (TBI) report experiencing fatigue which interferes with their rehabilitation and daily lifestyle, little research has investigated its nature, causes or progression. This paper will explore the concept of fatigue, its measurement and relationship with attention. Preliminary results of a study will be presented which had three aims: (a) to identify a scale which is a valid and reliable measure of fatigue in this population; (b) to investigate the hypothesized association between speed of information processing, vigilance and fatigue following TBI; and (c) to investigate the association of fatigue with demographic factors, injury severity, depression and anxiety. Method: A group of 34 TBI participants and demographically matched controls have completed the Fatigue Severity Scale, the Visual Analogue Scale for Fatigue, the Hospital Anxiety and Depression Scales, the NART, the Symbol Digit Modalities test, the Telephone Search and Telephone Search while Counting tasks, and computerized selective attention and vigilance tasks. Results: Results indicate significant fatigue levels evident on the Fatigue Severity Scale, significant impairments of speed of information processing, and greater variability in reaction times in TBI participants relative to controls. TBI participants with higher fatigue levels exhibited slower and more variable reaction times. Depression also contributed to reported fatigue, but these cases did not show slowed information processing. Discussion: Although mental slowing is associated with greater fatigue, it would appear that fatigue may have multiple causes, which need to be carefully investigated.

Correspondence: Carlo Ziino, Psychology, Monash University, 1 Ivan St, Doncaster,VIC3108, Australia.E-mail: carlo.ziino@med.monash.edu.au

\section{S. DIKMEN, C. BOMBARDIER, J. MACHAMER, J. FANN \& N. TEMKIN. NATURAL HISTORY OF DEPRESSION IN TRAU- MATIC BRAIN INJURY.}

Depression can significantly add to the suffering and functional impairment of persons with traumatic brain injury. However, the existing literature has yielded inconsistent information regarding the magnitude of the problem and risk factors for depression. Better understanding of this problem should help in prevention and treatment of depression OBJECTIVE: Prospectively examine the rates, risk factors, and phenomenology of depression over 3 to 5 years after TBI DESIGN: Inception cohort longitudinal study with subjects examined at 1, 6, and 12 months and 3 to 5 years after injury SETTING: Level 1 trauma center Patients: 283 consecutive admissions of adults with moderate to severe TBI INTERVENTIONS: N/A MAIN OUTCOME MEASURE: The 
Center for Epidemiologic Studies-Depression (CES-D) scale. RESULTS: The rates of moderate to severe depressive symptoms ranged from $31 \%$ at 1 month to $17 \%$ at 3 to 5 years. With one exception, the relationship between brain injury severity and depression was negligible. Less than high school education, pre-injury unstable work history and alcohol abuse predicted depression after injury. Examination of CES-D factors indicate that, in addition to somatic symptoms, both depressed affect and lack of positive affect contribute to elevated CES-D scores CONCLUSIONS: High rates of depressive symptoms cannot be dismissed on grounds that brain injury related somatic symptoms are mistaken for depression. Depressed affect and lack of positive affect are also elevated in persons with TBI. Pre-injury psychosocial factors are predictive of depression and should facilitate efforts to detect, prevent and treat depression after TBI.

Correspondence: Sureyya Dikmen, PhD, Rehabilitation Medicine, University of Washington, Box356490, Seattle,WA 98195.E-mail:dikmen@ u.washington.edu

\section{J. SUHR \& J. GUNSTAD. DO ANXIETY, EFFORT, OR DEPRES- SION EXPLAIN THE “DIAGNOSIS THREAT” EFFECT?}

Recently Suhr and Gunstad (2003) demonstrated that negative expectations about one's neurological status lead to poorer cognitive performance, an effect they termed "diagnosis threat." They speculated the effect could be related to increased anxiety or decreased effort. They further suggested individuals with high depression, who may have more negative preexisting expectations, would be more affected by such expectations than individuals with lower depression. In a replication and extension study, individuals with a history of mild head injury were randomly assigned to receive either neutral instructions prior to completing a neuropsychological battery (controls, $n=25$ ) or to have their attention called to their head injury history as a reason for being invited into the study (diagnosis threat group, $n=28$ ). Baseline measures of depression (BDI) were taken. Effort measures (Word Memory Test) and post-test anxiety (STAI) were included. The diagnosis threat group performed worse than controls on attention, psychomotor speed, and some memory tasks, but not on measures of executive functioning, post-test anxiety, or effort measures. Significantly more individuals in the diagnosis threat group $(46 \%)$ performed at least $1.5 \mathrm{SD}$ below the mean for their age on at least one neuropsychological test (versus $12 \%$ of controls). Effort and anxiety were not related to cognitive test performance for either group. Baseline depression was not related to test performance, nor did depression interact with expectations in explaining group differences in cognitive performance. Results provide further support for the "diagnosis threat" effect, but offer no support for effort, anxiety, or depression explanations for diminished performance.

Correspondence: Julie Suhr, Ph.D., Psychology, Ohio University, 200 Porter Hall, Athens, OH 45701.E-mail:suhr@ohio.edu

\section{S.T. GONTKOVSKY, N.B. MCDONALD, W.D. RUWE \& C.D. SPIELBERGER. STATE-TRAIT PERSONALITY CHARACTER- ISTICS FOLLOWING TRAUMATIC CLOSED HEAD INJURY.}

Personality change has long been documented as a common occurrence following acquired brain injury (ABI). Although certain behavioral changes may be anticipated based on anatomical location(s) of the le$\operatorname{sion}(\mathrm{s})$, such patterns often are unpredictable when associated with diffuse or multi-focal damage. In conjunction with the direct consequences of brain injury, the role of environmental factors also must be considered because many disturbances of post-morbid personality appear to be not so much a product of the injury itself as a secondary reaction to functional impairment and loss (Lezak, 1995). Indeed, personality changes following ABI commonly reflect complex interactions involving neurological dysfunction, present social demands, and previously established behavior patterns (Gainotti, 1993). This investigation examined the personality patterns, as measured by the State-Trait Personality Inventory (STPI; Spielberger, 1995), of 40 patients referred for outpatient neuropsychological evaluation following traumatic closed head injury (TCHI). Analyses revealed significant negative associations between severity of injury and scores on the STPI state and trait anxiety and depression scales. A significant positive association was found between time since injury and scores on the state curiosity scale. Males with TCHI had significantly higher scores on the STPI state depression scale and significantly lower state and trait curiosity scores, as compared with the STPI norms for working adults. Females with TCHI had significantly lower state anxiety and anger scores and lower trait anger and depression scores. These results are consistent with previous findings, indicating that personality change follows TCHI and demonstrate the sensitivity of the STPI in assessing these changes.

Correspondence: Samuel T. Gontkovsky, Psy.D., Neuropsychology, Methodist Rehabilitation Center, 22 Charleston Circle, Brandon, MS 39047.E-mail:stg@mmrcrehab.org

\section{S. MCDONALD \& S. FLANAGAN. PREDICTING DEFICITS IN SO- CIAL BEHAVIOUR AFTER TRAUMATIC BRAIN INJURY USING THE AWARENESS OF SOCIAL INFERENCE TEST (TASIT).}

There is a general lack of tests for assessing deficits in social perception, i.e. the ability to interpret social signals. The Awareness of Social Inference Test (TASIT) is one such instrument that uses videoed vignettes in 3 parts to assess (a) emotion recognition, (b) the ability to understand when a conversational inference such as sarcasm is being made (c) the ability to differentiate between different kinds of literally untrue comments (lies and sarcasm). This study reports on the validity of this instrument for predicting real-life difficulties with social encounters as experienced by adults with traumatic brain injuries (TBI). Twenty-one adults with chronic TBI were assessed (1) using TASIT and (2) for their social behaviour in a spontaneous encounter with a confederate of the opposite sex. The encounter was videotaped and later rated by independent raters using the Behavioural Referenced Rating System of Intermediate Social Skills Revised (BRISSR). A group of 21 normal adults matched for age and education were also tested on TASIT. The TBI group performed more poorly on TASIT than their non-brain-damaged peers indicating that they were having difficulties with social perception as measured by this instrument. In addition, there was a significant association between TASIT and BRISSR scores, especially those reflecting the ability to use humour appropriately and to focus upon the conversational partner's social needs. In conclusion it appears that TASIT is an instrument that is sensitive to real-world difficulties in managing social encounters.

Correspondence: Skye McDonald, PhD, School of Psychology, University of NSW, UNSW, Sydney, NSW 2052, Australia.E-mail:s.mcdonald@ unsw.edu.au

M.D. HORNER, P.L. FERGUSON, A. SELASSIE, L.A. LABBATE, K. TWEEDY \& J.D. CORRIGAN. PATTERNS OF ALCOHOL USE ONE YEAR AFTER TRAUMATIC BRAIN INJURY: A POPULATIONBASED, EPIDEMIOLOGICAL STUDY.

Previous studies of alcohol use in individuals with traumatic brain injury (TBI) have examined clinical samples, such as patients from rehabilitation programs. This study examined patterns of alcohol use one year after TBI in a population-based (non-clinical) sample. Participants were 1658 adults identified by review of a South Carolina statewide hospital discharge data set, on the basis of satisfying the CDC case definition of TBI, and were interviewed by telephone one year after their TBI-related discharge. Alcohol use in the month prior to interview was classified according to categories from the Quantity-Frequency-Variability Index. Heavy drinking (nearly daily with $>=5$ drinks at least occasionally, or at least weekly with $>=5$ drinks on most drinking occasions) was reported by $14 \%$ of participants, while $16 \%$ reported moderate drinking, $18 \%$ reported light drinking, and $52 \%$ reported infrequent drinking or abstinence. Only $6 \%$ reported drinking more in the 
month prior to interview than in the month before TBI, while $58 \%$ reported drinking the same amount as before TBI, and 36\% reported drinking less. A polychotomous logistic regression with 3 response levels (heavy, moderate, and abstinent/infrequent/light drinking) revealed that significant $(p<.05)$ predictors of heavy drinking were pre-TBI substance abuse treatment (odds ratio $[\mathrm{OR}]=2.03$ ), post-TBI diagnosis of depression $(\mathrm{OR}=1.96)$, male gender $(\mathrm{OR}=5.29)$, marital status of single $(\mathrm{OR}=1.83)$ or separated/divorced $(\mathrm{OR}=1.80)$, and better physical functioning as measured by $\mathrm{SF}-36(\mathrm{OR}=2.58)$. These results are largely consistent with those of previous studies of clinical samples, and support their generalizability.

Correspondence: Michael D. Horner, Ph.D., Psychiatry, Ralph H. Johnson VA Medical Center / Medical University of South Carolina, Mental Health Service (116), VAMC, 109 Bee St., Charleston, SC 29401. Email:hornermd@musc.edu

\section{J.A. TESTA, J.F. MALEC, A.M. MOESSNER \& A.W. BROWN. FAMILY FUNCTIONING IN PATIENTS WITH MILD OR MODER- ATE/SEVERE TBI IN COMPARISON TO AN ORTHOPEDIC IN- JURY GROUP.}

Objective: To identify differences in family functioning in patients hospitalized for mild TBI, moderate/severe TBI, or orthopedic injuries (OI). Participants: 44 OI patients, 47 mild TBI patients, and 75 moderate/severe TBI patients at discharge; 36 OI patients, 33 mild TBI patients, and 60 moderate/severe TBI patients at 1 year follow-up. Measures: Measures of family functioning (FAD), disability (DRS), and adaptability (MPAI) at hospital discharge and 1-Year follow-up. Results: Overall, family functioning variables were within normal limits for all three groups at discharge and 1-Year follow-up. Approximately 1/3 of each group were in the unhealthy range at discharge and Year 1 , which is comparable to reported pre-injury levels in TBI patients (Sander et al. 2003), but lower than post-TBI rates (Kreutzer et al. 1994). Distressed family functioning correlated with higher levels of disability and poorer adaptability in patients with moderate/severe TBI. Conclusions: In the majority of patients hospitalized for TBI or OI, family functioning was within normal limits at discharge and subsequent follow-up. While most families were in the healthy range of family functioning, there was a substantial minority of families who experience high levels of distress. Severity of disability appeared to contribute to this distress in the moderate/severe TBI group. However, increased distress was also present in less severely injured groups (mild TBI, OI), suggesting that family distress cannot be entirely attributed to the impact of injury. Patients and their families with unhealthy family functioning may require additional support and education following a significant physical injury, regardless of injury type.

Correspondence: Julie A. Testa, Ph.D., Psychiatry and Psychology, Mayo, 200 1st Street SW, GE 3-140,Rochester,MN55905.E-mail:testa.julie@ mayo.edu

\section{D.J. SCHRETLEN \& A.M. SHAPIRO. USE OF META-ANALYSIS TO ESTIMATE COGNITIVE DOMAIN-SPECIFIC RECOVERY FOL- LOWING TBI.}

Few researchers can follow traumatically brain injured (TBI) patients long enough to adequately characterize the course of their cognitive recovery. However, meta-analysis of cross-sectional studies conducted at different follow-up intervals can provide indirect evidence concerning rates of recovery from TBI. In a previous meta-analysis (Schretlen \& Shapiro, 2003), we found that recovery of overall cognitive functioning proceeded at different rates for individuals with mild head injury (MHI) vs. moderate-severe TBI. This paper presents a finer-grained analysis of specific cognitive outcomes following MHI and moderate-severe TBI. We conducted a meta-analysis of 34 mostly cross-sectional studies of the cognitive effects of MHI and moderate-severe TBI. These reported 405 comparisons of patients $(n=1801)$ and control subjects $(n=1110)$ on neuropsychological tests that we grouped by cognitive domain. Among studies of MHI, large effect sizes emerged for comparisons involving learning/memory and reaction time (Cohen's $d s=-.87$ and - .66 , respectively) conducted during the first 6 days post-injury. However, by 7-29 days post-injury, there were no differential effect of MHI on specific cognitive functions, and by 30-89 days, none of the effect sizes differed significantly from zero. In contrast, among patients with moderate-severe TBI, large effect sizes were observed in all cognitive domains during the first 6 months post-injury $(d s=-1.57$ to -.57 ). Dramatic improvements were observed for comparisons involving language, spatial processing, and psychomotor speed, although impairments persisted more than 2 years post-injury in nearly every cognitive domain. The clinical implications of these findings and suggestions for future research are discussed.

Correspondence: David J. Schretlen, Ph.D., Department of Psychiatry, Johns Hopkins University, 600 N. Wolfe Street, Meyer 218, Baltimore, MD 21287-7218.E-mail:dschret@jhmi.edu

\section{S. WARSCHAUSKY, J. DONDERS \& N. KIRSCH. SOCIAL PROB- LEM SOLVING AND SOCIAL INTEGRATION FOLLOWING TRAU- MATIC HEAD INJURY IN YOUNG ADULTS.}

This study examined assertive social problem solving (SPS) as a predictor of social integration after traumatic head injury (THI). The sample was comprised of forty-five participants, ages $17-23,53.3 \%$ male, a minimum of one year post-THI sustained after age $15,54.1 \%$ severe, length of coma $\mathrm{M}=9.54, \mathrm{SD}=19.61$ days. Social problem solving was assessed with the Response Generation Task (Sayers et al., 1995). Interrater reliability was established using two independent blinded raters, with $>90 \%$ agreement across categories. Neuropsychological measures included the Peabody Picture Vocabulary Test III, Trail Making Test Form B, Benton Visual Retention Test, Buschke Selective Reminding Task, Grooved Pegboard and the Dysexecutive Questionnaire (DEX) completed by subject and parent. Social integration was assessed with the Community Integration Questionnaire (CIQ). Hierarchical multiple regression analyses were used to evaluate the influence of injury severity, neuropsychological status and social problem-solving on self-perceptions of social integration. Severity of injury was not a significant predictor of assertive SPS or social integration. SPS variables were not significant predictors of social integration. Among neuropsychological variables, only self-DEX rating was a significant predictor of social integration. Assertiveness, as assessed with response generation tasks, does not appear to predict global social integration outcome. Traditional neuropsychological tests are sensitive to injury severity but do not predict social integration well; self-ratings of real-life executive skills can provide important incremental information in this regard.

Correspondence: Seth Warschausky, PhD, physical medicine and rehabilitation, university of michigan, Dept PM\&R, Box 0718, University of Michigan, Ann Arbor, MI 48109-0718. E-mail: sethaw@umich.edu

\section{T. HART, M. VACCARO, R. BUCHHOFER \& J. WHYTE. COMPUTER TECHNOLOGIES IN BRAIN INJURY REHABILITA- TION: CONSUMER PERSPECTIVES.}

Advances in computer technology offer applications to brain injury rehabilitation, including the use of portable computers as cognitive orthoses, and use of the Internet to reduce social isolation. As part of a research program investigating the utility of emerging computer technologies in rehabilitation, 80 persons with moderate to severe, chronic traumatic brain injury (TBI) were recruited from the community and outpatient/ residential treatment programs and given in-depth structured interviews to examine consumer experiences, attitudes and preferences regarding these technologies. The sample ranged in age from 17 to 71 , was $3 / 4$ male, and included 1/3 minority participants. Results indicated an overall high interest in learning and applying computer technologies in daily life. The proportion of participants expressing interest in learning to use portable electronics as reminding technologies was considerably higher than those expressing a need for 
reminders to accomplish everyday tasks. High levels of both need and interest were reported for keeping track of money, remembering things people tell you, and remembering things you need to do. Participants expressed a desire for devices that are simple to learn and have good technical support. Nearly half of the sample reported never using the Internet, supporting the concept of a digital divide affecting persons with disabilities. Participants expressed strong interest in learning more about brain injury information and communcation resources on the Internet and gaining improved access. Persons with significant brain injury thus appear receptive to computer technologies both as compensatory aids and as a means of staying connected with society, but may need structured training experiences to fully benefit.

Correspondence: Tessa Hart, PhD, Moss Rehabilitation Research Institute, 1200 W. Tabor Rd., Philadelphia, PA 19141.E-mail: thart@ einstein.edu

\section{R.A. LILLIE, D. LINDSAY \& C.A. MATEER. APPLICATION OF A NEW MEMORY-TRAINING PARADIGM TO INDIVIDUALS WITH TRAUMATIC BRAIN INJURY.}

Memory complaints are a common occurrence following traumatic brain injury (TBI) and can lead to profound difficulties in everyday life. Though compensatory mechanisms have shown considerable utility, efforts to improve memory per se have met with less success. A new training program created by Jennings and Jacoby (2001) has been shown to be effective at improving memory performance in a group of aging adults. This training program is grounded in a theoretical framework that conceptualizes memory as two independent processes: one related to conscious recollection and the other related to more implicit feelings of familiarity. To successfully complete the training program participants must suppress feelings of familiarity and rely on conscious recollection, a task generally difficult for individuals with TBI. As part of the current project, participants with a history of TBI and memory difficulties completed 7 days of memory training. At each visit, they were presented with a list of words to remember followed by a recognition test. Within the recognition test, some items were repeated. Participants were correctly told that if a word was repeated, then it was not on the learned list. In this way, feelings of familiarity are placed in opposition to conscious recollection. A spaced-retrieval approach was used in that the interval between repetition was slowly increased over time. Training was found to be effective; those individuals showing impaired performance at the first session were able to improve over time. Generalizability issues and implications for functional memory change will be discussed. Correspondence: Rema A. Lillie, BA, Psychology, University of Victoria, Psychology, University of Victoria, PO Box 3050 STN CSC, Victoria, BC V8W3P5, Canada.E-mail: rlillie@uvic.ca

\section{F. CONSTANTINIDOU. THE EFFECTS OF SYSTEMATIC CATEGO- RIZATION TRAINING IN POST ACUTE BRAIN INJURY REHABILI- TATION: PRELIMINARY FINDINGS.}

This study provides preliminary support on the effectiveness of a systematic categorization training program $(\mathrm{CP})$ in patients with moderate-severe traumatic brain injury (TBI) who were enrolled in post-acute rehabilitation. Following neuropsychological testing, 13 subjects received the CP training for 3-5 hours per week for 10-12 weeks. The CP training consisted of 8 levels and targeted concept formation, object categorization, and decision making abilities. The Mayo-Portland Adaptability Inventory-3 (MPAI-3) and the Community Integration Questionnaire (CIQ) were the two functional outcome measures administered before and after the CP training. Two categorization tests (administered before and after the CP training) and 3 probe tasks (administered at specified intervals during the CP training) were constructed to assess skills relating to categorization. T-tests revealed significant decrease in (MPAI3) scores suggestive of increased independence in Physical/Cognition, $p=.003$, Pain/Emotion, $p=.001$, Social Participation, $p=.0001$, and overall Total Performance, $p=.0001$. Significant improvement in the
(CIQ) total score, $\mathrm{p}=.023$ indicates improved social integration. Subjects improved significantly between their pre/post performance on the 2 categorization tests, $p=.017$, and $p=.035$, suggesting improvement in the categorization of basic objects and new situations that require rule-based learning. Based on the ANOVA, performance on the 3 probe tasks improved significantly accross time $p=.029$, indicating improvement in the ability to apply categorization and sorting skills into new situations. These findings suggest that subjects who received the $\mathrm{CP}$ and were enrolled in post-acute rehabilitation demonstrated significant improvement on functional outcome measures and on categorization abilities.

Correspondence: Fofi Constantinidou, Ph.D., Speech Pathology \& Audiology, Miami University, 2 Bachelor Hall, Oxford, OH 45056. E-mail: constaf@muohio.edu

\section{S.T. GONTKOVSKY, M. SHERER, S. WILLIAMS, R. NAKASE THOMPSON, A. SANDER \& W.M. HIGH. TBI OUTCOMES AS A FUNCTION OF DISTANCE FROM OUTPATIENT TREATMENT SERVICES.}

Research has indicated geographic location to be a significant predictor of various outcome measures for individuals following traumatic brain injury (TBI). For example, Farmer, Clark, and Sherman (2003) demonstrated increased openness to seeking social support and better quality of life following TBI for individuals residing in a rural location relative to those residing in an urban area. This investigation examined the relationship between distance from outpatient services and outcomes for individuals with TBI at one month post-discharge from inpatient rehabilitation. Participants were 187 consecutive admissions to two TBI Model Systems rehabilitation centers. Primary outcomes included compliance with prescription medications and frequency of headaches, seizures, falls, and rehospitalizations according to best source reports. Of 106 patients known to have been prescribed outpatient treatment, only $15 \%$ reported less than $100 \%$ compliance with medications. The majority $(69 \%)$ of the sample indicated no occurrence of headaches, with the remaining $31 \%$ reporting variability of occurrence ranging from more than one headache per day to more than one headache during the month. Only $5 \%$ and $14 \%$ reported experiencing seizures and falls, respectively. Additionally, $92 \%$ of patients reported zero rehospitalizations. Comparisons using inferential analyses between patients with and without complications revealed no significant differences in distance from outpatient services, although a trend toward significance was observed in the analysis of falls. Findings suggest noncompliance with medications and medical complications are minimal for individuals with TBI during the initial month following discharge from inpatient rehabilitation and do not appear to be a function of distance from outpatient services.

Correspondence: Samuel T. Gontkovsky, Psy.D., Neuropsychology, Methodist Rehabilitation Center, 1350 East Woodrow Wilson, Jackson, MS 39216.E-mail:stg@mmrcrehab.org.

\section{Y. RASSOVSKY, P. SATZ, M.S. ALFANO, R.K. LIGHT, D.L. MCARTHUR \& D. HOVDA. INFORMATION PROCESSING SPEED MEDIATES FUNCTIONAL OUTCOME IN TBI.}

Severe traumatic brain injury commonly results in impairment of the individual's adaptive functioning. Cognitive impairment is one potential factor (among others) that might account for this impairment, by interfering with the individual's ability to effectively cope with his/her environment. Indeed, using an archival data set, we recently compared several factors (neuropsychological, emotional, and behavioral status) hypothesized to mediate the relationship between injury severity and functional outcome and found that only neuropsychological status consistently mediated this relationship. We furthermore found that among the neurocognitive domains examined, reduced speed of information 
processing, but not memory impairment, mediated the relationship between injury severity and outcome. Given the pervasive memory complaints among patients with TBI and thereby the important implications these findings have for post-TBI rehabilitation of cognitive deficits, we sought to retest our hypotheses using another data set collected recently through the UCLA Brain Injury Research Center (BIRC). We thus compared the relative contribution of memory and information processing speed to functional impairment at 12-month post-injury, in 49 patients with moderate-to-severe TBI. Employing a structural equation modeling technique, we again found that information processing speed, but not memory, significantly mediated the relationship between TBI severity and post-TBI adaptive functioning. Although memory had a significant relationship with TBI severity, this construct had no significant relationship with functional outcome. These findings suggest that the impact of neurotrauma on information processing speed is more detrimental, than its effect on memory, to post-TBI social and occupational adjustment among patients with moderate-to-severe TBI. Correspondence: Yuri Rassovsky, Ph.D., Psychiatry and Biobehavioral Sciences, UCLA Neuropsychiatric Institute, UCLA Neuropsychiatric Institute and Hospital, 760 Westwood Plaza (C8-747/NPI), Los Angeles, CA90024-1759.E-mail:yurir@ucla.edu

\section{L.M. SCHUTT, M. SHERER, C. EVANS, C. VICKERY \& J. LEV- ERENZ. CASE MANAGEMENT AND EMPLOYMENT OUTCOMES FOLLOWING POST ACUTE BRAIN INJURY.}

Treatment in post-acute brain injury rehabilitation programs (PABIR) has been shown to be an effective way to improve emplovment outcomes for persons with traumatic brain injury (TBI). However, there has been concern over stability of employment after discharge. The present study investigated telephone follow-up as an intervention to improve stability of outcomes after PABIR. Participants were 15 persons with TBI who were placed in jobs at discharge from PABIR. Participant median age and education in years were 29 and 13 respectively. Causes of injury were motor vehicle collision $66.7 \%$, assault $13.4 \%$, auto-pedestrian $6.7 \%$, and fall $6.7 \%$. Participants were randomized to control (CG) or treatment (TG) groups. Participants randomized to $\mathrm{CG}$ received routine telephone follow-up at 3 months and one year post-discharge. Participants randomized to TG received monthly case management contacts. Services provided during these contacts included assistance with problem solving, education, referral to support agencies, and/or re-admittance to PABIR. Three month post-discharge employment data were available for 13 participants (8 of 8 TG. 5 of 7 CG). All 13 participants with data remained employed at 3 months post-discharge. One-year post-discharge outcome data were available for 11 of 15 participants ( 7 of 8 TG, 4 of 7 CG). Five of $7(71 \%)$ TG participants remained employed while 3 of $4(75 \%)$ CG participants remained employed. TG participants were less likely to be lost to follow-up as compared to CG participants. Findings indicate good durability of outcomes for all participants, but fail to show improved durability for the treatment group.

Correspondence: Linda M. Schutt, Ph.D., Neuropsychology, Methodist Rehabilitation Center, 1350 East Woodrow Wilson Drive, Jackson, MS 39216.E-mail: lmschutt@yahoo.com

\section{L.M. SCHUTT, M. SHERER, T. NICK, S.T. GONTKOVSKY, R. BROWN \& R. NAKSE-THOMPSON. IMPACT OF RURALITY OF RESIDENCE ON OUTCOME AFTER TRAUMATIC BRAIN INJURY.}

Persons living in rural communities are at greater risk to sustain traumatic brain injury (TBI) and have higher mortality rates for TBI. Some preliminary studies indicate that rural residence is also associated with poorer rehabilitation outcomes. The present investigation studied the impact of rural vs. urban residence on rehabilitation outcomes. The degree to which a participants residence was rural vs. urban was determined using the populations of the 3 largest towns in each county as described by Goodall, Karadar, and Tukey (1998). Participants were 90 persons with TBI admitted for inpatient brain injury rehabilitation. Sixtyfive participants were male and the median age was 29 years (range 16 to 87). Fifty-eight percent had at least a high school degree. Eightytwo percent sustained severe or moderate TBI. The primary outcome degree of disability as measured by the Disability Rating Scale, was collected at one year post-injury. Potential predictors of degree of disability examined were age, education level, injury severity (Glasgow Coma Scale at Emergency Department admission), degree of rurality of residence, and whether or not the participant still required medications, used alcohol post-injury, and reported any falls, headaches, seizures, or re-hospitalizations. Multivariable linear regression using these 10 predictors accounted for $31 \%$ of the variability in degree of disability. Significant predictors were degree of rurality of residence, injury severity, and whether or not the participant still required medications or used alcohol. Participants living in more rural counties had greater disability at follow-up after adjustment for all other predictors.

Correspondence: Linda M. Schutt, Ph.D., Neuropsychology, Methodist Rehabilitation Center, 1350 East Woodrow Wilson Drive, Jackson, MS 39216. E-mail: Imschutt@yahoo.com

\section{S.R. BEERS, S. WISNIEWSKI, M. BUTTERS \& E. DIXON. EFFECTS OF AMANTADINE HYDROCHLORIDE ON FUNCTIONAL OUTCOME OF ADULTS AFTER TRAUMATIC BRAIN INJURY.}

Severe traumatic brain injury (TBI) can result in neuropsychiatric deficits, including cognitive deficits, behavioral problems, mood disturbances, and personality changes. TBI commonly affects frontal brain regions and executive deficits can be enduring even years after injury. Based on animal studies, changes in dopamine metabolites are important in maintaining frontal brain processes. Uncontrolled clinical studies suggest that amantadine hydrochloride (AMH), a dopamine agonist, may reduce the neuropsychiatric symptoms, but controlled studies are limited. To assess AMH safety and efficacy in adults with severe TBI we completed a randomized, double-blind, placebo-controlled crossover clinical trial, hypothesizing that the AMH-treated group would achieve better scores than the placebo-treated group on the Neurobehavioral Rating Scale-Revised (NRS-R) and on executive function tests. AMH dose was $100 \mathrm{mg} /$ day titrated to a maximum of $400 \mathrm{mg} / \mathrm{dav}$. Patients completed an instrument to confirm dysexecutive syndrome. Randomized patients $(\mathrm{N}=25$; mean age $=36.0$ vrs, education $=13.0 \mathrm{vrs}$, and time since injury $=64.1 \mathrm{mo}$.) were tested at baseline and at the end of each 90-day treatment phase. Side effects were minimal and decreased within the first two weeks of treatment. No subjects withdrew because of side effects. ANOVA results indicated no between-group differences on the NRS $=\mathrm{R}(\mathrm{p}>.05)$ or on neuropsychological tests. Minimal effect sizes indicate that the results were not explained by insufficient power. Although TBI patients did not benefit from AMH, the sample was, on average, 5 years post TBI, well past the active recovery phase of 2 years. Thus, the possibility remains that AMH facilitates recovery when prescribed closer to time of injury.

Correspondence: Sue R. Beers, Ph.D., Psychiatry, University of Pittsburgh School of Medicine, WPIC, 3811 O, Pittsburgh, PA 15213. E-mail: beerssr@msx.upmc.edu

\section{J.E. CASS, H. HANNAY, C. CONTANT \& C. ROBERTSON. THRESHOLD THEORY, COGNITIVE RESERVE CAPACITY, AND OUTCOME FOLLOWING ADULT CLOSED HEAD INJURY.}

It has been observed for some time that there is not always a direct re lationship between the degree of brain damage or neuropathology and the clinical manifestation of that damage. The concept of cognitive reserve capacity has been proposed as a factor explaining this variability between brain damage and associated impairment (Satz, 1993: Stern, 2002). In the current study, we sought to investigate the association between indirect measures of cognitive reserve capacity (age, educational and occupational attainment, race, and preinjury risk factors) and outcome in an adult closed head injury population. Overall, results sup- 
ported the concept of reserve capacity. Controlling for injury severity, and hence indirectly degree of neuropathology, cognitive reserve capacity as measured by age, educational attainment, and the presence or absence of premorbid alcohol abuse were associated with global and $\operatorname{cog}$ nitive outcome. Results suggested that lower age, higher educational attainment, and the absence of an alcohol abuse history impart a $\operatorname{cog}_{-}$ nitive reserve which is associated with a better outcome. Alternatively, more advanced age, lower educational attainment, and premorbid alcohol abuse appear to reduce reserve capacity, placing these patients at an increased risk for poor outcome. Possible mechanisms for cognitive reserve capacity in closed head injury will be discussed.

Correspondence: Jennifer E. Cass, Ph.D., Department of Psychology, Children's Hospital, 700 Children's Dr., Columbus, OH 43205. E-mail: cassj@chi.osu.edu

\section{C.C. EVANS, M. SHERER, R. NAKASE-THOMPSON, T.G. NICK \& J. LEVERENZ. FINANCIAL BENEFITS AND EMPLOYMENT AF- TER POST-ACUTE BRAIN INJURY REHABILITATION.}

Previous literature has demonstrated that patients seeking or receiving financial compensation following mild to moderate brain injury report more symptoms and are less likely to return to gainful employment. The present study was designed to investigate the contribution of financial compensation to a larger model predicting employment status at discharge from post-acute brain injury rehabilitation in a heterogeneous patient sample. Participants (N=90) were predominantly male $(69 \%)$ and Caucasian $(69 \%)$, with moderate to severe TBI $(53 \%)$ or stroke (32\%). All participants had been gainfully employed pre-injury. The median age was 50 and median education level was 13 . The median time since injury (TSI) was 4 months and $61 \%$ of the subjects were receiving financial benefits due to their brain injuries. Results of a multivariable logistic regression analysis revealed that TSI $(p<.05)$ and benefit status $(p<.01)$ made significant, independent contributions to the prediction of employment status at discharge. Age, sex, and education did not make significant contributions to the model. The model accounted for $29 \%$ (R-squared) of the variability in employment status. Patients at the 75 th percentile of TSI (10 months) had $60 \%$ less odds of being employed as patients at the 25 th percentile (2 months) $(95 \%$ C.I., 0.17 to 0.96$)$. Patients who were not receiving any benefits postinjury had 4.68 times the odds of being employed than patients with benefits (95\% C.I., 1.58 to 13.83). Results indicate that financial compensation is an important predictor of return to work following rehabilitation independent of severity of brain injury.

Correspondence: Clea C. Evans, Ph.D. in Clinical Psychology, Methodist Rehabilitation Center Quest Program, 1910 Lakeland Drive, Suite C, Jackson,MS 39216.E-mail: cevans@mmrcrehab.org

\section{S. TAYLOR, J. DYWAN \& R. RODEN. HEAD INJURY ASSOCI- ATED WITH ORBITOFRONTAL FUNCTION IN ADOLESCENTS.}

The purpose of this study was to examine the degree to which head injury might affect adolescent development with respect to increasing maturation of prefrontal cortex (PFC). The Brock Adaptive Functioning Questionnaire (BAFQ) was administered to students across five grades at a local high school. The BAFQ is a self-report inventory that includes 12 scales assessing different aspects of frontal lobe function. Submitting data based on 773 completed questionnaires to a factor analysis revealed three factors which seemed to correspond to functionally distinct regions of the PFC: dorsolateral, orbitofrontal, and medial functions respectively. Based on data from high functioning students (GPA of B or above), the dorsolateral factor (e.g., planning) showed a developmental trend across grades, the midbrain factor (e.g., memory function) appeared sensitive to family stress but not grade level. Neither was influenced by incidence of self-reported head injury. After controlling for gender, degree of parental control, and family stress, the orbitofrontal factor (e.g., dyscontrol) was found to be strongly related to head injury, $\mathrm{F}(1,455)$ $=13.42, \mathrm{p}<.001$. The reported occurrence of 'other injury' was not re- lated to any of the BAFQ factors. These data suggest that head injury, even among high-functioning adolescents, can uniquely affect some aspects of adaptive function in ways that are consistent with the dynamics of high-velocity impact injuries and that may influence subsequent developmental trajectories.

Correspondence: Jane Dywan, PhD, Psychology, Brock University, 500 Glenridge Avenue, St. Catharines, ON L2S 3A1, Canada. E-mail: jdywan@brocku.ca

\section{R. WELLS \& J. DYWAN. PREDICTORS OF WELL-BEING IN FAMILY MEMBERS OF PERSONS WITH CLOSED HEAD INJURY.}

This study was conducted to determine which injury-related behavioural sequelae and/or life circumstances were most predictive of well-being in family members in the years following a traumatic brain injury (TBI). Self-administered questionnaire packages were sent to survivor and family member pairs who had agreed to take part in the study. Included in the package was a demographic survey, a caregiver stress inventory, a satisfaction with life questionnaire, and a medical symptoms checklist. Also included was the Brock Adaptive Functioning Questionnaire (BAFQ), a 12 scale inventory of various abilities associated with prefrontal cortex function as manifest in day to day life. There are two versions such that the survivors' abilities could be self-rated and rated by the family member. Results from 72 pairs who fully completed and returned the packages indicated that family members generally reported higher levels of satisfaction than dissatisfaction with their role. However, to the degree that mood and life satisfaction were affected, the best predictors were reduction of income from pre-injury levels and differences between self- and family-ratings on the BAFQ. That is, the degree to which those with TBI were unaware of changes in their level of adaptive behaviours was strongly predictive of negative changes in mood and life-satisfaction among family members.

Correspondence: Jane Dywan, PhD, Psychology, Brock University, 500 Glenridge Avenue, St. Catharines, ON L2S 3A1, Canada. E-mail: jdywan@brocku.ca

\section{B. SANTAMARIA, J. DYWAN \& S.J. SEGALOWITZ. EARLY STRUCTURAL ENCODING AND FACE PROCESSING DEFICITS AFTER CLOSED HEAD INJURY.}

Brain regions most at risk for damage during high-velocity impact injuries are also associated with the processing of face stimuli and emotional expression. There is growing evidence that those with closed head injury (CHI) have difficulty processing emotional expression. What is not clear is the stage at which the processing of emotional expression breaks down. Thus, electrophysiological indices of early structural processing of facial information (N170) were recorded while participants with and without CHI did a priming task in which they were asked to indicate whether sequentially presented faces were a 'match' or 'mismatch' on the basis of identity or emotional expression. Other measures of identity and emotion identification were used as well as a self- and collateral-rated emotional experience questionnaire. Behaviourally, those with CHI were less accurate on all measures of facial identity or emotional expression and had particular difficulty identifying disgust and sadness. Comparing their self-ratings with those of family members, they tended to underestimate the frequency and intensity with which they experienced anger and overestimated their ability to perceive fear in others. Their N170 to faces was only marginally delayed relative to controls but there was no difference in amplitude suggesting that face processing deficits cannot be accounted for by an impairment in structural encoding. However, the N1, thought to reflect selective attentional processes, was markedly attenuated in the CHI group, suggesting that they may have difficulty selecting information that is required for later processing and necessary for making appropriate social judgements and decisions. 
Correspondence: Jane Dywan, PhD, Psychology, Brock University, 500 Glenridge Avenue, St. Catharines, ON L2S 3A1, Canada. E-mail: jdywan@brocku.ca

\section{Invited Symposium/3:15-5:15 p.m.}

\section{Years On: HM and the Quest to Understand the Amnesic Syndrome}

\section{Discussant: Michael Kopelman}

\section{S. CORKIN. THE AMNESIC PATIENT H.M.: A HALF CENTURY OF LEARNING ABOUT MEMORY.}

Consider the following questions: Do you remember what you had for dinner last night? Do you know the capital of Indonesia? Can you describe how you maintain your balance when riding a bicycle? As you pondered each answer, you accessed information from different memory systems. Understanding that there are different kinds of memory, with different addresses in the brain, is the essence of the science of memory. The dissociation of memory capacities began with H.M., who became amnesic in 1953 following an experimental brain operation to palliate his intractable epilepsy. In that operation, medial temporal lobe structures were removed bilaterally, while neocortical areas were spared. Over the last 50 years, nearly 100 investigators, first at the Montreal Neurological Institute and since 1966 at MIT, have participated in studying H.M.'s memory capacities. We understand the rare opportunity we have had to work with him, and are grateful for his dedication to research. He has taught us a great deal about the cognitive and neural organization of memory. Specifically, experiments with H.M. have uncovered multiple dissociations of function, indicating specialization of particular brain circuits for specific memory capacities. Thus, his severe impairment in long-term declarative memory (in particular, episodic and semantic learning) is strong evidence that medial temporal lobe structures are critical for this system. At the same time, his short-term memory and long-term nondeclarative memory (skill learning, repetition priming) are preserved, so it is likely that structures beyond the medial temporal lobe (e.g.. neocortical and striatal circuits) support these systems.

Correspondence: Suzanne Corkin, Ph.D., MIT, MIT, Cambridge, MA 021xx.E-mail: corkin@MIT.EDU

\section{L.R. SQUIRE. THE HIPPOCAMPUS, THE MEDIAL TEMPORAL LOBE, AND MEMORY IMPAIRMENT.}

The medial temporal lobe is essential for the formation of long-term declarative memory. Declarative memory can be contrasted with a collection of nondeclarative memory abilities (e.g., habit and skill learning, simple forms of conditioning, and priming), which are independent of the medial temporal lobe. We have studied memoryimpaired patients with restricted bilateral hippocampal lesions and other patients with large bilateral medial temporal lobe lesions. The patients were impaired at learning new facts (semantic memory) as well as specific events (episodic memory). The patients with hippocampal lesions had temporally-graded retrograde amnesia covering several years, and the patients with larger lesions had more extensive retrograde amnesia. For all patients, very remote memory for autobiographical episodes was intact. In further studies of patients with restricted hippocampal lesions, memory for single items was impaired as much as memory for conjunctions. Recognition memory was also impaired, and items given Know responses were impaired along with items given Remember responses. Additional studies showed that recognition memory and the phenomenon of priming are independent phenomena. Neither perceptual nor conceptual fluency provides a source for feelings of familiarity that can support accurate recognition memory judgments. These and other findings suggest that simple dichotomies (episodic vs. semantic memory, conjunction memory vs. single-item memory, recollective vs. familiarity) do not adequately capture the division of labor between the hippocampus and adjacent medial temporal lobe cortex. As hypotheses about memory and memory impairment become increasingly specific, it becomes especially important to characterize in anatomical detail the locus and extent of damage in the patients being studied.

Correspondence: Larry R. Squire, Ph.D., Research and Psychiatry Services, Department of Veterans Affairs (116A, 3350 La Jolla Village Drive, San Diego, CA 92111. E-mail: lsquire@ucsd.edu

\section{VERFAELLIE. IMPAIRED AND PRESERVED MEMORY PROCESSES IN AMNESIA.}

Directly inspired by findings in HM, neuropsychological studies of memory have focused for many years on identifying dissociations between performance on implicit and explicit memory tasks. It is now clear, however, that amnesic patients do not perform normally on all implicit memory tasks. Moreover, their impairment in explicit memory is not necessarily equivalent across tasks. For this reason, we focus on the processes that mediate performance on both implicit and explicit tasks. This approach is illustrated through our work on item and associative recognition memory in amnesia as well as through studies of perceptual priming. Implications of our findings for theories about the mechanisms underlying normal memory functioning will also be discussed.

Correspondence: Mieke Verfaellie, PhD, Memory Disorders Research Center, Boston VAMC, 150 S Huntington Avenue, Boston, MA 02130. Email:verf@bu.edu

\section{NADEL. THE AMNESIC SYNDROME: CONSENSUS AND CONTEXT.}

Although full understanding of the amnesic syndrome, and the role played in it by various structures in the medial temporal lobe, remains elusive, the past 50 years has seen considerable progress towards such understanding. Areas of agreement are numerous, and a consensus has emerged around many of the key features of this syndrome. Most investigators would agree that (1) only some forms of memory are impaired in amnesia; (2) procedural aspects of memory are largely intact; (3) episodic aspects of memory are particularly impaired; (4) both anterograde and retrograde memory deficits are typically observed; (5) damage in the hippocampal complex, but not the amygdala, is largely responsible for the amnesic syndrome. However, disagreements persist in a number of areas: (1) the extent of retrograde amnesia remains unclear, as does its relation to the exact nature of the brain damage; (2) the extent of impairment to semantic memory is uncertain; (3) the possible differential impact of amnesia on free recall, and recognition remains a matter of debate; (4) whether amnesia equally effects all forms of recognition is unclear; (5) whether contextual aspects of memory are especially affected remains uncertain. Cognitive map theory spelled out a particular view of amnesia that will be reviewed, and updated in light of recent developments. Finally, issues that are in particular need of resolution, and the kinds of data that might lead to such resolution. will be discussed.

Correspondence: Lynn Nadel, Ph.D., Psychology, University of Arizona, 1503 E. University, Tucson, AZ 85721. E-mail: nadel@u.arizona.edu 
Paper Session 13/3:15-5:15 p.m.

\author{
Brain-Behavior Relationships in \\ Psychopathology
}

\begin{abstract}
M.E. ZIMMERMAN, P.K. SHEAR, M.P. DELBELLO, G.E. GETZ, M.L. SCHWIERS \& S.M. STRAKOWSKI. EXECUTIVE FUNCTIONING CORRELATES OF ANTERIOR CINGULATE SUBREGION VOLUMES IN BIPOLAR DISORDER.
\end{abstract}

Patients with bipolar disorder (BPD) demonstrate abnormalities in both cognitive ability and regional brain volumes. The present study examined whether MRI-derived gray and white matter volumes of anterior cingulate cortex (ACC) subregions (caudal, rostral, and subgenual) were associated with performance on cognitive tests of executive functioning in 27 patients with BPD and 22 healthy volunteers (HV). MANCOVA revealed no significant differences between groups in ACC subregion white matter $[\Lambda=0.91, \mathrm{~F}(3,44)=1.43, \mathrm{p}<0.25]$ and gray matter volumes $[\Lambda=0.95, \mathrm{~F}(3,44)=0.75, \mathrm{p}<0.53]$ after controlling for head size. MANOVA on the neuropsychological variables indicated an overall significant difference between groups $[\Lambda=0.71, \mathrm{~F}(3,45)=5.98, \mathrm{p}<0.002]$. Specifically, significant group differences were observed on the Trail Making Test part B $[F(1,47)=14.51, p<0.0004]$, Wisconsin Card Sorting Test $[\mathrm{F}(1,47)=6.04, \mathrm{p}<0.02]$, and WAIS-III Letter-Number Sequencing $(\mathrm{LNS})[\mathrm{F}(1,47)=11.07, \mathrm{p}<0.002]$. Multivariate regressions examining the relationship between ACC subregion volumes and neuropsychological test performance revealed no significant main effects; however, a trend was demonstrated for rostral ACC subregion grav matter volume $\left[\mathrm{R}^{2}=0.31, \mathrm{p}<0.07\right]$ in predicting performance on WAIS-III LNS. These findings are consistent with other reports in demonstrating deficits of executive functioning in patients with BPD during mania. However, there were neither significant group differences in ACC subregion gray and white matter volumes nor significant associations between ACC subregion volumes and performance on tests of executive functioning.

Correspondence: Molly E. Zimmerman, M.A., Psychiatry and Human Behavior, Brown University, Brown University, Box G-BH Psychology Training, Providence, RI 02912. E-mail:Molly_Zimmerman@Brown.edu

\section{J. JAEGER, S. BERNS, R. IANNUZZO, S. CONWAY, S. UZELAC, P. DEROSSI, J. BATES, C. GONZALEZ \& S. YECKER. DEFICITS IN NEUROCOGNITIVE FUNCTIONING IN BIPOLAR DISORDER PERSIST IN EUTHYMIA.}

Many studies have reported neurocognitive deficits in bipolar disorder (BPD), however few have distinguished cases by illness phase/polarity and none, to our knowledge, have examined patients longitudinally while in episode and again in euthymia. We report interim findings from an ongoing longitudinal follow-up study of neurocognitive deficits and disability in BPD. Inpatient BPD admissions are recruited, and consenting subjects ( $\mathrm{N}=140$ to date) are given a comprehensive neuropsychological test battery, HAM-D, CARS and PANSS. Testing is repeated after eight continuous weeks of euthymia. Here we report on all cases to date ( $\mathrm{N}=18$ ) having achieved sustained euthymia (12 males, age $=34.13$ (11.33), education=13.50 (2.62)), compared to 29 normal controls (16 males, age $=27.20(6.39)$, education=14.71 (1.37)). Measures were selected from a larger battery sampling several neurocognitive domains (Jaeger, 2003) to permit exploration of neurocognitive profile patterns. Alpha was set at $p<.01$ to accommodate multiple comparisons. Neuropsychological test scores changed strikingly little between baseline and euthymia. Of 25 measures considered, only three (indices of working memory and basic attention) changed significantly. When compared to normals (covarying age and education), patients in the euthymic state performed significantly worse on all measures of verbal memory, verbal and performance IQ, as well as measures of motor and information processing speed. None of the three measures that improved from baseline to euthymia were among those that distinguished euthymics from controls. It may be that neurocognitive recovery lags behind affective symptom recovery. We plan a longer follow-up in a larger sample to clarify state versus trait deficits in BPD.

Correspondence: Sarah Uzelac, Ph.D. Candidate, Hillside Hospital, 7559 263rd St., Glen Oaks, NY 11004.E-mail: suzelac@lij.edu

\section{J. VASSILEVA, R. GONZALEZ, D. PITRAK, R. NOVAK, G. NUN- NALLY, N. RAINS, A. BECHARA \& E. MARTIN. PROFILES OF EXECUTIVE DYSFUNCTION DIFFER ACCORDING TO DRUG ABUSE SEVERITY AND ANTISOCIALITY.}

Antisocial traits are common among substance abusers and both conditions are associated with deficits in executive cognitive functioning. However, few studies to date have investigated possible unique and synergistic effects of drug abuse severity and antisociality on cognitive functioning. In the present study, we evaluated three aspects of executive cognitive functioning in a group of $106 \mathrm{HIV}$-seronegative men classified according to severity of drug abuse and antisociality, as indexed by the Socialization Scale of the California Personality Inventory. Groups were well matched on demographic variables and measures of substance abuse-related comorbidities. Subjects were assessed on three types of executive functions known to be abnormal among substance abusers: (1) decision making, assessed by the Bechara Gambling Task; (2) working memory, assessed by a delayed non-match to sample task; and (3) response inhibition, tested by the computerized version of the Stroop task. Results indicate that (1) Drug abuse severity, but not antisociality, was associated with slower performance of the Stroop task; (2) Severity of drug abuse and antisociality showed interactive effects on the working memory task; and 3) Antisociality was associated with significantly more disadvantageous / risky decisions on the Bechara Gambling Task. irrespective of drug abuse severity. These preliminary results suggest a putative dissociation between the effects of antisociality and drug abuse on executive cognitive functioning. These data may be useful in developing models of neurocognitive dysfunction for substance abusers and may also inform the development of appropriate interventions for this population. Supported by HHS R01 DA12828.

Correspondence: Jasmin Vassileva, Ph. D., Psychiatry, University of Illinois at Chicago, Psychiatric Institute (MC 912), 1601 W. Taylor Street, Chicago,IL 60612.E-mail: jvassileva@psych.uic.edu

\section{K. PESCHARDT, A. LEONARD, J. MORTON \& J.R. BLAIR. DIFFERENTIAL STIMULUS-REWARD AND STIMULUS-PUNISH- MENT LEARNING IN INDIVIDUALS WITH PSYCHOPATHY.}

Similarly to many other mood and anxiety disorders psychopathy has been linked to reward/ punishment processing abnormalities. In psychopathy it has been suggested that there is hypo-sensitivity to punishment and/or normal or hyper-sensitivity to reward. However, there have been very few investigations of this issue. In this study, we investigated response choice as a function of learnt stimulus-reward/ stimulus-punishment associations in individuals with psychopathy $(\mathrm{n}=21)$ and comparison individuals $(\mathbf{n}=20)$ using the novel Differential Reward/ Punishment Learning Task. In this task, the participant has to choose between two objects presented on a computer screen. Because these objects can either involve one rewarding and one punishing object, two objects with different levels of punishment $(-100,-200,-400,-800$, or -1600$)$, or two objects with different levels of rewards $(100,200,400,800$, or 1600), response choice indexes not only sensitivity to reward/ punishment, but also sensitivity to reward/punishment level according to inter-reinforcement level interval. This study revealed first that individuals with psychopathy are severely impaired at learning stimulus-punishment associations, but also that they are mildly impaired at learning stimulus-reward associations. The implications of these results for current models of psychopathy are discussed. 
Correspondence: Karina Peschardt, National Institute of Mental Health, NIH, $15 K$ North Drive, Room 206, Bethesda, MD 20892-2670. E-mail: peschark@intra.nimh.nih.gov

\section{K.L. LOKKEN, A. BOEKA \& T. PATTERSON. COGNITIVE DEFICITS IN BULIMIA NERVOSA.}

Until recently, bulimia nervosa has been viewed predominantly as a psychological disorder stemming from psychodynamic or family-system conflict. Recent converging evidence suggests bulimia nervosa may be better characterized as a model neuropsychiatric syndrome. The aim of the present study was to further examine the hypothesized relationship between the presence and severity of bulimic symptoms and specific deficits on tests sensitive to frontal lobe dysfunction. Performances on a select battery of neuropsychological tests were compared between a group of 30 women clinically diagnosed with bulimia nervosa and a group of 30 women reporting few or no bulimic symptoms. The two groups were homogenous for age, educational level, handedness, body mass index, and verbal ability as measured by the WAIS-III Vocabulary subtest. Clinical symptomatology was measured by the Bulimia TestRevised (BULIT-R; a self-report questionnaire) and the Eating Disorder Examination (EDE; a semi-structured interview). The two groups significantly differed in their performances on several neuropsychological indices, including the Wisconsin Card Sorting Test, Trails B of the Halstead Reitan Battery, and the Paced Auditory Serial Addition Task. In addition, test performances on such measures were significantly correlated with severity of bulimic symptomatology as measured by the BULIT-R and the EDE, but were not correlated with depressive symptomatology as measured by the Beck Depression Inventory. Such preliminary results provide further evidence of selective impairment on tasks measuring executive functioning in individuals with bulimia nervosa. Results are discussed in terms of specific behavioral patterns and possible underlying pathophysiology of the disorder.

Correspondence: Kristine L. Lokken, Ph.D., Psychology, The University of Alabama, Box 870348, Department of Psychology, 348 Gordon Palmer Hall, Tuscaloosa, AL 35487-0348.E-mail:klokken@bama.ua.edu

\section{K.J. PRENTICE, A.S. BELLACK, J.M. GOLD \& W.T. CARPEN- TER. IMPROVING DECISIONAL CAPACITY FOR INFORMED CONSENT IN SCHIZOPHRENIA.}

We investigated whether decisional capacity for informed consent in schizophrenia patients is impaired and whether potential impairments can be alleviated with a standardized educational intervention. Informed consent is the primary means by which potential subjects can assure their rights to full autonomous participation in decision-making about clinical research participation. There is public concern that the mentally ill are deficient in their capacity to provide informed consent and therefore are not appropriate for participation in clinical research. Carpenter et al (2000) showed that, while schizophrenia patients are impaired on measures of decisional capacity, their performance improves with training. We tested patients' and controls' decisional capacity using the MacArthur Competence Assessment Tool - Clinical Research (MacCAT). Patients whose performance did not reach a pre-determined criterion were randomized to either Informed Consent Training (ICT) or to a control condition, Social Skills Training (SST). Preliminary analyses show that approximately $75 \%$ of the 90 patients tested scored below criterion on a key MacCAT decisional capacity index (understanding of critical elements of research participation). Patients in the ICT group showed a post-training increase in understanding of approximately $20 \%$, a change significantly greater than that seen in the control group $(8 \%)$. Additionally, though some psychiatric symptoms were significantly correlated with decisional capacity, performance on a variety of neurocognitive measures was a better predictor. Results suggest that a simple intervention can improve schizophrenia patients' decisional capacity, thus challenging the notion that unique and stringent safeguards are required for subject protection in schizophrenia research.
Correspondence: Kristen J. Prentice, Ph.D., Maryland Psychiatric Research Center, University of Maryland, P.O. Box 21247, Baltimore, MD 21228.E-mail:kprentice@mprc.umaryland.edu

\section{A.M. BRICKMAN, M.S. BUCHSBAUM, L. SHIHABUDDIN, W. BYNE, R. NEWMARK \& S.A. MITELMAN. THALAMUS SIZE AND OUTCOME IN SCHIZOPHRENIA.}

The thalamus has extensive and reciprocal connections to the striatum and cortex and its association nuclei are importantly involved in maintaining attention and modulation of sensory input. The disturbance of these functions in schizophrenia has implicated the thalamus as a nexus of defective circuits in schizophrenia. In the current study, the size of the thalamus was measured in 106 patients with schizophrenia and 42 matched normal controls using high-resolution magnetic resonance imaging (MRI). Schizophrenia patients were divided into poor-outcome $(n=54)$ and good-outcome $(n=52)$ subgroups based on longitudinal analysis of self-care deficits. The thalamus was manually traced on 5 axial levels proportionately from dorsal to ventral slices. Further, measurements of frontal lobe and temporal volume were made with a semiautomated program that calculated white and grey matter pixels within each Brodmann area. Schizophrenia patients, collapsed across goodand poor-outcome patients, had smaller thalami than normal controls at more ventral levels $(\mathrm{F}(4,584)=3.47, \mathrm{p}=0.008)$ and poor-outcome patients had significantly smaller ventral thalami than good-outcome patients $(\mathrm{F}(4,416)=9.66, \mathrm{p}<0.0001)$ when the two subgroups were compared. Within the schizophrenia patients, thalamus size was positively associated with frontal lobe and temporal lobe volume. These findings are consistent with post-mortem and MRI measurement suggesting reduction in volume of the pulvinar nucleus, a large and more ventral thalamic region with prominent connections to the temporal lobe. Together with previous analyses from our laboratory, the findings implicate posterior brain circuitry abnormalities in poor functional outcome of schizophrenia.

Correspondence: Adam M. Brickman, M.A., Department of Psychiatry, Mount Sinai School of Medicine, Neuroscience PET Laboratory Box 1505, One Gustave L. Levy Place, New York, NY 10029. E-mail: adam. brickman@mssm.edu

Paper Session 14/3:15-5:15 p.m.

\section{Attention Deficit Hyperactivity Disorder}

\section{A. ARBOLEDA, R.J. SARMIENTO, D.A. PINEDA \&. D.C. AGUIRRE. CORRELATION BETWEEN VOLUMES FROM CAUDATE NUCLEUS, AND SEMANTIC LANGUAGE TASK IN COLOMBIAN CHILDREN WITH ATTENTION-DEFICIT HYPER- ACTIVITY DISORDER.}

A Magnetic resonance imaging study comparing attention-deficit hyperactivity disorder (ADHD) children without learning disabilities (LD) and a control group revealed that both groups had left caudate nucleus head volumes (CNHV) significantly higher than the right, and there were no between-group differences (Pineda et. Al. 2002). This suggests that differences previously reported could be attributed to learning disabilities associated with ADHD. The objective of present study was to evaluate the correlation between volumes from the caudate nucleus and performance on a semantic language task in Colombian children with ADHD. The sample of well-controlled included 7- to 11-year-old Colombian children. Two groups of participants were selected, children with ADHD (combined and inattentive type) and children without disorders in a control group. Multiple methods for assessing ADHD were used to confirm the diagnoses. Participants with a history of language 
disorders, learning disabilities, depression, and other major neurological and psychiatric conditions were excluded. The children were tested with the WISC-R (Information and vocabulary), CELF 3 Spanish (concepts and directions, word classes), and the verbal fluency test (FAS) by phonologic and semantic guides. Finally all groups had 15 children, matched by sex ( 7 male, 8 female), age, socioeconomic status, and grade. Height, weight, head circumference, and encephalic index were statistically controlled. The result showed that the control group had a significantly higher Wechsler Full-Scale IQ than the groups with ADHD of the combined type and ADHD of the inattentive type $(\mathrm{P}<.001)$. Significant correlations between $\mathrm{CNHV}$ and semantic language variables were not observed. The implications of finding will be discussed related to factorial organization of the cognitive function model.

Correspondence: Alejandra Arboleda, Group of Neuroscience, University of Antioquia, Calle 62\# 52-72, Medellin 00, Colombia. E-mail: alear@epm.net.co

\section{S.H. MOSTOFSKY, S.L. RIMRODT, J. SCHAFER, A.C. BOYCE, M.C. GOLDBERG, J.J. PEKAR \& M.B. DENCKLA. ABNORMAL MOTOR CORTEX ACTIVATION IN ADHD: EVIDENCE FROM FMRI.}

Abnormalities on motor examination are a consistently reported finding in children with ADHD. Understanding the neural mechanisms that contribute to these abnormalities can provide increased insight into the neurologic basis of ADHD. FMRI was used to compare neural activation associated with performance of a simple finger-sequencing task in a group of 8 children with ADHD, ages 8-12 years with that in a group of 8 age- and gender-matched controls. Thirty-second blocks of righthanded finger sequencing (RHFS) were alternated with blocks of lefthanded finger sequencing (LHFS) and blocks of rest. FMRI group data were analyzed using separate random effects models designed to determine signal change patterns associated with RHFS and LHFS in children with ADHD and controls. Random effects models were also used to examine between-group differences in activation during RHFS and LHFS. Region-of-interest analyses revealed children with ADHD show increased activation, compared with controls, in the hand region of the ipsilateral motor cortex and mouth region of the contralateral motor cortex, which may reflect excessive mirror overflow and proximal/orofacial overflow movements, respectively. Children with ADHD also showed decreased activation in the contralateral hand motor cortex relative to controls, which may reflect impaired recruitment of neurons necessary for inhibition of surrounding and mirror motor regions. The findings suggest that children with ADHD have delayed or abnormal development of motor cortical systems necessary for execution of patterned movements, including intracortical and interhemispheric inhibitory systems important for inhibition of surrounding and mirror cortices that are extraneous to the performance of the task.

Correspondence: Stewart H. Mostofsky, M.D., Neurology, Kennedy Krieger Institute, Johns Hopkins University School of Medicine, 707 N. Broadway, Baltimore, MD 21205. E-mail: mostofsky@kennedykrieger.org

\section{E.M. MAHONE, C. PRAHME, C. KOTH, M.B. MORRIS \&. M.B. DENCKLA. EFFECTS OF AGE AND VERBAL IQ ON TIMED MOTOR PERFORMANCE IN CHILDREN.}

Assessment of neuromotor function, including motor speed and efficiency, is critical to investigating the neurobiologic basis of neurodevelopmental disorders. For the present study, integrity of the neuromotor system was assessed using the Physical and Neurological Examination for Subtle Signs (PANESS; Denckla, 1985). The PANESS includes assessment of gross and timed motor coordination tasks. Timed tasks include a sequence of 20 toe taps, 10 toe-heel taps, 20 hand pats, and 20 finger taps, 10 hand pronate-supinate, and 5 sequences of finger appositions, with all movements performed on left and right sides. Observations are made for presence of overflow and dysrhythmia. We examined performance on PANESS timed tasks in a mixed clinical sample of 170 right-handed children and 23 controls, ages 6-18. In both groups, timed performance decreased steadily across the age range on all twelve tasks. Examining only the clinical group, Verbal IQ was a significant predictor $(p<.05)$ of performance on 11 of the 12 tasks, after controlling for age. In a subset of boys (23 controls, 38 with ADHD), timed performance (age-corrected) was significantly slower for the ADHD group on both left- and right-sided task means, while no group differences were observed on overflow or dysrhythmia. Larger group differences in speed were observed for younger children. Discriminant function analysis, examining contribution to group discrimination (ADHD vs. control) of the twelve timed tasks revealed time for right-sided toe-heel taps as the best group discriminator. The PANESS represents a time-efficient and useful part of a comprehensive neurobehavioral assessment in children. Correspondence: Ernest M. Mahone, Ph.D., Neuropsychology, Kennedy Krieger Institute, 1750 East Fairmount Ave, Baltimore, MD 21231. Email:mahone@kennedykrieger.org.

\section{O.G. BERWID, E.A. CURKO, A. SANTRA, H.A. BENDER \& J.M. HALPERIN. SUSTAINED ATTENTION AND INHIBITORY CONTROL IN PRESCHOOLERS AT-RISK FOR AD/HD.}

Background: Studies of school-aged children, adolescents and adults have variably shown ADHD-related impairment in sustained attention, inhibitory control, and interference control. However, few studies have examined ADHD-associated patterns of performance in these domains among preschool children. Methods: A parametric version of a combined CPT and go/no-go task (CPT/GNG) and the Day-Night Stroop Task (DNST) were administered to an ethnically diverse sample of preschool children rated by parents and teachers as being either high-risk or lowrisk for ADHD. All children performed the DNST $(\mathrm{N}=62)$ and a subset of the sample $(\mathrm{N}=40)$ performed the CPT/GNG. Systematic analyses were conducted to assess task validity as well as the effects of age and risk status. Results: Significant main effects for Condition, Age and Risk Status were found on all tasks, as well as Age $\mathrm{x}$ Condition interactions for the CPT and DNST, the latter of which suggests that the tasks were sensitive to age-related changes in sustained attention and interference control, respectively. No significant Risk Status x Condition interactions were found, suggesting that preschoolers at risk for ADHD do not display specific deficits in sustained attention, inhibitory control or interference control. However, a significant 3-way Risk Status x Condition $\mathrm{x}$ Age interaction on the DNST revealed a possible lag in the development of interference control among high-risk children. Conclusions: ADHD-associated decrements in performance on these tasks appear to be attributable to generalized behavioral dysregulation rather than to specific cognitive deficits.

Correspondence: Olga Berwid, BA, Department of Psychology, Queens College/CUNY, 65-30 Kissena Boulevard, Flushing, NY 11367. E-mail: oberwid@hotmail.com

\section{P.K. SHEAR, M.P. DELBELLO, H.L. ROSENBERG, A.J. JAK \& S.M. STRAKOWSKI. COGNITIVE FUNCTIONING IN MANIC ADOLESCENTS WITH BIPOLAR DISORDER: CONTRIBUTION OF COMORBID ADHD.}

Bipolar disorder (BPD) is a severe mental illness that affects over 1\% of children and adolescents between the ages of 9 and 16. Adults with BPD are known to demonstrate cognitive deficits during episodes of abnormal mood that, in some individuals, persist also during euthymia. Little is known, however, about cognitive functioning in children and adolescents with this disorder. The present study examined cognitive ability in 24 manic adolescents with BPD and in a comparison group of 14 healthy adolescents from the community matched for age, sex and ethnicity. Because of the high comorbidity between childhood and adolescent BPD and ADHD, we further subdivided the ADHD group for certain analyses into 9 with BPD only and 15 with BPD+ADHD. It is 
striking that the BPD only group, despite substantial manic symptoms (mean Young Mania Rating Scale=32.9; $\mathrm{SD}=8.2$ ), performed comparably to controls on measures of total learning across trials (HVLT), sustained attention (CPT sensitivity), and sequencing (Trail Making Test). They were impaired, however, in their inhibition on the Stroop $(p<.01)$. In contrast, the BPD+ADHD group was significantly impaired in comparison to their peers who only had BPD in their sustained attention, sequencing and inhibition ( $p<.05$ for all comparisons). Taken together, these results suggest that adolescents with BPD may have executive dys- function, which is consistent with our previous report that this population is impaired on everyday tasks that require executive abilities, but that cognitive deficits are most prominent in those patients who also have comorbid ADHD. The findings also highlight the importance of examining further the contribution of comorbid ADHD to neuropsychological ability in this population.

Correspondence: Paula K. Shear, Ph.D., Psychology, University of Cincinnati, 429B Dyer Hall, Mail Location 0376, Cincinnati, OH 45221-0376. E-mail: shearpk@email.uc.edu

\section{SATURDAY MORNING, FEBRUARY 7, 2004}

\author{
Poster Session 10: Neuropsychological Effects of \\ Neurological Disorders including HIV, Substance \\ Abuse and Other Toxic Exposures, \\ Hormones/8:00-10:00 a.m.
}

\section{General Medical Disorders}

\section{K.A. WHITNEY, J. FINNA, L.A. BIELIAUSKAS \& J.N. HOOK. APPRAISAL OF ILLNESS AND NEUROPSYCHOLOGICAL FUNC- TION IN ELDERLY INPATIENTS WITH MULTIPLE MEDICAL PROBLEMS.}

Research suggests that damage to the frontal lobes puts individuals at greater risk for being unaware of their cognitive and behavioral impairments. The relationship between frontal lobe function and awareness of illness has been well-documented among individuals with hemiplegia, severe mental illnesses, and degenerative dementias. Yet, few studies have examined the relationship between neuropsychological factors and insight into illness in the general medical population. Lack of insight is of clinical importance within this population due to its potential relationship with treatment noncompliance. In the present study, nondemented geriatric inpatients were given a neuropsychological battery and the Revised Patient's Experience of Hospitalization (RPEQ) questionnaire to assess their : 1) acknowledgement of illness and beliefs about possible illness outcomes, 2) beliefs about need for treatment, and 3 ) extent of worry about illness. Participants included 36 inpatients with various medical problems and a Mini-Mental Status Exam score greater than or equal to 24 . Results of correlational analyses indicated that the patients' perceived need for treatment was negatively related to scores on neuropsychological tests commonly associated with frontal lobe functioning $(\mathrm{p}<.05)$. Perceived need for treatment did not have significant correlations with other domains of cognitive functioning. These results suggest that the relationship between tasks associated with frontal lobe function and awareness of illness is present even in less-impaired, general medical populations. Assessment with such tasks may contribute to identification of treatment compliance issues in these patients.

Correspondence: Kriscinda A. Whitney, Ph.D., University of Michigan Medical Center, 2102 Jackson Place, Ann Arbor, MI 48103. E-mail: kamarks@umich.edu

\section{A.J. WOODS \& V.W. MARK. COGNITIVE IMPAIRMENT IN “NON- NEUROLOGIC" ELDERLY HOSPITAL INPATIENTS.}

Cognitive decline with aging is well documented. Cognitive decline is also reportedly associated with various "non-neurologic" surgeries and medical illnesses. However, it is unclear whether elderly patients hospitalized for such disorders suffer cognitive decline beyond that experienced by community-living elderly subjects, because such patients are not routinely cognitively evaluated. The cognitive assessment of hospitalized patients who had been pre-morbidly functionally independent would help to determine whether they could be discharged home without further assistance. Furthermore, determining whether hospitalized inpatients cognitively differ from non-hospitalized participants would clarify to what extent the former group may be considered as "controls" in cognitive studies of hospitalized brain-lesioned patients. In the current study we assessed whether there are important cognitive differences between hospitalized "non-neurologic" elderly inpatients (HEI) $(\mathrm{n}=10)$ and, non-hospitalized, non-neurologic elderly participants (NHE) $(n=10)$. We comprehensively assessed cognitive ability with tests of executive function, verbal fluency, global cognition, and memory. Two questionnaires that evaluated prior medical history and substance abuse were included to evaluate the influence of pre-morbid factors. Results indicated that HEI demonstrated significantly lower scores than NHE on eleven of twelve cognitive measures. Pre-morbid factors were not associated with cognitive measures. Our results suggest that elderly patients hospitalized for non-brain related illness/injury should undergo routine cognitive evaluation when planning discharge arrangements. Furthermore, the use of "non-neurologic" inpatients as "controls" should be qualified when comparing their performance to brain-lesioned inpatients. Further studies are warranted to dissect the aspects of acute illness or hospitalization that contribute most to altered cognitive performance.

Correspondence: Adam J. Woods, B.S., Physical Medicine and Rehabilitation, University of Alabama at Birmingham, 2848 Regal Circle Apt. G, Birmingham, AL 35216.E-mail: awoods@uab.edu

\section{F.C. GOLDSTEIN, A.V. ASHLEY, L.J. FREEDMAN, L. PENIX, J. LAH, J. HANFELT \& A.I. LEVEY. HYPERTENSION AND COG- NITIVE PERFORMANCE IN AFRICAN AMERICANS WITH ALZHEIMER'S DISEASE.}

Hypertension is a vascular risk factor for cognitive impairment and Alzheimer's disease. However, the impact of hypertension on the cognitive features of patients who have already developed $A D$ has not been explored. This study examined the relationship between hypertension and cognitive performance in 34 African American patients with probable Alzheimer's disease. Of these, 13 were normotensive (systolic BP $\langle 140 \mathrm{~mm} \mathrm{Hg}$, diastolic BP $<90 \mathrm{~mm} \mathrm{Hg}$, and not taking blood pressure medication), whereas 21 patients had Stage 2 hypertension (systolic BP $>160 \mathrm{~mm} \mathrm{Hg}$ or diastolic BP $>100 \mathrm{~mm} \mathrm{Hg}$ ). The two groups were comparable in overall disease severity. We excluded any AD patients who had neuroradiologic evidence of current or previous large vessel strokes, or a focal neurologic examination consistent with current or previous strokes. The Mattis Dementia Rating Scale was administered to patients during their clinic visit. Multiple regression analyses were performed with gender, age, education, and hypertension (presence vs. absence) as predictors of cognitive performance. The overall regressions were significant for the Initiation/Perseveration and Conceptualization subscales. For both analyses, the presence of hypertension was associated with significantly $(p\langle .01)$ lower, and therefore, poorer performance. These results were unchanged after adjusting for other potential modifiers including the use of cholinesterase inhibitors. The findings indicate that hypertension is a risk factor for cognitive impairment in pa- 
tients who are diagnosed with probable AD. As such, they extend previous investigations demonstrating an association between hypertension as a risk factor for cognitive compromise in nondemented adults, and they highlight the importance of assessing and controlling hypertension in AD patients during the course of their clinical care.

Correspondence: Felicia C. Goldstein, Ph.D., Neurology, Emory University School of Medicine, 1841 Clifton Rd., N.E., Atlanta, GA 30329. E-mail:fgoldst@emory.edu

\section{D.L. MOUNT, F.C. GOLDSTEIN, L. HORNE-MOYER \& N.G. BLI- WISE. APOLIPOPROTEIN EE4 DOSE-DEPENDENCE AND COG- NITIVE FUNCTIONING IN AFRICAN-AMERICAN PATIENTS WITH ALZHEIMER'S DISEASE.}

The apolipoprotein E $\varepsilon 4$ allele increases Alzheimer's disease (AD) risk. Numerous empirical investigations have confirmed that inheritance of ApoE $\varepsilon 4$ is associated with a higher risk for $\mathrm{AD}$ in Caucasians. This relationship has yielded contradictory findings for African-Americans, as the lack of conclusive findings probably is due, in part, to methodological shortcomings. Research has shown that Caucasian ApoE $\varepsilon 4$ carriers exhibit poorer cognitive performance than $\varepsilon 4$ negative individuals. The aim of this study was to examine whether the ApoE $\varepsilon 4$ allele was a predictor of cognitive functioning, especially memory, in African-American $\mathrm{AD}$ patients newly diagnosed with probable $\mathrm{AD}$. The sample was made up of 65 newly diagnosed African-American patients with probable AD, participating in a NIA funded Alzheimer's Disease Center Registry study. The mean age was $77.1(\mathrm{SD}=6.9)$ and mean educational level was $9.4(\mathrm{SD}=4.0)$. The average years of dementia was $3.25(\mathrm{~N}=$ $60, \mathrm{SD}=2.40$ ). Seventy percent of the patients were ApoE $\varepsilon 4$ positive patients, whereas $29 \%$ of patients were ApoE $\varepsilon 4$ negative. There was no significant difference between the two population variances, except for vascular risk $(n=51,78.5 \%)$. The proportion of the outcome variables explained by predictor variables was generally small. Essentially, ApoE $\varepsilon 4$ score was significantly $(p<.04)$ associated with design copying (CERAD Praxis subtest), but other significant relationships were not observed with positive $\varepsilon 4$ status. These preliminary findings suggest that the ApoE $\varepsilon 4$ allele is not significantly predictive of cognitive functioning in African-Americans once they are diagnosed with $\mathrm{AD}$, at least on initial neuropsychological testing.

Correspondence: David L. Mount, Psy.D., Health Psychology, University of Missouri-Columbia, 38 Broadway Village Dr. Apt G, Columbia, MO 65201.E-mail:MountD@health.missouri.edu

\section{K.K. GROHMAN, W. FALS-STEWART \& M. BATES. COGNITIVE "REHABILITATION" WITH NEUROPSYCHOLOGICALLY INTACT SUBSTANCE ABUSERS .}

During the last 2 decades, several neuropsychological studies of individuals entering treatment for substance abuse have found that roughly one-third to one-half of these patients have measurable cognitive impairment. In addition, some investigations have also found a relationship between the cognitive status of these patients and indicators of treatment response and outcome; more specifically, impaired patients tend to be less participatory in treatment, and are more likely to violate program rules, be removed from residential treatment due to program rule violations, and use alcohol and other drugs more frequently after treatment discharge. Recently, some investigators have used cognitive rehabilitation exercises to accelerate the rate of cognitive recovery of impaired patients in substance abuse treatment, which, in turn, has led to improved treatment response. However, it is also plausible that cognitive rehabilitation could have a positive impact on all patients, regardless of cognitive status. In this investigation, we tested this hypothesis by randomly assigning substance-abusing patients in a residential treatment program with no evidence of cognitive impairment $(\mathbf{N}=120)$ to one of three conditions: (a) computer-assisted cognitive rehabilitation: (b) a computer-assisted typing tutorial; or (c) treatment as usual. Although we found no difference in terms of changes on a neuropsycho- logical test battery (perhaps due to ceiling effects), patients who received cognitive rehabilitation scored higher on indicators of treatment response (e.g., staff ratings, following program rules, remaining in treatment longer), and had better substance use outcomes during a 1-year posttreatment follow-up period.

Correspondence: Kerry Grohman, Ph.D., The Research Institute on Addictions, 1021 Main St, Buffalo, NY 14203.E-mail:grohman@ria. buffalo.edu

\section{P.J. MCNAMARA, B. MCGEENEY, A. BROWN, E. BENSON, A. SPIRO \& M.L. ALBERT. MEMORY RETRIEVAL, CHRONIC PAIN, AND FRONTAL SYSTEM FUNCTION.}

Objective: To assess 'observer' vs. 'field' memory retrieval preferences in patients with chronic pain, and to test the following predictions: persons who adopt the field perspective will report greater current pain relative to those who adopt the observer perspective and will evince poorer frontal system functioning, as measured by executive functioning tests. Methods: Sixty-one patients with chronic pain were asked to 1) recall a painful memory, 2) indicate whether they saw themselves in the memory (observer retrieval) or re-experienced events of the memory from the first person perspective (field retrieval), and 3) rate various phenomenologic properties of the memory. Twenty of these pain patients were also given the Stroop interference test, and the Tower of London executive function test to examine putative frontal system correlates of memory retrieval preferences. Results: Sixty percent $(60 \%)$ of patients reported observer memories. Observer memories were rated as more important and more often dreamt about than field memories. Retrieval of field memories was associated with higher present pain intensity scores, non-right-handedness and poorer performance on the Stroop and Tower of London tests. Discussion: Patients with chronic pain who adopt a field retrieval strategy when recalling painful memories may experience greater current pain severity than chronic pain patients who adopt observer retrieval strategies. Those adopting field retrieval strategies may also evidence frontal system dysfunction. Correspondence: Ariel Brown, BA, Research Service, Boston VA Medical Center, Department of Neurology (127), 150 South Huntington Ave., Boston,MA 02459.E-mail:Ariel.Brown@med.va.gov

\section{T.D. PARSONS, K.J. MILLER, N. RASGON, K. VAN HERLE, P.C. WHYBROW \& M.BAUER IMPROVED VERBAL MEMORY AS- SOCIATED WITH HYPOTHYROID TREATMENT.}

The thyroid produces hormones that regulate metabolism, mood, behavior, and cognition. The effect of hypothyroidism on adult cognitive function is a widely studied and controversial topic. Recent research suggests hypothyroidism is associated with a decrement in delayed recall of verbal information but not in other objective measures of cognition (Burmeister et al., 2001). In our study 24 individuals (14 hypothyroidism group; 10 control group) participated in an experiment designed to assess both the effect of hypothyroidism and hypothyroid treatment on cognitive function. As part of this project a standard neuropsychological battery was administered. Although verbal group effects were found between the hypothyroid and control groups, they were limited to verbal memory retrieval on the California Verbal Learning Test (CVLT). On Short Delay Free Recall $(p=.01)$, Long Delay Free Recall $(p=.05)$ and Long Delay Cued Recall $(p=.01)$, significant differences remained between groups despite the limited statistical power of this study. Contrariwise, there were no significant results found between hypothyroidism and control groups on attentional or nonverbal verbal tasks. When assessing the effects of hypothyroid treatment, results revealed increased performance on the CVLT Short Delay Free Recall $(p$ $=.01)$, Long Delay Free Recall $(\mathrm{p}=.05)$, and Long Delay Cued Recall $(p=.01)$. No practice effects were found. There were no significant differences between the control group and the treated hypothyroid group at time two of testing. In this study data from time one revealed that 
hypothyroidism was associated with decrements in recent verbal memory, particularly the recall of information after a delay. This data suggests that hypothyroid related memory deficits are not due to an attentional deficit, but retrieval deficits. These results also revealed a facilitative effect for hypothyroid treatment, indicating that verbal memory deficits resolve after treatment.

Correspondence: Thomas D. Parsons, PhD candidate, Rush-Presbyterian-St. Luke, 376 Vinings Drive, Bloomingdale, IL 60108. E-mail: tparsons@mednet.ucla.edu

\section{M.S. MARQUART, M.A. YOUNG \& N.H. PLISKIN. METAMEMORY IN ELECTRICAL INJURY PATIENTS: IMPACT OF DEPRESSIVE SYMPTOMS AND EXECUTIVE FUNCTION.}

Electrical injury (EI) patients endorse more physical, cognitive and emotional symptoms than age and educated matched controls with no history of an EI. These complaints are unrelated to injury parameters such as voltage exposure, current source or the severity of wound size. Performance based measures of cognitive function have found concentration, distractibility and memory deficits. However, EI patients' subjective memory complaints appear discrepant with the actual level of objectively measured memory dysfunction. In other medical populations, depression has been a key factor in the accuracy of self-reported memory problems, or metamemory, with depressed patients frequently overestimating their memory impairment. Conversely, executive dysfunction has been related to underestimation of memory impairment. A group of EI survivors exhibited more verbal memory deficits and higher levels of depressive symptoms than a demographically similar control sample of non-injured electricians. For the EI survivors, depression fully mediated the relationship between verbal memory performance and subjective memory beliefs. Executive dysfunction did not moderate the verbal memory-metamemory relationship.

Correspondence: Melissa S. Marquart, Ph.D., Psychiatry and Behavioral Sciences, Oklahoma University Health Sciences Center, 920 Stanton L. Young Blvd., WP 3440, P.O. Box 26901, Oklahoma City, OK 73104.E-mail: marquartmel@hotmail.com

\section{S.T. LIN, L.H. LU, S.C. SU, W.L. HWU, A. HUANG \& W.T. SOONG. NEUROPSYCHOLOGICAL PROFILE OF THREE CASES OF ADRENOLEUKODYSTROPHY.}

Adrenoleukodystrophy (ALD) is a X-linked metabolic disease characterized by accumulation of very long chain fatty acid (VLCFA) in the body and associated with demyelination. The childhood cerebral form of ALD (CCALD) has onset during the first decade of life. Disease progression is rapid and terminates in vegetative state or death. Dietary restriction plus Lorenzo's oil and bone marrow transplantation are potential treatments for CCALD. We describe the neuropsychological profile of three children with CCALD who were at different stages of the disease. The first case was asymptomatic but manifested subtle deficits in frontal functioning. The second case presented with impaired auditory perception, spatial deficit and related involvement of motor and visual skills, but with relatively intact verbal abilities. The last case presented with significant visuospatial, sensorimotor, and abstract reasoning deficits, but with relatively intact reading. The rate of disease progression was remarkably rapid in our last case. From the two latter cases, it is suspected that the rate of disease progression increased once visual processing deficits appear. However, this needs to be ascertained with longitudinal neuropsychological data documenting disease development. Neuropsychological evaluation plays an important role in the decision to pursue bone marrow transplantation. Psychological intervention should focus on supporting the family in dealing with this devastating disease.

Correspondence: Lisa H. Lu, Ph.D., Psychology, National Taiwan University, Roosevelt Rd., Section 4, No.1, Taipei 106, Taiwan. E-mail: lisalu@ntu.edu.tw
W. PERRY, L. MARON, R. HILSABECK, E. ZIEGLER, M. CARLSON \& T. HASSANEIN. NEUROPSYCHOLOGICAL CHARACTERIZATION OF PATIENTS AWAITING LIVER TRANSPLANTATION.

Liver transplantation is a life-saving and radical treatment for advanced chronic liver disease. Patients awaiting transplantation commonly present with cognitive dysfunction and affective disturbance (Hilsabeck et al., 2002). Despite the fact that the neuropsychological sequelae of liver disease is widely recognized, it has not been well characterized. The current study examined the neuropsychological performance of 55 patients (31 males and 24 females) with end stage liver disease seeking liver transplantation at the University of California, San Diego Medical Center. Subjects were administered a battery of tests including the Repeatable Battery for the Assessment of Neuropsychological Status (RBANS), Peabody Picture Vocabulary Test- Revised (PPVT-R), Trail Making Test, Grooved Pegboard and the Controlled Oral Word Association Test. Patients had a mean age of 51 (range 35-67), completed approximately 12.7 (range 5-18) years of education and were predominately right handed $(90 \%)$. The reason for transplant included Hepatitis $\mathrm{C}$ in $38.2 \%$ of cases, alcoholism in $14.5 \%$ and a combination of hepatitis $\mathrm{C}$ and alcoholism in $32.7 \%$ of the cases. Results revealed a significant difference between mean RBANS Total Score $(84.8$; $\mathrm{sd}=$ 15.8) and the PPVT-R (110.7; sd = 30.5), an estimate of premorbid verbal IQ $[\mathrm{t}(29)=-5.54 ; \mathrm{p}<.001]$ suggesting a generalized decline in cognitive functioning. Furthermore, severity and etiology of liver disease were significantly associated with degree of neuropsychological impairment, particularly in the domains of attention and psychomotor speed. Future directions involve evaluating patients post-transplantation to assess the stability of neuropsychological deficits over time. Correspondence: William Perry, Ph.D., Psychiatry, UCSD, UCSD Medical Center, 200 West Arbor Drive, San Diego, CA 92103-8218. E-mail: wperry@ucsd.edu

\section{L.C. BUTTERFIELD \& P.J. SHAPIRO. COGNITIVE COM- PLAINTS, COGNITIVE PERFORMANCE, AND PSYCHOLOGICAL DISTRESS AMONG MEN WITH GENITOURINARY CANCERS.}

Self-reports of subtle cognitive difficulties are common among cancer patients and may persist years after treatment completion. However, it is difficult to determine whether such complaints represent actual cognitive decline or reflect psychological distress associated with cancer diagnosis and treatment. Although previous studies have found actual cognitive decline among breast, lung, and lymphoma patients, there has been a notable lack of attention to cognitive function among men diagnosed and treated for genitourinary cancers. We examined subjective cognitive function, objective neurocognitive performance, and psychological distress in a pilot sample of men diagnosed with genitourinary cancers $(n=21)$. The sample consisted of prostate cancer $(P C)$ patients $(\mathrm{n}=6)$ and testicular cancer $(\mathrm{TC})$ survivors $(\mathrm{n}=15)$. Subjective cognitive function was measured with the Self-Rating Scale of Memory Function (Squire, Wetzel \& Slater, 1979), objective cognitive performance was assessed with a standard neurocognitive battery, and psychological distress was assessed using the Hopkins Symptom Checklist-25. Results show significant within-person functional deficits in verbal memory and fluency, mental flexibility, and visual processing (all ps <.05). Subjective cognitive function was associated with increased psychological distress $(r=-.613)$, with clinically distressed men reporting the greatest cognitive impairment $(p=.01)$. Subjective cognitive function was not associated with objective performance. Although men with genitourinary cancers do experience cognitive decline, cognitive complaints are more likely to indicate the presence of psychological distress. Self-ratings are not an adequate predictor of cognitive impairment and should not be used as the primary means to identify men with cognitive decline. Correspondence: London C. Butterfield, BA, Psychiatry, University of Pennsylvania, 519 S. 41st St., Apt. 1R, Philadelphia, PA 19104. E-mail: londonbutterfield@hotmail.com 


\section{S. LLANES, I. TORRES, J. ROESKE, A. MUNDT, S. KEEDY \& S. ZAKOWSKI. TEMPORAL LOBE RADIATION AND MEMORY IN ADULT BRAIN TUMOR PATIENTS.}

Partial brain radiotherapy (RT) is associated with memory deficits in the context of intact general intellectual functions in adult brain tumor patients during an early-delayed phase (Armstrong, et al., 2000; Torres et al., 2003). However, few prospective studies exist, and no studies have evaluated the relationship between memory and RT dose to specific brain regions. We utilized neuroimaging and computer software to quantify temporal lobe RT doses, and assessed verbal and visuospatial memory pre-RT and 7 weeks post-RT to examine RT effects on memory and its neuroanatomical basis in adult low-grade brain tumor patients treated with RT. Results show intact cognitive functions for these patients, and suggest relative verbal (but not visual) delayed memory declines at an early-delayed post-RT phase $(\mathrm{p}<.05)$; however, interpretation of these data is limited without a control group. Principal hypotheses were not supported: left- and right- TL RT dose did not predict residualized change in verbal or visuospatial delayed memory. Notably, left TL RT was moderately correlated $(\mathrm{r}=-.22)$ with residualized change in delayed story memory post RT, although statistical power was inadequate. Patients with hypothalamic-pituitary disease and left hemisphere tumors tended to show lower delayed verbal memory after RT. Fatigue and psychological distress also showed moderate correlations with delayed verbal memory $(r=-.24$ to -.61$)$ post RT. Like prior research, results suggest verbal memory declines during an earlydelayed RT phase. These data also highlight the potential influence of additional disease characteristics, emotional functions, and fatigue in this line of research.

Correspondence: Seoni Llanes, Ph.D., ADC, U.C. Davis, 150 Muir Road (127A), Martinez, CA 94553. E-mail: llanesmacy@yahoo.com

\section{S.P. CERCY. A CASE OF INCIDENTAL RADIATION-INDUCED ENCEPHALOPATHY ASSOCIATED WITH THE TREATMENT OF OROPHARYNGEAL SQUAMOUS CELL CARCINOMA.}

A 63 year-old man with metastatic squamous cell carcinoma involving the base of the tongue and right cervical lymph nodes was treated with surgical resection followed by radiation therapy (RT). He developed gradually progressive memory problems about $1 \frac{1 / 2}{2}$ years following completion of a standard course of RT consisting of 40 fractions distributed over a 16-week period for a total of $72 \mathrm{~Gy}$ (7200 rads) delivered to the primary lesion via left and right lateral upper neck ports, and an additional $45 \mathrm{~Gy}$ delivered to the lower anterior neck. Neurological examination, laboratory studies, and CT of the head were unremarkable. Neuropsychological evaluation elicited circumscribed impairments of visuospatial processing and visual memory, suggesting dysfunction of posterior hemispheres. Subsequent MRI of the brain was within normal limits but SPECT showed hypoperfusion of the left parietal region. The most plausible explanation for the patient's cognitive deficits is incidental radiation-induced encephalopathy. Whereas the cognitive effects of whole-brain irradiation for the prophylaxis and treatment of primary and metastatic brain tumors are well recognized, evidence from the research literature indicates that the potential for cognitive dysfunction attributable to incidental cranial irradiation from treatment of extraparenchymal neoplasms is clearly under-appreciated.

Correspondence: Steven P. Cercy, Ph.D., Psychology Division, New York Veterans Affairs Medical Center, Room 2656, 423 E 23rd Street, New York, NY 10010.E-mail: steven.cercy@med.va.gov

\section{J.M. FAIRBANKS, J. EVANS, T. VENTURA, R. SEYOUM \& K. MILLER. COGNITIVE FUNCTIONING IN BREAST CANCER PATIENTS AS A FUNCTION OF TREATMENT: A LONGITUDINAL ANALYSIS.}

In recent years, the effects of chemotherapy on cognitive functioning have received increased attention. Cross-sectional studies have indicated that adjuvant chemotherapy may have deleterious effects on cognitive functioning. A longitudinal study, assessing breast cancer patients was conducted to examine the effects of adjuvant chemotherapy on cognitive functioning. Thirty-three chemotherapy and 24 breast cancer patients not receiving chemotherapy were assessed prior to the first cycle of chemotherapy and later at follow-up. The average time between the completion of chemotherapy and follow-up was approximately 8 months. Participants were predominantly Caucasian, well-educated (14.9 years) and approximately 50 years in age. At baseline, no significant differences between groups were found on cognitive measures. Self-report measures of anxiety and depression revealed moderate levels of psychological distress. The chemotherapy participants reported significantly higher levels of state anxiety than the non-chemotherapy participants. Among the chemotherapy group, no correlations were found between psychological distress and cognitive performance. Forty-four participants (25 chemotherapy and 19 non-chemotherapy participants) completed the follow-up assessment. Results of repeated measures multivariate analyses of variance (MANOVAS) found no differences in cognitive performance, with the exception of a measure of executive functioning. Compared to the comparison participants, the chemotherapy participants failed to demonstrate a practice effect or improvement in performance on the Wisconsin Card Sorting Task. Overall, these results do not replicate earlier findings from cross-sectional studies, which suggested that chemotherapy utilization is associated with a decline in cognitive functioning.

Correspondence: Joy M. Fairbanks, M.S., Psychology, IUPUI, 708 E. 11th St. Apt 9, Indianapolis, IN 46202.E-mail: jmfairba@iupui.edu

\section{ANDERSON-HANLEY, D. EVERT, K. PAGE, K. OSMOND, J. OPPENHEIM, P. MILLER \& R. SPONZO. NEUROPSYCHOLOGICAL EFFECTS OF HORMONAL TREAT- MENTS FOR CANCER: A PILOT STUDY.}

Research indicates that detrimental neuropsychological effects can result from treatments for cancer (see meta-analytic results by AndersonHanley et al., in press). Less is known about the effects of newer hormonal treatments. In this pilot study two samples were utilized to clarify what, if any effect hormonal treatments might have on neuropsychological function. A sample of breast cancer patients ( $n=9$ ) was evaluated prior to and after discontinuation of a five-year hormonal treatment (Tamoxifen). A sample of prostate cancer patients $(n=6)$ was evaluated before and after starting treatments. Participants completed a battery of tests including: Trails A and B, Digit Span, Digit Symbol, RAVLT, Rey-O, Stroop, and Grooved Pegboard. Covariates were ruled out (e.g., depression). Performance was reassessed (using alternate forms where available) approximately three months post-withdrawal from Tamoxifen in the breast cancer sample, and three months after starting treatment in the prostate cancer sample. Statistically significant changes were found in the breast cancer sample, suggesting that discontinuing the hormonal treatment may have led to beneficial effects (i.e., in attention, working memory, and visuospatial memory; $p=.01, .02$, and .04 , respectively). In contrast, statistically significant changes were found in the prostate cancer sample suggesting that beginning hormonal treatment may have led to beneficial effects (i.e., in working memory and verbal memory; $\mathrm{p}=.05$ and .09 , respectively). Our findings are consistent with those of Paganini-Hill and Clark (2000), but contrast with Green and colleagues (2002); further study is recommended. Correspondence: Cay Anderson-Hanley, PhD, Psychology, Skidmore College, Dept. of Psychology, North Broadway, Saratoga Springs, NY 12866.E-mail: chanley@skidmore.edu

\section{J.S. WEFEL \& C.A. MEYERS. TAMOXIFEN ASSOCIATED NEU- ROTOXICITY IN WOMEN WITH BREAST CANCER.}

Tamoxifen (TAM) is a widely used selective estrogen receptor modulator for the treatment of early breast cancer. It is known to have both agonist and antagonist effects in the periphery and has been ascribed mainly 
antagonist effects in the brain. It has also been reported to influence production of several pro-inflammatory cytokines that are associated with cognitive dysfunction. Information regarding the potential neurotoxicity (i.e., cognitive dysfunction) of this therapy is of great clinical importance given that women with early breast cancer are expected to survive their illness and to live productive lives for many years. The current report summarizes results from an interim analysis of a longitudinal investigation that assessed 18 women both prior to initiating TAM therapy and after approximately 4.7 months on treatment utilizing a comprehensive neuropsychological battery of cognitive tests, mood, and quality of life measures. Additionally, 14 women at baseline and 9 women at follow-up provided serum specimens for cytokinetic (interleukin-1 $\beta$. interleukin- 6 , tumor necrosis factor- $\alpha$, interferon- $\gamma$ ) and hormonal (estradiol, cortisol) analysis. Results of the current investigation indicate a $56 \%$ incidence of neurotoxicity consisting of memory, executive, and motor dysfunction associated with increased affective distress, decreased QOL, and diminished ability to maintain productive activities (i.e., level of work). The development of neurotoxicity did not appear related to either baseline levels of cytokines or changes in cytokine concentration in the manner hypothesized. However, both suspected lifetime estradiol exposure and current concentrations of estradiol appeared to be related to neurotoxicity.

Correspondence: Jeffrey S. Wefel, Ph.D., Department of Neuro-Oncology, U.T. M.D. Anderson Cancer Center, 1515 Holcombe Blvd, Unit 431, Houston, TX 77030.E-mail: jwefel@mdanderson.org

\section{S.K. LAGEMAN. COGNITION IN BREAST CANCER PATIENTS.}

Cancer patients often report impaired cognition following their treatments, however, the extent and long-term nature of changes in cognition have not been systematically studied and premorbid assessments have not been conducted. The present study longitudinally investigated changes in cognition related to breast cancer treatments. Patients with Stages I-III breast cancer receiving standard adjuvant treatments (chemotherapy, radiation, and endocrine therapies) completed a neuropsychological battery before, during, and after their treatments. The testing battery consists of standardized neuropsychological tests designed to assess verbal and spatial memory, attention, concentration, mental flexibility, and inhibition. Questionnaires were administered to assess depression, anxiety, and cancer-related symptoms including fatigue, all known to impact cognitive performance. Preliminary data from twenty patients suggest mild performance deficits on neuropsychological tests sensitive to frontal lobe dysfunction among those receiving chemotherapy and radiation therapy. More specifically, error analyses of Trailmaking Tests A \& B, Stroop Test (interference condition), and Hopkins Verbal Learning Test provide additional characterization of the cognitive impairments expressed by a subset of breast cancer patients who received chemotherapy or radiation therapy in a variety of domains including memory, mental flexibility, and inhibition. Future plans include assessment of a healthy comparison group of age and education-matched women to determine the effects of repeated testing on performance. Systematic research concerning the neuropsychological consequences of breast cancer treatments has the potential to enhance the functional outcome of women receiving breast cancer treatments. Supported by the P.A. Foote Small Grants Program at the University of Florida (PI: Sarah Lageman, M.S.) and the University of Florida Opportunity Grant 2002 (PI: Eileen Fennell, Ph.D.).

Correspondence: Sarah K. Lageman, M.S., Clinical and Health Psychology, University of Florida, P.O. Box 100165, HPNP Building, Gainesville,FL32610-0165.E-mail: slageman@hp.ufl.edu

\section{J.S. WEFEL \& C.A. MEYERS. “CHEMOBRAIN?" PRE- CHEMOTHERAPY COGNITIVE IMPAIRMENT IN WOMEN WITH BREAST CANCER.}

Chemotherapy induced cognitive dysfunction in breast cancer patients has been previously described. However, these studies assessed only patients' post-chemotherapy cognitive functioning and thus may not accurately reflect changes in cognitive function associated with systemic chemotherapy. We evaluated neuropsychological function in 84 women prior to receiving adjuvant therapy for non-metastatic primary breast cancer. Prior to initiating systemic therapy, $35 \%$ of women in this sample demonstrated cognitive impairment. Verbal learning $(18 \%)$ and memory functions $(25 \%)$ were impaired significantly more frequently than normative expectations. Although not significant, nonverbal memory $(17 \%)$, psychomotor processing speed and attention (13\%), confrontational naming $(13 \%)$, visuoconstruction $(13 \%)$, and upper extremity fine motor dexterity $(12 \%)$ were more frequently impaired in our sample than expected. Mood disturbance was associated with only one marker variable in the domain of executive function and less than half of all patients who were classified as cognitively impaired endorsed significant affective distress. Thus, mood disturbance and cognitive impairment co-occurred, but mood disturbance was not a causal factor in the observed cognitive impairment. Menopausal status and HRT use were not related to cognitive impairment.

Correspondence: Jeffrey S. Wefel, Ph.D., Department of Neuro-Oncology, U.T. M.D. Anderson Cancer Center, 1515 Holcombe Blvd, Unit 431, Houston, TX 77030. E-mail: jwefel@mdanderson.org

\section{D.F. TATE, R. PAUL, J. GUNSTAD, A. JEFFERSON, A. BRICK- MAN \& R. COHEN. WHITE MATTER HYPERINTENSITIES, AT- TENTION, AND EXECUTIVE FUNCTIONING IN CHRONIC CAR- DIOVASCULAR DISEASE.}

Background: Patients experiencing chronic cardiovascular disease are at increased risk for developing significant cerebrovascular disease and dementia. However, few studies have examined neuroimaging markers of mild to moderate cerebrovascular disease and cognitive dysfunction in this population. Objective: The purpose of this study was to investigate the neuroimaging and neuropsychological correlates in a group of patients with chronic cardiovascular disease who were not demented. Methods: Participants included 17 men and 2 women with a mean age of 69.3 years $(\mathrm{SD}=9.7), 14.3$ years of education $(\mathrm{SD}=3.2)$, and an average MMSE score of $28.6(\mathrm{SD}=1.9)$. Each of the participants underwent FLAIR MR imaging and were administered a battery of neuropsychological tests. Subcortical and periventricular hyperintensities $(\mathrm{WMH})$ were quantified. Measures of WMH were then used to predict neuropsychological outcome on several measures of attention and executive functioning. Results: Analyses of the attention and executive neuropsychological domains revealed moderate relationships between periventricular hyperintensities and measures of executive functioning (Trails A, $\mathrm{R}^{2}=.32$; Letter Cancellation, $\mathrm{R}^{2}=.28$; Trails $\mathrm{B}, \mathrm{R}^{2}=.52$; Stroop Color/Word, $\left.\mathrm{R}^{2}=.30\right)$ whereas subcortical hyperintensities were not significantly related (Trails $\mathrm{A}, \mathrm{R}^{2}<.01$; Letter Cancellation, $\mathrm{R}^{2}<$ .01; Trails B, $\mathrm{R}^{2}<.01$; Stroop Color/Word $\left.\mathrm{R}^{2}=.02\right)$. Conclusions: These findings confirm recent findings in the stroke literature and are likely due to the disruption of long integrative network connections in the periventricular region.

Correspondence: David F. Tate, Ph.D., Brown University Medical School, 1 Hoppin Street, Providence, RI 02903.E-mail:David_Tate@Brown.edu

\section{E. GREEN, L. GRANDE, W. MCMULLEN, J. LEACH, J. RUDOLPH, M. BERGMANN, S. LEVKOFF \& E. MARCANTO- NIO. PREOPERATIVE NEUROPSYCHOLOGICAL TEST MEAS- URES ARE ASSOCIATED WITH POSTOPERATIVE DELIRIUM IN OLDER PATIENTS UNDERGOING CORONARY ARTERY BYPASS GRAFT (CABG) SURGERY.}

Objective: This study was performed to determine if preoperative neuropsychological test measures are associated with postoperative delirium after coronary artery bypass graft (CABG) surgery. Design: Prospective cohort study. Setting: Cardiothoracic surgery service at Beth Israel Deaconess Medical Center, Boston, Massachusetts. Patients: Thirty-eight patients aged 65 years or older undergoing urgent CABG surgery or 
CABG and simultaneous valve surgery. Measurements: All patients underwent preoperative assessments that included age, gender, education, Beck Anxiety Scale and a neuropsychological battery of thirteen measures assessing seven cognitive domains. Postoperative delirium was assessed using a standardized interview that included the MMSE, Digit Span, and Delirium Symptom Interview. Delirium was diagnosed using the Confusion Assessment Method Diagnostic Algorithm. Results: The mean age of the population was 76.2 years (range 66-90) with $79 \%$ being male. Twenty-one of the 38 patients (55\%) developed postoperative delirium. Delirium was associated with age, but not with gender, education or preoperative anxiety; therefore subsequent models were adjusted for age alone. The measures with the strongest association with postoperative delirium were (mean score in delirious, mean score in nondelirious, adjusted p-value): HVLT learning $(15.7 \pm 2.9,20.5 \pm 4.7, \mathrm{p}$ $=0.002)$ Digit Span backwards $(5.1 \pm 1.9,6.4 \pm 1.7, p=0.038)$, letter fluency $(30.4 \pm 10.2,40.9 \pm 13.5, p=0.020)$ and category fluency $(26.3 \pm 4.6,33.4 \pm 7.2, p=0.003)$. Conclusion: Preoperative measures of attention, learning and executive functioning are strongly associated with delirium after cardiac surgery. If confirmed in our larger sample, our preliminary findings suggest that these neuropsychological measures may be helpful in identifying patients at risk for developing delirium after CABG surgery.

Correspondence: Emily Green, Gerontology, Beth Israel Deaconess Medical Center, 185 Pilgrim Road, Palmer 117, Boston, MA 02215. E-mail: egreen1@bidmc.harvard.edu

\section{M.E. ZIMMERMAN \& M.S. ALOIA. GENDER DIFFERENCES IN THE RELATIONSHIP BETWEEN CEREBROVASCULAR DISEASE RISK FACTORS AND LEUKOARAIOSIS IN OLDER ADULTS.}

OBJECTIVE: Leukoaraiosis, or white matter disease, has been shown to be associated with an increased risk of stroke and vascular-related death. Furthermore, high blood pressure (BP) is a well-known risk factor for cerebrovascular disease, cognitive impairment, and dementia. Evidence has shown that gender differences exist in both the pathophysiology and incidence of cerebrovascular disease, with men exhibiting an increased prevalence of the disease. The objective of the current study was to assess the degree to which the relationship between BP and leukoaraiosis differs by gender in older adults. METHODS: We applied qualitative image analysis techniques to MRI data from the Cardiovascular Health Study (CHS) to identify periventricular hyperintensities (PH) and deep white matter subcortical hyperintensities (SH) on T2-weighted MRI brain images in 15 men and 12 women. The CHS is a community-based study of the prevalence of cardiovascular and cerebrovascular disease in older adults. RESULTS: Pearson correlation coefficients revealed significant association between BP and PH $(r=$ $0.53, \mathrm{p}<0.04)$ and BP and SH $(\mathrm{r}=0.55, \mathrm{p}<0.03)$ in men, but no such relationships in women $(r=-0.08, p<0.80 ; r=0.14, p<0.66$, respectively). CONCLUSIONS: Our findings suggest that gender differences exist in the relationship between BP, a potent risk factor for cerebrovascular disease, and leukoaraiosis in older adults. The presence of gender differences in this relationship may have important implications for the examination of cognitive functioning in individuals with cerebrovascular disease.

Correspondence: Molly E. Zimmerman, M.A., Psychiatry and Human Behavior, Brown University, Brown University, Box G-BH Psychology Training, Providence,RI 02912.E-mail:Molly_Zimmerman@Brown.edu

\section{R.F. KAPLAN \& I. ESTERLIS. PREDICATING REPORTED MEM- ORY LOSS IN POST TREATMENT LYME DISEASE.}

Lyme disease, caused by the tick borne spirochete, B. burgdoferi, has been associated with a number of chronic neurologic syndromes. For most patients, Lyme disease is successfully treated. However, a small percentage of patients report persistent symptoms, including memory loss, after standard antibiotic therapy. In patients with a positive serology to B. burgdorferi and abnormal cerebral spinal fluid, neuropsycho- logical testing typically shows mild memory problems. However, for patients with self-reported neurocognitive symptoms without other evidence of persistent infection, the results of neuropsychological testing are usually normal. To determine what attributes predicted self-reported memory disturbance, we studied 127 patients with previously treated documented Lyme disease. Symptom severity was measured from the SF-36 Health Survey. Attention and memory were assessed using the Auditory Verbal Learning Test, Benton Visual Retention Test, Symbol Digit Test and California Computerized Assessment Package. Mood was assessed using the Beck Depression Inventory (BDI) and MMPI-2. A forward stepwise regression analysis was computed with self-reported forgetfulness as the dependent variable, and age, education, symptom severity, neuropsychological test scores and mood scores as predictor variables. Higher BDI scores together with greater pain and fatigue predicted increased self-reported forgetfulness $(\mathrm{R} 2=.274, \mathrm{p}=.043)$. Neuropsychological test scores did not $(p>.10)$ increase prediction. These data suggest that depression and somatic symptoms are associated with perceived memory loss and have implications for other disorders, such as fibromyalgia, in which memory complaints are common.

Correspondence: Richard F. Kaplan, PhD, Psychiatry, UConn Health Center, 263 Farmington Avenue, Farmington, CT 06030. E-mail: kaplan@psychiatry.uchc.edu

\section{B.D. HOYT, B.J. MAKE, C.F. EMERY \& E. KOZORA. CLUSTERING AND SWITCHING IN VERBAL FLUENCY PERFOR- MANCE OF EMPHYSEMA PATIENTS.}

This study examined two components of phonemic and semantic verbal fluency performance (clustering and switching) in patients with moderate emphysema. Participants included 100 adults with emphysema and 25 healthy controls. Groups differences were nonsignificant for age, education, and gender. Due to suspected effects of hypoxemia, it was hypothesized that subjects with emphysema would generate fewer words on the phonemic fluency task and would exhibit a reduction in switching on both tasks relative to controls. Consistent with hypotheses, emphysema patients performed more poorly than controls on phonemic fluency $(\mathrm{p}<.01)$ and at a similar level to controls on semantic fluency ( $p>05)$. Hypotheses regarding the role of switching in verbal fluency performance were partially supported, as emphysema patients exhibited reduced switching compared to controls on the phonemic fluency task $(p<.01)$, but not on the semantic fluency task ( $>>05)$. Group differences in clustering were nonsignificant for both verbal fluency measures. Emphysema patients exhibited a similar pattern of verbal fluency performance to that observed in patients with frontal lobe lesions (Troyer et al., 1998), Huntingtons disease (Rich et al., 1999), and Parkinsons disease (Troyer et al., 1998). The verbal fluency performance of the emphysema patients in this study was also consistent with that observed in Parkinsons disease patients following pallidotomy (Troster et al., 2002; York et al., 2003). These findings support the hypothesis that hypoxemia-induced changes in cognitive function in emphysema are associated with disrupted functioning of the frontal lobes and/or associated frontal-subcortical circuits. This abstract was funded by the National Heart, Lung, and Blood Institute of the National Institutes of Health Grant R01-HL63761-01.

Correspondence: Brian D. Hoyt, Ph.D., National Jewish Medical and Research Center, 1400 Jackson St., Room A103, Denver, CO 80206. Email:HoytB@NJC.org.

\section{K.J. MILLER. COGNITIVE IMPAIRMENT ASSOCIATED WITH SLEEP APNEA: A DIFFERENTIAL DIAGNOSIS FOR ADULTS PRE- SENTING WITH MEMORY COMPLAINTS AND/OR INATTENTION. Objective: The proportion of people affected by obstructive sleep apnea syndrome (OSAS) increases with age, affecting more than $30 \%$ of older adults ( 65 and older). OSAS is characterized by excessive daytime sleepi- ness, nocturnal sleep disturbance, multiple emotional and psychosocial}


sequelae, and cognitive deficits. In current literature there is a controversy regarding the extent in which cognitive deficits are associated with daytime sleepiness or hypoxemia and the variable results that continuous positive airway pressure (CPAP) treatment has on cognitive impairments. Methods: Literature regarding clinical polysomnographic criteria for OSAS and cognitive impairment is presented. In particular this paper focuses on the neuropsychological impairment that is associated with sleep apnea, namely in the domains of: attention, memory, executive skills, and visual spatial functioning. Case studies illustrate these deficits in adults, who complain of memory impairment and/or inattention. Results: The neuropsychological data and medical histories for these cases are presented in order to better illuminate the need for differential diagnosis in patients who suffer from sleep apnea. These cases illustrate the how sleep apnea impacts emotional functioning, attention, and executive skills, which in turn impacts memory. Conclusions: This paper highlights how cognitive impairment due to sleep apnea may be misdiagnosed as dementia or Attention Deficit Disorder. The complexity of cognitive impairments that are associated with OSAS make it difficult for a clinician to properly diagnosis a patient, unless the etiology of sleep apnea is better understood. This paper highlights the etiology of sleep apnea and its impact on neuropsychological functioning. Correspondence: Karen J. Miller, Ph.D., NPI, UCLA Medical Center, Suite 88-201, 760 Westwood Plaza, Los Angeles, CA 90024. E-mail: kmiller@mednet.ucla.edu

\section{M.E. ZIMMERMAN \& M.S. ALOIA. SLEEP APNEA AND SUBCOR- TICAL HYPERINTENSITIES IN A COHORT OF OLDER ADULTS.}

OBJECTIVE: Subcortical hyperintensities (SH) on brain MRI may reflect microvascular disease. SH has been related to both cognitive dysfunction and impairments in tasks of daily living in older adults. Strong correlates of this radiological finding include age and blood pressure (BP). Sleep apnea syndrome (SAS) increases with age and results in elevated BP. The contribution of SAS to SH has not been studied independent of the effects of age and BP, which was the objective of this study. METHODS: We applied quantitative image analysis techniques to MRI data from an epidemiological data set of older adults with both MRIs and sleep studies. T2-weighted MRI brain images and sleep studies were examined in 27 older adults. Data were obtained from two groups of participants, matched on age and systolic blood pressure. The groups differed in the degree to which they exhibited events of apnea during an at-home sleep study. The apnea group had an average respiratory disturbance index (RDI; number of cessations of breathing per hour of sleep) of 54.6 (6.33), suggestive of severe sleep apnea. The control group had an RDI of 3.89 (2.50), well within the normal range for older adults. The apnea group showed a trend toward a greater prevalence of SH $(t=1.33, d=0.53)$, despite being no different in age and BP. CONCLUSIONS: Although elevated BP may serve as the mechanism for the development of SH in SAS, our findings suggest that SAS may contribute independently to the development of SH.

Correspondence: Molly E. Zimmerman, M.A., Psychiatry and Human Behavior, Brown University, Brown University, Box G-BH Psychology Training, Providence, RI 02912.E-mail:Molly_Zimmerman@Brown.edu

\section{J.N. HOOK, B. GIORDANI, M. STARKMAN, S. LANGENECKER, D.E. SCHTEINGART \& S. BERENT. NEUROPSYCHOLOGICAL IMPAIRMENTS ASSOCIATED WITH CUSHINGS DISEASE: ARE DEFICITS ON VERBAL TASKS MORE LIKELY? .}

Chronically elevated levels of glucocorticoids, as in Cushings disease (CD), have been found to have deleterious effects on the hippocampus, and thus, have been associated with observed impairments on learning and memory tasks. In CD research, there is some debate as to whether there is greater dysfunction visuospatial or verbal domains. Some researchers have reported greater visuospatial deficits while others have reported more pronounced verbal impairments, when comparing CD patients to controls. We studied a sample of 37 untreated CD patients
$(\mathrm{M}$-age $=42.70, \mathrm{SD}=14.88 ;$ females $=33)$ to investigate the relationship between verbal and visuospatial performance. As part of a larger study, we administered the Wechsler Memory Scale-III Logical Memory (LM) and Visual Reproduction (VR), as well as the Shipley Institute of Living Scale (computing both verbal and nonverbal IQs). Four paired t-tests were used to compare memory and IQ scores between visual and verbal domains. There were no significant differences between the LM versus VR age-corrected scaled scores on immediate recall or percent retention; however, the LM means were lower. Delayed LM scores were significantly lower than VR scores $(p<.05)$. Further the Shipleys verbal IQ was significantly lower than the nonverbal IQ ( $p<.05)$. Results of this study support the emerging body of research which suggests that CD appears to be more associated with deficits on verbal than nonverbal tasks. Furthermore, this finding suggests that chronically elevated levels of glucocorticoids likely affect the hippocampus and may also have a greater impact on left hemisphere associated functions.

Correspondence: Julie N. Hook, Ph.D., Psychiatry, Div of Neuropsychology, University of Michigan Medical Center, C-480 Med Inn Bld, Box, UMHS 1500 E. Medical Center Drive, Ann Arbor, MI 48109-0840. E-mail: jhook@umich.edu

\section{S.A. LANGENECKER, B. GIORDANI, M.N. STARKMAN, J.N. HOOK, D.E. SCHTEINGART \& S. BERENT. AGE EFFECTS OF HYPERCORTISOLEMIA IN CUSHING'S DISORDER:VULNER- ABILITY, PLASTICITY, AND RECOVERY OF FUNCTION.}

Cushing's disease provides an excellent model for understanding the impact of cortisol dysregulation upon limbic structures and cognitive dysfunction because subjects can be studied before and after treatment. To assess the effects of cortisol dysregulation in different age groups, 47 Cushing's disease (CD) patients were divided into three equal groups (M age Young Group $(\mathrm{Y})=23.2$ (5.4), $\mathrm{M}$ age Young-Middle Aged Group $(\mathrm{YM})=35.3$ (2.4), M age Middle-Aged Group $(\mathrm{M})=48.1$ (7.44). The three groups differed in age, but did not differ in education, average plasma cortisol, test-retest interval and estimated duration of illness. The younger age groups appeared to be most adversely affected by CD, for education corrected $\mathrm{z}$ scores on verbal memory (Memory Quotient (MQ); D = -.31 (Y) and -.13 (YM), .8 (M), Working Memory Index WMI; $(\mathrm{D}=-.3(\mathrm{Y}),-.32(\mathrm{YM})$, and $.05(\mathrm{M})$, but not performance IQ (PIQ; all D's $>-.1,<.21)$. Both of the younger groups showed the greatest improvement in MQ $(\mathrm{D}=.65(\mathrm{Y}), .6(\mathrm{YM})$ and $.42(\mathrm{M}))$, compared to the mid-aged group, while the young group showed the greatest improvement in WMI $(\mathrm{D}=.46(\mathrm{Y}), .33(\mathrm{YM}), .32(\mathrm{M}))$. The Middle-Aged Group demonstrated the greatest improvement in PIQ (D = .33 (Y), .34 (YM), and $.49(\mathrm{M})$ ). Older adults may be less vulnerable to the effects of hypercortisolemia, which may partially explain some disparate results of treatment for $\mathrm{CD}$ in the literature. The implications for the assessment and treatment of cortisol dysregulation are discussed.

Correspondence: Scott A. Langenecker, Ph.D., Psychiatry, University of Michigan Health Systems, C480 Med Inn Building, 1500 E. Medical Center Drive, Ann Arbor, MI 48109. E-mail: slangen@umich.edu

\section{M.M. SCHMITT, J.H. BAÑOS \& T.R. ELLIOTT. VERBAL LEARN- ING IN SPINAL CORD INJURY PATIENTS: EFFECTS OF AGE AND TIME SINCE INJURY.}

This study investigates the effects of age and time since injury onset on performance on the Rey Auditory Verbal Learning Test (RAVLT) in 203 individuals with Spinal Cord Injury (SCI) participating in inpatient rehabilitation. Participants were grouped by age (older $\propto 50$ years old, $n$ $=56$; younger $\leqq 39$ years old, $\mathrm{n}=147$ ) and time since injury onset (four weeks or less, $n=110$; greater than four weeks, $n=93$ ). Two by two ANOVAs (age $\mathrm{X}$ time since injury onset) were used to compare raw scores obtained on Trial 1, Trial 5, Trials 1-5 Total, the alternate list, LongDelay Recall, and Recognition False Positives. Results revealed a significant effect of age, with the older group displaying poorer performance than the younger group on all variables. Performance did not differ 
by time since injury, and the interaction term was not a significant predictor for any of these variables. Thus, the age difference in performance is not more pronounced for individuals with SCI who have been injured longer. The lack of significant interaction between time since injury onset and age suggests that experiencing an SCI does not place an individual at risk for experiencing long-term declines in verbal learning and memory beyond those seen in normal aging. Comparisons with normative data by age group yield similar results. There is some suggestion of a trend toward slightly lower performance by SCI patients, which may reflect sample characteristics. However, these differences do not become more pronounced in higher age groups.

Correspondence: Margaret M. Schmitt, M.A., Psychology, University of Alabama at Birmingham, UAB Spain Rehabilitation Center, SRC 530, 1717 6th Avenue South, Birmingham, AL 35249-7330. E-mail: pschmitt@uab.edu

\section{H.B. TRYGGVADOTTIR, M.K. JONSDOTTIR, K. KRISTJANS- SON, D. RYE \& T. SIGMUNDSSON. COGNITIVE FUNCTIONING IN RESTLESS LEGS SYNDROME.}

Background. Restless Legs Syndrome (RLS) is a common disorder which is often either misdiagnosed or underdiagnosed. It's pathophysiology is believed to involve central dopaminergic dysfunction. Patients with other motor syndromes linked to dopamine dysregulation such as Parkinson's disease, Tourette syndrome and attention deficit hyperactivity disorder (ADHD) show deficits on tests of attention and executive functioning. Thus one might postulate that patients with RLS would have similar difficulties but to a lesser extent than those with more serious illnesses. In this study we compared RLS patients to healthy volunteers on tests assessing attention and executive functioning. To our knowledge this is the first neuropsychological study of RLS. Method. Participants were 14 females and five males, with a mean age of 41 years (range 22-55). Sixteen were drug naïve. There were 18 controls matched on age, sex and occupation. Neuropsychological testing focused on planning, selective and sustained attention, flexibility of attention, spatial working memory, verbal fluency and reaction time. Five of the CANTABexpedio computerized tests were used but also more traditional measures (Stroop and verbal fluency). Matrix reasoning and similarities from the WAIS-III, the Epworth sleepiness scale and a quality of life scale were also administered. Results and discussion. The RLS patients performed significantly worse than the healthy controls on tests of verbal fluency, reaction time and sustained and selective attention. There was also a trend towards worse performance on other tests of executive functioning. The RLS group scored significantly higher on the sleepiness scale. These results may be consistent with the hypothesis that the pathophysiology of RLS involves the central dopamine system. This study awaits replication with a larger sample of patients in which daytime sleepiness needs to be ruled out as a causative factor, ideally be using sleep-deprived controls.

Correspondence: Maria K. Jonsdottir, Ph.D., Landspitali-University Hospital, Grensasvegur 62, Reykjavik 108, Iceland. E-mail: marijon@ landspitali.is

\section{J.S. KIXMILLER \& W. RIEMAN. COGNITIVE-BEHAVIORAL DEFICITS IN AN ADULT WITH DANDY-WALKER SYNDROME.}

Dandy Walker Syndrome (DWS) is a rare disorder characterized by congenital malformation of structures in posterior fossa and complete or partial agenesis of cerebellar vermis, cystic dilation of fourth ventricle, and frequently, hydrocephalus. While not yet determined, presence of associated abnormalities is suggestive of an early embryonal developmental disturbance. Mental retardation is commonly associated with this disorder, yet there is little published literature reporting on clinical descriptions of adults with lifelong Dandy-Walker Syndrome. Further, neuropsychological and behavioral characterization is sparse and management issues of associated problems have not been reported. We present cognitive and behavioral data on patient P.H., a middle-aged, African
American woman with Dandy-Walker syndrome since infancy. Neuropsychological evaluation results demonstrate low intellectual functioning along with significant, pervasive cognitive deficits. Further, formal evaluation of behavior (Vineland) as well as ward behavioral sampling observations document severe functional-behavioral deficits (i.e., communication, daily living skills, socialization, motor skills). Neuropsychiatric syndromes (e.g., psychosis, sexual preoccupation) are also described along with medication regimes that have corresponded to psychopharmacologic control of behavioral issues. Further, psychiatric rehabilitation strategies that have worked well in optimizing and sustaining her engagement in a long-term brain injured residential program are reviewed.

Correspondence: Jeffrey S. Kixmiller, Ph.D., UC Davis/VA Martinez, VANCHCS, 116, 150 Muir Road, Martinez, CA 94553. E-mail: jeff. kixmiller@med.va.gov

M. LACY, D. FRIM, T. DO \& C. CHIANG. NEUROCOGNITIVE CORRELATES OF ACUTE CHANGES IN INTERCRANIAL PRESSURE.

Objective: Acute neurocognitive changes as a function of decreased intracranial pressure in a group of hydrocephalic patients pre and post CFS drainage is presented. It is hypothesized that that greatest impact will be seen in the frontal subcortical network, with subtle improvements seen on measures of complex attention, executive functioning, and memory, whereas language, crystallized intelligence, and visuo-spatial processing will remain stable. Methods: 33 patients referred by neurosurgery completed a neuropsychological battery pre and post lumbar drain trial as part of a presurgical shunt workup. Results: Baseline testing revealed diffuse deficits in cognitive processing, evidenced by mild to moderate deficits in immediate and delayed memory, fluency, attention, processing speed, construction, and executive dysfunction. Post testing revealed improved attention/processing speed (Trails B), with a trend of improved immediate memory, complex attention, and cognitive flexibility following a decrease in ICP. We expect delayed improvements and thus six month follow up data will also be presented. In addition, we will present data on 36 hydrocephalics with programmable shunts who underwent testing under 2 conditions: pressure lowered or raised. Conclusions: Current data suggests that a decrease in ICP may improve cognitive functioning in the areas of memory, attention, and cognitive flexibility. Correspondence: Maureen Lacy, Ph.D, Psychiatry Dept, University of Chicago Medical Center, 5837 S. Maryland, Chicago, IL 60637. E-mail: mlacy@yoda.bsd.uchicago.edu

\section{Autoimmune Disorders}

\section{W. RASHIDZADA. AN OBJECTIVE MEASURE OF COGNITIVE FATIGUE.}

Cognitive fatigue refers to a failure to sustain effort over the course of a continuous cognitive task and has been shown to be a major challenge for many individuals diagnosed with chronic fatigue syndrome (CFS). This study was designed to examine cognitive fatigue in people diagnosed with CFS by utilizing an objective method of quantifying cognitive fatigue. Participants were 36 persons with CFS, and 36 age and education matched healthy controls (HC) who completed the Paced Auditory Serial Addition Test (PASAT) as part of a larger neuropsychological battery. The PASAT was scored via the traditional scoring method (total correct) and a dyad scoring method. PASAT trials were broken into first and second half scores to examine the impact of fatigue on performance. Utilizing the traditional scoring method, the PASAT number correct dropped significantly from earlier to later responses within PASAT trials in both groups, quantifying a fatigue effect. However, this cognitive fatigue effect was significantly greater in the HC group in the number of correct responses in each half of the PASAT compared to the CFS group. When cognitive fatigue was examined using dyad scores, both 
groups showed a reduction in the average dyad score from the first to the second half on all PASAT trials. Once again, the HC group had a greater percent drop in the percent dyad score in each half of all the PASAT trials compared to the CFS group. These results indicate that cognitive fatigue can be objectively assessed utilizing the PASAT. Correspondence: Wahid Rashidzada, M.D., Neuroscience and Neuropsychology, Kessler Medical Rehabilitation Research and Education Corp, 1199 Pleasant Valley Way, West Orange, NJ 07052. E-mail: wrashidzada@kmrrec.org

\section{E. KOZORA, M.C. ELLISON \& W. STERLING. PSYCHOMETRIC PROPERTIES OF THE PROPOSED AMERICAN COLLEGE OF RHEUMATOLGOY BRIEF NEUROPSYCHOLOGICAL BATTERY FOR SLE.}

This study aimed to examine the reliability and validity of the proposed American College of Rheumatology (ACR) neuropsychological battery for patients with systemic lupus erythematosus (SLE). METHODS: Thirty-one SLE patients with a history of neuropsychiatric symptoms (NP-SLE), 22 SLE patients without a history of NP symptoms (nonNP-SLE), and 25 healthy controls completed measures of cognition, depression, fatigue, and pain at baseline and one month follow-up. The one-hour proposed ACR-SLE battery (Liang et al., 1999) was compared to a four-hour comprehensive battery (CB) (Kozora et al., 1996). RESULTS: Seven of 12 measures from the ACR-SLE battery were lower in SLE compared to controls. Overall agreement between impairment on the ACR-SLE battery and CB was $90 \%$ using previously defined impairment on the CB and 4 of 12 scores impaired on the ACR-SLE battery. Almost perfect agreement between the two batteries was found for non-NP-SLE and healthy controls (95-96\%) and moderate agreement was reported for NP-SLE (81\%). Intraclass correlation coefficients for ACR-SLE tests ranged from .40 to .90 , indicating adequate reliability. Levels of depression, fatigue, pain and perceived cognitive difficulties were associated with cognitive decline in NP-SLE only. CONCLUSIONS: Reliability and validity of the ACR-SLE battery was established in this study. Agreement regarding classification for impairment was almost perfect for non-NP-SLE and moderate for the NP-SLE patients. The ACR battery is well designed for general classification of cognitive impairment in SLE. However, comprehensive testing may be useful in identifying specific deficits in NP-SLE. Mechanisms underlying depression, pain, and fatigue in SLE may be associated with cognitive dysfunction. Correspondence: Elizabeth Kozora, Ph.D., Medicine, National Jewish Medical and Research Center, 1400 Jackson Street, Denver, CO 80206. E-mail:Kozorae@njc.org

\section{E. KOZORA, M. ELLISON, D. ARCINIEGAS, S. WEST, C. FIL- LEY \& J. SIMON. MRI, MRS AND COGNITIVE ANALYSES IN NON-NP-SLE.}

This study analyzed quantitative MRI, MRS and neuropsychological data in patients with systemic lupus erythematosus without a history of neuropsychiatric disorders (non-NP-SLE). Subjects: Eight non-NP-SLE and 8 healthy controls (matched to the SLE patients based on age, education, gender and ethnicity) were included. SLE patients had a mean age of 43.0 , mean education of $16.1,7$ women, 1 male. The SLE patients had mild disease activity and a mean length of diagnosis of 7.8 months (SD=5.3). Results: The non-NP-SLE patients were significanlty more impaired than controls on auditory attention, visual attention, immediate and delayed visual memory. The NAA/Cr and $\mathrm{Ch} / \mathrm{Cr}$ ratios were determined from normal appearing white matter in the frontal lobes. A significant difference was found between the groups on the $\mathrm{Ch} / \mathrm{Cr}$ ratio $(\mathrm{t}=5.1, \mathrm{p}=0.04)$ SLE patients had a mean score of $1.34(\mathrm{SD}=0.5) \mathrm{com}$ pared to the control subjects who had a mean score of $1.16(\mathrm{SD}=0.6)$. No significant difference was found between the groups on the NAA/Cr level; SLE patients had a mean score of $1.95(\mathrm{SD}=0.7)$ and the control subjects had a mean score of $1.94(\mathrm{SD}=0.06)$. Correlational analyses indicated a trend relationship between $\mathrm{Ch} / \mathrm{Cr}$ and complex attention, au- ditory attention, and visual fluency. No relationship was reported between the NAA/Cr and neuropsychological measures. Elevated $\mathrm{Ch} / \mathrm{Cr}$ has been associated with inflammation, demyelination or gliosis in other populations and may suggest a similar pathologic process in SLE. Quantitative analysis of total brain volume and right and left hippocampal volumes divided by total brain volume (to adjust for brain size) were conducted. No significant differences between our groups were found with this small number of subjects.

Correspondence: Elizabeth Kozora, Ph.D., Medicine, National Jewish Medical and Research Center, 1400 Jackson Street, Denver, CO 80206. E-mail:Kozorae@njc.org.

\section{N. JOHNSON, L. FOWLKES, S. HOROWITZ, J. RODRIGUEZ, W. BARR, R. BURT \& A. TRAYNOR. NEUROPSYCHOLOGICAL CHANGES FOLLOWING HEMATOPOIETIC STEM CELL TRANS- PLANT FOR INTRACTABLE SYSTEMIC LUPUS ERYTHEMATOSUS.} Twenty-five (24 female, 1 male) severely ill subjects, age 16-52, with systemic lupus erythmatosus (SLE) were evaluated neuropsychologically prior to hematopoietic stem cell transplant (HSCT). All subjects had previously failed conventional treatment for SLE including intravenous cyclophosphamide, plasma exchange, oral azathrioprine and chronic glucocorticoid therapy as well as intermittent intravenous methylprednisolone therapy. The following neuropsychological tests were administered to characterize neuropsychological weaknesses. Wechsler Adult Intelligence Scale-Revised Digit Span subtest, Repeatable Battery for the Assessment of Neuropsychological Status (RBANS), Boston Naming Test, F-A-S Test, Trail Making Test, and Wide Range Achievement Test-3 (WRAT-3) Reading subtest. In order to identify areas of impairment at baseline, $\mathrm{z}$-scores were calculated individually for each subject on the basis of age and education-matched normative data for the following areas: attention, memory, language, visuospatial and executive functions. The baseline group demonstrated significant weaknesses on measures of attention (RBANS Attention Index Score; $z=-1.6$ ), executive functions (Trail Making Test Part B; $\mathrm{z}=-1.21$ ), and language (Boston Naming Test; $\mathrm{z}=-2.0)$. Thirteen subjects were available for repeat neuropsychological testing between 3 and 16 -months (mean $=9.8$ months) post HSCT. All patients were free from active lupus at the time of the post-treatment evaluation. A repeated measures ANOVA was used to analyze change in neuropsychological test scores. Significant improvements were noted in executive functions $(p<.01)$, memory $(p<.01)$, and $\operatorname{mood}(\mathrm{p}<.05)$. Although preliminary, these results suggest improvements in neuropsychological functioning in patients with SLE in association with disease remission following HCST.

Correspondence: Nancy Johnson, Ph.D., Cognitive Neurology and Alzheimer's Disease Center, Northwestern University Feinberg School of Medicine, 320 E. Superior, Suite 11-499, Chicago, IL 60611. E-mail: johnson-n@northwestern.edu

\section{A. CLARK, S.L. HOLLIDAY \& R.L. BREY. COGNITION AND MEDICATIONS IN SYSTEMIC LUPUS ERYTHEMATOSUS.}

Systemic lupus erythematosus (SLE) is an auto-immune disease with known central nervous system effects including psychosis, seizures, stroke, mood disorders, and diffuse cognitive impairment. Some have reported detrimental cognitive effects of steroids, while others have not. The cognitive effects of other medications used in SLE have not been rigorously studied. This study investigated the association of prednisone, nonsteroidal anti-inflammatory agents (NSAIDs), hydroxychloroquine, methotrexate, and azathioprine with cognition in a sample of 100 SLE patients. Patients received a standardized medical history, rheumatologic and psychiatric scales, and the Automated Neuropsychological Assessment Metrics (ANAM) every four months for three years. A SPSS mixed model analysis was used to assess the main effects of medications on ANAM performance, while controlling for depression, SLE disease activity, repeated testing, and education. Mean throughput scores from all ANAM subtests (number of correct responses per minute), was 
the dependent variable. Normative data from 60 neurologically-intact controls stratified by three age groups was used to compute T-scores for mean throughput. Results indicated that use of aspirin $(\mathrm{p}=.000)$ and NSAIDs $(\mathrm{p}=.031)$ were associated with better performance on ANAM, while only prednisone was related to decreased ANAM performance $(p=.000)$. These significant medication effects were independent of other significant effects for education $(p=.000)$, depression $(p=.000)$, visit number/practice effect $(p=.000)$ and SLE disease activity $(\mathrm{P}=.004)$. The results replicate prior studies finding cognitive impairment with prednisone and suggest that medications with anti-platelet/inflammatory effects may potentially improve cognitive performance in SLE. Clearly, random double-blinded trials will be necessary to confirm any direct causative effects.

Correspondence: Allison Clark, Psychology Service (116B), STXVAHCS, 7400 Merton Minter Blvd, San Antonio, TX 78284. E-mail: Allison. Clark@med.va.gov

\section{J.J. GAINES, J.L. SHUCARD, D.W. SHUCARD, J. SAVAGE \& R.H. BENEDICT. C-REACTIVE PROTEIN AND WORKING MEMORY DEFICITS IN SYSTEMIC LUPUS ERYTHEMATOSUS.}

Recent studies have highlighted the role of the inflammatory marker Creactive protein (CRP) as a predictor for vascular disease and stroke. Systemic Lupus Erythematosus (SLE) has been associated with (1) higher levels of CRP, (2) cerebrovascular disease, and (3) a subcortical pattern of cognitive deficits (e.g., lower processing speed, poor attention/working memory). These findings suggest the possibility of microvascular changes affecting cognitive function in SLE. However, to our knowledge no studies have yet attempted to relate levels of CRP with cognition in SLE. The present study investigated the relationship between CRP levels and executive function in SLE using the Paced Auditory Serial Attention Task (PASAT), a sensitive measure of processing speed and attention/working memory. CRP levels in the total patient group correlated negatively with the number of correct responses and percent correct dyads (two consecutive correct responses) on the PASAT $(r=-.39$ and -.37 , respectively, $p<.05)$. Subgroup comparisons, using analysis of variance, revealed that SLE patients with higher CRP relied more heavily on a less demanding but incorrect chunking strategy and made fewer correct responses on the PASAT than SLE patients with lower CRP. Higher-CRP SLE patients also performed more poorly on Trail Making Test Part B, another sensitive measure of executive function. Results suggest that CRP may be a sensitive marker for subtle cognitive impairment of a dysexecutive or subcortical nature in SLE, possibly due to a CNS microvascular inflammatory process. Correspondence: jeffrey J. gaines, Ph.D., Developmental and Behavioral Neurosciences, University of Buffalo Medical School, 66 Summer St., Apt. 7K, Buffalo, NY 14209. E-mail: gainesjeffreyj@hotmail.com

\section{N.A. DONINGER, T.O. UTSET \& J.W. FINK. RACE-RELATED EFFECTS OF SYSTEMIC LUPUS ERYTHEMATOSUS ON NEU- ROPSYCHOLOGICAL FUNCTION AND HEALTH STATUS.}

Epidemiological research indicates excess severity of disease impact among African-Americans with SLE relative to Caucasians. This study examined race-related differences in neuropsychological functioning and health related variables. African-Americans $(\mathrm{n}=34)$ and Caucasians ( $\mathrm{n}$ =14) fulfilling American College of Rheumatology criteria for SLE completed neuropsychological measures and instruments assessing pain, fatigue, depression, anxiety, and health-related quality of life. Groups were equivalent in age, education, and disease length. African-Americans and Caucasians did not differ on a global neurocognitive impairment rating after controlling for differences in estimates of premorbid cognitive ability (i.e., performance on the National Adult Reading Test). Additional analyses controlling for differences in premorbid ability indicated that African-Americans and Caucasians performed similarly on measures of verbal and visual memory, working memory, and motor speed. A statistical trend was observed on measures of attention/processing speed with African Americans performing worse than Caucasians $(p=.08)$. African-Americans and Caucasians did not differ in complaints of pain, fatigue, depression, and anxiety. There was a trend $(p=.06)$ indicating African-Americans endorsed greater impairment of physical functioning relative to Caucasians. These results are largely inconsistent with research indicating excess impairment among African-Americans with SLE. African-Americans and Caucasians were generally indistinguishable on composite measures of physical and emotional well-being and performed comparably on neurocognitive measures after controlling for differences in premorbid ability. Although the results are limited by the small number of Caucasians, these preliminary results suggest that findings of greater cognitive impairment among African-Americans may reflect initial differences in general cognitive ability.

Correspondence: Nicholas Doninger, Ph.D., Psychiatry, University of Chicago Medical Center, 5841 S. Maryland Ave., MC 3077, Chicago, IL 60637. E-mail:ndoninge@yoda.bsd.uchicago.edu

\section{N.A. DONINGER, T.O. UTSET \& J.W. FINK. NEUROPSYCHOLOGICAL AND CLINICAL CORRELATES OF DISABILITY STATUS IN SYSTEMIC LUPUS ERYTHEMATOSUS.}

Systemic lupus erythematosus (SLE) is a serious chronic disease, which can make employment difficult. The SLE related impairments potentially impacting functional ability are diverse and their relative contributions in determining disability status remains unclear. Fifty-five individuals fulfilling American College of Rheumatology criteria for SLE completed neuropsychological measures and health-related instruments to identify characteristics associated with work disability. Controlling for educational differences, individuals claiming work disability performed significantly worse than non-disabled individuals on measures of verbal and visual memory, attention/processing speed, working memory and motor speed. Affective pain complaints, depression, anxiety and fatigue were significantly more pronounced among individuals claiming disability relative to non-disabled individuals. Individuals claiming work disability endorsed significantly greater impairment across indices of health-related quality of life. Similar neuropsychological deficits were associated with external recognition of disability, i.e., receipt of social security disability or workers compensation. The association between disability and complaints of pain, depression, anxiety, and fatigue was non-significant when disability status was referenced to external criterion. In sum, neurocognitive dysfunction is more pronounced in individuals with Lupus who are unable to work; however, these results are limited by the absence of measures assessing effort and response bias in this particular sample. Disability evaluations should routinely employ neurocognitive measures, including indices of motivation and effort, to determine the impact of SLE on functional status. Although pain, depression, anxiety, and fatigue may contribute to self-reported disability, it is possible that elevated scores among the self-reported disabled reflect the stress associated with a change in functional status. Correspondence: Nicholas Doninger, Ph.D., Psychiatry, University of Chicago Medical Center, 5841 S. Maryland Ave., MC 3077, Chicago, IL 60637. E-mail: ndoninge@yoda.bsd.uchicago.edu

\section{Hormone Effects}

\section{J.J. DUNKIN, N. RASGON, K. WAGNER-STEH, S. DAVID, L. ALTSHULER \& R. ANDREA. PREDICTORS OF COGNITIVE PERFORMANCE IN HEALTHY POSTMENOPAUSAL WOMEN.}

Previous studies have found that reproductive events that change a woman's lifetime exposure to estrogen significantly affect cognitive performance in late life. These events include ages at menarche and menopause, number of children (parity), and exposure to exogenous estrogen such as ERT. In this study, 27 healthy laboratory-confirmed postmenopausal women not taking ERT were administered a complete neuropsychological battery. Neuropsychological test scores were 
Z-transformed and averaged to create four summary scores for the $\operatorname{cog}$ nitive domains of attention and processing speed (ATTN), verbal memory (VMEM), nonverbal memory (NVMEM), and executive functioning (EXEC). Four multiple linear regression equations were computed, predicting cognitive functioning in each of the four domains using age, years since menopause, number of children, body mass index (BMI), and estimated verbal IQ. For the ATTN summary score, BMI and VIQ were significant positive predictors of cognition, and parity was a significant negative predictor of cognition. For the EXEC summary score, VIQ was a significant positive predictor of cognition, with a trend level finding for parity as a negative predictor. For verbal and nonverbal memory, no variables were significant predictors. Results suggest that the number of children a woman has in her lifetime appears to have an adverse effect on cognition later in life, consistent with earlier studies. While estrogen levels increase in pregnancy, they decline dramatically postpartum and remain low for some time after birth. Further, women are also exposed to high progesterone levels during pregnancy which may antagonize estrogen effects during that time period. Finally, the number of children borne appears to affect estrogen levels later in life. In sum, research data continue to suggest that lifetime exposure to estrogen affects cognitive performance later in life.

Correspondence: Jennifer J. Dunkin, Ph.D., Psychiatry, UCLA, UCLA NPI C9-948B, 760 Westwood Plaza, Los Angeles, CA 90024. E-mail: jdunkin@mednet.ucla.edu

\section{J.J. DUNKIN, N. RASGON, K. WAGNER-STEH, S. DAVID, L. ALT- SHULER \& A. RAPKIN. USE OF REGRESSION-BASED CHANGE SCORES TO MEASURE EFFECTS OF ESTROGEN REPLACEMENT ON COGNITION IN HEALTHY, POSTMENOPAUSAL WOMEN.}

Early research studies found modest positive effects of estrogen on cognition in postmenopausal women for short-term use as well as long-term protection against neurodegenerative disorders such as Alzheimer's disease. More recent studies have failed to find any positive effects or have found negative effects. In this study, 8 healthy postmenopausal women with no medical contraindications and no psychiatric history were randomly assigned to receive estrogen (transdermal patch at a release rate of $0.1 \mathrm{mg} / \mathrm{day}$ ) and 9 were assigned to receive placebo (matching placebo patch). Subjects were administered a neuropsychological testing battery at baseline and at the end of the 10-week trial. Neuropsychological test scores were Z-transformed and averaged to create four cognitive domains: attention and processing speed (ATTN), executive functioning (EXEC), verbal memory (VMEM), and nonverbal memory (NVMEM). To control baseline variability and practice effects, four multiple linear regression equations were performed, with the time 2 summary score as the dependent variable, and the following predictors: time 1 summary score, age, years since menopause, body mass index (BMI), a dummy-coded variable representing active drug or placebo, and estimated verbal IQ. In all four equations, the time 1 summary score emerged as the strongest predictor of time 2 performance, and estrogen versus placebo was not found to be significant in any analysis. In addition, age, years since menopause, and BMI did not significantly predict change in cognitive functioning in any analysis. Estimated VIQ was a trendlevel predictor of change only in the EXEC analysis. In sum, no positive effects of estrogen on cognition were found in this placebo-controlled study. While this study adds to the growing negative literature on estrogen and cognitive performance, it may be that a longer trial is needed before any positive effects emerge and future research should be directed at that question. Correspondence: Jennifer J. Dunkin, Ph.D., Psychiatry, UCLA, UCLA NPI C9-948B, 760 Westwood Plaza, Los Angeles, CA 90024. E-mail: jdunkin@mednet.ucla.edu

\section{E.A. PECK, A.L. HESS \& C.S. MORRISSETTE. THE RELATION- SHIP OF NEUROPSYCHOLOGICAL FUNCTION AND HORMONE REPLACEMENT THERAPY IN POST-MENOPAUSAL WOMEN.}

It has been postulated that lower endogenous estrogen levels following menopause can account for the fact that post-menopausal women are at a greater risk than similarly-aged men for developing neuro-cognitive difficulties. In this regard, studies have focused on differences in cognitive functioning in women who are and are not on hormone replacement therapies (HRT). Prior research results have been mixed as to whether or not HRT in post-menopausal women may provide a protective factor against the development of cognitive difficulties. The present study assessed the relationship of prescribed HRT versus no HRT to cognitive functioning in postmenopausal women. 70 post-menopausal aged (49-85 years) were grouped on the basis of whether or not they had been treated with HRT. The groups were age-matched and compared on a battery of neuropsychological tests. Analyses of performances on different cognitive measures revealed no significant differences in verbal fluency, general cognitive functioning, and general memory scores. However, women on HRT scored significantly lower on a test of delayed auditory recognition memory. This is in direct contrast to other studies which have found that women on HRT tend to be protected against declines in verbal memory. Further analyses and implications for the use of HRT as a protective factor against cognitive decline in post-menopausal women will be discussed.

Correspondence: Edward A. Peck, PhD, NSV, Suite 127, 2010 Bremo Road, Richmond,VA 23226.E-mail: epeckphd@aol.com

\section{E. AVELEYRA, S. CARRANZA-LIRA \& F. OSTROSKY-SOLIS. NEUROPSYCHOLOGICAL AND ELECTROPHYSIOLOGICAL EVALUATION OF COGNITIVE FUNCTION IN POST- MENOPAUSAL WOMEN FOLLOWING HORMONE REPLACE- MENT THERAPY. .}

Evidence in clinical studies of cognition in women with menopause and hormone replacement therapy with estrogen (HRT) have produced conflicting results, some studies showing no beneficial effects of HRT on cognitive function (Rapp et al 2003, Shumaker et al 2003), while others revealing a benefit in different cognitive domains particularly: attention and working memory, verbal memory and reasoning (Rice et al 2000, Maki et al 2001), or on global cognitive functions (Yaffe et al 2000, Smith \& Zubieta, 2001, Zandi et al 2002). Therefore, the objective of this study was analyzed the neuropsychological and electrophysiological (Event potentials related: P300 and N400 components) profiles before and after of the HRT. Neuropsychological function were evaluated with a battery of test for the assessment of attention and memory previously standardized and validated in Spanish Speaking population (NEUROPSI: ATTENTION \& MEMORY, 2003). Thirty postmenopausal women participated. Ten were treated with conjugated equine estrogens (CEE) $0.625 \mathrm{mg} /$ day, ten were treated with CEE 0.625 $\mathrm{mg} /$ day and chlormadinone $1 \mathrm{mg} /$ day, and ten did not receive any treatment. The three groups were matched on age and years of education (mean 51.7 and 7.4 years). The results showed that the postmenopausal women presented significant changes in attention and memory. Discussions is center on the controversial effects of HRT on cognitive functions.

Correspondence: Elizabeth Aveleyra, National University of Mexico, Ave. Universidad \# 3004 Col. Copilco-Universidad, México 04510, Mexico. E-mail:aveleyra02@yahoo.com.mx

\section{K. WHITFIELD, D. GOODMAN \& A. THORNTON. INCREASED RE- SPONSE TIMEVARIABILITY IN THE LUTEAL PHASE OF THE MEN- STRUAL CYCLE ON A TEST OF PSYCHOMOTOR COORDINATION.}

Abstract Baseline neuropsychological testing is advocated in order to properly assess cognitive functioning following concussion. There are, however, other factors that may contribute to increased or decreased cognitive performance that may mask the effects of a concussion. For example, being a female has been identified as a major risk factor for recovery from mild concussion and while there is unequivocal experimental evidence linking hormones to cognition, these basic findings have not been systematically applied in the evaluation of concussion. Further, although increased performance variability is a well-known effect 
of mild concussion, many established tests used to evaluate the neurocognitive effects of concussion rely only on averages and do not take performance variability into account. The current study assessed the effect of hormonal fluctuation on non-concussed females across the menstrual cycle on tasks that were developed to be sensitive to concussion exposure. Specifically, 23 female participants were evaluated in both their luteal and menstrual phase on information processing tasks of varying complexity. We assessed phase differences by inspecting withintask reaction time (RT) variability and median RT differences. No effect of menstrual cycle phase was observed in comparisons of median reaction times across cycle phase. Analysis of the RT variability, however, revealed increases in the luteal phase relative to the menstrual phase for the most complex condition $(t=-2.22, p<.05)$. This finding suggests that increased ovarian hormones may be associated with decrements in sustained attention and that menstrual cycle phase should be considered when evaluating concussion outcome in females.

Correspondence: Kevin Whitfield, B.A., Psychology, Simon Fraser University, 8888 University Drive, Burnaby, BC V5A 1S6, Canada. E-mail: kwhitfie@sfu.ca

\section{K. MORDECAI, J. WOODARD, L. RUBIN \& P. MAKI. VERBAL AND VISUOSPATIAL ABILITIES IN ORAL CONTRACEPTIVE USERS.}

Performance on sexually dimorphic tasks varies across the menstrual cycle such that verbal performance improves while visuospatial performance worsens during the luteal (high estradiol) phase compared to the follicular (low estradiol) phase. Although oral contraceptives (OCs) increase exposure to exogenous estrogens, they decrease endogenous estrogen levels. It was predicted, therefore, that women receiving OCs (users) would have poorer verbal fluency performance and better mental rotations performance compared to women not receiving OCs (nonusers). Participants included 14 current OC-users and 14 nonusers who were not significantly different in terms of age and education level. All participants were tested once during the luteal phase of their cycle. Radioimmunoassay techniques were used to verify cycle phase for nonusers. Estradiol levels were significantly higher in the nonuser group $(p=.01)$. As expected, nonusers performed significantly better on tasks of phonemic $(p=.01)$ and ideational fluency $(p=.02)$. Although users performed better on a mental rotations task, this effect was not statistically significant. These preliminary results support the view that high estradiol levels inhibit visuospatial abilities and enhance verbal abilities. Ongoing data collection will speak to the effects of OCs across the menstrual cycle.

Correspondence: Kristen Mordecai, MA, Finch Univ of Health Sciences/Chicago Medical School, 1230 S. White Oak Dr., \#1126, Waukegan, IL 60085. E-mail: kristen.mordecai@finchcms.edu

\section{BURTON, D. HENNINGER \& J. HAFETZ. RELATIONSHIPS BETWEEN COGNITIVE MEASURES AND INDIRECT HORMONAL INDICES .}

Thirty-nine female undergraduate participants were evaluated on cognitive measures and indirect hormonal indices. The cognitive measures were the Vandenberg Mental Rotation Test and a written verbal fluency test involving generating words that begin with a specific letter. Indirect hormonal measures, which presumably reflect organizational hormonal effects, were also used. Participants rated their own amount of rough and tumble play, and play with boys during childhood, compared to other girls, on a 5-point scale. Finger lengths were measured, and ratios of the second to fourth finger length, and third to fifth finger length, were calculated. Other researchers have reported stable (from age two) gender differences in these ratios such that both ratios are larger for women than for men. The gender-typical finger length ratio patterns have also been shown to vary with homosexual/heterosexual status and in congenital adrenal hyperplasia, a syndrome marked by androgen abnormalities. Smaller finger length ratios (in the male-typical direction) were associated with increased reports of more rough and tumble play during childhood, as well as more childhood playing with boys; literature supports a relationship between these play variables and higher androgen levels during fetal development. Smaller ratios (male-typical direction) were also associated with higher scores on the mental rotation task, a task for which gender differences in favor of men are frequently reported. Surprisingly, smaller ratios were also associated with higher verbal fluency scores (perhaps related to the written format of this fluency test).

Correspondence: Leslie Burton, Ph.D., Psychology, Fordham University, 441 E. Fordham Rd., Bronx, NY 10458. E-mail: burton@fordham.edu

\section{Neurotoxic Exposure Effects}

\section{S. GYSENS \& R. BOWLER. FACTOR ANALYSIS STUDYTO DEVELOP A SENSITIVE NEUROPSYCHOLOGICAL SCREENING TEST BAT- TERY FOR THE EVALUATION OF MANGANESE EXPOSURE.}

Sixty-one welders with exposure to manganese fumes were tested with an extensive battery of neuropsychological tests including WAIS-III, WMS-III, WRAT-3, Boston Naming, Stroop, Rey Osterrieth, Fingertapping, Grooved Pegboard, Dynamometer, ACT, Trail Making, and Animal Naming. Principal Components analysis was performed to determine different domains of impairment in this group and to develop a sensitive screening battery. Analyses were replicated with a group of 137 solvent (ethylene dichloride (EDC)) exposed workers. Six factors explained $66 \%$ of the variance in the welders group: visual reaction time, general intelligences including verbal and visuospatial ability, verbal memory, attention and concentration, motor speed, and motor dexterity. Tests with a factor loading above .5 were included in the screening battery. When replicated in a group of solvent exposed workers, and in a mixed group comprised of both solvent and manganese exposed individuals, five factors explained $58 \%$ of the variance. The above factors were replicated with the exception of the motor factors which were reduced to only one factor. One-way ANOVA revealed a significant difference with regard to motor abilities $(p<0.000)$ with welders being more impaired than EDC exposed workers. This is consistent with the literature on Parkinsonian symptoms after Manganese exposure. Both groups did not differ significantly on other factors measuring attention, memory, reaction time and other verbal and visuo-spatial skills, with similar degrees of impairment.

Correspondence: Sabine Gysens, Ph.D., Psychology, San Francisco State University, PO Box 31637, San Francisco, CA 94131. E-mail: sgysens@ sfsu.edu

\section{R.M. BOWLER, S. GYSENS, H. ROELS \& E. DIAMOND. EXPOSURE TO MANGANESE IN WELDERS AND NEUROPSY- CHOLOGICAL FUNCTION.}

Sixty-one welders with exposure to manganese $(\mathrm{Mn})$ fumes referred by neurologists were tested. After excluding one woman and seven men (1 prior head injury, 1 stroke, 4 dementia and missing data, 1 poor vision. and 1 for poor effort) 53 remained for analysis. Thirty-four were white and 19 non-white and similar on age (mean $51.8 \mathrm{yrs}$ ) and education (mean $11.2 \mathrm{yrs}$ ). Mean duration of exposure to welding fumes was greater for whites (29.1 yrs) than non-whites (17.9 yrs). All but one were retired or disabled because of Mn-related symptoms (tremor, bradykinesia) similar to Parkinsons disease (PD). The WAIS-III and WMS-III, WRAT, Boston Naming, Stroop, Rey-Osterrieth, Fingertapping, Grooved Pegboard, Dynamometer, BAI, BDI and SCL-90, tests of vision (Lanthony d-15, Contrast Sensitivity, Schirmer) were administered. Welders scored within one sd of the mean on all tests except for Digit Symbol, Digits Backward, Processing Speed Index, Stroop, Trails A \& B, and all motor function tests, which were severely impaired. All had impaired scores on the Rey-Osterrieth and tremor tests. Scores on the WMS also reveal mild to moderate impairment on working memory and Symbol 
Search. Regression analyses between duration of exposure and test scores showed that length of exposure predicted scores on motor tests, visuospatial scanning and tracking, verbal abstraction, verbal learning, and working, immediate and delayed memory. An exposure index, developed by industrial hygienists, and neurological examination findings will be presented. These results are consistent with effects of manganese, similar to PD but with the exception of younger age of onset.

Correspondence: Rosemarie M. Bowler, Ph.D., Psychology, S.F.State Univ, 8371 Kent Drive, El Cerrito, CA 94530. E-mail: rbowl@sfsu.edu

\section{M.J. AUBERT, S.R. ANDREWS, L.B. FORMY-DUVAL, S.P. BERMUDEZ \& W.J. BURNS. INCREASED BLOOD LEAD LEVEL NEGATIVELY AFFECTS WISC-III PERFORMANCE.}

The purpose of this study was to examine the relationship between blood lead level and intelligence in children. Seventeen children who had been administered the Wechsler Intelligence Scale for Children (WISC-III) as part of a neuropsychological battery following lead poisoning were participants for this study. Correlation coefficients were calculated between blood lead level and each of the WISC IQ and Index scores. Three scores were found to significantly relate to blood lead level with $\mathrm{p}<$ .10: Full Scale IQ, Perceptual Organization Index, and Processing Speed Index. The relationship between blood lead level and three other scores (Verbal IQ, Performance IQ, and Freedom from Distractibility) approached significance. All correlations were negative suggesting that the higher the child's blood lead level the lower his or her score on the WISC measures. In addition, Multiple Regression Analysis was performed. Using blood lead level and age at initial lead exposure as independent variables, two models were significant at the .10 level. Specifically, 25.7 percent of an individual's score on the Verbal Comprehension Index was attributed to blood level and age at exposure. In addition, 18.9 percent of a child's score on Verbal IQ was attributed to blood lead level and age at exposure. Models for the Perceptual Organization Index and Full scale IQ also approached significance with 17.5 and 12.6 percent of scores on these indices being attributable to the independent variables, respectively. The above findings confirm that increased blood lead levels exert a significant negative effect on measured intelligence in children.

Correspondence: Melissa J. Aubert, M. S., Nova Southeastern University,7870 Sanibel Drive, Tamarac,FL 33321.E-mail: majaubert@ aol.com

\section{B.W. JASPER, R.O. HOPKINS \& L.K. WEAVER. EMOTIONAL FUNCTION FOLLOWING CARBON MONOXIDE POISONING: A LONGITUDINAL STUDY.}

Introduction: Carbon monoxide $(\mathrm{CO})$ is the most common cause of accidental poisoning in the United States. Cognitive sequelae following CO poisoning appears to be well established, yet emotional function has been given relatively little research attention. The purpose of this study is to assess emotional function following $\mathrm{CO}$ poisoning longitudinally. Methods: Subjects $(\mathrm{n}=127)$ were enrolled in a prospective study, 7 excluded due to non-English speaking, and 1 lost to follow-up at all 3 intervals, resulting in 119 subjects. 76 had accidental CO-exposure and 43 with suicide-attempt. Depression and anxiety were assessed using the Beck Depression Inventory (BDI) and Beck Anxiety Inventory (BAI) at 6 weeks, 6 and 12 months. Affective sequelae were considered to be present if $\mathrm{BDI} \geq 15$ or $\mathrm{BAI} \geq 15$, data are reported as percent with depression and anxiety at 6 weeks, 6 and 12 months. Results: Of the $119 \mathrm{CO}$ poisoned subjects, $\mathrm{n}=19(16 \%)$ had affective sequelae at 6 weeks. The mean BDI and BAI scores at 6 weeks were $8.1 \pm 9.9$ (range 0-42) and 7.3 \pm 8.7 (range $0-42$ ) respectively. Percent of subjects with elevated BDI scores was $15.1 \%(n=18)$ at 6 weeks, $15.1 \%(n=18)$ at 6 months, and $10.1 \%(\mathrm{n}=12)$ at 12 months. The percent of subjects with elevated
BAI scores $10.9 \%(n=13)$ at 6 weeks, $13.4 \%(n=16)$ at 6 months, and $10.1 \%(\mathrm{n}=12)$ at 12 months. Conclusions: Subjects with CO poisoning report symptoms of depression and anxiety at 6 weeks post-CO exposure. These symptoms remain over time with mild decline in depression at 12 months.

Correspondence: Bruce W. Jasper, B.S., Psychology, Brigham Young University, 1122 SWKT, Provo, UT 84604. E-mail: bwj4@email.byu.edu

\section{T. NOVAKOVIC-AGOPIAN \& R. BOWLER. ATTENTIONAL FUNCTIONS FOLLOWING DIFFERENT INDUSTRIAL NEURO- TOXIC EXPOSURES.}

Difficulties in the areas of attention and speed of processing information are one of the most common sequelae of neurotoxic exposure. Using computerized Visual Attention Test (VAT) battery, we evaluated 176 hazardous waste workers exposed to ethylene dichloride (EDC), 40 welders exposed to manganese fumes, and 194 control subjects. The VAT battery includes computerized attentional tests that assess an individual's speed of processing information, ability to orient and covertly shift attention, and ability to inhibit automatic orienting. These tests are based on the cognitive neuroscience and neuroimaging attentional research by Posner and others, and have been expanded and adapted for clinical use. Both exposed groups had significantly slower reaction time (RT) relative to controls, with a trend for welders to have the slowest RT. Both exposed groups had more difficulty inhibiting automatic orienting than control subjects. Individuals exposed to EDC had slower RT on the Orienting test than on the Inhibition of Automatic Orienting test. This was more pronounced in the invalid condition, when their attention was initially misguided to a location different from the one where the target appeared. Results will be discussed in the context of the current attentional theory. Also, the Visual Attention Test (VAT) battery will be presented.

Correspondence: Tatjana Novakovic-Agopian, Ph.D, California Pacific Medical Center, 661 Myra way, San Francisco, CA 94127.E-mail:tna@ cns-site.com

\section{K. SULLIVAN, M. KRENGEL, P. SUSAN \& R. WHITE. LONGITUDINAL COGNITIVE FUNCTIONING IN GULF WAR-ERA VETERANS.}

This study was designed in response to treatment-seeking GW veterans complaints of progressively worsening cognitive abilities since their return from the war. GW-veterans from an initial study (Time 1, 19951998), scored more poorly on neuropsychological test of motor, mood and acquisition of information than GW-era veterans who were not deployed. The etiology of the neuropsychological deficits was unclear, but studies from our lab suggested that the results may be related to environmental exposures experienced in the Gulf and were not solely attributable to stress or psychiatric diagnosis. If these deficits were attributable to neurotoxicant exposures, a progressively worsening cognitive status over time would be at odds with the usual course of CNS exposure to neurotoxicants. The current study was conducted to determine whether a worsening of performance had occurred in the same GW-veterans four years after their initial evaluations (Time 2, 1999-2003). Results of MANOVA analyses found that the $\mathrm{GW}$ deployed-veterans group did not perform significantly worse at Time 2 than at Time 1 . This suggests that there was no progressive cognitive decline associated with $\mathrm{GW}$ deployment. However, there was also no improvement over time in this group of treatment-seeking $\mathrm{GW}$ veterans. These results may still be attributable to neurotoxicant exposures, which often remit or remain static when removed from the initial exposure. Reasons for the veterans perceived diminution in functioning will be discussed, including associations with health concerns and functional status.

Correspondence: Kimberly Sullivan, Ph.D., Neurology, Boston University School of Medicine, 150 S. Huntington Ave. 116B-4, Boston, MA 02130.E-mail:kjsw118997@msn.com 
HIV

\section{M.A. RICHARDSON, E. MORGAN, T.M. KEANE \& HIV/AIDS STUDY GROUP. UTILITY OF THE HIV DEMENTIA SCALE VER- SUS STANDARD NEUROPSYCHOLOGICAL ASSESSMENT TECH- NIQUES IN ASSESSING RISK FOR SIGNIFICANT HIV-RELATED COGNITIVE MOTOR DEFICITS.}

Considerable literature reflects the range of neurocognitive complications associated with HIV disease. Early indicators of neurological damage include relatively poor performance on tests of: movement, coordination and gait; simple and divided attention and concentration (including performance on working memory tasks); reaction time; and mental flexibility. Efforts to develop screening techniques include the HIV Dementia Scale, a brief measure that has demonstrated promise in identifying individuals at high risk for significant cognitive-motor dysfunction associated with HIV disease but has not undergone extensive independent evaluation. The present study examines the utility of the HDS in a sample of HIV-seropositive adults with a co-morbid history of psychiatric and drug / alcohol abuse disorders. Forty subjects $(65 \%$ male; mean age: 41 years; mean education: 12.4 years; $50 \%$ African American, $30 \%$ Caucasian) recruited for a study of the impact of brief therapies designed to enhance relapse prevention, anxiety reduction and HIV treatment adherence (HIV/AIDS Cost Study), completed an extensive battery of neuropsychological measures, including the HDS. Forty percent of these subjects were identified as at high risk for significant cognitive-motor disorder (HDS total score $<10$ ). After controlling for age, education, constitutional illness (viral load), and concurrent depressed mood, those identified in the HDS high-risk group performed significantly worse on measures of simple and sustained divided attention, psychomotor speed, and working memory. However, traditional cut-offs for the HDS suggest only moderate clinical utility, correctly classifying 24 of 40 subjects $(60 \%)$ based on performance on traditional tests of neuropsychological functioning. Implications and limitations of the study are discussed.

Correspondence: Mark A. Richardson, PhD, Psychiatry, Boston University School of Medicine, 648 Beacon Street, Boston, MA 02215. Email:markrich@bu.edu

\section{E. MORGAN, C.A. CUEVAS, M. RICHARDSON, A.R. BOLLINGER, M.J. VIELHAUER, B. GOODIN \&. T.M. KEANE. NEUROPSYCHOLOGICAL FUNCTIONING IN DU- ALLY DIAGNOSED HIV-SEROPOSITIVE INDIVIDUALS AS A FUNCTION OF PTSD DIAGNOSIS.}

Despite some inconsistency in the literature regarding the effects of Posttraumatic Stress Disorder (PTSD) on neuropsychological functioning, substantial evidence has been presented indicating that individuals with PTSD show diminished performance on tasks of attention and memory. Individuals with a history of PTSD who are also HIV-seropositive could likely be at higher risk of significant neuropsychological dysfunction. The current study compared the performance of individuals with PTSD versus those without a PTSD diagnosis on several neuropsychological tasks focusing on attention, initial learning, recall following interference, and cognitive flexibility. Participants were HIVseropositive adults with substance abuse and mental health disorders who were currently enrolled in a larger HIV/AIDS Cost Study. A variety of traumatic experiences were endorsed by participants in the sample, including life-threatening illness, physical assaults, and assaults with weapons. However, the focal event for many of the PTSD diagnoses involved childhood sexual abuse or physical assaults. Participants completed a neuropsychological battery that included the Auditory Verbal Learning Test, Trail-Making Test, Digit Span, Rey Complex Figure Test. and the California Computerized Assessment Package. After assessing for potential covariates, including CD4 count, depressed mood, substance abuse severity, and estimated pre-morbid IQ, individuals with PTSD did not show significantly greater impairment on the selected neuropsychological tasks. Implications and limitations of the study are discussed.

Correspondence: Erin Morgan, B.A., Psychiatry, Boston Medical Center, One Boston Medical Center Place, Dowling 7 North, Boston, MA 02118.E-mail:erin.morgan@bmc.org

\section{V.J. HONN \& R.A. BORNSTEIN. HIGHLY ACTIVE ANTIRETROVI- RAL THERAPY (HAART) MAY IMPROVE NEUROPSYCHOLOGICAL PERFORMANCE IN INDIVIDUALS WITH HIV INFECTION.}

Current medical treatments for HIV, inluding protease inhibitors and multiple drug regimens, have been found to dramatically improve the health and longevity of individuals with HIV. Limited information is available regarding whether antiretroviral therapy can prevent or reverse the cognitive declines seen among some individuals with HIV and AIDS. This study compared the effects of highly active antiretroviral therapy, other antiretroviral medication regimens, and no medication use on neuropsychological performance. Participants included 96 HIVpositive individuals representing a diversity of disease stages, risk factors, and demographic characteristics. Each participant completed two comprehensive neuropsychological assessments, separated by one year. Results of regression analyses indicated that, after a year, HAART use was associated with stabilization in memory and improvements in psychomotor function. Participants using non-HAART regimens or no medications showed declines in memory and no change in psychomotor function. No differences were found for the effect of non-HAART regimens on cognitive function as compared to use of no medications. Potential psychosocial or disease-related moderators of the effect of medication on cognitive performance were explored, but no significant associations were found. The relationship between antiretroviral medication use and neuropsychological performance is most likely complex and determined by multiple factors. These results suggest that assessment of memory and psychomotor function may be important when evaluating the effectiveness of antiretroviral treatments for HIV.

Correspondence: Vanessa J. Honn, Ph.D., Psychology (116B-4), VA Boston Healthcare System, $150 \mathrm{~S}$. Huntington Ave (116B-4), Boston, MA 02130.E-mail: vhonn@bu.edu

\section{J.T. RAMSAY, E.M. WARRINER, B.N. AXELROD \&. S.B. ROURKE. LATENT STRUCTURE OF THE PATIENT'S AS- SESSMENT OF OWN FUNCTIONING QUESTIONNAIRE: A SUB- JECTIVE COGNITIVE EVALUATION TOOL FOR ADULTS LIVING WITH HIV/AIDS.}

Complaints about cognitive functioning are common in adults with HIV infection. The Patient's Assessment of Own Functioning Questionnaire (PAOF) is frequently used as a means of identifying and categorizing such cognitive complaints. Recent research shows that the PAOF yields important information about neuropsychological (e.g., problems with short term memory) and psychiatric functioning (e.g., presence of depression). However, the factor structure of the PAOF in this population has not been systematically examined. In the study reported here, the factor structure of the PAOF questionnaire was examined in a sample of 316 adults with HIV infection. A Confirmatory Factor Analysis (CFA) approach was used to evaluate eight different models of latent factor structure, ranging from a single-factor to six-factor models. A six-factor model provided the best account of the latent factor structure of the PAOF. The factors include items that were clustered in the following domains: language, sensory-perceptual skills, general memory, specific memory, problem solving-planning and spatial orientation.

Correspondence: Jason T. Ramsay, PhD, Neurobehavioural Research Unit, St. Michael, 30 Bond Street, 2-Shuter, rm 2-062, Toronto, ON M5B1W8,Canada.E-mail: ramsayj@smh.toronto.on.ca 


\section{A. LEVINE, A. KEUNING, R. WILKINSON, S. CASTELLON, M. LAM, D. HARDY, M. ROBINET, K. MASON, R. DURVASULA, H. MYERS, L. DOUG, T. NEWTON \& C. HINKIN. COGNITIVE IMPAIRMENT IS ASSOCIATED WITH MEDICATION ADHER- ENCE PATTERN IN HIV.}

Although the use of highly active antiretroviral therapy (HAART) in the treatment of HIV infection has greatly reduced mortality and improved quality of life, without strict adherence (e.g.., at least $90 \%$ of doses taken) viral suppression may fail and health status may worsen. The reasons for non-adherence are varied and complex, and are certain to differ between individuals. Through the use of cluster analysis we classified 222 $\mathrm{HIV}+$ individuals taking HAART into one of five groups based on their adherence patterns (objectively quantified using MEMS caps) over four weeks. These groups were good adherers $(>90 \%$ adherence), suboptimal adherers (75-90\%), two poor adhering groups ( $50 \%$ and $25 \%)$, and a group that varied significantly between weekend and weekday adherence $(57 \%$ and $75 \%$, respectively). Analyses of behavioral differences between these groups found that the poor weekend group had more members with global cognitive impairment than the other four groups $(91 \%$ versus $55-75 \%$; chi-square $=12.76, p=.01)$. Specifically, this group was poorer on attention measures $(p=.02)$. The group with the lowest adherence $(25 \%)$ had significantly more members with current substance abuse/dependence $(55 \%$ verses $16-23 \%$; chi square $=17.2, p=.002)$. Finally, the good adherers $(>90 \%)$ had the greatest number of members over the age of $50(33 \%)$, while the poorest adherers had the lowest number $(4 \%)$. These results suggest that certain patterns of poor adherence to HAART may be associated with specific factors such as cognitive impairment and substance use.

Correspondence: Andrew Levine, Ph.D., Psychiatry and Biobehavioral Sciences, UCLA-Neuropsychiatric Institute, 760 Westwood Plaza, Rm C8-747, Los Angeles, CA 90024.E-mail:ymc2272@hotmail.com

\section{R. ROBBINS, M. RIVERA MINDT, R.K. HEATON, T. MAR- COTTE, I. GRANT \& T. HNRC GROUP. ARE THERE ETHNICITY DIFFERENCES IN THE ABILITY OF NEUROPSYCHOLOGICAL TEST PERFORMANCE TO PREDICT FUNCTIONAL IMPAIRMENT IN HIV INFECTION?}

$\mathrm{HIV}$-associated neuropsychological (NP) impairment predicts increased rates of impairment on laboratory and real-life measures of everyday functioning, in general, but little research exists concerning these relationships in different race/ethnicity groups. Because race/ethnicity status is associated with NP performance differences, the current study explored whether such differences affect the ecological validity of NP tests in HIV-infected, racial/ethnic minority groups. Methods: $110 \mathrm{HIV}+$ participants (55 White \& 55 non-White; 34 African-American, 14 Hispanic, 7 Other) completed comprehensive NP and neuromedical evaluations, as well as standardized measures of everyday functioning. Participants in the ethnicity groups were matched on age, education, gender. AIDS/Non-AIDS status, CD4-count, and NP impairment. Results: Of the five subtests comprising the laboratory-based functional battery (Work-Assessment. Medication-Management. Financial-Management, Shopping and Cooking), the non-White group performed significantly worse on only one functional measure, Work-Assessment (Chi-square = 8.02, p <.01). Multiple regressions using $7 \mathrm{NP}$ domains, (clinical ratings based on demographically corrected t-scores: Verbal, Speed of Information Processing. Attention/Working Memory, Learning. Memory, Abstraction/Executive and Motor functioning), to predict performance on each of the functional measures yielded statistically significant models in all cases, for both the White and non-White groups, except for Shopping in the White group $(p=.40)$. Mean $\mathrm{R}$-squares (derived from the previously reported multiple regressions) for the non-White group $(\mathrm{R}$-square Mean $=.42 ;$ Median $=.44)$ compared favorably with that for the White group $(\mathrm{R}$-square Mean $=.37$ : Median $=.33)$. Conclusion: These results suggest that these NP tests have comparable ecological validity for White and racial/ethnic minority HIV+ adults.
Correspondence: Monica Rivera Mindt, Ph.D., Psychology/Psychiatry, Fordham University/Mt. Sinai Medical Center, Dept. of Psychology, LL808-F, 113 W.60th St., New York, NY 10026.E-mail: riveramindt@ fordham.edu

\section{R. BAIRD, M. RIVERA MINDT, E. RYAN, J. MONZONES, M. NASEER \& S. MORGELLO. THE UTILITY OF NORMS BASED ON EDUCATION VERSUS READING ABILITY IN THE PREDIC- TION OF FUNCTIONAL IMPAIRMENT IN HIV-INFECTION.}

Among ethnic minority populations, education level is often disconcordant with quality of education. In an inner-city, advanced HIV cohort. $69 \%$ of the cohort ( $\mathrm{N}=174)$ has a reading level that is lower than stated education. This study investigated how reading grade level versus education based norms differed, hypothesizing that literacy would be a superior proxy for educational quality in the prediction of functional impairment in HIV. Methods: Participants completed a comprehensive NP battery and a standardized activities of daily living (ADLs) questionnaire. $75 \%$ of the cohort was male (60\% African-American and $27 \%$ Hispanic), with a mean age of 43.5 (SD=7.6). Results: Although the mean education level was 11th grade ( $\mathrm{SD}=2.5)$, the mean WRAT-3 reading score was 5 th grade $(\mathrm{SD}=2.1 ; \mathrm{t}=24.9, p<.001)$. Rates of impairment on NP tests ranged from $35-68 \%$ with education-based norms and 25 $65 \%$ using WRAT-3 reading grade. The largest difference was with the Trail Making Test (TMT), such that 56\% (TMT-A) and 58\% (TMT-B) of the group was impaired using education and $35 \%$ (TMT-A) and $30 \%$ (TMT-B) was impaired using reading norms; with performance on educationally normed $t$-scores significantly lower $(p<.001)$. To understand the relationship of literacy to functional impairment, TMT-B, Grooved Pegboard-DH, and Digit Symbol-Coding were entered into a regression equation $(p<.05)$, but only TMT-B $(p<.05)$ was significantly associated with number of ADL complaints. Conclusions: The discrepancies between education and reading based norms suggest poor quality of education among our ethnically diverse cohort. Low literacy appears to have an important role in the prediction of functional impairment.

Correspondence: Reon Baird, PhD.-Neuropsychology, The Graduate Center of CUNY, 961 Eastlawn Drive, Teaneck, NJ 07666. E-mail: aldree@juno.com

\section{E. RYAN, M. RIVERA MINDT, J. MONZONES, M. NASEER, S. MORGELLO \& M. BRAIN BANK. LACK OF AGE-RELATED COGNITIVE DECLINE AMONG AN ADVANCED HIV COHORT}

Highly active antiretroviral treatment (HAART) has led to decreases in mortality thereby causing older adults to become a rapidly growing segment of the HIV/AIDS population. Whether aging expedites cognitive decline in HIV/AIDS has become an important question in neuroAIDS research. We investigated whether there was a detectable "aging effect" in a mostly minority, advanced HIV cohort. The cohort ( $43 \%$ Black and $34 \%$ Hispanic) was split into two groups: less than age 49 (N=84) and greater than or equal to age $49(\mathrm{~N}=26)$. Participants received a neuropsychological (NP) exam at the entry, 6 months, and 12 months visit. There was no significant difference in education, substance use, or HIV plasma RNA at baseline, however the older group had a significantly higher CD4 count (297.1 vs. 134.6) ( $\mathrm{F}=21.4, \mathrm{p}=.001)$. At the entry visit the older group exhibited less perseveration on card sorting. but after a Bonferroni correction, this finding did not maintain significance. Across the first two visits, the oroups performed equivalently such that there was no detectable age or age $X$ disease effect on a repeated measure multivariate ANOVA. Across the three visits (entry through 12 months) the older group performed significantly better on working memory and verbal fluency however, only $47 \%$ of the older group returned for the 12 month visit. The group that returned tended to be healthier and had a higher CD4 count at each visit. Thus, the findings appear to be confounded by factors related to follow-up and have implications for conducting longitudinal NP research with medically compromised older adults. 
Correspondence: Elizabeth Ryan, PhD, Psychiatry and Pathology, Mount Sinai School of Medicine, Box 1134-MHBB, One Gustave Levy Place, New York, NY 10128. E-mail: elizabeth.ryan@mssm.edu

\section{CHERNER, S. LETENDRE, M.J. TAYLOR, R.K. HEATON, I. GRANT \& THE HNRC GROUP. HEPATITIS C INFECTION IS INDEPENDENTLY ASSOCIATED WITH NEUROCOGNITIVE DYS- FUNCTION AMONG INDIVIDUALS WITH HIV CO-INFECTION AND/OR HISTORY OF METHAMPHETAMINE DEPENDENCE.}

Hepatitis $\mathrm{C}$ virus (HCV) infection affects over 170 million people worldwide. Evidence is emerging that HCV may be associated with neurocognitive dysfunction. HCV infection is frequently comorbid with HIV infection and drug dependence. We examined neuropsychological (NP) functioning in 400 study participants who were either normal controls or had HCV infection (HCV+), HIV infection (HIV+), history of methamphetamine dependence (Meth+), or combinations of these factors as risks for cognitive deficits $(\mathrm{HCV}-\mathrm{HIV}-\mathrm{Meth}-=80, \mathrm{HCV}+\mathrm{HIV}+$ Meth $+=35, \mathrm{HCV}+\mathrm{HIV}+$ Meth- $=8, \mathrm{HCV}+\mathrm{HIV}-\mathrm{Meth}+=32, \mathrm{HCV}+$ HIV- Meth- $=2, \mathrm{HCV}-\mathrm{HIV}+$ Meth+ = 59, HCV- HIV+ Meth- = 101, HCV- HIV- Meth+ = 83). All had negative urine toxicology results. Proportion of global NP impairment increased with the number of risk factors $(0=25 \%, 1=41 \%, 2=56 \%, 3=66 \%, \mathrm{X} 2=25.13, \mathrm{p}<.0001)$. Using multiple regression to account for effects of demographic variables, history of methamphetamine dependence, and HIV serostatus, we found that HCV serostatus was a significant predictor of cognitive functioning in the areas of Learning $(p<.001)$, Motor Skills $(p<.005)$, Delayed Recall $(p<.04)$, and Abstraction $(p<.02)$, with a trend in Speed of Information Processing $(p<.06)$. HCV serostatus did not predict scores in Attention/Working Memory or Verbal Fluency. Results suggest that HCV may contribute to the development of neurocognitive problems above and beyond the role of HIV infection and stimulant dependence. Further studies with unconfounded HCV+ samples are needed to discern the nature of NP deficits specific to HCV.

Correspondence: Mariana Cherner, PhD, Psychiatry, University of California San Diego, $150 \mathrm{~W}$.Washington St., 2nd floor, San Diego, CA 92103.E-mail:mcherner@ucsd.edu

J.R. SADEK, R.K. HEATON, S.P. WOODS, J.R. RIPPETH, M. CHERNER, C. YOUNG, D. LAZZARETTO, I. GRANT \& THE HNRC GROUP. THE IMPACT OF DEPRESSION ON SELF-REPORTED IMPAIRMENT IN HIV AND METHAMPHETAMINE USE. Self-reported cognitive and functional impairment often determines the course of clinical assessment and treatment. We analyzed self-reported cognitive complaints (Patient's Assessment of Own Functioning Inventory; PAOFI) and instrumental activities of daily living (IADLs) in $94 \mathrm{HIV}$-infected (HIV+) individuals, 96 individuals with a history of methamphetamine dependence (HIV-Meth+), 88 with both conditions $(\mathrm{HIV}+$ Meth+) and 89 controls (HIV-Meth-). The highest rate of neuropsychological (NP) impairment was in HIV+Meth+ $(51 \%)$ followed by HIV-Meth+ $(42 \%)$, HIV+Meth- $(34 \%)$, and HIV-Meth- controls $(25 \%)$. Higher rates of IADL impairment $(\mathrm{p}<.05)$ and worse PAOFI scores $(\mathrm{p}<.001)$ were observed in patient groups compared to controls. Depressive symptoms (Beck Depression Inventory; BDI) were also more frequent in patient groups $(\mathrm{p}<.001)$. BDI independently predicted PAOFI scores for all four groups $(p<.001)$, but NP impairment also independently predicted PAOFI scores in HIV+Meth+ and HIV-Meth+ $(p<.05)$. A different pattern was observed for IADLs: BDI scores predicted IADL impairment in all groups $(p<.05)$, but NP did not significantly predict IADL impairment for any group $(\mathrm{p}=.06$ for HIV +Meth+, $p>.09$ for all other groups). Previous studies observed that depression contributes to cognitive complaints. These data extend those findings to IADLs and suggest that NP impairment contributes differently to cog- nitive vs. IADL complaints. Future research should determine the degree to which depression biases patients' reporting of everyday functioning, versus actually causes reduced functioning. Still, especially in patients with depression, objective assessment may usefully inform interpretation of their subjective reports.

Correspondence: Joseph R. Sadek, Ph.D., Psychiatry, University of California, San Diego, HNRC, 2nd Floor, 150 W. Washington ST., San Diego, CA 92103.E-mail: jsadek@ucsd.edu

\section{A.R. KEUNING, S.D. MARION, R. SCHUG, S.A. CASTELLON, R.S. DURVASULA, D. HARDY, M.N. LAM, D. LONGSHORE, K.I. MASON, H. MYERS, T. NEWTON, M. STEFANIAK \& C.H. HINKIN. RECENT COCAINE USE IS ASSOCIATED WITH NEUROPSYCHOLOGICAL DYSFUNCTION AMONG HIV-IN- FECTED ADULTS.}

The deleterious effects of HIV-infection on cognitive performance are well-documented, but the impact of cocaine use on cognitive functioning is poorly understood. Although substance use is prevalent among HIV-infected individuals, few studies have examined the concomitant effects of HIV infection and cocaine use on neuropsychological function. The present study examined the relationship between current cocaine use and neuropsychological performance in $129 \mathrm{HIV}$-positive individuals, $59 \%$ testing positive on urine toxicology assays for recent cocaine use. A comprehensive battery of neuropsychological tests were administered to each patient. After calculating t-scores for each test using extant norms, the following composite domain scores were calculated: Information Processing Speed, Learning and Memory, Attention, Executive Functioning, Verbal fluency, and Motor Functioning, as well as a composite Global Functioning score. Results of independent samples t-tests revealed the Cocaine+ group demonstrated significantly worse global neuropsychological function than did the Cocaine negative group $(\mathrm{t}=2.51, \mathrm{p}=.01)$. In specific domains, recent cocaine use was significantly associated with slower information processing speed $(t=2.76$, $\mathrm{p}<.01)$ and worse learning and memory $(\mathrm{t}=2.61, \mathrm{p}=.01)$. A trend was found for poorer attention among the Cocaine+ group $(\mathrm{t}=1.88, \mathrm{p}$ $=.06)$. Post-hoc analyses demonstrated significant associations between cocaine use and poorer BVMT-R delayed recall, CVLT short delay free recall, PASAT, Digit Symbol, Symbol Search, and Grooved Pegboard scores. Thus, recent cocaine use is associated with neuropsychological dysfunction, over and above what can be attributed to the adverse effects of HIV-infection.

Correspondence: Allison R. Keuning, PhD, Neuropsychiatric Institute, UCLA, 760 Westwood Plaza, C8-746, Los Angeles, CA 90024. E-mail: akeuning@yahoo.com

\section{J.C. EISEN, S.A. SASSOON, M.J. ROSENBLOOM, C. KEMPER, S. DERESINSKI, A. PFEFFERBAUM \& E.V. SULLIVAN. DISRUPTION OF MOTOR COMPONENT PROCESSES BY ALCO- HOLISM, HIV INFECTION, AND THEIR COMORBIDITY.}

Both alcoholism and HIV infection can produce deficits in motor ability. Little is known, however, about which motor skills are affected by the highly prevalent comorbidity of these diseases or whether either disease selectively disrupts different components of motor control. We examined simple and complex components of motor ability in 27 persons with alcoholism (A), 22 with HIV infection (H), 29 comorbid for both diseases $(\mathrm{H}+\mathrm{A})$, and 20 age- and sex-matched controls. Hand dominance was determined quantitatively. Groups did not differ significantly from each other on simple tests of motor speed (Finger Tapping; movement time) or dexterity (Fine Finger Movement) for either hand. In contrast to performance on simple tasks, both alcohol groups had significantly prolonged reaction times bimanually, relative to controls and $\mathrm{H}$. on a two-choice task. On a complex test of fine finger movement speed 
and eye-hand coordination (Grooved Pegboard Test), $\mathrm{H}$ and A exhibited trends and $\mathrm{H}+\mathrm{A}$ demonstrated significant motor slowing of the dominant hand irrespective of peg drops, compared with controls; the nondominant hand condition elicited significant impairment in $\mathrm{A}$ and $\mathrm{H}+\mathrm{A}$. Slower reaction time was associated with slower speed of the dominant hand on this test in both alcohol groups. Motor performance did not relate to presence of self-reported symptoms or medically treated peripheral neuropathy. In conclusion, reaction time, but not other simple measures of motor ability, was vulnerable to alcoholism alone and alcoholism-HIV comorbidity and may underlie deficits on complex motor tasks involving sensorimotor coordination. [Support: AA12999, AA10723, AA05965]

Correspondence: Margaret J. Rosenbloom, M.A., Psychiatry \& Behavioral Sciences, Stanford University School of Medicine, 401 Quarry Rd, Stanford,CA 94305-5721.E-mail:mrosenbloom@stanford.edu

\section{S.A. SASSOON, J.C. EISEN, M.J. ROSENBLOOM, A. PFEFFER- BAUM \& E.V. SULLIVAN. A COMPONENT PROCESS ANALYSIS OF THE DIGIT SYMBOL TEST IN HIV, ALCOHOLISM AND THEIR COMORBIDITY.}

Multiple measures of WAIS-R Digit Symbol (DS) performance were used to identify component processes underlying CNS dysfunction in alcoholism (A) and HIV (H) infection. Specifically, we asked if alcoholism and HIV infection together $(\mathrm{H}+\mathrm{A})$ would exacerbate common deficits. The DS was administered to four age- and sex-matched groups: $31 \mathrm{~A}$. $25 \mathrm{H}, 32 \mathrm{H}+\mathrm{A}$, and 25 controls. We derived traditional age-scaled scores (based on performance at 90 seconds); measures of attentional maintenance, attentional waning, and associative learning (number completed each 15 seconds); speed and motor persistence (time to complete all 93 boxes); and declarative memory (unannounced recall of the symbols). Age-scaled scores differed significantly between groups, with $\mathrm{H}+\mathrm{A}$ and A showing the poorest performance, irrespective of errors committed. Survival analysis of time to complete all boxes revealed significantly distinct curves: $\mathrm{H}+\mathrm{A}$ was slowest and more similar to A than H. Repeatedmeasures analysis of performance over the first six 15-second epochs showed a significant group effect but not a time effect or interaction indicating neither attentional waning nor associative learning by any group. Groups performed equally well on incidental recall, suggesting that declarative memory did not contribute to DS performance. This component process analysis revealed that impaired DS performance in alcoholism, whether alone or comorbid with HIV infection, was primarily due to diminished response speed rather than impairment in associative learning, declarative memory, or attentional maintenance. Comorbid patients showed deficits that were more similar to those in alcoholism alone than those with HIV alone. [Supported by AA12999, AA05965, AA10723]

Correspondence: Stephanie A. Sassoon, Ph.D., Neuroscience Program, SRI International, 333 Ravenswood Ave., BN-165, Menlo Park, CA 94025.E-mail: stephanie.sassoon@sri.com

\section{E.V. SULLIVAN, M. ROSENBLOOM, M. SCHULTE, S. SASSOON, C. KEMPER, S. DERESINSKI \& A. PFEFFERBAUM. ATAXIA IN HIV INFECTION WHEN COMORBID FOR ALCOHOLISM.}

Instability of stance and gait commonly accompanies chronic alcoholism. can persist with sobriety, and puts alcohol abusers at increased risk of falling. Given the high prevalence of alcohol abuse comorbidity in HIV infection, this study examined the single and combined effects of these two conditions on ataxia. Accordingly, we administered the Fregly-Graybiel Ataxia Battery, a quantitative test of static balance and gait, to four age- and sex-matched groups: 31 alcoholics (A), 25 HIV-infected individuals $(H), 32$ individuals with $A$ and $H(H+A)$, and 25 controls $(C)$. $\mathrm{H}$ and $\mathrm{H}+\mathrm{A}$ were matched in viral load and $\mathrm{CD} 4$ counts; $\mathrm{A}$ and $\mathrm{H}+\mathrm{A}$ were matched in total lifetime alcohol consumption and days sober; and all three patient groups had similar Beck Depression Index scores. The patient groups did not differ from each other or from controls in ataxia performance when tested with eyes open but were impaired when tested with eyes closed. Specifically, the A and $\mathrm{H}+\mathrm{A}$ groups were equivalently impaired relative to the $\mathrm{C}$ and $\mathrm{H}$ groups on measures of static balance and gait, whereas the $\mathrm{H}$ group was impaired in gait only. Older age and higher alcohol consumption, but not number of days sober, correlated with lower scores on several ataxia measures in the alcohol groups. Neither CD4 counts nor viral load correlated with ataxia scores in the HIV groups. These results suggest that HIV-infection and alcohol abuse each increases the liability to falling, which can add substantial morbidity to the primary conditions. [Supported by AA12999, AA10723, AA05965] Correspondence: Edith V. Sullivan, Ph.D., Psychiatry \& Behavioral Sciences, Stanford University School of Medicine, 401 Quarry Road, Stanford, CA 94305-5723.E-mail: edie@stanford.edu

\section{Substance Abuse Effects}

\section{R. FAMA \& E.V. SULLIVAN. VISUOPERCEPTUAL LEARNING IN DETOXIFIED ALCOHOLIC MEN.}

Visuospatial deficits occur in chronic alcoholism, persist with sobriety, but do not extend to all types of visuospatial and visuoperceptual tasks. Multiple cognitive processes contribute to successful visuoperceptual performance. The processes invoked to perform a task may be altered by disease, suggesting strategy differences in performance. To examine component processes contributing to visuoperceptual learning in alcoholism, we tested 51 detoxified alcoholic men (ALC) and 63 age-matched normal control men (NC) with tasks assessing visuoperception (Gollin Incomplete Pictures Test initial session), visuoperceptual learning (Gollin 1 hour and 24 hour retest sessions), declarative memory (incidental recall of the 20 Gollin stimuli), and frontal/executive function (Wisconsin Card Sorting Test). ALC were impaired ( 0.5 SD below NC) on tests of visuoperception and executive function. By contrast, both groups showed equivalent learning and incidental recall of Gollin stimuli. Multiple regression analyses predicting visuoperceptual learning at 1 hour indicated that the component processes invoked differed between the ALC and NC groups. For ALC, incidental recall $(p=.01)$ and executive function $(p=.02)$ were unique predictors of 1 hour visuoperceptual learning, but visuoperception was not. For NC, visuoperception $(p=.0001)$ and incidental recall $(\mathrm{p}<.002)$ were significant predictors of visuoperceptual learning, whereas frontal/executive function was not. Recall and executive function endured as unique predictors of visuoperceptual learning at 24 hours in the ALC. Thus, alcoholics and controls engaged different component processes to achieve equivalent visuoperceptual learning levels. Specifically, although both groups invoked declarative memory, controls also invoked visuoperception whereas alcoholics invoked executive function in performing this visuoperceptual learning task. [Support: AA10723, AA05965]

Correspondence: Rosemary Fama, Ph.D., Neuroscience Program, SRI International, 333 Ravenswood Avenue, Menlo Park, CA 94025. E-mail: rfama@synapse.sri.com

\section{K. GROHMAN \& W. FALS-STEWART. DETECTING IMPAIR- MENT IN SUBSTANCE-ABUSING PATIENTS USING THE NEU- ROPSYCHOLOGICAL ASSESSMENT BATTERY (NAB).}

The Neuropsychological Assessment Battery (NAB; Stern \&. White, 2003) is a newly published comprehensive modular neuropsychological test battery developed to assess multiple areas of cognitive functioning in adults. The purpose of the present investigation was to examine the accuracy of the NAB in identifying cognitively impaired and unimpaired substance-abusing patients, compared to a screening battery with established accuracy in classifying these patients as impaired or unimpaired. As reported in many neuropsychological evaluations during the last 2 decades, $30 \%-50 \%$ of substance-abusing patients have general cognitive impairment. In the present study, we administered the screen- 
ing modules of the NAB to 84 substance-abusing patients entering one of two residential treatment programs; patients were also administered the Neuropsychological Screening Battery (NSB; Heaton et al., 1990). Using the Total Screening Index from the NAB, $32(38 \%)$ of the patients were classified as mildly or moderately impaired; the NSB identified 30 $(36 \%)$ patients as being cognitively impaired. Agreement between the two batteries was excellent (kappa $=.75, \mathrm{p}<.001)$; the sensitivity and specificity of the NAB were also acceptable (i.e., both exceeded .80). The NAB, with its strong psychometric properties, extensive normative data, and avoidance of floor and ceiling effects, holds promise as a comprehensive neuropsychological assessment tool for substance-abusing patients.

Correspondence: Kerry Grohman, Ph.D., The Research Institute on Addictions, 1021 Main St, Buffalo, NY 14203. E-mail: grohman@ria. buffalo.edu

D. JOVANOVSKI, S. ERB \& K. ZAKZANIS. META-ANALYTIC EVIDENCE OF NEUROCOGNITIVE DEFICITS IN COCAINE USERS.

The objective of the current study was to determine the type and magnitude of the specific cognitive deficits found as a result of cocaine use. An effect size analysis of neurocognitive function in cocaine users using meta-analytic principles was conducted. Effect sizes were calculated for each test variable across 15 empirical studies that met inclusion criteria. The results from 481 cocaine users and 586 healthy normal controls revealed that cocaine use had the largest effect on measures of attention. Moderate to large effect sizes $(\mathrm{d}>0.50)$ were also obtained on tests of visual memory and working memory. Minimal effect sizes were obtained on tests of verbal fluency and other language functions, and sensory-perceptual functions. Executive functioning tests produced mixed findings. Although the largest effect sizes were found on tests of attention, many of these attentional tasks were confounded tests of the various subcomponents of attention (i.e., information processing speed, focused, sustained, and divided); future research is required to make definitive conclusions regarding whether specific subcomponents are more impaired than others in cocaine users. The mixed findings on executive tasks revealed that more complex, multidimensional executive tasks are likely to be more impaired in cocaine users than simpler executive abilities, which remained largely intact. Meta-analytical results are consistent with findings from neuroimaging and neurochemical studies that have found cocaine use to be associated with dysfunctions in the anterior cingulate gyrus and orbitofrontal cortex, regions highly implicated in the mediation of attentional and executive functions, respectively.

Correspondence: Diana Jovanovski, Honours B.Sc., Division of Life Sciences, University of Toronto (at Scarborough), 1265 Military Trail, Scarborough, ON M1C 4B6, Canada.E-mail: diana.jovanovski@ utoronto.ca

\section{MOURATIDIS, J. POLING, A. OLIVETO, M. SOFUOGLU \& T. KOSTEN. CLASSICAL AND EMOTIONAL (COCAINE) STROOP PERFORMANCE IN COCAINE/OPIATE USERS SUPPORTED BY NIDA P50 DA 12762 AND NIDA K12 DA00167.}

Background: Cocaine users have demonstrated deficits in inhibitory control mechanisms. The Stroop Test requires participants to override a dominant tendency and is a measure of response inhibition and response conflict. This pilot study explored the feasibility of examining the neurocognitive relationship between cognition and emotion relating to the mechanisms of addiction with the classical and emotional Stroop tests. Methods: Participants included 29 treatment-seeking cocaine/opiate subjects (28 men and 1woman; 83\% Caucasian, 10\% African-American, 7\% Hispanic; mean age 34; mean HAM-D 10). Subjects took the classical (congruent and incongruent) and cocaine Stroop during screening. The cocaine trial consists of cocaine related words (crack) printed in red, green, and blue and matching the classical task parameters. In all trials the participant was asked to name the color of the ink. Results:
Data were analyzed using t-tests. Findings indicate that mean colorword interference score was $69(\mathrm{SD}=15)$. Mean reaction times for the congruent and incongruent trials were $784.98(\mathrm{SD}=249.19)$ and 908.49 $(\mathrm{SD}=294.72)$ respectively (p.<02). Mean reaction time for the cocaine trial was $736.04(\mathrm{SD}=171.70)$. There was no significant difference between their performance on the congruent trial and the cocaine trial, however, performance was faster on the cocaine trial than on the incongruent trial of the classical task (p.<.002). Conclusions: This is one of the first studies to develop a computerized cocaine Stroop and to compare performance on both the classical and cocaine Stroop tests within the same subjects and to demonstrate feasibility. Further studies will need to be conducted with larger sample sizes.

Correspondence: Maria Mouratidis, Psy.D., Psychiatry, Yale University, 950 Campbell Ave, Bldg. 35, West Haven, CT 06516. E-mail: maria. mouratidis@yale.edu

\section{S. WOODS, J.D. RIPPETH, E. CONOVER, A. GONGVATANA, R.K. HEATON, I. GRANT \& T. HNRC GROUP. DEFICITS IN EX- ECUTIVE CONTROL OF VERBAL LIST LEARNING AMONG INDI- VIDUALS WITH METHAMPHETAMINE DEPENDENCE.}

An emerging body of literature indicates that methamphetamine (MA) use is associated with neurotoxicity and neuropsychological impairment, especially in cognitive domains reliant on prefrontal-striatal circuits. Several studies also indicate that MA users exhibit deficits in verbal learning and memory, but the specific profile of these deficits has not heretofore been described. We examined the performance of 87 MA dependent $(\mathrm{MA}+)$ persons and 71 demographically comparable non-MA using controls (MA-) on the Hopkins Verbal Learning Test-Revised (HVLT-R). Abstinent at the time of evaluation, MA+ participants met diagnostic criteria for MA dependence during their lifetime, as well as criteria for abuse or dependence within 18 months of neuropsychological assessment. MA+ participants demonstrated significantly lower performance on HVLT-R total trials 1-3, semantic clustering, and delayed free recall, as well as a higher number of repetition errors. Trend-level differences indicated a lower learning slope and higher number of intrusions among MA+ subjects, whereas the groups were comparable in serial clustering, across-trial recall consistency, percent retained, recognition discriminability, and semantically-related false positive recognition errors. Taken together, these findings suggests that MA dependence is associated with a deficiency in executive control of verbal encoding and retrieval, perhaps attributable to prefrontal-striatal circuit neurotoxicity; indeed, similar verbal learning profiles are evident in samples with demonstrable frontal-basal ganglia pathology. Importantly, verbal encoding and retrieval deficits may interfere with MA dependent persons' acquisition of substance abuse treatment program rules and skills, which may lead to more frequent rule violations, premature dropout, and ultimately poorer treatment outcomes.

Correspondence: Steven Paul Woods, Psy:D., HNRC/Psychiatry, UCSD, 150 W. Washington St., 2nd Floor, San Diego, CA 92103. E-mail: spwoods@ucsd.edu

\section{K.L. MEDINA, P.K. SHEAR, K. CORCORAN, C. DRESSLER, C. DUCKWORTH, A. HURST \& J. PETERS. MDMA (ECSTASY) DOSAGE AND VERBAL MEMORY ABILITY.}

Numerous studies have demonstrated that ecstasy (MDMA) is a selective serotonin neurotoxin in several animal species (OShear, et al., 1998) and in humans (McCann, et al., 2000). Further, ecstasy users are known to demonstrate deficits in verbal memory compared to controls (Bolla, et al, 1998; Morgan, 1999). However, few studies have closely examined the relationship between lifetime, past year, or maximum dosage of ecstasy use in relation to memory ability while controlling for cannabis use, which is highly prevalent in this population. The goal of the present study is to examine the relationship between levels of ecstasy use and performance on the California Verbal Learning Test (2nd Edition) 
among 29 ecstasy users (13 women, 15 men). A series of multiple regressions were run to test whether past year, lifetime, and maximum dosages of ecstasy significantly predicted performance on several verbal memory indices after controlling for cannabis use, age, ethnicity, education, and gender. The primary results indicated that higher past year usage of ecstasy was related to poorer immediate memory $(p<.02)$, short delay cued recall $(\mathrm{p}<.03)$, long delay cued $(\mathrm{p}<.05)$ and free $(\mathrm{p}<.0 .03)$ recall, total recall $(p<.01)$, and total discriminability $(p<.02)$. Greater maximum dosage was related to poorer performance on immediate memory $(p<.01)$, long delay free recall $(p<.04)$, and short delay free recall $(p<.02)$. Lifetime ecstasy consumption was significantly related to poorer performance on long and short delay free recall $(p<.03, .02$, respectively) and discriminability $(p<.06)$. Thus, this study revealed significant dose-dependent relationships between ecstasy use and short-term, long-term, and recognition verbal memory ability among ecstasy users even after controlling for cannabis consumption.

Correspondence: Krista L. Medina, M.A., Psychology, University of Cincinnati, P.O Box 210376, Cincinnati,OH 45221.E-mail: lisdahk@ email.uc.edu

\section{K.K. ZAKZANIS \& Z. CAMPBELL. THE EFFECTS OF 3,4-METH- YLENEDIOXYMETHAMPHETAMINE (MDMA OR ECSTASY) USE ON VERBAL ABILITY.}

Recreational use of +/- 3,4- methylenedioxymethamphetamine (MDMA or Ecstasy) is rapidly on the rise. Quantitative evidence has shown that MDMA damages serotonergic neurons in animals and possibly humans. Moreover, it has also been shown that MDMA has negative effects on several aspects of neuropsychological function, such as memory and executive function. In an effort to extend the current literature, the present study attempted to further examine the effects of MDMA on areas of cognition that have received little attention thus far, namely, language and speech function. Participants, consisting of 18 abstinent MDMA users and 17 normal controls completed a questionnaire regarding the characteristics of their MDMA usage and other possible recreational drug experience. They then completed a neuropsychological test battery consisting of measures of language and speech (i.e., Boston Naming Test, Controlled Oral Word Association Test, Animal Fluency, Token Test, Word Repetition, Oral Sentence Reading), and a measure of intelligence (i.e., Wechsler Abbreviated Scale of Intelligence: WASI). Statistical comparisons between MDMA users and controls did not indicate differences on measures of language function. There was, however, evidence of a significant relationship between several characteristics of MDMA use and performance on the matrix reasoning subtest of the WASI. Overall, our results did not reveal impairments on any particular neuropsychological measure of language function. There was, however, evidence fitting an executive dysfunction profile, supporting existing literature of such impairments in MDMA users.

Correspondence: Zachariah Campbell, H.B.Sc. \& M.A., University of Toronto, 1265 Military Trail, Toronto, ON M1C 2A4, Canada. E-mail: zac.campbell@utoronto.ca

\section{K. ZAKZANIS \& Z. CAMPBELL. A TWO-YEAR FOLLOW-UP OF MEMORY FUNCTION IN BOTH FORMER AND CURRENT USERS OF +/- 3,4-METHYLENEDIOXYMETHAMPHETAMINE (MDMA OR ECSTASY).}

To investigate the long-term neurotoxic potential and functional consequences of continued MDMA (Ecstasy) use as well as relative abstinence from such drug use in humans over the course of 2 years. 15 MDMA users (8 current, 7 former) participated in a longitudinal study in which they completed a brief neuropsychological test battery composed mainly of retrospective and prospective memory tasks. All participants were current users at the baseline and 1-year follow up. Participants in the former group were abstinent at the 2-year follow up for less than one year. All participants were abstinent for at least 2 weeks on initial, 1 year and 2-year testing. At 1 -year, continued MDMA use was associated with progressive decline in terms of immediate and delayed recall. At 2 -years, the former user groups performance remained, for the most part, static and actually improved on some measures. The current user group, however, demonstrated further declines on many measures of immediate and delayed recall. Our results indicate that continued use of MDMA is associated with progressive declines in immediate and delayed recall. Abstinence from such use, for as little as one year, may result in some minor improvements in performance. Thus, although the functional consequences of MDMA appear to be detrimental to memory processes, these effects may be reversible with discontinued use.

Correspondence: Zachariah Campbell, H.B.Sc. \& M.A., University of Toronto, 1265 Military Trail, Toronto, ON M1C 2A4, Canada. E-mail: zac.campbell@utoronto.ca

\section{S. RAY, M.E. BATES \& B.M. BLY. THE ROLES OF ALCOHOL AND WORD FREQUENCY IN EXPLICIT MEMORY TASKS.}

Social drinkers' explicit (intentional) memory processes were examined following alcohol challenge using free recall and retroactive interference (RI) tasks. Word presentation frequency was manipulated during the study phase of the two explicit memory tasks. We hypothesized that acutely intoxicated individuals would be impaired in both free recall and RI tasks. The role of word frequency in the two memory tasks was exploratory. Using a within-subject design, 22 individuals (11 women) participated in two counterbalanced sessions (alcohol versus no-alcohol) separated by 1 week. In each session, participants studied two unique lists (List 1 and List 2) with multiple presentation frequencies of words (one through five). The critical measure in the RI task was the number of words participants mistakenly recalled from List 2 when asked to recall List 1 (intrusion errors). The target peak BAC in the alcohol session was $90 \mathrm{mg} / \mathrm{dl}$. Percent of words recalled in the free recall task was significantly lower in the alcohol than in the no-alcohol condition, F (1, $20)=25.22, p<.005$, and the mean number of intrusion errors was significantly higher in the alcohol condition than in the no-alcohol condition, $\mathrm{F}(21,20)=3.73, \mathrm{p}<.05$. Word frequency facilitated performance in the free recall task, $\mathrm{F}(4,80)=27.28, \mathrm{p}<.005$, but did not influence the number of intrusion errors in the RI task, $p>.60$. The findings are discussed in relation to data from studies on amnesic syndromes. Correspondence: Suchismita Ray, Ph.D., Center of Alcohol Studies, Rutgers University, Smithers Hall, 607 Allison Road, Piscataway, NJ 08854. E-mail:shmita@rci.rutgers.edu

\section{M.E. MCCOURT \& W. PASIEKA. THE EFFECT OF ACUTE ALCO- HOL INTOXICATION ON PANORAMIC VISUOSPATIAL ATTEN- TION: EXAGGERATION OF LEFTWARD BIAS IN LINE BISECTION.}

A hallmark of visuospatial neglect syndrome is that patients misbisect horizontal lines far rightward of veridical center. Neurologically normal subjects misbisect lines with a systematic leftward bias $(1,2)$. Neuroimaging studies in normals reveal predominant right hemisphere activation during line bisection tasks $(3,4)$. The current study was designed to assess potential alterations of panoramic visuospatial attention that might accompany acute alcohol intoxication, using a forced-choice tachistoscopic line bisection task as a performance measure (5). Subjects $(\mathrm{N}=18$; 10 male; strongly right-handed; mean age $=23$ years $)$ participated in both intoxicated (mean $\mathrm{BAC}=0.77$ ) and non-intoxicated conditions; the order of administration of the two conditions was counterbalanced across subjects. Mean leftward bisection error in the non-intoxicated condition was 0.26 degrees visual angle $(0.9 \%$ line length); bisection leftward error was significantly larger $(p<.002)$ when these subjects were intoxicated ( 0.36 degrees; $1.26 \%$ line length). These data suggest that alcohol exerts a differential effect on the left and right cerebral hemispheres which, in moderate doses and under acute conditions, appears to amplify right hemispheric control over the allocation 
of panoramic spatial attention. (1)Jewell \& McCourt (2000) Neuropsychologia, 38, 93-110; (2)Bowers \& Heilman (1980) Neuropsychologia, 18, 491-498; (3) Foxe et al. (2003) NeuroImage, 19, 710-726; (4) Fink et al. (2000) Neuropsychologia, 38, 1741-48; (5) McCourt \& Jewell (1999) Neuropsychologia, 37, 843-855.

Correspondence: Mark E. McCourt, Ph.D., Psychology, North Dakota State University, North Dakota State University, Fargo, ND 58105. Email:mark.mccourt@ndsu.nodak.edu

\section{.P. PAWLAK, B.E. MARSHA \& J. TONIGAN. INDIRECT EFFECTS OF NEUROPSYCHOLOGICAL ABILITY ON ADDICTION TREAT- MENT OUTCOME.}

Neuropsychological impairment may have important indirect effects on addiction treatment outcome via its influence on mediator variables. We used data from the outpatient sample of Project MATCH, a multisite study of alcohol treatment and client-treatment matching, to examine the direct and indirect effects of cognitive abilities on outcome assessed as percent days abstinent (PDA). Mediator variables were client therapist alliance and treatment retention. Participants were 952 men and women with alcohol use disorders who were randomly assigned to one of three treatment groups: Cognitive Behavioral (CBT, N=301), Motivational Enhancement (MET N=316), and Twelve Step Facilitation (TSF N=335). Treatment lasted for three months, and participants were followed for 15 months. Four neuropsychological measures were obtained at intake and at the 15 month follow up. Scores from the Trail Making Test Part B, Symbol Digit Modalities Test, and the Shipley Institute of Living (SIL) Abstraction Test formed an executive impairment index. SIL Vocabulary score was the index of verbal ability. A multigroup path model revealed that both executive impairment and vocabulary had high stability across time, and they also mutually influenced each other from baseline to the 15 months. Vocabulary positively predicted percent of treatment sessions attended, which in turn positively predicted PDA across all treatment groups. One suppression effect was identified in CBT. Vocabulary negatively predicted therapeutic alliance, which in turn positively predicted PDA. These results point to the potential utility of developing or modifying existing addiction treatments to capitalize on clients' verbal strengths or to compensate for verbal weaknesses.

Correspondence: Anthony P. Pawlak, Rutgers University, 10 Sandford St., Apt. \#1, New Brunswick, NJ 08901. E-mail: tonypete@eden.rutgers.edu

\section{Paper Session 15/9:00-11:00 a.m.}

\section{Neuropsychological Functioning in Temporal Lobe Epilepsy}

\section{W.B. BARR. DETECTION OF MALINGERING ON ROUTINE TESTING IN PATIENTS WITH TEMPORAL LOBE EPILEPSY. .}

Most methods for assessing effort and malingering on routine neuropsychological testing have been validated on samples of patients with mild traumatic brain injury (MTBI). It is not known whether these methods can be extended for use with other neurological groups. The goal of this study was to determine whether cutoff scores established for detecting suboptimal effort are appropriate for use with patients with temporal lobe epilepsy (TLE). Data from four commonly used tests were analyzed retrospectively in 127 patients undergoing neuropsychological assessment during presurgical monitoring. In each case, the diagnosis of TLE was confirmed by video-EEG. There was no obvious incentive for suboptimal performance. Cutoffs established for identification of decreased effort were applied to scores from the WAIS-R, WMS-R, WCST, and the CVLT. The resulting rates of individual scores below cutoff levels ranged from $3 \%$ to $17 \%$. There were no signs of suboptimal performance in two-thirds of the total sample. Only $2 \%$ exhibited two or more scores below cutoff levels. Methods for identifying suboptimal effort in MTBI patients appear to be appropriate for use in patients with TLE. The current findings suggest that scores below cutoff on more than one test are seen rarely in TLE patients undergoing presurgical workups.

Correspondence: William B. Barr, Ph.D., Neurology and Psychiatry, NYU School of Medicine, NYU Comprehensive Epilepsy Center, 403 East 34th Street, EPC - 4th Floor, New York, NY 10016. E-mail: william. barr@med.nyu.edu

\section{B. HERMANN, M. SEIDENBERG, R. HANSEN, C. DOW, J.J. JONES, B. BELL, P. RUTECKI \& A. WOODARD. PROGRESSION IN TEMPORAL LOBE EPILEPSY.}

Whether chronic temporal lobe epilepsy (TLE) is associated with progressive changes in brain structure and cognition remains controversial. Much of the available evidence is cross-sectional, with few modern prospective studies. We here present preliminary findings from a 4year prospective investigation of changes in cognition and brain structure in an overall cohort of 160 subjects with TLE and healthy controls. To date, 28 TLE and 21 controls have completed neuropsychological re-evaluation. Quantification of changes in volumetric measurements of total segmented gray matter, white matter, and CSF has been completed for 20 of these initial 49 subjects. Results indicate a significantly greater loss of total gray matter volume $(p=.043)$ and trend of greater accumulation of total CSF in the epilepsy subjects, with no difference in the rate of change in total white matter volume $(p=.29)$. Regarding cognition, there are significant test-retest differences between groups on the following measures: abbreviated WAIS-III Full Scale IQ ( $p=.003)$ and Performance IQ $(p=.001)$, Grooved Pegboard $(p=.003)$, and WMS General Memory $(p=.025)$, with the latter changes greater in delayed visual $(p=.041)$ than verbal memory $(p=.16)$. These cognitive changes were due to either lack of test-retest gain in the TLE patients compared to controls, frank decline in epilepsy patients, or a combination of these effects. In summary, prospective changes in brain structure and cognition were identified in TLE patients over a 4-year interval that are consistent with the hypothesis that chronic TLE may be associated with progressive adverse effects on brain and cognition. Correspondence: Bruce Hermann, PhD, Neurology, University of Wisconsin-Madison, 66 N. Highland Ave., Madison, WI 53792. E-mail: hermann@neurology:wisc.edu

\section{CHEUNG, A.S. CHAN, Y. CHAN \& J.M. LAM. A FMRI STUDY ON LANGUAGE PROCESSING IN CHINESE PATIENTS WITH TEMPORAL LOBE EPILEPSY.}

Our previous study on Chinese patients with temporal lobe lesion on the right heimsphere demonstrated similar severity of language impairment when compared to patients with left temporal lobe lesion. This result. which is somewhat inconsistent with findings on English-speaking patients leads to a speculation that both hemispheres may be important for processing Chinese. In order to further investigate the neurocognitive processing for Chinese, the brain activation during naming of the left temporal lobe epilepsy patients (LTLE) were examined by functional magnetic resonance imaging (fMRI). Seven right-handed and native Chinese-speaking patients with at least 5 years training in English were recruited. The activation paradigm was blocked-designed with 3 rest-task cycles (20-sec rest and 20-sec task). In the Chinese reading paradigm, eighteen two-character Chinese words were presented with 6 words in each task block, and subjects were instructed to read the words silently. Similar procedure was run in the English reading paradigm except the presented words were in English. Data were motion corrected, temporally and spatially smoothed and analyzed by the BrainVoyager. Consistent with the findings from the Western studies, activation in the left hemisphere was found in most of the patients (5/7) during 
English reading tasks. However, on reading Chinese, bilateral activation in the frontal area was found in 4 TLE patients and only 1 patient demonstrated left activation while the rest had right activation. Therefore, the results from the present study further supported our speculation that both hemispheres are involved for processing Chinese.

Correspondence: Agnes S. Chan, Ph.D., Psychology, Chinese University of Hong Kong, Sino Building, CUHK, Shatin, N.T. 00000, Hong Kong. E-mail:aschan@psy.cuhk.edu.hk

\section{D.L. DRANE, G.A. OJEMANN, D. TRANEL, J.G. OJEMANN \&.} J.W. MILLER. CATEGORY-SPECIFIC NAMING AND RECOGNITION DEFICITS IN PATIENTS WITH TEMPORAL LOBE EPILEPSY. We present data suggesting that patients with temporal lobe (TL) epilepsy exhibit a predictable pattern of category-specific naming and recognition deficits. All patients with dominant hemisphere anterior TL lesions ( $\mathrm{n}=3 ; 1$ presurgical/2 post-surgical) demonstrated naming deficits for unique objects (famous faces and landmarks) and animals while showing normal performance or only subtle decline in their ability to name tools. All patients with nondominant anterior TL lesions $(\mathrm{n}=3 ; 1$ presurgical/2 post-surgical) demonstrated recognition deficits for unique objects and animals and normal tool recognition. Naming performance was normal for all category-specific stimuli for patients with nondominant lesions. Patients with extratemporal lesions $(\mathrm{n}=2 ; 1$ presurgical/1 post-surgical) performed normally on all category-specific stimuli recognition and naming tasks. Impairment ratings were determined by comparing the performance of patients to normative data collected with healthy adults. Moreover, group differences were observed for all category-specific stimuli with the exception of tools. We believe that these results support Damasio's "mediational/convergence zone" model of semantic memory, which suggests that nondominant TL regions play a major role in binding sensory information into conceptual percepts, while dominant TL regions function to attach verbal labels to these percepts. While observed category-specific deficits were striking, they were missed by conventional naming tests, leading us to believe that such deficits are much more prevalent than recognized in both pre- and postsurgical epilepsy patients. Systematic investigation of such deficits could lead to more refined models of semantic memory, aid in the lateralization of hemispheric dysfunction, and contribute to modifications in surgical technique and patient selection in epilepsy surgery.

Correspondence: Daniel L. Drane, Ph.D., UW Regional Epilepsy Center, Harborview Medical Center, 325 Ninth Ave, Box 359745, Seattle, WA98104.E-mail:ddrane@u.washington.edu

\section{R. GRIFFITH, R.W. PYZALSKI, V. MAGNOTTA, D. O'LEARY, B. BELL, C. DOW, B.P. HERMANN \& M. SEIDENBERG. MEMORY FOR FAMOUS FACES AND THE TEMPORAL POLE: FUNCTIONAL IMAGING FINDINGS IN TEMPORAL LOBE EPILEPSY.}

Recent proposals suggest a critical role for the temporal pole region in semantic memory retrieval processes, particularly in the context of unique identification of specific persons and landmarks (Markowitsch et al., 1993; Tranel et al., 2001). Less clear is the potential interaction between the temporal poles and mesial temporal lobe structures in these processes. Using resting FDG PET, we examined the relationship between temporal pole and hippocampal activity with the identification and naming of famous faces and the ability to provide semantic information about the famous person in 14 patients with temporal lobe epilepsy (TLE). Significant correlations were observed between left temporal pole PET activity and famous face performance (range .55 to $.61, p<.05$ ) but not with right temporal pole activity. Left hippocampal PET activity showed weaker and non-significant correlations with famous face performance (range .21 to .44), and there were no significant relationships between right hippocampal PET and famous face identification. Temporal pole PET asymmetry indexes were strongly correlated with famous face performance, indicating that lower left-sided temporal pole activity relative to right temporal pole activity was associated with poorer famous faces performance. These findings suggest that the dominant hemisphere temporal pole plays a role in semantic memory for famous faces that is distinct from the hippocampus. These findings are consistent with a growing literature implicating the temporal pole regions in retrieval of unique identity information from semantic memory.

Correspondence: Randall Griffith, Ph.D., Neurology, University of Alabama at Birmingham, 1216 Jefferson Tower, 625 19th Street South, Birmingham,AL 35233.E-mail: rlgriffith@uabmc.edu

\section{TAYLOR, A. AUGUST, M. SAFER \& P. FEDIO. DIFFERENCES IN RELATING PERSONALLY RELEVANT EMOTIONAL EXPERI- ENCES BY PATIENTS FOLLOWING A UNILATERAL TEMPORAL LOBECTOMY.}

Patients with temporal lobe epilepsy may present with different interictal personality traits and emotional styles. A negative self-perception has been associated with left, and a positive self-image with right, temporal lesions. This study investigated how patients, following a unilateral left (LTL) or right (RTL) lobectomy, discussed personally relevant positive and negative experiences (enthusiastic, calm, angry, sad). The groups consisted of 9 LTL and 9 RTL patients, 20-45 years of age, who underwent a temporal lobectomy about 4 years earlier; 9 Ss formed a matched normal control (NC) group. Responses were scored as: total words expressed, total discussion time, and the number of times that "I" was used in their narration. Overall, the RTL patients tended to use more words and to speak for a longer period of time than the LTL and NC groups, who did not differ on these measures. The RTL patients used "I" more frequently than the LTL and NC subjects. This self-referencing was more pronounced for negative (angry, sad) than positive (enthusiastic, calm) emotional themes. In an earlier study, August et al. (1996) also found that presurgical RTL patients wrote more self-referencing statements than LTL patients. The self-referencing emphasis by RTL patients in reporting negative experiences may reflect an underlying agitation. This negative mood state, however, may be minimized or denied by RTL patients, who tend to maintain a positive self-image. Correspondence: paulfedio, Ph.D., Psychology, George Mason Un, 9408 Raintree Road,Burke,VA 22015.E-mail:pfedio@aol.com

\section{Paper Session 16/9:00-11:00 a.m.}

\section{Experimental Neuropsychological Studies of Normal Brain-Behavior Relationships}

\section{K.B. WALHOVD, A.M. FJELL \& I. REINVANG. VISUAL RECOG- NITION MEMORY INDEXED BY ERP.}

Visual object recognition memory was investigated by means of electrophysiological measures in an adult life span sample. 76 healthy, neuropsychologically screened participants (20-82 years) went through a continuous performance recognition task with multiple repetitions of drawings. The old-new ERP repetition effect (the difference in activation to previously presented and not previously presented objects) increased across three recognition trials, independently of performance increases. Further, the old-new effect was negatively correlated with age. In addition, younger persons showed more significant increases in activation across multiple repetitions of stimuli than did older persons. Implications of the findings are discussed, and it is speculated that old-new ERP effects may index consolidatory processes not accessible by behavioral measures alone, and these processes seem sensitive to normal aging.

Correspondence: Anders M. Fjell, Institute of Psychology, University of Oslo, Forskningvn 3b, Oslo 1094 Blindern, Norway.E-mail: andersmf@ psykologi.uio.no 


\section{T.W. WILSON, A.C. LEUTHOLD \& P.J. PARDO. ORTHOGRAPHIC STIMULI POSSESSING LEXICAL STATUS EVOKE EARLY LEFT PERISYLVIAN ACTIVATION.}

Lexical access research is typically grounded in one of two broadly construed theories (i.e., single route vs. dual-route approaches), each of which postulates a generic neural architecture and set of mechanisms subserving visual word recognition. Both theories evolved from a common set of fundamental behavioral observations, and both have been successfully implemented as computational models. However, neither the behavioral effects nor the computational modeling efforts have yielded decisive evidence for/against either theory. Functional neuroimaging can supply complementary evidence by elucidating the neurological validity of single versus dual-route models, and several hemodynamic studies have already employed lexical decision paradigms to investigate the static neural regions mediating word-level linguistic processing. Using Magnetic Source Imaging (MSI), we identified the dynamic temporal nature of the brain regions activated by linguistic items with varying lexical status. In all subjects, the time course of the neural signal markedly differentiated the two pronounceable conditions with high-frequency words eliciting left perisylvian activation in the first $300 \mathrm{msec}$, and legal pseudowords evoking spatially equivalent responses much later in the epoch. Conversely, the intensity and spatial distribution of left perisylvian activation was similar for the two pronounceable word classes. To unpronounceable consonant strings, left perisylvian cortices remained essentially dormant throughout the epoch. We conclude that the brain basis of lexical status is most explicitly represented in the dynamic time course of left perisylvian activation. and not in the precise locale or intensity of these active neural regions. Implications for current models of word recognition are discussed.

Correspondence: Tony W. Wilson, BS, Brain Sciences Center \& University of Minnesota, VAMC: Minneapolis \& University of Minnesota, 940 Franklin Terrace, Apt.311, Minneapolis, MN 55406.E-mail: tony@ brain.umn.edu

\section{N.W. PARK \& E. BARBUTO. EFFECTS OF DUAL TASK ON EN- CODING AND PRODUCTION OF NATURALISTIC ACTIONS.}

Stroke patients are more likely to make errors when performing familiar naturalistic actions (e.g., making a cup of coffee). They also take more trials and make more errors when attempting to learn and perform novel naturalistic actions (NNAs), such as transferring from a wheelchair, than age-matched controls. It has been proposed that these impairments arise because performance of naturalistic actions exceeds the available cognitive resources of stroke patients. The purpose of the current study was to investigate the role cognitive capacity and controlled processing play in the encoding and production of NNAs using a dual task experimental paradigm. College undergraduates were required to learn and perform a series of NNAs (e.g., ear guitar, bird feeder) under full attention or dual-task conditions. Attention was divided using a lag 1 task, which was performed concurrently with the NNA at encoding, at retrieval, or both at encoding and retrieval. Participants made significantly more errors performing NNAs when attention was divided at encoding $(\mathrm{M}=69.18, \mathrm{SD}=19.82)$, but not when attention was divided during retrieval $(\mathrm{M}=80.84, \mathrm{SD}=13.26)$. Analysis of secondary task performance showed that participants made more errors when the task was performed concurrently with the NNA at retrieval (M $=59.90, \mathrm{SD}=14.38)$, but not at encoding $(\mathrm{M}=70.76, \mathrm{SD}=16.21)$. These findings suggest that retrieval and performance of NNAs can occur successfully even when cognitive capacity is reduced, but that encoding of NNAs requires significant cognitive resources.

Correspondence: Norman W. Park, Ph.D., Psychology, York University, Atkinson Faculty, 4700 Keele Street, Toronto, ON M3J 1P3, Canada. E-mail:npark@yorku.ca

\section{M.J. LARSON, V. JONES, K.G. KELLY \& W.M. PERLSTEIN. DISSOCIATING COMPONENTS OF COGNITIVE CONTROL WITH HIGH-DENSITY ERPS: IMPLEMENTATION OF CONTROL, CON- FLICT PROCESSING AND ERROR MONITORING.}

Recent theories suggest that cognitive control is a dynamic process instantiated within a fronto-cortical network that implements strategic control over top-down processes, monitors and detects processing conflicts, and signals for adjustments in performance when necessary. We acquired high-density event related potentials (ERPs) while 24 neurologically-normal participants performed a cued, single-trial Stroop task that temporally dissociated instruction-related strategic processes (i.e., representing and maintaining the attentional demands of the task), from evaluative processes (i.e., conflict processing, error monitoring). On each task trial an auditory instructional cue was presented, followed, after a brief delay, by the Stroop stimulus to which subjects provided a vocal response. Subjects performed word-reading (WR) and color-naming (CN) tasks, each with congruent, neutral and incongruent conditions. ERPs were analyzed separately for instructional cue- (implementation of control), stimulus probe- (conflict), and response-locked (error processing) activity. Source localization methods estimated the potential roles of medial and lateral frontal cortex in these processes. Implementation of control was reflected in modulation of the right frontal instruction-related slow-wave associated with the more attentionally demanding task, showing greater negativity during the CN than WR task. A mid-to-lateral frontal stimulus-related conflict N450 was elicited by the incongruent CN-task condition. Response-locked ERPs to incorrect responses, collapsed across task conditions, revealed a similar mid-frontocentral error-related negativity (ERN). Error rates were greatest to the incongruent CN-task condition $[\mathrm{F}(2,46)=52.97, \mathrm{p}<.001]$, indicating Stroop error-rate interference. Overall, findings are consistent with a dissociation of strategic processes involved in the implementation of control from evaluative processes associated with conflict processing and error monitoring.

Correspondence: Michael J. Larson, University of Florida, 2114 SW 39th Dr, Gainesville, FL 32607.E-mail: mlarson@hp.ufl.edu

\section{J.S. HOLDSTOCK. THE EFFECT OF PERIRHINAL CORTEX PATHOLOGY ON INTRA-MODAL AND CROSS-MODAL OBJECT MATCHING IN HUMANS.}

Recent non-human primate research suggests that the perirhinal cortex has a role in object processing as well as memory, although there is no evidence to support the generalisation of this view to the human perirhinal cortex. I report the performance of two patients, whose common pathology was to the perirhinal cortex, on three object matching tasks which made no demands on long-term memory. The tasks required subjects to determine which of several choice shapes was identical to a simultaneously presented target shape. In two of the tasks (intra-modal) both the target and choice shapes were presented in the same modality: visual or tactile. In the third task (cross-modal) the target shape was presented tactually and the choice shapes were presented visually. Patient performance was compared with that of age and IQ matched healthy control subjects. Control subject performance, which was equivalent for the three tasks, indicated that the tasks were equally difficult. Using a cut-off of 1.96 SDs below the control mean as the criterion for impairment, the performance of both patients was markedly impaired on the cross-modal task, but unimpaired on the intra-modal tasks. These data provide the first human evidence for the view that the perirhinal cortex is involved in integrating different features of objects into a representation of the object as a whole. Whereas the cross-modal task required integration of tactile and visual features of the object, the intra-modal tasks could be solved by matching simple object features that would not require the perirhinal cortex.

Correspondence: Juliet S. Holdstock, BSc, PhD, Psychology, University of Liverpool, Eleanor Rathbone Building, Bedford Street South, Liverpool L69 3BX, United Kingdom. E-mail: j.holdstock@liverpool.ac.uk 


\section{A.M. FJELL, K.B. WALHOVD \& I. REINVANG. PREDICTIONS OF INTELLIGENCE FROM SPEED-OF-PROCESSING AND COR- TICAL VOLUME.}

In the present study, the relationship between cortical volume, the latency of the ERP component P3a (as a measure of speed-of-processing), and performance intelligence not adjusted for age differences, was investigated. 71 participants aged 20-88 years underwent a visual 3 -stimuli oddball ERP task, an MRI-scan, and intelligence testing. P3a latency and cortical volume shared $9 \%$ variance $(\mathrm{p}<.05)$ and both correlated with performance intelligence $(\mathrm{R} 2=.26$ and .40 , respectively, $\mathrm{p}<.05)$. The amount of explained variance increased significantly (to $\mathrm{R} 2=.51$ ) when both measures were used as simultaneous predictors. The relationships including latency were dependent on age, while the relationships including cortical volume were not. Thus, processing speed and cortical size seem to be complementary in prediction of performance intelligence. The theoretical implications are discussed.

Correspondence: Anders M. Fjell, Institute of Psychology, University of Oslo, Forskningvn 3b, Oslo 1094 Blindern, Norway.E-mail: andersmf@ psykologi.uio.no

\section{Symposium 18/9:00-11:00 a.m.}

\section{Emotion and Emotional Disorders: Diagnosis and Rehabilitation}

\section{Chair: Feggy Ostrosky-Solis}

\section{F. OSTROSKY-SOLIS. EMOTION AND EMOTIONAL DISOR- DERS: DIAGNOSIS AND REHABILITATION.}

Research on the neuropsychology of emotion and the neural mechanisms underlying emotional processing have received considerable attention in the last decade. Much relevant work has come from recent studies applying concepts and methods of cognitive neuroscience and neuroimaging techniques to the study of normal subjects and patients with neurological damage. This symposium aims to present an overview of our current knowledge of behavioral and psychophysiological studies on emotion in normal and brain damage subjects. The papers included will address key factors related to these issues, including new approaches to assess the measurement of distinct emotion components, how to identify the different neuronal systems subserving these emotion components, and describe the characteristics of these emotion components in normal aging, Alzheimer's disease and traumatic brain injury. Impaired socio-moral emotion and behavior has been reported in patients with frontal-lobe dysfunction, and although the brain correlates of basic emotions have been explored, the neural organization of "moral emotions" in the human brain is poorly understood. Recent findings with neuroimaging and psychophysiological techniques related to the processing of moral emotions in normal subjects will be presented and new data regarding the basis of impaired social adaptability in subjects with close head injury as well as objective behavioral rating scales for the evaluation of the non-cognitive changes in behavior, associated with frontal systems disruption will be review. The final paper describes behavioral and cognitive behavioral approaches that are used in the rehabilitation of Individuals with acquired disorders of emotional regulation. Suggestions for further research will be presented.

Correspondence: Feggy Ostrosky-Solis, UNAM, Av. Copilco-Universidad 3004, Distrito Federal 04510, Mexico. E-mail:feggy@prodigy.net.mx

\section{P. MALLOY. ASSESSING FRONTAL SYSTEMS BEHAVIOR CHANGE: BEYOND COGNITIVE MEASURES .}

Cognitive deficits due to damage or disease affecting frontal lobe systems are well known to clinical neuroscientists. There are a host of standardized measures of frontal cognitive changes, such as the Wisconsin Card Sorting Test and the Stroop Test. Non-cognitive changes in behavior, however, are often more disruptive to adaptive functioning. Despite the recognized importance of disruptive behaviors consequent to frontal lesions, only a few psychometric measures of behavior change in frontal disorders have been developed. Five behavior rating scales will be reviewed: the Behavior Rating Inventory of Executive Functions (BRIEF), the Dysexecutive Questionnaire (DEX), the Frontal Behavior Inventory (FBI), the Frontal Systems Behavior Scale (FrSBe), the Iowa Rating Scales of Personality Change (IRSPC), and the Neuropsychiatric Rating Scale (NPI). Other scales purporting to measure specific aspects of frontal functioning, but having less research support, will be described briefly. Scales will be compared and contrasted regarding content, reliability, validity, and ease of use. The BRIEF and FrSBe have good reliability and large-scale norms. No norms are available for the other scales. The FrSBe and IRSPC have been shown to be valid in discriminating frontal from nonfrontal lesioned patients, but this has not been shown in the other scales. The FBI and NPI require trained raters, whereas the FrSBe, IRSPC and BRIEF are administered to patients and/or family informants directly. The NPI and FBI are sensitive to certain changes in behavior attributed to frontal systems disruption, but have been validated primarily in dementia. Directions for scale development will be described.

Correspondence: Paul Malloy, National University of Mexico, Rivera de Cupia 110-71, Mexico City 11930, Mexico.E-mail:feggy@prodigy.net.mx

\section{F. OSTROSKY-SOLIS, A. VELEZ, N. ARIAS, R. CHAYO \& M. PEREZ. NEW PERSPECTIVES ON MORAL EMOTIONS: AN ELECTROPHYSIOLOGICAL STUDY.}

The experimental study of emotions requires stimuli that reliable evoked psychological and physiological reactions that vary systematically over the range of emotions and according to the dimension of valence (pleasant to unpleasant), arousal(calm-excited) and dominance ( high and low) ( Lang et al, 2001). Although the brain correlates of basic emotions have been explored, the neural organization of "moral emotions" in the human brain is poorly understood. Using functional magnetic resonance imaging Moll et al $(2001,2002)$ reported activation of specific neural structures while viewing scenes evocative of moral emotion. In the present study we recorded Event Related Potentials (ERP) on normal subjects while viewing pictures of emotionally charged scenes with and without moral content as well as emotionally neutral pictures. All the stimuli were previously standardized in our laboratory according to the dimension of morality (i.e. physical assaults, war scenes) neutral ( i. e. household objects, people ), and unpleasant pictures without moral content (i.e. body mutilation, dangerous animals). Unpleasant pictures with and without moral content prompt amarked positive-going slow wave, with higher amplitude at frontal, parietal and temporal sites of the left hemisphere. The latency of this component was earlier for the unpleasant pictures without moral content. The stimuli can be used in the basic investigation as well as in applied studies of emotions. Correspondence: Feggy Ostrosky-Solis, UNAM, Av. Copilco-Universidad 3004, Distrito Federal 04510, Mexico.E-mail:feggy@prodioy.net.mx

\section{A. KASZNIAK \& K. BURTON. A COMPONENTIAL/PSY- CHOPHYSIOLOGICAL APPROACH TO THE NEUROPSYCHOL- OGY OF EMOTION.}

Current theory in affective science conceptualizes emotion as proximally elicited by the appraisal of stimulus relevance in regard to motivational hierarchies (including self-preservation), and resulting in the activation of response tendencies manifest in multiple skeletal muscle, autonomic, and endocrine components. Recently, several laboratories have been applying research paradigms, employing stimulus selection, behavioral measures, and psychophysiological procedures motivated by this componential perspective, to the study of the emotional consequences of neurological damage and illness. This presentation will describe such 
a research paradigm employed in recent studies conducted within our Neuropsychology and Emotion laboratory. Specifically, we will explain our procedures for: the selection of standardized emotional stimuli; the collection of structured self-report data concerning subjective stimulus appraisal and judgments of the valence and arousal dimensions of experience; the measurement of subtle aspects of emotional expression through facial electromyography; the assessment of response tendencies through emotion modulation of the eye-blink startle response; and the evaluation of autonomic changes through the measurement of skin conductance potential. The application of this paradigm will be demonstrated with results obtained from our recent studies of: (1) the timecourse of emotion activation in health young adults,; and (2) comparisons of healthy younger and older adults, and persons with mild Alzheimers Disease in autonomic, facial expression and startle response modulation. The implications of these results for the future of clinical assessment of emotion and emotional disorders will be discussed.

Correspondence: Alfred Kaszniak, Ph.d., Psychology, National University of México, Rivera de Cupia 110, Mexico City 11930, Mexico. Email:feggy@prodigy.net.mx

\section{J. DYWAN . HEAD INJURY AND ALTERED IDENTIFICATION AND RESPONSE TO EMOTIONAL EXPRESSION.}

It is well established that when the head is subjected to high velocity impact, the orbital and medial regions of the prefrontal cortex (OMPFC) are vulnerable to shearing and contusional injuries. These prefrontal regions, through their links with cortical and limbic structures, are involved in the control of visceral functions as well as cognition. Damage to the OMPFC is often associated with changes in social adaptability and these changes typically persist over time and constitute a significant barrier to full recovery. Whereas few would dispute the link between OMPFC damage and impaired social adaptation, specific deficits would vary as a function of which frontal-subcortical circuits are affected. For example, the OMPFC has been associated with the suppression and inhibition of response tendencies and with the modulation of arousal through alterations in parasympathetic control. More recently, the links between the OMPFC and the amygdala have been associated with decoding and responding to emotional stimuli. Thus, the basis of impaired social adaptability may vary as a function of which system is impaired and a fuller understanding of the nature of such deficits would provide valuable guidance for necessary rehabilitation and support. The focus of this presentation will be to explore the basis of change in social adaptation following closed head injury through self- and collateral-reports of everyday behaviour (Brock Adaptive Functioning Questionnaire) as well as through laboratory evaluation of facial and emotionalexpression identification, electrodermal response to emotional expression, and electrophysiological response to the matching of facial and emotional identity.

Correspondence: Jane Dywan, National University of Mexico, Rivera de Cupia 110-71, Mexico City 11930, Mexico.E-mail:feggy@prodigy.net.mx

\section{MATEER. DISORDERS OF EMOTIONAL REGULATION: RE- HABILITATION CHALLENGES AND STRATEGIES.}

Individuals with acquired disorders of emotional regulation often pose significant challenges to rehabilitation. Impairments in self-regulation of mood and behavior, and in self-awareness of these changes can significantly impact emotional adjustment and psychosocial functioning. Assessment of emotional regulation needs to acknowledge the influence of pre-morbid regulation of mood and emotion, injury related alterations in awareness and self- regulation of affective behavior, and environmental factors that influence emotional behavior. Effective interventions include behavioral and cognitive behavioral approaches, depending largely on the individuals level of awareness and context dependency. Rehabilitation for these disorders is broadly conceptualized as shifting the individual from a more dependent, externally supported state to a more independent and self-regulated state. Illustrative examples of in- terventions will include 1) implementation of a reminding device for a severe amnesic with anxiety secondary to intrusive negative beliefs; 2 ) implementation of a self-monitoring program for management of frustration/anger in a client with severe traumatic brain injury; and 3) a successful anxiety management program focused on improving self-regulation of cognitive failures and reducing maladaptive thinking. Results will also be provided with respect to a group study comparing the effects of cognitively oriented versus adjustment-oriented interventions. Correspondence: Catherine Mateer, UNAM, Rivera de Cupia 110-71, Mexico City 11930, Mexico.E-mail:feggy@prodigy.net.mx

\section{Poster Session 11: Cognition and Epilepsy, Focal Lesions, Memory and Language Disorders, Laterality/10:15 a.m.-12:15 p.m.}

\section{Epilepsy}

\section{E. SOETY, M.K. YORK, H.S. LEVIN, D.D. ARMSTRONG, R. GROSSMAN, D. YOSHOR, W. HAMILTON, E. MIZRAHI, A. VERMA \& I. GOLDSMITH. PREOPERATIVE MEDICAL AND NEUROPSYCHOLOGICAL VARIABLES PREDICT PATHOLOGY IN ANTERIOR TEMPORAL LOBECTOMY PATIENTS.}

A subset of anterior temporal lobectomy (ATL) patients continue to experience a significant persistent seizures following surgery. Research suggests that the underlying neuropathology has a differential impact on seizure control after ATL. We sought to predict pathology category using preoperative medical and neuropsychological variables. Of the 180 patients who underwent ATL at our center, 83 (27 male, 56 female) English-speaking adults with complete preoperative neuropsychological evaluation were classified into the following three pathological categories: classic Ammon's horn sclerosis (cAHS = 57), atypical mesial sclerosis (Atypical $=15)$, and gangloglioma $(G G=11)$. A stepwise discriminant function analysis using statistically significant preoperative memory and intellectual variables from a prior group analysis as predictors of pathology resulted in inclusion of Nonverbal Selective Reminding delayed (NVSRT delay) memory score (Chi-square $=15.816$, $p<.0001$; eigenvalue of .219). The remaining cognitive measures did not add to the prediction of pathology. A second stepwise discriminant function analysis was performed using medical variables (i.e., age of seizure onset, number of seizures per month, and history of febrile seizures) as predictors of pathology. Febrile seizure history contributed significantly to prediction of pathology (Chi-square $=23.165, p<.0001$; eigenvalue $=.341$ ), specifically cAHS. Results of a statistical discriminant function analysis including preoperative memory performance and history of febrile seizures suggests that NVSRT delay did not add to the prediction of pathology above history of febrile seizures. These results suggest that preoperative neuropsychological variables are associated with pathology, but do not significantly increase pathology prediction above medical variables.

Correspondence: Elizabeth Soety, Ph.D., Neurosurgery, Baylor College of Medicine, 6560 Fannin, Suite 944, Houston, TX 77030. E-mail: esoety@bcm.tmc.edu

\section{C.R. MCDONALD, V. IRAGUI, E. TECOMA, J. ALKSNE \& M. NORMAN. COGNITIVE OUTCOME FOLLOWING GAMMA KNIFE SURGERY IN PATIENTS WITH TEMPORAL LOBE EPILEPSY.}

Gamma knife surgery (GKS) is a neurosurgical procedure longtime used for tumor and AVM treatment and recently in the treatment of temporal lobe epilepsy (TLE). GKS offers a noninvasive alternative to anterior temporal lobectomy (ATL), reducing risk of neurosurgical complications and reducing hospital stay. Preliminary GKS seizure outcome 
studies have shown significant seizure frequency reduction in patients 8-12 months post-procedure, with the majority of patients seizure-free by 15 months; however, the effect of GKS on cognitive functioning in TLE is unknown. We report the first neuropsychological outcome data on three patients, with confirmed Phase I and II video telemetry and hippocampal sclerosis, who underwent GKS treatment of left TLE. Two models of assessing cognitive change, the reliable change indices and regression-based norms for change, were used to measure pre- versus 13 to 27 month post-operative cognitive change. Results revealed a significant verbal memory (CVLT) decline following GKS. Importantly, no patients declined on measures of IQ, attention, visual memory, language, or visuoconstruction. Consistent with the left ATL literature, GKS was associated with decline in verbal memory with relative sparing of visual memory and other cognitive skills. GKS did not produce postoperative dysnomia in any patient. Up to 2 year post-procedure radiation-induced edema is common and was present at the time of testing, which may have affected verbal memory performances. While preliminary, these data suggest that GKS offers a less invasive surgical option to the standard ATL in the absence of severe neuropsychological morbidity. Correspondence: Carrie R. McDonald, Ph.D., Psychiatry, University of California, San Diego, 3927 Nobel Dr., \# 162, San Diego, CA 92122. E-mail: carrierm@ufl.edu

\section{S.L. GRIFFIN \& D. TRANEL. RELATIONSHIPS BETWEEN AGE OF ONSET, FUNCTIONAL REORGANIZATION, AND NEUROPSY- CHOLOGICAL OUTCOME IN TEMPORAL LOBECTOMY.}

Early onset (EO) epilepsy (typically defined as before age 10) has been associated with a better neuropsychological outcome following temporal lobectomy than late onset (LO) epilepsy. Differential opportunity for presurgical functional reorganization may account for this effect, but the relationships between age of onset, functional reorganization, and neuropsychological outcome remain poorly understood. We had a unique opportunity to address this knowledge gap, by taking advantage of a large database of temporal lobectomy subjects. We studied 37 left temporal lobectomy (LTL) and 29 right temporal lobectomy (RTL) subjects, who completed comprehensive neuropsychological assessment before surgery and $21.3(+/-24.6)$ months after surgery. Epilepsy onset age was $3.6(+/-2.9)$ years for EO subjects $(\mathrm{n}=34)$, and 18.2 years $(+/-8.0)$ for LO subjects $(\mathrm{n}=32)$. Analysis of variance revealed a main effect of age of onset for verbal memory, visual memory, and overall neuropsychological outcome: following surgery, LO subjects declined in these realms, whereas EO subjects improved. Fifty-eight subjects also underwent presurgical Wada testing, which resulted in classification of 23 subjects as having traditional functional organization (TFO), and 35 subjects as having nontraditional functional organization (NTFO). NTFO was found in $70 \%$ of $\mathrm{EO}$ subjects, as compared with $50 \%$ of LO subjects. Analysis of variance revealed a significant main effect of cerebral organization on verbal memory outcome: NTFO subjects demonstrated significant verbal memory improvement following lobectomy, and TFO subjects declined in this realm. Our findings provide partial support for a functional reorganization hypothesis as an explanatory factor the better neuropsychological outcome of EO epilepsy subjects.

Correspondence: Stefanie L. Griffin, Ph.D., Lakeview Neurorehabilitation Center, 101 Highwatch Road, Effingham Falls, NH 03814. E-mail: sgriffin@lakeview.ws

\section{K.L. ISAACS, J. PHILBECK, W.B. BARR, O. DEVINSKY \& K. ALPER. OBSESSIVE-COMPULSIVE SYMPTOMS IN PATIENTS WITH TEMPORAL LOBE EPILEPSY.}

The goals of this work were to determine: (a) the prevalence of significant obsessive-compulsive (OC) symptoms in patients with temporal lobe epilepsy (TLE), (b) the nature and extent of differences in self-reported OC symptoms between patients with TLE and a normative control group, and (c) whether differences exist between right and left hemisphere TLE patients with regard to the severity of their OC symptoms.
Patients with TLE ( $\mathrm{n}=30)$ were administered the Obsessive-Compulsive Inventory (OCI) to assess OC symptoms. As a group, patients with TLE displayed OC symptoms at a higher prevalence rate than the general population. In addition, TLE patients exhibited significantly elevated scores on all but three of the 16 OCI scales and subscales. There were no reliable differences in OC symptoms in patients with right versus left hemisphere seizure foci, although the right hemisphere patients tended to score higher on both scales of the OCI. The neuropsychiatric implications of this observation have yet to be determined. Results of the study suggest that obsessive-compulsive symptoms are elevated among patients with TLE compared with a normative sample.

Correspondence: Keren L. Isaacs, Ph.D., Neurology, New York University Medical Center, 560 1st Avenue, Rivergate, 4th Floor, New York, NY10001.E-mail:kerenisaacs@hotmail.com

\section{E.K. GEARY, J. PARRISH, M. SEIDENBERG \& B. HERMANN. NAMING PERFORMANCE AND MR VOLUMETRICS IN TEMPO- RAL LOBE EPILEPSY.}

Background: Confrontation naming ability is commonly impaired in temporal lobe epilepsy patients (TLE), particularly among those with a left-sided seizure focus. However, questions persist about the role of the hippocampus relative to lateral temporal neocortex in relation to naming impairment in TLE (Sawrie et al., 2000). We employed quantitative MRI volumetrics to examine the relative contribution of right and left temporal lobe regions (segmented gray and white matter) and hippocampus for naming performance in patients with unilateral TLE. Methods: 55 patients with TLE and 52 healthy controls were administered the Boston Naming Test (BNT). MRI regions of interest included the right and left temporal lobe decomposed into segmented gray and white matter volumes and hippocampus. Hierarchical multiple regression analyses were conducted to determine the unique and shared contribution of temporal lobe regions to BNT performance. Results: Both left temporal lobe white matter volume $\left(\mathrm{R}^{2}=12 \%\right)$ and left hippocampus volume $\left(R^{2}=14 \%\right)$ contributed significant unique variance to the prediction of naming performance in TLE. In contrast, left temporal lobe gray matter volume and right temporal lobe volumes did not contribute significantly to predicting naming performance. A model incorporating total intracranial volume, left temporal gray matter, left temporal white matter and left hippocampus yielded a multiple $\mathrm{R}$ of .67 accounting for $45 \%$ of the variance in BNT performance, $\mathrm{F}(4,50)=$ $10.274, p=.000$. Conclusions: These findings suggest a contribution of both the left hippocampus and left temporal lobe white matter for confrontation naming performance in TLE.

Correspondence: Elizabeth K. Geary, B.A., Psychology, Finch University of Health Sciences / Chicago Medical School, 4890 N. Ashland, Unit 3S, Chicago, IL 60640.E-mail: kookerb@mindspring.com

\section{J. PARRISH, M. SEIDENBERG, E. GEARY, B. HERMANN, R. HANSEN \& C. DOW. CEREBELLAR VOLUME AND MOTOR TIMING IN TEMPORAL LOBE EPILEPSY.}

Cerebellar atrophy is a well-known finding in chronic epilepsy, including temporal lobe epilepsy (TLE). Recent quantitative neuroimaging studies have begun to more precisely characterize the extent and etiology of this pathology, but much remains to be determined about the cognitive correlates of cerebellar atrophy in TLE. The purpose of this study was to examine the relationship between cerebellar volume in TLE patients and performance on a motor timing measure (paced finger tapping test; PFT). Previous studies have found an association between performance on timing measures, including the PFT, and cerebellum integrity and functioning. In the present study we examined manually traced cerebellar volumes in 27 TLE patients and 16 controls matched on age and gender. The TLE group had reduced total cerebellar volume $(\mathrm{F}(1,42)=5.17, \mathrm{p}=.028)$ compared to controls. Hierarchical regression analyses, after accounting for the influence of total cerebral volume, indicated that total cerebellar volume accounted for a significant 
amount of unique variance in predicting performance variability at the 300 milliseconds inter-stimulus interval of the PFT test ( $R$ squared change $=.407, \mathrm{p}<.001)$. These results are consistent with previous reports of cerebellar atrophy in TLE. More importantly, the findings demonstrate a unique contribution of cerebellar atrophy to the overall cognitive morbidity associated with TLE in general, and the behavioral implications of cerebellar damage for motor timing performance in particular.

Correspondence: Joy Parrish, Psychology, Finch University of Health Sciences/Chicago Medical School, 3333 Green Bay Road, North Chicago, IL 60064-3095. E-mail: joy:parrish@finchcms.edu

J.N. ABREU, G.F. XAVIER \& J.L. BUENO. RIGHT BUT NOT LEFT TEMPORAL LOBE EPILPESY DISRUPT WORKING SPATIAL AND OBJECT MEMORY .

This study aimed to assess Right Temporal Lobe Epilepsy (RTLE) and Right Temporal Lobe Epilepsy (LTLE) in Nine-box Maze (Brain and Cognition 41, 39-65, 1999), an instrument tha allows to assess spatial memory components, working and reference memory. Besides it, we aimed to assess spatial memory in allocentric or egocentrc manners, using a procedure that consisted in rotation of spatial cues. Twenty subjects (nRTLE $=10 ;$ nLTLE $=10$ ), male and female patients, and 18 healthy controls composed groups. Age, manual dominance, years of school, time between seizures, age of first seizure e maximum time without crisis were compared with no differences. The Nine-box Maze test was applied twice for each subject with spatial cues rotation. Besides, four subtests of WAIS-R were included and California Card Sorting Test, to assess frontal functioning. RTLE showed deficits for working spatial memory, but not for object memory ( $M=8,9$ e SD=3,9; $M=5,3$ e sd=2,8). No differences were observed for spatial or object reference memory. Inversed digit span and logical reasoning and were observed altered for $\operatorname{RTLE}(\mathrm{M}=2,3 \mathrm{sd}=0,3 ; \mathrm{M}=4,2 \mathrm{sd}=0,9)$, but not for LTLE $(\mathrm{M}=3,5 \mathrm{sd}=0,6$; $\mathrm{M}=5,3 \mathrm{sd}=0,6)$. Only RTLE showed differences on CCST when compared to control group. Our results showed deficits of working spatial and object memory for RTLE group, that corroborate to working memory theory about temporal lobe functioning.

Correspondence: Jose N. Abreu, Ph.D student, Psicologia, Faculdade Ruy Barbosa, Av. Luis Viana Filho, 2774 Ap. 604 Ed. Adriano - Imbuí, Salvador41770-000,Brazil.E-mail: neander@frb.br

\section{K.G. KELLY, M. SEIDENBERG, B. HERMANN, C. DOW \& P. RUTECKI. CONTRALATERAL HEMISPHERE STRUCTURE AND FUNCTION IN RIGHT TEMPORAL LOBE EPILEPSY.}

A growing body of neuropsychological and neuroimaging research suggests that brain abnormalities in Temporal Lobe Epilepsy (TLE) extend beyond the epileptogenic region. The present study employed quantitative MRI and neuropsychological testing to evaluate the structural and functional integrity of the hemisphere contralateral to the seizure focus in patients with unilateral TLE. The TLE group consisted of 17, EEGmonitored, patients with complex partial seizures originating in the right temporal lobe. The control group consisted of 82 neurologically healthy individuals. All subjects underwent a whole brain MRI brain scan and neuropsychological evaluation including 7 putative measures of left hemisphere function (e.g., Boston Naming Test, Grooved Pegboard: Dominant Right Hand). In addition, clinical epilepsy variables, including history of secondary generalized seizures, epilepsy duration, and age of onset, were identified through clinical interview. Statistical analyses were performed using z-scores adjusted for age, gender, and either height or education for MRI and neuropsychological variables, respectively. Overall, findings indicate the presence of contralateral hemisphere abnormalities in TLE. Specifically, right TLE patients performed significantly worse than controls on 6 of 7 measures of left hemisphere function. Four of these measures were significantly associated with left hemisphere white matter, after accounting for variance associated with the right hemisphere. Compared to controls, the right TLE group also had significant brain volume reduction in both hemispheres, which was most marked for white matter tissue volume. Although the small right TLE sample size limited within-group analyses, exploratory analyses identified a significant relationship between ipsilateral right hippocampal volume and epilepsy duration.

Correspondence: Kiesa G. Kelly, Ph.D., Clinical \& Health Psychology, University of Florida, PO Box 100165, Health Science Center, Gainesville,FL32610-0165.E-mail:kkelly@hp.ufl.edu

\section{V.S. PHATAK, S.J. SWANSON, T.A. HAMMEKE, T.M. DEER, M. SPANAKI, G.L. MORRIS \& W.M. MUELLER. THE NATURE OF VERBAL LEARNING DEFICITS IN TEMPORAL LOBECTOMY CANDIDATES.}

Previous research has demonstrated material specific memory deficits in temporal lobe epilepsy (TLE) patients. Verbal memory deficits are found in patients with left temporal lobe seizure foci. However, few studies have examined differences between left and right TLE candidates in learning over trials and delayed recall. The objective of the present study was to investigate the preoperative storage and retrieval abilities of left and right TLE patients. Participants were 127 epilepsy surgery candidates (72 right, 55 left) who were administered the Buschke verbal Selective Reminding Test (SRT). The SRT involves presentation of a 12word list followed by selective reminding of forgotten words in each of the subsequent five trials. SRT yields a long-term storage (LTS) and consistent long-term retrieval (CLTR) score for each of the six trials as well as a 30-minute delayed free recall. Analysis of variance was performed on LTS and CLTR scores for each of the six trials and delay scores. The right and left seizure focus groups showed a significant difference in the learning curve for both storage and retrieval consistency that was most apparent in the middle segments of the learning curve. Among the memory indices, delayed recall provided the best group discrimination. Results suggest that the left TLE group performed more poorly than the right TLE group on learning over trials, consistent long term retrieval, and delayed recall of verbal information, and that retrieval processes were more impaired than storage.

Correspondence: Vaishali S. Phatak, M.S., Psychology, University of Wisconsin-Milwaukee, 224 Garland Hall, 2441 E. Hartford Ave., Milwaukee,WI 53211.E-mail:vaishali@uwm.edu

\section{B.D. BELL, C. DOW, J. JONES, A. WOODARD, P. RUTECKI, B. HERMANN \& M. SEIDENBERG. COMPOSITE IMMEDIATE AND DELAYED WMS III INDEXES: APPROPRIATE FOR TEMPO- RAL LOBE EPILEPSY PATIENTS.}

Recent factor analyses of Wechsler Memory Scale III (WMS III) standardization data revealed a three-factor solution consisting of auditory. visual, and working memory (Tulsky et al., 2003). This model differs from the five-factor model described in the WMS III technical manual (1997). The latter, which included separate immediate (IMM) and delayed (DEL) auditory (AUD) and visual (VIS) memory factors, was rejected when model specification errors were recognized. But continued use of separate IMM and DEL indexes has been recommended because future studies with clinical groups might support the validity of the IMM/DEL distinction. We investigated the utility of separate IMM and DEL WMS III indexes in 88 TLE patients. Results were as follows: 1) There were no significant differences between the IMM and DEL indexes. 2) Compared to the standardization sample, the TLE group showed a significantly higher percentage of individuals with a large positive difference (IMM minus DEL > 11) between the AUD memory indexes. But this percentage was nonetheless fairly small (pts $=13 \%$, controls $=5 \%) .3$ ) The mean percent retention standard score was 10 (average) for all four memory subtests, and for each subtest only about $10 \%$ of the patients had impaired (SS < 6) percent retention scores. 4) Left hippocampal volume correlated significantly with both IMM and DEL AUD and VIS memory and right hippocampal volume correlated 
with both IMM and DEL VIS memory. 5) Results were not substantially affected by taking into account laterality and age of onset. Overall, these data suggest that the new AUD and VIS indexes (composites of IMM and DEL memory) derived from the WMS III standardization sample are appropriate for TLE patients.

Correspondence: Brian D. Bell, PhD, Neurology, University of Wisconsin, 600 Highland Ave., Madison, WI 53792. E-mail: bell@neurology. wisc.edu

\section{E.R. LARSON, T.A. HAMMEKE, S.J. SWANSON, M. SPANAKI, G.L. MORRIS, R. PHILLIPS \& W.M. MUELLER. USE OF A NEU- ROPSYCHOLOGICAL LATERALITY RATING SCALE TO PREDICT SIDE OF SEIZURE FOCUS IN PATIENTS WITH TEMPORAL LOBE EPILEPSY.}

Neuropsychological testing is conducted routinely in the evaluation of epilepsy surgery candidates. While multiple studies have found differences between left and right temporal lobectomy groups after surgery, few empirical studies have examined the usefulness of neuropsychological testing for lateralization of seizure foci preoperatively. In the present study, a lateralization rating (LR) scale was developed based on quantitative standard score comparisons between 1) verbal and nonverbal intelligence, 2) verbal and nonverbal memory 3) language and visuospatial tests, and 4) motor and sensory functions. Points were assigned based on pre-determined score discrepancies to yield a LR ranging from 3 (left hemisphere impairment) to negative 3 (right hemisphere impairment). Participants for this study included 72 non-retarded, left hemisphere language dominant patients who underwent left $(n=28)$ or right $(n=44)$ temporal lobectomy and were seizure free 6 months after surgery. Using discriminant function analysis, $69 \%$ of the patients were correctly classified into the left or right seizure focus group based on their preoperative neuropsychological LR. Multiple regression revealed that the neuropsychological LR did not significantly add to the variance accounted for by video-EEG monitoring and MRI. For patients with $\mathrm{LR}<0$ (suggesting right seizure focus), $93 \%$ were found to have right hemisphere pathology; however, only $58 \%$ of patients with LR>0 (suggesting left seizure focus) were correctly classified. Details of sensitivity, specificity, and classification will be presented.

Correspondence: Eric R. Larson, PhD, Neurology, Medical College of Wisconsin, 9200 West Wisconsin Avenue, Milwaukee, WI 53226-3596.

E-mail: elarson@mcw.edu

\section{GALUPO, C.T. JOHNSON \& E. DIDDLEMEYER. SPONTANEOUS STRATEGIES FOR PSYCHOLOGICAL CON- TROL/ABORTION OF SEIZURES: AN ANALYSIS.}

Research on the psychological management of seizures has focused on both self-induced seizure activity and abortive attempts (Fenwick \&. Brown, 1989; Antebi \& Bird, 1993; Cull, Fowler \& Brown, 1996; Goldstein, 1997). Past survey research indicates that between $39-53 \%$ of epileptics report an ability to abort some seizures (Antebi \& Bird, 1993; Spector, Goldstein, Cull \& Fenwick, 1994). The present research utilized an interview method to investigate the spontaneous (non-coached) strategies for abortive attempts used by individuals with seizure disorders. Adult volunteer participants were recruited from local university communities and through a local Epilepsy Foundation referral service. One-on-one interviews were conducted individually and audio-taped for transcription and off-line analysis. Interview questions focused on delineating the emotional, cognitive and behavioral strategies used by individuals in preventing seizure onset. Results of the present research are consistent with past literature that suggests that only a sub-set of individuals with seizure disorders attempt to abort seizure activity. Thematic analysis of interview content reveals that there are two sets of strategies related to seizure abortion which correspond to 1) a global perception of seizure susceptibility and 2) a more immediate perception or "aura" regarding impending seizure activity. Analysis also sug- gests that participants' spontaneous strategies for seizure abortion are more likely to be cognitive or behavioral in nature, rather than emotionally based. In addition, participants were more likely to employ behavioral strategies in response to global seizure susceptibility, and cognitive strategies in response to an aura.

Correspondence: Craig T. Johnson, Ph.D., Psychology, Towson University, 8000 YorkRoad, Towson, MD 21252.E-mail: cjohnson@towson.edu

\section{R. DAVIS, L. COLE DAVIS \& J. BREIER. PREDICTING SIDE OF EPILEPTIC FOCUS USING ACTUARIAL VS. CLINICAL PREDIC- TION: A PRELIMINARY COMPARISON.}

Predictions about side of epileptic focus are often made in part from neuropsychological test data. These predictions entail combining numerous data using clinically based heuristics, which have been found in other settings to be much less reliable and accurate than actuarial (formula-driven) predictions. We explored the feasibility of developing and applying an actuarial formula for predicting side of epileptic focus in patients who later underwent surgery. Results from the actuarial formula were compared to clinical predictions drawn from printed neuropsychological reports on these patients. Clinical predictions were accurate for $83.3 \%$ of left-sided operations, and for $71.7 \%$ of right-sided operations, yielding an overall correct prediction rate of $76.9 \%$. An actuarial prediction formula was then developed in a randomly selected subsample of patients, followed by cross-validation in a second subsample. In the first subsample, the following variables entered the prediction equation: Trails B, verbal fluency (FAS), Logical Memory II, and WCST perseverative errors, which correctly classified $87.5 \%$ of cases (69.2\% of left-sided, and $96.3 \%$ of right-sided patients). Upon crossvalidation in the second subsample, however, overall predictive accuracy shrank to $54.5 \%$ (27.8\% of left-sided, and $73.1 \%$ of right-sided patients). These findings indicate greater ease of prediction using formula-based approaches for right-sided as opposed to left-sided hemispheric dysfunction. Moreover, these results support the use of clinical prediction for the lateralization of epileptic focus.

Correspondence: Rob Davis, Psychology, The College of New Jersey, P.O. Box 7718, Ewing, NJ 08628-0718.E-mail: rdavis@tcnj.edu

T.M. DEER, V.S. PHATAK, S.J. SWANSON, T.A. HAMMEKE, G.L. MORRIS \& M. SPANAKI. SUBJECTIVE COGNITIVE COMPLAINTS AND OBJECTIVE COGNITIVE PERFORMANCE IN PRESURGICAL EPILEPSY PATIENTS.

Subjective cognitive complaints ( $\mathrm{SCC}$ ) have been found to be related to either objective test performance or to measures of emotional distress. We hypothesized that SCC in epilepsy surgery candidates would be more highly correlated with emotional than cognitive measures and that SCC would not account for unique variance in cognitive performance beyond the contribution of demographic and emotional variables. Participants were 190 epilepsy surgery candidates who completed neuropsychological testing and Quality of Life in Epilepsy (QOLIE-31) questionnaires. The QOLIE cognitive functioning subscale $(\mathrm{Qcf})$ was correlated with Boston Naming Test raw score $(r=0.197, \mathrm{p}<.01)$ and with WMS-R Logical Memory immediate score $(\mathrm{r}=.149, \mathrm{p}<.05)$ but no other cognitive scales. Qcf was strongly correlated with scale 2 from the MMPI2 (depression; $\mathrm{r}=-.402, \mathrm{p}<.001$ ) and with scale 7 (psychasthenia; $\mathrm{r}$ $=-.471, p<.001)$. Hierarchical multiple regression revealed that Qcf predicted significant unique variance in naming ability after demographic and emotional variables were entered $\left(\mathrm{Qcf} \underline{\mathrm{R}}^{2}\right.$ change $=.031, \mathrm{p}$ $<.02)$. It did not predict memory $\left(\underline{\mathrm{R}}^{2}\right.$ change $\left.=.012, \mathrm{p}=.147\right)$. Additionally, Qcf predicted naming ability among those anticipating left $\left(\underline{\mathrm{R}}^{2}\right.$ change $=.113, \mathrm{p}<.03)$, but not right temporal resections $\left(\underline{\mathrm{R}}^{2}\right.$ change $=.011, \mathrm{p}=.407)$. In summary, preoperative cognitive complaints are not strongly related to cognitive abilities, but are related to emotional distress. Further, among left temporal lobectomy candidates, ratings of cognitive functioning correlate significantly with preoperative naming ability. 
Correspondence: Teresa M. Deer, Ph.D, Neurology/Neuropsychology, Medical College of Wisconsin, Frodtert \& Medical College Clinics, $9200 \mathrm{~W}$. Wisconsin Ave., Milwaukee, WI 53226.E-mail: teresadeer@yahoo.com

\section{K.A. KIRLIN, L. SUSSKIND-WILDER, K.A. SMITH, A. HARVEY \& L.C. BAXTER. LONG-TERM FUNCTIONAL OUTCOME OF EPILEPSY PATIENTS POST-SELECTIVE AMYGDALOHIPPOCAM- PECTOMY.}

Temporal lobe epilepsy (TLE) accounts for $80 \%$ of focal epilepsies. Of the seizure disorders, TLE is the most frequently medically refractory $(50 \%)$ and is the most amenable to surgical intervention. Anterior temporal lobectomy (ATL) is the most commonly used surgical treatment of intractable TLE. However, standard ATL often involves the resection of functional cortical tissue in addition to the epileptic focus and has been associated with post-operative visual field cuts, language deficits, and verbal memory impairments. Numerous variations and modification of the standard ATL have been developed in efforts to identify more limited resections targeting the mesial temporal lobe structures where the majority of TLE seizures originate. Selective amygdalohippocampectomy (SAH) has demonstrated efficacy in significantly reducing or eliminating seizures in up to $90 \%$ of patients with mesial TLE. Debate remains, however as to which SAH operative approach leads to the most favorable cognitive outcome and few researchers have addressed the long-term functional outcome of patients post-SAH. The present study investigates the functional outcome of 61 TLE patients 1-5 years post minimal access, wand-guided $\mathrm{SAH}$, including employment status (no significant change pre to post-operatively), satisfaction with the procedure (92\% indicated they would repeat the procedure), frequency of seizures (100\% experienced a reduction), subjective memory and visual complaints (18\% and $13 \%$ respectively), driving status ( $46 \%$ improved from not driving to driving post-operatively), and need for medications ( $44 \%$ needed fewer medications post-operatively). Preliminary data on the pre and post-surgical cognitive and emotional functioning of a subset of the sample is also reviewed.

Correspondence: Kristin A. Kirlin, Ph.D., Clinical Neuropsychology, Barrow Neurological Insitute, 222 W. Thomas Rd. \#315, Phoenix, AZ 85013. E-mail:kkirlin@chw.edu

\section{D.W. LORING, K.J. MEADOR, G.P. LEE \& K. LEE. CONTRALATERAL THALAMIC ICTAL HYPERPERFUSION IN EPILEPSY IS ASSOCIATED WITH GREATER PERSONALITY ABNORMALITIES.}

Similarities between the personalities of some patients with epilepsy and those with schizophrenia have been an area long standing interest in the clinical neurosciences. The thalamus has been hypothesized to contribute to the perceptual and cognitive disturbances associated with schizophrenia, although results using MRI volumetry have been inconsistent. In the present study, we examined the relationship of contralateral thalamic involvement during seizures to personality characteristics as reflected by the Personality Assessment Inventory. Blood flow changes were recorded in 16 patients who were undergoing evaluation for epilepsy surgery. The distribution of blood flow changes during these seizures was assessed by subtraction SPECT (ictal period - interictal activity), which was co-registered to the patient's MRI. Patients were grouped according to whether they had secondary ictal hyperperfusion in the thalamus of hemisphere contralateral to seizure onset $(n=6)$ or no contralateral thalamic activity $(n=10)$. Patients with ictal contralateral thalamic hyperperfusion had higher scores on 8 of the 18 clinical scales of the PAI (ARD, MAN, PAR, SCZ, BOR, ALC, AGG, WRM), although no differences in cognitive neuropsychological function were noted. Although preliminary, these results are consistent with theories emphasizing thalamic dysfunction associated with atypical personality characteristics.
Correspondence: David W. Loring, Department of Neurology, Georgetown University Medical Center, 4000 Reservoir Road, NW, Building D, Washington, DC 20057.E-mail:dwl7@georgetown.edu

\section{ENG, P. CHIU \& B.K. SCHEFFT. MEMORY FOR ACTIONS: THE ENACTMENT EFFECT IN EPILEPSY.}

Patients with temporal lobe epilepsy frequently suffer from longterm memory deficits. In general, the main interventions currently available to control epileptic seizures are surgical and/or pharmacological, which may not necessarily ameliorate their memory deficits. The present study attempted to investigate the extent to which patients with epilepsy could be taught learning and memory strategies to help them compensate for their memory deficits. The specific mnemonic strategy under investigation was action enactment. A group of patients with intractable generalized and temporal lobe epilepsy and a control group were compared on their memory of 24 action phrases (e.g., open the book, break the toothpick) based on dependent measures of free recall, cued recall, and source discrimination. Half of the items were presented in the no-enactment condition and the other half were presented in the enactment condition. Results showed memory for items in the enactment condition to be significantly better compared to memory for items in the noenactment condition for both groups. While overall memory performance in the patient group was weaker than the control group, preliminary data suggest the magnitude of the enactment effect to be comparable between the two groups. Additional results and implications for the development of cognitive rehabilitation techniques will be discussed.

Correspondence: Michelle T. Eng, M.A., University of Cincinnati, 235 Loraine Ave., Apt. 7, Cincinnati, OH 45220.E-mail: engmt@email.uc.edu

\section{MYERS, C.M. ZAROFF, W.B. BARR, K. ALPER, D. LUCIANO \& O. DEVINSKY. PSYCHOEDUCATION IN THE TREATMENT OF PSYCHOLOGICAL NON-EPILEPTIC SEIZURES.}

Psychological non-epileptic seizures (PNES) are seizure-like events resulting from psychological factors, rather than a primarily neurological cause. The treatment of PNES and psychological symptoms associated with PNES in a structured psychotherapeutic format is not well researched. The current study utilized PNES-based psychoeducation in a group setting with seven individuals with a video EEG-confirmed diagnosis of PNES. All subjects underwent a structured 10-week treatment program. Seizure frequency was assessed before and after treatment. Standardized self-report measures, including the Davidson Trauma Scale (DTS), Curious Experiences Survey (CES), Quality of Life in Epilepsy 31 (QOLI 31), Coping Inventory for Stressful Situations (CISS). and State-Trait Anger Expression Inventory 2 (STAXI 2) were utilized pre and post-treatment to determine the degree of comorbid psychopathology. Following treatment, two subjects experienced a decrease and one an increase in seizure frequency. Four patients experienced no change in seizure frequency, likely due to a cessation of seizures at the time of treatment initiation in three subjects. In the total sample, significantly lower scores were evident post-treatment on the CES ( $p=$ $0.04)$ and on the total index scores of the QOLI $31(\mathrm{p}<0.01)$ and DTS $(p<0.01)$. Of the five scales of the CISS, there was a significant decrease in the Emotion scale $(p=0.03)$. None of the scores on the STAXI 2 were significantly different over time. The current results indicate the particular effectiveness of psychoeducation in a psychotherapeutic setting on improving quality of life and coping strategies and reducing posttraumatic and dissociative symptoms in individuals with PNES. Correspondence: Lorna Myers, PhD, Neurology, NYU Medical Center, 403 East 34th St, New York, NY 10016. E-mail: pichonina@aol.com 


\section{Focal Lesions}

\section{A. INSCORE \& D.E. JOHNSON-GREENE. HVLT LEARNING CHARACTERISTICS IN PATIENTS WITH STROKE.}

The Hopkins Verbal Learning Test (HVLT) is a well-validated and frequently used measure of verbal learning and memory. Previous studies of the HVLT have not examined the psychometric properties of learning characteristics that the instrument can yield, such as semantic and serial clustering and perseverations. We sought to develop scoring procedures and to validate these measures of learning in a sample of 104 patients. Participants were 39 patients with stroke (left $=12$; right $=$ 17; subcortical or brainstem $=10)$ and 65 patients who had recently undergone orthopedic surgery who served as the control group. Stroke and orthopedic control groups were equivalent with respect to age and educational level. Patients with stroke and orthopedic controls had equivalent numbers of serial clusters. However, in patients with stroke there were differences associated with the hemisphere affected. In patients with left hemisphere CVA there was less word acquisition, semantic clustering, serial clustering, and word retention compared to patients with right hemisphere CVA and orthopedic controls. In contrast, patients with right hemisphere stroke generated a significantly greater number of perseverations. These results demonstrate the impact of location of ischemic event on learning characteristics and highlight the contributions of each brain hemisphere to specific learning characteristics.

Correspondence: Anjeli Inscore, Physical Medicine and Rehabilitation, Johns Hopkins University School of Medicine, Good Samaritan Hospital POB, Suite 406, 5601 Lock Raven Blvd., Baltimore, MD 21239. Email: anjeli_inscore@yahoo.com

\section{C.J. YANUSAS. FACIAL AFFECT PERCEPTION: THE ROLE OF POST STROKE EMOTIONAL STATE.}

The differences in facial affect perception among stroke patients experiencing either a negative emotional state or no negative emotional state was investigated. Further, the role of reduced facial affect perception on post stroke interpersonal behavior and the level of post stroke emotional and behavioral change was analyzed. Ninety-five first time stroke survivors (left hemisphere stroke, $n=47$; right hemisphere stroke, $n=$ 48) receiving rehabilitation during the acute stages of recovery post stroke participated. The participants were equated on age, education. cognitive status, and stroke severity. Negative emotional state was measured through self and other reports on the Neuropsychological Behavior and Affect Profile. Five significant results were found. First, an interaction was found for negative emotional state and right hemisphere damage $(p<.01)$. Second, negative emotional state had an adverse influence on the accuracy of facial affect perception post stroke for both right and left hemisphere damaged participants $(p<.05)$. Third, facial affect perception ability was related to the quality of interpersonal interactions when compared to global ratings of social communication ( $p$ $<.01)$. Fourth, greater levels of depression, indifference, inappropriate behavior, and communication problems were found post stroke $(\mathrm{p}<$ $.01)$. Fifth, indifference/apathy was associated with depression $(p<.01)$. The findings suggest negative emotional state is a mediating variable for reduced facial affect perception post stroke. Further, the findings highlight the importance of facial affect perception in interpersonal communication and document that a significant amount of emotional and behavioral change occurs during the acute stages of recovery post stroke. Correspondence: christopher J. yanusas, Ph.D., neuropsychology, united health services hospitals, Sandiford Rehabilitation Center, 10-42 Mitchell Ave., Binghamton, NY 13903. E-mail: chris_yanusas@uhs.org

\section{J.I. SHENKER \& H. BRASHEAR. SELECTIVE SUBCORTICAL DAMAGE TO THE “WHAT”VS. “WHERE-HOW TO” VISUAL SYS- TEM IN A HUMAN.}

Occipitofugal cortical visual processing pathwavs diverge into two largely parallel "streams" (Ungerleider, Mishkin, 1982; Milner, Goodale, 1995).
A dorsal (parietal) stream specializes in processing spatial information, movement, and goal-oriented information. A ventral (temporal) stream specializes in processing form, color, and item recognition. This cortical dichotomy is well supported in humans. In non-human primates. convergent studies describe two subcortical visual paths: a "P system" (parvocellular) and an "M system" (magnocellular). These segregate in the retina, supply different lateral geniculate nucleus (LGN) layers, and divergently supply the ventral ( $\mathrm{P}$ dominant) and dorsal (M dominant) cortical streams. Little direct data address whether humans have the same system. We report a man with acute difficulty distinguishing colors and identifying letters and small objects in the left visual field. He could describe items' movements and spatial location. The defect subtended less than 5 degrees of visual angle to the left of fixation, beyond which he could distinguish colors and objects normally. Brain magnetic resonance imaging showed only an acute infarct of the superficial-most aspect of the right LGN. Since the outermost four of the six LGN layers are exclusively supplied by $\mathrm{P}$ system afferents, we argue that this man had "pure" $P$ system dysfunction causing relative failure of the ventral visual processing stream. We know of no other published case of such a selective lesion with examination of these visual functions. This case argues for separable subcortical visual processing streams in humans that may resemble non-human $\mathrm{M}$ and $\mathrm{P}$ systems.

Correspondence: Joel I. Shenker, M.D., Ph.D., Neurology, University of Virginia, PO Box 800394, UVA Health System, Charlottesville, VA 22908-0394.E-mail: jis2p@virginia.edu

\section{E.K. HILL, J.D. WRIGHT, W. KNYSZ \& K. PODELL. NEUROPSYCHOLOGICAL PROFILE OF MELAS SYNDROME. .}

Reviews of the neuropsychological deficits observed in mitochondrial myopathy, encephalopathy, lactic acidosis, and stroke-like episode (MELAS) syndrome are sparse. The mechanism of stroke-like episodes in the disease is unclear, and proposed pathologies include angiopathy leading to ischemia or direct neuronal death due to oxidative metabolism abnormalities. We present a detailed neuropsychological case study of a 33-year-old male who had presented with partial seizures and subsequently diagnosed with MELAS. Neuroimaging revealed a large area of acute ischemia within the right temporal, occipital, and parietal lobes. Acutely, the patient was tangential, impulsive, disinhibited, irritable, and distractible with poor insight. He also demonstrated a left-side neglect and homonymous hemianopsia. The patient underwent a comprehensive outpatient neuropsychological evaluation one month later, during which he showed significant executive deficits, in that his behavior was notably field dependent and he was strikingly anosognosic. He had deficient working memory abilities, only completed three correct sequences on Trails B in five minutes, achieved no categories on the WCST, and had impaired verbal fluency. He also displayed impaired visual construction abilities, although his left-sided neglect and hemianopsia had resolved. In summary, results indicated generalized CNS dysfunction, primarily impacting the prefrontal systems with a superimposed right hemisphere component. These results are compared to other neuropsychological findings reported in patients with MELAS syndrome. The implications of these results in further understanding the underlying pathology of the CNS involvement in MELAS and how executive functions can be disturbed by non-frontal lesions is also discussed.

Correspondence: Erin K. Hill, PsyD, Harvard Medical School, $400 \mathrm{~W}$. Cummings Park, BMG 1725-122, Woburn, MA 01801.E-mail: erinkhill@ comcast.net

\section{T.L. VERAMONTI, B. SILVER \& D.K. MERCER. POSTERIOR VARIANT ALIEN HAND SYNDROME AFTER LEFT THALAMIC INFARCT.}

Alien hand syndrome (AHS) classically consists of autonomous movements perceived as being outside voluntary control accompanied by feelings of estrangement and personification of the affected limb. The wide range of behavioral differences observed in patients with varying neu- 
roanatomical findings has led to the identification of dissociable subtypes of AHS. In patients with the frontal variant (involving the anterior corpus callosum alone or in conjunction with medial frontal regions), behavioral manifestations include exploratory grasping, compulsive manipulation, and intermanual conflict. In contrast, patients with the posterior variant have been described as displaying levitation of the affected limb but decreased grabbing and groping, and absence of intermanual conflict. The majority of posterior AHS cases have involved extensive lesions to the posterior circulation in the nondominant hemisphere with a few cases having documented infarcts confined largely to the nondominant right thalamus. We report an unusual case of posterior variant AHS after a lesion in the dominant left thalamus, suggesting that the neuroanatomical regions responsible for AHS may require re-examination. The patient initially reported feeling as if the right side of her body had a "mind of its' own" and was embarrassed by episodes in which she had unknowingly stroked the hair of her therapist or "found" her right hand in her dinner plate. Consistent with observations about other posterior variant cases, the patient made excellent functional gains during the course of rehabilitation. Neuropsychological testing results and performance on the Naturalistic Action Test (a test of everyday action impairments) are reported.

Correspondence: Tracy L. Veramonti, M.A., Psychology, University of Houston, 126 Heyne Building, Houston, TX 77204-5022. E-mail: tveramonti@ev1.net

\section{J. MEDINA \& B. RAPP. A CASE OF TACTILE SYNCHIRIA: PRE- SERVED SOMATOTOPY?}

DLE is a 69-year old male who suffered a left hemisphere CVA. Although DLE was able to correctly detect the presence of tactile stimuli administered to either hand, he was selectively impaired in reporting the location of stimuli presented to his right hand. Additionally DLE exhibited a robust case of tactile synchiria, a condition in which a sensation produced by a stimulus (typically ipsilesional) is perceived on both sides. To investigate this deficit, DLE was presented with: a tactile stimulus to his left hand only, his right hand only, the same location on both hands, or a different location on both hands. He was instructed to indicate the location of the presented stimulus/stimuli. DLE was highly accurate at localizing stimuli presented to the same location on both hands. He also accurately indicated when stimuli were presented to the right hand, although he did not accurately report their location on the right hand. When presented with single stimulus on the left hand, he indicated the correct location on the left hand, but also reported a sensation in the same location on the right hand on $90 \%$ of the trials. When stimulated at different locations on the two hands, DLE indicated the same location for both hands on $82 \%$ of the trials. On virtually all occasions, the synchiric right-hand "phantom" sensation was experienced on the right hand at the corresponding location as the left-hand stimulus. We discuss these results in the context of theories of cortical reorganization and body image.

Correspondence: Jared Medina, Department of Cognitive Science, Johns Hopkins University, 243 Krieger Hall, 3400 N Charles St, Baltimore, MD 21218.E-mail:medina@cogsci.jhu.edu

\section{G. JEWELL, T. KRETZMER, A. MEIDINGER, A.J. WOODS, H. MURPHY, S. LIEM, V.W. MARK \& M. MENNEMEIER. MERGING NEUROPSYCHOLOGY AND PSYCHOPHYSICS: RIGHT-HEMISPHERE DOMINANCE FOR RATIO SCALING. .}

Theoretical models of neglect focus on deficits of spatial attention, intention, and mental representation. However, neglect following righthemisphere injury alters ratio scaling, a property of sensory systems in which perception is sensitive to proportional rather than incremental changes in stimulus intensity. Sensory continua can be divided into two classes: prothetic and metathetic. Prothetic continua involve judgments of how much (ie. stimulus intensity) and correspond to power (log-log) functions. Metathetic continua involve judgments of what or where and correspond to linear functions. Although neglect is typically thought of as a spatial disorder (where), psychophysical studies of neglect have examined only prothetic judgments (intensity or how much). We examined control subjects and subjects with unilateral lesions due to stroke on spatial and non-spatial prothetic (area, loudness) and metathetic (position, pitch) tasks using ratio and category scaling techniques. Braininjured groups were formed based on lesion laterality and neglect status. Neglect specific alterations in ratio scaling were noted for both metathetic and prothetic spatial judgements (area, position). Righthemisphere injury was associated with alterations in the ratio scaling of a non-spatial prothetic task (loudness). Left-hemisphere injury was not associated with altered ratio scaling. Right hemisphere injury had little effect on category scaling. Neglect severity and altered ratio scaling for spatial stimuli were both associated with lesion volume. The righthemisphere appears to be dominant in forming mental representations of stimulus intensity and damage to it results in a reliance on categorization. Neglect involves alterations of ratio scaling for both prothetic (intensity) and metathetic (position) properties of spatial stimuli. Correspondence: George Jewell, M.S., Physical Medicine \& Rehabilitation, University of Alabama at Birmingham, 175 Stonebridge Circle, Pelham, AL 35124. E-mail: George24709@msn.com

\section{E. VAKIL, I. BUSHARIA \& N. SOROKER. CONTEXT EFFECT IN PATIENTS WITH RIGHT AND LEFT HEMISPHERIC LESIONS.}

Context effect is said to have occurred when stimuli from the study phase are identified more accurately in the test phase when presented with the original contextual information than when presented with either different context or without context. In this study we investigated the role of the cerebral hemispheres in the utilization of contextual information in a verbal memory task. Patients with right (RHL) $(n=13)$ and left (LHL) ( $n=11)$ hemispheric lesions and a matched control group ( $n=12)$ participated in this study. Participants were presented with 90 pairs of words. One word from each pair was the target word (to be remembered), and the other word was the context word (to be ignored). At test, some of the target words were presented with their original context words and others were presented with either a new context word or with no context at all. The control group recognized correctly more target words than the patient groups. The LHL group recognized correctly more target words than the RHL group. These results indicate that even with a verbal memory task, the LHL group utilized contextual information better than the RHL group. This suggests that the right hemisphere has a cardinal role in processing contextual information.

Correspondence: Eli Vakil, PhD, Psychology, Bar Ilan University, Ramat Gan, Ramat Gan 52900, Israel.E-mail:vakile@mail.biu.ac.il

\section{J.E. BOOTH, R.M. BUSCH \& R. VANDERPLOEG. COGNITIVE DEFICITS ASSOCIATED WITH RIGHT CEREBELLAR INSULT: A CASE STUDY.}

Historically, the cerebellum was thought to be involved primarily in the control of balance and coordinated movement. However, over the past decade, this subcortical structure has been demonstrated to have a role in higher cognitive functions, including attention, language, temporal processing, visuospatial abilities, and memory (e.g., Justus \& Ivry, 2001). We present a case study of a 36 year-old Caucasian male who sustained a gunshot wound to the right suboccipital area during combat. A right resection of the lateral third of the cerebellum was performed the day after the injury. He presented as severely ataxic in all motor movements, worse on the right, with severely dysarthric speech. Neuropsychological evaluation revealed impairment in specific aspects of executive functioning (e.g., working memory, sequencing, and information processing speed) that came into play particularly on tasks of higher cognitive load. These deficits had a greater impact on verbal than on non-verbal abilities. For example, he had normal forward digit span (7 digits; 81st percentile) but significant difficulty with digits backward (3 digits; 3rd percentile). Similarly, verbal fluency tasks were problematic (COWA = 
3rd percentile; Animals $=3$ rd percentile; Supermarket items $=7$ th percentile). In contrast, visuospatial span was normal (WMS-R Visual Spatial Span $=46$ th percentile forward; 75th percentile backward). General intellectual ability remained intact (WAIS-III Similarities $=50$ th percentile; Information $=75$ th percentile $)$ and he demonstrated a strength with nonverbal abstract reasoning (WAIS-III Matrix Reasoning $=95$ th percentile; Block Design $=63$ rd percentile). In addition to his general ataxia, he demonstrated significant difficulty learning new complex motor sequences (Luria complex motor sequences). Anatomical correlates are discussed as well as interpretation of the neuropsychological results in relation to current findings in the literature.

Correspondence: Rodney Vanderploeg, Ph.D., Psychology Service, 116B, James A. Haley Veterans, 13000 Bruce B. Downs Blvd., Tampa, FL 33612. E-mail: rodney:vanderploeg@med.va.gov

\section{J.C. FLORES LAZARO, F. OSTROSKY-SOLIS \& J. CHAVEZ GARCIA. METACOGNITION AND FRONTAL LOBE DAMAGE.}

Metacognition is referred as the capacity to evaluate and control our own cognitive processes, it requires consciousness and volitional control of actions, memory and thoughts. Frontal lobes functions have been implicated in all these processes (Shimamura, 2000). The present study analyze the effects of frontal lobe lesions in metacognition. In each patient we analyzed the: feeling of knowing (development prediction), monitoring and correcting, as well as proper set out of a efficient mnemonic strategy. A nine word list was presented in the same order to 6 frontal lobe damage patients ( 2 patients with right damage, 2 with left damage and 2 with bilateral damage). Lesion was identified with neuroimaging studies. Results showed that metamemory performance and judgments are affected in different forms according to the site of the lesion Patients with left lesions shows less impairments than patients with right and. bilateral lesions, particularly in monitoring capacity and in the capacity of making correct adjustment between predictions and performance. Discussion centers on how different site of frontal lobe damage affects metamemory processes and suggestions for further research in this area.

Correspondence: Julio C. Flores Lazaro, Master in Science, Laboratory of Neuropsychology and psychophisiology, National University of Mexico, Avenida Universidad 3004, Copílco, Mexico city 04510, Mexico. E-mail: juliodf@hotmail.com

\section{S. RAVIZZA, M. BEHRMANN \& J.A. FIEZ. DOES THE RIGHT PARIETAL LOBE CONTRIBUTE TO VERBAL WORKING MEMORY PERFORMANCE? A CASE STUDY.}

The left inferior parietal cortex has been claimed to be the site of the verbal short-term store, yet imaging studies report activity of a homologous right-hemisphere region in working memory tasks as well. What is the right parietal cortex contributing to the performance of verbal working memory tasks? We tested a patient with a lesion in the right parietal lobe and six elderly controls on verbal, object, and spatial versions of the N-back task. For the spatial and object N-back, the patient was at chance in all load conditions $(0-, 1$-, \& 2-back) whereas he was impaired in only the memory conditions of the verbal N-back. Given that we had presented stimuli at multiple locations in the verbal N-back, we wondered if the patient would improve if we presented letters in the center of the screen. Although his performance dramatically improved, he still displayed difficulty with the task. As this patient scored below average on the digits backward (23rd percentile) but not forward test of the WMS-R (52nd percentile), we wondered if the right parietal lobe would only be necessary on working memory tasks requiring manipulation of the items to be recalled. Alternatively, an impairment of spatial processing may underlie all the memory deficits exhibited by this patient. To test this hypothesis, the patient performed an auditory and visual item recognition task. His poor performance on the visual, but not the auditory version of this task, suggested that the right parietal region is primarily recruited when memory tasks require visuospatial processing.

Correspondence: Susan Ravizza, Psychology, University of Pittsburgh, 640 LRDC, 3939 O'Hara St., Pittsburgh,PA 15260.E-mail: ravizza@ pitt.edu

\section{Memory Disorders}

\section{R.D. JONES, K. MANZEL, K. DAY \& D. TRANEL. NEURAL COR- RELATES OF REMOTE AUTOBIOGRAPHICAL MEMORY.}

Neural correlates of remote memory were investigated using structural neuroimaging and a standardized measure of autobiographical memory (the Iowa Autobiographical Memory Questionnaire-Childhood; IAMQC). A target group of eight brain damaged subjects was chosen based on performances in the bottom $20 \%$ of a distribution of scores on the IAMQ-C derived from a sample of neurologic patients. This target group was compared to eight brain damaged subjects who were matched on naming ability, but who performed in the top half of the distribution of IAMQ-C scores. All subjects had stable lesions due to stroke, anoxia, surgical resection, or encephalitis, and were studied an average of two years after the onset of the lesion. There were no differences between groups in age, education, or score on a test of naming $(p>.05)$. Target and comparison subjects recalled $62 \%$ and $95 \%$ of sampled childhood memories respectively $(p<001)$. Analysis of lesions reflected that target subjects had lesions in or near the basal forebrain $(n=2)$ or in bilateral temporal lobes $(n=5)$. Lateral temporal cortex was involved in $5 / 5$ of this latter group. There was one case of a unilateral right temporal lesion in the target group. In the comparison group lesions were consistently outside the areas of the basal forebrain or lateral temporal cortices bilaterally. These findings suggest that remote memory impairments are associated with lesions in temporal cortex bilaterally and in the area of the basal forebrain. In the temporal lobes, lateral cortices may play a particularly important role in supporting remote autobiographical memory.

Correspondence: Robert D. Jones, Ph.D., Neurology, University of Iowa, 200 Hawkins Drive, Department of Neurology, Iowa City, IA 52242. Email:robert-jones@uiowa.edu

\section{J.C. ADAIR, S.L. RUIZ \& D.M. SCHNYER. METAMEMORY IN BASAL FOREBRAIN (BF) AMNESTIC SYNDROME.}

Besides learning deficits, patients with BF injury may manifest a constellation of associated symptoms that suggest faulty monitoring of recall and recognition processes. To test this hypothesis, we compared such a patient to age- and education-matched control subjects using quantifiable self-judgments of retrieval and recognition ability. The patient noted amnesia after resection of an orbitofrontal tumor. Testing two years later confirmed severe amnesia for both verbal and nonverbal material with relative preservation of other cognitive functions. Brain MRI exhibited encephalomalacia affecting the BF rostral to the anterior commissure. The patient's retrospective monitoring accuracy for retrieval was slightly below control values (patient 0.38 , control 95\% CI 0.56 $0.74)$. Negative judgments $(0.80,0.59-0.83)$ were more accurate than affirmative judgments $(-0.41,0.24-0.67)$. In contrast, the patient's prediction of recognition success fell far below control values $(-0.60,0.08-$ $0.43)$, with affirmative judgments accounting for the difference $(-0.72$, 0.24-0.67). The patient's BF lesion selectively influenced separate aspects of memory monitoring.

Correspondence: John Adair, Neurology, University of New Mexico, ACC 2nd floor, UNMHSC, 2211 Lomas Blvd NE, Albuquerque, NM 87131. E-mail:John.Adair@med.va.gov 


\section{B.J. DIAMOND, J. DELUCA \& O. NOSKIN. RECOVERY FROM CONFABULATION AND EFFECTS ON AWARE AND UNAWARE MEMORY IN ANTERIOR COMMUNICATING ARTERY ANEURYSM .}

Neurobehavioral disturbances following Anterior Communicating Artery (ACoA) aneurysm may include impaired memory and executive function, personality change and confabulation. This study examined changes in aware and unaware memory for complex visual-spatial information during and after confabulation. FP was a 64-year-old amnesic female with a ruptured and repaired ACoA aneurysm. During confabulation. FP achieved 0 categories on the Wisconsin Card Sort Test (WCST); 6 words on Word Fluency (CFL) and 2 on Rey figure immediate recall (RIR). To improve and assess memory, the Rey Organization and Extended Memory (R-OEM) protocol was used to impose an organizational learning strategy. The strategy modestly improved immediate recall (i.e., 4); recognition was intact, even at a 30-minute delay and a total 'extended' score consisting of sub-unit recognition, spatial assembly and discrimination was 13.5 out of 20 achieved in the absence of any recall of the previous learning episode. After confabulation, there were modest improvements in recall (Rey-IR: 9.5) and word fluency (CFL: 8). Following the organization procedure, FP attained scores of: 12 on Rey-IR and 19 on the 'extended' measure, a near perfect score with little or no recall of the previous learning episode. During confabulation, recall was profoundly impaired while recognition and implicit memory were better. After confabulation, recall improved following the organizational procedure and performance on the 'extended' visual-spatial tasks showed dramatic improvement. Recovery from confabulation may be associated with differential effects on aware and unaware memory as well responsiveness to executive-type learning strategies.

Correspondence: Bruce J. Diamond, PhD, Psychology/PM\&R, WPU/UMDNJ, Box 43592, Upper Montclair, NJ 07043. E-mail: diamondb@wpunj.edu

\section{K.M. METCALF \& M. COLTHEART. THE ORIGIN AND NATURE OF CONFABULATION: A LONGITUDINAL EXAMINATION OF NEUROPSYCHOLOGICAL FUNCTIONING IN A SPONTANEOUS AND A PROVOKED CONFABULATOR.}

Confabulation can be defined as statements or actions that involve unintentional distortions of memory - in other words, lying without the intent to deceive. Confabulating patients are often unaware of their memory difficulties and are convinced of the veracity of their incorrect statements. It is generally accepted that there are two main forms of confabulations: provoked confabulations (false responses to questions probing memory), and spontaneous confabulations (sustained and often fantastical false memories). Previous research has shown that the symptom of confabulation often resolves over time with concurrent improvements in neuropsychological functioning, but the exact nature of this improvement has been greatly debated. Two amnesic patients who exhibited confabulation were recruited to look at the phenomenon of confabulation over time. One patient exhibited provoked confabulation, while the other produced florid spontaneous confabulations which he occasionally acted upon. Both patients suffered from severe and widespread neurological damage. The current study examined the frequency and content of these patients' confabulations and compared this to their neuropsychological functioning over a twelve-month period. Neuropsychological testing consisted of an examination of their intellectual, memory, and executive functioning. The two participants demonstrated very similar patterns of intellectual and memory functioning but differences in their pattern of executive dysfunction were evident. The quantity of confabulations decreased significantly over the twelve month period with concurrent changes to the content, and manner of the confabulation. Contributions of these results towards an understanding of the neuropsychological deficits involved in the two types of confabulation will be presented.
Correspondence: Kasey M. Metcalf, Macquarie Centre for Cognitive Science, Macquarie University, Macquarie University, Division of Psychology and Linguistics, Sydney, NSW 2109, Australia.E-mail: kasey@ maccs.mq.edu.au

\section{D.E. HANNULA, P. MENOCCI, D. TRANEL \& N.J. COHEN. AMNESIA AND FUNCTIONAL DISSOCIATIONS WITHIN THE HIPPOCAMPAL SYSTEM: DEFICITS IN MEMORY FOR SCENES VS MEMORY FOR THE RELATIONS AMONG OBJECTS WITHIN SCENES.}

Amnesia following hippocampal system damage can be characterized as a deficit in declarative memory, involving memory for relations among constituent elements of scenes or events. Recently, the role of different hippocampal system structures in memory has been questioned. Here, we report dissimilar memory performance in patients with damage limited to hippocampus and patients whose damage extends into perirhinal cortex and associated parahippocampal structures. Six patients, classified as amnesic on the basis of extensive, standardized neuropsychological testing, completed this experiment. For four patients, amnesia resulted from an anoxic episode, with damage limited to hippocampus proper. For the remainder, amnesia resulted from herpes simplex encephalitis; damage included hippocampus and surrounding cortical areas. Memory for a series of rendered scenes was tested in a continuous recognition task. For each scene, patients indicated whether it had already been presented, and if so, whether any objects had changed location. There were 0,4 , or 8 intervening trials between subsequent presentations of the same scene. Anoxics had difficulty identifying changes in object location, and thus could not distinguish manipulated from intact scenes at the longer lags; however, they successfully identified repeated scenes as old, irrespective of lag. Accordingly, hippocampal damage was associated with poor memory for relations, leaving memory for previous occurrence of scenes intact. Encephalitics performed poorly on both tasks; at longer lags, they could not distinguish manipulated from intact scenes, or old from new scenes. Accordingly, damage to hippocampus and the parahippocampal region impaired both memory for relations and memory for the scenes themselves.

Correspondence: Deborah E. Hannula, MA, Psychology, University of Illinois, 603 E. Daniel Street, Champaign, IL 61820.E-mail: hannula@ s.psych.uiuc.edu

\section{S.M. STARK, C.E. STARK \& B. GORDON. THE ROLE OF VARI- ANCE IN GENERALIZATION: EVIDENCE FROM AN AMNESIC PATIENT.}

New learning of semantic information is profoundly impaired in amnesia following damage to the medial temporal lobes (MTL). Several reports have demonstrated that rigorous training with errorless learning techniques have allowed even severely amnesic patients to acquire some new semantic information. However, while use of semantic information in normal individuals is highly flexible, semantic information acquired by amnesic patients through errorless learning seems to be stored in a narrow and inflexible form, as they fail to utilize it in even mildly novel situations. Insights from a connectionist model of cortical and medial temporal lobe memory systems suggest that errorless learning methods eliminate the variability that can give semantic information flexibility. To further test this model, we trained a severely amnesic patient, T.E., on new semantic information both with and without variance in training. In the No Variance condition, we presented a single item repeatedly, while in the Variance condition, we presented multiple semantically-related versions of an item during training. T.E. was then tested on repeated information and on novel, but related information to assess generalization. T.E. demonstrated better learning and generalization of semantic concepts following variant training relative to training without variance. These results extend our previous findings to new semantic domains, emphasizing the generalizability of this training. 
Correspondence: Shauna M. Stark, M.S., Department of Neurology, Johns Hopkins University, 1629 Thames Street, Suite 350, Baltimore, MD 21231. E-mail:sstark2@jhmi.edu

\section{Language Disorders}

\section{C.A. MORELLI, D.L. KENDALL, J.C. ROSENBEK, A. RIESTRA, K. WOMACK, H. QIN, K. REID, D.B. EFROS \& L.J. GONZALEZ ROTHI. EDUCATION AND APHASIA SEVERITY.}

Rationale: The concept of enriched environments has been linked to the experience provided by formal education. Hebb (1949) demonstrated that environmental enrichment could positively influence both function and structure of the nervous system in rats. This is but one piece of evidence that led to the hypothesis that elaboration may yield neuroprotection from injury through redundancy. This notion is compatible with findings of Smith (1971) \& Connor et al. (2001) that aphasia severity and educational level correlated in $78 \& 39$ stroke subjects respectively. However, Duffy \& Keith (1980), Miceli et al., (1981), and Ross \& Wertz (2001) did not. In this presentation we report the results of an analysis of educational levels and aphasia severity in an additional 96 subjects. Methods: A clinical database from individuals with a single left CVA referred for speech and language services was retrospectively examined. Educational level (less than high school and equal to or greater than high school) and Western Aphasia Battery Aphasia Quotient $(A Q)$ were extracted and cases in which these were present were included in the dataset for this study. Results: A t-test revealed no significant differences in mean aphasia severity $(A Q)$ between educational levels (<HS: $n=36$, mean $A Q=53.314 ; ~ \geq H S$ : $n=60$, mean $A Q=57.072$; $\mathrm{p}=0.5661)$. Discussion: While education has been shown to provide a neuroprotective advantage against the effects of aging, no relationship was found between education and aphasia severity in this large corpus of stroke survivors. Acknowledgement: This work was funded by VA RR\&D BRRC.

Correspondence: Claudia A. Morelli, MS, Communication Sciences \& Disorders, University of Florida, 336 Dauer Hall, P.O. Box 117420, Gainesville,FL32611-7420.E-mail: cmmoreli@yahoo.com

\section{GRINDROD \& S.R. BAUM. THE EFFECT OF UNILATERAL LEFT AND RIGHT HEMISPHERE LESIONS ON SENSITIVITY TO GLOBAL CONTEXT IN LEXICAL AMBIGUITY RESOLUTION.}

There is considerable debate regarding the ability of the left (LH) and right hemispheres (RH) to use context in lexical ambiguity resolution (e.g., bat: an animal or a baseball club), especially given the divergent findings noted by studies of unilaterally brain-damaged patients (Grindrod \& Baum, 2003; Swaab et al., 1998; Tompkins et al., 2000). While a great deal of research has explored these patients' ability to use local (single-sentence) contexts in ambiguity resolution, little research has examined their ability to use larger contexts of two or more sentences. To address this issue, the present study investigated ambiguity resolution in a global (two-sentence) context in patients with unilateral LH $(\mathrm{N}=10)$ or RH lesions $(\mathrm{N}=8)$ compared to individuals without brain damage $(\mathrm{N}=9)$. Subjects participated in a cross-modal semantic priming task, in which they first heard biased two-sentence passages ending in ambiguous words and then made lexical decisions on visually presented targets, related to either the first or second meaning of the ambiguity. At a short $(0 \mathrm{~ms})$ ISI, none of the groups showed priming for ambiguous word meanings. At a long $(750 \mathrm{~ms})$ ISI, control subjects only showed priming for contextually appropriate meanings. In contrast, patients with LH damage failed to show priming for either meaning, while patients with RH damage only showed priming for appropriate meanings in contexts biased toward the first meaning. These results indicate that both $\mathrm{LH}$ and $\mathrm{RH}$ damage disrupt the process of ambiguity resolution. Specifically, both patient groups exhibit deficits in accessing ambiguous word meanings, rather than in using context.
Correspondence: Christopher M. Grindrod, MA, School of Communication Sciences and Disorders, McGill University, 1266 Pine Ave. W., Montreal, QC H3G 1A8, Canada. E-mail: christopher.grindrod@mail. mcgill.ca

\section{G. STEFANATOS, A. GERSHKOFF \& S. MADIGAN. A TEMPORAL} WINDOW ON PURE WORD DEAFNESS.

Pure word deafness (PWD) is a rare neurological syndrome of critical importance to our understanding of the functional architecture of auditory cognition and speech processing. It has been argued that PWD resulting from bilateral temporal lesions is associated with general deficits in auditory temporal processing, while unilateral temporal lesions result in more specific deficiencies involving phonemic aspects of speech processing. We report a case of pure word deafness resulting from a unilateral hemorrhagic infarct and describe a detailed analysis of her ability to process speech and nonspeech sounds. We examined environmental sound identification, phoneme discrimination and identification, gap detection, click fusion, sound localization and frequency modulation analysis. On speech discrimination tasks, she demonstrated good vowel discrimination but poor differentiation of stop consonant-vowel syllables, even those with extended formant frequency transitions. Significant differences were observed in discriminating periodic and transient frequency modulations. While she could detect repetitive (periodic) frequency modulations, she was unable to reliably discriminate transient frequency changes of the same overall duration and frequency excursion. By contrast, aspects of gap dicrimination, click fusion, and sound localization that depended on millisecond-level temporal resolution of auditory events were relatively intact. These results suggest that unilateral lesions particularly impede spectrotemporal analysis of transient frequency modulations occurring within a temporal window of a few hundred milliseconds, but leave intact other aspects of temporal processing, even though these may require a higher degree of resolution. These findings have important implications for our conceptualization of PWD and its subtypes.

Correspondence: Gerry Stefanatos, D.Phil., Albert Einstein Medical Center, 1200 West Tabor Road, Philladelphia,PA 19141.E-mail:stefanag@ einstein.edu

\section{D.H. WU, S. WALLER \& A. CHATTERJEE. CONCEPTUAL AND LINGUISTIC KNOWLEDGE IN BRAIN-DAMAGED PATIENTS.}

Models of language processing often postulate related but distinct conceptual and linguistic representations. According to these models, patients with brain damage might exhibit language deficits due to impairment to linguistic knowledge or to conceptual knowledge that expresses itself in verbal tasks. To test the hypothesis that linguistic processing can be selectively disrupted while conceptual processing is relatively preserved, 18 patients with left hemisphere lesion were examined with an array of verbal and nonverbal tasks. Patients with intact conceptual knowledge but disrupted linguistic knowledge would show deficits on verbal tasks (single word comprehension, thematic role assignment, detection of semantic and syntactic anomaly in sentences, and/or picture naming of single words) with relative preservation of performance on nonverbal tasks (selecting pictures for coherence, and matching pictures based on their meaning). The results showed that eleven patients had either a ceiling or floor performance on the tasks. One patient showed mild impairment on both verbal and nonverbal tasks. However, six patients performed more accurately at nonverbal (pictorial) than verbal tasks, which demonstrated relative preservation of conceptual knowledge in contrast to linguistic knowledge. These findings indicated that conceptual processing can be relatively preserved with language impairment in brain-damaged patients.

Correspondence: Denise H. Wu, Department of Neurology, University of Pennsylvania, 3400 Spruce St., Philadelphia, PA 19104. E-mail: wuhsien@mail.med.upenn.edu 


\section{S.S. RUBIN \& J.B. DAVIS. ENVIRONMENTAL SYMBOL RECOG- NITION OF PERSONS WITH AND WITHOUT APHASIA .}

There are many kinds of signs/symbols in the environment; highway and traffic signs, company logos, and environmental signs like those for restrooms or handicapped services. People who are neurologically and/or linguistically impaired, such as persons with aphasia, may rely on these signs to function within the environment. However, persons with aphasia may have difficulty comprehending both linguistic and nonlinguistic visual stimuli and thus may not be able to exploit the non-linguistic nature of environmental symbols. Thus, the purpose of this study was to provide a description as to how participants with aphasia performed on an environmental symbol recognition task. Six participants with aphasia and 6 control participants were given an environmental symbol recognition task in which they were asked to associate 32 environmental symbols (for example, U.S. Mail, McDonalds Arches, Hospital symbol etc.) with their associated target responses. Results indicate that participants with aphasia scored significantly less accurate and took considerably longer to provide responses, as compared to control participants. Results of this investigation provide additional evidence that the processing deficit associated with aphasia cuts across domains to include not only linguistic symbols but nonlinguistic symbols as well. Such apparent recognition (processing) deficits may impact on the functional interactions and daily living skills of those with aphasia, as well as those with other neurological disorders. Finally, the stimuli and paradigm used in this study may be considered an initial step in developing a more complete test of environmental symbol recognition.

Correspondence: Scott S. Rubin, Ph.D., Speech Pathology \& Audiology, University of South Alabama, 2000 University Commons, Mobile, AL 36688.E-mail:srubin@usouthal.edu

\section{A. YEAGER \& S.S. RUBIN. LEXICAL AND ENVIRONMENTAL STIMULI PROCESSING IN APHASIA.}

For decades, researchers have sought to determine whether language shifts to the right hemisphere after focal damage to the left hemisphere (Moore \& Papanicolaou, 1992). Currently, there is a lack of information regarding how aphasic individuals process environmental sounds, and what impact a possible shift of language would have on environmental processing. Therefore, two groups were examined using two dichotic listening tasks, which evaluated lexical and environmental sound recognition and the observable perceptual interference effects when the two were combined. Participants pressed the green button if the auditorily presented sound/word visually matched the picture/word, whereas if the auditory and visual stimuli were incongruent, the participant pressed the red button. The results suggested the recognition task was significantly less difficult than the perceptual interference task. There were significant reaction time effects with word recognition faster than environmental sounds. In the first task, the control group demonstrated an REA in both conditions, which could suggest the left hemisphere is responsible for language processing. Environmental sounds could be bilaterally represented with a semantic encoding strategy facilitating the REA. The perceptual interference effects were approximately equivalent with lexical and environmental affecting each other. The aphasic group demonstrated an LEA in both conditions in the first task, which could suggest the right hemisphere's role in language processing following stroke. It seems that environmental processing was also affected by the damage. This group demonstrated large interference effects. However, it seems that lexical information has a greater impact on environmental sound processing. Correspondence: Amy Yeager, Ph.D., Knollwood Hospital, 5600 Girby Road, Mobile, AL 36693. E-mail: dramycat03@yahoo.com

P.I. MARTIN, M.A. NAESER, K.W. DORON, A. BOGDAN,
E.H. BAKER, H.E. SEEKINS, J. KURLAND, P. RENSHAW \&
D. YURGELUN-TODD. OVERT NAMING IN APHASIA: HEMODY-
NAMIC DELAY DESIGN AND ANALYSIS WITH FMRI BOLD.
We developed a desion which relies on hemodynamic response delay and We developed a design which relies on hemodynamic response delay and
dispersion (Friston et al., 1994; Eden et al., 1999) to obtain task-re- lated information after the task (thus minimizing motion artifact associated with overt speech). Our block design consisted of alternating conditions: overt picture Naming (18sec, activation; TR=3); silently viewing Patterns (12sec, control). During each 12sec Pattern epoch, there continued to be approximately 6 sec of hemodynamic response from overt Naming (hemodynamic delay Naming, hdN). Thus, the first 6 sec of the Pattern condition (hdN) were then compared to the last 6 sec of the Pattern condition using SPM 99. This analysis has been completed with two R-handed, male aphasia patients. Patient \#1 (59 Yr., 10 Yr. poststroke) had mild nonfluent speech and LMCA cortical/subcortical lesion; he named $40 \%$ of the pictures. Patient \#2 (56 Yr., 1 Yr. poststroke) had severe nonfluent speech and only subcortical lesion; he named $10 \%$. Patient \#1 had significant activation $(\mathrm{p}<.01)$ in L and R SMA (more extensive, R SMA); R sensorimotor (mouth); and R BA 21, 37. Patient \#2 had more extensive activation in both hemispheres, including L and R SMA (much more extensive, R SMA); R motor (mouth) and $\mathrm{L}$ sensorimotor (mouth); R temporal lobe BA 22, 21, 20, 38, fusiform gyrus and BA 37 and L temporal lobe BA 21, 20 and 38; and other ROIs. The increased activation during overt naming in Patient \#2 may have represented a widespread maladaptive plasticity with poor modulation of the bi-lateral language network for naming.

Correspondence: Paula I. Martin, Harold Goodglass Boston University Aphasia Research Center, V.A. Boston Healthcare System, Psychology Research (116-B), 150 South Huntington Avenue, Boston, MA 02130. E-mail:paulak@bu.edu

\section{A. COLANGELO \& L. BUCHANAN. PHONOLOGICAL PROCESSING IN DEEP DYSLEXIA.}

Deep dyslexia is an acquired reading disorder in which a previously literate adult produces semantic errors during reading and evidences impaired nonword reading. Most models of deep dyslexia assume multiple loci of damage that impairs the semantic system and obliterates phonological processing. Several recent findings challenge conceptualizations of deep dyslexia that hinge on complete inability to process phonology: Buchanan, Hildebrandt, and MacKinnon $(1994,1996)$ demonstrated a significant pseudohomophone effect, as well as semantic priming with pseudohomophone primes in lexical decision. Cumulatively, these results indicate that deep dyslexics are sensitive to implicit phonological information despite impaired explicit access. For the first time, we will present data that provides clear evidence that deep dyslexics are capable of processing phonology on an explicit level. In the current investigation, a patient with deep dyslexia was asked to read 20 lists comprised of 14 pseudohomophones. The real word phonological equivalents to the pseudohomophones on each list converged in meaning on one nonpresented word. Each list was followed by a forced choice trial that included the converged word for that list and a semantically related word that was not strongly associated to the real word phonological representations of all pseudohomophones for that list. The results of this manipulation revealed $100 \%$ accuracy on the forced-choice trials. These findings cannot be explained by traditional multiple loci damage accounts, but are consistent with the Failure of Inhibition Hypothesis as an explanation for reading errors in deep dyslexia.

Correspondence: Lori Buchanan, Psychology, University of Windsor, 401 Sunset Avenue, 173 Chrysler Hall South, Windsor, ON N9B3P4, Canada. E-mail: buchanan@uwindsor:ca

\section{M.L. HENRY, P.M. BEESON \& S.Z. RAPCSAK. LESION LOCA- TION IN ACQUIRED AGRAPHIA.}

Dual route models of spelling postulate a lexical-semantic route whereby orthographic word forms are retrieved via semantics, and a sublexical (phonological) route that is necessary to assemble spellings for unfamiliar words or pronounceable nonwords. Damage to the lexical-semantic spelling route results in lexical agraphia, which is characterized by impaired spelling of irregular words (e.g., circuit). Damage to phonological spelling procedures results in difficulty spelling unfamiliar words 
and nonwords (e.g., bludge), and is referred to as phonological agraphia. Based on our review of the literature, we propose that the status of lexical-semantic and phonological spelling abilities relates to the integrity of left hemisphere extrasylvian and perisylvian regions, respectively. We report here on a study designed to examine lesion location relative to spelling ability in individuals with acquired agraphia due to cerebrovascular event. Six individuals with extrasylvian and five with perisylvian lesions were administered a comprehensive test battery designed to examine the relative status of phonological and lexical-semantic spelling processes. Spelling performance was examined with regard to the effects of regularity (regular vs. irregular) and lexicality (real word vs. nonword spelling). Lesion data and spelling performance revealed that individuals with extrasylvian lesions demonstrated significant regularity effects and no lexicality effects, consistent with reliance on a phonological strategy for spelling. Individuals with perisylvian lesions demonstrated impaired nonword spelling relative to real words, with no significant effect of regularity. These data support the role of the left perisylvian region in phonological spelling processes, and the involvement of left posterior extrasylvian regions in lexical-semantic spelling. Correspondence: Pelagie M. Beeson, Ph.D., Speech \& Hearing Sciences, University of Arizona, PO Box 210071, Tucson, AZ 85721-0071. Email: pelagie@u.arizona.edu

\section{BALASUBRAMANIAN. PURE AGRAPHIA: A CASE REPORT.}

Ever since Wernicke (1903) postulated the existence of pure or isolated agraphia, the causal lesion that was observed initially in the frontal lobe, came to be supplemented by lesions in the parietal lobe. In a more recent overview of the lesions causing pure agraphia, Roeltgen (1994) reports on seven different lesion sites. In addition to the lesion site, the symptom complex of pure agraphia also came under the scrutiny of researchers (Menon \& Desmond, 2001., Croisle, Laurent, Michel, \& Trillet, 1990., Miceli, Silveri, \& Caramazza, 1985). The current study analyzed the characteristics of pure agraphia using the methods of psycholinguistic assessment of language performance in aphasics (PALPA, Kay, Lesser, \& Coltheart, 1992). The subject of the current study was CBH, a 59-year old female with a history of bilateral parietal lobe lesion and word finding and writing difficulties. Tests administered to the subject include 1) Boston Diagnostic Aphasia Examination, 2) Boston Naming Test, 3) Reading Comprehension Battery for Aphasia, 4) Discourse Comprehension Test, and 5) Numerical Problem Solving subtest of Minnesota Test of Differential Diagnosis of Aphasia. CBHs performance was characterized by moderate difficulty in word finding, and spelling words. Severely impaired performance was noted on division, multiplication and complex addition and subtraction problems. Subtests related to reading and writing modalities from PALPA were administered to attain a comprehensive assessment of $\mathrm{CBH}$ s reading and writing. Her performance on these tasks was analyzed in terms of leading models of writing/reading to understand the nature of agraphia.

Correspondence: Venu Balasubramanian, Ph.D, Speech-Language Pathology \& Audiology, Seton Hall University, McQuaid Hall, 400 South Orange Ave, South Orange, New Jersey, NJ07079.E-mail: balasuve@ shu.edu

\section{DE RIESTHAL \& R.T. WERTZ. INFLUENCE OF THE STIMULUS MODALITY ON PANTOMIME PERFORMANCE IN APHASIA.}

A model of gestural production (Ochipa \& Rothi, 2000) suggests that whereas auditory and printed stimuli must activate semantic information prior to activating a gestural-movement representation in the action output lexicon for the production of a pantomime, visual input from an object or picture may activate these representations in the action output lexicon directly, without prior retrieval of semantic information. Thus, it may be hypothesized that aphasic individuals with semantic deficits may generate pantomimes more accurately when presented with picture stimuli than auditory or printed stimuli. The purpose of this study was to examine differences in aphasic pantomime performance among three stimulus conditions: pictorial, auditory, and printed. Participants were 12 individuals with chronic aphasia resulting from a single left hemisphere CVA. Three experimental tasks were administered. In each task, 20 object-stimuli were presented and the participant responded by demonstrating the use of the object. Tasks differed by stimulus mode: picture, auditory, or printed. In the pictorial condition, blackline drawings for each object were presented. In the auditory and printed conditions, sentence descriptions for each object were presented. Performance in each task was scored using the PICA (Porch, 1981) 16point multidimensional scoring system. Results indicated that pantomime performance was significantly better in the pictorial condition compared to the auditory $[\mathrm{F}(1,132)=12.843, \mathrm{p}<.002]$ and printed conditions $[\mathrm{F}(1,132)=44.682, \mathrm{p}<.002]$. There was no significant difference in performance between the auditory and printed conditions $[\mathrm{F}(1,132)=$ $9.616, p>.002]$. The results of the present investigation support the stated hypothesis and suggest that gestural movement representations may be activated directly from visual-object information, while auditory and printed descriptions may require intervening activation of semantic information.

Correspondence: Michael de Riesthal, Ph.D., Neurology (127), VA North Florida/South Georgia Healthcare System, 1601 SW Archer Rd., Gainesville, FL 32608.E-mail:michael.deriesthal2@med.va.gov

\section{Laterality}

\section{HISCOCK, R. INCH \& C.T. EWING. WHAT STAGE OF AUDI- TORY PROCESSING PRODUCES THE RIGHT-EAR ADVANTAGE? A SIGNAL-DETECTION STUDY .}

Attempts to specify the source of the right-ear advantage (REA) in dichotic listening for verbal stimuli typically have supported one of two mechanisms: (1) a fixed perceptual superiority for the right-ear-toleft-auditory-cortex pathway or (2) a dynamic allocation of attention that favors the right side of space. Recent findings from signal-detection tasks indicate that volitional shifts of attention affect the REA for localization but not detection. The objective of the present study is to determine which of the two processes-detection or localization-accounts for the REA on a standard dichotic listening test. Accordingly, stimuli from the Halwes Fused Dichotic Words Test (FDWT) were administered to 120 university students (108 right-handers, 12 left-handers). Each participant heard 240 pairs of words under standard testing conditions and another 180 pairs in a signal-detection task with left-ear, right-ear and divided-attention conditions. The results indicated an REA for standard testing $(p<.0001)$ and for detection sensitivity $(p<.0001)$. In contrast, the analysis for localization sensitivity yielded a significant Attention $x$ Ear interaction $(p<.0001)$. An REA for localization materialized when attention was directed to the right but disappeared when attention was directed to the left. The only significant correlation between asymmetry on the standard test and the various indices of asymmetry on the signal-detection task was a correlation of .57 between REA on the standard task and asymmetry of detection sensitivity. REA on the standard task was not correlated with asymmetry of localization sensitivity or response bias. The results indicate that the REA on the standard task reflects a fixed early-stage asymmetry that is not altered by volitional shifts of attention. Attention affects a later stage of processing, which involves localizing left- and right-ear signals.

Correspondence: Merrill Hiscock, Ph.D., Psychology, University of Houston, Heyne Bldg, Room 126, Houston, TX 77204-5022. E-mail: mhiscock@uh.edu

\section{N.L. RUSSELL \& D. VOYER. TARGET DETECTION IN DICHOTIC LISTENING: A COMPARISON OF WORDS AND SYLLABLES.}

The present study investigated the reliability and magnitude of auditory laterality effects using different types of verbal material. Sixty par- 
ticipants completed a dichotic target detection task in one of three conditions (syllables, neutral words, words with emotion). In each condition, participants monitored for a specific target word or syllable (as appropriate) and indicated whether it was presented to either ear on each trial. Results showed a significant overall right ear advantage (REA). However, the REA was less reliable and smaller in the syllables condition than in the word condition (regardless of whether an emotional component was included). It thus appears that including an emotional component in the stimuli does not influence auditory laterality when the task involves focusing solely on language aspects of the stimuli. The results also suggest that the use of word stimuli might produce a better measure of laterality than syllables in a target detection task. Correspondence: Nancy L. Russell, BA, Psychology, UNB, Bag Service 45444, Fredericton, NB E3B 6E4, Canada.E-mail:nancy.r@unb.ca

\section{K. STRELNIKOV. A COMPARISON OF MOTOSENSOR LATERAL- ITY PROFILE WITH HEMISPHERIC COGNITIVE STYLES.}

The goal of this study was to investigate the difference between two approaches to brain asymmetry assessment: basing on motor and sensor preferences and basing on the models of hemispheric cognitive styles. The experimental paradigm was chosen under the influence of Luria conception of the partial hemispheric dominance. To study this we used the results of two popular brain asymmetry questionnaires: a modification of Oldfield test for Russian subjects, and a Russian version of Benziger Thinking Style Assessment (BTSA). According to the standard methods of these questionnaires' data analysis, we segregated subjects $(n=64)$ into right and left hemisphere dominance groups. Comparison of the results for each questionnaire revealed the following: the results of the two tests agreed in $41 \pm 3 \%(p<0,01)$, the right hemisphere dominance was found in $5 \%$ of subjects by motor-sensor criteria and in $55 \%$ by cognitive style criteria. In male the results agreed in $43 \pm 5 \%$ and in female in $40 \pm 3 \%(p<0,05)$. We conclude that, on the one hand, the motor and sensor preferences criteria are not sufficient for deciding upon the hemispheric cognitive styles prevalence and, on the other hand, the hemispheric cognitive style models may not be adequate enough at present and need to be further elaborated. We presume, that our results support the idea of partial hemispheric dominance and provide evidence for the necessity of detailed studies in this direction.

Correspondence: Kuzma Strelnikov, Institute of the Human Brain RAS, Oboronnaya 15-66, Saint-Petersburg 198099, Russian Federation. Email:strelkuz@hotmail.com

\section{J. GRAFF-RADFORD, G.P. CRUCIAN \& K.M. HEILMAN. LEFT HEMISPHERE-RIGHT HAND PROXIMAL INTENTIONAL BIAS.}

Most of the visual cognitive activities performed by the left hemisphere (e.g., reading) take place in proximal (peripersonal) space, but most visual cognitive activities mediated by the right hemisphere (e.g., facial recognition) take place in distal (extrapersonal) space. Heilman et al. (1995) demonstrated that the left (versus right) hemisphere has a visual attentional bias toward the body. The purpose of this study was to learn if, in addition to the left hemisphere=s proximal-peripersonal sensory-attentional bias, the left hemisphere-right hand also has a proximal motor-intentional bias. Eight right-handed men and eight righthanded women (mean age 23.5) were blindfolded and had their left or right or both hands placed one or two inches from the left or right margin of a 8.5 by 11 inch paper. The paper was placed sideways (long side in the coronal place) directly in front of the subject and the subjects were asked to move their hand or hands horizontally (along the intersection of the transverse and coronal planes) until the hand or hands reached their midline (intersection of the midsagittal and transverse planes). There were 6 different conditions, with 5 trials in each condition. We measured the degree of deviation from the coronal plane that could either be toward the subject (proximal) or away from the subject (distal) for each hand and then compared left versus right hand deviation. We found that the right hand had more proximal deviation than did the left hand, suggesting that, in addition to a proximal attentional bias, the left hemisphere-right hand also has a proximal motor-intentional bias. In many bimanual activities performed by right-handed people, when the hands are not adjacent to each other, the right hand is held closer to the body than is the left (e.g., writing on paper, shooting a gun or a bow). Thus, we cannot tell if this hand-hemispheric asymmetry is learned or endowed.

Correspondence: Gregory P. Crucian, PhD, Neurology, University of Florida, 100 S. Newell Drive, Rm. L3-100, Gainesville, FL 32610. Email: crucigp@neurology.ufl.edu

\section{VOYER \& J.D. INGRAM. ATTENTION CONTROL AND THE MAGNITUDE OF LATERALITY EFFECTS IN THE FUSED DICHOTIC WORDS TASK.}

The purpose of the present study was to examine the claim that the fused dichotic words task (FDWT) developed by Wexler and Halwes (1983) is an attention-free technique. Previous work with this task has shown that it is not affected by endogenous attentional manipulations. The value of this evidence is weakened by the fact that endogenous attention control is not always effective. Accordingly, the present study used a tone cue presented either 150 or $450 \mathrm{~ms}$ before target presentation to control attention. This form of exogenous cuing has been shown to be quite effective in various settings. Thus, the magnitude and reliability of the right ear advantage (REA) in the FDWT was examined in an exogenous cuing condition (requiring participants to report the word presented to the cued ear), as well as in a free recall condition (requiring participants to report the one word they believed was presented). Results showed that the cue was ineffective and that the magnitude and reliability of the REA was statistically similar in both task conditions. In view of the demonstrated effectiveness of exogenous cuing in other dichotic tasks, these findings strongly support claims that the FDWT is not affected by attentional factors.

Correspondence: Daniel Voyer, PhD, Psychology, University of New Brunswick, Bag Service \#45444, Fredericton, NB E3B 6E4, Canada. E-mail:voyer@unb.ca

\section{A.Y. ZHELTUKHIN. EFFECTS OF NON-DOMINANT HAND PERFORMANCE ON PROCESSING SPEED.}

In this study, we compared the effects of non-dominant hand performance in 2 tasks of different cognitive load. A group of young healthy adults $(\mathrm{N}=47$, mean age $=20.3[\mathrm{SD}=0.3]$, mean years of education $=$ $14.2[\mathrm{SD}=0.2], \mathrm{N}$ left-handed $=6$ ) performed a computerized version of the Digit-Symbol Coding (DSC) test, which closely emulated the paper-and-pencil format, and a computerized letter fluency (LF) test (writing the letter 'l' repeatedly for 10 seconds). The participants were asked to complete both tasks twice, first with the dominant hand (D) and then with the non-dominant hand (ND). For each participant, we computed the average speed (the length of strokes divided by the duration of strokes) and the average reduction in speed (Speed D minus Speed ND). The participants performed significantly faster on DSC-D than on DSC-ND $(\mathrm{F}(1,92)=48.6, \mathrm{p}<.01)$ and consequently completed more units $(F(1,92)=57.9, p<.01)$. They also displayed a significantly higher speed on LF-D than on LD-ND $(F(1,92)=10.8, p<.01)$, but the drop in speed in the ND condition was more dramatic in the cognitively demanding DSC than in $\operatorname{LF}(F(1,92)=4.3, p<.05)$. We also observed that the participants used the same strategy in the attempt to offset the speed reduction in the ND condition on both tests. They made significantly shorter strokes (DSC: $\mathrm{F}(1,92)=21.1$, $\mathrm{p}<.01 ; \mathrm{LF}: \mathrm{F}(1$, $92)=6.9, \mathrm{p}<.01)$.

Correspondence: Alexander Y. Zheltukhin, Neurostyles, Inc., 1075 Bradford Drive, Roswell, GA 30076.E-mail: azheltukhin@neurostyles.com 


\section{A.Y. ZHELTUKHIN \& J.L. WOODARD. NON-DOMINANT HAND PERFORMANCE ON THE CLOCK-DRAWING TEST.}

Two groups of young healthy adults (Group ND: $\mathrm{N}=24$, mean age $=$ $20.4[\mathrm{SD}=0.4]$, mean years of education $=14.3[\mathrm{SD}=0.2], \mathrm{N}$ left-handed $=3 ;$ Group $\mathrm{D}: \mathrm{N}=24$, mean age $=20.5[\mathrm{SD}=0.5]$, mean years of education $=14.3[\mathrm{SD}=0.3], \mathrm{N}$ left-handed $=3$ ) performed a computerized version of the Clock-Drawing Test. Participants drew the face of a clock with the clock hands pointing at ten after eleven. Group ND used the non-dominant hand. Group D drew with the dominant hand. Group D outperformed Group ND $(\mathrm{F}(1,46)=27.2, \mathrm{p}<.01)$, drawing the strokes faster $(F(1,46)=32.6, p<.01)$ and making shorter pauses between the strokes $(\mathrm{F}(1,46)=18.6, \mathrm{p}<.01)$. Group ND made more errors in the placement of hands and the sequencing of the clock digits $(F(1,46)$ $=4.1, \mathrm{p}<.05)$. Group ND spent more time than Group D on drawing the clock hands $(F(1,46)=6.7, p<.01)$. But there were no group differences in drawing the clock circle. This discrepancy indicates that the utilization of the non-dominant hand had a detrimental effect on the processing speed rather than on the motor speed. $84 \%$ of Group ND $(\mathrm{N}=20)$ drew the clock digits in the ascending order (1 through 12). 50 $\%$ of Group D drew 3-6-9-12 first and then filled in the remaining digits, which proved effective in maintaining the accurate spacing between the digits and helped to avoid errors.

Correspondence: Alexander Y. Zheltukhin, Neurostyles, Inc., 1075 Bradford Drive, Roswell, GA 30076.E-mail:azheltukhin@neurostyles.com

\section{W.F. MCKEEVER, J. MCSWEENY, M. DENNIS, S. SMITH, G. SUMMERS, T. KINKAID \& L.M. BAILEY. GREATER ACTIVA- TION OF THE RIGHT THAN LEFT ANGULAR GYRUS DURING WRITING IN BOTH INVERTED AND NON-INVERTED SINISTRAL WRITERS.}

McKeever (2003) recently proposed a purely genetic theory for the inheritance of handedness for writing. The theory posits that handedness for writing is due to a single $X$-linked gene that has three alleles. It suggests that handwriting posture, in addition to hand preference for writing, may be accounted for by the model, although the model could still account for the latter even if the handwriting posture predictions should fail to be supported by future data. The model posits that inverted handwriting posture in sinistral individuals reflects a "dominance" of the left hemisphere angular gyrus, while non-inverted hand posture in sinistral individuals reflects a relative "dominance" of the right angular gyrus during writing. We initiated an fMRI study of the comparative activation levels of the left and right angular gyri during writing trials. Data from the first 9 subjects is reported. Of the 9,5 were non-inverted sinistrals, 3 were inverted sinistrals, and 1 was an inverted dextral. The fMRI scans for functional imaging used the BOLD technique to provide measures of the relative levels of oxygen metabolism in different brain areas, including the angular gyrus. A counterbalanced, within-subject block design, utilizing tasks of listening, of speaking, and of writing to dictation was employed. For the writing trials, results showed greater activation of the right than left angular gyrus in all sinistral writers. The inverted dextral showed greater activation of the left angular gyrus. Results suggest greater activation of the angular gyrus contralateral to the writing hand, regardless of handwriting posture.

Correspondence: Walter F. McKeever, Ph.D., Psychology, University of Toledo, 16420 S. 36th St., Phoenix, AZ, AZ 85048.E-mail:wfmckeever@ hotmail.com

\section{L.M. BAILEY \& W.F. MCKEEVER. HANDEDNESS AND THE FIVE FACTOR MODEL OF PERSONALITY.}

The possible relationship between handedness and personality became of interest to researchers because of speculation that handedness is associated with cerebral organizational differences. In this study, the possible relationship between handedness and a variety of personality traits was investigated. Personality traits were assessed using the NEO-Five Factor Inventory (NEO-FFI) of Costa and McCrae (1992). The five fac- tors of the NEO-FFI and 13 sub-factors of the NEO-FFI identified by Saucier (1998) were assessed in this study. A total of 330 University of Toledo students participated in this research. A series of multivariate and univariate statistical analyses were performed to test for possible relationships between handedness measures and personality traits. Left handed participants were found to score lower than right handed participants on the cluster variable Conscientiousness-Dependability. Additionally, left-handed females were found to rate themselves higher than left handed males on the cluster variable Extraversion-Sociability. When data for males and females was analyzed separately, right handed males were found to score higher than left handed males on the Sociability variable. An additional set of analyses that included a more continuous classifications of handedness showed that strongly left handed participants scored lower on the Extraversion factor than did strongly right handed and mixed handed participants. These results indicate handedness may be differentially related to the more narrowly defined subfactors of the five-factor model rather than the major personality dimensions. Furthermore, these results provide support for the notion that the relationship between handedness and personality

Correspondence: Lisa M. Bailey, Ph.D., Cognitive Neurology and Alzheimer's Disease Center, Northwestern University Medical School, 320 E. Superior, Searle 11-447, Chicago,IL 60611.E-mail: L-bailey3@ northwestern.edu

\section{S. WU, W. MCKEEVER, S. SMITH \& K. GAYETSKY. FAMILIAL SINISTRALITY AND INTERHEMISPHERIC TRANSFER TIME.}

This study examines the relationship between familial sinistrality (FS) and interhemispheric transfer time (ITT). Interhemispheric transfer time was measured by a simple reaction time protocol, the Poffenberger paradigm (Poffenberger, 1912), which measures manual reaction times to lateralized light signals. A prior study by McKeever and Gandy (1997) found that right-handed individuals with a positive familial sinistrality (FS+) showed a decreased ITT as compared to individuals without a family history of left-handedness (FS-). Previous literature indicated that left-handed individuals who write with an inverted hand posture have been connected with positive familial sinistrality (McKeever, 1979, McKeever and VanDeventer, 1989). Left-handed individuals who write with this inverted posture have also demonstrated a decreased ITT (McKeever and Hoff, 1979;1983, Levy and Wagner, 1984). This combined literature suggested the possible link between familial sinistrality and the absence of a significant ITT. Data is presented on 63 right-handed participants ( 32 female, 31 male). This sample size and examination of gender differences is a significant expansion from the study by McKeever and Gandy (1997), which utilized 24 total participants (21 female, 3 male). Results indicate no significant differences between FS+ and FS- individuals regarding ITT, failing to replicate the previous findings cited by McKeever and Gandy. Findings are also presented regarding other examined variables, including gender differences. Discussion is made regarding implications of present study and comparison with findings by McKeever and Gandy. Present results redirect examination of decreased ITT towards original connections with handedness and handwriting posture, as opposed to familial sinistrality. Correspondence: Stephen Wu, M.A., University of Toledo, 239 1/2 Newport Ave., Long Beach, CA 90803. E-mail: wustephen1@yahoo.com

\section{K. STRELNIKOV \& T. CHERNIGOVSKAYA. HEMISPHERIC INVOLVEMENT IN PROSODIC CLUES PROCESSING.}

Hemispheric specialization for lingusictic prosody perception was studied in 20 normal subjects, using monaural listening technique and in 150 PET scans of 12 normal subjects. Stimuli were Russian phrases with different syntagmatic segmentation. The place of a semantic pause changed the meaning of an utterance (e.g. "To take not, to leave", "To take, not to leave"), and the subjects were to press the button to one of the two target variants, providing accuracy and reaction time measures. No significant interhemispheric difference was found in monaural 
testing. The same task in the PET study recruited right posterior inferior frontal gyrus (BA 44) and right cerebellum. Earlier studies revealed left hemisphere prevalence in linguistic prosody perception and syntactic processing. Right posterior inferior frontal gyrus activation was associated with pitch perception while right cerebellum activation with verbal fluency and semantic prediction. Our results are consistent with the claim, that hemispheric asymmetry for syntax processing, coded by prosody, considerably depends on the acoustic properties of the stimuli. Correspondence: Kuzma Strelnikov, Institute of the Human Brain RAS, Oboronnaya 15-66, Saint-Petersburg 198099, Russian Federation. Email:strelkuz@hotmail.com

\section{M.F. SYMINGTON, L.K. PAUL \& W.S. BROWN. REASONING AND DECISION MAKING IN INDIVIDUALS WITH AGENESIS OF THE CORPUS CALLOSUM.}

Previous research has indicated that individuals with agenesis of the corpus callosum (ACC) have diminished interhemispheric transfer and deficits in some domains of higher cognitive processing, particularly in complex novel problem solving. Anecdotal reports suggest deficits in decision-making in adults of normal intelligence with ACC. There is also the suggestion of poor psychosocial judgment and insight in ACC. It was hypothesized that individuals with ACC would demonstrate deficits in a decision making tasks that would be evidenced in poor performance on the Wisconsin Card Sorting Task (WSCT) and the Gambling Task (GT; Bechara, et al., 1994). Twelve individuals with ACC and normalrange IQs (>80) were compared to 12 age and IQ matched controls. Individuals with ACC performed significantly worse than age and IQmatched controls on the number of categories completed on the WCST $(\mathrm{p}<.05)$. Individuals with ACC also demonstrated a trend for a greater number of perseverative errors than controls $(p=.06)$. Cognitive modeling analyses of trial-to-trial performance on the GT (Busemeyer and Stout, 2002) revealed that acallosal participants tended to perform worse than controls on the learning parameter of the GT ( $p=.07)$. No significant differences or trends were found between groups on parameters measuring motivation and selection consistency. Taken together, these results suggest that individuals with ACC demonstrate difficulty learning from task feedback, have problems strategizing and imagining consequences for actions, and have difficulty with concept formation, all of which affect successful decision making.

Correspondence: Warren S. Brown, Ph.D., Fuller Graduate School of Psychology, Travis Research Institute, 180 N. Oakland Ave, Pasadena, CA 91101.E-mail:wsbrown@fuller.edu

\section{G. SCHILMOELLER, K. SCHILMOELLER \& D. DOHERTY. SOCIAL INTERACTION IN INDIVIDUALS WITH AND WITHOUT A CORPUS CALLOSUM.}

While some researchers report that people with agenesis of the corpus callosum (ACC) and normal IQ may be clinically asymptomatic (e.g., Wisniewski \& Jeret, 1994), Brown and Paul (2000) report atypical psychosocial functioning in such young adults. To examine social functioning and ACC, we surveyed families of individuals from 19 mos to 21 yrs who showed age-appropriate communication ability - 91 with complete ACC, 36 with partial ACC, and 149 siblings with a corpus callosum for comparison. We measured social functioning indirectly (selfhelp skills; motor skills; mood; autistic-like behaviors) as well as directly (positive social interaction; social difficulty; aggression). A two-way ANOVA showed neither main nor interaction effects for ACC and age on the positive social interaction scale. There were both main effects and an interaction effect for ACC and age on the self-help and motor skills scales. Individuals with ACC had poorer self-help and motor skills than siblings though those skills improved over time for both groups. ACC was associated with autistic-like behaviors though not with social difficulty, aggression, or mood. However, main effects for age resulted for both groups on the mood, social difficulty, and aggression scales. Older individuals were moodier. Individuals were reported to be more aggres- sive and have more social difficulties during the school years than during the preschool or adolescent years. These results suggest that individuals with $\mathrm{ACC}$ experience challenges in personal functioning areas (self-help, motor skills, autistic-like behaviors) making them different from peers without ACC. These differences may impede the development of friendships between individuals with $\mathrm{ACC}$ and their peers. Correspondence: Gary Schilmoeller, University of Maine, 5749 Merrill Hall Rm 118, Orono, ME 04469-5749. E-mail: RHD351@maine.edu

\section{A. LAUTZENHISER, A.D. HART, K. MCBURNEY-REBOL, D. WALLACE, L.K. PAUL \& W.S. BROWN. EMOTIONAL RESPON- SIVENESS IN AGENESIS OF THE CORPUS CALLOSUM.}

Agenesis of the Corpus Callosum (ACC) is a congenital condition in which part or all of the corpus callosum fails to develop. Past research has found that persons with ACC appear to have difficulty with the comprehension of social context as contained in the stimuli of the Thematic Apperception Test (TAT) such that they provide narratives with diminished social and emotional content (Paul, Schieffer, \& Brown, 2003). However, it is unclear if their TAT responses indicate a deficit in verbal expressions of emotion (as in alexithymia), or if they have diminished reactivity and psychophysiological responsiveness to emotionally laden stimuli. This study compared the psychophysiological reactions (facial electromyography and electrodermal responses) and ratings of emotion to standardized emotionally laden pictures (the International Affective Picture System, or IAPS). Nine persons with ACC (IQs >80) were compared to 9 age- and IQ-matched controls. Normative data for the IAPS suggests that it is capable of evoking emotion congruent electromyography and electrodermal responses. There were significant differences between groups, with participants with ACC exhibiting decreased facial EMG responsiveness to positive and negative slides $(p<.01)$. There were no differences between groups in electrodermal responses. Significant differences were also found with respect to verbal ratings of emotion $(\mathrm{p}<.02)$, with participants with ACC rating positive slides as less positive and negative slides as less arousing than did controls. These data suggest diminished emotional reactivity in individuals with ACC with respect to facial muscles, but normal autonomic responsiveness. Correspondence: Warren S. Brown, Ph.D., Fuller Graduate School of Psychology, Travis Research Institute, 180 N. Oakland Ave, Pasadena, CA 91101. E-mail: wsbrown@fuller.edu

\section{S. SYMINGTON, L.K. PAUL, M. ONO, M. SYMINGTON \&. W.S. BROWN. THEORY OF MIND IN INDIVIDUALS WITH AGEN- ESIS OF THE CORPUS CALLOSUM.}

Clinical observations and previous research have suggested that individuals with agenesis of the corpus callosum (ACC) have inadequate psychosocial skills. The social naiveté, lack of self-awareness, and diminished social insight seen in this population can be further understood by examining their capacity to formulate a theory of mind (ToM). ToM refers to one's ability to represent and infer the mental states of other persons. In this study, the Theory of Mind Story Task, the Adult Faux Pas Test, and The Awareness of Social Inference Test (TASIT) were administered to 10 individuals with ACC, 1 individual with partial ACC, and 9 age- and IQ-matched controls. A repeated-measures ANOVA revealed that individuals with ACC did significantly worse on the TASIT than controls $(p<.02)$. In a post-hoc analysis it was found that the group difference was most highly significant $(p<.001)$ for section three of the TASIT which relies most heavily on ToM capacity. A significant difference was also found on the Adult Faux Pas Test, where individuals with ACG again performed worse than controls $(p<.05)$. However, no significant group differences were found on the cumulative score of the Theory of Mind Story Task or on any of its subcomponents: physical 
stories, social stories (ToM), and response time. These results are consistent with our previous finding of diminished comprehension of humor and nonliteral language in ACC, and further suggest that diminished ability to construct an accurate ToM is an important factor contributing to the social deficits seen in individuals with ACC.

Correspondence: Warren S. Brown, Ph.D., Fuller Graduate School of Psychology, Travis Research Institute, 180 N. Oakland Ave, Pasadena, CA 91101.E-mail:wsbrown@fuller:edu

\section{Paper Session 17/11:15 a.m.-1:15 p.m.}

\section{Genomic Effects on Neuropsychological Functioning}

\section{R.M. BILDER, K.A. NOLAN, J. VOLAVKA, H.M. LACHMAN \&. A.A. GRACE. GENOMIC EFFECTS ON NEUROPSYCHOLOGICAL STABILITY AND PLASTICITY IN SCHIZOPHRENIA.}

Neuropsychological (NP) deficits are prominent in schizophrenia and dopamine (DA) dysfunctions are implicated in theories of both pathophysiology and treatment. A common functional polymorphism, Val158Met in exon III of the catechol-O-methyltransferase (COMT) gene, leads to a 3- to 4-fold difference in COMT enzyme activity, markedly altering catecholamine catabolism. A growing literature documents effects of this polymorphism on cognitive and behavioral phenotypes, but reports conflict and yield generally modest associations (i.e., $~ 4 \%$ shared variance between phenotype and genotype). Prevailing models emphasize COMT effects on prefrontal DA, but biophysical models suggest more specific effects on tonic and phasic DA in both cortical and subcortical systems. We hypothesized that tonic and phasic DA respectively regulate NP stability and plasticity. Two separate studies of schizophrenia were conducted relating NP phenotypes to COMT genotype. In the first study a standard neuropsychological battery revealed strongest associations ( $11 \%$ variance shared with genotype) for selected measures consistent with the hypothesis that the Met allele is associated with increased stability of executive functions and working memory representations. In the second study, a more specific experimental task (computerized "competing programs") was used. The Met allele was associated with superior performance on "stability" measures, but poorer performance on "switching" measures. A composite index of "switch-cost" shared $41 \%$ of variance with genotype. These findings suggest that measures of cognitive stability-plasticity may relate meaningfully to neuropsychopharmacological models under potent genomic control, with implications for the pathophysiology and treatment of ADHD, OCD, impulse control disorders, and traumatic brain injury. Correspondence: Robert M. Bilder, Ph.D., Psychiatry and Biobehavioral Sciences, UCLA, 760 Westwood Plaza, NPI Room C8-849, Los Angeles, CA90024.E-mail: rbilder@mednet.ucla.edu

\section{J.S. WEFEL \& C.A. MEYERS. APOE GENOTYPE AND COGNI- TIVE FUNCTION IN BRAIN TUMOR PATIENTS DIAGNOSED WITH HIGH GRADE GLIOMA.}

Primary brain tumors and therapeutic modalities used to treat these cancers are often associated with progressive cognitive decline. The identification of genetic risk factors that may predispose a patient to developing greater cognitive dysfunction secondary to their cancer or neurotoxicity secondary to anti-neoplastic therapies is of interest. The apolipoprotein E (APOE) genotype has previously been described as a risk factor for the development of Alzheimer's disease (AD), impaired attention and working memory in early $\mathrm{AD}$, and earlier onset of age-related memory decline in otherwise cognitively healthy subjects. APOE e4 genotype has also been associated with increased length of coma af- ter traumatic brain injury (TBI), worse acute TBI related cognitive dysfunction, and worse learning and recall performance in TBI patients. We serially evaluated attention and memory function in twelve high grade primary brain tumor patients who had an ef allele (e4+) and twelve patients without an e4 allele (e4-). The e4 groups were well matched on tumor histopathology, intracerebral tumor location, age, education, Karnofsky Performance Status, and Functional Independence Measure ratings. All patients previously underwent craniotomy and received adjuvant radiotherapy and chemotherapy. No statistically significant differences were detected between the e4+ and e4- patients two years post diagnosis in attention or memory function. Relative to their baseline performances, patients' performances were grossly stable across the interim assessment period. A mixed pattern of attention and memory changes, which while not statistically significant were associated with moderate effect sizes differences, will be described. The relationship between APOE status, treatment parameters, and cognitive function in survivors of high grade glioma will be discussed. Correspondence: Jeffrey S. Wefel, Ph.D., Department of Neuro-Oncology, U.T. M.D. Anderson Cancer Center, 1515 Holcombe Blvd, Unit 431, Houston, TX 77030.E-mail: jwefel@mdanderson.org

\section{B. PARMENTER, D.R. DENNEY \& S. LYNCH. THE RELATION- SHIP BETWEEN THE APOE E4 ALLELE AND COGNITIVE IMPAIR- MENT IN PATIENTS WITH MULTIPLE SCLEROSIS.}

Several studies have explored the role of the apolipoprotein E $\varepsilon 4$ allele in multiple sclerosis (MS). Surprisingly, most of these studies have focused on physical disability even though this allele is frequently associated with dementing illnesses (e.g., Alzheimers Disease) and approximately $50 \%$ of patients with MS experience some decline in cognitive performance. The one MS study that focused on the $\varepsilon 4$ allele and $\operatorname{cog}_{-}-$ nitive functioning utilized a small sample and failed to find an association between cognitive impairment and possession of the allele, although a significant relationship between cognitive impairment and the AA genotype at the -491 locus of the promoter region was reported. The current study was designed to investigate these relationships further, using a larger sample of patients with clinically definite MS. Three hundred patients underwent genotyping to determine their $\varepsilon 4$ and -491 status. Of these patients, 261 were administered the following neuropsychological measures: the California Verbal Learning Test-II, the Tower of London, the Paced Auditory Serial Attention Test, the FAS Verbal Fluency Test, and the Spatial Recall Task. Neither the $\varepsilon 4$ allele nor the $-491 \mathrm{AA}$ genotype was associated with poorer performance on any of the aforementioned neuropsychological measures. However, when patients were classified as either cognitively impaired or cognitively intact based on their performance across the full battery of tests, cognitively impaired patients were more likely to possess the $\varepsilon 4$ allele, but not the AA genotype.

Correspondence: Brett A. Parmenter, MA, Psychology, University of Kansas, 319 Humphrey Street, Floor 2, New Haven, CT 06511. Email:brettp@ukans.edu

\section{T.W. SCHMITZ, T.N. KAWAHARA-BACCUS, S. ASTHANA, M. SAGER, H. ROWLEY \& S.C. JOHNSON. APOLIPOPROTEIN E GENOTYPE AFFECTS NEURAL ACTIVATION IN THE MESIAL TEMPORAL LOBE OF A COGNITIVELY NORMAL COHORT WITH FAMILIAL HISTORY OF AD. \\ Research has consistently linked genotypic expression of the Ap-} polipoprotein e4 (APOe4) allele with increased risk of developing Alzheimers Disease (AD). The aim of this functional MRI study was to determine if mesial temporal lobe (MTL) activation during a memoryencoding task was differentially affected between APOe4 positive (e3/e4 or e4/e4) and APOe4 negative individuals. Participants were recruited from the Wisconsin Registry for Alzheimers Prevention (WRAP), which represents a research cohort of adults (45-60) with one or both parents prospectively diagnosed with AD. During the fMRI scan, participants 
were required to distinguish previously learned line drawings from novel line drawings (Snodgrass set). Paradigm: During echoplanar scanning, line drawings were presented every four seconds. Condition 1 consisted of novel items not viewed before; condition 2 consisted of familiar items learned in a training set viewed 30 and 15 minutes prior to the scan. The order and length of the conditions were pseudorandom to reduce stimulus predictability. The task duration was 4 minutes and $42 \mathrm{sec}$ onds and was presented twice using equivalent forms. Imaging parameters were as follows: sagittal plane; $\mathrm{TR}=2$; repetitions $141 ; \mathrm{TE}=30 \mathrm{~ms}$; Matrix 64x64; number of slices $=30$; slice thickness $4 \mathrm{~mm}$ with $1 \mathrm{~mm}$ skip. Images were realigned, normalized, and smoothed to $8 \mathrm{~mm}$ using SPM99. Nineteen e4 positive and 24 e4 negative participants were compared in a random effects analysis. Hippocampal response was higher among the e4 negative group, with activation loci occurring bilaterally. These results indicate that MTL functioning may be affected by AD progression prior to the onset of clinical symptoms.

Correspondence: Taylor W. Schmitz, BS, Medicine / Geriatrics, University of Wisconsin, Veteran's Administrative Hospital (GRECC 11G), 2500

OverlookTerrace,Madison,WI53705.E-mail:tws@medicine.wisc.edu

\section{Paper Session 18/11:15 a.m.-1:15 p.m.}

\section{Neuropsychological Functioning in Multiple Sclerosis}

\section{CHRISTODOULOU, L.B. KRUPP, P. MELVILLE, W.F. SCHERL, T. MORGAN, W.S. MACALLISTER, D.M. CANFORA, S.A. BERRY \& S. MILLER. LONGITUDINAL ASSOCIATION OF SELF-REPORTED COGNITIVE DYSFUNCTION AND NEUROPSY- CHOLOGICAL PERFORMANCE IN PERSONS WITH MULTIPLE SCLEROSIS.}

Objective: To assess relations between self-reported cognitive dysfunction and neuropsychological (NP) performance over 24-weeks in a cognitively impaired multiple sclerosis (MS) patient sample. Methods: Subjects were 56 persons with MS assessed at weeks 0 and 24 during a clinical trial to enhance cognition with a cholinesterase inhibitor (donepezil). They had a mean age of 43.8 years $(\mathrm{SD}=8.2)$ and $14.7(\mathrm{SD}=2.2)$ years of education. The majority were women $(69.6 \%)$. Their disease course was relapsing remitting $(58.9 \%)$, secondary progressive $(37.5 \%)$, or primary progressive $(3.6 \%)$. Selection criteria included at least mild cognitive impairment on the Rey Auditory Verbal Learning Test, and the absence of major depression. A modified Brief Repeatable Battery formed the core of the NP protocol. Total score on the 5-Item Perceived Deficits Questionnaire assessed subjective perception of cognitive impairment. Results: PDQ and NP scores did not correlate with one another at either baseline or 24 weeks. However, change on the PDQ did correlate with change in overall NP performance $(r=-0.530, \mathrm{p}<.001 ; 24$ weeks baseline), and with change on the following individual tasks: 10/36 Spatial Recall Test $(r=-0.381, p=.004)$, Symbol Digit Modalities Test $(r$ $=-0.366, p=.006)$. When examined separately, the placebo and donepezil groups displayed generally similar results. Conclusions: Changes on the self-report measure of cognitive impairment correlated with changes in NP performance even though two types of measures did not correlate with one another at any given point in time. These data provide preliminary support for the possible use of self-report scales to assess cognitive change over time. However, these results must be replicated and extended to a broader sample of persons with MS. Correspondence: Christopher Christodoulou, Neurology, SUNY Stony Brook, HSC T12-033 B, Stony Brook, NY 11794-8121. E-mail: christopher.christodoulou@sunysb.edu
G.J. CHELUNE, K.P. FEISTHAMEL, G. DORI \& L. STONE. PREVALENCE AND ESTIMATED RISK OF COGNITIVE DEFICITS ON THE WAIS-III AND WMS-III AMONG PATIENTS WITH MULTIPLE SCLEROSIS.

Estimates of the prevalence of cognitive dysfunction in multiple sclerosis (MS) vary widely depending on the tests used, composition of the patient sample, and criteria for defining impairment. We examined the prevalence and estimated relative risk (odds ratio) of neurocognitive impairment on six cognitive dimensions defined by the joint factor structure of the WAIS-III and WMS-III in 314 clinically definite MS patients; 221 relapsing remitting MS (RRMS), 69 secondary progressive MS (SPMS), and 24 primary progressive MS (PPMS). Scores falling below the 5th percentile of the Wechsler-III standardization samples using either the age-corrected standard scores or the new demographic norms corrected for age, education, gender, and ethnicity defined impairment. Compared to the demographically corrected T-scores, age corrected standard scores grossly underestimated the prevalence of cognitive deficits. Across groups, the risk of Verbal Comprehension (VC) deficits was the lowest $(\mathrm{OR}=2.5)$, whereas the odds of Processing Speed (PS) and Visual Memory (VM) deficits were the highest (OR=11.6 and 7.1). As expected, the prevalence of impairment in RRMS was generally low $(\langle 20 \%)$, except for PS $(26.2 \%$; OR=6.8). Cognitive deficits were most prevalent in SPMS, with prevalence rates ranging from $24.6 \%$ for VC to $76.8 \%$ for PS (ORs from 6.2 to 63.2.). Prevalence of deficits in PPMS fell in between RRMS and SPMS. These results emphasize the importance of correcting for demographically relevant variables, and also suggest that prevalence estimates of cognitive dysfunction in MS should be reported separately by disease course as results can be easily skewed by the composition of sample.

Correspondence: Gordon J. Chelune, Ph.D., Mellen Center (U-10), Cleveland Clinic Foundation, 9500 Euclid Avenue, Cleveland, OH 44195. Email: cheluneg@ccf.org

\section{B. BAUGHMAN, M. BASSO, C. GHORMLEY, N. LOWERY, R. SINCLAIR, R. TETT, P. ARNETT \& J. JOHNSON. NEUROPSYCHOLOGICAL DEFICIT PREDICTS WORK FUNC- TION IN EMPLOYED PATIENTS WITH M.S.}

Among people with multiple sclerosis (MS), 90\% will become symptomatic between 15 and 50 years of age. Thus, this disease strikes individuals during peak years of employment. Yet, $70-80 \%$ of patients are unemployed, largely because of symptoms associated with the disease. Factors that predict unemployment in M.S. have been examined in several studies, with impaired mobility seeming to be the most salient predictor of disability and unemployment. Yet, individuals with M.S. tend to have pronounced cognitive difficulties. However, relatively little research has examined the extent to which cognitive deficits influence work performance. Accordingly, the study examined the relationship between cognitive function in M.S. and work performance. A neuropsychological battery was administered to 15 outpatients with M.S. Work performance was evaluated by supervisors, and it was self-evaluated by patients. To reduce multicollinearity, number of impaired scores on neuropsychological tests was summed. Together with this impairment index, patient mobility, age and education were entered into a regression equation with work performance ratings serving as dependent variables. Cognitive impairment predicted work performance ratings by the supervisors and self-ratings by the patients $(\mathrm{r}=.4-.6)$. Mobility failed to predict work performance. Notably, patients rated their own performance more favorably as their neuropsychological function worsened, whereas supervisors rated performance more negatively as cognitive function deteriorated. Thus, as neuropsychological dysfunction increases, M.S. patients become less accurate in appraising their performance, and their work performance deteriorates. Implications for clinical practice and rehabilitation are discussed.

Correspondence: Michael Basso, Ph.D., Psychology, University of Tulsa, 600 South College Avenue, Tulsa, OK 74104.E-mail: michael-basso@ utulsa.edu 


\section{W. BEATTY, B. GORETTI, G. SIRACUSA, V. ZIPOLI, E. PORTACCIO \& M. AMATO. CHANGES IN COGNITIVE FATIGUE OVER THE WORKDAY IN MS.}

Fatigue, a common symptom of multiple sclerosis (MS), is associated with impairment in performing daily activities, poor quality of life and premature retirement from the workforce. There is little doubt that patients with MS can exhibit marked weakness and other objective signs of physical fatigue. However, whether cognitive performance by patients declines more rapidly than that by controls as a function of time engaged in mental activity remains controversial. Krupp and Elkin reported more rapid deterioration of performance by MS patients on two of five cognitive measures when subjects performed three hours of continuously effortful tasks between baseline and post-test. Others, using shorter and less taxing interpolated tasks found similar changes in performance over time for patients and controls. In the present study participants completed a timed walk, fatigue ratings and four cognitive tests that emphasized processing novel information before they went to work and again after completing a normal workday. Patients walked more slowly and performed more poorly on the cognitive tests, but they did not show more decline from baseline to post-test on any of these objective measures of fatigue. By contrast, subjective ratings of fatigue showed a greater increase over the day for patients than for controls. These results confirm other reports that patients' subjective ratings of their fatigue are not valid indicators of their actual performance on cognitive tests. Furthermore, laboratory studies that report "objective" cognitive fatigue in MS may utilize conditions that model the cognitive fatigue associated with the jobs patients actually perform rather poorly. Correspondence: William Beatty, University of Oklahoma Health Sciences Center, P.O. Box 26901 - ROB410, Oklahoma City, OK 73190. E-mail:william-beatty@ouhsc.edu

\section{BASSO, C. GHORMLEY, N. LOWERY, J. JOHNSON \& P. ARNETT. NEUROPSYCHOLOGICAL IMPAIRMENT PREDICTS FUNC- TIONAL OUTCOMES IN MULTIPLE SCLEROSIS.}

Previous research indicates that multiple sclerosis (MS) is associated with impaired self-care and vocational status. However, factors that contribute to functional impairment are poorly understood. In this regard, accumulating evidence indicates MS corresponds with significant neuropsychological impairment. There is some evidence, although nascent, that neurocognitive deficits contribute to diminished functional outcomes (cf. Higginson et al., 2000), yet this research has tended to examine subsets of neuropsychological function and adaptive behavior. Towards this end, 50 outpatients diagnosed with MS were administered the Wisconsin Card Sorting Test, Trailmaking Tests A and B, COWAT, Seashore Rhythm Test, CVLT-II, digit span, and letter number sequencing from the WMS-III. Adaptive function was examined via the Sickness Impact Profile, Incapacity Status Scale, Environmental Status Scale, and work status. Level of disease impairment was measured with the ambulation index. To reduce multicollinearity, neuropsychological scores were subjected to a principal components analysis, and executive function, attention-concentration, learning-retrieval, and learning-recognition components emerged. Together with ambulation index, age and education, these component scores served as independent variables in multiple regression analyses. Learning-retrieval and recognition predicted multiple functional outcomes, and executive function predicted ability to manage domestic activities. Ambulation index significantly predicted these outcomes, and cognitive and motoric impairment accounted for equivalent proportions of variance in adaptive function. Semi-partial correlations ranged from .3-.5. These findings indicate that neuropsychological deficits predict functional impairment and work status in MS, and this occurs independently of motoric impairment. Theoretical and clinical implications of these findings are discussed.

Correspondence: Michael Basso, Ph.D., Psychology, University of Tulsa, 600 South College Avenue, Tulsa,OK 74104.E-mail:michael-basso@ utulsa.edu

\section{E.A. GAUDINO, J. DELUCA, J. KALMAR, M.A. SHAWARYN, N.B. MOORE \& J. HALPER. AN MS OUTCOME MEASURE PRE- DICTS OBSERVED PERFORMANCE ON A COGNITIVELY COM- PLEX ADL.}

Investigating the relationship between clinical outcome measures and performance in activities of daily living (ADLs) is a primary goal in multiple sclerosis (MS) research. In such research it is important to consider both the physical and the cognitive demands of the ADLs. We investigated the relationship between three outcome measures sensitive to physical and cognitive impairment (Nine Hole Peg Test, 25ft. Walk, and PASAT) and direct, objective measures of functional capacity in ADLs. Participants with MS ( $\mathrm{n}=58)$ and healthy controls $(\mathrm{n}=28)$ received the Nine Hole Peg Test, 25ft. Walk, and PASAT (measuring upper-body functioning, lower-body functioning and information processing speed, respectively). Participants also underwent the Executive Function Performance Test (EFPT), in which they were required to complete a cognitively simple ADL (making a telephone call) and a cognitively complex ADL (paying two bills with insufficient funds). These tasks were designed to be insensitive to physical impairment while varying in their cognitive complexity. Regression analyses revealed that measures of physical function did not predict performance on these ADLs. The PASAT did not predict performance on the simple telephone task but did significantly contribute to the prediction of performance on the complex paying bills task $(\mathrm{p}<.05)$. Performance on the EFPT appears to be independent of physical capacity. Furthermore, only performance on the more complex cognitive task of the EFPT was predicted by information processing speed. By varying the cognitive complexity of the ADL task we were better able to elucidate the relationship between performance on MS outcome measures and everyday functioning.

Correspondence: Elizabeth A. Gaudino, Ph.D., Reserach, Kessler Medical Rehabilitation Research and Education Corporation (KMRREC), 1199 Pleasant Valley Way, West Orange, NJ 07052. E-mail: egaudinogoering@yahoo.com

Symposium 19/11:15 a.m.-1:15 p.m.

\section{Executive Functions in Aging: Integration of Behavioral, ERP and fMRI Studies}

\author{
Chair: Yaakov Stern \\ Discussant: Jordan Grafman
}

\section{D.J. WEGESIN, R. HOLTZER, Y. STERN, B.C. RAKITIN, J. GRAFMAN \& Y. STERN. EXECUTIVE FUNCTIONS IN AGING: INTEGRATION OF BEHAVIORAL, ERP AND FMRI STUDIES.}

This symposium is concerned with the effect of aging on four different aspects of executive function. The first presenter will report a study of age-related decline in source memory using behavioral and electrophysiological indices, i.e., event-related brain potentials (ERPs). Poor source memory in the elders was related to absent episodic memory effect in the right prefrontal cortex, as measured by the ERPs. The second presenter will discuss the results from a novel dual-task paradigm used to identify cognitive processes that underlie the negative effect of aging on time-sharing. Results from this study revealed that extending the temporal overlap between individual tasks and resource competition during encoding and output were important in explaining the disproportionate dual-task costs observed in the elders. The third presenter will discuss an event-related functional MRI study of a delayed match to sample task conducted with young and old participants. The behavioral data, consistent with previous studies, showed an age-related decline in working memory. The fMRI data demonstrates the association 
between task performance and the activation of specific brain areas through the use of a general linear model including behavioral measures. The fourth discussion looks at the ability of elders to simultaneously time an interval while conducting other mental operations. Results indicate that age-related problems in motor planning are exacerbated in dual task situations. This symposium integrates information from the fields of cognitive psychology, neuropsychology and neuroscience. Converging evidence will be presented in favor of specific age-related deficits in four theory-based paradigms of executive functions.

Correspondence: Roee Holtzer, Ph.D., Columbia University, 630 West 168th Street, P\&S Box 16, New York, NY 10032.E-mail: rh2034@ columbia.edu

\section{WEGESIN. SOURCE MEMORY DEFICITS AND EXECUTIVE DYSFUNCTION IN OLDER ADULTS.}

Older adults are less adept at monitoring the context of information they have received and are less able to recover the context or source of previously experienced events. In fact, age-related declines in source memory are nearly twice the magnitude of declines in content (item) memory. Neuropsychological studies have revealed dissociable neuroanatomical systems underlying item and source memory, whereby item memory is more dependent on intact medial temporal lobe function, and source memory is more dependent on intact frontal lobe function. Therefore, impaired source memory in the context of intact item memory in older adults suggests that the frontal lobes are especially susceptible to the deleterious effects of aging. We report age-related decline in source memory using behavioral and electrophysiological indices, i.e., event-related brain potentials (ERPs). ERPs revealed that both age groups showed a robust early, posterior-maximal episodic memory (EM) effect. However, ERPs of the old failed to show a late, right-prefrontal EM effect, which was present in the ERPs of the young. Participants also completed a test of executive function, the Wisconsin Card Sorting Test (WCST), and aging effects were obtained. Further, scores on the WCST were used to dichotomize older adults into hi and low performers. A dissociation was obtained on the experimental measures, whereby high WCST performers showed superior performance on source memory, but equivalent performance on item memory, compared to low WCST performers. Overall, results suggest that frontal lobe dysfunction associated with aging contributes to impaired source memory performance among older adults.

Correspondence: Domonick Wegesin, Neurology, Columbia University, 630 W. 168th St., Box 16, New York, NY 10032.E-mail: djw20@ columbia.edu

\section{R. HOLTZER. EXECUTIVE CONTROL OF WORKING MEMORY IN AGING.}

Dual-task methodology can be utilized to examine the effects of memory load and interference on age-related variance in executive control of working memory. This can be accomplished by systematically manipulating the extent of interference with specific components of memory tasks and by quantifying the cost of this interference on performance. The present study examined age differences in executive control of working memory using a novel dual-task paradigm. We assessed whether: 1) age-related dual-task costs were observed when each single task was processed via separate modality 2) degree of temporal overlap differentially affected age-related dual-task performance 3) vulnerability of specific memory mechanisms to interference differed with age. Methods: Participants were 16 young $($ mean age $=21)$ and 16 old (mean age $=74)$ individuals. The dual-task conditions were comprised of two individual tasks that are presumably processed via separate perceptual modalities: a delayed visual recognition task; and an auditory digit span task. The degree of overlap between the two single tasks was manipulated in two independent dual-task conditions. Results: Aging was associated with disproportionate dual-task costs that increased as a function of extending the overlap between the individual tasks. Moreover, encoding and output operations were especially susceptible to interference in old age. Hence, conceptualization of executive control of working memory should take into account resource competition between specific memory operations. Conclusion: Executive control of working memory is taxed by the aging process.

Correspondence: Roee Holtzer, Ph.D., Columbia University, 630 West 168th Street, P\&S Box 16, New York, NY 10032.E-mail: rh2034@ columbia.edu

\section{Y. STERN, E. ZARAHN \& B. RAKITIN. FMRI STUDY OF DE- LAYED MATCH TO SAMPLE PERFORMANCE IN YOUNG AND ELDERLY ADULTS.}

We implemented a delayed match to sample task, to look at working memory ans speed of processing in young and elderly individuals. In this task, 1, 3 or 6 letters are presented for 3 seconds. There is a 7 second retention period and then a probe letter is presented for 3 seconds. The subject responses with a differential button press to indicate whether or not the probe was in the original study set. In an initial study, we found that elderly adults had a larger overall reaction time and that the increase in reaction time that occurs at probe for 1,3 and 6 letters (RT slope) was greater in the older subjects. The latter indicates slower speed of processing. In a follow-up study, where subjects received extensive training, the overall difference in speed between young and old was much reduced, but both the intercept and RT slope effects remained significant. Global tests of fMRI studies comparing young and old subjects during task performance indicated that there were overall differences in activation between young and old adults during the retention and probe period. Also, the slope of the relationship between changes in RT and changes in activation across study set sizes differed in the young and old adults. More localized tests were able to localize some of these group differences. We also sought to replicate previously published results using this task. Replication was difficult, perhaps because of the low subject size and power in the majority of studies.

Correspondence: Yaakov Stern, PhD, Columbia University, $630 \mathrm{~W}$ 168th St, P\&S Box 16, New York, NY 10032. E-mail:ys11@columbia.edu

\section{B.C. RAKITIN. AGE-RELATED CHANGES TO DUAL-TASK TIME PRODUCTION.}

Timing is an executive function to the extent that it controls other functions such as motor planning, and the role of timing as an executive function becomes even more apparent as cognitive processes are added to simple timing tasks. Recent data has indicated that not only are basic timing mechanisms affected by aging, but that combining timing with other cognitive tasks magnifies these changes. The data from the current experiment further examines this issue by comparing simple time production (matching a response's latency to a target time interval) with a "choice timing" task that adds a spatial discrimination component to a time production task. This latter task therefore requires subjects to determine both which response to make and when to emit it. Furthermore, testing occurred over the course of three consecutive days in order to compare the retention of memories for time intervals acquired under conditions of varying difficulty. Results indicated that simple time productions by young participants increase in duration over the two-day retention interval. In contrast, older participants' simple time productions shorten substantially over testing. These age-related differences are even greater for the choice timing task. Additional studies indicate that feedback during performance can help alleviate these age-related timing problems. One implication is that dual-tasking exacerbates age-related timing errors. Therefore, as tasks get more difficult and as time since learning increases elderly individuals may be more prone to motor planning problems. Human factors engineers should take into account these differences between old and young users.

Correspondence: Brian C. Rakitin, Ph.D., Cognitive Neuroscience Division of the Taub Institute, Columbia University, 630 West 168th Street, P\&S Box 16, New York, NY 10032.E-mail:br130@columbia.edu 